\title{
LOS GRADOS DE LA UNIVERSIDAD \\ DE IRACHE (1613-1700)
}

RAFAEL RAMIS BARCELÓ PEDRO RAMIS SERRA

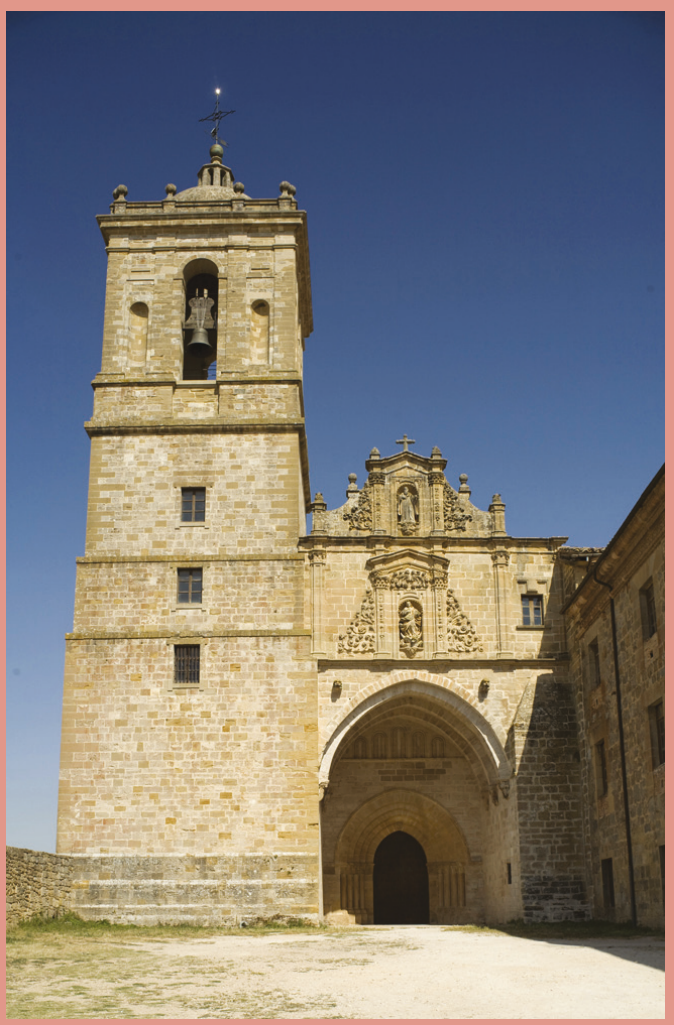



LOS GRADOS DE LA UNIVERSIDAD DE IRACHE

(1613-1700) 
The Figuerola Institute

Programme: History of Universities

The Programme "History of Universities" of the Figuerola Institute of Social Science History -a part of the Carlos III University of Madrid- is devoted to improve the overall knowledge on the highlearning academic institutions, since their inception in the Late Middle Ages, until our days. The Programme uses an interdisciplinary approach, and it is open to all branches of related knowledge, such as the history of institutions, of science, and of cultural and social events. A number of experts from several countries have participated in the Programme, bringing in their specialized knowledge and dedication to the subject of their expertise.

To give a better visibility of its activities, the Programme has published in its Book Series a number of monographs on the different aspects of its academic discipline.

Publisher:

Carlos III University of Madrid

Book Series:

History of Universities

Editorial Committee:

Manuel Ángel Bermejo Castrillo, Universidad Carlos III de Madrid

Gian Paolo Brizzi, Alma Mater Studiorum - Università di Bologna

Elena Hernández Sandoica, Universidad Complutense de Madrid

Françoise Hiraux, Université catholique de Louvain

Manuel Martínez Neira, Universidad Carlos III de Madrid

More information at www.uc3m.es/history_universities 
LOS GRADOS DE LA UNIVERSIDAD DE IRACHE

(1613-1700)

RAFAEL RAMIS BARCELÓ

PEDRO RAMIS SERRA

DYKINSON

2020 
Historia de las Universidades, 57

ISSN: 1886-0710

Motivo de cubierta:

Monasterio de Santa María de Irache

https://commons.wikimedia.org/wiki/user:PMRMaeyaert

(C) 2020 Autores

Editorial Dykinson

c/ Meléndez Valdés, 61 - 28015 Madrid

Tlf. (+34) 915442846

E-mail: info@dykinson.com

http://www.dykinson.com

Preimpresión: TALLERONCE

ISBN: 978-84-1377-164-9

Depósito legal: M-29504-2020

Versión electrónica disponible en e-Archivo

http://hdl.handle.net/10016/31395

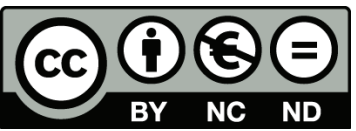

Licencia Creative Commons Atribución-NoComercial-SinDerivadas 3.0 España 
Para Catalina Inés, Pedro y Antonio Barceló Carbonell, y Juan Miralles Santandreu 



\section{ÍNDICE}

11 Introducción

15 Estudio preliminar

111 Grados de la Universidad de Irache

601 Bibliografía

611 Índice onomástico 
B. A. Bachiller en Artes

B. C. Bachiller en Cánones

B. L. Bachiller en Leyes

B. M. Bachiller en Medicina

B. T. Bachiller en Teología

Br. Bachiller

C. R. S. A. Ordo Canonicorum Regularium Sancti Augustini

Dr. Doctor

D. C. Doctor en Cánones

D. L. Doctor en Leyes

D. M. Doctor en Medicina

D. T. Doctor en Teología

L. A. Licenciado en Artes

L. C. Licenciado en Cánones

L. L. Licenciado en Leyes

L. M. Licenciado en Medicina

L. T. Licenciado en Teología

Ldo. Licenciado

M. A. Maestro en Artes

Mtro. Maestro

O. Praem. Ordo Praemonstratensis

O. S. B. Ordo Sancti Benedicti

O. Cist. Ordo Cisterciensis

O. C. Ordo Fratrum Beatissimae Mariae Virginis de Monte Carmelo

O. de M. Ordo Beatae Mariae Virginis de Mercede

O. P. Ordo Praedicatorum

O. S. A. Ordo Fratum Sancti Augustini

O. SS. T. Ordo Sanctissimae Trinitatis redemptionis captivorum

s. f. $\sin$ foliar

S. J. Societatis Iesu 


\section{INTRODUCCIÓN}

Presentamos en este libro la relación de graduados y reprobados por la Universidad de Irache desde 1613 hasta 1700. En la Abadía de Irache, se fundó una Universidad a partir de unos privilegios que habían sido concedidos a la Abadía de Sahagún. En Irache estudiaron diversas generaciones de benedictinos y de jóvenes navarros, y se graduaron muchos estudiantes foráneos, que procedían de diversos puntos de la Península Ibérica. Al ser una universidad tan frecuentada, en la que se graduaron miles de alumnos, era necesario estudiarla con detalle.

La historiografía de la Universidad de Irache es amplia y contiene trabajos de gran interés. La descripción de las fuentes preparada por Simón Pérez es una guía inestimable para el investigador, al tiempo que los estudios de Ernesto Zaragoza sobre los abades y los profesores constituyen instrumentos de gran utilidad. Lo mismo puede decirse del excelente libro que Fernando Serrano ha dedicado a los graduados en Medicina. El estudio de Ibarra Murillo, publicado en difíciles circunstancias, en 1939, es muy valioso, aunque incompleto. Era necesario retomar el análisis de los grados, que, junto con las cátedras y las matrículas, constituyen la espina dorsal del examen de cualquier institución universitaria.

En Irache, a diferencia de muchas otras universidades que hemos trabajado, han substistido muchas fuentes, y están bien conservadas. Esa es una de las razones por las que la historiografía ha podido ser más pródiga que en otras instituciones. En otros casos (recordemos, por ejemplo, el de Lérida), tuvimos que espigar en todas las fuentes posibles, a fin de lograr unos pocos datos. En Irache, sucede al revés: los libros de grados son una fuente tan prolija, que incluso hemos tenido que seleccionar la información para presentarla de manera útil y comprensible al lector.

En la época que analizamos, hay más de seis mil egresados, de los cuales hemos confeccionado una ficha lo más sintética posible: contienen, en líneas sucesivas, el nombre y apellidos, los grados logrados en la Universidad, la fecha del otorgamiento del grado, los miembros que otorgan o presiden el grado o grados, la localidad de origen y diócesis, otros datos que aparecen en el manuscrito sobre el graduando, y el folio en que está inscrito. Descartamos otras informaciones, como se explica en el Estudio preliminar, por ser prolijas e irrelevantes. 
Al haber tantos graduados y al adquirir ya el libro unas dimensiones considerables, creímos conveniente -aunque no sin dudas- detener nuestro estudio en 1700. El cuatrienio de los abades acababa en 1701, de modo que hubiéramos podido dar cuenta de los cambios y de las nuevas graduaciones, que fueron importantes en los años 1701 y 1702. Sin embargo, el contexto de la Guerra de Sucesión abría una nueva dinámica que tenía que ser analizada en profundidad hasta, como mínimo, la Paz de Utrecht. De ahí que hayamos preferido acotar nuestro estudio hasta 1700 , coincidiendo con la muerte de Carlos II, aunque somos conscientes de que queda una segunda parte (17011807), mucho más voluminosa que la que aquí presentamos, que no sabemos si podremos llegar a publicar.

De momento, ofrecemos al público lector el estudio del siglo XVII, y dejamos para otra ocasión el análisis de la Universidad de Irache bajo los Borbones, en un contexto legislativo y sociológico distinto. Hay rasgos, sin embargo, que, lejos de menguar, se incrementaron exponencialmente en el siglo XVIII. Uno de los más destacados es el crecimiento del número de graduados. La Universidad de Irache, en la época que estudiamos, fue frecuentada por estudiantes que procedían de toda la geografía peninsular, especialmente de su parte más septentrional. Dio un gran servicio no solamente al Reino de Navarra (en el que pronto hubo la competencia de la Universidad de Pamplona, en manos de los dominicos), sino también a Castilla, León y Aragón. Hubo también egresados gallegos, catalanes, andaluces, valencianos... En el siglo XVIII hubo aún una mayor movilidad geográfica, y un aumento de la ratio de graduados en muchas Facultades.

Bajo los Austrias Menores, Irache fue un centro auxiliar de las Universidades Mayores castellanas, y también de las de Aragón o Cataluña. Precisamente, nuestro interés en Irache empezó al constatar la cantidad de estudiantes de la Corona de Aragón que acudían al monasterio a graduarse. No solamente eran artistas y teólogos, sino importantes juristas (legistas y canonistas), cuyas trayectorias a veces no eran suficientemente conocidas. En todo caso, los datos que ofrecemos pueden ayudar a la confección de numerosas prosopografías. Hemos esbozado las de los benedictinos, a fin de mostrar que la flor y la nata de la Congregación (Aguirre, Lardito, Espinosa, Sala...) se graduó en Irache. El lector interesado podrá obtener mayor información de cada uno de los benedictinos en los trabajos de Ernesto Zaragoza. De los demás graduados, hemos apuntado las tendencias generales, y hemos destacado la ejecutoria de algunos de los más sobresalientes. 
Sin duda, este libro es un pequeño paso más en la historia de la Universidad de Irache, que necesita de ulteriores estudios. Creemos que, tras el gran esfuerzo de Fernando Serrano para analizar la Facultad de Medicina, se sucederán otros con el resto de las Facultades.

$$
* *
$$

Empezamos hace cuatro años con el estudio de las fuentes de la Universidad de Irache, si bien hasta ahora no hemos podido concluir el libro. Debemos agradecer la profesionalidad de los técnicos del Archivo General de Navarra, y la ayuda prestada por dos historiadores: por un lado, el profesor Fernando Serrano Larráyoz, quien nos facilitó el hallazgo de algunas fuentes y, por otra, de Mn. Ernest Zaragoza Pascual, historiador infatigable de los benedictinos hispanos, y autor de cientos de escritos sobre el tema, quien nos ha aclarado muchas dudas y nos ha proporcionado información adicional sobre algunos monjes.

Dedicamos el libro, con afecto, a los hermanos Catalina Inés, Pedro y Antonio Barceló Carbonell, y a Juan Miralles Santandreu. Agradecemos, una vez más, el apoyo del Prof. Manuel Martínez Neira en la confección de este libro. La obra se encuadra en los proyectos del Plan Nacional que dirigen, respectivamente, los profesores Tomàs de Montagut y José Juan Moreso, y en las líneas de investigación del Instituto de Estudios Hispánicos en la Modernidad (IEHM), Unidad asociada al CSIC.

Para facilitar el manejo de la obra, hemos procurado normalizar las grafías. Por ser un libro tan extenso y con una nómina tan amplia de graduados, hemos optado por incluir al final un índice alfabético onomástico. En cuanto a las búsquedas más precisas, los lectores interesados las podrán hacer directamente en el PDF, colgado en la red y de libre acceso.

Presentamos, en definitiva, el resultado final y esperamos que pueda ser de utilidad no solamente para la comunidad académica, sino para quienes sientan curiosidad por la congregación benedictina, Irache, Navarra, y sus conexiones con toda la geografía hispana. 



\section{Estudio PRELIMinar}

La Universidad de Irache ha sido objeto de diversos estudios. Faltaba, sin embargo, un análisis completo de los grados académicos. En este libro se presentan los resultados del primer período (1613-1700), y queda para otra ocasión abordar todo el siglo XVIII, una época no menos interesante.

En el estudio preliminar trataremos, en primer lugar, las fuentes y la bibliografía, para estudiar a continuación la Universidad de Irache en su contexto. Seguidamente analizaremos los Estatutos de la institución y la nómina de los benedictinos que se graduaron en dicha sede. Por último, daremos una información sintética acerca de las tendencias de los egresados de las diversas Facultades y los rasgos biográficos de los principales graduados.

\section{Las fuentes y la bibliografía: estado de la cuestión}

Se conserva en buen estado la mayor parte de las fuentes de la Universidad de Irache. Ello explica que se hayan escrito ya diversos trabajos sobre la misma. El libro de Simón Pérez ${ }^{1}$ detalla los materiales que han llegado hasta nuestros días, conservados casi en su totalidad en el Archivo Real y General de Navarra (AGN). Nosotros solamente vamos a utilizar los manuscritos del AGN, 542 (1613-1657), 539 (1658-1687) y 549 (1687-1700), correspondientes a los grados académicos, si bien, para un análisis completo de la historia de la institución, hay otros pendientes de estudio (matrículas, gastos...). En la sección de Universidades del Archivo Histórico Nacional se encuentran diversos títulos de los egresados de la época que estudiamos en el libro, que pueden consultarse en la red ${ }^{2}$.

Por la abundancia de fuentes, puede decirse que la historiografía sobre la Universidad de Irache es extensa y, en comparación con otras sedes, mucho más rica y detallada. Una visión panorámica, que sigue siendo útil, es la obra de Ibarra Murillo3 $^{3}$, que supone una síntesis de la historia del Monasterio y de la Universidad. En cuanto a los grados, Ibarra, en unas condiciones precarias,

1 A. Simón Pérez, El Monasterio y la Universidad de Irache: inventario del archivo (siglos XVI-XIX), Pamplona, Gobierno de Navarra, 2003.

2 AHN, Universidades, Car. 18, n. 25 y n. 26.

3 J. Ibarra Murillo, Historia del Monasterio benedictino y Universidad literaria de Irache, Pamplona, Impr. "La Acción Social”, 1939. 
hizo acopio de los datos más importantes, y aportó mucha documentación. El notable libro de Ibarra presenta la información de una manera algo desordenada, y tiende a evitar los egresados menos destacados y los reprobados. De ahí que sea necesario un estudio exhaustivo de todos los graduados. Hemos cotejado los nombres de los graduados que aparecían en los manuscritos con los que figuraban en el libro de Ibarra y nos hemos decantado, en diversas ocasiones, por otra solución, si bien la paleografía -en muchos casos- no es fácil. En otros casos, la propuesta de atribución de Ibarra claramente no se corresponde con el verdadero personaje que se graduó, sino con un homónimo. Hemos intentado deshacer estos malentenidos, aunque no resulta sencillo, por el elevado número de familiares con el mismo nombre.

Una síntesis de conjunto sobre la historia de la institución fue publicada en inglés por Román Ríos ${ }^{4}$ en The Downside Review. La transferencia desde Sahagún y los orígenes de la institución docente fueron estudiados no solamente por Ibarra, sino también por Goñi Gaztambide ${ }^{5}$, quien analizó asimismo los primeros graduados que se recogen en el manuscrito AGN 21 (15801594). Cándido Ajo contextualizó ${ }^{6}$ la Universidad de Irache en el marco de las Universidades hispánicas y Linage Conde hizo lo propio en el ámbito del benedictinismo ${ }^{7}$.

Hay dos trabajos de Ernesto Zaragoza que resultan asimismo de gran utilidad. Por un lado, el Abadologio ${ }^{8}$, pues, como escribió Fr. Antonio de Yepes, “...es tambien el Abad de Hyrache, Rector de la Vniuersidad, que està incorporada en la casa, por merced de los Sumos Pontifices, y de los Reyes ${ }^{9}$. Por otro, la relación de profesores de la Universidad ${ }^{10}$, información extracta-

4 R. Ríos, “The Benedictine University of Hirache, c. 1500-1835”, The Downside Review, 60 (1942), pp. 285-294.

5 J. Goñi Gaztambide, “Orígenes de la universidad benedictina de Irache”, Príncipe de Viana, 245 (2008), pp. 841-868.

6 C. M. Ajo, Historia de las Universidades hispánicas, III, Ávila, CSIC, 1959, pp. 330-334.

7 A. Linage Conde, "La Universidad de Irache en el Benedictinismo", Príncipe de Viana. Anejo, 15 (1993), pp. 211-217.

8 E. Zaragoza Pascual, “Abadologio del Monasterio de Santa María la Real de Irache”, Studia Monastica, 35/1 (1993), pp. 161-202.

9 A. de Yepes, Coronica general de la Orden de San Benito, Patriarca de Religiosos, tomo III, centuria III, En la Vniversidad de $\mathrm{N}^{\mathrm{a}} \mathrm{S}^{\mathrm{a}}$ la Real de Yrache, de la Orden de San Benito, por Nicolas de Assiayn, Impresor del Reino de Navarra, 1610, p. 387v.

10 E. Zaragoza Pascual, "Profesores benedictinos del Colegio y Universidad de Ira- 
da de los Capítulos de la Congregación. Ambos trabajos hacen innecesaria la confección aquí de un Abadologio y de una lista de profesores, pues es inútil reiterar esta información, que complementamos a lo largo del libro, con otros matices. En este sentido, dedicamos nuestros esfuerzos a presentar, en el cuarto apartado, una relación biográfica de todos los benedictinos graduados en Irache hasta 1700.

En tiempos más recientes se ha publicado el excelente libro de Fernando Serrano Larráyoz ${ }^{11}$ sobre los graduados en Medicina (1613-1769), que consideramos modélico en su ejecución. Los interesados en los estudios médicos en Irache deben acudir a dicha obra, que no podemos superar. Por esa razón, no vamos a profundizar en el presente estudio en los egresados en la Facultad de Medicina, sino que nos vamos a centrar en los graduados en Artes, Teología, Derecho civil y Derecho canónico.

Sobre los estatutos de la Universidad, puede verse el trabajo de Fernando Serrano y Gerardo Martínez ${ }^{12}$. Han aparecido también sendos avances del presente libro, que ahora mejoramos y enmendamos en algún punto, sobre los períodos que abarcan desde 1613 a 1620 y de 1621 a $1630^{13}$.

En cuanto a la contextualización, siguen siendo útiles los artículos de Pérez Goyena ${ }^{14}$ sobre el pensamiento benedictino y los de García M. Colombás

che”, en L. E. Rodríguez-San Pedro Bezares y Juan Luis Polo Rodríguez (eds.), Universidades hispánicas: Colegios y conventos universitarios en la Edad Moderna, Vol. 1, 2009, Salamanca, Universidad de Salamanca, pp. 303-358.

11 F. Serrano Larráyoz, Graduados en Medicina por la Universidad de Irache (16131769), Pamplona, Editorial Universitas, 2019.

12 F. Serrano Larráyoz y G. Martínez Hernández, "Los 'Estatutos de la Universidad Real de Hyrache en el Reyno de Navarra' (1618) y la concesión de grados en Medicina durante el siglo XVII", en D. Ruiz-Berdún (dir.), Ciencia y técnica en la universidad: trabajos de historia de las ciencias y de las técnicas, Vol. 1, Alcalá, Universidad de Alcalá, 2018, pp. 43-52.

13 R. Ramis Barceló y P. Ramis Serra, "Grados de la Universidad de Irache (16131620)”, Studia monastica, 6o/1 (2018), pp. 119-180; y R. Ramis Barceló y P. Ramis Serra, "Grados de la Universidad de Irache (1621-1630)", Studia monastica, 62/1 (2020), pp. 177-230.

14 A. Pérez Goyena, "La Teología dogmática entre los benedictinos españoles de la Observancia”, Razón y Fe, 44 (1916), pp. 61-72; A. Pérez Goyena, "La literatura teológica entre los benedictinos españoles”, Razón y Fe, 48 (1917), pp. 174-179 y 49 (1917), pp. 167-179; A. Pérez Goyena, "Controversias teológicas de los padres benedictinos de la Observancia”, Razón y Fe, 49 (1917), pp. 308-313; A. Pérez Goyena, "La literatura teológica española. Los grandes teólogos benedictinos”, Razón y Fe, 50 (1918), pp. 45-63. 
sobre los estudios y las cátedras de la Congregación vallisoletana ${ }^{15}$. Resulta también muy esclarecedora la síntesis de Zaragoza Pascual ${ }^{16}$ sobre el papel de los estudios en el monacato hispano de la época moderna. Para la formación intelectual en las diversas Abadías benedictinas, son muy importantes los artículos de Ernesto Zaragoza ${ }^{17}$ sobre los diversos Colegios de la Congregación.

Por último, sobre la Congregación vallisoletana en el siglo XVII, más allá del amplio estudio de Ernesto Zaragoza sobre Los Generales de la Congregación de San Benito de Valladolid ${ }^{18}$, es fundamental consultar los Abadologios y libros de gradas $^{19}$ que el mismo autor ha ido publicando de casi todas las

15 G. M. Colombás, "Historia de la fundación de tres cátedras de Teología de la Universidad de Salamanca (1692)”, Hispania Sacra, 13 (1960), pp. 305-394; G. M. Colombás, "Los estudios en la Congregación de San Benito de Valladolid”, en Los monjes y los estudios. Actas de la IV Semana de Estudios Monásticos, Poblet, Abadia de Poblet, 1963, pp. 339-362.

16 E. Zaragoza Pascual, "Los Estudios y Colegios monásticos españoles (siglos XVXIX)”, Memoria Ecclesiae, 13 (1998), pp. 377-424.

17 E. Zaragoza Pascual, "Profesores del Colegio benedictino de San Vicente de Oviedo (1617-1835)”, Boletín del Real Instituto de Estudios Asturianos, 137 (1991), pp. 323-356; E. Zaragoza Pascual, "Profesores de los Colegios benedictinos asturianos de Obona y Celorio (siglos XVII-XIX)”, Boletín del Real Instituto de Estudios Asturianos, 139 (1992), pp. 277-304; E. Zaragoza Pascual, "Profesores del Colegio Benedictino de San Juan de Poyo (1610-1835)”, Compostellanum, 45/3-4 (2000), pp. 757-781; E. Zaragoza Pascual, "Profesores del Colegio benedictino de San Salvador de Lérez (1661-1835)", El Museo de Pontevedra, 56 (2002), pp. 181-190; E. Zaragoza Pascual, "Profesores de los Colegios benedictinos de San Julián de Samos y San Esteban de Ribas de Sil (s. XVI-XIX)”, Estudios mindonienses, 21 (2005), pp. 771-804; E. Zaragoza Pascual, "Profesores del Colegio benedictino de San Vicente de Salamanca (1589-1835)", Salmanticensis, 52/2 (2005), pp. 287-341; E. Zaragoza Pascual, "Profesores del Colegio benedictino de San Andrés de Espinareda (1641-1835)”, Compostellanum, 51/1-2 (2006), pp. 115-145; E. Zaragoza Pascual, "Profesores de los Colegios benedictinos de San Benito de Zamora, San Isidro de Dueñas y San Pedro de Eslonza (siglos XVII-XIX)”, Compostellanum, 52/1-2 (2007), pp. 73-114.

18 E. Zaragoza Pascual, Los Generales de la Congregación de San Benito de Valladolid, 6 vols., Silos, Abadía de Silos, 1973-87.

19 E. Zaragoza Pascual, "Los monjes de Sopetrán (1601-1758)", Wad-al Hayara: Revista de estudios de Guadalajara, 5 (1978), pp. 123-141; E. Zaragoza Pascual, "Abadologio del Monasterio de San Pedro de Eslonza (siglos X-XIX)”, Archivos Leoneses, 75 (1984), pp. 163-186; E. Zaragoza Pascual, “Abadologio del Monasterio de San Claudio de León (14171835)”, Archivos Leoneses, 78 (1985), pp. 355-370; E. Zaragoza Pascual, "Abadologio del Monasterio de San Salvador de Cornellana (siglos XII-XIX)", Boletín de Letras del Real Instituto de Estudios Asturianos, 119 (1986), pp. 879-904; E. Zaragoza Pascual, "Monaco- 
logio emilianense (1500-1833)", Studia monastica, 29/2 (1987), pp. 291-331; E. Zaragoza Pascual, “Abadologio del Monasterio de Montserrat de Madrid (1641-1835)", Studia monastica, 29/1 (1987), pp. 125-153; E. Zaragoza Pascual, "Abadologio del Monasterio de San Martín de Madrid (1594-1835)”, Anales del Instituto de Estudios Madrileños, 25 (1988), pp. 151-182; E. Zaragoza Pascual, "Abadologio (siglos X-XX) y Libro de Gradas del Monasterio de San Isidro de Dueñas”, Archivos Leoneses, 89-9o (1991), pp. 189-226; E. Zaragoza Pascual, "Libros de gradas de los monjes de San Martín Pinario de Santiago de Compostela (1502-1833)", Estudios Mindonenses, 7 (1991), pp. 471-557; E. Zaragoza Pascual, "Monjes profesos de Montserrat (1493-1833)", Studia monastica, 33/2 (1991), pp. 329-377; E. Zaragoza Pascual, “Abadologio del Monasterio de Ntra. Sra. de El Espino”, Boletín de la Institución Fernán González, 206 (1993), pp. 19-36; E. Zaragoza Pascual, "Abadologio del Monasterio de San Pedro de Cardeña (Siglos IX-XX)”, Boletín de la Institución Fernán González, 207 (1993), pp. 367-397; E. Zaragoza Pascual, “Abadologio del Monasterio de San Zoilo de Carrión de los Condes (s. XI-XIX) y libro de gradas de los monjes que profesaron en él (1593-1833)", Publicaciones de la Institución Tello Téllez de Meneses, 64 (1993), pp. 273-322; E. Zaragoza Pascual, "Abadologio del Monasterio de Nuestra Señora de Sopetrán (1372-1835)”, Wad-al Hayara: Revista de estudios de Guadalajara, 20 (1993), pp. 223-240; E. Zaragoza Pascual, “Abadologio del Monasterio de San Salvador de Oña (siglos XI-XIX)”, Burgense: Collectanea Scientifica, 35/2 (1994), pp. 557-594; E. Zaragoza Pascual, “Abadologio del Monasterio de San Salvador de Lérez (Siglos XVI-XIX)”, El Museo de Pontevedra, 48 (1994), pp. 405-436; E. Zaragoza Pascual, “Abadologio del Monasterio de san Martín Pinario: 898-1835”, Compostellanum, 39/1-2 (1994), pp. 209-240; E. Zaragoza Pascual, “Abadologio del Monasterio de San Salvador de Lorenzana (1015-1835)”, Estudios mindonienses, 11 (1995), pp. 179-203; E. Zaragoza Pascual, "Abadologio del Monasterio de San Pedro de Arlanza: siglos X-XIX”, Boletín de la Institución Fernán González, 210 (1995), pp. 85-110; E. Zaragoza Pascual, "Catálogo de monjes profesos del Monasterio de San Benito El Real de Valladolid (1436-1831)”, Studia monastica, 38/1 (1996), pp. 83-129; E. Zaragoza Pascual, “Abadologio del Monasterio de san Julián de Samos (siglos VIII-XX)”, Estudios mindonienses, 12 (1996), pp. 469-503; E. Zaragoza Pascual, "Abadologio (15031835) y Libro de Gradas (s. XVII-XIX) del Monasterio de San Benito de Sevilla”, Studia monastica, 39/2 (1997), pp. 377-402; E. Zaragoza Pascual, “Abadologio del Monasterio de San Juan Bautista de Burgos”, en S. López Santidrián (dir.), San Lesmes en su tiempo: Simposio organizado por la Facultad de Teología y la Parroquia de San Lesmes con el patrocinio del Ayuntamiento de Burgos, en el IX centenario de la muerte del Patrono de la Ciudad (1097-1997), Burgos, Publicaciones de la Facultad de Teología del Norte de España, 1997, pp. 345-384; E. Zaragoza Pascual, "Abadologio (siglos X-XIX) y Libro de gradas de los monjes (1715-1833) del Monasterio de Santa María La Real de Nájera”, Studia monastica, 40/1 (1998), pp. 121-158; E. Zaragoza Pascual, Abaciologi del Monestir de Sant Feliu de Guíxols (segles X-XIX), Montserrat, Abadia de Montserrat, 1998; E. Zaragoza Pascual, "Abadologio del Monasterio de San Vicente de Oviedo", Studium Ovetense, 26 (1998), pp. 135-165; E. Zaragoza Pascual, Abadologio de Santo Domingo de Silos, Burgos, Institución 
sedes. Sobre la Congregación benedictina claustral Tarraconense y Cesaraugustana $^{20}$, sigue siendo muy útil el libro de conjunto del benemérito historiador, que tantas páginas ha escrito sobre la historia del monaquismo hispano. Asimismo, continúa siendo muy esclarecedor, como panorámica general, el

"Fernán González”, 1998; E. Zaragoza Pascual, “Abadologio del Monasterio de San Salvador de Celanova (Siglos X-XIX)”, Compostellanum, 45/1-2 (2000), pp. 81-100; E. Zaragoza Pascual, “Abadologio del Monasterio de San Millán de la Cogolla (siglos VI-XIX)”, Studia monastica, 42/1 (2000), pp. 185-223; E. Zaragoza Pascual, “Abadologio del Monasterio de Nuestra Señora de Valvanera (siglos X-XX)”, Studia monastica, 43/2 (2001), pp. 333-372; E. Zaragoza Pascual, "Abadologio del Monasterio de Ntra Sra. de la Anunciación del Bueso: (1460-1789)”, Investigaciones históricas, 21 (2001), pp. 19-46; E. Zaragoza Pascual, “Abadologio del Monasterio de san Esteban de Ribas de Sil (siglos X-XIX)”, Compostellanum, 47/3-4 (2002), pp. 359-400; E. Zaragoza Pascual, "Abadologio del Monasterio de San Benito el Real de Valladolid (1390-1835)”, Investigaciones históricas, 23 (2003), pp. 203-260; E. Zaragoza Pascual, "Abadologio del Monasterio de San Juan Bautista de Poyo (ss. XIIXIX)”, Compostellanum, 48, 1-4 (2003), pp. 391-426; E. Zaragoza Pascual, “Abadologio del Monasterio de San Pedro de Villanueva (siglos XII-XIX)", Boletín de Letras del Real Instituto de Estudios Asturianos, 164 (2004), pp. 73-102; E. Zaragoza Pascual, “Abadologio del Monasterio de San Salvador de Celorio (siglos XI-XIX)”, Boletín de Letras del Real Instituto de Estudios Asturianos, 165 (2005), pp. 105-136; E. Zaragoza Pascual, "Abadologio y Priorologio de Santo Toribio de Liébana (siglos LX-XIX)”, Altamira, 67 (2005), pp. 35-63; E. Zaragoza Pascual, "Abadologio del Monasterio de San Juan Bautista de Corias (Siglos XI-XIX)”, Boletín de Letras del Real Instituto de Estudios Asturianos, 167 (2006), pp. 135172; E. Zaragoza Pascual, "Abadologio del Monasterio de San Vicente del Pino de Monforte de Lemos (siglos XV-XIX)”, Estudios mindonienses, 24 (2008), pp. 487-512; E. Zaragoza Pascual, "Abadologio del Monasterio de San Benito de Sahagún (Siglos X-XIX)”, Compostellanum, 55/1-2 (2010), pp. 99-147; E. Zaragoza Pascual, "Abadologio del Monasterio de San Vicente de Salamanca (Siglos XIII-XIX)”, Salmanticensis, 59/2 (2012), pp. 291-379; E. Zaragoza Pascual, “Gradas del monasterio de Santa María de la Real de Nájera (1500-1833)”, Studia Monastica, 54/2 (2012), pp. 355-388; E. Zaragoza Pascual, "Gradas del Monasterio de Sahagún (s. XVI-XIX)”, Studia monastica, 55/2 (2013), pp. 311-373; E. Zaragoza Pascual, "Abadologio del Monasterio de San Andrés de Espinareda (ss. XI-XIX)”, Compostellanum, 6o/1-2 (2015), pp. 207-237; E. Zaragoza Pascual, "Abadologio (siglos X-XX) y libro de gradas (1614-1830) del Monasterio de San Isidro de Dueñas”, Studia monastica, 59/1 (2017), pp. 119-162; E. Zaragoza Pascual, “Abadologio del Monasterio de San Benito de Zamora (1400-1835)”, Anuario del Instituto de Estudios Zamoranos Florián de Ocampo, 33 (2018), pp. 345-387. [Citaremos a continuación estos trabajos de forma abreviada].

20 E. Zaragoza Pascual, Història de la Congregació Benedictina Claustral Tarraconense i Cesaraugustana (1215-1835), Montserrat, Publicacions de l'Abadia de Montserrat, 2004; para Cataluña, véase también E. Zaragoza Pascual, Catàleg dels monestirs catalans, Montserrat, Abadia de Montserrat, 1997. 
tomo VII de La tradición benedictina, de García M. Colombás ${ }^{21}$, que sabe situar las Congregaciones hispanas en su contexto europeo.

\section{La Universidad de Irache en su contexto}

Entramos a estudiar a continuación el doble contexto de la Universidad de la Abadía de Irache: por un lado, como sede de estudios en el marco de la Orden benedictina (esencialmente, en el seno de la Congregación benedictina de Valladolid, aunque también frecuentada por la Congregación benedictina claustral Tarraconense y Cesaraugustana) y, por otro, en el marco de las Universidades hispánicas.

\subsection{Irache y la Orden benedictina}

En este apartado vamos a abordar, en primer lugar, la formación de la Congregación observante de San Benito de Valladolid, para pasar después a estudiar el papel de los estudios y los centros de enseñanza en la misma. En tercer lugar, analizaremos los orígenes de la Universidad de Irache y, por último, compararemos el caso de Irache con las demás universidades benedictinas.

\subsubsection{El nacimiento de la Congregación observante de Valladolid}

A finales del siglo XV, las principales Abadías de la Península Ibérica estaban sujetas a la dependencia de Cluny. Tras años de encomiendas, el estado espiritual de las mismas estaba sumido en una completa decadencia. Una reforma observante se había iniciado ya en San Benito de Valladolid en 1390. Los Reyes Católicos quisieron devolver las Abadías a la observancia y constituir, a partir del modelo de Valladolid, una Congregación de cenobios en sus reinos que no dependiese de Cluny. Poco a poco, esta reforma observante fue agrupando a los monasterios de la Provincia Benedictina Claustral de Toledo (Burgos y León) y luego, en los siglos XV y XVI, a los de la Provincia Benedictina Claustral Compostelana (Galicia y Asturias). Con ello, gracias a los esfuerzos reformadores de los Reyes Católicos, se llegó a reunir en la Congregación de Valladolid a la mayoría de los Monasterios benedictinos existentes en la Península Ibérica ${ }^{22}$.

21 G. M. Colombás, La tradición benedictina. Ensayo histórico, Tomo VII, 2, Zamora, Ediciones Monte Cassino, 1998.

22 Seguimos la exposición de E. Zaragoza Pascual, "Fernando el Católico y la reforma 
Con la colaboración de Fernando el Católico, se intentó la reforma de las Abadías benedictinas de la Congregación benedictina claustral Tarraconense y Cesaraugustana, pues solamente dos Monasterios aceptaron la observancia vallisoletana: el de Montserrat y el de Sant Feliu de Guíxols. Desde el siglo XIV, la Congregación Benedictina Claustral Tarraconense y Cesaraugustana estaba divida en dos provincias, a saber: la Tarraconense y la Cesaraugustana. La primera agrupaba, en el Rosellón, las Abadías de Sant Miquel de Cuixà, Sant Martí del Canigó y Santa Maria de Arles; mientras que, en Cataluña, las de Sant Llorenç de Bagà, Sant Pau del Camp de Barcelona, Sant Pere de Besalú, Sant Salvador de Breda, Sant Pere de Camprodón, Sant Andreu de Sureda, Sant Quirze de Colera, Sant Pere de Galligants, Santa Maria de Gerri, Sant Llorenç de Sous, Santa Cecilia de Montserrat, Sant Llorenç del Munt, Sant Pere de la Portella, Santa Maria de Ripoll, Sant Pere de Roda, Sant Cugat del Vallés, Santa Maria de Serrateix, Sant Sadurní de Tavèrnoles, Santa Maria de Roses, Santa Maria de Amer, Sant Esteve de Banyoles y el Priorato de Santa Maria de Meià. La provincia Cesaraugustana estaba integrada por las Abadías aragonesas: San Juan de la Peña, Nuestra Señora de Alaón, y San Victorián de Asán, así como unas Abadías femeninas en Jaca y Navarra ${ }^{23}$.

Tras numerosas gestiones en Roma, nació, en el capítulo de 1500, la Congregación observante de Valladolid, pues -como hemos subrayado- el Monasterio de San Benito de Valladolid sirvió de modelo para introducir la restauración de la vida monástica observante de la Península. Al fallecer los Reyes Católicos, la Congregación observante de San Benito contaba con más de una veintena de Abadías, las más importantes del solar hispano y, hasta la desamortización de Mendizábal, llegó a comprender las siguientes: en Galicia, San Martín Pinario y San Paio de Antealtares de Santiago de Compostela, San Juan de Poyo, San Salvador de Lérez, San Pedro de Tenorio, San Salvador de Celanova, San Esteban de Ribas de Sil, San Vicente del Pino de Monforte de Lemos, San Julián de Samos y San Salvador de Lorenzana; en Asturias, San Vicente, Santa María de la Vega y San Pelayo de Oviedo (los dos últimos de religiosas), San Juan Bautista de Corias, San Salvador de Celorio, San Salvador de Cornellana, San Pedro de Villanueva y Santa María de Obona; en León tenía las Abadías de San Claudio de León, San Benito de Sahagún, San Pedro de Montes, San Andrés de Espinareda, San Pedro

de los benedictinos y benedictinas españoles (1474-1516)", Anuario de Historia de la Iglesia, 26 (2017), pp. 157-184.

23 Ibidem, pp. 163-164. 
de Eslonza, San Vicente de Salamanca, San Benito de Zamora y el cenobio de monjas de Santa María de Vega de la Serrana; en Castilla la Vieja tenía las Abadías burgalesas de Oña, San Juan de Burgos, San Pedro de Cardeña, San Pedro de Arlanza, Santo Domingo de Silos, Santa María de Obarenes y Nuestra Señora del Espino, así como las palentinas de San Zoilo de Carrión de los Condes, San Isidro de Dueñas, Nuestra Señora de la Misericordia de Frómista y las vallisoletanas de San Benito el Real de Valladolid, cuna y cabeza de la Congregación, y Nuestra Señora del Bueso; en la Rioja tenía las Abadías de Santa María la Real de Nájera, San Millán de la Cogolla, y Santa María de Valvanera; en Navarra, la de Irache; en Cataluña, las de Montserrat, Sant Benet de Bages, Sant Genís de Fontanes y Sant Feliu de Guíxols; en Castilla la Nueva tenía las Abadías de San Martín y Montserrat en Madrid, y la de religiosas de San Plácido; Nuestra Señora de Sopetrán, en Guadalajara, y San Benito de Huete, en Cuenca; y, por último, solamente una en Andalucía, San Benito de Sevilla ${ }^{24}$.

La Congregación de Valladolid se intitulaba "Congregación de San Benito de España e Inglaterra”, y los Generales lo eran “de España e Inglaterra”, lo cual, según Colombás, era "tan rotundo como inexacto, pues ni la Congregación abarcaba todos los Monasterios benedictinos de España, ni pertenecieron a ella los benedictinos ingleses del exilio, salvo por un reducido lapso de tiempo y nunca en su totalidad ${ }^{25}$ ". En todo caso, como así aparece reiteradas veces en los manuscritos, no les regatearemos -a los pomposos Abades generales- su debido tratamiento.

\subsubsection{Centros de estudio}

García M. Colombás dio una interpretación bastante negativa del desarrollo de los estudios en la Congregación vallisoletana. No hay duda de que, desde 1500, se hicieron notables esfuerzos para incrementar el nivel formativo de los monjes, si bien, en su juicio histórico, "lo que faltaba era organización, colaboración, protección por parte de las autoridades de la Orden"26".

En 1504 se incorporó a la Congregación el Colegio de Salamanca. Poco después, Fr. Alonso de Toro abrió dos nuevos Colegios, en Frómista y en Irache, y alcanzó de Clemente VII en 1534 una licencia pontificia para conferir

24 Idem, pp. 164-167.

25 G. M. Colombás, La tradición benedictina, Vol. VII/2, p. 532.

26 G. M. Colombás, "Los estudios en la Congregación de San Benito de Valladolid", p. 359 . 
grados en Sahagún, con los mismos privilegios que las Universidades de Salamanca y Alcalá ${ }^{27}$.

El Capítulo de 1553 estatuía que, más allá del Colegio salmantino, hubiera Colegios en Arlanza, Eslonza, Ribas de Sil, Irache y San Vicente de Oviedo. Tres años después, el Capítulo general consideró excesivo el número de Colegios y determinó que solamente hubiera tres en toda la Congregación: Irache y Ribas de Sil, para la enseñanza de Artes, y San Vicente de Salamanca, para la Teología ${ }^{28}$. Se estableció asimismo que el número máximo de colegiales fuese el siguiente: 10 en Irache, 12 en Ribas del Sil, 20 en Salamanca y 10 en San Martín Pinario, que a la sazón era Colegio de Pasantes, es decir, de aquellos que habían finalizado la Teología y que repasaban las enseñanzas antes de convertirse en profesor (Lector) o en Predicador.

En 1575, se establecieron los siguientes Colegios generales de Filosofía: Ribas de Sil (12 estudiantes), Irache (10), Samos (12). Y para el estudio de la Teología había un máximo de 20 estudiantes destinados al Colegio de Salamanca. Luego había Colegios menores o particulares, en los que se daban rudimentos de Filosofía y Teología: Sahagún (15 estudiantes), Oña (15), San Millán, Santiago y Celanova (10 cada uno), Cornellana (12), Arlanza y San Claudio de León. Quedaban Eslonza, Espinareda, Dueñas y Lérez como estudios de Latinidad. Estos Colegios fueron reducidos, en 1601, a seis de Filosofía (Samos, Ribas de Sil, Irache, Arlanza, Bages y Zamora) y a uno de Teología (Salamanca) ${ }^{29}$. Como puede verse, la Congregación se debatía entre diversas formas de organización colegial.

Las Constituciones de 1612 ordenaron que hubiera solamente cuatro Colegios de Artes (Irache, Eslonza, Samos y Ribas de Sil) y tres de Teología (Salamanca, Irache y Oviedo), más uno de Pasantes en San Juan de Poyo ${ }^{30}$. Vemos, por lo tanto, que a comienzos del período estudiado en este libro, Irache tenía ya un estatuto especial en el seno de la Congregación, ya que era Colegio de Artes y de Teología.

En el Capítulo de 1661 se abrieron Colegios en El Espino, Obarenes, Dueñas, Obona, Lérez y Cornellana, así como se ordenó el traslado temporal del

27 E. Zaragoza Pascual, "Los Estudios y Colegios monásticos españoles (siglos XVXIX)", p. 384 .

28 G. M. Colombás, "Los estudios en la Congregación de San Benito de Valladolid", pp. 346-347.

29 E. Zaragoza Pascual, "Los Estudios y Colegios monásticos españoles (siglos XVXIX)", pp. 389-390.

30 Ibidem, p. 391. 
Colegio de Espinareda a San Juan de Corias ${ }^{31}$. El Capítulo de 1677 determinó el número máximo de alumnos de cada Colegio de Filosofía: Ribas de Sil (38 filósofos), Celorio (20), Poyo (22), Irache (16) y Lérez - de nueva creación- (12). En los Colegios de Teología se estableció el número máximo de estudiantes que indicamos a continuación: Salamanca (40), Espinareda (34), Irache (16), Oviedo (30). Zaragoza Pascual indica que eran en total 108 filósofos y 120 teólogos, un número jamás alcanzado hasta el momento. En cambio, el Capítulo de 1685 mandó que el número disminuyese, ya que consideraba excesivo el total de estudiantes ${ }^{32}$. Ello da fe de la baja proporción de monjes con formación completa y de la errática política educativa por parte de la Congregación.

En 1706, momento posterior del período que aquí analizamos, de acuerdo con las Constituciones establecidas en aquel año, tenía que haber nueve Colegios: cuatro Colegios de Artes (Irache, Ribas de Sil, Espinareda, Celorio), cuatro Colegios de Teología (San Vicente de Salamanca, Irache, San Vicente de Oviedo y San Juan de Poyo), y uno, San Pedro de Eslonza, para Pasantes ${ }^{33}$.

No hay duda de que los benedictinos tardaron un siglo (desde los Reyes Católicos hasta comienzos del siglo XVII) para organizar un sistema educativo más o menos duradero, y que nunca gozó de la estabilidad de otras órdenes religiosas, dedicadas con mayor ahínco al estudio. Tampoco su plan de estudios fue excesivamente original ni brillante: tres años de Filosofía, y tres años de Teología, completados por una pasantía de tres años más. Luego se incorporaban al púlpito como Predicadores o a las aulas como Lectores ${ }^{34}$.

Los monjes más brillantes (o más protegidos) acudían a estudiar a Salamanca, mientras que Irache estuvo siempre en un segundo plano. Sin embargo, como los Lectores con tres años de experiencia o los Predicadores con seis años de púlpito podían acceder a los grados, era muy normal que acudieran a Irache para recibir los grados, pues en Salamanca eran mucho más costosos. De ahí que los benedictinos graduados por Irache fuesen la flor y nata de la Congregación durante el período estudiado.

Precisamente, tal y como destaca Colombás ${ }^{35}$, la promoción de los estudios

31 Idem, p. 392.

32 Idem, p. 394.

33 G. M. Colombás, "Los estudios en la Congregación de San Benito de Valladolid", p. 347 .

34 E. Zaragoza Pascual, "Los Estudios y Colegios monásticos españoles (siglos XVXIX)”, p. 392.

35 G. M. Colombás, "Los estudios en la Congregación de San Benito de Valladolid", pp. 350-351. 
durante la época moderna supuso el aumento de las desigualdades entre los monjes. Solo los que poseían estudios tenían cargos docentes, de predicación o de gobierno. Luego, tales cargos suponían exenciones y privilegios (dispensas de coro, mesa separada, honores en el tratamiento, ración suplementaria de comida...) que generaban conflictos entre los monjes.

Sea como fuere, la minoría con estudios alcanzó importantes cargos no solamente en la Orden, sino también en la Iglesia. Ello no se debe tanto a la ciencia y a las virtudes de los benedictinos, cuanto a su importante peso en toda la catolicidad, debido al considerable patrimonio de sus monasterios, enriquecidos desde la Alta Edad Media con donaciones, mandas... que incrementaron sobremanera sus propiedades.

\subsubsection{De Sahagún a Irache}

Solamente en este contexto de poder se comprende la erección del Colegio universitario de Sahagún y su transferencia a Irache. Para entender mejor la situación, tenemos que proporcionar algunas notas acerca del establecimiento del Colegio del Monasterio de Sahagún. Subrayemos que era el único Monasterio de la Corona de Castilla que parecía tener unos muy modestos intereses académicos en la época bajomedieval y que, hasta 1494, no se incorporó a la Congregación vallisoletana ${ }^{36}$.

En cumplimiento de la bula Summi magistri dignatio, de 20 de junio de 1336, los benedictinos intentaron establecer un Colegio Universitario en Sahagún ${ }^{37}$. Para ello, pretendieron asignar diezmos prediales y personales de cuatro iglesias dependientes del Monasterio, lo que aseguraba el sostenimiento de un Maestro y la adquisición de libros. El 30 de agosto de 1403, por bula de Benedicto XIII, Sahagún se convertía en Colegio universitario ${ }^{38}$. Clemente VII erigió la Universidad de Sahagún mediante una bula de 6 de mayo de 1534, si bien la decisión de ponerla en funcionamiento tardó un tiempo en tomarse. Tras algunas dilaciones, empezaron las obras, y en el Capítulo de 1550 se mandó al Abad de Sahagún que continuase las obras a fin de es-

36 E. Zaragoza Pascual, Los Generales de la Congregación de San Benito de Valladolid, Vol. 2, p. 39.

37 Seguimos a F. J. Fuente Fernández, "La universidad benedictina de Sahagún: 1534-1616”, en J. Paniagua Pérez y M. I. Viforcos Marinas (eds.), Fray Bernardino de Sahagún y su tiempo, León, Universidad de León, 2000, pp. 51-68.

38 J. M. Cuenca Coloma, Sahagún: Monasterio y villa (1085-1985), Valladolid, Estudio Agustiniano, 1985, p. 108. 
tablecer aulas para instalar la Universidad. Al parecer había poco interés en acondicionar el Monasterio, pues muchos de los monjes querían conservar su paz y quietud.

En cambio, el Abad de Salamanca, Juan de Medina, ordenó que en 1544 se estableciese un Colegio de Artes y Teología en el Monasterio de Irache, que había sido reformado por Fr. Diego de Sahagún ${ }^{39}$. Desde 1549 parece que empezó a ser concurrido por seglares ${ }^{40}$. Desconocemos cuando empezó a funcionar la Universidad de Sahagún, pero lo cierto es que parece que coexistió como sede académica con Irache, que había recibido el reconocimiento de las Universidades de Alcalá y de Valladolid ${ }^{41}$, y que, en 1569, logró también que sus cursos fueran admitidos por parte de la Universidad de Salamanca. Ante la desidia del Monasterio leonés, el navarro apostó fuerte por la enseñanza.

El Capítulo de 1583 trasladó los privilegios docentes de Sahagún a Irache. Subsistió un Colegio para monjes en Sahagún, "porque no cumple aya allí Estudio General y Universidad 42". El 21 de agosto de 1587, la Universidad salmantina reconocía los títulos expedidos por Irache ${ }^{43}$. Indica Goñi que:

"Si tomamos como punto de partida la cifra mínima de cuarenta años, tendremos que la transferencia se verificaría en 1575, pero tres años después el Estudio de Sahagún continuaba despachando títulos universitarios, ya que el 11 octubre 1578 fray Luis de León se graduó de artes en el Colegio benedictino de San Facundo de Sahagún. Hubo, por tanto, un período más o menos largo en que coexistieron las universidades de Sahagún e Irache. Coexistían cuando en 1568 el Colegio de Irache inició sus gestiones para obtener el reconocimiento universitario. Yepes, en 1610, no sabe nada de tal traslación y parece dar a entender que no estaba muy lejana la fecha en que Sahagún había dejado de usar el privilegio de dar grados 4 "”.

Ciertamente, durante un tiempo, tanto Irache como Sahagún concedieron grados en virtud de la bula de 1534, si bien parece ser que Sahagún dejó de

39 E. Zaragoza Pascual, Los Generales de la Congregación de San Benito de Valladolid, Vol. 2, p. 171.

40 E. Zaragoza Pascual, "Los Estudios y Colegios monásticos españoles (siglos XVXIX)”, p. 390.

41 A. Linage Conde, "La Universidad de Irache en el Benedictinismo", p. 212.

42 E. Zaragoza Pascual, "Los Estudios y Colegios monásticos españoles (siglos XVXIX)", p. 390. Copiamos la cita literalmente.

43 F. J. Fuente Fernández, "La universidad benedictina de Sahagún: 1534-1616”, pp. 67-68.

44 J. Goñi Gaztambide, “Orígenes de la universidad benedictina de Irache”, p. 852. 
darlos a finales del siglo XVI. Fr. Antonio de Yepes, que acudió a Irache para imprimir su Coronica general de la Orden de San Benito en 1610, escribió que

“...en Hyrache de muchos años a esta parte vienen monges de diferentes casas de la Orden a oyr Artes, y Teologia, y acuden tambien seglares de Nauarra, Guipuzcoa, Alaba, Castilla, y Rioja, y ganan en esta Vniversidad sus cursos, y despues se graduan en las Facultades que han oydo, y quando despues van à las Vniversidades de Valladolid, Alcala, Salamanca, y otras de España, se les admiten los cursos aquí ganados, y se estiman los grados de la misma manera, que si huuieran oydo, y graduandose por aquellas illustrisimas Vniversidades 45 ".

Los títulos expedidos no se limitaban a Artes y Teología, que eran las materias que se leían en Irache, sino que “...he visto graduarse en esta casa personas de muchas calidades y ventajas, en Artes, Teologia, Canones, Leyes y Medicina ${ }^{46 "}$. Con ello, se reconocía la graduación en todas las Facultades, aunque no hubiera enseñanza de las mismas.

En 1615, Irache había dado pacíficamente los grados durante más cuarenta años, con el respaldo de la Universidad de Salamanca, que reconocía expresamente la validez de los mismos. En aquel momento se logró el pleno reconocimiento pontificio. Antonio de Alvarado, Abad de Irache, solicitó a Paulo V el traslado de la Universidad de Sahagún a Irache, alegando que, tras muchos años de enseñanza en Sahagún, el Abad General de la Congregación había decidido trasladar la Universidad a Irache, en la que se cultivaban las enseñanzas desde hacía cuarenta años, y que sus títulos eran reconocidos por las demás universidades. Los cardenales dieron voto favorable a la propuesta, y el Pontífice, con fecha de 7 de diciembre de 1615 mandó al oficial eclesiástico de Pamplona que comprobase lo alegado por Irache y que, si era verdad, procediese al traslado. El 31 de octubre de 1616, los monjes de Irache presentaron en Pamplona los privilegios de Sahagún y, tras la deposición de los testigos, se decretó su transferencia el 2 de diciembre de 1616, bajo pena de excomunión y multa de mil ducados al que no lo acatase ${ }^{47}$.

Todo apunta a que Sahagún no aceptó de grado el traslado hecho por mandato del General. Es más, parece ser que hubo una cierta tirantez entre ambos Monasterios y que la consecución del reconocimiento de Irache por parte de

45 A. de Yepes, Coronica general de la Orden de San Benito, III, pp. 387v-388r.

46 Ibidem, p. 388r.

47 J. Goñi Gaztambide, "Orígenes de la universidad benedictina de Irache", pp. 850856; y F. J. Fuente Fernández, “La universidad benedictina de Sahagún: 1534-1616”, p. 68. 
la Universidad de Salamanca terminó decantando el interés de la Congregación hacia la Abadía navarra. En todo caso, todo parece apuntar a que en Sahagún, en ningún momento, hubo interés por desarrollar la Universidad. El Abad Facundo de Torres, al percatarse de que el Colegio de Irache finalmente había quedado constituido en Universidad con los privilegios de Sahagún, intentó recuperarlos durante su segundo Abadiato (1617-1621) ${ }^{48}$, aunque nada pudo hacer al respecto.

Por lo tanto, Irache colacionó grados desde mediados del siglo XVI, aceptados en Salamanca desde 1587, y con pleno reconocimiento pontificio desde 1616. Los Estatutos definitivos de la Universidad, como veremos después, se publicaron en 1618. Nosotros estudiamos los grados conferidos desde 1613, cuando empezó el "Registro y Libro de Grados mayores y menores dados en esta Universidad de Hyrache. Siendo secretario de esta Universidad de Hyrache Fr. Ramiro de Goñi desde primero de Mayo de 1613 años”.

Hay que añadir que, en 1613, en virtud de las Constituciones de Sahagún de $1612^{49}$, empezaron los Abadiatos cuatrienales en la Congregación vallisoletana. La formación académica pasó a ser un requisito prácticamente indispensable para ocupar los cargos más destacados. Como veremos después, muchos de los Abades fueron graduados en Irache.

Desde 1613, Irache fue solamente una universidad pontificia. Los benedictinos se preocuparon de que el monarca les diese también el privilegio real, que obtuvieron en 1665. Felipe IV admitió la traslación de los privilegios de Sahagún, confirmó la potestad de graduar en todas las Facultades, y le concedió la jurisdicción civil y criminal al Rector en causas menores. Sin embargo, el monarca inicialmente se opuso a la colación de los grados en Medicina. Con todo, dicha restricción fue anulada al poco tiempo, de modo que los médicos se siguieron graduando en Irache ${ }^{50}$.

\subsubsection{Las universidades benedictinas}

Para comprender el alcance de Irache en el seno de la Orden de San Benito, tenemos que examinar los dos focos universitarios que germinaron en la época moderna: el castellano-navarro y el bávaro-austríaco. Frente a los mauristas franceses, dedicados al estudio de las fuentes y a la erudición, ha-

48 E. Zaragoza Pascual, “Abadologio de Sahagún”, p. 129.

49 J. M. Cuenca Coloma, Sahagún: Monasterio y villa (1085-1985), p. 148.

50 J. Ibarra Murillo, Historia..., p. 248; C. M. Ajo, Historia de las Universidades hispánicas, III, p. 332. 
llamos notables similitudes entre la erección de universidades benedictinas en Castilla-Navarra y Baviera-Austria, las cuales aprovecharon la coyuntura favorable de ambos entornos, que coadyuvaba a la floración de centros de enseñanza superior para las respectivas congregaciones.

El caso castellano lo hemos analizado antes, y solamente nos queda recalcar el intento frustrado de instituir una Universidad en el Monasterio de San Vicente de Oviedo. En efecto, los monjes ovetenses hicieron lo posible, a comienzos del siglo XVII, para lograr que el Colegio monástico tuviera un carácter universitario y pudiera conferir grados. Se trataba de un momento delicado, ya que estaba en marcha la creación de la Universidad de Oviedo, gracias al testamento de Fernando de Valdés, Inquisidor General y Presidente del Consejo de Castilla, quien fundó los Colegios de San Pelayo y San Gregorio. La institución universitaria gozó de fuero por bula emitida el 15 de octubre de 1574 por Gregorio XIII ${ }^{51}$.

Mientras tanto, el 1 de octubre de 1601, en virtud de otra bula papal, se erigió en Universidad el Colegio de San Vicente, con las mismas prerrogativas que gozaban las de Salamanca y Alcalá. Los primeros lectores fueron los benedictinos Pedro de Marcilla, Gaspar de Avilés y Juan Díaz. Hubo algunas diferencias entre los profesores y la Congregación en dicha erección, pues la bula no había obtenido la aprobación real. En estas circunstancias, el abad Pedro de Marcilla fue depuesto de su cargo por el General de la Congregación en 1603 , por haberle desobedecido ${ }^{52}$.

El Monasterio se opuso a la creación de la Universidad colegial ovetense y la Congregación amenazó con quitar a los Pasantes de San Vicente. La ciudad envió una petición al Capítulo general de 1604, en la cual solicitaba que dicho Colegio fuese conservado y que se permitiera a los monjes opositar a las cátedras de la Universidad que se estaba creando a partir del testamento de Valdés. La Congregación dio permiso a los monjes regentar cátedras en la futura Universidad, con tal que no tuvieran que acceder a ellas mediante oposición. El Colegio de Pasantes fue trasladado primero a Eslonza (1607-10) y luego a San Juan de Poyo (1610-17) y, con ello, San Vicente quedó sin colegiales ${ }^{53}$.

51 Véase M. Á. Faya Díaz, "La fundación de la Universidad: las memorias y obras pías del arzobispo Fernando de Valdés y sus vicisitudes”, en J. Uría González, C. García García, A. Terrón Bañuelos (coord.), Historia de la Universidad de Oviedo, Oviedo, Universidad de Oviedo, Vol. 1, 2008, pp. 35-81.

52 E. Zaragoza Pascual, "Profesores de San Vicente de Oviedo (1617-1835)", p. 324.

53 Ibidem, p. 325 . 
Felipe III, estimando favorablemente el proyecto iniciado por Valdés, y a la vista de la bula conseguida en 1574, emitió una real pragmática, suscrita el 18 de mayo de 1604, en la que confirmaba la bula papal. La sede universitaria fue inaugurada solemnemente el 21 de septiembre de $1608^{54}$ y acogió los estudios de Artes, Cánones, Leyes y Teología.

Como reacción a la erección de la Universidad de Oviedo, la Congregación de Valladolid acordó, en el Capítulo general de 1610, suprimir los Colegios de Teología de Oña y Zamora, y crear nuevamente un Colegio de Teología en el Monasterio de San Vicente de Oviedo ${ }^{55}$. El Colegio de San Vicente siguió con un pleito con la Universidad ovetense y continuó colacionando grados hasta el 9 de abril de 1618, cuando fueron reafirmadas las vindicaciones de la Universidad y se desestimó las de San Vicente, que dejó definitivamente de llamarse Universidad.

Sin embargo, parece ser que San Vicente no dejó de dar grados, pues todavía la Universidad de Oviedo, en 1647, se quejó de que los concedía ${ }^{56}$. La Universidad amenazó con quitar las cátedras a los benedictinos si no dejaba de conferirlos. A partir de entonces, no volvieron a existir quejas y los benedictinos se graduaron por la Universidad de Oviedo, en la que enseñaban, o bien en la de Irache. Tenemos que recalcar que algunos de los benedictinos de esta época es posible que se hubieran graduado, hasta 1647, en la Universidad del Colegio de San Vicente, que nunca tuvo reconocimiento civil. Si se encontraran fuentes de grados de esta época referentes al Colegio de los benedictinos de Oviedo, tal vez se podría esclarecer la cuestión.

Pasando a Baviera, hay que indicar que los impulsos del monje humanista Nikolaus Ellenbog ayudaron a preparar el camino para una Universidad en la Abadía de Ottobeurer. En efecto, las Abadías de Donauwörth, Elchingen, Irsee, Ochsenhausen, Ottobeuren, Weingarten, Wiblingen y Zwiefalten decidieron, bajo la sugerencia y el liderazgo de la principesca Abadía de Kempten, establecer una Universidad benedictina en Ottobeuren, que se había convertido en un centro de atracción intelectual, básicamente gracias a Ellenbog57.

Varias circunstancias adversas llevaron a la incipiente Universidad de

54 J. Rodríguez Muñoz, “Estudios, profesorado y estudiantes”, en J. Uría González, C. García García, A. Terrón Bañuelos (coord.), Historia de la Universidad de Oviedo, pp. 95-128, especialmente p. 95.

55 E. Zaragoza Pascual, "Profesores de San Vicente de Oviedo (1617-1835)”, p. 325.

56 J. Rodríguez Muñoz, "Estudios, profesorado y estudiantes”, pp. 118-119.

57 F. Zoepfl, "Geschichte der ehemaligen Universität Ottobeuren”, Archiv für die Geschichte des Hochstifts Augsburg, 5 (1916-1919), pp. 517-562. 
Ottobeuren a ser reubicada, el 17 de diciembre de 1544, en el Monasterio de Elchingen, cerca de Ulm, y fue víctima de la guerra en 1546. Sin embargo, este breve intento no cayó en saco roto, pues, al fundarse la Universidad de Salzburgo, la Abadía de Ottobeuren proporcionó seis de los primeros profesores, así como a los dos primeros rectores de la nueva Universidad. Y Ottobeuren continuó siendo un gran apoyo científico de la Universidad salzburguesa hasta 1806.

Los benedictinos, llamados a Salzburgo por el arzobispo Markus Sittikus, abrieron por primera vez un Colegio, pensado para contrarrestar el predominio de los jesuitas en otras universidades. El 8 de octubre de 1622, el arzobispo Paris Lodron inauguró la Universidad de Salzburgo, bajo la dirección de los benedictinos ${ }^{5}$. En 1625, una bula papal confirmaba la erección pontificia de la Universidad. En ese momento, un grupo de treinta y tres monasterios benedictinos de Suiza, Baviera y Austria se hizo cargo de la construcción, mantenimiento y gestión de la Universidad. Los monjes enviaron a sus correligionarios más sabios como profesores, y sus estudiantes se formaron en la nueva sede, a la vera del río Salzach. La Universidad de Salzburgo tenía inicialmente tres Facultades: Filosofía, Teología y Derecho. La Facultad de Medicina solo existió entre 1632 y 1635 .

Lo que nos interesa aquí es comparar la Universidad de Irache con la de Salzburgo, las dos únicas de cuño benedictino en Europa. La Abadía navarra logró la creación de la Universidad gracias a la transferencia de los privilegios de Sahagún, si bien la iniciativa, la gestión y el profesorado corrió íntegramente a cargo de la Orden benedictina. En el caso de Salzburgo, la situación fue algo distinta. El Arzobispo buscó una congregación para hacerse cargo de una futura Universidad, de acuerdo con unas condiciones impuestas por el prelado. Tras el fracaso de las negociaciones con diversas órdenes religiosas, al final los benedictinos aceptaron, y volcaron sus energías y sus caudales en ese proyecto, del cual, décadas más adelante, se sintieron plenamente orgullosos.

Y es que Irache era una Abadía apartada, a la que los estudiantes debían acudir adrede, mientras que Salzburgo era una ciudad arzobispal de gran nombradía. En Irache solo enseñaron -y muy modestamente- la Filosofía y la Teología, si bien graduaban en Medicina, Leyes y Cánones. En Salzburgo se buscó que la docencia estuviese abierta a los seglares y, para la enseñanza de Leyes y otras disciplinas, fue necesario el concurso de personas ajenas a la Congregación benedictina.

58 K. F. Hermann, "Das Werk der Erzbischöfe Markus Sittikus und Paris Lodron” en VVAA, Universität Salzburg 1622-1962-1972, Salzburg, Universität Salzburg, 1972, pp. 3-34. 
Vemos, por tanto, que también hay similitudes notables entre Salzburgo e Irache, pues ambas fueron apoyadas firmemente por las respectivas Congregaciones benedictinas, fueron erigidas canónicamente en las mismas fechas y tuvieron un sistema de gobierno y gestión parecido.

También en un sentido intelectual ambas universidades se mostraron apasionadamente a favor del concepcionismo, que fue sostenido con ardor ${ }^{59}$. Y en cuanto a la Filosofía y la Teología, en ambas cultivaron un tomismo injertado en la escuela anselmiana. En este sentido, cabe destacar la influencia del cardenal Aguirre entre los profesores salzburgueses. Ello, sin embargo, no permite afirmar que en Salzburgo hubiera un intento tan nítido de restaurar las cátedras anselmianas como tuvieron Aguirre y sus seguidores en Castilla. Más bien se enseñó un tomismo ecléctico, que favoreció la adopción de algunas soluciones novedosas ${ }^{60}$.

\subsection{Irache y las universidades hispánicas}

Tenemos que analizar ahora la Universidad de Irache en el contexto de las Universidades hispánicas. En primer lugar, lo haremos a partir de la tipología, mientras que en un segundo apartado nos concentraremos en la perspectiva geográfica.

\subsubsection{Irache como universidad monacal}

Según Mariano Peset, las universidades hispánicas de la época moderna pueden dividirse en claustrales, colegiales, conventuales y municipales ${ }^{61}$. La Universidad de Irache sería conventual, o mejor dicho, monacal. No hay diferencias sustanciales entre las universidades conventuales y las monacales ${ }^{62}$ : simplemente, las primeras estaban regidas por órdenes de vida activa, mientras que las segundas estaban a cargo de las órdenes de vida contemplativa.

59 A. Linage Conde, "La Universidad de Irache en el Benedictinismo", p. 215.

60 Véase E. J. Bauer, Thomistische Metaphysik an der alten Benediktineruniversität Salzburg: Darstellung and Interpretation einer philosophischen Schule des 17./18. Jahrhunderts, Innsbruck, Tyrolia-Verlag, 1996.

61 M. Peset, "La organización de las universidades españolas en la edad moderna", en A. Romano (ed.), Studi e Diritto nell'area mediterranea in età moderna, Messina, Rubbettino, 1993, pp. 73-122.

62 Un estudio de conjunto de estos conventos-universidad en el siglo XVII puede verse en C. M. Ajo, Historia de las universidades hispánicas, III, pp. 47-154 y 325-349. 
En el caso de la Península Ibérica ${ }^{63}$, las universidades monacales estaban en lugares apartados, mientras que las conventuales se erigieron en ciudades. Junto con Irache, la otra Universidad monacal era la de El Escorial, gestionada por los jerónimos. Sin embargo, tenían rasgos muy diferentes, pues el Colegio escurialense era de muy reducidas dimensiones y muy poco frecuentado. Se trataba más bien de un privilegio más de El Escorial, que no solamente era Monasterio, Panteón y Residencia real, sino Colegio universitario con facultad para colacionar grados.

Irache, al contrario, era un centro muy frecuentado, abierto a los seglares y con una nómina de miles de graduados. Se parecía más a las Universidades gestionadas por los dominicos. En Castilla, había las de Almagro ${ }^{64}$ (compartida con la Orden de Calatrava) y Ávila ${ }^{65}$, mientras que en la Corona de Aragón, la Orden de Predicadores tenía las de Solsona, Tortosa y Orihuela. En el Reino de Navarra, se fundó la de Pamplona ${ }^{66}$, como veremos seguidamente.

Las Universidades de Pamplona y Tortosa ${ }^{67}$ eran Colegios que enseñaban Filosofía y Teología, y colacionaban grados en ambas Facultades. La Universidad de Orihuela no la regían únicamente los dominicos, sino que lo hacían en colaboración con la Ciudad y el Cabildo ${ }^{68}$. En cambio, la Universidad de Ávila se parecía mucho a la Irache, porque ambas eran muy concurridas y graduaban en todas las Facultades, aunque solamente hubiera Facultad de

63 Sobre las Universidades hispánicas, véase R. Ramis Barceló, "La política universitaria de los Austrias en la Península Ibérica”, en G. P. Brizzi y A. Mattone (ed.), Le origini dello Studio Generale sassarese nel mondo universitario europeo dell'età moderna, Bolonia, CLUEB, 2013, pp. 103-116.

64 D. Sánchez de la Nieta, La Universidad de Almagro. Tres siglos de actividad (1574-1824), Ciudad Real, Museo de Ciudad Real, 1981; J. C. Vizuete Mendoza, Los antiguos Colegios-Universidad de Toledo y Almagro (siglos XVI-XIX), Toledo, Publicaciones de la Universidad de Castilla-La Mancha, 2010.

65 C. M. Ajo, "Origen y desarrollo de la que fue célebre Universidad de Ávila (15041824)”, Estudios Abulenses, 1 (1954), pp. 5-55.

66 J. Salvador y Conde, La Universidad de Pamplona en el s. XVII, Pamplona, Diputación Foral de Navarra, 1977.

67 R. Ramis Barceló y P. Ramis Serra, Estudios sobre la Universidad de Tortosa (1600-1717), Madrid, Dykinson, 2020.

68 M. Martínez Gomis, La Universidad de Orihuela, 1610-1807. Un centro de estudios superiores entre el Barroco y la Ilustración, 2 vols, Alicante, Instituto de Estudios Juan Gil Albert, 1987. Véase también R. Ramis Barceló y P. Ramis Serra, "Los primeros grados de la Universidad de Orihuela (1610-1643)”, Estudis. Revista de Historia Moderna, 43 (2017), pp. 235-260. 
Filosofía y de Teología ${ }^{69}$. Tanto en Irache como en Ávila, se colacionaban grados en Leyes y Cánones, siempre y cuando los estudiantes pudiesen mostrar que habían asistido a los cursos de una Universidad aprobada ${ }^{70}$. La diferencia entre Ávila e Irache era que en la primera, según los Estatutos, se podía dar solamente el grado de D. M., mientras que la de Irache concedía todos los grados de Medicina ${ }^{71}$. Hubo en Ávila muy pocos grados en Medicina, aunque -según Herráez Hernández ${ }^{72}-$ hubo, como mínimo dos de B. M. y varios de L. M. Por lo tanto, Ávila e Irache eran, en gran medida, sedes auxiliares en las que los estudiantes de otras universidades y colegios iban a graduarse.

Solsona llevaba esta práctica al extremo y también graduaba en todas las Facultades, aunque sin privilegios ${ }^{73}$. En realidad, la mayor diferencia entre Solsona, por un lado, e Irache y Ávila, por otro, era que en la primera graduaron siempre sin privilegios y sin el reconocimiento de ninguna otra universidad. En cambio, las Universidades de Irache y de Ávila eran reconocidas por las demás, y también por el monarca.

En las Universidades mayores, eran conscientes de que muchos estudiantes no podían desembolsar las sumas requeridas para graduarse en Salamanca, Valladolid, Alcalá (o incluso en otras mucho más económicas como Sigüenza o Santiago), y admitían que sus estudiantes se fueran a graduar a estas otras sedes más modestas, como Irache o Ávila.

En realidad, por tanto, la importancia de Irache no reside solamente en ser la Universidad más antigua y concurrida del Reino de Navarra, en la que se graduaron muchos de sus naturales, sino en haber acogido a centenares de estudiantes de las Universidades mayores y menores de Castilla, así como también de la Corona de Aragón. Por esa razón, Irache alcanzó notoriedad en toda la Península y acudieron a ella alumnos de todas partes.

Hay que subrayar que el elevado número de graduados, que puede compararse una vez más al de Ávila, atrajo la animadversión de muchos críticos, quienes consideraban que no era sino un subterfugio que permitía a muchos estudiantes graduarse con un grado de exigencia mucho más bajo que en

69 J. M. Herráez Hernández, Universidad y universitarios en Ávila durante el siglo XVII: análisis y cuantificación, Ávila, Institución “Gran Duque de Alba”, 1994, p. 95.

70 Ibidem, p. 233.

71 Idem, p. 234.

72 Idem, pp. 165-167.

73 R. Ramis Barceló "Sobre los privilegios de la Universidad de Solsona y los grados en leyes, cánones y medicina durante el siglo XVII”, Glossae. European Journal of Legal History, 12 (2015), pp. 661-678. 
otras sedes. Don Diego de Torres y Villarroel, Catedrático de Matemáticas en Salamanca ya en el XVIII, escribiría de un personaje que:

"graduóse entre gallos y medianoche y comprando la borla incurrió en una simonía civil de las muchas que se cometen en la Corte, adonde vienen a recuas los mulos cargados de panzas de doctores, licenciados y bachilleres de las Universidades de Sigüenza, Osuna, Irache y otras de la propia harina ${ }^{74}$."

En este caso, Irache era comparada con otras universidades colegiales, como Sigüenza y Osuna, en las que la colación de los títulos era también, al parecer, excesivamente generosa. Cierto es que en el siglo XVIII el número de graduados fue creciendo, como puede verse, y de forma muy espectacular, incluso en la Facultad de Medicina ${ }^{75}$. Sea como fuere, y si nos atenemos exclusivamente el aspecto legal, la Universidad de Irache colacionaba los grados con validez y puede compararse más a la de Ávila que a la de Solsona.

\subsubsection{Irache en la geografía universitaria}

Nuestra Señora la Real de Irache está situada a unos tres kilómetros de Estella, "en la jurisdicción del lugar de Ayegui, al pie del Montejurra, en un paraje ameno, cuyo suelo es fértil en frutas y legumbres ${ }^{76}$ ". Se sabe que en el año 958 ya tenía un Abad llamado Teudano. San Veremundo, Abad que fue de Irache, dotó de gran nombradía al cenobio, que fue enriquecido con diversas donaciones de los monarcas navarros ${ }^{77}$.

No había, en el siglo XVI, ninguna Universidad en el Reino de Navarra, y esa fue una circunstancia clave para que la Congregación vallisoletana se decidiera a trasladar allí los privilegios de Sahagún. Existía, fuera de los confines del Reino, una Universidad en Oñate, fundada por Rodrigo Mercado y Zuazola, Obispo de Ávila y Presidente de la Chancillería de Granada, quien gestionó una bula de Paulo III de 23 de abril de 1540, para que hubiera un Colegio con Maestros y estudiantes vascos, en el que se leyese Artes y Cánones. El fundador, Doctor en ambos derechos, valoraba, ante todo, la faceta jurídi-

74 D. de Torres y Villarroel, Sueños Morales, visiones y visitas de Torres con Don Francisco de Quevedo..., Madrid, Joseph Doblado, 1796, p. 136.

75 F. Serrano Larráyoz, Graduados en Medicina por la Universidad de Irache (16131769), pp. 35-36.

76 E. Zaragoza Pascual, Los Generales de la Congregación de San Benito de Valladolid, Vol. 2, p. 171.

77 E. Zaragoza Pascual, “Abadologio de Irache”, pp.167-168. 
ca. El Colegio albergaba a doce colegiales y profesores de la Universidad; dos debían de ser de Oñate, dos de Guipúzcoa, dos de Vizcaya, dos de Álava; y los restantes de Castilla, Aragón, León, Navarra y Portugal ${ }^{78}$.

El Colegio tenía incorporada la Universidad de Sancti Spiritus, cuya existencia fue muy precaria y en la que se llegó a enseñar, en distintos intervalos, Teología, Derecho civil o canónico. Contaba con estudiantes matriculados, que procedían sobre todo de las tres Vascongadas y Navarra, y de algunos puntos de la Cornisa Cantábrica. Durante el siglo XVII, la Universidad de Oñate sufrió una cierta crisis, motivada por la competencia de Irache, que graduaba en todas las Facultades. Con todo, una parte de los alumnos vascos y del Norte del Reino de Navarra se siguió graduando en Oñate. Sin embargo, la presencia de las Universidades de Pamplona y de Irache condujo a Oñate, en el último cuarto del siglo XVII, a un progresivo descenso ${ }^{79}$, mientras que Irache mantuvo una notable regularidad.

Hemos hecho mención antes a la Universidad de Pamplona, que fue rival directa de la Irache. De hecho, el proyecto de establecer una Universidad en la capital del Reino de Navarra era un plan que estaba presente desde mediados del siglo XVI. Se quiso poner en funcionamiento una Universidad en el Convento de Santiago, en un régimen mixto, para religiosos y seglares, similar al que luego se desarrolló en Orihuela. Estaba proyectado que tuviera todas las Facultades y, de hecho, se hicieron todas las gestiones destinadas a lograr esa nueva realidad universitaria. Sin embargo, no llegó a cuajar, según Salvador y Conde, por dos motivos: por un lado, por la falta de dinero y, por otra, por la tenaz oposición de los benedictinos de Irache $^{80}$. El historiador dominico indicó que

“...Ya que no se hizo Universidad del Reino, los dominicos fundaron una en su convento de Santiago de Pamplona. Para ello obtuvieron Breve Pontificio de Urbano VIII en 1624 y Cédula Real de Felipe IV en 1630. La fundación se llevó a cabo este mismo año y siguió funcionando hasta 1771. Apoyaron su fundación la ciudad de Pamplona, el Reino

78 La evolución de la institución puede verse en M. R. Ayerbe Iríbar, "Universidad de 'Sancti Spiritus' de Oñate: fuentes y líneas de investigación”, en L. E. Rodríguez San Pedro Bezares y J. L. Polo Rodríguez (eds.), Universidades Hispánicas. Modelos territoriales en la Edad Moderna (II), Salamanca, Universidad de Salamanca, 2007, pp. 97-161.

79 M. Torremocha Hernández, "La población estudiantil de la Universidad de Oñate. Siglo XVII”, Investigaciones históricas, 15 (1995), pp. 209-240, especialmente, p. 222.

80 J. Salvador y Conde, La Universidad en Pamplona, Madrid, Instituto Jerónimo Zurita-CSIC, 1949, pp. 76-77. 
y el Cabildo catedralicio. Se opusieron a ella la Universidad de Irache y el Colegio de la Compañía en Pamplona. Se enseñaron en ella las Facultades de Filosofía y Teología. Quiso el convento añadir las de Leyes y Medicina y para ello obtuvo licencia del rey. El Reino de Navarra influenciado por la Universidad de Irache, se opuso tenazmente, y los dominicos, a pesar de tener todas las autorizaciones, no las utilizaron ${ }^{81}$ ".

El Consejo de Navarra se negó a dar el placet al breve pontificio. Empezó una guerra entre los dominicos de Pamplona y los benedictinos de Irache. Los monjes alegaban que ya bastaba su Universidad para el Reino y que muchos trabajos les había costado transferirla de Sahagún a Irache, y que lo habían hecho persuadidos por las autoridades navarras. Añadían que en Irache se graduaban los alumnos de los jesuitas, agustinos, carmelitas, franciscanos... y que incluso los dominicos mandaban sus estudiantes a gradurse a Irache. Si se concedía el rango de Universidad al Convento de Santiago de Pamplona, las demás órdenes también querrían una universidad para ellas, con las mismas razones que podían dar los dominicos. Desde el Convento de Santiago, respondían que, con la Universidad en Pamplona, se daría cumplimiento a un objetivo que el Reino había tenido desde hacía años y que en nada perjudicaba a Irache ${ }^{82}$.

Al final, gracias a los apoyos que los dominicos tenían en Madrid, llegó la cédula real de Felipe IV en 1630 y pronto comenzó a funcionar la Universidad de Pamplona, que graduó solamente en Artes y Teología. Es cierto que puede notarse un descenso de los estudiantes de Artes graduados en Irache a partir de ese año, aunque los alumnos de los jesuitas y de otras órdenes siguieron graduándose en la Abadía. Si examinamos la relación de graduados que aporta Salvador y Conde, se puede concluir que la Universidad de Pamplona tuvo solamente un alcance local, en la que se graduaron los dominicos, sus alumnos y algunos regnícolas ${ }^{83}$.

Las Universidades de Pamplona y Oñate, situadas en un radio geográfico muy próximo, mantenían una competencia directa con Irache. A una mayor distancia estaban situadas las universidades aragonesas, Huesca y Zaragoza, que concedían grados en todas las Facultades. No pocos estudiantes de Medicina, Leyes o Cánones, así como algunos teólogos de ambas sedes acudieron a graduarse a Irache, para no hacerlo en el lugar en el que habían seguido los

81 Ibidem, pp. 78-79.

82 Idem, pp. 119-128.

83 Idem, pp. 161-181. 
estudios $^{84}$. En Irache, al parecer, los ejercicios resultaban menos complejos y los examinadores eran menos exigentes. En un radio algo más alejado, en Castilla, estaban las Universidades de Osma y Sigüenza, que también aportaron algunos alumnos a Irache.

A unos trescientos kilómetros se hallaban dos de las Universidades mayores de Castilla (Valladolid y Alcalá), así como también la más antigua de las Universidades catalanas: Lérida. Hubo una relación continua, especialmente con Valladolid y Alcalá, como veremos después. Un grupo representativo de colegiales y manteístas de ambas Universidades se graduó en Irache, y también algunos egresados del Monasterio navarro fueron después colegiales mayores. Con la Universidad de Lérida existieron menos vínculos.

Por último, las Universidades de Oviedo y Salamanca, situadas a unos cuatrocientos kilómetros, tuvieron también relación con Irache. Con Salamanca fueron lazos muy intensos, tal y como se desprende de las anotaciones de los grados, mientras que con Oviedo fueron menos relevantes. Recordemos, en fin, que los Colegios benedictinos en Oviedo ${ }^{85}$, Salamanca, Valladolid y Santiago $^{86}$ favorecieron la presencia de los monjes en las cátedras de sus respectivas Universidades. Muchos de ellos, acompañados de otros religiosos, acudieron a graduarse a Irache.

\section{Los Estatutos de la Universidad de Irache}

En 1613, la organización de la Universidad de Irache se basaba en unos Estatutos de 1597, que fueron puestos al día y aprobados por Fr. Antonio de Castro, General de la Congregación de España e Inglaterra, el 15 de mayo de 1618. Pronto hubo quejas por la colación irregular de los grados en Irache, si bien

84 R. Ramis Barceló, "La peregrinatio academica y la movilidad estudiantil en la Corona de Aragón (ss. XIV-XVIII)”, en C. Fernández Cortizo y D. L. González Lopo (eds.), La movilidad estudiantil en Europa y América (siglos XIII al XXI). De la Peregrinatio Academica al Programa Erasmus, Santiago, Alvarellos Editora, 2020, pp. 69-104, especialmente p. 93.

85 V. Beltrán de Heredia, "La Facultad de Teología de la Universidad de Oviedo", en Miscelánea Beltrán de Heredia, Vol. 4, Salamanca, San Esteban, 1973, pp. 387-439.

86 V. Beltrán de Heredia, "Los benedictinos en la Universidad de Santiago", Boletín de la Real Academia Gallega, 179 (126), pp. 263-268; 181 (1926), pp. 12-19; V. Beltrán de Heredia, "La Facultad de Teología en la Universidad de Santiago", en Miscelánea Beltrán de Heredia, Vol. 4, pp. 191-309; J. R. Barreiro Fernández, Historia de la Universidad de Santiago de Compostela, Vol. 1, Santiago, Universidad de Santiago de Compostela, 2000, pp. 228-232. 
los Estatutos de 1618 fueron confirmados una y otra vez -la primera de ellas, el 15 de enero de 1628- a lo largo de la centuria ${ }^{87}$. Veamos seguidamente los rasgos generales de estos Estatutos de la Universidad Real de Hyrache en el Reyno de Navarra, conservados en la Biblioteca General de Navarra (BGN).

En el capítulo primero se hacía referencia a que el Abad, como en casi todas las Universidades monásticas, era Rector, Canciller y Maestrescuela de la Universidad, de modo que extendía su jurisdicción abacial a la jurisdicción escolástica. En ausencia del Abad, el Prior desempeñaba sus funciones ${ }^{88}$.

El capítulo segundo regulaba la composición del claustro, compuesto del propio Rector, un Regente, los Maestros y Lectores en Teología y Artes, así como el Prior del Monasterio, al que se le exigía que fuera "letrado, tal que pueda argüir y poner codlibetos en los exámenes”, el Maestro de estudiantes, un Pasante de Teología (si lo había), y los graduados de Maestros por la propia Universidad. Se preceptuaba que, en ausencia del Abad o del Prior, ningún Regente o Lector podía poner en la cárcel a los estudiantes y se penaba con cuatro reales la ausencia de los actos de un miembro del claustro que estuviese en la casa. Se ordenaba que no se decidiese ningún asunto importante sin el parecer de todo el claustro. También se mandaba la utilización del voto secreto por parte de los miembros del claustro, "por abas blancas y negras", como era habitual en las universidades, tanto para autorizar o no la graduación de los estudiantes como para las penitencias que debía cumplir el aspirante que no llegara a superar favorablemente las pruebas ${ }^{89}$.

En el capítulo tercero se ordenaba que todos los estudiantes matriculados se hicieran cofrades y que acudieran los domingos primeros de mes a la procesión de la Virgen, así como se mandaba que los estudiantes tenían que ir a cantar la misa de Nuestra Señora después de la lección de Prima, así como a una serie de misas que quedaban indicadas en el texto. Ordenaba que ningún alumno se pudiera matricular de Artes, sin que el Maestro de Artes hiciera constar su suficiencia, y que, para ganar curso en las Facultades, bastaba con cursar la mayor parte del año, y que, si por impedimento no se podía acabar un curso, se podría suplir al siguiente. Se ordenó que hubiera conclusiones de Artes y Teología, alternativamente, cada ocho días, y que fueran castigados

87 F. Serrano Larráyoz, Graduados en Medicina por la Universidad de Irache (16131769), p. 14.

88 BGN, Estatutos de la Universidad Real de Hyrache en el Reyno de Navarra, ff. $5 \mathrm{r}-6 \mathrm{r}$.

89 BGN, Estatutos de la Universidad Real de Hyrache..., ff. 6r-7r. 
los estudiantes que no acudieran a las mismas. Los alumnos no podían llevar vestidos de seda, ni armas defensivas ni ofensivas, aunque sí podían tener una espada en su aposento. Quedaban prohibidos los juegos de naipes y las escapadas a Estella, tanto de día como de noche ${ }^{90}$.

En el capítulo cuarto se detallaban las características del Secretario de la Universidad, cargo que debía recaer en un monje del Monasterio, a elección del Abad. Al Secretario le correspondía recibir la documentación de los que acudían a graduarse. Tenía que conservar los títulos y cursos de otros centros de enseñanza que los interesados llevaban para graduarse. Se disponía que el Secretario debía guardar la documentación en su celda, y que, si tenía muchos papeles, los llevara al archivo de la casa. Al Secretario le tocaba entregar el título a los nuevos graduados. Se mandaba asimismo que en el libro de grados correspondiente se anotara el día, mes, año y los puntos que leía cada graduado ${ }^{91}$.

Los capítulos quinto y sexto detallaban las obligaciones que tenían, respectivamente, el Maestro de ceremonias, y el Bedel y Alguacil. El primero tenía que acompañar al graduando e instruirle en las ceremonias, avisar a los Maestros que habían de acudir a la capilla y llevarles las conclusiones. El bedel había de ser un hermano lego, ayudante del Maestro de ceremonias, que fungiera también como alguacil, y que "con bara lebantada" prendiera a los estudiantes y los llevara a la cárcel ${ }^{92}$.

El capítulo séptimo ordenaba que, para graduarse de Bachiller, los candidatos tenían que haber asistido a alguna Universidad o Colegio aprobado, y tener la certificatoria de los cursos pertinentes. Estos requisitos no podían dispensarse sin la autorización de dos terceras partes del claustro. Para Artes era necesario llevar tres cursos aprobados, aunque por suficiencia bastaban dos años de oyente. Para Bachiller en Teología, tenía que haber cursado cuatro años enteros, aunque el cuarto fuera inceptum pro Completo. Para Bachiller en Cánones tenían que cursar cinco años, pero el último podía declararlo también inceptum pro Completo. Si el Bachiller en Cánones tenía dos cursos de Leyes (Código o Digesto), podía graduarse en Leyes, y lo mismo si el Bachiller legista ganaba dos cursos de Decretales, Sexto o Clementinas, se podía graduar en Cánones. Se ordenaba que, en la Facultad de Medicina, no podía graduarse nadie que no llevase carta de Bachiller en Artes o se graduase allí, así como que no tuviera cuatro cursos enteros probados de Medicina. Para los

90 BGN, Estatutos de la Universidad Real de Hyrache..., ff. 7r-10r.

91 BGN, Estatutos de la Universidad Real de Hyrache..., ff. 10r-11r.

92 BGN, Estatutos de la Universidad Real de Hyrache..., ff. 11r-12r. 
grados en Medicina no se tenían que dar penitencias, sino que se debía despedir a los que no fueran aptos. Para la graduación de Bachiller en Medicina y Leyes debían asistir dos Médicos y Letrados, para que, con su parecer, se diera o no el grado. Y si no hubiera dos, que acudiera, como mínimo, uno ${ }^{93}$.

En el capítulo octavo se detallaban los requisitos para el grado de Licenciado. Desde la graduación de Bachiller debían pasar dos años para obtener el grado de Licenciado. Quien hubiera de graduarse, tenía que repetir una hora entera, aunque el Maestrescuela y el Claustro podían hacer alguna dispensa. Si solamente se quería incorporar, trayendo carta de examen de una Universidad aprobada, no era necesario que repitiera. Se ordenaba que la elección de puntos se hiciera en presencia del Secretario. La lección de Capilla tenía que durar una hora y la votación para determinar el resultado se tenía que realizar en el primer escrutinio, sin posibilidad de un segundo. Las penitencias, salvo en la Facultad de Medicina, se tenían que dar según el parecer de todo el claustro. También a las Licenciaturas de Medicina y Leyes tenían que asistir dos médicos o legistas, respectivamente, o -al menos- uno. El licenciado tenía que jurar que no se graduaría en virtud de aquel grado por otra Universidad sin pedir primero licencia a la de Irache ${ }^{94}$.

El capítulo noveno ordenaba que nadie se graduara de Doctor sin tener un título de Licenciado de una Universidad aprobada o que se hubiera graduado en Irache. Para el Doctorado en Leyes era necesaria la presencia de dos legistas y, para el de Medicina, era preceptiva la presencia de dos médicos o, como mínimo, de uno. Tenía que haber dos quodlibetos para cada doctorando. Los Licenciados y los Doctores se podían incorporar con mayoría de votos del claustro. Los graduandos tenían que hacer el juramento inmaculista ${ }^{95}$.

El capítulo décimo estatuía que el Abad y Rector tenía que dar todos los grados de Licenciado y de Doctor. En cuanto a los de Bachiller, el Regente y los Lectores de Teología debían otorgar los grados alternativamente, por su orden. Los grados de Bachiller en Artes los confería el Lector de Artes. Y los demás grados en Artes, si no los daba el Abad, los tenía que dar el Lector de Artes, y en su ausencia, el Regente y los Lectores en Teología. Si no hubiera ningún monje conventual, se mandaba que los colacionara el Maestro de estudiantes o el Pasante del Colegio ${ }^{96}$.

93 BGN, Estatutos de la Universidad Real de Hyrache..., ff. 12r-13r.

94 BGN, Estatutos de la Universidad Real de Hyrache..., ff. 13r-14v.

95 BGN, Estatutos de la Universidad Real de Hyrache..., ff. 14v-15r.

96 BGN, Estatutos de la Universidad Real de Hyrache..., ff. 15r-16r. 
El undécimo capítulo trataba de los legistas y médicos que eran llamados para graduar a los candidatos, y se mandaba que cada uno tuviera que hacer dos argumentos y algunas preguntas. Para el doctorado, tenían que proponer cada uno un quodlibet y, examinada la cuestión con argumentos, se pedía que la probaran pro utraque parte. Por el examen de Licenciado cobraban doce reales y, por el de Doctor, diez reales ${ }^{97}$.

El capítulo decimosegundo trataba de las propinas ${ }^{98}$. Los Doctores en Teología, Cánones, Leyes y Medicina debían pagar treinta ducados, que se repartían de la forma siguiente: quince para la casa, dos para los oficiales y, de los trece restantes, el Abad Rector se llevaba la tercera parte, y las otras dos se tenían que distribuir por partes iguales entre las personas del Claustro. Del grado de Licenciado en dichas Facultades, se pagaban veinticinco ducados, repartidos de la forma siguiente: trece para la casa, dos para los oficiales, mientras que, de los diez restantes, el Abad se llevaba la tercera parte y las otras dos se repartían entre los miembros del claustro.

El grado de Bachiller en todas las Facultades exigía cinco ducados por la aprobación por curso y, por suficiencia, seis reales más. De los cinco ducados, dos eran para la casa, seis reales de estancias, once reales para el que confería el grado, y los dieciséis reales restantes para los oficiales: seis para el secretario, cuatro para el escribano, dos para el sello, dos para el Maestro de ceremonias, y dos para el bedel. En cuanto al grado de Maestro en Artes, se pagaban veinte ducados. De estos, había dos para los oficiales y dos para las estancias. De los dieciséis restantes, la casa se llevaba ocho, y de los otros ocho, el Abad se llevaba la tercera parte, mientras que las otras dos se dividían igualmente con los miembros del claustro. En cuanto al grado de Licenciado en Artes, se pagaban dieciséis ducados; había dos para las estancias y dos para los oficiales. De los doce restantes, había seis para la casa y, de los seis que quedaban, dos eran para el Abad y los padres del Claustro, sacando tres reales para el Presidente y cuatro para el Prior. Los otros dos ducados se repartían entre los oficiales.

Los Estatutos concluían ordenando que, si alguien de la comarca quisiera graduarse y acudir a los doctorados a ganar las propinas, debía pagar cien ducados. Para los benedictinos de la Congregación que se graduasen, bastaban cien reales "para dar un Asueto al sancto conuento"99".

97 BGN, Estatutos de la Universidad Real de Hyrache..., ff. $16 \mathrm{rv}$.

98 BGN, Estatutos de la Universidad Real de Hyrache..., ff. 16v-18v.

99 BGN, Estatutos de la Universidad Real de Hyrache..., f. 18v. 
Como indica Cándido $\mathrm{Ajo}^{100}$, se escribió en el abadiato de Fr. Juan Sánchez (1674-1677), un nuevo Ceremonial de la Universidad de Sancta María de Hyrache corregido y enmendado, que, sobre todo, modificaba algunos puntos referentes a los grados.

En cuanto al bachillerato, se indicaba que, en las cinco Facultades, el Canciller concedía el grado, a petición del interesado. El procedimiento era el siguiente: los aspirantes eran recibidos por el maestro de ceremonias, quien los llevaba ante el secretario, a depositar los derechos (salvo en Medicina, que se pagaba después del aprobado); el secretario comprobaba los justificantes de cursos y mandaba al profesor correspondiente la conclusión de la cuestión que iba a desarrollar el aspirante. Si la graduación era por suficiencia, tenían que examinarle y, aprobado, un lector le imponía el bonete, con autoridad apostólica y regia, y el nuevo bachiller subía al sitial; luego, los estudiantes "pateaban" y se concluía así la función.

Para la licenciatura, primero se hacía el depósito, y luego

"se tocaba a la repetición, donde acudían los padres colegiales con el «maestrescuela» y maestros en fila y silencio; el bedel con maza en medio; allí el aspirante desarrollaba la tesis dada por el maestro de estudiantes; iban luego a la «doctoral» y a la vez que se daban los piques salían todos menos el claustro; si resultaba aprobado entraban los demás para presenciar la toma de grado, que daba el canciller en persona con la fórmula indicada, previa profesión de fe $\mathrm{e}^{101}$ ".

Por último, en cuanto al doctorado, hay que decir que se colacionaba en la iglesia, en la que se llevaban a cabo dos "quodlibetos", a los que debía responder el graduado, vestido con el "capirote" del color de la Facultad en la que quisiera graduarse. Junto con la profesión de fe, juraban también no doctorarse en otra sede sin el beneplácito del claustro de Irache; que si hacían falta lectores, acudirían a Irache a enseñar; que defenderían la Purísima Concepción; y que protegerían también a la Universidad (y que los médicos avisarían a los enfermos graves para que recibieran los santos sacramentos $)^{102}$.

Como puede verse, por un lado, las graduaciones en Irache no eran muy costosas, sobre todo si las comparamos con las de las Universidades mayores. En Salamanca, por ejemplo, solamente para obtener grados en Artes, los candidatos tenían que pedir préstamos de 150 o 200 ducados, mientras que

100 C. M. Ajo, Historia de las Universidades hispánicas, III, p. 333.

101 Ibidem, p. 334.

102 Idem. 
en Irache los doctorados en las Facultades mayores costaban 30 ducados, y los de Artes, $25^{103}$. Las propinas de Irache estaban en consonancia con las de Ávila y otras universidades menores, aunque eran superiores a las de universidades fraudulentas, como la de Solsona.

Por otro lado, los requisitos para lograr los grados eran muy asequibles. Los Estatutos daban pie a una lectura generosa de las aprobaciones de cursos, que contribuyeron a la dudosa fama de Irache. Como veremos después, durante la segunda mitad del siglo XVII empezaron a reprobar a algunos candidatos, pues antes -de acuerdo con la documentación manuscrita- se le daba el grado prácticamente a todos los aspirantes.

Hay que concluir, en fin, que Irache era una Universidad muy reducida, compuesta del Abad-Rector-Cancelario, de unos pocos Lectores de Artes y Teología, y de algunos cargos subalternos. La gestión estaba a cargo de los monjes de la Abadía y solamente para la colación de los grados mayores de Leyes y Medicina asistían médicos o legistas. En la misma Abadía había dependencias para estudiantes que no pertenecían a la Congregación, que seguían los cursos que allí se dictaban. Asimismo, diversas órdenes religiosas, que daban clases de Artes en sus conventos de Pamplona, llevaban a Irache a sus estudiantes para que se graduaran.

Si solamente se hubieran graduado estos alumnos de Pamplona más los de la casa, la Universidad de Irache hubiera sido más o menos como la de los dominicos de Pamplona. Sin embargo, el verdadero punto de atracción era la posibilidad de lograr todos los grados mayores y menores a un precio asequible, y sin muchas dificultades. De ahí el flujo permanente, sobre todo de canonistas y teólogos, y en menor medida, de médicos y legistas, que analizaremos con mayor detenimiento en el apartado quinto.

\section{Los benedictinos: rectores, lectores y graduados}

Los protagonistas de la Universidad de Irache eran, sin duda, los benedictinos, que ejercían todos cargos y desempeñaban las funciones docentes. No repetiremos aquí los datos del Abadologio de Irache ni las provisiones para el estudio, que pueden encontrarse en los ya citados estudios de Ernesto Zaragoza $^{104}$. Ofrecemos aquí una breve prosopografía de los 238 benedictinos

103 L. E. Rodríguez-San Pedro Bezares, La Universidad salmantina del Barroco, periodo 1598-1625, Tomo II, Salamanca, Universidad de Salamanca, 1986, pp. 793-795.

104 Junto con los trabajos de Zaragoza Pascual, hay que tener en cuenta la obra de un 
graduados en Irache, en el orden cronológico que aparecen en el registro de grados. Vamos a destacar solamente los aspectos académicos, los cargos ocupados y su producción intelectual.

Entre los graduados se hallan tanto los Predicadores de diferentes Abadías como los Lectores y Regentes que, tras haber cumplido sus años de púlpito y de docencia, pedían ser graduados al Capítulo General. Tras la aprobación capitular, acudían a Irache. Junto con estos, hallamos los Abades y Generales, así como otros cargos de la Congregación (Secretario, Definidor, Procurador...). Aparecen también los profesores de las Universidades ya indicadas (Salamanca, Oviedo, Santiago...), que acudieron a Irache a graduarse porque resultaba mucho más económico. Los graduados eran, en definitiva, los profesores y otros cargos de la Abadía de Irache, junto con la élite de la Congregación vallisoletana.

$\mathrm{Al}$ recibir la autorización del General, solían graduarse en grupo, en pocos días. Se les concedía, por lo general, todos los grados de Artes y Teología (B. A. / L. A. / M. A. / B. T. / L. T. / M. T.), a menos que, por diversas razones, el candidato ya tuviera alguno de los grados. Normalmente, recibían los grados del Abad-Rector-Canciller, salvo que - por cuestión de deferencia- presidiese el General de la Congregación, presente en Irache por alguna circunstancia.

Fr. Plácido de Reinoso. También llamado Plácido de Reinosa. Natural de Oviedo, aunque profeso en Valladolid, donde tomó el hábito en 1593. Fue Lector de Artes en el Colegio de Zamora (1604-1607) y Regente de estudios en Oviedo (1610-1613). Recibió todos los grados de Filosofía y Teología en Irache en 1613. Fue Catedrático de Vísperas de Teología de la Universidad de Oviedo desde 1615 a 1616, y de Prima desde 1616 hasta 1633, que obtuvo la jubilación. Murió en 1637. Escribió diversas obras y se imprimieron El Maestro Christiano (Valladolid, 1618), obra de contenido moral y catequético, así como un Memorial en defensa del estado eclesiastico y religioso (Madrid, 1627) ${ }^{105}$.

Fr. Juan de Valenzuela. Natural de Córdoba, profesó en Montserrat en 1597. Fue Procurador General de la Congregación en Roma (1595-1598), Abad de Sant Feliu de Guíxols (1598-1601), de Bages (1607) y de Montserrat (1607-1610). Se graduó de B. A. / M. A. / B. T. / D. T. en 1613. Fue Definidor (1604-1607) y Visita-

graduado de Irache, G. de Argaiz, La Perla de Cataluña. Historia de nuestra Señora de Monserrate, Madrid, imprenta de Andres Garcia de la Iglesia, 1677, y también J. Pérez de Urbel, Varones insignes de la Congregación de Valladolid, Pontevedra, Museo Provincial, 1967.

105 E. Zaragoza Pascual, “Abadologio de Oviedo”, p. 150; V. Beltrán de Heredia, "La Facultad de Teología de la Universidad de Oviedo”, p. 420. 
dor general (1610-1613), Predicador de Montserrat (1615-1617) y Abad de Valvanera, cargo en el que falleció, en $1618^{106}$.

Fr. Rosendo de San Martín. Profeso en Celanova, fue Lector de Tercia (16041607), Lector de Prima (1621-1622) y Regente (1613-1617, 1621-1622) en Irache, en cuyo cargo falleció el 15 de julio de 1622. Fue también Regente de estudios (1610-1613), Lector y Abad de Poyo (1617-1621) ${ }^{107}$.

Fr. Andrés de Esparza. Era profeso de San Isidro de Dueñas, Abadía en la que fue Regente de estudios, al tiempo que era Definidor general (1617-1621), y dos veces Abad (1614-1617; 1629-1631), cargo en el que murió. Había sido Lector de Artes (1604-1607) y de Teología (1607-1613) de Samos, así como Lector en Irache (1613-1614), donde recibió los grados. Fue Abad en Ribas de Sil (1621-1625) y durante su Abadiato se hizo la biblioteca del Monasterio. Fue también Definidor general juez de la Congregación (1625-1629) ${ }^{108}$.

Fr. Pedro Marín. Era natural de Enciso (La Rioja) y profeso en Nájera, en 1595. Fue Lector de Ribas de Sil (1604-1610), donde escribió un curso de Filosofía. Recibió en Irache los grados de B. A. / M. A. / B. T. / M. T. Fue Prior de Salamanca, tres veces Abad de Nájera (1621-1625, 1629-1633, 1637-1641), y otras tres Definidor general (1625-1629, 1633-1637, 1641-1645). Falleció en 1642, con muy buena fama ${ }^{109}$.

Fr. Juan de Victoria. Al parecer, era profeso de Montserrat, y perteneció a la expedición que mandó esta Abadía para fundar en México y Lima. Embarcó en Barcelona el 27 de noviembre de 1598. Después de su estadía en Lima, regresó a la Península Ibérica y recibió en Irache todos los grados de Filosofía y Teología el 6 de mayo de $1614^{110}$.

Fr. Luis Flores. Llamado también Luis Flórez. Profeso en Sahagún, tomó el hábito en 1591. Fue Lector de Artes (1610-1613), Maestro de estudiantes (1613-

106 E. Zaragoza Pascual, “Abadologio de Valvanera”, p. 353; E. Zaragoza Pascual, Abaciologi de Sant Feliu de Guíxols, pp. 40-41.

107 E. Zaragoza Pascual, "Profesores de Irache”, p. 309; E. Zaragoza Pascual, “Abadologio de Poyo", p. 406.

108 E. Zaragoza Pascual, “Abadologio de Ribas de Sil”, p. 380; E. Zaragoza Pascual, “Abadologio de Dueñas”, pp. 142-143.

109 E. Zaragoza Pascual, “Abadologio de Nájera”, p. 137.

110 E. Zaragoza Pascual, "Monjes de Montserrat”, p. 344; E. Zaragoza Pascual, Los Generales..., Vol. 3, pp. 206-209. 
1617) y Regente (1621-1623) del Colegio de Salamanca. Fue Lector de Tercia de Teología de Irache (1617-1621), en la que recibió todos los grados de Artes y Teología en 1614. Fue Abad de Valvanera (1624-1625), Eslonza (1625-1629) y Sahagún (1632-1637), así como Maestro general y un orador muy reputado ${ }^{111}$.

Fr. Plácido Rodríguez. Conocido también como Plácido Rodríguez de Lima. Era natural de Puente de Barca (Portugal) y monje profeso de San Martín Pinario desde 1594. Recibió todos los grados de Artes y Teología en 1614. Fue Abad de Obarenes (1621-1625) y Santiago (1629-1633). Se desempeñó como Catedrático de Prima de Teología (1631-1633) de la Universidad de Santiago de Compostela. Se dice que hubo polémica porque incorporó los grados obtenidos en Osma; creemos que debió incorporar los de Irache. Al parecer, escribió un Memorial sobre el uso de la cogulla con mangas (Madrid, 1636), que no hemos podido consultar, de cara al pleito que la Congregación sostuvo contra los monjes basilianos acerca del uso exclusivo de la cogulla ampla et manicata, un tema que dio mucho de sí en la ciencia monástica del siglo XVII ${ }^{112}$.

Fr. Francisco de Lerma. Natural de Burgos, profesó en el cenobio de San Juan Bautista de su ciudad. Recibió todos los grados en Irache en 1615. Fue Predicador general de la Congregación, Abad de San Juan Bautista (1625-1629) y murió, siendo Definidor general, el 17 de septiembre de $1630^{113}$.

Fr. Alonso de Barrantes. Profesó en Carrión de los Condes, fue Maestro de estudiantes en Ribas de Sil, Predicador en Carrión, Definidor general y finalmente Abad de Carrión (1601-1607 y 1610-1613), año en el que fue elegido General de la Congregación (1613-1617). Como tal recibió todos los grados en Irache, en 1616. Fue Definidor general y, en 1625, fue elegido Abad de Sopetrán (Guadalajara), aunque en 1627 renunció a su cargo. Falleció en Madrid el 15 de mayo de $1627^{114}$.

Fr. Alonso de Vítores. Nació en Burgos en 1580. Tras estudiar Cánones en Salamanca, tomó el hábito benedictino en San Juan Bautista de Burgos, en 1596. Fue Predicador en Nájera (1607-1610), San Juan de Burgos (1610-1613) e Ira-

111 E. Zaragoza Pascual, "Profesores de Salamanca”, pp. 294-295; E. Zaragoza Pascual, “Abadologio de Sahagún”, p. 130.

112 E. Zaragoza Pascual, "Abadologio de Obarenes”, p. 35; V. Beltrán de Heredia, "La Facultad de Teología de Santiago”, p. 231; E. Zaragoza Pascual, “Abadologio de San Martín Pinario", p. 223.

113 E. Zaragoza Pascual, “Abadologio de Burgos”, pp. 368-369.

114 E. Zaragoza Pascual, Los Generales..., Vol. 4, pp. 33-58; E. Zaragoza Pascual, “Abadologio de Carrión de los Condes...”, p. 295. 
che, donde residió también como Definidor y Predicador general (1625-1629). En 1617, recibió todos los grados en Irache. Fue Abad de San Vicente de Salamanca (1629-1633), Abad general de la Congregación de Valladolid (1633-1637), y Abad de San Martín de Madrid (1645-1649). Fue Predicador del Rey desde 1632, aunque sin salario. Escribió El Sol de Occidente (Madrid, 1645-1647) en dos tomos, en los que demostró, entre otros puntos, que la cogulla talar y manicata era la propia del hábito de los benedictinos. Luego fue Obispo de Almería, Orense y Zamora. Falleció en Zamora en $1660^{115}$.

Fr. Mauro García de Mendoza. Fue Lector segundo de Dueñas (1613-17) y en Irache se desempeñó como Lector segundo (1617-1621) y, más adelante, como vicecanciller (1621-1625) de Irache. En esa Universidad recibió todos los grados en $1617^{116}$.

Fr. Antonio de Castro. Conocido también como Antonio Fernández de Castro, fue hijo ilegítimo del Conde de Lemos. Nació hacia 1580, estudió en Sopetrán y profesó en Oña. Fue Abad de San Pedro de Montes (1610-1613); nombrado Definidor en el Capítulo de 1613, y General de la Orden para España e Inglaterra (1617-1621), cargo con el que recibió todos los grados en Irache en 1618. Fue Abad de San Martín de Madrid (1621-1625), Abad de Oña (1633-1635, 1645-1649) y de Irache (1637-1641). Falleció en $1651^{117}$.

Fr. Bernardo de Seija. Natural de Puentedeume (Santiago), profesó en San Martín Pinario en 1597. Fue Maestro en Samos (1610-1623), Lector segundo (1617-1621) y Regente de estudios (1621-1625) en Poyo. Se graduó en Irache en 1618. Fue Catedrático de Prima de Teología de la Universidad de Santiago desde 1623 hasta 1630, año de su fallecimiento ${ }^{118}$.

Fr. Mauro de Villarroel. Natural de Tordesillas, profesó en Lorenzana, en 1597. Estudió Filosofía en Irache y Teología en San Vicente de Salamanca. Se graduó en Irache en 1619. Ocupó distintos varios cargos docentes en los Colegios de la Congregación y fue Abad de Lorenzana (1613-1617; 1621-1625), y Ribas de Sil (1629-1631), así como General de la Congregación (1631-1633), lapso que de-

115 E. Zaragoza Pascual, “Abadologio de Burgos”, p. 368; F. Negredo del Cerro, Los Predicadores de Felipe IV, Madrid, Actas, 2006, p. 460.

116 E. Zaragoza Pascual, "Profesores de Irache", p. 310.

117 E. Zaragoza Pascual, Los Generales..., Vol. 4, pp. 59-69; E. Zaragoza Pascual, "Abadologio de Irache", p. 183.

118 V. Beltrán de Heredia, "Benedictinos en Santiago", p. 266; E. Zaragoza Pascual, “Profesores en Samos”, p. 773. 
dicó muy especialmente al gobierno de los monjes ingleses dependientes de la congregación vallisoletana, y a la erección de los Monasterios de Viena y Bezděz (República Checa), dedicados ambos a Ntra. Sra. de Montserrat. Fue nombrado Abad de San Vicente de Salamanca en 1635 y luego Obispo de Jaca en 1636, ciudad en la murió en $1646^{119}$.

Fr. Hernando Enríquez. Seguramente era profeso de Arlanza. Era Lector de Artes de Irache (1617-1621), cuando se graduó de B. A. / B. T. en 1620. Fue Maestro de Estudiantes en Irache (1621-1625), Abad de Arlanza (1629-1633) y Definidor general (1633-1637)

Fr. Francisco Muñoz. Profeso en Valladolid, fue Lector de Teología en Samos (1613-1617), en Poyo (1617-1621) y luego Abad de Poyo (1621-1625) y Regente de Pasantes (1629-1633). Se graduó en Irache en 1621. Fue asimismo Maestro general y Abad de Tenorio (1641-1645)

Fr. Andrés González de Villa y Arellano. Más conocido como Andrés de Villa, profesó en Valladolid en 1597. Fue Lector de Teología en Poyo (1617-1620), Maestro de Estudiantes de Irache (1620-1621), donde se graduó en 1621, y Lector de Teología en Oviedo (1621-1625), Visitador general (1637-1641), así como Abad dos veces de Valladolid (1625-1629 y 1645-1646) ${ }^{122}$.

Fr. José Somelino. Procedente de Montecassino, recibió todos los grados el 27 de mayo de 1622, de manos de Fr. Antonio Cornejo.

Fr. Francisco de Acebedo. También conocido como Francisco de Acevedo, era natural de Mondoñedo y profeso de San Martín Pinario, donde había tomado el hábito en 160o. Fue Pasante en San Julián de Samos, se graduó de L. T. / M. T. en Irache en 1622 y fue Abad de Obarenes (1625-1629) ${ }^{123}$.

Fr. Agustín de Benavente. Nació en Medina del Campo en 1580 y tomó el hábito en Valladolid en 1596. Fue Pasante (1610-1613), Prior de Irache (1614-1617),

119 E. Zaragoza Pascual, Los Generales..., Vol. 4, pp. 123-131; E. Zaragoza Pascual, “Abadologio de Lorenzana”, p. 193.

120 E. Zaragoza Pascual, “Abadologio de Arlanza”, p. 100; E. Zaragoza Pascual, "Profesores en Irache", p. 310.

121 E. Zaragoza Pascual, “Abadologio de Poyo”, p. 406.

122 E. Zaragoza Pascual, “Abadologio de Valladolid”, p. 235.

123 E. Zaragoza Pascual, “Abadologio de Obarenes”, pp. 35-36; E. Zaragoza Pascual, "Profesores en Samos”, pp. 773-774. 
Abad de Frómista (1618-1621) y Predicador de diversos cenobios. Fue Abad de Valladolid (1629-1633, 1646), San Juan de Poyo (1637-1641) y Definidor general (1633-1637). Graduado en Irache en 1624, según Zaragoza, fue Catedrático de la Universidad de Valladolid y consultor de la Inquisición. Fue autor de la obra mística Luzes de Dios, resplandor de las Llagas de Christo Señor nuestro (Valladolid, 1647), en dos volúmenes ${ }^{124}$.

Fr. Juan de Jaraba. Procedente de Montserrat, donde había tomado el hábito en 1609, recibió los grados de L. A. / M. A. / L. T. / M. T. en Irache, en 1624. Fue Abad de Alaón desde 1633 hasta 1651, año de su fallecimiento. Fue Presidente de la Congregación benedictina (1636) y participó en las Cortes aragonesas ${ }^{125}$.

Fr. Pedro Luis de Santa Fe Otamendi. Profeso en Montserrat en 1610, recibió en Irache todos los grados el 15 de agosto de 1625. Fue Abad de Bages (1617-1621), Alaó (1629-1632) y San Juan de la Peña. Murió el 19 de agosto de $1638^{126}$.

Fr. Francisco de Borja. Profeso en Sahagún, era hijo de Juan de Vega, primer Conde de Grajal y de Tomasa Enríquez de Borja, descendiente de San Francisco de Borja. Fue profesor de Teología en Salamanca, y se graduó en Irache en 1625. Fue nombrado Predicador real sin gajes en 1633. Fue Arzobispo de Charcas (Bolivia) y falleció en $1635^{127}$.

Fr. Miguel de Luján. Era madrileño, pero había tomado el hábito en San Martín Pinario en 1610, cenobio en el que fue Lector, Predicador mayor (1625-1629), y dos veces Abad (1645-1649 y 1657-1661). Fue Maestro de estudiantes en Irache, y recibió todos los grados en Teología en 1626. Fue también Abad de El Espino (1637-1641), Definidor y Predicador general. Falleció en $1664^{128}$.

Fr. José de Carmona. También conocido como José Delgado de Carmona, era natural de Belorado (Burgos) y tomó el hábito en Nájera en 1610. Fue Lector

124 E. Zaragoza Pascual, “Abadologio de Frómista”, pp. 148-149; E. Zaragoza Pascual, “Abadologio de Valladolid”, pp. 235-236.

125 J. I. Gómez Zorrazquino, Patronazgo y clientelismo: Instituciones y ministros reales en el Aragón de los siglos XVI y XVII, Zaragoza, Universidad de Zaragoza, 2016, p. 553; E. Zaragoza Pascual, "Monjes de Montserrat”, p. 347.

126 E. Zaragoza Pascual, "Monjes de Montserrat", p. 347; E. Zaragoza Pascual, Catàleg dels monestirs catalans, pp. 16 y 29.

127 J. Ibarra Murillo, Historia..., p. 290; F. Negredo del Cerro, Los Predicadores de Felipe IV, pp. 442-443.

128 E. Zaragoza Pascual, “Abadologio de San Martín Pinario”, p. 224. 
y Regente de Estudios (1629-1633) en Irache, donde recibió todos los grados de Teología en 1626. Fue Abad de Oviedo (1633-1637), Regente de estudios en Salamanca (1637-1641) y Abad de Espinareda (1641-1645), así como Definidor y Maestro general. Murió en Nájera en $1647^{129}$.

Fr. Plácido de Urbina. Profeso de Valladolid, fue Lector de Artes en Irache (1617-1625), donde recibió todos los grados en 1627. Fue Lector de Artes (16251633) y Regente de Estudios (1633-1637) de Poyo, Abad de Lemos (1641-1644 y 1654-1657), de Espinareda (1645-1649) e Irache (1657-1561). Fue calificador de la Inquisición y dejó manuscrito un Defensorio de las inmunidades y essenciones de la Religion de San Benito (AHN). Murió hacia $1670^{130}$.

Fr. Martín de Riaño. Natural de Burgos, hijo de una familia noble, había tomado el hábito en San Juan Bautista, en 1603. Fue profesor en los Colegios de Ribas de Sil, Irache y Oviedo. Siendo Regente del Colegio de Oviedo recibió todos los grados en Irache, en 1628. Fue Abad de San Juan de Burgos (1629-1633 y 1637-1641), de Sopetrán (1645-1649), Predicador del Rey y Predicador general de la Congregación, en cuyo cargo murió en Burgos, en $1649^{131}$.

Fr. Mauro de Tobar. Conocido también como Mauro de Tovar y Valle, nació en Villacastín en 1586. Tomó el hábito en Valladolid en 1600 y estudió en Irache. Fue Predicador de diversos Monasterios. Recibió los grados en Irache en 1629. Fue Abad de Monforte de Lemos (1629-1633), Valladolid (1633-1637), y Predicador real. Felipe IV lo presentó para el obispado de Caracas y fue consagrado en 1639. Rigió esa diócesis hasta que fue nombrado Obispo de Chiapas, donde residió hasta su muerte, acaecida en $1666^{132}$.

Fr. Gregorio Parcero de Castro. Nacido en Tuy en 1566, tomó el hábito en San Martín Pinario en 1590. Estudió en Ribas de Sil y Salamanca, y enseñó en la Universidad de Irache, en la que recibió el grado de M. T. en 1629. Fue Abad de San Vicente de Oviedo (1607-1610 y 1613-1617) y San Martín Pinario (1621-1625). Ese año fue fue electo Abad general de la Congregación de Valladolid (1625-1629), etapa en la que logró que Roma confirmara la unión de la Congregación benedic-

129 E. Zaragoza Pascual, "Profesores de Irache”, pp. 310-311; E. Zaragoza Pascual, "Profesores de Salamanca”, pp. 296-297.

130 E. Zaragoza Pascual, "Abadologio de Espinareda”, pp. 222-223; E. Zaragoza Pascual, “Abadologio de Irache”, p. 184.

131 E. Zaragoza Pascual, "Abadologio de Burgos”, p. 369; E. Zaragoza Pascual, “Abadologio de Sopetrán”, p. 233; F. Negredo del Cerro, Los Predicadores de Felipe IV, p. 456.

132 E. Zaragoza Pascual, “Abadologio de Valladolid”, pp. 236-237. 
tina inglesa a la vallisoletana. En 1629 fue nombrado Abad de San Martín de Madrid, y luego Obispo de Elna (1631-1634), Gerona (1634-1655) y Tortosa (16551663). Murió en Tortosa en 1663, a los 97 años $^{133}$.

Fr. Plácido de Salazar. Natural de Palencia, tomó el hábito en Nájera en 1608, y presentándose como Catedrático en la Universidad de Oviedo, pasó a la de Irache para recibir todos los grados en 1629. Tras haber sido Lector del Colegio de Ribas de Sil y Procurador general de la Congregación en Roma (1639-1641), fue Abad de Nájera (1641-1645) y de San Vicente de Salamanca (1645-1649). Murió siendo Definidor general el 6 de mayo de $1649^{134}$.

Fr. Francisco de Lemos. Natural de Madrid, tomó el hábito en Carrión en 1614, y siguió la carrera del púlpito. Llegó a ser calificador de la Inquisición y Predicador general de la Congregación. Recibió todos los grados en la Universidad de Irache, en 1629. Fue dos veces Abad de Carrión (1637-1641 y 1645-1649), así como un prolífico escritor. Dejó manuscritos tres tomos De Angelis, y publicó el primer tomo de Threnodus Ieremias (Madrid, 1649). El segundo tomo quedó manuscrito. Falleció en $1654^{135}$.

Fr. Gregorio de Sámano. Era hijo natural de Gregorio de Sámano, Caballero de la Orden de San Juan. Tomó el hábito en Valladolid en 1605, estudió en Irache, y luego fue Abad de Zamora (1621-1625, 1632-1633, 1644-1646) y de Monforte de Lemos (1633-1634). Recibió todos los grados en Irache en 1629. Fue Predicador general $(1649-1653)^{136}$.

Fr. Juan Díaz de Lavandero. Natural de Boadilla del Camino, ingresó en San Zoilo de Carrión de los Condes en 1692. Fue profesor de Artes en San Vicente de Oviedo y fue Abad de San Zoilo en tres ocasiones (1607-1610, 1613-1617 y 16211625). Fue elegido General de la Congregación "de España e Inglaterra” y, como tal, recibió todos los grados en Irache, en 1629. Falleció repentinamente en 1631 en San Zoilo ${ }^{137}$.

Fr. Antonio de Salinas. Natural de Burgos e hijo de una ilustre familia. Tomó

133 E. Zaragoza Pascual, Los Generales..., Vol. 4, pp. 103-115; E. Zaragoza Pascual, “Abadologio de San Martín Pinario”, pp. 221-222.

134 E. Zaragoza Pascual, "Profesores de Oviedo", p. 330.

135 E. Zaragoza Pascual, “Abadologio de San Zoilo”, p. 298.

136 E. Zaragoza Pascual, "Abadologio de Valladolid”, p. 239; E. Zaragoza Pascual, "Abadologio de Zamora”, p. 369.

137 E. Zaragoza Pascual, Los Generales..., Vol. 4, pp. 117-121. 
el hábito en el cenobio de San Juan Bautista de su ciudad natal, el 13 de octubre de 1596. Fue Predicador de Valladolid (1610-1613), Abad de Burgos (1613-1617), Predicador general y Procurador de la Congregación en Roma (1625-1629). Recibió todos los grados de Artes y Teología en Irache en $1630^{138}$.

Fr. José Valle de la Cerda. Nacido en Cuenca en 1601, era hijo de Luis Valle de la Cerda, Contador mayor del Consejo de la Santa Cruzada y de Luisa de Alvarado. Tras estudiar en la Universidad de Alcalá, tomó el hábito en San Martín de Madrid, en 1618. Estudió Filosofía en Ribas de Sil y Teología en San Vicente de Salamanca, de donde fue Abad (1635-1637). Fue Catedrático de Santo Tomás (1634-1635), y de Prima de Teología (1636-1637) en la Universidad de Salamanca. Fue Obispo de Almería (1637-1639) y de Badajoz (1639-1644). Murió en Zafra en 1644. Escribió con profundidad teológica sobre diversos temas y fue un ardiente defensor de la Inmaculada. Dio a las prensas varios tratados teológicos. Quizás el más interesante sea Maria effigies, revelatioque Trinitatis et atributorum Dei (Salamanca, 1640), reimpreso a lo largo del siglo XVII ${ }^{139}$.

Fr. Matías de Hevia. Tras tomar el hábito en San Martín Pinario en 1616, fue Lector en Irache (1629-1633), donde se graduó en Artes y Teología en 1631. Luego fue Lector (1637-1641, 1645-1646) y Abad (1637-1641) de Salamanca, así como opositor a la cátedra de Santo Tomás de la Universidad salmantina en 1635. Murió en Salamanca en $1646^{140}$.

Fr. Plácido de Bárcena. Profeso en San Benito de Valladolid en el Abadiato de Alonso de Corral (1601-1604), era B. T. por la Universidad de Valladolid. Recibió los títulos de Teología en Irache, en $1631^{141}$.

Fr. Antonio de Escaules. Natural de Abbeville (diócesis de Amiens), tomó el hábito en Montserrat el 11 de noviembre de 1620. Se graduó de Artes y Teología en la Universidad de Irache en 1633. Murió en 1638, siendo Catedrático de Lenguas en la Universidad de Salamanca ${ }^{142}$.

138 E. Zaragoza Pascual, “Abadologio de Burgos”, p. 368.

139 J. Barrientos García, La Facultad de Teología de la Universidad de Salamanca a través de los libros de visitas de cátedras (1560-1641), Madrid-Porto, Sindéresis, 2018, pp. 297 y 550-551; E. Zaragoza Pascual, "Profesores de Salamanca”, p. 296.

140 E. Zaragoza Pascual, "Profesores de Irache”, p. 311; J. Barrientos García, La Facultad de Teología..., pp. 553-554.

141 E. Zaragoza Pascual, "Profesos de Valladolid", p. 101.

142 E. Zaragoza Pascual, "Monjes de Montserrat”, p. 348. 
Fr. Francisco Salvador. Natural de Lumbreras (La Rioja), tomó el hábito en Sahagún en 1614. Estudió en los Colegios de Ribas de Sil (Orense) y de San Vicente de Salamanca. Fue Lector de Filosofía en Celorio (1625-1629), y luego de Teología en Irache (1629-1633), donde se graduó en 1633. Fue Regente de estudios de Irache (1633-1637) y también en el Colegio de Oviedo (1637-1641). Fue Catedrático de Sagrada Escritura en la Universidad de Oviedo (1638-1641). Fue Abad de Sahagún (1645-1649), Abad general de la Congregación (1649-1653) y finalmente Abad de San Martín de Madrid (1653-1654), donde murió en 1654 ${ }^{143}$.

Fr. Jerónimo de Pereira. Natural de Redondela (Pontevedra), profesó en San Martín Pinario en 1596 y recibió todos los grados de Artes y Teología en Irache, en 1633. Fue Abad de Lérez (1629-1633) y siguió la carrera del púlpito. Fue Predicador en distintos Monasterios, y falleció en Nájera, siendo ya Predicador general ${ }^{144}$.

Fr. Gabriel de la Riba de Herrera. Natural de Santander, ingresó en 1603 en San Isidro de Dueñas. Estudió en Samos y en Salamanca. Fue Lector de Artes en Oña (1617-1621) y desde 1621 a 1625, Predicador mayor. Fue Abad de San Isidro de Dueñas (1625-1629) y de Irache (1633-1637). Se graduó de Artes y Teología a comienzos de su Abadiato. Desde 1637 a 1641 fue Definidor general y, de 1641 a 1645, Abad general de la Congregación. Luego fue Abad de Nájera (1645-1649) y Definidor (1649-1653). Rehusó el Abadiato de Irache en 1653 y se retiró a Oña, donde murió al año siguiente ${ }^{145}$.

Fr. Pedro de Pazos. Profeso en el Monasterio de Cardeña en 1613, había sido Vicecanciller y Lector de Teología (1629-1633) de Irache, donde recibió todos los grados de Filosofía y Teología, en 1633. Fue Maestro de estudiantes del Colegio de San Vicente de Oviedo (1637-1641) ${ }^{146}$.

Fr. José Amunárriz. Según Ibarra se llamaba José Amunarriz y Vargas. Era profeso de Nájera y Predicador. Recibió todos los grados de Artes y Teología en Irache, en $1633^{147}$.

143 E. Zaragoza Pascual, Los Generales..., Vol. 4, pp. 195-201. V. Beltrán de Heredia, “Teología en Oviedo”, p. 428; E. Zaragoza Pascual, “Abadologio de Sahagún”, p. 131.

144 E. Zaragoza Pascual, "Abadologio de Lérez”, p. 417.

145 E. Zaragoza Pascual, Los Generales..., Vol. 4, pp. 161-168; E. Zaragoza Pascual, "Abadologio de Irache”, pp. 182-183.

146 E. Zaragoza Pascual, "Profesores de Oviedo", p. 331; J. Ibarra Murillo, Historia..., p. 332.

147 J. Ibarra Murillo, Historia..., p. 284. 
Fr. Martín Martínez. Natural de Alesón (La Rioja), tomó el hábito en San Millán de la Cogolla en 1602. Tras cursar los estudios de Filosofía y Teología en los Colegios de la Congregación, fue Lector y Predicador de algunos de ellos. Habiendo muerto el Cronista general de la Congregación, fue designado como tal en 1633. Se graduó de Artes y Teología en Irache, en 1633, y fijó su residencia en Valladolid, donde falleció en 1635. Varias de sus obras se publicaron póstumamente $^{148}$.

Fr. Antonio de Torres. Profeso en San Martín Pinario, obtuvo los grados de Artes y Teología en Irache, en 1633.

Fr. Ramiro de Goñi. Era natural de Viana, y había profesado en Irache, en cuya Universidad fue Secretario (1613), Lector (1617-1625), Maestro de Estudiantes (1625-1629) y Abad (1629-1631). Se graduó de M. T. en 1633. Murió hacia $1650^{149}$.

Fr. Miguel de Barreda. También conocido por Miguel de Barrera (o de la Barrera). Era hijo del Monasterio de Oña. Siendo Predicador general, se graduó en la Universidad de Irache en 1633. Fue Catedrático de Artes en la Universidad de Oviedo (1630-1637), Regente de estudios del Colegio de Eslonza (1637-1641), Procurador general de la Congregación en Roma (1641-1645) y Abad de Corias (1669-1673). Murió en San Vicente de Oviedo ${ }^{150}$.

Fr. Francisco de Vega y Vargas. Natural de Medina del Campo, tomó el hábito en Valladolid en 1602. Fue Abad de Frómista (1621-1625), Zamora (1641-1644), Oviedo (1645-1649), Rector del Colegio de Infantes de Valladolid (1633-1637 y 1644-1645), Abad de Valladolid (1637-1641 y 1653-1657). Se graduó en la Universidad de Irache en 1633. Dejó algunos escritos sin publicar y murió en $1659^{151}$.

Fr. Francisco Cambero. Natural de Alfaro (La Rioja), tomó el hábito en Santiago. Fue Regente en Poyo (1629-1633), y Lector y Regente de estudios de Irache, donde recibió todos los grados de Filosofía y Teología en 1633. Luego fue Lector en Espinareda, Maestro general de la Congregación y examinador sinodal de Santiago ${ }^{152}$.

148 E. Zaragoza Pascual, Los Generales..., Vol. 4, pp. 432 y 501.

149 E. Zaragoza Pascual, "Abadologio de Irache”, p. 182.

150 E. Zaragoza Pascual, "Abadologio de Corias”, p. 158; V. Beltrán de Heredia, "La Facultad de Teología de Oviedo”, p. 158.

151 E. Zaragoza Pascual, "Abadologio de Valladolid”, p. 237.

152 E. Zaragoza Pascual, "Profesores de Irache”, p. 311; E. Zaragoza Pascual, "Profesores de Poyo", p. 762. 
Fr. Gaspar Tapia. También conocido por Gaspar Tàpies, nació en Vic y profesó en Montserrat en 1618. Recibió todos los grados de Artes y Filosofía en Irache, en 1633. Fue Abad de Bages (1637-1641) y falleció en $1684^{153}$.

Fr. Francisco Maluenda. Natural de Burgos, hijo de una destacada familia, tomó el hábito en San Juan en 1607, y siguió la carrera del púlpito. Fue Lector de Teología de la Universidad de Irache, donde se graduó en 1634, y luego fue Abad de San Juan de Burgos (1634-1637), de Eslonza (1641-1645) y Definidor general (1645-1649). Falleció en San Juan de Burgos, en $1665^{154}$.

Fr. Antonio de Venegas. Natural de Córdoba, profesó en Samos y siguió la carrera del púlpito hasta ser Predicador general. Se graduó en Irache en 1634 . Fue Abad de Valvanera (1633-1637), San Pedro de Villanueva (1640-1641), San Juan de Poyo (1645-1649) y Celorio (1653-1654). Fue mayordomo del Colegio de Salamanca (1649-1653). No se sabe si murió en Córdoba o en Granada ${ }^{15}$.

Fr. Íñigo de Castañiza. Natural de Boadilla del Camino (Palencia), era sobrino del venerable Fr. Juan de Castañiza. Tomó el hábito en Oña, de donde fue Abad (1627-1629), y en Celorio (1637-1641), donde murió hacia 1642. Había sido Predicador en Huete y en Oña. Recibió los grados de Artes y Teología en la Universidad de Irache en $1634^{156}$.

Fr. Francisco Palomino. Era natural de Casaseca de las Chanas (Zamora) y tomó el hábito en Nájera en 1603. Siguió la carrera del púlpito y fue Predicador de diversos monasterios. Recibió todos los grados en Irache, en 1635. Fue Prior (1625-1633) y Abad (1633-1637) de Nájera, donde murió, siendo Definidor general, en 1641. Fue Predicador real de Felipe IV y Carlos II ${ }^{157}$.

Fr. Diego Ponce de León. Nació en Sevilla en 1593, en una familia noble. Fue Catedrático de Cánones de la Universidad de Salamanca y, con posterioridad, tomó el hábito benedictino en Corias, en 1623. Se graduó de Artes y Teología en Irache, en 1635. Fue Abad de San Benito de Sevilla (1637-1638) y Cronista general de la Congregación. Para poder dedicarse por completo a esta tarea, renunció a la

153 E. Zaragoza Pascual, Catàleg dels monestirs catalans, p. 29; E. Zaragoza Pascual, “Monjes de Montserrat”, pp. 347-348.

154 E. Zaragoza Pascual, "Abadologio de Burgos”, p. 369.

155 E. Zaragoza Pascual, “Abadologio de Valvanera”, p. 356.

156 E. Zaragoza Pascual, “Abadologio de Celorio”, pp. 120-121.

157 E. Zaragoza Pascual, “Abadologio de Nájera”, pp. 137-138; F. Negredo del Cerro, Los Predicadores de Felipe IV, p. 454. 
Abadía de Sevilla y se trasladó a Valladolid. Fue elegido dos veces Abad de Corias (1645-1649, 1661-1665) y una de San Vicente de Oviedo (1653-1657). Falleció en Corias en 1678. Dejó muchos trabajos manuscritos ${ }^{158}$.

Fr. Plácido Maldonado. Solamente sabemos que se graduó de B. A. / B. T. en Irache el 23 de abril de 1636 y que había sido predicador de Irache desde 1625 .

Fr. Pedro Díaz de Inguanzo. Profeso en Samos, fue Prior (1633-1637), y Lector en la Universidad de Irache, en la que recibió todos los grados en 1637. Fue Regente de estudios en Poyo (1637-1645) y Espinareda (1645-1647), y dos veces Abad de Samos (1647-1649, 1653-1656) y una de Poyo (1661-1665). Fue Maestro general de la Congregación ${ }^{159}$.

Fr. Plácido del Río. Era natural de Palencia y profesó en San Zoilo. Fue Predicador (1629-1633), Lector de Teología en Irache (1634-1637), donde se graduó en 1637, Regente de estudios de Salamanca (1637-1641), Abad de Carrión de los Condes (1641-1645 y 1649-1653) y Regente de Pasantes de Eslonza (1645-1649). Finalmente, fue Abad de San Pedro de Montes (1661-1663), donde murió en $1663^{160}$.

Fr. Miguel de Andueza. Probablemente era de Logroño, y tomó el hábito en San Millán en 1607, cenobio del que fue dos veces Abad (1637-1641 y 1645-1649) y una de Obarenes (1653-1657). Se había graduado en Artes y Teología en Irache en 1637. Fue Definidor general (1649-1653) y calificador de la Inquisición ${ }^{161}$.

Fr. Juan Manuel de Espinosa. Nacido en Sevilla en 1598, tomó el hábito, con su hermano Luis, en Montserrat, en 1619. Estudió en Irache, Salamanca y Eslonza. Recibió los grados de Teología en Irache, en 1637, y fue nombrado Abad de Montserrat (1637-1641). Los monjes catalanes expulsaron de Montserrat a los castellanos y al Abad, que tomó posesión de un nuevo Monasterio en Madrid para los monjes expulsos (1641-1645). Fue nombrado, en 1645, General de la Congregación y Abad de Salamanca. Fue Abad del nuevo Monasterio de Montserrat de Madrid (1649-1653). Visitó, en 1653, la Abadía catalana de Montserrat y fue pre-

158 E. Zaragoza Pascual, “Abadologio de Sevilla”, p. 390; E. Zaragoza Pascual, “Abadologio de Oviedo", p. 152.

159 J. Ibarra Murillo, Historia..., p. 304; E. Zaragoza Pascual, "Abadologio de Poyo", pp. 410-411.

160 E. Zaragoza Pascual, “Abadologio de Carrión de los Condes”, p. 298; E. Zaragoza Pascual, "Profesores de Salamanca”, p. 297.

161 E. Zaragoza Pascual, “Abadologio de San Millán”, p. 206. 
sentado para la mitra de la Seo de Urgel, de la que no pudo tomar posesión hasta 1660. En 1663 fue presentado para el Arzobispado de Tarragona, donde tomó posesión y murió en $1679^{162}$.

Fr. Alonso Gadea. Natural de Toledo, tomó el hábito en Montserrat. Recibió todos los grados de Teología en Irache, en $1637^{163}$.

Fr. Diego de Sandoval. Natural de Valladolid, tomó el hábito en Sahagún en 1621 y siguió la carrera del púlpito. Se graduó en Irache, en 1637. Fue nombrado Predicador general en 1653, así como Abad de Espinareda (1653-1657), Definidor general (1657-1661), Abad electo de San Feliu de Guíxols, renunció al cargo porque no pudo tomar posesión debido a la Guerra. Murió siendo Abad de San Mancio en $1674^{164}$.

Fr. José de Porrasa. Natural de Barcelona, tomó el hábito en Montserrat en 1589. Fue Abad de Bages (1614-1617 y 1629-1633), Montserrat (1633-1635) y Arles (1635-1644). Como “Abad perpetuo de Arles, del Consejo de su Majestad”, recibió todos los grados de Artes y Teología en Irache, en 1637. Murió en Elna en $1644^{165}$.

Fr. Diego de Silva y Pacheco. Probablemente era hijo bastardo del Conde de Cifuentes. Nacido en Santiago en 1606, a los 13 años ingresó en el Colegio de Infantes de San Benito de Valladolid, aunque tomó el hábito en el Monasterio de San Juan de Burgos en 1622. Fue Lector de Vísperas, Regente y Lector de Prima en Irache, donde se graduó en 1638. Fue Regente de Eslonza (1649-1653), Abad de San Juan de Burgos (1645-1649), Lector de Teología del Colegio de Salamanca (1653-1654), Abad de San Martín de Madrid (1654-1657, 1661-1665), Abad general de la Congregación (1657-1661) y Obispo de Guadix (1668-1675) y, por último, de Astorga (1675-1677), donde murió en mayo de 1677. Fue Predicador de Felipe IV. Publicó Commentaria literalia, moralia, mystica in Genesim (Madrid, 1666); cuatro volúmenes de Commentaria theologica a la Summa de Santo Tomás de Aquino (Madrid, 1663-1671); e Historia de la Imagen Sagrada de Ntra. Sra. de Valvanera (Madrid, 1665) ${ }^{166}$.

162 E. Zaragoza Pascual, Los Generales..., Vol. 4, pp. 169-188.

163 E. Zaragoza Pascual, “Monjes de Montserrat”, p. 348.

164 E. Zaragoza Pascual, "Abadologio de Espinareda”, p. 223.

165 E. Zaragoza Pascual, "Monjes de Montserrat”, p. 344; E. Zaragoza Pascual, Catàleg dels monestirs catalans, p. 24, 29 y 156.

166 A. Pérez Goyena, "La literatura teológica española...”, pp. 48-49; E. Zaragoza Pascual, Los Generales..., Vol. 4, pp. 213-226; E. Zaragoza Pascual, "Profesores de Irache”, pp. 311-312; F. Negredo del Cerro, Los Predicadores de Felipe IV, p. 460. 
Fr. Martín Izquierdo. Tomó el hábito en San Millán de la Cogolla y profesó en 1617. Fue Predicador de San Millán (1625-1629), Lector (1637-1645), Regente (1645-1649) y Abad de Irache (1649-1653), donde recibió todos los grados de Artes y Teología en 1638. Fue Definidor general $(1653-1657)^{167}$.

Fr. Diego de Marcilla. Tomó el hábito en 1618 en San Millán de la Cogolla, y fue Maestro de estudiantes de Oviedo (1629-1637). Fue nombrado Maestro de estudiantes en Irache, donde recibió todos los grados en 1638. Murió joven, siendo Regente de Irache, en $1647^{168}$.

Fr. Francisco Crespo. Nació en Calatayud y tomó el hábito en 1624 en Montserrat. Fue Lector de Irache desde 1637 a 1649. Recibió todos los grados de Artes y Teología en 1638. Fue Regente segundo y Abad de Eslonza (1649-1653), Visitador general (1653-1657), Abad de Montserrat (1653) y de Bages (1657-1660), Abad perpetuo de San Victorián de Asán, en Huesca (1660-1668) y Presidente de la Provincia benedictina claustral de Aragón y Navarra (1664-1668). Fue un fecundo escritor y un defensor acérrimo de la Inmaculada Concepción, especialmente en su obra Tribunal thomisticum de Immaculato Deiparae Conceptu (Barcelona, 1657). Murió en $1668^{169}$.

Fr. Cecilio de Heredia. Fue predicador desde 1629. Le dio licencia para graduarse el Capítulo General de 1637. Tomó en Irache todos los grados de Artes y Teología en 1638.

Fr. Benito Nevado. Era profeso de Arlanza y se graduó de Artes y Teología en 1638. Tras ser Abad en Arlanza (1645-1649), fue Procurador general de la Congregación en Roma (1649-1657) ${ }^{170}$.

Fr. Agustín de Enríquez. Recibió licencias del Capítulo General de 1637 para graduarse. Tomó todos los grados de Artes y Teología en la Universidad de Irache en 1638 .

Fr. Gregorio de Quintanilla. Nació en Valladolid y tomó el hábito benedictino en Sahagún, en 1625. Colegial en San Vicente de Salamanca, fue discípulo de Fr. Antonio Descaules. Se graduó de Artes y Teología en Irache, en 1638. A la muer-

167 E. Zaragoza Pascual, "Profesores de Irache", p. 311.

168 E. Zaragoza Pascual, "Profesores de Irache”, p. 312.

169 E. Zaragoza Pascual, Catàleg dels monestirs catalans, pp. 26, 29 y 156; E. Zaragoza Pascual, "Profesores de Irache”, p. 312.

170 E. Zaragoza Pascual, “Abadologio de Arlanza”, p. 101. 
te del Maestro, en 1638, opositó a su cátedra de la Universidad de Salamanca, que fue ganada por Lope de Vera, quien fue encarcelado por la Inquisición al año siguiente, acusado de judaizante. Quintanilla ocupó interinamente su puesto de Catedrático y en 1649 fue nombrado Abad de Sahagún, aunque renunció a la Abadía dos años después, para regentar la Cátedra de Lenguas de la Universidad de Salamanca, en la que estuvo hasta 1657, cuando se retiró de nuevo a Sahagún a causa de la oposición que encontró uno de sus sermones. Desde 1661 a 1665 fue de nuevo Abad de Sahagún, cargo que simultaneó con la cátedra, ocupación a la que se dedicó en exclusiva desde 1665 hasta su muerte, acaecida en 1674. Ese mismo año se publicó, en las prensas salmantinas, Tabernaculum foederis, un voluminoso comentario al Éxodo ${ }^{171}$.

Fr. Pedro del Valle. Profeso de Ribas de Sil, donde fue Prior (1625-1629) y tres veces Abad (1631-1633, 1637-1641, 1642-1645), se graduó en L. T. / M. T. en Irache en 1639. Murió en 1645 y fue enterrado en la Iglesia abacial ${ }^{172}$.

Fr. Pedro Vélez (de Guevara). Era natural de Burgos y profeso de San Juan de Burgos. Fue predicador de algunos monasterios desde 1628, entre ellos del de San Juan de Burgos (1633-1641, 1645-1649), Visitador general, y Abad de Burgos (1641-1645, 1649-1653) y de Celorio (1661-1665). Se graduó en Irache de Artes y Teología en 1639. Murió en Nájera en $1668^{173}$.

Fr. Juan de Dueñas. Nació en Dueñas y hacia 1620 tomó el hábito en Ribas de Sil. Durante varios años fue Maestro de estudiantes en San Vicente de Oviedo e Irache y, como tal, se graduó de Artes y Teología en 1639. Desde 1649 hasta 1653 y de 1657 a 1661 fue Abad de Ribas de Sil. En 1661 fue nombrado General de la Congregación, aunque murió al poco tiempo, cuando llevaba a cabo la visita canónica en San Millán ${ }^{174}$.

Fr. Jerónimo Velarde. Natural de Madrid, tomó el hábito en Sahagún en 1608. Se graduó en Irache en 1639. Fue Abad de Santa María de Piasca y San Mancio de Medina de Rioseco, de Espinareda (1633-1637), Secretario del General (1637-1641), Abad de Sahagún (1641-1645), Definidor (1645-1649), Abad de Poyo (1649-1653), Definidor (1653-1657), y Abad de Sahagún desde 1657 hasta 1660, año de su muerte ${ }^{175}$.

171 E. Zaragoza Pascual, “Abadologio de Sahagún”, p. 132.

172 E. Zaragoza Pascual, “Abadologio de Ribas de Sil”, p. 381.

173 E. Zaragoza Pascual, "Abadologio de Burgos”, pp. 370-371.

174 E. Zaragoza Pascual, Los Generales..., Vol. 4, pp. 227-239.

175 E. Zaragoza Pascual, “Abadologio de Sahagún”, pp. 131 y 133. 
Fr. Juan Rodríguez. Profeso de San Claudio de León, fue Predicador. Luego fue Secretario del Abad General, y se graduó en Artes y Teología en Irache, en 1639. Fue elegido Abad de Dueñas, aunque rehusó para seguir siendo Secretario del General. Desempeñó los cargos de Abad de Obona (1629-1633), Irache (1641-1645), dos veces Abad de Dueñas (1649-1657) y Maestro de Teología en Dueñas (1661-1665) ${ }^{176}$.

Fr. Francisco de Morales. Era natural de Tordesillas (Valladolid), y profesó en Carrión en 1637. Recibió en Irache todos los grados de Artes y Teología en $1639^{177}$.

Fr. Ambrosio Gómez de Salazar. Nació en Madrid en 1610 y profesó en San Millán de la Cogolla. Fue Definidor y Predicador general. Se graduó de Artes y Teología en Irache en 1640. Fue Abad de San Millán desde 1653 hasta 1657. Destacó mucho más como Predicador que como escritor, si bien dio a las prensas varios escritos panegíricos. Falleció en $1659^{178}$.

Fr. Antonio de Cantabrana. Nacido en Valladolid en 1597, y profesó en el Monasterio de su ciudad natal. Fue Abad de los Monasterios de San Benito de Zamora (1629-1630) y de Lemos (1652-1654). Antes había sido dos veces Prior de su Monasterio de profesión y, como tal, se graduó de Artes y Teología en Irache, en 1640. Fue nombrado Cronista de la Congregación y prepararó el octavo volumen de la Crónica del padre Yepes, aunque quedó manuscrito, al igual que el noveno. Falleció en $1662^{179}$.

Fr. Juan de Gayangos. Natural de Madrid, tomó el hábito en Sahagún en 1602. Fue Predicador de Poyo, Predicador y Abad de Sahagún (1637-1641). Como tal, se graduó Artes y Teología en Irache, en $1640^{180}$.

Fr. Mauro de Olabarrieta. Era natural de Santo Domingo de la Calzada y había profesado en Valvanera en 1603. Fue Predicador de Valvanera (1625-1629) y escribió la historia del Monasterio. Se graduó de Filosofía y Teología en Irache en 1640. Fue Abad de Valvanera durante cuatro cuatrienios (1629-1633, 1637-1641, $1645-1649$ y 1657-1661). Murió en fama de santidad ${ }^{181}$.

176 E. Zaragoza Pascual, “Abadologio de Dueñas”, p. 144; E. Zaragoza Pascual, “Abadologio de Irache”, pp. 183-184.

177 E. Zaragoza Pascual, “Abadologio de Carrión de los Condes”, p. 311.

178 E. Zaragoza Pascual, “Abadologio de San Millán”, pp. 207-208.

179 E. Zaragoza Pascual, “Abadologio de Zamora”, p. 370.

180 E. Zaragoza Pascual, “Abadologio de Sahagún”, p. 130.

181 E. Zaragoza Pascual, “Abadologio de Valvanera”, pp. 355-356. 
Fr. Pedro de Álvarez. Solamente sabemos que recibió en Irache los grados de M. A. / M. T. en 1640.

Fr. Leandro Noguerol. Profeso en Celanova, fue Maestro de Estudiantes (1637-1641), Regente del Colegio de Salamanca (1641-1649), y se graduó de Artes y Filosofía en Irache, en 1642. Fue Catedrático de Santo Tomás en la Universidad de Salamanca, Abad de Celanova (1649-1653) y Definidor general (1653-1654), en cuyo cargo murió en Madrid, en $1654^{182}$.

Fr. Íñigo Royo. Nació en Calatayud en 1610. De noble familia, tomó el hábito en Montserrat en 1624. Fue Predicador en Austria (1632-1636), donde contribuyó a la fundación de Montserrat de Viena y a la reforma del cenobio de Montserrat de Praga. Pasó a residir en Montserrat de Barcelona (1637-1641), del que fue expulsado por su adhesión a Felipe IV. Se graduó de Artes y Teología en Irache en 1642. Fue Abad del Bueso (1645-1647), pero renunció porque fue presentado para Abad perpetuo del Monasterio de San Victorián en 1647. El rey le presentó para Obispo de Jaca, pero no tomó posesión porque fue designado Arzobispo de Sassari (1660-1670), hasta que pidió volver a la Península y, conservando el título arzobispal, estuvo en Albarracín (1670-1672) y en Barbastro, diócesis que rigió desde 1673 hasta su muerte, acaecida en $1673^{183}$.

Fr. Rosendo Álvarez. Profeso en Celanova, fue Maestro de Estudiantes (16371641), Lector (1645-1649) y Regente (1649-1653) de San Vicente de Salamanca. Se graduó en Irache de M. T., en $1644^{184}$.

Fr. Alonso Ramírez. Tomó el hábito en Sopetrán en 1609. Fue Abad de Lérez (1636-1637) y Predicador de San Martín, en Madrid. Recibió todos los grados de Filosofía y Teología en Irache en 1644. Murió de una caída en Sopetrán en $1646^{185}$.

Fr. Luis Burgos. Natural de Dueñas, tomó el hábito en San Claudio en 1623. Fue Lector de Teología en el Monasterio (1645-1649). Previamente obtuvo todos los grados en Artes y Teología en Irache, en 1644. Con posterioridad, fue Abad de San Claudio (1649-1653)

182 E. Zaragoza Pascual, "Profesores de Salamanca", p. 297; E. Zaragoza Pascual, "Abadologio de Celanova”, p. 91.

183 E. Zaragoza Pascual, Los Generales..., Vol. 4, pp. 474-475; E. Zaragoza Pascual, Catàleg dels monestirs catalans, p. 26; E. Zaragoza Pascual, “Monjes de Montserrat”, pp. 348-349.

184 E. Zaragoza Pascual, "Profesores de Salamanca”, p. 297.

185 E. Zaragoza Pascual, "Monjes de Sopetrán”, p. 125;

186 E. Zaragoza Pascual, “Abadologio de San Claudio de León”, p. 366. 
Fr. José de Magarola. Nacido en Barcelona en 1612 en el seno de una familia noble. Tras estudiar en la Universidad de Salamanca, tomó el hábito en Montserrat en 1628. Expulsado de Montserrat, pasó a Madrid. Como "Abad de Camporredondo", recibió todos los grados en Irache, en 1644. Fue Abad de Camprodón hasta 1676, aunque, por razón de la Guerra de Secesión, no pudo tomar la posesión de aquel Monasterio hasta 1653. Tuvo que reconstruir buena parte del cenobio. Fue diputado de la Generalitat de Cataluña (1664-1668) ${ }^{187}$.

Fr. Benito de Añaños. Procedente de San Juan de la Peña, recibió en Irache todos los grados de Teología en 1645 .

Fr. Bernabé Martel. Era profeso en San Benito de Sevilla, Predicador y Abad (1637-1641) en Lorenzana, y Abad de Irache (1645-1649), donde recibió todos los grados de Artes y Teología en 1645. Luego fue Abad de San Pedro de Montes (1653-1657) y Definidor general (1657-1661) ${ }^{188}$.

Fr. Juan de Bustinza. Profeso en Sevilla, se graduó en Irache de L. A. / M. A. / L. T. / D. T. en 1645. Fue Abad de Sevilla en dos ocasiones (1633-1637 y 16411645). En 1645 fue nombrado Definidor general ${ }^{189}$.

Fr. José Enríquez. Profeso de Valladolid, siguió la carrera del púlpito. Fue Lector en Irache, donde se graduó de Artes y Filosofía en 1645. Luego fue Predicador de Zamora (1645-1649 y 1653-1657), y Abad de Frómista (1657-1660). Murió en $1660^{190}$.

Fr. Benito González. Nació en Bargota (Navarra) en 1587 y tomó el hábito en San Millán de la Cogolla en 1605. Fue Lector de Artes (1617-1625), Predicador (1625-1629) y Abad (1629-1633) de San Millán. Recibió en Irache todos los grados en Artes y Teología en 1645. Se retiró al Priorato emilianense de Nuestra Señora de la Esclavitud, cerca de Cihuri, donde estuvo el resto de su vida dedicado a la oración. Falleció en fama de santidad en $1673^{191}$.

187 E. Zaragoza Pascual, Catàleg dels monestirs catalans, p. 63; E. Zaragoza Pascual, “Monjes de Montserrat”, p. 349.

188 E. Zaragoza Pascual, "Abadologio de Lorenzana”, p. 194; E. Zaragoza Pascual, "Abadologio de Irache”, p. 184.

189 E. Zaragoza Pascual, “Abadologio de Sevilla”, p. 390.

190 E. Zaragoza Pascual, “Abadologio de Frómista”, p. 151; E. Zaragoza Pascual, "Profesores de Salamanca”, p. 312.

191 E. Zaragoza Pascual, “Abadologio de San Millán”, p. 206. 
Fr. Francisco de Velesar. Conocido también como Francisco de Belezar, era natural de Colmenar Viejo y tomó el hábito en Montserrat en 1617. Recibió en Irache todos los grados en 1654. Falleció en 1658, tras haber sido Abad de Fontaines ${ }^{192}$.

Fr. Juan Ojalvo. Era profeso de Arlanza, donde fue tres veces Abad (16411645, 1649-1653, 1657). Fue también Secretario de la Congregación (1645-1649) y Definidor general (1653-1657). Recibió todos los grados en Irache, en 1645. Murió hacia $1665^{193}$.

Fr. Juan de Samaniego. Natural de Haro (La Rioja), era profeso de San Juan de Burgos. Fue Lector de Artes de Espinareda (1641-1645), de Vísperas en Irache (1645-1649), Abad (1653-1657) de San Juan de Burgos. Fue también "acompañado" del Abad general (1657-1661) y murió en Burgos en $1685^{194}$.

Fr. Pedro de Vergaño. Era natural de Aguilar de Campoo (Palencia) y profeso de Celanova. Se graduó en Irache en 1645, donde fue Regente de Estudios (16471651) y Abad (1665-1669). Fue asimismo Abad de Poyo (1657-1660), de Celanova (1660-1661) y Definidor general juez y Maestro general (1669), en cuyo cargo murió en Sahagún en $1669^{195}$.

Fr. Alejandro Marín. Era natural de Soto de Cameros y tomó el hábito en Nájera en 1627. Siguió la carrera del púlpito, y fue Predicador de Nájera (1645-1649, 1653-1657), así como Predicador general de la Congregación. Recibió todos los grados de Artes y Teología en Irache en 1647. Fue tres veces Abad de Nájera (1665$1669,1673-1676,1681-1683)$ y Definidor general (1669-1673). Falleció en $1683^{196}$.

Fr. Juan de Rojas. Natural de Logroño, era hijo de Nájera, donde tomó el hábito en 1607. Recibió todos los grados de Artes y Teología en Irache en 1647. Murió en Nájera en $1652^{197}$.

Fr. Diego de Almeida. Natural de Ceuta, tomó el hábito en San Martín Pinario y siguió la carrera del púlpito. Se graduó de Artes y Teología en Irache, en 1647. Fue Predicador de Felipe IV ${ }^{198}$.

192 E. Zaragoza Pascual, “Monjes de Montserrat”, p. 347.

193 E. Zaragoza Pascual, "Abadologio de Arlanza”, p. 101.

194 E. Zaragoza Pascual, "Profesores de Irache”, p. 313.

195 E. Zaragoza Pascual, “Abadologio de Irache”, p. 185; E. Zaragoza Pascual, "Profesores de Irache", p. 313.

196 E. Zaragoza Pascual, “Abadologio de Nájera”, p. 139.

197 E. Zaragoza Pascual, "Gradas de Nájera”, p. 362.

198 G. de Argaiz, La Perla de Cataluña..., p. 461. F. Negredo del Cerro, Los Predicadores de Felipe $I V$, no le cuenta entre los predicadores. 
Fr. Plácido Núñez. Hijo de San Benito el Real de Valladolid, fue predicador desde 1637. Tras las licencias del Capítulo General de 1645, se graduó de Artes y Teología en Irache, en 1647.

Fr. Benito Fernández del Corral. Profeso de San Millán de la Cogolla, donde tomó el hábito en 1622. Fue dos veces Abad de su Monasterio de profesión (16411645 y 1649-1653). Se graduó de Artes y Teología en Irache, en 1648. Luego fue Visitador general (1653-1656), en cuyo cargo murió en Montserrat ${ }^{199}$.

Fr. Plácido Riquer. Natural de Benabarre, tomó el hábito en 1618 en Montserrat. Se graduó de Artes y Teología en Irache, en 1648. Fue Abad de Montserrat (1665-1668) y de Sant Feliu de Guíxols ${ }^{200}$.

Fr. Gregorio Tamarón. Natural de La Guardia (Álava), había tomado el hábito en Sopetrán en 1621. Fue Predicador general de la Congregación, calificador de la Inquisición y se graduó de Artes y Teología en Irache, en 1648. Fue nombrado Abad perpetuo en Escocia, y fue electo Obispo de una diócesis de Hungría, pero no llegó a ser consagrado, al no tener dicha sede suficientes ingresos. En 1652 pidió una renta sobre las iglesias de Cataluña. Finalmente, le dieron una pensión sobre la mitra de Granada. Murió en $1681^{201}$.

Fr. Luis de Vergara. Era natural de Valladolid. Tomó el hábito en Santiago en 1625. Se graduó de Artes y Teología en Irache, en 1648. Ejerció como Predicador en Santiago, Carrión y Lorenzana. Murió en Mondoñedo ${ }^{202}$.

Fr. Plácido de Haro. Hermano bastardo de Don Luis de Haro, nació hacia 1622, de la relación de su padre con doña Bernardina de Navarrete Sotomayor. Reconocido por el padre, estudió en Salamanca. Profesó en Celanova y se graduó de Artes y Teología en Irache, en 1648. Su hermano consiguió que Felipe IV lo nombrara Predicador real en $1652^{203}$.

199 E. Zaragoza Pascual, “Abadologio de San Millán”, pp. 206-207.

200 E. Zaragoza Pascual, "Monjes de Montserrat”, pp. 347-348; E. Zaragoza Pascual, Abaciologi de Sant Feliu de Guíxols, p. 50.

201 Archivo de la Corona de Aragón, Consejo de Aragón, Leg. 304, n. 12; E. Zaragoza Pascual, “Abadologio de Sopetrán”, p. 233.

202 E. Zaragoza Pascual, "Gradas de San Martín Pinario”, p. 489.

203 R. Valladares, "Haro sin Mazarino. España y el fin del 'orden de los Pirineos' en 1661”, Pedralbes, 29 (2009), pp. 339-393, especialmente, pp. 353-354. F. Negredo del Cerro, Los Predicadores de Felipe IV, p. 448. 
Fr. Juan de Lezana. Natural de Amusco (Palencia), tomó el hábito en Eslonza, en 1631 y fue Maestro de estudiantes de Espinareda (1645-1649). Fue Lector de Vísperas de Irache (1649-1653), y allí se graduó de Artes y Teología en 1648. Debió de morir en Eslonza hacia 1665, después de haber sido Abad (1653-1657) ${ }^{204}$.

Fr. Atiliano de Collantes. Era natural de Madrid y profeso de Sahagún, cenobio donde había tomado el hábito en 1609. Fue Predicador (1625-1633) y Abad (1645-1649) de El Espino. Como tal, se graduó de Artes y Teología en 1649 en Irache $^{205}$.

Fr. Pedro de Úriz. Natural de Sangüesa (Navarra) y tomó el hábito en Nájera en 1631. Fue Pasante de Eslonza, Prior de Espinareda (1641-1645) y de Irache (1645-1649), donde se graduó en Artes y Filosofía en 1649. Fue Abad en Nájera (1649-1653), de Irache (1654-1657) y Definidor general (1657-1658). Murió en Sahagún en $1658^{206}$.

Fr. Benito Salazar. Natural de Baños de Río Tobía (la Rioja), donde nació en 1615. Tomó el hábito benedictino en 1629. Fue Maestro de estudiantes del Colegio de Oviedo (1645-1647) y Vicerregente del de Eslonza (1649), Lector de Vísperas en Salamanca (1649). Se graduó de Artes y Teología en Irache, en 1649, y fue Abad de Lérez (1649-1657), Secretario general de la Congregación de Valladolid (1657-1661), Maestro general, dos veces Abad de San Millán (1661-1665, 16731677), Procurador general de la Congregación en Roma (1669-1673), Abad general de la Congregación (1677-1681), Abad de Montserrat de Madrid (1681-1682) y Obispo de Barcelona desde 1683 hasta su muerte en $1692^{207}$.

Fr. Alonso García [de Losada]. Nació en 1614 en Monforte de Lemos, tomó el hábito en Samos en 1633. Fue Regente de Oviedo (1645-1649), así como Maestro de estudiantes (1649-1653), Regente de estudios (1653-1656) y Lector de Tercia de Teología (1657-1661) del Colegio de Salamanca. Se graduó de Artes y Teología en Irache en 1649, y en 1651 ganó la cátedra de Escoto de la Universidad de Salamanca, que regentó hasta 1655. Fue dos veces Abad de Samos (1656-1657, 1661-1665), Definidor general (1657-1661, 1665-1669), Calificador de la Inquisición, miembro de la Real Junta de la Inmaculada, Lector de Teología de Irache

204 E. Zaragoza Pascual, "Profesores de Irache", p. 313.

205 E. Zaragoza Pascual, “Abadologio de Espino”, p. 28.

206 E. Zaragoza Pascual, “Abadologio de Nájera”, p. 138; E. Zaragoza Pascual, “Abadologio de Irache", p. 184.

207 E. Zaragoza Pascual, Los Generales..., Vol. 4, pp. 285-294 y 355-356; E. Zaragoza Pascual, “Abadologio de San Millán”, pp. 209-210. 
(1669-1671), y Obispo auxiliar de Plasencia y titular de Constantina. Murió en Samos en $1684^{208}$.

Fr. Diego Malo de Andueza. Tomó el hábito en San Millán en 1632. Se graduó de Artes y Teología en Irache, en 1649. Fue Lector de Teología (1641-1645) y Predicador (1649-1657), así como Predicador general. Fue Abad de Eslonza (1657-1661) y San Millán (1665-1669). Escribió varios tomos de sermones y comentó la Sagrada Escritura, especialmente el primer libro de los Reyes. Su obra más popular fue el Arte de merecer mucho con pocas obras, mediante la divina gracia (Madrid, 1666) ${ }^{209}$.

Fr. Pedro Ruiz del Burgo. Era natural de Viana y tomó el hábito en Nájera, en 1624. Se graduó de Artes y Teología en Irache, en 1649. Falleció en 1671, después de una vida muy observante ${ }^{210}$.

Fr. Alonso Díez de Neila. Natural de Torrecilla de Cameros, tomó el hábito en Nájera en 1630. Fue Predicador en Nájera (1641-1645) y Sevilla (1657-1661). Se graduó de Artes y Teología en Irache, en 1649. Después de ser Abad de Nájera (1661-1665), fue Abad de Sevilla (1665-1669), Definidor general (1669-1673) y Abad de Celorio (1673-1676), donde murió en 1676 ${ }^{211}$.

Fr. Gregorio de Olmos. Era natural de Nájera, donde tomó el hábito en 1609. Se graduó de Artes y Teología en Irache, en 1649. Murió en Nájera en $1660^{212}$.

Fr. José de Valdivieso. Hijo de Valladolid, donde profesó en 1628, fue Predicador (1633-1637), Abad de Oviedo (1657-1661), Monforte de Lemos (1646), y Prior mayor de Salamanca (1649-1649). Se graduó de Artes y Teología en Irache, en 1649. Fue Abad de San Pedro de Montes (1663-1665) y de Valladolid (16651669). El Capítulo de 1665 le nombró Predicador general ${ }^{213}$.

Fr. Gregorio de Castro. Natural de Burgos, tomó el hábito en San Juan Bautista en 1630. Fue Lector de Vísperas de Teología de Espinareda (1645-1649) y Lector de Tercia en Irache (1649-1657), donde se graduó de Artes y Teología en 1650. Fue Abad de San Juan de Burgos (1669-1672), aunque renunció por enfermedad. Murió en $1682^{214}$.

208 E. Zaragoza Pascual, “Abadologio de Samos”, pp. 486-487.

209 E. Zaragoza Pascual, “Abadologio de San Millán”, pp. 209-210.

210 E. Zaragoza Pascual, "Gradas de Nájera”, p. 364.

211 E. Zaragoza Pascual, "Abadologio de Nájera”, p. 139.

212 E. Zaragoza Pascual, "Gradas de Nájera”, p. 363.

213 E. Zaragoza Pascual, “Abadologio de Valladolid”, pp. 240-241.

214 E. Zaragoza Pascual, "Profesores de Irache”, p. 313. 
Fr. Bernardo de Estúñiga. Natural de las Heras de la Peña (Palencia). Tomó el hábito en Carrión en 1632, y se graduó de Artes y Teología en Irache en 1650. Fue Predicador de los Monasterios de Valladolid (1657-1661) y Montserrat de Madrid (1665-1659, 1673-1677 y 1680-1685), así como Definidor general (16901693). Fue Predicador de Felipe IV y Carlos II. Murió en 1699. Dejó algunas obras inéditas ${ }^{215}$.

Fr. Esteban de Sugadi. Profeso de Valladolid donde había tomado el hábito hacia 1625, fue nombrado Predicador en 1637. Luego fue Abad de Zamora (16491651) y se graduó de Artes y Teología en 1650 en Irache. Fue Rector del Colegio de Infantes de Valladolid (1657-1661), Abad de Monforte (1661-1665) y Prior de San Salvador de Chantada (1651, 1665-1669) y de San Benito de Valladolid (16691673). Murió en San Martín de Madrid en $1679^{216}$.

Fr. Rosendo Álvarez. Profeso en Celanova, desarrolló buena parte de la vida en el Colegio de Salamanca, en el que fue Maestro de Estudiantes (1637), luego Lector (1645-1649) y Regente (1649-1653). Aunque hizo su examen el 26 de junio de 1644, le dieron todos los grados de Artes y Teología en Irache en 1650. Rehusó ser Abad de Celanova para continuar con su enseñanza en Salamanca ${ }^{217}$.

Fr. Manuel Corera. Profeso en Valladolid. Fue predicador desde 1637 y ejerció en Monforte de Lemos en 1645. El Capítulo general de 1649 le dio licencia para graduarse. Recibió todos los grados de Artes y Teología en Irache en 1650.

Fr. Pedro de Bárcena. Natural de Valladolid, profesó en San Zoilo de Carrión de los Condes en 1624, y recibió todos los grados de Artes y Teología en Irache en $1650^{218}$.

Fr. Jerónimo de Torquemada. Natural de Santiago, tomó el hábito en San Claudio de León en 1628 y siguió la carrera del púlpito. Recibió los grados de Artes y Teología en Irache, en 1650. Fue Abad de San Claudio de León (1665-1669) ${ }^{219}$.

Fr. Gregorio de Toledo. Nació en Santo Domingo de la Calzada en 1615. Ingresó en el Colegio de Infantes de Valladolid en 1628 y profesó en San Benito.

215 E. Zaragoza Pascual, “Abadologio de Carrión de los Condes”, pp. 299-300; F. Negredo del Cerro, Los Predicadores de Felipe IV, p. 446.

216 E. Zaragoza Pascual, “Abadologio de Monforte”, p. 503.

217 E. Zaragoza Pascual, "Profesores de Salamanca”, p. 297.

218 E. Zaragoza Pascual, “Abadologio de Carrión de los Condes”, p. 310.

219 E. Zaragoza Pascual, “Abadologio de San Claudio de León”, p. 367. 
Fue Predicador (1641-1645, 1649-1657) y Lector de Teología moral de Valladolid (1645-1649). Se graduó de Artes y Teología en Irache, en 1650. Fue dos veces Abad de Monforte de Lemos (1658-1661, 1665-1666) y una de Ribas de Sil (16691672), Abad de Valladolid (1672-1673) y Abad de Irache (1677-1679). Murió en Logroño, llevado en litera a causa de su enfermedad, en $1679^{220}$.

Fr. Mauro de Somoza. Era profeso de Celanova y había sido Pasante y Lector de Poyo (1645-1649). Recibió los grados de B. A. / B. T. / L. T. / D. T. en Irache, en 1651. Fue Lector de Vísperas en el Colegio de Salamanca (1653-1655), luego Regente (1655-1661), Abad de Salamanca (1661-1665) y Lector de Tercia (1665-1681). Todo ello lo compaginó con las cátedras de Artes (1651-1658), Lógica (1658-1659), Escoto (1659-1660), Durando (1664-1668), Sagrada Escritura (1668-1675) y Vísperas (1675-1677) de la Universidad de Salamanca. Fue también Definidor general (1665-1669), teólogo real, y calificador de la Inquisición. Escribió varias obras, que quedaron manuscritas, y es autor de muchas censuras inquisitoriales. Murió en Salamanca en $1680^{221}$.

Fr. Anselmo Pérez. Natural de Viniegra de Yuso (La Rioja), recibió el hábito en Lorenzana, en 1634, fue Maestro general y Lector de la Universidad de Irache (1649-1653), donde se graduó en Artes y Teología en 1651. Fue cuatro veces Abad de Lorenzana (1653-1657, 1661-1665, 1670-1673, 1677-1681), Visitador General (1665-1669, 1673-1677) y Definidor general $(1681-1685)^{222}$.

Fr. Mauro de Ponte. Natural de Santiago de Compostela, tomó el hábito en 1624 en San Martín Pinario. Recibió en Irache los grados de B. T. / L. T. / D. T. en 1651. Falleció en $1670^{223}$.

Fr. Rosendo de Mújica. Tomó el hábito en Celanova, en 1628. En 1645 fue Predicador de San Claudio de León y se graduó de Artes y Teología en Irache, en 1651. Fue Abad de Celanova (1653-1657, 1661, 1673-1677 y 1685-1689). Fue Abad general de la Congregación (1661-1665) y Abad de Montserrat de Madrid (1665-1669). Fue Predicador de Felipe IV y luego de Carlos II. Falleció en Celanova en $1692^{224}$.

220 E. Zaragoza Pascual, “Abadologio de Monforte”, p. 503; E. Zaragoza Pascual, “Abadologio de Irache”, pp. 186-187.

221 E. Zaragoza Pascual, "Profesores de Salamanca", p. 299; E. Zaragoza Pascual, "Abadologio de Salamanca", p. 340.

222 E. Zaragoza Pascual, "Abadologio de Lorenzana”, p. 194.

223 E. Zaragoza Pascual, "Gradas de San Martín Pinario”, pp. 488-499.

224 E. Zaragoza Pascual, Los Generales..., Vol. 4, pp. 241-248; E. Zaragoza Pascual, “Abadologio de Celanova”, p. 91; F. Negredo del Cerro, Los Predicadores de Felipe IV, p. 452. 
Fr. Antonio Rodríguez. Siendo Prior Mayor de S. Vicente de Salamanca, recibió los grados de B. A. / B. T. / L. T. / D. T. en 1652 en Irache. Fue Predicador desde 1649, y estuvo destinado en Celanova (1657-1661) y San Claudio de León (1661-1665).

Fr. Juan de la Riba. Ingresó en Oña en 1633, y fue Lector de Filosofía en Ribas de Sil, Lector de Teología en Poyo y en San Vicente de Oviedo, desde donde se desplazó a Irache para obtener, en 1652, los grados de B. A. / B. T. / L. T. / D. T. Desde 1657 a 1661 fue Abad de Oña y desde 1661 a 1665, Definidor general y Regente del Colegio de Eslonza. En 1665 fue elegido Abad de Oña y General de la Congregación. Renunció al Abadiato dos años después, para dedicarse por completo al generalato. Desde 1668, fue Predicador de Carlos II. Se retiró a Oña, donde murió en $1690^{225}$.

Fr. Manuel de Lebrija. Natural de Valladolid, tomó el hábito en Carrión de los Condes en 1631. Se graduó en Irache de B. A. / L. T. / M. T. en $1653^{226}$.

Fr. Antonio de Isla. Fue natural de Oimbra (Orense) y profeso en Oña. Fue Prior de Espinareda, Oña, Espinosa de los Monteros, San Miguel de Miengo, Liébana (1661-1664) y Abad de Obona (1665-1668), donde murió de gota. Se había graduado en Teología en Irache en $1653^{227}$.

Fr. Prudencio de Murga. Natural de Madrid, tomó el hábito en Nájera el 29 de marzo de 1618. Estudió Filosofía en Irache y Teología en Salamanca. Fue Predicador (1637-1641), y recibió todos los grados de Teología en Irache, en 1654. Fue Abad de Nájera (1653-1657) y murió de gota en $1657^{228}$.

Fr. Antonio del Castillo. Profeso de Valladolid, fue Maestro de estudiantes (1653-1661), Regente (1661-1665), Abad (1665-1669, 1673-1675) y Lector de Vísperas (1669-1673) del Colegio de Salamanca. Recibió los grados de L. A. / D. A. / L. T. / D. T. en Irache en 1655. Fue Catedrático de Artes (1661-1670) y Lógica (1670-1675) en la Universidad de Salamanca. Murió en Salamanca en 1675, después de haber sido Definidor general (1669-1673) ${ }^{229}$.

225 E. Zaragoza Pascual, Los Generales..., Vol. 4, pp. 249-256 y 339-344; E. Zaragoza Pascual, “Abadologio de Oña”, p. 579; F. J. García Pérez, "Los Predicadores reales de Carlos II”, Archivo Ibero-Americano, 75 (2015), p. 698.

226 E. Zaragoza Pascual, “Abadologio de Carrión de los Condes”, p. 310.

227 E. Zaragoza Pascual, “Abadologio de Liébana”, p. 47.

228 E. Zaragoza Pascual, "Abadologio de Nájera”, pp. 138-139.

229 E. Zaragoza Pascual, "Profesores de Salamanca”, p. 299; E. Zaragoza Pascual, “Abadologio de Salamanca”, p. 341. 
Fr. Antonio de Otero. Era profeso de San Benito de Valladolid. Recibió todos los grados de Artes y Teología en Irache en 1656. Fue Abad de Frómista (16651669) y de El Espino (1669-1673)230.

Fr. José de Argaiz. Profeso de San Millán de la Cogolla, donde había tomado el hábito en 1630, siendo Predicador Mayor de Valladolid (1653-1657), recibió en Irache los grados de Teología en 1657. Fue Predicador en San Claudio (1657-1661) y Abad de Lérez (1665-1667) ${ }^{231}$.

Fr. Anselmo López. Natural de Monforte de Lemos y profeso de San Juan de Burgos, fue Lector de Artes (1645-1649), Maestro de estudiantes (1649-1657) y Regente de estudios (1657-1660) de Irache, donde se graduó de M. T. en 1657. Luego fue Abad de Espinareda (1660-1661), San Juan de Burgos (1661-1665) y Obona $(1677-1681)^{232}$.

Fr. Pedro de Murga. Natural de San Millán de la Cogolla, donde nació en 1620, profesó en Irache, donde pasó prácticamente toda su vida. Siendo Predicador y Maestro en Irache, recibió el grado de M. T. en 1657. En realidad, Murga no fue Lector en Irache, sino un investigador y tratadista del Derecho canónico. Se trata de uno de los grandes canonistas del siglo XVII, quien, con el beneplácito de sus superiores, dedicó toda su vida al estudio. Sus Quaestiones pastorales (Lyon, 1657 y 1658, 2 vols.) y Disquisitiones morales et canonicae (Lyon, 1666, 2 vols.) tuvieron un gran impacto en Europa y en América ${ }^{233}$.

Fr. Juan de Legazpi. Era profeso de Cornellana. Ocupó los cargos de Predicador de Sevilla (1673-1677), de Montserrat de Madrid (1661-1665, 1669-1673). Se graduó de Artes y Teología en Irache en 1659. Fue Maestro general, Abad de Cornellana (1677-1681), de Ribas de Sil (1686-1689) y Definidor (1701-1705). Fue asimismo predicador de Carlos II desde $1675^{234}$.

Fr. Benito de Vicuña. Era navarro, aunque había tomado el hábito en San Millán de la Cogolla en 1625. Recibió todos los grados de Artes y Filosofía en Irache en 1660. Fue Abad de San Millán (1657-1661)235.

230 E. Zaragoza Pascual, “Abadologio de Espino”, p. 29.

231 E. Zaragoza Pascual, “Abadologio de Lérez”, pp. 419-420.

232 E. Zaragoza Pascual, "Profesores de Irache", p. 313.

233 G. de Argaiz, La Perla de Cataluña..., p. 470.

234 E. Zaragoza Pascual, “Abadologio de Cornellana”, pp. 893-894; F. J. García Pérez, "Los Predicadores reales de Carlos II", p. 702.

235 E. Zaragoza Pascual, “Abadologio de San Millán”, pp. 208-209. 
Fr. Ildefonso de Escudero. Para Zaragoza Pascual, era Alfonso Escudero, procedente de Zamora. Había enseñado en Irache desde 1649 y, cuando recibió los grados de Artes y Teología en 1660, era Lector de Tercia. Luego fue tercer Regente de Eslonza (1661-1665) ${ }^{236}$.

Fr. Gregorio de Silva. Tomó el hábito en Sevilla hacia 1645. Fue Maestro de estudiantes (1653-1657), Regente de estudios (1665-1669) y Abad (1669-1673) de Oviedo, Regente de Poyo (1661-1665), Catedrático de Sagrada Escritura (16641668) y de Vísperas de Teología (1668-1669) y de Prima (1669-1678) en la Universidad de Oviedo, así como Definidor general (1673-1677). Falleció en $1678^{237}$.

Fr. José Sáenz de Aguirre. Se trata de la figura más importante de la Congregación en el siglo XVII. Nacido en Logroño en 1630 en una familia noble, estudió en Salamanca. Tomó el hábito en San Millán en 1645. Estudió en San Vicente de Salamanca y Eslonza. Fue Lector de Teología en Poyo (1653-1657); Lector de Artes y Maestro de estudiantes en Irache (1657-1661), donde recibió todos los grados de Artes y Teología en 1660. Fue Lector de Teología en Poyo (1661-1665), Maestro de estudiantes (1665-1669), Regente (1669-1677), Abad (1677-1681) y Lector de Tercia (1681-1685) en San Vicente de Salamanca. En la Universidad de Salamanca, fue Catedrático de Teología Moral, Teología Escolástica y Sagrada Escritura. Aguirre quso relanzar la la doctrina de san Anselmo, intentando minimizar sus diferencias con Santo Tomás. Propuso dotar en la Universidad de Salamanca dos cátedras (de Prima y Vísperas) para la Congregación benedictina, con la condición de que los benedictinos dotarían una tercera dedicada al estudio de la Teología de San Anselmo. Las nuevas cátedras fueron aprobadas, no sin oposición, por Carlos II el 11 de marzo de 1693. Su defensa del Papa contra el galicanismo, le valió el capelo cardenalicio en 1686. En Roma fue nombrado miembro de las congregaciones del Índice, del Concilio, de Ritos y del Santo Oficio. Murió en Roma en $1699^{238}$.

Fr. Felipe Vamonde. Conocido también como Felipe de Bahamonde y Castro. Natural de la Coruña. Tomó el hábito en San Juan de Burgos. Fue Predicador y Lector de Artes en Irache (1656-1661), donde se graduó de Artes y Teología en 1660. Fue Lector de Teología en Salamanca (1661-1673), donde también fue Abad (1669-1673), así como también Abad de San Juan de Burgos (1677-1681). Se retiró a Sahagún, lugar en el que murió en $1682^{239}$.

236 E. Zaragoza Pascual, "Profesores de Irache", p. 314.

237 V. Beltrán de Heredia, "La Facultad de Teología de la Universidad de Oviedo”, pp. 421, 426, 429; E. Zaragoza Pascual, "Profesores de Oviedo", pp. 332-333.

238 A. Pérez Goyena, “La literatura teológica española...”, pp. 51-54; G. M. Colombás, La tradición benedictina, vol. VII, pp. 625-632.

239 E. Zaragoza Pascual, “Abadologio de Burgos”, p. 374. 
Fr. José Fernández. Natural de Lumbreras (La Rioja), tomó el hábito en Nájera en 1634. Siendo Abad de Nájera (1657-1661), se graduó en Irache de Artes y Teología en 1660. Luego fue Visitador (1661-1665) y fue nombrado Abad de San Claudio de León (1669), puesto al que renunció, aunque murió al cabo de poco.

Fr. Juan Agüero. Natural de Palencia, tomó el hábito en Cardeña en 1613. Fue Lector de Filosofía de Irache (1638), donde se graduó de Artes y Teología muchos años después, en 1660. Fue tres veces Abad de Cardeña (1649-1653, 1657-1661, 1665-1669) y una del Bueso. Fue también Definidor general (1661-1665, 16691673). Murió en $1678^{240}$.

Fr. Andrés de la Moneda. Nació en Burgos, en el seno de una familia noble. Tomó el hábito en San Juan, en 1640. Estudió Filosofía en Irache y Teología en Salamanca. Fue Regente de estudios en Eslonza, Abad de Burgos (1657-1661) y se graduó de Artes y Teología en Irache en 1660. Desempeñó los cargos de Definidor (1661-1665), Abad de Irache (1669-1673) y General (1675-1677) de la Congregación. Luego fue Abad de San Martín de Madrid (1677-1681) y Obispo de Almería desde 1683 hasta su muerte en 1687. Publicó un curso completo de Filosofía y otro de Teología, en los que comparaba el pensamiento de Santo Tomás con el de San Anselmo ${ }^{241}$.

Fr. Jerónimo de Velasco y Mendoza. Hijo del Conde de Revilla, había nacido en Barrios de Bureba (Burgos) en 1625 y tomado el hábito en San Juan de Burgos en 1638. Se graduó de Artes y Teología en Irache en 1661. Ocupó los cargos de Abad de El Espino (1657-1661), Obona (1664-1665), San Juan de Burgos (16651669) y Espinareda (1669-1673). Fue presentado para mitra de Alguer en 1684 y en dicha sede murió en $1692^{242}$.

Fr. Plácido de Puga. Nació en Valladolid en 1616 e ingresó en el Colegio de Infantes de Valladolid en 1626. Tomó el hábito en San Benito de Valladolid y fue Pasante de Ribas de Sil (1645-1647). En la Universidad de Valladolid leyó varias cátedras de Filosofía y Teología. Fue Abad (1657-1661) de San Vicente de Salamanca, Definidor y Juez, así como Lector de Teología (1661-1665). Se graduó de Artes en Irache, en 1661. En la Universidad de Salamanca fue Catedrático de Filosofía (1665-1669), en que pasó a ocupar la de Teología de Santo Tomás, que rigió desde 1680 hasta su muerte ${ }^{243}$.

240 E. Zaragoza Pascual, “Abadologio de Cardeña”, p. 386.

241 A. Pérez Goyena, "La literatura teológica española...”, pp. 49-51; E. Zaragoza Pascual, Los Generales..., Vol. 4, pp. 277-283 y 433-434; E. Zaragoza Pascual, "Abadologio de Irache", pp. 185-186.

242 E. Zaragoza Pascual, “Abadologio de Espino”, p. 28.

243 E. Zaragoza Pascual, “Abadologio de Salamanca”, pp. 339-340. 
Fr. José Gómez. Tomó el hábito en Nájera, en 1639. Desde 1649 a 1669 fue profesor de Artes y Teología en los Colegios de Celorio (1649-1653), San Vicente de Oviedo (1657-1661), y San Vicente de Salamanca (1661-1665). Recibió los grados de Artes y Teología en Irache en 1661. Fue Abad de Nájera (1669-1673) y General de la Congregación desde 1673 hasta su muerte, acaecida en $1675^{244}$.

Fr. Íñigo de Ruiloba. Natural de Oreña (Santander), tomó el hábito en Oña en 1644. Fue Lector de los Colegios de Poyo (1657-1661), Ribas de Sil y de Irache, donde se graduó en Artes y Teología en 1661, siendo electo Procurador general de la Congregación en Roma (1661-1665). Fue Abad de Oña (1667-1669 y 16761677), de Lérez (1673-1676), y Definidor General (1669-1673 y 1677-1678), en cuyo cargo murió ${ }^{245}$. No debe confundirse con el homónimo Abad de Valladolid.

Fr. Gregorio de Argaiz. Nació en 1602 y profesó en Oña en 1619. Estudió Filosofía en Samos y Teología en Salamanca. Se dedicó a investigar en los archivos de la Congregación, y a escribir una voluminosa obra histórica. Como Predicador, recibió todos los grados de Artes y Teología en Irache, en 1661. Se trasladó a San Martín de Madrid, para supervisar la publicación de su obra. Fue el Cronista de la Congregación desde 1665 hasta su muerte, en 1678. Su obra historiográfica sigue siendo útil en nuestros días y, entre ella, destacan los volúmenes de La Soledad laureada por San Benito y sus hijos en las iglesias de España (6 vols.) y La Perla de Cataluña. Historia de nuestra Señora de Monserrate (Madrid, 1677)246.

Fr. Gregorio Enríquez. Profeso en Celanova, Predicador general, se graduó en Irache de Artes y de Teología en 1662. Fue Abad de Eslonza (1669-1673)247.

Fr. Plácido de Esles. Natural de Abionzo (Cantabria), profesó en San Juan de Burgos, donde había tomado el hábito en 1636. Se graduó en Irache de Artes y de Teología en 1662. Fue Abad de Poyo (1660-1661) y de Celorio (1665-1665). Murió en San Martín de Madrid en $1670^{248}$.

Fr. Antonio Maseda. Natural de Recemil (Lugo), profesó en San Julián de Samos, donde fue dos veces Abad (1661, 1665-1669) así como Abad de Tenorio (1657-1661). Cuando fue Secretario general de la Congregación (1661-1665), se

244 E. Zaragoza Pascual, Los Generales..., Vol. 4, pp. 271-276, 348-355; E. Zaragoza Pascual, "Profesores de Salamanca", pp. 300-301.

245 E. Zaragoza Pascual, “Abadologio de Oña”, pp. 579-580.

246 J. Pérez de Urbel, Varones insignes..., pp. 59-62.

247 E. Zaragoza Pascual, “Abadologio de Eslonza”, p. 179.

248 E. Zaragoza Pascual, “Abadologio de Poyo”, p. 410. 
graduó de Artes y Filosofía en Irache, en 1662. Fue Visitador general (16691672) y murió en el Priorato samonense de San Eufrasio, en $1673^{249}$. No creemos que sea el mismo personaje presente en las primeras graduaciones de este libro.

Fr. Gregorio de Canduela. Había sido Maestro de estudiantes extraordinario de Salamanca (1653-1657) y Lector de Tercia de Teología de Oviedo (1657-1661). Fue Regente y Lector de Prima en Irache (1661-1665), donde recibió todos los grados en Artes y Teología en $1662^{250}$.

Fr. Alonso de Mier. Natural de Plecín de Aller, en Peñamellera (Asturias). Profesó en Carrión de los Condes en 1645, fue Lector de Vísperas de Irache (16611665) y recibió todos los grados de Artes y Teología en 1662. Luego fue Procurador general de la Congregación en Roma (1665-1697), donde fue también calificador y consultor de la Congregación Romana de los Ritos, y Maestro general. Murió, propuesto para un obispado, en octubre de $1706^{251}$.

Fr. Manuel Vela. Profeso de San Benito de Valladolid, fue Lector de Artes (1657-1665) y Lector de Vísperas de Teología (1665-1673) en Irache, donde recibió todos los grados en Artes y Filosofía en 1662. Fue Abad de San Vicente de Oviedo (1681-1685), de Irache (1693-1697), Definidor general (1697-1701) y Maestro general hasta su muerte, acecida hacia $1710^{252}$.

Fr. Plácido Martínez. Natural de Foncea (La Rioja), tomó el hábito en Oña en 1633, cenobio en el que fue Prior (1657-1661), Abad (1661-1665, 1669-1673) y Prior-presidente (1665-1667). Se graduó en 1673 de B. A. / B. T. / L. T. / D. T. en Irache. Fue asimismo Prior de Tejada y de Liébana, así como también Definidor general (1665-1669, 1673-1675) $)^{253}$.

Fr. Primitivo Laso. Natural de Valladolid, era profeso del Monasterio de Nájera. Pasante de estudios en Celorio en 1645, fue luego Lector de Vísperas de Teología de San Juan de Poyo (1653-1657) y Regente de estudios del Colegio de San

249 E. Zaragoza Pascual, “Abadologio de Samos”, p. 487; E. Zaragoza Pascual, "Profesores de Irache”, p. 310.

250 E. Zaragoza Pascual, "Profesores de Salamanca", p. 299; E. Zaragoza Pascual, "Profesores de Irache", p. 314.

251 E. Zaragoza Pascual, "Profesores de Irache”, p. 314.

252 E. Zaragoza Pascual, "Profesores de Irache”, p. 314; E. Zaragoza Pascual, "Abadologio de Irache”, pp. 188-189.

253 E. Zaragoza Pascual, “Abadologio de Oña”, p. 579. 
Pedro de Eslonza (1657-1665), del que pasó a Irache, también como Regente, y donde se graduó en Artes y Teología en $1664^{254}$.

Fr. Benito de Mondragón. Recibió todos los grados en Artes y Filosofía en Irache en 1664. Había sido Predicador de Sahagún (1657-1661) y, desde 1661, Prior y predicador de Salamanca.

Fr. José de Noboa. Natural de Monterrey (Orense), era profeso de San Claudio de León, donde había tomado el hábito en 1650. Fue Pasante de Espinareda (1661-1665), Lector de Vísperas de Teología en Irache, donde se graduó en Artes y Teología. Luego fue Lector de Teología moral (1669-1673) y Abad (1677-1679) de San Claudio de León, en cuyo cargo murió en $1679^{255}$.

Fr. Pedro de Castro. Había sido Pasante de Ribas de Sil (1661-1665), Maestro de Estudiantes de Irache (1665-1669), donde recibió todos los grados en Artes y Teología en 1664. Luego fue Lector de Tercia de Poyo (1669-1673) y de Irache $(1673-1677)^{256}$.

Fr. Juan Sánchez. Puede ser que sea el homónimo Abad de Arlanza (16691673). Había nacido en Nájera en 1619 y profesado en Nájera, donde recibió el hábito en 1635. Fue Predicador de los Monasterios de Nájera (1661-1665) y Montserrat de Madrid (1681-1685). Recibió los grados de B. A. / B. T. / L. T. / M. T. en Irache en 1664. Murió en Nájera en $1693^{257}$.

Fr. Gabriel de Ceballos. Predicador, fue Pasante segundo en Ribas de Sil (1657-1661) y recibió los grados de B. A. / B. T. / L. T. / M. T. en Irache en $1664^{258}$.

Fr. Mauro de Sosa. Era natural de Salvatierra de Tormes (Salamanca). Tomó el hábito en Santiago en 1639. Fue predicador de San Juan de Burgos, Montserrat, Nájera, Santiago y Valladolid. Recibió los grados de B. A. / B. T. / L. T. / M. T. en Irache en 1664. Murió en el priorato de Cambre ${ }^{259}$.

Fr. José de Olaeta. Natural de Arteaga (Vizcaya) y profeso en Espino, donde tomó el hábito en 1645, fue Pasante primero en Ribas de Sil (1657-1661) y Regen-

254 E. Zaragoza Pascual, "Profesores en Obona y Celorio”, p. 290.

255 E. Zaragoza Pascual, "Abadologio de San Claudio", p. 367.

256 E. Zaragoza Pascual, "Profesores de Irache”, p. 315.

257 E. Zaragoza Pascual, “Abadologio de Arlanza”, p. 102.

258 E. Zaragoza Pascual, "Profesores de Samos”, p. 777.

259 E. Zaragoza Pascual, “Gradas de San Martín Pinario”, p. 493. 
te de Dueñas (1665-1669). Recibió todos los grados de Artes y Teología en Irache, en $1664^{260}$.

Fr. Plácido Oroz. Recibió todos los grados de Artes y Teología en Irache, en 1664. Fue Abad de San Victorián y Presidente de la Provincia cesaraugustana de la Congregación benedictina claustral (1671-1674, 1679-1682, 1685-1689, 1692-1703)

Fr. Manuel de Olivar. Era profeso de Arlanza y había estudiado en Salamanca (1650-1653). Recibió todos los grados de Artes y Teología en Irache, en 1664. Fue Predicador de San Benito de Zamora (1661-1665) y de San Benito de Huete (16731677), así como Abad de Arlanza (1665-1669)262.

Fr. Juan de Valcázar. Natural de Burgos, tomó el hábito en Cardeña en 1640. Fue Lector de Artes de Espinareda (1657-1661) y Lector de Tercia de Teología de Poyo (1661-1665), antes de ser Regente y Lector de Prima (1665-1669) en Irache, donde se graduó de Artes y Teología en 1665. Luego fue dos veces Abad de Cardeña (1669-1673, 1681-1685), y una de Oviedo (1669). Murió en 1685. Dejó algunos manuscritos ${ }^{263}$.

Fr. Primitivo Ruiz. Era natural de Cerrazo y profeso de Sahagún. Fue Pasante de Espinareda (1657-1661), Lector de Tercia (1665-1669) y Regente de estudios (1669-1673) de Irache. Se graduó en Irache el 20 de enero de 1665 y fue Abad de Eslonza (1677-1678) y de Sahagún (1678-1679), en cuyo cargo murió en $1679^{264}$.

Fr. Jerónimo de la Hoz. Natural de Burgos, profeso en San Juan, tomó el hábito en 1649. Fue Predicador en los Monasterios de Valladolid (1657-1661), Sevilla (1661-1665) y Montserrat (1669-1673). Recibió todos los grados de Artes y Teología en Irache, en 1667. Fue Procurador general de la Congregación (16651669), Definidor general (1669-1673) y Abad de Burgos desde 1673 hasta 1677, año de su muerte ${ }^{265}$.

Fr. Pedro Bernet. Fue Prior de Luesia y, como Prior del Convento de San Juan de la Peña, recibió los grados de Teología en Irache en $1669^{266}$.

260 E. Zaragoza Pascual, "Profesores de Samos", p. 777.

261 E. Zaragoza Pascual, Història de la Congregació..., p. 413.

262 E. Zaragoza Pascual, "Abadologio de Arlanza”, pp. 101-102.

263 E. Zaragoza Pascual, "Profesores de Irache”, p. 315; E. Zaragoza Pascual, “Abadologio de Cardeña”, p. 347.

264 E. Zaragoza Pascual, “Abadologio de Sahagún”, pp. 134-135.

265 E. Zaragoza Pascual, “Abadologio de Burgos”, pp. 373-374.

266 N. Juan García, “Contribución a las trazas arquitectónicas del siglo XVII: el di- 
Fr. Lesmes Pérez. Se graduó en Teología en Irache, en 1669. Fue predicador de San Martín de Madrid (1661-1665) y Predicador general desde 1669.

Fr. Benito de Iglesias. Era Natural de Nájera, y profeso de Oña donde tomó el hábito en 1636. En tanto que Prior de Irache, se graduó de B. A. / B. T. / L. T. / D. T. en la Universidad de la Abadía, en 1669.

Fr. Pedro García. Natural de Alocén y profeso de Sopetrán, donde tomó el hábito en 1642. Tras estudiar en Salamanca (1653), fue Pasante (1657-1661) y Lector (16611665) de Celorio y de Tercia de Teología de Dueñas (1665-1669), Lector de Tercia en Irache (1669-1673), donde se graduó de B. A. / B. T. / L. T. / D. T. en 1669. Fue Abad de Ribas de Sil (1673-1677) y de Irache (1685-1686), donde murió en $1686^{267}$.

Fr. Manuel de Paredes. Siendo Lector de Teología de Irache, se graduó de B. A. / B. T. / B. T. / D. T. en 1669.

Fr. Antonio de Heredia. Tomó el hábito en Sopetrán en 1638. De 1649 a 1653 fue Lector de Artes, Abad de Sopetrán (1657-1661, 1665-1669), Definidor general (1661-1665). General de la Congregación (1669-1673), recibió los grados de B. A. / B. T. / L. T. / D. T. en Irache. En 1671 se imprimieron en Madrid, por orden suya, las Constituciones de la Congregación, adaptación de las de 1611, y al año siguiente, en Salamanca, una Instrucción de religiosos para fomentar la piedad de los monjes. Fue Abad de Montserrat de Madrid (1673-1677), Abad de Irache (1681-1685) y falleció en Madrid en $1689^{268}$.

Fr. José de Alarcos. Tomó el hábito en San Millán de la Cogolla. Fue Predicador del Rey y Maestro en Teología. Se graduó de B. A. / B. T. / L. T. / D. T. en Irache en 1669. Fue Abad de San Millán (1669-1673), Secretario de la Congregación (1673-1677), Abad de Ribas de Sil (1677-1681) y Visitador general (1681-1685)

Fr. Juan Tribaldos. Se graduó, tras recibir las licencias en el Capítulo de 1669, de B. A. / B. T. / L. T. / D. T. en Irache, ese mismo año. Fue Predicador General desde 1677.

seño de la iglesia del Monasterio nuevo de San Juan de la Peña del arquitecto zaragozano Miguel Ximénez”, Artigrama, 22 (2007), p. 588.

267 E. Zaragoza Pascual, "Profesores de Irache”, p. 315; E. Zaragoza Pascual, “Abadologio de Irache”, p. 188.

268 E. Zaragoza Pascual, Los Generales..., Vol. 4, pp. 257-270 y 344-348; E. Zaragoza Pascual, “Abadologio de Irache”, p. 187.

269 F. J. García Pérez, “Los Predicadores reales de Carlos II”, p. 700. 
Fr. Francisco Ribas (o Rivas). Fue predicador desde 1657. Se desempeñó en Carrión (1661-1665) y Nájera (1669-1673). Se le dio licencia para graduarse en el Capítulo general de 1669. Recibió todos los grados de Teología en Irache, en 1670. Fue Predicador de Sevilla (1677-1681 y 1681-1685), así como Maestro general desde 1685 .

Fr. José de Zañartu. Era hijo de una ilustre familia de Sevilla y hacia 1647 tomó el hábito en San Benito de Sevilla. Desde 1669 hasta 1677 enseñó en San Vicente de Salamanca. Recibió todos los grados de Filosofía y Teología en Irache en 1671. Abad de Sevilla (1677-1681), fue Abad general de la Congregación (16811685), y luego Abad de San Martín de Madrid, cargo al que renunció, y finalmente Abad de Montserrat de Madrid (1689-1693). Rechazó varias mitras y abadiatos por motivos de salud ${ }^{270}$.

Fr. Bartolomé Bustamante. Natural de las inmediaciones de Santillana (Cantabria). En 1641 tomó el hábito en Sahagún, donde fue Prior (1657-1660) y Abad (1669-1673). Recibió todos los grados de Artes y Teología en Irache, en $1672^{271}$.

Fr. Antonio de Quevedo. Natural de Belorado (Burgos), tomó el hábito en Nájera en 1648. Recibió los grados de B. A. / B. T. / L. T. / D. T. en 1673, en Irache, mientras era Abad de Villanueva (1673-1677). Había sido Prior de Irache (16691673), "acompañado" del Abad general (1677-1681), Abad de Poyo (1681-1683), Nájera (1683-1685), y Definidor general (1685-1688), en cuyo cargo murión ${ }^{272}$.

Fr. Francisco de Ojea. Profeso de Celanova, fue Lector de Artes en Irache (16691673), donde se graduó de B. A. / B. T. / L. T. / D. T. en Irache en 1673, y de Vísperas de Teología en Poyo (1673-1677). Fue Regente de Estudios en Espinareda (16771681), Eslonza (1681-1685), San Vicente de Oviedo (1685-1689), Abad de Dueñas (1693-1697), Irache (1701-1705) y Tenorio (1709-1713). Murió en Celanova en $1715^{273}$.

Fr. Bernardo de Viñuelas. Natural de Alaminos (Guadalajara), profeso de Sopetrán en 1652, fue Predicador de Sahagún (1669-1673), San Martín Pinario (1673-1677) y Valladolid (1677-1681). Recibió los grados de B. A. / B. T. / L. T. / D. T en Irache en 1673. Luego fue Definidor general (1685-1688), en cuyo cargo murió en $1688^{274}$.

270 E. Zaragoza Pascual, Los Generales..., Vol. 4, pp. 299-303; E. Zaragoza Pascual, "Profesores de Salamanca", p. 303.

271 E. Zaragoza Pascual, “Abadologio de Sahagún”, p. 134.

272 E. Zaragoza Pascual, "Abadologio de Villanueva”, p. 90.

273 E. Zaragoza Pascual, “Abadologio de Irache”, p. 189.

274 E. Zaragoza Pascual, “Abadologio de Sopetrán”, p. 285. 
Fr. Veremundo Ibáñez. Natural de Zuruquiain, Valle de Yerri, tomó el hábito en Nájera en 1657. Recibió los grados de B. A. / B. T. / L. T. / D. T. en Irache en 1673. Murió en 1695.

Fr. Diego de Basanta. Natural de Salamanca, tomó el hábito en San Juan de Burgos en 1658. Fue Mastro de Estudiantes, Lector de Vísperas (1677-1681) y Regente (1681-1685) del Colegio de Salamanca. Recibió todos los grados de Artes y Filosofía en Irache en 1673. Fue Pasante de Ribas de Sil (1669-1673) y Definidor general (1677-1681). Murió hacia 1690, presentado para el obispado de Buenos Aires, y dejó diversos manuscritos 275 .

Fr. Manuel de Porras. Manuel de Porras y Mardones, natural de Poza de la Sal (Burgos), tomó el hábito en Nájera en 1638. Recibió los grados de B. A. / B. T. / L. T. / D. T. en Irache en 1673. Fue dos veces Abad de Nájera (1677-1681, 1685-1686), una vez definidor y visitador general, y vicario de las benedictinas de San Plácido de Madrid (1681-1685). Murió, con fama de muy observante, el 29 de noviembre de $1686^{276}$.

Fr. Martín de Arenas. Natural de Llanes (Asturias), tomó el hábito en Silos en 1654, y profesó en 1655. Siguió la carrera del púlpito y fue Predicador de Salamanca (1669-1673), de Guíxols (1673-1677) y Zamora (1677-1681), Secretario general de la Congregación (1685-1689). El Capítulo general de 1673 le dio licencia para graduarse y recibió ese mismo año los grados de B. A. / B. T. / L. T. / D. T. en Irache. Fue Abad de Obarenes (1683-1685) y de Abad de Irache (1689-1693). Murió el 12 de octubre de $1697^{277}$.

Fr. Bernardo Vargas. Conocido como Bernardo Ordóñez Vargas, era natural de Villarrobledo (Albacete) y tomó el hábito en Silos el 25 de setiembre de 1651. Fue Abad de Silos (1669-1673, 1677-1681) y del Bueso (1673-1677), así como Definidor general. Recibió todos los grados de Artes y Teología en Irache en 1673. Murió en San Frutos del Duratón (Segovia) el 2 de febrero de $1686^{278}$.

Fr. Bernardo Gómez. Natural de Madrid, tomó el hábito en Sahagún, donde

275 E. Zaragoza Pascual, "Profesores de Salamanca”, p. 303.

276 E. Zaragoza Pascual, "Abadologio de Nájera”, p. 140; E. Zaragoza Pascual, "Gradas de Nájera”, p. 366.

277 E. Zaragoza Pascual, “Abadologio de Obarenes”, pp. 38-39; E. Zaragoza Pascual, “Abadologio de Irache”, p. 188.

278 E. Zaragoza Pascual, Abadologio de Santo Domingo de Silos, p. 62; E. Zaragoza Pascual, “Abadologio del Bueso", p. 36. 
fue Prior (1669-1673) y Abad (1673-1677), así como Definidor general. Recibió los grados de B. A. / B. T. / L. T. / D. T. en Irache en $1673^{279}$.

Fr. José de Portillo. Profeso de San Millán de la Cogolla, donde tomó el hábito en 1646. Recibió los grados de B. A. / B. T. / L. T. / D. T. en Irache en 1673. Fue Abad de Espinareda desde 1689 hasta 1692, año de su fallecimiento ${ }^{280}$.

Fr. Martín de Aguirre. Natural de Munguía (Vizcaya), tomó el hábito en Nájera en 1640. Recibió los grados de B. A. / B. T. / L. T. / D. T. en Irache en 1673. Fue vicario de las benedictinas de San Plácido de Madrid, Abad de Espinareda (1677-1681), y Visitador general desde 1681 hasta su muerte, acaecida en $1682^{281}$.

Fr. José Ruiz. Natural de Alfaro (La Rioja), donde nació en 1637. Tomó el hábito en Valvanera en 1653 y después en Salamanca. Fue Regente (1673-1681) y Abad (1679-1681) de Irache, donde había recibido los grados de B. A. / B. T. / L. T. / D. T. en 1673. Fue elegido Abad general de la Congregación en el capítulo de 1681, murió ese mismo año y fue enterrado en Montserrat ${ }^{282}$.

Fr. Mauro de Soria. Era natural de Alfaro (La Rioja) y profeso de Oña, donde había tomado el hábito en 1655. Fue Maestro de estudiantes (1673-1677), Lector de Tercia (1677-1681) y Regente de estudios (1681-1685) de Irache, donde recibió los grados de B. A. / B. T. / L. T. / D. T. en 1673. Fue Abad de Eslonza desde 1693, hasta su muerte en $1695^{283}$.

Fr. Plácido Sanz. Tomó el hábito en Sahagún en 1616. Sabemos que fue mayordomo de San Vicente de Salamanca (1654-1658). Recibió los grados de Artes en Irache en $1673^{284}$.

Fr. Pedro de Vergara. Natural de Nájera, profesó en Oña, y fue Prior de Oña, Tejada, Espinosa de los Monteros y Liébana. Fue elegido Abad de Oña, en 1673. Como tal, se graduó de B. A. / B. T. / L. T. en Irache, en 1674. Murió en $1676^{285}$.

Fr. Juan de Solís. Era profeso de San Juan de Corias. Le dio licencia para

279 E. Zaragoza Pascual, “Abadologio de Sahagún”, p. 134.

280 E. Zaragoza Pascual, “Abadologio de Espinareda”, p. 226.

281 E. Zaragoza Pascual, "Abadologio de Espinareda”, p. 225.

282 E. Zaragoza Pascual, "Profesores de Salamanca”, pp. 302-303.

283 E. Zaragoza Pascual, "Profesores de Irache”, p. 316.

284 E. Zaragoza Pascual, "Gradas de Sahagún”, p. 317.

285 E. Zaragoza Pascual, “Abadologio de Oña”, p. 580. 
graduarse el Capítulo general de 1673. Se graduó de B. A. / B. T. / L. T. / D. T. en Irache, en 1674. Fue predicador de Carrión (1677-1681).

Fr. Francisco de Ceballos. Conocido también como Francisco de Cevallos, era natural de Valladolid y profeso de San Benito de su ciudad. Educado de niño en el Colegio de Infantes, fue Regente de Eslonza (1653-1657) y de Oviedo (1657-1661), y profesor en la Universidad ovetense. Era graduado por la Universidad de Salamanca, pues el Capítulo general de 1649 le dio 250 ducados para graduarse allí. Se graduó en Irache de B. A. / B. T. / L. T. / D. T., en 1674. También fue Definidor general juez (1665-1669), Abad de Valladolid (1661-1665, 1669-1670) y murió en San Martín de Madrid en $1670^{286}$.

Fr. Benito Sala. Fue una de las figuras más sobresalientes de la Congregación durante la centuria. Nació en Gerona en 1646. Ingresó en la escolanía de Montserrat en 1652, donde tomó el hábito en 1658. Estudió Teología en San Vicente de Salamanca (1665-1668) y fue Lector de Artes en Ribas de Sil (1669-1673), Secretario del Consejo y Maestro de estudiantes (1673-1677), Regente de estudios (1677- 1781) y Lector de Vísperas de Teología (1681-1682) del Colegio de Salamanca. Recibió todos los grados de Filosofía y Teología en Irache, en 1675. En la Universidad de Salamanca, ocupó diversas cátedras. Fue Abad de Montserrat (1682-1684) y preconizado Obispo de Barcelona en 1699. Tuvo un papel destacadísimo en la Guerra de Sucesión, en el bando austracista. En 1712, fue nombrado Inquisidor General de todos los Reinos de España y fue creado cardenal en 1713, aunque Felipe V no le aceptó como tal. Después de muchos avatares, llegó a Roma y recibió el capelo cardenalicio. Falleció en $1715^{287}$.

Fr. Juan de Castro. Tomó el hábito benedictino en Santo Domingo de Silos en 1651. Estudió en San Vicente de Salamanca. Recibió en 1676 los grados de B. A. / B. T. / L. T. / D. T. en Irache. Fue Abad de San Martín de Madrid (1673-1677) y, por tres cuatrienios, Abad de Silos (1681-1685, 1689-1693, 1697-1701). Falleció en 1711. Escribió un Compendio de la admirable vida del gran Padre y Patriarcha San Benito, abbad, escrita por su hixo, San Gregorio el Magno (Madrid, $1688)^{288}$.

Fr. Juan de Isla. Natural de Madrid y profeso en San Juan de Burgos, donde

286 E. Zaragoza Pascual, "Profesores de Salamanca”, p. 297; E. Zaragoza Pascual, “Abadologio de Valladolid”, p. 240.

287 E. Zaragoza Pascual, "Profesores de Salamanca", pp. 303-304.

288 J. Pérez de Urbel, Varones insignes..., pp. 99-100; E. Zaragoza Pascual, “Abadologio de San Martín de Madrid”, p. 167. 
tomó el hábito en 1650, siguió la carrera del púlpito como Predicador en Burgos (1665-1669), San Benito de Huete (1669-1673), San Martín de Madrid (16731677), y llegó a ser Predicador general. Se graduó de B. A. / B. T. / L. T. / D. T., en Irache, en 1676. Fue Abad de San Juan de Burgos (1681-1685), y Definidor general. Murió siendo Obispo auxiliar electo de Burgos en $1687^{289}$.

Fr. Vicente Díez. Natural de León, tomó el hábito en San Claudio en 1656. Había sido Maestro de estudiantes de Oviedo (1673-1677), Lector de Vísperas de Teología (1677-1681) y Lector de Tercia de Irache (1681-1684?), Abad de San Claudio (1684-1685) y Regente de Eslonza (1685-1689). Recibió los grados de B. A. / L. A. / B. T. / L. T. / D. T. en Irache, en $1677^{290}$.

Fr. Diego Ruiz. Natural de San Asensio (La Rioja), tomó el hábito en San Millán en 1647. Fue Abad de San Millán (1677-1681 y 1685-1689) y Secretario general de la Congregación (1681-1685). Recibió todos los grados de Artes y Teología en Irache, en 1679, y se le dispensaron los actos literarios, por constar su suficiencia. Falleció en $1703^{291}$.

Fr. Alonso de Verdesoto. Natural de Martín Muñoz (Segovia), profeso de Sahagún, donde tomó el hábito en 1664. Fue Lector de Artes en Irache (1669-1673), Maestro de estudiantes en Poyo (1673-1677), Lector de Vísperas en Espinareda (1677-1678), Maestro de Estudiantes en Irache (1678-1681), Regente de estudios en Eslonza (1681-1685), Abad de Sahagún (1685-1689) y Abad de San Claudio (1693-1697). Se graduó en Irache de B. A. / B. T. / L. T. / D. T. en 1681.

Fr. José de Soto. Natural de Quintanillabón (Burgos) y profeso de Oña, donde había tomado el hábito en 1644. Fue Prior de Arredondo, mayordomo de Oña, Prior de Miengo, Espino y Liébana, donde fue Abad (1681-1684), Abad de Tenorio (1685-1689), y Definidor general (1681-1685), en cuyo cargo se graduó de B. A. / B. T. / L. T. / M. T. en Irache, en $1682^{292}$.

Fr. Domingo La Ripa. Nació en Hecho (Huesca), en 1622 y estudió en la Universidad de Huesca, donde fue profesor. En 1650, tomó el hábito en San Juan de la Peña. Desempeñó diversos cargos en la Congregación, y se le designó Cronista del Reino de Aragón en las Cortes de 1686. Se graduó de B. A. / B. T. / L. T. / D. T. en Irache en 1683. Fue autor de diversas obras históricas, entre ellas Corona

289 E. Zaragoza Pascual, "Abadologio de Burgos”, p. 375.

290 E. Zaragoza Pascual, "Profesores de Irache", p. 317.

291 E. Zaragoza Pascual, “Abadologio de San Millán”, p. 210.

292 E. Zaragoza Pascual, “Abadologio de Liébana”, p. 48 
Real del Pirineo, establecida y disputada. Dedicada a la Ilustrísima Diputación del Reyno de Aragón (Zaragoza, 1685-1686, 2 vols.). Murió en 1696293.

Fr. Tomás de Sarasa. Natural de Ayerbe, fue Prior de Luesia. Recibió los grados de Teología en Irache en 1683. Dio la benvenida a Felipe V, primero en 1705, y luego en 1711. Fue nombrado en 1716, por el rey, Abad de San Juan de la Peña, cargo que ocupó hasta su muerte, acaecida en 1726. Había sido Presidente de la Provincia cesaraugustana de la Congregación benedictina claustral (1721$1724)^{294}$.

Fr. Matías Visús. Natural de Salinas de Jaca, y monje de San Juan de la Peña, recibió en Irache los grados de B. A. / B. T. / L. T. / D. T. en 1683.

Fr. Diego de la Moneda. Natural de Burgos, donde profesó en San Juan. Era sobrino de Andrés de la Moneda, que fue Abad general. Recibió los grados de B. A. / B. T. / L. T. / D. T. en Irache en 1683, y fue Abad de San Juan de Burgos (1685-1689). Fue asimismo "acompañado" del General ${ }^{295}$.

Fr. Francisco de Zárraga. Lector de Teología moral en de Nájera, recibió los grados de B. A. / B. T. / L. T. / D. T. en Irache en 1683. Autor de Seneca iuez de si mismo, impugnado, defendido y ilustrado en la causa politica y moral que litigan Don Alonso Nuñez... (Burgos, 1684). Fue Predicador de Carlos II desde $1686^{296}$.

Fr. Juan Catalán. Natural de Madrid, profesó en Montserrat en 1668. Fue Predicador y se graduó de B. A. / B. T. / L. T. / D. T. en Irache, en $1684^{297}$.

Fr. Pedro de Rojas. Tomó el hábito en San Benito de Valladolid en 1667, a los 17 años. Se graduó de B. A. / B. T. / L. T. / M. T. en Irache, en $1685^{298}$.

Fr. Juan de Pazos. Profeso de Samos, fue Predicador en este monasterio

293 J. M. Vallejo García-Hevia, “Domingo La Ripa”, en Diccionario Biográfico Español, vol. XXVIII, Madrid, Real Academia de la Historia, 2009, p. 524.

294 E. Zaragoza Pascual, Història de la Congregació..., p. 413; N. Juan García, "San Juan de la Peña, la Monarquía y los conflictos bélicos en los siglos XVII y XVIII”, Studium, 12 (2006), pp. 209-230, especialmente pp. 222 y 225-226.

295 E. Zaragoza Pascual, “Abadologio de Burgos”, p. 375.

296 F. J. García Pérez, “Los Predicadores reales de Carlos II”, p. 705.

297 E. Zaragoza Pascual, "Monjes de Montserrat", p. 356.

298 E. Zaragoza Pascual, "Monjes de Valladolid”, p. 103. 
(1681-1685), y en los de León (1865-1689, 1693-1697) y Lemos (1689-1693). Se graduó de B. A. / B. T. / L. T. / M. T. en Irache en 1685. Fue designado Abad de Espinareda (1699-1701), por renuncia de su antecesor, y luego elegido Definidor general (1701-1705) y Predicador general ${ }^{299}$.

Fr. Jacinto Díez. Profeso en Carrión, sobresalió como orador sagrado en Oviedo (1677-1681), Montserrat de Madrid (1681-1685), San Claudio (1717-1721) y San Martín Pinario (1721-1725). Se graduó de B. A. / B. T. / L. T. / M. T. en Irache en 1685. Fue dos veces Definidor general (1693-1697, 1709-1713), Abad de Lorenzana (1686-1689), Ribas de Sil (1689-1693), y tres veces de Carrión (1697-1701, 1705-1709, 1713-1717). Publicó diversos sermones ${ }^{300}$.

Fr. Torcado de Salazar. Era natural de Nájera y profeso de Celanova. En 1681 había sido elegido Abad de Tenorio, renunció para poder aceptar la Abadía de su Monasterio de profesión (1681-1685). Se graduó de B. A. / B. T. / L. T. / M. T. en Irache en 1685. Fue Visitador general (1685-1689) y murió en $1705^{301}$.

Fr. Juan Bautista Lardito. Nacido en Madrid hacia 1648, profesó en San Martín en 1665. Fue Pasante de Artes de Obona (1673-1677), Lector de Filosofía de San Juan de Poyo (1677-1681), Maestro de estudiantes de Irache (1681-1685), y Lector de Vísperas de Teología de Salamanca (1685-1689). Se graduó en Irache de B. A. / B. T. / L. T. / M. T. en 1685. En la Universidad de Salamanca detentó la cátedra de Físicos (1687-1692) y la de Prima de Teología (1692-1703). Asimismo fue Regente de estudios y Lector de Tercia de Teología (1689-1693) y dos veces Abad de San Vicente de Salamanca (1693-1697, 1701-1705). Colaboró activamente con el cardenal Aguirre en la fundación de tres cátedras de Teología de Salamanca. Fue Abad general (1705-1709) y Abad de San Martín de Madrid (1709-1713). Fue examinador sinodal del arzobispado de Toledo, teólogo del rey y miembro de la Real Junta de la Inmaculada Concepción, así como autor de diversas obras ${ }^{302}$.

Fr. Diego Gómez. Era natural de Arnedo. Profesó en San Millán de la Cogolla, donde tomó el hábito el 13 de junio de 1663. Se graduó en Irache de B. A. / B. T. / L. T. / M. T. en $1685^{303}$.

299 E. Zaragoza Pascual, “Abadologio de Espinareda”, p. 228.

300 E. Zaragoza Pascual, “Abadologio de Carrión de los Condes”, p. 301.

301 E. Zaragoza Pascual, "Abadologio de Celanova”, p. 93.

302 A. Pérez Goyena, "La literatura teológica española...”, pp. 55-56; E. Zaragoza, Los Generales..., Vol. V, pp. 45-49 y 489-490; E. Zaragoza Pascual, "Profesores de Irache”, pp. 317-318.

303 E. Zaragoza Pascual, "Monacologio emilianense”, p. 302. 
Fr. Benito de Ulloa. Procedente de Valladolid, se graduó en Irache de B. A. / B. T. / L. T. / M. T. en 1685. Fue Predicador de Nájera (1685-1689) y de Santiago (1689-1693).

Fr. Gregorio Ruiz. Natural de Cerrato (Palencia), y profeso en Carrión, estudió en San Vicente de Oviedo, siguió la carrera del púlpito y fue Predicador en Valladolid (1685-1686). Fue Abad de Irache (1686-1689), donde se graduó de B. A. / B. T. / L. T. / M. T. en 1686; así como Secretario de la Congregación (16801693); y Abad de Carrión (1693-1697). Murió en $1699^{304 .}$

Fr. José Ramírez. Natural de Valladolid, tomó el hábito en Valvanera en 1653. Siguió la carrera del púlpito en Valladolid (1673-1677), Salamanca (1677-1681) y Ávila (1681-1685). Se graduó en Irache de B. A. / B. T. / L. T. / M. T. en 1686. Fue dos veces Abad de Valvanera (1685-1689, 1693-1697). Falleció en $1710^{305}$.

Fr. Manuel Navarro de Céspedes. Natural de Madrid, tomó el hábito en San Martín Pinario, en 1670. Estudió en Irache (1675-1678), y luego fue Pasante en Celorio y Ribas de Sil. Después fue segundo Maestro de estudiantes (1685-1689), Lector de Vísperas de Teología (1689-1693), Regente de estudios (1693-1697), Lector de Tercia de Teología (1701-1709) y Abad (1697-1701, 1709, 1713-1717) de San Vicente de Salamanca. Recibió los grados de L. A. / D. A. / B. T. / L. T. / D. T. en 1689 en Irache. Regentó las cátedras de Artes (1690-1692), de Vísperas de Teología (1692-1703) y de Prima (1703-1712) de la Universidad de Salamanca. Fue también Maestro general de la Congregación, Definidor general (1693-1697) y Predicador de Carlos II. Intervino en diversas polémicas intelectuales y publicó diferentes obras teológicas. Murió en $1723^{306}$.

Fr. Manuel de Quirós. Era natural de Toro (Zamora), donde había nacido en 1651-1652. Ingresó en el Colegio de Infantes de Valladolid en 1662 y allí tomó el hábito en 1664. Fue Maestro de estudiantes en Salamanca (1681-1685), Regente segundo de Eslonza (1685-1689), Lector de Vísperas (1689-1693) de Salamanca e intentó obtener, infructosamente, la cátedra de Vísperas de Teología fundada por el cardenal Aguirre. Obtuvo los grados de B. A. / B. T. / L. T. / D. T. en Irache, en 1689. Fue Abad de de Espinareda (1693-1697); el rey Carlos II le presentó para el

304 E. Zaragoza Pascual, “Abadologio de Carrión de los Condes”, p. 301; E. Zaragoza Pascual, “Abadologio de Irache”, p. 188.

305 E. Zaragoza Pascual, “Abadologio de Valvanera”, p. 358.

306 A. Pérez Goyena, "La literatura teológica española...”, pp. 56-58; E. Zaragoza Pascual, "Profesores de Salamanca", p. 307; F. J. García Pérez, "Los Predicadores reales de Carlos II”, p. 710. 
obispado de Oaxaca en 1697 y murió al poco de llegar a su diócesis, en 1699. Dejó dos tratados manuscritos ${ }^{307}$.

Fr. José Gobeo. Era natural de San Asensio (La Rioja) y tomó el hábito en Valvanera en 1679. Siguió la carrera del púlpito, siendo Predicador en los Monasterios de Nájera (1685-1689) y Soria (1693-1701), así como Predicador general y regio. Obtuvo los grados de B. A. / B. T. / L. T. / D. T. en Irache, en 1689. Fue asimismo Abad de Valvanera (1689-1693), Villanueva (1713-1717), Tenorio (17171721) y Lérez (1721-1725) 308 .

Fr. José Fernández. Natural de Viguera (La Rioja), tomó el hábito en San Millán de la Cogolla en 1665. Había sido Lector de Poyo (1681-1685) y, después de ser Regente de Irache (1685-1693), fue Abad de San Millán (1693-1697), Definidor general y Lector de Teología moral en San Juan de Burgos (1697-1701). Había recibido los grados de B. A. / M. A. / B. T. / M. T. en Irache en 1691. Murió en San Millán en 1710. Hizo la traducción y edición de la Philosophia del Cielo enseñada por la Sabiduría increada de Santa Gertrudis (Barcelona, 1691) ${ }^{309}$.

Fr. José de Osorio. Fue Pasante primero (1677-1681) y Lector (1681-1685) de Ribas de Sil. Fue asimismo Lector (1681-1685), Maestro de estudiantes (16851689), Lector de Vísperas de Teología (1689-1693) y Regente de estudios (16931697) de Irache, donde se graduó de B. A. / M. A. / B. T. / M. T. en $1691^{310}$.

Fr. Plácido Mosquera. Natural de Sa, junto a Ribadavia, tomó el hábito en San Martín Pinario en 1671. Fue Predicador en San Martín (1693-1701) y Salamanca (1709-1713), así como Predicador general. Fue Abad de San Martín (1701-1705) y Poyo (1717-1721). Recibió todos los grados de Artes y Teología en Irache, en 1692. Se conservan algunos de sus sermones impresos como Oracion panegyrica annual, que en la mas plausible celebridad le consagra à Dios, y al siempre venerado Apostol Santiago (Santiago, 1686) ${ }^{311}$.

307 E. Zaragoza Pascual, "Profesores de Salamanca", p. 305; E. Zaragoza Pascual, "Abadologio de Espinareda”, p. 227.

308 E. Zaragoza Pascual, “Abadologio de Lérez”, p. 423; E. Zaragoza Pascual, “Abadologio de Valvanera”, p. 358; F. J. García Pérez, "Los Predicadores reales de Carlos II”, p. 711.

309 E. Zaragoza Pascual, "Profesores de Irache”, p. 318; E. Zaragoza Pascual, “Abadologio de San Millán”, pp. 211-212.

310 E. Zaragoza Pascual, "Profesores de Irache”, p. 319.

311 E. Zaragoza Pascual, “Abadologio de San Martín Pinario”, p. 228. 
Fr. Baltasar Domper. Profeso en San Juan de la Peña y Prior de Naval, recibió en Irache los grados de Teología en 1693. Asistió al besamanos a Felipe V en Zaragoza, en $1711^{312}$.

Fr. José Plácido Cabrero. Nació en 1657 en Bolea. Ingresó en San Juan de la Peña en 1681. Recibió los grados de L. A. / B. T. / L. T. / D. T. en Irache, en 1693. Abad de Alaón (1716-1737), fue presidente de la Provincia cesaraugustana de la Congregación benedictina claustral (1718-1721, 1724-1727, 1730-1734, 1737-1740) ${ }^{313}$.

Fr. Francisco López. Religioso de San Juan de la Peña, se graduó en Irache de B. A. / B. T. / L. T. / D. T. en 1693.

Fr. Juan de Cañas. Nacido en Granada, tomó el hábito en Oña en 1671. Siguió la carrera del púlpito, siendo Predicador de Oña, Medina del Campo y Valladolid. Siendo Abad de Oña (1693-1697), recibió todos los grados de Artes y Teología en Irache, en 1694. Fue Juez y Predicador de Valladolid, hasta que fue electo nuevamente Abad de Oña (1709-1713) ${ }^{314}$.

Fr. Benito de Anguiano. Natural de Huércanos (La Rioja), tomó el hábito en Nájera en 1671. Pasante (1681-1685) y Lector de Artes (1685-1689) en Irache, fue Abad de Nájera (1689-1693), y luego Lector de Teología moral de San Juan de Burgos (1693), Definidor general (1693-1694) y Lector de Tercia de Irache, donde se graduó en Artes y Teología en 1694. Murió ese mismo año ${ }^{315}$.

Fr. Plácido Vea. Natural de Fitero (Navarra) y profeso de San Millán de la Cogolla, donde había tomado el hábito en 1671, fue Pasante de Obona (1681-1685) y Lector de Artes de Espinareda (1685-1689). En Irache fue Maestro de estudiantes (1689-1693), Lector de Vísperas de Teología (1693-1697), Lector de Prima y Regente de estudios (1697-1704). Recibió allí todos los grados de Artes y Teología en 1694. Luego fue Abad de San Millán (1704-1709), Eslonza (1713-1717) y Dueñas (1721-1724), Lector de Teología moral de San Martín de Madrid (1709-1713) y dos veces Definidor general (1709-1713, 1717-1721). Murió en 1724 $4^{316}$.

312 E. Zaragoza Pascual, Història de la Congregació..., p. 212; N. Juan García, "San Juan de la Peña...”, p. 225.

313 E. Zaragoza Pascual, Història de la Congregació..., p. 413; M. C. Palacín Zueras, "El Real Monasterio de San Juan de la Peña y la desamortización”, Argensola, 111 (1997), pp. 153-186, especialmente p. 176.

314 E. Zaragoza Pascual, "Abadologio de Oña”, p. 582.

315 E. Zaragoza Pascual, "Profesores de Irache", p. 318.

316 E. Zaragoza Pascual, "Profesores de Irache”, pp. 319-320. 
Fr. Íñigo de Ruiloba. Natural de Rudaguera (Cantabria), tomó el hábito en Valladolid en 1679. Tras ser Lector de Artes de Irache, donde se graduó en Artes y Teología en 1694, fue Lector de Teología moral de Valladolid (1697-1701, 1709), Predicador y Abad de Monforte de Lemos (1705-1709) y Abad de Valladolid (1709), en cuyo cargo murió en $1709^{317}$.

Fr. Gregorio Ruiz. Nació en Cerrazo hacia 1647-1648, e ingresó en el Colegio de Infantes de Valladolid en 1669. Tomó el hábito en San Benito en 1673, y siguió la carrera de Predicador, que desempeñó en Valladolid durante tres trienios. En Irache, se graduó en Artes y Teología en 1695. Fue nombrado Predicador general en 1709. Fue Abad de Zamora (1689-1693), Prior (1681-1685) y Abad de Valladolid (1697-1701). Fue Definidor general (1693-1697) y Abad de Espinareda (17161721). Murió en $1724^{318}$.

Fr. Plácido de Pinillos. Era natural de Murillo de Río Leza. Tomó el hábito en San Millán en 1675. Siguió la carrera del púlpito: fue predicador de Zamora y doce años predicador de San Millán, así como ocho provisor de su Abadía. Siendo Predicador Mayor en San Martín Pinario, recibió en 1699 los grados de B. A. / B. T. / L. T. / D. T. en Irache. Murió en $1718^{319}$.

Fr. Gregorio de Haro. Profeso de San Martín Pinario, fue Lector de Artes de Lérez (1689-1693) y Maestro de estudiantes de Poyo (1693-1697), Lector de Vísperas de Irache (1697-1701), donde se graduó en Artes y Teología en 1699, y Regente de Poyo (1701-1705). Luego fue nombrado Abad de San Martín Pinario (1709-1713) y murió en Santiago en $1724^{320}$.

\section{Los graduados}

En este último apartado vamos a analizar tanto los datos globales de los graduados como la trayectoria de los más destacados. Salta a la vista que no podremos dedicar una reseña a cada uno de los más de seis mil egresados. Solamente queremos poner de manifiesto el tipo de graduado en las diferentes facultades, con la finalidad de conocer sus rasgos generales.

317 E. Zaragoza Pascual, "Profesores de Irache”, pp. 320-321.

318 E. Zaragoza Pascual, "Abadologio de Valladolid”, pp. 244-245.

319 E. Zaragoza Pascual, "Monacologio emilianense", p. 304.

320 E. Zaragoza Pascual, "Profesores de Irache”, p. 321; E. Zaragoza Pascual, “Abadologio de San Martín Pinario”, p. 228. 


\subsection{Datos globales}

Aunque sea muy difícil dar estadísticas precisas, porque a veces los asientos archivísticos están incompletos o su interpretación es compleja, ofrecemos unas indicaciones que tienen que ser tomadas en un sentido aproximativo, a fin de conocer mejor las tendencias.

\subsubsection{Estadísticas de aprobados y reprobados}

En la Universidad de Irache solamente había estudios de Artes y Teología, si bien colacionaba grados en todas las Facultades. Como se podrá ver seguidamente, el título más solicitado fue el de B. C., seguido del de B. A. En cuanto a los títulos de Doctor, el que más se colacionó fue el de D. T., seguido por el de D. C. No deja de ser una paradoja que, sin tener profesores de Cánones, en Irache se graduaran 3272 B. C., procedentes de los puntos más variados de la geografía peninsular.

El número de reprobados fue muy bajo. Prácticamente aprobaron todos los estudiantes que se presentaron a examen durante la primera mitad del siglo XVII. A partir de entonces, suspendieron a algunos, sobre todo en Derecho canónico. Las cifras, en términos absolutos, son las siguientes:

\begin{tabular}{|l|r|}
\hline B. A. & 2093 \\
\hline L. A. & 271 \\
\hline M.A / D.A. & 169 \\
\hline Reprobados & 5 \\
\hline
\end{tabular}

\begin{tabular}{|l|r|}
\hline B. T. & 1150 \\
\hline L. T. & 477 \\
\hline D. T. & 341 \\
\hline Reprobados & 39 \\
\hline
\end{tabular}

\begin{tabular}{|l|r|}
\hline B. C. & 3272 \\
\hline L. C. & 555 \\
\hline D. C. & 231 \\
\hline Reprobados & 163 \\
\hline
\end{tabular}




\begin{tabular}{|l|r|}
\hline B. L. & 110 \\
\hline L. L. & 136 \\
\hline D. L. & 63 \\
\hline Reprobados & 1 \\
\hline
\end{tabular}

\begin{tabular}{|l|r|}
\hline B. M. & 292 \\
\hline L. M. & 68 \\
\hline D. M. & 68 \\
\hline Reprobados & 5 \\
\hline
\end{tabular}

El mayor número de reprobados se encontraba en la Facultad de Cánones, mientras que, en segundo lugar, se negó el título a algunos aspirantes en Teología. Hubo más egresados médicos que legistas y, en cuanto a la Facultad de Artes, debe indicarse que los grados de L. A. y D. A. los recibieron, casi con exclusividad, los benedictinos graduados. Una proporción muy importante de graduados en L. T. y D. T. fueron también los hijos de San Benito.

\subsubsection{Lugar de procedencia}

En primer lugar, vamos a referirnos a las Diócesis de procedencia de los egresados, en un sentido descendente: Burgos (3645), Pamplona (1179), Calahorra (570), Tarazona (192), Zaragoza (103), Toledo (56), Palencia (55), Valladolid (47), Jaca (34), Huesca (34), Osma (33), Sigüenza (18), Barbastro (17), León (14), Lérida (14), Cuenca (14), Astorga (13), Orense (12), Sevilla (12), Santiago (12), Teruel (10), Zamora (10), Bayona (9), Ávila (9), Tortosa (9), Córdoba (7), Segovia (7), Lisboa (6), Tuy (6), Tarragona (5), Lisboa (6), Cartagena (5), Plasencia (4), Coria (3), Mallorca (3), Coimbra (3), Valencia (3), Badajoz (3), Gerona (3), Urgell (2), Cáller (2), Canarias (2), Granada (2), Almería (1), Elna (1), La Habana (1), Charcas (1), Ciudad de Plata (1), Lima (1), Nullius Diocesis (60).

De ello se desprende que más de la mitad de los egresados en Irache provino de la Archidiócesis de Burgos. A una distancia considerable, la Diócesis de Pamplona aportó más de un milenar de graduados, que solamente representaban un tercio de la de Burgos. La de Calahorra contribuyó al número total con la mitad de los egresados de Pamplona. A fin de conocer mejor esta realidad, veamos a continuación la distribución por ciudades en las Diócesis más representativas. 
En cuanto a la Archidiócesis de Burgos, hay que resaltar las siguientes poblaciones: Burgos (387), Melgar de Fernamental (65), Villasandino (63), Medina de Pomar (61), Frías (60), Sasamón (50), Laredo (50), Castrojeriz (48), Briviesca (41), Pancorbo (37), Castro Urdiales (36), Poza (36), Santibáñez (30), Presencio (27), Cerezo (27), Villasilos (23), Villadiego (22), Bureba (22) y Guriezo (21). De la Diócesis de Pamplona, destacan: Pamplona (314), Estella (83), Arróniz (27) y Falces (22). De la Diócesis de Calahorra, sobresalen: Arnedo (39), Logroño (34) y Calahorra (22). En cuanto a la Diócesis de Tarazona, descuellan: Tudela (44), Alfaro (40), Tarazona (24) y Calatayud (19).

Hubo muy pocos graduados que procedieran de fuera de la Monarquía Hispánica. Llegaban a Irache desde lugares lejanos de América (Perú, Cuba) y de las islas mediterráneas (Mallorca, Cerdeña). Hallamos algunos irlandeses, que habían sido acogidos por la Monarquía católica, con el fin de enviar nuevos misioneros a su tierra.

En cuanto a las Universidades de procedencia, de acuerdo con la documentación, podemos afirmar que la Universidad de la cual provenían más aspirantes a los grados fue Salamanca (50), seguida de Huesca (26), Valladolid (19), Alcalá (10) y Oñate (9). Debe añadirse, de la Corona de Aragón, la Universidad de Zaragoza, en la cual habían estudiado algunos candidatos. Encontramos asimismo alumnos que procedían de Pamplona, Granada, Valencia...

\subsubsection{Sociología de los graduados}

Debemos distinguir entre los graduados clérigos y los seglares. Hubo una amplia representación del clero secular, en sus diferentes capas (desde prelados hasta curas párrocos y vicarios), y del regular, con presencia abundante de la gran mayoría de órdenes religiosas y militares presentes en Navarra, Castilla y Aragón.

Tendremos ocasión luego de conocer estos grupos con más detalle. Baste ahora indicar que la Universidad graduó a sus propios colegiales, y también a los colegiales de otras instituciones presentes en Pamplona (jesuitas, teatinos y carmelitas), así como de los dominicos, hasta que fundaron su Universidad en Pamplona. Después, algunos de los estudiantes del Convento-Universidad de Santiago de Pamplona, acudieron a título privado a recibir otros títulos a Irache, aunque nunca más lo hicieron como acto corporativo, al terminar el ciclo de Artes.

Sobresale, en el clero regular, la presencia de los ya citados 238 egresados benedictinos, a la que se deben sumar 37 mercedarios, 36 cistercienses, 20 
carmelitas, 12 premonstratenses, 11 agustinos, 2 trinitarios, un canónigo regular de San Agustín, 7 miembros de la Orden de Calatrava, 4 de la Orden de Santiago, 2 de la Orden de Alcántara y un caballero de la Orden de Montesa.

Entre el clero secular destacan 38 canónigos, tanto de catedrales como de colegiatas. Entre las catedrales, deben destacarse las de Pamplona ${ }^{321}$, Burgos, León, Valladolid y Zaragoza, a las que hay que sumar un representante de las de Palencia, Calahorra, Barcelona... La Colegiata más destacada es la de Roncesvalles, seguida por las de Aguilar de Campoo, Daroca, Lerma, Calatayud, Pastrana...

Deben añadirse algunos colegiales mayores y menores, y ciertos hijos de las casas aristocráticas de Castilla y de Navarra. Algunos de ellos habían acudido a las Universidades mayores a estudiar, y luego se graduaban en Irache. Otros, en cambio, recibieron algunos grados en el Monasterio antes de ingresar en Colegios mayores ${ }^{322}$.

Como solía acostumbrarse en las universidades de la época, muchos hermanos, amigos o coterráneos acudían a graduarse en grupo para compartir los gastos y defenderse contra las adversidades. Hay numerosos ejemplos de religiosos (los monjes José Miguel Llorca, Benito Guembe y Antonio Ros, tres cistercienses del Monasterio de Iranzu; o los carmelitas Juan de Ollo, Clemente de Azcona y Jerónimo Luengo), hermanos (v.g. Roque y Ventura de Mier y Terán, Manuel y Pedro de Ornedo, Diego y José de Varona, Pedro y Silvestre de Roba...) o vecinos que se graduaron el mismo día (entre ellos, Bernardo de Astorga y Santiago de Almurrio, de Melgar de Fernamental; San-

321 Marqués de Jaureguizar, "Relación de los canónigos de la santa Iglesia de Pamplona”, Hidalguía, 127 (1974), pp. 887-944.

322 Sobre los Colegios mayores, véase A. M. Carabias Torres, M. A. Benito Rodríguez, M. Carrasco Mateos, M. A. Pérez Paniagua, "Catálogo de colegiales del Colegio mayor de San Bartolomé en el siglo XVII”, Studia Historica. Historia Moderna, 3 (1990), pp. 183265; L. Ferrer Ezquerra e H. Misol García, Catálogo de Colegiales del Colegio Mayor de Santiago el Cebedeo, del Arzobispo, de Salamanca, Salamanca, Universidad de Salamanca, 1956; L. M. Gutiérrez Torrecilla, Catálogo biográfico de colegiales y capellanes del Colegio Mayor de San Ildefonso de la Universidad de Alcalá de Henares (1508-1786), Alcalá, Universidad de Alcalá de Henares, 1992; J. de Rojas Contreras, Historia del Colegio Viejo de San Bartolomé Mayor de la Universidad de Salamanca, Madrid, por Andrés Ortega, 1768; M. A. Sobaler Seco, Catálogo de colegiales del Colegio Mayor de Santa Cruz de Valladolid (1484-1786), Valladolid, Universidad de Valladolid, 2000. Actualmente está en curso el proyecto "Diccionario biográfico de Colegiales Mayores españoles (1560-1650)", de la Universidad Carlos III. 
tos Hierro del Solar y Diego Marroquín y Montehermoso, ambos de Cerceda; o Pedro Martínez y José de Vitas, ambos de Tudela y estudiantes de Leyes en Zaragoza) o con pocos días de diferencia (como Juan García y Fernando Ortúñez, de Villaneta, de la Abadía de Covarrubias, que se graduaron en el espacio de ocho días, sin que nadie más lo hiciera entre ambos).

\subsection{Los graduados por Facultades}

Pasemos, por último, al estudio de los graduados por Facultades. Solamente examinaremos las de Artes, Teología, Cánones y Leyes, puesto que la de Medicina ha sido estudiada muy detalladamente por Fernando Serrano.

Dámaso de Lario ha acuñado la feliz expresión "Escuelas de Imperio ${ }^{323 "}$ para referirse a los Colegios mayores de las Universidades hispánicas. A continuación veremos de qué forma los egresados de Irache, en una escala mucho menor, participaron de esa burocracia civil o eclesiástica. Los que lograron ser admitidos en un Colegio mayor, obtuvieron una mayor proyección.

\subsubsection{Facultad de Artes}

Los estudios de Latinidad y Filosofía se impartían en numerosos colegios y conventos de Pamplona. Sin embargo, aunque hubieran cursado los estudios preceptivos, dichas instituciones no podían graduar. Por esta razón, Irache resultaba un lugar de peregrinación necesaria para todos estos estudiantes, que se examinaban en un mismo día. Se trataba de un acto meramente formal, puesto que ya habían sido aprobados por sus respectivos maestros colegiales o conventuales. Simplemente, en Irache repetían un ejercicio para demostrar su aptitud, y eran graduados.

En paralelo, todos los estudiantes que vivían en Irache, al acabar los estudios de Artes, podían examinarse, de acuerdo con lo preceptuado en las Constituciones. De este modo, en la Facultad de Artes examinaron a muchos estudiantes del Reino de Navarra y de sus inmediaciones.

Como indicó Ibarra, "estos adolescentes, cursantes en los Colegios de Pamplona, cuales eran los de la Anunciada, de la Compañía de Jesús, de Santiago, de los Padres Dominicos, del Colegio del convento del Carmen y de los franciscanos ${ }^{324}$ ", se graduaron sistemáticamente en Irache hasta 1624, año en

323 D. de Lario, Escuelas de imperio. La formación de una élite en los Colegios Mayores (siglos XVI-XVII), Madrid, Dykinson, 2019.

324 J. Ibarra Murillo, Historia..., p. 287. 
el que el Colegio de Santiago recibió la bula de la concesión de grados. Como resultaba más cómodo graduarse en la misma ciudad de Pamplona, muchos de los Colegios decidieron que sus estudiantes lo harían con los dominicos, a partir de 1630, año en el que se puso en funcionamiento la Universidad de Pamplona. Solamente los jesuitas, por su feroz oposición a la Universidad de los dominicos en la capital de Navarra, continuaron acudiendo a Irache.

En la relación de graduados y reprobados, hemos intentado identificar la procedencia de los estudiantes, siempre y cuando resulta posible (indicando, por ejemplo, que eran estudiantes del Colegio de los jesuitas, de los carmelitas o que eran discípulos de un maestro dominico).

Ibarra ofrece bastante información sobre estos bachilleres ${ }^{325}$, e incluso destaca algunos que luego sobresalieron en su ejecutoria posterior. Estos datos resultan, sin duda, muy relevantes, para ulteriores estudios sobre la historia social y cultural del Reino de Navarra en el siglo XVII.

Entre los alumnos que solamente se graduaron en Artes, hay que destacar a Mateo de Castro, canónigo de Palencia ${ }^{326}$; Martín Ardaiz, canónigo de Roncesvalles $^{327}$; Juan de Aguirre, Oidor real del consejo de Navarra, Colegial de San Bartolomé de Salamanca ${ }^{328}$; José de Badarán, que hizo los estudios jurídicos en Oñate, luego fue Colegial de San Bartolomé y se desempeñó como Alcalde de Casa y Corte y Oidor en Pamplona ${ }^{329}$; Fausto de Eusa, que fue Catedrático en la Universidad de Huesca, Colegial en el Mayor de San Bartolomé y Catedrático en la Universidad de Salamanca hasta su muerte en $1633^{330}$; el mercedario Fr. José Burdeos, que ocupó importantes cargos en su Orden ${ }^{331}$, o Domingo Pérez de Atocha, Colegial de San Ildefonso y canónigo de Pamplona ${ }^{332}$.

A continuación damos noticia, por grupos, de los graduados más notables.

325 Ibidem, pp. 286-296.

326 A. Cabeza, Clérigos y señores: política y religión en Palencia en el Siglo de Oro, Palencia, Diputación Provincial de Palencia, 1996, p. 385.

327 J. Ibarra Murillo, Historia..., p. 282.

328 M. D. Martínez Arce, Aproximación a la justicia en Navarra durante la Edad Moderna: jueces del Consejo Real en el siglo XVII, Pamplona, Ediciones Fecit, 2005, pp. 192 y 268; A. M. Carabias Torres et alt., “Catálogo de colegiales...”, p. 199.

329 M. D. Martínez Arce, Aproximación a la justicia..., p. 295.

330 J. Ibarra Murillo, Historia..., p. 307; A. M. Carabias Torres et alt., "Catálogo de colegiales...”, p. 202.

331 J. Goñi Gaztambide, Historia de los Obispos de Pamplona. Siglo XVII, Vol. VI, Pamplona, Universidad de Navarra, 1979, p. 460.

332 L. M. Gutiérrez Torrecilla, Catálogo biográfico..., p. 83. 
Si al analizar la sociología de los graduados poníamos el foco en el estatus de los mismos en el momento de graduarse, nos centramos ahora en su proyección posterior. Hay que subrayar asimismo que se hace la clasificación a partir de los grados conferidos en Irache. Muchos que se graduaron en Leyes o en Cánones en Irache, lo habían hecho en el otro Derecho en otra sede. Por esa razón, muchos de los canonistas que aquí se destacan brillaron como legistas y viceversa.

\subsubsection{Facultad de Teología}

Los egresados en Teología fueron siempre eclesiásticos, regulares y seculares. Entre los primeros, tenemos que destacar los cistercienses, los carmelitas, los mercedarios y los premonstratenses, que tuvieron una proyección dentro de los cauces de sus órdenes religiosas. Los segundos fueron curas párrocos, canónigos y beneficiados, algunos de los cuales llegaron a ceñir mitras y a ocupar destacados puestos en la burocracia eclesial hispana.

Entre los regulares, hay que destacar, ante todo, a los cistercienses: Ángel del Águila, Abad de la Espina y de la Oliva ${ }^{333}$; Manuel de Cereceda, Abad de la Oliva (1640-1644); Juan Jiménez de Tabar, cisterciense de Tarazona, Abad de Veruela ${ }^{334}$; Antonio de Peralta, Abad de San Salvador de Leire ${ }^{335}$; el erudito y Predicador Germán de Buges, autor de Primera parte de la Cosmographia christiana y descripcion graciosa del Reyno de Christo y de su dotrina euangelica: para los misterios del Aduiento y Quaresma (Burgos, 1623); Esteban Blanco de Morales, Rector del Colegio de San Bernardo de Huesca; y, sobre todo, al historiador Miguel Ramón Zapater, autor de Císter militante en las campañas de la Iglesia contra la sarracena furia (Zaragoza, 1662).

El carmelita más famoso fue Marco Antonio Alegre de Casanate, quien renunció a ser secretario de Felipe III, y prefirió dedicarse al estudio histórico y teológico, especialmente en su controvertida obra Paradisus carmelitici decoris, cum apologia pro Joanne XLIV, partriarcho Hierosolymitano (Lyon, 1639) ${ }^{336}$.

333 M. D. Yáñez Neira, "El Monasterio de la Espina y sus Abades”, Archivos leoneses, 26 (1972), p. 116.

334 España sagrada, Vol. L, Madrid, Imprenta de José Rodríguez, 1866, p. 228.

335 Á. Cristóbal Martín, Confianza, fidelidad y obediencia: servidores inquisitoriales y dependencias personales en la ciudad de Logroño, siglo XVIII, Logroño, Instituto de Estudios Riojanos, 1994, pp. 36 y 68.

336 B. Velasco Bayón, Historia del carmelo español, Vol. 1, Roma, Institutum Carmelitanum, 1990, p. 48. 
De los premonstratenses, el más importante fue Felipe Bernal, Definidor general y Reformador general de los premonstratenses en España, desde 1627 hasta 1630, así como Abad de San Norberto de Madrid (1615-1618), Santa María de la Vid de Burgos (1618-1621) y, durante dos trienios, de Ibeas (1636-1639, 1648-1651)

De los Mercedarios, sobresale Juan de Villoria, Secretario General de la Orden de la Merced; hay que destacar, entre los agustinos, a Fr. Martín Cornejo, madrileño, que fue Prior en los Conventos de Ciudad Rodrigo, Burgos y Madrid, así como Rector del Colegio de Alcalá338; y a José de Enguita, Lector de Teología en Sto. Tomás de Villanueva; y, entre las órdenes militares, a Bartolomé Pérez de Espejo, de la Orden de Santiago y a Frey Juan Fernández Rojo, de Calatrava ${ }^{339}$.

Entre los seculares, los más importantes fueron los que llegaron a la dignidad episcopal: Gabriel Esparza, Colegial de San Bartolomé, canónigo de Pamplona, y Obispo que fue de Badajoz, Salamanca y, finalmente, de Calahorra ${ }^{340}$; Antonio Paino, quien desempeñó varias mitras, entre ellas, las de Burgos y Sevilla ${ }^{341}$; Juan Francisco de Ochoa, que fue Maestrescuela de Salamanca y Obispo de Palencia ${ }^{342}$; o Pedro Tapis García, quien fue Obispo de Durango y Obispo electo de Guadalajara ${ }^{343}$.

Un grupo mucho más reducido lo conforman los que desempeñaron cargos, tanto en la burocracia civil como en la eclesiástica: algunos ejemplos podrían ser Francisco de Zárate, que fue Consejero de la Inquisición, Presidente de la Chancillería de Valladolid y Obispo de Segovia y Cuenca ${ }^{344}$; y Diego

337 J. Goñi Gaztambide, "Los premonstratenses en España”, Hispania sacra, 21 (1968), pp. 57-85.

338 J. A. Álvarez y Baena, Hijos de Madrid ilustres en santidad, dignidades, armas, ciencias y artes, Tomo IV, Madrid, en la Oficina de Benito Cano, 1791, p. 84.

339 M. D. Couto de León, Pruebas para ingreso de religiosos en las Órdenes de Santiago, Calatrava y Alcántara, Madrid, Ministerio de Cultura, 1980, p. 36.

340 J. Goñi Gaztambide, Historia de los Obispos de Pamplona..., pp. 216-217; A. M. Carabias Torres et alt., "Catálogo de colegiales...", p. 210.

341 J. Ibarra Murillo, Historia..., pp. 331-332.

342 D. Quijada Álamo, "El Cabildo de la Iglesia Catedral de Palencia: canónigos y Predicadores del sermón fúnebre regio durante el setecientos”, Estudios Humanísticos, 13 (2014), p. 98.

343 J. R. Gurpegui Resano, Pedro Tapiz y García (1673-1722), Andosilla, Ayuntamiento de Andosilla, 2004.

344 J. de Rojas Contreras, Historia del Colegio Viejo..., pp. 49 y 66. 
de Tejada, Inquisidor, Obispo de Ciudad Rodrigo y Pamplona, Arzobispo de Burgos, Virrey y Capitán general de Navarra ${ }^{345}$.

Sobresalen varios canónigos de catedrales y colegiatas, como Miguel de Eraso, canónigo de Pamplona ${ }^{346}$; Sebastián Calderón ${ }^{347}$, canónigo de Burgos; Juan de Echegaray, canónigo de Calahorra; Lorenzo Beltrán, Capellán primero de la Emperatriz y Deán de Ciudad Rodrigo; Alonso González Alvar, Abad de la Colegial de Aguilar de Campoo; Juan Crisóstomo de Iñíguez y Puyo, Arcediano y canónigo de Daroca; Pedro García de Galdeano, Abad de Galdeano; Francisco de Lama, canónigo de Puebla de los Ángeles; o Juan de Echalaz, canónigo de Roncesvalles ${ }^{348}$.

Se graduaron asimismo otros personajes que alcanzaron solamente beneficios menores o que, a la sazón, se desempeñaban como vicarios. Un ejemplo podría ser el de Diego de Ayarra, Vicario de Valtierra. Y cabe añadir, por último, que tres de los cuatro irlandeses que aparecen en la nómina de grados, se doctoraron en Teología: Daniel Núñez, Guillermo Ocón y Gofredo Daniel ${ }^{349}$.

\subsubsection{Facultad de Cánones}

Los graduados en Cánones fueron eclesiásticos en bastantes casos, aunque no en todos. Debe distinguirse entre los que emprendieron la carrera de la burocracia civil y los que siguieron el cursus eclesiástico. Unos llegaron a ocupar puestos destacados en la jurisdicción del Reino de Navarra y en las Audiencias de otros puntos de la Monarquía hispánica; otros ocuparon cargos en la Inquisición o alcanzaron la dignidad episcopal. Los colegiales mayores, como era común en aquellas fechas, llegaron a puestos más encumbrados.

En un primer grupo englobamos a aquellos que hicieron simultáneamente una carrera civil y eclesiástica: destacaron Gil (Carrillo) de Albornoz, Regente del Consejo de Navarra, del Consejo de la Inquisición, Gobernador del Milanesado, Arzobispo de Taranto y finalmente cardenal ${ }^{350}$; Francisco de Aguirre,

345 J. Goñi Gaztambide, Historia de los Obispos de Pamplona..., pp. 259-286.

346 Marqués de Jaureguizar, "Relación de los canónigos...”, p. 899.

347 E. García de Quevedo, "De bibliografía burgense”, Boletín de la Comisión Provincial de Monumentos Históricos y Artísticos de Burgos, 11/3 (1933), p. 461.

348 J. Ibarra Murillo, Historia..., p. 304.

349 Ibidem, p. 393.

350 V. Guitarte Izquierdo, Episcopologio español (150o-1699): españoles obispos en España, América, Filipinas y otros países, Roma, Instituto Español de Historia Eclesiástica, 1994, p. 153. 
que fue colegial de Oviedo, y miembro del Consejo de Santa Clara de Nápoles, así como Obispo de Crotona (1556), y Tropea (1564) ${ }^{351}$; Martín López, que fue Oidor de Granada y Regente de Navarra, así como Obispo de Calahorra y Arzobispo de Valencia ${ }^{352}$; o Francisco Marín de Rodezno, Consejero de la Inquisición, Presidente de la Chancillería de Granada y Prior de Roncesvalles ${ }^{353}$.

En un segundo grupo reunimos a quienes se desempeñaron solamente en la carrera eclesiástica: Andrés Bravo, canónigo de Sigüenza, Abad de Santa Coloma, Inquisidor en Mallorca, Llerena, Barcelona y Zaragoza, consejero del Tribunal de la Suprema, Obispo de Cartagena y de Sigüenza ${ }^{354}$; Diego Martínez Zarzosa, Obispo que fue de Tuy, Cartagena y Málaga ${ }^{355}$; Antonio de Valdés, canónigo vallisoletano, que primero fue Obispo de Mondoñedo, y luego ocupó la sede ovetense y ejerció como Rector de la Universidad, hasta que en 1642 fue nombrado Obispo de Osuna, y en 1654 Obispo de Córdoba, donde falleció en $1657^{356}$; José de la Peña, Obispo de las Diócesis de Orense y de Calahorra ${ }^{357}$; Pedro de Manjarrés, Inquisidor y luego Obispo de Mallorca, Tarazona, Segovia y Granada ${ }^{358}$; Francisco Calderón de la Barca, Colegial de San Ildefonso y Predicador, que llegó a ser Obispo de Salamanca ${ }^{359}$; Juan Marín de Rodezno, Fiscal y Presidente de la Inquisición, y Obispo de Badajoz ${ }^{360}$; Pedro Herrera y Soto, Colegial mayor de Santa Cruz, Arcediano de Écija y canónigo de Sevilla, Inquisidor de Granada, y Fiscal del Consejo de Inquisi-

351 P. Molas, “Colegiales mayores de Castilla en la Italia española”, Studia historica. Historia moderna, 8 (1990), p. 181.

352 E. Callado Estela, "El arzobispo de Valencia don Martín López de Hontiveros”, en E. Callado Estela (ed.), La Catedral Barroca. Iglesia, sociedad y cultura en la Valencia del siglo XVII, Vol. I, Valencia, Institució Alfons el Magnànim, 2018, pp. 33-56.

353 L. Ferrer Ezquerra y H. Misol García, Catálogo de colegiales..., pp. 153-154.

354 T. Minguella, Historia de la diócesis de Sigüenza y de sus Obispos, vol. III, [S.1.: s.n.], 1913, pp. 73-84.

355 V. Guitarte Izquierdo, Episcopologio español (150o-1699), p. 173.

356 J. Ibarra Murillo, Historia..., p. 343.

357 M. C. Jiménez Zubiría, “Aproximación biográfica a la figura de D. José de la Peña García, Obispo de las diócesis de Orense y de Calahorra-La Calzada, natural de la villa de Valtierra (Navarra)", Revista del Centro de Estudios Merindad de Tudela, 25 (2017), pp. 99-123.

358 España Sagrada, Vol. XLIX, Madrid, Imprenta de José Rodríguez, 1866, p. 274.

359 L. M. Gutiérrez Torrecilla, Catálogo biográfico..., pp. 23-24.

360 P. Rubio Merino, "Marín de Rodezno”, en Q. Aldea Vaquero, T. Marín Martínez y J. Vives Gatell (dirs.), Diccionario de Historia Eclesiástica de España, Vol. III, Madrid, CSIC, 1973, p. 1420. 
ción ${ }^{361}$; o Matías de Rada, Colegial de San Ildefonso, Caballero de Calatrava y Maestrescuela de Salamanca ${ }^{362}$.

Un tercer grupo lo constituyen los que siguieron exclusivamente una carrera civil, entre los que cabe distinguir entre los que sirvieron en diversos Reinos de la Monarquía Hispánica y los que se quedaron en el Reino de Navarra. Entre los primeros, cabe destacar a Miguel López de Dicastillo, Catedrático de la Universidad de Alcalá de Henares, Alcalde de la Real Corte Mayor de Navarra, Consejero del Consejo Real de Navarra, y Oidor del Consejo de Indias ${ }^{363}$; Pedro de Amézqueta, que fue sucesivamente Alcalde de la Sala de hijosdalgo de la Real Chancillería de Valladolid, Alcalde del crimen de la misma Chancillería, Alcalde de Casa y Corte y Consejero del Consejo Real de Castilla ${ }^{364}$; Antonio de Feloaga, Colegial del Arzobispo, Caballero de Santiago, Catedrático en la Universidad de Salamanca y Fiscal del Consejo de Indias ${ }^{365}$; Jerónimo de Oroz, Catedrático de las Universidades de Alcalá y Valladolid, Oidor de la Chancillería de Granada y Alcalde de Casa y Corte de Madrid, así como notable tratadista jurídico ${ }^{366}$; José de Arredondo, Colegial de San Ildefonso y Catedrático en Alcalá, que llegó a Consejero de Indias ${ }^{367}$; Martín Beltrán de Arnedo, Colegial de Oviedo, que fue Fiscal de la Chancillería de Valladolid y Regente del Consejo de Navarra, así como miembro del Consejo Real ${ }^{368}$; Carlos Saracoiz, Colegial de San Ildefonso, Catedrático en Alcalá, Oidor del Consejo de Navarra, y Regente de las Audiencias de Valencia y Cataluña ${ }^{369}$; o Antonio de Espinosa Salcedo, Oficial y Abogado de la Suprema

361 M. Alcocer Martínez, Historia de la Universidad de Valladolid, Vol. 3, Valladolid, Imprenta castellana, 1918, p. 235.

362 L. M. Gutiérrez Torrecilla, Catálogo biográfico..., pp. 87-88.

363 M. D. Martínez Arce, Aproximación a la justicia..., pp. 137-139, 150, 155, 160162, 167, 191-193, 195-196, y passim; L. M. Gutiérrez Torrecilla, Catálogo biográfico..., pp. 60-61.

364 J. Ibarra Murillo, Historia..., p. 279.

365 J. L. Barrio Moya, "El abogado navarro Don Antonio de Feloaga y Ozcoidi, Fiscal del Real Consejo de Indias durante el reinado de Felipe IV", Boletín de la Real Sociedad Bascongada de Amigos del País, 65/2 (2009), pp. 667-688; C. Domínguez Rodríguez, Los Oidores de las Salas de lo Civil de la Chancillería de Valladolid, Valladolid, Universidad de Valladolid, 1997, p. 148.

366 M. Alcocer Martínez y S. Rivera, Historia de la Universidad de Valladolid: Biobibliografías de juristas notables, Valladolid, La Casa social católica, 1924, pp. 121-122.

367 L. M. Gutiérrez Torrecilla, Catálogo biográfico..., p. 15.

368 J. Fayard, Los ministros del Consejo Real de Castilla..., p. 82.

369 L. M. Gutiérrez Torrecilla, Catálogo biográfico..., p. 101. 
Inquisición, Alcalde Mayor de Chinchilla y Villena, Auditor General de Guerra en las fronteras de Portugal, Corregidor de Santo Domingo de la Calzada, Aranda de Duero y Sepúlveda ${ }^{370}$. Entre los segundos, destacamos a Jerónimo de Feloaga, Procurador de Pamplona, Diputado del Reino de Navarra, Alcalde de la Real Corte Mayor de Navarra y Consejero del Consejo Real de Navarra $^{371}$; y a Miguel de Arrizaga, que llegó a Oidor de la Cámara de Comptos ${ }^{372}$.

Un cuarto grupo lo constituyen los canónigos. Entre ellos tuvieron un peso muy destacado los de Pamplona y Roncesvalles: cabe destacar a Cristóbal de Atocha, canónigo y clavario mayor de la Colegiata de Roncesvalles 373 ; Juan Antonio de Arizaleta, Abad de Zubiri y canónigo de Roncesvalles ${ }^{374}$; Fernando de Elcarte, canónigo de Pamplona y Arcediano de Valeaybar ${ }^{375}$; Jerónimo de Eguía, canónigo de Pamplona ${ }^{376}$; Cristóbal Gayarre y Atocha, Colegial de San Ildefonso y canónigo de Pamplona ${ }^{377}$; o Francisco de Asiáin y Medrano, también canónigo de Pamplona ${ }^{378}$. Los canónigos de otras catedrales o colegiatas graduados en cánones son asimismo numerosos. Se puede destacar a Juan de la Regata ${ }^{379}$ y Juan Bautista Espinosa, canónigos de Burgos; Antonio Osorio de Lugones y Sandoval, Chantre de la Catedral de Astorga; Pedro de Ezquerra, Arcediano de Vizcaya; Valeriano Dolz del Castellar, Arcipreste de la Catedral de Tarazona; o Francisco Antonio de Erill, que era Caballero del Hábito de Santiago y Arcediano de la Catedral de Barcelona ${ }^{380}$.

En este grupo se pueden integrar otros eclesiásticos notables como Francisco Navarrete, Inquisidor y Vicario General de Pamplona; Mateo de Guevara, Vicario General de Plasencia; o Roque Santos de San Pedro, Provisor y Vicario General de Pamplona. En esta misma categoría se puede asimilar a

370 V. Dávila Jalón, “Los burgaleses en las órdenes nobiliarias españolas”, Boletín de la Institución Fernán González, 120 (1952), p. 237.

371 M. D. Martínez Arce, Aproximación a la justicia..., pp. 142-144 y passim.

372 J. Ibarra Murillo, Historia..., p. 283.

373 Ibidem, pp. 284-285.

374 Idem, p. 285.

375 Marqués de Jaureguizar, “Relación de los canónigos...”, p. 901.

376 J. Ibarra Murillo, Historia..., p. 305.

377 L. M. Gutiérrez Torrecilla, Catálogo biográfico..., p. 48.

378 Marqués de Jaureguizar, "Relación de los canónigos...”, p. 901.

379 J. Ortiz de la Azuela, Monografía de la antigua Colegiata de Santillana del Mar, Santander, [s.e.], 1919, p. 68.

380 P. Fatjó Gómez, “Aproximación a una élite institucional de la Catalunya moderna: los capitulares de la Seo de Barcelona en el siglo XVII”, Pedralbes, 13/2 (1993), p. 160. 
los miembros de las Órdenes militares, como Fernando de Mendoza y Sotomayor, Caballero de Santiago ${ }^{381}$; García de Moreta Maldonado y Paz, Rector del Colegio de Alcántara de Salamanca; Gaspar de Anaya, de la Orden de Alcántara; o Pascual de Villacampa, Caballero del Orden de Montesa ${ }^{382}$.

Un quinto grupo está compuesto por clérigos seculares que habían alcanzado beneficios, como Diego Castro Ruiz de la Peña, Cura y Beneficiado; Rafael Siurana, Rector de la Iglesia de Santa Cruz, de Zaragoza ${ }^{383}$; José Martínez, Beneficiado en Pampliega; Martín Martínez, Beneficiado de Urroz; o cargos, como el notario apostólico Juan Gascón de Viana ${ }^{384}$, que incorporó su grado a Irache.

Un último grupo lo componen los nobles o miembros de familias destacadas, como García de Toledo Moctezuma, aristócrata de Coria, o Gil Ramírez de Arellano, de ilustre familia de juristas. Mención especial merece el aristócrata Marcos de Viana Beaumont ${ }^{385}$, que recibió todos los grados de Leyes y Cánones el mismo día.

\subsubsection{Facultad de Leyes}

La mayoría de los graduados en Leyes hicieron un cursus regnícola y sirvieron en el Reino de Navarra, desempeñando la abogacía o cargos en la Administración. Unos pocos se graduaron en Leyes para pasar después a otras sedes y llegar a ocupar puestos más encumbrados. La mayoría de los graduados en Leyes en Irache procedía de los Reinos de Navarra y de Aragón, si bien hubo algunos egresados catalanes de cierta importancia.

Un primer grupo reúne a los que llevaron a cabo una carrera en diversos reinos. Entre ellos, destaca, sobre todo, Juan Crisóstomo Vargas Machuca, Catedrático en la Universidad de Zaragoza, lugarteniente del Justicia de Aragón y

381 E. González López, El águila caída: Galicia en los reinados de Felipe IV y Carlos II, Santiago, Editorial Galaxia, 1973, p. 85.

382 J. Cerdà i Ballester, Los caballeros y religiosos de la Orden de Montesa en tiempo de los Austrias (1592-1700), Madrid, CSIC, 2014, pp. 300-301.

383 C. Tomás Laguía, La insigne Colegiata de Santa María de Mora de Rubielos, Teruel, CSIC, 1964, p. 36.

384 Acta Curiarum Regni Sardiniae, 18. Il Parlamento del viceré Fabrizio Doria duca di Avellano (1641-1643), a cura di Giovanni Murgia, Cagliari, Consiglio regionale della Sardegna, 2006, p. 279.

385 P. van Kerrebrouck, Les Capétiens: 987-1328, Vol. 2, Villeneuve d'Asq., 2000, p. 215 . 
Consejero en Santa Clara de Nápoles, donde publicó su célebre obra Decisiones utriusque supremi tribunalis regni Aragoniae, placitis et sententiis supremorum tribunalium regni Neapolis illustratae (Nápoles, 1676) ${ }^{386}$; José Porter y Casanate, que podría ser el célebre Juan José Porter y Casanate, cronista aragonés ${ }^{387}$; Juan de Lizarazu, Procurador de los Tribunales Reales de Navarra, Oidor del Consejo Real de Navarra, Presidente de la Audiencia de Charcas (Perú) y Presidente de la Audiencia de Lima (Perú) ${ }^{388}$; Esteban de Marichalar, que ascendió desde Alcalde de la Audiencia de Sevilla a Ministro del Consejo de Castilla ${ }^{389}$; o Baltasar Francisco Álvarez de Medrano, que fue Alcalde del Crimen de la Chancillería de Valladolid, Alcalde del Crimen supernumerario en la Chancillería de Granada, Alcalde de Casa y Corte en Madrid, Oidor de la Audiencia de Barcelona y Ministro togado del Consejo de Hacienda ${ }^{390}$.

Un segundo grupo es el de los legistas con proyección solamente en el Reino de Navarra: Francisco de Azpilicueta, que llegó a ser Oidor del Supremo Consejo de Navarra ${ }^{391}$; José de Aranguren, Abogado del Real Consejo desde 1630 ${ }^{392}$; Francisco Enríquez de Ablitas, que fue Alcalde de Corte y Oidor del Supremo Consejo ${ }^{393}$; Pedro de Oscariz, que fue Relator del Tribunal de la Real Corte de Navarra y luego Relator del Real Consejo en 1635 394 ; José Villava, de quien Ibarra indica que fue Abogado del tribunal de la Real Corte y luego Abogado del Supremo Consejo de Navarra ${ }^{395}$; Martín Juan de Mur, que fue autor de varias alegaciones jurídicas ${ }^{396}$; los hermanos Pedro y Juan Montero

386 M. Alonso y Lambán, "Apuntes sobre juristas aragoneses de los siglos XVI y XVII”, Anuario de Historia del Derecho Español, 33 (1963), p. 635.

387 A. Gascón de Gotor, “Un Porter y Cassanate: Juan José, cronista de Aragón”, Boletín del Museo Provincial de Bellas Artes de Zaragoza y de la Real Academia de Nobles y Bellas Artes de San Luis, 1 (1950), pp. 31-35. La historiografía aduce que había estudiado en Salamanca, aunque se graduó en Zaragoza en una fecha mucho más tardía.

388 M. D. Martínez Arce, Aproximación a la justicia..., pp. 191-193, 195, 199, 203205 y passim.

389 Ibidem, pp. 166-169, 189, 191-193, 196.

390 P. Gan Giménez, La Real Chancillería de Granada (1505-1834), Granada, Centro de Estudios Históricos de Granada y su Reino, 1988, p. 182.

391 J. Ibarra Murillo, Historia..., p. 279.

392 Ibidem, p. 281.

393 M. D. Martínez Arce, Aproximación a la justicia..., passim.

394 J. Ibarra Murillo, Historia..., p. 328.

395 Ibidem, p. 343.

396 A. S. Wilkinson y A. Ulla Lorenzo, Iberian Books Volumes II \& III, Leiden, Brill, 2015, pp. 635, 684, 782. 
de Espinosa, quienes escalaron los peldaños de la carrera jurisdiccional en Navarra $^{397}$; o Ceferino de Ulibarri, Abogado del Real Consejo y luego Vicario general de Pamplona ${ }^{398}$.

Un tercer grupo lo componen los legistas aragoneses, catalanes o castellanos que llevaron a cabo una trayectoria local o regnícola. Es el caso, por ejemplo, de Agustín Piñana (Agustí Pinyana), jurista de Tortosa y luego de la Real Audiencia de Barcelona ${ }^{399}$, que fue insaculado como diputado real por Tortosa ${ }^{400}$, al igual que Luis Fuster. Ambos fueron graduados el mismo día en Irache.

Un cuarto grupo serían los eclesiásticos, como Tomás de Medina, Canónigo de Calatayud, o Diego Calixto Ramírez, Capellán Real del Pilar, y Rector de la Universidad de Zaragoza ${ }^{401}$.

Un último grupo lo constituirían aquellos que se graduaron en Leyes y en Cánones, como los hermanos Antonio y Lorenzo Perlines, quienes recibieron los grados de B. L. / L. C. / D. C. el mismo día. Antonio fue Procurador ante la Real Chancillería de Valladolid, mientras que Lorenzo desempeñó las Cátedras de Vísperas y Prima de Leyes en la Universidad vallisoletana ${ }^{402}$. Otro ejemplo podría ser Juan Simón de Murugarren, quien, tras graduarse de B. C. en Salamanca, obtuvo los grados de B. L. / L. L. / L. C. en Irache, luego fue Colegial en San Ildefonso de Alcalá (1652), y en la Universidad alcalaína fue Catedrático de Decretales, Sexto y Vísperas, para terminar como Alcalde del Consejo de Navarra en $1669^{403}$.

Fueron muy raros los casos de graduados en Leyes, Cánones y Teología; sin embargo, debe constatarse el de Isidro Pérez, natural de Benavente, que se graduó de B. C. / B. L. / B. T. / L. C. en 1628.

397 J. Ibarra Murillo, Historia..., p. 324.

398 J. Goñi Gaztambide, Historia de los Obispos de Pamplona..., pp. 391-392.

399 E. Querol Coll, Estudis sobre cultura literària a Tortosa a l'edat moderna, Montserrat, Abadia de Montserrat, 2006, p. 19.

400 E. Serra i Puig, Els Llibres de l'ànima de la Diputació del General de Catalunya (1493-1714), Barcelona, IEC, 2015, p. 570.

401 F. de Latassa, Biblioteca nueva de los escritores aragoneses: que florecieron desde el año de 1600 hasta 1640, Tomo II, Pamplona, en la Oficina de Joaquín de Domingo, 1799, p. 398.

402 M. Alcocer Martínez, Historia de la Universidad de Valladolid, Vol. 3, pp. 100, 149, 159.

403 L. M. Gutiérrez Torrecilla, Catálogo biográfico..., p. 75. 


\section{Conclusiones}

La Universidad de Irache no solamente fue la primera y la más importante del Reino de Navarra, sino un notable polo de atracción para estudiantes del Septentrión peninsular. La historiografía había destacado, ciertamente, que en Irache se habían graduado muchos estudiantes, y que su fama era bastante mediocre. En las páginas anteriores hemos intentado aprehender la Universidad en sus justas dimensiones, a partir de la nómina de graduados desde 1613 hasta 1700. Queda una segunda fase, hasta 1807, que es necesario cubrir para lograr una comprensión global de la institución. Permanecen asimismo muchos ángulos inexplorados, como son las matrículas, la hacienda..., que esperan todavía a sus historiadores.

Indicadas todas estas limitaciones, debemos subrayar otras. Hemos llevado a cabo el estudio a partir de una fuente tan relevante como es la de los libros de grados, que no hemos explotado con todas sus potencialidades, ni hemos cotejado con otras fuentes manuscritas. No hemos indicado ni los puntos que leyeron los diversos graduados, ni los testigos, ni los nombres de los secretarios. Al contrario, hemos intentado ofrecer los datos mínimos, pues la presentación de todos los datos hubiera obligado a preparar un volumen de unas dimensiones mucho mayores, y con numerosos datos de menor relevancia. Sin ánimo de ofender en la comparación, resulta claro que los testigos en las graduaciones no tienen el mismo interés en las Universidades mayores que en las menores, y los puntos no pasan de ser algo completamente anecdótico.

Las fichas de aprobados y reprobados están ordenadas tal como aparecen en el original, si bien hemos acumulado, en la misma ficha, todos los datos que iban apareciendo de un mismo personaje, de tal forma que cada una es un resumen de la vida académica del mismo. Contienen, en líneas sucesivas: en mayúsculas, el nombre y apellidos; el o los grados conseguidos en la Universidad; la fecha o fechas del otorgamiento del grado o grados; los miembros que otorgaron o presidieron el grado (o grados); la población de origen y diócesis (entre paréntesis); la orden a la que pertenecían, si procede; el cargo u ocupación del graduando; el folio (o folios) en que estaba inscrito.

Constan graduados sin apellidar, y también otros con una mera descripción física; incluso hay algunos con apellidos y descripción física. Los secretarios, a veces se olvidaron de registrar el grado; otras, lo hicieron sin mencionar la Facultad. Cuando se indican puntos suspensivos puede ser por dos 
motivos: porque no aparece ningún dato (el secretario no puso el día de la graduación, el nombre del graduado o del grado...), o porque no hemos sido capaces de dar una interpretación paleográfica convincente.

La calificación solía anotarse especialmente en el caso de que fuera negativa, es decir, en el caso en que fueran reprobados, una o dos veces, por incapaces o insuficientes. Muchas veces el suspenso se indicaba con el término "calabazas" (sic). A partir de la documentación, constatamos diversos grados de "penitencia" para volverse a presentar: de dos, tres, cuatro y seis meses de estudio.

Sentado lo anterior, y a partir de los datos que hemos recabado, podemos ofrecer cinco conclusiones generales sobre la Universidad de Irache y sus graduados durante el siglo XVII.

La primera es que la Universidad de Irache debe ser encuadrada entre las universidades monacales y tiene que ser estudiada no solamente en el contexto hispánico, sino también en el ámbito del benedictinismo europeo. De hecho, Irache y Salzburgo, tras el fracaso de las Universidades de Ottobeurer y del Colegio de San Vicente de Oviedo, fueron las dos únicas universidades europeas regentadas por la Orden de San Benito hasta el siglo XIX. Hay notables analogías tanto en el momento de la erección, como en la gestión y el enfoque ideológico, aunque deben mostrarse también algunas diferencias: la más importante es que la de Salzburgo fue promovida por el Arzobispo de la ciudad y regentada por los benedictinos por un acuerdo, mientras que la de Irache, aunque iniciada y gestionada por los benedictinos, procedía de la traslación de los privilegios de Sahagún.

En el ámbito hispánico, Irache no puede compararse con la Universidad de el Escorial, en manos de los jerónimos, pues fue muy poco representativa y escasamente concurrida. Más bien deben buscarse analogías con las universidades conventuales hispánicas, en manos de la Orden de Predicadores. Algunas de ellas solamente graduaban en las materias que enseñaban (como Tortosa o la de Pamplona), mientras que otras podían hacerlo también en otras Facultades, como sucedió en Ávila o Solsona. Hay que recalcar que, pese a las burlas sobre el bajo nivel de Irache, la Universidad monástica navarra, a diferencia de Solsona, graduaba con todos los privilegios.

En segundo lugar, como universidad monacal, el Abad era, al mismo tiempo, el Rector y el Canciller. Daba los grados con validez pontificia, pues era una Universidad aprobada por la Santa Sede, y reconocida por el resto de las Universidades mayores. Felipe IV, en 1665, le otorgó los privilegios civi- 
les. Existían pocos cargos: Regente de Estudios, Lectores de Artes y Teología, Maestro de Estudiantes, Maestro de ceremonias, Secretario y Bedel-alguacil. Los grados se dispensaban sin grandes dispendios y, precisamente, la escasez de trámites y de requisitos económicos la hacían muy atractiva para muchos estudiantes.

No debe perderse de vista tanto su función ad intra como la que ejerció ad extra. En el seno de la Congregación de Valladolid, el Colegio de Irache fue el lugar de formación de diversos monjes. Junto con el Colegio de San Vicente de Oviedo y el de San Vicente de Salamanca, era el lugar de enseñanza de las élites monacales. En el marco de las Universidades hispánicas, fue el lugar de graduación por excelencia de los estudiantes navarros (especialmente antes de 1630, cuando empezó a graduar la Universidad de Pamplona), así como un centro auxiliar para la obtención de grados para los alumnos de otras sedes.

En tercer lugar, por la tipología de los graduados, debemos distinguir entre los clérigos y los seglares. Los primeros fueron los más destacados, y comprendían los regulares y los seculares. Entre los primeros, no solamente hallamos a los miembros de la Orden benedictina (tanto los de la Congregación de Valladolid, como los de la Congregación Tarraconense y Cesaraugustana), sino los de otras órdenes y congregaciones (cistercienses, premonstratenses, agustinos, mercedarios, carmelitas..., así como egresados de las órdenes militares). Entre los segundos había numerosos canónigos, beneficiados, curas párrocos y vicarios. Los seglares eran, en muchas ocasiones, alumnos que seguían los cursos de Artes, o que se graduaban de Leyes o de Medicina.

En cuarto lugar, los más de seis mil graduados que contamos en los 87 años analizados arrojan una estadística bastante elevada. Muchos consiguieron en Irache diversos grados. Los benedictinos recibieron, en general, todos los de Artes y Teología. Junto los los estudiantes de Artes, el grado más solicitado fue el de B. C., que abría las puertas a diferentes prebendas y cargos eclesiásticos. Frente a los grados de Artes, Teología y, sobre todo, Cánones, los de Medicina y Leyes representaron una proporción mucho menor. Hubo 5 reprobados en Medicina y uno en Leyes, frente a los 5 de Artes, los 39 de Teología y los 163 de Cánones.

En cuanto a los lugares de procedencia de los egresados, debemos instistir en la estratégica ubicación geográfica del Monasterio, en el Norte de la Península Ibérica: de hecho, los estudiantes acudían desde Galicia, las dos Castillas, Aragón y Cataluña. Las diócesis más concurridas fueron Burgos (3645), Pamplona (1179), Calahorra (570), Tarazona (192) y Zaragoza (103). Los estudian- 
tes navarros y vascos también se podían graduar en Oñate o en Pamplona, si bien, como puede verse, muchos de la Archidiócesis de Burgos lo hicieron en Irache. Hay que tener en cuenta asimismo la atracción que suscitaba en la Diócesis de Calahorra y en todo el Reino de Aragón. Puede decirse que Irache fue también una sede auxiliar para las Universidades Mayores (Salamanca, Valladolid y Alcalá), y muy especialmente para las aragonesas (Huesca y Zaragoza).

Por último, en cuanto a la trayectoria de los graduados, debemos distinguir entre los benedictinos y el resto de los titulados. Para la Congregación vallisoletana, Irache era el lugar de graduación de aquellos que habían cumplido ya con sus años de púlpito o de enseñanza. Muchos de los que se graduaron ocuparon luego lugares de responsabilidad en el seno de la Orden (no solamente los abades de los diversos cenobios, sino los Abades generales que, casi sin excepción, recibieron sus grados en Irache). Algunos de estos monjes destacaron en el ámbito de la predicación (llegaron a ser predicadores de Felipe IV y Carlos II), de la enseñanza (fueron catedráticos en las Universidades de Santiago, Oviedo, Salamanca o Valladolid), del estudio (notables historiadores, filósofos y teólogos) o en el gobierno de la Iglesia (obispos y arzobispos, e incluso dos cardenales, Aguirre y Sala).

Para el resto de los graduados, hay que distinguir entre los regnícolas, que normalmente se graduaron en Artes, Leyes o Medicina, y tuvieron una proyección más bien local, y los foráneos, que acudieron a Irache, en su mayoría, en búsqueda de un título de Teología o Cánones. Hubo navarros que, tras graduarse en Irache, lograron una plaza en un Colegio mayor, y fueron escalando los puestos en la burocracia civil o eclesiástica; sin embargo, la mayoría tuvo una ejecutoria mucho más limitada, restringida a su ciudad o Reino.

En todo caso, como hemos podido comprobar en el último apartado, algunos de los egresados llevaron a cabo una carrera brillante, bien en la Iglesia (inquisidores, obispos...), bien en la Administración civil (en Reales Consejos, Audiencias, Chancillerías...) Lo cierto es que, sin los títulos de una Universidad mayor, los grados de Irache no tenían gran proyección. La mayoría de los egresados tuvieron una carrera modesta, y se acomodaron en algún puesto menor de la Administración local o en algún beneficio eclesiástico. De ahí la importancia de los grados en Derecho canónico que, en no pocos casos, complementaban a los de Derecho civil obtenidos en otra sede.

En definitiva, la Universidad de Irache fue una sede muy concurrida, que colacionó grados a numerosos clérigos y a no pocos seglares. El estudio de 
los grados, lejos de tener un alcance meramente local o regnícola, como tienen muchas de las universidades aragonesas o catalanas, rebasa el ámbito del Reino de Navarra y se proyecta hacia los Reinos de Castilla y León, sin olvidar la importante nómina de aragoneses y catalanes que recibieron sus borlas en esa sede abacial, a los pies del Montejurra.

El Monasterio de Irache, desde su establecimiento, fue un hito para muchos peregrinos que avanzaban hacia Santiago de Compostela. Podemos dar fe, con los datos antes expuestos, de la existencia también de una peregrinatio academica a Irache, que cubría las más variadas rutas y desde los más recónditos lugares de la geografía peninsular. A continuación, en la relación de aprobados y reprobados, se pueden leer más detalles de su provechosa estancia en la Abadía. 


\section{GRADOS DE LA UNIVERSIDAD DE IRACHE \\ (1613-1700)}

VASCO FERREIRA

B. M.

2-5-1613

Dr. Benito Nole

Braganza. Miranda (Portugal)

AGN, Irache, Lib. 542, 1r.

JUAN VICENTE

B. T. / L. T.

6-5-1613 / 7-5-1613

Fr. Antonio Maseda

Lardero (Calahorra)

AGN, Irache, Lib. 542, 1 rv.

FRANCISCO DE ARCE

B. L.

7-5-1613

Fr. Antonio Maseda

Madrid (Toledo)

AGN, Irache, Lib. 542, 1r.

JUAN LÓPEZ DE LA IGLESIA

B. M.

7-5-1613

Dr. Murrugarren

Villegas (Burgos)

AGN, Irache, Lib. 542, 1v.

PEDRO DEL ACEBAL

B. C.

9-5-1613

Fr. Antonio Maseda

Sopuerta (Burgos)

AGN, Irache, Lib. 542, 1v.

ALONSO DE LA PEÑA

B. C.
14-5-1613

..

Oriella (Burgos)

AGN, Irache, Lib. 542, 1 v.

ALONSO PÉREZ

B. A. / L. A.

16-5-1613 / 17-5-1613

Fr. Antonio Maseda

Osorno (Palencia)

AGN, Irache, Lib. 542, 2 r.

ANDRÉS DE OLARAN

B. A.

22-5-1613

Fr. Antonio Maseda

Cegama (Pamplona).

AGN, Irache, Lib. 542, 2r.

ANDRÉS DE ZÚÑIGA

L. C.

23-5-1613

Fr. Antonio Maseda

Zúñiga (Calahorra)

AGN, Irache, Lib. 542, 2r.

ALONSO DOMÍNGUEZ GALINDO

L. C.

28-5-1613

Fr. Antonio Maseda

Pbro. del hábito de Calatrava

AGN, Irache, Lib. 542, 2v.

DIONISIO DE MAZA

L. C. / D. C.

28-5-1613

Fr. Antonio Maseda 
Pbro. del hábito de Calatrava

AGN, Irache, Lib. 542, 2v.

\section{DIEGO GARCÍA}

B. C.

28-5-1613

Fr. Antonio Maseda

Sasamón (Burgos)

AGN, Irache, Lib. 542, 2v.

\section{JUAN JIMÉNEZ}

B. A. / L. A. / M. A. / B. T. / L. T. / M. T. 30-5-1613

Fr. Antonio Maseda

O. Cist.

De Tobar

AGN, Irache, Lib. 542, 2v-3r.

JUAN SÁNCHEZ

B. M.

31-5-1613

Dr. Arróniz

Villalón (León)

AGN, Irache, Lib. 542, 3r.

\section{ALONSO GONZÁLEZ ALBAR}

B. T. / L. T. / M. T.

1-6-1613 / 2-6-1613

Fr. Antonio Maseda

Diezma (Palencia)

Abad de la Colegial de Aguilar de Campoo

AGN, Irache, Lib. 542, 3r.

JUSTO BUIL

L. M. / D. M.

3-6-1613

Dr. Murugarren

Torrejón del Rey (Toledo)

AGN, Irache, Lib. 542, 3rv, 4r.

PEDRO DE UZQUIANO

B. C.

5-6-1613

Fr. Rosendo de San Martín

Delica (Calahora)

AGN, Irache, Lib. 542, 3v.

MIGUEL MONTERO

L. C.
11-6-1613

Fr. Rosendo de San Martín

Ginco (Orense)

AGN, Irache, Lib. 542, 3v.

JUAN SÁNCHEZ

B. C.

14-6-1613

Fr. Andrés de Esparza

Viana (Calahorra)

AGN, Irache, Lib. 542, 3v.

GABRIEL DE PÁRAMO Y SANDE

D. A. / B. T.

18-6-1613 / 22-6-1621

Fr. Antonio Maseda

Lodosa (Pamplona)

Residente en Atienza

L. A. por esta Facultad.

AGN, Irache, Lib. 542, 4r, 98v.

PLÁCIDO DE REINOSO

B. A. / L. A. / M. A. / B. T. / L. T. / M. T. 18-6-1613

Fr. Antonio de Alvarado, Abad, Rector y

Canciller.

O. S. B.

AGN, Irache, Lib. 542, 4r.

JUAN VALENCIA DE LEÓN

B. C.

24-6-1613

Fr. Rosendo de San Martín

Ginzo (Orense)

AGN, Irache, Lib. 542, 4r.

PEDRO DE PADILLA

L. C. / D. C.

25-6-1613

Fr. Antonio de Alvarado

Llerena (Nullius diocesis)

AGN, Irache, Lib. 542, 4r.

JUAN DE CIRIZA

L. C. / D. C.

28-6-1613

Fr. Antonio de Alvarado

C. R. S. A. 
Pamplona

AGN, Irache, Lib. 542, 4v.

JUAN DE VALENZUELA

B. A. / M. A. / B. T. / D. T.

29-6-1613

Fr. Antonio de Alvarado, Abad, Rector y

Canciller

O. S. B.

AGN, Irache, Lib. 542, 4V.

ROSENDO DE SAN MARTÍN

B. A. / L. A. / M. A. / B. T. / L. T. / M. T. 2-7-1613

Fr. Antonio de Alvarado

O. S. B.

AGN, Irache, Lib. 542, 4V.

ANDRÉS DE ESPARZA

B. A. / L. A. / M. A. / B. T. / L. T. / M. T.

2-7-1613

Fr. Antonio de Alvarado

O. S. B.

AGN, Irache, Lib. 542, 4v-5r.

LUCAS DE LLAEDA SALAZAR

B. C.

4-7-1613

Fr. Rosendo de San Martín

Burgos

AGN, Irache, Lib. 542, 5r.

JUAN DE NALDA

B. L.

10-7-1613

Fr. Rosendo de San Martín

Arnedo

AGN, Irache, Lib. 542, 5r.

LEÓN DE GUILLÉN

B. A.

10-7-1613

Fr. Antonio Maseda

Pamplona

AGN, Irache, Lib. 542, 5r.

MIGUEL DE BAYONA

B. A.
10-7-1613

Fr. Antonio Maseda

Falces (Pamplona)

AGN, Irache, Lib. 542, 5r.

JUAN DE ARRANEGUI

B. A.

10-7-1613

Fr. Antonio Maseda

Pamplona

AGN, Irache, Lib. 542, 5 r.

PEDRO DE LA RESECABA

B. A.

10-7-1613

Fr. Antonio Maseda

Pamplona

AGN, Irache, Lib. 542, 5v.

FAUSTO DE GÜESA

B. A.

10-7-1613

Fr. Antonio Maseda

Pamplona

AGN, Irache, Lib. 542, 5v.

ÍNIIGO RECALDE

B. A.

10-7-1613

Fr. Antonio Maseda

Ygal (Pamplona)

AGN, Irache, Lib. 542, 5v.

JUAN DE MENDI

B. A.

10-7-1613

Fr. Antonio Maseda

Pamplona

AGN, Irache, Lib. 542, 5v.

MIGUEL DE ARDANAZ

B. A.

10-7-1613

Fr. Antonio Maseda

Burlada (Pamplona)

AGN, Irache, Lib. 542, 5v.

LUIS DE GUEVARA

B. A. 
10-7-1613

Fr. Antonio Maseda

Pamplona

AGN, Irache, Lib. 542, 5 v.

MIGUEL DE ARNICA

B. A.

10-7-1613

Fr. Antonio Maseda

Pamplona

AGN, Irache, Lib. 542, 5v.

JUAN DE OLLOQUI

B. A.

10-7-1613

Fr. Antonio Maseda

Huarte (Pamplona)

AGN, Irache, Lib. 542, 6r.

JUAN DE AÑOA

B. A.

10-7-1613

Fr. Antonio Maseda

Villalba (Pamplona)

AGN, Irache, Lib. 542, 6r.

MARTÍN DE RADA

B. A.

10-7-1613

Fr. Antonio Maseda

Olcoz (Pamplona)

AGN, Irache, Lib. 542, 6r.

PEDRO DE OLOAIZ

B. A.

10-7-1613

Fr. Antonio Maseda

Maquirriain (Pamplona)

AGN, Irache, Lib. 542, 6r.

MIGUEL DE ARLEGUI

B. A.

10-7-1613

Fr. Antonio Maseda

Villatuerta (Pamplona)

AGN, Irache, Lib. 542, 6r.

MARTÍN DE EGUIARRETA

B. A.
10-7-1613

Fr. Antonio Maseda

Adiós (Pamplona)

AGN, Irache, Lib. 542, 6r.

MARTÍN DE BEUNZA

B. A.

10-7-1613

Fr. Antonio Maseda

Pamplona

AGN, Irache, Lib. 542, 6r.

MIGUEL DE SANZ

B. A.

10-7-1613

Fr. Antonio Maseda

Pamplona

AGN, Irache, Lib. 542, 6v.

SEBASTIÁN DE SANTOS

B. A. / B. L. / L. L.

10-7-1613 / 2-7-1620 / 27-10-1628

Fr. Antonio Maseda / Fr. Hernando Enrí-

quez / Fr. Gregorio Bravo de Sotomayor

Pamplona

AGN, Irache, Lib. 542, 6v, 89r, 161v.

DIEGO DE SARASA Y ARCE

B. A.

10-7-1613

Fr. Antonio Maseda

Tafalla (Pamplona)

AGN, Irache, Lib. 542, 6v.

MIGUEL DE AZPILICUETA

B. A.

10-7-1613

Fr. Antonio Maseda

Azpilicueta (Pamplona)

AGN, Irache, Lib. 542, 6v.

LOPE DE HUARTE

B. A.

10-7-1613

Fr. Antonio Maseda

Pamplona

AGN, Irache, Lib. 542, 6v. 
MARTÍN DE EUSA

B. A.

10-7-1613

Fr. Antonio Maseda

Villalba (Pamplona)

AGN, Irache, Lib. 542, 6v.

JUAN DE ESPOZ

B. A.

10-7-1613

Fr. Antonio Maseda

Pamplona

AGN, Irache, Lib. 542, 6v.

FRANCISCO RUIZ DE LEZA

L. C. / D. C.

7-8-1613

Fr. Antonio de Alvarado

Salinas de Añana (Burgos)

AGN, Irache, Lib. 542, 6v-7r.

JUAN BAUTISTA DE VILLANUEVA

L. C.

10-8-1613

Fr. Antonio de Alvarado

Madrid (Toledo)

AGN, Irache, Lib. 542, 7r.

PEDRO MARÍN

B. A. / M. A. / B. T. / M. T.

21-8-1613

Fr. Antonio de Alvarado

O.S. B.

De Ntra. Señora de Nájera

AGN, Irache, Lib. 542, 7r.

FRANCISCO LÓPEZ MARTÍNEZ

L. C. / D. C.

26-8-1613

Fr. Antonio de Alvarado

Valladolid

AGN, Irache, Lib. 542, 7rv.

PEDRO DE PERALTA

B. C.

29-8-1613

Fr. Rosendo de San Martín

Peralta (Pamplona)

AGN, Irache, Lib. 542, 7v.
PEDRO DE AMÉZQUETA

L. C.

31-8-1613

Fr. Antonio de Alvarado

Pamplona

AGN, Irache, Lib. 542, 7v.

BENITO DE CASTRO

B. L.

1-9-1613

Fr. Rosendo de San Martín

Madrid (Toledo)

Dr. y Catedrático en Valladolid

AGN, Irache, Lib. 542, $7 \mathrm{v}$.

DOMINGO GONZÁLEZ

B. C.

2-9-1613

Fr. Rosendo de San Martín

Haedo (Burgos)

AGN, Irache, Lib. 542, 7v-8r.

JUAN RODRÍGUEZ

B. C.

7-9-1613

Fr. Rosendo de San Martín

Melgar de Ramental (Burgos)

AGN, Irache, Lib. 542, 8r.

JERÓNIMO PÉREZ DE LA VEGA

B. C.

7-9-1613

Fr. Rosendo de San Martín

[Melgar de] Fernamental (Burgos)

AGN, Irache, Lib. 542, 8r.

FRANCISCO GALLEGO

L. C.

15-9-1613

Fr. Antonio de Alvarado

Esparrag... (Nullius Diocesis)

AGN, Irache, Lib. 542, 8r.

ANTONIO DEL RÍO

L. C. / D. C.

15-9-1613

Fr. Antonio de Alvarado 
Villalpando (León)

AGN, Irache, Lib. 542, 8r.

GASPAR DÍAZ

B. C.

19-9-1613

Fr. Rosendo de San Martín

Villasidro (Burgos)

AGN, Irache, Lib. 542, 8r.

JUAN DE PECHECHEA

B. A.

19-9-1613

Fr. Antonio Maseda

Tafalla (Pamplona)

AGN, Irache, Lib. 542, 8v.

LEANDRO CONDE DE ÁVILA

L. C.

22-9-1613

Fr. Antonio de Alvarado

Valladolid

AGN, Irache, Lib. 542, 8v.

JUAN DE VILLANUEVA

B. C.

25-9-1613

Fr. Rosendo de San Martín

Aro (Burgos)

AGN, Irache, Lib. 542, 8v.

PEDRO DE PAREDES

B. C.

29-9-1613

Fr. Rosendo de San Martín

Melgar de Fernamental (Burgos)

AGN, Irache, Lib. 542, 8v.

\section{FRANCISCO DE CEGAMA}

B. L.

5-10-1613

Fr. Mauro García de Mendoza, vicecanciller

Estella (Pamplona)

AGN, Irache, Lib. 542, 8v.

FRANCISCO DE PORRAS

B. C.

7-10-1613
Fr. Mauro García de Mendoza

Burgos

AGN, Irache, Lib. 542, 8v.

CRISTÓBAL DE TORRES

L. C.

13-10-1613

Fr. Antonio de Alvarado

Torre de Lobatón (Palencia)

AGN, Irache, Lib. 542, 9r.

\section{SANCHO DE ITUREN}

B. A.

17-10-1613

Fr. Antonio Maseda

Pamplona

AGN, Irache, Lib. 542, 9r.

JUAN DE ORBEA

B. T. / M. T.

17-10-1613

Fr. Antonio de Alvarado

Eibar (Pamplona)

O. C.

AGN, Irache, Lib. 542, 9r.

JUAN FERNÁNDEZ DE HERRERA

B. T.

30-10-1613

Fr. Mauro García de Mendoza

Ponferrada (Astorga)

AGN, Irache, Lib. 542, 9r.

FRANCISCO DE FRÍAS

B. C.

3-11-1613

Fr. Rosendo de San Martín

Briviesca (Burgos)

AGN, Irache, Lib. 542, 9v.

DIEGO DE SOTO

B. C.

3-11-1613

Fr. Rosendo de San Martín

Briviesca (Burgos)

AGN, Irache, Lib. 542, 9v.

JERÓNIMO DE EGUÍA

L. C. / D. C. 
11-11-1613

Fr. Antonio de Alvarado

Estella (Pamplona)

AGN, Irache, Lib. 542, 9v.

JUAN DE HERRERA

B. C.

14-11-1613

Fr. Benito de Cobillas, vicecanciller

Medinaceli (Sigüenza)

AGN, Irache, Lib. 542, 9v.

L. C.

14-11-1613

Fr. Antonio de Alvarado

Logroño (Calahorra)

AGN, Irache, Lib. 542, 9v-10r.

... DE MENDOZA

L. C. / D. C.

27-11-1613

Fr. Antonio de Alvarado

Ledesma (Salamanca)

AGN, Irache, Lib. 542, 1 or.

GINÉS DE PEÑALVER

B. T. / L. T. / D. T.

27-11-1613

Fr. Antonio de Alvarado

Murguia (Cartagena)

Canónigo de Pastrana

AGN, Irache, Lib. 542, 1 or.

FRANCISCO DEL FOZ

L. C.

4-12-1613

Fr. Antonio de Alvarado

Laredo (Burgos)

AGN, Irache, Lib. 542, 1 or.

GABRIEL DE CONCHILLOS

B. C.

5-12-1613

Fr. Rosendo de San Martín

Azañón (Toledo)

AGN, Irache, Lib. 542, $10 \mathrm{v}$.
B. T. / L. T.

19-12-1613

Fr. Antonio de Alvarado

Pamplona

AGN, Irache, Lib. 542, $10 v$.

... RUBIO

B. C.

24-12-1613

Fr. Benito de Cobillas

Grávalos (Calahorra)

AGN, Irache, Lib. 542, $10 \mathrm{v}$.

JUSTO TOMÁS

L. C.

10-1-1614

Fr. Antonio de Alvarado

Fuenmayor (Calahorra)

AGN, Irache, Lib. 542, $10 \mathrm{v}$.

PEDRO DE CERECEDA

B. C.

12-1-1614

Fr. Benito de Cobillas

Hajo (Burgos)

AGN, Irache, Lib. 542, $10 \mathrm{v}$.

FERNANDO DE SALAZAR Y VELASCO

L. C.

4-2-1614

Fr. Mauro García de Mendoza

Oña

AGN, Irache, Lib. 542, 11r.

JUAN MANZANO

L. C.

21-3-1614

Fr. Antonio de Alvarado

Gata (Coria)

AGN, Irache, Lib. 542, 11r.

LUIS LÓPEZ

B. L. / L. C. / D. C.

26-3-1614

Fr. Antonio de Alvarado

Dueñas (Palencia)

AGN, Irache, Lib. 542, 11r. 
JUAN LÓPEZ CUAZU

L. C.

5-4-1614

Fr. Antonio de Alvarado

Zuazu (Calahorra)

AGN, Irache, Lib. 542, 11v.

JUAN DE ALVARADO

L. C. / D. C.

7-4-1614

Fr. Antonio de Alvarado

Ciudad de los Reyes, Indias Occidentales

(Lima)

AGN, Irache, Lib. 542, 11v.

\section{... DOMIN}

B. T.

7-4-1614

Fr. Rosendo de San Martín

Calatayud (Tarazona)

O. C.

AGN, Irache, Lib. 542, 11v.

JUAN DE AYALA

B. C. / L. C.

20-4-1614

Fr. Antonio de Alvarado

Burgos

AGN, Irache, Lib. 542, 11v.

PEDRO FERNÁNDEZ DE VILA

L. C.

20-4-1614

Fr. Antonio de Alvarado

... de Gaibor (Mondoñedo)

AGN, Irache, Lib. 542, 11v-12r.

JUAN VALLEJO

B. C.

14-5-1614

Fr. Benito de Cobillas

Burgos

AGN, Irache, Lib. 542, 12 r.

FRANCISCO GÓMEZ URBAN

B. A.

14-5-1614

Fr. Antonio Maseda
Haro (Calahorra)

AGN, Irache, Lib. 542, 12 r.

JUAN DE VICTORIA

B. A. / L. A. / M. A. / B. T. / L. T. / M. T.

6-5-1614

Fr. Antonio de Alvarado

O. S. B.

De la casa de Monserrat

AGN, Irache, Lib. 542, 12 r.

JUAN RAMÍREZ DE NÁJERA

L. C.

15-5-1614

Fr. Antonio de Alvarado

Calahorra

AGN, Irache, Lib. 542, 12 r.

JUAN GUTIÉRREZ

B. C.

17-5-1614

Fr. Mauro García

Villadiego (Burgos)

AGN, Irache, Lib. 542, 12v.

GUILLERMO GIL

B. C.

17-5-1614

Fr. Mauro García

Villobeta (Nullius diocesis)

AGN, Irache, Lib. 542, $12 \mathrm{v}$.

MARTÍN DE IRISARRI

B. A.

24-5-1614

Fr. Antonio Maseda

Villatuerta (Pamplona)

AGN, Irache, Lib. 542, $12 \mathrm{v}$.

JUAN DE SILVA

B. C. / L. C.

24-5-1614

Fr. Antonio de Alvarado

Cuéllar (Sigüenza)

AGN, Irache, Lib. 542, $12 \mathrm{v}$.

MATEO DE PALOMERA

B. C. 
26-5-1614

Fr. Rosendo de San Martín

Río (Burgos)

AGN, Irache, Lib. 542, $12 \mathrm{v}$.

BLAS PÉREZ DE LA TORRE

L. C.

29-5-1614

Fr. Antonio de Alvarado

Ágreda (Tarazona)

AGN, Irache, Lib. 542, 13 r.

ALONSO LÓPEZ

B. C.

31-5-1614

Fr. Mauro García de Mendoza

Villadiego (Burgos)

Pbro.

AGN, Irache, Lib. 542, 13 r.

FRANCISCO MARCO

L. C.

6-6-1614

Fr. Antonio de Alvarado

Tafalla (Pamplona)

AGN, Irache, Lib. 542, 13r.

PEDRO DE PORRES

B. T.

10-6-1614

Fr. Benito de Cobillas

Villadiego (Palencia)

AGN, Irache, Lib. 542, 13 rv.

MIGUEL DE GAZÓLAZ

B. A.

12-6-1614

Fr. Antonio Maseda

Gazólaz (Pamplona)

AGN, Irache, Lib. 542, 13v.

BERNARDO DE RETA

B. A.

12-6-1614

Fr. Antonio Maseda

Murillo (Pamplona)

AGN, Irache, Lib. 542, 13v.
JUAN DE AZPILICUETA

B. A.

12-6-1614

Fr. Antonio Maseda

Pamplona

AGN, Irache, Lib. 542, $13 \mathrm{v}$.

JUAN DE LANBARREN

B. A.

12-6-1614

Fr. Antonio Maseda

Pamplona

AGN, Irache, Lib. 542, $13 \mathrm{v}$.

JUAN DE UDAVE

B. A.

12-6-1614

Fr. Antonio Maseda

Pamplona

AGN, Irache, Lib. 542, 13v.

HERNANDO DE RECALDE

B. A.

12-6-1614

Fr. Antonio Maseda

Salinas (Pamplona)

AGN, Irache, Lib. 542, 13v.

MARTÍN DE SUESCUN

B. A.

12-6-1614

Fr. Antonio Maseda

Pamplona

AGN, Irache, Lib. 542, 13v.

PEDRO DE ARGANDA

B. A.

12-6-1614

Fr. Antonio Maseda

Pamplona

AGN, Irache, Lib. 542, 13v.

JUAN DE MARCHUETA

B. A.

12-6-1614

Fr. Antonio Maseda

Pamplona

AGN, Irache, Lib. 542, 13v. 
FERMÍN DE NOAIN

B. A.

12-6-1614

Fr. Antonio Maseda

Noain (Pamplona)

AGN, Irache, Lib. 542, 13v.

PEDRO MURRUGARREN

B. A.

12-6-1614

Fr. Antonio Maseda

Pamplona

AGN, Irache, Lib. 542, 13v.

MIGUEL DE IRIONDO

B. A.

12-6-1614

Fr. Antonio Maseda

Pamplona

AGN, Irache, Lib. 542, 13v.

MARTÍN DE ILZARBE

B. A.

12-6-1614

Fr. Antonio Maseda

Artica (Pamplona)

AGN, Irache, Lib. 542, 13v.

\section{MARTÍN UGALDE}

B. A.

12-6-1614

Fr. Antonio Maseda

Pamplona

AGN, Irache, Lib. 542, 13v.

MARTÍN DE AZPILICUETA

B. A.

12-6-1614

Fr. Antonio Maseda

Pamplona

AGN, Irache, Lib. 542, 13v.

\section{JUAN DE CIRIZA}

B. A.

12-6-1614

Fr. Antonio Maseda

Ulcarrun (Pamplona)

AGN, Irache, Lib. 542, 13v.

\section{JUAN MANSO}

B. A.

12-6-1614

Fr. Antonio Maseda

Arana (Calahorra)

AGN, Irache, Lib. 542, $13 \mathrm{v}$.

MATEO DE ARANDA

B. T.

19-6-1614

Fr. Benito de Cobillas

Lerma (Burgos)

AGN, Irache, Lib. 542, $13 \mathrm{v}$.

ANTONIO CAMINO DE POLANCO

L. C. / D. C.

22-6-1614

Fr. Antonio de Alvarado

Ajo (Burgos)

AGN, Irache, Lib. 542, 14 r.

DIEGO SÁNCHEZ DE SAAVEDRA

L. T. / D. T.

22-6-1614

Fr. Antonio de Alvarado

Santiago de Adelan (Mondoñedo)

AGN, Irache, Lib. 542, 14r.

FRANCISCO GONZÁLEZ

B. T. / L. T. / D. T.

22-6-1614

Fr. Mauro García de Mendoza

Osorno (Palencia)

AGN, Irache, Lib. 542, 14r.

JUAN BARBA DE ESPINOSA

L. M. / D. M.

22-6-1614

Fr. Antonio de Alvarado / Dr. Arróniz, Mé-

dico de Estella

Astudillo (Palencia)

AGN, Irache, Lib. 542, 14v.

GASPAR LUIS CAMACHO DE URREA

L. L. / D. L.

22-6-1614

Fr. Antonio de Alvarado / Dr. Castillo, Letrado de Estella 
Zaragoza

AGN, Irache, Lib. 542, 14v.

JUAN DE OREMIANA

B. C.

25-6-1614

Fr. Mauro García de Mendoza

Penagos (Burgos)

Pbro.

AGN, Irache, Lib. 542, 14v.

FELIPE BERNAL

B. T. / L. T. / M. T.

¿-7-1614

Fr. Antonio de Alvarado

O. Praem.

AGN, Irache, Lib. 542, 14v-15r.

MIGUEL GUIZA DE CEGAMA

L. C.

6-7-1614

Fr. Antonio de Alvarado

Bilbao (Calahorra)

AGN, Irache, Lib. 542, 15r.

SEBASTIÁN CANO

B. T. / D. T.

12-7-1614

Fr. Antonio de Alvarado

Torquemada (Palencia)

AGN, Irache, Lib. 542, 15 r.

JUAN DE LORRAIN

B. A. / L. A.

14-7-1614

Fr. Antonio Maseda

Asua (Calahorra)

AGN, Irache, Lib. 542, 15rv.

DIEGO DE ALCÁNTARA

B. C.

22-7-1614

Fr. Mauro García de Mendoza

Cartagena

AGN, Irache, Lib. 542, 15v.

LUCAS DE MACEDA

B. C.
4-8-1614

Fr. Benito de Cobillas

Burgos

AGN, Irache, Lib. 542, 15v.

LUIS FLÓREZ

B. A. / L. A. / M. A. / B. T. / L. T. / M. T. 29-8-1614

Fr. Antonio de Alvarado

O. S. B.

Del monasterio de Sahagún

AGN, Irache, Lib. 542, 15v.

JUAN DE VALCÁZAR

L. L.

26-8-1614

Fr. Antonio de Alvarado

AGN, Irache, Lib. 542, 15v.

FRANCISCO DE AGUIRRE

L. C.

28-8-1614

Fr. Antonio de Alvarado

Briviesca (Burgos)

AGN, Irache, Lib. 542, 16r.

FEDERICO RAMÍREZ

B. T. / L. T. / M. T.

7-9-1614

Fr. Antonio de Alvarado

O. Praem.

AGN, Irache, Lib. 542, 16rv.

JUAN ROMERO BOTELLA

B. T. / L. T. / M. T.

10-9-1614

Fr. Mauro García de Mendoza

Canarias

AGN, Irache, Lib. 542, 16v.

ANDRÉS DE QUINTANILLA

B. C.

6-10-1614

Fr. Benito de Cobillas

Presencio (Burgos)

AGN, Irache, Lib. 542, 17r. 
JUAN BOCANGELINO BABA

L. C. / D. C.

7-10-1614

Fr. Benito de Cobillas

Toledo

AGN, Irache, Lib. 542, 17 r.

\section{SANJUÁN LÓPEZ}

B. M. / L. M. / D. M.

7-10-1614

Fr. Benito de Cobillas / Dr. Murrugarren

Santiago de Compostela

AGN, Irache, Lib. 542, 17r.

PEDRO MARCEL

B. A. / L. A. / M. A. / B. T. / L. T. / M. T. 9-10-1614

Fr. Benito de Cobillas

Soria (Osma)

AGN, Irache, Lib. 542, 17rv.

FRANCISCO LADRÓN DE CEGAMA

L. C.

13-10-1614

Fr. Antonio de Alvarado

Estella (Pamplona)

AGN, Irache, Lib. 542, 17v.

HERNANDO DE SOBREMAZAS

L. C.

14-10-1614

Fr. Antonio de Alvarado

... (Burgos)

AGN, Irache, Lib. 542, 17v.

ALONSO DEL CASTILLO

L. C. / D. C.

22-10-1614

Fr. Antonio de Alvarado

Llerena (Nullius Diocesis)

AGN, Irache, Lib. 542, $17 \mathrm{v}$.

FRANCISCO DE VILELLA

B. C. / L. C. / D. C.

25-10-1614

Fr. Benito de Cobillas

Urgel

Estudiante de Zaragoza y Alcalá

AGN, Irache, Lib. 542, 18 r.
LUCAS FIGUERAS

B. T. / L. T. / M. T.

30-10-1614

Fr. Antonio de Alvarado

Logroño (Calahorra)

AGN, Irache, Lib. 542, 18r.

FRANCISCO DEL CASTILLO ALVARADO

B. L.

31-10-1614

Fr. Benito de Cobillas

... (Burgos)

Colegial del Col. Mayor de Salamanca

AGN, Irache, Lib. 542, 18rv.

JUAN DE ARCE

B. C.

31-10-1614

Fr. Benito de Cobillas

Celada (Burgos)

AGN, Irache, Lib. 542, 18v.

JUAN GONZÁLEZ

B. C. / L. C. / D. C.

5-11-1614

Fr. Antonio de Alvarado

Nalda (Calahorra)

AGN, Irache, Lib. 542, 18v.

FRANCISCO VERDEGUER

L. L. / D. L.

5-11-1614

Fr. Antonio de Alvarado

Barbastro

AGN, Irache, Lib. 542, 18v-19r.

BERNARDO DE CALATAYUD

B. C. / L. C.

16-11-1614 / 26-4-1615

Fr. Benito de Cobillas / Fr. Antonio de Alvarado

Estella (Pamplona)

AGN, Irache, Lib. 542, 19r, $23 \mathrm{v}$.

JUAN HURTADO DE MENDOZA

L. T. / D. T.

16-11-1614

Fr. Antonio de Alvarado 
Herreras (Palencia)

AGN, Irache, Lib. 542, 19r.

B. C.

18-11-1614

Fr. Mauro García de Mendoza

$\cdots$

AGN, Irache, Lib. 542, 19 r.

JUAN MARTÍNEZ

L. C.

19-11-1614

Fr. Antonio de Alvarado

Balbes (Burgos)

AGN, Irache, Lib. 542, 19 rv.

PLÁCIDO RODRÍGUEZ

B. A. / L. A. / M. A. / B. T. / L. T. / M. T.

21-11-1614

Fr. Antonio de Alvarado

O. S. B.

AGN, Irache, Lib. 542, 19v.

JERÓNIMO ROMERO

B. A.

21-11-1614

Fr. Antonio de Maceda, vicecanciller O. de M.

AGN, Irache, Lib. 542, 19v.

SIMÓN DE SADA

B. A.

21-11-1614

Fr. Antonio de Maceda

O. de M.

AGN, Irache, Lib. 542, 19v.

SEBASTIÁN DE GANUZA

B. A.

21-11-1614

Fr. Antonio de Maceda

O. de M.

AGN, Irache, Lib. 542, 19v.

JUAN LÓPEZ DE RIBAFORADA

B. A.
21-11-1614

Fr. Antonio de Maceda

O. de M.

AGN, Irache, Lib. 542, 19v.

BERNARDO DE IRISARRI

B. A.

21-11-1614

Fr. Antonio de Maceda

O. de M.

AGN, Irache, Lib. 542, 19v.

MARTÍN DE CALATAYUD

B. A.

21-11-1614

Fr. Antonio de Maceda

O. de M.

AGN, Irache, Lib. 542, 19v.

JUAN DE PUERTA

L. C. / D. C.

26-11-1614

Fr. Antonio de Alvarado

Colindres (Burgos)

AGN, Irache, Lib. 542, $20 r$.

FRANCISCO DÍAZ DE MEDINA

L. C. / D. C.

4-12-1614

Fr. Antonio de Alvarado

Lerma

AGN, Irache, Lib. 542, 2 or.

FRANCISCO RUIZ

B. C. / L. C. / D. C.

27-12-1614

Fr. Antonio de Alvarado

Campeche (Yucatán)

AGN, Irache, Lib. 542, 20 rv.

...

B. C. / L. C. / D. C.

¿ं-1-1615

Fr. Antonio de Alvarado

Mallorca

AGN, Irache, Lib. 542, $20 v$.

PEDRO GÓMEZ DEL CORNO

B. C. / L. C. / D. C. 
3-1-1615

Fr. Antonio de Alvarado

Santillana (Burgos)

AGN, Irache, Lib. 542, $20 v$.

\section{FRANCISCO DE LA ANDIÓN}

B. A.

7-1-1615

Fr. Mauro García de Mendoza

La Raga (Pamplona)

AGN, Irache, Lib. 542, 21r.

\section{JORGE NUNES}

L. M. / D. M.

19-1-1615

Fr. Benito de Cobillas

Santa María, Coimbra (Portugal)

AGN, Irache, Lib. 542, 21r.

\section{JUAN DE FREGO}

B. T. / L. T. / D. T.

8-2-1615

Fr. Gabriel de Guevara, vicecanciller

Pamplona

AGN, Irache, Lib. 542, 21rv.

JUAN DE YUBERO E ILZARBE

B. T. / L. T.

23-3-1615

Fr. Gabriel de Guevara

Izarbe (Pamplona)

AGN, Irache, Lib. 542, 21v.

ANDRÉS REAL

B. C.

30-3-1615

Fr. Mauro García de Mendoza

Cornudilla (Burgos)

AGN, Irache, Lib. 542, 21v.

PEDRO DE BERRIA

L. A.

2-4-1615

Fr. Antonio de Maceda

Abaurrea (Pamplona)

AGN, Irache, Lib. 542, 22r.

JERÓNIMO DE IPENGA

B. T.
2-4-1615

Fr. Gabriel de Guevara

Tarazona

AGN, Irache, Lib. 542, 22r.

DIEGO JIMÉNEZ

L. C. / D. C.

4-4-1615

Fr. Benito de Cobillas

Arnedo (Calahorra)

Pbro.

AGN, Irache, Lib. 542, 22 rv.

PEDRO DE BALANZA

L. L. / D. L.

5-4-1615

Fr. Gabriel de Guevara

Pamplona

AGN, Irache, Lib. 542, 22v.

PEDRO FERNÁNDEZ DE RETANA

B. T.

10-4-1615

Fr. Gabriel de Guevara

Zurbano (Calahorra)

AGN, Irache, Lib. 542, 22v-23r.

JOSÉ DE SALCEDO

B. C. / L. C.

11-4-1615

Fr. Mauro García de Mendoza

Nájera (Calahorra)

AGN, Irache, Lib. 542, 23r.

JUAN PÉREZ DE GRANADA

L. C. / D. C.

22-4-1615

Fr. Benito de Cobillas

Zamora

AGN, Irache, Lib. 542, 23 r.

PEDRO PAULO JUÁREZ

L. L.

25-4-1615

Fr. Antonio de Alvarado

Falces (Pamplona)

AGN, Irache, Lib. 542, 23 r. 
MARTÍN MARTÍNEZ

B. L.

26-4-1615

Fr. Mauro García de Mendoza

Aoiz (Pamplona)

AGN, Irache, Lib. 542, 24r.

JUAN DE CANTABRANA

B. L. / L. L.

26-4-1615

Fr. Antonio de Alvarado

Valladolid

AGN, Irache, Lib. 542, 24 r.

AGUSTÍN DE ONTANEDA

B. M. / L. M. / D. M.

26-4-1615

Fr. Antonio de Alvarado // Dres. Murugarren / Amunárriz

Aguayo (Burgos)

AGN, Irache, Lib. 542, 24v.

GASPAR FERNÁNDEZ

B. M. / L. M.

26-4-1615

Fr. Antonio de Alvarado // Dres. Murugarren / Amunárriz

Zamora

AGN, Irache, Lib. 542, 24v.

JERÓNIMO PUEBLA DE OREJA CAMARGO

L. L. / D. L.

28-4-1615

Fr. Antonio de Alvarado // Ldos. Urra y Legama

Valladolid

AGN, Irache, Lib. 542, 25r.

JUAN MERLO

L. C.

12-5-1615

Fr. Benito de Cobillas

Zamora

AGN, Irache, Lib. 542, 25r.

M. DE BASABE

B. C.
16-5-1615

Fr. Antonio de Maceda

Bachicabo (Burgos)

AGN, Irache, Lib. 542, 25 rv.

JUAN DE TASUGUERAS

B. C.

20-5-1615

Fr. Gabriel de Guevara

Bárcena (Burgos)

AGN, Irache, Lib. 542, $25 \mathrm{v}$.

JUAN RODRÍGUEZ

B. C.

24-5-1615

Fr. Benito de Cobillas

Quintana de Valdivieso (Burgos)

AGN, Irache, Lib. 542, 25v.

\section{LUIS DE SENOSIÁIN}

B. A. / L. A.

21-6-1615

Fr. Antonio de Maceda

Puente la Reina (Pamplona)

AGN, Irache, Lib. 542, 26r.

MARTÍN DE VERIAIN

B. A.

20-6-1615

Fr. Antonio de Maceda

Mañeru (Pamplona)

AGN, Irache, Lib. 542, 26r.

SALVADOR DE ELIO

B. A.

12-7-1615

Fr. Antonio de Maceda

Pamplona

AGN, Irache, Lib. 542, 26r.

MARTÍN DE VILLENA

B. A.

12-7-1615

Fr. Antonio de Maceda

Pamplona

AGN, Irache, Lib. 542, 26v.

GERARDO DE AZPILCUETA

B. A. 
12-7-1615

Fr. Antonio de Maceda

Pamplona

AGN, Irache, Lib. 542, 26v.

JUAN DE ENÉRIZ

B. A.

12-7-1615

Fr. Antonio de Maceda

Olaiz

AGN, Irache, Lib. 542, 26v.

PEDRO DE ENÉRIZ

B. A.

12-7-1615

Fr. Antonio de Maceda

Obanos

AGN, Irache, Lib. 542, 26v.

JUAN DE VERGARA

B. A.

12-7-1615

Fr. Antonio de Maceda

Enériz

AGN, Irache, Lib. 542, 26v.

JERÓNIMO DE JÁUREGUI

B. A.

12-7-1615

Fr. Antonio de Maceda

Pamplona

AGN, Irache, Lib. 542, 26v.

SANCHO DE GOÑI

B. A.

12-7-1615

Fr. Antonio de Maceda

Pamplona

AGN, Irache, Lib. 542, 26v.

JUAN DE URDÁNIZ

B. A.

12-7-1615

Fr. Antonio de Maceda

Pamplona

AGN, Irache, Lib. 542, 26v.

MARTÍN DE AOIZ

B. A.
12-7-1615

Fr. Antonio de Maceda

Aoiz

AGN, Irache, Lib. 542, 26v.

MARTÍN DE AYA

B. A.

12-7-1615

Fr. Antonio de Maceda

Pamplona

AGN, Irache, Lib. 542, 26v.

PEDRO DE ELSO

B. A.

12-7-1615

Fr. Antonio de Maceda

Pamplona

AGN, Irache, Lib. 542, 26v.

PEDRO DE ESPARZA

B. A.

12-7-1615

Fr. Antonio de Maceda

Aste...

AGN, Irache, Lib. 542, 26v.

JUAN DE MONTALVO

B. A.

12-7-1615

Fr. Antonio de Maceda

Pamplona

AGN, Irache, Lib. 542, 26v.

FRANCISCO DE MURILLO

B. A.

12-7-1615

Fr. Antonio de Maceda

Murillo

AGN, Irache, Lib. 542, 26v.

JUAN DE LINAROZ

B. A.

12-7-1615

Fr. Antonio de Maceda

Pamplona

AGN, Irache, Lib. 542, 26v.

JUAN DE ARTETA

B. A. 
12-7-1615

Fr. Antonio de Maceda

Arteta (Pamplona)

AGN, Irache, Lib. 542, 26v.

MIGUEL CALVO

L. C. / D. C.

31-7-1615

Fr. Antonio de Alvarado

Hinojosa (Teruel)

AGN, Irache, Lib. 542, 26v.

DIEGO MORENO

B. T. / L. T.

12-8-1615 / 3-2-1624

Fr. Mauro García de Mendoza

Estella (Pamplona)

AGN, Irache, Lib. 542, 26v, $119 r$.

PEDRO DE MENA

L. C.

13-8-1615

Fr. Antonio de Alvarado

Urueria (Palencia)

AGN, Irache, Lib. 542, 27r.

PEDRO GARCÍA DE PEREDO

B. C.

18-8-1615

Fr. Mauro García de Mendoza

Argomedo (Burgos)

AGN, Irache, Lib. 542, 27 r.

JUAN PÉREZ

B. C. / L. C.

25-8-1615

Fr. Mauro García de Mendoza / Fr. Antonio

de Alvarado

Ventosa (Palencia)

AGN, Irache, Lib. 542, 27r.

FRANCISCO LEQUIRIA CEBALLOS

L. C.

26-8-1615

Fr. Antonio de Alvarado

Herrera del Pisuerga (Palencia)

AGN, Irache, Lib. 542, 27v.
ANTONIO MUÑOZ DE CASTAÑEDA

L. C.

26-8-1615

Fr. Antonio de Alvarado

Herrera (Palencia)

AGN, Irache, Lib. 542, 27v.

FRANCISCO DE LERMA

B. A. / L. A. / M. A. / B. T. / L. T. / M. T. 30-8-1615

Fr. Antonio de Alvarado

O. S. B.

AGN, Irache, Lib. 542, 27v.

JUAN DE VICUÑA

B. A.

3-9-1615

Fr. Mauro García de Mendoza

Estella (Pamplona)

AGN, Irache, Lib. 542, 28r.

ÁLVARO DE PÁRAMO Y SANDE

B. A.

3-9-1615

Fr. Mauro García de Mendoza

Morón (Sigüenza)

AGN, Irache, Lib. 542, 28r.

JOSÉ CERÓN

L. C.

7-9-1615

Fr. Antonio de Alvarado

Valladolid

AGN, Irache, Lib. 542, 28r.

CRISTÓBAL DE AGUILAR

B. L.

11-9-1615

Fr. Mauro García de Mendoza

Valladolid

AGN, Irache, Lib. 542, 28v.

TOMÁS DE LUZÓN

B. T. / L. T. / D. T. 11-9-1615 / 12-9-1615

Fr. Mauro García de Mendoza / Fr. Antonio de Alvarado

Roa (Osma)

AGN, Irache, Lib. 542, 28v. 
FLAMINIO BACCI ELPIDIANO

B. M. / D. M.

16-9-1615

Fr. Antonio de Alvarado / Dr. Murrugarren

Roma

AGN, Irache, Lib. 542, 29r.

PEDRO GONZÁLEZ DE MORA

L. C. / D. C.

22-9-1615

Fr. Antonio de Alvarado.

Salas de los Barrios (Astorga)

AGN, Irache, Lib. 542, 29 r.

MIGUEL DE ELIZONDO

B. L.

25-9-1615

Fr. Mauro García de Mendoza

Pamplona

AGN, Irache, Lib. 542, 29 r.

FRANCISCO DE ELIZONDO

L. L.

26-9-1615

Fr. Antonio de Alvarado

Pamplona

AGN, Irache, Lib. 542, 29 r.

BARTOLOMÉ FERNÁNDEZ

B. T.

8-10-1615

Fr. Mauro García de Mendoza

La Coronada (Nullius diocesis)

Estudiante en Salamanca

AGN, Irache, Lib. 542, 29v.

ANDRÉS FERNÁNDEZ

B. T.

8-10-1615

Fr. Antonio de Alvarado

La Coronada (Nullius diocesis)

AGN, Irache, Lib. 542, $29 \mathrm{v}$.

MARTÍN DE AZCONA

L. C.

11-10-1615

Pamplona

AGN, Irache, Lib. 542, $29 \mathrm{v}$.
GREGORIO RUIZ DE SAGREDO Y PORRES

B. C. / L. C.

14-10-1615

Fr. Antonio de Alvarado

Santa Olalla (Burgos)

Magistral de Salamanca

AGN, Irache, Lib. 542, 3or.

JUAN RUIZ DE HUERTAS

L. C. / D. C.

19-10-1615

Fr. Antonio de Alvarado

Pbro. del hábito de Calatrava

AGN, Irache, Lib. 542, 3or.

ANDRÉS DE ZABALLOS

B. C.

1-11-1615

Fr. Gabriel de Guevara

Burgos

AGN, Irache, Lib. 542, 3or.

PEDRO DE CUEVAS

B. C.

6-11-1615

Fr. Mauro García de Mendoza

Mena (Burgos)

AGN, Irache, Lib. 542, 3or.

FRANCISCO BLANCO

B. T.

9-11-1615

Fr. Benito de Cobillas

Laredo (Burgos)

AGN, Irache, Lib. 542, 3 or.

PEDRO BERDEJO

B. M.

11-11-1615

Fr. Gabriel de Guevara / Dr. Jerónimo de

Murugarren

Campillo de Altobuey (Cuenca)

AGN, Irache, Lib. 542, 30v.

JUAN BAUTISTA DIEGO DE SEDANO

B. C.

13-11-1615 
Fr. Mauro García de Mendoza

Santibáñez (Burgos)

AGN, Irache, Lib. 542, 31r.

\section{BARTOLOMÉ RODRÍGUEZ}

B. T.

21-11-1615

Fr. Benito de Cobillas

Pedrosa de Río Úrbel (Burgos)

AGN, Irache, Lib. 542, 31r.

\section{ALONSO DE MADRID}

B. M.

30-11-1615

Fr. Gabriel de Guevara / Dr. Jerónimo de Murugarren

Albacete (Cartagena)

AGN, Irache, Lib. 542, 31r.

DIEGO DE PARTE ARROYO

B. C.

3-12-1615

Fr. Mauro García de Mendoza

Miñana (Burgos)

AGN, Irache, Lib. 542, 31rv.

DIEGO DE CHUECA

L. T. / D. T.

10-12-1615

Fr. Antonio de Alvarado

... (Tarazona)

AGN, Irache, Lib. 542, 31v.

ANTONIO DE MENDOZA E HIJAR

L. C.

14-12-1615

Fr. Antonio de Alvarado

Zalamea (Nullius diocesis)

AGN, Irache, Lib. 542, 31v.

PEDRO LÓPEZ LOBO

B. L.

23-12-1615

Fr. Gabriel de Guevara

Segura

AGN, Irache, Lib. 542, 31v.

MARIO DE EZA Y ROSALES

B. C. / L. C.
25-12-1615

Fr. Mauro García de Mendoza

AGN, Irache, Lib. 542, 31v.

GONZALO DE BERRIO

B. C. / L. C. / D. C.

6-1-1616 / 11-1-1616

Fr. Benito de Cobillas / Fr. Gabriel de Gue-

vara

Soria (Osma)

Chantre

AGN, Irache, Lib. 542, 31v.

JUAN LUCERO

B. C. / L. C. / D. C.

15-1-1616 /16-1-1616

Fr. Gabriel de Guevara / Fr. Mauro García de Mendoza

Alfaro

Chantre y canónigo

AGN, Irache, Lib. 542, 32r.

JUAN DE FRESNEDA

L. C. / D. C.

25-1-1616

Fr. Mauro García de Mendoza

Villarejo de Fuentes (Cuenca)

AGN, Irache, Lib. 542, 32r.

BARTOLOMÉ DE GAYARRE

L. A.

26-1-1616

Fr. Mauro García de Mendoza

Garde (Pamplona)

AGN, Irache, Lib. 542, 32r.

FRANCISCO DE COS Y DEL CORRO

L. C.

30-1-1616

Fr. Benito de Cobillas

San Vicente de la Barquera (Burgos)

AGN, Irache, Lib. 542, 32v.

JORGE DE BURGOS

L. T. / D. T.

7-2-1616

Fr. Benito de Cobillas 
Tarazona

AGN, Irache, Lib. 542, 32v.

PEDRO RUIZ DE ALLENDE

B. C.

9-2-1616

Fr. Gabriel de Guevara

Escalada (Burgos)

AGN, Irache, Lib. 542, 32v.

MIGUEL BARBO

L. A.

12-2-1616

Fr. Juan de Redia, Vicecanciller

Pamplona

AGN, Irache, Lib. 542, 32v-33r.

NICOLÁS DE LA CALVA

L. C. / D. C.

13-2-1616

Fr. Gabriel de Guevara

Palencia

AGN, Irache, Lib. 542, 33r.

JUAN DE VALLE

B. C. / L. C. / D. C.

25-2-1616

Fr. Antonio de Alvarado

Vitoria (Burgos)

AGN, Irache, Lib. 542, 33r.

BERNARDO DE ALZUETA Y REPARAZ

B. A.

4-3-1616

Fr. Juan de Radin, vicecanciller

Pamplona

AGN, Irache, Lib. 542, 33r.

MANUEL FUERTES

B. C.

14-3-1616

Fr. Benito de Cobillas

Palenzuela (Burgos)

AGN, Irache, Lib. 542, 33r.

JUSTO MARTÍNEZ DE ARROYO

B. C. / L. C.

$1-4-1616$ / 2-4-1616
Fr. Juan de Radin / Fr. Antonio de Alvarado

Romancos (Toledo)

AGN, Irache, Lib. 542, 33v.

ALONSO DE BARRANTES

B. A. / L. A. / D. A. / B. T. / L. T. / M. T.

6-4-1616

Fr. Antonio de Alvarado

O. S. B.

General de la Orden en España

AGN, Irache, Lib. 542, 33v.

PEDRO DE ARINES Y TRONCOSO

L. C.

9-4-1616

Fr. Antonio de Alvarado

M... (Tuy)

AGN, Irache, Lib. 542, 33v.

FRANCISCO DE MORENTÍN

L. C.

15-4-1616

Fr. Antonio de Alvarado

Lodosa (Pamplona)

AGN, Irache, Lib. 542, 34r.

JUAN HERNÁNDEZ

B. C.

16-4-1616

Fr. Benito de Cobillas

Munilla (Burgos)

Estudiante en Valladolid

AGN, Irache, Lib. 542, 34r.

MANUEL DE ALMEIDA

B. C. / L. C.

16-4-1616 / 17-4-1616

Fr. Gabriel de Guevara / Fr. Antonio de Alvarado

Beuza

Estudiante en Sevilla y Salamanca

AGN, Irache, Lib. 542, 34r.

MIGUEL DE GARIBAY

B. T.

29-4-1616

Fr. Mauro García de Mendoza

AGN, Irache, Lib. 542, 34V. 
JUAN DE CABRERA

B. M.

3-5-1616

Fr. Gabriel de Guevara / Dr. Jerónimo de Murrugarren

Hinojosa del Duque (Córdoba)

Estudiante en Salamanca

AGN, Irache, Lib. 542, 34v.

PEDRO GIRÓN PACHECO

L. C. / D. C.

4-5-1616

Fr. Antonio de Alvarado

Puebla de Montalván (Toledo)

B. C. en Salamanca

AGN, Irache, Lib. 542, 34v.

JUAN DE BONILLA

L. C.

4-5-1616

Fr. Antonio de Alvarado

Bedón (Burgos)

AGN, Irache, Lib. 542, 34v.

HERMENEGILDO DE VIDAURRETA

B. C.

14-5-1616

Fr. Benito de Cobillas

Calahorra (Calahorra)

Estudiante en Alcalá y Valladolid

AGN, Irache, Lib. 542, 35r.

JUAN DE SOMAVILLA

B. C.

16-5-1616

Fr. Mauro García de Mendoza

Bárcena (Burgos)

Estudiante en Valladolid

AGN, Irache, Lib. 542, 35r.

LORENZO REJÓN

B. C.

18-5-1616

Fr. Benito de Cobillas

Leganés (Toledo)

Estudiante en Salamanca

AGN, Irache, Lib. 542, 35r.

\section{LORENZO CHACÓN}

B. C. / L. C.

18-5-1616

Fr. Gabriel de Guevara / Fr. Antonio de Al-

varado

Madrid (Toledo)

Estudiante en Salamanca

AGN, Irache, Lib. 542, 35r.

MARTÍN NEGRETE

B. C.

31-5-1616

Fr. Benito de Cobillas

Bárcena (Burgos)

Estudiante en Valladolid

AGN, Irache, Lib. 542, 35v.

\section{JUAN MARTÍNEZ}

B. C.

11-6-1616

Fr. Benito de Cobillas

Tapuerca (Burgos)

AGN, Irache, Lib. 542, 35v.

ANTONIO ALBERTO VIEJO

L. C. / D. C.

18-6-1616

Fr. Antonio de Alvarado

Zaragoza

AGN, Irache, Lib. 542, 35v.

\section{JUAN ANDRÉS DE ESPINOSA}

B. A.

20-6-1616

Fr. Juan de Redín, Vicecancelario

Lapuente (Pamplona)

AGN, Irache, Lib. 542, 36r.

MARTÍN PARRAST

B. A.

20-6-1616

Fr. Juan de Redín

Pamplona

AGN, Irache, Lib. 542, 36r.

BERNARDO DE URIBARRI

B. A.

20-6-1616 
Fr. Juan de Redín

Artozqui (Pamplona)

AGN, Irache, Lib. 542, 36r.

JUAN DE EBALOS

B. A.

20-6-1616

Fr. Juan de Redín

Muruzábal (Pamplona)

AGN, Irache, Lib. 542, 36r.

\section{EUGENIO DE ARTAZU}

B. A.

20-6-1616

Fr. Juan de Redín

Lapuente (Pamplona)

AGN, Irache, Lib. 542, 36r.

BALTASAR DE OZCÁRIZ

B. A.

20-6-1616

Fr. Juan de Redín

Pamplona

AGN, Irache, Lib. 542, 36r.

MIGUEL DE UCAR Y AZCONA

B. A.

20-6-1616

Fr. Juan de Redín

Ascona (Pamplona)

AGN, Irache, Lib. 542, 36r.

JUAN DE BICURIA

B. A.

20-6-1616

Fr. Juan de Redín

Navarrete (Pamplona)

AGN, Irache, Lib. 542, 36r.

JUAN DE CLAVERÍA

B. A.

20-6-1616

Fr. Juan de Redín

Pamplona

AGN, Irache, Lib. 542, 36r.

JOSÉ DE GURPEGUI

B. A.
20-6-1616

Fr. Juan de Redín

Pamplona

AGN, Irache, Lib. 542, 36r.

DOMINGO MARTÍNEZ DE MORENTÍN

B. A.

20-6-1616

Fr. Juan de Redín

Los Arcos (Pamplona)

AGN, Irache, Lib. 542, 36r.

GABRIEL DE MAYA

B. A.

20-6-1616

Fr. Juan de Redín

Pamplona

AGN, Irache, Lib. 542, 36r.

MIGUEL DE OLÓNDRIZ

B. A. / B. C. / L. C.

20-6-1616 / 6-5-1620 / 22-4-1623

Fr. Juan de Redín / Fr. Benito de Cobillas /

Fr. Mauro García de Mendoza

Puente la Reina (Pamplona)

AGN, Irache, Lib. 542, 36r, 87v, 111v.

MIGUEL DE IRURZUM

B. A.

20-6-1616

Fr. Juan de Redín

Pamplona

AGN, Irache, Lib. 542, 36r.

JUAN DE ROTETA

B. A.

20-6-1616

Fr. Juan de Redín

Pamplona

AGN, Irache, Lib. 542, 36r.

JERÓNIMO DE FORTUNIO

B. A.

20-6-1616

Fr. Juan de Redín

Pamplona

AGN, Irache, Lib. 542, 36r. 
JUAN DE HEBALLEN

B. A.

20-6-1616

Fr. Juan de Redín

Arre (Pamplona)

AGN, Irache, Lib. 542, 36r.

JUAN DE VICUÑA

B. A.

20-6-1616

Fr. Juan de Redín

Legasa (Pamplona)

AGN, Irache, Lib. 542, 36r.

JUAN DE GORGUIARAN

B. A.

20-6-1616

Fr. Juan de Redín

Pamplona

AGN, Irache, Lib. 542, 36r.

JUAN DE CHAVARRÍA

B. A.

20-6-1616

Fr. Juan de Redín

Pamplona

AGN, Irache, Lib. 542, 36r.

FRANCISCO DE BOLÍN

B. A.

20-6-1616

Fr. Juan de Redín

Pamplona

AGN, Irache, Lib. 542, 36r.

MARTÍN RODRÍGUEZ

B. A.

20-6-1616

Fr. Juan de Redín

Raga (Pamplona)

AGN, Irache, Lib. 542, 36r.

BELTRÁN DE MORONDO

B. A. / L. A.

20-6-1616 / 20-2-1622

Fr. Juan de Redín / Fr. Antonio Cornejo

Ollera (Pamplona)

AGN, Irache, Lib. 542, 36r, 101v.

\section{BERNABÉ DÍEZ}

B. A.

20-6-1616

Fr. Juan de Redín

Estella (Pamplona)

AGN, Irache, Lib. 542, 36r.

MATEO DE LESACA

B. A.

20-6-1616

Fr. Juan de Redín

Estella (Pamplona)

AGN, Irache, Lib. 542, 36r.

MARTÍN DE LIZALDE

B. A.

20-6-1616

Fr. Juan de Redín

Múzquiz (Pamplona)

AGN, Irache, Lib. 542, 36r.

LUIS DE ABADÍA

B. A.

20-6-1616

Fr. Juan de Redín

Fuenterrabía (Pamplona)

AGN, Irache, Lib. 542, 36r.

BELTRÁN DE ABADÍA

B. A.

20-6-1616

Fr. Juan de Redín

Loyola (Francia)

AGN, Irache, Lib. 542, 36r.

PEDRO DE LIZARI

B. A.

20-6-1616

Fr. Juan de Redín

San Juan de Luz (Bayona)

AGN, Irache, Lib. 542, 36r.

JUAN DE GOMEZCORTA

B. A.

20-6-1616

Fr. Juan de Redín

Vergara (Calahorra)

AGN, Irache, Lib. 542, 36r. 
PEDRO DE BUSTOS Y ESPINOSA

L. L. / D. L.

23-6-1616

Fr. Antonio de Alvarado

Belorado (Burgos)

AGN, Irache, Lib. 542, 36v.

BARTOLOMÉ DE SAN CEBRIÁN

B. C.

24-6-1616

Fr. Mauro García de Mendoza

Bodadella de Villamar (Burgos)

Estudiante en Valladolid

AGN, Irache, Lib. 542, 36v.

MARTÍN MARTÍNEZ DE OQUELLU LUZURIAGA

B. A.

1-7-1616

Fr. Juan de Redín

Salvatierra (Calahorra)

Estudiante en Pamplona

AGN, Irache, Lib. 542, 36v.

MENDO LÓPEZ

L. M. / D. M.

9-7-1616

Fr. Antonio de Alvarado / Dr. Jerónimo de

Murugarren

Porto Alegre. Portugal

AGN, Irache, Lib. 542, 37r.

ALONSO DE CASTELVÍ Y AIMERICH

B. C. / L. C. / D. C.

11-7-1616 / 12-7-1616

Fr. Benito de Cobillas / Fr. Antonio de Al-

varado

Cáller

AGN, Irache, Lib. 542, 37rv.

FRANCISCO GÓMEZ

B. L. / L. L. / D. L.

11-7-1616 / 12-7-1616

Fr. Benito de Cobillas / Fr. Antonio de Al-

varado

Cáller

AGN, Irache, Lib. 542, 37rv.
JUAN PONS

B. C. / L. C. / D. C.

11-7-1616 / 12-7-1616

Fr. Benito de Cobillas / Fr. Antonio de Al-

varado

Alayor (Mallorca)

AGN, Irache, Lib. 542, 37rv.

LOPE DE UGARTE

B. C. / L. C. / D. C.

14-7-1616 / 5-12-1620

Fr. Gabriel de Guevara / Fr. Luis Flórez

Pamplona

AGN, Irache, Lib. 542, 38r, 94r.

MIGUEL GUTIÉRREZ

B. C.

15-7-1616

Fr. Benito de Cobillas

Osornillo (Palencia)

AGN, Irache, Lib. 542, 38r.

DAMIÁN MARQUÉS DE PRADO

B. C.

23-7-1616

Fr. Mauro García de Mendoza

Covarrubias

Estudiante en Salamanca

AGN, Irache, Lib. 542, 38r.

LUIS DE SAGARRAGA

B. L.

30-7-1616

Fr. Gabriel de Guevara

Valladolid

Estudiante en Salamanca

AGN, Irache, Lib. 542, 38r.

ANDRÉS GARCÍA

B. C.

3-8-1616

Fr. Benito de Cobillas

Villanueva (Burgos)

AGN, Irache, Lib. 542, 38v.

JUAN ALONSO GONZÁLEZ

B. C.

25-8-1616 
Fr. Benito de Cobillas

Tremello (Burgos)

AGN, Irache, Lib. 542, 38v.

JUAN ALONSO IZQUIERDO

B. C.

8-8-1616

Fr. Gabriel de Guevara

Castillo de la Reina (Osma)

AGN, Irache, Lib. 542, 38v.

JUAN DE LA CUESTA

B. C.

8-8-1616

Fr. Benito de Cobillas

Heras (Burgos)

AGN, Irache, Lib. 542, 38v.

JUAN ANSÓN

B. C.

13-8-1616

Fr. Benito de Cobillas

Castro Urdiales (Burgos)

AGN, Irache, Lib. 542, 39r.

ALONSO MARQUÉS

B. C.

3-9-1616

Fr. Gabriel de Guevara

Alaejos (Valladolid)

AGN, Irache, Lib. 542, 39r.

PEDRO PEDROSA

B. C.

13-9-1616

Fr. Gabriel de Guevara

Castro Genil (Burgos)

AGN, Irache, Lib. 542, 39r.

CRISTÓBAL DE LLANO PERAZA

B. C.

16-9-1616

Fr. Mauro García de Mendoza

Ocaria (Toledo)

AGN, Irache, Lib. 542, 39r.

PEDRO DE LOS ARCOS

B. M.
19-9-1616

Fr. Gabriel de Guevara

Nájera (Calahorra)

AGN, Irache, Lib. 542, 39v.

JUAN PALOMINO

B. C.

22-9-1616

Fr. Gaspar de Liendo

Villa Sandino (Burgos)

AGN, Irache, Lib. 542, 39v.

JUAN DE BUSTAMANTE

B. C.

26-9-1616

Fr. Gaspar de Liendo, vicecanciller

Bribiesca (Burgos)

AGN, Irache, Lib. 542, 39v.

DIEGO CORONADO

B.C. / L. C.

27-9-1616

Fr. Gaspar de Liendo

Valladolid

AGN, Irache, Lib. 542, 39v.

JUAN VELAZ

B. T.

30-9-1616

Fr. Gaspar de Liendo

Estella (Pamplona)

AGN, Irache, Lib. 542, 40r.

BENITO PÉREZ DE ÁLAVA

B. L. / L. L. / D. L.

6-10-1616

Fr. Juan de Redín

Segovia

AGN, Irache, Lib. 542, 40r.

PEDRO DE AIBAR

L. L.

6-10-1616

Fr. Agustín de Benavente, prior

Corella (Pamplona)

AGN, Irache, Lib. 542, 40r.

JUAN MARTÍNEZ DE SANTIAGO

B. A. 
7-10-1616

Fr. Juan de Redín

... (Calahorra)

AGN, Irache, Lib. 542, 40r.

MARTÍN MARTÍNEZ DE LOZOÑO

L. A.

7-10-1616

Fr. Agustín de Benavente

... (Calahorra)

AGN, Irache, Lib. 542, $40 v$.

\section{MATÍAS SANZ}

B. A.

8-10-1616

Fr. Agustín de Benavente

Arlanzón (Burgos)

AGN, Irache, Lib. 542, $40 \mathrm{v}$.

PEDRO DE LA PUENTE

B. T. / L. T. / D. T.

10-10-1616

Fr. Agustín de Benavente

Calahorra

Visitador General del Obispado

AGN, Irache, Lib. 542, $40 v$.

\section{PEDRO DE COLINA}

B. C.

14-10-1616

Fr. Benito de Cobillas

Valle de Colina (Burgos)

AGN, Irache, Lib. 542, $40 \mathrm{v}$.

JUAN DE CABRERA

L. M. / D. M.

23-10- 1616

Fr. Antonio de Alvarado / Dr. Murugarren

Torrelobatón (Palencia)

AGN, Irache, Lib. 542, 41r.

JUAN ZAPATIER CARPIO

B. A. / B. M.

25-10-1616 / 26-10-1616

Fr. Mauro García de Mendoza / Fr. Benito

de Cobillas

Binaced (Lérida)

AGN, Irache, Lib. 542, 41r.
MIGUEL TAMAMES

L. C. / D. C.

3-11-1616

Fr. Antonio de Alvarado

Almeida (Zamora)

AGN, Irache, Lib. 542, 41r.

MIGUEL ALONSO

L. C.

3-11-1616

Fr. Antonio de Alvarado

Tudera (Zamora)

AGN, Irache, Lib. 542, 41v.

ANTONIO LÓPEZ

B. T. / D. T.

6-11-1616 / 7-11-1616

Fr. Mauro García de Mendoza

Viana (Calahorra)

AGN, Irache, Lib. 542, 41v.

JUAN ELBIZ PADRÓN

B. A. / L. A. / M. A. / D. T.

29-11-1616 / 30-11-1616

Fr. Juan de Redín / Fr. Antonio de Alvara-

do

Villalón (León)

AGN, Irache, Lib. 542, 42r.

MIGUEL DE OCAMPO Y CIENFUEGOS

L. T.

30-11-1616

Fr. Antonio de Alvarado

Sahún

AGN, Irache, Lib. 542, 42v.

JUAN GONZÁLEZ DE GINÉS

B. C.

1-12-1616

Fr. Benito de Cobillas

Montego de Acebes (Burgos)

AGN, Irache, Lib. 542, 42v.

BARTOLOMÉ MANTILLA

B. C.

7-12-1616

Fr. Benito de Cobillas

Ormazos (Burgos)

AGN, Irache, Lib. 542, 42v. 
ESTEBAN DE CARVAJAL

B. C. / L. C. / D. C.

9-12-1616 /10-12-1616

Fr. Gabriel de Guevara / Fr. Antonio de Alvarado

Talavera (Toledo)

AGN, Irache, Lib. 542, 43r.

TOMÁS DE AGÜERO

L. C. / D. C.

10-12-1616

Fr. Antonio de Alvarado

Suesa (Burgos)

AGN, Irache, Lib. 542, 43r.

\section{JUAN CORNEJO}

L. C. / D. C.

10-12-1616

Fr. Antonio de Alvarado

Portillo (Valladolid)

AGN, Irache, Lib. 542, 43r.

ANTONIO PERLINES

B. L. / L. C. / D. C.

10-12-1616

Fr. Gabriel de Guevara / Fr. Antonio de Alvarado

Valladolid

AGN, Irache, Lib. 542, 43v.

LORENZO PERLINES

B. L. / L. C. / D. C.

10-12-1616

Fr. Gabriel de Guevara / Fr. Antonio de Al-

varado

Valladolid

AGN, Irache, Lib. 542, 43v.

MIGUEL PARRAST

L. C.

14-12-1616

Fr. Antonio de Alvarado

Pamplona

AGN, Irache, Lib. 542, 44r.

FRANCISCO GARCÍA DE OLALLA

B. C.

14-12-1616
Fr. Mauro García de Mendoza

Brieva (Calahorra)

AGN, Irache, Lib. 542, 44r.

JUAN DE VILLORIA

B. T. / L. T. / D. T.

26-12-1616

Fr. Benito de Cobillas / Fr. Antonio de Alvarado

Salamanca

Secretario General de la O. de M.

AGN, Irache, Lib. 542, 44r.

BERNARDO DEL FUEGO

B. A.

7-1-1617

Fr. Juan de Redín

Tarazona

AGN, Irache, Lib. 542, 44v.

DIONISIO DE LERMA

B. A.

7-1-1617

Fr. Juan de Redín

Tudela (Tarazona)

AGN, Irache, Lib. 542, 44v.

ALONSO DE VÍTORES

B. A. / L. A. / M. A. / B. T. / L. T. / D. T.

10-1-1617

Fr. Juan de Redín / Fr. Antonio de Alvara-

do

Burgos

O. S. B.

AGN, Irache, Lib. 542, 44v.

ALFONSO DE NOJA CASTILLO

B. C.

21-1-1617

Fr. Gabriel de Guevara

Castro Urdiales (Burgos)

AGN, Irache, Lib. 542, 44v.

JERÓNIMO ALBOREZ

B. C.

22-1-1617

Fr. Benito de Cobillas

Villasol (Burgos)

AGN, Irache, Lib. 542, 45r. 
BERNARDO DE ALZUETA

B. M. / L. M. / D. M.

15-1-1617

Fr. Gabriel de Guevara // Dres. Murugarren / Arróniz

Pamplona

AGN, Irache, Lib. 542, 45r.

DOMINGO PÉREZ

B. C.

6-2-1617

Fr. Juan de Redín

Presencio (Burgos)

AGN, Irache, Lib. 542, 45v.

FRANCISCO ZÁRATE

B. T.

18-2-1617

Fr. Mauro García de Mendoza

Burgos

AGN, Irache, Lib. 542, 45v.

BLAS SANZ

L. A.

7-3-1617

Fr. Juan de Redín

Viguera (Calahorra)

AGN, Irache, Lib. 542, 45v.

\section{JUAN ROMERO}

L. A.

7-3-1617

Fr. Juan de Redín

Viguera (Calahorra)

AGN, Irache, Lib. 542, 45v.

FRANCISCO DE MENA

L. C. / D. C.

21-3-1617

Fr. Antonio de Alvarado

Arévalo (Ávila)

Provisor del Obispado de Calahorra

AGN, Irache, Lib. 542, 46r.

DIEGO DE REDONDO

B. C.

24-3-1617

Fr. Benito de Cobillas
Limpias (Burgos)

AGN, Irache, Lib. 542, 46r.

FRANCISCO DE PALACIOS

B. C.

1-4-1617

Fr. Benito de Cobillas

Limpias (Burgos)

AGN, Irache, Lib. 542, 46r.

MATEO RUIZ DE HUIDOBRO

B. C.

8-4-1617

Fr. Gabriel de Guevara

Santa Olalla (Burgos)

AGN, Irache, Lib. 542, 46r.

ANDRÉS LLORENTE

B. C.

12-4-1617

Fr. Benito de Cobillas

Sevilla

AGN, Irache, Lib. 542, 46r.

FERNANDO DE LAS CABEZAS

L. C.

12-4-1617

Fr. Benito de Cobillas

Zamora

AGN, Irache, Lib. 542, 46r.

BARTOLOMÉ DE PALACIOS

B. C.

20-4-1617

Fr. Benito de Cobillas

Biáñez (Burgos)

AGN, Irache, Lib. 542, 46r.

FRANCISCO FERNÁNDEZ VELASCO

B. M.

22-4-1617

Fr. Mauro García de Mendoza / Dr. Murugarren

Larraga (Pamplona)

AGN, Irache, Lib. 542, 46v.

JERÓNIMO DOMÍNGUEZ

L. T. / D. T. 
30-4-1617

Fr. Benito de Cobillas

Pamplona

Prior del Carmen

O. C.

AGN, Irache, Lib. 542, 46v.

GABRIEL DE ZABALZA

L. L.

29-4-1617

Fr. Mauro García de Mendoza // Dres. Castillo / Estella

Tafalla (Pamplona)

AGN, Irache, Lib. 542, 47r.

FRANCISCO MARTÍNEZ DE UZQUIANO

B. T.

1-5-1617

Fr. Benito de Cobillas

San Vicente de Triviño (Calahorra)

AGN, Irache, Lib. 542, 47r.

MAURO GARCÍA DE MENDOZA

B. A. / L. A. / M. A. / B. T. / L. T. / M. T.

4-5-1617

Fr. Benito de Cobillas

O. S. B.

Lector de Teología de Irache

AGN, Irache, Lib. 542, 47r.

MANUEL DE MORALEGRE

B. C.

6-5-1617

Fr. Benito de Cobillas

Burgos

AGN, Irache, Lib. 542, 47v.

RODRIGO DE FIGUEROA

B. C. / L. C.

9-5-1617

Fr. Benito de Cobillas / Fr. Mauro García

de Mendoza

Medina (Toledo)

Canónigo de León

AGN, Irache, Lib. 542, 47v.

MARCOS FERNÁNDEZ

B. A.
17-5-1617

Fr. Juan de Redín

Ribarteme (Santiago)

AGN, Irache, Lib. 542, 47v.

ONOFRE PARDO DE SANTOYA

L. C. / D. C.

25-5-1617

Fr. Lorenzo de Frías, Abad y Rector

Pancorbo (Burgos)

AGN, Irache, Lib. 542, 48r.

CRISTÓBAL DE AÑORBE

B. T. / L. T.

27-5-1617

Fr. Mauro García de Mendoza

Muruzábal (Pamplona)

AGN, Irache, Lib. 542, 48r.

FERNANDO DE LORCA

B. C. / L. C.

29-5-1617

Fr. Mauro García de Mendoza

Cazorla (Toledo)

AGN, Irache, Lib. 542, 48v.

GABRIEL DE LAVA

B. C.

1-6-1617

Fr. Benito de Cobillas

Pamplona

AGN, Irache, Lib. 542, 48v.

DIEGO DE MEÑACA

B. C. / L. C. / D. C.

4-6-1617

Fr. Mauro García de Mendoza / Fr. Benito

de Cobillas

Madrid (Toledo)

AGN, Irache, Lib. 542, 49r.

JUAN DE ECHARRI

B. A.

5-6-1617

Fr. Juan de Redín

Aldaz (Pamplona)

AGN, Irache, Lib. 542, 49r. 
FERNANDO DE ELCARTE

B. A. / B. C.

5-6-1617 / 22-9-1621

Fr. Juan de Redín / Fr. Benito de la Serna

Pamplona

AGN, Irache, Lib. 542, 49r, 100v.

JUAN GÓMEZ

B. A.

5-6-1617

Fr. Juan de Redín

Salinas (Pamplona)

AGN, Irache, Lib. 542, 49r.

PEDRO GUEMBE

B. A.

5-6-1617

Fr. Juan de Redín

Astráin (Pamplona)

AGN, Irache, Lib. 542, 49r.

IGNACIO DE PEÑA

B. A.

5-6-1617

Fr. Juan de Redín

Ibilcieta (Pamplona)

AGN, Irache, Lib. 542, 49r.

JUAN DE NUIN

B. A. / B. T. / L. T.

5-6-1617 / 15-7-1626

Fr. Juan de Redín / Fr. José de Carmona

Nuin (Pamplona)

AGN, Irache, Lib. 542, 49r, 139r.

MARTÍN DE ERICE

B. A. / L. T.

5-6-1617 / 8-2-1632

Fr. Juan de Redín / Fr. Matías de Hevia

Obanos (Pamplona)

AGN, Irache, Lib. 542, 49r, 186v.

JUAN DE LOYOLA TORRE

B. A.

5-6-1617

Fr. Juan de Redín

Pasajes (Pamplona)

AGN, Irache, Lib. 542, 49r.

\section{JUAN DE AGUIRRE}

B. A.

5-6-1617

Fr. Juan de Redín

Lumbier (Pamplona)

AGN, Irache, Lib. 542, 49r.

JUAN DE VIDONDO

B. A.

5-6-1617

Fr. Juan de Redín

Arrieta (Pamplona)

AGN, Irache, Lib. 542, 49v.

JUAN DE EZPELETA

B. A.

5-6-1617

Fr. Juan de Redín

Pamplona

AGN, Irache, Lib. 542, 49v.

MARTÍN DE ARANO

B. A.

5-6-1617

Fr. Juan de Redín

Elduayen (Pamplona)

AGN, Irache, Lib. 542, 49v.

AGUSTÍN DE GORRIA

B. A.

5-6-1617

Fr. Juan de Redín

Olite (Pamplona)

AGN, Irache, Lib. 542, 49v.

JUAN CASTRILLEJO

B. C.

24-6-1617

Fr. Luis Florez, vicecanciller

Tabanera (Burgos)

AGN, Irache, Lib. 542, 49v.

ALONSO DÍEZ DE PIMENTEL

B. M.

29-6-1617

Fr. Benito de Cobillas

Lisboa

AGN, Irache, Lib. 542, 5 or. 
FRANCISCO DE TORRES

B. C.

29-6-1617

Fr. Mauro García de Mendoza

Burgos

AGN, Irache, Lib. 542, 5or.

ANDRÉS TEJEDOR

B. C.

13-7-1617

Fr. Luis Flórez, Regente y Vicecanciller

Villaizan (Burgos)

AGN, Irache, Lib. 542, 5 or.

BARTOLOMÉ DE SALAZAR

B. L. / L. C.

23-7-1617

Fr. Benito de Cobillas / Fr. Luis Flórez

Valladolid

AGN, Irache, Lib. 542, $50 v$.

BENITO GÓMEZ RACIONERO

B. A. / B. T. / L. T. / D. T.

28-7-1617

Fr. Juan de Redín / Fr. Luis Flórez / Fr. Lorenzo de Frías

... (Burgos)

AGN, Irache, Lib. 542, 51r.

JUAN MARTÍNEZ

B. C.

4-8-1617

Fr. Luis Flórez

Quintanapalla (Burgos)

AGN, Irache, Lib. 542, 51v.

JERÓNIMO DE MILLÁN

L. L. / D. L. / D. C.

22-8-1617

Fr. Lorenzo de Frías

Lisboa

L. C. por Coimbra

AGN, Irache, Lib. 542, 51v-52r.

JUAN ÁLVAREZ DE VILLARROEL

L. C.

26-8-1617

Fr. Lorenzo de Frías
Pedrosa (León)

AGN, Irache, Lib. 542, 52v.

FRANCISCO DE ESPINOSA

L. C. / D. C.

28-8-1617

Fr. Lorenzo de Frías

Madrid (Toledo)

AGN, Irache, Lib. 542, 53r.

DIEGO DE YANGUAS

L. C / D. C

4-9-1617

Fr. Lorenzo de Frías

Nájera (Calahorra)

AGN, Irache, Lib. 542, 53r.

PEDRO ÁLVAREZ

B. C. / L. C. / D. C.

6-9-1617

Fr. Luis Flórez

Ayamonte (Sevilla)

AGN, Irache, Lib. 542, 53v.

DIEGO DE MONROY

B. T.

8-9-1617

Fr. Luis Flórez

Mijancas (Calahorra)

AGN, Irache, Lib. 542, 54r.

MATEO LÓPEZ

B. C.

12-9-1617

Fr. Luis Flórez

Herrán (Burgos)

AGN, Irache, Lib. 542, 54r.

JUAN GARCÍA

B. C.

22-9-1617

Fr. Mauro García de Mendoza

Villamediana (Calahorra)

AGN, Irache, Lib. 542, 54v.

JOSÉ DE PEREDA

B. C. / L. C.

29-9-1617 
Fr. Luis Flórez / Fr. Lorenzo de Frías Ólvega (Tarazona)

AGN, Irache, Lib. 542, 54v.

\section{ANDRÉS ÁLVAREZ}

B. C.

1-10-1617

Fr. Luis Flórez

Canarias

AGN, Irache, Lib. 542, 55r.

JUAN JACINTO VELÁZQUEZ

B. C. / L. C. / D. C.

3-10-1617

Fr. Luis Flórez / Fr. Lorenzo de Frías

Ciudad de la Plata (Diócesis de Charcas)

AGN, Irache, Lib. 542, 55r.

JUAN DE ERVITI

L. L. / D. L.

3-10-1617

Fr. Lorenzo de Frías

Pamplona

AGN, Irache, Lib. 542, 55v.

PEDRO DE BUERAS

B. C.

3-10-1617

Fr. Luis Flórez

Bueras (Burgos)

AGN, Irache, Lib. 542, 56r.

FRANCISCO DE ESPINOSA

L. C.

14-10-1617

Fr. Lorenzo de Frías

Curiel (Palencia)

AGN, Irache, Lib. 542, 56r.

PEDRO MIGUEL NAVARRO

B. C. / L. C.

18-10-1617

Fr. Luis Flórez / Fr. Lorenzo de Frías

Añón (Tarazona)

AGN, Irache, Lib. 542, 56v.

LOPE GARCÍA DE TÉBAR

L. C. / D. C.
23-10-1617

Fr. Lorenzo de Frías

Villanueva de la Jara (Cuenca)

AGN, Irache, Lib. 542, 56v.

PEDRO MICÓN

B. M. / L. M. / D. M.

1-11-1617

Fr. Mauro García de Mendoza / Fr. Lorenzo

de Frías

Tolosa (Francia)

AGN, Irache, Lib. 542, 57r.

FRANCISCO VALLES

L. C.

3-11-1617

Fr. Lorenzo de Frías

Alfaro (Tarazona)

AGN, Irache, Lib. 542, 57v.

PEDRO MARTÍNEZ SANCHO

L. C. / D. C.

16-11-1617

Fr. Lorenzo de Frías

Anguiano (Calahorra)

AGN, Irache, Lib. 542, 57v.

JUAN DE LASALA

B. A. / L. A.

17-11-1617

Fr. Juan de Redín / Fr. Lorenzo de Frías

Pamplona

AGN, Irache, Lib. 542, 58r.

JUAN DE VELILLA

L. C.

18-11-1617

Fr. Lorenzo de Frías

Osma

Colegial

AGN, Irache, Lib. 542, 58v.

FRANCISCO DE CASTRO

B. L. / L. L. / D. L. / L. C.

19-11-1617

Fr. Luis Flórez

Plasencia

AGN, Irache, Lib. 542, 58v-59r. 
MARTÍN DE ALBALA

B. C.

19-11-1617

Fr. Benito de Cobillas

Pasarón (Plasencia)

AGN, Irache, Lib. 542, 59r.

JUAN BARCOS

B. T.

29-11-1617

Fr. Benito de Cobillas

Sagon (Jaca)

AGN, Irache, Lib. 542, 59v.

DIEGO TOMÁS

L. C.

29-11-1617

Fr. Benito de Cobillas

Nájera (Calahorra)

AGN, Irache, Lib. 542, 59v.

PEDRO DE HERENCIA

B. C.

30-11-1617

Fr. Mauro García de Mendoza

Herencia (Diocesis Nullius)

AGN, Irache, Lib. 542, 59v.

JUAN DE LAS HERAS

B. C. / L. C.

30-11-1617

Fr. Lorenzo de Frías

AGN, Irache, Lib. 542, 6or.

RODRIGO DE SANMARTÍN

B. C.

9-12-1617

Fr. Luis Flórez

Castrojeriz (Burgos)

AGN, Irache, Lib. 542, 6or.

MARTÍN FERNÁNDEZ

B. C.

15-12-1617

Fr. Mauro García de Mendoza

Villanueva (Burgos)

AGN, Irache, Lib. 542, 6or.
JUAN DE PALACILLO

L. C.

15-12-1617

Fr. Lorenzo de Frías

Burgos

AGN, Irache, Lib. 542, $60 v$.

GREGORIO GARCÍA

L. C.

16-12-1617

Fr. Lorenzo de Frías

Almazul (Osma)

AGN, Irache, Lib. 542, $60 v$.

PEDRO GONZÁLEZ DE CURBANO

L. C.

22-12-1617

Fr. Lorenzo de Frías

Castillo (Calahorra)

AGN, Irache, Lib. 542, $60 v$.

JUAN MARCOS DE LA TORRE

L. L. / D. L.

13-1-1618

Fr. Lorenzo de Frías

N... (Cuenca)

AGN, Irache, Lib. 542, 61r.

FRANCISCO JIMÉNEZ DE OCO

B. C.

16-1-1618

Fr. Benito de Cobillas

Pamplona

AGN, Irache, Lib. 542, 61r.

CLEMENTE DE BÁRCENA

B. C.

16-1-1618

Fr. Benito de Cobillas

Oña (Burgos)

AGN, Irache, Lib. 542, 61v.

SEBASTIÁN TREVIÑO

B. T. / L. T. / D. T.

24-1-1618

Fr. Lorenzo de Frías

Clérigo, Pbro. del hábito de Calatrava

AGN, Irache, Lib. 542, 61v-62r. 
ANTONIO DE CASTRO

B. A. / L. A. / M. A. / B. T. / L. T. / M. T. 1-2-1618

Fr. Lorenzo de Frías

O. S. B.

General de la Orden para España e Inglaterra

Abad de Oña

AGN, Irache, Lib. 542, 62rv.

JUAN DE HUARTE

L. M. / D. M.

8-2-1618

Fr. Benito de Cobillas

Tudela (Tarazona)

AGN, Irache, Lib. 542, 63r.

\section{DAMIÁN MÁRQUEZ}

B. L.

10-2-1618

Fr. Mauro García de Mendoza

Covarrubias (Burgos)

AGN, Irache, Lib. 542, 63r.

ANDRÉS SÁNCHEZ DE LA CUESTA

B. T. / L. T. / M. T.

17-2-1618

Fr. Lorenzo de Frías

O. SS. T.

AGN, Irache, Lib. 542, 63v.

\section{JERÓNIMO JULIÁN}

B. C.

18-2-1618

Fr. Luis Flórez

Tudela (Calahorra)

AGN, Irache, Lib. 542, 63v-64r.

\section{PEDRO DE ALGUERO}

B. C. / L. C.

23-2-1618 / 24-2-1618

Fr. Benito de Cobillas / Fr. Lorenzo de Frías

Somo (Burgos)

AGN, Irache, Lib. 542, 64r.

\section{JUAN VELARDE}

L. C.

27-2-1618
Fr. Lorenzo de Frías

Santillana (Burgos)

AGN, Irache, Lib. 542, 64r.

GASPAR DE VILLELA

L. C. / B. L.

22-3-1618

Fr. Lorenzo de Frías / Fr. Benito de Cobillas

Bilbao (Calahorra)

AGN, Irache, Lib. 542, 64v.

MATÍAS DE ESCALANTE Y SARABIA

B. C.

27-3-1618

Fr. Mauro García de Mendoza

Laredo (Burgos)

AGN, Irache, Lib. 542, 64v.

ESTEBAN GARCÍA

B. T.

29-3-1618

Fr. Mauro García de Mendoza

Villasilos (Burgos)

AGN, Irache, Lib. 542, 64v.

AMBROSIO PÉREZ

B. C.

29-3-1618

Fr. Mauro García de Mendoza

Villasilos (Burgos)

AGN, Irache, Lib. 542, 64v.

FRANCISCO MARTÍNEZ

B. T.

6-4-1618

Fr. Benito de Cobillas

Bernedo (Calahorra)

AGN, Irache, Lib. 542, 65r.

JUAN ESTEBAN

B. A.

6-4-1618

Fr. Juan de Redín

Pamplona

Clérigo Beneficiado de Olite

AGN, Irache, Lib. 542, 65r.

JUAN DE URRUTIA

B. A. 
6-4-1618

Fr. Juan de Redín

Guirguillano (Pamplona)

AGN, Irache, Lib. 542, 65r.

PEDRO MARTÍNEZ DE LUCO

B. A.

6-4-1618

Fr. Juan de Redín

Ulibarri - Gamboa (Calahorra)

AGN, Irache, Lib. 542, 65r.

MARCOS DE ÁVILA MERCADILLO

L. L.

7-4-1618

Fr. Lorenzo de Frías

Monterrey (Orense)

AGN, Irache, Lib. 542, 65r.

MARTÍN BASURTO DE VALDÉS

L. T. / D. T.

7-4-1618

Fr. Lorenzo de Frías

Salamanca

B. T. en Salamanca

AGN, Irache, Lib. 542, 65v.

HERNANDO DE MARÍN

B. A.

7-4-1618

Fr. Juan de Redín

Arzoz (Pamplona)

AGN, Irache, Lib. 542, 65v.

VÍCTORES DE RUILÓPEZ

B. C.

13-4-1618

Fr. Juan de Redín

Fresnedo (Burgos)

AGN, Irache, Lib. 542, 65v.

DOMINGO RUIZ

B. A.

14-4-1618

Fr. Juan de Redín

Munain (Calahorra)

AGN, Irache, Lib. 542, 65v.
GABRIEL MARTÍNEZ

B. A.

20-4-1618

Fr. Juan de Redín

Arróniz (Pamplona)

AGN, Irache, Lib. 542, 66r.

\section{PEDRO DE PARAYOS}

B. C.

21-4-1618

Fr. Benito de Cobillas

Laredo (Burgos)

AGN, Irache, Lib. 542, 66r.

\section{FRANCISCO VISO}

B. A.

24-4-1618

Fr. Juan de Redín

Peralta (Pamplona)

AGN, Irache, Lib. 542, 66r.

PEDRO DE ARAMENDIA

B. A.

25-4-1618

Fr. Juan de Redín

Galdiano (Pamplona)

AGN, Irache, Lib. 542, 66r.

PEDRO DE DALLO

B. A.

25-4-1618

Fr. Juan de Redín

Igúzquiza (Pamplona)

AGN, Irache, Lib. 542, 66r.

JERÓNIMO DÍAZ DE LA PEÑA

B. C.

26-4-1618

Fr. Benito de Cobillas

Cain (Burgos)

AGN, Irache, Lib. 542, 66v.

JUAN DE MUNÁRRIZ

B. T. / L. T.

26-4-1618 / 27-4-1618

Fr. Benito de Cobillas / Fr. Mauro García

de Mendoza

Irujo (Pamplona)

AGN, Irache, Lib. 542, 66v. 
JUAN SÁNCHEZ DE VICUÑA

B. A.

26-4-1618

Fr. Juan de Redín

Vicuña (Calahorra)

AGN, Irache, Lib. 542, 66v.

DIEGO DE ANDOSILLA Y ARRIETA

B. A. / L. A.

28-4-1618

Fr. Juan de Redín

Calahorra

AGN, Irache, Lib. 542, 67r.

CELEDÓN DE ANDOSILLA Y ARRIETA

B. A. / L. A.

28-4-1618

Fr. Juan de Redín

Calahorra

AGN, Irache, Lib. 542, 67r.

JUAN LÓPEZ DE ABÁIGAR

B. A.

6-5-1618

Fr. Juan de Redín

Olerna (Pamplona)

AGN, Irache, Lib. 542, 67r.

AGUSTÍN DE ABERASTURI Y GUEVARA

B. A.

6-5-1618

Fr. Juan de Redín

Monasterioguren (Calahorra)

AGN, Irache, Lib. 542, 67r.

PEDRO GUTIÉRREZ

B. C.

9-5-1618

Fr. Luis Flórez

Alaejos (Valladolid)

AGN, Irache, Lib. 542, 67v.

GREGORIO DE LUZÁRRAGA

B. A.

11-5-1618

Fr. Juan de Redín

Salvatierra (Calahorra)

AGN, Irache, Lib. 542, 67v.
FRANCISCO DE SAGREDO

B. C.

16-5-1618

Fr. Mauro García de Mendoza

Burgos

AGN, Irache, Lib. 542, 67v.

DIEGO DÍAZ SALGADO

L. C.

17-5-1618

Fr. Luis Flórez

Monterrey (Orense)

B. C. en Salamanca

AGN, Irache, Lib. 542, 67v.

PEDRO DE OSTÉRIZ

B. A.

22-5-1618

Fr. Juan de Redín

Ostériz (Pamplona)

AGN, Irache, Lib. 542, 67v.

DIEGO FERNÁNDEZ DE CÓRDOBA

B. C. / L. L. / D. L.

23-5-1618

Fr. Benito de Cobillas / Fr. Lorenzo de Frías

Córdoba

AGN, Irache, Lib. 542, 68r.

JUAN NÚÑEZ DE MURUA

B. A.

24-5-1618

Fr. Juan de Redín

Vitoria (Calahorra)

AGN, Irache, Lib. 542, 68r.

VÍCTORES DE LOSANTOS

L. C.

29-5-1618

Fr. Lorenzo de Frías

Belorado (Burgos)

B. C. en Valladolid

Canónigo

AGN, Irache, Lib. 542, 68r.

ANTONIO SANZ

B. T. / L. T. / D. T.

3-6-1618 
Fr. Benito de Cobillas / Fr. Lorenzo de Frías O. C.

Provincia de Aragón

AGN, Irache, Lib. 542, 68r.

JUAN DE LIZARAZU

L. L. / D. L.

10-6-1618

Fr. Lorenzo de Frías

Pamplona

AGN, Irache, Lib. 542, 68v.

MATEO DE CASTRO

B. A. / L. A.

25-6-1618

Fr. Lorenzo de Frías

Logroño (Calahorra)

Canónigo de Palencia

AGN, Irache, Lib. 542, 68v.

\section{ALONSO NAVAS}

B. A. / L. A.

30-6-1618 / 1-7-1618

Fr. Benito de Cobillas

Calahorra

AGN, Irache, Lib. 542, 68v-69r.

MARTÍN FERNÁNDEZ DE ZÁRATE

L. C. / D. C.

30-6-1618

Fr. Luis Flórez

Laguardia (Calahorra)

AGN, Irache, Lib. 542, 69r.

MIGUEL POLO

L. M. / D. M.

2-7-1618

Fr. Mauro García de Mendoza

Pamplona

B. M. en Valencia

AGN, Irache, Lib. 542, 69rv.

ALONSO GONZÁLEZ

L. C.

5-7-1618

Fr. Luis Flórez

Biedma (Palencia)

Canónigo de León

AGN, Irache, Lib. 542, 69v.
MIGUEL DE SADA MURILLO

B. L. / L. L.

7-7-1618 / 17-4-1622

Fr. Benito de Cobillas / Fr. Francisco de

Borja

Leache (Pamplona)

AGN, Irache, Lib. 542, 69v, 103v.

PEDRO BRAVO DE PEREDA

B. C.

11-7-1618

Fr. Benito de Cobillas

Burgos

AGN, Irache, Lib. 542, 70r.

BERNARDO DE SEIJA

B. A. / B. T. / L. A. / M. A. / L. T. / M. T. 13-7-1618

Fr. Mauro García de Mendoza / Fr. Luis

Flórez

O. S. B.

Puentedeume (Santiago)

AGN, Irache, Lib. 542, 70r.

BALTASAR DE SAN JUAN

B. C. / L. C.

14-7-1618

Fr. Luis Flórez / Fr. Benito de Cobillas

Soria (Osma)

AGN, Irache, Lib. 542, 7 or.

FRANCISCO DE RIBERO

B. C.

15-7-1618

Fr. Mauro García de Mendoza

Ampuero (Burgos)

AGN, Irache, Lib. 542, $70 v$.

FRANCISCO VÉLEZ DE LOYOLA

B. T.

17-7-1618

Fr. Benito de Cobillas

O. de M.

Madrid. Provincia de Castilla

AGN, Irache, Lib. 542, $70 v$.

ANDRÉS DE ZAMORA

D. M. 
17-7-1618

Fr. Lorenzo de Frías

Valladolid

Pbro. y médico

B. M. / L. M. en Valladolid

AGN, Irache, Lib. 542, $70 v$.

FRANCISCO DEL RÍO

B. C.

2-8-1618

Fr. Luis Flórez

Villasilos (Burgos)

AGN, Irache, Lib. 542, 70v.

MIGUEL DE LERMA

B. C. / L. C. / D. C. 5-8-1618 / 7-8-1618

Fr. Mauro García de Mendoza / Fr. Lorenzo

de Frías

Tudela (Tarazona)

Canónigo de Valladolid

AGN, Irache, Lib. 542, 71rv.

LORENZO FRANCÉS DE URRIGOITI

L. C. / D. C. / B. L.

6-8-1618

Fr. Lorenzo de Frías / Fr. Luis Flórez

Tudela (Tarazona)

AGN, Irache, Lib. 542, 71r.

\section{FRANCISCO MAULEÓN}

B. C.

7-8-1618

Fr. Benito de Cobillas

Tudela (Tarazona)

AGN, Irache, Lib. 542, 71r.

MIGUEL GONZÁLEZ

B. T.

10-8-1618

Fr. Mauro García de Mendoza

Villasilos (Burgos)

AGN, Irache, Lib. 542, 71v.

JOSÉ DE ARANGUREN

B. L. / L. L.

21-8-1618 / 14-4-1621

Fr. Benito de Cobillas / Fr. Lorenzo de Frías
Aranguren (Pamplona)

AGN, Irache, Lib. 542, 71v, 96r.

\section{LUCAS DE LAPUENTE}

B. C.

27-8-1618

Fr. Benito de Cobillas

Valmaseda (Burgos)

AGN, Irache, Lib. 542, 71v.

BERNARDO DE CASSO

B. A.

30-8-1618

Fr. Benito de Cobillas

AGN, Irache, Lib. 542, 71v.

DIEGO GARCÍA

B. A. / B. T. / L. T.

7-9-1618

Fr. Benito de Cobillas / Fr. Lorenzo de Frías

Fuentes de Nava (Palencia)

Maestrescuela

AGN, Irache, Lib. 542, 72r.

DIEGO SÁNCHEZ DE LA ROSA

L. C. / D. C.

8-9-1618

Fr. Lorenzo de Frías

Alburquerque (Badajoz)

AGN, Irache, Lib. 542, 72r.

AMBROSIO FERNÁNDEZ DE TORRES

B. T. / L. T.

10-9-1618

Fr. Lorenzo de Frías

Los Arcos (Pamplona)

AGN, Irache, Lib. 542, 72v.

PEDRO MÉNDEZ

L. C. / D. C.

12-9-1618

Fr. Lorenzo de Frías

Villamoros (León)

B. C. en Salamanca

AGN, Irache, Lib. 542, 72v.

PEDRO DÍAZ

B. C. 
14-9-1618

Fr. Benito de Cobillas

Quintana (Burgos)

AGN, Irache, Lib. 542, $72 \mathrm{v}$.

MIGUEL DE PATERNINA

L. C. / D. C.

18-9-1618

Fr. Lorenzo de Frías

Labastida (Calahorra)

AGN, Irache, Lib. 542, 73r.

MELCHOR DE MORALES

L. M. / D. M.

18-9-1618

Fr. Lorenzo de Frías / Dr. Murugarren

Puerto Alegre (Portugal)

AGN, Irache, Lib. 542, 73r.

JUAN RUIZ DE LARRAMENDI

L. A. / L. T.

19-9-1618 / 24-9-1618

Fr. Lorenzo de Frías

Larraona (Calahorra)

Pbro.

AGN, Irache, Lib. 542, 73rv.

JUAN DE HUERTA

L. A.

22-9-1618

Fr. Benito de Cobillas

Valdeavellano (Toledo)

AGN, Irache, Lib. 542, 73v.

JUAN DE NAVAS

B. A.

24-9-1618

Fr. Benito de Cobillas

San Martín de Unx (Pamplona)

AGN, Irache, Lib. 542, 73v.

DIEGO DE LA LANZA

B. L. / L. L.

2-10-1618 / 3-10-1618

Fr. Benito de Cobillas

Sigüenza

AGN, Irache, Lib. 542, 73v-74r.
ANTONIO VÁZQUEZ

B. L.

3-10-1618

Fr. Benito de Cobillas

Logroño (Calahorra)

AGN, Irache, Lib. 542, $73 v$.

AMBROSIO DE MURO

B. A.

5-10-1618

Fr. Hernando Enríquez, Lector en Artes y

Vicecanciller

Cintruénigo (Tarazona)

AGN, Irache, Lib. 542, 74r.

ANTONIO BOLAÑOS

B. C. / B. L.

5-10-1618

Fr. Benito de Cobillas

Sevilla

AGN, Irache, Lib. 542, 74r.

BARTOLOMÉ DE MONTAÑANA AGUI-

RRE

B. C.

5-10-1618

Fr. Benito de Cobillas

Tarazona

Canónigo de Berlanga

AGN, Irache, Lib. 542, 74r.

MIGUEL DE CASTRO

L. C.

7-10-1618

Fr. Benito de Cobillas

Abarca (Palencia)

Pbro.

AGN, Irache, Lib. 542, 74r.

PEDRO PÉREZ

B. C.

10-10-1618

Fr. Benito de Cobillas

Olmos de la Picaza (Burgos)

AGN, Irache, Lib. 542, 74v.

FELIPE DÍAZ DE VALDIVIESO

B. C. / L. C. 
12-10-1618 / 13-10-1618

Fr. Benito de Cobillas / Fr. Lorenzo de Frías

Panizares (Burgos)

Pbro. y chantre

AGN, Irache, Lib. 542, 74v.

JUAN BAUTISTA CORTÉS

B. C.

16-10-1618

Fr. Luis Flórez

Fresnedo (Burgos)

AGN, Irache, Lib. 542, 75r.

MANUEL DE CABAÑAS

L. L. / D. L.

19-10-1618

Fr. Lorenzo de Frías

Calatayud (Tarazona)

B. L. en Zaragoza

AGN, Irache, Lib. 542, 75r.

MARTÍN BAPTISTA

B. C.

21-10-1618

Fr. Benito de Cobillas

Covaleda (Osma)

AGN, Irache, Lib. 542, 75v.

DIEGO DE OCÓN Y CIRIZA

B. C.

22-10-1618

Fr. Luis Flórez

Pamplona

AGN, Irache, Lib. 542, 75v.

JUAN MIGUEL NIÑO DE RIBERA

B. C.

24-10-1618

Fr. Benito de Cobillas

Canarias

AGN, Irache, Lib. 542, 75v.

DOMINGO DE CASTRO

B. C.

26-10-1618

Fr. Luis Flórez

Burgos

AGN, Irache, Lib. 542, 75v.

\section{MARTÍN LÓPEZ}

L. T. / D. T.

7-10-1618

Fr. Lorenzo de Frías

Almodóvar del Pinar (Cuenca)

B. T. en Salamanca

AGN, Irache, Lib. 542, 76r.

JOSÉ DE CALDONIA

B. C.

3-11-1618

Fr. Benito de Cobillas

Burgos

AGN, Irache, Lib. 542, 76r.

\section{JUAN ORTOLANO}

B. T.

13-11-1618

Fr. Mauro García de Mendoza

Tórtoles (Burgos)

AGN, Irache, Lib. 542, 76r.

MATEO DE VILLA

B. C. / L. C.

26-11-1618

Fr. Lorenzo de Frías

Ballesteros (Burgos)

Pbro. Administrador Hospital de San Lá-

zaro

AGN, Irache, Lib. 542, 76rv.

GIL DE ALBORNOZ

L. C. / D. C.

15-11-1618

Fr. Lorenzo de Frías

Valladolid

Regente del Real Consejo de Navarra

AGN, Irache, Lib. 542, 76v.

PEDRO DE LA HERRÁN

L. C.

30-11-1618

Fr. Lorenzo de Frías

Sámano (Burgos)

AGN, Irache, Lib. 542, 76v.

JUAN DE VALLEJO

L. C. 
2-1-1619

Fr. Lorenzo de Frías

Burgos

Inquisidor de Logroño

AGN, Irache, Lib. 542, 77r.

MAURO DE VILLARROEL

B. C. / L. C. / D. C. / B. T. / L. T. / D. T.

16-1-1619

Fr. Lorenzo de Frías

Tordesillas

O.S. B.

AGN, Irache, Lib. 542, 77r.

VALERIANO DOLZ DEL CASTELLAR

B. L. / L. L.

10-3-1619 / 14-6-1623

Fr. Benito de Cobillas / Fr. Pedro de Santa

$\mathrm{Fe}$

Castellar (Teruel)

AGN, Irache, Lib. 542, 77r, 113v.

PEDRO GUTIÉRREZ DE LLANO

B. A. / L. A. / M. A.

13-3-1619 / 14-3-1619

Fr. Hernando Enríquez / Fr. Lorenzo de

Frías

Grijota (Palencia)

AGN, Irache, Lib. 542, 77v.

\section{MARCOS DE VIANA BEAUMONT}

B. L. / L. L. / D. L. / B. C. / L. C. / D. C.

16-3-1619

Fr. Lorenzo de Frías

Alfaro (Tarazona)

AGN, Irache, Lib. 542, 77v.

MARTÍN ZEMENO

L. C. / D. C.

17-3-1619

Fr. Lorenzo de Frías

Campillo de Altobuey (Cuenca)

B.C. en Salamanca

AGN, Irache, Lib. 542, 78r.

JUAN DOMINGO RAMÍREZ CHÁVEZ SANTUCHO Y RADA

L. C. / D. C.
18-3-1619

Fr. Lorenzo de Frías

Zaragoza

B. C. en Zaragoza

AGN, Irache, Lib. 542, 78r.

PEDRO DEL HIERRO

B. C.

26-4-1619

Fr. Luis Flórez

Islares (Burgos)

AGN, Irache, Lib. 542, 78r.

DIEGO GARCÍA DE SOTO

B. C.

27-4-1619

Fr. Benito de Cobillas

Lebrija (Sevilla)

AGN, Irache, Lib. 542, 78v.

JUAN BAUTISTA MÉNDEZ DE LOYOLA

L. C. / D. C.

12-5-1619

Fr. Luis Flórez

Burgos

AGN, Irache, Lib. 542, 78v.

BERNABÉ DE HERRERA

B. C.

15-5-1619

Fr. Mauro García de Mendoza

Madrid (Toledo)

AGN, Irache, Lib. 542, 78v.

DAMIÁN DE CERECEDA Y MENA

L. C. / D. C.

21-5-1619

Fr. Mauro García de Mendoza

María (Almería)

B. C. en Salamanca

AGN, Irache, Lib. 542, 78v.

MATEO DEL RÍO

B. T.

24-5-1619

Fr. Luis Flórez

Villasilos (Burgos)

AGN, Irache, Lib. 542, 79r. 
FRANCISCO PÉREZ

B. C.

26-5-1619

Fr. Luis Flórez

Villasilos (Burgos)

AGN, Irache, Lib. 542, 79r.

\section{SANTIAGO SARMIENTO}

B. C.

26-5-1619

Fr. Mauro García de Mendoza

Bisjueces (Burgos)

AGN, Irache, Lib. 542, 79r.

ISIDRO DEL CERRO

B. L. / L. L.

3-6-1619 / 4-6-1619

Fr. Luis Flórez

Toledo

AGN, Irache, Lib. 542, 79r.

ANTONIO NAVARRO

B. T.

4-6-1619

Fr. Luis Flórez

Alfaro (Tarazona)

AGN, Irache, Lib. 542, 79v.

GUILLERMO BARÓN

B. C. / L. C. / D. C.

8-6-1619 / 9-6-1619

Fr. Mauro García de Mendoza

Madrid (Toledo)

AGN, Irache, Lib. 542, 79v.

BELTRÁN GARRO

B. A. / L. A.

11-6-1619

Fr. Hernando Enríquez

Burguete (Pamplona)

Abad de Oroz-Betelu

AGN, Irache, Lib. 542, 8or.

DIEGO DEL CASTILLO

L. C. / D. C.

20-6-1619

Fr. Luis Flórez

Aguilar de Cervera (Calahorra)

AGN, Irache, Lib. 542, 8or.
BARTOLOMÉ LOZANO DE SARASA

B. A.

25-6-1619

Fr. Hernando Enríquez

Villafranca (Pamplona)

AGN, Irache, Lib. 542, 8or.

JOSÉ DE VIVERO

B. A.

Discípulo de Fco. Pimentel

27-6-1619

Fr. Hernando Enríquez

Pamplona

AGN, Irache, Lib. 542, 8ov.

JUAN DE SAN MARTÍN

B. A.

27-6-1619

Discípulo de Fco. Pimentel

Fr. Hernando Enríquez

Pamplona

AGN, Irache, Lib. 542, 8ov.

JOSÉ DE VIDARTE

B. A.

27-6-1619

Discípulo de Fco. Pimentel

Fr. Hernando Enríquez

Pamplona

AGN, Irache, Lib. 542, 80v.

ANDRÉS DE AGUIDIANO

B. A.

27-6-1619

Discípulo de Fco. Pimentel

Fr. Hernando Enríquez

Pamplona

AGN, Irache, Lib. 542, 80v.

PEDRO DE LABIANO

B. A.

27-6-1619

Discípulo de Fco. Pimentel

Fr. Hernando Enríquez

Pamplona

AGN, Irache, Lib. 542, 80v.

FRANCISCO DE HUARTE

B. A. 
27-6-1619

Discípulo de Fco. Pimentel

Fr. Hernando Enríquez

Pamplona

AGN, Irache, Lib. 542, 8ov.

\section{LORENZO DE OLANO}

B. A.

27-6-1619

Discípulo de Fco. Pimentel

Fr. Hernando Enríquez

Pamplona

AGN, Irache, Lib. 542, 80v.

JOSÉ DE DONA MARÍA

B. A.

27-6-1619

Discípulo de Fco. Pimentel

Fr. Hernando Enríquez

Pamplona

AGN, Irache, Lib. 542, 80v.

LORENZO DE ARÓSTEGUI

B. A.

27-6-1619

Discípulo de Fco. Pimentel

Fr. Hernando Enríquez

Pamplona

AGN, Irache, Lib. 542, 80v.

GABRIEL DE IRIGARRI

B. A.

27-6-1619

Discípulo de Fco. Pimentel

Fr. Hernando Enríquez

Pamplona

AGN, Irache, Lib. 542, 80v.

FRANCISCO DE OLÓNDRIZ

B. A.

27-6-1619

Discípulo de Fco. Pimentel

Fr. Hernando Enríquez

Pamplona

AGN, Irache, Lib. 542, 8ov.

MIGUEL DE ARIZAGA

B. A.
27-6-1619

Discípulo de Fco. Pimentel

Fr. Hernando Enríquez

Sanguesa (Pamplona)

AGN, Irache, Lib. 542, $80 v$.

JUAN DE TAFALLA

B. A. / B. T. / L. T.

27-6-1619 / 24-3-1632 / 25-3-1632

Discípulo de Fco. Pimentel

Fr. Hernando Enríquez // Fr. Francisco

Salvador / Fr. Ramiro de Goñi

Falces (Pamplona)

AGN, Irache, Lib. 542, 80v, 188r.

GABRIEL DE ARANAZ

B. A.

27-6-1619

Discípulo de Fco. Pimentel

Fr. Hernando Enríquez

Lesaca (Pamplona)

AGN, Irache, Lib. 542, $80 v$.

MIGUEL DE IDOCÍN

B. A.

27-6-1619

Discípulo de Fco. Pimentel

Fr. Hernando Enríquez

Idocín (Pamplona)

AGN, Irache, Lib. 542, 8ov.

FERMÍN DE VERGARA

B. A.

27-6-1619

Discípulo de Fco. Pimentel

Fr. Hernando Enríquez

Enériz (Pamplona)

AGN, Irache, Lib. 542, 8ov.

MIGUEL DE LUQUÍN

B. A.

27-6-1619

Discípulo de Fco. Pimentel

Fr. Hernando Enríquez

Abarzuza (Pamplona)

AGN, Irache, Lib. 542, 8ov.

JUAN DE ISITURRI

B. A. 
27-6-1619

Discípulo de Fco. Pimentel

Fr. Hernando Enríquez

Zabaldica (Pamplona)

AGN, Irache, Lib. 542, 80v.

\section{MIGUEL DE OLABERRI}

B. A.

27-6-1619

Discípulo de Fco. Pimentel

Fr. Hernando Enríquez

Erdiozain (Pamplona)

AGN, Irache, Lib. 542, 80v.

PEDRO DE UNZUÉ Y ASIAIN

B. A.

27-6-1619

Discípulo de Fco. Pimentel

Fr. Hernando Enríquez

Puente la Reina (Pamplona)

AGN, Irache, Lib. 542, 80v.

LUIS DE UZTÁRROZ

B. A.

27-6-1619

Discípulo de Fco. Pimentel

Fr. Hernando Enríquez

Tafalla (Pamplona)

AGN, Irache, Lib. 542, 8ov.

BERNARDINO DE ARIZALETA

B. A.

27-6-1619

Discípulo de Fco. Pimentel

Fr. Hernando Enríquez

Zubiri (Pamplona)

AGN, Irache, Lib. 542, 80v.

PEDRO DE DICASTILLO

B. A.

27-6-1619

Discípulo de Fco. Pimentel

Fr. Hernando Enríquez

Muniain (Pamplona)

AGN, Irache, Lib. 542, 8ov.

MIGUEL DE IRAIZOZ

B. A.
27-6-1619

Discípulo de Fco. Pimentel

Fr. Hernando Enríquez

Guaraz (Pamplona)

AGN, Irache, Lib. 542, 8ov.

PEDRO DE IZCO

B. A.

27-6-1619

Discípulo de Fco. Pimentel

Fr. Hernando Enríquez

Izco (Pamplona)

AGN, Irache, Lib. 542, 80v.

JUAN DE AXULAR

B. A.

27-6-1619

Discípulo de Fco. Pimentel

Fr. Hernando Enríquez

Urdax (Pamplona)

AGN, Irache, Lib. 542, 80v.

JUAN DE SORO

B. A.

27-6-1619

Discípulo de Fco. Pimentel

Fr. Hernando Enríquez

Ayechu (Pamplona)

AGN, Irache, Lib. 542, 80v.

FAUSTO DE ARAMENDÍA

B. A.

27-6-1619

Discípulo de Fco. Pimentel

Fr. Hernando Enríquez

Aramendía (Pamplona)

AGN, Irache, Lib. 542, 80v.

JUAN DE ELIZARI

B. A.

27-6-1619

Discípulo de Fco. Pimentel

Fr. Hernando Enríquez

Oroz-Betelu (Pamplona)

AGN, Irache, Lib. 542, 8ov.

MIGUEL DE EZPELETA

B. A. 
27-6-1619

Discípulo de Fco. Pimentel

Fr. Hernando Enríquez

Garísoain (Pamplona)

AGN, Irache, Lib. 542, 80v.

\section{BERNARDO DE GOÑI Y ASTRÁIN}

B. A.

27-6-1619

Discípulo de Fco. Pimentel

Fr. Hernando Enríquez

Astráin (Pamplona)

AGN, Irache, Lib. 542, 80v.

\section{JUAN DE GANUZA}

B. A. / B. T. / L. T.

27-6-1619 / 7-1-1627

Fr. Hernando Enríquez // Fr. Juan de Re-

dín / Fr. Gregorio Bravo de Sotomayor

Discípulo de Fco. Pimentel

Galdeano (Pamplona)

AGN, Irache, Lib. 542, 80v, 144v.

PEDRO DE ARBIZU

B. A.

27-6-1619

Discípulo de Fco. Pimentel

Fr. Hernando Enríquez

Iturgoyen (Pamplona)

AGN, Irache, Lib. 542, 80v.

PEDRO DE ZUMETA

B. A.

27-6-1619

Discípulo de Fco. Pimentel

Fr. Hernando Enríquez

San Sebastián (Pamplona)

AGN, Irache, Lib. 542, 80v.

MIGUEL DE OSÉS

B. A.

27-6-1619

Discípulo de Fco. Pimentel

Fr. Hernando Enríquez

Labeaga (Pamplona)

AGN, Irache, Lib. 542, 80v.

LORENZO PÉREZ

B. A.
27-6-1619

Discípulo de Fco. Pimentel

Fr. Hernando Enríquez

Puente (Pamplona)

AGN, Irache, Lib. 542, 8ov.

MARTÍN DE GUELBENZU

B. A.

27-6-1619

Discípulo de Fco. Pimentel

Fr. Hernando Enríquez

Guelbenzu (Pamplona)

AGN, Irache, Lib. 542, 8ov.

MIGUEL DE JUARBE

B. A.

27-6-1619

Discípulo de Fco. Pimentel

Fr. Hernando Enríquez

Juarbe (Pamplona)

AGN, Irache, Lib. 542, 8ov.

JERÓNIMO DE GOÑI

B. A.

27-6-1619

Discípulo de Fco. Pimentel

Fr. Hernando Enríquez

Salinas de Oro (Pamplona)

AGN, Irache, Lib. 542, 8ov.

\section{JUAN DE ANDUEZA}

B. A.

27-6-1619

Discípulo de Fco. Pimentel

Fr. Hernando Enríquez

Villanueva (Pamplona)

AGN, Irache, Lib. 542, 80v.

\section{VENTURA DE URIZ}

B. A.

27-6-1619

Discípulo de Fco. Pimentel

Fr. Hernando Enríquez

Güesa (Pamplona)

AGN, Irache, Lib. 542, $80 v$.

MIGUEL DE ALDARRA OYANUME

B. A. 
27-6-1619

Discípulo de Fco. Pimentel

Fr. Hernando Enríquez

Urnieta (Pamplona)

AGN, Irache, Lib. 542, 80v.

LORENZO DE SAN MARTÍN

B. A.

27-6-1619

Discípulo de Fco. Pimentel

Fr. Hernando Enríquez

San Miguel (Bayona)

AGN, Irache, Lib. 542, 8ov.

MARTÍN DE CHINIGARRO

B. A.

27-6-1619

Discípulo de Fco. Pimentel

Fr. Hernando Enríquez

San Juan de Luz (Bayona)

AGN, Irache, Lib. 542, $80 v$.

ESTEBAN DE ARRAIDU

B. A.

27-6-1619

Discípulo de Fco. Pimentel

Fr. Hernando Enríquez

Ayherra (Bayona)

AGN, Irache, Lib. 542, 8ov.

JUAN DE ETCHEVERZ

B. A.

27-6-1619

Discípulo de Fco. Pimentel

Fr. Hernando Enríquez

Amenduz (Dax)

AGN, Irache, Lib. 542, 8ov.

FELIPE MARTÍNEZ

B. A.

27-6-1619

Discípulo de Fco. Pimentel

Fr. Hernando Enríquez

Arnedo (Calahorra)

AGN, Irache, Lib. 542, 80v.

JUAN DE MAEZTU

B. A.
27-6-1619

Discípulo de Fco. Pimentel

Fr. Hernando Enríquez

Marañón (Calahorra)

AGN, Irache, Lib. 542, 8ov.

JUAN GARRIDO

B. A.

27-6-1619

Discípulo de Fco. Pimentel

Fr. Hernando Enríquez

Arnedo (Calahorra)

AGN, Irache, Lib. 542, 80v.

FRANCISCO DE ALMARZA

B. A.

27-6-1619

Discípulo de Fco. Pimentel

Fr. Hernando Enríquez

Ocón (Calahorra)

AGN, Irache, Lib. 542, 80v.

FRANCISCO DE PENIN

L. C.

1-7-1619

Fr. Lorenzo de Frías

Sabuecedo (Orense)

B. C.

AGN, Irache, Lib. 542, 81r.

ALONSO SUÁREZ DE PENIN

L. C.

1-7-1619

Fr. Lorenzo de Frías

Sabuecedo (Orense)

B. C.

AGN, Irache, Lib. 542, 81r.

LORENZO DE VIDANIA

L. C. / D. C.

2-7-1619

Fr. Lorenzo de Frías

Victoria (Calahorra)

B. C. en Salamanca

AGN, Irache, Lib. 542, 81r.

DIEGO DE ENCÍO

L. C. / D. C. 
5-7-1619

Fr. Lorenzo de Frías

Miranda de Ebro (Calahorra)

B. C. en Salamanca

AGN, Irache, Lib. 542, 81v.

PEDRO DE BARRIO

L. C.

5-7-1619

Fr. Lorenzo de Frías

Rocamundo (Burgos)

B. C.

AGN, Irache, Lib. 542, 81v.

ESTEBAN VERGEA GUEVARA

B. C.

6-7-1619

Fr. Luis Flórez

Madrid (Toledo)

AGN, Irache, Lib. 542, 81v.

ANDRÉS DE MANSILLA

B. C.

10-7-1619

Fr. Mauro García de Mendoza

Pedrosa del Río Úrbel (Burgos)

AGN, Irache, Lib. 542, 81v.

JUAN DEL BARRIO

B. C.

11-7-1619

Fr. Luis Flórez

Pedrosa del Río Úrbel (Burgos)

AGN, Irache, Lib. 542, 81v.

HERNANDO RODRÍGUEZ

L. C.

13-7-1619

Fr. Mauro García de Mendoza

Burgos

Canónigo

B. L. en Oñate

AGN, Irache, Lib. 542, 82r.

JUAN DE VALDIVIESO

B. C.

18-7-1619

Fr. Luis Flórez
Puente de Panizares (Burgos)

AGN, Irache, Lib. 542, 82r.

PEDRO DE PESADAS

B. C.

18-7-1619

Fr. Mauro García de Mendoza

Pedrosa del Río Úrbel (Burgos)

AGN, Irache, Lib. 542, 82r.

SEBASTIÁN DE LOS ARCOS SALAZAR

L. C. / D. C.

2-8-1619

Fr. Diego de Salazar, vicecanciller

Nájera (Nullius Diocesis)

B. C. por Salamanca

AGN, Irache, Lib. 542, 82r.

PEDRO PÉREZ DE REGULES

L. C. / D. C.

2-8-1619

Fr. Lorenzo de Frías

Nájera (Nullius Diocesis)

B. C. en Oñate

AGN, Irache, Lib. 542, $82 \mathrm{v}$.

MARTÍN GARCÍA

B. T.

12-8-1619

Fr. Mauro García de Mendoza

Alfaro (Tarazona)

L. A.

AGN, Irache, Lib. 542, 82v.

FRANCISCO DE CASTRO BERMÚDEZ

B. T. / L. T. / D. T.

27-8-1619 / 28-8-1619

Fr. Mauro García de Mendoza / Fr. Lorenzo

de Frías

Granada

AGN, Irache, Lib. 542, 82v.

LUIS DE CASTRONOVO

B. T.

4-9-1619

Fr. Benito de Cobillas

O. S. A.

Aviñon y Tolosa

AGN, Irache, Lib. 542, 83r. 
JUAN TASTEO

B. T.

4-9-1619

Fr. Benito de Cobillas

O. S. A.

Aviñon y Tolosa

AGN, Irache, Lib. 542, 83r.

SIMÓN PRIETO

B. C.

16-9-1619

Fr. Mauro García de Mendoza

Cabárceno (Burgos)

AGN, Irache, Lib. 542, 83r.

FERNANDO GONZÁLEZ DE HOYOS

B. C. / L. C

25-9-1619

Fr. Benito de Cobillas

Sorella (Burgos)

AGN, Irache, Lib. 542, 83r.

FRANCISCO CARLOS

B. A.

26-9-1619

Fr. Luis Flórez

Sangüesa (Pamplona)

AGN, Irache, Lib. 542, 83v.

JUAN DE ARÉCHAGA ARISPE

L. C.

29-9-1619

Fr. Lorenzo de Frías

Burgos

B. C. por Oñate

AGN, Irache, Lib. 542, 83v.

MANUEL OREJÓN

L. C. / D. C. / B. T.

30-9-1619 / 28-9-1619

Fr. Lorenzo de Frías / Fr. Luis Flórez

Alba de Tormes (Salamanca)

B. C. por Salamanca

AGN, Irache, Lib. 542, 83v.

JUAN DE BERZOSA

B. C.

2-10-1619
Fr. Benito de Cobillas

Burgos

AGN, Irache, Lib. 542, 84r.

ANTONIO PÉREZ

L. T. / D. T.

14-10-1619

Fr. Lorenzo de Frías

Arnedo (Calahorra)

B. T. por Valladolid

AGN, Irache, Lib. 542, 84r.

GASPAR DE BEDOYA

B. T.

22-10-1619

Fr. Mauro García de Mendoza

O. de M.

Castilla

AGN, Irache, Lib. 542, 84r.

JUAN LÓPEZ DE ARCHAJA

B. L.

24-10-1619

Fr. Luis Flórez

Vitoria (Calahorra)

AGN, Irache, Lib. 542, 84r.

RODRIGO DE PAREDES Y HERRERA

B. C. / L. C.

29-10-1619 / 30-10-1619

Fr. Benito de Cobillas / Fr. Luis Flórez

Madrid (Toledo)

AGN, Irache, Lib. 542, 84v.

ROQUE DE ANO

L. C.

9-11-1619

Fr. Lorenzo de Frías

Hazas (Burgos)

B.C. por Valladolid

AGN, Irache, Lib. 542, 84v.

MIGUEL DE ALBALA ÍÑIGO

B. A.

23-11-1619

Fr. Hernando Enríquez

Pasarón (Plasencia)

AGN, Irache, Lib. 542, 84v. 
MANUEL CARVAZ

B. C.

23-11-1619

Fr. Benito de Cobillas

Valencia de Alcántara (Soria)

AGN, Irache, Lib. 542, 85r.

\section{CRISTÓBAL BARBO}

B. C.

2-12-1619

Fr. Luis Flórez

Pamplona

L. A.

AGN, Irache, Lib. 542, 85r.

\section{SEBASTIÁN BULLÓN}

B. C

13-12-1619

Fr. Benito de Cobillas

Aguilar de Campoo (Burgos)

Comisario del Sto. Oficio

AGN, Irache, Lib. 542, 85r.

PEDRO DE VILLARROEL

B. L.

16-12-1619

Fr. Benito de Cobillas

Sahagún (Nullius Diocesis)

AGN, Irache, Lib. 542, 85r.

LUCAS DE LARREA

L. C. / D. C.

8-1-1620

Fr. Lorenzo de Frías

Argómariz (Calahorra)

Pbro.

B. C. por Oñate

AGN, Irache, Lib. 542, 85v.

MARTÍN DE ARGOS

L. C.

15-1-1620

Fr. Lorenzo de Frías

Arnuero (Burgos)

B. C. por Valladolid

AGN, Irache, Lib. 542, 85v.

PEDRO SAINZ PRIETO

L. C.
2-2-1620

Fr. Lorenzo de Frías

Hazas (Burgos)

B. C. por Valladolid

AGN, Irache, Lib. 542, 85v-86r.

JUAN MANSO

B. T. / L. T.

10-2-1620 / 11-2-1620

Fr. Mauro García de Mendoza / Fr. Lorenzo

de Frías

Bargota (Calahorra)

AGN, Irache, Lib. 542, 86r.

FRANCISCO SÁENZ

B. C.

24-2-1620

Fr. Luis Flórez

Quintanilla de San García (Burgos)

AGN, Irache, Lib. 542, 86r.

JOSÉ DE GUABARRI

B. C.

8-3-1620

Fr. Benito de Cobillas

Portugalete (Burgos)

AGN, Irache, Lib. 542, 86r.

HERNANDO DE LA TORRE

L. C.

12-3-1620

Fr. Luis Flórez

Serdio (Burgos)

B. C. por Valladolid

AGN, Irache, Lib. 542, 86v.

GONZALO DE ANGULO

B. C.

22-3-1620

Fr. Mauro García de Mendoza

Villanueva de Valdegarcía (Burgos)

AGN, Irache, Lib. 542, 86v.

ALONSO DE URREA

B. T. / L. T. / D. T.

27-3-1620 / 28-3-1620

Fr. Mauro García de Mendoza / Fr. Lorenzo de Frías 
Fuentes (Toledo)

AGN, Irache, Lib. 542, 86v.

HERNANDO ENRÍQUEZ

B. A. / B. T.

30-3-1620

Fr. Luis Flórez

O. S. B.

AGN, Irache, Lib. 542, 87r.

FRANCISCO OLÓRIZ

B. L.

24-4-1620

Fr. Benito de Cobillas

Valtierra (Pamplona)

AGN, Irache, Lib. 542, 87r.

\section{JUAN ESCRIBANO}

B. C.

25-4-1620

Fr. Benito de Cobillas

Villavedón (Burgos)

AGN, Irache, Lib. 542, 87r.

JUAN GÓMEZ

B. C.

2-5-1620

Fr. Benito de Cobillas

San Mateo (Burgos)

AGN, Irache, Lib. 542, 87r.

FRANCISCO PÉREZ

B. C.

4-5-1620

Fr. Benito de Cobillas

Comillas (Burgos)

AGN, Irache, Lib. 542, 87r.

FELIPE MACHADO ESPÍNOLA

L. T. / D. T.

6-5-1620

Fr. Lorenzo de Frías

La Laguna (Tenerife)

AGN, Irache, Lib. 542, 87v.

DOMINGO DE SALDAÑA

L. C. / D. C.

6-5-1620
Fr. Lorenzo de Frías

Habana (Cuba)

B.C. en Sevilla

AGN, Irache, Lib. 542, 87v.

JUAN DE LA HOYA

L. C.

7-5-1620

Fr. Lorenzo de Frías

Argoños

B.C. por Valladolid

AGN, Irache, Lib. 542, 88r.

JUAN DE QUINTANILLA

B. C.

9-5-1620

Fr. Benito de Cobillas

Olmillos (Burgos)

AGN, Irache, Lib. 542, 88r.

DIEGO DE CORRAL

B. C.

9-5-1620

Fr. Benito de Cobillas

Sasamón (Burgos)

AGN, Irache, Lib. 542, 88r.

ANTONIO DE LA RIBA HERRERA

B. C. / L. C.

20-5-1620 / 29-10-1621

Fr. Luis Flórez

Santander (Burgos)

AGN, Irache, Lib. 542, 88r, 101r.

GABRIEL DE ESLAVA

L. C.

21-5-1620

Fr. Lorenzo de Frías

Pamplona

AGN, Irache, Lib. 542, 88r.

FELIPE GONZÁLEZ

L. C.

28-5-1620

Fr. Lorenzo de Frías

Villa de Pun (Calahorra)

B.C. por Salamanca

AGN, Irache, Lib. 542, 88v. 
GABRIEL DEL CORRAL

L. C. / D. C.

28-5-1620

Fr. Lorenzo de Frías

Belorado (Burgos)

AGN, Irache, Lib. 542, 88v.

ANDRÉS DE ARCE

L. C.

28-5-1620

Fr. Lorenzo de Frías

San Pedro de Moarves (Palencia)

L. C. por Salamanca

AGN, Irache, Lib. 542, 88v.

FRANCISCO RADA RIBERO

L. C.

5-6-1620

Fr. Lorenzo de Frías

Burgos (Rada)

B. C. por Salamanca

AGN, Irache, Lib. 542, 89r.

FRANCISCO DE CÉSPEDES

L. M. / D. M.

11-6-1620

Fr. Lorenzo de Frías // Dr. Arróniz / Dr.

Bernardo de Alzueta

Villadiego (Burgos)

B. M. por Salamanca

AGN, Irache, Lib. 542, 89r.

JUAN MAESTRO

B. C.

25-5-1620

Fr. Luis Flórez

Villasandino (Burgos)

AGN, Irache, Lib. 542, 89r.

FELIPE DE GAZTELU

B. A.

30-6-1620

Fr. Hernando Enríquez

Pamplona

AGN, Irache, Lib. 542, 89v.

RAFAEL DE ZAY

B. A.
30-6-1620

Fr. Hernando Enríquez

Pamplona

AGN, Irache, Lib. 542, 89v.

MARTÍN DE SAN ESTEBAN

B. A.

30-6-1620

Fr. Hernando Enríquez

Uterga (Pamplona)

AGN, Irache, Lib. 542, 89v.

DIEGO DE ARTEAGA

B. A.

30-6-1620

Fr. Hernando Enríquez

Pamplona

AGN, Irache, Lib. 542, 89v.

JUAN DE CIRIZA

B. A.

30-6-1620

Fr. Hernando Enríquez

Pamplona

AGN, Irache, Lib. 542, 89v.

JUAN DE ZUAZU

B. A.

30-6-1620

Fr. Hernando Enríquez

Pamplona

AGN, Irache, Lib. 542, 89v.

PEDRO DE OSCÁRIZ

B. A. / B. L.

30-6-1620 / 17-6-1621

Fr. Hernando Enríquez / Fr. Benito de la

Serna

Pamplona

AGN, Irache, Lib. 542, 89v, 98v.

JUAN DE VILLAVA

B. A.

30-6-1620

Fr. Hernando Enríquez

Puente la Reina (Pamplona)

AGN, Irache, Lib. 542, 89v. 
MARTÍN DE GALAR

B. A.

30-6-1620

Fr. Hernando Enríquez

Arre (Pamplona)

AGN, Irache, Lib. 542, 89v.

\section{DIEGO ZURIA}

B. A.

30-6-1620

Fr. Hernando Enríquez

Ujué (Pamplona)

AGN, Irache, Lib. 542, 89v.

JUAN DE VILLARREAL

B. A.

30-6-1620

Fr. Hernando Enríquez

Riezu (Pamplona)

AGN, Irache, Lib. 542, 89v.

MARTÍN TOMÁS

B. A.

30-6-1620

Fr. Hernando Enríquez

Idocin (Pamplona)

AGN, Irache, Lib. 542, 89v

JUAN DE IRIBAS

B. A.

30-6-1620

Fr. Hernando Enríquez

Arre (Pamplona)

AGN, Irache, Lib. 542, 89v.

JUAN MARTÍNEZ DE EGUIARRETA

B. A.

30-6-1620

Fr. Hernando Enríquez

Rentería (Pamplona)

AGN, Irache, Lib. 542, 89v.

JUAN DE ERAZU

B. A.

30-6-1620

Fr. Hernando Enríquez

Pamplona

AGN, Irache, Lib. 542, 89v.
FRANCISCO DE ARIA

B. A.

30-6-1620

Fr. Hernando Enríquez

Huarte (Pamplona)

AGN, Irache, Lib. 542, 89v.

MARTÍN DE BEUNZA

B. A.

30-6-1620

Fr. Hernando Enríquez

Beunza (Pamplona)

AGN, Irache, Lib. 542, 89v.

MARTÍN DE ARDAIZ

B. A.

30-6-1620

Fr. Hernando Enríquez

Ardaiz (Pamplona)

AGN, Irache, Lib. 542, 89v.

JUAN DE ILUNDÁIN

B. A.

30-6-1620

Fr. Hernando Enríquez

Ilundáin (Pamplona)

AGN, Irache, Lib. 542, 89v.

JUAN BAUTISTA DE HERRERA

B. C. / L. C. / D. C.

7-7-1620

Fr. Lorenzo de Frías

Plasencia

Canónigo de Plasencia

Estudios en Osuna

AGN, Irache, Lib. 542, 89v.

ANTONIO RUIZ

B. C.

11-7-1620

Fr. Luis Flórez

Villaveta (Burgos)

AGN, Irache, Lib. 542, 9or.

JUAN DE ARBIZU

B. T. / L. T.

21-7-1620

Fr. Mauro García de Mendoza / Fr. Lorenzo

de Frías 
Arenaza (Calahorra)

AGN, Irache, Lib. 542, 9or.

JUAN DE CUETO

B. A. / B. T.

25-7-1620 / 9-5-1621

Fr. Hernando Enríquez / Fr. Benito de Cobillas

Estella (Pamplona)

AGN, Irache, Lib. 542, 90r, 97r.

\section{ANTONIO ALMAZÁN GRIJALVA}

B. C. / L. C. / D. C.

28-7-1620 / 29-7-1620

Fr. Mauro García de Mendoza / Fr. Lorenzo de Frías

Plasencia

Canónigo de Plasencia. Estudiante en Salamanca

AGN, Irache, Lib. 542, 9orv.

JERÓNIMO DE GAVADI

B. L. / L. L.

30-7-1620 / 15-1-1632

Fr. Mauro García de Mendoza / Fr. Ramiro

de Goñi

Pamplona

AGN, Irache, Lib. 542, 90v, 186r.

\section{JUAN DE SALCEDO}

B. C.

31-7-1620

Fr. Hernando Enríquez

Soria (Osma)

AGN, Irache, Lib. 542, 90v.

PABLO LAGUNA

B. C. / L. C.

1-8-1620

Fr. Hernando Enríquez / Fr. Lorenzo de

Frías

El Espinar (Segovia)

Maestrescuela

AGN, Irache, Lib. 542, 90v.

ANDRÉS DEL CASTILLO

L. M. / D. M.

6-8-1620 / 1-9-1620
Fr. Lorenzo de Frías / Dr. Arróniz / Dr. Bernardo de Alzueta / Fr. Diego de Salazar

Tarazona

B. M. por Zaragoza

AGN, Irache, Lib. 542, 91rv.

MARTÍN ESCUER

L. M. / D. M.

10-8-1620

Fr. Lorenzo de Frías // Dr. Arróniz / Dr.

Bernardo de Alzueta

Lanaja (Huesca)

AGN, Irache, Lib. 542, 91r.

FRANCISCO ENRÍQUEZ DE ABLITAS

B. L. / L. L.

25-8-1620 / 16-9-1623

Fr. Andrés de Villa, vicecanciller / Fr. Francisco de Borja

Arguedas (Pamplona)

Estudiante en Huesca

AGN, Irache, Lib. 542, 91v, $115 \mathrm{v}$.

PEDRO ZAITEGUI

B. C.

27-8-1620

Fr. Mauro García de Mendoza

Burgos

AGN, Irache, Lib. 542, 91v.

MARCOS DE LIAÑO

L. A. / M. A.

27-8-1620

Fr. Diego de Salazar, vicecanciller

Salamanca

AGN, Irache, Lib. 542, 91v.

FRANCISCO DE LA VEGA

B. C. / L. C.

5-9-1620

Fr. Mauro García de Mendoza / Fr. Lorenzo

de Frías

Hoz (Burgos)

Oidor del Consejo de Toledo

AGN, Irache, Lib. 542, 92r.

PEDRO GONZÁLEZ DE RIAÑO

B. C. 
15-9-1620

Fr. Mauro García de Mendoza

Nestar (Burgos)

AGN, Irache, Lib. 542, 92r.

JUAN MORENO

B. C.

17-9-1620

Fr. Mauro García de Mendoza

Cubillo (Burgos)

Estudiante en Salamanca

AGN, Irache, Lib. 542, 92r.

BARTOLOMÉ DE ...

L. C.

20-9-1620

Fr. Diego de Salazar

... (Burgos)

AGN, Irache, Lib. 542, 92r.

ANTONIO DE PERALTA

B. T. / L. T. / M. T.

24-9-1620

Fr. Mauro García de Mendoza / Fr. Lorenzo

de Frías

Corella (Pamplona)

O. Cist.

Abad de San Salvador de Leyre

AGN, Irache, Lib. 542, 92v.

\section{MANUEL DE CASTREJÓN}

B. C.

26-9-1620

Fr. Mauro García de Mendoza

Ágreda (Tarazona)

AGN, Irache, Lib. 542, 92v.

DOMINGO DE MANSILLA

L. C.

2-10-1620

Fr. Lorenzo de Frías

Pedrosa de Río Úrbel (Burgos)

AGN, Irache, Lib. 542, 92v.

PEDRO DE MUNILLA

L. L.

8-10-1620

Fr. Luis Flórez
Tudela (Tarazona)

AGN, Irache, Lib. 542, 93r.

JUAN DE BERÁN

B. C.

9-10-1620

Fr. Luis Flórez

Miranda de Ebro (Burgos)

AGN, Irache, Lib. 542, 93r.

FRANCISCO AGUSTÍN

L. C. / D. C.

17-10-1620

Fr. Benito de Cobillas

Calderón (Nullius Diocesis)

AGN, Irache, Lib. 542, 93r.

DOMINGO ARRUTARTE

B. T.

20-10-1620

Fr. Benito de Cobillas

Tolosa (Pamplona)

Estudiante en Granada

AGN, Irache, Lib. 542, 93v.

CRISTÓBAL DE SALINAS AVELLANEDA

L. C. / D. C.

7-11-1620

Fr. Mauro García de Mendoza

Salinas (Burgos)

AGN, Irache, Lib. 542, 93v.

MIGUEL DE IRISARRI

B. T. / L. T.

19-11-1620

Fr. Benito de Cobillas / Fr. Lorenzo de Frías

Lesera

AGN, Irache, Lib. 542, 93v-94r.

AMBROSIO DE SANTA CRUZ

B. C. / L. C.

26-11-1620 /27-11-1620

Fr. Benito de Cobillas / Fr. Lorenzo de Frías

Soria (Osma)

AGN, Irache, Lib. 542, 94r.

HERNANDO DE LA SOTA Y ACEVEDO

L. C. 
22-1-1621

Fr. Benito de Cobillas

Cortambasaguas (Burgos)

B. C. Valladolid

AGN, Irache, Lib. 542, 94v.

JUAN ORTIZ DE VARDEBI

B. T.

23-1-1621

Fr. Mauro García de Mendoza

Délica (Calahorra)

AGN, Irache, Lib. 542, 94v.

DIEGO DE LA MANO

B. T.

31-1-1621

Fr. Luis Flórez

Quintanadueñas (Burgos)

AGN, Irache, Lib. 542, 94V.

JUAN CUBILLO

B. C.

2-2-1621

Fr. Luis Flórez

Villanueva (Burgos)

AGN, Irache, Lib. 542, 94v.

MIGUEL CANTÓN

B. C.

18-2-1621

Fr. Luis Flórez

Villanueva (Burgos)

AGN, Irache, Lib. 542, 94v.

FRANCISCO MUÑOZ

B. A. / L. A. / M. A. / B. T. / L. T. / D. T.

3-3-1621

Fr. Benito de Cobillas

Valladolid

O. S. B.

Lector de Teología del Colegio de San Juan

del Poyo

AGN, Irache, Lib. 542, 95r.

ANDRÉS GONZÁLEZ DE VILLA Y ARELLANO

B. A. / L. A. / M. A. / B. T. / L. T. / D. T. 7-11-1621
Fr. Lorenzo de Frías

O. S. B.

Maestro de Estudiantes de esta Universi-

dad

AGN, Irache, Lib. 542, 95r.

ANDRÉS DE LA TORRE

B. C.

29-3-1621

Fr. Benito de Cobillas

Arnedo (Calahora)

AGN, Irache, Lib. 542, 95v.

MIGUEL SANZ DE JUNGUITO

B. T.

4-4-1621

Fr. Benito de Cobillas

AGN, Irache, Lib. 542, 95v.

PEDRO DE BARREDA ESTRADA

L. C.

11-4-1621

Fr. Lorenzo de Frías

Santillana (Burgos)

AGN, Irache, Lib. 542, 95v.

PEDRO DE VISEDA CEBALLOS

L. C.

11-4-1621

Fr. Lorenzo de Frías

Santillana (Burgos)

AGN, Irache, Lib. 542, 95v.

DIEGO DE BARREDA

L. C.

11-4-1621

Fr. Lorenzo de Frías

Santillana (Burgos)

AGN, Irache, Lib. 542, 95v.

JERÓNIMO MARTÍNEZ RUBIO

L. C. / D. C.

13-4-1621

Fr. Lorenzo de Frías

Ródenas (Albarracín)

AGN, Irache, Lib. 542, 96r. 


\section{JERÓNIMO DE MORENTÍN}

B. $\mathrm{T}$.

16-4-1621

Fr. Benito de Cobillas

Falces (Pamplona)

AGN, Irache, Lib. 542, 96r.

PEDRO BRIONES DE AYALA

B. C. / L. C.

27-4-1621 / 28-4-1621

Fr. Benito de Cobillas / Fr. Mauro García de Mendoza

Toledo

AGN, Irache, Lib. 542, 96r.

\section{ANDRÉS BRAVO}

B. C. / L. C.

27-4-1621 / 28-4-1621

Fr. Benito de Cobillas / Fr. Mauro García de Mendoza

Martín Muñoz de las Posadas (Ávila)

Estudiante en Salamanca

Abad en Sigüenza

AGN, Irache, Lib. 542, 96v.

PEDRO DE ZÚÑIGA

L. C.

28-4-1621

Fr. Mauro García de Mendoza

Domingo de la Calzada (Calahorra)

AGN, Irache, Lib. 542, 96v.

\section{PEDRO ÁLVAREZ}

B. C.

1-5-1621

Fr. Benito de Cobillas

Loranquillo (Burgos)

AGN, Irache, Lib. 542, 97r.

JUAN GÓMEZ DE SALINAS

B. T.

7-5-1621

Fr. Mauro García de Mendoza

Pamplona

AGN, Irache, Lib. 542, 97r.

TOMÁS CORONEL

B. A. / L. A.
8-5-1621 / 9-5-1621

Fr. Hernando Enríquez

Estella (Pamplona)

AGN, Irache, Lib. 542, 97r.

MIGUEL MARTÍNEZ TAZA

L. C.

11-5-1621

Fr. Mauro García de Mendoza

Lodosa (Pamplona)

AGN, Irache, Lib. 542, 97v.

PEDRO DE ARCE

L. C.

19-5-1621

Fr. Benito de Cobillas

Ballesteros (Burgos)

AGN, Irache, Lib. 542, 97v.

JUAN GÓMEZ GARCÍA

B. C.

25-5-1621

Fr. Benito de Cobillas

Cadiñanos (Burgos)

AGN, Irache, Lib. 542, 97v.

ANDRÉS DE GALVÁN

B. C.

26-5-1621

Fr. Benito de Cobillas

Castro Urdiales (Burgos)

AGN, Irache, Lib. 542, $97 \mathrm{v}$.

MIGUEL DE LARRAIZAR

B. A.

29-5-1621

Fr. Hernando Enríquez

Puente la Reina (Pamplona)

AGN, Irache, Lib. 542, 98r.

MIGUEL DE ZABALZA

B. A.

29-5-1621

Fr. Hernando Enríquez

Erdozain (Pamplona)

AGN, Irache, Lib. 542, 98r.

JUAN BINUELO

L. C. 
5-6-1621

Fr. Benito de Cobillas

Espinosa de los Monteros (Burgos)

AGN, Irache, Lib. 542, 98r.

FAUSTO DE ECHEVERRÍA

B. A.

5-6-1621

Fr. Hernando Enríquez

Azcoitia (Pamplona)

AGN, Irache, Lib. 542, 98r.

FRANCISCO IDIAGUEZ

L. C.

16-5-1621

Fr. Benito de la Serna, Vicecanciller Azcoitia (Pamplona)

AGN, Irache, Lib. 542, 98r.

DOMINGO DE OYARBIDE

L. C.

17-6-1621

Fr. Mauro García de Mendoza

Azcoitia (Pamplona)

AGN, Irache, Lib. 542, 98v.

FRANCISCO CASTILLO DE FILORGA

B. L.

22-6-1621

Fr. Lorenzo de Frías

Pamplona

AGN, Irache, Lib. 542, 98v.

ANDRÉS DE LA GÁNDARA

B. C.

22-6-1621

Fr. Benito de la Serna

Santander (Burgos)

AGN, Irache, Lib. 542, 98v.

GONZALO DE ARGUIÑANO

B. T. / L. T.

22-6-1621 / 23-6-1621

Fr. Mauro García de Mendoza

Garsoain (Pamplona)

AGN, Irache, Lib. 542, 99r.

ESPINA DE VELASCO

L. C.
26-6-1621

Fr. Benito de la Serna

Ampuero (Burgos)

AGN, Irache, Lib. 542, 99r.

FRANCISCO DELGADO

B. C.

27-6-1621

Fr. Mauro García de Mendoza

Villaveta (Nullius Diocesis)

AGN, Irache, Lib. 542, 99r.

ANTONIO GIL DEL CORRAL

B. A. / B. T.

27-6-1621 / 13-4-1624

Fr. Benito de la Serna

Villasandino (Burgos)

AGN, Irache, Lib. 542, 99r, $120 r$.

FRANCISCO GARCÍA

B. C.

21-7-1621

Fr. Mauro García de Mendoza

Villamel (Burgos)

AGN, Irache, Lib. 542, 99v.

MARTÍN DE BERRIA

L. L.

12-8-1621

Fr. Antonio Cornejo, Abad y Rector

Pamplona

AGN, Irache, Lib. 542, 99v.

FRANCISCO DE LA PORTILLA

L. C.

22-8-1621

Fr. Gregorio de Miranda

San Vicente (Burgos)

AGN, Irache, Lib. 542, 99v.

JERÓNIMO DE MIRANDA

L. C. / D. C.

28-8-1621

Fr. Antonio Cornejo

Medina de Pomar (Burgos)

AGN, Irache, Lib. 542, 99v-10or.

ALBERTO DE EGUIERRETA

B. A. 
1-9-1621

Fr. Mauro García de Mendoza

O. C.

Pamplona

AGN, Irache, Lib. 542, 100r.

\section{SIMÓN DE BUERAS}

L. C.

1-9-1621

Fr. Mauro García de Mendoza

Bueras (Burgos)

AGN, Irache, Lib. 542, 100 .

TOMÁS DE SESMA

L. L.

11-9-1621

Fr. Antonio Cornejo

Corella (Tarazona)

AGN, Irache, Lib. 542, 100 .

TOMAS DE MUR

L. L.

22-9-1621

Fr. Antonio Cornejo

Tudela (Pamplona)

AGN, Irache, Lib. 542, 100 .

GREGORIO DE SALAZAR SOLÓRZANO

B. C.

26-9-1621

Fr. Mauro García de Mendoza

Sevilla

AGN, Irache, Lib. 542, 100v.

HERNANDO DE VALDIZAN

B. C.

26-9-1621

Fr. Mauro García de Mendoza

Briviesca (Burgos)

AGN, Irache, Lib. 542, 100v.

FRANCISCO DE MORCATE

B. T.

27-9-1621

Fr. Gregorio de Miranda

Salas (Burgos)

AGN, Irache, Lib. 542, $100 v$.
FRANCISCO HERNÁNDEZ BASURTO

B. C.

16-10-1621

Fr. Benito de la Serna

Vellejimeno (Burgos)

AGN, Irache, Lib. 542, 100v.

MARTÍN DE AZPILICUETA

B. C.

30-10-1621

Fr. Rosendo de San Martín, vicecanciller

Barásoain (Pamplona)

AGN, Irache, Lib. 542, 101r.

MELCHOR SÁNCHEZ

L. C. / D. C.

8-12-1621

Fr. Antonio Cornejo

El Pobo (Teruel)

AGN, Irache, Lib. 542, 101r.

BLAS GONZÁLEZ DE RIVERO

L. C. / D. C.

10-12-1621

Fr. Antonio Cornejo

Madrid (Toledo)

AGN, Irache, Lib. 542, 101r.

JUAN DE CABERNI

L. C. / D. C.

16-1-1622

Fr. Antonio Cornejo

Barbastro

AGN, Irache, Lib. 542, $101 \mathrm{v}$.

DIEGO GUTIÉRREZ DE TEJO

B. C.

23-2-1622

Fr. Benito de la Serna

San Vicente de la Barquera (Burgos)

AGN, Irache, Lib. 542, $101 \mathrm{v}$.

SANCHO ORTIZ DE MONTELLANO

B. C.

2-3-1622

Fr. Mauro García de Mendoza

Castro Urdiales (Burgos)

AGN, Irache, Lib. 542, 101v. 
FRANCISCO DE AZPILICUETA

L. L.

6-3-1622

Fr. Antonio Cornejo

Pamplona

AGN, Irache, Lib. 542, 102 r.

GABRIEL DE HUARTE

L. C.

6-3-1622

Fr. Antonio Cornejo

Huarte (Pamplona)

AGN, Irache, Lib. 542, 102 r.

PEDRO NAVARRO

B. C.

14-3-1622

Fr. Fco. de Borja, Vicecanciller

Villasilos (Burgos)

AGN, Irache, Lib. 542, 102 r.

ROQUE DE RUEDA

B. C.

14-3-1622

Fr. Benito de la Serna

Villasilos (Burgos)

AGN, Irache, Lib. 542, $102 \mathrm{r}$.

SEBASTIÁN LÓPEZ DE TOJAL

B. C.

16-3-1622

Fr. Mauro García de Mendoza

Talavera de la Reina (Badajoz)

AGN, Irache, Lib. 542, $102 \mathrm{v}$.

FERNANDO DE SAN MARTÍN

B. T. / L. T. / D. T.

22-3-1622

Fr. Francisco de Borja

Burgos

AGN, Irache, Lib. 542, 102v.

\section{ALEJANDRO MARTÍNEZ}

B. C.

23-3-1622

Fr. Mauro García de Mendoza

Pampliega (Burgos)

AGN, Irache, Lib. 542, 102v.

\section{FRANCISCO MARTÍNEZ}

B. C.

23-3-1622

Fr. Francisco de Borja

Pampliega (Burgos)

AGN, Irache, Lib. 542, 102v.

DOMINGO DEL PORTILLO

B. C.

30-3-1622

Fr. Benito de la Serna

Sámano (Burgos)

AGN, Irache, Lib. 542, 102v.

MARTÍN DE ECHALECU

B. T. / L. T.

2-4-1622

Fr. Francisco de Borja

Echalecu (Pamplona)

AGN, Irache, Lib. 542, 103 r.

FRANCISCO ALONSO

B. A. / L. A.

2-4-1622 / 24-3-1624

Fr. Pedro de Santa Fe, vicecanciller / Fr.

Francisco de Borja

Corera (Calahorra)

AGN, Irache, Lib. 542, 103r, 119v.

GABRIEL DE MENCOA

B. A.

2-4-1622

Fr. Pedro de Santa Fe

Tafalla (Pamplona)

AGN, Irache, Lib. 542, 103r.

PEDRO JIMÉNEZ

B. A.

2-4-1622

Fr. Pedro de Santa Fe

Fuenmayor (Calahorra)

AGN, Irache, Lib. 542, 103 r.

RAFAEL PÉREZ

B. A.

2-4-1622

Fr. Pedro de Santa Fe

Cirauqui (Pamplona)

AGN, Irache, Lib. 542, 103r. 
JOSÉ DE BADARÁN

B. A.

2-4-1622

Fr. Pedro de Santa Fe

Falces (Pamplona)

AGN, Irache, Lib. 542, 103r.

MARCIAL DE EZPELETA

B. A.

2-4-1622

Fr. Pedro de Santa Fe

Pasajes (Pamplona)

AGN, Irache, Lib. 542, 103 r.

DIEGO DE CASTRO

B. A.

2-4-1622

Fr. Pedro de Santa Fe

Tudela (Tarazona)

AGN, Irache, Lib. 542, 103 r.

PEDRO MAZO

B. A.

2-4-1622

Fr. Pedro de Santa Fe

Pamplona

AGN, Irache, Lib. 542, 103 r.

MARTÍN DE OLÓNDRIZ

B. A.

2-4-1622

Fr. Pedro de Santa Fe

Pamplona

AGN, Irache, Lib. 542, 103 r.

MARCOS DE LUQUÍN

B. A.

2-4-1622

Fr. Pedro de Santa Fe

Morestín (Pamplona)

AGN, Irache, Lib. 542, 103 r.

JOSÉ DE TAFALLA

B. A.

2-4-1622

Fr. Pedro de Santa Fe

Tafalla (Pamplona)

AGN, Irache, Lib. 542, 103 r.
JOSÉ DE VERGARA

B. A.

2-4-1622

Fr. Pedro de Santa Fe

Muruzábal (Pamplona)

AGN, Irache, Lib. 542, 103 r.

JUAN DE BERIÁIN

B. A.

2-4-1622

Fr. Pedro de Santa Fe

Uterga (Pamplona)

AGN, Irache, Lib. 542, 103 r.

\section{JUAN DE REDÍN}

B. A.

2-4-1622

Fr. Pedro de Santa Fe

Aybar (Pamplona)

AGN, Irache, Lib. 542, 103r.

JUAN DE GARCERÓN

B. A.

2-4-1622

Fr. Pedro de Santa Fe

Oroquieta (Pamplona)

AGN, Irache, Lib. 542, 103 r.

JUAN DE URDÁNIZ

B. A.

2-4-1622

Fr. Pedro de Santa Fe

Pamplona

AGN, Irache, Lib. 542, 103 r.

JUAN DE BERRENECHEA

B. A.

2-4-1622

Fr. Pedro de Santa Fe

Idiazábal (Pamplona)

AGN, Irache, Lib. 542, 103 r.

JUAN DE URETA

B. A.

2-4-1622

Fr. Pedro de Santa Fe

Añorbe (Pamplona)

AGN, Irache, Lib. 542, 103 r. 


\section{MARTÍN DE LEOZ}

B. A.

2-4-1622

Fr. Pedro de Santa Fe

Obanos (Pamplona)

AGN, Irache, Lib. 542, 103r.

JUAN PASCUAL

B. A. / L. A.

2-4-1622 / 24-3-1624

Fr. Pedro de Santa Fe / Fr. Mauro García de Mendoza

Corera (Calahorra)

AGN, Irache, Lib. 542, 103r, 119v.

\section{MELCHOR DE SUSPIRÓN Y ORTIZ}

B. A.

2-4-1622

Fr. Pedro de Santa Fe

Olite (Pamplona)

AGN, Irache, Lib. 542, 103 r.

MARTÍN DE LIZASO

B. A.

2-4-1622

Fr. Pedro de Santa Fe

Salinas de Oro (Pamplona)

AGN, Irache, Lib. 542, 103r.

MIGUEL DE LARRASOAÑA

B. A.

2-4-1622

Fr. Pedro de Santa Fe

Pamplona

AGN, Irache, Lib. 542, 103 r.

ANTONIO DE SENDRA

B. A.

2-4-1622

Fr. Pedro de Santa Fe

Ujué (Pamplona)

AGN, Irache, Lib. 542, 103r.

PEDRO DE SAGÜÉS

B. A.

2-4-1622

Fr. Pedro de Santa Fe

Olóriz (Pamplona)

AGN, Irache, Lib. 542, 103 r.
MARTÍN DE LIZASO

B. A.

2-4-1622

Fr. Pedro de Santa Fe

Alcoz (Pamplona)

AGN, Irache, Lib. 542, 103 r.

SEBASTIÁN DE IDOCIN

B. A.

2-4-1622

Fr. Pedro de Santa Fe

Alzorriz (Pamplona)

AGN, Irache, Lib. 542, 103r.

DIEGO DE AQUERRETA

B. A.

2-4-1622

Fr. Pedro de Santa Fe

Huarte (Pamplona)

AGN, Irache, Lib. 542, 103 r.

ESTEBAN DE OYEREGUI

B. A.

2-4-1622

Fr. Pedro de Santa Fe

Pamplona

AGN, Irache, Lib. 542, 103r.

FERMÍN DE AZCÁRATE

B. A.

2-4-1622

Fr. Pedro de Santa Fe

Munárriz (Pamplona)

AGN, Irache, Lib. 542, 103 r.

PEDRO PÉREZ

B. A.

2-4-1622

Fr. Pedro de Santa Fe

Iturgoyen (Pamplona)

AGN, Irache, Lib. 542, 103 r.

JUAN PÉREZ DE GORRITI

B. A.

2-4-1622

Fr. Pedro de Santa Fe

Álava (Pamplona)

AGN, Irache, Lib. 542, 103 r. 
JUAN PORTAL

B. A.

2-4-1622

Fr. Pedro de Santa Fe

Huarte (Pamplona)

AGN, Irache, Lib. 542, 103 r.

MARTÍN DE ARISTU

B. A.

2-4-1622

Fr. Pedro de Santa Fe

Arrieta (Pamplona)

AGN, Irache, Lib. 542, 103 r.

JUAN BAUTISTA OCHOA

B. A.

2-4-1622

Fr. Pedro de Santa Fe

Aloz (Pamplona)

AGN, Irache, Lib. 542, 103 r.

JUAN DE VIGUEZAL

B. A. / L. A.

2-4-1622

Fr. Pedro de Santa Fe

Unciti (Pamplona)

AGN, Irache, Lib. 542, 103 rv.

JUAN DE GÜEMES

B. C.

13-4-1622

Fr. Mauro García de Mendoza

Castañeda (Burgos)

AGN, Irache, Lib. 542, 103v.

JUAN RUIZ BARBADO

L. C.

16-4-1622

Fr. Mauro García de Mendoza

Cobillos (Burgos)

AGN, Irache, Lib. 542, $103 \mathrm{v}$.

PEDRO GARCÍA

B. C.

25-4-1622

Fr. Benito de la Serna

Villasilos (Burgos)

AGN, Irache, Lib. 542, 104r.
FRANCISCO BAUTISTA GIRALDO

B. C.

25-4-1622

Fr. Mauro García de Mendoza

Villasandino (Burgos)

AGN, Irache, Lib. 542, 104r.

LUIS FÉLIX DE RADA

B. T. / L. T. / D. T.

26-4-1622 / 19-2-1625

Fr. Mauro García de Mendoza / Fr. Antonio

Cornejo

Alfaro (Tarazona)

AGN, Irache, Lib. 542, 104r, 127r.

\section{TORIBIO CRESPO}

B. C.

26-4-1622

Fr. Benito de la Serna

Rucandio (Burgos)

AGN, Irache, Lib. 542, 104r.

TOMAS DEL HOYO

B. C.

27-4-1622

Fr. Francisco de Borja

Villanueva de Villacardo (Burgos)

AGN, Irache, Lib. 542, 104 r.

DIEGO DE ARNALDO

L. T. / D. T.

28-4-1622

Fr. Antonio Cornejo

Alcántara (Coria)

AGN, Irache, Lib. 542, 104v.

ANTONIO DE MOLLES

B. T.

30-4-1622

Fr. Mauro García de Mendoza

O. de M.

AGN, Irache, Lib. 542, 104v.

LUIS DE BUILLA

L. C. / D. C.

4-5-1622

Fr. Antonio Cornejo

Sahagún (Nullius Diocesis)

AGN, Irache, Lib. 542, 105r. 
JUAN DE COSSÍO

B. C.

9-5-1622

Fr. Francisco de Borja

San Vicente de la Barquera (Burgos)

AGN, Irache, Lib. 542, 105 r.

MARTÍN DE PORRAS

L. C.

14-5-1622

Fr. Francisco de Borja

Santa Cruz (Burgos)

AGN, Irache, Lib. 542, 105r.

JERÓNIMO MARTÍNEZ

B. C.

20-5-1622

Fr. Mauro García de Mendoza

Medina de Pomar (Burgos)

AGN, Irache, Lib. 542, 105 r.

ALONSO RUIZ DE LA RABIA

B. C.

21-5-1622

Fr. Benito de la Serna

Comillas (Burgos)

AGN, Irache, Lib. 542, 105 r.

FRANCISCO DE ARTACHO Y GAMBOA

B. C. / L. C.

22-5-1622

Fr. Francisco de Borja

Atienza (Sigüenza)

Graduado en Salamanca

AGN, Irache, Lib. 542, 105v.

PEDRO RUIZ

B. C.

27-5-1622

Fr. Mauro García de Mendoza

Soto Avellanos (Burgos)

AGN, Irache, Lib. 542, $105 \mathrm{v}$.

JOSÉ SOMELINO

B. A. / L. A. / M. A. / B. T. / L. T. / D. T.

27-5-1622

Fr. Antonio Cornejo

O. S. B. de Monte Casino

AGN, Irache, Lib. 542, 105v.

TOMÁS DE MENA

B. C.

31-5-1622

Fr. Mauro García de Mendoza

Burgos

AGN, Irache, Lib. 542, 105v.

DIEGO MARTÍNEZ DE ZARZOSA

D. C.

31-5-1622

Fr. Mauro García de Mendoza

Calahorra

L. C. en Huesca

Cura parroquial en Valdeavellano

AGN, Irache, Lib. 542, 106r.

BENITO DE ARAUJO

L. C.

2-6-1622

Fr. Mauro García de Mendoza

Villanueva de los Infantes (Orense)

AGN, Irache, Lib. 542, 106r.

FRANCISCO DE ACEBEDO

L. T. / M. T.

3-6-1622

Fr. Benito de la Serna

San Martín de Santiago (Galicia)

O. S. B.

AGN, Irache, Lib. 542, 106r.

BERNARDO PÉREZ

L. - / D. -

11-6-1622

Fr. Antonio Cornejo

Villada (León)

AGN, Irache, Lib. 542, 106v.

ALONSO GARCÍA PARACUELLOS

B. - / L. -

1-7-1622

Fr. Antonio Cornejo

Consuegra (Nullius Diocesis)

Canónigo de Lorca

AGN, Irache, Lib. 542, 106v. 


\section{PEDRO GARCÍA}

L. -

1-7-1622

Fr. Antonio Cornejo

Cabanillas (Toledo)

AGN, Irache, Lib. 542, 106v.

PEDRO GARCÍA DE SOTO

B. C.

13-7-1622

Fr. Mauro García de Mendoz

Burgos

AGN, Irache, Lib. 542, 106v.

\section{ANTONIO HERRERA}

B. C.

16-7-1622

Fr. Benito de la Serna

Villasandino (Burgos)

AGN, Irache, Lib. 542, 106v.

DOMINGO DE MIÑÓN

B. C.

29-7-1622

Fr. Mauro García de Mendoza

Ros (Burgos)

AGN, Irache, Lib. 542, 107 r.

JERÓNIMO PÉREZ

B. T. / L. T.

12-8-1622

Fr. Antonio Cornejo

O. Cist.

Convento de Santa Fe, Zaragoza

AGN, Irache, Lib. 542, 107 r.

FRANCISCO GIL

B. A.

21-8-1622

Fr. Mauro García de Mendoza

Logroño (Calahorra)

AGN, Irache, Lib. 542, 107 r.

DIEGO DEL MORAL

B. L. / L. L.

29-8-1622

Fr. Antonio Cornejo

Navarrete (Calahorra)

AGN, Irache, Lib. 542, $107 \mathrm{v}$.
DIEGO DE LA PORTILLA

L. C. / D. C.

6-9-1622

Fr. Mauro García de Mendoza

Villadiego (Burgos)

AGN, Irache, Lib. 542, $107 \mathrm{v}$.

FRANCISCO DE LA MAZA

B. C.

10-9-1622

Fr. Benito de la Serna

Laredo (Burgos)

AGN, Irache, Lib. 542, $107 \mathrm{v}$.

MIGUEL DE ALTERAIN

B. C.

10-9-1622

Fr. Benito de la Serna

Beriáin (Pamplona)

AGN, Irache, Lib. 542, $107 \mathrm{v}$.

ANTONIO ROGEL

B. M. / L. M. / D. M.

19-9-1622

Fr. Antonio Cornejo y Médicos de Estella

Estella (Pamplona)

AGN, Irache, Lib. 542, 108r.

FRANCISCO MORANTE DE LA MADRID

L. C.

1-10-1622

Fr. Antonio Cornejo

Reinosa (Burgos)

AGN, Irache, Lib. 542, 108r.

PEDRO DEL CERRO SARAVIA

B. C.

3-10-1622

Fr. Mauro García de Mendoza

Resines (Burgos)

AGN, Irache, Lib. 542, 108r.

\section{MARTÍN ZORILLA}

B. C.

3-10-1622

Fr. Benito de la Serna

Bárcena (Burgos)

AGN, Irache, Lib. 542, 108r. 
PEDRO DE CAMPO

B. T. / L. T. / D. T.

11-10-1622

Fr. Antonio Cornejo

AGN, Irache, Lib. 542, 108v.

PEDRO DE ORONIO

B. C. / L. C.

11-10- 1622

Fr. Antonio Cornejo

Agreda (Tarazona)

AGN, Irache, Lib. 542, 108v.

DOMINGO DE AXAUS

L. T.

13-10-1622

Fr. Antonio Cornejo

Jaca

AGN, Irache, Lib. 542, 108v.

BERNABÉ GARCÍA

B. C.

19-10-1622

Fr. Benito de la Serna

Pedroso (Burgos)

AGN, Irache, Lib. 542, 109 r.

ÁLVARO PÉREZ ARACIEL

B. C. / L. C.

23-10-1622

Fr. Antonio Cornejo

Alfaro (Tarazona)

AGN, Irache, Lib. 542, 109 r.

\section{GARCÍA OSORIO}

B. T. / L. T. / D. T.

13-11-1622

Fr. Antonio Cornejo

O. Praem.

AGN, Irache, Lib. 542, 109r.

\section{LORENZO ANGULO}

B. T. / L. T. / D. T.

17-11-1622 / 18-11-1622

Fr. Mauro García de Mendoza / Fr. Benito

de la Serna

Montilla (Córdoba)

AGN, Irache, Lib. 542, 109r.

\section{GONZALO TOMÁS}

B. C. / L. C.

20-11-1622

Fr. Mauro García de Mendoza / Fr. Fran-

cisco de Borja

Almendral (Badajoz)

AGN, Irache, Lib. 542, 109v.

\section{JUAN DE ARGÜELLO}

B. L.

29-11-1622

Fr. Benito de la Serna

Villafranca (Nullius Diocesis)

AGN, Irache, Lib. 542, 109v.

FRANCISCO DE AZGOITIA

L. C.

29-11-1622

Fr. Mauro García de Mendoza

Azpeitia (Pamplona)

AGN, Irache, Lib. 542, 109v.

\section{ANTONIO EGUILUZ}

L. C.

8-12-1622

Fr. Benito de la Serna

Guernica (Calahorra)

AGN, Irache, Lib. 542, 109v.

JUAN SAZ

B. C.

11-12-1622

Fr. Francisco de Borja

Burgos

AGN, Irache, Lib. 542, 110 .

BERNARDO DE SAN ANDRÉS

B. C.

19-1-1623

Fr. Mauro García de Mendoza

Saldaña (León)

AGN, Irache, Lib. 542, 11 or.

JUAN DE MOLLEDA CEBIS

B. C.

17-1-1623

Fr. Benito de la Serna

Cades (Burgos)

AGN, Irache, Lib. 542, 110 . 
JUAN DE ENCISO

B. C.

18-1-1623

Fr. Mauro García de Mendoza

Calahorra

AGN, Irache, Lib. 542, 110r.

GERMÁN DE BUGES

B. T. / L. T. / M. T.

15-1-1623

Fr. Antonio Cornejo

O. Cist.

AGN, Irache, Lib. 542, $110 v$.

PEDRO DE BERNEDO

B. T.

10-2-1623

Fr. Benito de la Serna

Barbadillo del Mercado (Burgos)

AGN, Irache, Lib. 542, $110 v$.

FRANCISCO ALONSO

B. C.

12-2-1623

Fr. Mauro García de Mendoza

Presencio (Burgos)

AGN, Irache, Lib. 542, $110 v$.

JUAN MARTÍNEZ DE LITURBIDE

L. C. / D. C.

18-2-1623

Fr. Antonio Cornejo

Tolosa (Pamplona)

AGN, Irache, Lib. 542, $110 v$.

PEDRO SANCTORES DE URQUIETA

B. A.

18-2-1623

Fr. Pedro de Sta. Fe

Guernica (Calahorra)

AGN, Irache, Lib. 542, $110 v$.

MARTÍN DE LUENGO

L. L. / D. L.

11-3-1623

Fr. Antonio Cornejo

Falces (Pamplona)

AGN, Irache, Lib. 542, 111r.
LUIS DE MUR

L. L.

11-3-1623

Fr. Antonio Cornejo

Tudela (Tarazona)

AGN, Irache, Lib. 542, 111r.

PEDRO ORTIZ DE REJAS

B. C.

17-3-1623

Fr. Benito de la Serna

Redecilla del Campo (Burgos)

AGN, Irache, Lib. 542, 111r.

ÁLVARO DE CADAVAL Y MONTENEGRO

L. C. / D. C.

20-3-1623

Fr. Antonio Cornejo

Bayona (Tuy)

AGN, Irache, Lib. 542, 111r.

AMBROSIO NAVAS

B. L.

3-4-1623

Fr. Antonio Cornejo

Pamplona

AGN, Irache, Lib. 542, 111v.

PEDRO DE LLANO

B. C.

$-/-/ 1623$

Fr. Benito de la Serna

Castro Urdiales (Burgos)

AGN, Irache, Lib. 542, 111v.

PEDRO ORTIZ

B. C.

19-4-1623

Fr. Mauro García de Mendoza

Orrantia (Burgos)

AGN, Irache, Lib. 542, 111v.

BERNARDO MARTÍNEZ

L. L.

22-4-1623

Fr. Antonio Cornejo

Pamplona

AGN, Irache, Lib. 542, 112r. 
TADEO DE CEVALLOS

B. C.

28-4-1623

Fr. Benito de la Serna

Villadiego (Burgos)

AGN, Irache, Lib. 542, 112r.

JUAN DE FONTECHA

B. C.

4-5-1623

Fr. Mauro García de Mendoza

Portillo (Burgos)

AGN, Irache, Lib. 542, 112r.

JUAN DE CUBILLA

B. C.

4-5-1623

Fr. Benito de la Serna

Portillo (Burgos)

AGN, Irache, Lib. 542, 112r.

PEDRO DE HOYO

B. C. / L. C.

8-5-1623

Fr. Mauro García de Mendoza / Fr. Antonio

Cornejo

Hoz (Burgos)

AGN, Irache, Lib. 542, 112v.

FELIPE DE BURUAGA

B. C. / L. C.

17-5-1623

Fr. Mauro García de Mendoza / Fr. Antonio

Cornejo

Chavarri (Calahorra)

AGN, Irache, Lib. 542, $112 \mathrm{~V}$.

B. NIETO

B. C.

18-5-1623

Fr. Mauro García de Mendoza

Palenzuela (Burgos)

AGN, Irache, Lib. 542, $112 \mathrm{v}$.

ANTONIO LÓPEZ

B. C.

27-5-1623

Fr. Mauro García de Mendoza
Los Balbases (Burgos)

AGN, Irache, Lib. 542, 112v.

FELIPE DE ANTUÑANO

B. C.

28-5-1623

Fr. Mauro García de Mendoza

Orrantia (Burgos)

AGN, Irache, Lib. 542, 113 r.

FRANCISCO SÁEZ

B. C. / L. C.

8-6-1623

Fr. Pedro de Santa Fe / Fr. Antonio Cornejo

Procedente de Granada

Diócesis de Burgos

AGN, Irache, Lib. 542, 113 r.

JUAN IZQUIERDO

B. C.

8-6-1623

Fr. Pedro de Santa Fe

Villanueva

AGN, Irache, Lib. 542, 113 r.

GABRIEL DE FARO

L. C.

11-6-1623

Fr. Pedro de Santa Fe

Fitero (Tarazona)

AGN, Irache, Lib. 542, 113 r.

RODRIGO DE ESCOBAR

B. C.

12-6-1623

Fr. Pedro de Santa Fe

Boadilla de Río Seco

AGN, Irache, Lib. 542, 113v.

JOSÉ DE LA PEÑA

L. C.

12-6-1623

Fr. Pedro de Santa Fe

Valtierra (Pamplona)

AGN, Irache, Lib. 542, 113v.

FÉLIX DE RADA

B. C. 
21-6-1623

Fr. Pedro de Santa Fe

Alfaro (Tarazona)

AGN, Irache, Lib. 542, 113v.

FRANCISCO NEGRETE

B. C.

22-6-1623

Fr. Pedro de Santa Fe

Burceña (Burgos)

AGN, Irache, Lib. 542, 113v.

\section{JUAN DE EZQUERRA}

B. A.

28-6-1623

Fr. Pedro de Santa Fe

Alumno de Fr. Juan Martínez, O. P. Orisoain (Pamplona)

AGN, Irache, Lib. 542, 114r.

\section{JUAN DE IRIARTE}

B. A.

28-6-1623

Fr. Pedro de Santa Fe

Alumno de Fr. Juan Martínez, O. P.

Eraso (Pamplona)

AGN, Irache, Lib. 542, 114r.

PEDRO DE SAGASETA

B. A.

28-6-1623

Fr. Pedro de Santa Fe

Alumno de Fr. Juan Martínez, O. P. Meariniz (Bayona)

AGN, Irache, Lib. 542, 114r.

MARTÍN DE ORICAIN

B. A.

28-6-1623

Fr. Pedro de Santa Fe

Alumno de Fr. Juan Martínez, O. P.

Arre (Pamplona)

AGN, Irache, Lib. 542, 114r.

MARTÍN PÉREZ

B. A.

28-6-1623

Fr. Pedro de Santa Fe
Alumno de Fr. Juan Martínez, O. P.

Ciriza (Pamplona)

AGN, Irache, Lib. 542, 114r.

MARTÍN DE NABEZ

B. A.

28-6-1623

Fr. Pedro de Santa Fe

Alumno de Fr. Juan Martínez, O. P.

Abárzuza (Pamplona)

AGN, Irache, Lib. 542, 114r.

\section{JUAN LÓPEZ DE VERA}

B. A.

28-6-1623

Fr. Pedro de Santa Fe

Alumno de Fr. Juan Martínez, O. P. Puente la Reyna (Pamplona)

AGN, Irache, Lib. 542, 114r.

\section{PASCUAL DE OSA}

B. A.

28-6-1623

Fr. Pedro de Santa Fe

Alumno de Fr. Juan Martínez, O. P. Lizoáin (Pamplona)

AGN, Irache, Lib. 542, 114r.

\section{PEDRO DE UTERGA}

B. A.

28-6-1623

Fr. Pedro de Santa Fe

Alumno de Fr. Juan Martínez, O. P.

Esparza (Pamplona)

AGN, Irache, Lib. 542, 114r.

\section{PEDRO DE GÜESA}

B. A.

28-6-1623

Fr. Pedro de Santa Fe

Alumno de Fr. Juan Martínez, O. P.

Cáseda (Pamplona)

AGN, Irache, Lib. 542, 114r.

\section{JUAN DE VIRUETE}

B. A.

28-6-1623

Fr. Pedro de Santa Fe 
Alumno de Fr. Juan Martínez, O. P. Viruete (Pamplona)

AGN, Irache, Lib. 542, 114r.

JUAN DE USTARROZ

B. A.

28-6-1623

Fr. Pedro de Santa Fe

Alumno de Fr. Juan Martínez, O. P.

Ustarroz

AGN, Irache, Lib. 542, 114r.

MIGUEL DE BO...

B. A.

28-6-1623

Fr. Pedro de Santa Fe

Alumno de Fr. Juan Martínez O. P.

Pamplona

AGN, Irache, Lib. 542, 114r.

JUAN DE ALDAZ

B. A.

28-6-1623

Fr. Pedro de Santa Fe

Alumno de Fr. Juan Martínez O. P.

Sagués (Pamplona)

AGN, Irache, Lib. 542, 114r.

PEDRO DE ECHART

B. A.

28-6-1623

Fr. Pedro de Santa Fe

Alumno de Fr. Juan Martínez O. P.

Faro (Bayona)

AGN, Irache, Lib. 542, $114 \mathrm{r}$.

LEÓN DE ASIAIN

B. A.

28-6-1623

Fr. Pedro de Santa Fe

Alumno de Fr. Juan Martínez O. P.

Puente la Reina (Pamplona)

AGN, Irache, Lib. 542, 114r.

FRANCISCO BARAJO

L. C.

29-6-1623

Fr. Antonio Cornejo
Valmaseda (Burgos)

AGN, Irache, Lib. 542, 114 r.

MIGUEL RAM DE MONTORO

L. L.

30-6-1623

Fr. Antonio Cornejo

Tarazona

AGN, Irache, Lib. 542, 114v.

PEDRO ENRÍQUEZ

L. T. / M. T.

11-6- 1623

Fr. Antonio Cornejo

O. S. A.

AGN, Irache, Lib. 542, 114v.

DOMINGO DE VILLAMIEL

B. C.

19-7-1623

Fr. Pedro de Santa Fe

Burgos

AGN, Irache, Lib. 542, 114v.

JUAN NAVARRO

B. A. / L. A. / D. A.

24-7-1623

Fr. Pedro de Santa Fe / Fr. Antonio Cornejo

Fitero (Nullius Diocesis)

AGN, Irache, Lib. 542, 114v.

\section{DOMINGO MARTÍNEZ}

B. C.

8-8-1623

Fr. Francisco de Borja

Vilviestre (Osma)

AGN, Irache, Lib. 542, 115r.

ANTONIO AMIGO DE ARENILLAS

L. C.

17-8-1623

Fr. Antonio Cornejo

Madrid (Toledo)

AGN, Irache, Lib. 542, 115r.

MARTÍN LÓPEZ DE GAUNA

B. A.

24-8-1623 
Fr. Francisco de Borja

Estella (Pamplona)

AGN, Irache, Lib. 542, 115r.

BARTOLOMÉ FERNÁNDEZ

B. C.

27-8-1623

Fr. Francisco de Borja

Ventosa (Burgos)

AGN, Irache, Lib. 542, 115r.

ANTONIO OSORIO DE LUGONES Y SANDOVAL

B. C. / L. C. / D. C.

22-9-1623

Fr. Francisco de Borja

Astorga

Chantre de la Catedral

AGN, Irache, Lib. 542, 115v.

FRANCISCO ALONSO

B. T. / L. T.

23-9-1623

Fr. Francisco de Borja

Contreras (Burgos)

AGN, Irache, Lib. 542, 115v.

PEDRO GONZÁLEZ DE COGOLLOS

B. C.

23-9-1623

Fr. Francisco de Borja

Presencio (Burgos)

AGN, Irache, Lib. 542, 116r.

PEDRO DE ARROYO

B. C.

26-9-1623

Fr. Francisco de Borja

Santa Olalla (Burgos)

AGN, Irache, Lib. 542, 116r.

JUAN GALARÓN

B. C.

1-10-1623

Fr. Benito de la Serna

Yudego (Burgos)

AGN, Irache, Lib. 542, 116r.
SEBASTIÁN DÍAZ DE QUINTANILLA

B. C.

1-10-1623

Fr. Francisco de Borja

Cerezo (Burgos)

AGN, Irache, Lib. 542, 116r.

DIEGO DE RUIZ

B. A.

2-10-1623

Fr. Pedro de Santa Fe

Torme (Burgos)

AGN, Irache, Lib. 542, 116r.

FRANCISCO PABLOS

B. C.

13-10-1623

Fr. Francisco de Borja

Viniegra (Burgos)

Estudiante en Salamanca

AGN, Irache, Lib. 542, 116v.

ANDRÉS DE LA BOLLADA

B. C.

15-10-1623

Fr. Francisco de Borja

Burgos

AGN, Irache, Lib. 542, 116v.

DIEGO DE LA CUESTA

B. C.

15-10-1623

Fr. Benito de la Serna

Burgos

AGN, Irache, Lib. 542, $116 \mathrm{v}$.

PEDRO DE BEREZIARTUA

B. T. / L. T.

18-10-1623

Fr. Benito de la Serna

Segura (Pamplona)

AGN, Irache, Lib. 542, 116v.

ALONSO LAÍNEZ

L. L.

20-10-1623

Fr. Mauro García de Mendoza

Corella (Tarazona)

AGN, Irache, Lib. 542, $116 \mathrm{v}$. 


\section{JUAN GONZÁLEZ}

L. C.

28-10-1623

Fr. Francisco de Borja

Montejo (Burgos)

AGN, Irache, Lib. 542, 117r.

JUAN DE LA CALLEJA

B. C.

31-10-1623

Fr. Mauro García de Mendoza

Villadiego (Burgos)

AGN, Irache, Lib. 542, $117 \mathrm{r}$.

\section{MARTÍN DE LUSARETA}

L. T.

1-11-1623

Fr. Antonio Cornejo

Adiós (Pamplona)

AGN, Irache, Lib. 542, $117 \mathrm{r}$.

PEDRO DE LA CUESTA

B. C.

5-11-1623

Fr. Francisco de Borja

Quintana (Burgos)

AGN, Irache, Lib. 542, 117r.

BARTOLOMÉ DÍAZ DE LA NAVILLA

B. C.?

5-11-1623

Fr. Mauro García de Mendoza

Poza (Burgos)

AGN, Irache, Lib. 542, 117r.

PEDRO FRANCÉS

L. L.

9-11-1623

Fr. Antonio Cornejo

Tudela (Tarazona)

AGN, Irache, Lib. 542, $117 \mathrm{v}$.

PEDRO MIGUEL

B. C.

12-11-1623

Fr. Benito de la Serna

Puente Toma (Burgos)

AGN, Irache, Lib. 542, $117 \mathrm{v}$.

\section{ALONSO CORTÉS}

Artes

30-11-1623

Reprobado por unanimidad

Cifuentes (Sigüenza)

AGN, Irache, Lib. 542, $117 \mathrm{v}$.

JERÓNIMO JULIÁN FRANCÉS

L. C.

1-12-1623

Fr. Antonio Cornejo

Tudela (Tarazona)

AGN, Irache, Lib. 542, 117v.

MARTÍN CORNEJO

B. T. / L. T. / M. T.

5-12-1623

Fr. Antonio Cornejo / Fr. Francisco de Borja

O.S. A.

AGN, Irache, Lib. 542, $117 \mathrm{v}$.

FELIPE DÍAZ DE VALDIVIESO

B. C.

8-12-1623

Fr. Mauro García de Mendoza

Villarcayo (Burgos)

Estudiante en Salamanca

AGN, Irache, Lib. 542, 118r.

AGUSTÍN LÓPEZ SASE

L. C.

17-12-1623

Fr. Mauro García de Mendoza

Miedes (Tarazona)

AGN, Irache, Lib. 542, 118r.

DOMINGO DE BONA

L. L.

28-12-1623

Fr. Antonio Cornejo

Vic (Cataluña)

AGN, Irache, Lib. 542, 118r.

BERNABÉ GONZÁLEZ

B. T.

29-12-1623

Fr. Benito de la Serna 
Presencio (Burgos)

AGN, Irache, Lib. 542, 118v.

ESTEBAN DE LA GARZA

B. C.

5-1-1624

Fr. Francisco de Borja

Arroyo (Burgos)

AGN, Irache, Lib. 542, 118v.

MARTÍN DE EZCURRA

M. T.

13-1-1624

Fr. Antonio Cornejo

Pamplona

AGN, Irache, Lib. 542, 118v.

DIEGO SÁNCHEZ DE GARAY

L. L.

24-1-1624

Fr. Antonio Cornejo

Villoslada (Calahorra)

AGN, Irache, Lib. 542, 118v.

BALTASAR GÓMEZ

L. C. / D. C.

11-2-1624

Fr. Francisco de Borja

Calatayud (Tarazona)

AGN, Irache, Lib. 542, 119r.

JUAN DE OLLO

B. A.

15-2-1624

Fr. Pedro de Santa Fe

O. C.

Pamplona

AGN, Irache, Lib. 542, 119r.

CLEMENTE DE AZCONA

B. A.

15-2-1624

Fr. Pedro de Santa Fe

O. C.

Pamplona

AGN, Irache, Lib. 542, 119r.

JERÓNIMO DE UNZU

B. A.
15-2-1624

Fr. Pedro de Santa Fe

O. C.

Pamplona

AGN, Irache, Lib. 542, 119 r.

FELIPE PÉREZ

B. A.

15-2-1624

Fr. Pedro de Santa Fe

Éibar (Pamplona)

AGN, Irache, Lib. 542, 119 r.

JUAN BAUTISTA GANDINO

B. A.

15-2-1624

Fr. Pedro de Santa Fe

Eugui (Pamplona)

AGN, Irache, Lib. 542, 119 r.

JUAN DE ARGAÑO

B. A.

15-2-1624

Fr. Pedro de Santa Fe

Azpíroz (Pamplona)

AGN, Irache, Lib. 542, 119r.

PEDRO FÉLIX

B. A.

15-2-1624

Fr. Pedro de Santa Fe

Aniz de Ituren (Pamplona)

AGN, Irache, Lib. 542, 119r.

ESTEBAN DE JÁUREGUI

B. A.

15-2-1624

Fr. Pedro de Santa Fe

Segura (Pamplona)

AGN, Irache, Lib. 542, 119r.

MARTÍN DE ZUNZARREN

B. A.

15-2-1624

Fr. Pedro de Santa Fe

Beariz (Pamplona)

AGN, Irache, Lib. 542, $119 r$. 
BALTASAR DE ARIZÁBAL

B. A.

15-2-1624

Fr. Pedro de Santa Fe

Pamplona

AGN, Irache, Lib. 542, 119 r.

MARTÍN DE IRAOLA

B. A.

15-2-1624

Fr. Pedro de Santa Fe

Isasondo (Pamplona)

AGN, Irache, Lib. 542, 119r.

PEDRO DE LIZASO

B. A.

15-2-1624

Fr. Pedro de Santa Fe

Villava (Pamplona)

AGN, Irache, Lib. 542, 119r.

FRANCISCO ROMEO

B. T. / L. T. / D. T.

15-2-1624 / 11-6-1633

Fr. Mauro García de Mendoza / Fr. Francisco Cambero

O. C.

Zaragoza

M. A.

AGN, Irache, Lib. 542, 119r, 198r.

\section{LUIS IBÁÑNZZ}

B. C.

8-3-1624

Fr. Mauro García de Mendoza

Sotresgudo (Burgos)

AGN, Irache, Lib. 542, 119.

PEDRO DE CESURA HURTADO

B. C.

12-3-1624

Fr. Francisco de Borja

Burgos

AGN, Irache, Lib. 542, $119 \mathrm{v}$.

PEDRO DE SALAZAR

B. C. / L. C.

12-3-1624
Fr. Mauro García de Mendoza / Fr. Benito de la Serna

Madrid (Toledo)

Deán de Siguenza

AGN, Irache, Lib. 542, 119v.

DIONISIO PENA

B. C.

13-4-1624

Fr. Benito de la Serna

Villasandino (Burgos)

AGN, Irache, Lib. 542, 12 or.

DIEGO AGUADO

B. C.

13-4-1624

Fr. Benito de la Serna

Villasandino (Burgos)

AGN, Irache, Lib. 542, 12 or.

ANTONIO ÁLVAREZ

B. C.

13-4-1624

Fr. Mauro García de Mendoza

Villasandino (Burgos)

AGN, Irache, Lib. 542, 12 or.

SANTIAGO CRUZADO

B. C.

13-4-1624

Fr. Mauro García de Mendoza

Villasandino (Burgos)

AGN, Irache, Lib. 542, 120 .

DIEGO PRIETO

B. C.

13-4-1624

Fr. Mauro García de Mendoza

Villasandino (Burgos)

AGN, Irache, Lib. 542, 120 .

PEDRO MARTÍNEZ

B. C.

14-4-1624

Fr. Benito de la Serna

Villasandino (Burgos)

AGN, Irache, Lib. 542, 12 or. 
ESTEBAN DE HAZA

L. T. / D. T.

19-4-1624

Fr. Benito de la Serna

Estella (Pamplona)

AGN, Irache, Lib. 542, 120 .

PEDRO MIGUEL

L. C. / D. C.

20-4-1624

Fr. Mauro García de Mendoza

Villar del Río (Calahorra)

AGN, Irache, Lib. 542, 12 or.

FRANCISCO SANTOS

B. C.

25-4-1624

Fr. Francisco de Borja

Villasandino (Burgos)

AGN, Irache, Lib. 542, $120 v$.

LORENZO GIMÉNEZ

L. C.

25-4-1624

Fr. Francisco de Borja

Pamplona

AGN, Irache, Lib. 542, $120 v$.

JUAN DE BASCONES

B. C.

26-4-1624

Fr. Mauro García de Mendoza

Covarrubias (Nullius Diocesis)

AGN, Irache, Lib. 542, $120 v$.

JUAN SÁNCHEZ DE ÁVILA

B. $\mathrm{M}$.

26-4-1624

Fr. Benito de la Serna

... (Toledo)

AGN, Irache, Lib. 542, $120 v$.

PEDRO DE HARO

B. M.

26-4-1624

Fr. Francisco de Borja

... (Toledo)

AGN, Irache, Lib. 542, 120v.
JUAN DE LA REGATA

B. C. / L. C. / D. C.

3-5-1624 / 1-10-1629

Fr. Benito de la Serna / Fr. Francisco Sal-

vador

Cianca (Burgos)

Canónigo de Burgos

AGN, Irache, Lib. 542, 120v, 168r.

JUAN BAUTISTA GARCÍA

B. C.

3-5-1624

Fr. Francisco de Borja

Burgos

AGN, Irache, Lib. 542, $120 v$.

AGUSTÍN DE BENAVENTE

L. A. / M. A. / L. T. / M. T.

21-5-1624

Fr. Antonio Cornejo

O. S. B.

San Benito el Real de Valladolid

AGN, Irache, Lib. 542, 121 r.

JUAN DE JARABA

L. A. / M. A. / L. T. / M. T.

21-5-1624

Fr. Antonio Cornejo

O. S. B.

Ntra. Señora la Real de Montserrat

AGN, Irache, Lib. 542, 121r.

DIEGO DE CASTEJÓN Y CONTRERAS

L. C.

21-5-1624

Fr. Benito de la Serna

Agreda (Tarazona)

AGN, Irache, Lib. 542, 121 .

JUAN LLORENTE

B. C. / L. C. / D. C.

22-5-1624

Fr. Mauro García de Mendoza

Agreda (Tarazona)

AGN, Irache, Lib. 542, 121 r.

GASPAR LUIS

B. C. 
1-6-1624

Fr. Benito de la Serna

Burgos

AGN, Irache, Lib. 542, 121r.

MIGUEL DE MUÉS

B. A.

1-6-1624

Fr. Pedro de Santa Fe

Villatuerta (Pamplona)

AGN, Irache, Lib. 542, 121V.

BERNARDO DE PORTAL

B. A.

1-6-1624

Fr. Pedro de Santa Fe

Cirauqui (Pamplona)

AGN, Irache, Lib. 542, 121v.

JUAN DE OCHOA

B. A.

1-6-1624

Fr. Pedro de Santa Fe

Piedramillera (Pamplona)

AGN, Irache, Lib. 542, $121 \mathrm{v}$.

RAMIRO MARTÍNEZ

B. A.

1-6-1624

Fr. Pedro de Santa Fe

Arellano (Pamplona)

AGN, Irache, Lib. 542, 121v.

JUAN DOMÍNGUEZ

B. A.

1-6-1624

Fr. Pedro de Santa Fe

Belascoain (Pamplona)

AGN, Irache, Lib. 542, $121 \mathrm{v}$.

MIGUEL DE GANUZA

B. A.

1-6-1624

Fr. Pedro de Santa Fe

Estella (Pamplona)

AGN, Irache, Lib. 542, $121 \mathrm{v}$.

FRANCISCO DE DURANGO

B. A.
1-6-1624

Fr. Pedro de Santa Fe

Estella (Pamplona)

AGN, Irache, Lib. 542, $121 \mathrm{v}$.

PEDRO DE ARIAS

B. A.

1-6-1624

Fr. Pedro de Santa Fe

Dicastillo (Pamplona)

AGN, Irache, Lib. 542, 121v.

DIEGO CALIXTO RAMÍREZ

L. L. / D. L.

12-6-1624

Fr. Francisco de Borja

Zaragoza

AGN, Irache, Lib. 542, $121 \mathrm{v}$.

JERÓNIMO DE SUVIA

B. C.

13-6-1624

Fr. Francisco de Borja

Burgos

AGN, Irache, Lib. 542, 121v.

JUAN DE LEÓN

B. C.

13-6-1624

Fr. Mauro García de Mendoza

Burgos

AGN, Irache, Lib. 542, 121v.

DIEGO DE AYERRA

B. A.

17-6-1624

Fr. Benito de la Serna

Valtierra (Pamplona)

AGN, Irache, Lib. 542, 121v.

ANDRÉS GARCÍA DEL MORAL

B. C.

18-6-1624

Fr. Francisco de Borja

Medina de Pomar

AGN, Irache, Lib. 542, 122 r.

ALONSO DE TEJERINA

L. C. / D. C. 
2-7-1624

Fr. Benito de la Serna

Cisneros (León)

AGN, Irache, Lib. 542, 122 r.

LUCAS MELÉNDEZ DE MIRANDA

B. C.

4-7-1624

Fr. Mauro García de Mendoza

Guadalajara (Toledo)

AGN, Irache, Lib. 542, 122 r.

FRANCISCO MANUEL

L. C. / D. C.

7-7-1624

Fr. Mauro García de Mendoza

Villalón (León)

AGN, Irache, Lib. 542, 122 r.

\section{SEBASTIÁN MECA}

B. C.

8-7-1624

Fr. Benito de la Serna

Alfaro (Tarazona)

AGN, Irache, Lib. 542, 122 r.

JUAN DE OCHOA

L. C.

11-7-1624

Fr. Benito de la Serna

San Martín de Unx (Burgos)

AGN, Irache, Lib. 542, $122 \mathrm{v}$.

ALONSO ESTÉBANEZ

B. C.

12-7-1624

Fr. Francisco de Borja

Aguilar (Burgos)

AGN, Irache, Lib. 542, $122 \mathrm{v}$.

ATANASIO JIMÉNEZ

L. C.

27-7-1624

Fr. Benito de la Serna

Arnedo (Calahorra)

AGN, Irache, Lib. 542, 122v.

JUAN BAUTISTA DE GAMARRA

L. C.
31-7-1624

Fr. Antonio Cornejo

Foronda (Calahorra)

AGN, Irache, Lib. 542, $122 \mathrm{~V}$.

BERNABÉ ORTIZ

B. C.

4-8-1624

Fr. Mauro García de Mendoza

Espinosa del Camino (Burgos)

AGN, Irache, Lib. 542, 123 r.

JUAN MARTÍNEZ

B. T.

8-8-1624

Fr. Francisco de Borja

Cogollos (Burgos)

AGN, Irache, Lib. 542, 123 r.

FRANCISCO DE ORTEGA

B. C.

10-8-1624

Fr. Mauro García de Mendoza

Presencio (Burgos)

AGN, Irache, Lib. 542, 123r.

MARTÍN JUAN DE MUR

L. L.

14-8-1624

Fr. Francisco de Borja

Zaragoza

AGN, Irache, Lib. 542, 123 r.

JUAN BERNAL

B. C.

21-8-1624

Fr. Mauro García de Mendoza

Villanueva del Conde (Burgos)

AGN, Irache, Lib. 542, $123 \mathrm{v}$.

DIEGO SANZ

B. T.

23-8-1624

Fr. Mauro García de Mendoza

Soria (Osma)

AGN, Irache, Lib. 542, $123 \mathrm{v}$.

MIGUEL DE GORRI

B. L. 
26-8-1624

Fr. Francisco de Borja

Viana (Calahorra)

AGN, Irache, Lib. 542, $123 \mathrm{v}$.

JOSÉ BRAVO

B. C.

3-9-1624

Fr. Mauro García de Mendoza

Burgos

AGN, Irache, Lib. 542, 124r.

DOMINGO DE MIERES

L. C.

4-9-1624

Fr. Mauro García de Mendoza

Liérganes (Burgos)

AGN, Irache, Lib. 542, 124r.

\section{ALONSO GARCÍAS}

B. C.

4-9-1624

Fr. Francisco de Borja

Presencio (Burgos)

AGN, Irache, Lib. 542, 124r.

JERÓNIMO MARTÍNEZ

L. C.

10-9-1624

Fr. Francisco de Borja

Sordillos (Burgos)

AGN, Irache, Lib. 542, 124r.

JUAN DE NEGRETE

B. T. / L. T.

10-9-1624 / 11-9-1624

Fr. Mauro García de Mendoza

Agüero (Burgos)

AGN, Irache, Lib. 542, 124V.

JUAN DE MORALES BUENAÑO ANGUI-

TA

L. C.

14-9-1624

Fr. Francisco de Borja

Martos (Osuna)

AGN, Irache, Lib. 542, 124v.
JUAN DE LOS COCTOS SOTO

L. C.

19-9-1624

Fr. Francisco de Borja

Santander (Burgos)

AGN, Irache, Lib. 542, 124v.

RAMIRO DE GORRI

B. L.

22-9-1624

Fr. Francisco de Borja

Viana (Calahorra)

AGN, Irache, Lib. 542, 125r.

MARTÍN ANTONIO DE PUERTA

L. - / D. -

25-9-1624

Fr. Francisco de Borja

Colindres (Burgos)

AGN, Irache, Lib. 542, 125r.

ANDRÉS SARABIA

B. C.

25-9-1624

Fr. Francisco de Borja

Laredo (Burgos)

AGN, Irache, Lib. 542, 125r.

PEDRO DEL CASTILLO

B. C.

25-9-1624

Fr. Francisco de Borja

Laredo (Burgos)

AGN, Irache, Lib. 542, 125r.

JERÓNIMO DE LA MUELA

L. C.

29-9-1624

Fr. Francisco de Borja

Molina de Aragón (Sigüenza)

AGN, Irache, Lib. 542, 125r.

ANTONIO MEDEROS

B. A.

8-10-1624

Fr. Bernardo de la Puerta, vicecanciller Atienza (Sigüenza)

AGN, Irache, Lib. 542, 125v. 
PEDRO DE CESO

B. A.

21-10-1624

Fr. Mauro García de Mendoza

Castillonuevo (Pamplona)

AGN, Irache, Lib. 542, 125v.

MARTÍN DE REIZU

B. -

21-10-1624

Fr. Mauro García de Mendoza

Puente la Reina (Pamplona)

AGN, Irache, Lib. 542, 125v.

PEDRO DE LUMBRERAS

L. C. / D. C.

26-10-1624

Fr. Mauro García de Mendoza

Logroño (Calahorra)

AGN, Irache, Lib. 542, 125v.

FRANCISCO DE BRIZUELA

B. C. / L. C. / D. C.

27-10-1624 / 23-6-1625

Fr. Mauro García de Mendoza

Berlanga (Sigüenza)

AGN, Irache, Lib. 542, 125v, 131r.

ALONSO FREILE

B. C.

13-11-1624

Fr. Francisco de Borja

Tórtoles (Burgos)

AGN, Irache, Lib. 542, 126r.

MARTÍN DÍAZ DE POZAS

B. $\mathrm{T}$.

17-11-1624

Fr. Mauro García de Mendoza

Lacrilla

AGN, Irache, Lib. 542, 126r.

JUAN MARTÍNEZ

B. C.

19-11-1624

Fr. Mauro García de Mendoza

Rui...

AGN, Irache, Lib. 542, $126 r$.

\section{JUAN DE MALUENDA}

B. M.

20-11-1624

Fr. Francisco de Borja

Calatayud (Zaragoza)

AGN, Irache, Lib. 542, 126r.

SEBASTIÁN DE MECA

L. C.

29-11-1624

Fr. Mauro García de Mendoza

Alfaro (Tarazona)

AGN, Irache, Lib. 542, 126r.

JUAN DE VICURIA

L. T. / D. T.

29-11-1624

Fr. Antonio Cornejo

Estella (Pamplona)

AGN, Irache, Lib. 542, $126 \mathrm{v}$.

MIGUEL DE LIÑÁN Y DE GALIANO

L. C. / D. C.

16-12-1624

Fr. Antonio Cornejo

Calatayud (Tarazona)

AGN, Irache, Lib. 542, 126v.

MIGUEL DE LEBRIJA

L. C. / D. C.

3-1-1625

Fr. Antonio Cornejo

C. R. S. A.

AGN, Irache, Lib. 542, $126 \mathrm{v}$.

MIGUEL GARCÍA

B. C.

4-1-1625

Fr. José de Carmona

Quintana (Burgos)

AGN, Irache, Lib. 542, 127r.

FERNANDO DE MIRANDA

B. C.

26-1-1625

Fr. Mauro García de Mendoza

Castrojeriz

AGN, Irache, Lib. 542, $127 r$. 
JOSÉ DE VIBERRI

B. C.

4-2-1625

Fr. Francisco de Borja

Pamplona

AGN, Irache, Lib. 542, 127 r.

JUAN DE QUINTANA

B. C.

23-2-1625

Fr. José de Carmona

Brul (Burgos)

AGN, Irache, Lib. 542, 127r.

ESTEBAN GUTIÉRREZ DE MEDINA

B. A. / B. T. / L. T. / D. T.

23-2-1625 / 24-2-1625

Fr. Antonio Cornejo

Serencia - Priorato de San Juan

AGN, Irache, Lib. 542, $127 \mathrm{v}$.

MARTÍN DE PARRAST

L. C.

14-3-1625

Fr. Antonio Cornejo

Pamplona

AGN, Irache, Lib. 542, $127 \mathrm{v}$.

RAFAEL SIURANA

L. C. / D. C.

3-4-1625

Fr. Antonio Cornejo

Ráfales (Zaragoza)

AGN, Irache, Lib. 542, $127 \mathrm{v}$.

JUAN DE VESGA Y VALDERRAMA

B. C.

24-3-1625

Fr. José de Carmona

Navarrete (Calahorra)

AGN, Irache, Lib. 542, 128r.

MIGUEL URDÁNIZ

L. L.

4-4-1625

Fr. Antonio Cornejo

Pamplona

AGN, Irache, Lib. 542, 128r.
MARTÍN DE ALPIZUETA

L. C.

4-4-1625

Fr. Antonio Cornejo

Pamplona

AGN, Irache, Lib. 542, 128r.

TOMÁS DE ROBLES Y LERMA

B. C. / L. C.

19-4-1625

Fr. Francisco de Borja

Arnedo (Calahorrra)

AGN, Irache, Lib. 542, 128v.

BERNARDINO DE VEGA

L. C. / D. C.

15-4-1625

Fr. Bernardo de la Puerta

Sahagún (Palencia)

AGN, Irache, Lib. 542, 128v.

ALONSO DE IRISARRI

B. A.

24-4-1625

Fr. Bernardo de la Puerta

Pamplona

AGN, Irache, Lib. 542, 128v.

DIEGO DE EGUÉS

B. A.

24-4-1625

Fr. Bernardo de la Puerta

Pamplona

AGN, Irache, Lib. 542, 128v.

JOSÉ DE LODOSA

B. A.

24-4-1625

Fr. Bernardo de la Puerta

Puente la Reina (Pamplona)

AGN, Irache, Lib. 542, 128v.

JOSÉ DE OTEIZA

B. A.

24-4-1625

Fr. Bernardo de la Puerta

Pamplona

AGN, Irache, Lib. 542, 128v. 
JUAN DE ARANCENA

B. A.

24-4-1625

Fr. Bernardo de la Puerta

Ciga (Pamplona)

AGN, Irache, Lib. 542, 128v.

FRANCISCO LAZCANO

B. A.

24-4-1625

Fr. Bernardo de la Puerta

Estella (Pamplona)

AGN, Irache, Lib. 542, 128v.

NICOLÁS DE CIORDIA

B. A.

24-4-1625

Fr. Bernardo de la Puerta

Pamplona

AGN, Irache, Lib. 542, 128v.

MATEO DE GARRO

B. A.

24-4-1625

Fr. Bernardo de la Puerta

Pamplona

AGN, Irache, Lib. 542, 128v.

ANTONIO DE VIGURIA

B. A.

24-4-1625

Fr. Bernardo de la Puerta

Villafranca (Pamplona)

AGN, Irache, Lib. 542, 128v.

MIGUEL DE ERVITI

B. A.

24-4-1625

Fr. Bernardo de la Puerta

Pamplona

AGN, Irache, Lib. 542, 128v.

IVO DE ILUNDÁIN

B. A.

24-4-1625

Fr. Bernardo de la Puerta

Ilundáin (Pamplona)

AGN, Irache, Lib. 542, 128v.

\section{LUIS DE EGUILIOR}

B. A.

24-4-1625

Fr. Bernardo de la Puerta

Pamplona

AGN, Irache, Lib. 542, 128v.

LUIS PÉREZ DE SAGASETA

B. A.

24-4-1625

Fr. Bernardo de la Puerta

Pamplona

AGN, Irache, Lib. 542, 128v.

MARTÍN DE CIRIZA

B. A.

24-4-1625

Fr. Bernardo de la Puerta

Artazcoz (Pamplona)

AGN, Irache, Lib. 542, 128v.

JUAN DE MADARIAGA

B. A.

24-4-1625

Fr. Bernardo de la Puerta

Estella (Pamplona)

AGN, Irache, Lib. 542, 128v.

JUAN BAUTISTA DE VITORINO

B. A.

24-4-1625

Fr. Bernardo de la Puerta

Villafranca (Pamplona)

AGN, Irache, Lib. 542, 128v.

MARCOS DE ANDRADE

B. A.

24-4-1625

Fr. Bernardo de la Puerta

Artajona (Pamplona)

AGN, Irache, Lib. 542, 128v.

FERMÍN DE IRIGOYEN

B. A.

24-4-1625

Fr. Bernardo de la Puerta

A... (Pamplona)

AGN, Irache, Lib. 542, 128v. 


\section{MARTÍN DE IRIARTE}

B. A.

24-4-1625

Fr. Bernardo de la Puerta

Cirauqui (Pamplona)

AGN, Irache, Lib. 542, 128v.

MARTÍN DE ERASO

B. A.

24-4-1625

Fr. Bernardo de la Puerta

Neguri (Pamplona)

AGN, Irache, Lib. 542, 128v.

JUAN GARCÍA DE GALDEANO

B. A.

24-4-1625

Fr. Bernardo de la Puerta

Pamplona

AGN, Irache, Lib. 542, 129 r.

FRANCISCO DE MAULEÓN

B. A. / L. A.

24-4-1625

Fr. Bernardo de la Puerta

Arróniz (Pamplona)

AGN, Irache, Lib. 542, 129 r.

MIGUEL DE SALINAS

B. A.

24-4-1625

Fr. Bernardo de la Puerta

Salinas (Pamplona)

AGN, Irache, Lib. 542, 129 r.

DIEGO SÁNCHEZ

B. A.

24-4-1625

Fr. Bernardo de la Puerta

Pamplona

AGN, Irache, Lib. 542, 129 r.

JUAN DE EZPELETA

B. A.

24-4-1625

Fr. Bernardo de la Puerta

Pamplona

AGN, Irache, Lib. 542, 129 r.
MARTÍN DE JACUE

B. A.

24-4-1625

Fr. Bernardo de la Puerta

Pamplona

AGN, Irache, Lib. 542, 129 r.

ANTONIO DE LIZASOAIN

B. A.

24-4-1625

Fr. Bernardo de la Puerta

Aoiz (Tarazona)

AGN, Irache, Lib. 542, 129 r.

MARTÍN DE EZPELETA

B. A.

24-4-1625

Fr. Bernardo de la Puerta

Pamplona

AGN, Irache, Lib. 542, 129 r.

PEDRO NAVARRO

B. A.

24-4-1625

Fr. Bernardo de la Puerta

Viana (Pamplona)

AGN, Irache, Lib. 542, 129 r.

ALONSO DE SALINAS

B. A.

24-4-1625

Fr. Bernardo de la Puerta

Salinas (Pamplona)

AGN, Irache, Lib. 542, $129 r$.

SANTIAGO DE CASTRO

B. C.

27-4-1625

Fr. José de Carmona

Castrojeriz (Burgos)

AGN, Irache, Lib. 542, 129r.

JUAN MARTÍNEZ

B. C.

30-4-1625

Fr. Francisco de Borja

Santibáñez (Burgos)

AGN, Irache, Lib. 542, $129 v$. 
GASPAR GONZÁLEZ

B. C.

3-5-1625

Fr. José de Carmona

Villasandino (Burgos)

AGN, Irache, Lib. 542, $129 \mathrm{v}$.

JUAN GONZÁLEZ

B. C.

3-5-1625

Fr. José de Carmona

Villasandino (Burgos)

AGN, Irache, Lib. 542, $129 \mathrm{v}$.

PEDRO GUTIÉRREZ

B. C.

3-5-1625

Fr. José de Carmona

Villasandino (Burgos)

AGN, Irache, Lib. 542, 129v.

PEDRO DE OLÓRIZ

L. L.

5-5-1625

Fr. José de Carmona

Pamplona

AGN, Irache, Lib. 542, $129 \mathrm{v}$.

JUAN IBÁÑNEZ

L. L.?

11-5-1625

Fr. José de Carmona

Canilla de Jubara (Calahorra)

AGN, Irache, Lib. 542, $129 \mathrm{v}$.

CRISTÓBAL DÍAZ ANDINO

B. C.

29-5-1625

Fr. Plácido de Urbina

Moneo (Burgos)

AGN, Irache, Lib. 542, 13 or.

DIEGO DÍAZ DE ARBEIZA

B. A. / B. M.

2-6-1625

Fr. Juan de Radin

Estella (Pamplona)

AGN, Irache, Lib. 542, 13 or.
JUAN GARCÍA DE PRADO

B. C.

6-6-1625

Fr. José de Carmona

Renedo (Burgos)

AGN, Irache, Lib. 542, 13 or.

JUAN DE SERVITA

B. A. / L. T. / M. T.

8-6-1625

Fr. Mauro García de Mendoza, Rector y

Abad

O. C.

AGN, Irache, Lib. 542, 13 or.

MIGUEL DE GRESA

B. T.

7-6-1625

Fr. José de Carmona

Valmaseda (Burgos)

AGN, Irache, Lib. 542, $130 v$.

PEDRO RUIZ

B. C.

11-6-1625

Fr. José de Carmona

Carranza (Burgos)

AGN, Irache, Lib. 542, 130v.

PEDRO DE LAS HERAS

B. C.

13-6-1625

Fr. Francisco de Borja

Barbadillo del Mercado (Burgos)

AGN, Irache, Lib. 542, $130 v$.

ANTONIO RODRÍGUEZ

B. C.

13-6-1625

Fr. Francisco de Borja

Castrojeriz (Burgos)

AGN, Irache, Lib. 542, $130 v$.

FRANCISCO DE TREJANOS

B. C.

14-6-1625

Fr. José de Carmona

Villasilos (Burgos)

AGN, Irache, Lib. 542, $130 v$. 


\section{MARCOS LÓPEZ}

B. C.

20-6-1625

Fr. José de Carmona

Zumel (Burgos)

AGN, Irache, Lib. 542, $130 v$.

FRANCISCO TOMÉ

B. C.

21-6-1625

Fr. José de Carmona

... (Burgos)

AGN, Irache, Lib. 542, $130 v$.

ANTONIO HURTADO DE MENDOZA

L. C.

22-6-1625

Fr. Mauro García de Mendoza

Castro (Burgos)

AGN, Irache, Lib. 542, $130 v$.

JUAN SIMÓN DE ...

L. - / D. -

22-6-1625

...

AGN, Irache, Lib. 542, 131r.

PEDRO DE RIBAS

B. A. / B. T.

22-6-1625

Fr. Mauro García de Mendoza

O. Cist.

Sta. María de Veruela

AGN, Irache, Lib. 542, 131r.

PEDRO DE SOTO

L. C.

26-6-1625

Fr. Mauro García de Mendoza

Torrecilla (Calahorra)

AGN, Irache, Lib. 542, 131r.

FRANCISCO DE URRETA

B. C.

3-7-1625

Fr. José de Carmona

Burgos

AGN, Irache, Lib. 542, 131r.

\section{PEDRO DE ALTUNA}

B. L. / L. L.

7-7-1625 / 1-7-1628

Fr. Juan de Redín / Fr. Bernardo de Hon-

tiveros

Metauten (Pamplona)

AGN, Irache, Lib. 542, 131v, 158v.

ANTONIO LÓPEZ DE PLASENCIA

B. C. / L. C. / D. C.

14-8-1625

Fr. Mauro García de Mendoza

Racionero de Plasencia

AGN, Irache, Lib. 542, 131v.

\section{FRANCISCO GARRIDO}

B. A. / L. A. / D. A.

14-8-1625

Fr. Mauro García de Mendoza

Alfaro (Calahorra)

AGN, Irache, Lib. 542, 131v.

PEDRO DE SANTA FE

B. A. / L. A. / D. A. / B. T. / L. T. / D. T.

15-8-1625

Fr. Mauro García de Mendoza

O.S. B.

De Silos. Profeso en Montserrat

AGN, Irache, Lib. 542, 131v.

\section{JUAN AGUSTÍN DE USCARRÉS}

B. A.

17-8-1625

Fr. Bernardo de la Puerta

Tudela (Nullius Diocesis)

AGN, Irache, Lib. 542, 132r.

PEDRO DE LA PUENTE MONTECILLO

B. C.

24-8-1625

Fr. José de Carmona

Llanes (Burgos)

AGN, Irache, Lib. 542, 132r.

JUAN RAMÍREZ DE RIGA

B. C.

26-8-1625

Fr. Juan de Redín 
Matute (Pamplona)

AGN, Irache, Lib. 542, 132r.

\section{DIEGO LÓPEZ DE MIRAFUENTES}

B. A.

4-9-1625

Fr. Bernardo de la Puerta

Falces (Pamplona)

AGN, Irache, Lib. 542, 132 r.

FELIPE DE LOPE

B. C.

8-9-1625

Fr. Juan de Redín

San Vicente de Toranzo (Burgos)

AGN, Irache, Lib. 542, 132r.

MIGUEL DE ARBIZU

B. T. / L. T. / D. T.

8-9-1625 / 9-9-1625

Fr. Juan de Redín / Fr. Mauro García de

Mendoza

... (Zaragoza)

AGN, Irache, Lib. 542, 132v.

PEDRO DE EZQUERRA

B. C. / L. C. / D. C.

12-9-1625 / 13-9-1625

Fr. Juan de Redín / Fr. Mauro García de

Mendoza

Alfaro (Calahorra)

AGN, Irache, Lib. 542, $132 \mathrm{v}$.

\section{BERNARDO DE SOTO}

B. C.

18-9-1625

Fr. Juan de Redín

Santa María del Campo

AGN, Irache, Lib. 542, 133 r.

JOSÉ DEL RÍO

B. A. / L. A. / M. A.

25-9-1625

Fr. Juan de Redín / Fr. Mauro García de

Mendoza

Laredo (Burgos)

AGN, Irache, Lib. 542, 133r.

\section{PEDRO DE OZCÁRIZ}

L. T.

12-10-1625

Fr. Juan de Redín

Pamplona

AGN, Irache, Lib. 542, 133r.

TOMÉ DEL RÍO

B. C.

17-10-1625

Fr. Juan de Redín

Castro (Burgos)

AGN, Irache, Lib. 542, $133 v$.

JUAN PACHECO

B. C.

4-10-1625

Fr. Juan de Redín

Alcedo (Burgos)

AGN, Irache, Lib. 542, 133v.

MARCOS DE ARGUETA

L. C.

8-10-1625

...

AGN, Irache, Lib. 542, 133 v.

ANDRÉS DE MONEO

B. C.

15-10-1625

Fr. José de Carmona

Villamayor [de los Montes] (Burgos)

AGN, Irache, Lib. 542, 133v.

ALONSO DE MONTEALEGRE

B. A. / L. A.

19-10-1625

Fr. Mauro García de Mendoza

Toro (Zamora)

AGN, Irache, Lib. 542, 134r.

JACOBO DE RIOJA BADILLO

B. C.

19-10-1625

Fr. Juan de Redín

... Palencia

AGN, Irache, Lib. 542, 134r. 
DOMINGO DE ITURGAIZ

L. C.

22-10-1625

Fr. Mauro García de Mendoza

Guetaria (Pamplona)

AGN, Irache, Lib. 542, 134r.

JOAQUÍN DE VILLAFRANCA

L. C.

22-10-1625

Fr. Mauro García de Mendoza

Ranilla de Guetaria (Pamplona)

AGN, Irache, Lib. 542, 134r.

CRISTÓBAL FERNÁNDEZ DE VILLAROEL

L. C.

27-10-1625

Fr. Juan de Redín

Castrojeriz (Burgos)

AGN, Irache, Lib. 542, 134v.

FRANCISCO DE FRÍAS

B. C.

4-11-1625

Fr. Juan de Redín

Logroño (Calahorra)

AGN, Irache, Lib. 542, 134v.

GARCÍA DE TOLEDO MOCTEZUMA

B. C. / L. C.

16-11-1625

Fr. Mauro García de Mendoza

Cáceres (Coria)

AGN, Irache, Lib. 542, 134v.

MARTÍN DE LA PUENTE

B. C. / L. C.

23-11-1625

Fr. José de Carmona

Yanguas (Calahorra)

AGN, Irache, Lib. 542, 134V.

FRANCISCO DE BORJA

B. A. / L. A. / D. A. / B. T. / L. T. / D. T.

23-12-1625

Fr. Juan de Redín

O. S. B.

AGN, Irache, Lib. 542, 135r.
GREGORIO DE TORRECILLA

B. T. / L. T.

23-12-1625

Fr. Juan de Redín

Dagrón (Calahorra)

AGN, Irache, Lib. 542, 135r.

FRANCISCO DE ESCALANTE

B. C.

5-3-1626

Fr. Francisco de Borja

Castillo de Mencía (Burgos)

AGN, Irache, Lib. 542, 135r.

SIMÓN PÉREZ

B. C.

6-3-1626

Fr. José de Carmona

... (Burgos)

AGN, Irache, Lib. 542, 135v.

JERÓNIMO DE LERMA

B. C. / L. C.

10-3-1626

Fr. Mauro García de Mendoza

Alfaro (Calahorra)

AGN, Irache, Lib. 542, 135v.

JERÓNIMO DE SANTOS

B. C.

12-3-1626

Fr. Francisco de Borja

Rinconejos (Burgos)

AGN, Irache, Lib. 542, 135v.

GUILLERMO FERNÁNDEZ

B. C.

12-3-1626

Fr. Francisco de Borja

Lobillo

AGN, Irache, Lib. 542, 135v.

MIGUEL DE TORRES

B. C.

17-3-1626

Fr. Juan de Redín

Horna (Burgos)

AGN, Irache, Lib. 542, 136r. 
FRANCISCO SÁNCHEZ

B. C.

20-3-1626

Fr. Francisco de Borja

Celada del Camino (Burgos)

AGN, Irache, Lib. 542, 136r.

VICENTE DE URVINO

B. C.

21-3-1626

Fr. Juan de Redín

Berberana (Burgos)

AGN, Irache, Lib. 542, 136r.

JERÓNIMO DE YANGUAS

L. M. / D. M.

24-3-1626

Fr. José de Carmona

Haro (Calahorra)

AGN, Irache, Lib. 542, 136r.

ADRIÁN ISAURRAGA

B. A.

29-3-1626

Fr. Bernardo de la Puerta

Aulestia (Calahorra)

AGN, Irache, Lib. 542, 136v.

PEDRO DE ANGULO

B. A. / L. A. / M. A.

1-4-1626

Fr. Mauro García de Mendoza

Madrid (Toledo)

AGN, Irache, Lib. 542, 136v.

MIGUEL DE LOYA

B. C.

1-6-1626

Fr. José de Carmona

Sangüesa (Pamplona)

AGN, Irache, Lib. 542, 136v.

JOSÉ DE JUBERA

B. A.

12-6-1626

Fr. Bernardo de la Puerta

Soria (Osma)

AGN, Irache, Lib. 542, 136v.
FRANCISCO DE LA SARRA VENERO

B. C.

26-4-1626

Fr. Francisco de Borja

Meruelo (Burgos)

AGN, Irache, Lib. 542, 137r.

JUAN GONZÁLEZ

B. C.

29-4-1626

Fr. Juan de Redín

Quintana de Coma (Burgos)

AGN, Irache, Lib. 542, 137r.

MIGUEL DE ERASO

L. T. / D. T.

1-5-1626

Fr. Mauro García de Mendoza

Chávarri (Pamplona)

Canónigo de Pamplona

AGN, Irache, Lib. 542, 137r.

JERÓNIMO DÍEZ MAESTRO

B. C.

16-5-1626

Fr. José de Carmona

Padilla de Arriba (Burgos)

AGN, Irache, Lib. 542, $137 \mathrm{v}$.

ANTONIO DE ALCOCER

L. C.

23-5-1626

Fr. Mauro García de Mendoza

Toledo

AGN, Irache, Lib. 542, $137 \mathrm{v}$.

JUAN CORNEJO

B. T. / L. T. / D. T.

24-5-1626

Fr. Mauro García de Mendoza

O. Praem.

AGN, Irache, Lib. 542, 137v.

ANTONIO BLANCO

B. C.

25-5-1626

Fr. José de Carmona

Palenzuela (Burgos)

AGN, Irache, Lib. 542, 138r. 
BERNARDO BLANCO

B. C.

25-5-1626

Fr. José de Carmona

Palenzuela (Burgos)

AGN, Irache, Lib. 542, 138r.

JUAN DE ALARCÓN

B. C.

2-6-1626

Fr. Bernardo de la Puerta

Almodóbar (Cuenca)

AGN, Irache, Lib. 542, 138r.

JUAN DE LUCIO PARDO

B. C.

2-5-1626

Fr. José de Carmona

Urmaela? (Burgos)

AGN, Irache, Lib. 542, 138r.

JOSÉ DE VIVERO

L. C.

9-6-1626

Fr. Mauro García de Mendoza

Pamplona

AGN, Irache, Lib. 542, 138r.

J. PARDO

B. C.

10-6-1626

Fr. José de Carmona

Marmellar (Burgos)

AGN, Irache, Lib. 542, 138v.

DIEGO PLAZUELA DE MONTESERÍN

...

11-6-1626

Fr. José de Carmona

Madrid (Toledo)

AGN, Irache, Lib. 542, 138v.

PEDRO BRACHO

B. C.

8-7-1626

Fr. José de Carmona

Ruiseñada (Burgos)

AGN, Irache, Lib. 542, 138v.
JUAN DE POZAL

B. C.

10-7-1626

Fr. José de Carmona

... (Burgos)

AGN, Irache, Lib. 542, 138v.

DIEGO DE MEDRANO

B. C.

12-7-1626

Fr. Bernardo de la Puerta

Agreda (Tarazona)

AGN, Irache, Lib. 542, 139r.

JUAN DE RIAÑO

L. T.

15-7-1626

Fr. José de Carmona

Arre (Pamplona)

AGN, Irache, Lib. 542, 139r.

ONOFRE IBÁÑEZ

B. A. / L. A.

15-7-1626

Fr. José de Carmona

Peralta (Pamplona)

AGN, Irache, Lib. 542, 139v.

DOMINGO SANTIAGO PÉREZ

B. T.

21-7-1626

Fr. Bernardo de la Puerta

Canicosa (Osma)

AGN, Irache, Lib. 542, 139v.

FRANCISCO DE SANTA MARÍA

D. L.

31-7-1626

Fr. José de Carmona

Quea (Burgos)

AGN, Irache, Lib. 542, 139v.

DOMINGO DE LA AZUELA VELASCO

L. C. / D. C.

4-8-1626

Fr. Juan de Redín

Azuela (Burgos)

AGN, Irache, Lib. 542, 140r. 


\begin{tabular}{|c|c|}
\hline ANTONIO LORENTE & MIGUEL DE ... \\
\hline L. C. / D. C. & B. A. \\
\hline $10-8-1626$ & $22-8-1626$ \\
\hline Fr. José de Carmona & Fr. Bernardo de la Puerta \\
\hline Rencaña (Calahorra) & Pamplona \\
\hline AGN, Irache, Lib. 542, 14 or. & AGN, Irache, Lib. 542, $140 \mathrm{v}$. \\
\hline JERÓNIMO DE SILOS & MARTÍN DE SETA \\
\hline B. A. & B. A. \\
\hline $13-8-1626$ & $22-8-1626$ \\
\hline Fr. Bernardo de la Puerta & Fr. Bernardo de la Puerta \\
\hline Fitero (Tarazona) & Pamplona \\
\hline AGN, Irache, Lib. 542, 14 or. & AGN, Irache, Lib. 542, $140 v$. \\
\hline ANTONIO SALVADOR & BARTOLOMÉ DE ARLANAZ \\
\hline B. A. & B. A. \\
\hline $22-8-1626$ & $22-8-1626$ \\
\hline Fr. Bernardo de la Puerta & Fr. Bernardo de la Puerta \\
\hline Lumbreras (Calahorra) & Pamplona \\
\hline AGN, Irache, Lib. 542, $140 v$. & AGN, Irache, Lib. 542, $140 v$. \\
\hline JUAN DE ZAMORA & JUAN JIMÉNEZ \\
\hline B. A. / L. A. & B. A. \\
\hline $22-8-1626$ & $22-8-1626$ \\
\hline Fr. Bernardo de la Puerta & Fr. Bernardo de la Puerta \\
\hline Pamplona & Pamplona \\
\hline AGN, Irache, Lib. 542, $140 v$. & AGN, Irache, Lib. 542, $140 \mathrm{v}$ \\
\hline SEBASTIÁN DE SILDIAS & ESTEBAN DE AVACIOSA \\
\hline B. A. & B. A. \\
\hline $22-8-1626$ & $22-8-1626$ \\
\hline Fr. Bernardo de la Puerta & Fr. Bernardo de la Puerta \\
\hline Pamplona & Pamplona \\
\hline AGN, Irache, Lib. 542, $140 v$. & AGN, Irache, Lib. 542, $140 v$. \\
\hline MIGUEL DE CIZUR & ESTEBAN DE SARRO \\
\hline B. A. & B. A. \\
\hline $22-8-1626$ & $22-8-1626$ \\
\hline Fr. Bernardo de la Puerta & Fr. Bernardo de la Puerta \\
\hline Pamplona & Pamplona \\
\hline AGN, Irache, Lib. 542, $140 v$. & AGN, Irache, Lib. 542, $140 \mathrm{v}$. \\
\hline MARTÍN FERNÁNDEZ DE MENDIBIDE & MIGUEL PÉREZ \\
\hline B. A. & B. C. \\
\hline $22-8-1626$ & $1-9-1626$ \\
\hline Fr. Bernardo de la Puerta & Fr. Bernardo de la Puerta \\
\hline Pamplona & Mahamud (Burgos) \\
\hline AGN, Irache, Lib. 542, $140 \mathrm{ov}$ & AGN, Irache, Lib. 542, 141r. \\
\hline
\end{tabular}


FAUSTO DE EUSA

B. L.

10-9-1626

Fr. Bernardo de la Puerta

Pamplona

AGN, Irache, Lib. 542, 141r.

MIGUEL MATÍAS

B. C.

10-9-1626

Fr. Bernardo de la Puerta

Mahamud (Burgos)

AGN, Irache, Lib. 542, 141r.

JUAN DE OTAMENDI Y MONREAL

B. A.

20-9-1626

Fr. José de Carmona

Barasoain (Pamplona)

AGN, Irache, Lib. 542, 141r.

MIGUEL ESCUDERO DE PERALTA

B. C. / L. C.

26-9-1626

Fr. José de Carmona

Comella (Tarazona)

AGN, Irache, Lib. 542, 141v.

ESTEBAN DE PERALTA

B. T. / L. T. / D. T.

28-9-1626

Fr. José de Carmona

O. Cist.

AGN, Irache, Lib. 542, 141v.

MIGUEL DE LUJÁN

B. T. / L. T. / M. T.

16-4-1626

Fr. Mauro García de Mendoza

O. S. B.

AGN, Irache, Lib. 542, 141v.

MARTÍN DE SANTOLARIA

L. T.

6-10-1626

Fr. José de Carmona

Pradoluengo (Burgos)

AGN, Irache, Lib. 542, 142 r.
MARTÍN LORENTE

B. A. / L. A. / B. T. / L. T.

10-10-1626

Fr. Bernardo de la Puerta / Fr. José de Carmona

Mainar (Zaragoza)

AGN, Irache, Lib. 542, 142r.

ANTONIO PAINO

B. T. / L. T.

21-10-1626

Fr. Gregorio Bravo de Sotomayor, Abad y

Rector

Ruiseco (Palencia)

AGN, Irache, Lib. 542, 142r.

MARTÍN DÍAZ

L. T. / D. T.

23-10-1626

Fr. Gregorio Bravo de Sotomayor

Poza (Burgos)

AGN, Irache, Lib. 542, $142 \mathrm{v}$.

FRANCISCO GARCÍA DE ARNEDO

B. C.

4-11-1626

Fr. Juan de Redín

Burgos

AGN, Irache, Lib. 542, 142v.

JUAN BAUTISTA GRACIA

L. C.

4-11-1626

Fr. Gregorio Bravo de Sotomayor

Burgos

AGN, Irache, Lib. 542, $142 \mathrm{v}$.

FERNANDO IBÁÑEZ

L. C. / D. C. / B. L. / L. L. / D. L.

6-11-1626

Fr. Gregorio Bravo de Sotomayor

Tuy

AGN, Irache, Lib. 542, 143r.

ANDRÉS DE ORTEGA

L. T. / B. C.

7-11-1626 / 26-11-1626

Fr. Gregorio Bravo de Sotomayor / Fr. José 
de Carmona

Saldaña (Burgos)

AGN, Irache, Lib. 542, 143 r.

JOSÉ DE CARMONA

B. T. / L. T. / D. T.

10-11-1626

Fr. Gregorio Bravo de Sotomayor

O. S. B.

Catedrático de Teología de Irache

AGN, Irache, Lib. 542, $143 \mathrm{v}$.

ANTONIO ZAPATA

L. C. / D. C.

2-12-1626

Fr. Gregorio Bravo de Sotomayor

Magaña (Calahorra)

AGN, Irache, Lib. 542, 143v.

FRANCISCO DE TOBAR

L. T.

17-12-1626

Fr. Gregorio Bravo de Sotomayor

Burgos

AGN, Irache, Lib. 542, 144r.

JUAN ANTONIO DE ORTEGA

B. T. / L. T. / D. T.

19-12-1626

Fr. Gregorio Bravo de Sotomayor

Logroño (Calahorra)

AGN, Irache, Lib. 542, 144r.

MARCOS DEL RÍO

B. -

25-12-1626

Fr. José de Carmona

Puente (Burgos)

AGN, Irache, Lib. 542, 144 r.

JUAN DE VIÑEGRA

B. A.?

28-12-1626

Fr. Francisco de Borja

Estella (Pamplona)

AGN, Irache, Lib. 542, 144 r.

GREGORIO GARCÍA

B. C.
4-1-1627

Fr. Francisco de Borja

Burgos

AGN, Irache, Lib. 542, 144v.

FRANCISCO QUINTANA

B. -

28-2-1627

Fr. José de Carmona

Sasamón (Burgos)

AGN, Irache, Lib. 542, 144V.

JUAN PADELLANO

B. C.

28-2-1627

Fr. José de Carmona

Villasandino (Burgos)

AGN, Irache, Lib. 542, 144v.

PEDRO CABEZA

B. - / L. - / D. -

2-3-1627

Fr. José de Carmona / Fr. Gregorio Bravo

de Sotomayor

Zaragoza

AGN, Irache, Lib. 542, 145r.

JOSÉ DE BIDUARTE

L. -

2-3-1627

Fr. Gregorio Bravo de Sotomayor

Pamplona

AGN, Irache, Lib. 542, 145r.

JUAN DE HOYA

B. C.

7-3-1627

Fr. Gregorio Pariero, vicecanciller

Rebolledo (Burgos)

AGN, Irache, Lib. 542, 145r.

OLÓNDRIZ

Estudiante con sobrenombre (sic)

B. -

9-2-1627

Fr. José de Carmona

Pamplona

AGN, Irache, Lib. 542, 145r. 
JUAN MARTÍNEZ DE PORRES

L. T. / D. T.

20-3-1627

Fr. Gregorio Bravo de Sotomayor

Aguilar de Campoo (Burgos)

AGN, Irache, Lib. 542, 145r.

JUAN DE ARRESE

B. A.

26-3-1627

Fr. Bernardo de la Puerta

Estella (Pamplona)

AGN, Irache, Lib. 542, 145v.

\section{RAMIRO DE TORRES}

B. A.

26-3-1627

Fr. Bernardo de la Puerta

Los Arcos (Pamplona)

AGN, Irache, Lib. 542, 145v.

JOSÉ DE MUNÁRRIZ Y LIZÁRRAGA

B. A.

26-3-1627

Fr. Bernardo de la Puerta

Estella (Pamplona)

AGN, Irache, Lib. 542, 145v.

\section{MARTÍN DE AMATRIAIN}

B. A.

26-3-1627

Fr. Bernardo de la Puerta

Olcoz (Pamplona)

AGN, Irache, Lib. 542, 145v.

ANDRÉS DE BONETA

B. A.

26-3-1627

Fr. Bernardo de la Puerta

Estella (Pamplona)

AGN, Irache, Lib. 542, 145v.

FRANCISCO GONZÁLEZ

B. A.

26-3-1627

Fr. Bernardo de la Puerta

Vitoria (Calahorra)

AGN, Irache, Lib. 542, 145v.

\section{JUAN PÉREZ DE SAN ROMÁN}

B. A.

26-3-1627

Fr. Bernardo de la Puerta

Guereña (Calahorra)

AGN, Irache, Lib. 542, 145v.

FRANCISCO ÁLVAREZ

B. C.

28-3-1627

Fr. José de Carmona

Villasandino (Burgos)

AGN, Irache, Lib. 542, 145v.

PEDRO DE DIEGO

B. C.

28-3-1627

Fr. José de Carmona

Castrillo de Murcia (Burgos)

AGN, Irache, Lib. 542, 145v.

DIEGO GIL

B. C.

28-3-1627

Fr. José de Carmona

Villasandino (Burgos)

AGN, Irache, Lib. 542, 145v.

MIGUEL JIMÉNEZ

B. A. / L. T. / D. T.

29-3-1627 / 15-6-1636 / 19-8-1642

Fr. Bernardo de la Puerta / Fr. Pedro Díaz

de Inguanzo / Fr. Juan Rodríguez, Abad

Morentín (Pamplona)

AGN, Irache, Lib. 542, 145v, 221r, $263 \mathrm{v}$.

LORENZO DE ARTETA

B. A.

8-4-1627

Fr. Bernardo de la Puerta

Pamplona

AGN, Irache, Lib. 542, 145v.

JUAN DE IRIARTE

B. A.

8-4-1627

Fr. Bernardo de la Puerta

Sarigurren (Pamplona)

AGN, Irache, Lib. 542, 145v. 
MARTÍN DE ZUGARRONDO

B. A.

8-4-1627

Fr. Bernardo de la Puerta

Adiós (Pamplona)

AGN, Irache, Lib. 542, 145v.

CARLOS DE VILLANUEVA

B. A.

8-4-1627

Fr. Bernardo de la Puerta

Adiós (Pamplona)

AGN, Irache, Lib. 542, 145v.

\section{LUIS HERRERA}

B. A.

8-4-1627

Fr. Bernardo de la Puerta

Herrera (Pamplona)

AGN, Irache, Lib. 542, 146r.

BARTOLOMÉ DE AGUIRRE

B. A.

8-4-1627

Fr. Bernardo de la Puerta

Morico (Pamplona)

AGN, Irache, Lib. 542, 146r.

ÍNIIGO DE MAISTERRA

B. A.

8-4-1627

Fr. Bernardo de la Puerta

Esparza (Pamplona)

AGN, Irache, Lib. 542, 146 r.

ANTONIO DE JAURRIETA

B. A.

8-4-1627

Fr. Bernardo de la Puerta

Artieda (Pamplona)

AGN, Irache, Lib. 542, 146r.

\section{MARTÍN DE ARLEGUI}

B. A.

8-4-1627

Fr. Bernardo de la Puerta

Arlegui (Pamplona)

AGN, Irache, Lib. 542, 146r.

\section{JUAN DE ZUGARRONDO}

B. A.

8-4-1627

Fr. Bernardo de la Puerta

Garínoain (Pamplona)

AGN, Irache, Lib. 542, 146r.

MARTÍN DE MORALES

B. A.

8-4-1627

Fr. Bernardo de la Puerta

Pamplona

AGN, Irache, Lib. 542, $146 \mathrm{r}$.

JUAN URROZ

B. A.

8-4-1927

Fr. Bernardo de la Puerta

Urroz (Pamplona)

AGN, Irache, Lib. 542, 146r.

JUAN MARTÍN DE SAN PABLO

B. A.

8-4-1627

Fr. Bernardo de la Puerta

Lesaca (Pamplona)

AGN, Irache, Lib. 542, 146r.

PEDRO DÍAZ

B. A.

8-4-1627

Fr. Bernardo de la Puerta

Cáseda (Pamplona)

AGN, Irache, Lib. 542, $146 r$.

MIGUEL DE ERRO

B. A. / L. A.

8-4-1627

Fr. Bernardo de la Puerta / Fr. Gregorio

Bravo de Sotomayor

Erro (Pamplona)

AGN, Irache, Lib. 542, 146r.

ÍNIIGO GARVIDE

B. A. / L. A.

8-4-1627

Fr. Bernardo de la Puerta / Fr. Gregorio

Bravo de Sotomayor 
Ochogavía (Pamplona)

AGN, Irache, Lib. 542, 146r.

DIEGO DE VÍCTORES

B. C.

13-4-1627

Fr. Hernando Enríquez, Vicecanceller

Sasamón (Burgos)

AGN, Irache, Lib. 542, 146r.

LÁZARO DE ISAR

B. C.

¿ं-4-1627

Fr. Francisco Cambero, Vicecanciller

Tudela (Burgos)

AGN, Irache, Lib. 542, 146v.

GREGORIO DE SALAZAR SOLÓRZANO

L. C.

27-4-1627

Fr. Gregorio Bravo de Sotomayor

Palencia

AGN, Irache, Lib. 542, 146v.

MARTÍN IBÁÑEZ

L. C.

28-4-1627

...

Puente Agüero (Burgos)

AGN, Irache, Lib. 542, 146v.

\section{ANTONIO DE VILLEGAS}

B. A.

2-5-1627

Fr. Hernando Enríquez

Melgar (Burgos)

AGN, Irache, Lib. 542, 146v.

DIEGO PASCUAL

B. A.

6-5-1627

O. de M.

AGN, Irache, Lib. 542, 147r.

DIEGO SÁEZ DE BUSTAMANTE

B. C.

14-5-1627
Fr. José de Carmona

Aguilar de Campoo (Burgos)

AGN, Irache, Lib. 542, 147r.

JUAN DE EGUAS

B. A.

15-5-1627

Fr. Francisco Cambero

Tudela (Pamplona)

AGN, Irache, Lib. 542, 147r.

JUAN LÓPEZ DE VARO

B. C.

17-5-1627

Fr. Francisco Cambero

Pomar (Burgos)

AGN, Irache, Lib. 542, 147r.

DIEGO DE TEJADA

B. A.

22-5-1627

Fr. Bernardo de la Puerta

Ucera (Burgos)

AGN, Irache, Lib. 542, 147r.

PEDRO DURÁN

B. A.

26-5-1627

Fr. Bernardo de la Puerta

Ganda (Burgos)

AGN, Irache, Lib. 542, 147v.

DOMINGO DANERO

B. C.

28-5-1627

Fr. José de Carmona

Mantilla (Burgos)

AGN, Irache, Lib. 542, 147v.

DIONISIO RODRÍGUEZ

B. C.

30-5-1627

...

Carrión (Palencia)

AGN, Irache, Lib. 542, $147 \mathrm{v}$.

ANTONIO GÓMEZ DE CAPEÑA

B. C. 
1-6-1627

Fr. Francisco Cambero

Escobedos (Burgos)

AGN, Irache, Lib. 542, 148r.

FRANCISCO FERNÁNDEZ

B. C.

6-6-1627

Fr. José de Carmona

Ruseras (Burgos)

AGN, Irache, Lib. 542, 148r.

PEDRO DE SOTILLO

B. C.

9-6-1627

Fr. Hernando Enríquez

Portugalete (Burgos)

AGN, Irache, Lib. 542, 148r.

JUAN GÓMEZ

B. C.

21-6-1627

Fr. Francisco Cambero

Santa María del Campo (Burgos)

AGN, Irache, Lib. 542, 148 r.

SEBASTIÁN DE CARRANZA Y MONTAÑO B. C. / L. C. / D. C.

25-6-1627 / 1-11-1641

Fr. José de Carmona / Fr. Juan Rodríguez, abad

Zalla (Burgos)

AGN, Irache, Lib. 542, 148v, $260 v$.

JUAN GUILLÉN DE ALLÉS

B. C. / L. C.

26-6-1627

Fr. Hernando Enríquez / Fr. Gregorio Bra-

vo de Sotomayor

Villafranca (Pamplona)

AGN, Irache, Lib. 542, 148v.

JUAN RUIZ DE ESCALONA

B. C.

29-6-1627

Fr. Francisco Cambero

Lences (Burgos)

AGN, Irache, Lib. 542, 148v.
PEDRO SANZ DE LA HERRÁN

B. C.

1-7-1627

Fr. José de Carmona

Burgos

AGN, Irache, Lib. 542, 149r.

BLAS ORDÓÑEZ DE LARA

B. C.

5-7-1627

Fr. Hernando Enríquez

Pampliega (Burgos)

AGN, Irache, Lib. 542, 149 r.

AGUSTÍN DE ANCHETA

B. C. / L. C.

7-7-1627 / 30-6-1634

Fr. Francisco Cambero

Burgos

AGN, Irache, Lib. 542, 149r, 208r.

JUAN DE FLANDES

B. A.

16-7-1627

Fr. José de Carmona

Logroño (Calahorra)

AGN, Irache, Lib. 542, 149 r.

DIEGO CAMBERO

B. C.

18-7-1627

Fr. José de Carmona

Herce (Calahorra)

AGN, Irache, Lib. 542, 149 r.

DIEGO DE IRIARTE

B. $\mathrm{M}$.

31-7-1627

Fr. Hernando Enríquez

Burgos

AGN, Irache, Lib. 542, 149v.

MARTÍN SÁNCHEZ DE MOREDA

B. M.

31-7-1627

Fr. Hernando Enríquez

Burgos

AGN, Irache, Lib. 542, $149 v$. 
ANTONIO PÉREZ

B. C.

4-8-1627

Fr. José de Carmona

Los Balbases (Burgos)

AGN, Irache, Lib. 542, 149v.

JUAN DE ROSALES

B. C.

28-8-1627

Fr. Hernando Enríquez

Manzanedillo (Burgos)

AGN, Irache, Lib. 542, 149v.

PLÁCIDO DE URBINA

B. A. / L. A. / D. A. / B. T. / L. T. / D. T. 2-9-1627

Fr. Hernando Enríquez

O. S. B.

Lector en Teología

Monasterio de San Juan del Poyo

AGN, Irache, Lib. 542, 150r.

ANTONIO MÉNDEZ DE SALAS

B. C.

6-9-1627

Fr. Francisco Cambero

Santo Domingo de la Calzada (Calahorra)

AGN, Irache, Lib. 542, 150r.

JUAN DE BAÑARES

B. C.

6-9-1627

Fr. Francisco Cambero

Gañón (Calahorra)

AGN, Irache, Lib. 542, 15 or.

ROQUE DE SOTO

L. C.

23-9-1627

Fr. Hernando Enríquez

Calahorra

AGN, Irache, Lib. 542, 15 or.

JUAN DE RÚA Y HERRERA

B. C.

30-9-1627

Fr. José de Carmona
Logroño (Calahorra)

AGN, Irache, Lib. 542, $150 v$.

JUAN BAUTISTA NÚÑEZ DE LA PEÑA

B. $\mathrm{T}$.

30-9-1627

Fr. Hernando Enríquez

Poza (Burgos)

AGN, Irache, Lib. 542, $150 v$.

SEBASTIÁN DE CENARRO

L. C. / D. C.

7-10-1627

Fr. José de Carmona

Valmaseda (Burgos)

AGN, Irache, Lib. 542, $150 v$.

DIEGO DE LA MONEDA

B. C.

10-10-1627

Fr. Francisco Cambero

Lerma (Burgos)

AGN, Irache, Lib. 542, $150 v$.

ANDRÉS PÉREZ

B. C.

10-10-1627

Fr. Francisco Cambero

Quintanilla (Burgos)

AGN, Irache, Lib. 542, $150 v$.

JUAN DE VALLEJO

B. C.

10-10-1627

Fr. Francisco Cambero

Burgos

AGN, Irache, Lib. 542, $150 v$.

BERNARDO ÁLVARO

L. L. / D. L.

13-10-1627

Fr. Gregorio Bravo de Sotomayor

Calatayud (Tarazona)

AGN, Irache, Lib. 542, 151r.

JUAN DE LA ARENA

B. T.

23-10-1627 
Fr. Hernando Enríquez

Poza (Burgos)

AGN, Irache, Lib. 542, 151r.

TOMÁS DE AVELLANEDA

B. T. / L. T. / D. T.

26-10-1627

Fr. Hernando Enríquez

O. Praem.

AGN, Irache, Lib. 542, 151r.

VÍCTORES LÓPEZ DE TEJADA

B. C.

27-10-1627

Fr. Hernando Enríquez

Cerezo (Burgos)

AGN, Irache, Lib. 542, 151r.

\section{PEDRO CONDE}

B. C.

27-10-1627

Fr. Francisco Cambero

Rublacedo de Abajo (Burgos)

AGN, Irache, Lib. 542, 151r.

COSME MARTÍNEZ CALDERÓN

B. C.

29-10-1627

Fr. José de Carmona

Poza (Burgos)

AGN, Irache, Lib. 542, 151v.

AGUSTÍN MARTÍNEZ DE PESQUERA

L. C.

5-11-1627

Fr. José de Carmona

Valladolid

B. C. Canónigo

AGN, Irache, Lib. 542, 151v.

FRANCISCO DE SORIA

B. T.

16-11-1627

Fr. Hernando Enríquez

Ojacastro (Burgos)

AGN, Irache, Lib. 542, 151v.

FRANCISCO DEL PONTÓN

B. C.
25-11-1627

Fr. Francisco Cambero

Galizano (Burgos)

AGN, Irache, Lib. 542, 151v.

FRANCISCO MÉNDEZ

L. M. / D. M.

14-12-1627

Trancoso (Viseo) Portugal

AGN, Irache, Lib. 542, 151v-152r.

MARTÍN DE CEBAUZ

B. C. / L. C.

22-12-1627

Fr. José de Carmona

Calahorra

Canónigo de Álava. Provisor de Calahorra

AGN, Irache, Lib. 542, 152r.

MANUEL DE LIZAUR

B. C. / L. C.

22-12-1627

Fr. José de Carmona

Calahorra

AGN, Irache, Lib. 542, 152r.

FRANCISCO DE MONTEMAYOR

L. C.

23-12-1627

Fr. Francisco Cambero

Murillo de Río Leza (Calahorra)

AGN, Irache, Lib. 542, 152r.

FRANCISCO DE INOGEDA

B. C. / L. C.

30-12-1627

Fr. Francisco Cambero

Cuenca

AGN, Irache, Lib. 542, 152v.

PEDRO DE LA FUENTE

B. C.

31-12-1627

Fr. José de Carmona

Sopeñano (Burgos)

AGN, Irache, Lib. 542, 152v.

HERNANDO VIZQUEY Y AMBILA

L. M. / D. M. 
2-1-1628

Fr. Gregorio Bravo de Sotomayor

Berdún (Jaca)

AGN, Irache, Lib. 542, 153r.

PEDRO DE SAMANIEGO

B. C. / L. C. / D. C.

23-1-1628 / 22-8-1637 / 24-8-1637

Fr. Francisco Cambero / Fr. Antonio de

Castro

Préjano (Calahorra)

AGN, Irache, Lib. 542, 153r, 229v.

JOSÉ MARTÍNEZ

B. C.

12-2-1628

Fr. José de Carmona

... (Burgos)

Beneficiado en Pampliega

AGN, Irache, Lib. 542, 153 r.

JUAN CALVO

B. C.

20-2-1628

Fr. Hernando Enríquez

Castrojeriz (Burgos)

AGN, Irache, Lib. 542, 153v.

\section{JUAN LÓPEZ}

B. L.

28-2-1628

Fr. José de Carmona

Alfaro (Tarazona)

AGN, Irache, Lib. 542, $153 \mathrm{v}$.

GASPAR PÉREZ

B. C.

1-3-1628

Fr. José Henríquez, vicecanciller

Pampliega (Burgos)

AGN, Irache, Lib. 542, 153v.

MARCOS DE ATIENZA

L. C. / D. C.

1-3-1628 / 2-3-1628

Fr. Gregorio Bravo de Sotomayor

Nájera (Calahorra)

AGN, Irache, Lib. 542, 153v.
JUAN DÍAZ DE BASURTO

L. T.

11-3-1628

Fr. Gregorio Bravo de Sotomayor

... (Calahorra)

AGN, Irache, Lib. 542, 154r.

BARTOLOMÉ DE LA SERA

L. C.

13-3-1628

Fr. José de Carmona

Villusto (Nullius Diocesis)

AGN, Irache, Lib. 542, 154v.

FRANCISCO DE CESTONA

B. C.

24-3-1628

Fr. José de Carmona

Castro Urdiales (Burgos)

AGN, Irache, Lib. 542, 154v.

TOMÁS RUIZ DE LOZARES

B. C.

25-3-1628

Fr. José de Carmona

Bascuñuelos (Burgos)

AGN, Irache, Lib. 542, 154V.

NICOLÁS DE BASCONES

B. C.

30-3-1628

Fr. José de Carmona

Sasamen (Burgos)

AGN, Irache, Lib. 542, 154v.

JOSÉ VILLAVA

B. L. / L. L. / D. L.

1-4-1628

Fr. Hernando Enríquez

Zaragoza

AGN, Irache, Lib. 542, 155r.

FELIPE VÉLEZ

L. C.

4-4-1628

Fr. José de Carmona

Ajo (Burgos)

AGN, Irache, Lib. 542, 155r. 
BARTOLOMÉ DE SALINAS

B. C.

10-4-1628

Fr. Hernando Enríquez

Olmedillo (Burgos)

AGN, Irache, Lib. 542, 155v.

SEBASTIÁN MIGUEL DE LOMAS

B. T.

13-4-1628

Fr. José de Carmona

Pedrosa de Río Urbel (Burgos)

AGN, Irache, Lib. 542, 155v.

\section{JUAN MUÑOZ}

B. C.

15-4-1628

Fr. José Henríquez

Sta. María del Campo (Burgos)

AGN, Irache, Lib. 542, 155v.

BARTOLOMÉ MOLINERO

B. C.

20-4-1628

Fr. José de Carmona

Herrera de Valdecañas (Burgos)

AGN, Irache, Lib. 542, 155v.

JOSÉ DE EGUES

B. L.

21-4-1628

Fr. José de Carmona

Tudela (Tarazona)

AGN, Irache, Lib. 542, 155v.

MARTÍN CORRAL Y GUZMÁN

L. C. / D. C.

26-4-1628

Fr. Gregorio Bravo de Sotomayor

Córdoba

AGN, Irache, Lib. 542, 156r.

MARTÍN DE URRIZOLA

L. L.

27-4-1628

Fr. Gregorio Bravo de Sotomayor

Pamplona

AGN, Irache, Lib. 542, 156r.
JOSÉ BURUTÁIN

L. L.

27-4-1628

Fr. Gregorio Bravo de Sotomayor

Pamplona

AGN, Irache, Lib. 542, 156r.

FRANCISCO CIDAD

B. C.

29-4-1628

Fr. Pedro de Pazos, vicecanciller

Villegas (Burgos)

AGN, Irache, Lib. 542, 156v.

ANDRÉS RUIZ

B. C.

30-4-1628

Fr. Pedro de Pazos

Presencio (Burgos)

AGN, Irache, Lib. 542, 156v.

MARTÍN DE ZULAIBA

B. C.

9-5-1628

Fr. Bernardo de Hontiveros, vicecanciller

Burgos

AGN, Irache, Lib. 542, 156v.

JERÓNIMO GUTIÉRREZ

B. C.

10-5-1628

Fr. José de Carmona

Villanueva del Valle de Cabezón (Burgos)

AGN, Irache, Lib. 542, 156v.

JUAN DE CASTILLA

B. C.

11-5-1628

Fr. Hernando Enríquez

Villanueva de Valdegovía (Burgos)

AGN, Irache, Lib. 542, 156v.

\section{MIGUEL SÁNCHEZ}

B. A.

15-5-1628

Fr. Pedro de Pazos

Morentín (Pamplona)

AGN, Irache, Lib. 542, 157r. 
JUAN DE SOSA

B. A.

15-5-1628

Fr. Pedro de Pazos

Ayesa (Pamplona)

AGN, Irache, Lib. 542, 157r.

MARTÍN DE GORRAIZ

B. A.

15-5-1628

Fr. Pedro de Pazos

Ongoz (Pamplona)

AGN, Irache, Lib. 542, 157r.

PEDRO DE LANZ

B. A.

15-5-1628

Fr. Pedro de Pazos

Lanz (Pamplona)

AGN, Irache, Lib. 542, 157r.

JUAN DE ALQUIZ

B. A.

15-5-1628

Fr. Pedro de Pazos

Pamplona

AGN, Irache, Lib. 542, 157r.

MIGUEL DE TORRES

B. A.

15-5-1628

Fr. Pedro de Pazos

Amatriain (Pamplona)

AGN, Irache, Lib. 542, 157r.

JUAN RAMÍREZ DE ESPARZA

B. A.

15-5-1628

Fr. Pedro de Pazos

Aldaz (Pamplona)

AGN, Irache, Lib. 542, 157 r.

PASCUAL DE ALQUAZ

B. A.

15-5-1628

Fr. Pedro de Pazos

Beunza (Pamplona)

AGN, Irache, Lib. 542, 157 r.
PEDRO DE ECHEGOYEN

B. A. / L. A.

15-5-1628

Fr. Pedro de Pazos

Falces (Pamplona)

AGN, Irache, Lib. 542, 157r.

MARTÍN DE ARIZMENDI

B. A. / L. A.

15-5-1628

Fr. Pedro de Pazos, M. A.

Andoáin (Pamplona)

AGN, Irache, Lib. 542, 157 r.

\section{ALONSO FOLGOSO}

B. C.

17-5-1628

Fr. Bernardo de Hontiveros Cortegada (Pamplona)

AGN, Irache, Lib. 542, 157r.

TOMÁS DE CASAS

B. C.

17-5-1628

Fr. Bernardo de Hontiveros

Azones (Orense)

AGN, Irache, Lib. 542, 157 r.

FRANCISCO DÍAZ

B. C.

18-5-1628

Fr. Bernardo de Hontiveros Abiada (Burgos)

AGN, Irache, Lib. 542, 157v.

JUAN DE IGOA

B. T. / L. T. / D. T.

18-5-1628/ 19-5-1628

Fr. Bernardo de Hontiveros

Berástegui (Pamplona)

AGN, Irache, Lib. 542, 157v.

GASPAR GARCÍA

B. C.

19-5-1628

Fr. Bernardo de Hontiveros

Villasandino (Burgos)

AGN, Irache, Lib. 542, 157v. 
JUAN CRISTÓBAL

B. C.

19-5-1628

Fr. Bernardo de Hontiveros

Villasandino (Burgos)

AGN, Irache, Lib. 542, 157v.

MIGUEL MARCOS DE LUCÍA

B. C.

29-5-1628

Fr. Bernardo de Hontiveros

Castrojeriz (Burgos)

AGN, Irache, Lib. 542, 157v.

JUAN MANSO

B. C.

29-5-1628

Fr. José de Carmona

Sta. María del Campo (Burgos)

AGN, Irache, Lib. 542, 158r.

JUAN SOBRINO

B. C.

29-5-1628

Fr. Bernardo de Hontiveros

Sta. María del Campo (Burgos)

AGN, Irache, Lib. 542, 158r.

ANTONIO DE NOYA CASTILLO

B. C.

1-6-1628

Fr. José de Carmona

Castro Urdiales (Burgos)

AGN, Irache, Lib. 542, 158r.

FRANCISCO BENITO

B. T.

10-6-1628

Fr. Bernardo de Hontiveros

Santa Olalla (Burgos)

AGN, Irache, Lib. 542, 158r.

DIEGO DE ARCE REBOLLEDO

L. C.

16-6-1628

Fr. José de Carmona

Reinosa (Burgos)

AGN, Irache, Lib. 542, 158r.

\section{JUAN GARCÍA}

B. C.

6-7-1628

Fr. José de Carmona

Burgos

AGN, Irache, Lib. 542, 158v.

JERÓNIMO ESCRIBANO

B. C.

6-7-1628

Fr. José de Carmona

Burgos

AGN, Irache, Lib. 542, 158v.

JUAN FRANCISCO DE BRIONES

B. C.

9-7-1628

Fr. José de Carmona

Alfaro (Tarazona)

AGN, Irache, Lib. 542, 158v.

SIMÓN DE RUIZ

B. C.

13-7-1628

Fr. Bernardo de Hontiveros

Berzosilla (Burgos)

Clérigo

AGN, Irache, Lib. 542, 159r.

JUAN GARCÍA

B. C.

13-7-1628

Fr. Bernardo de Hontiveros

Villanueva (Burgos)

AGN, Irache, Lib. 542, 159 r.

ANDRÉS ORTIZ DE ZÁRATE

B. C.

14-7-1628

Fr. Bernardo de Hontiveros

Burgos

AGN, Irache, Lib. 542, 159r.

JUAN PARDO

B. T.

19-7-1628

Fr. José de Carmona

Quintanillas (Burgos)

AGN, Irache, Lib. 542, 159r. 
MARTÍN DE RIAÑO

B. A. / L. A. / M. A. / B. T. / L. T. / M. T. 25-7-1628

Fr. José de Carmona

O. S. B.

Regente del Colegio de San Vicente de Oviedo

AGN, Irache, Lib. 542, 159 r.

ANTONIO GONZÁLEZ

B. C.

28-7-1628

Fr. Bernardo de Hontiveros

Ruseras (Burgos)

AGN, Irache, Lib. 542, 159v.

JUAN DE ARCINIEGA

B. C.

9-8-1628

Fr. José de Carmona

Burgos

AGN, Irache, Lib. 542, 159v.

TOMÁS ANGULO DE AEDO

B. C.

13-8-1628

Fr. Bernardo de Hontiveros

Valmaseda (Burgos)

AGN, Irache, Lib. 542, 159v.

JUAN DE VALLEJERA

B. C.

26-8-1628

Fr. Bernardo de Hontiveros

Santillana (Palencia)

AGN, Irache, Lib. 542, 159v.

GIL RAMÍREZ DE ARELLANO

B. C. / L. C.

25-8-1628 / 26-8-1628

Fr. José de Carmona

Madrid (Toledo)

AGN, Irache, Lib. 542, 16 or.

FRANCISCO MERINO

B. C.

5-9-1628

Fr. José de Carmona
Quintanilla del Río Fresno (Burgos)

AGN, Irache, Lib. 542, 16or.

\section{ALONSO PÉREZ}

B. C.

18-9-1628

Fr. Bernardo de Hontiveros

Manciles (Burgos)

AGN, Irache, Lib. 542, 16 or.

\section{EUGENIO DE ARTAZU}

L. C.

19-9-1628

Fr. Bernardo de Hontiveros

Puente la Reina (Pamplona)

AGN, Irache, Lib. 542, $160 v$.

ISIDRO PÉREZ

B. C. / B. L. / B. T. / L. C.

6-10-1628 / 7-10-1628

Fr. José de Carmona / Fr. Bernardo de Hontiveros / Fr. Gregorio Bravo de Sotomayor

Benavente (Oviedo)

AGN, Irache, Lib. 542, $160 v$.

BERNABÉ DE LA CONESA

B. C.

8-10-1628

Fr. Bernardo de Hontiveros

Puerto (Burgos)

AGN, Irache, Lib. 542, 161r.

ANTONIO DE PALACIOS

B. C.

9-10-1628

Fr. José de Carmona

Biañez, del Barrio de Carranza (Burgos)

AGN, Irache, Lib. 542, 161r.

FERNANDO DE ELCARTE

L. C.

9-10-1628

Fr. Gregorio Bravo de Sotomayor

Pamplona

Canónigo de Pamplona y Arcediano de Valeaybar

AGN, Irache, Lib. 542, 161r. 
LUIS DE QUIÑNONES

B. C.

13-10-1628

Fr. José de Carmona

León

AGN, Irache, Lib. 542, 161r.

JUAN FERNÁNDEZ ROJO

L. T. / M. T.

18-10-1628

Fr. Gregorio Bravo de Sotomayor

Frey. Orden de Calatrava

AGN, Irache, Lib. 542, 161r.

\section{JUAN DE PINEDO}

B. T. / D. T.

22-10-1628

Fr. José de Carmona / Fr. Gregorio Bravo

de Sotomayor

O. de M.

AGN, Irache, Lib. 542, 161v.

JUAN RUIZ DE ESPINOSA

B. C.

25-10-1628

Fr. Hernando Enríquez

Iniestra (Burgos)

AGN, Irache, Lib. 542, 161v.

JUAN PABLOS

B. C.

25-10-1628

Fr. José de Carmona

Canales (Burgos)

AGN, Irache, Lib. 542, 161v.

JUAN DE UDOBRO

B. C.

30-10-1628

Fr. Bernardo de Hontiveros

Quintanilla-Sobresierra (Burgos)

AGN, Irache, Lib. 542, 162r.

ANDRÉS DE MAGAZ

B. C.

20-11-1628

Fr. Fernando Henríquez

Magaz (Palencia)

AGN, Irache, Lib. 542, 162 r.
BLAS DE LA HERA

B. C.

19-11-1628

Fr. José de Carmona

Sasamón (Burgos)

AGN, Irache, Lib. 542, 162 .

\section{LÁZARO DE PALACIOS}

B. C.

19-11-1628

Fr. José de Carmona

Yudego (Burgos)

AGN, Irache, Lib. 542, 162r.

ANTONIO DE VALDÉS

L. C.

3-12-1628

Fr. Gregorio Bravo de Sotomayor

Valladolid

Canónigo de Valladolid

AGN, Irache, Lib. 542, 162 r.

PEDRO DE CELADA

B. C.

19-12-1628

Fr. Fernando Henríquez

Ibáñez (Burgos)

AGN, Irache, Lib. 542, 162 r.

JUAN DÍAZ

B. C.

19-12-1628

Fr. Fernando Henríquez

Ibáñez (Burgos)

AGN, Irache, Lib. 542, 162r.

PEDRO GARCÍA

B. C.

19-12-1628

Fr. Fernando Henríquez

Ros (Burgos)

AGN, Irache, Lib. 542, 162r.

GASPAR DE SANMARTÍN

B. C.

3-1-1629

Fr. Fernando Henríquez

Burgos

AGN, Irache, Lib. 542, $162 \mathrm{~V}$. 
RODRIGO DE LA CUESTA

B. C.

11-1-1629

Fr. José de Carmona

Tobar (Burgos)

AGN, Irache, Lib. 542, 162v.

ANDRÉS DE SAN MARTÍN

B. C.

17-1-1629

Fr. Bernardo de Hontiveros

Cervatos (Burgos)

AGN, Irache, Lib. 542, 162v.

JOSÉ DE CAZABAL

B. T.

14-2-1629

Fr. Fernando Henríquez

Lepe (Sevilla)

AGN, Irache, Lib. 542, 162v.

JUAN MACHÓN

B. C.

28-2-1629

Fr. José de Carmona

Presencio (Burgos)

AGN, Irache, Lib. 542, 162v.

FERNANDO GÓMEZ

B. C.

6-3-1629

Fr. Bernardo de Hontiveros ... (Burgos)

AGN, Irache, Lib. 542, 162v.

FRANCISCO DE ARCE

B. C.

12-3-1629

Fr. José de Carmona

Carriedo (Burgos)

AGN, Irache, Lib. 542, 162v.

PEDRO GONZÁLEZ DE CASTAÑEDA

B. C.

12-3-1629

Fr. José de Carmona

Aloños (Burgos)

AGN, Irache, Lib. 542, 162v.
ANDRÉS DE LA CRUZ

B. C.

19-3-1629

Fr. Bernardo de Hontiveros

Balmaseda

AGN, Irache, Lib. 542, 163r.

PEDRO DEL CAMPO

B. C.

24-3-1629

Fr. José de Carmona

Santisteban (Burgos)

AGN, Irache, Lib. 542, 163 r.

\section{DIEGO DE CABAÑAS}

B. C.

25-3-1629

Fr. Bernardo de Hontiveros

Oteo (Burgos)

AGN, Irache, Lib. 542, 163 r.

ESTEBAN DEL CORRAL

B. C.

25-3-1629

Fr. Bernardo de Hontiveros

Villabasil (Burgos)

AGN, Irache, Lib. 542, 163r.

JUAN PEREGRINO

B. C.

26-4-1629

Fr. Hernando Enríquez

Landilla del Puerto (Burgos)

AGN, Irache, Lib. 542, 163r.

MAURO DE TOBAR

M. T.

28-4-1629

Fr. Gregorio Bravo de Sotomayor

O. S. B.

Profeso en Valladolid

AGN, Irache, Lib. 542, 163 r.

JUAN DE LA CALLE

B. C.

28-4-1629

Fr. Gregorio Bravo de Sotomayor Ocón (Calahorra)

AGN, Irache, Lib. 542, 163 r. 


\section{ANDRÉS GARCÍA}

B. C.

26-4-1629

Fr. Bernardo de Hontiveros

Burgos

AGN, Irache, Lib. 542, $163 \mathrm{v}$.

\section{MARCOS ZÚMEL}

B. C. / L. C.

16-4-1629 / 3-3-1643

Fr. Bernardo de Hontiveros / Fr. Juan Rodríguez, abad

Burgos

AGN, Irache, Lib. 542, 163v, 265v.

JUAN DE ZUALDE

B. A.

3-5-1629

Fr. Pedro de Pazos

Vizcaya

AGN, Irache, Lib. 542, $163 \mathrm{v}$.

ANDRÉS DE PALENCIA

B. C.

6-5-1629

Fr. Bernardo de Hontiveros

Olmos de la Picaza (Burgos)

AGN, Irache, Lib. 542, $163 \mathrm{v}$.

IGNACIO GONZÁLEZ

B. C. / L. C.

8-5-1629 / 16-11-1631

Fr. José de Carmona / Fr. Ramiro de Goñi

Burgos

AGN, Irache, Lib. 542, 163v, 184v.

JUAN MARTÍN DE ARDAIZ

L. A.

9-5-1629

Fr. Pedro de Pazos

Ardaiz (Pamplona)

AGN, Irache, Lib. 542, 163v.

JUAN PARDO

B. C.

10-5-1629

Fr. Bernardo de Hontiveros

Bedón (Burgos)

AGN, Irache, Lib. 542, $163 \mathrm{v}$.

\section{GREGORIO PARCERO}

M. T.

10-5-1629

Fr. José de Carmona

O. S. B.

General de la Orden de España e Inglaterra

AGN, Irache, Lib. 542, 164r.

PEDRO HERRERO

B. A. / L. A.

11-5-1629

Fr. Pedro de Pazos

Fr. Gregorio Parcero

Clavijo (Calahorra)

AGN, Irache, Lib. 542, 164 r.

DOMINGO DE RASO

B. C. / D. C.

13-5-1629

Fr. José de Carmona

Bestué (Barbastro)

AGN, Irache, Lib. 542, 164 r.

ATILANO GIL

B. T.

13-5-1629

Fr. José de Carmona

O. Cist.

AGN, Irache, Lib. 542, 164 r.

JUAN VELÁZQUEZ

B. C.

18-5-1629

Fr. Bernardo de Hontiveros

Canales (Burgos)

AGN, Irache, Lib. 542, 164 r.

BARTOLOMÉ GÓMEZ

B. C.

18-5-1629

Fr. Bernardo de Hontiveros

Canales (Burgos)

AGN, Irache, Lib. 542, 164r.

JUAN BAUTISTA DEL REBOLLAR

B. C.

21-5-1629

Fr. Bernardo de Hontiveros 
AGN, Irache, Lib. 542, 164v.

BERNABÉ DE VILLAESCUSA

B. C.

25-5-1629

Fr. José de Carmona

Burgos

AGN, Irache, Lib. 542, 164v.

ANTONIO GONZÁLEZ

B. C.

27-5-1629

Fr. Bernardo de Hontiveros

Burgos

AGN, Irache, Lib. 542, 164v.

ANTONIO DE ARBIZU

B. A.

1-6-1629

Fr. Pedro de Pazos

Pamplona

AGN, Irache, Lib. 542, 164v.

MIGUEL DE ECHEVERRI

B. A.

1-6-1629

Fr. Pedro de Pazos

Pamplona

AGN, Irache, Lib. 542, 164v.

BERNARDO DE PERALTA

B. A.

1-6-1629

Fr. Pedro de Pazos

Pamplona

AGN, Irache, Lib. 542, 164v.

PEDRO ELSO

B. A.

1-6-1629

Fr. Pedro de Pazos

Pamplona

AGN, Irache, Lib. 542, 164v.

PEDRO DE ROSA

B. A.

1-6-1629
Fr. Pedro de Pazos

Pamplona

AGN, Irache, Lib. 542, 164V.

SIMÓN DE LINZOAIN

B. A.

1-6-1629

Fr. Pedro de Pazos

Pamplona

AGN, Irache, Lib. 542, 164v.

GASPAR DE ECHEGUREN

B. A.

1-6-1629

Fr. Pedro de Pazos

Pamplona

AGN, Irache, Lib. 542, 164v.

MARTÍN DE MURILLO

B. A.

1-6-1629

Fr. Pedro de Pazos

Pamplona

AGN, Irache, Lib. 542, 164v.

ESTEBAN DE ARBELOA

B. A.

1-6-1629

Fr. Pedro de Pazos

Pamplona

AGN, Irache, Lib. 542, 164v.

MIGUEL DE BERIAIN

B. A.

1-6-1629

Fr. Pedro de Pazos

Pamplona

AGN, Irache, Lib. 542, 164v.

IGNACIO GAZTELU Y LATASA

B. A.

1-6-1629

Fr. Pedro de Pazos

Pamplona

AGN, Irache, Lib. 542, 164v.

JUAN ESTEBAN Y ELGUETA

B. A. 
1-6-1629

Fr. Pedro de Pazos

Pamplona

AGN, Irache, Lib. 542, 164v.

\section{JUAN DE GÁRRIZ}

B. A.

1-6-1629

Fr. Pedro de Pazos

Pamplona

AGN, Irache, Lib. 542, 164v.

JUAN DE MURILLO

B. A.

1-6-1629

Fr. Pedro de Pazos

Pamplona

AGN, Irache, Lib. 542, 164v.

JUAN DE LIZ

L. C.

8-6-1629

Fr. José de Carmona

Pontevedra (Santiago)

AGN, Irache, Lib. 542, 164v.

FRANCISCO DE QUIRANO

L. C.

10-6-1629

Fr. José de Carmona

Irigo (Burgos)

AGN, Irache, Lib. 542, 165 r.

JUAN DE PINEDO

B. C.

23-6-1629

Fr. José de Carmona

Burgos

AGN, Irache, Lib. 542, 165r.

JUAN DE ASCARAY

B. C.

24-6-1629

Fr. Francisco Salvador

Castrojeriz (Burgos)

AGN, Irache, Lib. 542, 165 r.

MARCELINO MARTÍNEZ

L. C. / D. C.
24-6-1629 / 29-4-1641

Fr. Matías de Hevia / Fr. Martín Izquierdo

Alpeñés (Zaragoza)

AGN, Irache, Lib. 542, 165r, 257r.

JAIME GUDEL

L. C. / D. C.

24-6- 1629

Fr. Matías de Hevia

Puebla de Castro (Barbastro)

AGN, Irache, Lib. 542, 165r.

MARTÍN PÉREZ DE ELIZALDE

B. A.

30-6-1629

Fr. Pedro de Pazos

Tolosa (Pamplona)

AGN, Irache, Lib. 542, 165r.

JUAN MARTÍNEZ DE ELIZALDE

B. A.

30-6-1629

Fr. Pedro de Pazos

Tolosa (Pamplona)

AGN, Irache, Lib. 542, 165 r.

MANUEL DE OTAOLA

B. A.

30-6-1629

Fr. Pedro de Pazos

Tolosa (Pamplona)

AGN, Irache, Lib. 542, 165 r.

ANTONIO GÓMEZ

B. C.

6-7-1629

Fr. Matías de Hevia

Ampuero (Burgos)

AGN, Irache, Lib. 542, $165 \mathrm{v}$.

PEDRO ABAD FERNÁNDEZ

B. C.

9-7-1629

Fr. Francisco Salvador

Castrillo del Val (Burgos)

AGN, Irache, Lib. 542, 165v.

PEDRO JACOME

B. M. 
14-7-1629

Fr. José de Carmona / Dr. Alzueta

Buarcos (Coimbra)

AGN, Irache, Lib. 542, 165v.

ANDRÉS SANCHO

B. C.

15-7-1629

Fr. Matías de Hevia

Ares (Burgos)

AGN, Irache, Lib. 542, $165 \mathrm{v}$.

JUAN RUIZ DE COLINA

B. C.

15-7-1629

Fr. Matías de Hevia

Ynestra (Burgos)

AGN, Irache, Lib. 542, 165v.

ANTONIO DE LA CANAL

B. C.

16-7-1629

Fr. Matías de Hevia

San Vicente de la Barquera (Burgos)

AGN, Irache, Lib. 542, 165v.

JUAN DE LIENDO

B. C.

17-7-1629

Fr. Matías de Hevia

Castro Urdiales (Burgos)

AGN, Irache, Lib. 542, 165v.

ANTONIO PARCERO

B. C. / L. C.

23-8-1629

Fr. José de Carmona / Fr. Ramiro de Goñi,

Abad y Rector

Tuy

AGN, Irache, Lib. 542, 166r.

DIEGO DE FRUTOS

B. C. / D. C.

27-8-1629

Fr. José de Carmona

Berlanga

AGN, Irache, Lib. 542, 166r.
PLÁCIDO DE SALAZAR

B. A. / L. A. / M. A. / B. T. / L. T. / M. T. 29-8-1629

Fr. Ramiro de Goñi

O.S. B.

Catedrático de la Universidad de Oviedo AGN, Irache, Lib. 542, 166r.

FRANCISCO DE LEMOS

B. A. / L. A. / M. A. / B. T. / L. T. / M. T. 29-8-1629

Fr. Ramiro de Goñi

O. S. B.

AGN, Irache, Lib. 542, 166v.

JUAN DE BERASTEGUI

B. C.

30-8-1629

Fr. Francisco Salvador

Balmaseda (Burgos)

AGN, Irache, Lib. 542, 166v.

ANTONIO GÓMEZ

L. M. / D. M.

31-8-1629

Fr. Ramiro de Goñi / Dr. Bernardo de Alzueta

Lerín (Pamplona)

AGN, Irache, Lib. 542, 166v.

JUAN DE ELZAMENDI Y MONREAL

B. T.

6-9-1629

Fr. José de Carmona

Barasuain (Pamplona)

AGN, Irache, Lib. 542, 166v.

PEDRO JORDÁN

B. A. / L. A.

7-9-1629 / 5-2-1630

Fr. Matías de Hevia / Fr. Ramiro de Goñi

Olite (Pamplona)

AGN, Irache, Lib. 542, 166v.

JUAN DE LA ARENA

B. T.

9-9-1629

Fr. Francisco Salvador 
Cerizo (Burgos)

AGN, Irache, Lib. 542, $167 \mathrm{r}$.

\section{RAIMUNDO DE ALEGUI}

L. L.

10-9-1629

Fr. Ramiro de Goñi

Pamplona

AGN, Irache, Lib. 542, $167 \mathrm{r}$.

JUAN DE URRA Y ARIZALA

L. C.

11-9-1629

Fr. Ramiro de Goñi

Estella (Pamplona)

AGN, Irache, Lib. 542, $167 \mathrm{r}$.

GASPAR DE ANAYA

B. C. / L. C.

14-9-1629

Fr. Francisco Salvador / Fr. Ramiro de Goñi

Valencia de Alcántara

Frey de la Orden de Alcántara

AGN, Irache, Lib. 542, 167r.

DIEGO MARTÍNEZ DE MORENTÍN

B. A.

19-9-1629

Fr. José de Carmona

Los Arcos (Pamplona)

AGN, Irache, Lib. 542, $167 \mathrm{v}$.

FRANCISCO DE LEÓN

B. C.

20-9-1629

Fr. Matías de Hevia

Burgos

AGN, Irache, Lib. 542, 167v.

JUAN DÍAZ DE LA FUENTE

B. C.

24-9-1629

Fr. José de Carmona

Montorio (Burgos)

AGN, Irache, Lib. 542, $167 \mathrm{v}$.

ALONSO ROJO

B. C. / L. C.
29-9-1629 / 30-9-1629

Fr. Matías de Hevia

La Banza (Palencia)

AGN, Irache, Lib. 542, $167 \mathrm{v}$.

LÁZARO DE CASTRO

B. C.

30-9-1629

Fr. Francisco Salvador

Burgos

AGN, Irache, Lib. 542, $167 \mathrm{v}$.

PEDRO DE ANGULO

B. C.

30-9-1629

Fr. Matías de Hevia / Fr. Francisco Salva-

dor

Burgos

AGN, Irache, Lib. 542, 168r.

JOSÉ BARREDA

B. C.

6-10-1629

Fr. Francisco Salvador

San Vicente de la Barquera (Burgos)

AGN, Irache, Lib. 542, 168r.

GREGORIO DE SÁMANO

B. A. / L. A. / M. A. / B. T. / L. T. / M. T.

17-10-1629

Fr. Ramiro de Goñi

O. S. B.

AGN, Irache, Lib. 542, 168r.

JUAN DE LA PEÑA

B. C.

27-10-1629

Fr. José de Carmona

Villasandino (Burgos)

AGN, Irache, Lib. 542, 168v.

JUAN DEL MAZO PEREDA

B. C.

2-11-1629

Fr. Francisco Salvador

Colindres (Burgos)

AGN, Irache, Lib. 542, 168v. 
JUAN LÓPEZ DE URRA

B. T. / L. T. / D. T.

15-11-1629 / 16-11-1629 / 7-12-1629

Fr. Francisco Salvador / Fr. Ramiro de Goñi

Puente la Reina (Pamplona)

AGN, Irache, Lib. 542, 168v-169r.

JAIME PORTOLÉS

B. T. / L. T. / M. T.

16-11-1629

Fr. Francisco Salvador / Fr. Ramiro de Goñi

Alcañiz (Zaragoza)

AGN, Irache, Lib. 542, 168v.

\section{PEDRO PEÑA}

B. T.

18-11-1629

Fr. Matías de Hevia

Villasandino (Burgos)

AGN, Irache, Lib. 542, 169 r.

PEDRO DE VILLANUEVA

B. C.

28-11-1629

Fr. Francisco Salvador

San Martín de Don (Burgos)

AGN, Irache, Lib. 542, 169r.

\section{CLEMENTE DE LOYA}

L. C.

7-12-1629

Fr. Ramiro de Goñi

Sangüesa (Pamplona)

AGN, Irache, Lib. 542, 169 r.

SALVADOR MARTÍN

B. T. / L. T. / D. T.

16-12-1629

Fr. Ramiro de Goñi

Valdenas-Daroca

AGN, Irache, Lib. 542, 169 r.

PEDRO PÉREZ

B. C.

16-12-1629

Fr. Matías de Hevia

Castrillo de Murcia (Burgos)

AGN, Irache, Lib. 542, 169v.

\section{JUAN DÍAZ}

B. T. / L. T. / M. T.

18-12-1629

Fr. Ramiro de Goñi

O.S. B.

General de España e Inglaterra

AGN, Irache, Lib. 542, 169v.

\section{PEDRO DE ARROYO}

B. C.

13-1-1630

Fr. Francisco Salvador

Arcellares (Burgos)

AGN, Irache, Lib. 542, 170 or.

PEDRO DE SOSA

B. C.

25-1-1630

Fr. Francisco Salvador

Calahorra

AGN, Irache, Lib. 542, 17 or.

PEDRO FERNÁNDEZ DE CÉSPEDES

B. C. / L. C.

29-1-1630

Fr. Matías de Hevia

Medina de Pomar (Burgos)

AGN, Irache, Lib. 542, 17 or.

PEDRO DE SALAZAR Y VELASCO

B. C.

3-2-1630

Fr. Matías de Hevia

Orduña (Calahorra)

AGN, Irache, Lib. 542, 17 or.

JUAN FERNÁNDEZ

B. A.

4-2-1630

Fr. Pedro de Pazos

Villatuerta (Pamplona)

AGN, Irache, Lib. 542, 170r.

PEDRO MARTÍNEZ

B. A. / L. A.

4-2-1630

Fr. Pedro de Pazos / Fr. Ramiro de Goñi Chávarri (Pamplona)

AGN, Irache, Lib. 542, $170 v$. 
FRANCISCO GONZÁLEZ

B. T.

12-3-1630

Fr. José de Carmona

Torquemada (Palencia)

AGN, Irache, Lib. 542, $170 \mathrm{v}$.

JUAN BAUTISTA EGUILUZ CORQUERA B. C. / L. C.

12-3-1630 / 13-3-1630

Fr. Francisco Salvador

Becia (Calahorra)

AGN, Irache, Lib. 542, $170 v$.

SIMÓN DE EGUILUZ CORQUERA

B. C.

12-3-1630 / 13-3-1630

Fr. Francisco Salvador

Becia (Calahorra)

AGN, Irache, Lib. 542, $170 v$.

ANTONIO DE PEREDA

L. L. / D. L.

18-3-1630

Fr. José de Carmona / Ldo. Altuna, Letrado

Ollauri (Calahorra)

AGN, Irache, Lib. 542, 171r.

FRANCISCO LADRÓN

B. A.

23-3-1630

Fr. Pedro de Pazos

Arcaute (Calahorra)

AGN, Irache, Lib. 542, 171r.

HERNANDO DE HUIDOBRO

B. C.

24-3-1630

Fr. José de Carmona

Huespeda (Burgos)

AGN, Irache, Lib. 542, 171r.

BARTOLOMÉ FERNÁNDEZ DE CARRIÓN

L. C.

3-4-1630

Fr. Francisco Salvador

Carrión (Burgos)

AGN, Irache, Lib. 542, $171 \mathrm{v}$.
JUAN GASCÓN DE VIANA

D. C.

10-4-1630

Recibe de nuevo el D. C. en Irache

Fr. Ramiro de Goñi

Salmerón (Cuenca)

Se incorpora a la Universidad

AGN, Irache, Lib. 542, $171 \mathrm{v}$.

JUAN PÉREZ

B. C.

20-4-1630

Fr. Francisco Salvador

Villamartín (Burgos)

AGN, Irache, Lib. 542, 171v.

\section{SEBASTIÁN CALDERÓN}

L. T. / D. T.

22-4-1630

Fr. Ramiro de Goñi

Burgos

Canónigo de Burgos

AGN, Irache, Lib. 542, 171v.

JUAN PABLO GÓMEZ

B. C.

25-4-1630

Fr. José de Carmona

Burgos

AGN, Irache, Lib. 542, 172r.

ANTONIO ÁLVAREZ

B. C.

27-4-1630

Fr. José de Carmona

Villasandino (Burgos)

AGN, Irache, Lib. 542, 172r.

MIGUEL CORREDOR

B. C.

27-4-1630

Fr. José de Carmona

Sasamón (Burgos)

AGN, Irache, Lib. 542, 172r.

SEBASTIÁN DE SEDANO

L. C.

1-5-1630 
Fr. Ramiro de Goñi

Horna (Burgos)

AGN, Irache, Lib. 542, 172r.

FRANCISCO MARTÍNEZ

B. C.

10-5-1630

Fr. Matías de Hevia

Sasamón (Burgos)

AGN, Irache, Lib. 542, 172r.

JUAN BAUTISTA DE ESPINOSA

L. C. / D. C.

23-5-1630

Fr. Ramiro de Goñi

Burgos

Canónigo de Burgos

AGN, Irache, Lib. 542, 172r.

ÁNGEL MORANTE DE LA MADRID

L. C. / D. C.

26-5-1630

Fr. Francisco Salvador / Fr. José de Carmona

Reinosa (Burgos)

AGN, Irache, Lib. 542, 172v.

FRANCISCO DE URIBE

B. C.

4-6-1630

Fr. José de Carmona

Villalba (Burgos)

AGN, Irache, Lib. 542, 172v.

MIGUEL GARCÍA

B. C.

9-6-1630

Fr. Francisco Salvador

Sasamón (Burgos)

AGN, Irache, Lib. 542, $172 \mathrm{v}$.

FRANCISCO RODRÍGUEZ DE AYALA

B. C.

18-6-1630

Fr. Matías de Hevia

Burgos

AGN, Irache, Lib. 542, 172v.
ESTEBAN DE ANGULO

B. C.

19-6-1630

Fr. José de Carmona

Burgos

AGN, Irache, Lib. 542, 172v.

DIEGO SANTOS

B. M.

7-8-1630

Fr. José de Carmona / Dr. Alzueta

Pamplona

AGN, Irache, Lib. 542, 173r.

JUAN MARTÍNEZ DE TORRES

B. C.

15-8-1630

Fr. Francisco Salvador

Burgos

AGN, Irache, Lib. 542, 173 r.

MIGUEL GARCÍA

B. C.

19-8-1630

Fr. José de Carmona

Arlanzón (Burgos)

AGN, Irache, Lib. 542, 173 r.

JUAN BAUTISTA RODRÍGUEZ

B. A.

28-8-1630

Fr. Francisco Salvador

Lisboa

AGN, Irache, Lib. 542, 173r.

JUAN CORDERO

B. C.

29-8-1630

Fr. José de Carmona

Retuerto (Burgos)

AGN, Irache, Lib. 542, 173r.

DOMINGO DE BERINGAS

B. C.

4-9-1630

Fr. Francisco Salvador

Santillana. Valle de Carranza (Burgos)

AGN, Irache, Lib. 542, 173 r. 


\author{
PEDRO FERNÁNDEZ \\ B. C. \\ 10-9-1630 \\ Fr. José de Carmona \\ Atapuerca (Burgos) \\ AGN, Irache, Lib. 542, 173v. \\ SEBASTIÁN CABALLERO QUINTANO \\ B. C. \\ 10-9-1630 \\ Fr. José de Carmona \\ La Penilla (Burgos) \\ AGN, Irache, Lib. 542, 173v. \\ FRANCISCO ALONSO \\ B. C. \\ 11-9-1630 \\ Fr. José de Carmona \\ Los Carabeos (Burgos) \\ AGN, Irache, Lib. 542, 173v. \\ ANTONIO DE ESPINOSA Y SALCEDO \\ L. C.? \\ 11-9-1630 \\ Fr. José de Carmona \\ Roa (Osma) \\ AGN, Irache, Lib. 542, 173v. \\ LÁZARO DE SANTANDER \\ B. C. \\ 15-9-1630 \\ Fr. Francisco Salvador \\ Castrojeriz (Burgos) \\ AGN, Irache, Lib. 542, 173v. \\ ANTONIO SALINAS \\ B. A. / L. A. / M. A. / B. T. / L. T. / M. T. \\ 16-9-1630 \\ Fr. Ramiro de Goñi \\ O. S. B. \\ Profeso de San Juan de Burgos \\ AGN, Irache, Lib. 542, 173v. \\ GASPAR DE CARIAGA \\ B. T. \\ 19-9-1630 \\ Fr. José de Carmona \\ Ampuero (Burgos) \\ AGN, Irache, Lib. 542, 174r.
}

\section{JUAN BERMEJO}

B. C.

21-9-1630

Fr. Francisco Salvador

Santecilla (Burgos)

AGN, Irache, Lib. 542, 174r.

DIEGO FERRER

L. L. / D. L.

23-9-1630

Fr. Ramiro de Goñi / Ldo. Calatayud

Montealbo (Tarragona)

AGN, Irache, Lib. 542, 174r.

\section{LOPE DE UNDIANO}

L. C.

24-9-1630

Fr. Ramiro de Goñi

Abraiza (Pamplona)

AGN, Irache, Lib. 542, 174r.

FELIPE DE BARCENA

B. C.

3-10-1630

Fr. José de Carmona

Villadiego (Burgos)

AGN, Irache, Lib. 542, 174V.

CLEMENTE CALLEJA

B. C.

5-10-1630

Quintanadueñas (Burgos)

Insuficiente, depositando 71 reales en plata, con derecho a otro examen

Clérigo, Pbro.

AGN, Irache, Lib. 542, 174v.

JUAN SÁEZ CUESTA DE VICUÑA

B. A.

9-10-1630

Fr. Francisco Salvador

Yécora (Calahorra)

AGN, Irache, Lib. 542, 174v.

JERÓNIMO LÓPEZ

B. A.

9-10-1630

Fr. Francisco Salvador 
Quintanilla de Santa Gadea (Burgos)

AGN, Irache, Lib. 542, 175r.

GÓMEZ MARTÍN CORTÉS

L. C.

9-10-1630

Fr. Ramiro de Goñi

Montijo (Nullius Diocesis)

AGN, Irache, Lib. 542, 175r.

BARTOLOMÉ DE BURDASPAL Y BERBE-

\section{RANA}

B. L. / L. L.

17-10-1630

Fr. Ramiro de Goñi

Villafranca (Pamplona)

AGN, Irache, Lib. 542, 175r.

JOSÉ DE LA CERDA

B. A. / B. T. / L. A. / M. A. / L. T. / M. T.

19-10-1630 / 20-10-1630

Fr. Ramiro de Goñi

O. S. B.

AGN, Irache, Lib. 542, 175v.

JUAN LÓPEZ DE LANA

B. C.

2-11-1630

Fr. José de Carmona

Tortuera (Sigüenza)

AGN, Irache, Lib. 542, 175v.

JORGE NÚÑEZ

B. A.

3-11-1630

Fr. José de Carmona

Lisboa

AGN, Irache, Lib. 542, 175v.

MARTÍN GONZÁLEZ DE LEZCANO Y TRONCÓNIZ

L. C.

10-11-1630

Fr. José de Carmona

Troncóniz (Calahorra)

AGN, Irache, Lib. 542, 175v.

NICOLÁS DE HERRERA

B. C.
12-11-1630

Fr. Francisco Salvador

Asbeidia (Nullius Diocesis)

AGN, Irache, Lib. 542, 176r.

\section{ESTEBAN DE SALINAS}

B. C.

29-11-1630

Fr. Matías de Hevia

Lastras (Burgos)

AGN, Irache, Lib. 542, 176r.

MARTÍN DE REA

B. C.

2-12-1630

Fr. José de Carmona

Cameno (Burgos)

AGN, Irache, Lib. 542, 176r.

ALONSO DE DUEÑAS

B. T.

5-12-1630

Fr. Francisco Salvador

Castrillo de Murcia (Burgos)

AGN, Irache, Lib. 542, 176r.

NICOLÁS GARCÍA

B. C.

5-12-1630

Fr. Matías de Hevia

Castro Urdiales (Burgos)

AGN, Irache, Lib. 542, 176r.

JUAN LÓPEZ

B. C.

8-12-1630

Fr. José de Carmona

Torme (Burgos)

AGN, Irache, Lib. 542, 176r.

NICOLÁS DE SAN PEDRO

L. C. / D. C.

11-12-1630

Fr. Ramiro de Goñi

Haro (Calahorra)

AGN, Irache, Lib. 542, 176v.

FRANCISCO REVALLOS BRAVO

L. C. 
13-12-1630

Fr. Ramiro de Goñi

Las Presillas (Burgos)

AGN, Irache, Lib. 542, 176v.

MATÍAS DE HEVIA

B. A. / L. A. / M. A. / B. T. / L. T. / M. T.

5-1-1631 / 18-9-1631

Fr. Francisco Salvador / Fr. Ramiro de Goñi

O. S. B.

Lector de Teología en Irache

Profeso en San Martín de Santiago

AGN, Irache, Lib. 542, 177r, 183 r.

JUAN MORATE

B. C.

8-1-1631

Fr. Francisco Salvador

Villasandino (Burgos)

AGN, Irache, Lib. 542, 177r.

DOMINGO PEÑA

B. C.

23-1-1631

Fr. José de Carmona

Burgos

AGN, Irache, Lib. 542, 177r.

LORENZO DE SOTO VARGAS

B. C.

24-1-1631

...

Cameno (Burgos)

AGN, Irache, Lib. 542, 177r.

JUAN GONZÁLEZ DE PAREDES

B. C.

10-2-1631

...

Melgar (Burgos)

AGN, Irache, Lib. 542, 177r.

JUAN DE VILLASANDINO

B. C.

10-2-1631

Fr. José de Carmona

Melgar (Burgos)

AGN, Irache, Lib. 542, $177 \mathrm{v}$.
PEDRO DE MEDIAVILLA

B. C.

10-2-1631

Fr. Regente

Melgar (Burgos)

AGN, Irache, Lib. 542, $177 \mathrm{v}$.

GABRIEL DE ESPARZA

L. T. / M. T.

20-2-1631

Fr. Ramiro de Goñi, Abad y Rector

Pamplona

AGN, Irache, Lib. 542, $177 \mathrm{v}$.

JUAN CRISÓSTOMO DE VARGAS

L. L. / D. L.

24-2-1631

Fr. Ramiro de Goñi / Ldo. Calatayud, Letrado de Estella

Almunia (Zaragoza)

AGN, Irache, Lib. 542, $177 \mathrm{v}$.

JUAN NAVARRO DE IRAZÁBAL

B. T. / L. T. / M. T.

27-2-1631 / 28-2-1631

Fr. Ramiro de Goñi

Viana (Calahorra)

AGN, Irache, Lib. 542, 178r.

JUAN DE PORRES

L. C. / D. C.

3-3-1631

Fr. Ramiro de Goñi

Segovia

Inquisidor de Logroño

AGN, Irache, Lib. 542, 178r.

BARTOLOMÉ ORTIZ

B. C.

10-3-1631

Fr. José de Carmona

Puerto de Santoria (Burgos)

AGN, Irache, Lib. 542, 178v.

BERNARDO RETA

L. A.

18-3-1631

Fr. Ramiro de Goñi 
Murillo (Pamplona)

AGN, Irache, Lib. 542, 178v.

\section{MARCOS GARCÍA}

B. C.

24-3-1631

Fr. Francisco Salvador

Melgar de Fernamental (Burgos)

AGN, Irache, Lib. 542, 178v.

\section{JUAN LÓPEZ}

B. C.

2-4-1631

Fr. José de Carmona

Melgar de Fernamental (Burgos)

AGN, Irache, Lib. 542, 178v.

\section{MARTÍN SÁNCHEZ DE LA TORRE}

B. A. / L. A.

2-4-1631

Fr. Pedro Díaz, M. A.

Vallejo (Burgos)

AGN, Irache, Lib. 542, 178v.

FRANCISCO PUGA

B. C.

28-4-1631

Fr. Francisco Salvador

Burgos

AGN, Irache, Lib. 542, 179r.

VÍCTORES SÁENZ DE LA MALETA

B. C.

5-5-1631

Fr. Francisco Salvador

Quintanilla de San García (Burgos)

AGN, Irache, Lib. 542, 179r.

JERÓNIMO ... MODREGO

B. C.

15-5-1631

Fr. Francisco Salvador

Pozuelo (Zaragoza)

AGN, Irache, Lib. 542, 179 r.

\section{JUAN IBÁÑEZ}

B. C.

16-5-1631
Fr. Francisco Salvador

Nidáguila (Burgos)

AGN, Irache, Lib. 542, 179 r.

ANDRÉS IBÁÑEZ

B. C.

19-5-1631

Fr. José de Carmona

Sotresgudo (Burgos)

AGN, Irache, Lib. 542, 179r.

JUAN DÍEZ MATA

B. C.

19-5-1631

Fr. José de Carmona

Ubierna (Burgos)

AGN, Irache, Lib. 542, 179 r.

BARTOLOMÉ FERNÁNDEZ

B. C.

21-5-1631

Fr. Francisco Salvador

La Cuadra (Burgos)

AGN, Irache, Lib. 542, 179v.

ENRIQUE DE QUESADA Y TOLEDO

B. C.

25-5-1631

Fr. José de Carmona

Baeza (Jaén)

AGN, Irache, Lib. 542, 179v.

MIGUEL DE LEGASA

L. L.

29-5-1631

Fr. Ramiro de Goñi

Pamplona

Ldo. Calatayud

AGN, Irache, Lib. 542, $179 v$.

JUAN LORENZO CASADO

L. C. / D. C.

30-5-1631

Fr. Ramiro de Goñi

Tarazona

AGN, Irache, Lib. 542, $179 v$.

PEDRO AGUILÓN BRIZ

B. C. / L. C. 
8-6-1631

Fr. Francisco Salvador / Fr. Ramiro de Goñi Villar de los Navarros (Zaragoza)

AGN, Irache, Lib. 542, 18 or.

\section{SEBASTIÁN DE CASTRO}

B. C.

13-6-1631

Fr. Francisco Salvador

Burgos

AGN, Irache, Lib. 542, 18 or.

\section{JUAN GÓMEZ DE LA SERNA}

B. C.

17-6-1631

Fr. José de Carmona

Palenzuela (Burgos)

AGN, Irache, Lib. 542, 18 or.

JOSÉ ACEITORES

B. C.

17-6-1631

Fr. José de Carmona

Palenzuela (Burgos)

AGN, Irache, Lib. 542, 18 or.

\section{MARCOS ANTONIO BERGANZA}

B. A.

30-6-1631

Fr. Pedro Díaz de Inguanzo

Arróniz (Pamplona)

AGN, Irache, Lib. 542, 18 or.

JUAN GÓMEZ

B. A.

2-7-1631

Fr. Pedro Díaz

Lisboa

AGN, Irache, Lib. 542, $180 v$.

DOMINGO DE LA PLAZA

B. C.

2-7-1631

Fr. Francisco Salvador

Yudego (Burgos)

AGN, Irache, Lib. 542, $180 v$.

PEDRO ZORRILLA

B. T. / L. T. / D. T.
11-7-1631 / 12-7-1631

Fr. Matías de Hevia / Fr. Ramiro de Goñi

Toba de Valdivielso (Burgos)

AGN, Irache, Lib. 542, 180v.

FRANCISCO BERNARDINO

B. C.

12-7-1631

Fr. Matías de Hevia

Burgos

AGN, Irache, Lib. 542, 180v.

BARTOLOMÉ DE FRANCIA

L. M. / D. M.

12-7-1631

Fr. Ramiro de Goñi / Dr. Alzueta

Tudela (Tarazona)

AGN, Irache, Lib. 542, 181r.

\section{GREGORIO MARTÍNEZ}

B. C.

16-7-1631

Fr. Francisco Salvador

Melgar de Fernamental (Burgos)

AGN, Irache, Lib. 542, 181r.

PASCUAL JUÁREZ

B. C.

16-7-1631

Fr. Francisco Salvador

Melgar de Fernamental (Burgos)

AGN, Irache, Lib. 542, 181r.

PEDRO DE BAYO

B. L. / L. L.

19-7-1631

Fr. Ramiro de Goñi

Corella (Tarazona)

AGN, Irache, Lib. 542, 181r.

MIGUEL LÓPEZ DE BARRIONUEVO

B. A.

22-7-1631

Fr. Pedro Díaz de Inguanzo

Viana (Calahorra)

AGN, Irache, Lib. 542, $181 \mathrm{v}$.

BARTOLOMÉ DE LA GUARDIA

B. A. 
22-7-1631

Fr. Pedro Díaz de Inguanzo

Viana (Calahorra)

AGN, Irache, Lib. 542, 181v.

JUAN ANTONIO SAN MARTÍN

B. A.

22-7-1631

Fr. Pedro Díaz de Inguanzo

Viana (Calahorra)

AGN, Irache, Lib. 542, 181v.

ESTEBAN DE CORRAL

L. C.

24-7-1631

Fr. Matías de Hevia

Villabasil (Burgos)

AGN, Irache, Lib. 542, 181v.

\section{HERNANDO SANTOS}

B. C.

24-7-1631

Fr. Francisco Salvador

Melgar de Fernamental (Burgos)

AGN, Irache, Lib. 542, 181v.

MARCO ANTONIO ALEGRE CASANATE

B. T. / L. T. / D. T.

24-7-1631 / 25-7-1631

Fr. José de Carmona / Fr. Ramiro de Goñi

O. C.

Provincia de Aragón

AGN, Irache, Lib. 542, 181v-182r.

JUAN DE CABEZÓN

B. C.

27-7-1631

Fr. Matías de Hevia

Castrojeriz (Burgos)

AGN, Irache, Lib. 542, 182 r.

JUAN SÁENZ PÉREZ

B. C.

14-8-1631

Fr. Francisco Salvador

Marmellar (Nullius Diocesis)

AGN, Irache, Lib. 542, 182r.
FRANCISCO DE LA LLANILLA

B. C.

30-8-1631

Fr. José de Carmona

Ampuero (Burgos)

AGN, Irache, Lib. 542, 182r.

MIGUEL DE ARRIZAGA

L. C.

10-9-1631

Fr. Francisco Salvador

Güesa (Pamplona)

AGN, Irache, Lib. 542, 182v.

\section{JUAN JIMÉNEZ}

B. C.

12-9-1631

Fr. Matías de Hevia

Espinosa de los Monteros (Burgos)

AGN, Irache, Lib. 542, $182 \mathrm{v}$.

FRANCISCO DE QUÍLEZ

B. A.

12-9-1631

Fr. Pedro Díaz

Arróniz (Pamplona)

AGN, Irache, Lib. 542, $182 \mathrm{v}$.

FRANCISCO DE MURO

L. M. / D. M.

16-9-1631

Fr. Ramiro de Goñi / Dr. Alzueta / Ldo. On-

tiveros

Corella (Tarazona)

AGN, Irache, Lib. 542, 183 r.

GREGORIO DE URBINA

B. C.

27-9-1631

Fr. Francisco Salvador

Melgar de Fernamental (Burgos)

AGN, Irache, Lib. 542, $183 \mathrm{v}$.

\section{ANTONIO RODRÍGUEZ}

B. C.

3-10-1631

Fr. Matías de Hevia

Castrojeriz (Burgos)

AGN, Irache, Lib. 542, $183 \mathrm{v}$. 
PEDRO ORTIZ

B. C.

10-10-1631

Fr. José de Carmona

Burgos

AGN, Irache, Lib. 542, 183v.

JUAN RUBIO

B. C.

15-10-1631

Fr. José de Carmona

Santuade (Burgos)

AGN, Irache, Lib. 542, $183 \mathrm{v}$.

SEBASTIÁN GOMBO

B. C.

25-10-1631

Fr. Matías de Hevia

Agüero (Burgos)

AGN, Irache, Lib. 542, 184 r.

\section{GREGORIO ESCUDERO}

L. C.

30-10-1631

Fr. Ramiro de Goñi

Pradoluengo (Burgos)

AGN, Irache, Lib. 542, 184 r.

PLÁCIDO DE BÁRCENA

B. T. / L. T. / M. T.

4-11-1631

Fr. José de Carmona / Fr. Ramiro de Goñi

O. S. B.

B. T. en Valladolid

Profeso de San Benito, Valladolid

AGN, Irache, Lib. 542, 184 r.

PEDRO MURILLO

B. T. / L. T. / D. T.

18-11-1631

Fr. Matías de Hevia / Fr. Francisco Salva-

dor

Perdiguera (Zaragoza)

AGN, Irache, Lib. 542, 184v.

JUAN MARTÍNEZ DEL PINO

B. C.

24-11-1631
Fr. Francisco Salvador

Burgos

AGN, Irache, Lib. 542, 185 r.

FRANCISCO RUIZ

B. C.

20-12-1631

Fr. Matías de Hevia

Burgos

AGN, Irache, Lib. 542, 185 r.

ANTONIO DE SABOYA

B. C.

23-12-1631

Fr. José de Carmona

Valladolid

AGN, Irache, Lib. 542, 185v.

VICENTE DE LA SERRADA

L. C.

31-12-1631

Fr. Mauro de Villarroel

Huesca

AGN, Irache, Lib. 542, $185 \mathrm{v}$.

LORENZO DE ESPINOSA

B. A.

5-1-1632

Fr. Juan Díaz, Lector de Artes

Puente la Reina (Pamplona)

AGN, Irache, Lib. 542, 186r.

FRANCISCO DE LA PUENTE

B. C.

10-1-1632

Fr. José de Carmona

Balmaseda (Burgos)

AGN, Irache, Lib. 542, 186r.

DOMINGO DE PERAGALLO

B. C.

7-2-1632

Fr. Matías de Hevia

Ampuero (Burgos)

AGN, Irache, Lib. 542, 186r.

MIGUEL GUILLÉN

L. T. / D. T. 
13-2-1632

Fr. José de Carmona

Lerma (Nullius Diocesis)

AGN, Irache, Lib. 542, 186v.

JERÓNIMO GÓMEZ

B. C.

17-2-1632

Fr. José de Carmona

Taños (Burgos)

AGN, Irache, Lib. 542, 186v.

BENITO DE SALA LLAUDES

L. C. / D. C.

4-3-1632

Fr. Francisco Salvador

Figueras (Girona)

AGN, Irache, Lib. 542, 187 r.

MANUEL ALONSO DE AZAGRA

B. T.

14-3-1632

Fr. Matías de Hevia

Aldeanueva (Calahorra)

AGN, Irache, Lib. 542, 187 r.

\section{MATEO BLANCO}

B. C.

14-3-1632

Fr. Matías de Hevia

Hormaza (Burgos)

AGN, Irache, Lib. 542, 187 r.

PEDRO DE LA HEDILLA

L. C. / D. C.

22-3-1632

Fr. Ramiro de Goñi

Laredo (Burgos)

AGN, Irache, Lib. 542, $187 \mathrm{rv.}$

JUAN ORTIZ

L. T. / D. T.

23-3-1632

Fr. Ramiro de Goñi

Luceni (Zaragoza)

AGN, Irache, Lib. 542, 187v.

JUAN MARTÍNEZ DE VILLAÑANA

B. C.
23-3-1632

Fr. Matías de Hevia

Villañana (Burgos)

AGN, Irache, Lib. 542, $187 \mathrm{v}$.

FRANCISCO RODRÍGUEZ DE LA LASTRA

B. C.

5-4-1632

Fr. Francisco Salvador

Olea (Burgos)

AGN, Irache, Lib. 542, 188r.

JUAN DE AZCONA

L. L.

6-4-1632

Fr. Ramiro de Goñi / Ldo. José de Vich

Pamplona

AGN, Irache, Lib. 542, 188r.

FRANCISCO RUIZ DE SOBREMONTE

B. C.

11-4-1632

Fr. José de Carmona

Vallaren del Arco (Burgos)

AGN, Irache, Lib. 542, 188v.

PEDRO DE PEREGRÍN

B. T. / L. T.

16-4-1632

Fr. Francisco Salvador

Pobo (Sigüenza)

AGN, Irache, Lib. 542, 188v.

ALEJO GUTIÉRREZ

B. C.

28-4-1632

Fr. Matías de Hevia

Villasandino (Burgos)

AGN, Irache, Lib. 542, 188v.

JOSÉ GÓMEZ DE CORNEJO

L. C.

9-5-1632

Fr. Ramiro de Goñi

Méjico

AGN, Irache, Lib. 542, 188v.

JUAN DE GORRITI

B. A. 
18-5-1632

Fr. Juan Díaz

Azcoitia (Pamplona)

Alumno S. J.

AGN, Irache, Lib. 542, 189 r.

JUAN PARÍS

B. A.

18-5-1632

Fr. Juan Díaz

Pamplona

Alumno S. J.

AGN, Irache, Lib. 542, 189 r.

BALTASAR DE LASAGA

B. A.

18-5-1632

Fr. Juan Díaz

Pamplona

Alumno S. J.

AGN, Irache, Lib. 542, 189 r.

JUAN DE MICHETO

B. A.

18-5-1632

Fr. Juan Díaz

Badostain (Pamplona)

Alumno S. J.

AGN, Irache, Lib. 542, 189 r.

\section{JUAN DE ARANGUREN}

B. A.

18-5-1632

Fr. Juan Díaz

Abínzano (Pamplona)

Alumno S. J.

AGN, Irache, Lib. 542, 189 r.

MARTÍN DE ALBÉNIZ

B. A.

18-5-1632

Fr. Juan Díaz

Azcona (Pamplona)

Alumno S. J.

AGN, Irache, Lib. 542, 189 r.

JUAN DE LEZÁUN

B. A.
18-5-1632

Fr. Juan Díaz

Dicastillo (Pamplona)

Alumno S. J.

AGN, Irache, Lib. 542, 189r.

MIGUEL DE LIZASOAIN

B. A.

18-5-1632

Fr. Juan Díaz

Asiain (Pamplona)

Alumno S. J.

AGN, Irache, Lib. 542, 189 r.

PEDRO GARCÍA

B. A.

18-5-1632

Fr. Juan Díaz

Mañeru (Pamplona)

Alumno S. J.

AGN, Irache, Lib. 542, 189 r.

MARTÍN DE TURRILLAS

B. A.

18-5-1632

Fr. Juan Díaz

Pamplona

Alumno S. J.

AGN, Irache, Lib. 542, 189 r.

MARTÍN DE ESQUIROZ

B. A.

18-5-1632

Fr. Juan Díaz

Eguiarreta (Pamplona)

Alumno S. J.

AGN, Irache, Lib. 542, 189 r.

PEDRO DE LASA

B. A.

18-5-1632

Fr. Juan Díaz

Iturgoyen (Pamplona)

Alumno S. J.

AGN, Irache, Lib. 542, 189r.

JUAN DE EGUIARRETA

L. L. 
18-5-1632

Fr. Matías de Hevia

Pamplona

AGN, Irache, Lib. 542, 189 r.

ESTEBAN FERNANDO DE ZUBIAUR

L. C. / D. C.

22-5-1632

Fr. Hernando de Amezcua

Llodio (Calahorra)

AGN, Irache, Lib. 542, 189v.

MIGUEL MERINO

B. T. / L. T. / M. T.

25-5-1632

Fr. Francisco Salvador

O. Praem.

AGN, Irache, Lib. 542, 189v.

JUAN PÉREZ DE FRÍAS

B. C.

4-6-1632

Fr. Francisco Salvador

Losantos (Burgos)

AGN, Irache, Lib. 542, 19or.

ANDRÉS RUBIO

B. C.

9-6-1632

Fr. Matías de Hevia

Alaejos (Valladolid)

AGN, Irache, Lib. 542, 19 or.

JUAN DE LODOSA

B. C.

14-7-1632

Fr. Matías de Hevia

Izarde (Burgos)

AGN, Irache, Lib. 542, 190r.

FRANCISCO GUILAZ

L. A.

24-7-1632

Fr. Pedro Díaz

Arróniz (Pamplona)

AGN, Irache, Lib. 542, 190r.

AGUSTÍN RUIZ DEL CASTILLO

B. C.
24-7-1632

Fr. Matías de Hevia

Hesles (Burgos)

AGN, Irache, Lib. 542, $190 v$.

MARTÍN FERNÁNDEZ DE BONILLA

L. C. / D. C.

27-7-1632

Fr. Matías de Hevia

Villanueva de los Infantes (Toledo)

AGN, Irache, Lib. 542, $190 v$.

JUAN MARTÍNEZ DE SAN MARTÍN

L. L.

5-8-1632

Fr. Ramiro de Goñi

Pamplona

AGN, Irache, Lib. 542, $190 v$.

MARTÍN DE RIPALDA

L. L.

18-8-1632

Fr. Ramiro de Goñi

Olite

AGN, Irache, Lib. 542, 191r.

MATÍAS GARCÍA

B. C.

24-8-1632

Fr. José de Carmona

Redecilla del Campo (Burgos)

AGN, Irache, Lib. 542, 191r.

MIGUEL ...

B. C.

26-8-1632

Fr. Francisco Salvador

Burgos

AGN, Irache, Lib. 542, 191 r.

SIMÓN DE MANSILLA

B. C.

11-9-1632

Fr. Francisco Salvador

Pedrosa del Río Urbel (Burgos)

AGN, Irache, Lib. 542, 191r.

MARTÍN CALZAS

B. C. 
15-9-1632

Fr. José de Carmona

Alaejos (Valladolid)

AGN, Irache, Lib. 542, 191v.

LUIS ÁLVAREZ DE QUIÑONES

B. C.

30-9-1632

Fr. José de Carmona

Aguilar de Campoo (Burgos)

AGN, Irache, Lib. 542, 191v.

MATÍAS LÓPEZ

B. C.

30-9-1632

Fr. José de Carmona

Modúbar de San Adrián (Burgos)

AGN, Irache, Lib. 542, $191 \mathrm{v}$.

FRANCISCO SÁNCHEZ DE MOREDA

B. A.

8-10-1632

Fr. José de Carmona

Viguera (Calahorra)

AGN, Irache, Lib. 542, 191v.

PEDRO LLANO VELASCO

B. C.

8-10-1632

Fr. José de Carmona

Riaño (Burgos)

AGN, Irache, Lib. 542, 191v.

\section{ANTONIO DE TORANZO}

B. C.

17-10-1632

Fr. Francisco Salvador

Castrillo de Matajudíos (Burgos)

AGN, Irache, Lib. 542, 192r.

PEDRO SÁENZ

B. C.

17-10-1632

Fr. Francisco Salvador

Villamediana (Burgos)

AGN, Irache, Lib. 542, 192r.

GASPAR LÓPEZ

B. C.
18-10-1632

Fr. Francisco Salvador

Linares (Burgos)

AGN, Irache, Lib. 542, 192 r.

SANTIAGO ALONSO

B. C.

23-10-1632

Fr. Matías de Hevia

Villasandino (Burgos)

AGN, Irache, Lib. 542, 192r.

FRANCISCO DE IGUAL

B. C.

1-11-1632

Fr. Francisco Salvador

Armuero (Burgos)

AGN, Irache, Lib. 542, 192 .

\section{DIEGO MORRAS}

B. A.

9-11-1632

Fr. Pedro Díaz

Igúzquiza (Pamplona)

AGN, Irache, Lib. 542, 192r.

PEDRO MARTÍNEZ

B. C.

16-11-1632

Fr. José de Carmona

Guerico (Burgos)

AGN, Irache, Lib. 542, $192 \mathrm{v}$.

JERÓNIMO CALVO

L. T. / D. T.

18-11-1632

Fr. Ramiro de Goñi

Jaca

AGN, Irache, Lib. 542, $192 \mathrm{v}$.

ESTEBAN DEL COTERO

B. C.

21-11-1632

Fr. Matías de Hevia

San Pantaleón (Burgos)

AGN, Irache, Lib. 542, $192 \mathrm{~V}$.

MARTÍN DE ORTIZ DE OTEO

B. C. 
23-11-1632

Fr. José de Carmona

Arroyuelo (Burgos)

AGN, Irache, Lib. 542, 192v.

AMBROSIO DE ESTÉBANEZ

B. C.

24-11-1632

Fr. Matías de Hevia

Villasandino (Burgos)

AGN, Irache, Lib. 542, 192v.

JUAN FRANCO

B. C.

29-11-1632

Fr. Francisco Salvador

Briviesca (Burgos)

AGN, Irache, Lib. 542, 193 r.

MARTÍN DE OQUERULI SANTA CRUZ

L. C.

7-12-1632

Fr. José de Carmona

Salvatierra (Calahorra)

AGN, Irache, Lib. 542, 193 r.

DIEGO DE SAN MARTÍN

B. C.

18-12-1632

Fr. José de Carmona

Briviesca (Burgos)

AGN, Irache, Lib. 542, 193r.

ALONSO MARTÍNEZ

B. C.

21-12-1632

Fr. Matías de Hevia

Pedrosa (Burgos)

AGN, Irache, Lib. 542, 193r.

PEDRO DE BURGOS

B. C.

5-1-1633

Fr. Francisco Salvador

Balmaseda (Burgos)

AGN, Irache, Lib. 542, 193v.

GABRIEL DE SAN ROMÁN

B. C.
19-1-1633

Fr. José de Carmona

Santa Cruz de Juarros (Burgos)

AGN, Irache, Lib. 542, $193 \mathrm{v}$.

JUAN DE LA GUARDIA

B. C.

27-1-1633

Fr. Matías de Hevia

La Braya (Calahorra)

AGN, Irache, Lib. 542, $193 \mathrm{v}$.

\section{DIEGO MARTÍNEZ}

B. C.

10-2-1633

Fr. Francisco Salvador

Hontanas (Burgos)

AGN, Irache, Lib. 542, 193v.

ANTONIO DE ESCAULES

B. A. / L. A. / M. A. / L. T. / M. T.

24-2-1633

Fr. Pedro Díaz de Inguanzo / Fr. José de

Carmona

O. S. B.

Catedrático de Lenguas en la Universidad de Salamanca

AGN, Irache, Lib. 542, 193 v.

JUAN MAZA

B. A.

24-2-1633

Fr. Pedro Díaz de Inguanzo

Fuenmayor (Calahorra)

AGN, Irache, Lib. 542, 194 r.

DIEGO DE BÁRCENA

B. C.

10-3-1633

Fr. José de Carmona

Mazuela (Burgos)

AGN, Irache, Lib. 542, 194 r.

ANDRÉS DE MARAÑÓN

B. C.

17-3-1633

Fr. Matías de Hevia

Fresnedo (Burgos)

AGN, Irache, Lib. 542, 194 r. 
ANTONIO DE FELOAGA

L. C.

18-3-1633

Fr. Ramiro de Goñi

Pamplona

AGN, Irache, Lib. 542, 194 r.

JERÓNIMO BALLESTER

L. L. / D. L.

20-3-1633

Fr. Ramiro de Goñi

Alcoriza (Zaragoza)

AGN, Irache, Lib. 542, 194v.

FRANCISCO SALVADOR

B. A. / L. A. / M. A. / B. T. / L. T. / D. T. 28-3-1633

Fr. Ramiro de Goñi

O. S. B.

Lector de Teología de Irache

AGN, Irache, Lib. 542, 194v.

JOSÉ PORTER Y CASANATE

L. L. / D. L.

4-4-1633

Fr. José de Carmona

Zaragoza

AGN, Irache, Lib. 542, 194v.

PEDRO DE URRA

B. A.

19-4-1633

Fr. Pedro Díaz

Arguiñano (Pamplona)

AGN, Irache, Lib. 542, 195r.

JULIÁN DE LIZA

B. C.

21-4-1633

Fr. Francisco Salvador

Pancorbo (Burgos)

AGN, Irache, Lib. 542, 195r.

JUAN DE MEDRANO

B. T. / L. T.

27-4-1633

Fr. Francisco Salvador

Pamplona

AGN, Irache, Lib. 542, 195r.
HERNANDO DE LA MATA LINARES

B. C.

6-5-1633

Fr. Francisco Salvador

Valle de Peñarrubia (Burgos)

AGN, Irache, Lib. 542, 195r.

JERÓNIMO PEREIRA

B. A. / L. A. / M. A. / B. T. / L. T. / D. T. 17-5-1633

Fr. Pedro Díaz / Fr. Francisco Cambero

O. S. B.

Profeso de San Martín de Santiago

AGN, Irache, Lib. 542, 195v.

FRANCISCO DESCARAY

B. C.

27-5-1633

Fr. Francisco Salvador

Castrojeriz (Burgos)

AGN, Irache, Lib. 542, 195v.

JOAQUÍN DE PLANTADA

B. C.

2-6-1633

Fr. Francisco Salvador

Castro Urdiales (Burgos)

AGN, Irache, Lib. 542, 195v.

ALONSO DE LOS RÍOS

B. C. / L. C. / D. C.

2-6-1633 / 29-4-1636

Fr. Francisco Salvador / Fr. Gabriel de La

Riba de Herrera

Madrid (Toledo)

AGN, Irache, Lib. 542, 195v, $220 r$.

JUAN DE BÁRCENA

L. C.

3-6-1633

Fr, Gabriel de La Riba de Herrera, abad y canciller

Beri... (Burgos)

AGN, Irache, Lib. 542, 196r.

GABRIEL DE LA RIBA DE HERRERA

B. A. / L. A. / M. A. / B. T. / L. T. / D. T. 2-6-1633 
Fr. Francisco Salvador

O. S. B.

Abad de Irache

Hijo de San Isidro de Dueñas

AGN, Irache, Lib. 542, 196r.

PEDRO PAZOS

B. A. / L. A. / M. A. / B. T. / L. T. / D. T. 3-6-1633

Fr. Gabriel de La Riba de Herrera

O. S. B.

Profeso de la casa de Cardeña

AGN, Irache, Lib. 542, $196 \mathrm{r}$.

JOSÉ AMUNÁRRIZ

B. A. / L. A. / M. A. / B. T. / L. T. / D. T. 11-6-1633

Fr. Gabriel de La Riba de Herrera

O. S. B.

Predicador

Profeso de la Casa de Nájera

AGN, Irache, Lib. 542, 196v.

JOSÉ PÉREZ DE MOREDA

B. C.

16-6-1633

Fr. Francisco Cambero

Alfaro (Tarazona)

AGN, Irache, Lib. 542, 197r.

MARTÍN MARTÍNEZ

B. A. / L. A. / M. A. / B. T. / L. T. / D. T. 21-6-1633

Fr. Gabriel de La Riba de Herrera

O. S. B.

Predicador

Profeso en San Millán

AGN, Irache, Lib. 542, 197r.

DAMIÁN DE FRÍAS

B. T.

26-6-1633

Fr. Pedro Díaz

Poza (Burgos)

AGN, Irache, Lib. 542, 197r.

ANTONIO DE TORRES

B. A. / L. A. / M. A. / B. T. / L. T. / D. T.
4-7-1633

Fr. Gabriel de La Riba de Herrera

O. S. B.

Profeso de San Martín de Santiago

AGN, Irache, Lib. 542, 197v.

JUAN DE BECARES

L. C.

6-7-1633

Fr. Pedro Díaz de Inguanzo

Sestao (Calahorra)

Clérigo Pbro.

AGN, Irache, Lib. 542, $197 \mathrm{v}$.

JUAN DE BILBAO BASOZÁBAL

B. C.

6-7-1633

Fr. Pedro Díaz de Inguanzo

Sto. Domingo (Calahorra)

AGN, Irache, Lib. 542, 197v.

FRANCISCO DE SAN MARTÍN

B. C.

7-7-1633

Fr. Pedro Díaz de Inguanzo

Burgos

AGN, Irache, Lib. 542, 197v.

JUAN MARTÍNEZ

B. C.

7-7-1633

Fr. Pedro Díaz de Inguanzo

Villalaín (Burgos)

AGN, Irache, Lib. 542, $197 \mathrm{v}$.

SIMÓN BENITO

B. C.

9-7-1633

Fr. Pedro Díaz de Inguanzo

Villandiego (Burgos)

AGN, Irache, Lib. 542, 198r.

FERNANDO DÍAZ DE VILLEGAS

B. C.

17-7-1633

Fr. Francisco Salvador

Burgos

AGN, Irache, Lib. 542, 198r. 
JUAN DE ECHALAZ

D. T.

29-7-1633

Fr. Gabriel de La Riba de Herrera

L. T. en Salamanca

...

AGN, Irache, Lib. 542, 198r.

MIGUEL DE ARI...

L. -.

7-8-1633

Fr. Gabriel de La Riba de Herrera

Pamplona

AGN, Irache, Lib. 542, 198v.

\section{DIEGO RAM...}

B. C.

7-8-1633

Fr. Francisco Salvador

Valle de Guireo (Burgos)

AGN, Irache, Lib. 542, 198v.

FRANCISCO DE ZUBIAGA

L. C.

12-8-1633

Fr. Gabriel de La Riba de Herrera

Portugalete (Burgos)

AGN, Irache, Lib. 542, 199 r.

\section{RAMIRO DE GOÑI}

M. T.

18-8-1633

Fr. Gabriel de La Riba de Herrera

O. S. B.

De Irache

AGN, Irache, Lib. 542, 199r.

MIGUEL DE BARREDA

B. A. / L. A. / M. A. / B. T. / L. T. / D. T. 3-9-1633

Fr. Gabriel de La Riba de Herrera

O. S. B.

Hijo de Oña

AGN, Irache, Lib. 542, 199r.

RAIMUNDO DÍAZ DE GARIBAY

B. T. / L. T. / D. T.

7-9-1633
Fr. Gabriel de La Riba de Herrera

O. Cist.

Predicador

Monasterio de Veruela

AGN, Irache, Lib. 542, 199 r.

JUAN DE SAN MILLÁN

B. T.

7-9-1633

Fr. Francisco Salvador

Fresneda (Burgos)

AGN, Irache, Lib. 542, 200 .

ANTONIO DE LA FUENTE

B. C.

11-9-1633

Fr. Francisco Salvador

... Pamplona

AGN, Irache, Lib. 542, 200 .

MARTÍN DE SANTISTEBAN

B. T.

15-9-1633

Fr. Gabriel de La Riba de Herrera

Pamplona

Abad de Uterga

AGN, Irache, Lib. 542, $200 v$.

JUAN DE CIRIZA

B. T.

15-9-1633

Fr. Gabriel de La Riba de Herrera

Ciriza (Pamplona)

AGN, Irache, Lib. 542, $200 v$.

FRANCISCO DÍEZ DE MIRANDA

B. C.

19-9-1633

Fr. Francisco Salvador

Castrojeriz (Burgos)

AGN, Irache, Lib. 542, 201r.

FRANCISCO DE VEGA Y VARGAS

B. A. / L. A. / M. A. / B. T. / L. T. / D. T.

24-9-1633

Fr. Gabriel de La Riba de Herrera

O. S. B.

Casa de Valladolid

AGN, Irache, Lib. 542, 201r. 


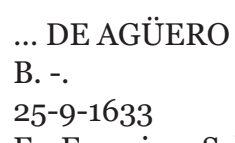

Fr. Francisco Salvador

Rucandio (Burgos)

AGN, Irache, Lib. 542, 201r.

LUCAS PÉREZ ROJO

B. C.

26-9-1633

Fr. Francisco Cambero

Mirabeche (Burgos)

AGN, Irache, Lib. 542, $201 \mathrm{v}$.

JUAN MARTÍNEZ DE ALCÁNTARA

B. C.

29-9-1633

Fr. Francisco Salvador

Melgar de Fernamental (Burgos)

AGN, Irache, Lib. 542, 201v.

JUAN DEL CASTILLO

B. A.

8-10-1633

Fr. Diego de Silva

Logroño (Calahorra)

AGN, Irache, Lib. 542, 201v.

DIEGO DE LA PUENTE MONTECILLO

L. C.

12-10-1633

Fr. Francisco Salvador

Solares (Burgos)

AGN, Irache, Lib. 542, 201v.

FRANCISCO CAMBERO

B. A. / L. A. / M. A. / B. T. / L. T. / D. T.

17-10-1633

Fr. Gabriel de La Riba de Herrera

O. S. B.

Lector de Irache

AGN, Irache, Lib. 542, 202 r.

GASPAR TAPIA

B. A. / L. A. / M. A. / B. T. / L. T. / D. T.

27-10-1633

Fr. Gabriel de La Riba de Herrera

O. S. B.
Profeso de Ntra. Sra. de Montserrat

AGN, Irache, Lib. 542, 202 r.

\section{ALONSO GONZÁLEZ}

B. C.

30-10-1633

Fr. Plácido del Río

... Burgos

AGN, Irache, Lib. 542, 202v.

PEDRO DE LAÍNEZ

B. A. / L. A. / M. A. / B. T. / L. T. / D. T. 2-11-1633

Fr. Gabriel de La Riba de Herrera

Predicador general

Casa de Sto. Domingo

AGN, Irache, Lib. 542, 202v.

\section{DOMINGO GONZÁLEZ}

B. C.

$-/-/ 1633$

Fr. Francisco Salvador

Villagutiérrez (Burgos)

AGN, Irache, Lib. 542, 202v.

DOMINGO PARDO

B. C.

$-/-/ 1633$

Fr. Francisco Salvador

Arnedillo (Burgos)

AGN, Irache, Lib. 542, 202v.

SANCHO DE ILUNDÁIN

L. A.

19-11-1633

Fr. Diego de Silva

Ilundain (Pamplona)

AGN, Irache, Lib. 542, 203 r.

JUAN BÁÑEZ

B. C.

22-11-1633

Fr. Plácido del Río

Burgos

AGN, Irache, Lib. 542, 203 r.

JERÓNIMO DE FELOAGA

L. C. 
25-11-1633

Fr. Plácido del Río

Pamplona

AGN, Irache, Lib. 542, 203 r.

BLAS DE BUSTILLO

B. C.

26-11-1633

Fr. Francisco Salvador

Valladolid

AGN, Irache, Lib. 542, 203v.

\section{PASCUAL DE MARCOS}

B. C.

1-12-1633

Fr. Francisco Salvador

Ruandio (Burgos)

AGN, Irache, Lib. 542, 203v.

JOSÉ DE CASANOVA

B. M.

17-12-1633

Fr. Plácido del Río

Biel (Pamplona)

AGN, Irache, Lib. 542, $203 \mathrm{v}$.

\section{JERÓNIMO DE OROZ}

B. C.

20-12-1633

Fr. Francisco Salvador

Burguete (Pamplona)

AGN, Irache, Lib. 542, 203v.

GABRIEL DÍAZ

L. A.

3-1-1634

Fr. Diego de Silva

Arróniz (Pamplona)

AGN, Irache, Lib. 542, $204 r$.

JUAN BAUTISTA DE URO

B. C.

5-2-1634

Fr. Francisco Salvador

Laredo (Burgos)

AGN, Irache, Lib. 542, $204 r$.

SANCHO DE VILLEGAS

B. C.
25-2-1634

Fr. Plácido del Río

Jebel, valle de Toranzo (Burgos)

AGN, Irache, Lib. 542, 204 r.

MELCHOR DE VILLARÓN

B. C.

4-3-1634

Fr. Francisco Salvador

Medina de Pomar (Burgos)

AGN, Irache, Lib. 542, 204 r.

FRANCISCO ANTONIO MATIENZO DE

LA ÁGUILA

B. T. / L. T.

$-/-/ 1634$

Fr. Francisco Salvador

Fr. Gabriel de La Riba de Herrera

Ávila

AGN, Irache, Lib. 542, 204v.

JUAN DE REBOLLAR

B. C.

19-4-1634

Fr. Plácido del Río

Josa (Burgos)

AGN, Irache, Lib. 542, 205 r.

LEÓN FRANCÉS

B. C.

24-4-1634

Fr. Francisco Salvador

Villobeta (Nullius Diocesis)

AGN, Irache, Lib. 542, 205 r.

FRANCISCO DE PADILLA

B. C.

24-4-1634

Fr. Francisco Salvador

Villasilos (Burgos)

AGN, Irache, Lib. 542, 205 r.

LORENZO DE TOUBES

B. C.

26-4-1634

Fr. Plácido del Río

Burgos

AGN, Irache, Lib. 542, 205 r. 
PEDRO DE QUINTANA

B. C. / L. C.

1-5-1634 / 21-7-1639

Fr. Francisco Cambero / Fr. Antonio de

Castro

Isla (Burgos)

AGN, Irache, Lib. 542, 205v, 244r.

BONIFACIO HURTADO LADRÓN DE CEGAMA

L. C.

4-5-1634

Fr. Francisco Salvador

Estella (Pamplona)

AGN, Irache, Lib. 542, 205v.

JUAN DE MAZA

B. A.

13-5-1634

Fr. Diego de Silva

Fuenmayor (Calahorra)

AGN, Irache, Lib. 542, $205 \mathrm{v}$.

BARTOLOMÉ SANZ

B. C.

14-5-1634

Fr. Francisco Salvador

Castrillo de Murcia (Burgos)

AGN, Irache, Lib. 542, 206r.

\section{MARTÍN MARTÍNEZ}

B. C. / L. C.

21-5-1634 / 22-5-1634

Fr. Plácido del Río

Urroz (Pamplona)

Beneficiado de Urroz

AGN, Irache, Lib. 542, 206r.

LAUREANO GIL

B. T. / L. T. / D. T.

22-5-1634 / 23-5-1634

Fr. Francisco Cambero / Fr. Gabriel de La

Riba de Herrera

Villarroya de los Pinares (Zaragoza)

AGN, Irache, Lib. 542, 206rv.

JUAN ANTONIO CUELLO

B. T. / M. A. / D. T.
22-5-1634 /23-5-1634

Fr. Francisco Cambero / Fr. Gabriel de La

Riba de Herrera

Zaragoza

AGN, Irache, Lib. 542, 206rv.

LAMBERTO LÓPEZ

L. T. / D. T.

23-5-1634

Fr. Gabriel de La Riba de Herrera

Villarluengo (Zaragoza)

AGN, Irache, Lib. 542, 206rv.

\section{MIGUEL IÑÍGUEZ}

L. C.

24-5-1634

Fr. Gabriel de La Riba de Herrera

Tudela (Navarra)

AGN, Irache, Lib. 542, 207 r.

FRANCISCO MALUENDA

B. A. / L. A. / M. A. / B. T. / L. T. / D. T. 2-6-1634

Fr. Gabriel de La Riba de Herrera

O. S. B.

Hijo y Abad de San Juan de Burgos

AGN, Irache, Lib. 542, 207 r.

ANTONIO VENEGAS

B. A. / L. A. / M. A. / B. T. / L. T. / D. T. 2-6-1634

Fr. Gabriel de La Riba de Herrera

O. S. B.

Abad del Monasterio de Valvanera

Hijo de San Julián de Samos

AGN, Irache, Lib. 542, 207 r.

ÍNIIGO DE CASTAÑIZA

B. A. / L. A. / M. A. / B. T. / L. T. / D. T. 6-6-1634

Fr. Gabriel de La Riba de Herrera

O.S. B.

AGN, Irache, Lib. 542, 207r.

PEDRO DE AYALA

L. C.

13-6-1634

Fr. Gabriel de La Riba de Herrera 
Navarrete (Calahorra)

Calahorra

AGN, Irache, Lib. 542, 207v.

\section{MIGUEL GIMÉNEZ}

B. T.

14-6-1634

Fr. Plácido del Río

Morentín (Pamplona)

AGN, Irache, Lib. 542, $207 \mathrm{v}$.

\section{MARTÍN DE ARMENDÁRIZ}

B. C. / L. C. / D. C.

29-6-1634 / 8-8-1634

Fr. Francisco Cambero / Fr. Plácido del Río / Fr. Gabriel de La Riba de Herrera

Olcoz (Pamplona)

AGN, Irache, Lib. 542, 207v-208v.

BERNARDO DE SANCHA VALDERRAMA

B. T. / L. T.

15-7-1634

Fr. Francisco Salvador

Arenzana de Abajo (Calahorra)

AGN, Irache, Lib. 542, 208r.

PEDRO GONZÁLEZ

B. T.

18-7-1634

Fr. Plácido del Río

Alfaro (Tarazona)

AGN, Irache, Lib. 542, 208v.

LESMES GARCÍA

B. C.

2-8-1634

Fr. Francisco Salvador

Burgos

AGN, Irache, Lib. 542, 208v.

FRANCISCO RUIZ DE LA RABIA

B. C.

6-8-1634

Fr. Plácido del Río

Comillas (Burgos)

AGN, Irache, Lib. 542, 208v.

MARTÍN DE RUIZ GAMARRA

D. C.
10-8-1634

Fr. Francisco Cambero

Burgos

AGN, Irache, Lib. 542, 209r.

FRANCISCO DE MUGA

B. C.

22-8-1634

Fr. Francisco Salvador

Burgos

AGN, Irache, Lib. 542, 209 r.

PEDRO DE ISAR

B. C.

25-8-1634

Fr. Plácido del Río

Iglesias (Burgos)

AGN, Irache, Lib. 542, 209 r.

ANDRÉS DE PEDROSA

B. C.

6-9-1634

Fr. Rosendo Álvarez

Hormazas (Burgos)

AGN, Irache, Lib. 542, 209 r.

MATEO ARNEDO

L. C.

15-9-1634

Fr. Plácido del Río

Tudela (Tarazona)

AGN, Irache, Lib. 542, 209 r.

ÍNIGO DE VARONA

L. C. / D. C.

17-9-1634

Fr. Plácido del Río

Bárcena (Burgos)

AGN, Irache, Lib. 542, 209v.

DIONISIO TOMEI

B. T. / L. T. / D. T.

23-9-1634 / 24-9-1634

Fr. Plácido del Río / Fr. Francisco Cambero

Daroca (Zaragoza)

AGN, Irache, Lib. 542, 210 orv.

DIEGO RUIZ DE LA CALLEJA

L. L. 
24-9-1634

Fr. Francisco Cambero

Frías (Burgos)

AGN, Irache, Lib. 542, $209 v$.

ORENCIO BERNUÉS VILLACAMPA

L. T. / D. T.

28-9-1634 / 29-9-1634

Fr. Francisco Cambero

Aniés (Huesca)

AGN, Irache, Lib. 542, 210 rv.

ANTONIO DE PEDROSA

B. C.

3-10-1634

Fr. Plácido del Río

Hormazas (Burgos)

AGN, Irache, Lib. 542, $210 v$.

SEBASTIÁN DE IBARROLA

B. C.

13-10-1634

Fr. Francisco Salvador

Herrán (Burgos)

AGN, Irache, Lib. 542, 211 r.

JUAN JIMÉNEZ

B. A.

14-10-1634

Fr. Diego de Silva

Arnedo (Calahorra)

AGN, Irache, Lib. 542, 211r.

ANTONIO DE LANA

B. T.

15-10-1634

Fr. Francisco Cambero

Burgos

AGN, Irache, Lib. 542, 211r.

AMBROSIO RODRÍGUEZ FLORES

B. C.

19-10-1634

Fr. Plácido del Río

Burgos

AGN, Irache, Lib. 542, 211r.

JUAN SÁENZ

B. C.
22-10-1634

Fr. Francisco Salvador

Tamarón (Burgos)

AGN, Irache, Lib. 542, 211 r.

JUAN DE HAZAS

B. C.

19-11-1634

Fr. Francisco Cambero

Arnuero (Burgos)

AGN, Irache, Lib. 542, 211v.

FRANCISCO PEDRO

B. T. / L. T. / D. T.

27-11-1634 / 28-11-1634

Fr. Plácido del Río /

Fr. Gabriel de La Riba de Herrera

Tronchón (Tarazona)

AGN, Irache, Lib. 542, 211v.

ROQUE DE ARROYO

B. C.

29-11-1634

Fr. Francisco Cambero

Melgar (Burgos)

AGN, Irache, Lib. 542, 212r.

DOMINGO DE RUBAYO

B. C.

1-12-1634

Fr. Plácido del Río

Solares (Burgos)

AGN, Irache, Lib. 542, 212r.

BARTOLOMÉ MAÑAS

B. T. / L. T. / D. T.

16-12-1634

Fr. Gabriel de La Riba de Herrera

O. Cist.

Predicador

Hijo del Monasterio de Veruela

AGN, Irache, Lib. 542, 212r.

JUAN DE HERAS MIERA

B. C.

25-12-1634

Fr. Plácido del Río

Liérganes (Burgos)

AGN, Irache, Lib. 542, 212r. 
SEBASTIÁN RAMÍREZ

B. M. / L. M. / D. M.

12-1-1635/ 15-1-1635

Fr. Francisco Cambero / Fr. Gabriel de La

Riba de Herrera

Estella (Pamplona)

AGN, Irache, Lib. 542, 212v.

MARTÍN GONZÁLEZ

B. C.

2-2-1635

Fr. Diego de Araujo

Iglesias (Burgos)

AGN, Irache, Lib. 542, 213 r.

MIGUEL CABERNI

L. C. / D. C.

6-2-1635

Fr. Gabriel de La Riba de Herrera

Barbastro (Barbastro)

AGN, Irache, Lib. 542, 213 r.

DIEGO ORTIZ DE ZÁRATE

B. C.

23-3-1635

Fr. Plácido del Río

Orduña (Calahorra)

AGN, Irache, Lib. 542, 213 r.

PEDRO RUIZ DE SOMOCURCIO

B. C.

29-4-1635

Fr. Diego de Araujo

Zalla (Burgos)

AGN, Irache, Lib. 542, 213v.

FRANCISCO FRAILE

B. C.

13-5-1635

Fr. Plácido del Río

Portoles (Burgos)

AGN, Irache, Lib. 542, 213v.

MIGUEL DE AZPARREN

B. A. / B. T. / L. T.

21-5-1635 / 28-12-1641

Fr. Diego de Silva / Fr. Juan Rodríguez, abad
Pamplona

AGN, Irache, Lib. 542, 213v, 261r.

JUAN RAMOS DE IRAZAZÁBAL

B. A.

21-5-1635

Fr. Diego de Silva

Renteria (Pamplona)

AGN, Irache, Lib. 542, $213 v$.

ANTONIO CASA DE UBANTE

B. A.

21-5-1635

Fr. Diego de Silva

Fuenterrabía (Pamplona)

AGN, Irache, Lib. 542, $213 v$.

JERÓNIMO FRANCISCO MORALES

B. A.

21-5-1635

Fr. Diego de Silva

Valtierra (Pamplona)

AGN, Irache, Lib. 542, $213 v$.

MIGUEL DE GOYENECHEA

B. A.

21-5-1635

Fr. Diego de Silva

Azpilicueta (Pamplona)

AGN, Irache, Lib. 542, $213 \mathrm{v}$.

MARTÍN DE UGARTE

B. A.

21-5-1635

Fr. Diego de Silva

Pasajes (Pamplona)

AGN, Irache, Lib. 542, $213 v$.

JUAN DE AGUIRRE

B. T. / L. T.

23-5-1635 / 24-5-1635

Fr. Plácido del Río / Fr. Gabriel de La Riba

de Herrera

Arroyabe (Calahorra)

AGN, Irache, Lib. 542, 213v-214r.

ESTEBAN VELASCO DE MORALES

B. T. / L. T. / D. T. 
3-6-1635

Fr. Gabriel de La Riba de Herrera

O. Cist.

Predicador

Rector del Colegio de San Bernardo de

Huesca

AGN, Irache, Lib. 542, 214r.

MARTÍN ÁLVARO

B. T. / L. T. / D. T.

3-6-1635

Fr. Gabriel de La Riba de Herrera

O. Cist.

Predicador

Calificador del Santo Oficio

AGN, Irache, Lib. 542, 214r.

PEDRO DE ARCE

B. C.

6-6-1635

Fr. Plácido del Río

Valle de Carriendo (Burgos)

AGN, Irache, Lib. 542, 214v.

PEDRO REQUESENS

L. C. / D. C.

16-6-1635

Fr. Francisco Cambero / Fr. Gabriel de La

Riba de Herrera

Amberes

AGN, Irache, Lib. 542, 214v.

EUGENIO DE SALAZAR

B. C.

1-6-1635

Fr. Francisco Cambero

Luzueta (Burgos)

AGN, Irache, Lib. 542, 214v.

JUAN DE AROCHE

B. $\mathrm{M}$.

5-6-1635

Fr. Francisco Cambero

Corella (Tarazona)

AGN, Irache, Lib. 542, 215r.

ALONSO DE SALINAS

B. C.
9-6-1635

Fr. Francisco Cambero

Bribiesca (Burgos)

AGN, Irache, Lib. 542, 215r.

PEDRO DE MERCADILLO

B. C.

16-6-1635

Fr. Diego de Araujo

Sopuerta (Burgos)

AGN, Irache, Lib. 542, 215r.

BERNABÉ DE AMEZ

B. C.

16-7-1635

Fr. Diego de Araujo

Sopuerta (Burgos)

AGN, Irache, Lib. 542, 215 r.

JUAN DE QUINTANA

B. C.

18-7-1635

Fr. Diego de Araujo

Frías (Burgos)

AGN, Irache, Lib. 542, 215 r.

MIGUEL DE PALACIO

B. C.

9-8-1635

Fr. Diego de Araujo

Valle de Carranza (Burgos)

AGN, Irache, Lib. 542, 215r.

PEDRO AGRAMONT

B. A. / B. T.

15-8-1635

Fr. Diego de Araujo

O. S. A.

AGN, Irache, Lib. 542, $215 \mathrm{v}$.

PEDRO MARTÍNEZ

B. A. / B. T.

29-8-1635 / 16-9-1639

Fr. Diego de Silva

Villar del Río de Yanguas (Calahorra)

AGN, Irache, Lib. 542, 215v, 246v.

FRANCISCO PALOMINO

B. A. / L. A. / M. A. / B. T. / L. T. / D. T. 
8-9-1635

Fr. Gabriel de La Riba de Herrera

O. S. B.

Abad del Monasterio de Santa María de Nájera

AGN, Irache, Lib. 542, 215v.

PEDRO DE SANZ DE LA CANTERA

B. C.

12-9-1635

Fr. Diego de Araujo

M... (Burgos)

AGN, Irache, Lib. 542, 215v.

JUAN BAUTISTA DE CONTRERAS

L. C. / D. C.

19-9-1635

Fr. Gabriel de La Riba de Herrera

Cabra (Córdoba)

AGN, Irache, Lib. 542, 216r.

DIEGO PONCE DE LEÓN

B. A. / L. A. / M. A. / B. T. / L. T. / D. T. 24-9-1635

Fr. Gabriel de La Riba de Herrera

O. S. B.

AGN, Irache, Lib. 542, 216r.

ATANASIO FERNÁNDEZ

B. C.

22-10-1635

Fr. Diego de Araujo

Valluércanes (Burgos)

AGN, Irache, Lib. 542, 216r.

ESTEBAN GONZÁLEZ

B. C.

26-10-1635

Fr. Francisco Cambero

Pozancos (Burgos)

AGN, Irache, Lib. 542, $216 \mathrm{v}$.

ANDRÉS DE ALVARADO

B. C.

26-10-1635

Fr. Francisco Cambero

Aguilar de Campoo (Burgos)

AGN, Irache, Lib. 542, 216v.

\section{JUAN SAINZ}

B. C.

30-10-1635

Fr. Plácido del Río

Olmillos (Burgos)

AGN, Irache, Lib. 542, 216v.

ANDRÉS DE LEIVA

B. C.

2-1-1636

Fr. Diego de Araujo

Burgos

AGN, Irache, Lib. 542, 216v.

GABRIEL ELIZONDO

L. M. / D. M.

31-1-1636

Fr. Gabriel de La Riba de Herrera

Estella (Pamplona)

AGN, Irache, Lib. 542, 216v-217r.

DOMINGO PABLO DE SAN PEDRO

B. C.

10-2-1636

Fr. Diego de Araujo

Canales (Burgos)

AGN, Irache, Lib. 542, $217 \mathrm{r}$.

BARTOLOMÉ DÍAZ

B. C.

13-2-1636

Fr. Plácido del Río

Río de Loza (Burgos)

AGN, Irache, Lib. 542, 217 r.

JUAN JERÓNIMO DE ESQUER Y MIRA-

VETE

L. T. / D. T.

15-2-1636

Fr. Gabriel de La Riba de Herrera

Zaragoza

AGN, Irache, Lib. 542, 217r.

VICENTE LÓPEZ

L. T. / D. T.

16-1-1636

Tiermas (Pamplona)

AGN, Irache, Lib. 542, $217 \mathrm{r}$. 


\section{GREGORIO GURMENDI \\ L. C. \\ 19-2-1636}

Fr. Gabriel de La Riba de Herrera

San Sebastián del Pasaje (Pamplona)

AGN, Irache, Lib. 542, $217 \mathrm{v}$.

ANDRÉS MONASTERIO

B. C.

1-3-1636

Fr. Diego de Araujo

Celada del Camino (Burgos)

AGN, Irache, Lib. 542, 217v.

BERNARDO DE TAMAYO

B. C.

4-3-1636

Fr. Francisco Cambero

Burgos

AGN, Irache, Lib. 542, 217v.

PEDRO GREGORIO

B. C.

7-3-1636

Fr. Plácido del Río

Pancorbo (Burgos)

AGN, Irache, Lib. 542, $217 \mathrm{v}$.

JUAN DEL PUERTO

B. A.

7-3-1636

Fr. Diego de Silva

... (Calahorra)

AGN, Irache, Lib. 542, 217v.

ANDRÉS GONZÁLEZ JUNGUIRO

B. A.

7-3-1636

Fr. Diego de Silva

... (Calahorra)

AGN, Irache, Lib. 542, $217 \mathrm{v}$.

ALEJANDRO GONZÁLEZ JUNGUIRO

B. A.

7-3-1636

Fr. Diego de Silva

... (Calahorra)

AGN, Irache, Lib. 542, 218r.
LEONARDO VENTURA Y LUNA

B. A.

19-3-1636

Fr. Diego de Silva

Falces (Pamplona)

AGN, Irache, Lib. 542, 218r.

JUAN SENAR DE SALINAS

L. C.

1-4-1636

Fr. Gabriel de La Riba de Herrera

Salinas (Pamplona)

AGN, Irache, Lib. 542, 218r.

RODRIGO DE LA PEÑA

B. A.

$-/-/ 1636$

Fr. Diego de Silva

Valle de Carranza (Burgos)

AGN, Irache, Lib. 542, 218v.

JUAN DE ORANEGUI

L. A.

10-4-1636

Fr. Gabriel de La Riba de Herrera

L... (Calahorra)

AGN, Irache, Lib. 542, 218v.

FRANCISCO DE VELASCO

B. A. / B. T.

17-4-1636

Fr. Diego de Silva

Olmillos (Burgos)

AGN, Irache, Lib. 542, 219 r.

MANUEL DEL VALLE

B. C.

17-4-1636

Fr. Diego de Araujo

Mansilla de la Sierra (Burgos)

AGN, Irache, Lib. 542, 219v.

BARTOLOMÉ PARAVICINI

B. C. / L. C.

19-4-1636

Fr. Diego de Araujo

Madrid (Toledo)

AGN, Irache, Lib. 542, $219 \mathrm{v}$. 
CRISTÓBAL DE ATOCHA

B. C. / L. C.

21-4-1636

Fr. Francisco Barovero / Fr. Gabriel de La Riba de Herrera

Valle de Roncal (Pamplona)

Canónigo y clavero de Roncesvalles

AGN, Irache, Lib. 542, 219v.

PEDRO HURTADO DE SALCEDO

L. C. / D. C.

29-4-1636

Fr. Gabriel de La Riba de Herrera

Valmaseda (Burgos)

AGN, Irache, Lib. 542, 220 .

\section{DIEGO GÓMEZ}

B. C.

23-4-1636

Fr. Plácido del Río

Sotopalacios (Burgos)

AGN, Irache, Lib. 542, 222v.

PLÁCIDO MALDONADO

B. A. / B. T.

23-4-1636

Fr. Francisco Cambero

O. S. B.

AGN, Irache, Lib. 542, 222v.

JUAN LÓPEZ DE REBOLLEDA

B. C.

27-4-1636

Fr. Diego de Araujo

Uría (Burgos)

AGN, Irache, Lib. 542, 222v.

LUIS FERNÁNDEZ DE MENDOZA

L. C.

10-5-1636

...

Arnedo (Calahorra)

AGN, Irache, Lib. 542, 222v.

\section{MARCOS DEL CAMPO}

B. C.

19-5-1636

Fr. Plácido del Río
Santa Gadea (Burgos)

AGN, Irache, Lib. 542, 222v.

FRANCISCO DE HERRADOR

B. C.

20-5-1636

Fr. Plácido del Río

Laredo (Burgos)

AGN, Irache, Lib. 542, 221 .

DIEGO DELGADO

B. C.

20-5-1636

Fr. Plácido del Río

Puerto (Burgos)

AGN, Irache, Lib. 542, 221 r.

\section{SEBASTIÁN SALDÍAS}

B. T. / L. T.

15-6-1636

Fr. Pedro Díaz de Inguanzo

Unzué (Pamplona)

AGN, Irache, Lib. 542, 221r.

ALONSO QUINTANO

B. C.

19-6-1636

Fr. Plácido del Río

Castromorca (Burgos)

AGN, Irache, Lib. 542, 221v.

MARTÍN DE LAHOZ

B. C.

19-6-1636

Fr. Plácido del Río

Castro Urdiales (Burgos)

AGN, Irache, Lib. 542, $221 \mathrm{v}$.

JUAN DE LA FUENTE

B. T.

27-6-1636

Fr. Plácido del Río

Pancorbo (Burgos)

AGN, Irache, Lib. 542, $221 \mathrm{v}$.

JUAN DE CÉSPEDES

B. A. / L. M. / D. M.

14-7-1636 / 19-6-1640 
Fr. Diego de Silva // Fr. Antonio de Castro / Dr. Lisondo

Montejo de San Miguel (Burgos)

AGN, Irache, Lib. 542, 221v, 251v.

JUAN SEDANO

B. C.

16-7-1636

Fr. Plácido del Río

Mazuelo (Burgos)

AGN, Irache, Lib. 542, 221v.

$\cdots$

$-/-/ 1636$

AGN, Irache, Lib. 542, 222rv.

BERNARDO GARCÍA

B. C.

1-10-1636

Fr. Plácido del Río

Melgar (Burgos)

AGN, Irache, Lib. 542, 223 r.

PEDRO DE PEÑARANDA

B. C.

1-10-1636

Fr. Plácido del Río

Melgar (Burgos)

AGN, Irache, Lib. 542, 223 r.

JOSÉ LÓPEZ DE LLOVERA

B. C.

5-10-1636

Fr. Plácido del Río

Valle de Galdames (Burgos)

AGN, Irache, Lib. 542, 223 r.

JUAN SANZ

B. C.

7-10-1636

Fr. Plácido del Río

Villafranca de Montes de Oca (Burgos)

AGN, Irache, Lib. 542, 223 r.

FRANCISCO GALERÓN

B. C.
27-10-1636

Fr. Francisco Cambero

Olmillos (Burgos)

AGN, Irache, Lib. 542, 223 r.

FELIPE DE LA REGATA

B. C.

31-10-1636

Fr. Diego de Araujo

Franca (Burgos)

AGN, Irache, Lib. 542, 223 r.

PEDRO DÍEZ BLANCO

B. C.

8-11-1636

Fr. Plácido del Río

Olmillos (Burgos)

AGN, Irache, Lib. 542, 223v.

PEDRO DE ANGULO

B. C. / L. C.

9-11-1636 /10-11-1636

Fr. Francisco Cambero / Fr. Gabriel de La

Riba de Herrera

Nalda (Calahorra)

AGN, Irache, Lib. 542, 223v.

PEDRO GÓMEZ DE VELASCO

B. C.

13-11-1636

Fr. Diego de Araujo

Mansilla (Burgos)

AGN, Irache, Lib. 542, 223v.

JUAN DE LA VIÑUELA

B. C.

15-11-1636

Fr. Diego de Araujo

Burgos

AGN, Irache, Lib. 542, 223v.

PEDRO MARTÍNEZ

B. C.

23-11-1636

Fr. Regente

Villambistia (Burgos)

AGN, Irache, Lib. 542, 224 r. 
JUAN NEGRETE

B. C.

23-11-1636

Fr. Regente

Aldeavueva Valle de Carranza (Burgos)

AGN, Irache, Lib. 542, 224r.

JUAN DE VERDES CASTILLO

B. C.

8-12-1636

Fr. Diego de Araujo

Carazo (Burgos)

AGN, Irache, Lib. 542, 224r.

BLAS TASADURA

B. C.

13-12-1636

Fr. Francisco Cambero

Hornillos (Burgos)

AGN, Irache, Lib. 542, 224 r.

VENTURA RODRÍGUEZ

B. C.

$-/-/ 1636$

Fr. Diego de Araujo

Castro Urdiales (Burgos)

AGN, Irache, Lib. 542, 224r.

MIGUEL IZU

L. L.

26-1-1637

Fr. Plácido del Río

Pamplona

AGN, Irache, Lib. 542, 224V.

MIGUEL DE PANDO

B. C.

29-1-1637

Fr. Plácido del Río

Villaverde (Burgos)

AGN, Irache, Lib. 542, 224v.

JUAN DE VALLENILLA

B. C.

30-1-1637

Fr. Francisco Cambero

Burgos

AGN, Irache, Lib. 542, 224V.

\section{JUAN GÓMEZ}

B. C.

4-2-1637

Fr. Diego de Araujo

Aguilar de Campoo (Burgos)

AGN, Irache, Lib. 542, 224v.

PAULO DE LA CERVILLA

B. C. / L. C.

22-2-1637 / 23-2-1637

Fr. Plácido del Río / Fr. Gabriel de La Riba

de Herrera

Entrena (Calahorra)

AGN, Irache, Lib. 542, 225r.

JUAN DE COLINA

B. T.

25-2-1637

Fr. Diego de Araujo

Los Barrios (Burgos)

AGN, Irache, Lib. 542, 225r.

MATEO EZQUERRA

B. T.

5-3-1637

Fr. Diego de Araujo

Xibara (Burgos)

AGN, Irache, Lib. 542, 225 r.

JUAN DE CEVALLOS

B. C.

11-3-1637

Fr. Plácido del Río

Aguilar de Campoo (Burgos)

AGN, Irache, Lib. 542, $225 \mathrm{v}$.

JUAN FRANCISCO RIQUELME

B. C. / L. C.

15-3-1637 / 16-3-1637

Fr. P. Regente / Fr. Diego de Araujo

Sevilla

AGN, Irache, Lib. 542, $225 \mathrm{v}$.

LUIS JIMÉNEZ DE MURILLO

B. C. / L. C.

3-4-1637

Fr. Plácido del Río

Zaragoza 
Canónigo de la Seo de Zaragoza

AGN, Irache, Lib. 542, 225v.

JUAN CID SALGADO

L. C.

6-4-1637

Fr. Plácido del Río

Orense

AGN, Irache, Lib. 542, 225v.

MARTÍN LADRÓN DE CEGAMA

L. L.

16-4-1637

Fr. P. Regente

Estella

AGN, Irache, Lib. 542, 226r.

JOSÉ DE ENGUITA

L. T. / D. T.

17-4-1637

Fr. Gabriel de La Riba de Herrera

O. S. A.

Cazorla

Lector de Teología en Sto. Tomás de Villanueva

AGN, Irache, Lib. 542, 226r.

JOSÉ SERRANO

B. C. / L. C. / D. C.

17-4-1637

Fr. Francisco Cambero / Fr. Diego de Silva

Calcena (Tarragona)

AGN, Irache, Lib. 542, 226r.

FRANCISCO DE SALINAS MEDINILLA

L. C.

20-4-1637

Fr. Gabriel de La Riba de Herrera

Briviesca (Burgos)

AGN, Irache, Lib. 542, 226v.

\section{MARTÍN DE ORCASITAS}

B. C.

20-4-1637

Fr. Diego de Araujo

Campijo (Burgos)

AGN, Irache, Lib. 542, 226v.
PEDRO DE SARACHEGA

B. C.

20-4-1637

Fr. Diego de Araujo

Vizcaya (Burgos)

AGN, Irache, Lib. 542, 226v.

DIEGO BENITO

B. C.

2-5-1637

Fr. Diego de Araujo

Revilla del Campo (Burgos)

AGN, Irache, Lib. 542, 226v.

SEBASTIÁN BENITO

B. C.

2-5-1637

Fr. Diego de Araujo

Revilla del Campo (Burgos)

AGN, Irache, Lib. 542, 226v.

ALONSO DE CAÑAS

L. C.

6-5-1637

Fr. Diego de Silva

Nájera (Calahorra)

AGN, Irache, Lib. 542, 227 r.

JUAN FERNÁNDEZ MONTOTO

B. C.

8-5-1637

Fr. Diego de Araujo

Montoto (Burgos)

AGN, Irache, Lib. 542, 227 r.

LOPE FRANCISCO DE LOS RÍOS

B. C.

17-5-1637

Fr. Diego de Araujo

Córdoba

AGN, Irache, Lib. 542, 227 r.

MANUEL MARTÍNEZ DE ZUAZO

B. C.

12-5-1637

Fr. Diego de Silva

Burgos

AGN, Irache, Lib. 542, $227 r$. 
FRANCISCO DE SUNIEGA

B. C.

12-5-1637

Fr. Diego de Silva

San Marcos del Valle de Aras (Burgos)

AGN, Irache, Lib. 542, 227r.

DOMINGO GUTIÉRREZ

B. C.

17-5-1637

Fr. Diego de Silva

Palacios de Benaver (Burgos)

AGN, Irache, Lib. 542, $227 \mathrm{r}$.

PEDRO DE ZÁRATE

B. C.

21-5-1637

Fr. Diego de Silva

Haro (Calahorra)

AGN, Irache, Lib. 542, $227 \mathrm{v}$.

PEDRO DÍAZ DE INGUANZO

B. A. / L. A. / M. A. / B. T. / L. T. / D. T.

27-5-1637

Fr. Diego de Araujo, Regente y Vicecanciller

O. S. B.

AGN, Irache, Lib. 542, $227 \mathrm{v}$.

PEDRO DE NAVIA

L. C. / D. C.

2-6-1637

Fr. Diego de Araujo

Villagarcía. Abad de Bayona

Visitador del obispado de Burgos

AGN, Irache, Lib. 542, $227 \mathrm{v}$.

LORENZO ALONSO

B. C.

5-6-1637

Fr. Diego de Araujo

Palenzuela (Burgos)

AGN, Irache, Lib. 542, $227 \mathrm{v}$.

JOSÉ SANZ DE SAYE

B. $\mathrm{M}$.

10-6-1637

Fr. Diego de Silva
Argoitz (Pamplona)

AGN, Irache, Lib. 542, 228r.

PEDRO GIL DE SEVILLA

B. T.

12-6-1637

Fr. Diego de Silva

Villa de Veite (Pamplona)

AGN, Irache, Lib. 542, 228 r.

MIGUEL TURMO

L. C.

15-6-1637

Fr. Antonio de Castro, Abad y Rector

El Grado (Barbastro)

AGN, Irache, Lib. 542, 228 r.

PEDRO DE CASTARRUBIO

L. C.

16-6-1637

Fr. Antonio de Castro

Sandoval (Burgos)

AGN, Irache, Lib. 542, 228r.

JUAN DE CORADA

B. C. / L. C.

30-6-1637 / 12-3-1641

Fr. Diego de Silva / Fr. Martín Izquierdo

Villadiego (Burgos)

AGN, Irache, Lib. 542, 228r, 255r.

\section{DIEGO FERNÁNDEZ}

B. C.

15-7-1637

Fr. Diego de Silva

Ventrosa (Burgos)

AGN, Irache, Lib. 542, 228v.

JUAN FERNÁNDEZ DE FONTECHA

B. C.

21-7-1637

Fr. Diego de Silva

Aguilar de Campoo (Burgos)

AGN, Irache, Lib. 542, 228v.

JUAN DE AGÜERO

B. C.

21-7-1637 
Fr. Diego de Silva

Aguilar de Campoo (Burgos)

AGN, Irache, Lib. 542, 228v.

\section{SIMÓN DE TERÁN}

B. C.

21-7-1637

Fr. Diego de Silva

Aguilar de Campoo (Burgos)

AGN, Irache, Lib. 542, 228v.

\section{PEDRO DE NAVASCUÉS}

B. M.

22-7-1637

Fr. Diego de Araujo

Cintruénigo (Tarazona)

AGN, Irache, Lib. 542, 228v.

TOMÁS PÉREZ DE AMALLO

B. C.

23-7-1637

Fr. Diego de Araujo

Valle de ... (Burgos)

AGN, Irache, Lib. 542, 228v.

JUAN FRANCISCO RUIZ

L. L. / D. L.

25-7-1637

Fr. Antonio de Castro

Sorbiñán (Tarazona)

AGN, Irache, Lib. 542, 229 r.

DIEGO DE TEJADA

B. T. / L. T.

28-7-1637 / 10-10-1639

Fr. Diego de Araujo

Colegial de S. Bartolomé de Salamanca

Ocón (Calahorra)

AGN, Irache, Lib. 542, 229r, 247r.

ANDRÉS RODRÍGUEZ DE SOLÓRZANO

B. T. / L. T.

9-8-1637 / 10-8-1637

Fr. Antonio de Castro

Quintanilla del Monte (Burgos)

AGN, Irache, Lib. 542, 229 r.

IGNACIO DE SOTO

B. C.
10-8-1637

Fr. Diego de Silva

Aguilar de Campoo (Burgos)

AGN, Irache, Lib. 542, 229r.

JUAN DÍAZ

B. C.

14-8-1637

Fr. Diego de Araujo

Pradilla (Burgos)

AGN, Irache, Lib. 542, 229v.

JUAN DE BALPUERTA

B. C.

16-8-1637

Fr. Diego de Silva

Lerma (Nullius Diocesis)

AGN, Irache, Lib. 542, 229v.

JUAN GIL DE ALFARO

B. C.

24-8-1637

Fr. Diego de Silva

Enciso (Calahorra)

AGN, Irache, Lib. 542, 229v.

PEDRO FERNÁNDEZ DE MATA

B. C.

27-8-1637

Fr. Martín Izquierdo

Jermez de Arcos (Burgos)

AGN, Irache, Lib. 542, 229v.

DOMINGO DE LA PEÑA

B. C.

27-8-1637

Fr. Martín Izquierdo

Jermez de Arcos (Burgos)

AGN, Irache, Lib. 542, 229v.

ANDRÉS HERRERO

B. C.

4-9-1637

Fr. Diego de Silva

Masa (Burgos)

AGN, Irache, Lib. 542, 230 .

PEDRO DE MOREDA

B. C. 
6-9-1637

Fr. Martín Izquierdo

Navarrete (Calahorra)

AGN, Irache, Lib. 542, 230 .

\section{SEBASTIÁN DE ORTEGA}

B. T.

12-9-1637

Fr. Diego de Silva

Masa del Arco (Burgos)

AGN, Irache, Lib. 542, 23 or.

\section{NICOLÁS DE ARCE}

B. C.

9-9-1637

Fr. Martín Izquierdo

Santibáñez (Burgos)

AGN, Irache, Lib. 542, 23 or.

\section{PLÁCIDO DEL RÍO}

B. A. / L. A. / M. A. / B. T. / L. T. / D. T.

12-9-1637

Fr. Antonio de Castro

O. S. B.

Lector en Irache

Lector en San Vicente de Salamanca

AGN, Irache, Lib. 542, 23 or.

\section{MIGUEL ANDUEZA}

B. A. / L. A. / M. A. / B. T. / L. T. / D. T. 17-9-1637

Fr. Antonio de Castro

O. S. B.

Abad de San Millán de la Cogolla

AGN, Irache, Lib. 542, $230 v$.

\section{PEDRO DE ARCE}

B. A.

17-9-1637

Fr. Diego de Araujo

Marquina (Calahorra)

AGN, Irache, Lib. 542, $230 v$.

JUAN GARCÍA

B. C.

19-9-1637

Fr. Diego de Araujo

Burgos

AGN, Irache, Lib. 542, $230 v$.
PEDRO DE QUINTANILLA

B. C.

30-9-1637

Fr. Diego de Silva

Liaño (Burgos)

AGN, Irache, Lib. 542, $230 v$.

JUAN MANUEL DE ESPINOSA

B. T. / L. T. / D. T.

5-10-1637

Fr. Antonio de Castro

O. S. B.

AGN, Irache, Lib. 542, 231r.

ALONSO GADEA

B. T. / L. T. / D. T.

5-10-1637

Fr. Antonio de Castro

O. S. B.

AGN, Irache, Lib. 542, 231r.

DIEGO DE SANDOVAL

B. T. / L. T. / D. T.

5-10-1637

Fr. Antonio de Castro

O. S. B.

AGN, Irache, Lib. 542, 231r.

MARTÍN DE ROCAFORTE

B. M. / L. M. / D. M.

5-10-1637 / 11-10-1637

Fr. Diego de Araujo / Fr. Antonio de Castro

Estella (Pamplona)

AGN, Irache, Lib. 542, 231rv.

MATEO PÉREZ

B. C.

10-10-1637

Fr. Martín Izquierdo

Olmos de la Picaza (Burgos)

AGN, Irache, Lib. 542, 231v.

MATÍAS DE GARRALDA

L. C.

16-10-1637

Fr. Antonio de Castro

Pamplona

AGN, Irache, Lib. 542, 231v. 
PEDRO MIÑÓN

B. A. / B. T.

29-10-1637 / 25-10-1645

Fr. Diego de Silva / Fr. Francisco Crespo

Ros (Burgos)

AGN, Irache, Lib. 542, 231v, 285v.

ÍNIGO DE PÁRAMO

B. T. / L. T. / D. T.

29-10-1637

Fr. Antonio de Castro

Lodosa (Pamplona)

AGN, Irache, Lib. 542, 232r.

\section{MARTÍN DE CENARRO}

B. C.

6-11-1637

Fr. Diego de Araujo

Balmaseda (Burgos)

AGN, Irache, Lib. 542, 232r.

PEDRO RUIZ DE DULANTO

B. C.

12-11-1637

Fr. Diego de Araujo

Suzana (Burgos)

AGN, Irache, Lib. 542, 332r.

FRANCISCO DE SECADURA

B. C.

11-12-1637

Fr. Martín Izquierdo

... (Burgos)

AGN, Irache, Lib. 542, 232v.

JOSÉ DE PORRASA

B. A. / L. A. / M. A. / B. T. / L. T. / D. T.

26-12-1637

Fr. Antonio de Castro, Abad, Rector y Canciller

O. S. B.

Abad perpetuo de Arles, del Consejo de su

Majestad

AGN, Irache, Lib. 542, 232v.

DIEGO DE SILVA

B. A. / L. A. / M. A. / B. T. / L. T. / D. T. 12-1-1638
Fr. Antonio de Castro

O. S. B.

Lector de Irache

AGN, Irache, Lib. 542, 232v.

MARTÍN IZQUIERDO

B. A. / L. A. / M. A. / B. T. / L. T. / D. T. 12-1-1638

Fr. Antonio de Castro

O.S. B.

Lector de Irache

AGN, Irache, Lib. 542, 232v.

\section{DIEGO MARCILLA}

B. A. / L. A. / M. A. / B. T. / L. T. / D. T. 12-1-1638

Fr. Antonio de Castro

O. S. B.

Lector de Irache

AGN, Irache, Lib. 542, 232v.

FRANCISCO CRESPO

B. A. / L. A. / M. A. / B. T. / L. T. / D. T.

12-1-1638

Fr. Antonio de Castro

O. S. B.

Lector de Irache

AGN, Irache, Lib. 542, 232v.

MARTÍN BAZÁN DE LARRALDE

B. C. / L. C.

18-2-1638 / 8-4-1641

Fr. Martín Izquierdo

Pamplona

AGN, Irache, Lib. 542, 233r, 256r.

\section{MARTÍN VILLAVA}

L. L.

23-1-1638

Fr. Martín Izquierdo

Pamplona

AGN, Irache, Lib. 542, 233 r.

CECILIO DE HEREDIA

B. A. / L. A. / M. A. / B. T. / L. T. / D. T. 22-1-1638

Fr. Diego de Araujo

O. S. B.

AGN, Irache, Lib. 542, 233 r. 
ANTONIO DE MARQUINA

B. C.

23-1-1638

Fr. Martín Izquierdo

Covarrubias (Diocesis Nullius)

AGN, Irache, Lib. 542, 233r.

JOSÉ DE VILLEGAS

B. C.

23-1-1638

Fr. Martín Izquierdo

Sasamón (Burgos)

AGN, Irache, Lib. 542, 233v.

FRANCISCO DE GANDARILLAS

B. C.

25-1-1638

Fr. Diego de Silva

Cabárzano (Burgos)

AGN, Irache, Lib. 542, 233v.

MATÍAS GONZÁLEZ DE CANEDA

B. C.

30-1-1638

Fr. Martín Izquierdo

Salazar (Burgos)

AGN, Irache, Lib. 542, 233v.

LOPE DE BORRICÓN

B. C.

30-1-1638

Fr. Martín Izquierdo

Salazar (Burgos)

AGN, Irache, Lib. 542, 233v.

LOPE DEL CAMPO

B. C.

31-1-1638

Fr. Martín Izquierdo

Guardia (Burgos)

AGN, Irache, Lib. 542, 233v.

PEDRO DE LAHERRÁN

B. C.

1-2-1638

Fr. Diego de Silva

Pámanes (Burgos)

AGN, Irache, Lib. 542, 233v.

\section{ROQUE GONZÁLEZ}

B. C.

2-2-1638

Fr. Diego de Silva

Sosa Belarios (Burgos)

AGN, Irache, Lib. 542, 234 r.

TOMÁS DEL POZO

B. C.

2-2-1638

Fr. Diego de Silva

Sasamón (Burgos)

AGN, Irache, Lib. 542, 234 r.

DIEGO DE VILLANUEVA

B. C.

3-2-1638

Fr. Diego de Silva

Calla (Burgos)

AGN, Irache, Lib. 542, 234 r.

FRANCISCO GIL DE MENDOZA

B. C.

6-2-1638

Fr. Diego de Araujo

Burgos

AGN, Irache, Lib. 542, 234r.

MATÍAS DE LA IGLESIA

B. C.

6-2-1638

Fr. Diego de Araujo

Villamayor de Treviño (Burgos)

AGN, Irache, Lib. 542, 234r.

JUAN LÓPEZ DE ENRIQUE

L. T. / D. T.

7-2-1638

Fr. Antonio de Castro

Villarreal (Jaca)

AGN, Irache, Lib. 542, 234v.

MARCOS GONZÁLEZ DE RUEDA

B. C.

8-2-1638

Fr. Diego de Silva

Salazar (Burgos)

AGN, Irache, Lib. 542, 234v. 
JUAN MARTÍNEZ

B. C.

12-2-1638

Fr. Diego de Araujo

Fuente Vibel (Burgos)

AGN, Irache, Lib. 542, 234v.

AGUSTÍN DE ORDUÑA

B. C.

13-2-1638

Fr. Martín Izquierdo

Fresneda (Burgos)

AGN, Irache, Lib. 542, 234V.

JERÓNIMO DE GÓMEZ

B. C.

14-2-1638

Fr. Diego de Araujo

Salazar (Burgos)

AGN, Irache, Lib. 542, 235r.

AGUSTÍN RUIZ

B. C.

14-2-1638

Fr. Diego de Araujo

Sta. María de Riva Redonda (Burgos)

AGN, Irache, Lib. 542, 235r.

LORENZO DE PEREDA

B. C.

15-2-1638

Fr. Diego de Araujo

Salazar (Burgos)

AGN, Irache, Lib. 542, 235r.

PEDRO DE SALCEDO

B. C.

23-2-1638

Fr. Martín Izquierdo

Sodupe (Burgos)

AGN, Irache, Lib. 542, 235r.

JUAN FRANCISCO ANDRÉS

L. C. / D. C.

28-2-1638

Fr. Antonio de Castro

Zaragoza

AGN, Irache, Lib. 542, 235v.
JUAN RIQUELME

D. C.

6-3-1638

Fr. Antonio de Castro

Sevilla

AGN, Irache, Lib. 542, $235 \mathrm{v}$.

FRANCISCO FERNÁNDEZ

B. C.

11-3-1638

Fr. Martín Izquierdo

Hinojedo (Burgos)

AGN, Irache, Lib. 542, 235v.

JOSÉ DE PEÑARANDA

B. C.

13-3-1638

Fr. Diego de Silva

Burgos

AGN, Irache, Lib. 542, $235 \mathrm{v}$.

ALONSO DE RAMÍREZ DE SALAMANCA

B. C.

14-3-1638

Fr. Martín Izquierdo

Burgos

AGN, Irache, Lib. 542, 236r.

ANTONIO BLANCO DE CETINA

B. A. / B. M. / L. M. / D. M.

17-3-1638

Fr. Francisco Crespo / Fr. Diego de Araujo

/ Fr. Martín Izquierdo

Terrer (Tarazona)

AGN, Irache, Lib. 542, 236 r.

BENITO NEVADO

B. A. / L. A. / M. A. / B. T. / L. T. / D. T. 20-3-1638

Fr. Antonio de Castro

O. S. B.

AGN, Irache, Lib. 542, 236v.

FRANCISCO GUTIÉRREZ AVINA

L. C. / D. C.

8-4-1638

Fr. Antonio de Castro

Tarazona

AGN, Irache, Lib. 542, 236v. 
MARTÍN PEIRON Y QUERALT

L. C. / D. C.

8-4-1638

Fr. Antonio de Castro

Zaragoza

AGN, Irache, Lib. 542, 236v.

JUAN MONTERO DE ESPINOSA

L. L. / D. L.

8-4-1638

Fr. Antonio de Castro

Pamplona

AGN, Irache, Lib. 542, 236v.

PEDRO MONTERO DE ESPINOSA

L. L. / D. L.

8-4-1638

Fr. Antonio de Castro

Pamplona

AGN, Irache, Lib. 542, 236v.

TOMÁS DE MEDINA

L. L. / D. L.

12-4-1638

Fr. Antonio de Castro

Tarazona

Canónigo de Sta. María de Calatayud

AGN, Irache, Lib. 542, 237 r.

\section{AGUSTÍN DE ENRÍQUEZ}

B. A. / L. A. / M. A. / B. T. / L. T. / D. T. 13-4-1638

Fr. Antonio de Castro

O. S. B.

AGN, Irache, Lib. 542, 237 r.

JUAN DEL CORRO BUSTAMANTE

B. C.

18-4-1638

Fr. Diego de Silva

San Vicente de la Barquera (Burgos)

AGN, Irache, Lib. 542, 237r.

MATEO DE GUEVARA

L. C. / D. C.

2O-4-1638

Fr. Antonio de Castro

Sevilla
Vicario General de Plasencia

AGN, Irache, Lib. 542, $237 \mathrm{v}$.

JOSÉ DEL SANTÍSIMO

B. T.

20-4-1638

Fr. Martín Izquierdo

O. C.

AGN, Irache, Lib. 542, $237 \mathrm{v}$.

FRANCISCO ARANGUREN

B. A.

9-5-1638

Fr. Francisco Crespo

Idiaza (Pamplona)

Alumno S. J.

AGN, Irache, Lib. 542, $237 \mathrm{v}$.

JUAN DE ERAUL Y ROMERO

B. A.

9-5-1638

Fr. Francisco Crespo

Sesma (Pamplona)

Alumno S. J.

AGN, Irache, Lib. 542, $237 \mathrm{v}$.

PEDRO DE LANDA

B. A.

9-5-1638

Fr. Francisco Crespo

Ruzu (Pamplona)

Alumno S. J.

AGN, Irache, Lib. 542, $237 \mathrm{v}$.

MIGUEL DE LARRÁINZAR

B. A.

9-5-1638

Fr. Francisco Crespo

Larráinzar (Pamplona)

Alumno S. J.

AGN, Irache, Lib. 542, $237 \mathrm{v}$.

MIGUEL DE SAN VICENTE

B. A.

9-5-1638

Fr. Francisco Crespo

Monreal (Pamplona)

Alumno S. J.

AGN, Irache, Lib. 542, $237 \mathrm{v}$. 
SIMÓN DE GAZTEA LÓPEZ

B. A.

9-5-1638

Fr. Francisco Crespo

Irañeta (Pamplona)

Alumno S. J.

AGN, Irache, Lib. 542, 237v.

PEDRO DE ESPINOSA

B. A.

9-5-1638

Fr. Francisco Crespo

Lacin de Olite (Pamplona)

Alumno S. J.

AGN, Irache, Lib. 542, 237v.

JUSTO DE OSTA Y OLAEGUI

B. A.

9-5-1638

Fr. Francisco Crespo

Valle de Urroz (Pamplona)

Alumno S. J.

AGN, Irache, Lib. 542, $237 \mathrm{v}$.

PEDRO DE CALVA

B. A.

9-5-1638

Fr. Francisco Crespo

Idocin (Pamplona)

Alumno S. J.

AGN, Irache, Lib. 542, 237v.

JUAN DE AGUIRRE

B. A.

9-5-1638

Fr. Francisco Crespo

Donamaría (Pamplona)

Alumno S. J.

AGN, Irache, Lib. 542, $237 \mathrm{v}$.

SANCHO URSUA DE ARRECHEA

B. A.

9-5-1638

Fr. Francisco Crespo

Elizondo (Pamplona)

Alumno S. J.

AGN, Irache, Lib. 542, 237v.
JUAN DE LAS HERAS

B. A.

9-5-1638

Fr. Francisco Crespo

Asiain (Pamplona)

Alumno S. J.

AGN, Irache, Lib. 542, $237 \mathrm{v}$.

GASPAR DEL CAMPO

B. C.

5-5-1638

Fr. Martín Izquierdo

Riscano (Burgos)

AGN, Irache, Lib. 542, 238 r.

JUAN PARDO DE VALENCIA

B. A.

8-5-1638

Fr. Francisco Crespo

Burgos

AGN, Irache, Lib. 542, 238r.

GABRIEL BERNARDO DE TORRES

B. C.

19-5-1638

Fr. Diego de Silva

Villarcayo (Burgos)

AGN, Irache, Lib. 542, 238r.

JUAN DE LAS HERAS

B. C.

28-5-1638

Fr. Martín Izquierdo

Barbadillo (Burgos)

AGN, Irache, Lib. 542, 238 r.

JUAN RUIZ DE MATA

B. C.

20-6-1638

Fr. Diego de Silva

Villegas (Burgos)

AGN, Irache, Lib. 542, 238v.

BERNABÉ ROJO

B. C.

20-6-1638

Fr. Diego de Silva

Villegas (Burgos)

AGN, Irache, Lib. 542, 238v. 
JUAN FRANCISCO LARRIMPE Y MENDANIA

L. M. / D. M.

21-6-1638

Fr. Diego de Silva

Sangüesa (Pamplona)

AGN, Irache, Lib. 542, 238v.

MEDA DE TAMAYO

B. C.

29-6-1638

Fr. Diego de Araujo

Barrios de Bureba (Burgos)

AGN, Irache, Lib. 542, 238v.

JUAN BAUTISTA DE VILLAMOR

B. C.

9-7-1638

Fr. Diego de Silva

Burgos

AGN, Irache, Lib. 542, 238v.

MATÍAS DE PESQUERA

B. T.

21-7-1638

Fr. Diego de Silva

Olmozas (Burgos)

AGN, Irache, Lib. 542, 239r.

JUAN DE ICEDO

B. T.

21-7-1638

Fr. Diego de Silva

Villadiego (Burgos)

AGN, Irache, Lib. 542, 239 r.

MATÍAS DE NIEVA

L. T. / D. T.

22-7-1638

Fr. Diego de Silva

O. Cist.

AGN, Irache, Lib. 542, 239 r.

JUAN DE PORRAS

B. C.

27-7-1638

Fr. Diego Marcilla, vicecanciller

Villadiego (Burgos)

AGN, Irache, Lib. 542, 239 r.
MARTÍN DE LEOZ

L. M. / D. M.

9-9-1638

Fr. Francisco Crespo

Cintruénigo (Tarazona)

AGN, Irache, Lib. 542, $239 r$.

JUAN DE UROSTE SALAZAR

D. C.

12-9-1638

Fr. Francisco Crespo

Medina de Pomar (Burgos)

AGN, Irache, Lib. 542, 239v.

GREGORIO DE QUINTANILLA

B. A. / L. A. / M. A. / B. T. / L. T. / D. T.

29-9-1638

Fr. Diego de Silva

O. S. B.

AGN, Irache, Lib. 542, 239v.

JUAN DE CAPILLOS

B. A.

2-10-1638

Fr. Diego de Silva

Baquerín (Palencia)

AGN, Irache, Lib. 542, 239v.

GABRIEL DEL SOLAR TORAYA

B. C.

11-10-1638

Fr. Diego de Silva

Aguilar (Burgos)

AGN, Irache, Lib. 542, 239v.

JUAN GUTIÉRREZ

B. C.

16-11-1638

Fr. Martín Izquierdo

Loma (Burgos)

AGN, Irache, Lib. 542, 239v.

VENTURA PARCERO Y BAZÁN

B. C. / L. C. / D. C.

17-11-1638 /18-11-1638

Fr. Diego de Silva

Tuy

AGN, Irache, Lib. 542, 240 . 
NARCISO CASSART

L. C. / D. C.

18-11-1638

Fr. Diego de Silva

Gerona

AGN, Irache, Lib. 542, 240 or.

FRANCISCO AMETLLER

L. L. / D. L.

18-11-1638

Fr. Diego de Silva

La Bisbal (Gerona)

AGN, Irache, Lib. 542, 240 or.

SEBASTIÁN DE SALANUEVA

B. A.

2-12-1638

Fr. Francisco Crespo

Arróniz (Pamplona)

AGN, Irache, Lib. 542, $240 v$.

JUAN CESTERO

B. C.

2-12-1638

Fr. Diego de Araujo

Alejos (Valladolid)

AGN, Irache, Lib. 542, $240 v$.

JUAN VELLAZ

L. T. / D. T.

3-12-1638

Fr. Martín Izquierdo

Estella (Pamplona)

AGN, Irache, Lib. 542, $240 v$.

NICOLÁS DE ASIAIN

B. A.

9-12-1638

Fr. Francisco Crespo

Arróniz (Pamplona)

AGN, Irache, Lib. 542, $240 v$.

PEDRO DE CEBALLOS

B. C.

22-12-1638

Fr. Martín Izquierdo

Treceño (Burgos)

AGN, Irache, Lib. 542, 241r.
JOSÉ DE ALBARES

B. C.

31-12-1638

Fr. Diego de Silva

Herrera (Palencia)

AGN, Irache, Lib. 542, 241r.

IGNACIO DE LATASA

B. L.

10-1-1639

Fr. Diego de Silva

Pamplona

AGN, Irache, Lib. 542, 241r.

LUIS DE OSCÁRIZ

L. C.

11-1-1639

Fr. Diego de Silva

Pamplona

AGN, Irache, Lib. 542, 241r.

JUAN DE ACEVEDO

B. C.

29-1-1639

Fr. Diego de Araujo

Ezcaray (Burgos)

AGN, Irache, Lib. 542, $241 \mathrm{v}$.

HERNANDO GONZÁLEZ DE HOYOS

B. C.

1-3-1639

Fr. Diego de Silva

Sotilla (Burgos)

AGN, Irache, Lib. 542, 241v.

PEDRO BAJO

B. C.

1-3-1639

Fr. Diego de Silva

Corralejo (Burgos)

AGN, Irache, Lib. 542, 241v.

MATEO ALONSO

B. C.

6-3-1639

Fr. Diego de Araujo

Anero (Burgos)

AGN, Irache, Lib. 542, $241 \mathrm{v}$. 
JOSÉ MARTELL

L. L. / D. L.

10-3-1639

Fr. Diego de Araujo

Tarragona

AGN, Irache, Lib. 542, 241v.

SEBASTIÁN DE TRECEDO

B. C.

11-3-1639

Fr. Diego de Silva

Nidáguila (Burgos)

AGN, Irache, Lib. 542, 242r.

JUAN DE HUIDOBRO

B. C.

11-3-1639

Fr. Diego de Silva

Montorio (Burgos)

AGN, Irache, Lib. 542, 242r.

GASPAR DE ÁLAVA

B. C.

14-3-1639

Fr. Diego de Araujo

Burgos

AGN, Irache, Lib. 542, 242r.

GASPAR BARONA

B. C.

14-3-1639

Fr. Diego de Araujo

Burgos

AGN, Irache, Lib. 542, 242 r.

JUAN FERNÁNDEZ DE ESTOLA

B. T.

14-3-1639

Fr. Diego de Araujo

Burgos

AGN, Irache, Lib. 542, 242 r.

MARCOS DE HERVÍAS

B. C.

15-3-1639

Fr. Martín Izquierdo

Hervías (Calahorra)

AGN, Irache, Lib. 542, 242r.

\section{PEDRO DE AGUIRRE}

B. C.

2-4-1639

Fr. Diego de Silva

Bur... (Tarazona)

AGN, Irache, Lib. 542, 242 r.

L. C. / D. C.

2-4-1639

...

AGN, Irache, Lib. 542, 242v.

JUAN ESQUER

B. A. / B. T. / L. T. / D. T.

2-4-1639 / 3-4-1639

Fr. Francisco Crespo / Fr. Martín Izquierdo

Castejón de Monegros (Huesca)

AGN, Irache, Lib. 542, 242v.

PEDRO DE MORALES

B. A.

4-4-1639

Fr. Francisco Crespo

San Millán (Calahorra)

AGN, Irache, Lib. 542, 242v.

LORENZO MONTERO DE LA CONCHA

L. C. / D. C.

7-4-1639

Fr. Martín Izquierdo

Hesles (Burgos)

AGN, Irache, Lib. 542, 243 r.

MANUEL DE ERZI

B. A. / L. A.

13-4-1639 /14-4-1639

Fr. Francisco Crespo / Fr. Antonio de Castro

Ocón (Calahorra)

AGN, Irache, Lib. 542, 243 r.

LORENZO DE ITURRIALDE

B. C.

17-4-1639

Fr. Martín Izquierdo

Salinas de Añana (Burgos)

AGN, Irache, Lib. 542, 243 r. 


\section{MARTÍN DE MURILLO}

L. A.

29-4-1639

Fr. Diego de Araujo

Larequi (Pamplona)

AGN, Irache, Lib. 542, 243r.

PEDRO DEL VALLE

L. T. / M. T.

29-4-1639

Fr. Antonio de Castro

O. S. B.

Abad de San Esteban de Ribas

AGN, Irache, Lib. 542, 243r.

JUAN POZA

B. C.

30-4-1639

Fr. Diego de Silva

Coculina (Burgos)

AGN, Irache, Lib. 542, $243 v$.

JERÓNIMO TÉLLEZ LIZANA

B. C.

2-5-1639

Fr. Diego de Araujo

Briviesca (Burgos)

AGN, Irache, Lib. 542, 243v.

ANDRÉS DE ONTIVEROS

B. A.

AGN, Irache, Lib. 542, 6-5-1639

Estella (Pamplona)

AGN, Irache, Lib. 542, 243v.

JUAN DE ARENAS

B. C.

14-5-1639

Fr. Diego de Silva

Ampuero (Burgos)

AGN, Irache, Lib. 542, 243v.

PEDRO DE SETIÉN

B. C.

14-5-1639

Fr. Diego de Silva

Ampuero (Burgos)

AGN, Irache, Lib. 542, 243v.

\section{ANTONIO GÓMEZ}

L. C.

14-5-1639

Fr. Antonio de Castro

Ampuero (Burgos)

AGN, Irache, Lib. 542, 243v.

FRANCISCO PÉREZ

B. C.

18-5-1639

Fr. Diego de Araujo

Burgos

AGN, Irache, Lib. 542, 244r.

ANTONIO DE LA VILLANA

B. C.

18-5-1639

Fr. Diego de Araujo

Puerto de Santoña (Burgos)

AGN, Irache, Lib. 542, 244 r.

\section{GREGORIO FERNÁNDEZ}

B. C.

22-5-1639

Fr. Martín Izquierdo

Villadiego (Burgos)

AGN, Irache, Lib. 542, 244 r.

PEDRO JIMÉNEZ

B. A.

30-5-1639

Fr. Diego de Silva

O. de M.

Arguedas

AGN, Irache, Lib. 542, 244 r.

ESTEBAN VIU

L. C. / D. C.

1-6-1639

Fr. Antonio de Castro

Tamarite (Lérida)

AGN, Irache, Lib. 542, 244 r.

MARTÍN DE ALDAMA

B. C.

5-6-1639

Fr. Diego de Araujo

Sto. Domingo de la Calzada (Calahorra)

AGN, Irache, Lib. 542, 244r. 
FRANCISCO DE AIBAR

L. C.

5-6-1639

Fr. Antonio de Castro

Corella (Tarazona)

AGN, Irache, Lib. 542, 244v.

\section{FRANCISCO SIMÓN}

B. C.

21-5-1639

Fr. Diego de Silva

Cañizal (Burgos)

AGN, Irache, Lib. 542, 244v.

PEDRO DE BIDAJÚN

B. A. / B. M. / L. M. / D. M.

28-6-1639 / 29-6-1639

Fr. Martín Izquierdo / Fr. Antonio de Castro / Dr. Elizalde

Burguete (Pamplona)

AGN, Irache, Lib. 542, 244v.

ANDRÉS MIGUEL

B. T.

8-7-1639

Fr. Diego de Silva

Villanosa (Burgos)

AGN, Irache, Lib. 542, 244V.

FRANCISCO DE VILLANUEVA

B. C.

15-7-1639

Fr. Diego de Araujo

Landa (Burgos)

AGN, Irache, Lib. 542, 245r.

JUAN RUIZ DE LA PEÑA

B. C.

22-7-1639

Fr. Diego de Araujo

Quintana (Burgos)

AGN, Irache, Lib. 542, 245r.

GIL DE ALFARO

B. C.

27-7-1639

Fr. Diego de Silva

Erze (Calahorra)

AGN, Irache, Lib. 542, 245r.
SEBASTIÁN DE LOS RÍOS

B. C.

28-7-1639

Fr. Martín Izquierdo

Villaisidro (Burgos)

245r.

ALONSO BARAHONA

B. C.

28-7-1639

Fr. Martín Izquierdo

Olmillos (Burgos)

AGN, Irache, Lib. 542, 245 r.

JOSÉ GUTIÉRREZ

B. L.

30-7-1639

Fr. Diego de Silva

B. C.

Valladolid

AGN, Irache, Lib. 542, $245 \mathrm{v}$.

MIGUEL SALANO Y ECHEVERZ

L. T. / D. T.

2-8-1639

Fr. Martín Izquierdo

Zarauz (Bayona)

AGN, Irache, Lib. 542, 245v.

JUAN GIL LÓPEZ

B. M.

5-8-1639

Fr. Martín Izquierdo

Allo (Pamplona)

AGN, Irache, Lib. 542, 245v.

PEDRO CASTAÑOS

B. C.

17-8-1639

Fr. Martín Izquierdo

Burgos

AGN, Irache, Lib. 542, $245 \mathrm{v}$.

MARCOS DE BOBADILLA

B. C.

24-8-1639

Fr. Diego de Araujo

Quintanillas (Burgos)

AGN, Irache, Lib. 542, 245v. 
LORENZO BELTRÁN

B. T. / L. T. / D. T.

30-8-1639

Fr. Antonio de Castro

Arnedo (Calahorra)

Capellán de Emperadores y Primero de la

Emperatriz

Deán de Ciudad Rodrigo

AGN, Irache, Lib. 542, 246r.

\section{ANTONIO GAYAN}

B. C.

30-8-1639

Fr. Martín Izquierdo

Burgos

AGN, Irache, Lib. 542, 246r.

ROQUE BENITO

B. C.

30-8-1639

Fr. Martín Izquierdo

Revilla (Burgos)

AGN, Irache, Lib. 542, 246r.

FRANCISCO MARTÍNEZ

B. T.

1-9-1639

Fr. Diego de Silva

Quintanillas (Burgos)

AGN, Irache, Lib. 542, 246r.

MIGUEL GONZÁLEZ

B. T.

9-9-1639

Fr. Diego de Araujo

Estépar (Burgos)

AGN, Irache, Lib. 542, 246r.

GABRIEL SÁINZ DE DUEÑAS

B. C.

19-9-1639

Fr. Diego de Silva

Castrillo de Murcia (Burgos)

AGN, Irache, Lib. 542, 246v.

BARTOLOMÉ DE DIEGO

B. C.

19-9-1639
Fr. Diego de Silva

Castrillo de Murcia (Burgos)

AGN, Irache, Lib. 542, 246v.

BERNARDO DE ARANAZ

B. A.

22-9-1639

Fr. Diego de Silva

Arnedo (Calahorra)

AGN, Irache, Lib. 542, 246v.

MANUEL MARTÍNEZ DEL ÁGUILA

B. C. / L. C. / D. C.

22-9-1639 / 6-2-1640 / 20-7-1647

Fr. Diego de Silva / Fr. Diego de Silva / Fr.

Bernabé Martel, abad

Arnedo (Calahorra)

AGN, Irache, Lib. 542, 246v, 248v, 295v.

\section{SEBASTIÁN ORTIZ}

B. C.

24-9-1639

Fr. Diego de Araujo

Pancorbo (Burgos)

AGN, Irache, Lib. 542, 246v.

PEDRO VÉLEZ

B. A. / L. A. / M. A. / B. T. / L. T. / D. T.

6-10-1639

Fr. Antonio de Castro

O.S. B.

Burgos

AGN, Irache, Lib. 542, 247r.

JUAN DE OLIVÁN

L. A.

31-10-1639

Fr. Antonio de Castro

Asenjo (Calahorra)

AGN, Irache, Lib. 542, 247 r.

JOAQUÍN DE GUEVARA Y ZABALA

L. C.

2-11-1639

Fr. Antonio de Castro

Durango (Calahorra)

AGN, Irache, Lib. 542, 247v. 
JUAN DE DUEÑAS

B. A. / L. A. / M. A. / B. T. / L. T. / D. T. 2-11-1639

Fr. Antonio de Castro

O. S. B.

Maestro de Estudiantes de Irache

Hijo de San Esteban de Ribas de Sil

AGN, Irache, Lib. 542, 247v.

\section{LORENZO MORENO}

B. C.

9-11-1639

Fr. Martín Izquierdo

Mazuela (Burgos)

AGN, Irache, Lib. 542, $247 \mathrm{v}$.

\section{MARTÍN RAMÍREZ}

B. C.

5-12-1639

Fr. Diego de Silva

Burgos

AGN, Irache, Lib. 542, $247 \mathrm{v}$.

MATÍAS DE LATORRE

B. C.

6-12-1639

Fr. Diego de Araujo

Vizcaya (Calahorra)

AGN, Irache, Lib. 542, 247v.

JUAN ANTONIO DE ARIZALETA

L. C.

8-12-1639

Fr. Antonio de Castro

Abad de Zubiri

Canónigo de Roncesvalles

AGN, Irache, Lib. 542, 248r.

MIGUEL IRIBARREN

L. C.

8-12-1639

Fr. Antonio de Castro

Abad de Garralda

Canónigo de Roncesvalles

AGN, Irache, Lib. 542, 248r.

JUAN DE LA ARENA

L. T.
14-12-1639

Fr. Antonio de Castro

Cerezo (Burgos)

AGN, Irache, Lib. 542, 248r.

JOSÉ BELTRÁN

B. C.

15-12-1639

Fr. Diego de Araujo

Galilea (Burgos)

AGN, Irache, Lib. 542, 248r.

JERÓNIMO VELARDE

B. A. / L. A. / M. A. / B. T. / L. T. / D. T.

17-12-1639

Fr. Antonio de Castro

O. S. B.

Hijo de Sahagún

AGN, Irache, Lib. 542, 248r.

JUAN RODRÍGUEZ

B. A. / L. A. / M. A. / B. T. / L. T. / D. T. 17-12-1639

Fr. Antonio de Castro

O. S. B.

Secretario de la Orden

Hijo de San Isidro

AGN, Irache, Lib. 542, 248r.

FRANCISCO DE MORALES

B. A. / L. A. / M. A. / B. T. / L. T. / D. T. 17-12-1639

Fr. Antonio de Castro

O. S. B.

Hijo de Valladolid

AGN, Irache, Lib. 542, 248r.

ÁNGEL DEL ÁGUILA

B. A. / L. A. / M. A. / B. T. / L. T. / D. T. 5-1-1640

Fr. Diego de Araujo

O. Cist.

Abad de la Oliva (Navarra)

AGN, Irache, Lib. 542, 248v.

MIGUEL DE GARRALDA

B. T. / L. T.

5-1-1640 
Fr. Diego de Silva

Garralda (Pamplona)

AGN, Irache, Lib. 542, 248v.

MARTÍN GARCÍA

B. T. / L. T.

5-1-1640

Fr. Diego de Silva

Garralda (Pamplona)

AGN, Irache, Lib. 542, 248v.

JUAN DE BRACAMONTE Y ALARCÓN

B. A. / B. T. / L. T. / D. T.

1-2-1640

Fr. Diego de Araujo

Valladolid

AGN, Irache, Lib. 542, 248v.

FRANCISCO DE CEBALLOS MADRID

B. C.

15-2-1640

Fr. Diego de Araujo

Valle de Buelna (Burgos)

AGN, Irache, Lib. 542, 248v.

JUAN DE LORRIGUI

L. C. / D. C.

18-2-1640

Fr. Diego de Araujo

Autol (Calahorra)

AGN, Irache, Lib. 542, 248v.

FAUSTO RODRÍGUEZ DE SEGURA

B. A. / L. A.

20-2-1640

Fr. Pedro Bergaño, M. A.

Aguilar de Navarra

AGN, Irache, Lib. 542, 249r.

PEDRO DE UGARTE

B. A.

22-2-1640

Fr. Pedro Bergaño

San Sebastián (Pamplona)

AGN, Irache, Lib. 542, 249 r.

GASPAR BERMÚDEZ

B. A.
25-2-1640

Fr. Pedro Bergaño

Madrid

AGN, Irache, Lib. 542, 249 r.

JUAN MARTÍNEZ

B. A. / B. M.

26-2-1640

Fr. Diego de Araujo

Ituero (Burgos)

AGN, Irache, Lib. 542, 249 r.

JUAN SANZ

B. C.

9-3-1640

Fr. Diego de Silva

Barrio de la Bureba (Burgos)

AGN, Irache, Lib. 542, 249 r.

FRANCISCO OCHOA

L. L.

9-3-1640

Fr. Martín Izquierdo

Tudela (Tarazona)

AGN, Irache, Lib. 542, 249v.

LUCAS DE ILARDUYA

B. C.

16-3-1640

Fr. Diego de Araujo

Logroño (Calahorra)

AGN, Irache, Lib. 542, $249 v$.

FRANCISCO DE MONTOYA

B. C. / L. C.

16-3-1640

Fr. Diego de Araujo

Beraventilla (Calahorra)

AGN, Irache, Lib. 542, 249v.

JUAN AGUSTÍN DE LAS FOYAS

L. T. / D. T.

3-4-1640

Fr. Martín Izquierdo

Almunia (Zaragoza)

AGN, Irache, Lib. 542, 249v.

JUAN SERRANO Y LUNA

B. L. / L. L. 
13-4-1640

Fr. Diego de Silva / Ldo. Ablitas, Letrado Corella (Tarazona)

AGN, Irache, Lib. 542, 250 or.

\section{GREGORIO DE VACA Y CASTRO}

L. C. / D. C.

18-4-1640

Fr. Diego de Araujo

Aranda del Duero (Osma)

AGN, Irache, Lib. 542, 25 or.

JUAN DE RIBERO Y CASA

B. C.

20-4-1640

Fr. Diego de Araujo

Limpias (Burgos)

AGN, Irache, Lib. 542, 25 or.

PEDRO TRIANA

B. C.

20-4-1640

Fr. Diego de Silva

Pasamón (Burgos)

AGN, Irache, Lib. 542, 250r.

MATÍAS BENITO

B. C.

25-4-1640

Fr. Diego de Araujo

Canales (Burgos)

AGN, Irache, Lib. 542, $250 v$.

\section{ANTONIO BENITO}

B. C.

25-4-1640

Fr. Diego de Araujo

Canales (Burgos)

AGN, Irache, Lib. 542, $250 v$.

JOSÉ GARCÍA

B. C.

25-4-1640

Fr. Diego de Araujo

Burgos

AGN, Irache, Lib. 542, $250 v$.

TORIBIO FERNÁNDEZ

B. C.
1-5-1640

Fr. Diego de Silva

Burgos

AGN, Irache, Lib. 542, 250v.

MARTÍN SIERRA SALAZAR

L. C.

13-5-1640

Fr. Diego de Silva

Santullán (Burgos)

AGN, Irache, Lib. 542, $250 v$.

ANTONIO HERNÁNDEZ

B. A. / B. T.

13-5-1640

Fr. Pedro Bergaño

Ventosa (Burgos)

AGN, Irache, Lib. 542, $250 v$.

MARTÍN SÁNCHEZ DE OLALLA

B. C.

14-5-1640

Fr. Diego de Araujo

Brieba (Burgos)

AGN, Irache, Lib. 542, 251 r.

JUAN SANTOS

B. C.

15-5-1640

Fr. Diego de Araujo

Melgar (Burgos)

AGN, Irache, Lib. 542, 251r.

FERMÍN DE MARICHALAR

L. L.

19-5-1640

Fr. Martín Izquierdo / Ldo. Cegama

Pamplona

AGN, Irache, Lib. 542, 251r.

MARTÍN DE ORCONDONA

L. A. / M. A. / B. T.

14-6-1640

Fr. Antonio de Castro

Inestrillas (Calahorra)

AGN, Irache, Lib. 542, 251r.

DIEGO DE CASTAÑEDA

B. C. 
23-6-1640

Fr. Diego de Araujo

Viana del Bello (Astorga)

AGN, Irache, Lib. 542, 251v.

PEDRO DEL BARRIO

L. C. / D. C.

7-7-1640

Fr. Diego de Araujo

Arango (Tarazona)

AGN, Irache, Lib. 542, 251v.

JUAN DE SORRIBA

B. C.

19-7-1640

Fr. Diego de Araujo

Castro Urdiales (Burgos)

AGN, Irache, Lib. 542, 251v.

MIGUEL DE QUINTANA

B. C. / L. C.

27-7-1640 / 22-7-1658

Fr. Diego de Araujo / Fr. Ildefonso de Escudero

Frías (Burgos)

AGN, Irache, Lib. 542, 252r, s. f.

AMBROSIO GÓMEZ

B. A. / L. A. / M. A. / B. T. / L. T. / D. T.

3-8-1640

Fr. Antonio de Castro

O. S. B.

Hijo de San Millán de la Cogolla

AGN, Irache, Lib. 542, 252r.

ANTONIO DE CANTABRANA

B. A. / L. A. / M. A. / B. T. / L. T. / D. T.

12-8-1640

Fr. Antonio de Castro

O. S. B.

Hijo y Prior de San Benito de Valladolid

AGN, Irache, Lib. 542, 252r.

\section{ANTONIO SÁEZ}

B. C.

3-9-1640

Fr. Martín Izquierdo

Olmillos (Burgos)

AGN, Irache, Lib. 542, 252r.
GREGORIO DE ALEMPARTE Y MONTES

B. C.

5-9-1640

Fr. Diego de Araujo

Tuy

AGN, Irache, Lib. 542, 252v.

FRANCISCO ARROYO

B. C.

5-9-1640

Fr. Diego de Araujo

Santa Olalla (Burgos)

AGN, Irache, Lib. 542, 252v.

FERNANDO DE MENDOZA Y SOTOMAYOR

B. C. / L. C.

5-9-1640

Fr. Antonio de Castro

Pontevedra (Santiago)

Caballero de Santiago

AGN, Irache, Lib. 542, 252v.

PEDRO PASCUAL

B. C.

19-9-1640

Fr. Martín Izquierdo

Mazuelo (Burgos)

AGN, Irache, Lib. 542, 252v.

DIEGO GÓMEZ PIMENTEL

B. A.

20-9-1640

Fr. Diego de Araujo

Madrid (Toledo)

AGN, Irache, Lib. 542, 252v.

MARTÍN DE SERRALTA

L. C. / D. C.

28-9-1640

Fr. Diego de Araujo

Otañes (Burgos)

AGN, Irache, Lib. 542, 253 r.

FRANCISCO DE AISANOA

B. A.

13-10-1640

Fr. Pedro Bergaño 
Pamplona

AGN, Irache, Lib. 542, 253r.

JUAN DE GAYANGOS

B. A. / L. A. / M. A. / B. T. / L. T. / D. T.

14-10-1640

Fr. Antonio de Castro

O. S. B.

Abad de Sahagún

AGN, Irache, Lib. 542, 253 r.

MAURO DE OLABARRIETA

B. A. / L. A. / M. A. / B. T. / L. T. / D. T.

14-10-1640

Fr. Antonio de Castro

O. S. B.

Abad de Valvanera

AGN, Irache, Lib. 542, 253r.

JUAN MIGUEL DE OCAMPO CIENFUEGOS

B. C. / L. C. / D. C.

15-10-1640

Fr. Antonio de Castro

Sahagún (Nullius Diocesis)

AGN, Irache, Lib. 542, 253v.

MIGUEL MARTÍNEZ

L. C.

15-10-1640

Fr. Antonio de Castro

Mendigorría (Pamplona)

AGN, Irache, Lib. 542, $253 \mathrm{v}$.

FRANCISCO GURÉNDEZ

B. C. / L. C.

16-10-1640

Fr. Antonio de Castro

Ramelluri (Calahorra)

AGN, Irache, Lib. 542, $253 \mathrm{v}$.

FRANCISCO DE AMPUERO

B. C.

17-10-1640

Fr. Martín Izquierdo

Castro Urdiales (Burgos)

AGN, Irache, Lib. 542, 254r.
ANTONIO DE MUSANRIETA

B. C.

17-10-1640

Fr. Martín Izquierdo

Castro Urdiales (Burgos)

AGN, Irache, Lib. 542, 254 r.

ANTONIO NAVAMUEL SOBREMONTE

L. C. / D. C.

3-11-1640 / 4-11-1640

Fr. Antonio de Castro

Reinosa (Burgos)

AGN, Irache, Lib. 542, 254r.

JUAN GONZÁLEZ DE QUEVEDO ALVARADO

L. C.

3-11-1640

Fr. Antonio de Castro

Reinosa (Burgos)

AGN, Irache, Lib. 542, 254r.

JUAN DEL BARRIO

B. C.

9-12-1640

Fr. Diego de Araujo

Laserna (Burgos)

AGN, Irache, Lib. 542, 254r.

PEDRO DE ÁLVAREZ

M. A. / M. T.

13-12-1640

Fr. Diego de Araujo

O. S. B.

AGN, Irache, Lib. 542, $254 \mathrm{~V}$.

FRANCISCO GARCÍA BERMEJO

L. C. / D. C.

14-12-1640

Fr. Martín Izquierdo

Lerma (Nullius Diocesis)

AGN, Irache, Lib. 542, 254v.

JUAN DE CASTRESANA

B. C.

16-12-1640

Fr. Diego de Araujo

Burgos

AGN, Irache, Lib. 542, 254v. 
FRANCISCO RUIZ DE PRADILLA

B. C.

19-12-1640

Fr. Diego de Silva

Aguas Cándidas (Burgos)

AGN, Irache, Lib. 542, 254v.

PEDRO BERRIA Y ENECOIZ

L. C.

29-1-1641

Fr. Antonio de Castro, Abad y Rector

Abaurrea de Navarra

Canónigo de Roncesvalles

AGN, Irache, Lib. 542, 254v.

FRANCISCO DE URREA

L. C. / D. C.

11-2-1641

Fr. Antonio de Castro, abad

Épila (Zaragoza)

AGN, Irache, Lib. 542, 255r.

FRANCISCO MUÑOZ

B. T. / L. T. / D. T.

11-2-1641

Fr. Antonio de Castro, abad

Alfambra (Zaragoza)

AGN, Irache, Lib. 542, 255r.

JUAN BAUTISTA DEL PUERTO

B. T. / L. T.

18-2-1641

Fr. Antonio de Castro, abad

Alea (Calahorra)

AGN, Irache, Lib. 542, 255 r.

\section{ALONSO RODRÍGUEZ ARIAS}

B. A.

25-2-1641

Fr. Diego de Araujo

Villanueva de Valdueza (Astorga)

AGN, Irache, Lib. 542, 255 r.

JOSÉ CALLEJA

L. C.

12-3-1641

Fr. Martín Izquierdo,Vicecanciller

Villadiego (Burgos)

AGN, Irache, Lib. 542, 255 r.
JOSÉ DE VILLAMAYOR

B. A. / B. T.

24-3-1641

Fr. Martín Izquierdo

O. S. A.

AGN, Irache, Lib. 542, 255v.

FRANCISCO DE HERAS

L. C.

24-3-1641

Fr. Diego de Araujo, Regente

Liérganes (Burgos)

AGN, Irache, Lib. 542, 255v.

ESTEBAN DE BARREDA

L. C.

6-4-1641

Fr. Martín Izquierdo

Briviesca (Burgos)

AGN, Irache, Lib. 542, 255v.

PEDRO MANJARRÉS DE HEREDIA

L. C. / D. C.

7-4-1641

Fr. Diego de Araujo

Navarrete (Calahorra)

Inquisidor, Capellán del Príncipe Fernando

Racionero de Toledo y Jaén

AGN, Irache, Lib. 542, 255v.

\section{PEDRO DE OLEA}

L. C.

8-4-1641

Fr. Diego de Araujo

Sardero (Calahorra)

AGN, Irache, Lib. 542, 256r.

JAIME TEJERO

B. A. / B. T. / L. T. / D. T.

8-4-1641

Fr. Diego de Araujo

Zaragoza

AGN, Irache, Lib. 542, 256r.

LUIS ZAPATA

L. C. / D. C.

10-4-1641

Fr. Martín Izquierdo 
Madrid (Toledo)

Canónigo

AGN, Irache, Lib. 542, 256r.

MARTÍN DE HERRERA

L. C.

13-4-1641

Fr. Diego de Araujo

Navarrete (Calahorra)

AGN, Irache, Lib. 542, 256v.

MIGUEL RUIZ

B. C.

20-4-1641

Fr. Martín Izquierdo

Barrios de Bureba (Burgos)

AGN, Irache, Lib. 542, 256v.

MARTÍN DE ZUNZARREN

L. M. / D. M.

21-4-1641

Fr. Martín Izquierdo

Estella (Pamplona)

AGN, Irache, Lib. 542, 256v.

MIGUEL DE AZCONA DE LIZAIN

L. L.

22-4-1641

Fr. Martín Izquierdo

Estella (Pamplona)

AGN, Irache, Lib. 542, 256v.

DIEGO PÉREZ DE LARREA

L. C.

23-4-1641

Fr. Pedro de Vergano, Vicecanciller

Nájera (Calahorra)

AGN, Irache, Lib. 542, 257 r.

JUAN DE LA BUSTILLA

B. C.

6-5-1641

Fr. Martín Izquierdo

Vega (Burgos)

AGN, Irache, Lib. 542, 257 r.

JUAN FERNÁNDEZ DE VIRUÉS

B. C.
9-5-1641

Fr. Martín Izquierdo

Cadiñanos (Burgos)

AGN, Irache, Lib. 542, 257r.

JUAN DE MONTENEGRO

B. C.

10-5-1641

Fr. Martín Izquierdo

Mansilla (Burgos)

AGN, Irache, Lib. 542, 257r.

FERNANDO DE LA MOLINA

B. C.

10-5-1641

Fr. Martín Izquierdo

San Vicente de la Barquera (Burgos)

AGN, Irache, Lib. 542, 257 r.

JUAN NADAL

L. L. / D. L.

14-5-1641

Fr. Martín Izquierdo

La Luenga (Zaragoza)

AGN, Irache, Lib. 542, $257 \mathrm{v}$.

PEDRO FERNÁNDEZ DE MIÑANO

B. A.

15-5-1641

Fr. Pedro de Vergano

Peralta (Pamplona)

AGN, Irache, Lib. 542, $257 \mathrm{v}$.

ANTONIO HERNÁNDEZ

B. A.

15-5-1641

Fr. Pedro de Vergano

Peralta (Pamplona)

AGN, Irache, Lib. 542, $257 \mathrm{v}$.

PEDRO MAULEÓN

B. A.

15-5-1641

Fr. Pedro de Vergano

Estella (Pamplona)

AGN, Irache, Lib. 542, $257 \mathrm{v}$.

DIEGO DE CASTRO RUIZ DE LA PEÑA

L. C. 
15-5-1641

Fr. Martín Izquierdo

Oria (Burgos)

Cura y beneficiado

AGN, Irache, Lib. 542, $257 \mathrm{v}$.

JUAN DE VICUÑA

L. T. / D. T.

22-5-1641

Fr. Martín Izquierdo

Legasa (Pamplona)

AGN, Irache, Lib. 542, 257v.

JOSÉ RODRÍGUEZ

B. T.

26-5-1641

Fr. Martín Izquierdo

Labanera (Burgos)

AGN, Irache, Lib. 542, 258 r.

PEDRO FERNÁNDEZ

B. T.

26-5-1641

Fr. Martín Izquierdo

San Felices (Burgos)

AGN, Irache, Lib. 542, 258 r.

\section{MARTÍN COSCÓN}

B. C.

3-6-1641

Fr. Francisco Crespo, vicecanciller

Huesca

AGN, Irache, Lib. 542, 258r.

FERNANDO DE SANTANDER

B. C.

10-6-1641

Fr. Martín Izquierdo

Laredo (Burgos)

AGN, Irache, Lib. 542, 258 r.

JUAN BAUTISTA DE URO

B. C.

10-6-1641

Fr. Martín Izquierdo

Laredo (Burgos)

AGN, Irache, Lib. 542, 258r.
LUIS DE LA PIEDRA

B.C.

10-6-1641

Fr. Martín Izquierdo

Laredo (Burgos)

AGN, Irache, Lib. 542, 258r.

GASPAR DE SALAZAR

B. C.

14-6-1641

Fr. Martín Izquierdo

Briviesca (Burgos)

AGN, Irache, Lib. 542, 258r.

\section{MELCHOR ESCUDERO}

B. C.

15-6-1641

Fr. Martín Izquierdo

Grisaleña (Burgos)

AGN, Irache, Lib. 542, 258r.

ANTONIO SUÁREZ

B. C.

21-6-1641

Fr. Francisco Crespo

Grijalba (Burgos)

AGN, Irache, Lib. 542, 258r.

NICOLÁS EGUIGUREN

B. A. / B. T. / L. T.

21-6-1641

Fr. Juan Rodríguez, Abad y Rector

Eibar (Calahorra)

AGN, Irache, Lib. 542, 258v.

JUAN MARTÍNEZ DE ARES

B. C.

28-6-1641

Fr. Martín Izquierdo

Burgos

AGN, Irache, Lib. 542, 258v.

FRANCISCO YAGO

L. T. / D. T.

29-6-1641

Fr. Juan Rodríguez, abad

Calatayud (Tarazona)

AGN, Irache, Lib. 542, 258v. 


\section{ANDRÉS GARCÍA}

B. C.

3-7-1641

Fr. Martín Izquierdo

Mansilla (Burgos)

AGN, Irache, Lib. 542, 258v.

FERNANDO SÁNCHEZ DE CASIGUERA

L. C.

7-7-1641

Fr. Diego de Silva, Regente

Rada (Burgos)

AGN, Irache, Lib. 542, 259 r.

JUAN DE BARCINA

B. C.

24-7-1641

Fr. Diego de Silva

Burgos

AGN, Irache, Lib. 542, 259r.

JUAN DE LANGARICA

B. C.

24-7-1641

Fr. Diego de Silva

Burgos

AGN, Irache, Lib. 542, 259 r.

JOSÉ LÓPEZ DE ANGUIANO

B. T. / L. T.

25-7-1641

Fr. Juan Rodríguez, abad

Arnedo (Calahorra)

AGN, Irache, Lib. 542, 259 r.

ANTONIO JOSÉ DE AOIZ

L. C.

9-8-1641

Fr. Juan Rodríguez, abad

Tarazona

AGN, Irache, Lib. 542, 259 r.

AGUSTÍN DE IRICIO

B. C. / L. C.

23-8-1641

Fr. Juan Rodríguez, abad Arenzana de Abajo (Calahorra)

AGN, Irache, Lib. 542, 259v.
FRANCISCO DE LARREA

B. C.

26-8-1641

Fr. Diego de Silva

Castro Urdiales (Burgos)

AGN, Irache, Lib. 542, $259 \mathrm{v}$.

FRANCISCO GARCÍA DE COSSÍO

B. C.

4-9-1641

Fr. Francisco Crespo

San Sebastián de Garabanda (Burgos)

AGN, Irache, Lib. 542, $259 \mathrm{v}$.

PEDRO BADARÁN

L. C. / D. C.

10-9-1641

Fr. Juan Rodríguez, abad

Navarrete (Calahorra)

AGN, Irache, Lib. 542, 259v.

PEDRO OGAZÓN

B. C.

11-9-1641

Fr. Martín Izquierdo

Medina de Pomar (Burgos)

AGN, Irache, Lib. 542, $259 \mathrm{v}$.

FRANCISCO ALONSO

B. C.

11-9-1641

Fr. Martín Izquierdo

Medina de Pomar (Burgos)

AGN, Irache, Lib. 542, $259 \mathrm{v}$.

MARTÍN AGUADO

B. C.

17-9-1641

Fr. Francisco Crespo

Burgos

AGN, Irache, Lib. 542, 259v.

DIEGO DE CONCHA

B. C.

19-9-1641

Fr. Francisco Crespo

Burgos

AGN, Irache, Lib. 542, 260 . 
JUAN DE UTERGA

B. A. / B. T.

21-9-1641

Fr. Diego de Silva

Muruzábal (Pamplona)

AGN, Irache, Lib. 542, 26 or.

\section{SALVADOR DE OLÁIZ}

B. A.

23-9-1641

Fr. Pedro Vergaño

Villana (Pamplona)

AGN, Irache, Lib. 542, 260 .

BERNARDO DE GOÑI

B. A. / L. T.

3-10-1641 / 28-11-1641

Fr. Pedro de Vergaño / Fr. Juan Rodríguez, abad

Asterain (Pamplona)

AGN, Irache, Lib. 542, $260 r v$.

MIGUEL PÉREZ

B. A.

3-10-1641

Fr. Pedro de Vergaño

Asterain (Pamplona)

AGN, Irache, Lib. 542, 26 or.

MARTÍN DE SUBICA

B. A.

3-10-1641

Fr. Pedro de Vergaño

Zubica (Pamplona)

AGN, Irache, Lib. 542, 26 or.

JUAN LOZANO

B. T.

3-10-1641

Fr. Francisco Crespo

Ainar (Pamplona)

AGN, Irache, Lib. 542, 260 .

GREGORIO DE LARA

B. C.

10-10-1641

Fr. Diego de Silva

Burgos

AGN, Irache, Lib. 542, 26 or.

\section{MARCOS DE GOITIA}

B. C.

16-10-1641

Fr. Martín Izquierdo

Vitoria (Calahorra)

AGN, Irache, Lib. 542, 26 or.

JOSÉ DE HARO

B. C.

22-10-1641

Fr. Francisco Crespo

Laredo (Burgos)

AGN, Irache, Lib. 542, 26 or.

JUAN DE BERZOSA

B. C.

4-11-1641

Fr. Diego de Silva

Báscones de Ebro (Burgos)

AGN, Irache, Lib. 542, $260 v$.

DIEGO GONZÁLEZ

B. C.

21-11-1641

Fr. Diego de Silva

Rojas (Burgos)

AGN, Irache, Lib. 542, $260 v$.

GABRIEL PÉREZ DE PALACIO

B. C.

23-11-1641

Fr. Francisco Crespo

Caballeros (Burgos)

AGN, Irache, Lib. 542, $260 v$.

JERÓNIMO FERNÁNDEZ DE ALDEA

L. C. / D. C.

27-11-1641

Fr. Juan Rodríguez, abad

Zaragoza

AGN, Irache, Lib. 542, $260 v$.

ROQUE SERRANO

L. C. / D. C.

2-12-1641

Fr. Juan Rodríguez, abad

Cretas (Tortosa)

AGN, Irache, Lib. 542, 26ov. 
JUAN DE LA RIVA

B. C.

10-12-1641

Fr. Diego de Silva

Cogollos (Burgos)

AGN, Irache, Lib. 542, 260v.

DIEGO DÍAZ

B. C.

16-12-1641

Fr. Francisco Crespo

Burgos

AGN, Irache, Lib. 542, 261r.

MANUEL DE CERECEDA

B. T. / L. T. / D. T.

19-1-1642

Fr. Juan Rodríguez, abad

Yanguas

O. Cist.

Abad de Sta. María la Real de la Oliva

AGN, Irache, Lib. 542, 261 .

ESTEBAN GRISALVO RAMOS

B. A. / B. T.

23-1-1642

Fr. Diego de Silva

Los Balvases (Burgos)

AGN, Irache, Lib. 542, 261r.

DIEGO GONZÁLEZ DE CASTRO

B. C.

2-2-1642

Fr. Diego de Silva

Los Balvases (Burgos)

AGN, Irache, Lib. 542, 261r.

PEDRO DE ZALDU

B. C.

3-2-1642

Fr. Francisco Crespo

Burgos

AGN, Irache, Lib. 542, 261r.

JUAN DE ARAGÓN

B. C.

3-2-1642

Fr. Francisco Crespo
Ubierna (Burgos)

AGN, Irache, Lib. 542, 261 .

GONZALO MORENO

B. T.

24-2-1642

Fr. Diego de Silva

Arguiñano (Pamplona)

AGN, Irache, Lib. 542, 261v.

DIEGO DE ZUBIZARRETA

B. C. / L. C.

5-3-1642 / 22-11-1646

Fr. Martín Izquierdo / Fr. Bernabé Martel, abad

Ermua (Calahorra)

AGN, Irache, Lib. 542, 261v, 292r.

FERNANDO DE ARBARCA

B. C.

5-3-1642

Fr. Martín Izquierdo

Abadiano (Calahorra)

AGN, Irache, Lib. 542, $261 \mathrm{v}$.

MIGUEL DE URRUTIA

B. A.

7-3-1642

Fr. Pedro de Vergaño

Arguiñano (Pamplona)

AGN, Irache, Lib. 542, 261v.

FRANCISCO MATANZA

B. C.

16-3-1642

Fr. Diego de Silva

Villaverde (Burgos)

AGN, Irache, Lib. 542, $261 \mathrm{v}$.

PEDRO DE SAN JUAN DE BONILLA

B. C.

19-3-1642

Fr. Diego de Silva

Villa del Ciego (Calahorra)

AGN, Irache, Lib. 542, 261v.

MIGUEL GALLO

B. C. 
21-3-1642

Fr. Diego de Silva

Burgos

AGN, Irache, Lib. 542, 261v.

JUAN GÓMEZ DE RUFRANCOS

B. C.

21-3-1642

Fr. Diego de Silva

Burgos

AGN, Irache, Lib. 542, 261v.

NICOLÁS DE URRACA

B. C.

30-3-1642

Fr. Francisco Crespo

Arenzana de Abajo (Calahorra)

AGN, Irache, Lib. 542, 261v.

JUAN DE MIRANDA

B. A.

30-3-1642

Fr. Pedro de Vergaño

Lizárraga (Pamplona)

AGN, Irache, Lib. 542, 261v.

MARTÍN GÓMEZ MARAÑÓN

B. A.

7-4-1642

Fr. Pedro de Vergaño

Torralba (Calahorra)

AGN, Irache, Lib. 542, 261v.

BARTOLOMÉ DE ÁLVARO

B. C.

9-4-1642

Fr. Martín Izquierdo

Villasandino (Burgos)

AGN, Irache, Lib. 542, 262 r.

JUAN DE AGUIRRE

B. T. / L. T.

9-4-1642 / 15-4-1642

Fr. Francisco Crespo / Fr. Juan Rodríguez,

abad

Valle de Ibargoiti (Pamplona)

AGN, Irache, Lib. 542, 262r.

\section{JUAN DE PALACIO}

B. A. / B. T.

16-4-1642 / 3-5-1645

Fr. Pedro de Vergaño / Fr. Diego de Silva Urturi (Calahorra)

AGN, Irache, Lib. 542, 262r, 281r.

\section{MARTÍN DE MARZANA}

B. C.

30-4-1642

Fr. Diego de Silva

Burgos

AGN, Irache, Lib. 542, 262 r.

LEANDRO NOGUEROL

B. A. / L. A. / M. A. / B. T. / L. T. / D. T. 12-5-1642

Fr. Plácido de Salazar, vicecanciller

O. S. B.

Regente de Salamanca

AGN, Irache, Lib. 542, 262 r.

JUAN MARTÍNEZ

B. C.

17-5-1642

Fr. Martín Izquierdo

Saelices (Burgos)

AGN, Irache, Lib. 542, 262 r.

CELEDÓN ALCALDE

B. A.

18-5-1642

Fr. Pedro de Vergaño

Ausejo (Calahorra)

AGN, Irache, Lib. 542, 262v.

MATEO LÓPEZ CHÁLEZ

L. C. / D. C.

27-5-1642

Fr. Juan Rodríguez, abad

Miades (Tarazona)

AGN, Irache, Lib. 542, 262v.

JUAN DE BARRENECHE

B. A.

27-5-1642

Fr. Pedro de Vergaño

Lesaca (Pamplona)

AGN, Irache, Lib. 542, 262v. 
RAFAEL DE ENDARA

B. A.

27-5-1642

Fr. Pedro de Vergaño

Lesaca (Pamplona)

AGN, Irache, Lib. 542, 262v.

MIGUEL DE OLLO

B. A.

27-5-1642

Fr. Pedro de Vergaño

Lerate (Pamplona)

AGN, Irache, Lib. 542, 262v.

JUAN DE ALBIUR

B. A.

27-5-1642

Fr. Pedro de Vergaño

Murillo (Pamplona)

AGN, Irache, Lib. 542, 262v.

IGNACIO DE BELASCOÁIN

B. A.

27-5-1642

Fr. Pedro de Vergaño

Belascoáin (Pamplona)

AGN, Irache, Lib. 542, 262v.

JUAN GARCÍA DE OROZ

B. A.

27-5-1642

Fr. Pedro de Vergaño

Salinas (Pamplona)

AGN, Irache, Lib. 542, 262v.

ALEJANDRO ECHANAGUSIA

B. A.

27-5-1642

Fr. Pedro de Vergaño

Arriaraz (Pamplona)

AGN, Irache, Lib. 542, 262v.

SEBASTIÁN DE BERICE

B. A.

27-5-1642

Fr. Pedro de Vergaño

Obanos (Pamplona)

AGN, Irache, Lib. 542, 262v.

\section{SANCHO DE URDIROZ}

B. A.

27-5-1642

Fr. Pedro de Vergaño

Badostáin (Pamplona)

AGN, Irache, Lib. 542, 262v.

MIGUEL ALONSO

B. A.

27-5-1642

Fr. Pedro de Vergaño

Urroz (Pamplona)

AGN, Irache, Lib. 542, $262 \mathrm{v}$.

\section{JUAN IRIGOYEN}

B. A.

27-5-1642

Fr. Pedro de Vergaño

Menz (Pamplona)

AGN, Irache, Lib. 542, 262v.

PEDRO ARANGUREN

B. A.

27-5-1642

Fr. Pedro de Vergaño

Aranguren (Pamplona)

AGN, Irache, Lib. 542, 262v.

JUAN DE ZABALEGUI

B. A.

27-5-1642

Fr. Pedro de Vergaño

Pamplona

AGN, Irache, Lib. 542, $262 \mathrm{v}$.

JUAN DE ORCOYEN

B. A.

27-5-1642

Fr. Pedro de Vergaño

Tiebas (Pamplona)

AGN, Irache, Lib. 542, 262v.

ALEJANDRO DE ITURRALDE

B. A.

27-5-1642

Fr. Pedro de Vergaño

Irurita (Pamplona)

AGN, Irache, Lib. 542, 262v. 
JUAN DE ARTASO

B. A.

27-5-1642

Fr. Pedro de Vergaño

Miranda (Pamplona)

AGN, Irache, Lib. 542, 262v.

JUAN DE EZCAR Y OZCOZ

B. A.

27-5-1642

Fr. Pedro de Vergaño

Pamplona

AGN, Irache, Lib. 542, 262v.

PEDRO DE VERA

B. A.

27-5-1642

Fr. Pedro de Vergaño

Monrreal (Pamplona)

AGN, Irache, Lib. 542, 262v.

JULIÁN LOZANO

B. A. / L. A.

5-6-1642 / 15-2-1645

Fr. Francisco Crespo / Fr. Juan Rodríguez, abad

Jubera (Calahorra)

AGN, Irache, Lib. 542, 262v, 279r.

ANDRÉS GARCÍA DE SANTIAGO

B. C.

19-6-1642

Fr. Diego de Silva

Izcarar (Burgos)

AGN, Irache, Lib. 542, 262v.

PEDRO DE VALVERDE

B. C.

30-6-1642

Fr. Martín Izquierdo

Frías (Burgos)

AGN, Irache, Lib. 542, 263 r.

FRANCISCO VERGADO

B. T. / L. T. / D. T.

5-7-1642

Fr. Juan Rodríguez, abad

Madrid (Toledo)

AGN, Irache, Lib. 542, 263 r.
FRANCISCO DE LA GÁNDARA

B. C.

6-7-1642

Fr. Juan Rodríguez

Tarrueza (Burgos)

AGN, Irache, Lib. 542, 263r.

JUAN SALVADOR

B. C.

7-7-1642

Fr. Diego de Silva

Sandoval (Burgos)

AGN, Irache, Lib. 542, 263 r.

ÍNIGO ROYO

B. A. / L. A. / M. A. / B. T. / L. T. / D. T.

24-7-1642

Fr. Francisco Crespo

O. S. B.

Hijo de la Casa Ntra. Sra. de Monserrat

AGN, Irache, Lib. 542, 263 r.

JUAN DE OLEAMENDI Y MONREAL

L.T. / D. T.

30-7-1642

Fr. Diego de Silva

Barásoain (Pamplona)

AGN, Irache, Lib. 542, $263 \mathrm{v}$.

FRANCISCO DE LA CUESTA

B. C.

30-7-1642

Fr. Martín Izquierdo

Quintana de Bureba (Burgos)

AGN, Irache, Lib. 542, 263v.

MARTÍN DE CAMINO

B. C.

2-8-1642

Fr. Francisco Crespo

Los Barrios (Burgos)

AGN, Irache, Lib. 542, 263v.

JUAN DE LA FLOR

B. C.

11-8-1642

Fr. Francisco Crespo

Carandía (Burgos)

AGN, Irache, Lib. 542, 263v. 
ANTONIO DEL CAMPO

B. A. / B. T.

29-8-1642

Fr. Benito de Salazar / Fr. Martín Izquierdo

Boadilla de Rioseco (León)

AGN, Irache, Lib. 542, 263v.

MANUEL FERNÁNDEZ

B. C.

30-8-1642

Fr. Diego de Silva

Palenzuela (Burgos)

AGN, Irache, Lib. 542, 263v.

PEDRO VAL

B. C.

30-8-1642

Fr. Diego de Silva

Palenzuela (Burgos)

AGN, Irache, Lib. 542, 263v.

DIEGO JALÓN

B. C.

30-8-1642

Fr. Diego de Silva

Burgos

AGN, Irache, Lib. 542, 263v.

ANTONIO DE HERRERA

B. C.

3-9-1642

Fr. Diego de Silva

Burgos

AGN, Irache, Lib. 542, 264r.

MIGUEL LÓPEZ DE SAN JUAN

B. M.

3-9-1642

Fr. Francisco Crespo

Villafranca (Pamplona)

AGN, Irache, Lib. 542, 264 r.

DIEGO ORDÁS

B. T. / L. T. / D. T.

6-9-1642

Fr. Juan Rodríguez, abad

Iznatoraf (Jaén)

AGN, Irache, Lib. 542, 264r.

\section{DIEGO GARCÍA}

B. C.

10-9-1642

Fr. Diego de Silva

Villanueva del Río Ubierna (Burgos)

AGN, Irache, Lib. 542, 264 r.

LUIS MAURICIO INDURÁIN

L. L. / D. L.

13-9-1642

Fr. Juan Rodríguez, abad

Albarracín

AGN, Irache, Lib. 542, 264 r.

LUIS GONZÁLEZ DEL VALLE

B. A. / B. T.

16-9-1642

Fr. Benito de Salazar / Fr. Francisco Crespo

Villaldemiro (Burgos)

AGN, Irache, Lib. 542, 264v.

JUAN DE URRIZOLA

L. L.

8-10-1642

Fr. Juan Rodríguez, abad

Pamplona

AGN, Irache, Lib. 542, 264v.

CEFERINO DE ULIBARRI

L. L.

8-10-1642

Fr. Juan Rodríguez, abad

Pamplona

AGN, Irache, Lib. 542, 264v.

BARTOLOMÉ DE CASUSO

B. C.

8-10-1642

Fr. Diego de Silva

Villa del Puerto (Burgos)

AGN, Irache, Lib. 542, 264v.

DOMINGO DE GARAY

B. C.

28-10-1642

Fr. Martín Izquierdo

Galdames (Burgos)

AGN, Irache, Lib. 542, 264v. 
ANTONIO BUESO

L. T. / D. T.

Fr. Juan Rodríguez, abad

Málaga

AGN, Irache, Lib. 542, 264v.

ONOFRE PARDO

B. C.

6-11-1642

Fr. Francisco Crespo

Zuñeda (Burgos)

AGN, Irache, Lib. 542, 264v.

DIEGO DE AYARRA

B. T. / L. T. / D. T.

21-11-1642 / 22-11-1642 / 20-11-1645

Fr. Martín Izquierdo / Fr. Juan Rodríguez, abad // Fr. Bernabé Martel, abad

Vicario de Valtierra

Valtierra (Pamplona)

AGN, Irache, Lib. 542, 264v, 286r.

\section{ANTONIO PANIAGUA}

B. C.

25-11-1642

Fr. Diego de Silva

Fernamental (Burgos)

AGN, Irache, Lib. 542, 265 r.

ANTONIO MATÍAS COSCOLÍN DE VALDÉS

L. L. / D. L.

29-11-1642

Fr. Juan Rodríguez, abad

Tarazona

AGN, Irache, Lib. 542, 265 r.

MIGUEL CALMEDO

B. M.

29-11-1642

Fr. Martín Izquierdo

Pamplona

AGN, Irache, Lib. 542, 265r.

FERMÍN DE MARICHALAR

B. C.

8-12-1642
Fr. Francisco Crespo

Pamplona

AGN, Irache, Lib. 542, 265 r.

FRANCISCO DE VITORIA

B. C.

15-1-1643

Fr. Diego de Silva

Burgos

AGN, Irache, Lib. 542, 265 r.

FRANCISCO GUTIÉRREZ DE AYALA

L. C.

7-2-1643

Fr. Diego de Silva

Burgos

AGN, Irache, Lib. 542, 265 r.

CARLOS ROMEO

L. L.

9-2-1643

Fr. Juan Rodríguez, abad

Miranda

...

AGN, Irache, Lib. 542, 265v.

JUAN DE LASAGA

L. L.

9-2-1643

Fr. Juan Rodríguez, abad

Pamplona

AGN, Irache, Lib. 542, 265v.

JUAN MARTÍNEZ MATARRAL

B. C.

5-3-1643

Fr. Martín Izquierdo

Linares (Burgos)

AGN, Irache, Lib. 542, 265v.

JUAN GARCÍA Y CEBRIÁN

B. C. / L. C. / D. C.

20-3-1643

Fr. Juan Rodríguez, abad

Alfambra (Teruel)

AGN, Irache, Lib. 542, 265v.

JUAN FRANCISCO CEPERA

L. C. / D. C. 
24-3-1643

Fr. Juan Rodríguez, abad

Cretas (Tortosa)

AGN, Irache, Lib. 542, 266r.

BALTASAR CHACÓN MAZA

L. C. / D. C.

26-3-1643

Fr. Juan Rodríguez, abad

Baeza (Jaén)

Orden de Calatrava

AGN, Irache, Lib. 542, 266r.

CRISTÓBAL DE ARRIBILLAGA

B. A.

7-4-1643

Fr. Diego de Silva

Leiza (Pamplona)

AGN, Irache, Lib. 542, 266r.

LUIS FUSTER

L. L. / D. L.

9-4-1643

Fr. Juan Rodríguez, abad

Tortosa

AGN, Irache, Lib. 542, 266r.

AGUSTÍN PIÑANA

L. L. / D. L.

9-4-1643

Fr. Juan Rodríguez, abad

Tortosa

AGN, Irache, Lib. 542, 266r.

ANTONIO HERNÁNDEZ

L. A.

16-4-1643

Fr. Juan Rodríguez, abad

Peralta (Pamplona)

AGN, Irache, Lib. 542, 266v.

DOMINGO HURTADO

B. C.

23-4-1643

Fr. Martín Izquierdo

Dueñas (Burgos)

AGN, Irache, Lib. 542, 266v.
JUAN GONZÁLEZ

B. C.

28-4-1643

Fr. Francisco Crespo

Salazar de Amaya (Burgos)

AGN, Irache, Lib. 542, 266v.

ANTONIO JORDÁN GALBA

B. C. / L. C. / D.C.

9-5-1643

Fr. Juan Rodríguez, abad

Tauste (Zaragoza)

AGN, Irache, Lib. 542, 266v.

LESMES DE SAN MARTÍN

B. C.

13-5-1643

Fr. Diego de Silva

Burgos

AGN, Irache, Lib. 542, $267 r$.

JUAN CAMBERO

B. C.

23-5-1643

Fr. Martín Izquierdo

Soria (Osma)

AGN, Irache, Lib. 542, $267 \mathrm{r}$.

JOSÉ NIÑO ESPAÑOL DE MUR

L. L. / D. L

4-6-1643

Fr. Juan Rodríguez, abad

Sos (Pamplona)

AGN, Irache, Lib. 542, 267 r.

JUAN OCHOA DE ZUASTI

L. C.

6-6-1643

Fr. Juan Rodríguez, abad

Salinas (Pamplona)

AGN, Irache, Lib. 542, 267 r.

GREGORIO ARROYO

B. C.

28-6-1643

Fr. Francisco Crespo

Arroyo (Burgos)

AGN, Irache, Lib. 542, $267 \mathrm{v}$. 
JOSÉ SANDINO

B. C.

7-7-1643

Fr. Diego de Silva

Sasamón (Burgos)

AGN, Irache, Lib. 542, 267v.

BLAS DE HERRERA

B. C.

7-7-1643

Fr. Diego de Silva

Sasamón (Burgos)

AGN, Irache, Lib. 542, 267v.

ANDRÉS LÓPEZ TELLO

B. C.

7-7-1643

Fr. Diego de Silva

Sasamón (Burgos)

AGN, Irache, Lib. 542, 267v.

DIEGO DEL POZO TELLO

B. C.

7-7-1643

Fr. Diego de Silva

Sasamón (Burgos)

AGN, Irache, Lib. 542, 267v.

JUAN DE TORRES PEDROSA

B. C.

12-7-1643

Fr. Francisco Crespo

Palenzuela (Burgos)

AGN, Irache, Lib. 542, 267v.

DIEGO SAIZ

B. C.

14-7-1643

Fr. Francisco Crespo

Palenzuela (Burgos)

AGN, Irache, Lib. 542, 268r.

PEDRO MARTÍNEZ

B. C.

15-7-1643

Fr. Francisco Crespo

Tornil (Burgos)

AGN, Irache, Lib. 542, 268r.

\section{JUAN DE LOS POZOS}

B. C. / L. C.

19-7-1643 / 5-10-1649

Fr. Martín Izquierdo / Fr. Pedro de Verga-

ño

Briviesca (Brugos)

AGN, Irache, Lib. 542, 268r, 324v.

PEDRO CALDERÓN MATAJUDÍOS

B. C.

11-8-1643

Fr. Francisco Crespo

Castrillo de Matajudíos (Burgos)

AGN, Irache, Lib. 542, 268r.

\section{NICOLÁS GONZÁLEZ}

B. C.

11-8-1643

Fr. Diego de Silva

Iglesias (Burgos)

AGN, Irache, Lib. 542, 268v.

JUAN DE LA REA ZÚÑIGA

B. C.

15-8-1643

Fr. Martín Izquierdo

Santander (Burgos)

AGN, Irache, Lib. 542, 268v.

JUAN DE SICILIA

B. C.

18-8-1643

Fr. Diego de Silva

Iglesias (Burgos)

AGN, Irache, Lib. 542, 268v

JUAN DE LOMA

B. C.

19-8-1643

Fr. Diego de Silva

Celada del Camino (Burgos)

AGN, Irache, Lib. 542, 268v.

LUCAS BUSQUETA

L. L.

26-8-1643

Fr. Martín Izquierdo

Corella (Tarazona)

AGN, Irache, Lib. 542, 269 r. 
RODRIGO CORRAL

B. C.

31-8-1643

Fr. Martín Izquierdo

Sandino (Burgos)

AGN, Irache, Lib. 542, $269 r$.

FRANCISCO PÉREZ

B. C.

2-9-1643

Fr. Diego de Silva

Villegas (Burgos)

AGN, Irache, Lib. 542, 269 r.

JUAN JIMÉNEZ BAROJA

B. A.

3-9-1643

Fr. Benito de Salazar

Arnedo (Calahorra)

AGN, Irache, Lib. 542, $269 \mathrm{v}$.

JUAN DE CHÁVARRI

L. M. / D. M.

5-9-1643

Fr. Juan Rodríguez, abad

Estella (Pamplona)

AGN, Irache, Lib. 542, 269v.

AMBROSIO IBÁÑNEZ

B. C.

7-9-1643

Fr. Benito de Salazar

Arenillas de Río Pisuerga (Burgos)

AGN, Irache, Lib. 542, 269v.

FRANCISCO LÓPEZ

B. C.

7-9-1643

Fr. Benito de Salazar

Villobeta (Burgos)

AGN, Irache, Lib. 542, 269v.

\section{JERÓNIMO GARCÍA}

B. A

12-9-1643

Fr. Benito de Salazar

O. de M.

Alfambra (Teruel)

AGN, Irache, Lib. 542, 269v.
VALERIO GARCÍA

B. A.

12-9-1643

Fr. Benito de Salazar

O. de M.

Alfambra (Teruel)

AGN, Irache, Lib. 542, 269v.

JUAN DE ULIBARRI

B. A.

12-9-1643

Fr. Benito de Salazar

O. de M.

Estella (Pamplona)

AGN, Irache, Lib. 542, 269v.

APARICIO DE LA ISECA

B. C.

13-9-1643

Fr. Diego de Silva

Valmaseda (Burgos)

AGN, Irache, Lib. 542, 270 .

JUAN LERÍN

B. C. / B. L. / L. L.

15-9-1643

Fr. Diego de Silva

Alfaro (Tarazona)

AGN, Irache, Lib. 542, 270 .

JOSÉ DE LA TORRE

B. A. / B. T. / L. T. / D. T.

18-9-1643

Fr. Diego de Silva

Zaragoza

AGN, Irache, Lib. 542, 270 .

JUAN BAUTISTA DE LAGUNILLA

B. C. / L. C. / D. C.

25-9-1643

Fr. Juan Rodríguez, abad

Arnedo (Calahorra)

AGN, Irache, Lib. 542, $270 v$.

ANTONIO GÓMEZ MARAÑÓN

B. A.

25-9-1643

Fr. Benito de Salazar 
Burgos

AGN, Irache, Lib. 542, $270 v$.

PABLO JIMÉNEZ

B. L. / L. L. / D. L.

26-9-1643

Fr. Juan Rodríguez, abad

Mallorca

AGN, Irache, Lib. 542, 271r.

JUAN ANTONIO DE MORALES

B. C.

1-10-1643

Fr. Diego de Silva

Burgos

AGN, Irache, Lib. 542, 271r.

JUAN ANTONIO DE ARCE

B. C.

7-10-1643

Fr. Martín Izquierdo

Briviesca (Burgos)

AGN, Irache, Lib. 542, 271r.

PEDRO DE LAMO

B. C.

8-10-1643

Fr. Francisco Crespo

Respenda (Burgos)

AGN, Irache, Lib. 542, 271v.

BENITO DE OJEDA

B. C. / L. C. / D. C.

11-10-1643 / 11-5-1651

Fr. Diego de Silva / Fr. Pedro de Vergaño

Molina (Burgos)

AGN, Irache, Lib. 542, 271v, 347v.

DIEGO DE LA PEÑA BLANCA

B. C.

22-10-1643

Fr. Martín Izquierdo

San Julián de Musques (Burgos)

AGN, Irache, Lib. 542, 271v.

PEDRO GIL

B. C.

19-11-1643
Fr. Martín Izquierdo

Castrillo de Matajudíos (Burgos)

AGN, Irache, Lib. 542, 271v.

\section{DIEGO MERINO}

B. C.

12-12-1643

Fr. Diego de Silva

Castro Urdiales (Burgos)

AGN, Irache, Lib. 542, 271v.

MARTÍN DE LAS HERAS

B. C.

12-12-1643

Fr. Diego de Silva

Sámano (Burgos)

AGN, Irache, Lib. 542, 271v.

\section{ANTONIO RAMOS}

B. C.

12-12-1643

Fr. Francisco Crespo

Melgar de Fernamental (Burgos)

AGN, Irache, Lib. 542, 272r.

DOMINGO MARCO ENRÍQUEZ

B. A. / B. M.

24-12-1643

Fr. Francisco Crespo

Cascante (Tarazona)

AGN, Irache, Lib. 542, 272 .

JUAN DÍAZ DE AGUSTÍN

B. C.

26-12-1643

Fr. Francisco Crespo

Ubierna (Burgos)

AGN, Irache, Lib. 542, 272 .

MARCOS SERRANO

B. C.

7-1-1644

Fr. Francisco Crespo

Quinta de Bureba (Burgos)

AGN, Irache, Lib. 542, 272v.

JOSÉ DE SALAMANCA

B. C. / L. C. 
8-1-1644

Fr. Juan Rodríguez, abad

Burgos

AGN, Irache, Lib. 542, 272v.

ANDRÉS DE BERNALES

B. C.

8-1-1644

Fr. Francisco Crespo

Limpias (Burgos)

AGN, Irache, Lib. 542, $272 \mathrm{v}$.

\section{JUAN DÍEZ}

B. C.

16-1-1644

Fr. Martín Izquierdo

Sandino (Burgos)

AGN, Irache, Lib. 542, $272 \mathrm{v}$.

JUAN DE HINOJEDO REINOSO

L. C. / D. C.

16-1-1644

Fr. Juan Rodríguez, abad

Saldaña (León)

AGN, Irache, Lib. 542, 273 r.

DOMINGO DE MIJARES

B. C.

16-1-1644

Fr. Martín Izquierdo

Laredo (Burgos)

AGN, Irache, Lib. 542, 273 r.

ENRIQUE DE LA GARMA

L. A. / M. A. / L. T. / M. T.

28-1-1644

Fr. Juan Rodríguez, abad

O. Cist.

AGN, Irache, Lib. 542, 273r.

JUAN GARCÍA

B. T.

7-2-1644

Fr. Martín Izquierdo

Torquemada (Palencia)

AGN, Irache, Lib. 542, 273 r.

FRANCISCO DE GAMBOA LIAÑO

B. T. / L. T. / D. T.
7-2-1644

Fr. Martín Izquierdo

Cogolludo (Toledo)

AGN, Irache, Lib. 542, 273v.

PEDRO DE SENA EDILLA

B. C.

6-3-1644

Fr. Martín Izquierdo

Laredo (Burgos)

AGN, Irache, Lib. 542, $273 \mathrm{v}$.

LUCAS GALLO

B. C.

13-3-1644

Fr. Francisco Crespo

Tovar (Burgos)

AGN, Irache, Lib. 542, $273 v$.

ANTONIO SEIRA

B. A. / B. T. / L. T. / D. T.

26-3-1644

Fr. Juan Rodríguez, abad

Monzón (Lérida)

O. SS. T.

AGN, Irache, Lib. 542, $273 \mathrm{v}$.

JACINTO DE GUEVARA

B. A. / B. M . / L. M. / D. M.

28-3-1644 / 28-6-1649/ 3-8-1650

Fr. Benito de Salazar / Fr. Domingo Gutiérrez // Dr. Lizondo / Fr. Martín Izquierdo Estella (Pamplona)

AGN, Irache, Lib. 542, 274r, 319r, 336r.

JERÓNIMO DE YANGUAS

B. C.

20-4-1644

Fr. Diego de Silva

Sto. Domingo de la Calzada (Calahorra)

AGN, Irache, Lib. 542, 274 r.

FRANCISCO DE MAESTRESALA SAMANIEGO

B. A.

1-5-1644

Fr. Benito de Salazar

San Vicente de la Rioja (Calahorra)

AGN, Irache, Lib. 542, 274 r. 
FRANCISCO DE CHAGUE SARASA

B. C.

2-5-1644

Fr. Diego de Silva

Artajo (Pamplona)

AGN, Irache, Lib. 542, 274r.

ANTONIO DE OLIVER

B. M. / L. M.

15-5-1644

Fr. Juan Rodríguez, abad

Cuenca

AGN, Irache, Lib. 542, 274v.

MARCOS DE LA SOTA

B. C.

22-5-1644

Fr. Diego de Silva

Galdames (Burgos)

AGN, Irache, Lib. 542, 274v.

ROSENDO ÁLVAREZ

M. T.

26-5-1644

Fr. Juan Rodríguez, abad

O. S. B.

AGN, Irache, Lib. 542, 274v.

MARTÍN DE CASAL

B. C.

27-5-1644

Fr. Martín Izquierdo

Chávarri (Burgos)

AGN, Irache, Lib. 542, 274v.

PEDRO GIL

B. C.

31-5-1644

Fr. Francisco Crespo

Villoneta (Nullius Diocesis)

AGN, Irache, Lib. 542, 274v.

MIGUEL DE VILLAESCUSA

B. C.

31-5-1644

Fr. Francisco Crespo

Castro Genil (Burgos)

AGN, Irache, Lib. 542, 274v.
JOSÉ DE ESPINOSA

B. C.

7-6-1644

Fr. Martín Izquierdo

Logroño (Calahorra)

AGN, Irache, Lib. 542, 275r.

JUAN MARTÍNEZ DE TODA

B. A.

10-6-1644

Fr. Benito de Salazar

Arenzana de Abajo (Calahorra)

AGN, Irache, Lib. 542, 275r.

AGUSTÍN GÓMEZ

B. C.

15-6-1644

Fr. Francisco Crespo

Noja (Burgos)

AGN, Irache, Lib. 542, 275r.

ALONSO RAMÍREZ

B. A. / L. A. / D. A. / B. T. / L. T. / D. T.

2-7-1644

Fr. Juan Rodríguez, abad

O.S. B.

Hijo del Monasterio de Sopetrán

AGN, Irache, Lib. 542, 275r.

MANUEL DE OTÁÑNZZ

B. C.

5-7-1644

Fr. Diego de Silva

Otáñez (Burgos)

AGN, Irache, Lib. 542, $275 \mathrm{v}$.

IGNACIO DE CEBALLOS

L. C.

14-7-1644

Fr. Juan Rodríguez, abad

Puente Viesgo (Burgos)

AGN, Irache, Lib. 542, 275v.

JUAN LÓPEZ BARAHONA

B. C.

17-7-1644

Fr. Martín Izquierdo

Medina de Pomar (Burgos)

AGN, Irache, Lib. 542, 275v. 
LUIS BURGOS

B. A. / L. A. / D. A. / B. T. / L. T. / D. T. 26-7-1644

Fr. Juan Rodríguez, abad

O. S. B.

Hijo de San Claudio de León

AGN, Irache, Lib. 542, 276r.

JUAN PARDO DE LA TORRE

B. C.

30-7-1644

Fr. Francisco Crespo

Villana (Burgos)

AGN, Irache, Lib. 542, 276r.

FERNANDO DE AOIZ

B. A.

8-8-1644

Fr. Benito de Salazar

Pamplona

Estudiante en la Universidad de Pamplona

AGN, Irache, Lib. 542, 276r.

DOMINGO MEZÓN

L. T. / M. T.

9-8-1644

Fr. Juan Rodríguez, abad

O. S. A.

Val de San Martín

Comunidad de Daroca. Zaragoza

AGN, Irache, Lib. 542, 276r.

JOSÉ LÓPEZ BARRIONUEVO

B. A. / B. T. / L. T. / D. T.

-/8-1644 / 20-5-1649

Fr. Benito de Salazar / Fr. Martín Izquierdo, Abad y Rector

Viana (Calahorra)

Pbro.

AGN, Irache, Lib. 542, 276v, 316v.

PEDRO ÁLVAREZ

B. A. / B. T.

16-8-1644

Fr. Benito de Salazar

Modubar (Burgos)

AGN, Irache, Lib. 542, 276v.
DOMINGO FERNÁNDEZ VIZARRA

B. A.

12-9-1644

Fr. Benito de Salazar

Sádaba (Pamplona)

AGN, Irache, Lib. 542, 276v.

FRANCISCO GONZÁLEZ

B. A. / B. T. / L. T. / D. T.

15-9-1644

Fr. Juan Rodríguez, abad

Jaca

AGN, Irache, Lib. 542, 276v.

GABRIEL DE CHERÁN

B. C.

27-9-1644

Fr. Martín Izquierdo

Aguilar de Campoo (Burgos)

AGN, Irache, Lib. 542, 277r.

BARTOLOMÉ RUIZ

B. C.

27-9-1644

Fr. Martín Izquierdo

Aguilar de Campoo (Burgos)

AGN, Irache, Lib. 542, 277r.

PEDRO DE LLANO

B. C.

3-10-1644

Fr. Martín Izquierdo

Galdames (Burgos)

AGN, Irache, Lib. 542, 277 r.

FRANCISCO DE SALAZAR Y CEPEDA

B. L.

7-10-1644

Fr. Juan Rodríguez, abad

Valladolid

AGN, Irache, Lib. 542, 277 r.

JUAN DE OVIEDO VERGARA

B. C.

13-10-1644

Fr. Diego de Silva

Quintana de Bureba (Burgos)

AGN, Irache, Lib. 542, $277 \mathrm{v}$. 
ALONSO RODRÍGUEZ

B. T. / L. A. / L. T.

17-10-1644 / 1-5-1645

Fr. Diego de Silva

Villanueva de Valdueza (Astorga)

AGN, Irache, Lib. 542, 277v, 281r.

FRANCISCO GONZÁLEZ

B. A.

24-10-1644

Fr. Martín Izquierdo

Villanueva de Valverde (Plasencia)

AGN, Irache, Lib. 542, 277v.

ANDRÉS LÓPEZ NIETO

B. C.

29-10-1644

Fr. Francisco Crespo

Sasamón (Burgos)

AGN, Irache, Lib. 542, 277v.

ÍÑIGO MARTÍNEZ DE SALAZAR

B. C.

29-10-1644

Fr. Diego de Silva

Traspaderne (Burgos)

AGN, Irache, Lib. 542, 277v.

JOSÉ DE MAGAROLA

B. A. / L. A. / D. A. / B. T. / L. T. / D. T. 2-11-1644

Fr. Francisco Crespo

O.S. B.

Abad de Camporredondo

Hijo de Ntra. Sra. de Monserrat

AGN, Irache, Lib. 542, 278 r.

SANTIAGO GUTIÉRREZ

B. C.

2-11-1644

Fr. Diego de Silva

Aguilar de Campoo (Burgos)

AGN, Irache, Lib. 542, 278r.

DIEGO MARTÍNEZ DE LOSA

B. C.

8-11-1644

Fr. Diego de Silva
Bustillo

AGN, Irache, Lib. 542, 278r.

JUAN SÁEZ DE CORTÉS

B. C. / L. C. / D. C.

24-11-1644

Fr. Francisco Crespo

Zaragoza

AGN, Irache, Lib. 542, 278r.

JUAN JACINTO DE TORNÉS

B. M. / L. M. / D. M.

12-12-1644

Fr. Juan Rodríguez, abad

Jaca

AGN, Irache, Lib. 542, 278v.

FRANCISCO DE ARZANE

B. C.

-/1-1645

Fr. Diego de Silva

Zalla (Burgos)

AGN, Irache, Lib. 542, 278v.

BARTOLOMÉ PÉREZ DE ESPEJO

L. T. / D. T.

22-1-1645

Fr. Juan Rodríguez, abad

Orden de Santiago

Montalbo (Cuenca)

AGN, Irache, Lib. 542, 278v.

TORIBIO RUIZ DE LA VEGA

B. C.

3-2-1645

Fr. Martín Izquierdo

Cabanzón (Burgos)

AGN, Irache, Lib. 542, 279r.

JUAN ALONSO

L. A.

15-2-1645

Fr. Juan Rodríguez, abad

Ocón (Calahorra)

AGN, Irache, Lib. 542, $279 r$.

DIEGO GALLO DE ESCALADA

B. C. 
26-2-1645

Fr. Francisco Crespo

Villasilos (Burgos)

AGN, Irache, Lib. 542, 279v.

MARTÍN DE ASTUDILLO

B. C.

26-2-1645

Fr. Francisco Crespo

Villasilos (Burgos)

AGN, Irache, Lib. 542, $279 v$.

PEDRO BUENO

B. C.

26-2-1645

Fr. Francisco Crespo

Villasilos (Burgos)

AGN, Irache, Lib. 542, 279v.

MARTÍN GARCÍA

B. C.

31-3-1645

Fr. Francisco Crespo

Tudela (Nullius Diocesis)

AGN, Irache, Lib. 542, 279v.

JOSÉ RUIZ

L. T. / M. T.

6-4-1645

Fr. Diego de Silva

O. S. A.

AGN, Irache, Lib. 542, 279v.

FRANCISCO DE ALAIZA Y VICUÑA

B. A.

9-4-1645

Fr. Benito de Salazar

Calahorra

AGN, Irache, Lib. 542, 279v.

MARTÍN PÉREZ DE HEREDIA

B. A.

9-4-1645

Fr. Benito de Salazar

Calahorra

AGN, Irache, Lib. 542, 279v.

FAUSTO RUIZ DE MUNIAIN

B. A.
9-4-1645

Fr. Benito de Salazar

Gordoa (Calahorra)

AGN, Irache, Lib. 542, $279 v$.

FRANCISCO GONZÁLEZ DE HEREDIA

B. A.

9-4-1645

Fr. Benito de Salazar

Calahorra

AGN, Irache, Lib. 542, 279v.

LÁZARO ROMEO

B. C. / L. C. / D. C.

8-4-1645

Fr. Martín Izquierdo

Zaragoza

AGN, Irache, Lib. 542, 28 or.

FRANCISCO CABALLERO

B. T. / L. T. / D. T.

11-4-1645

Fr. Francisco Crespo

O. Praem.

AGN, Irache, Lib. 542, 28 or.

JUAN DE GUELBENZU Y VILLALVA

L. M. / D. M.

12-4-1645

Fr. Diego de Silva

Villalba (Pamplona)

AGN, Irache, Lib. 542, $280 v$.

JUAN DE HUARTE

B. A. / B. M. / L.M. / D. M.

26-4-1645 / 7-3-1650

Fr. Benito de Salazar / Fr. Martín Izquier-

do, abad / Dr. Lizondo

Pamplona

AGN, Irache, Lib. 542, 280v, 330r.

CARLOS RODRÍGUEZ

B. A.

1645

Fr. Benito de Salazar

Huarte (Pamplona)

AGN, Irache, Lib. 542, $280 v$. 
JUAN LÓPEZ DE LEZCANO

B. A.

26-4-1645

Fr. Benito de Salazar

Añorbe (Pamplona)

AGN, Irache, Lib. 542, $280 v$.

PEDRO ORTIZ

B. A.

26-4-1645

Fr. Benito de Salazar

Nazar (Pamplona)

AGN, Irache, Lib. 542, $280 v$.

SANCHO DE ARRAIZA

B. A.

26-4-1645

Fr. Benito de Salazar

Enériz (Pamplona)

AGN, Irache, Lib. 542, $280 v$.

PEDRO GARCÍA DE GALDEANO

B. A.

26-4-1645

Fr. Benito de Salazar

Galdeano (Pamplona)

AGN, Irache, Lib. 542, $280 v$.

JUAN GARCÍA DE CAMPOS

B. A.

26-4-1645

Fr. Benito de Salazar

Isasondo (Pamplona)

AGN, Irache, Lib. 542, $280 v$.

MATEO DE IRACHETA

B. A.

26-4-1645

Fr. Benito de Salazar

Garinoain (Pamplona)

AGN, Irache, Lib. 542, $280 v$.

\section{MARTÍN DE BUITRAGO}

B. A.

26-4-1645

Fr. Benito de Salazar

Fuenterrabía (Pamplona)

AGN, Irache, Lib. 542, $280 v$.

\section{MARTÍN DE ANDÍA}

B. A.

26-4-1645

Fr. Benito de Salazar

Pamplona

AGN, Irache, Lib. 542, $280 v$.

GONZALO DE ANSÓ

B. A.

26-4-1645

Fr. Benito de Salazar

Garisoain (Pamplona)

AGN, Irache, Lib. 542, $280 v$.

JUAN DE LA PEÑA

B. C.

9-5-1645

Fr. Francisco Crespo

Santibáñez (Burgos)

AGN, Irache, Lib. 542, 281r.

BENITO DE AÑAÑOS

B. T. / L. T. / D. T.

13-5-1645

Fr. Francisco Crespo

O. S. B.

De San Juan de la Peña

AGN, Irache, Lib. 542, 281v.

FRANCISCO DE APARICIO

B. C.

13-5-1645

Fr. Francisco Crespo

Padilla de Arriba (Burgos)

AGN, Irache, Lib. 542, 281v.

PEDRO DE CASILLAS

B. C.

16-5-1645

Fr. Francisco Crespo

Burgos

AGN, Irache, Lib. 542, 281v.

LUCAS PANDO

B. C.

16-5-1645

Fr. Francisco Crespo

Valle de Guriezo (Burgos)

AGN, Irache, Lib. 542, 281v. 
PEDRO DE ARANDIA DELGADO

B. C.

6-6-1645

Fr. Benito de Salazar

Burgos

AGN, Irache, Lib. 542, 282r.

BERNABÉ MARTEL

B. A. / L. A. / D. A. / B. T. / L. T. / D. T. 10-6-1645

Fr. Diego de Silva

O. S. B.

Hijo de Lorenzana

AGN, Irache, Lib. 542, 282 r.

JUAN DE BUSTINZA

L. A. / M. A. / L. T. / D. T.

10-6-1645

Fr. Bernabé Martel, Abad y Rector

O. S. B.

Hijo de Sevilla

AGN, Irache, Lib. 542, 282 .

ESTEBAN DE GAUNA

B. C.

16-6-1645

Fr. Martín Izquierdo

Calahorra

AGN, Irache, Lib. 542, 282v.

JOSÉ ENRÍQUEZ

B. A. / L. A. / M. A. / B. T. / L. T. / D. T. 19-6-1645

Fr. Bernabé Martel, abad

O. S. B.

Hijo de Valladolid

AGN, Irache, Lib. 542, 282v.

FRANCISCO MARCOS

B. C.

7-7-1645

Fr. Francisco Crespo

Ormacas (Burgos)

AGN, Irache, Lib. 542, 282v.

TOMÁS DE VALLADOLID

L. L. / D. L.

27-7-1645
Fr. Martín Izquierdo

Calatayud (Tarazona)

AGN, Irache, Lib. 542, 283 r.

JUAN ROJO

B. C.

24-8-1645

Fr. Martín Izquierdo

Villagutiérrez (Burgos)

AGN, Irache, Lib. 542, 283 r.

\section{BENITO GONZÁLEZ}

B. A. / L. A. / M. A. / B. T. / L. T. / D. T.

29-8-1645

Fr. Bernabé Martel, abad

O. S. B.

Hijo de San Millán

AGN, Irache, Lib. 542, 283 r.

\section{SANTIAGO DE CORTIGUERA}

B. M.

3-9-1645

Fr. Martín Izquierdo

Mazcuerras (Burgos)

AGN, Irache, Lib. 542, 283v.

JORGE GRACIÁN

B. T. / L. T. / D. T.

5-9-1645

Fr. Bernabé Martel, abad

Zaragoza

AGN, Irache, Lib. 542, 283v.

ANDRÉS DÍAZ

B. C.

10-9-1645

Fr. Martín Izquierdo

Cerezo (Burgos)

AGN, Irache, Lib. 542, 283v.

FRANCISCO GAVILÁN

B. C.

11-9-1645

Fr. Martín Izquierdo

Poza (Burgos)

AGN, Irache, Lib. 542, 283v.

JOSÉ DEL RINCÓN

B. C. 
16-9-1645

Fr. Martín Izquierdo

Villasandino (Burgos)

AGN, Irache, Lib. 542, 284 r.

JUAN GARCÍA

L. C.

18-9-1645

Fr. Bernabé Martel, abad

Soria (Osma)

AGN, Irache, Lib. 542, 284r.

PEDRO GIL DE ALFARO

L. C.

19-9-1645

Fr. Bernabé Martel, abad

Herce (Calahorra)

AGN, Irache, Lib. 542, 284r.

PEDRO RODRÍGUEZ

B. C.

22-9-1645

Fr. Martín Izquierdo

Ocelano (Burgos)

AGN, Irache, Lib. 542, 284v.

FRANCISCO DE VELESAR

B. T. / L. T. / D. T.

28-9-1645

Fr. Bernabé Martel, abad

O. S. B.

Hijo de Ntra. Sra. de Montserrat

AGN, Irache, Lib. 542, 284v.

JUAN FRANCISCO MORENO

L. C. / D. C.

28-9-1645

Fr. Bernabé Martel, abad

Villanueva de Huerva (Zaragoza)

AGN, Irache, Lib. 542, 284v.

DANIEL NÚÑEZ

B. T. / L. T. / D. T.

30-9-1645

Fr. Bernabé Martel, abad

Reino de Irlanda

AGN, Irache, Lib. 542, 285r.
GUILLERMO OCÓN

B. T. / L. T. / D. T.

30-9-1645

Fr. Bernabé Martel. abad

Reino de Irlanda

AGN, Irache, Lib. 542, 285r.

GOFREDO DANIEL

B. T. / L. T. / D. T.

30-9-1645

Fr. Bernabé Martel, abad

Reino de Irlanda

AGN, Irache, Lib. 542, 285 r.

DOMINGO NEGRETE

B. C.

3-10-1645

Fr. Francisco Crespo

Sangrices (Burgos)

AGN, Irache, Lib. 542, 285r.

ANTONIO DE ORDUÑA

B. C.

10-10-1645

Fr. Martín Izquierdo

Herrera de Valdecañas (Burgos)

AGN, Irache, Lib. 542, 285 r.

PEDRO DE LA CALLEJA

B. C.

23-10-1645

Fr. Martín Izquierdo

Sasamón (Burgos)

AGN, Irache, Lib. 542, 285v.

ANTONIO GUTIÉRREZ

B. A.

23-10-1645

Fr. Martín Izquierdo

Toro (Zamora)

AGN, Irache, Lib. 542, 285v.

JOSÉ GARCÍA

B. C.

23-10-1645

Fr. Martín Izquierdo

Grijalbo (Burgos)

AGN, Irache, Lib. 542, 285v. 
JUAN DOMINGO DE ARTIOLA

B. C. / L. C. / D. C.

1-11-1645

Fr. Martín Izquierdo

Canónigo de la Sta. Iglesia de Zaragoza

AGN, Irache, Lib. 542, 286r.

\section{PEDRO DE ECHASO}

L. M. / D. M.

20-11-1645

Fr. Bernabé Martel, abad

Estella (Pamplona)

AGN, Irache, Lib. 542, 286r.

\section{MIGUEL NIETO}

B. C.

22-11-1645

Fr. Francisco Crespo

Tordómar (Burgos)

AGN, Irache, Lib. 542, 286r.

\section{ALONSO GARCÍA}

B. C.

22-11-1645

Fr. Francisco Crespo

Tordómar (Burgos)

AGN, Irache, Lib. 542, 286r.

BARTOLOMÉ ASENJO

B. C.

23-11-1645

Fr. Martín Izquierdo

Celada de la Torre (Burgos)

AGN, Irache, Lib. 542, 286r.

JUAN OJALVO

B. A. / L. A. / M. A. / B. T. / L. T. / D. T. 2-12-1645

Fr. Manuel de Espinosa, General de la Congregación

O. S. B.

Secretario de la Orden

AGN, Irache, Lib. 542, 286v.

JUAN DE SAMANIEGO

B. A. / L. A. / M. A. / B. T. / L. T. / D. T. 2-12-1645

Fr. Manuel de Espinosa, General de la Congregación
O. S. B.

Lector de Vísperas de Irache

AGN, Irache, Lib. 542, 286v.

\section{PEDRO DE VERGAÑO}

B. A. / L. A. / M. A. / B. T. / L. T. / D. T.

2-12-1645

Fr. Manuel de Espinosa, General de la Congregación

O. S. B.

Maestro de Estudios de Irache

AGN, Irache, Lib. 542, 286v.

BERNARDO POLO DE GÁMIZ

B. C. / L. C. / D. C.

2-12-1645

Fr. Bernabé Martel, abad

Almoracid de Zorita

Tesorero de Pastrana

Toledo

AGN, Irache, Lib. 542, 286v.

MIGUEL MARÍN PARDINA

L. M. / D. M.

16-12-1645

Fr. Bernabé Martel / Dr. Lizondo

Peñarroya (Zaragoza)

AGN, Irache, Lib. 542, 286r.

MARTÍN DE PIÑEÑORI

B. C.

22-12-1645

Fr. Francisco Crespo

Galdames (Burgos)

AGN, Irache, Lib. 542, 286v.

SIMÓN FERNÁNDEZ DE CELIS

B. C.

18-1-1646

Fr. Pedro de Vergaño

Abiada (Burgos)

AGN, Irache, Lib. 542, 287 r.

\section{MARTÍN ORTIZ}

B. C.

12-2-1646

Fr. Martín Izquierdo

Bachicabo (Burgos)

AGN, Irache, Lib. 542, 287 r. 
PEDRO GONZÁLEZ

B. C.

13-2-1646

Fr. Martín Izquierdo

Matajudíos (Burgos)

AGN, Irache, Lib. 542, 287r.

SEBASTIÁN MARTÍNEZ DE BUSTO

B. C.

11-2-1646

Fr. Pedro de Vergaño

Recibo (Burgos)

AGN, Irache, Lib. 542, 287r.

ANTONIO DE ESPINOSA

B. C.

22-2-1646

Fr. Francisco Crespo

Calahorra

AGN, Irache, Lib. 542, 287 r.

JUAN DE RAMOS

B. C.

22-2-1646

Fr. Francisco Crespo

Calahorra

AGN, Irache, Lib. 542, 287r.

PEDRO MARTÍNEZ

B. C.

14-3-1646

Fr. Juan de Samaniego, vicecanciller

La Nuez de Santibáñez (Burgos)

AGN, Irache, Lib. 542, 287r.

\section{MARTÍN FERNÁNDEZ CORNEJO}

B. T.

15-3-1646

Fr. Juan de Samaniego

Bustos (Burgos)

AGN, Irache, Lib. 542, $287 \mathrm{v}$.

\section{LUCAS RODRÍGUEZ}

B. T.

16-3-1646

Fr. Juan de Samaniego

Lodosa (Burgos)

AGN, Irache, Lib. 542, 287v.
FRANCISCO GONZÁLEZ DE MANSILLA

B. A. / B. T.

5-4-1646

Fr. Anselmo López / Fr. Francisco Crespo

Burgos

AGN, Irache, Lib. 542, 287v.

DOMINGO DE FORES

B. T.

5-4-1646

Fr. Francisco Crespo

La Nuez de Santibáñez (Burgos)

AGN, Irache, Lib. 542, 287v.

JOSÉ SÁNCHEZ

B. A. / B. T. / L. T. / D. T.

10-4-1646

Fr. Francisco Crespo

Trasobares (Zaragoza)

AGN, Irache, Lib. 542, $287 \mathrm{v}$.

GREGORIO GARCÍA DEL CASTILLO

B. C.

19-4-1646

Fr. Juan de Samaniego

Galanes? (Burgos)

AGN, Irache, Lib. 542, 288r.

JUAN DE REINARES

B. A. / B. M.

24-4-1646

Fr. Francisco Crespo

Sesma (Pamplona)

AGN, Irache, Lib. 542, 288r.

FRANCISCO DE SANTANDER

B. C.

1-5-1646

Fr. Francisco Crespo

Castro Urdiales (Burgos)

AGN, Irache, Lib. 542, 288r.

PEDRO DE PRADO

B. A. / L. T. / D. T.

3-5-1646 / 12-9-1652

Fr. Anselmo López, vicecanciller / Fr. Pedro de Vergaño 
Camprobín, Abadía de San Millán (Nullius Diocesis)

AGN, Irache, Lib. 542, 288r, 369v.

ANTONIO ORTIZ

B. C.

14-5-1646

Fr. Juan de Samaniego

Foncea (Burgos)

AGN, Irache, Lib. 542, 288r.

JUAN ÁLVAREZ

L. C. / D. C.

16-5-1646

Fr. Martín Izquierdo

Loja (Quito)

AGN, Irache, Lib. 542, 288v.

PATRICIO CAHESIO

B. C. / L. C. / D. C.

17-5-1646

Fr. Francisco Crespo

Limerick (Irlanda)

AGN, Irache, Lib. 542, 288v.

JOSÉ DE CAVIA

B. C.

22-5-1646

Fr. Martín Izquierdo

Quintana de Somuño (Burgos)

AGN, Irache, Lib. 542, 288v.

JUAN RUIZ DE SOTO

B. C.

24-5-1646

Fr. Francisco Crespo

Quintanaélez (Burgos)

AGN, Irache, Lib. 542, 288v.

PEDRO GÓMEZ

B. C.

29-5-1646

Fr. Martín Izquierdo

Aguilar de Campoo (Burgos)

AGN, Irache, Lib. 542, 288v.

JUAN DE ESTEBAN

B. T.
31-5-1646

Fr. Martín Izquierdo

Prádanos (Burgos)

AGN, Irache, Lib. 542, 289 r.

BERNARDINO DE EZCARAY

B. C.

1-6-1646

Fr. Francisco Crespo

Castrojeriz (Burgos)

AGN, Irache, Lib. 542, 289 r.

DIEGO DE CARRANZA

B. C.

2-6-1646

Fr. Martín Izquierdo

Ampuero (Burgos)

AGN, Irache, Lib. 542, 289 r.

LORENZO DE QUIJANO

B. C.

8-6-1646

Fr. Martín Izquierdo

Villasilos (Burgos)

AGN, Irache, Lib. 542, 289 r.

FRANCISCO DE URRUTIA

B. C.

8-6-1646

Fr. Francisco Crespo

Briviesca (Burgos)

AGN, Irache, Lib. 542, 289 r.

FRANCISCO GARCÍA DEL MORAL

B. C.

10-6-1646

Fr. Juan de Samaniego

Villalaín (Burgos)

AGN, Irache, Lib. 542, 289 r.

PABLO DE CONGOSTO

B. C.

25-6-1646

Fr. Martín Izquierdo

Peones (Burgos)

AGN, Irache, Lib. 542, 289v.

MARTÍN DEL CAÑO

B. C. 
30-6-1646

Fr. Francisco Crespo

Valluércanes (Burgos)

AGN, Irache, Lib. 542, 289v.

MARTÍN BELTRÁN DE ARNEDO

B. C.

3-7-1646

Fr. Martín Izquierdo

Ocón (Calahorra)

AGN, Irache, Lib. 542, 289v.

ANTONIO ALONSO

B. C.

6-7-1646

Fr. Martín Izquierdo

Montejo (Burgos)

AGN, Irache, Lib. 542, 289v.

JUAN DE ALVARADO

B. C.

7-8-1646

Fr. Francisco Crespo

Laredo (Burgos)

AGN, Irache, Lib. 542, 289v.

FRANCISCO DE HARO

B. C.

7-8-1646

Fr. Francisco Crespo

Laredo (Burgos)

AGN, Irache, Lib. 542, 289v.

PEDRO PORTER DE BELMONTE

B. T. / L. T. / D. T.

11-8-1646

Fr. Bernabé Martel, abad

Manzanera (Teruel)

AGN, Irache, Lib. 542, 289v.

JUAN DE FELGUERO SARABIA

B. C.

20-8-1646

Fr. Juan de Samaniego

Lombera (Burgos)

AGN, Irache, Lib. 542, 290 or.

GIL DE URBINA

B. C.
24-8-1646

Fr. Juan de Samaniego

Burgos

AGN, Irache, Lib. 542, 290 .

JUAN MARÍN DE RODEZNO

B. C. / L. C. / D. C.

6-9-1646 / 7-9-1646

Fr. Martín Izquierdo / Fr. Bernabé Martel, abad

Nájera (Calahorra)

AGN, Irache, Lib. 542, 290 .

JUAN JUNCO DE ILLANES

L. C. / D. C.

23-9-1646

Fr. Bernabé Martel, abad

Toledo

Madrid. Canónigo

Abad de San Quirce, de la Catedral de Bur-

gos

AGN, Irache, Lib. 542, $290 v$.

BERNARDINO DE MENA

B. C.

25-9-1646

Fr. Pedro de Vergaño

Briviesca (Burgos)

AGN, Irache, Lib. 542, $290 v$.

JUAN DE NAVARRIETA

B. A.

26-9-1646

Fr. Anselmo López

Estella (Pamplona)

AGN, Irache, Lib. 542, $290 v$.

PEDRO NÚÑEZ GIL

L. C. / D. C.

26-9-1646

Fr. Juan de Samaniego

Fuenmayor (Calahorra)

AGN, Irache, Lib. 542, $290 \mathrm{v}$.

JUAN BAUTISTA DE ARMIÑNO

B. C.

26-9-1646

Fr. Pedro de Vergaño 
Ond[arroa] (Burgos)

AGN, Irache, Lib. 542, 291 r.

DOMINGO RUIZ

B. C.

29-9-1646

Fr. Juan de Samaniego

Burgos

AGN, Irache, Lib. 542, 291r.

JOSÉ CARRERA

B. $\mathrm{T}$.

29-9-1646

Fr. Juan de Samaniego

Jaca

AGN, Irache, Lib. 542, 291r.

\section{GREGORIO RODRIGO}

B. C.

3-10-1646

Fr. Pedro de Vergaño

Sta. María del Carrizo (Burgos)

AGN, Irache, Lib. 542, 291r.

SIMÓN DE ANGULO

B. C.

3-10-1646

Fr. Juan de Samaniego

Burgos

AGN, Irache, Lib. 542, 291r.

JUAN DE LARA

B. C.

3-10-1646

Fr. Juan de Samaniego

Burgos

AGN, Irache, Lib. 542, 291r.

PEDRO GINEL

B. C.

5-10-1646

Fr. Pedro de Vergaño

Albacastro (Burgos)

AGN, Irache, Lib. 542, 291r.

DIEGO DE UNDA

B. A.

6-10-1646
Fr. Anselmo López

Viana (Calahorra)

AGN, Irache, Lib. 542, $291 v$.

GABRIEL DE IBARRA

B. C.

8-10-1646

Fr. Pedro de Vergaño

AGN, Irache, Lib. 542, 291v.

JOSÉ DE CÁRCAR

B. A.

8-10-1646

Fr. Anselmo López

O. Cist.

AGN, Irache, Lib. 542, $291 \mathrm{v}$.

FERMÍN DE EZPELETA

B. C.

19-10-1646

Fr. Martín Izquierdo

Pamplona

AGN, Irache, Lib. 542, $291 v$.

FRANCISCO PÉREZ MACHUCA

B. A. / B. T.

5-11-1646

Fr. Juan de Samaniego

Burgos

AGN, Irache, Lib. 542, 291v.

FRANCISCO DE LA PEÑA

B. C.

10-11-1646

Fr. Pedro de Vergaño

Grijalba (Burgos)

AGN, Irache, Lib. 542, $291 v$.

ANTONIO GARCÍA DE VELASCO

B. C.

28-11-1646

Fr. Martín Izquierdo

Canales

Burgos

AGN, Irache, Lib. 542, 292 r.

FRANCISCO DE CADENA

L. C. 
4-12-1646

Fr. Martín Izquierdo

Limpias (Burgos)

AGN, Irache, Lib. 542, 292r.

\section{LORENZO LUIS DE SANTAFE}

B. L.

30-12-1646

Fr. Martín Izquierdo

Huesca

AGN, Irache, Lib. 542, 292r.

FRANCISCO BAGUER SARASA

L. L.

1-1-1647

Fr. Juan de Samaniego

Artajona (Pamplona)

AGN, Irache, Lib. 542, 292v.

\section{MATEO GONZÁLEZ}

B. C.

20-1-1647

Fr. Pedro de Vergaño

Los Balbases (Burgos)

AGN, Irache, Lib. 542, 292v.

ANDRÉS DE PEREA

B. C.

23-1-1647

Fr. Martín Izquierdo

Barriga (Burgos)

AGN, Irache, Lib. 542, 292v.

BALTASAR DE LA MATA

B. C.

29-1-1647

Fr. Pedro de Vergaño

Burgos

AGN, Irache, Lib. 542, 292v.

FRANCISCO DE LA PEÑA

B. C.

29-1-1647

Fr. Pedro de Vergaño

Villarcayo (Burgos)

AGN, Irache, Lib. 542, 292v.

ALEJANDRO MARÍN

B. A. / L. A. / M. A. / B. T. / L. T. / D. T.
1-2-1647

Fr. Bernabé Martel, abad

O. S. B.

Hijo de la Real de Nájera

AGN, Irache, Lib. 542, 293 r.

JUAN DE FONCUEVA

B. C.

1-3-1647

Fr. Martín Izquierdo

Castrillo (Burgos)

AGN, Irache, Lib. 542, 293 r.

FRANCISCO CALDERÓN DE LA BARCA

B. C.

2-3-1647

Fr. Pedro de Vergaño

Aguilar de Campoo (Burgos)

AGN, Irache, Lib. 542, 293 r.

FRANCISCO DÍAZ DE VALDIVIESO

B. C.

3-3-1647

Fr. Martín Izquierdo

Villarcayo (Burgos)

AGN, Irache, Lib. 542, 293 r.

DIEGO DE OJEDA

B. C.

3-3-1647

Fr. Martín Izquierdo

Jilones (Burgos)

AGN, Irache, Lib. 542, 293 r.

JUAN DE MAEDA SALAZAR

L. C.

31-3-1647

Fr. Bernabé Martel, abad

Burgos

AGN, Irache, Lib. 542, 293v.

DOMINGO MANSO

B. C.

31-3-1647

Fr. Juan de Samaniego

Santa María del Campo (Burgos)

AGN, Irache, Lib. 542, 293v. 
MARTÍN DE ANDUEZA

B. A.

19-4-1647

Fr. Anselmo López

Urdánoz (Pamplona)

AGN, Irache, Lib. 542, 293v.

FRANCISCO GIL

B. A.

29-4-1647

Fr. Anselmo López

Alcanadre (Calahorra)

AGN, Irache, Lib. 542, $293 v$.

DIEGO LÓPEZ DEL VALLE

B. C.

2-5-1647

Fr. Pedro de Vergaño

Mijangos (Burgos)

AGN, Irache, Lib. 542, 293v.

JUAN DE PAMPLIEGA

B. C.

8-5-1647

Fr. Martín Izquierdo

Mahamud (Burgos)

AGN, Irache, Lib. 542, 294r.

FRANCISCO TEJEDOR

B. C.

8-5-1647

Fr. Martín Izquierdo

Mahamud (Burgos)

AGN, Irache, Lib. 542, 294 r.

JOSÉ DE SOTO

B. A. / B. T. / L. T. / D. T.

11-5-1647

Fr. Juan de Samaniego / Fr. Bernabé Mar-

tel, abad

O. Praem.

AGN, Irache, Lib. 542, 294r.

FRANCISCO ALONSO VELÁZQUEZ

L. C. / D. C.

13-5-1647

Fr. Bernabé Martel, abad

Burgos

AGN, Irache, Lib. 542, 294 r.
FELIPE RUIZ

B. C.

13-5-1647

Fr. Martín Izquierdo

Valbuena (Burgos)

AGN, Irache, Lib. 542, 294v.

JUAN DÍAZ

B. C.

17-5-1647

Fr. Pedro de Vergaño

Ayoluengo (Burgos)

AGN, Irache, Lib. 542, 294V.

JUAN VAL

B. C.

17-5-1647

Fr. Pedro de Vergaño

Quintanas de Valdelucio (Burgos)

AGN, Irache, Lib. 542, 294v.

PEDRO DE SINOVAS

B. C.

20-5-1647

Fr. Martín Izquierdo

Villafruela (Burgos)

AGN, Irache, Lib. 542, 294v.

JUAN DE LLANILLO

B. C.

25-5-1647

Fr. Pedro de Vergaño

Boada (Burgos)

Pbro.

AGN, Irache, Lib. 542, 294v.

JOSÉ MARTEL

L. C. / D. C.

29-5-1647

Fr. Pedro de Vergaño

Zaragoza.

Deán de Jaca

AGN, Irache, Lib. 542, 294v.

JULIÁN ANDRÉS USTÁRROZ

B. C. / L. C. / D. C.

16-6-1647

Fr. Bernabé Martel, abad 
Borja (Tarragona)

AGN, Irache, Lib. 542, 295r.

\section{BARTOLOMÉ CALLEJA}

B. C.

18-6-1647

Fr. Martín Izquierdo

Melgar de Fernamental (Burgos)

AGN, Irache, Lib. 542, 295r.

\section{FAUSTO DE BURUTÁIN}

L. L.

24-6-1647

Fr. Bernabé Martel, abad

Pamplona

AGN, Irache, Lib. 542, 295r.

FRANCISCO DE TORRES

B. C.

9-7-1647

Fr. Pedro de Vergaño

Allo (Pamplona)

AGN, Irache, Lib. 542, 295v.

\section{ANTONIO DE LUNA Y PERALTA}

L. C.

10-7-1647

Fr. Bernabé Martel, abad

Corella (Tarazona)

AGN, Irache, Lib. 542, 295v.

\section{JUAN DE SALDAÑA BRAVO}

B. A. / B. T. / L. T.

22-7-1647 / 12-5-1654

Fr. Anselmo López / Fr. Pedro de Úriz, abad

Burgos

AGN, Irache, Lib. 542, 296r, 387r.

TOMÁS DE BERRAGIA

B. C.

27-7-1647

Fr. Martín Izquierdo

Medina de Pomar (Burgos)

AGN, Irache, Lib. 542, $296 r$.

\section{ANTONIO RAMÍREZ DE ARELLANO}

B. C.

29-7-1647
Fr. Pedro de Vergaño

Madrid (Toledo)

AGN, Irache, Lib. 542, 296r.

\section{ANTONIO SALINAS}

B. C.

29-7-1647

Fr. Pedro de Vergaño

Madrid (Toledo)

AGN, Irache, Lib. 542, 296r.

JOSÉ DE MAYA

B. A.

6-8-1647

Fr. Juan de Lezama, vicecanciller

Medrano (Calahorra)

AGN, Irache, Lib. 542, 296r.

PASCUAL DE LA FUENTE

B. C.

8-8-1647

Fr. Martín Izquierdo

Montealegre del Valle de Sámano (Burgos)

AGN, Irache, Lib. 542, 296v.

JULIÁN DE VILLAR

B. C.

8-8-1647

Fr. Martín Izquierdo

Somorrostro (Burgos)

AGN, Irache, Lib. 542, 296v.

\section{ANTONIO SANTOS}

B. C.

15-8-1647

Fr. Pedro de Vergaño

Santa María del Campo (Burgos)

AGN, Irache, Lib. 542, 296v.

\section{LUIS CLAVIJO}

B. C. / B. L.

19-8-1647

Fr. Martín Izquierdo

Madrid (Toledo)

AGN, Irache, Lib. 542, 296v.

\section{DIEGO GONZÁLEZ}

B. C. 
22-8-1647

Fr. Pedro de Vergaño

Melgar de Fernamental (Burgos)

AGN, Irache, Lib. 542, 297 r.

\section{GREGORIO DEL BUSTO}

L. C.

28-8-1647

Fr. Bernabé Martel, abad

Viana (Calahorra)

AGN, Irache, Lib. 542, 297 r.

AGUSTÍN DE RETOLA

B. C.

31-8-1647

Fr. Pedro de Vergaño

Zalla (Burgos)

AGN, Irache, Lib. 542, 297 r.

JUAN DE ROJAS

B. A. / L. A. / M. A. / B. T. / L. T. / D. T. 3-9-1647

Fr. Martín Izquierdo

O. S. B.

Hijo de la Real de Nájera

AGN, Irache, Lib. 542, 297 r.

JOSÉ DE LA TORRE

L. M. / D. M.

6-9-1647

Fr. Martín Izquierdo

Cinctorres (Tortosa)

AGN, Irache, Lib. 542, $297 \mathrm{v}$.

JUAN DE MANZANARES

B. T.

13-9-1647

Fr. Pedro de Vergaño

Ezcaray (Burgos)

AGN, Irache, Lib. 542, $297 \mathrm{v}$.

DIEGO DE ALMEIDA

B. A. / L. A. / M. A. / B. T. / L. T. / D. T. 15-9-1647

Fr. Bernabé Martel

O. S. B.

Hijo de San Martín de Santiago

AGN, Irache, Lib. 542, $297 \mathrm{v}$.

\section{ROQUE DE VIVAR}

B. C.

15-9-1647

Fr. Martín Izquierdo

Quintanilla (Burgos)

AGN, Irache, Lib. 542, $297 \mathrm{v}$.

ANDRÉS ANTONIO GONZÁLEZ DE LLU-

BA

L. C. / D. C.

19-9-1647

Fr. Martín Izquierdo

Ariza (Sigüenza)

AGN, Irache, Lib. 542, 297r bis.

ANTONIO DE CASTRO

B. C. / L. C. / D. C.

27-9-1647

Fr. Bernabé Martel, abad

Villafranca del Bierzo (Astorga)

Pbro.

AGN, Irache, Lib. 542, 297r bis.

ANTONIO DE LA VENERA

B. A.

2-10-1647

Fr. Anselmo López

Bilbao (Calahorra)

AGN, Irache, Lib. 542, 297r bis.

ANDRÉS RUIZ DE GAONA

B. A.

9-10-1647

Fr. Anselmo López

Arrauri (Calahorra)

Estudiante en Pamplona

AGN, Irache, Lib. 542, 297v bis.

MIGUEL DE EGUZQUIZA

B. A.

10-10-1647

Fr. Anselmo López

San Sebastián (Pamplona)

AGN, Irache, Lib. 542, 297v bis.

JOSÉ LÓPEZ

B. A.

10-10-1647 
Fr. Anselmo López

Los Arcos (Pamplona)

AGN, Irache, Lib. 542, 297v bis.

PLÁCIDO NÚÑEZ

B. A. / L. A. / M. A. / B. T. / L. T. / D. T.

13-10-1647

Fr. Bernabé Martel, abad

O. S. B.

Hijo de San Benito el Real de Valladolid

AGN, Irache, Lib. 542, 297v bis.

FRANCISCO DE ZÁRATE

B. T. / L. T. / D. T.

14-10-1647

Fr. Bernabé Martel, abad

Arcos (Calahorra)

AGN, Irache, Lib. 542, 297v bis.

JOSÉ DE RODRIGO

B. C.

20-10-1647

Fr. Pedro de Vergaño

Ojacastro (Burgos)

AGN, Irache, Lib. 542, 298r.

ALONSO GUTIÉRREZ DE LOS RÍOS

B. C.

27-10-1647

Fr. Martín Izquierdo

Padilla de Abajo (Burgos)

AGN, Irache, Lib. 542, 298r.

JUAN DE BEZANA

B. C.

18-11-1647

Fr. Pedro de Vergaño

Amaya (Burgos)

AGN, Irache, Lib. 542, 298r.

MATÍAS FRANCISCO FEMAT

B. A. / B. M.

22-11-1647 / 23-11-1647

Fr. Anselmo López / Fr. Pedro de Vergaño

/ Dr. Lizondo

Miranda de Arga (Pamplona)

AGN, Irache, Lib. 542, 298r.
PEDRO MARTÍNEZ DE GAVIDIA

B. C. / L. C.

25-11-1647

Fr. Bernabé Martel, abad

Calahorra

AGN, Irache, Lib. 542, 298v.

JUAN MARTÍNEZ DE SANTAYANA

B. C.

27-11-1647

Fr. Pedro de Vergaño

Fonseca (Burgos)

AGN, Irache, Lib. 542, 298v.

\section{JUAN GARCÍA}

B. C.

17-12-1647

Fr. Juan de Samaniego

Padilla de Abajo (Burgos)

AGN, Irache, Lib. 542, 298v.

\section{JUAN GUTIÉRREZ}

B. C.

20-12-1647

Fr. Pedro de Vergaño

Hoz (Burgos)

AGN, Irache, Lib. 542, 298v.

MARTÍN DE MUSQUES

B. C.

2-1-1648

Fr. Pedro de Vergaño

Valle de Somorrostro. Sta. Juliana de Aban-

to (Burgos)

AGN, Irache, Lib. 542, 299 r.

JUAN DE SALAZAR

B. C.

7-1-1648

Fr. Juan de Samaniego

Burgos

AGN, Irache, Lib. 542, 299 r.

JUAN GARCÍA TRUCHUELO

B. C.

15-1-1648

Fr. Pedro de Vergaño

Mijangos (Burgos)

AGN, Irache, Lib. 542, 299 r. 
FRANCISCO BUENDÍA

L. L. / D. L.

26-1-1648

Fr. Bernabé Martel, abad

Tortosa

AGN, Irache, Lib. 542, 299 r.

MARTÍN DE ARGUIÑANO EQUIZA

B. A.

2-2-1648

Fr. Anselmo López

Tafalla (Pamplona)

AGN, Irache, Lib. 542, 299v.

BENITO FER[NÁNDEZ] DEL CORRAL

B. A. / L. A. / M. A. / B. T. / L. T. / D. T.

1-3-1648

Fr. Bernabé Martel, abad

O. S. B.

Montserrat

AGN, Irache, Lib. 542, 299v.

PLÁCIDO RIQUER

B. A. / L. A. / M. A. / B. T. / L. T. / D. T. 1-3-1648

Fr. Bernabé Martel, abad

O. S. B.

Montserrat

AGN, Irache, Lib. 542, 299v.

JERÓNIMO ESTEBAN LÓPEZ Y TORRELLAS

B. A. / B. M. / L. M. / D. M.

5-3-1648

Fr. Anselmo López / Fr. Bernabé Martel, abad

Monzón (Lérida)

AGN, Irache, Lib. 542, 299v.

JUAN DE SALAZAR Y VELASCO

B. C.

8-3-1648

Fr. Juan de Samaniego

Frías (Burgos)

AGN, Irache, Lib. 542, 30or.

FRANCISCO DE VIVAR

B. A.
12-3-1648

Fr. Pedro de Vergaño

Burgos

AGN, Irache, Lib. 542, 30or.

BARTOLOMÉ DE GARAY

B. C.

14-3-1648

Fr. Pedro de Vergaño

Castro Urdiales (Burgos)

AGN, Irache, Lib. 542, 30or.

DOMINGO GARCÍA

B. C.

15-3-1648

Fr. Martín Izquierdo

Calleja, Valle de Carranza (Burgos)

AGN, Irache, Lib. 542, 30or.

FRANCISCO DE HUERTA

B. C.

24-3-1648

Fr. Juan de Samaniego

Castro Genil (Burgos)

AGN, Irache, Lib. 542, 30or.

JOSÉ MARTÍNEZ DE ARTAJONA

B. A.

2-4-1648

Fr. Pedro de Vergaño

Milagro (Pamplona)

AGN, Irache, Lib. 542, 300v.

ANTONIO DE CASARES Y GARAY

B. C.

2-4-1648

Fr. Pedro de Vergaño

Galdames (Burgos)

AGN, Irache, Lib. 542, 300v.

PEDRO RUIZ DE ARRIOLA

B. A.

2-4-1648

Fr. Martín Izquierdo

Arriola (Calahorra)

AGN, Irache, Lib. 542, 300v.

FRANCISCO RUIZ DE ORDOÑANA

B. A. 
2-4-1648

Fr. Martín Izquierdo

Ordoñana (Calahorra)

AGN, Irache, Lib. 542, 300v.

JERÓNIMO ARCAYA

B. A.

4-4-1648

Fr. Anselmo López

Torres (Calahorra)

AGN, Irache, Lib. 542, 300v.

PEDRO DE FRÍAS

B. C.

14-4-1648

Fr. Martín Izquierdo

Iglesias (Burgos)

AGN, Irache, Lib. 542, 301r.

\section{ANDRÉS CUBILLO}

B. A.

$17-4-1648$

Fr. Anselmo López

Lara (Burgos)

AGN, Irache, Lib. 542, 301r.

MARTÍN DE ESPINAL

B. A. / L. A.

22-4-1648 / 5-7-1649

Fr. Anselmo López / Fr. Domingo Gutiérrez

Espinal (Pamplona)

AGN, Irache, Lib. 542, 301r, 319r.

CRISTÓBAL DE SANTIBÁÑEZ

B. C.

23-4-1648

Fr. Martín Izquierdo

Dueñas (Burgos)

AGN, Irache, Lib. 542, 301r.

VENTURA GALVÁN

B. C.

24-4-1648

Fr. Pedro de Vergaño

Herrera (Burgos)

AGN, Irache, Lib. 542, 301v.

PEDRO DE SANMARTÍN

L. L.
25-4-1648

Fr. Bernabé Martel, abad

Gordoguela (Calahorra)

AGN, Irache, Lib. 542, 301v.

MATÍAS DELGADO HERRERO

B. C.

28-4-1648

Fr. Martín Izquierdo

Santibáñez (Burgos)

AGN, Irache, Lib. 542, 301v.

GABRIEL GONZÁLEZ

B. C.

30-4-1648

Fr. Juan de Samaniego

Villasilos (Burgos)

AGN, Irache, Lib. 542, 301v.

JUAN LORENZO

B. C.

30-4-1648

Fr. Pedro de Vergaño

Castro (Burgos)

AGN, Irache, Lib. 542, 302r.

PEDRO DE IBERO

B. A.

1-5-1648

Fr. Anselmo López

Ibero (Pamplona)

AGN, Irache, Lib. 542, 302r.

JOSÉ RAMÍREZ DE BAQUEDANO

B. A. // B. T. / L. T. / D. T.

4-4-1648 // 1-4-1651

Fr. Anselmo López / Fr. Martín Izquierdo, abad

San Martín (Pamplona)

AGN, Irache, Lib. 542, 302r, 344r.

JUAN MIGUEL DE ECHARRI

B. A.

5-4-1648

Fr. Anselmo López

Arre (Pamplona)

AGN, Irache, Lib. 542, 302v. 
MARTÍN DE BELZUNCE

B. A.

5-4-1648

Fr. Anselmo López

Pamplona

AGN, Irache, Lib. 542, 302v.

PEDRO DE URTASUN

B. A.

5-4-1648

Fr. Anselmo López

Elcano (Pamplona)

AGN, Irache, Lib. 542, 302v.

MARTÍN DE MAYA

B. A.

5-4-1648

Fr. Anselmo López

Maya (Pamplona)

AGN, Irache, Lib. 542, 302v.

PEDRO USÚN

B. A.

5-4-1648

Fr. Anselmo López

Castillonuevo (Pamplona)

AGN, Irache, Lib. 542, 302v.

JUAN DE ALDAZ

B. A.

5-4-1648

Fr. Anselmo López

Aldana (Pamplona)

AGN, Irache, Lib. 542, 302v.

MIGUEL DE ITURRIA

B. A.

5-4-1648

Fr. Anselmo López

Vera (Pamplona)

AGN, Irache, Lib. 542, 302v.

MIGUEL MARTÍNEZ

B. A.

5-4-1648

Fr. Anselmo López

Pamplona

AGN, Irache, Lib. 542, 302v.
JOSÉ DE SOLA

B. A.

5-4-1648

Fr. Anselmo López

Tudela (Nullius Diocesis)

AGN, Irache, Lib. 542, 302v.

JUAN DE ASIÁIN

B. A.

5-4-1648

Fr. Anselmo López

Olóriz (Pamplona)

AGN, Irache, Lib. 542, 302v.

MIGUEL DE ITURBIDE

B. A.

5-4-1648

Fr. Anselmo López

Yanci (Pamplona)

AGN, Irache, Lib. 542, 302v.

SEBASTIÁN DE ZUAZU

B. A.

5-4-1648

Fr. Anselmo López

Pamplona

AGN, Irache, Lib. 542, 302v.

JUAN DE VIZCAY

B. A.

5-4-1648

Fr. Anselmo López

Pueyo (Pamplona)

AGN, Irache, Lib. 542, 302v.

TOMÁS IGNACIO DE BEINZA

B. A.

5-4-1648

Fr. Anselmo López

Pamplona

AGN, Irache, Lib. 542, 302v.

ANDRÉS DE APESTEGUÍA

B. A.

5-4-1648

Fr. Anselmo López

Eraso (Pamplona)

AGN, Irache, Lib. 542, 302v. 
DIEGO DE ECHARREN

B. A.

5-4-1648

Fr. Anselmo López

Falces (Pamplona)

AGN, Irache, Lib. 542, 302v.

JUAN DE ECHEVERRÍA Y LANZ

B. A.

5-4-1648

Fr. Anselmo López

Eguaras (Pamplona)

AGN, Irache, Lib. 542, 302v.

JUAN DE RECALDE

B. A.

5-4-1648

Fr. Anselmo López

Espinal (Pamplona)

AGN, Irache, Lib. 542, 302v.

PEDRO JORGE DE ARTETA

B. A.

5-4-1648

Fr. Anselmo López

Pamplona

AGN, Irache, Lib. 542, 302v.

PEDRO DE IRISARRI

B. A.

5-4-1648

Fr. Anselmo López

Yanci (Pamplona)

AGN, Irache, Lib. 542, 302v.

MARTÍN DE ITURBURRU Y ERASO

B. A.

5-4-1648

Fr. Anselmo López

Elizondo (Pamplona)

AGN, Irache, Lib. 542, 302v.

PEDRO ALEGRÍA SIL DE LA PUENTE

B. A.

5-4-1648

Fr. Anselmo López

Pamplona

AGN, Irache, Lib. 542, 302v.
MIGUEL DE BALEZTENA

B. A.

5-4-1648

Fr. Anselmo López

Urroz (Pamplona)

AGN, Irache, Lib. 542, 302v.

MARTÍN ESCUDERO

B. A.

5-4-1648

Fr. Anselmo López

Los Arcos (Pamplona)

AGN, Irache, Lib. 542, 302v.

ALONSO LÓPEZ

B. A.

5-4-1648

Fr. Anselmo López

Pamplona

AGN, Irache, Lib. 542, 302v.

PEDRO IZQUIERDO

B. A.

5-4-1648

Fr. Anselmo López

Los Arcos (Pamplona)

AGN, Irache, Lib. 542, 302v.

AGUSTÍN DE AZNÁREZ

B. A.

5-4-1648

Fr. Anselmo López

Pamplona

AGN, Irache, Lib. 542, 302v.

JUAN DE URNIZA

B. A.

5-4-1648

Fr. Anselmo López

Pamplona

AGN, Irache, Lib. 542, 302v.

MIGUEL DE ELIZALDE Y URSUA

B. A.

5-4-1648

Fr. Anselmo López

Pamplona

AGN, Irache, Lib. 542, 302v. 
MATÍAS COLOMO

B. A.

5-4-1648

Fr. Anselmo López

Miranda de Arga (Pamplona)

AGN, Irache, Lib. 542, 302v.

MANUEL DE CELADA

B. C.

7-5-1648

Fr. Martín Izquierdo

Santibáñez (Burgos)

AGN, Irache, Lib. 542, 303r.

GREGORIO TAMARÓN

B. A. / L. A. / M. A. / B. T. / L. T. / D. T. 11-5-1648

Fr. Martín Izquierdo

O. S. B.

Hijo de Santa María de Sopetrán

Obispo electo de Alemania

Calificador de la Suprema y General Inquisición

AGN, Irache, Lib. 542, 303r.

PEDRO MÍNGUEZ

B. C.

15-5-1648

Fr. Martín Izquierdo

Tabanera (Burgos)

AGN, Irache, Lib. 542, 303r.

JUAN LÓPEZ DE CELADA

B. C.

15-5-1648

Fr. Pedro de Vergaño

Poza (Burgos)

AGN, Irache, Lib. 542, 303v.

\section{MARTÍN IBARRA}

L. L.

16-5-1648

Fr. Pedro de Vergaño

Villaro (Calahorra)

AGN, Irache, Lib. 542, 303v.

LUIS DE VERGARA

B. A. / L. A. / M. A. / B. T. / L. T. / D. T.
21-5-1648

Fr. Pedro de Vergaño

O. S. B.

Predicador

Hijo de San Martín de Santiago

AGN, Irache, Lib. 542, 303v.

FRANCISCO DE PUERTAS

B. C.

27-5-1648

Fr. Martín Izquierdo

San Vicente de la Barquera (Burgos)

AGN, Irache, Lib. 542, 304r.

JUAN GARCÍA ESCUDERO

B. C.

3-6-1648

Fr. Juan de Samaniego

Viniegra (Burgos)

AGN, Irache, Lib. 542, 304r.

PEDRO GARCÍA DEL CAMPO

B. C.

4-6-1648

Fr. Pedro de Vergaño

Olmos de la Picaza (Burgos)

AGN, Irache, Lib. 542, 304r.

JOSÉ DE LA IGLESIA

B. C.

4-6-1648

Fr. Pedro de Vergaño

Vilamayor de Iribiño (Burgos)

AGN, Irache, Lib. 542, 304r.

JUAN CAPACHO

B. C.

5-6-1648

Fr. Martín Izquierdo

Poza (Burgos)

AGN, Irache, Lib. 542, 304v.

JUAN DE GAMECHO Y ECHANDIA

B. A.

6-6-1648

Fr. Pedro de Vergaño

Mundaca (Calahorra)

AGN, Irache, Lib. 542, 304v. 
FRANCISCO DE URTIAGA

B. C.

13-6-1648

Fr. Martín Izquierdo

Güeñes (Burgos)

AGN, Irache, Lib. 542, 304v.

JUAN DE SANTELIUS

B. C.

19-6-1648

Fr. Juan de Samaniego

Laredo (Burgos)

AGN, Irache, Lib. 542, 305r.

PEDRO DE VILLOTA PALACIO

B. C.

29-6-1648

Fr. Pedro de Vergaño

Laredo (Burgos)

AGN, Irache, Lib. 542, 305r.

SEBASTIÁN DE ARCE

B. C.

8-7-1648

Fr. Martín Izquierdo

Burgos

AGN, Irache, Lib. 542, 305v.

BERNARDINO GUTIÉRREZ DE ROJAS

ANGULO

B. C.

14-7-1648

Fr. Martín Izquierdo

...

AGN, Irache, Lib. 542, 305v.

FRANCISCO SANZ DE ESPIGA

B. C.

14-7-1648

Fr. Pedro de Vergaño

Mayorga (Burgos)

AGN, Irache, Lib. 542, 305v.

JUAN DE LA TORRE NEGRETE

B. C.

16-7-1648

Fr. Martín Izquierdo

Los Caños (Burgos)

AGN, Irache, Lib. 542, 305v.
FRANCISCO LÓPEZ

B. C.

25-7-1648

Fr. Pedro de Vergaño

Poza (Burgos)

AGN, Irache, Lib. 542, 306r.

LUIS DE LA CARRERA

B. C.

25-7-1648

Fr. Pedro de Vergaño

Orón (Burgos)

AGN, Irache, Lib. 542, 306r.

FRANCISCO GONZÁLEZ DE SALCES

B. C.

14-8-1648

Fr. Martín Izquierdo

Cervatos (Burgos)

AGN, Irache, Lib. 542, 306r.

JUAN CALVO SERRANO

B. $\mathrm{T}$.

14-8-1648

Fr. Martín Izquierdo

Huerta de Arriba (Burgos)

AGN, Irache, Lib. 542, 306r.

PEDRO CABA

B. C.

22-8-1648

Fr. Pedro de Vergaño

Villadiego (Burgos)

AGN, Irache, Lib. 542, 306v.

FRANCISCO ANDRÉS

B. A.

24-8-1648

Fr. Martín Izquierdo

Alesanco (Calahorra)

AGN, Irache, Lib. 542, 306v.

ANTONIO DELGADO

B. C.

29-8-1648

Fr. Pedro de Vergaño

Villa de Puerto de Santoña (Burgos)

AGN, Irache, Lib. 542, 306v. 
PEDRO DE SOLÓRZANO

B. C.

29-8-1648

Fr. Pedro de Vergaño

Villa de Puerto de Santoña (Burgos)

AGN, Irache, Lib. 542, 306v.

\section{DIONISIO MARTÍNEZ}

B. C.

11-9-1648

Fr. Martín Izquierdo

Ros (Burgos)

AGN, Irache, Lib. 542, 307r.

\section{ANTONIO ALARCÓN}

B. C.

20-9-1648

Fr. Martín Izquierdo

Lisboa (Portugal)

AGN, Irache, Lib. 542, 307r.

\section{FRANCISCO COLMENARES}

B. C.

2O-9-1648

Fr. Martín Izquierdo

Soto (Burgos)

AGN, Irache, Lib. 542, 307v.

MIGUEL DE SESMA

L. L.

21-9-1648

Fr. Martín Izquierdo

Tudela (Tarazona)

AGN, Irache, Lib. 542, 307v.

JUAN BARONA

B. A.

25-9-1648

Fr. Pedro de Vergaño

Valderrama (Burgos)

Pbro.

AGN, Irache, Lib. 542, 308r.

LÁZARO MARCOS

B. C.

25-9-1648

Fr. Pedro de Vergaño

Villusto (Burgos)

AGN, Irache, Lib. 542, 308r.
ALONSO GUTIÉRREZ DEL ÁGUILA

B. T. / L. T. / D. T.

26-9-1648

Fr. Pedro de Vergaño

Argecilla (Sigüenza)

Pbro.

AGN, Irache, Lib. 542, 308r.

ANTONIO SESE

B. C. / L. C. / D. C.

27-9-1648

Fr. Pedro de Vergaño

Sella (Barbastro)

AGN, Irache, Lib. 542, 308v.

PEDRO RUIZ

B. C.

29-9-1648

Fr. Pedro de Vergaño

Padilla de Abajo (Burgos)

AGN, Irache, Lib. 542, 308v.

BENITO DE LA CUESTA

B. C.

29-9-1648

Fr. Pedro de Vergaño

Melgar de Fernamental (Burgos)

AGN, Irache, Lib. 542, 308v.

DIEGO DE IRIARTE

B. A.

30-9-1648

Fr. Pedro de Vergaño

Burgos

AGN, Irache, Lib. 542, 309r.

PEDRO CORADA

B. A. / B. T.

30-9-1648

Fr. Pedro de Vergaño

Villadiego (Burgos)

AGN, Irache, Lib. 542, 309r.

FRANCISCO DOREDEA

B. C.

6-10-1648

Fr. Pedro de Vergaño

Riocavado (Burgos)

AGN, Irache, Lib. 542, 309v. 
PEDRO DE LARRAURI

B. C.

11-10-1648

Fr. Martín Izquierdo

Rasines (Burgos)

AGN, Irache, Lib. 542, 309v.

DIEGO DE LARRAURI

B. C.

11-10-1648

Fr. Martín Izquierdo

Rasines (Burgos)

AGN, Irache, Lib. 542, 309v.

JUAN GREGORIO DE MÚJICA Y BUITRÓN

B. A. / B. M. / L. M. / D. M.

12-10-1648 / 13-10-1648

Fr. Martín Izquierdo

Egea de los Caballeros (Zaragoza)

AGN, Irache, Lib. 542, 310r.

PLÁCIDO DE HARO

B. A. / L. A. / B. T. / L. T. / D. T.

16-10-1648

Fr. Pedro de Vergaño

Predicador

O. S. B.

Hijo de Celanova

AGN, Irache, Lib. 542, 310v.

\section{JERÓNIMO PUIG}

L. L. / D. L.

2-11-1648

Fr. Bernabé Martel, abad

Valdealgorfa (Zaragoza)

AGN, Irache, Lib. 542, 310v.

CRISTÓBAL LABARRIETA

B. C.

3-11-1648

Fr. Juan de Samaniego

Utanez (Burgos)

AGN, Irache, Lib. 542, 311r.

ANTONIO SÁNCHEZ

B. T.

3-11-1648
Fr. Juan de Samaniego

Burgos

B. A. / L. A. en Alcalá

AGN, Irache, Lib. 542, 311r.

MATEO DE ARANDA

L. T. / D. T. / B. C.

25-11-1648

Fr. Martín Izquierdo

Lerma (Nullius Diocesis)

Canónigo de Lerma. Vicario General

AGN, Irache, Lib. 542, 311r.

JOSÉ DE VILLEGAS

B. C.

10-12-1648

Fr. Juan de Samaniego

Melgar de Fernamental (Burgos)

AGN, Irache, Lib. 542, 311v.

TOMÁS MIGUEL DE SAMITIER

B. $\mathrm{T}$.

14-12-1648

Fr. Martín Izquierdo

Anso (Jaca)

Pbro.

AGN, Irache, Lib. 542, 311v.

JUAN DE LEZANA

B. A. / L. A. / M. A. / B. T. / L. T. / D. T. 26-12-1648

Fr. Bernabé Martel, abad

O. S. B.

Predicador

AGN, Irache, Lib. 542, 311v.

JUAN SEBASTIÁN BERNAD

B. A. / B. T.

30-12-1648

Fr. Domingo Gutiérrez, Lector de Artes

Anso (Jaca)

AGN, Irache, Lib. 542, 312r.

ANTONIO ORTIZ DE VÍCTORES

B. C.

6-1-1649

Juan de Lezana, vicecanciller

Belorado (Calahorra)

AGN, Irache, Lib. 542, 312r. 
DIEGO DEL HOYO

B. C.

9-1-1649

Fr. Pedro de Vergaño

Villanueva de Ribacardo (Burgos)

AGN, Irache, Lib. 542, 312r.

PEDRO DE LA SERNA

B. C.

14-1-1649

Fr. Juan de Lezana, vicecanciller

Montorio (Burgos)

AGN, Irache, Lib. 542, 312v.

MANUEL DÍAZ

B. A.

14-1-1649

Fr. Domingo Gutiérrez

Corera (Calahorra)

AGN, Irache, Lib. 542, 312v.

JUAN VICENTE PUJOL

B. T. / L. T. / D. T.

16-1-1649

Fr. Pedro de Vergaño

Mallén (Zaragoza)

Pbro.

AGN, Irache, Lib. 542, 312v.

FRANCISCO DE MATA

B. C.

27-1-1649

Fr. Juan de Lezana

Burgos

AGN, Irache, Lib. 542, 313r.

PEDRO DE DOMAICA

B. C.

2-2-1649

Fr. Juan de Lezana

Burgos

AGN, Irache, Lib. 542, 313r.

ALONSO ROJO

B. C.

8-2-1649

Fr. Martín Izquierdo

Terradillo (Burgos)

AGN, Irache, Lib. 542, 313r.
ATILIANO DE COLLANTES

B. A. / L. A. / M. A. / B. T. / L. T. / D. T.

8-2-1649

Fr. Martín Izquierdo

O. S. B.

Abad de Ntra. Sra. del Espino

Hijo de Sahagún

AGN, Irache, Lib. 542, 313r.

PEDRO DE LA CALLEJA

B. C.

8-2-1649

Fr. Pedro de Vergaño

San Martín de Sosa (Burgos)

AGN, Irache, Lib. 542, 313v.

JUAN DE PALACIO

B. C.

13-2-1649

Fr. Juan de Lezana

Carranza (Burgos)

AGN, Irache, Lib. 542, 313v.

MARTÍN DE SOTO Y GUZMÁN

B. C.

21-2-1649

Fr. Martín Izquierdo

Briviesca (Burgos)

AGN, Irache, Lib. 542, 313v.

LUIS DE TREBILLA

B. C.

7-3-1649

Fr. Pedro de Vergaño

Valle de Carranza (Burgos)

AGN, Irache, Lib. 542, 314r.

MELCHOR DE MENDIVIL

B. A. / B. T. / L. T. / D. T.

8-3-1649 / 9-3-1649

Fr. Juan de Lezana

Mendivil (Calahorra)

Pbro.

AGN, Irache, Lib. 542, 314r.

PEDRO DE LA LLANDERA

B. C.

14-3-1649 
Fr. Martín Izquierdo

San Vicente Valle de Gruezo (Burgos)

AGN, Irache, Lib. 542, 314v.

JOSÉ HERNÁNDEZ DE SOTO

L. C.

24-3-1649

Fr. Bernabé Martel

Sto. Domingo de La Calzada (Calahorra)

AGN, Irache, Lib. 542, 314v.

FRANCISCO PÉREZ BARCENILLA

B. C.

24-3-1649

Fr. Juan de Lezana

Guriezo (Burgos)

AGN, Irache, Lib. 542, 314v.

AGUSTÍN DEL ARCO

L. L.

26-3-1649

Fr. Bernabé Martel, abad

Tudela (Nullius Diocesis)

AGN, Irache, Lib. 542, 315r.

JUAN DE ECHEGARAY

B. A. / B. T. / L. T. / D. T.

2-4-1649 / 3-4-1649

Fr. Juan de Lezana / Fr. Bernabé Martel,

abad

Logroño (Calahorra)

Canónigo

AGN, Irache, Lib. 542, 315r.

PEDRO DE ÚRIZ

B. A. / L. A. / M. A. / B. T. / L. T. / D. T.

11-4-1649

Fr. Bernabé Martel, abad

O. S. B.

Hijo de S. María la Real de Nájera

AGN, Irache, Lib. 542, 315v.

FRANCISCO DE SANTACLARA

B. C.

28-4-1649

Fr. Juan de Lezana

Castrojeriz (Burgos)

AGN, Irache, Lib. 542, 315v.
CRISTÓBAL DE URUÑUELA

L. C. / D. C.

29-4-1649

Fr. Pedro de Úriz

Nájera (Nullius Diocesis)

Pbro.

AGN, Irache, Lib. 542, 315v.

JERÓNIMO SEDANO

B. C.

11-5-1649

Fr. Pedro de Vergaño

Quintana (Burgos)

AGN, Irache, Lib. 542, 316r.

JUAN DÍEZ

B. C.

20-5-1649

Fr. Juan de Lezana

Burgos

AGN, Irache, Lib. 542, 316r.

FRANCISCO DE UGARTE

B. A.

20-5-1649

Fr. Domingo Gutiérrez

San Sebastián (Calahorra)

AGN, Irache, Lib. 542, 316r.

BENITO SALAZAR

B. A. / L. A. / M. A. / B. T. / L. T. / D. T.

21-5-1649

Fr. Martín Izquierdo, abad

O. S. B.

Hijo de San Millán de la Cogolla

AGN, Irache, Lib. 542, 316v.

MATEO DE CAMARGO ARCE

B. C.

22-5-1649

Fr. Juan de Lezana

Carafa (Burgos)

AGN, Irache, Lib. 542, 316v.

MIGUEL JOSÉ [PÉREZ] DE OLIVÁN Y VAQUER

B. L. / L. L. / D. L. / L. C. / D. C.

22-5-1649 
Fr. Martín Izquierdo, abad

Arcediano en la Metropolitana de Zaragoza

AGN, Irache, Lib. 542, 317r.

BERNABÉ ROMEU

B. A. / B. T. / L. T. / D. T.

22-5-1649

Fr. Martín Izquierdo, abad

Fresno (Tarazona)

AGN, Irache, Lib. 542, 317r.

ADRIÁN GONZÁLEZ

B. C.

23-5-1649

Fr. Juan de Lezana

Valtierra (Burgos)

AGN, Irache, Lib. 542, 317r.

JOSÉ DÍAZ

B. C.

29-5-1649

Fr. Juan de Lezana

Gredilla de Sedano (Burgos)

AGN, Irache, Lib. 542, 317v.

JUAN DE VILLANUEVA

B. C.

30-5-1649

Fr. Pedro de Vergaño

Liendo (Burgos)

AGN, Irache, Lib. 542, 317v.

PEDRO DEL VALLE

B. C.

30-5-1649

Fr. Pedro de Vergaño

Valle de Guriezo (Burgos)

AGN, Irache, Lib. 542, 317v.

JOSÉ BARRIGA DE MATA

B. C.

5-6-1649

Fr. Pedro de Vergaño

Burgos

AGN, Irache, Lib. 542, 317v.

ALONSO GARCÍA

B. A. / L. A. / M. A. / B. T. / L. T. / D. T.
5-6-1649

Fr. Martín Izquierdo, abad

O. S. B.

Hijo de San Julián de Samos

AGN, Irache, Lib. 542, 318r.

PEDRO GONZÁLEZ

B. A.

7-6-1649

Fr. Domingo Gutiérrez

Arróniz (Pamplona)

AGN, Irache, Lib. 542, 318r.

DIEGO MALO DE ANDUEZA

B. A. / L. A. / M. A. / B. T. / L. T. / D. T. 10-6-1649

Fr. Martín Izquierdo, abad

O. S. B.

Hijo de San Millán

AGN, Irache, Lib. 542, 318r.

ANDRÉS DE ZULAIBAR

B. C.

18-6-1649

Fr. Juan de Lezana

Burgos

AGN, Irache, Lib. 542, 318v.

MARTÍN DE ZULAIBAR

B. C.

18-6-1649

Fr. Juan de Lezana

Burgos

AGN, Irache, Lib. 542, 318v.

DIEGO RUIZ MAROTO

B. A. / B. T.

18-6-1649

Fr. Juan de Lezana

Villegas (Burgos)

AGN, Irache, Lib. 542, 318v.

LUCAS RUIZ DE CENES

B. A. / B. T.

18-6-1649

Fr. Juan de Lezana

Villadiego (Burgos)

AGN, Irache, Lib. 542, 318v. 
MIGUEL DEL CASTILLO

B. C.

21-6-1649

Fr. Juan de Lezana

Pancorbo (Burgos)

AGN, Irache, Lib. 542, 318v.

ANDRÉS MARTÍNEZ

B. C.

26-6-1649

Fr. Pedro de Vergaño

Villasandino (Burgos)

AGN, Irache, Lib. 542, 319r.

PEDRO RUIZ DEL BURGO

B. A. / L. A. / M. A. / B. T. / L. T. / D. T. 7-7-1649

Fr. Pedro de Vergaño

O. S. B.

Hijo de S. María la Real de Nájera

AGN, Irache, Lib. 542, 319v.

NICOLÁS FERNÁNDEZ DE ANGULO

B. C.

15-7-1649

Fr. Pedro de Vergaño

Las Vesgas (Burgos)

AGN, Irache, Lib. 542, 319v.

\section{ALONSO PEÑA}

B. C.

18-7-1649

Fr. Juan de Lezana

Tapia (Burgos)

AGN, Irache, Lib. 542, 319v.

ALONSO DE NEILA

B. A. / L. A. / M. A. / B. T. / L. T. / D. T.

21-7-1649

Fr. Martín Izquierdo, abad

O. S. B.

Predicador

Hijo de N. S. la Real de Nájera

AGN, Irache, Lib. 542, $320 r$.

DIEGO PASCUAL

B. C.

2-8-1649
Fr. Juan de Lezana

Burgos

AGN, Irache, Lib. 542, 320 .

FRANCISCO SAINZ DE ZALDÚA

B. C.

8-8-1649

Fr. Pedro de Vergaño

Valgañón (Burgos)

AGN, Irache, Lib. 542, $320 v$.

ANTONIO DE ZÁRRAGA

B. C.

12-8-1649

Fr. Benito de Salazar

Arnedo (Calahorra)

AGN, Irache, Lib. 542, $320 v$.

JOSÉ DE SOTO

B. C.

13-8-1649

Fr. Juan de Lezana

Briviesca (Burgos)

AGN, Irache, Lib. 542, $320 v$.

GASPAR BARAONA

B. A. / B. T.

13-8-1649

Fr. Juan de Lezana

Nuez (Burgos)

AGN, Irache, Lib. 542, 321r.

DIEGO DE SALINAS MEDINILLA

B. C.

2-9-1649

Fr. Juan de Lezana

Cerezo (Burgos)

AGN, Irache, Lib. 542, 321r.

JUAN DE SALINAS MEDINILLA

B. C.

2-9-1649

Fr. Juan de Lezana

Cerezo (Burgos)

AGN, Irache, Lib. 542, 321r.

GABRIEL DE VILLEGAS

B. C. 
6-9-1649

Fr. Pedro de Vergaño

Sasamón (Burgos)

AGN, Irache, Lib. 542, 321r.

\section{JUAN DE VILLADIEGO}

B. C.

6-9-1649

Reprobado por Fr. Pedro de Vergaño

Reexaminado por Fr. Martín Izquierdo, abad

Sasamón (Burgos)

AGN, Irache, Lib. 542, 321v.

\section{JUAN DE VALLEJO}

B. C.

7-9-1649

Fr. Juan de Lezana

Ormazos (Burgos)

AGN, Irache, Lib. 542, 321v.

\section{ANDRÉS DELGADO}

B. C.

10-9-1649

Fr. Gregorio de Castro

Zarratón (Burgos)

AGN, Irache, Lib. 542, 322r.

\section{JUAN DE QUINTANO}

B. C.

11-9-1649

Fr. Juan de Lezana

Villaescusa (Burgos)

AGN, Irache, Lib. 542, 322r.

\section{MATEO DE VIANA CALDERÓN}

B. A.

13-9-1649

Fr. Domingo Gutiérrez

Leza (Calahorra)

AGN, Irache, Lib. 542, 322r.

JUAN GONZÁLEZ DE LA CUESTA PEDROSA

B. A. / B. T. / L. T. / D. T.

14-9-1649

Fr. Martín Izquierdo, abad

O. Praem.

AGN, Irache, Lib. 542, 322v.
AGUSTÍN OSORIO

B. A. / B. T.

14-9-1649

Fr. Martín Izquierdo, abad

O. Preaem.

AGN, Irache, Lib. 542, 322v.

\section{GREGORIO OLMOS}

B. A. / L. A. / M. A. / B. T. / L. T. / D. T.

15-9-1649

Fr. Martín Izquierdo, abad

O. S. B.

Hijo de Ntra. Sra. de Nájera

AGN, Irache, Lib. 542, 322v.

LUIS JUÁNIZ DE ECHALAZ

L. C. / D. C.

18-9-1649

Fr. Martín Izquierdo, abad

Arcediano en Pamplona

Pamplona

AGN, Irache, Lib. 542, 323r.

MIGUEL LÓPEZ DE ESPINOSA

L. C. / D. C.

18-9-1649 / 24-9-1649

Fr. Martín Izquierdo, abad

Antol (Calahorra)

AGN, Irache, Lib. 542, 323r.

JOSÉ NAVARRO

B. $\mathrm{M}$.

24-9-1649

Fr. Domingo Gutiérrez

Alfaro (Tarazona)

AGN, Irache, Lib. 542, 323v.

ANDRÉS DE LA INCERA

B. C.

26-9-1649

Fr. Gregorio de Castro

Adal (Burgos)

AGN, Irache, Lib. 542, 323v.

LUIS DE VALLE Y ALVARADO

B. C.

26-9-1649

Fr. Gregorio de Castro 
Prabes (Burgos)

AGN, Irache, Lib. 542, 323v.

SEBASTIÁN VERINO

B. A. / B. T. / L. T. / D. T.

27-9-1649

Fr. Gregorio de Castro

O. Praem.

AGN, Irache, Lib. 542, 324r.

JUAN SANZ DE ASÚA

B. C.

29-9-1649

Fr. Gregorio de Castro

Burgos

AGN, Irache, Lib. 542, 324r.

JOSÉ DE VALDEVIESO

B. A. / L. A. / M. A. / B. T. / L. T. / D. T.

1-10-1649

Fr. Pedro de Vergaño

O. S. B.

Hijo de El Real de Valladolid

AGN, Irache, Lib. 542, 324r.

TOMÁS DE IBAIZÁBAL

B. A. / L. A.

2-10-1649

Fr. Juan de Lezana

Bilbao (Calahorra)

AGN, Irache, Lib. 542, 324v.

MARTÍN ORTIZ DE VITORIA

B. C.

5-10-1649

Fr. Pedro de Vergaño

Briviesca (Burgos)

AGN, Irache, Lib. 542, 324v.

JOSÉ DE MONTERRUBIO

B. C.

11-10-1649

Fr. Gregorio de Castro

Cerezo (Burgos)

AGN, Irache, Lib. 542, 325r.

ÁNGEL DE MONREAL Y SARRIÁ

B. A. / B. T.
14-10-1649

Fr. Juan de Lezana

O. Cist.

Hijo de la Oliva

AGN, Irache, Lib. 542, 325r.

PEDRO DEL HOYO PELEGRÍN

B. C.

15-10-1649

Fr. Juan de Lezana

Puerto de Santoña (Burgos)

AGN, Irache, Lib. 542, 325r.

FRANCISCO DEL HOYO

B. C.

23-10-1649

Fr. Gregorio de Castro

Puerto de Santoña (Burgos)

AGN, Irache, Lib. 542, 325v.

FRANCISCO DEL CASTILLO

B. C.

23-10-1649

Fr. Gregorio de Castro

Burgos

AGN, Irache, Lib. 542, 325v.

FRANCISCO CALVO

B. C.

26-10-1649

Fr. Pedro de Vergaño

Villasilla (Burgos)

AGN, Irache, Lib. 542, 325v.

MIGUEL DE COSSÍO

B. C.

29-10-1649

Fr. Pedro de Vergaño

Villanueva de Henares (Burgos)

AGN, Irache, Lib. 542, 325v.

MIGUEL DE AYALA

B. C.

30-10-1649

Fr. Pedro de Vergaño

Villavedón (Burgos)

AGN, Irache, Lib. 542, 326r. 
MARTÍN RUIZ

B. C.

30-10-1649

Fr. Pedro de Vergaño

Amaya (Burgos)

AGN, Irache, Lib. 542, 326r.

JACINTO MANRIQUE

B. C.

30-10-1649

Fr. Pedro de Vergaño

Santibáñez (Burgos)

AGN, Irache, Lib. 542, 326r.

ALONSO MERINO DE PORRAS

B. C.

9-11-1649

Fr. Juan de Lezana

Pesquera de Sedano (Burgos)

AGN, Irache, Lib. 542, 326r.

\section{MATEO DE PUENTE}

B. C.

10-11-1649

Fr. Pedro de Vergaño

Tribrisca (Burgos)

AGN, Irache, Lib. 542, 326v.

MATEO DEL RÍO

B. C.

12-11-1649

Fr. Domingo Gutiérrez

Villasilos (Burgos)

AGN, Irache, Lib. 542, 326v.

PEDRO DE SANTA MARÍA

B. C.

24-11-1649 Reprobado por dos veces, con opción a volverse a presentar

1-8-1652 Aprobado

Fr. Juan de Lezana

Pangusión (Burgos)

AGN, Irache, Lib. 542, 326v, 366r.

\section{JUAN DE GANUZA}

B. A.

25-11-1649

Fr. Domingo Gutiérrez
Arróniz (Pamplona)

AGN, Irache, Lib. 542, 327r.

MANUEL GARCÍA

B. C.

3-12-1649

Fr. Gregorio de Castro

Villatoro (Burgos)

AGN, Irache, Lib. 542, 327r.

ANDRÉS DE MONTEÓN

B. A.

4-12-1649

Fr. Domingo Gutiérrez

Nájera (Nullius Diocesis)

AGN, Irache, Lib. 542, 327r.

JOSÉ DE VAÑES

B. C.

9-12-1649

Fr. Juan de Lezana

Burgos

AGN, Irache, Lib. 542, 327v.

JUAN BAUTISTA ARBIZU

B. C.

9-12-1649

Fr. Juan de Lezana

Burgos

AGN, Irache, Lib. 542, 327v.

FRANCISCO SANZ VALIENTE

B. C.

19-12-1649

Reprobado por dos veces

Villafranca de Montes de Oca (Burgos)

AGN, Irache, Lib. 542, 327v.

DIEGO DE LA PEÑA

B. C.

6-1-1650

Fr. Gregorio de Castro

Avellanosa (Burgos)

AGN, Irache, Lib. 542, 328r.

FRANCISCO GONZÁLEZ DE SALCEDO

B. C.

11-1-1650 
Fr. Juan de Lezana

Calatayud

AGN, Irache, Lib. 542, 328r.

JERÓNIMO MARTÍNEZ

B. T. / L. T. / D. T.

12-1-1650

Fr. Martín Izquierdo, abad

Soria (Osma)

AGN, Irache, Lib. 542, 328r.

\section{GREGORIO DE CASTRO}

B. A. / L. A. / M. A. / B. T. / L. T. / D. T.

12-1-1650

Fr. Martín Izquierdo, abad

O. S. B.

Lector en Irache

Profeso de San Juan de Burgos

AGN, Irache, Lib. 542, 328v.

\section{SEBASTIÁN MARTÍNEZ}

B. C.

14-1-1650

Fr. Juan de Lezana

Lantadilla (Palencia)

AGN, Irache, Lib. 542, 328v.

\section{SIMÓN DE MURUGARREN}

B. L. / L. L. / L. C.

27-1-1650 / 8-8-1651

Fr. Gregorio de Castro / Fr. Martín Izquierdo, abad

Luquín (Pamplona)

B. C. en Salamanca

AGN, Irache, Lib. 542, 328v, 353v.

BARTOLOMÉ GUTIÉRREZ DE LA RASI-

LLA

B. C.

31-1-1650

Fr. Juan de Lezana

Los Corrales de Buelna (Burgos)

AGN, Irache, Lib. 542, 329r.

FRANCISCO DE MURGA

B. C. / L. C.

7-2-1650

Fr. Martín Izquierdo, abad
San Millán de la Cogolla (Nullius Diocesis)

Prebendado en Málaga

AGN, Irache, Lib. 542, 329r.

BERNARDO DE ESTÚÑIGA

B. A. / L. A. / M. A. / B. T. / L. T. / D. T.

20-2-1650

Fr. Martín Izquierdo, abad

O. S. B.

Predicador

AGN, Irache, Lib. 542, 329v.

FRANCISCO DE EGUILUZ

B. T. / L. T. / D. T.

22-2-1650

Fr. Martín Izquierdo, abad

Salinas (Burgos)

AGN, Irache, Lib. 542, 329v.

ESTEBAN DE SUGADI

B. A. / L. A. / M. A. / B. T. / L. T. / D. T.

26-2-1650

Fr. Martín Izquierdo, abad

O. S. B.

AGN, Irache, Lib. 542, 329v.

ROSENDO ÁLVAREZ

B. A. / L. A. / M. A. / B. T. / L. T. / D. T.

27-2-1650

Fr. Martín Izquierdo, abad

O. S. B.

Certificación de su examen hecho el 26-6-

1644

AGN, Irache, Lib. 542, 33 or.

DIEGO PÉREZ

B. C.

8-3-1650

Fr. Juan de Lezana

Novales (Burgos)

AGN, Irache, Lib. 542, 330v.

JUAN DE COVARRUBIAS

B. C.

8-3-1650

Fr. Juan de Lezana

Tabanera (Burgos)

AGN, Irache, Lib. 542, $330 v$. 
JACINTO DE VALLES

B. C.

$-/ 3-1650$

Fr. Gregorio de Castro

Villarán (Burgos)

AGN, Irache, Lib. 542, 330v.

JACINTO DE VELARDE

B. $\mathrm{T}$.

21-3-1650

Fr. Juan de Lezana

Viérnoles (Burgos)

AGN, Irache, Lib. 542, 330v.

FERNANDO DE CORCUERA

B. C.

26-3-1650

Fr. Juan de Lezana

Salinas (Burgos)

AGN, Irache, Lib. 542, 331r.

\section{MARTÍN FRANCÉS}

B. A.

26-3-1650

Fr. Domingo Gutiérrez

Corera (Calahorra)

AGN, Irache, Lib. 542, 331r.

ALBERTO PÉREZ

B. A. / B. A. / B. M.

27-3-1650

Fr. Domingo Gutiérrez / Dr. Lizondo

La Zurda (Huesca)

AGN, Irache, Lib. 542, 331r.

JUAN DE SARMIENTO

B. C.

7-4-1650

Fr. Gregorio de Castro

Huérmeces (Burgos)

AGN, Irache, Lib. 542, 331v.

ANDRÉS GÓMEZ DE SALAZAR

B. C.

7-4-1650

Fr. Pedro de Vergaño

Cascajares (Burgos)

AGN, Irache, Lib. 542, 331v.

\section{JOSÉ LARRUY}

B. C.

13-4-1650

Fr. Juan de Lezana

Solar (Lérida)

AGN, Irache, Lib. 542, 331v.

\section{MARTÍN DE SALINAS}

B. A.

25-4-1650

Fr. Domingo Gutiérrez

Obanos (Pamplona)

AGN, Irache, Lib. 542, 332r.

BENITO VILLAR RUIZ

B. C.

27-4-1650

Fr. Juan de Lezana

Nazar (Calahorra)

AGN, Irache, Lib. 542, 332r.

ANDRÉS LASTERRA

L. L.

28-4-1650

Fr. Martín Izquierdo, abad

Artajona (Pamplona)

AGN, Irache, Lib. 542, 332r.

FRANCISCO DE GUINEA SALAZAR

B. C.

28-4-1650

Fr. Pedro de Vergaño

Osma (Calahorra)

AGN, Irache, Lib. 542, 332v.

JOSÉ DE NÁJERA SALVADOR

B. C.

28-4-1650

Fr. Gregorio de Castro

Ojacastro (Burgos)

AGN, Irache, Lib. 542, 332v.

\section{MANUEL CORERA}

B. A. / L. A. / M. A. / B. T. / L. T. / D. T. 1-5-1650

Fr. Martín Izquierdo, abad

O. S. B.

Profeso en Valladolid

AGN, Irache, Lib. 542, 332v. 
FRANCISCO SÁENZ VALIENTE

B. C.

6-5-1650

Fr. Gregorio de Castro

Villafranca Montes de Oca (Burgos)

AGN, Irache, Lib. 542, 333r.

\section{GREGORIO CORREA}

B. A.

7-5-1650

Fr. Domingo Gutiérrez

O. de M.

Provincia de Castilla

AGN, Irache, Lib. 542, 333r.

FRANCISCO DE ELORZA

B. T.

7-5-1650

Fr. Pedro de Vergaño

Antoniano (Calahorra)

AGN, Irache, Lib. 542, 333r.

JOSÉ DE PALACIOS

B. C.

16-5-1650

Fr. Juan de Lezana

Revilla del Campo (Burgos)

AGN, Irache, Lib. 542, 333v.

BLAS HERNÁIZ PÉREZ

B. C.

16-5-1650

Fr. Juan de Lezana

Burgos

AGN, Irache, Lib. 542, 333v.

PEDRO DE BÁRCENA

B. A. / L. A. / M. A. / B. T. / L. T. / D. T.

24-5-1650

Fr. Martín Izquierdo, abad

O. S. B.

Profeso en San Zoilo

AGN, Irache, Lib. 542, 333v.

JUAN GÓMEZ DE CADIÑANOS

B. C.

25-5-1650

Fr. Gregorio de Castro
Gabanes (Burgos)

AGN, Irache, Lib. 542, 334r.

FRANCISCO DE ARAUJO

B. C.

27-5-1650

Fr. Gregorio de Castro

Viana del Bollo (Astorga)

AGN, Irache, Lib. 542, 334r.

ANTONIO ESCUDERO

B. C.

31-5-1650

Fr. Juan de Lezana

Yudego (Burgos)

Arróniz

AGN, Irache, Lib. 542, 334r.

JUAN DE ARROYO

B. C.

11-6-1650

Fr. Pedro de Vergaño

Talamillo (Burgos)

AGN, Irache, Lib. 542, 334v.

FRANCISCO BRAVO

B. C.

11-6-1650

Fr. Pedro de Vergaño

San Mamés de Abar (Burgos)

AGN, Irache, Lib. 542, 334v.

MANUEL IZQUIERDO

B. A.

12-6-1650

Fr. Domingo Gutiérrez

Ocón (Pamplona)

AGN, Irache, Lib. 542, 334v.

PEDRO BLANCO

B. C.

22-6-1650

Fr. Pedro de Vergaño

Pozancos (Burgos)

AGN, Irache, Lib. 542, 335r.

DIEGO LÓPEZ DE ANGULO

B. C. 
26-6-1650

Fr. Pedro de Vergaño

Cascajares (Burgos)

AGN, Irache, Lib. 542, 335r.

PEDRO MARTÍNEZ DE ALVINAGORTA

B. A.

5-7-1650

Fr. Domingo Gutiérrez

Aulestia (Calahorra)

AGN, Irache, Lib. 542, 335r.

\section{BERNARDO MARTÍNEZ}

B. A.

11-7-1650

Fr. Domingo Gutiérrez

Arróniz (Pamplona)

AGN, Irache, Lib. 542, 335r.

FRANCISCO DE LARRINAGA

B. A. / B. T. / L. T. / D.T.

20-7-1650

Fr. Martín Izquierdo, abad

Arnedo (Calahorra)

AGN, Irache, Lib. 542, 335v.

ANDRÉS GONZÁLEZ

B. C.

28-7-1650

Fr. Pedro de Vergaño

Villafría (Burgos)

AGN, Irache, Lib. 542, 335v.

JUAN ALONSO

B. C.

30-7-1650

Fr. Pedro de Vergaño

Olleros (Burgos)

AGN, Irache, Lib. 542, 335v.

\section{ALONSO DE ALARCÓN}

B. C.

30-7-1650

Fr. Martín Izquierdo, abad

Hontecillas (Cuenca)

AGN, Irache, Lib. 542, 335v.

\section{PEDRO FRANCO}

B. C.
10-8-1650

Fr. Pedro de Vergaño

Poza (Burgos)

AGN, Irache, Lib. 542, 336r.

GREGORIO DE NÁJERA CASTILLO

B. C.

$13-8-1650$

Fr. Juan de Lezana

Burgos

AGN, Irache, Lib. 542, 336v.

JUAN DE CARVAJAL Y MENDOZA

B. C.

17-8-1650

Fr. Martín Izquierdo, abad

Madrid (Toledo)

AGN, Irache, Lib. 542, 336v.

JOSÉ DE TORRES CHASCO

B. A.

20-8-1650

Fr. Domingo Gutiérrez

O. de M.

AGN, Irache, Lib. 542, 336v.

JERÓNIMO DE TORQUEMADA

B. A. / L. A. / M. A. / B. T. / L. T. / D. T.

30-8-1650

Fr. Francisco Crespo, Abad de San Pedro de

Eslonza y Vicecanciller de Irache

O. S. B.

Predicador

Profeso en San Claudio de León

AGN, Irache, Lib. 542, 337r.

ANTONIO MARTÍNEZ CUMPLIDO

B. C.

2-9-1650

Fr. Pedro de Vergaño

Haro (Calahorra)

AGN, Irache, Lib. 542, 337r.

DOMINGO DE BARRIO

B. C.

5-9-1650

Fr. Pedro de Vergaño

Presencio (Burgos)

AGN, Irache, Lib. 542, 337r. 
FRANCISCO SECO

B. C.

13-9-1650

Fr. Gregorio de Castro

Melgar de Fernamental (Burgos)

AGN, Irache, Lib. 542, 337v.

BERNABÉ MARTÍNEZ DE ALCÁNTARA

B. C.

13-9-1650

Fr. Gregorio de Castro

Melgar de Fernamental (Burgos)

AGN, Irache, Lib. 542, 337v.

\section{MATÍAS GONZÁLEZ}

B. C.

15-9-1650

Fr. Gregorio de Castro

Melgar de Fernamental (Burgos)

AGN, Irache, Lib. 542, 337v.

FRANCISCO DE TOLEDO

B. C.

17-9-1650

Fr. Pedro de Vergaño

Tabanera (Burgos)

AGN, Irache, Lib. 542, 337v.

GONZALO DEL BUSTO

B. A.

22-9-1650

Fr. Pedro de Vergaño

Viana (Calahorra)

Estudiante en Pamplona

AGN, Irache, Lib. 542, 338r.

MATEO JUÁREZ

B. C.

23-9-1650

Fr. Gregorio de Castro

Melgar de Fernamental (Burgos)

AGN, Irache, Lib. 542, 338r.

\section{JUAN MARÍN}

B. A.

25-9-1650

Fr. Gregorio de Castro

Villamediana (Calahorra)
Estudiante en Alcalá

AGN, Irache, Lib. 542, 338r.

\section{FRANCISCO CLARET}

B. A. / B. T. / L. T. / D. T.

30-9-1650

Fr. Pedro de Vergaño

Preixana (Solsona)

AGN, Irache, Lib. 542, 338v.

JUAN FRANCISCO JARABO

B. M. / L. M. / D. M.

3-10-1650

Fr. Gregorio de Castro / Dr. Jacinto de Guevara

Calatayud (Tarazona)

Estudiante en Valencia

AGN, Irache, Lib. 542, 338v.

DIEGO DE ALVARADO

L. C.

5-10-1650

Fr. Pedro de Vergaño

Limpias (Burgos)

AGN, Irache, Lib. 542, 338v.

CRISTÓBAL GAYARRE Y ATOCHA

L. C. / D. C.

5-10-1650

Fr. Gregorio de Castro / Dr. Luis Echalar

Garda (Pamplona)

AGN, Irache, Lib. 542, 339r.

JACINTO MARTÍNEZ

B. C.

9-10-1650

Fr. Martín Izquierdo, abad

Logroño (Calahorra)

AGN, Irache, Lib. 542, 339r.

DIEGO DE ESCALONA

B. A.

16-10-1650

Fr. Pedro de Vergaño

Arnedo (Calahorra)

AGN, Irache, Lib. 542, 339r.

ANTONIO LÓPEZ DE VILLEGAS

B. C. 
31-10-1650

Fr. Gregorio de Castro

Monegro (Burgos)

AGN, Irache, Lib. 542, 339v.

FRANCISCO DE PEÑARANDA

B. C.

5-11-1650

Fr. Gregorio de Castro

Burgos

AGN, Irache, Lib. 542, 339v.

MIGUEL GIL

L. L. / D. L.

11-11-1650

Fr. Pedro de Vergaño

Zaragoza

AGN, Irache, Lib. 542, 339v.

MATEO MORENO DE CISNEROS

B. T. / L. T. / D. T.

20-11-1650

Fr. Martín Izquierdo, abad

... (Osma)

AGN, Irache, Lib. 542, 340 .

PEDRO TURLAN

B. C. / L. C. / D. C.

25-11-1650

Fr. Martín Izquierdo, abad

Navascués (Zaragoza)

AGN, Irache, Lib. 542, 340v.

PEDRO PÉREZ

B. A. / B. T.

1-12-1650

Fr. Domingo Gutiérrez

Castrojeriz (Burgos)

AGN, Irache, Lib. 542, $340 v$.

PEDRO DE LAGUARDIA

B. C.

2-12-1650

Fr. Pedro de Vergaño

Mansilla de la Sierra (Burgos)

AGN, Irache, Lib. 542, 340v.

GONZALO DE EULATE

B. C./ L. C.
10-12-1650

Fr. Martín Izquierdo, abad

Eulate (Calahorra)

AGN, Irache, Lib. 542, 341r.

GREGORIO DE TOLEDO

B. A. / B. T. / L. T. / D. T.

21-12-1650

Fr. Martín Izquierdo, abad

O. S. B.

Predicador

Profeso de San Benito de Valladolid

AGN, Irache, Lib. 542, 341r.

LUCAS MERINO

B. C.

21-12-1650

Fr. Juan de Lezana

Burgos

AGN, Irache, Lib. 542, 341v.

MAURO DE SOMOZA

B. A. / B. T. / L. T. / D. T.

1-1-1651

Fr. Martín Izquierdo, abad

O. S. B.

Profeso en Celanova

AGN, Irache, Lib. 542, 341v.

PEDRO DE URRACA

B. C.

24-1-1651

Fr. Pedro de Vergaño

Baños (Calahorra)

AGN, Irache, Lib. 542, 341v.

FRANCISCO SÁENZ

B. A.

7-2-1651

Fr. Domingo Gutiérrez

Lodosa (Pamplona)

AGN, Irache, Lib. 542, 342r.

GREGORIO DE LARRAGA

B. $\mathrm{M}$.

7-2-1651

Fr. Gregorio de Castro / Dr. Francisco de Guevara 
Valtierra (Pamplona)

AGN, Irache, Lib. 542, 342r.

\section{GREGORIO MARTÍNEZ}

B. C.

8-2-1651

Fr. Juan de Lezana

Medina de Pomar (Burgos)

AGN, Irache, Lib. 542, 342r.

PEDRO RUIZ DE ANDREO

B. A. / B. T.

15-2-1651

Fr. Anselmo López

Barnes (Burgos)

AGN, Irache, Lib. 542, 342v.

FRANCISCO RUIZ TRECHUELO

B. C.

15-2-1651

Fr. Gregorio de Castro

Casares (Burgos)

AGN, Irache, Lib. 542, 342v.

JUAN GÓMEZ

B. C.

2-3-1651

Fr. Juan de Lezana

Toba (Burgos)

AGN, Irache, Lib. 542, 342v.

ANTONIO COSCULLUELA

B. C.

2-3-1651

Fr. Juan de Lezana

El Grado (Barbastro)

AGN, Irache, Lib. 542, 343r.

FRANCISCO DE PEREDA

B. C.

7-3-1651

Fr. Gregorio de Castro

Bocos (Burgos)

AGN, Irache, Lib. 542, 343r.

FRANCISCO FERNÁNDEZ

B. C.

17-3-1651
Fr. Gregorio de Castro

Beleña (Burgos)

AGN, Irache, Lib. 542, 343r.

PEDRO DE LABID

B. C.

18-3-1651

Fr. Juan de Lezana

Logroño (Calahorra)

AGN, Irache, Lib. 542, 343v.

GABRIEL DE YURRE

B. A.

26-3-1651

Fr. Domingo Gutiérrez

S. Vicente (Calahorra)

AGN, Irache, Lib. 542, 343v.

LORENZO DE VICUÑA

B. A.

26-3-1651

Fr. Domingo Gutiérrez

G... (Calahorra)

AGN, Irache, Lib. 542, 343v.

BALTASAR LÓPEZ DE VERGARA

B. A.

29-3-1651

Fr. Domingo Gutiérrez

Zuazo (Calahorra)

AGN, Irache, Lib. 542, 344r.

JUAN LÓPEZ

B. C.

30-3-1651

Fr. Gregorio de Castro

Valderías (Burgos)

AGN, Irache, Lib. 542, 344r.

BARTOLOMÉ ARGENTÉ

L. M. / D. M.

4-4-1651

Fr. Martín Izquierdo / Dr. Jacinto Guevara

Tarragona

AGN, Irache, Lib. 542, 344v.

ANTONIO DE CASCAJARES Y BLANCAS

B. C. / L. C. 
6-4-1651

Fr. Martín Izquierdo, abad

Belchite (Zaragoza)

AGN, Irache, Lib. 542, 344v.

MARTÍN AZPILIAGA

B. C.

8-4-1651

Fr. Pedro de Vergaño

La Revilla (Burgos)

AGN, Irache, Lib. 542, 345r.

FRANCISCO DE SALAMANCA

B. C.

11-4-1651

Fr. Juan de Lezana

Burgos

AGN, Irache, Lib. 542, 345r.

JUAN DE ZADORNIL

B. A.

11-4-1651

Fr. Juan de Lezana

... (Burgos)

AGN, Irache, Lib. 542, 345v.

FRANCISCO DE OCÓN

B. A.

$13-4-1651$

Fr. Domingo Gutiérrez

Aldeanueva (Calahorra)

AGN, Irache, Lib. 542, 345v.

MARCOS GONZÁLEZ

B. C. / L. C.

14-4-1651 / 19-10-1658

Fr. Pedro de Vergaño / Fr. Anselmo López

Medina de Pomar (Burgos)

AGN, Irache, Lib. 542, 345v, s. f.

TOMÁS DE URIBARREN

B. A.

25-4-1651

Fr. Domingo Gutiérrez

Zizur Mayor (Pamplona)

AGN, Irache, Lib. 542, 346r.

PEDRO DE AZCÁRATE

B. A.
25-4-1651

Fr. Domingo Gutiérrez

Munárriz (Pamplona)

AGN, Irache, Lib. 542, 346r.

ANTONIO DE ARISTEGUI

B. A.

25-4-1651

Fr. Domingo Gutiérrez

Pamplona

AGN, Irache, Lib. 542, 346r.

JUAN PÉREZ

B. A.

25-4-1651

Fr. Domingo Gutiérrez

Arcos (Pamplona)

AGN, Irache, Lib. 542, 346r.

MARTÍN CONGET

B. A.

25-4-1651

Fr. Domingo Gutiérrez

Castillonuevo (Pamplona)

AGN, Irache, Lib. 542, 346r.

MIGUEL DE COSTARENA

B. A.

25-4-1651

Fr. Domingo Gutiérrez

Errazu (Pamplona)

AGN, Irache, Lib. 542, 346r.

PEDRO ARRICHEA

B. A.

25-4-1651

Fr. Domingo Gutiérrez

Maza (Pamplona)

AGN, Irache, Lib. 542, 346r.

JERÓNIMO DE SALANABA

B. A.

25-4-1651

Fr. Domingo Gutiérrez

Pamplona

AGN, Irache, Lib. 542, 346r.

JUAN DE BARANDALLA

B. A. 
25-4-1651

Fr. Domingo Gutiérrez

Nazar (Pamplona)

AGN, Irache, Lib. 542, 346r.

MIGUEL DE IBARROLA

B. A.

25-4-1651

Fr. Domingo Gutiérrez

Pamplona

AGN, Irache, Lib. 542, 346r.

PEDRO DE SANMARTÍN

B. A.

25-4-1651

Fr. Domingo Gutiérrez

Barrañán (Pamplona)

AGN, Irache, Lib. 542, 346r.

JUAN DE BARRENECHEA

B. A.

25-4-1651

Fr. Domingo Gutiérrez

Errazu (Pamplona)

AGN, Irache, Lib. 542, 346r.

MIGUEL DE URROZ

B. A.

25-4-1651

Fr. Domingo Gutiérrez

Ordanaz (Pamplona)

AGN, Irache, Lib. 542, 346r.

JUAN DE MENDIONDO

B. A.

25-4-1651

Fr. Domingo Gutiérrez

Ituren (Pamplona)

AGN, Irache, Lib. 542, 346r.

JUAN DE GUERRA

B. A.

25-4-1651

Fr. Domingo Gutiérrez

Sorauren (Pamplona)

AGN, Irache, Lib. 542, 346r.

MARTÍN DE ALDUNATE

B. A.
25-4-1651

Fr. Domingo Gutiérrez

Artaiz (Pamplona)

AGN, Irache, Lib. 542, 346r.

FRANCISCO DE BALANZA

B. A.

25-4-1651

Fr. Domingo Gutiérrez

Urroz (Pamplona)

AGN, Irache, Lib. 542, 346r.

GREGORIO RUIZ

B. A. / B. T.

1-5-1651

Fr. Juan de Lezana

San Pedro Samuel (Burgos)

AGN, Irache, Lib. 542, 346v.

PEDRO RUIZ DE ARBOSO

B. C.

5-5-1651

Fr. Gregorio de Castro

Arboso - Carranza

AGN, Irache, Lib. 542, 346v.

GABRIEL DE VELLISCA

B. A.

6-5-1651

Fr. Domingo Gutiérrez

Saceda del Río (Cuenca)

AGN, Irache, Lib. 542, 346v.

ANTONIO DE ARAMBURU

B. L. / L. L. / D. L.

7-5-1651

Fr. Gregorio de Castro

Espinal (Pamplona)

AGN, Irache, Lib. 542, 347r.

FRANCISCO PARDO

B. C.

8-5-1651

Fr. Gregorio de Castro

Ormaza (Burgos)

AGN, Irache, Lib. 542, 347r.

FRANCISCO DE BELTRÁN

B. C. 
26-5-1651

Fr. Martín Izquierdo, abad

Viguera (Calahorra)

AGN, Irache, Lib. 542, 348r.

JUAN PÉREZ

B. T.

26-5-1651

Fr. Gregorio de Castro

Miñón (Burgos)

AGN, Irache, Lib. 542, 348r.

JUAN DE LIMPIAS

B. C.

28-5-1651

Fr. Gregorio de Castro

Colindres (Burgos)

AGN, Irache, Lib. 542, 348r.

GREGORIO DE ACEDO

B. A.

30-5-1651

Fr. Gregorio de Castro

Espronceda (Calahorra)

AGN, Irache, Lib. 542, 348v.

JOSÉ DOMÍNGUEZ

B. A. / B. M.

3-6-1651

Fr. Gregorio de Castro / Dr. Jacinto de Guevara

Tudela (Nullius Diocesis)

AGN, Irache, Lib. 542, 348v.

JOSÉ LÓPEZ

B. C.

6-6-1651

Fr. Gregorio de Castro

Burgos

AGN, Irache, Lib. 542, 349r.

SANTIAGO DE MUGA

B. C.

7-6-1651

Fr. Gregorio de Castro

Colindres (Burgos)

AGN, Irache, Lib. 542, 349r.
ANDRÉS GONZÁLEZ

B. C.

9-6-1651

Fr. Gregorio de Castro

Vilvestre (Burgos)

AGN, Irache, Lib. 542, 349r.

DIEGO DE GAMBOA

B. C.

9-6-1651

Fr. Gregorio de Castro

Logroño (Calahorra)

AGN, Irache, Lib. 542, 349v.

JACINTO DE SOMOZA

B. C.

14-6-1651

Fr. Juan de Lezana

Escalante (Burgos)

AGN, Irache, Lib. 542, 349v.

FERNANDO DÍAZ

B. C.

17-6-1651

Fr. Juan de Lezana

Lerma (Nullius Diocesis)

AGN, Irache, Lib. 542, 349v.

JUAN SANZ

B. $\mathrm{T}$.

17-6-1651

Fr. Juan de Lezana

Lerma (Nullius Diocesis)

AGN, Irache, Lib. 542, 350r.

MARTÍN GARCÍA

B. C.

25-6-1651

Fr. Gregorio de Castro

Mazuela (Burgos)

AGN, Irache, Lib. 542, 350r.

JUAN FERNÁNDEZ DE VALDERRAMA

B. C.

25-6-1651

Fr. Gregorio de Castro

Cascajares (Burgos)

AGN, Irache, Lib. 542, 350r. 
JUAN DE PAREDES

L. L. / D. L.

1-7-1651

Fr. Martín Izquierdo, abad

Villaescusa (Burgos)

B. L. en Valladolid

AGN, Irache, Lib. 542, 350v.

\section{GABRIEL DE PEREDA}

B. C.

2-7-1651

Fr. Gregorio de Castro

Salazar (Burgos)

AGN, Irache, Lib. 542, 350v.

MARTÍN DE ANTEZANA

B. A.

12-7-1651

Fr. Gregorio de Castro

Algueta (Calahorra)

AGN, Irache, Lib. 542, 351r.

MARTÍN DE LENCES

B. C.

15-7-1651

Fr. Gregorio de Castro

San Martín de Biedma (Burgos)

AGN, Irache, Lib. 542, 351r.

PABLO GARCÍA

B. C.

19-7-1651

Fr. Gregorio de Castro

Santa Cruz del Pozo (Burgos)

AGN, Irache, Lib. 542, 351r.

ANTONIO GARCÍA

B. C.

25-7-1651

Fr. Gregorio de Castro

San Pedro Manrique (Calahorra)

AGN, Irache, Lib. 542, 351v.

PEDRO GARCÍA DE OBALLE

B. L.

27-7-1651

Fr. Juan de Lezana

Astorga

AGN, Irache, Lib. 542, 351v.
MARTÍN BECERRA

L. A. / D. A. / L. T. / D. T.

29-7-1651

Fr. Martín Izquierdo, abad

O. Cist.

AGN, Irache, Lib. 542, 351v.

LORENZO DELGADO

B. C.

29-7-1651

Fr. Martín Izquierdo, abad

Burgos

AGN, Irache, Lib. 542, 352r.

JUAN AGUAYO

B. C.

29-7-1651

Fr. Martín Izquierdo, abad

Burgos

AGN, Irache, Lib. 542, 352r.

LUCAS SERENA

L. L. / D. L.

30-7-1651

Fr. Martín Izquierdo, abad // Ldo. Fco. de Cegama

Zaragoza

B. L.

AGN, Irache, Lib. 542, 352v.

\section{MIGUEL DE IRIBAS}

B. A.

1-8-1651

Fr. Gregorio de Castro

Manero (Pamplona)

AGN, Irache, Lib. 542, 353r.

JERÓNIMO DE RADA

L. C. / D. C.

1-8-1651

Fr. Martín Izquierdo, abad

Pamplona

AGN, Irache, Lib. 542, 353r.

SEBASTIÁN DE ERICE

L. T. / D. T.

7-8-1651

Fr. Martín Izquierdo, abad 
Obanos (Pamplona)

AGN, Irache, Lib. 542, 353v.

JUAN DE ARCE

B. C.

15-8-1651

Fr. Martín Izquierdo, abad

Rubena (Burgos)

AGN, Irache, Lib. 542, 354r.

BARTOLOMÉ DE AVELLANOSA

B. -

20-8-1651

Fr. Martín Izquierdo, abad

Celada del Camino (Burgos)

AGN, Irache, Lib. 542, 354r.

PEDRO DE FUICA Y VERÁRTEGUI

B. T.

24-8-1651

Fr. Martín Izquierdo, abad

Laredo (Burgos)

AGN, Irache, Lib. 542, 354r.

JUAN DE VILLEGAS

B. C.

30-8-1651

Fr. Juan de Lezana

Burgos

AGN, Irache, Lib. 542, 354v.

ANSELMO PÉREZ

B. A. / L. A. / M. A. / B. T. / L. T. / D. T. 31-8-1651

Fr. Martín Izquierdo, abad

O. S. B.

Profeso en San Salvador de Lorenzana

AGN, Irache, Lib. 542, 354v.

\section{JUAN DE AYENDI}

B. A.

16-9-1651

Fr. Gregorio de Castro

Tolosa (Pamplona)

AGN, Irache, Lib. 542, 354v.

MANUEL DE CASTELLANOS

B. C.
22-9-1651

Fr. Gregorio de Castro

Torresandino (Burgos)

AGN, Irache, Lib. 542, 355r.

SANTIAGO DE IZCARI

B. C.

27-9-1651

Fr. Gregorio de Castro

Sto. Domingo de la Calzada (Calahorra)

AGN, Irache, Lib. 542, 355r.

PEDRO DE LETE

B. A. / L. A.

28-9-1651

Fr. Martín Izquierdo, abad

Estella (Pamplona)

AGN, Irache, Lib. 542, 355r.

JUAN RUIZ

B. A.

30-9-1651

Fr. Gregorio de Castro

Hiniestra (Burgos)

AGN, Irache, Lib. 542, 355r.

MATEO DE ECHAURI Y ZÁRATE

B. A. / L. A.

3-10-1651

Fr. Gregorio de Castro

Tudela (Nullius Diocesis)

AGN, Irache, Lib. 542, 355r.

JOSÉ DE ILZARBE

B. A. / L. A.

3-10-1651

Fr. Gregorio de Castro

Tudela (Nullius Diocesis)

AGN, Irache, Lib. 542, 355r.

PEDRO DÍEZ

B. C. / L. C.

4-10-1651

Fr. Gregorio de Castro

Ezernes (Burgos)

AGN, Irache, Lib. 542, 355r.

JACINTO FERNÁNDEZ DE SAN SALVADOR

B. C./ L. C. 
4-10-1651

Fr. Gregorio de Castro

Santillana (Burgos)

AGN, Irache, Lib. 542, 356r.

FELIPE MARTÍNEZ

B. C.

6-10-1651

Fr. Gregorio de Castro

Ontanas (Burgos)

AGN, Irache, Lib. 542, 356r.

\section{ANTONIO CARRERO}

B. C. / L. C.

11-10-1651

Fr. Gregorio de Castro

Ontanas (Burgos)

AGN, Irache, Lib. 542, 356r.

FERMÍN DE VICUÑA

L. L.

11-10-1651

Fr. Gregorio de Castro / Ldo. Fco. de Cegama

Pamplona

AGN, Irache, Lib. 542, 356v.

JUAN APERIUCHEA

L. L.

11-10-1651

Fr. Gregorio de Castro / Ldo. Fco. de Cegama

Tudela (Pamplona)

AGN, Irache, Lib. 542, 356v.

JUAN FUERTES

B. $\mathrm{T}$.

21-10-1651

Fr. Gregorio de Castro

Fogo (Jaca)

AGN, Irache, Lib. 542, 357r.

JOSÉ PÉREZ BLANCO

B. C.

29-10-1651

Fr. Gregorio de Castro

San Asensio (Calahorra)

AGN, Irache, Lib. 542, 357r.
GARCÍA DE MIERA RUBALCABA

L. C.

6-11-1651

Fr. Martín Izquierdo, abad

Liérganes (Burgos)

AGN, Irache, Lib. 542, 357r.

FRANCISCO DE LOIZAGA

B. C.

11-11-1651

Fr. Gregorio de Castro

Sopuerta (Burgos)

AGN, Irache, Lib. 542, 357v.

MAURO DE PONTE

B. T. / L. T. / D. T.

11-11-1651

Fr. Juan de Lezana

O. S. B.

Profeso en San Martín de Santiago

AGN, Irache, Lib. 542, 357v.

ROSENDO DE MÚJICA

B. A. / L. A. / M. A. / B. T. / L. T. / D. T.

17-11-1651

Fr. Martín Izquierdo, abad

O. S. B.

Profeso en Celanova

AGN, Irache, Lib. 542, 358r.

JUAN DE MATA

B. T.

21-11-1651

Fr. Juan de Lezana

Celadilla-Sotobrín (Burgos)

AGN, Irache, Lib. 542, 358v.

LUCAS PASCUAL DE ZORRILLA

B. A. / B. T.

25-11-1651

Fr. Gregorio de Castro

Sta. María de Invierno (Burgos)

AGN, Irache, Lib. 542, 358v.

FRANCISCO DE BREBILLA

B. C.

27-11-1651

Fr. Juan de Lezana 
Berriatúa (Calahorra)

AGN, Irache, Lib. 542, 358v.

VICENTE MORROGÓN

B. C.

27-11-1651

Fr. Juan de Lezana

Valle de Areco (Burgos)

AGN, Irache, Lib. 542, 359r.

\section{DIEGO SÁNCHEZ DE LA VEGA}

B. C.

5-12-1651

Fr. Gregorio de Castro

Cabuérniga (Burgos)

AGN, Irache, Lib. 542, 359r.

\section{PEDRO PANIAGUA}

B. A.

\section{5-12-1651}

Fr. Andrés de La Moneda, vicecanciller

Calahorra

AGN, Irache, Lib. 542, 359r.

ESTEBAN DE LANDETA

B. C.

17-12-1651

Fr. Pedro de Vergaño

Galdamez (Burgos)

AGN, Irache, Lib. 542, 359v.

DIEGO JIMÉNEZ DE ARELLANO LAGUNILLA

B. A. / B. T. / L. T. / D. T.

22-12-1651

Fr. Martín Izquierdo, abad

Arnedo (Calahorra)

Arcediano de Calahorra

AGN, Irache, Lib. 542, 359v.

FRANCISCO DE MENDÍVIL

B. C.

13-1-1652

Fr. Pedro de Vergaño

Portugalete (Burgos)

AGN, Irache, Lib. 542, 36or.

FRANCISCO DE LARREGUI

B. A.
13-1-1652

Fr. Andrés de La Moneda

Autol (Calahorra)

AGN, Irache, Lib. 542, 36or.

JUAN ANDRÉS MONTAÑA DE SALAZAR

B. C.

9-2-1652

Fr. Gregorio de Castro

Portugalete (Burgos)

AGN, Irache, Lib. 542, 36or.

\section{MATEO GÓMEZ DE VELASCO}

B. C.

11-2-1652

Fr. Gregorio de Castro

Haedo (Burgos)

AGN, Irache, Lib. 542, 36ov.

MARTÍN SÁNCHEZ DE LA CUEVA

B. C.

14-2-1652

Fr. Pedro de Vergaño

Portugalete (Burgos)

AGN, Irache, Lib. 542, 36ov.

BENITO RODRÍGUEZ

B. C.

18-2-1652

Fr. Gregorio de Castro

Villanueva de Argaño (Burgos)

AGN, Irache, Lib. 542, 360v.

ANDRÉS DE LA FUENTE

B. C.

22-2-1652

Fr. Juan de Lezana

Villanueva de Argaño (Burgos)

AGN, Irache, Lib. 542, 361r.

GREGORIO DÍEZ TRUCHUELO

B. C.

24-2-1652

Fr. Gregorio de Castro

Valdelacuesta (Burgos)

AGN, Irache, Lib. 542, 361r.

BARTOLOMÉ RAMÍREZ

B. C. 
24-2-1652

Fr. Gregorio de Castro

Medina de Pomar (Burgos)

AGN, Irache, Lib. 542, 361r.

JUAN DE GOIRI

B. C.

3-3-1652

Fr. Juan de Lezana

Castro Urdiales (Burgos)

AGN, Irache, Lib. 542, 361v.

ANDRÉS DE AZOFRA SAMANIEGO

B. C.

3-3-1652

Fr. Juan de Lezana

Nájera (Calahorra)

AGN, Irache, Lib. 542, 361v.

\section{JUAN FRANCISCO FERRER}

B. A. / B. M.

11-3-1652

Fr. Gregorio de Castro / Dr. Jacinto de Guevara

Calatayud (Tarazona)

AGN, Irache, Lib. 542, 361v.

JUAN DEL CASTILLO

B. C.

16-3-1652

Fr. Gregorio de Castro

Retuerto (Burgos)

AGN, Irache, Lib. 542, 362r.

SIMÓN GONZÁLEZ DE PEDROSA

B. C.

18-3-1652

Fr. Pedro de Vergaño

Cerezo (Burgos)

AGN, Irache, Lib. 542, 362r.

PEDRO HORNILLOS

B. C.

11-4-1652

Fr. Gregorio de Castro

Castrillo de Murcia (Burgos)

AGN, Irache, Lib. 542, 362r.
JOSÉ DE SÁMANO

B. C.

15-4-1652

Fr. Juan de Lezana

Santurce (Burgos)

AGN, Irache, Lib. 542, 362v.

DIEGO CALLEJA

B. C.

19-4-1652

Fr. Gregorio de Castro

Sasamón (Burgos)

AGN, Irache, Lib. 542, 362v.

FRANCISCO DE VILLEGAS

B. C.

19-4-1652

Fr. Gregorio de Castro

Sasamón (Burgos)

AGN, Irache, Lib. 542, 362v.

DIEGO DEL POZO

B. C.

19-4-1652

Fr. Gregorio de Castro

Sasamón (Burgos)

AGN, Irache, Lib. 542, 362v.

LUCAS DE QUINTANA

B. C.

20-4-1652

Fr. Pedro de Vergaño

Quintanavides (Burgos)

AGN, Irache, Lib. 542, 362v.

DIEGO DE ARCE

B. C.

5-5-1652

Fr. Juan de Lezana

Ubierna (Burgos)

AGN, Irache, Lib. 542, 363r.

ANTONIO RODRÍGUEZ

B. A. / B. T. / L. T. / D. T.

6-5-1652

Fr. Martín Izquierdo, abad

O.S. B.

Prior Mayor de S. Vicente de Salamanca

AGN, Irache, Lib. 542, 363r. 
LUIS DE SALCEDO Y ARBIZU

B. C.

8-5-1652

Fr. Martín Izquierdo, abad

Soria (Osma)

AGN, Irache, Lib. 542, 363v.

JUAN DE AYALA

B. C.

9-5-1652

Fr. Pedro de Vergaño

Villadiego (Burgos)

AGN, Irache, Lib. 542, 363v.

\section{ANTONIO GARCÍA}

B. C.

12-5-1652

Fr. Pedro de Vergaño

Castrillo de Murcia (Burgos)

AGN, Irache, Lib. 542, 363v.

PEDRO SÁNCHEZ

B. C.

15-5-1652

Fr. Juan de Lezana

Valle de Sosa (Burgos)

AGN, Irache, Lib. 542, 364r.

JUAN DE VALDERRAMA

B. C.

9-6-1652

Fr. Pedro de Vergaño

Lences (Burgos)

AGN, Irache, Lib. 542, 364r.

\section{PEDRO GUTIÉRREZ}

B. C.

14-6-1652

Fr. Juan de Lezana

Melgar de Fernamental (Burgos)

AGN, Irache, Lib. 542, 364r.

DAMIÁN DE GAVILÁN

B. C.

17-6-1652

Fr. Juan de Lezana

Poza (Burgos)

AGN, Irache, Lib. 542, 364V.
ESTEBAN GARCÍA DE ROQUE

B. C.

17-6-1652

Fr. Juan de Lezana

Poza (Burgos)

AGN, Irache, Lib. 542, 364v.

PEDRO DE SALABERRI

L. C. / D. C.

20-6-1652

Fr. Martín Izquierdo, abad

Maya (Pamplona)

AGN, Irache, Lib. 542, 364v.

JUAN DE RADA

L. L.

2-7-1652

Fr. Martín Izquierdo, abad / Ldo. Fco. de

Cegama

Pamplona

AGN, Irache, Lib. 542, 365r.

SEBASTIÁN DE SEGURA

B. M.

4-7-1652

Fr. Pedro de Vergaño / Dr. Jacinto de Guevara

Lerín (Pamplona)

AGN, Irache, Lib. 542, 365r.

GARCÍA DE MORETA MALDONADO Y PAZ

L. C. / D. C.

10-7-1652

Fr. Martín Izquierdo, abad

Frey Caballero de la Orden de Alcántara

Rector del Colegio de Alcántara de Salamanca

AGN, Irache, Lib. 542, 365v.

JUAN DE SEDANO

B. C.

13-7-1652

Fr. Juan de Lezana

Villarmero (Burgos)

AGN, Irache, Lib. 542, 365v.

FRANCISCO DÍEZ

B. C. 
13-7-1652

Fr. Juan de Lezana

Villarmero (Burgos)

AGN, Irache, Lib. 542, 365v.

ENRIQUE DE VIRIERZ

B. C.

17-7-1652

Fr. Juan de Lezana

Pamplona

AGN, Irache, Lib. 542, 366r.

FERNANDO GUTIÉRREZ DE TERÁN

B. C.

3-8-1652

Fr. Andrés de La Moneda

Revilla de Santullán (Burgos)

AGN, Irache, Lib. 542, 366r.

MARCOS LÓPEZ

B. C.

5-8-1652

Fr. Juan de Lezana

Ordaniz (Burgos)

AGN, Irache, Lib. 542, 366v.

DIEGO RUIZ MARTÍNEZ

B. C.

5-8-1652

Fr. Juan de Lezana

Aguilar de Campoo (Burgos)

AGN, Irache, Lib. 542, 366v.

TOMÁS HERRERO

B. T.

9-8-1652

Fr. Juan de Lezana

Masa (Burgos)

AGN, Irache, Lib. 542, 366v.

JUAN DE LAEZAÚN Y ANDIA

L. C.

14-8-1652

Fr. Juan de Lezana

Estella (Pamplona)

AGN, Irache, Lib. 542, 367r.

JUAN GASPAR DE RILLO

B. A.
18-8-1652

Fr. Andrés de La Moneda

Castejón de Tornos (Zaragoza)

AGN, Irache, Lib. 542, 367r.

JUAN DE ITURIAL

B. C.

27-8-1652

Fr. Pedro de Vergaño

Salinas de Añana (Burgos)

AGN, Irache, Lib. 542, 367v.

TOMÁS GÓMEZ

B. C.

31-8-1652

Fr. Juan de Lezana

Villaquirán de los Infantes (Burgos)

AGN, Irache, Lib. 542, 367v.

MARTÍN DE VALLEJO

B. C.

2-9-1652

Fr. Pedro de Vergaño

Anco, del Valle de Mena (Burgos)

AGN, Irache, Lib. 542, 368r.

JUAN DE LA IGLESIA

B. T.

2-9-1652

Fr. Pedro de Vergaño

Fresneda (Burgos)

B. A.

AGN, Irache, Lib. 542, 368r.

JUAN DE LA RIBA

B. A. / B. T. / L. T. / D. T.

7-9-1652

Fr. Pedro de Vergaño

O. S. B.

Profeso en Oña

Lector de Vísperas en San Vicente de Oviedo

AGN, Irache, Lib. 542, 368r.

SIMÓN GONZÁLEZ DE MARSILLA

B. C.

9-9-1652

Fr. Juan de Lezana 
Pedrosa de Río de Urbel (Burgos)

AGN, Irache, Lib. 542, 368v.

ANDRÉS DE BÁRCENA

B. C.

12-9-1652

Fr. Pedro de Vergaño

Santa María de Tajadura (Burgos)

AGN, Irache, Lib. 542, 369r.

\section{JUAN DE RENEDO}

B. T.

12-9-1652

Fr. Juan de Lezana

Guadilla de Villamar (Burgos)

AGN, Irache, Lib. 542, 369r.

PEDRO DE LA VEGA

B. C.

16-9-1652

Fr. Juan de Lezana

- (Burgos)

AGN, Irache, Lib. 542, 369v.

JOSÉ DE MENDIETA

B. C. / L. C.

24-9-1652

Fr. Juan de Lezana

Bilbao (Calahorra)

AGN, Irache, Lib. 542, 370r.

JOSÉ DE LA FUENTE

B. A.

24-9-1652

Fr. Andrés de La Moneda

Bilbao (Calahorra)

AGN, Irache, Lib. 542, $370 v$.

...

1652

...

AGN, Irache, Lib. 542, 371r.

FRANCISCO DE CANZANO

B. C.

25-9-1652

Fr. Pedro de Vergaño

Labastida (Calahorra)

AGN, Irache, Lib. 542, 371v.

\section{BARTOLOMÉ CALDERÓN}

B. C.

4-10-1652

Fr. Pedro de Vergaño

Reinosa (Burgos)

AGN, Irache, Lib. 542, 371v.

JOSÉ DE IRIGOYEN

B. A.

7-10-1652

Fr. Andrés de La Moneda

Pamplona

AGN, Irache, Lib. 542, 371v.

PEDRO GUTIÉRREZ

B. C.

12-10-1652

Fr. Pedro de Vergaño

Ormacas (Burgos)

AGN, Irache, Lib. 542, 372r.

JUAN DE UNGO

B. C.

14-10-1652

Fr. Juan de Lezana

Villafría (Burgos)

AGN, Irache, Lib. 542, 372r.

JUAN DE PAREDES

B. C.

25-10-1652

Fr. Juan de Lezana

Ameyugo (Burgos)

AGN, Irache, Lib. 542, 372v.

MELCHOR DE AHEDO

B. C.

30-10-1652

Fr. Juan de Lezana

Gibaja (Burgos)

AGN, Irache, Lib. 542, 372v.

TOMÁS MIGUEL

B. C.

11-11-1652

Fr. Gregorio de Castro

Villaquirán de los Infantes (Burgos)

AGN, Irache, Lib. 542, 373r. 
JOSÉ GUTIÉRREZ

B. C.

21-11-1652

Fr. Gregorio de Castro

Burgos

AGN, Irache, Lib. 542, 373r.

MATEO LLORENTE

B. C.

21-11-1652

Fr. Gregorio de Castro

Los Tremellos (Burgos)

AGN, Irache, Lib. 542, 373r.

JOSÉ GARCÍA

B. C.

27-11-1652

Fr. Pedro de Vergaño

Dicastillo (Burgos)

AGN, Irache, Lib. 542, 373v.

LORENZO DE MENDOZA

B. C.

27-11-1652

Fr. Pedro de Vergaño

Arróniz (Burgos)

AGN, Irache, Lib. 542, 373v.

MANUEL MONTE DE VERGARA Y RESA

L. C. / D. C.

27-11-1652

Fr. Pedro de Vergaño

Calahorra

AGN, Irache, Lib. 542, 373v.

MIGUEL LÓPEZ

B. C. / L. C.

27-11-1652

Fr. Pedro de Vergaño

Dicastillo (Pamplona)

AGN, Irache, Lib. 542, 374r.

JOSÉ DE SALAZAR

B. C.

11-12-1652

Fr. Gregorio de Castro

Osma (Calahorra)

AGN, Irache, Lib. 542, 374r.
JUAN DE NOUNA

B. A. / B. T.

12-12-1652

Fr. Gregorio de Castro

Quintana (Burgos)

AGN, Irache, Lib. 542, 374v.

JUAN GARCÍA RAMÍREZ

L. C.

18-12-1652

Fr. Martín Izquierdo, abad

Fuentes de Nava (Palencia)

Deán de Palencia

AGN, Irache, Lib. 542, 374V.

PEDRO DE ANO

B. C.

31-12-1652

Fr. Gregorio de Castro

Las Azas (Burgos)

AGN, Irache, Lib. 542, 375r.

\section{DIEGO DE CHARREN}

B. C.

10-1-1653

Fr. Gregorio de Castro

Falces (Pamplona)

AGN, Irache, Lib. 542, 375r.

MATEO GARCÍA

B. C.

12-1-1653

Fr. Gregorio de Castro

Burgos

AGN, Irache, Lib. 542, 375r.

JUAN DE ARANDA

L. C. / D. C.

16-1-1653

Fr. Martín Izquierdo, abad

Agüero (Pamplona)

AGN, Irache, Lib. 542, 375v.

TOMÁS DE LA IGLESIA

B. T.

28-1-1653

Fr. Gregorio de Castro

Villegas (Burgos)

AGN, Irache, Lib. 542, 375v. 


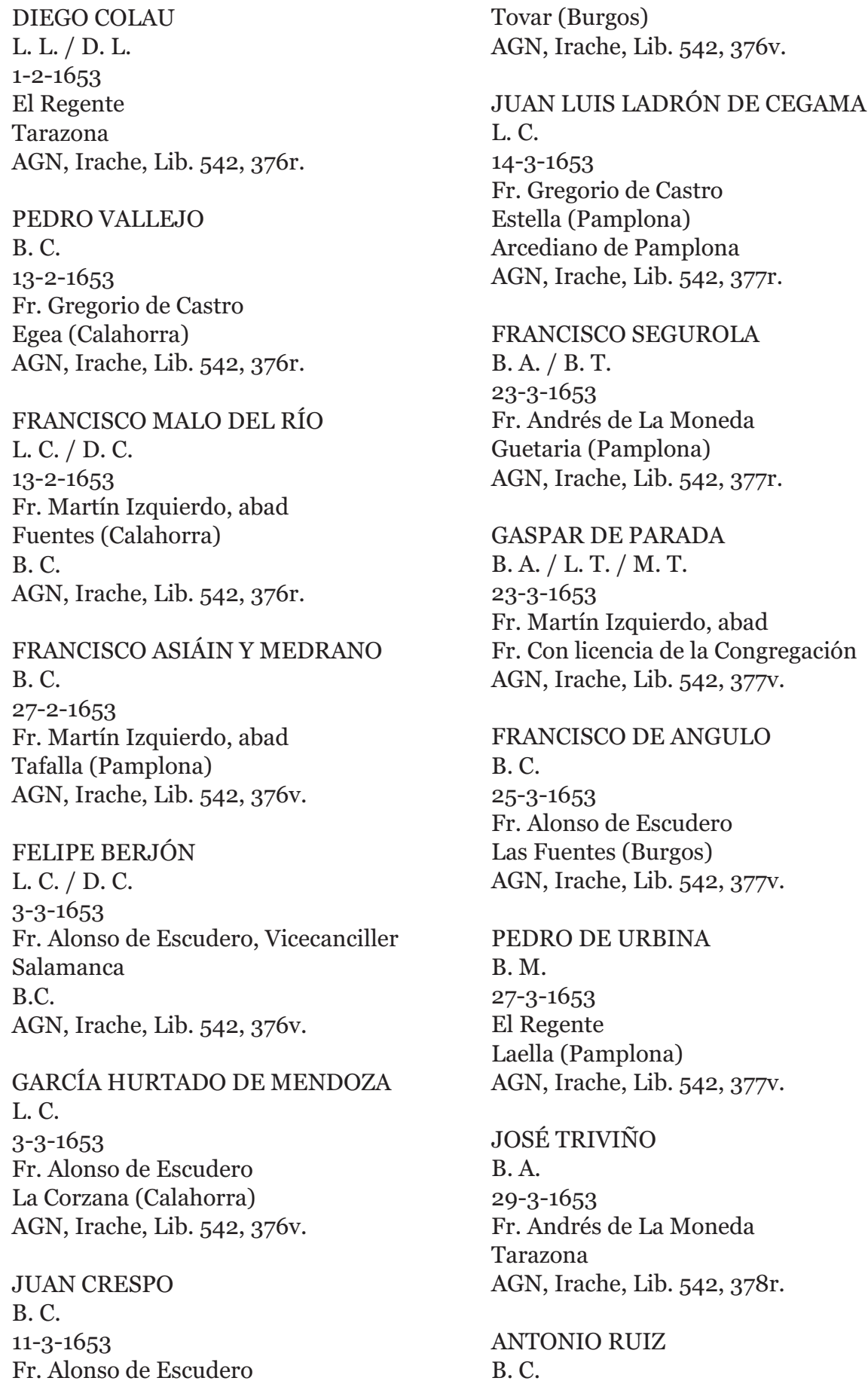


29-3-1653

Fr. Alonso de Escudero

Requejo (Burgos)

AGN, Irache, Lib. 542, 378r.

\section{MANUEL DE LEBRIJA}

B. A. / L. T. / M. T.

8-4-1653

Fr. Martín Izquierdo, abad

O. S. B.

AGN, Irache, Lib. 542, 378r.

ANDRÉS DE UGALDE ORMAECHEA

B. A. / L. A.

15-4-1653

Fr. Martín Izquierdo, abad

Bilbao (Calahorra)

AGN, Irache, Lib. 542, 378v.

\section{PEDRO DE VELONDIA}

B. C.

18-4-1653

Fr. Alonso de Escudero

Villanueva del Conde (Burgos)

AGN, Irache, Lib. 542, 378v.

FRANCISCO SANTAMARÍA

B. A. / B. T.

18-4-1653

Fr. Andrés de La Moneda

Antezana (Calahorra)

AGN, Irache, Lib. 542, 378v.

JUAN DE SANTA MARÍA

B. A.

18-4-1653

Fr. Andrés de La Moneda

Antezana (Calahorra)

AGN, Irache, Lib. 542, 378v.

FRANCISCO ORTIZ

B. C.

24-4-1653

Fr. Gregorio de Castro

Pancorbo (Burgos)

AGN, Irache, Lib. 542, 379r.

MATÍAS LÓPEZ

B. C.
26-4-1653

Fr. Alonso de Escudero

Pancorbo (Burgos)

AGN, Irache, Lib. 542, 379r.

\section{SEBASTIÁN PARDO}

B. C.

26-4-1653

Fr. Alonso de Escudero

Pancorbo (Burgos)

AGN, Irache, Lib. 542, 379r.

SEBASTIÁN DE SALAZAR

B. C.

26-4-1653

Fr. Alonso de Escudero

Pancorbo (Burgos)

AGN, Irache, Lib. 542, 379r.

LESMES DE CASTRESANA

B. C.

29-4-1653

Fr. Gregorio de Castro

Burgos

AGN, Irache, Lib. 542, 379r.

FELIPE GUTIÉRREZ

B. C.

29-4-1653

Fr. Gregorio de Castro

Burgos

AGN, Irache, Lib. 542, 379v.

LORENZO BAUTISTA DE ROMERO

B. C.

29-4-1653

Fr. Alonso de Escudero

San Pedro de Sanguas (Calahorra)

AGN, Irache, Lib. 542, 379v.

BLAS JULIÁN DE LA PUENTE

B. T.

4-5-1653

Fr. Alonso de Escudero

Yzcaray (Burgos)

AGN, Irache, Lib. 542, 379v.

FERNANDO DE CASTILLO Y NALDA

B. C. 
8-5-1653

Fr. Gregorio de Castro

Navarrete (Calahorra)

AGN, Irache, Lib. 542, 379v.

GREGORIO ARROYO VÉLEZ DE VALDIVIESO

L. C.

12-5-1653

Fr. Pedro de Vergaño

Arroyo (Burgos)

AGN, Irache, Lib. 542, 379v.

PEDRO FERNÁNDEZ MOROSO

B. C.

13-5-1653

El Regente

Sotillo (Burgos)

AGN, Irache, Lib. 542, 380r.

JUAN DE LEIVA

B. A.

22-5-1653

Fr. Andrés de La Moneda

Ávalos (Calahorra)

AGN, Irache, Lib. 542, 380r.

JOSÉ MARTÍNEZ JOVER

L. C. / D. C.

5-6-1653

Fr. Alonso de Escudero

Sta. María de la Redonda (Burgos)

AGN, Irache, Lib. 542, 38 or.

\section{ALONSO GARCÍA}

B. C.

8-6-1653

Fr. Alonso de Escudero

Castrojeriz (Burgos)

AGN, Irache, Lib. 542, 380r.

\section{JUAN FERNÁNDEZ}

B. C.

11-6-1653

Fr. Gregorio de Castro

Jaramillo (Burgos)

AGN, Irache, Lib. 542, 380r.
VICENTE DEL CAMPO

B. A. / B. T.

18-6-1653

Fr. Gregorio de Castro

Núñez de Santibáñez (Burgos)

AGN, Irache, Lib. 542, 380v.

\section{DIEGO FERNÁNDEZ}

B. C.

18-6-1653

Fr. Alonso de Escudero

Montejo de San Miguel (Burgos)

AGN, Irache, Lib. 542, $380 v$.

\section{DIEGO DE VIDORRETA}

B. M.

27-6-1653

Fr. Pedro de Vergaño

Calahorra

B. A.

AGN, Irache, Lib. 542, 380v.

ANDRÉS DE VADILLO

B. C.

30-6-1653

Fr. Alonso de Escudero

Carrión (Burgos)

AGN, Irache, Lib. 542, 381r.

MIGUEL DE LA PEÑA

B. C.

7-7-1653

Fr. Alonso de Escudero

Medina de Pomar (Burgos)

AGN, Irache, Lib. 542, 381r.

JUAN DE ROBLES

B. C.

10-7-1653

Fr. Pedro de Vergaño

Arcellares (Burgos)

AGN, Irache, Lib. 542, 381r.

FRANCISCO MANSILLA

B. C.

16-7-1653

Fr. Alonso de Escudero

Santibáñez (Burgos)

AGN, Irache, Lib. 542, 381r. 
SEBASTIÁN ORTEGA

B. A. / B. T.

22-7-1653

Fr. Alonso de Escudero

Santibáñez (Burgos)

AGN, Irache, Lib. 542, 381v.

FRANCISCO DE MENDIGUREN

B. A.

31-7-1653

Fr. Andrés de La Moneda

...

AGN, Irache, Lib. 542, 381v.

JUAN DE LORCA Y ARASO

B. A.

2-8-1653

Fr. Andrés de La Moneda

Estella (Pamplona)

AGN, Irache, Lib. 542, 381v.

BENITO GONZÁLEZ

B. C.

2-8-1653

El Regente

Burgos

AGN, Irache, Lib. 542, 381v.

ANTONIO MÉNDEZ

B. C.

6-8-1653

Fr. Alonso de Escudero

Burgos

AGN, Irache, Lib. 542, 381v.

FELIPE GUTIÉRREZ

B. C.

8-8-1653

Fr. Alonso de Escudero

Poza (Burgos)

AGN, Irache, Lib. 542, 382r.

JUAN GÓMEZ

B. C.

13-8-1653

El Regente

Toba (Burgos)

AGN, Irache, Lib. 542, 382r.
JOSÉ FERNÁNDEZ DE ENCINILLAS

B. C.

13-8-1653

El Regente

La Alm... (Burgos)

AGN, Irache, Lib. 542, 382r.

ANDRÉS DE URÍAS DE LA FUENTE

B. C.

27-8-1653

Fr. Alonso de Escudero

San Vicente de la Barquera (Burgos)

AGN, Irache, Lib. 542, 382r.

JUAN DE QUEVEDO

B. C.

6-9-1653

Fr. Pedro de Vergaño

Condado de Castaneda (Burgos)

AGN, Irache, Lib. 542, 382r.

FRANCISCO DE AGUILAR

B. C.

20-9-1653

El Regente

Osorno (Palencia)

AGN, Irache, Lib. 542, 382v.

DIEGO DE LA HERA

B. C.

1-10-1653

Fr. Alonso de Escudero

Sudupe (Burgos)

AGN, Irache, Lib. 542, 382v.

SIMÓN GONZÁLEZ

B. A.

13-10-1653

Fr. Pedro de Vergaño

Alaejos (Valladolid)

AGN, Irache, Lib. 542, 382v.

JUAN GARCÍA MARRÓN

B. C.

18-10-1653

El Regente

Lences (Burgos)

AGN, Irache, Lib. 542, 382v. 
FRANCISCO GUTIÉRREZ DE LA PEÑA B. A. / B. T.

28-10-1653

Fr. Pedro de Vergaño

Villadiego (Burgos)

AGN, Irache, Lib. 542, 383r.

DIEGO ALONSO DE OJEDA

B. C.

29-10-1653

Fr. Alonso de Escudero

Tamayo (Burgos)

AGN, Irache, Lib. 542, 383r.

JUAN DÍEZ UTEBO

B. C.

2-11-1653

Fr. Pedro de Vergaño

Villadiego (Burgos)

AGN, Irache, Lib. 542, 383r.

\section{ALONSO MEDIANO}

B. C.

2-11-1653

Fr. Pedro de Vergaño

Villadiego (Burgos)

AGN, Irache, Lib. 542, 383r.

ANTONIO DE FELOAGA

B. L.

3-11-1653

Fr. Pedro de Úriz, Abad y Rector

Pamplona

AGN, Irache, Lib. 542, 383r.

JUAN RODRÍGUEZ

B. C.

7-11-1653

Fr. Alonso de Escudero

Quintana (Burgos)

AGN, Irache, Lib. 542, 383v.

DIEGO ANTONIO DE SANJUÁN

B. C. / L. C.

11-11-1653

Fr. Pedro de Úriz, abad

Fuenmayor (Calahorra)

AGN, Irache, Lib. 542, 383v.
TOMÁS DEL CAMPO

B. C.

11-11-1653

Fr. Alonso de Escudero

Zendejo (Burgos)

AGN, Irache, Lib. 542, 383v.

SIMÓN RUIZ DE LA REVILLA

B. C.

12-11-1653

Fr. Alonso de Escudero

Traspadierna (Burgos)

AGN, Irache, Lib. 542, 384r.

TOMÁS DEL CERRO

B. C.

12-11-1653

Fr. Andrés de La Moneda

C... (Burgos)

AGN, Irache, Lib. 542, 384r.

JUAN DEL CAMPO

B. C.

12-11-1653

Fr. Alonso de Escudero

Burgos

AGN, Irache, Lib. 542, 384r.

JUAN DE RODRIGO

B. C.

16-11-1653

Fr. Alonso de Escudero

Santa María del Campo (Burgos)

AGN, Irache, Lib. 542, 384r.

ANTONIO DE PALACIO

B. C.

18-11-1653

Fr. Pedro de Vergaño

Medina de Pomar (Burgos)

AGN, Irache, Lib. 542, 384v.

ANTONIO DE ISLA

B. T. / L. T. / D. T.

30-12-1653

El Regente

O. S. B.

AGN, Irache, Lib. 542, 384v. 
B. C.

3-1-1654

Fr. Anselmo López

Santa María del Campo (Burgos)

AGN, Irache, Lib. 542, 384v.

CARLOS DEL HOYO

B. C.

9-1-1654

El Regente

Laredo (Burgos)

AGN, Irache, Lib. 542, 384v.

JACINTO PÉREZ DE NUEROS

L. C.

23-1-1654

Fr. Pedro de Úriz, abad

Cataláin (Tarazona)

AGN, Irache, Lib. 542, 385r.

FRANCISCO DE URÍA Y MÚJICA

B. A. / L. A.

22-2-1654

Fr. Andrés de La Moneda

Anteiglesia (Calahorra)

AGN, Irache, Lib. 542, 385r.

\section{ALONSO DÍEZ}

B. C.

8-2-1654

El Regente

Oradano (Burgos)

AGN, Irache, Lib. 542, 385r.

ANTONIO DE CAVALLERICES

B. C.

27-2-1654

El Regente

Cabezón (Burgos)

AGN, Irache, Lib. 542, 385v.

MIGUEL GIL

B. A.

11-3-1654

Fr. Andrés de La Moneda

Aucejo (Calahorra)

AGN, Irache, Lib. 542, 385v.

\section{JUAN MARTÍNEZ DE ARAS}

B. A.

19-3-1654

Fr. Andrés de La Moneda

Viana (Calahorra)

AGN, Irache, Lib. 542, 385v.

FRANCISCO DOMINGO GÓMEZ

B. C.

27-3-1654

Fr. Alonso de Escudero

Maseda (Burgos)

AGN, Irache, Lib. 542, 386r.

JUAN PÉREZ

B. A. / B. T.

6-4-1654

Fr. Andrés de La Moneda

Villarmentero (Burgos)

AGN, Irache, Lib. 542, 386r.

BERNARDO PÉREZ DE CORELLA

B. C.

9-4-1654

Fr. Alonso de Escudero

Espinosa de los Monteros (Burgos)

AGN, Irache, Lib. 542, 386r.

\section{JUAN RUIZ DE LUZURIAGA}

B. A.

16-4-1654

Fr. Andrés de La Moneda

Gasio (Calahorra)

AGN, Irache, Lib. 542, 386r.

JOSÉ DE YOLDI

B. A.

21-4-1654

Fr. Andrés de La Moneda

Aberín (Pamplona)

AGN, Irache, Lib. 542, 386v.

JUAN DE IRISARRI

B. A.

21-4-1654

Fr. Andrés de La Moneda

Oses (Bayona)

AGN, Irache, Lib. 542, 386v. 
FERNANDO DE GAZÓLAZ

B. A.

21-4-1654

Fr. Andrés de La Moneda

Auriz (Pamplona)

AGN, Irache, Lib. 542, 386v.

JUAN DE GILAR

B. A.

21-4-1654

Fr. Andrés de La Moneda

Arróniz (Pamplona)

AGN, Irache, Lib. 542, 386v.

JOSÉ DE ARLEGUI

B. A.

21-4-1654

Fr. Andrés de La Moneda

Enériz (Pamplona)

AGN, Irache, Lib. 542, 386v.

PEDRO DE CHÁVARRI

B. A.

21-4-1654

Fr. Andrés de La Moneda

Los Arcos (Pamplona)

AGN, Irache, Lib. 542, 386v.

\section{ALONSO GONZÁLEZ}

B. A.

21-4-1654

Fr. Andrés de La Moneda

Pamplona

AGN, Irache, Lib. 542, 386v.

DOMINGO APALATE

B. A.

21-4-1654

Fr. Andrés de La Moneda

Oses (Bayona)

AGN, Irache, Lib. 542, 386v.

MIGUEL DE URRUTIA

B. A.

21-4-1654

Fr. Andrés de La Moneda

Balderro (Pamplona)

AGN, Irache, Lib. 542, 386v.
BAUTISTA DE OLAGARAY Y LIZONDO

B. A.

21-4-1654

Fr. Andrés de La Moneda

Baztán (Pamplona)

AGN, Irache, Lib. 542, 386v.

JUAN MARTÍNEZ DE SILARAGA

B. A.

21-4-1654

Fr. Andrés de La Moneda

Olaz (Pamplona)

AGN, Irache, Lib. 542, 386v.

MIGUEL DE MIAS

B. A.

21-4-1654

Fr. Andrés de La Moneda

Bugarte (Pamplona)

AGN, Irache, Lib. 542, 386v.

JUAN DE MAYA

B. A.

21-4-1654

Fr. Andrés de La Moneda

Maya (Pamplona)

AGN, Irache, Lib. 542, 386v.

FRANCISCO DE URIERTA

B. A.

21-4-1654

Fr. Andrés de La Moneda

Añorbe (Pamplona)

AGN, Irache, Lib. 542, 386v.

JUAN DE ERMIAGA

B. A.

21-4-1654

Fr. Andrés de La Moneda

Santisteban (Pamplona)

AGN, Irache, Lib. 542, 386v.

PEDRO DE ESQUÍROZ

B. A. / B. M.

29-4-1654

Fr. Andrés de La Moneda

Adiós (Pamplona)

AGN, Irache, Lib. 542, 386v. 
FELIPE DE LA POSTILLA

B. C.

3-5-1654

El Regente

Reinosa (Burgos)

AGN, Irache, Lib. 542, 386v.

\section{MARTÍN MÁRQUEZ}

B. A.

11-5-1654

Fr. Andrés de La Moneda

Sesma (Pamplona)

AGN, Irache, Lib. 542, 387r.

JUAN GALLEGO GONZÁLEZ

B. A. / B. T.

12-5-1654

Fr. Andrés de La Moneda

Fr. Alonso de Escudero

Aradano (Burgos)

AGN, Irache, Lib. 542, 387r.

JERÓNIMO PÉREZ

B. M.

18-5-1654

Fr. Andrés de La Moneda

Monroyo (Zaragoza)

AGN, Irache, Lib. 542, 387v.

\section{ANTONIO DE VEGA}

B. C.

22-5-1654

Fr. Pedro de Vergaño

Vebrado (Burgos)

AGN, Irache, Lib. 542, 387v.

JOSÉ DE AYALDE

B. C.

23-5-1654

Fr. Alonso de Escudero

Usúrbil (Pamplona)

AGN, Irache, Lib. 542, 387v.

VICENTE DE TRAMBARRIA

B. C.

29-5-1654

Fr. Alonso de Escudero

Valmaseda (Burgos)

AGN, Irache, Lib. 542, 387v.
FRANCISCO MARRÓN Y MURGA

L. C. / D. C.

31-5-1654

Fr. Pedro de Úriz, abad

Miranda (Burgos)

AGN, Irache, Lib. 542, 387v.

MIGUEL BONETA

B. A. / B. M.

6-6-1654

Fr. Andrés de La Moneda

Pamplona

AGN, Irache, Lib. 542, 388r.

\section{JUAN IBÁÑEZ DE BASTERRECHEA}

B. A. / L. A.

6-6-1654

Fr. Pedro de Úriz, abad

Puebla de Mundaka (Calahorra)

AGN, Irache, Lib. 542, 388r.

JUAN ORTIZ DE ECHEANDIA DE GAME-

$\mathrm{CHO}$

L. A.

6-6-1654

Fr. Pedro de Úriz, abad

Puebla de Mundaka (Calahorra)

AGN, Irache, Lib. 542, 388r.

TOMÁS DEL PIÑAL

B. C.

8-6-1654

Fr. Alonso de Escudero

Las Pilas (Burgos)

AGN, Irache, Lib. 542, 388v.

FELIPE DE LA SIERRA

B. C.

10-6-1654

Fr. Alonso de Escudero

Ajo (Burgos)

AGN, Irache, Lib. 542, 388v.

FRANCISCO DE LIAÑO

B. C.

11-6-1654

El Regente

Torresandino (Burgos)

AGN, Irache, Lib. 542, 388v. 
JUAN DE LA FUENTE

B. C.

25-6-1654

El Regente

Padilla (Burgos)

AGN, Irache, Lib. 542, 388v.

JOSÉ DE IRÚN

B. A.

27-6-1654

Fr. Andrés de La Moneda

Corella (Tarazona)

AGN, Irache, Lib. 542, 388v.

JOSÉ DE TROCÓNIZ

B. T. / L. T. / D. T.

27-6-1654

Fr. Pedro de Úriz, abad

Vitoria (Calahorra)

AGN, Irache, Lib. 542, 389r.

MIGUEL MUÑOZ Y AGUSEJO

B. A. / B. M.

1-7-1654

Fr. Soria, M. A.

Tudela (Tarazona)

AGN, Irache, Lib. 542, 389r.

JUAN PÉREZ ARNAL

L. L. / D. L.

5-7-1654

El Regente

Teruel

AGN, Irache, Lib. 542, 389r.

PEDRO DE ARRIAGA Y ZUAZU

L. C.

8-7-1654

Fr. Alonso de Escudero

Burgos

AGN, Irache, Lib. 542, 389v.

JERÓNIMO GONZÁLEZ

B. A.

9-7-1654

Fr. Alonso de Escudero

Arnedo (Calahorra)

AGN, Irache, Lib. 542, 389v.
FRANCISCO MARÍN DE RODEZNO

B. C. / L. C.

16-7-1654

El Regente

Nájera (Calahorra)

AGN, Irache, Lib. 542, 389v.

JUAN DÍAZ DE LA COMA

B. C.

1-8-1654

Fr. Alonso de Escudero

Cilleruelo (Burgos)

AGN, Irache, Lib. 542, 389v.

MELCHOR LÓPEZ DE TORREJÓN

L. C.

4-8-1654

Fr. Pedro de Úriz, abad

Viana (Calahorra)

AGN, Irache, Lib. 542, 39or.

ANTONIO DE AYA

L. L.

5-8-1654

Fr. Pedro de Úriz, abad

Pamplona

AGN, Irache, Lib. 542, 39or.

FRANCISCO SALDAÑA BRAVO

B. A. / B. T.

7-8-1654

Fr. Alonso de Escudero

Burgos

AGN, Irache, Lib. 542, 39or.

FRANCISCO ARANGUREN

L. C.

8-8-1654

Fr. Pedro de Úriz, abad

Pamplona

AGN, Irache, Lib. 542, 390v.

MIGUEL FERNÁNDEZ Y VIZARRA

L. M. / D. M.

31-8-1654

Fr. Pedro de Úriz, abad

Sádaba (Pamplona)

AGN, Irache, Lib. 542, 390v. 
ANTONIO DE VILLEGAS

B. C. / L. C.

5-9-1654

Fr. Pedro de Úriz, abad

Burgos

AGN, Irache, Lib. 542, 391r.

ANTONIO ESTEBAN DE PUIG

B. C. / L. C.

12-9-1654

Fr. Pedro de Úriz, abad

Valdeargoza (Zaragoza)

AGN, Irache, Lib. 542, 391r.

JUAN BAUTISTA PECIÑA RAMÍREZ

B. A.

19-9-1654

Fr. Alonso de Escudero

Logroño (Calahorra)

AGN, Irache, Lib. 542, 391r.

DOMINGO DE BALLENT

B. C.

1-10-1654

Fr. Alonso de Escudero

Santa Engracia (Burgos)

AGN, Irache, Lib. 542, 391v.

JOSÉ DÍEZ

B. C.

1-10-1654

El Regente

Melgar de Fernamental (Burgos)

AGN, Irache, Lib. 542, 391v.

AGUSTÍN DE RETA

B. C.

8-10-1654

Fr. Pedro de Úriz, abad

Pamplona

AGN, Irache, Lib. 542, 391v.

ALONSO DE MEDIAVILLA

B. C.

13-10-1654

Fr. Pedro de Soria, vicecanciller Melgar de Fernamental (Burgos)

AGN, Irache, Lib. 542, 391v.
FRANCISCO OCHOA DE CERQUERA

B. C.

14-10-1654

Fr. Alonso de Escudero

V... (Burgos)

AGN, Irache, Lib. 542, 392r.

FRANCISCO SAIZ

B. C.

22-10-1654

Fr. Pedro de Vergaño, Regente

Melgar (Burgos)

AGN, Irache, Lib. 542, 392r.

DOMINGO RUIZ

B. C.

11-11-1654

Fr. Pedro de Soria

Poza (Burgos)

AGN, Irache, Lib. 542, 392r.

MILLÁN SÁEZ DE CANTABRANA

B. C.

19-11-1654

Fr. Alonso de Escudero

Treviana (Burgos)

AGN, Irache, Lib. 542, 392v.

PRUDENCIO DE MURGA

B. T. / L. T. / M. T.

27-11-1654

Fr. Pedro de Úriz, abad

O.S. B.

Abad de Nájera

AGN, Irache, Lib. 542, 392v.

JERÓNIMO BAROJA

B. C.

30-11-1654

Fr. Pedro de Vergaño

Autol (Calahorra)

AGN, Irache, Lib. 542, 392v.

DIEGO GONZÁLEZ

B. C.

1-12-1654

Fr. Pedro de Soria

Arnedo (Calahorra)

AGN, Irache, Lib. 542, 392v. 
ANTONIO GONZÁLEZ

B. C.

5-12-1654

Fr. Alonso de Escudero

Medina de Pomar (Burgos)

AGN, Irache, Lib. 542, 393r.

TOMÁS ALFONSO

B. A. / B. T.

14-12-1654

Fr. Pedro de Vergaño

Zumiel (Burgos)

AGN, Irache, Lib. 542, 393r.

JUAN LÓPEZ DE ZERRÓN OZALLA

B. C.

20-12-1654

Fr. Pedro de Soria

Sótil (Calahorra)

AGN, Irache, Lib. 542, 393r.

JOSÉ HURTADO

B. T.

28-12-1654

Fr. Alonso de Escudero

Belorado (Burgos)

AGN, Irache, Lib. 542, 393r.

PEDRO RICO

B. C.

30-12-1654

Fr. Pedro de Soria

Iglesias (Burgos)

AGN, Irache, Lib. 542, 393v.

JUAN ALONSO MARTÍNEZ

B. C.

8-1-1655

Fr. Pedro de Soria

Aguilar de Bureba (Burgos)

AGN, Irache, Lib. 542, 393v.

COSME CARDERÓN DEL CASTILLO

L. C. / D. C.

17-1-1655

Fr. Pedro de Úriz, abad

Poza (Burgos)

AGN, Irache, Lib. 542, 393v.
BERNABÉ GIL DE QUINTANA

B. T.

29-1-1655

Fr. Alonso de Escudero

Aguilar de Bureba (Burgos)

AGN, Irache, Lib. 542, 394r.

JUAN DÍEZ DE VALDIVIESO

B. C.

31-1-1655

Fr. Pedro de Vergaño

Vilarcayo (Burgos)

AGN, Irache, Lib. 542, 394r.

DIEGO DE ANGULO

B. C.

6-2-1655

Fr. P. de Soria

Valdelacuesta (Burgos)

AGN, Irache, Lib. 542, 394r.

MANUEL DE LOSA

B. C.

7-2-1655

Fr. Alonso de Escudero

Santo Domingo (Calahorra)

AGN, Irache, Lib. 542, 394r.

JUAN CARO

B. C. / L. C.

26-2-1655

Fr. Pedro de Úriz, abad

Morón (Sevilla)

AGN, Irache, Lib. 542, 394v.

MATEO ANSÓN

B. C.

28-2-1655

Fr. P. de Soria

Pedrosa del Páramo (Burgos)

AGN, Irache, Lib. 542, 394v.

PEDRO DEL BARRIO MIRÓN

B. T.

12-3-1655

Fr. Alonso de Escudero

Arlazón (Burgos)

AGN, Irache, Lib. 542, 394v. 
GASPAR DE SANTA... ALBIEZ

B. C.

15-3-1655

Fr. Pedro de Vergaño

Soria (Osma)

AGN, Irache, Lib. 542, 394v.

FRANCISCO ANGULO

B. C.

20-3-1655

Fr. Pedro de Soria

P... (Burgos)

AGN, Irache, Lib. 542, 395r.

FRANCISCO DE AGÜERO

B. C.

20-3-1655

Fr. Alonso de Escudero

Oreja (Burgos)

AGN, Irache, Lib. 542, 395r.

DOMINGO DE ORNAT

B. T.

22-3-1655

Fr. Pedro de Vergaño

Ansón

AGN, Irache, Lib. 542, 395r.

FRANCISCO DE LA MAZONA

B. C.

27-3-1655

Fr. Pedro de Soria

Castro (Burgos)

AGN, Irache, Lib. 542, 395r.

PEDRO MARTÍNEZ

B. C.

31-3-1655

Fr. Gregorio de ...

Zarzosa (Burgos)

AGN, Irache, Lib. 542, 395v.

FRANCISCO DE ARTETA

B. A.

3-4-1655

Fr. Mauro Velázquez, vicecanciller

Estella (Pamplona)

AGN, Irache, Lib. 542, 395v.
MIGUEL DE CABERNO

B. $\mathrm{T}$.

9-4-1655

Fr. Pedro de Vergaño

Barbastro

AGN, Irache, Lib. 542, 395v.

JUAN ARIAS

B. C.

10-4-1655

Fr. Pedro de Soria

Corvera

AGN, Irache, Lib. 542, 395v.

JUAN GÓMEZ HIERRO

B. C.

20-4-1655

Fr. Alonso de Escudero

Pangusión (Burgos)

AGN, Irache, Lib. 542, 396r.

PRUDENCIO GONZÁLEZ DE ANGULO

B. A. / B. T. / L. T. / D. T.

14-4-1655 / 5-4-1666

Fr. Mauro Velázquez / Fr. Pedro Bergaño,

abad

Navarrete (Calahorra)

AGN, Irache, Lib. 542, 396r; Lib. 539, 56r.

GABRIEL DE BRIZUELA

L. C.

14-4-1655

Fr. Pedro de Úriz, abad

Puente (Burgos)

AGN, Irache, Lib. 542, 396r.

PEDRO DE AYALA

B. C.

14-4-1655

Fr. Pedro de Vergaño

Pancorbo (Burgos)

AGN, Irache, Lib. 542, 396v.

DIEGO JIMÉNEZ

B. T.

19-4-1655

Fr. Pedro de Soria

Mataleberas (Tarazona)

AGN, Irache, Lib. 542, 396v. 
FRANCISCO DE CASARES

B. T.

28-4-1655

Fr. Mauro Velázquez

Escorci (Burgos)

AGN, Irache, Lib. 542, 396v.

$\cdots$

AGN, Irache, Lib. 542, 397r.

PEDRO DE MARUZA

B. C.

28-4-1655

Fr. Pedro de Vergaño

Valdés (Burgos)

AGN, Irache, Lib. 542, 398r.

TOMÁS CALLE

B. C.

28-4-1655

Fr. Pedro de Vergaño

Quintanilla (Burgos)

AGN, Irache, Lib. 542, 398r.

PEDRO DE RUESGA

B. C.

28-4-1655

Fr. Pedro de Vergaño

Quintanilla (Burgos)

AGN, Irache, Lib. 542, 398r.

PEDRO BUSTAMANTE

B. C.

30-4-1655

Fr. Mauro Velázquez

Tanos (Burgos)

AGN, Irache, Lib. 542, 398r.

JUAN TOMÉ

B. C.

3-5-1655

Fr. Alonso de Escudero

Tamarón (Burgos)

AGN, Irache, Lib. 542, 398r.

PEDRO MIGUEL

B. C.
3-5-1655

Fr. Alonso de Escudero

Tamarón (Burgos)

AGN, Irache, Lib. 542, 398v.

JUAN ANTÓN

B. C.

13-5-1655

Fr. Alonso de Escudero

Tamarón (Burgos)

AGN, Irache, Lib. 542, 398v.

FRANCISCO RUIZ DE PEREDA

L. L. / D. L.

14-5-1655

Fr. Pedro de Úriz, abad

Tarazona

AGN, Irache, Lib. 542, 398v.

JACINTO GARCÍA

B. C.

27-5-1655

Fr. Alonso de Escudero

Medina de Pomar (Burgos)

AGN, Irache, Lib. 542, 399r.

JOSÉ LÓPEZ BARRÓN

B. C.

27-5-1655

Fr. Alonso de Escudero

Medina de Pomar (Burgos)

AGN, Irache, Lib. 542, 399r.

DIEGO SANZ DE LA MALETA

B. C.

29-5-1655

Fr. Pedro de Soria

Quintanilla (Burgos)

AGN, Irache, Lib. 542, 399r.

MANUEL SAINZ

B. M.

4-6-1655

Fr. Alonso de Escudero

Cervera (Calahorra)

AGN, Irache, Lib. 542, 399v.

LÁZARO MARTÍNEZ DE ROCAS

B. C. 
5-6-1655

Fr. Pedro de Soria

San Bartolomé (Burgos)

AGN, Irache, Lib. 542, 399v.

FRANCISCO MARTÍNEZ DE SOTO

B. C.

5-6-1655

Fr. Pedro de Soria

Valle de Val (Burgos)

AGN, Irache, Lib. 542, 399v.

JUAN DE LA FUENTE

L. T. / D. T.

11-6-1655

Fr. Pedro de Úriz, abad

Pancorbo (Burgos)

AGN, Irache, Lib. 542, 40or.

LORENZO MARTÍNEZ

B. A.

12-6-1655

Fr. Mauro Velázquez

O. de M.

AGN, Irache, Lib. 542, 400 .

BARTOLOMÉ GARCÍA DE MAYOR

B. T.

14-6-1655

Fr. Alonso de Escudero

Grañón (Calahorra)

AGN, Irache, Lib. 542, $400 v$.

JOSÉ GIL DE VELASCO

B. C.

12-7-1655

Fr. Pedro de Vergaño

Grijalba (Burgos)

AGN, Irache, Lib. 542, $400 v$.

MARCOS DE GIBARA

B. C.

19-7-1655

Fr. Alonso de Escudero

Rasines (Burgos)

AGN, Irache, Lib. 542, $400 v$.

JUAN DE MONTOYA

B. C.
21-7-1655

Fr. Pedro de Vergaño

Mirón (Calahorra)

AGN, Irache, Lib. 542, 401r.

LORENZO DEL DIESTRO

B. C.

21-7-1655

Fr. Pedro de Vergaño

Mogro (Burgos)

AGN, Irache, Lib. 542, 401r.

ANTONIO DE LAISECA

B. C.

29-7-1655

Fr. Alonso de Escudero

Villaverde (Burgos)

AGN, Irache, Lib. 542, 401r.

JUAN DÍEZ DE BON Y LUGA

B. C.

29-7-1655

Fr. Pedro de Vergaño

... (Burgos)

AGN, Irache, Lib. 542, 401v.

JUAN DE ECHALAZ

B. C.

2-8-1655

Fr. Pedro de Úriz, abad

Enériz (Pamplona)

AGN, Irache, Lib. 542, 401v.

AGUSTÍN DE ECHALAZ

B. C.

2-8-1655

Fr. Pedro de Úriz, abad

Muruzábal (Pamplona)

AGN, Irache, Lib. 542, 401v.

LUIS DE ECHALAZ

L. T. / D. T.

2-8-1655

Fr. Pedro de Úriz, abad

Enériz (Pamplona)

AGN, Irache, Lib. 542, 402r.

DIEGO DE ARENZANA

B. C. 
3-8-1655

Fr. Pedro de Vergaño

Arenzana (Nullius Diocesis)

AGN, Irache, Lib. 542, 402r.

PEDRO RUIZ DE ...

B. C.

4-8-1655

Fr. Pedro de Úriz, abad

Villarcayo (Burgos)

AGN, Irache, Lib. 542, 402r.

PEDRO FERNÁNDEZ DEL CAMPO

B. A. / B. T.

10-8-1655

Fr. Mauro Velázquez

Quintanilla (Burgos)

AGN, Irache, Lib. 542, 402v.

ANTONIO DEL CASTILLO

L. A. / D. A. / L. T. / D. T.

28-8-1655

Fr. Pedro de Úriz, abad

O. S. B.

AGN, Irache, Lib. 542, $402 \mathrm{v}$.

MANUEL DE GARAY

B. C.

30-8-1655

Fr. Pedro de Vergaño

Orduña (Calahorra)

AGN, Irache, Lib. 542, 403r.

DIEGO DE OLARTE

L. T. / D. T.

12-9-1655

Fr. Pedro de Úriz, abad

Villabañe (Calahorra)

AGN, Irache, Lib. 542, 403r.

JUAN PÉREZ

B. C.

12-9-1655

Fr. Pedro de Vergaño

Villadiego (Burgos)

AGN, Irache, Lib. 542, 403v.

DIEGO LÓPEZ RUIZ

B. A. / B. T. / L. T.
15-9-1655 / 21-9-1655

Fr. Pedro de Vergaño

Briviesca (Burgos)

AGN, Irache, Lib. 542, 403v-404r.

DOMINGO FERNÁNDEZ DE LA PEÑA

B. C.

15-9-1655

Fr. Domingo Gutiérrez

Vicana (Burgos)

AGN, Irache, Lib. 542, 403v.

JUAN RUIZ

B. A.

26-9-1655

Fr. Pedro de Vergaño

Santo Domingo (Burgos)

AGN, Irache, Lib. 542, 404r.

MIGUEL DE GARRAZA

B. A. / B. M.

27-9-1655

Fr. Pedro de Vergaño

Sesma (Pamplona)

AGN, Irache, Lib. 542, 404v.

JUAN SALCEDO

B. A.

2-10-1655

Fr. Pedro de Vergaño

O. de M.

AGN, Irache, Lib. 542, 404v.

RAFAEL DE VALARZA

B. L. / B. C.

5-10-1655

Fr. Alonso de Escudero

Pamplona

AGN, Irache, Lib. 542, 404v.

JUAN GALLO

B. C.

6-10-1655

Fr. Alonso de Escudero

Robledo (Burgos)

AGN, Irache, Lib. 542, 404v.

GASPAR GÓMEZ DE LA FUENTE

B. C. 
13-10-1655

Fr. Alonso de Escudero

Burgos

AGN, Irache, Lib. 542, 405r.

CRISTÓBAL DE OLIVARES Y MÚJICA

B. C.

13-10-1655

Fr. Alonso de Escudero

Burgos

AGN, Irache, Lib. 542, 405r.

FRANCISCO DELGADO

B. A. / B. M. / L. M. / D. M.

22-10-1655

Fr. Pedro de Úriz, abad / Dr. Morras

Altea (Tarazona)

AGN, Irache, Lib. 542, 405r.

JERÓNIMO SEVILLA

L. M. / D. M.

27-10-1655

Fr. Alonso de Escudero / Dr. Morras

Tarazona

AGN, Irache, Lib. 542, 405v.

MARTÍN DE ACEDO

B. C.

29-10-1655

Fr. Pedro de Vergaño

Molleda (Burgos)

AGN, Irache, Lib. 542, 405v.

LESMES DE AMPIANO IBARRA

B. C.

30-10-1655

Fr. Alonso de Escudero

Burgos

AGN, Irache, Lib. 542, 405v.

MIGUEL SANTOS

B. C.

31-10-1655

Fr. Domingo Gutiérrez

San Llorente (León)

AGN, Irache, Lib. 542, 406r.

JUAN MANERO

B. C.
1-11-1655

Fr. Domingo Gutiérrez

Cerezo (Burgos)

AGN, Irache, Lib. 542, 406r.

DOMINGO BRAIDINA

B. A. / B. M.

5-11-1655

Fr. Mauro Velázquez

Ansó (Jaca)

AGN, Irache, Lib. 542, 406r.

FRANCISCO MENDIGUREN

B. T.

6-11-1655

Fr. Mauro Velázquez

Burgos

AGN, Irache, Lib. 542, 406v.

TOMÁS DÍEZ DE MEDINA

B. A. / B. M. / L. M. / D. M.

30-11-1655

Fr. Pedro de Úriz, abad / Dr. Moras

Viana (Calahorra)

AGN, Irache, Lib. 542, 406v.

JUAN DE LA PEÑA

B. C.

10-12-1655

Fr. Pedro de Vergaño

Vernal (Burgos)

AGN, Irache, Lib. 542, 406v.

FRANCISCO DE MATA

B. C.

12-12-1655

Fr. Pedro de Vergaño

Quintana (Burgos)

AGN, Irache, Lib. 542, 407r.

FRANCISCO DE ARGUIANO

B. A. / B. T.

18-12-1655

Fr. Alonso de Escudero

Burgos

AGN, Irache, Lib. 542, 407r.

DIEGO OGAZÓN

B. A. 
30-12-1655

Fr. Pedro de Vergaño

O. Cist.

AGN, Irache, Lib. 542, 407r.

\section{GREGORIO RODRÍGUEZ}

B. C.

6-1-1656

Fr. Domingo Gutiérrez

Villamorón (Burgos)

AGN, Irache, Lib. 542, 407v.

\section{MARTÍN SAINZ}

B. C.

9-1-1656

Fr. Domingo Gutiérrez

Quintanavides (Burgos)

AGN, Irache, Lib. 542, 407v.

JUAN DE ACASTEJO

B. C.

14-1-1656

Fr. Domingo Gutiérrez

Concejo de Calla (Burgos)

AGN, Irache, Lib. 542, 407v.

JUAN ANTONIO DE SAN CRISTÓBAL

B. C.

14-1-1656

Fr. Domingo Gutiérrez

Concejo de Calla

AGN, Irache, Lib. 542, 407v.

ANTONIO B...

B. A. / B. T.

27-1-1656

Fr. Pedro de Vergaño

Olmillos (Burgos)

AGN, Irache, Lib. 542, 408r.

MARTÍN DE MARQUINA

B. M.

27-1-1656

Fr. Alonso de Escudero

Adiós (Pamplona)

AGN, Irache, Lib. 542, 408r.

MIGUEL DE BUSTO

B. C.
29-1-1656

Fr. Alonso de Escudero

Valluércanes (Burgos)

AGN, Irache, Lib. 542, 408r.

JUAN DE LA TORRE

B. C.

3-2-1656

Fr. Pedro de Vergaño

Rubales (Burgos)

AGN, Irache, Lib. 542, 408r.

PEDRO DÍAZ DE COSÍO

B. C.

9-2-1656

Fr. Alonso de Escudero

Carmona (Burgos)

AGN, Irache, Lib. 542, 408v.

SEBASTIÁN ALONSO PÉREZ

B. C.

14-2-1656

Fr. Domingo Gutiérrez

Miñón (Burgos)

AGN, Irache, Lib. 542, 408v.

MANUEL ZAMARÓN

B. C.

15-2-1656

Fr. Pedro de Vergaño

Valbas (Burgos)

AGN, Irache, Lib. 542, 408v.

FELIPE RIBERO BARREDA

B. C.

17-2-1656

Fr. Pedro de Vergaño

Casar (Burgos)

AGN, Irache, Lib. 542, 408v.

ANTONIO DE LA IGLESIA

B. C.

24-2-1656

Fr. Domingo Gutiérrez

San Pedro Samuel (Burgos)

AGN, Irache, Lib. 542, 409r.

JERÓNIMO MARTÍNEZ

B. A. / B. T. 
24-2-1656

Fr. Domingo Gutiérrez

Miñón (Burgos)

AGN, Irache, Lib. 542, 409r.

MIGUEL FERNÁNDEZ DE AHUMADA

B. C. / L. C. / D. C.

9-3-1656

Fr. Pedro de Úriz, abad

Frías (Burgos)

AGN, Irache, Lib. 542, 409r.

JUAN MARCOS

B. A. / B. T.

10-3-1656

Fr. Mauro Velázquez

Los Ormajos (Burgos)

AGN, Irache, Lib. 542, 409v.

\section{MIGUEL GALLÓN}

B. A. / B. T.

21-3-1656

Fr. Domingo Gutiérrez

Prozo (Osma)

AGN, Irache, Lib. 542, 409v.

PEDRO DE CARRILLO

B. T.

26-3-1656

Fr. Alonso de Escudero

Viana (Calahorra)

AGN, Irache, Lib. 542, 409v.

MIGUEL DE MECA BOBADILLA

D. C.

29-3-1656

Fr. Pedro de Úriz, abad

Alfaro (Tarazona)

AGN, Irache, Lib. 542, 409v.

ALONSO DE VILLODAS

B. C.

9-4-1656

Fr. Domingo Gutiérrez

Quincoces (Burgos)

AGN, Irache, Lib. 542, 410r.

PEDRO DE DECA

B. A.
11-4-1656

Fr. Mauro Velázquez

Calahorra

AGN, Irache, Lib. 542, 410r.

\section{ANTONIO ZULOAGA}

L. L.

21-4-1656

Fr. Pedro de Úriz, abad / Dr. Juan de Lazáun

Pamplona

AGN, Irache, Lib. 542, 410r.

MIGUEL MALLÉN

B. A.

2-5-1656

Fr. Mauro Velázquez

Alfaro (Tarazona)

AGN, Irache, Lib. 542, 410r.

PEDRO MURILLO

B. A.

2-5-1656

Fr. Mauro Velázquez

Lumbier (Pamplona)

AGN, Irache, Lib. 542, 410v.

JOSÉ CUADRADO

B. A.

2-5-1656

Fr. Mauro Velázquez

... (Pamplona)

AGN, Irache, Lib. 542, $410 v$.

JUAN MATÍAS DE ENÉRIZ

B. A.

2-5-1656

Fr. Mauro Velázquez

Obanos (Pamplona)

AGN, Irache, Lib. 542, $410 \mathrm{v}$.

JUAN DE BORDA

B. A.

2-5-1656

Fr. Mauro Velázquez

Maya (Pamplona)

AGN, Irache, Lib. 542, $410 \mathrm{v}$. 
MIGUEL YERES

B. A.

2-5-1656

Fr. Mauro Velázquez

Ripodas (Pamplona)

AGN, Irache, Lib. 542, $410 v$.

JUAN DE IBARRA

B. A.

2-5-1656

Fr. Mauro Velázquez

Obanos (Pamplona)

AGN, Irache, Lib. 542, 410v.

ESTEBAN DE CASANUEVA

B. A.

2-5-1656

Fr. Mauro Velázquez

Orio (Pamplona)

AGN, Irache, Lib. 542, $410 v$.

IGNACIO DE ECHEVESTE

B. A.

2-5-1656

Fr. Mauro Velázquez

Andoáin (Pamplona)

AGN, Irache, Lib. 542, $410 v$.

JUAN DE SALINAS

B. A.

2-5-1656

Fr. Mauro Velázquez

Garísoain (Pamplona)

AGN, Irache, Lib. 542, $410 v$.

MARTÍN DEL PRA

B. A.

2-5-1656

Fr. Mauro Velázquez

Itoiz (Pamplona)

AGN, Irache, Lib. 542, $410 v$.

MIGUEL ALONSO

B. C.

16-5-1656

Fr. Pedro de Vergaño

Villanueva (Burgos)

AGN, Irache, Lib. 542, $410 v$.
JUAN MARTÍNEZ DE VALLE

B. A. / L. A.

17-5-1656

Fr. Pedro de Úriz, abad

V... (Calahorra)

AGN, Irache, Lib. 542, 410v.

PEDRO DE LA CABAÑA

B. C.

26-5-1656

Fr. Alonso de Escudero

Ano (Burgos)

AGN, Irache, Lib. 542, 411r.

ANDRÉS DE SARABIA

B. C.

26-5-1656

Fr. Alonso de Escudero

Laredo (Burgos)

AGN, Irache, Lib. 542, 411r.

DOMINGO DE LLAÑO

B. C.

1-6-1656

Fr. Pedro de Vergaño

Valle (Burgos)

AGN, Irache, Lib. 542, 411r.

BLAS DE CASTAÑEDA

B. A.

6-6-1656

Fr. Mauro Velázquez

Collazos (Palencia)

AGN, Irache, Lib. 542, 411r.

DOMINGO DÍAZ

B. C.

14-6-1656

Fr. Alonso de Escudero

Sta. María de Ribarredonda (Burgos)

AGN, Irache, Lib. 542, 411r.

\section{ALONSO PÉREZ GONZÁLEZ}

B. C.

25-6-1656

Fr. Domingo Gutiérrez

Melgar (Burgos)

AGN, Irache, Lib. 542, 411v. 


\section{TORIBIO SERNA}

B. C.

25-6-1656

Fr. Domingo Gutiérrez

Melgar (Burgos)

AGN, Irache, Lib. 542, 411v.

JUAN GARCÍA

B. C.

29-6-1656

Fr. Alonso de Escudero

Quintana (Burgos)

AGN, Irache, Lib. 542, 411v.

\section{LUCAS GONZÁLEZ}

B. C.

2-7-1656

Fr. Domingo Gutiérrez

Sta. María de Ribarredonda (Burgos)

AGN, Irache, Lib. 542, 411v.

JUAN DE TOMÁS

B. T.

5-7-1656

Fr. Pedro de Vergaño

Santiponce (Burgos)

AGN, Irache, Lib. 542, 411v.

\section{SEBASTIÁN DE LIZARRAGA}

B. A. / L. A.

8-7-1656

Fr. Pedro de Úriz, abad

Tolosa (Pamplona)

AGN, Irache, Lib. 542, 412 .

JUAN LLORENTE

B. T.

8-7-1656

Fr. Alonso de Escudero

Quintanilla (Burgos)

AGN, Irache, Lib. 542, 412r.

GABRIEL DE TAMARIT

L. L. / D. L.

9-7-1656

Fr. Pedro de Úriz, abad / Ldo. Cegama

Cala... (Tortosa)

AGN, Irache, Lib. 542, 412r.
JUAN LÓPEZ DE ARCINIEGA

B. A. / B. T.

10-7-1656

Fr. Domingo Gutiérrez

Bascuñuelos (Burgos)

AGN, Irache, Lib. 542, 412v.

PEDRO DE CASUSO

B. C.

11-7-1656

Fr. Mauro Velázquez

Suesa (Burgos)

AGN, Irache, Lib. 542, 412v.

PEDRO DE ARTZAIN

B. C.

4-8-1656

Fr. Domingo Gutiérrez

Arnuero (Burgos)

AGN, Irache, Lib. 542, 412v.

ENRIQUE URRIÉS Y CRUZAT

L. C.

8-8-1656

Fr. Prudencio de Muga, Abad de Sta. María

de Nájera, vicecanciller

Pamplona

Canónigo de Pamplona

AGN, Irache, Lib. 542, 412v.

DIEGO DE JACA

B. A. / B. T.

17-8-1656

Fr. Pedro de Úriz, abad

O. de M.

AGN, Irache, Lib. 542, 413r.

JUAN LÓPEZ BORRICÓN

...

19-8-1656

Fr. Pedro de Vergaño

Butrena (Burgos)

AGN, Irache, Lib. 542, 413r.

MARTÍN DE VALENCIA

B. A.

4-9-1656

Fr. Domingo Gutiérrez 
San Martín (Pamplona)

AGN, Irache, Lib. 542, 413r.

FELIPE DE ARIAS Y MEDINA

B. C.

11-9-1656

Fr. Alonso de Escudero

AGN, Irache, Lib. 542, 413r.

ALONSO CALVO

B. C.

15-9-1656

Fr. Domingo Gutiérrez

Busto (Burgos)

AGN, Irache, Lib. 542, 413v.

\section{MATEO MARTÍNEZ}

B. C.

15-9-1656

Fr. Domingo Gutiérrez

Juarros (Burgos)

AGN, Irache, Lib. 542, 413v.

DOMINGO DE ARENAS ALVARADO

B. C.

27-9-1656

Fr. Mauro Velázquez

Hoz de Marrón (Burgos)

AGN, Irache, Lib. 542, 413v.

\section{RAFAEL ALONSO MARDONES}

B. C.

27-9-1656

Fr. Domingo Gutiérrez

Pedrosa, Valle de Tobalina (Burgos)

AGN, Irache, Lib. 542, 413v.

\section{DIEGO DE ECHARREN}

L. C.

28-9-1656

Fr. Pedro de Úriz, abad

Falces (Pamplona)

AGN, Irache, Lib. 542, 414r.

\section{PEDRO DE OCIO}

L. C.

10-10-1656
Fr. Pedro de Úriz, abad

Santo Domingo (Calahorra)

AGN, Irache, Lib. 542, 414r.

JOSÉ DE OIPA

B. A. / B. M.

11-10-1656

Fr. Pedro de Vergaño

Tudela (Tarazona)

AGN, Irache, Lib. 542, 414r.

MIGUEL DE GUEVARA

B. A. / B. M.

11-10-1656

Fr. Pedro de Vergaño

Tudela (Tarazona)

AGN, Irache, Lib. 542, 414r.

FRANCISCO DE HORCASITAS

B. C.

13-10-1656

Fr. Alonso de Escudero

La Nuez (Burgos)

AGN, Irache, Lib. 542, 414v.

PEDRO DE VANDERAL

B. C.

18-10-1656

Fr. Pedro de Vergaño

Valle de Licundo (Burgos)

AGN, Irache, Lib. 542, 414v.

MATEO DE AGÜERO Y SARABIA

B. C.

23-10-1656

Fr. Alonso de Escudero

Cereceda (Burgos)

AGN, Irache, Lib. 542, 414v.

LUIS DE LAMA

B. C.

4-11-1656

Fr. Domingo Gutiérrez

Gete (Burgos)

AGN, Irache, Lib. 542, 414v.

JUAN FRANCISCO DE EBRERA

B. A. / B. M. 
10-11-1656

Fr. Pedro de Vergaño

Ambel (Tarazona)

AGN, Irache, Lib. 542, 415r.

JERÓNIMO MARTÍNEZ

B. A. / B. T.

12-11-1656

Fr. Alonso de Escudero

Palacios de Benaver (Burgos)

AGN, Irache, Lib. 542, 415r.

DIEGO DE TORANZO

B. C.

26-11-1656

Fr. Domingo Gutiérrez

Castro Urdiales (Burgos)

AGN, Irache, Lib. 542, 415r.

FRANCISCO ARTETA

B. M.

29-11-1656

Fr. Pedro de Vergaño

Estella (Pamplona)

AGN, Irache, Lib. 542, 415r.

ANTONIO DE OTERO

B. A. / L. A. / M. A. / B. T. / L. T. / D. T.

1-12-1656

Fr. Pedro de Úriz, abad

O. S. B.

AGN, Irache, Lib. 542, 415v.

PEDRO GUTIÉRREZ GAYÓN

B. A. / B. T.

12-12-1656

Fr. Alonso de Escudero

Cango (Burgos)

AGN, Irache, Lib. 542, 415v.

AGUSTÍN DE SALAZAR

B. C.

13-12-1656

Fr. Domingo Gutiérrez

Sopuerta (Burgos)

AGN, Irache, Lib. 542, 415v.

GASPAR DE CEBALLOS

B. C.
19-12-1656

Fr. Pedro de Vergaño

Parras (Burgos)

AGN, Irache, Lib. 542, 416r.

JUAN DE PÁRAMO

B. T.

19-12-1656

Fr. Alonso de Escudero

Burgos

AGN, Irache, Lib. 542, 416r.

\section{MATÍAS DE CORELLA}

B. A. / B. T.

14-12-1656

Fr. Domingo Gutiérrez

Pedrosa (Burgos)

AGN, Irache, Lib. 542, 416r.

IGNACIO DEL RÍO

B. A. / B. T.

14-12-1656

Fr. Domingo Gutiérrez

Lodoso (Burgos)

AGN, Irache, Lib. 542, 416r.

DOMINGO DE TEJADA

B. C.

1-1-1657

Fr. Alonso de Escudero

Palacio (Burgos)

AGN, Irache, Lib. 542, 416r.

JUAN ORTIZ

B. C.

10-1-1657

Fr. Domingo Gutiérrez

Santos (Burgos)

AGN, Irache, Lib. 542, 416v.

JUAN DE ORTEGA

B. C.

12-1-1657

Fr. Alonso de Escudero

Cobejo (Burgos)

AGN, Irache, Lib. 542, 416v.

LUCAS DE VILLADIEGO

B. C. 
16-1-1657

Fr. Domingo Gutiérrez

Sasamón (Burgos)

AGN, Irache, Lib. 542, 416v.

JUAN DE AVENDAÑO

B. C.

18-1-1657

Fr. Pedro de Vergaño

Sordillos (Burgos)

AGN, Irache, Lib. 542, 417r.

FRANCISCO MARTÍNEZ DE SOMAVILLA

B. A. / B. T.

20-1-1657

Fr. Alonso de Escudero

Totero (Burgos)

AGN, Irache, Lib. 542, 417r.

MANUEL DE PAZ Y NOVOA

B. A. / B. T.

4-2-1657

Fr. Pedro de Úriz, abad

O. Praem.

AGN, Irache, Lib. 542, 417r.

FRANCISCO RAMOS

B. M.

5-2-1657

Fr. Pedro de Vergaño

Sangüesa (Pamplona)

AGN, Irache, Lib. 542, 417v.

FRANCISCO DE IRABIEN

L. C.

8-2-1657

Fr. Pedro de Úriz, abad

Maroño (Calahorra)

AGN, Irache, Lib. 542, 417v.

JUAN LADRÓN

B. C.

19-2-1657

Fr. Alonso de Escudero

Castrojeriz (Burgos)

AGN, Irache, Lib. 542, 417v.

BERNARDO DE ESCOBAR

B. C.
24-2-1657

Fr. Alonso de Escudero

Sopuerta (Burgos)

AGN, Irache, Lib. 542, 417v.

JOSÉ DE LA CEPINA

B. L.

25-2-1657

Fr. Alonso de Escudero

Huesca

AGN, Irache, Lib. 542, 418r.

JUAN DE LA BASTIDA

B. A.

2-3-1657

Fr. Mauro Velázquez

Calahorra

AGN, Irache, Lib. 542, 418r.

PEDRO DE DUEÑAS

B. C.

13-3-1657

Fr. Mauro Velázquez

Olmillos (Burgos)

AGN, Irache, Lib. 542, 418r.

BERNARDO SÁNCHEZ DE COS

B. C.

14-3-1657

Fr. Pedro de Vergaño

Aguilar (Burgos)

AGN, Irache, Lib. 542, 418r.

JUAN PARDO

B. A. / B. T.

16-3-1657

Fr. Mauro Velázquez

Palacios de Benaver (Burgos)

AGN, Irache, Lib. 542, 418v.

ANTONIO DE ISLA

B. C.

18-3-1657

Fr. Pedro de Vergaño

Beroyo (Burgos)

AGN, Irache, Lib. 542, 418v.

ANTONIO DE SAN CRISTÓBAL

B. C. 
20-3-1657

Fr. Pedro de Vergaño

Castro Urdiales (Burgos)

AGN, Irache, Lib. 542, 418v.

JULIÁN MONEDERO

B. C.

20-3-1657

Fr. Pedro de Vergaño

Villusto (Burgos)

AGN, Irache, Lib. 542, 418v.

\section{ALFONSO DE VILLASANDINO}

B. C.

21-3-1657

Fr. Alonso de Escudero

Melgar (Burgos)

AGN, Irache, Lib. 542, 419r.

ADRIANO DE MONREAL Y SORIA

B. A. / L. A. / M. A. / B. T. / L. T. / D. T.

22-3-1657

Fr. Pedro de Úriz, abad

O. Cist.

AGN, Irache, Lib. 542, 419r.

SIMÓN ELORZA

B. A. / B. T.

5-4-1657

Fr. Alonso de Escudero

Barcina del Barco (Burgos)

AGN, Irache, Lib. 542, 419r.

GABRIEL MARTÍNEZ DE SUSO

B. A. / B. T.

5-4-1657

Fr. Mauro Velázquez

Burgos

AGN, Irache, Lib. 542, 419r.

ALONSO FERNÁNDEZ

B. C.

6-4-1657

Fr. Pedro de Vergaño

Corias (Burgos)

AGN, Irache, Lib. 542, 419v.

FRANCISCO DÍAZ RODRÍGUEZ

B. C.
14-4-1657

Fr. Alonso de Escudero

Requejo (Burgos)

AGN, Irache, Lib. 542, 419v.

\section{DIEGO RUIZ}

B. C.

19-4-1657

Fr. Domingo Gutiérrez

Ojos del Tozo (Burgos)

AGN, Irache, Lib. 542, 419v.

JUAN DE LA CANTERA

B. C.

19-4-1657

Fr. Domingo Gutiérrez

San Martín de Losa (Burgos)

AGN, Irache, Lib. 542, 419v.

ATANASIO PASCASIO DE BOBADILLA

L. C.

21-4-1657

Fr. Domingo Gutiérrez

Arnedo (Calahorra)

AGN, Irache, Lib. 542, 420 .

ALONSO GARCÍA

B. C.

24-4-1657

Fr. Domingo Gutiérrez

Villahizán (Burgos)

AGN, Irache, Lib. 542, 420 .

JUAN DE MIRAVECHE

B. C.

25-4-1657

Fr. Domingo Gutiérrez

Frías (Burgos)

AGN, Irache, Lib. 542, $420 r$.

ESTEBAN FERNÁNDEZ

B. C.

25-4-1657

Fr. Domingo Gutiérrez

Imaña (Burgos)

AGN, Irache, Lib. 542, 420 .

ANDRÉS LÓPEZ DE CADIÑANOS

B. C. 
25-4-1657

Fr. Domingo Gutiérrez

Extremiana (Burgos)

AGN, Irache, Lib. 542, 420 .

ANDRÉS PÉREZ

B. C.

1-5-1657

Fr. Domingo Gutiérrez

Sotragero (Burgos)

AGN, Irache, Lib. 542, $420 v$.

\section{TORIBIO FERNÁNDEZ}

B. C.

1-5-1657

Fr. Alonso de Escudero

Canduela (Burgos)

AGN, Irache, Lib. 542, $420 v$.

\section{JUAN BRAVO}

B. C.

3-5-1657

Fr. Domingo Gutiérrez

Campoo (Burgos)

AGN, Irache, Lib. 542, $420 v$.

JUAN DE BRIZUELA

B. C.

9-5-1657

Fr. Alonso de Escudero

Medina de Pomar (Burgos)

AGN, Irache, Lib. 542, $420 v$.

\section{GREGORIO GÓMEZ}

B. C.

13-5-1657

Fr. Alonso de Escudero

Medina de Pomar (Burgos)

AGN, Irache, Lib. 542, $420 v$.

DOMINGO BRINGAS

B. C.

14-5-1657

Fr. Alonso de Escudero

Ampuero (Burgos)

AGN, Irache, Lib. 542, 421r.

SEBASTIÁN GARCÍA CLEMENTE

B. C.
24-5-1657

Fr. Mauro Velázquez

Pancorbo (Burgos)

AGN, Irache, Lib. 542, 421r.

\section{BERNARDO CALVO}

B. C.

28-5-1657

Fr. Gregorio de Silva, vicecanciller

Otañes (Burgos)

AGN, Irache, Lib. 542, 421r.

\section{DOMINGO ÁLVAREZ}

B. C.

28-5-1657

Fr. Gregorio de Silva

Castrojeriz (Burgos)

AGN, Irache, Lib. 542, 421r.

IGNACIO DE LARREA Y VALDIVIESO

B. C.

4-6-1657

Fr. Domingo Gutiérrez

Granada

AGN, Irache, Lib. 542, 421r.

FRANCISCO ERASO

B. C.

4-6-1657

Fr. Domingo Gutiérrez

Tafalla (Pamplona)

AGN, Irache, Lib. 542, 421r.

PEDRO IBÁÑEZ

B. $\mathrm{M}$.

4-6-1657

Fr. Domingo Gutiérrez

Corera (Calahorra)

AGN, Irache, Lib. 542, $421 \mathrm{v}$.

PABLO GIMÉNEZ

B. C. / L.C. / D. C.

7-6-1657

Fr. Alonso de Escudero

Cenarve (Jaca)

AGN, Irache, Lib. 542, 422v.

FRANCISCO DE URRUTIA

B. C. 
22-6-1657

Fr. Gregorio de Silva

Concejo de Calle (Burgos)

AGN, Irache, Lib. 542, 422v.

FRANCISCO GONZÁLEZ

B. C.

26-6-1657

Fr. Anselmo López, Regente

Villanueva (Burgos)

AGN, Irache, Lib. 542, 422r.

FRANCISCO GONZÁLEZ DE REBA

B. C.

3-7-1657

Fr. Alonso de Escudero

Barreda (Burgos)

AGN, Irache, Lib. 542, 422r.

FRANCISCO DE CAMPOMANES

L. T. / D. T.

9-7-1657

Fr. Alonso de Escudero

O. Cist.

Burgos

AGN, Irache, Lib. 542, 422r.

JOSÉ ARREDONDO

L. C.

9-7-1657

Fr. Gregorio de Silva

Arredondo (Burgos)

AGN, Irache, Lib. 542, 422v.

SEBASTIÁN CALVO

B. T.

13-7-1657

Fr. Gregorio de Silva

Burgos

AGN, Irache, Lib. 542, 422v.

ANDRÉS DE LA TORRE

B. C.

15-7-1657

Fr. Anselmo López

Vella Campo (Burgos)

AGN, Irache, Lib. 542, 422v.
SEBASTIÁN DE BALMACEDA SALAR

B. C.

15-7-1657

Fr. Alonso de Escudero

Balmaceda (Burgos)

AGN, Irache, Lib. 542, 423r.

\section{PEDRO SANZ}

B. C.

16-7-1657

Fr. Gregorio de Silva

Villadiego (Burgos)

AGN, Irache, Lib. 542, 423r.

JUAN SOMERO DE ARENAS

B. A. / B. T.

6-8-1657

Fr. Anselmo López

Castrojeriz (Burgos)

AGN, Irache, Lib. 542, 423r.

FELIPE DE FANDUAS

B. A.

7-8-1657

Fr. Gregorio de Silva

Pamplona

AGN, Irache, Lib. 542, 423r.

DIEGO HERNÁNDEZ DE LA TORRE

B. T.

10-8-1657

Fr. Alonso de Escudero

Arguiano (Calahorra)

AGN, Irache, Lib. 542, 423v.

JUAN DE AHEDO

B. C.

18-8-1657

Fr. Gregorio de Silva

Valle Carranza (Burgos)

AGN, Irache, Lib. 542, 423v.

FRANCISCO DE PALACIOS

L. A.

23-8-1657

Fr. Plácido de Urbina, Maestro General, abad

Nájera (Calahorra)

AGN, Irache, Lib. 542, 423v. 
ANTONIO DE CUREDA Y HURTADO

B. C.

13-9-1657

Fr. Gregorio de Silva

Vilnar (Calahorra)

AGN, Irache, Lib. 542, 424r.

SEBASTIÁN BLANCO

B. A. / B. T.

14-9-1657

Fr. Alonso de Escudero

Burgos

AGN, Irache, Lib. 542, 424r.

JUAN DE PINEDO

B. A. / B. T.

14-9-1657

Fr. Alonso de Escudero

Gruendes (Burgos)

AGN, Irache, Lib. 542, 424r.

JUAN DE REVUELTA

B. C.

16-9-1657

Fr. Gregorio de Silva

Praves (Burgos)

AGN, Irache, Lib. 542, 424r.

ANTONIO SÁNCHEZ DE LA GÁNDARA

B. C.

18-9-1657

Fr. Alonso de Escudero

Valle de Toranzo (Burgos)

AGN, Irache, Lib. 542, 424r.

ALONSO DE LISARRI

L. M. / D. M.

28-9-1657

Fr. Plácido Urbina, abad

Falces (Pamplona)

AGN, Irache, Lib. 542, 424v.

FELIPE ILASO

B. T.

29-9-1657

Fr. Alonso de Escudero

Poza (Burgos)

AGN, Irache, Lib. 542, 424V.
JOSÉ DE NEVADO

B. C.

1-10-1657

Fr. Alonso de Escudero

Burgos

AGN, Irache, Lib. 542, 425r.

DOMINGO SÁNCHEZ DE TRÁPAGA

B. C.

1-10-1657

Fr. Alonso de Escudero

Quintana (Burgos)

AGN, Irache, Lib. 542, 425r.

FÉLIX DE SALTO

B. A. / B. T.

5-10-1657

Fr. Anselmo López

O. Cist.

AGN, Irache, Lib. 542, 425r.

LORENZO MARGÁIN

B. A.

5-10-1657

Fr. Anselmo López

AGN, Irache, Lib. 542, 425v.

JUAN JALÓN

B. A.

8-10-1657

Fr. Gregorio de Silva

Corera (Calahorra)

AGN, Irache, Lib. 542, 425v.

BLAS DE BARANGO

B. C.

8-10-1657

Fr. Gregorio de Silva

Balmaseda (Burgos)

AGN, Irache, Lib. 542, 425v.

JERÓNIMO VIRTO

B. A.

11-10-1657

Fr. Felipe de Vamonde, vicecanciller

O. Cist.

AGN, Irache, Lib. 542, 426r. 
NICOLÁS PÉREZ

B. A.

11-10-1657

Fr. Felipe de Vamonde

O. Cist.

AGN, Irache, Lib. 542, 426r.

PEDRO RUIZ

B. A. / B. M.

11-10-1657 / 12-10-1657

Fr. Felipe de Vamonde / Fr. Gregorio de

Silva

Aldeanueva (Calahorra)

AGN, Irache, Lib. 542, 426r.

FRANCISCO DE LAMO

B. A. / B. T.

15-10-1657

Fr. Anselmo López

Villasidro (Burgos)

B. A. en Ávila

AGN, Irache, Lib. 542, 426v.

ANTONIO SÁENZ

B. A. / B. T.

15-10-1657

Fr. Felipe de Vamonde

O. Cist.

AGN, Irache, Lib. 542, 426v.

\section{MATEO DE IRUCETA}

L. A.

19-10-1657

Fr. Plácido Urbina, abad

Garinoain (Pamplona)

AGN, Irache, Lib. 542, 426v.

GREGORIO GARCÍA

B. C.

24-10-1657

Fr. Alonso de Escudero

Val (Burgos)

AGN, Irache, Lib. 542, 427r.

FRANCISCO RUIZ

B. C.

25-10-1657

Fr. Gregorio de Silva
Casares del Arroyo (Burgos)

AGN, Irache, Lib. 542, 427r.

JOSÉ DE MAÑERAS

B. L. / L. L.

3-11-1657

Fr. Plácido Urbina, abad

Tudela (Nullius Diocesis)

AGN, Irache, Lib. 542, 427r.

LUCAS PÉREZ

B. C.

9-11-1657

Fr. Gregorio de Silva

Villasandino (Burgos)

AGN, Irache, Lib. 542, 427v.

\section{JUAN MARCOS}

B. C.

9-11-1657

Fr. Gregorio de Silva

Villasandino (Burgos)

AGN, Irache, Lib. 542, 427v.

GASPAR MARCOS

B. C.

12-11-1657

Fr. Anselmo López

Villasandino (Burgos)

AGN, Irache, Lib. 542, 427v.

\section{MIGUEL MORATE}

B. C.

12-11-1657

Fr. Anselmo López

Villasandino (Burgos)

AGN, Irache, Lib. 542, 427v.

JUAN DEL HIERRO

B. C.

18-11-1657

Fr. Gregorio de Silva

Villasandino (Burgos)

AGN, Irache, Lib. 542, 427v.

JOSÉ DE ARGAIZ

B. T. / L. T. / D. T.

21-11-1657 
Fr. Plácido Urbina, abad

O. S. B.

Predicador mayor de Valladolid

San Millán de la Cogolla

AGN, Irache, Lib. 542, 428r.

FRANCISCO TURRILLAS

B. A. / L. A.

29-11-1657

Fr. Felipe de Vamonde

Ozcoidi (Pamplona)

AGN, Irache, Lib. 542, 428r.

JUAN DE MENDIZÁBAL

B. A. / B. M.

29-11-1657

Fr. Felipe de Vamonde

Pamplona

AGN, Irache, Lib. 542, 428r.

TOMÁS SIMÓN

B. C.

12-12-1657

Fr. Alonso de Escudero

Sasamón (Burgos)

AGN, Irache, Lib. 542, 428r.

DIEGO RUIZ DE SANTAYANA

B. A. / B. T.

17-12-1657

Fr. Gregorio de Silva

Espinosa (Burgos)

AGN, Irache, Lib. 542, 428r.

GONZALO DE VILLA

B. C.

20-12-1657

Fr. Anselmo López

Puerto Santoña (Burgos)

AGN, Irache, Lib. 542, 428v.

FERNANDO DEL MAZO CALDERÓN

B. C.

25-12-1657

Fr. Alonso de Escudero

AGN, Irache, Lib. 542, 428v.
PRUDENCIO DE MANZANARES

B. C.

25-12-1657

Fr. Alonso de Escudero

Valle del Meruelo (Burgos)

AGN, Irache, Lib. 542, 428v.

ANTONIO DE PEDROSO

B. C.

28-12-1657

Fr. Gregorio de Silva

Baños de Río Tobía (Calahorra)

AGN, Irache, Lib. 542, 428v.

\section{ANSELMO LÓPEZ}

M. T.

23-12-1657

Fr. Diego de Silva, General de la Orden

O. S. B.

Maestro en Irache

AGN, Irache, Lib. 542, 428v.

JUAN DE RUIZ

M. T.

23-12-1657

Fr. Diego de Silva, General de la Orden

O. S. B.

Maestro en Irache

AGN, Irache, Lib. 542, 428v.

PEDRO DE MURGA

M. T.

28-12-1657

Fr. Diego de Silva, General de la Orden

O. S. B.

Maestro en Irache

Predicador

AGN, Irache, Lib. 542, 428v.

JUAN ÁNGEL DEL RÍO

B. C.

8-1-1658

Fr. Anselmo López, Regente

Puerto (Burgos)

AGN, Irache, Lib. 539, s. f.

FRANCISCO ÁLVAREZ

B. C. 
12-1-1658

Fr. Ildefonso de Escudero

... Burgos

AGN, Irache, Lib. 539, s. f.

JOSÉ DE LARRAURI

B. C.

$2-/-/ 1658$

Fr. Gregorio de Silva

Rasines (Burgos)

AGN, Irache, Lib. 539, s. f.

FRANCISCO DE SANTIBÁÑEZ

B. C.

$3-/-/ 1658$

Fr. Anselmo López

Castrillo de Matajudíos (Burgos)

AGN, Irache, Lib. 539, s. f.

JOSÉ PASCUAL JORDÁN

B. A. / B. M.

$12 / 1 / 1658$

Fr. Felipe de Vamonde

Cubel (Tarazona)

AGN, Irache, Lib. 539, s. f.

PEDRO DE ALMAR

B. C.

$15-/-/ 1658$

Fr. Gregorio de Silva

Burgos

AGN, Irache, Lib. 539, s. f.

ANDRÉS DEL POZO

B. C.

20-/-/1658

Fr. Anselmo López

Valluércanes (Burgos)

AGN, Irache, Lib. 539, s. f.

ANDRÉS DEL MORAL

B. C.

$11-/-/ 1658$

Fr. Gregorio de Silva

Sotresgudo (Burgos)

AGN, Irache, Lib. 539, s. f.

PEDRO BENITO

B. C.
$11-/-/ 1658$

Fr. Gregorio de Silva

Sotresgudo (Burgos)

AGN, Irache, Lib. 539, s. f.

PEDRO DE HERRERA Y SOTO

B. C. / L.C. / D. C.

14-1-1658

Fr. Plácido Urbina, abad

Sevilla

AGN, Irache, Lib. 539, s. f.

DIEGO DE BROAÑO Y MALDONADO

B. C.

$14-/-/ 1658$

Fr. Ildefonso de Escudero

Sepúlveda (Segovia)

AGN, Irache, Lib. 539, s. f.

FRANCISCO DE SIERRA ALTA

B. C.

15/-/1658 // 4-7-1658

Sin graduar

Fr. Gregorio de Silva

Antón (Burgos)

AGN, Irache, Lib. 539, s. f.

JUAN DEL RÍO

B. C.

24-/-/1658

Anselmo López, Regente

Acedillo (Burgos)

AGN, Irache, Lib. 539, s. f.

FRANCISCO FERNÁNDEZ DE MARMA-

NILLO

B. C.

29-/-/1658

Fr. Gregorio de Silva

Oriñuela (Calahorra)

AGN, Irache, Lib. 539, s. f.

SANTIAGO GONZÁLEZ

B. C.

5-5-1658

Fr. Gregorio de Silva

Salcedillo (Burgos)

AGN, Irache, Lib. 539, s. f. 


\section{JUAN DE IRULEGUI}

B. A.

7-5-1658

Fr. Felipe de Vamonde

Burguete (Pamplona)

AGN, Irache, Lib. 539, s. f.

\section{JUAN DE VERA}

B. A.

7-5-1658

Fr. Felipe de Vamonde

Monreal (Pamplona)

AGN, Irache, Lib. 539, s. f.

\section{ANTONIO DE ARANGUREN}

B. A.

7-5-1658

Fr. Felipe de Vamonde

Aibar (Pamplona)

AGN, Irache, Lib. 539, s. f.

JOSÉ DE ACEDO

\section{B. A. / B. T.}

7-5-1658 / 30-3-1662

Fr. Felipe de Vamonde / Fr. Alonso de Mier Falces (Pamplona)

B. A. en el Colegio S. J. de Pamplona

AGN, Irache, Lib. 539, s. f., 3or.

\section{LEÓN DE LARRUMBE}

B. A.

7-5-1658

Fr. Felipe de Vamonde

Zugarramendi (Pamplona)

AGN, Irache, Lib. 539, s. f.

JUAN DE FRÍAS

B. A.

7-5-1658

Fr. Felipe de Vamonde

Zugarramendi (Pamplona)

AGN, Irache, Lib. 539, s. f.

\section{FRANCISCO MINER}

B. A. / L. A.

7-5-1658

Fr. Plácido Urbina, abad

Hernani (Pamplona)

AGN, Irache, Lib. 539, s. f.
DIONISIO DE ALQUIZA

B. A. / L. A.

7-5-1658

Fr. Plácido Urbina, abad

Alguiza (Pamplona)

AGN, Irache, Lib. 539, s. f.

SANTIAGO DE LA TOBA

B. C.

9-5-1658

Fr. Anselmo López

Castro Urdiales (Burgos)

AGN, Irache, Lib. 539, s. f.

LÁZARO LÓPEZ

B. C.

16-5-1658

Fr. Ildefonso de Escudero

Melgar de Fernamental (Burgos)

AGN, Irache, Lib. 539, s. f.

ROQUE LÓPEZ

B. C.

16-5-1658

Fr. Gregorio de Silva

Matajudíos (Burgos)

AGN, Irache, Lib. 539, s. f.

\section{MARCOS TEZANOS}

B. C.

16-5-1658

Fr. Gregorio de Silva

... (Burgos)

AGN, Irache, Lib. 539, s. f.

\section{ALONSO RUIZ}

B. C.

16-5-1658

Fr. Gregorio de Silva

... (Burgos)

AGN, Irache, Lib. 539, s. f.

BERNARDO SILA

B. $T$.

19-5-1658

Fr. Gregorio de Silva

Villa Sila (Burgos)

AGN, Irache, Lib. 539, s. f. 
PEDRO DE LA MAZA

B. C.

19-5-1658

Fr. Gregorio de Silva

Laredo (Burgos)

AGN, Irache, Lib. 539, s. f.

FRANCISCO ORTIZ

B. C.

23-5-1658

Fr. Ildefonso de Escudero

Lama (Burgos)

AGN, Irache, Lib. 539, s. f.

ANDRÉS DE LA TORRE

B. C.

27-5-1658

Fr. Gregorio de Silva

Valle de Carranza (Burgos)

AGN, Irache, Lib. 539, s. f.

DIEGO DE BULLÁN

B. C.

27-5-1658

Fr. Gregorio de Silva

Baules (Burgos)

AGN, Irache, Lib. 539, s. f.

\section{FRANCISCO CACHO}

B. A. / B. T.

1-6-1658

Fr. Felipe de Vamonde

Laredo (Burgos)

AGN, Irache, Lib. 539, s. f.

BRAULIO DE ASTORGA

B. C.

5-6-1658

Fr. Anselmo López

Guerricaiz (Calahorra)

AGN, Irache, Lib. 539, s. f.

RUY SALAZAR

B. C.

5-6-1658

Fr. Anselmo López

Guerricaiz (Calahorra)

AGN, Irache, Lib. 539, s. f.
LUCAS DE LA TEJERA

B. C.

11-6-1658

Fr. Gregorio de Silva

Santecilla (Burgos)

AGN, Irache, Lib. 539, s. f.

JERÓNIMO MARCOS

B. A. / B. T.

19-6-1658

Fr. Felipe de Vamonde

Villarzan (Burgos)

AGN, Irache, Lib. 539, s. f.

JUAN CERRO

B. C.

19-7-1658

Fr. Gregorio de Silva

Ampuero (Burgos)

AGN, Irache, Lib. 539, s. f.

JUAN DE LA BRA...

B. C.

20-7-1658

Fr. Gregorio de Silva

Frías (Burgos)

AGN, Irache, Lib. 539, s. f.

PEDRO SANZ DE LA CUEVA

B. C.

23-7-1658

Fr. Gregorio de Silva

Balmaseda (Burgos)

AGN, Irache, Lib. 539, s. f.

DIEGO MARTÍNEZ DE LA QUINTANA

B. C.

23-7-1658

Fr. Gregorio de Silva

Valle de Arzentales (Burgos)

AGN, Irache, Lib. 539, s. f.

JACINTO UROIZ

B. A. / L. A.

23-7-1658

Fr. Felipe de Vamonde

San Sebastián (Pamplona)

AGN, Irache, Lib. 539, s. f. 
FRANCISCO FERNÁNDEZ DE MIÑANO

L. C.

24-7-1658

Fr. Gregorio de Silva

Peralta (Pamplona)

AGN, Irache, Lib. 539, s. f.

FRANCISCO FERNÁNDEZ

B. A. / B. T.

30-7-1658

Fr. Felipe de Vamonde

Valderrama (Burgos)

AGN, Irache, Lib. 539, s. f.

PEDRO DE SAN BENITO

B. C.

1-8-1658

Fr. Ildefonso de Escudero

Santa Olalla (Burgos)

AGN, Irache, Lib. 539, s. f.

JOSÉ GONZÁLEZ

B. C.

1-8-1658

Fr. Anselmo López

Rioseras (Burgos)

AGN, Irache, Lib. 539, s. f.

MIGUEL MARTÍNEZ DE GARAIZ

B. C.

1-8-1658

Fr. Anselmo López

Rioseras (Burgos)

AGN, Irache, Lib. 539, s. f.

JUAN CANTÓN

B. C.

1-8-1658

Fr. Anselmo López

Peñahorada (Burgos)

AGN, Irache, Lib. 539, s. f.

ANDRÉS DE HERNANDO

B. A. / B. T.

3-8-1658

Fr. Felipe de Vamonde

Santa Olalla (Burgos)

AGN, Irache, Lib. 539, s. f.
FERNANDO DE MEDRANO

B. C.

4-8-1658

Fr. Anselmo López

Logroño (Calahorra)

AGN, Irache, Lib. 539, s. f.

VÍCTORES MARTÍNEZ

B. C.

12-8-1658

Fr. Ildefonso de Escudero

Villarán (Burgos)

AGN, Irache, Lib. 539, s. f.

ANDRÉS TEJERO

B. C.

22-8-1658

Fr. Gregorio de Silva

Herrera de Valdecañas (Burgos)

AGN, Irache, Lib. 539, s. f.

DOMINGO DE UBERRICHAGA

B. C.

28-8-1658 / 26-10-1658

No se le graduó

Fr. Anselmo López

Medina de Pomar

Burgos

AGN, Irache, Lib. 539, s. f.

DIEGO DE SOLÓRZANO

B. C.

4-9-1658

Fr. Gregorio de Silva

Beranga (Burgos)

AGN, Irache, Lib. 539, s. f.

PEDRO DE ARCE SOLÓRZANO

B. C.

4-9-1658

Fr. Gregorio de Silva

Beranga (Burgos)

AGN, Irache, Lib. 539, s. f.

FRANCISCO DE LA QUINTANA

B. C.

18-9-1658

Fr. Gregorio de Silva 
Sopuerta (Burgos)

AGN, Irache, Lib. 539, s. f.

JOSÉ GARCÍA

B. C.

25-9-1658

Fr. Ildefonso de Escudero

Padilla de Abajo (Burgos)

AGN, Irache, Lib. 539, s. f.

ANDRÉS HERNANDO

B. T.

26-9-1658

Fr. Gregorio de Silva

Santa Olalla (Burgos)

AGN, Irache, Lib. 539, s. f.

PEDRO HERRERO

B. A.

30-9-1658

Fr. Gregorio de Silva

Sandoval (Burgos)

AGN, Irache, Lib. 539, s. f.

PEDRO GARCÍA

B. T.

30-9-1658

Fr. Gregorio de Silva

Agés (Burgos)

AGN, Irache, Lib. 539, s. f.

\section{ANDRÉS FERNÁNDEZ}

B. C.

9-10-1658

Fr. Ildefonso de Escudero

Valderrama (Burgos)

AGN, Irache, Lib. 539, s. f.

DOMINGO LABORDA

B. C.

9-10-1658

Fr. Ildefonso de Escudero

Palo (Barbastro)

AGN, Irache, Lib. 539, s. f.

JUAN DOMINGO SOLANO

B. C.

10-10-1658
Fr. Ildefonso de Escudero

Palo (Barbastro)

AGN, Irache, Lib. 539, s. f.

FRANCISCO DE GUZMÁN

B. C.

19-10-1658

Fr. Plácido Urbina, abad

Sanlúcar (Sevilla)

AGN, Irache, Lib. 539, s. f.

PEDRO CARRILLO

B. C.

19-10-1658

Fr. Gregorio de Silva

Viana (Calahorra)

AGN, Irache, Lib. 539, s. f.

MANUEL DE PINEDO

B. C.

18-10-1658

Fr. Anselmo López

Castrojeriz (Burgos)

AGN, Irache, Lib. 539, s. f.

PEDRO ZAPATA

B. C. / L. C.

30-10-1658

Fr. Plácido Urbina, abad

Calahorra

AGN, Irache, Lib. 539, s. f.

JERÓNIMO RAMÍREZ

B. L. / L. L. / D. L.

6-11-1658

Fr. Plácido Urbina, abad

Ariza (Sigüenza)

AGN, Irache, Lib. 539, s. f.

MARTÍN DEL BARRIO

B. A. / B. T.

30-12-1658

Fr. Felipe de Vamonde

Villambistia (Burgos)

AGN, Irache, Lib. 539, s. f.

MARCOS DE LODOSA

B. C. 
29-1-1659 / 3-3-1659

No se le graduó

Fr. Gregorio de Silva

Quintanillas (Burgos)

AGN, Irache, Lib. 539, s. f.

JUAN ZÚMEL

B. A. / B. T.

31-1-1659 / 21-6-1659

Fr. Felipe de Vamonde / Fr. Regente

Pedrosa del Río Urbel (Burgos)

AGN, Irache, Lib. 539, s. f., 9r.

TOMÁS DE ANGLÁS

B. A. / B. M.

9-2-1659

Fr. Felipe de Vamonde

Mallén (Zaragoza)

AGN, Irache, Lib. 539, s. f.

VALENTÍN DE LA IGLESIA

B. A. / B. T.

20-2-1659

Fr. Felipe de Vamonde

Santa María Tajadura (Burgos)

AGN, Irache, Lib. 539, s. f.

MIGUEL DE CEREZO

B. A. / B. T.

2-3-1659

Fr. Felipe de Vamonde

Sta. María de Ribarredondo (Burgos)

AGN, Irache, Lib. 539, s. f.

JOSÉ DE SANTAFÉ

B. L.

3-3-1659

Fr. Ildefonso de Escudero

Guiscar

AGN, Irache, Lib. 539, s. f.

FRANCISCO DE UNDIANO

B. A.

18-3-1659

Fr. Felipe de Vamonde

O. C.

AGN, Irache, Lib. 539, s. f.
FRANCISCO BERNARDO PONCE

B. C. / L. C. / D. C.

19-3-1659

Fr. Gregorio de Silva

…

Canónigo de Montearagón

AGN, Irache, Lib. 539, s. f.

AGUSTÍN GONZÁLEZ

B. C.

19-3-1659

Fr. Gregorio de Silva

Sta. María de Ribarredondo (Burgos)

AGN, Irache, Lib. 539, 7r.

MARTÍN DE AZAS

B. C.

20-3-1659

Fr. Anselmo López

Liendo (Burgos)

AGN, Irache, Lib. 539, 7r.

FRANCISCO IBÁÑEZ

B. A. / B. M.

26-3-1659

Fr. Felipe de Vamonde / Fr. Ildefonso de

Escudero

Used (Zaragoza)

AGN, Irache, Lib. 539, 7r.

BERNARDO DE SALAZAR

B. C.

27-3-1659

Fr. Gregorio de Silva

San Martín del Don (Burgos)

AGN, Irache, Lib. 539, 7r.

MIGUEL OCHOA

B. A.

28-3-1659

Fr. Felipe de Vamonde

Alda

AGN, Irache, Lib. 539, 7r.

SIMÓN DEL MORAL

B. C.

28-3-1659

Fr. Anselmo López 
Hontomín (Burgos)

AGN, Irache, Lib. 539, 7r.

JUAN SEGURA

B. A. / B. T.

7-4-1659

Fr. Ildefonso de Escudero

Santa Eulalia (Burgos)

AGN, Irache, Lib. 539, $7 \mathrm{v}$.

FRANCISCO DOMÍNGUEZ

B. A.

18-4-1659

Fr. Felipe de Vamonde

Tenerife

AGN, Irache, Lib. 539, $7 \mathrm{v}$.

DOMINGO GIL

B. C.

24-4-1659

Fr. Gregorio de Silva

Carranza (Burgos)

AGN, Irache, Lib. 539, 7v.

JUAN MARTÍNEZ

B. A.

29-4-1659

Fr. Felipe de Vamonde

Penches (Burgos)

AGN, Irache, Lib. 539, 7v.

JOSÉ DE YOLDI

B. $\mathrm{M}$.

6-5-1659

Fr. Felipe de Vamonde

Añorbe (Pamplona)

AGN, Irache, Lib. 539, 7v.

FRANCISCO DE EGEA

B. A.

6-5-1659

Fr. Felipe de Vamonde

San Martín de Unx (Pamplona)

Colegio S. J.

AGN, Irache, Lib. 539, 8r.

MARTÍN DEL PUCIO IRIGOYEN

B. A.
6-5-1659

Fr. Felipe de Vamonde

San Martín de Unx (Pamplona)

Colegio S. J.

AGN, Irache, Lib. 539, 8r.

JUAN FRANCISCO PARDO

B. A.

6-5-1659

Fr. Felipe de Vamonde

Pamplona

Colegio S. J.

AGN, Irache, Lib. 539, 8r.

MIGUEL URRUTIA

B. A.

6-5-1659

Fr. Felipe de Vamonde

Pamplona

Colegio S. J.

AGN, Irache, Lib. 539, 8r.

JUAN MARTÍN DE OLANO

B. A.

6-5-1659

Fr. Felipe de Vamonde

Pamplona

Colegio S. J.

AGN, Irache, Lib. 539, 8r.

JUAN DE AZCÁRATE

B. A.

6-5-1659

Fr. Felipe de Vamonde

Pamplona

Colegio S. J.

AGN, Irache, Lib. 539, 8r.

JERÓNIMO PÉREZ

B. A.

6-5-1659

Fr. Felipe de Vamonde

Obanos (Pamplona)

Colegio S. J.

AGN, Irache, Lib. 539, 8r.

JUAN FERMÍN DE MÚZQUIZ

B. A. 
6-5-1659

Fr. Felipe de Vamonde

Obanos (Pamplona)

Colegio S. J.

AGN, Irache, Lib. 539, 8r.

MATEO DE REZUSTA

B. A.

6-5-1659

Fr. Felipe de Vamonde

Segura (Pamplona)

Colegio S. J.

AGN, Irache, Lib. 539, 8r.

MARTÍN DOMÍNGUEZ DE VIDAURRETA

B. A.

6-5-1659

Fr. Felipe de Vamonde

Belascoáin (Pamplona)

Colegio S. J.

AGN, Irache, Lib. 539, 8r.

NICOLÁS DE LABIANO

B. A.

6-5-1659

Fr. Felipe de Vamonde

Larrasoaña (Pamplona)

Colegio S. J.

AGN, Irache, Lib. 539, 8r.

PEDRO DE ECHEVERRÍA

B. A.

6-5-1659

Fr. Felipe de Vamonde

Estella (Pamplona)

Colegio S. J.

AGN, Irache, Lib. 539, 8r.

MARTÍN DE JURIO

B. A.

6-5-1659

Fr. Felipe de Vamonde

Lerga (Pamplona)

Colegio S. J.

AGN, Irache, Lib. 539, 8r.

MIGUEL DE ALDUNATE

B. A.
6-5-1659

Fr. Felipe de Vamonde

Redín (Pamplona)

Colegio S. J.

AGN, Irache, Lib. 539, 8r.

JUAN DE ECHENIQUE

B. A.

6-5-1659

Fr. Felipe de Vamonde

Errazu (Pamplona)

Colegio S. J.

AGN, Irache, Lib. 539, 8r.

JOSÉ MARTÍNEZ

B. A.

6-5-1659

Fr. Felipe de Vamonde

Urroz (Pamplona)

Colegio S. J.

AGN, Irache, Lib. 539, 8r.

JOSÉ DE EGUIZÁBAL

B. A.

6-5-1659

Fr. Felipe de Vamonde

Vergara (Calahorra)

Colegio S. J.

AGN, Irache, Lib. 539, 8r.

FRANCISCO ZORRILLA

B. C.

9-5-1659

Fr. Gregorio de Silva

Villarcayo (Burgos)

AGN, Irache, Lib. 539, 8r.

TOMÁS GONZÁLEZ

B. A. / B. T.

15-5-1659

Fr. Ildefonso de Escudero

Ezcaray (Burgos)

AGN, Irache, Lib. 539, 8v.

LUCAS FERNÁNDEZ

B. C.

16-5-1659

Fr. Gregorio de Silva 
Villar del Valle de Mena (Burgos)

AGN, Irache, Lib. 539, 8v.

\section{BERNARDO GARCÍA}

B. A. / L. A.

26-5-1659

Fr. Felipe de Vamonde

Antor (Calahorra)

AGN, Irache, Lib. 539, 8v.

PEDRO JOSÉ DEL ARCO

B. L.

27-5-1659

Fr. Ildefonso de Escudero

Tudela (Nullius Diocesis)

AGN, Irache, Lib. 539, 8v.

\section{FRANCISCO DE OBREGÓN}

B. C.

7-6-1659

Fr. Gregorio de Silva

Santa María del Valle (Burgos)

AGN, Irache, Lib. 539, 8v.

PEDRO LÓPEZ

B. C.

7-6-1659

Fr. Gregorio de Silva

Aguayo (Burgos)

AGN, Irache, Lib. 539, 8v.

JUAN MARTÍNEZ DE MONTERRUBIO

B. A. / B. T.

9-6-1659

Fr. Ildefonso de Escudero

Tripana (Burgos)

AGN, Irache, Lib. 539, 9r.

JUAN GARCÍA

B. C.

13-6-1659

Fr. Gregorio de Silva

Gurriezo (Burgos)

AGN, Irache, Lib. 539, 9r.

PEDRO DE ASAS

B. C.

20-6-1659
Fr. Regente

Noja (Burgos)

AGN, Irache, Lib. 539, 9r.

JUAN TAMBO

B. A. / B. M.

30-6-1659

Fr. Ildefonso de Escudero

Ablitas (Tarazona)

Testimonio de Estudios en Valencia

AGN, Irache, Lib. 539, 9r.

JUAN GONZÁLEZ

B. A. / B. T.

22-7-1659

Fr. Felipe de Vamonde

Pedrosa del Río Urbel (Burgos)

AGN, Irache, Lib. 539, 1 or.

\section{FRANCISCO TORRIENTES}

B. C.

29-7-1659

Fr. Ildefonso de Escudero

Barrios de Colina (Burgos)

AGN, Irache, Lib. 539, 1 or.

\section{MARTÍN LÓPEZ DE GAUNA}

B. M. / L. M. / D. M.

29-7-1659

Abad-Rector y Claustro

Estella (Pamplona)

D. M. por Valencia

Incorporación a la Universidad de Irache

AGN, Irache, Lib. 539, 1 or.

FRANCISCO DE COLINA

B. T.

31-7-1659

Fr. Gregorio de Silva

Iniesta (Burgos)

AGN, Irache, Lib. 539, $10 \mathrm{v}$.

PEDRO SARABIA VILLASANTE

B. C.

2-8-1659

Fr. Anselmo López

Arroyo (Burgos)

AGN, Irache, Lib. 539, $10 v$. 
JOSÉ DE SAGASTI

B. A. / B. T.

18-8-1659

Fr. Felipe de Vamonde

Irache (Pamplona)

AGN, Irache, Lib. 539, 10v.

JUAN MARTÍNEZ

B. A.

2-9-1659

Fr. Felipe de Vamonde

Peralta (Pamplona)

AGN, Irache, Lib. 539, $10 \mathrm{v}$.

\section{SIMÓN DÍEZ}

B. A. / B. T.

4-9-1659

Fr. Gregorio de Silva

Quintavides (Burgos)

AGN, Irache, Lib. 539, $10 \mathrm{v}$.

\section{AGUSTÍN SUSINOS}

B. C.

4-9-1659 No se le dio el grado

17-12-1659 No se le dio el grado

10-12-166o Aprobado

Fr. Gregorio de Silva / Fr. Alonso de Escu-

dero

Olmillos (Burgos)

AGN, Irache, Lib. 539, 11r, 14r, 21v.

\section{FERNANDO DEL HOYO}

B. C.

17-9-1659

Fr. Ildefonso de Escudero

Pardiernaga de Trasmiera (Burgos)

AGN, Irache, Lib. 539, 11r.

\section{FRANCISCO CALVO}

B. T.

17-9-1659

Fr. Ildefonso de Escudero

Huerta de Arriba (Burgos)

AGN, Irache, Lib. 539, 11r.

JOSÉ DE SADA

B. C. / L. C.

18-9-1659
Fr. Gregorio de Silva

Zaragoza

AGN, Irache, Lib. 539, 11r.

JUAN MERINO

B. C.

19-9-1659

Fr. Gregorio de Silva

Grisaleña (Burgos)

AGN, Irache, Lib. 539, 11v.

JUAN FRANCISCO LIZAUN Y OLLO

B. C. / L. C.

23-9-1659

Fr. Ildefonso de Escudero

Estella (Pamplona)

AGN, Irache, Lib. 539, 11v.

JOSÉ MORQUEDO

B. C.

28-9-1659

Fr. Gregorio de Silva

Pancorbo (Burgos)

AGN, Irache, Lib. 539, $11 \mathrm{v}$.

TOMÁS DE APARICIO

B. C.

29-9-1659

Fr. Ildefonso de Escudero

Frías (Burgos)

AGN, Irache, Lib. 539, 11v.

JUAN GARCÍA

B. C.

4-10-1659

Fr. Ildefonso de Escudero

Ros (Burgos)

AGN, Irache, Lib. 539, 12r.

MARTÍN PÉREZ VENERO

B. C.

6-10-1659

Fr. Gregorio de Silva

Noja (Burgos)

AGN, Irache, Lib. 539, 12r.

JOSÉ DE QUINTANA

B. C. / L. C. 
7-10-1659

Fr. Plácido Urbina, abad

Burgos

AGN, Irache, Lib. 539, 12r.

ÍNIIGO DE FRÍAS

B. C.

9-10-1659

Fr. Ildefonso de Escudero

Quintanilla de San García (Burgos)

AGN, Irache, Lib. 539, 12 r.

JOSÉ BURDEOS

B. A.

11-10-1659

Fr. Gregorio de Silva

O. de M.

AGN, Irache, Lib. 539, $12 \mathrm{v}$.

FELIPE LÓPEZ

B. C.

13-10-1659

Fr. Gregorio de Silva

Barrio (Burgos)

AGN, Irache, Lib. 539, 12v.

FRANCISCO DÍAZ RODRÍGUEZ

B. C.

13-10-1659

Fr. Gregorio de Silva

Barrio (Burgos)

AGN, Irache, Lib. 539, 12v.

JUAN GONZÁLEZ ESCUDERO

B. A.

25-10-1659

Fr. Felipe de Vamonde

Arnedo (Calahorra)

AGN, Irache, Lib. 539, 12v.

JUAN DE CABILLO

B. A. / B. T.

1-11-1659

Fr. Felipe de Vamonde

Lara (Burgos)

AGN, Irache, Lib. 539, 12v.

JOSÉ DE VILLEGAS

B. A. / B. T.
1-11-1659

Fr. Felipe de Vamonde

Sasamón (Burgos)

AGN, Irache, Lib. 539, 13 r.

GASPAR GÓMEZ

B. A. / B. M.

7-11-1659

Fr. Felipe de Vamonde

Estella (Pamplona)

AGN, Irache, Lib. 539, 13r.

DIEGO DE VILLADIEGO

B. A. / B. T.

13-11-1659

Fr. Gregorio de Silva

Sasamón (Burgos)

AGN, Irache, Lib. 539, 13 r.

JUAN DE VALTIERRA

B. C.

13-11-1659

Fr. Gregorio de Silva

Sasamón (Burgos)

AGN, Irache, Lib. 539, 13 r.

MARTÍN JIMÉNEZ DE ESPARZA

L. C.

16-11-1659

Fr. Plácido Urbina, abad

Ezcároz (Pamplona)

AGN, Irache, Lib. 539, 13 r.

CRISTÓBAL SANZ DE VALDIVIESO

B. C.

19-11-1659

Fr. Anselmo López

Cañizares (Burgos)

AGN, Irache, Lib. 539, $13 \mathrm{v}$.

TOMÁS DÍEZ DE LA CUESTA

B. C.

26-11-1659

Fr. Ildefonso de Escudero

Dobro (Burgos)

AGN, Irache, Lib. 539, 13v.

FRANCISCO DE OLMOS

B. A. / B. T. 
26-11-1659

Fr. Anselmo López

Pedrosa del Páramo (Burgos)

AGN, Irache, Lib. 539, 13v.

JOSÉ SANZ MARERO

B. C.

26-11-1659

Fr. Anselmo López

Treviano (Burgos)

AGN, Irache, Lib. 539, 13v.

\section{FRANCISCO GALLEGO}

B. $\mathrm{T}$.

27-11-1659

Fr. Ildefonso de Escudero

Cabado

AGN, Irache, Lib. 539, 13v.

JOSÉ LÓPEZ TELLO

B. A. / B. T.

1-12-1659

Fr. Gregorio de Silva

Sasamón (Burgos)

AGN, Irache, Lib. 539, 13v.

\section{ANTONIO RODRÍGUEZ}

B. C.

1-12-1659 No se le dio el grado

Fr. Alonso Escudero

Sasamón (Burgos)

AGN, Irache, Lib. 539, 14r.

\section{MIGUEL DE BASCONES}

B. C.

1-12-1659 No se le dio el grado

21-4-166o No se le dio el grado

Fr. Alonso Escudero

Sasamón (Burgos)

AGN, Irache, Lib. 539, 14r, 16v.

PEDRO JAIME

B. C.

17-12-1659

Fr. Gregorio de Silva

Melgar de Fernamental (Burgos)

AGN, Irache, Lib. 539, 14r.

\section{PEDRO DÍEZ DE MATA}

B. A. / B. T.

22-12-1659

Fr. Felipe de Vamonde

Insuficiente. No se le graduó en Teología.

Huérmeces (Burgos)

AGN, Irache, Lib. 539, 14r.

JOSÉ ALONSO

B. A.

22-12-1659

Fr. Felipe de Vamonde

Osejo (Calahorra)

AGN, Irache, Lib. 539, 14r.

JUAN DE LEGAZPI

B. A. / L. A. / M. A. / B. T. / L. T. / D. T.

26-12-1659

Fr. Diego de Silva, General de la Orden de

San Benito de España e Inglaterra

O. S. B.

Predicador

AGN, Irache, Lib. 539, 14v.

BENITO DE VICUÑA

B. A. / L. A. / M. A. / B. T. / L. T. / D. T.

7-1-1660

Fr. Diego de Silva, General

O. S. B.

Abad de San Millán

AGN, Irache, Lib. 539, 14v.

ILDEFONSO DE ESCUDERO

B. A. / L. A. / M. A. / B. T. / L. T. / D. T.

7-1-1660

Fr. Diego de Silva, General

O. S. B.

Maestro en Irache

AGN, Irache, Lib. 539, 14v.

GREGORIO DE SILVA

B. A. / L. A. / M. A. / B. T. / L. T. / D. T.

7-1-1660

Fr. Diego de Silva, General

O. S. B.

Maestro en Irache

AGN, Irache, Lib. 539, 14v. 
JOSÉ DE AGUIRRE

B. A. / L. A. / M. A. / B. T. / L. T. / D. T. 7-1-1660

Fr. Diego de Silva, General

O. S. B.

AGN, Irache, Lib. 539, 15r.

FELIPE VAMONDE

B. A. / L. A. / M. A. / B. T. / L. T. / D. T. 7-1-1660

Fr. Diego de Silva, General

O. S. B.

Maestro en Irache

AGN, Irache, Lib. 539, 15r.

JUAN MARQUINA

B. A. / B. M.

24-1-1660

Fr. Felipe de Vamonde

Lodosa (Pamplona)

AGN, Irache, Lib. 539, 15r.

TORIBIO GARCÍA

B. C.

25-1-1660

Fr. Ildefonso de Escudero

Padilla de Abajo (Burgos)

AGN, Irache, Lib. 539, 15r.

JUAN GARCÍA

B. C.

27-1-1660

Fr. Ildefonso de Escudero

Tabanera (Burgos)

AGN, Irache, Lib. 539, 15v.

FRANCISCO DE COVARRUBIAS

B. C.

27-1-1660

Fr. Ildefonso de Escudero

Tabanera (Burgos)

AGN, Irache, Lib. 539, 15v.

DIEGO DE MATA

B. T.

12-2-166o

Fr. Anselmo López

Huérmeces (Burgos)

AGN, Irache, Lib. 539, 15v.

\section{LUCAS LÓPEZ}

B. A. / B. T.

28-2-1660

Fr. Anselmo López

Villalobos (Burgos)

AGN, Irache, Lib. 539, 15v.

JOSÉ FERNÁNDEZ

B. A. / L. A. / M. A. / B. T. / L. T. / D. T.

8-3-1660

Fr. Plácido Urbina, abad

O. S. B.

Abad de Nájera

AGN, Irache, Lib. 539, $15 \mathrm{v}$.

PEDRO SERRANO

B. A.

9-3-1660

Fr. Felipe de Vamonde

Viana (Calahorra)

AGN, Irache, Lib. 539, 16r.

\section{ILDEFONSO OVEJAS}

B. A.

20-3-1660

Fr. Felipe de Vamonde

Igea de Cornago (Calahorra)

AGN, Irache, Lib. 539, 16r.

FRANCISCO CARRERA

B. A. / B. T.

23-3-1660

Fr. Ildefonso de Escudero

Gradilla de la Polera (Burgos)

AGN, Irache, Lib. 539, 16r.

JUAN FRANCISCO DE ABIELSA

B. A. / B. M.

19-4-1660

Fr. Ildefonso de Escudero

Zaragoza

AGN, Irache, Lib. 539, 16r.

JUAN DE GÜEMES CEBALLOS

B. C.

25-4-1660

Fr. Alonso de Escudero

Castañeda (Burgos)

AGN, Irache, Lib. 539, 16v. 
JUAN DANIEL CAPALBO

B. T.

2-5-1660

Fr. Alonso de Escudero

Gere (Barbastro)

AGN, Irache, Lib. 539, 16v.

JUAN JOSÉ DE TEJADA

B. C.

4-5-166o

Fr. Alonso de Escudero

Galilea (Calahorra)

AGN, Irache, Lib. 539, 16v.

CRISTÓBAL DE LEDESMA

B. C.

8-5-166o

Fr. Alonso de Escudero

Grieba (Burgos)

AGN, Irache, Lib. 539, 17r.

JACINTO DE ORTEGA

B. A. / B. T.

8-5-1660

Fr. Alonso de Escudero

Isar (Burgos)

AGN, Irache, Lib. 539, 17r.

JOSÉ DE ARIA

B. A.

11-5-1660

Fr. Alonso de Escudero

Pamplona

AGN, Irache, Lib. 539, 17r.

FERMÍN DE ESPARZA

B. A.

11-5-1660

Fr. Alonso de Escudero

Pamplona

AGN, Irache, Lib. 539, 17 r.

FRANCISCO DE ELCARTE

B. A.

11-5-1660

Fr. Alonso de Escudero

Pamplona

AGN, Irache, Lib. 539, 17r.
JUAN DE GARRALDA

B. A.

11-5-1660

Fr. Alonso de Escudero

Armazo (Pamplona)

AGN, Irache, Lib. 539, 17 r.

IGNACIO DE ZOZAYA

B. A.

11-5-1660

Fr. Alonso de Escudero

Santisteban (Pamplona)

AGN, Irache, Lib. 539, 17r.

PEDRO RIPALDA

B. A.

11-5-1660

Fr. Alonso de Escudero

Murillo de Lónguida (Pamplona)

AGN, Irache, Lib. 539, 17 r.

JUAN JOSÉ MAULEÓN

B. A.

11-5-1660

Fr. Alonso de Escudero

Falces (Pamplona)

AGN, Irache, Lib. 539, 17r.

FERMÍN DE ROA

B. A.

11-5-1660

Fr. Alonso de Escudero

Salinas (Pamplona)

AGN, Irache, Lib. 539, 17r.

JUAN DE ZAMORA

B. A.

11-5-1660

Fr. Alonso de Escudero

Irún (Pamplona)

AGN, Irache, Lib. 539, 17 r.

PEDRO JIMÉNEZ

B. A.

11-5-1660

Fr. Alonso de Escudero

Cózar (Pamplona)

AGN, Irache, Lib. 539, 17r. 
JUAN DE LACUNZA

B. A.

11-5-1660

Fr. Alonso de Escudero

Undiano (Pamplona)

AGN, Irache, Lib. 539, 17r.

JUAN DE ALCALDE

B. C.

12-5-166o

Fr. Alonso de Escudero

¿....arais? (Burgos)

AGN, Irache, Lib. 539, 17v.

JUAN GONZÁLEZ DE PEDROSO

B. C.

12-5-1660

Fr. Alonso de Escudero

Cerezo (Burgos)

AGN, Irache, Lib. 539, 17v.

FRANCISCO DE SALINAS

B. C.

14-5-1660

Fr. Alonso de Escudero

Cerezo (Burgos)

AGN, Irache, Lib. 539, 17v.

SANTIAGO DÍAZ DE ROBLES

B. C.

24-5-1660

Fr. Alonso de Escudero

Santa Olalla (Burgos)

AGN, Irache, Lib. 539, 17v.

PEDRO PÉREZ

B. C.

24-5-1660

Fr. Alonso de Escudero

Santa Olalla (Burgos)

AGN, Irache, Lib. 539, 18r.

MIGUEL DE CASTRO

B. C.

22-6-1660

Fr. Alonso de Escudero

Tapia (Burgos)

AGN, Irache, Lib. 539, 18r.
DOMINGO DE GAZTAÑAGA

B. A. / B. T.

30-6-1660

Fr. Alonso de Escudero

Ypuz (Pamplona)

AGN, Irache, Lib. 539, 18r.

JUAN BERNAL

B. C.

10-7-1660

Fr. Alonso de Escudero

Villanueva de Río Ubiel (Burgos)

AGN, Irache, Lib. 539, 18r.

JACINTO GARCÍA

B. C.

10-7-1660

Fr. Alonso de Escudero

Villanueva de Río Ubiel (Burgos)

AGN, Irache, Lib. 539, 18r.

JERÓNIMO GARCÍA SALÓN

B. C.

12-7-1660

Fr. Alonso de Escudero

Calahorra

AGN, Irache, Lib. 539, 18v.

PEDRO DE LAS RIBAS

B. C

14-7-1660

Fr. Alonso de Escudero

Sopuerta (Burgos)

AGN, Irache, Lib. 539, 18v.

JERÓNIMO DE AZCONA

B. T. / L. T. / D. T.

14-7-1660 / 29-8-1661

Fr. Alonso de Escudero / Fr. Manuel Gue-

rra, abad

Urbio (Pamplona)

B. A. Estudiante en Salamanca

AGN, Irache, Lib. 539, 18v, 27r.

MARTÍN DE EJEA

B. M. / L. M. / D. M.

24-7-166o / 20-12-1672

Fr. Alonso de Escudero / Fr. Andrés de la 
Moneda, Abad

Irurozqui (Pamplona)

AGN, Irache, Lib. 539, 18v, 116r.

\section{JUAN DE SALINAS}

B. T.

27-7-1660

Fr. Alonso de Escudero

Villalobos (Burgos)

AGN, Irache, Lib. 539, 18v.

\section{JUAN PANAO}

B. A. / B. T.

3-8-1660

Fr. Alonso de Escudero

Burgos

AGN, Irache, Lib. 539, 18v.

\section{MANUEL PANDO}

B. A. / B. T.

3-8-1660

Fr. Alonso de Escudero

Burgos

AGN, Irache, Lib. 539, $19 r$.

FAUSTINO DE BÁRCENA

B. C.

25-8-1660

Fr. Íñigo de Ruiloba

Villadiego (Burgos)

AGN, Irache, Lib. 539, 19r.

MARTÍN DEL CASTILLO

B. T.

26-8-1660

Fr. Íñigo de Ruiloba

Castillo (Calahorra)

AGN, Irache, Lib. 539, 19r.

ANTONIO GUTIÉRREZ Y DE NORIEGA

B. C.

27-8-1660

Fr. Alonso de Escudero

Villadiego (Burgos)

AGN, Irache, Lib. 539, 19r.

FRANCISCO DE MONTENEGRO

B. C.
27-8-1660

Fr. Alonso de Escudero

Mansilla (Burgos)

AGN, Irache, Lib. 539, 19r.

MANUEL DE BÁRCENA

B. A. / B. T.

8-9-166o

Fr. Íñigo de Ruiloba

Villadiego (Burgos)

AGN, Irache, Lib. 539, 19v.

ANTONIO DE ANGULO

B. C.

11-9-1660

Fr. Ildefonso de Escudero

Espinosa de los Monteros (Burgos)

AGN, Irache, Lib. 539, 19v.

MANUEL BAQUERO Y ZALDÍVAR

B. A. / B. T.

14-9-1660

Fr. Ildefonso de Escudero

Anguiano (Calahorra)

Estudiante en Salamanca

AGN, Irache, Lib. 539, 19v.

JUAN AGÜERO

B. A. / L. A. / M. A. / B. T. / L. T. / D. T.

15-9-1660

Fr. Plácido Urbina, abad

O. S. B.

Abad de Cardeña

AGN, Irache, Lib. 539, 19v.

FRANCISCO ALONSO

B. A. / B. T.

15-9-1660

Fr. Íñigo de Ruiloba

Zalduendo (Burgos)

AGN, Irache, Lib. 539, 20 .

FRANCISCO CASCAJARES

L. C.

17-9-1660

Fr. Plácido Urbina, abad

Tudela (Nullius Diocesis)

AGN, Irache, Lib. 539, $20 r$. 
JAIME LIARTE

B. A. / B. M.

17-9-1660

Fr. Alonso de Escudero

Almudévar (Huesca)

AGN, Irache, Lib. 539, $20 r$.

\section{GASPAR GARCÍA DE OLEA}

B. A. / B. T.

20-9-1660

Fr. Alonso de Escudero

Villasandino (Burgos)

AGN, Irache, Lib. 539, 20 .

FRANCISCO DE BERASTEGUI

B. C.

24-9-1660

Fr. Íñigo de Ruiloba

Balmaseda (Burgos)

AGN, Irache, Lib. 539, 20 .

ANDRÉS DE LA MONEDA

B. A. / L. A. / M. A. / B. T. / L. T. / D. T.

28-9-1660

Fr. Plácido Urbina, abad

O. S. B.

Abad de San Juan de Burgos

AGN, Irache, Lib. 539, $20 \mathrm{v}$.

\section{FRANCISCO PALACIO}

B. C.

30-9-1660

Fr. Íñigo de Ruiloba

Rumoroso (Burgos)

AGN, Irache, Lib. 539, $20 v$.

FRANCISCO GUTIÉRREZ DE RIVA

B. C.

30-9-1660

Fr. Íñigo de Ruiloba

Rumoroso (Burgos)

AGN, Irache, Lib. 539, $20 v$.

JUAN DE LA PEÑA

B. A. / B. T.

9-10-1660

Fr. Íñigo de Ruiloba

Castro Urdiales (Burgos)

AGN, Irache, Lib. 539, $20 v$.
JOSÉ FRANCISCO DE BAQUEDANO

L. L.

16-10-1660

Fr. Plácido Urbina, abad

..

AGN, Irache, Lib. 539, $20 v$.

LUCAS HERNANDO

B. A. / B. T.

29-10-1660

Fr. Anselmo López

Uzquiza (Burgos)

AGN, Irache, Lib. 539, 21r.

JOSÉ FERNÁNDEZ DE HEREDIA

L. L.

16-11-166o

Fr. Plácido Urbina, abad

Calatayud

AGN, Irache, Lib. 539, 21r.

PEDRO PÉREZ

B. A. / B. T.

27-11-166o

Fr. Manuel (Bela) Vela, Maestro en Artes

Santibáñez (Burgos)

AGN, Irache, Lib. 539, 21 r.

PEDRO DE CHAVARRIA

B. A. / B. T.

27-11-166o

Fr. Manuel Vela

Burgos

AGN, Irache, Lib. 539, 21 r.

DIEGO DE CHINCHÓN

B. A. / B. T.

27-11-1660

Fr. Manuel Vela

Burgos

AGN, Irache, Lib. 539, 21r.

BERNARDINO ÁLVAREZ

B. A. / B. T.

27-11-1660

Fr. Manuel Vela

Santibáñez (Burgos)

AGN, Irache, Lib. 539, 21r. 
MATÍAS DE ARCE

B. C.

2-12-1660

Fr. Manuel Vela

AGN, Irache, Lib. 539, $21 \mathrm{v}$.

JUAN BAUTISTA DE ARCE

B. A.

2-12-1660

B. T. Reprobado

Fr. Manuel Vela

AGN, Irache, Lib. 539, 21v.

FELIPE SANTIAGO

B. C.

5-12-1660

Fr. Íñigo de Ruiloba

Villandiego (Burgos)

AGN, Irache, Lib. 539, $21 \mathrm{v}$.

JUAN SANZ

B. C

6-12-166o

Fr. Alonso de Escudero

Bañuelos (Burgos)

AGN, Irache, Lib. 539, 21v.

ESTEBAN BAUTISTA

B. C.

10-12-166o

Fr. Alonso de Escudero

Yundego (Burgos)

AGN, Irache, Lib. 539, 21v.

MARTÍN GONZÁLEZ

B. C.

12-12-166o

Fr. Íñigo de Ruiloba

Castil de Peones (Burgos)

AGN, Irache, Lib. 539, 22r.

JUAN DE LA PEÑA

B. A.

16-12-166o

Fr. Alonso de Escudero

Yudego (Burgos)

AGN, Irache, Lib. 539, 22r.
JOSÉ ARRANZ

B. C.

18-12-1660

Fr. Alonso de Escudero

Arnedo (Calahorra)

AGN, Irache, Lib. 539, 22r.

PEDRO DE GALDAMES

B. C.

24-12-1660

Fr. Alonso de Escudero

Galdames (Burgos)

AGN, Irache, Lib. 539, 22r.

JOSÉ PEÑEÑORI

B. C.

24-12-166o

Fr. Alonso de Escudero

Gadames (Burgos)

AGN, Irache, Lib. 539, 22r.

ANTONIO DE LLANO

B. C.

31-12-1660

Fr. Íñigo de Ruiloba

Somorrostro (Burgos)

AGN, Irache, Lib. 539, 22v.

FRANCISCO DE MURRIETA

B. C.

31-12-166o

Fr. Íñigo de Ruiloba

San Román (Burgos)

AGN, Irache, Lib. 539, 22v.

PABLO DE LOS RÍOS

B. C.

2-1-1661

Fr. Íñigo de Ruiloba

Villamartín (Burgos)

AGN, Irache, Lib. 539, $22 \mathrm{v}$.

JUAN DE ELENA

B. A. / B. T.

5-1-1661

Fr. Manuel Vela

Ecclesia Rubia del Enebral (Burgos)

AGN, Irache, Lib. 539, 22v. 
PEDRO DE LOS HEROS

B. C.

5-1-1661

Fr. Manuel Vela

Del Concejo de San Pedro de Abando (Burgos)

AGN, Irache, Lib. 539, 22v.

JUAN DE FRÍAS

B. A. / B. T.

9-1-1661

Fr. Manuel Vela

Pancorbo (Burgos)

AGN, Irache, Lib. 539, 22v.

PEDRO GÓMEZ

B. C.

9-1-1661

Fr. Manuel Vela

Pancorbo (Burgos)

AGN, Irache, Lib. 539, 22v.

PEDRO SAN FUENTES

B. C.

9-1-1661

Fr. Alonso de Escudero

AGN, Irache, Lib. 539, 22v.

ALONSO PÉREZ

B. C.

13-1-1661

Fr. Alonso de Escudero

Quintanilla

AGN, Irache, Lib. 539, 22v.

LOPE MONTAÑO

B. C.

18-1-1661

Fr. Íñigo de Ruiloba

Portugalete (Burgos)

AGN, Irache, Lib. 539, 23 r.

BARTOLOMÉ VELA

B. T.

19-1-1661

Fr. Íñigo de Ruiloba

Quintanilla de Bon (Burgos)

AGN, Irache, Lib. 539, 23 r.

\section{PEDRO GARCÍA}

B. A. / B. T.

22-1-1661

Fr. Manuel Vela

Cuzeurri (Calahorra)

AGN, Irache, Lib. 539, 23 r.

JUAN ANTONIO DE SAN MARTÍN

B. C.

23-1-1661

Fr. Alonso de Escudero

Portugalete (Burgos)

AGN, Irache, Lib. 539, 23 r.

MANUEL MARTÍNEZ GAMARRA

B. L.

29-1-1661

Fr. Íñigo de Ruiloba

S. Domingo de la Calzada (Calahorra)

AGN, Irache, Lib. 539, 23 r.

JOSÉ AMO

B. C.

7-2-1661

Fr. Alonso de Escudero

Padilla (Burgos)

AGN, Irache, Lib. 539, 23r.

DIEGO DE AMO

B. C.

12-2-1661

Fr. Alonso de Escudero

Tapia (Burgos)

AGN, Irache, Lib. 539, $23 \mathrm{v}$.

MANUEL DE CLARES

B. M.

12-2-1661

Fr. Manuel Vela

Zaragoza

AGN, Irache, Lib. 539, $23 \mathrm{v}$.

DIEGO DE ARANA

B. A.

20-2-1611

Fr. Manuel Vela

Arnedo (Calahorra)

AGN, Irache, Lib. 539, $23 \mathrm{v}$. 
ALONSO DE ISLA

B. A. / B. T.

18-3-1611

Fr. Manuel Vela

Burgos

AGN, Irache, Lib. 539, $23 \mathrm{v}$.

IGNACIO PÉREZ

B. L.

23-3-1661

Fr. Alonso de Escudero

... Aragón

AGN, Irache, Lib. 539, 24 r.

FRANCISCO DE ARCE GALA

B. C.

25-3-1661

Fr. Alonso de Escudero

Robledo de Sobresierra (Burgos)

AGN, Irache, Lib. 539, 24r.

MARTÍN SÁNCHEZ

L. L.

4-4-1661

Fr. Alonso de Escudero

Arcilla (Zaragoza)

AGN, Irache, Lib. 539, 24r.

JUAN ORTIZ DE MUNATTONES

B. C.

9-4-1661

Fr. Alonso de Escudero

Cerezo (Burgos)

AGN, Irache, Lib. 539, 24r.

(Sin apellidar)

Descripción física

B. C.

9-4-1661

Fr. Íñigo de Ruiloba

...

AGN, Irache, Lib. 539, 24r.

(Sin apellidar)

Descripción física

L. T. / D. T.

9-4-1661

Fr. Íñigo de Ruiloba
O. C.

AGN, Irache, Lib. 539, 24 rv.

(Sin apellidar)

Descripción física

L. T. / D. T.

9-4-1661

Fr. Íñigo de Ruiloba

Fr. Plácido Urbina, abad

O. C.

AGN, Irache, Lib. 539, 24rv.

JOSÉ CARRILLO

L. T. / D. T.

9-4-1661

Fr. Plácido Urbina, abad

O. C.

AGN, Irache, Lib. 539, 24v.

JERÓNIMO DE VELASCO

B. T. / L. T. / D. T.

10-4-1661

Fr. Plácido Urbina, abad

O. S. B.

Abad del Espino

AGN, Irache, Lib. 539, 24v.

JUAN DE OCHOA

L. C.

10-4-1661

Fr. Regente

Briviesca (Nullius Diocesis)

AGN, Irache, Lib. 539, 24v.

PEDRO DE ANGULO

B. C.

12-4-1661

Fr. Regente

Villota (Burgos)

AGN, Irache, Lib. 539, 24v.

SANTIAGO DE REGE...

B. C. / L. C. / D. C.

18-4-1661

Fr. Plácido Urbina, abad

AGN, Irache, Lib. 539, 24v. 
BALTASAR ANTONIO DE LA PEÑA

B. A. / B. T.

22-4-1661

Fr. Alonso de Escudero

Burgos

AGN, Irache, Lib. 539, 25r.

JUAN CAMPO

B. C.

23-4-1661

Fr. Alonso de Escudero

T... (Burgos)

AGN, Irache, Lib. 539, 25r.

JUAN DE VILLOSLADA

B. A. / B. T.

29-4-1661

Fr. Manuel Vela

Medina de Pomar (Burgos)

AGN, Irache, Lib. 539, 25v.

DIEGO DE TORRES

B. C.

2-5-1661

Fr. Alonso de Escudero

Villavelayo (Burgos)

AGN, Irache, Lib. 539, 25v.

FRANCISCO GUTIÉRREZ

B. C.

2-5-1661

Fr. Alonso de Escudero

Villavelayo (Burgos)

AGN, Irache, Lib. 539, 25v.

JUAN ANTONIO DE LEÓN

B. A.

5-5-1661

Fr. Manuel Vela

O. de M.

AGN, Irache, Lib. 539, 25v.

JUAN ANTONIO GIL

B. A.

5-5-1661

Fr. Manuel Vela

O. de M.

AGN, Irache, Lib. 539, 25v.

\section{VÍCTORES GARCÍA}

B. C.

12-5-1661

Fr. Alonso de Escudero

S... (Burgos)

AGN, Irache, Lib. 539, 25v.

BERNARDO FERNÁNDEZ

B. A.

17-5-1661

Fr. Manuel Vela

Ribafrecha (Calahorra)

AGN, Irache, Lib. 539, $25 \mathrm{v}$.

IGNACIO DE GOSEGUIN

B. A.

17-5-1661

Fr. Manuel Vela

Lezcano (Pamplona)

AGN, Irache, Lib. 539, 25v.

JOSÉ DE AZPES

B. A.

17-5-1661

Fr. Manuel Vela

Pamplona

AGN, Irache, Lib. 539, $25 \mathrm{v}$.

FAUSTO DE LA CRU...

B. A.

17-5-1661

Fr. Manuel Vela

Pamplona

AGN, Irache, Lib. 539, 25v.

JUAN DE LIZERI

B. A.

17-5-1661

Fr. Manuel Vela

Pamplona

AGN, Irache, Lib. 539, 25v.

JUAN DE ULAS

B. A.

17-5-1661

Fr. Manuel Vela

Badosa (Pamplona)

AGN, Irache, Lib. 539, 25v. 
PEDRO DE ESCARDI

B. A.

17-5-1661

Fr. Manuel Vela

Pamplona

AGN, Irache, Lib. 539, 25v.

DIONISIO DE ARZUN

B. A.

17-5-1661

Fr. Manuel Vela

Fuenterrabía (Pamplona)

AGN, Irache, Lib. 539, 25v.

JUAN DE CASARES

B. A.

17-5-1661

Fr. Manuel Vela

San Sebastián (Pamplona)

AGN, Irache, Lib. 539, 25v.

MIGUEL DE ARZAMENDIA

B. A.

17-5-1661

Fr. Manuel Vela

Arén

Pamplona

AGN, Irache, Lib. 539, 25v.

Descripción física

B. A.

17-5-1661

Fr. Manuel Vela

AGN, Irache, Lib. 539, 26r.

MARTÍN DE GILABERT

B. A.

26-5-1661

Fr. Manuel Vela

O. de M.

AGN, Irache, Lib. 539, 26r.

MARTÍN DE VILLALBILLA

B. C.

27-5-1661

Fr. Alonso de Escudero

Villaizán (Burgos)

AGN, Irache, Lib. 539, 26r.
JUAN DE MENDAZA

B. A.

31-5-1661

Fr. Manuel Vela

Falces (Pamplona)

AGN, Irache, Lib. 539, 26r.

FRANCISCO BURRIELA

B. A.

1-6-1661

Fr. Manuel Vela

Calahorra

AGN, Irache, Lib. 539, 26r.

JUAN DE ZÁRATE

B. C.

10-6-1661

Fr. José de Aguirre

Burgos

AGN, Irache, Lib. 539, 26v.

FRANCISCO DE ZITANO

B. C.

12-6-1661

Fr. José de Aguirre

Valmaseda (Burgos)

AGN, Irache, Lib. 539, 26v.

JOSÉ SANZ

B. C.

12-6-1661

Fr. José de Aguirre

AGN, Irache, Lib. 539, 26v.

AMBROSIO SANTIAGO DE HERAS

B. C.

23-6-1661

Fr. Alonso de Escudero

Burgos

AGN, Irache, Lib. 539, 26v.

FRANCISCO DE VILLOSLADA

B. M.

3-8-1661

Fr. Manuel Vela

Autol (Calahorra)

AGN, Irache, Lib. 539, 26v. 
MANUEL DE PALACIOS

B. $\mathrm{M}$.

3-8-1661

Fr. Manuel Vela

Escalante (Calahorra)

AGN, Irache, Lib. 539, 26v.

JOSÉ PARICIO

B. A.

28-8-1661

Fr. Manuel Vela

Cariñena (Zaragoza)

AGN, Irache, Lib. 539, 26v.

PLÁCIDO DE PUGA

B. A. / L. A. / M. A.

29-8-1661

Fr. Manuel Guerra, Abad y Rector

O. S. B.

Definidor de la Orden y Juez

AGN, Irache, Lib. 539, 27r.

JOSÉ GÓMEZ

B. A. / L. A. / M. A. / B. T. / L. T. / D. T.

29-8-1661

Fr. Manuel Guerra, abad

O. S. B.

AGN, Irache, Lib. 539, 27r.

ANTONIO DE TALLEDO

B. C.

8-9-1661

Fr. Antonio Zapata

Otáñez (Burgos)

AGN, Irache, Lib. 539, 27v.

JUAN DE GUINEA

B. A. / B. T.

14-9-1661

Fr. Regente

Villanañe (Burgos)

AGN, Irache, Lib. 539, 27v.

ALEJANDRO MARRACO

B. A. / B. M.

15-9-1661

Fr. Antonio Zapata

Hecho (Jaca)

AGN, Irache, Lib. 539, 27v.
PEDRO FERNÁNDEZ DE SIETES

B. T.

25-9-1661

Fr. Regente

Villaviciosa (Oviedo)

AGN, Irache, Lib. 539, $27 \mathrm{v}$.

ÍNIIGO DE RUILOBA

B. A. / L. A. / M. A. / B. T. / L. T. / D. T. 25-9-1661

Fr. Gregorio de Canduela, vicecanciller

O. S. B.

Maestro en Irache

Procurador General de Congregación en la Corte Romana

AGN, Irache, Lib. 539, 27v.

JUAN MARTÍNEZ DE OSMA

B. C.

27-9-1661

Fr. Antonio Zapata

San Zadornil (Burgos)

AGN, Irache, Lib. 539, $27 \mathrm{v}$.

LUCAS JACA

L. C.

2-10-1661

Fr. Manuel Guerra, abad

Mallén (Zaragoza)

AGN, Irache, Lib. 539, 28r.

PEDRO DE LA TORRE

B. C.

4-10-1661

Fr. Regente

Poza (Burgos)

AGN, Irache, Lib. 539, 28r.

DIEGO RUBÍN

B. C.

7-10-1661

Fr. Antonio Zapata

Valle (Burgos)

AGN, Irache, Lib. 539, 28r.

GREGORIO DE ARGAIZ

B. A. / L. A. / M. A. / B. T. / L. T. / D. T.

8-10-1661 
Fr. Manuel Guerra, abad

O. S. B.

Predicador

AGN, Irache, Lib. 539, 28r.

\section{ANTONIO PELÁEZ}

B. C.

10-10-1661

Fr. Regente

Padilla de Abajo (Burgos)

AGN, Irache, Lib. 539, 28r.

\section{FRANCISCO CALVO}

B. C.

10-10-1661

Fr. Regente

Padilla de Abajo (Burgos)

AGN, Irache, Lib. 539, 28r.

\section{MATÍAS DE SOBEJANO}

B. A. / B. M.

11-10-1661

Fr. Manuel Vela, Fr. Regente

Pamplona

AGN, Irache, Lib. 539, 28v.

DIEGO GÓMEZ DE SALAZAR

B. C.

22-10-1661

Fr. Antonio Zapata

Estrimiana (Burgos)

AGN, Irache, Lib. 539, 28v.

JUAN FERNÁNDEZ DE LA PEÑA

B. A.

25-10-1661

Fr. Manuel Vela

Oña (Burgos)

AGN, Irache, Lib. 539, 28v.

\section{AGUSTÍN GONZÁLEZ}

B. C.

26-10-1661

Fr. Alonso de Mier

Quintana de la Cuesta (Burgos)

AGN, Irache, Lib. 539, 28v.

PEDRO LÓPEZ DE REBOLLEDA

B. C.
26-10-1661

Fr. Regente

Quintana de la Cuesta (Burgos)

AGN, Irache, Lib. 539, 28v.

PEDRO HIPÓLITO

B. A. / B. T.

30-10-1661

Fr. Alonso de Mier

Olmillos (Burgos)

AGN, Irache, Lib. 539, 28v.

JUAN MARTÍNEZ DE LA HERRÁN

B. C.

30-10-1661

Fr. Alonso de Mier

Moneo (Burgos)

AGN, Irache, Lib. 539, 28v.

FRANCISCO LÓPEZ DEL ÁGUILA

B. A. / B. M.

8-11-1661

Fr. Antonio Zapata

Tudela

AGN, Irache, Lib. 539, 28v.

TOMÁS DE ALLENDE

B. C.

9-11-1661

Fr. Antonio Zapata

Otáñez (Burgos)

AGN, Irache, Lib. 539, 29r.

LEONARDO GARCÍA

B. C.

11-11-1661

Fr. Alonso de Mier

Pancorbo (Burgos)

AGN, Irache, Lib. 539, $29 r$.

MANUEL DE CASTRO

B. C.

13-11-1661 / 19-12-1661

Insuficiente

Fr. Gregorio de Canduela

Los Balbases (Burgos)

AGN, Irache, Lib. 539, $29 r v$. 
ALONSO DE ARRIAGA

B. A.

19-11-1661

Fr. Manuel Vela

Valladolid

AGN, Irache, Lib. 539, 29v.

JUAN ESTEBAN DE LA PORTILLA

B. C.

10-12-1661

Fr. Alonso de Mier

Villa de Puerto (Burgos)

AGN, Irache, Lib. 539, 29v.

LORENZO DE AGUERO

B. C.

10-12-1661

Fr. Alonso de Mier

Villa de Puerto (Burgos)

AGN, Irache, Lib. 539, 29v.

DOMINGO DE TIEBAS

B. A. / B. M.

15-12-1661

Fr. Manuel Vela

Tudela (Nullius Diocesis)

AGN, Irache, Lib. 539, 29v.

JUAN RODRÍGUEZ OLEA

B. T.

19-12-1661

Fr. Gregorio de Canduela

Villanueva de Henares (Burgos)

B. A. en Salamanca

AGN, Irache, Lib. 539, 29v.

JUAN DE SOTO

B. A. / B. T.

4-1-1662

Fr. Alonso de Mier

Briviesca (Burgos)

AGN, Irache, Lib. 539, 29v.

JOSÉ GUTIÉRREZ

B. C.

9-1-1662

Fr. Gregorio de Canduela

AGN, Irache, Lib. 539, 29v.
ESTEBAN DE AMECHEZURRA

B. C.

19-1-1662

Fr. Gregorio de Canduela

Balmaseda (Burgos)

AGN, Irache, Lib. 539, 29v.

DIEGO DE LOS HEROS

B. C.

19-1-1662

Fr. Gregorio de Canduela

Balmaseda (Burgos)

AGN, Irache, Lib. 539, 29v.

\section{SANTIAGO ROJO}

B. C.

22-1-1662

Fr. Gregorio de Canduela

Palacios (Burgo)

AGN, Irache, Lib. 539, 29v.

JUAN URBAN BARONA

B. C.

27-1-1662

Fr. Gregorio de Canduela

Villanueva del Conde (Burgos)

AGN, Irache, Lib. 539, 29v.

LUCAS DE MANZANEDA

B. C.

3-2-1662

Fr. Alonso de Mier

Balmaseda (Burgos)

AGN, Irache, Lib. 539, 3or.

MATEO GÓMEZ DE SOTO

B. C.

11-2-1662

Fr. Alonso de Mier

Terrazos (Burgos)

AGN, Irache, Lib. 539, 3or.

FRANCISCO SERÍN Y LARRAZA

L. T.

8-3-1662

Fr. Manuel Guerra, abad

Viana (Calahorra)

AGN, Irache, Lib. 539, 3or. 
VICENTE GARCÍA DE ISABA

B. M.

18-3-1662

Fr. Alonso de Mier

Pamplona

AGN, Irache, Lib. 539, 3or.

JOSÉ ESTRICH

B. M.

1-4-1662

Fr. Alonso de Mier / Dr. Gauna Martín

Martín (Zaragoza)

B. A. en Zaragoza

AGN, Irache, Lib. 539, 3orv-31r.

JOSÉ DE AZPE

L. A.

4-4-1662

Fr. Maestro Vela

Pamplona

AGN, Irache, Lib. 539, 31r.

JUAN DÍEZ DE LA PEÑA

L. C. / D. C.

7-4-1662

Fr. Gregorio de Canduela

Rueda (Burgos)

AGN, Irache, Lib. 539, 31r.

GARCÍA HERMOSA

B. C.

8-4-1662

Fr. Alonso de Mier

Dueñas (Burgos)

AGN, Irache, Lib. 539, 31r.

ESTEBAN DE QUINTANA

$-/-/ 1662$

Fr. Alonso de Mier

Laredo (Burgos)

AGN, Irache, Lib. 539, 31r.

MARCOS JIMÉNEZ

B. C. / L. C. / D. C.

11-4-1662

Fr. Manuel Guerra, abad

Jaca

AGN, Irache, Lib. 539, 31v.
JOSÉ FORCADA

B. $\mathrm{M}$.

13-4-1662

Fr. Alonso de Mier

La Muela (Zaragoza)

B. A. en Lérida

AGN, Irache, Lib. 539, 31v.

MATÍAS DE LEÓN

L. C.

14-4-1662

Fr. Manuel Guerra, abad

Castillo (Burgos)

AGN, Irache, Lib. 539, 31v.

AGUSTÍN DE ARELLANO

B. A.

21-4-1612

Fr. Manuel Vela

O. S. A.

AGN, Irache, Lib. 539, 31v.

DIEGO FELIZ GARCÍA

B. A. / B. M.

21-4-1662

Fr. José de Aguirre

Falces (Pamplona)

AGN, Irache, Lib. 539, 31v.

PEDRO DE VILLEGAS

B. C.

4-5-1662

Fr. José de Aguirre

Villahoz (Burgos)

AGN, Irache, Lib. 539, 32r.

DOMINGO LISÓN

B. A.

9-5-1662

Fr. Manuel Vela, M. A.

Cárcar (Pamplona)

AGN, Irache, Lib. 539, 32r.

PEDRO PERALTA

B. A.

9-5-1662

Fr. Manuel Vela, M. A.

Pamplona

AGN, Irache, Lib. 539, 32r. 
JOSÉ DE LIZARRAGA

B. A.

9-5-1662

Fr. Manuel Vela, M. A.

Ziarzabal (Pamplona)

AGN, Irache, Lib. 539, 32r.

ANDRÉS DE CIGA

B. A.

9-5-1662

Fr. Manuel Vela, M. A.

Pamplona

AGN, Irache, Lib. 539, 32r.

BARTOLOMÉ DE ARRASTIA

B. A.

9-5-1662

Fr. Manuel Vela, M. A.

Pamplona

AGN, Irache, Lib. 539, 32r.

JUAN DE BORDA

B. A.

9-5-1662

Fr. Manuel Vela, M. A.

Arizcun (Pamplona)

AGN, Irache, Lib. 539, 32r.

JUAN DE HUESA

B. A.

9-5-1662

Fr. Manuel Vela, M. A.

Ustés (Pamplona)

AGN, Irache, Lib. 539, 32r.

PEDRO FERNÁNDEZ

B. A.

9-5-1662

Fr. Manuel Vela, M. A.

Urroz (Pamplona)

AGN, Irache, Lib. 539, 32r.

MARTÍN DE BERASTEGUI

B. A.

9-5-1662

Fr. Manuel Vela, M. A.

Arbizu (Pamplona)

AGN, Irache, Lib. 539, 32r.
CRISTÓBAL DE AMATRIAIN

B. A. / B. M.

9-5-1662 / 6-5-1667

Fr. Manuel Vela, M. A.

Pamplona

AGN, Irache, Lib. 539, 32r, 65r.

JUAN AMBROSIO RODRÍGUEZ

B. A.

9-5-1662

Fr. Manuel Vela, M. A.

Larraga (Pamplona)

AGN, Irache, Lib. 539, 32r.

\section{JUAN DE AÑOA}

B. A.

9-5-1662

Fr. Manuel Vela, M. A.

Viana (Pamplona)

AGN, Irache, Lib. 539, 32r.

PEDRO DE OSÉS

B. A. / B. M.

9-5-1662 / 18-3-1669

Fr. Manuel Vela, M. A. / Fr. Primitivo Ruiz

Mañeru (Pamplona)

AGN, Irache, Lib. 539, 32r, 80v.

\section{JUAN DE LEZÁUN}

B. A.

9-5-1662

Fr. Manuel Vela, M. A.

Adiós (Pamplona)

AGN, Irache, Lib. 539, 32r.

CLEMENTE GORRÁIZ

B. A.

9-5-1662

Fr. Manuel Vela, M. A.

Pamplona

AGN, Irache, Lib. 539, 32r.

PEDRO IRIARTE

B. A.

9-5-1662

Fr. Manuel Vela, M. A.

Urbicáin (Pamplona)

AGN, Irache, Lib. 539, 32r. 
JACINTO RUIZ DE PAZUENGOS

B. A. / B. M.

9-5-1662 / 24-8-1664

Fr. Manuel Vela, M. A. / Fr. José de Aguirre

Estella (Pamplona)

AGN, Irache, Lib. 539, 32r, 43v.

\section{VICENTE GONZÁLEZ}

B. A.

9-5-1662

Fr. Manuel Vela, M.A.

San Sebastián (Pamplona)

AGN, Irache, Lib. 539, 32r.

\section{MARTÍN DE ARRUBIA}

B. A.

9-5-1662

Fr. Manuel Vela, M.A.

Villarreal (Pamplona)

AGN, Irache, Lib. 539, 32r.

\section{MANUEL ELÍAS DON GUILLÉN}

B. A. / B. T. / L. T. / D. T.

16-5-1662

Fr. Manuel Guerra, abad

O. C.

Bayona

AGN, Irache, Lib. 539, 32r.

LUCAS DEL ARCO

B. C.

18-5-1662

Fr. José de Aguirre

Arcentales (Burgos)

AGN, Irache, Lib. 539, 32v.

GREGORIO ENRÍQUEZ

B. A. / L. A. / M. A. / B. T. / L. T. / D. T.

4-6-1662

Fr. Rosendo de Mújica, General de O. S. B.

O. S. B.

AGN, Irache, Lib. 539, 32v.

ANDRÉS LÓPEZ FRÍAS

B. C.

5-6-1662

Fr. José de Aguirre

Panillo (Burgos)

AGN, Irache, Lib. 539, 32v.

\section{PLÁCIDO DE ESLES}

B. A. / L. A. / M. A. / B. T. / L. T. / D. T. 5-6-1662

Fr. Rosendo de Mújica, General de O. S. B. O. S. B.

AGN, Irache, Lib. 539, 32v.

ANTONIO MASEDA

B. A. / L. A. / M. A. / B. T. / L. T. / D. T. 5-6-1662

Fr. Rosendo de Mújica, General de O. S. B.

O. S. B.

AGN, Irache, Lib. 539, 32v.

GREGORIO DE CANDUELA

B. A. / L. A. / M. A. / B. T. / L. T. / D. T. 5-6-1662

Fr. Rosendo de Mújica, General de O. S. B.

O. S. B.

Regente de Irache

AGN, Irache, Lib. 539, 32v.

ALONSO DE MIER

B. A. / L. A. / M. A. / B. T. / L. T. / D. T. 5-6-1662

Fr. Rosendo de Mújica, General de O. S. B.

O. S. B.

Lector de Teología en Irache

AGN, Irache, Lib. 539, 32v.

\section{MANUEL VELA}

B. A. / L. A. / M. A. / B. T. / L. T. / D. T.

5-6-1662

Fr. Rosendo de Mújica, General de O. S. B.

O. S. B.

Lector de Artes en Irache

AGN, Irache, Lib. 539, 32v.

(Sin apellidar)

Descripción física

L. M. / D. M.

12-6-1662

No fue digno del grado

Barbastro

AGN, Irache, Lib. 539, 32v.

DIEGO DE URQUIJO

... 
23-6-1662

Calabazas

San Julián de Musques (Burgos)

AGN, Irache, Lib. 539, 33r.

PEDRO BLANCO

B. A. / B. T. / L. T.

24-6-1662

Fr. Alonso de Mier

Blacos (Osma)

AGN, Irache, Lib. 539, 33r.

PEDRO DE BARRIOS

B. A. / B. T.

25-6-1662

Fr. Manuel Vella

Arcos (Burgos)

AGN, Irache, Lib. 539, 33r.

JUAN FRANCISCO DE ELORZA

B. A.

6-7-1662

Fr. Manuel Vella

Mendívil (Pamplona)

AGN, Irache, Lib. 539, 33r.

MARTÍN DE HERRERA

B. C.

7-7-1612

Fr. Gregorio de Canduela

Cascajares (Burgos)

AGN, Irache, Lib. 539, 33r.

MANUEL DE MOLLINEDO

B. C.

8-7-1612

Fr. Alonso de Mier

Sopuerta (Burgos)

AGN, Irache, Lib. 539, 33r.

PEDRO ROYO

B. A.

25-7-1662

Fr. Manuel Vela

Borja (Tarazona)

AGN, Irache, Lib. 539, 33v.

JUAN DE ARZABE

B. C.
25-7-1662

Fr. José de Aguirre

Concejo de Zalla (Burgos)

AGN, Irache, Lib. 539, 33v.

JOSÉ SINUÉS

B. A. / B. M.

29-7-1662

Fr. Manuel Vela

Mallén (Zaragoza)

AGN, Irache, Lib. 539, 33v.

JUAN DE REZA

B. A.

31-7-1662

Fr. Manuel Vela

Villanueva (Pamplona)

AGN, Irache, Lib. 539, 33v.

BARTOLOMÉ DE MENDIETA

B. C.

2-8-1662

Fr. Alonso de Mier

Valle de Sopuerta (Burgos)

AGN, Irache, Lib. 539, 33v.

ESTEBAN DE LA TEJADA

B. C.

2-8-1662

Fr. Alonso de Mier

Concejo de Somorostro (Burgos)

AGN, Irache, Lib. 539, 33v.

ANDRÉS FERNÁNDEZ DE OCHOA

L. A.

9-8-1662

Fr. Manuel Vela

Urroz (Pamplona)

AGN, Irache, Lib. 539, 33v.

ANTONIO DE URDAIZ

B. L.

19-8-1612

Fr. Alonso de Mier

AGN, Irache, Lib. 539, 34r.

JUAN ALONSO FERNÁNDEZ

B. C. 
11-9-1612

Fr. Alonso de Mier

Quintana Río (Burgos)

AGN, Irache, Lib. 539, 34r.

LUCAS MARTÍNEZ DE BUSTOS

B. C.

22-9-1662

Fr. Alonso de Mier

Cubo (Burgos)

AGN, Irache, Lib. 539, 34r.

MATÍAS DE LARRAÑAGA

B. A. / B. T. / L. T. / D. T.

23-9-1662

Fr. Manuel Guerra, abad

Estella (Pamplona)

AGN, Irache, Lib. 539, 34r.

PEDRO DE NAVARRETE

B. A.

26-9-1662

Fr. Alonso de Mier

Nájera (Nullius Diocesis)

AGN, Irache, Lib. 539, 34r.

SIMÓN LÓPEZ

B. C.

1-10-1662

Fr. Manuel Vela

Cubo (Burgos)

AGN, Irache, Lib. 539, 34v.

BENITO DE IGAR

B. A.

7-10-1662

Fr. Manuel Vela

O. Cist.

AGN, Irache, Lib. 539, 34v.

ANTONIO LEZCANO

B. C. / L. C. / D. C.

9-10-1662

Fr. Alonso de Mier

Vitoria (Calahorra)

AGN, Irache, Lib. 539, 34v.

ALONSO DE ROJAS

B. C.
28-10-1662

Fr. Regente

Lobón (Palencia)

AGN, Irache, Lib. 539, 34v.

FRANCISCO GARCÍA

B. A. / B. T.

28-10-1612

Fr. Alonso de Mier

Sotrojero (Burgos)

AGN, Irache, Lib. 539, 34V.

JUAN MIGUEL SERAZ

B. L. / L. L. / D. L.

30-10-1612

Fr. José de Aguirre / Juan de Lezama, letrado

Leciñena (Zaragoza)

AGN, Irache, Lib. 539, 35r.

PEDRO DE MONTERRUBIO

B. A. / B. T.

7-11-1662

Fr. Regente / Fr. Manuel Vela

Treviana (Burgos)

AGN, Irache, Lib. 539, 35r.

DIEGO SÁINZ DE OCÓN

B. A.

17-11-1662

Fr. Alonso de Mier

Murillo (Calahorra)

AGN, Irache, Lib. 539, 35r.

DOMINGO GÁRATE

B. A. / B. M.

1-12-1662

Fr. Manuel Vela

Vidángoz (Pamplona)

AGN, Irache, Lib. 539, 35r.

MANUEL DE VALENCIA

B. A. / B. T.

14-12-1662

Fr. Manuel Vela / Fr. José de Aguirre

Burgos

AGN, Irache, Lib. 539, 35v. 
TORIBIO DÍAZ REAL

B. C.

14-12-1662

Fr. Regente

Burgos

AGN, Irache, Lib. 539, 35v.

JUAN GONZÁLEZ DE ARCE

B. A. / B. T.

4-1-1663

Fr. Alonso de Mier

Santibáñez (Burgos)

AGN, Irache, Lib. 539, 35v.

FELIPE DE ARCE

B. A. / B. T.

4-1-1663

Fr. Alonso de Mier

San Martín de Ubierna (Burgos)

AGN, Irache, Lib. 539, 35v.

PEDRO GONZALO

B. A. / B. T.

13-1-1613

Fr. Manuel Vela / Fr. José de Aguirre

Báñez (Burgos)

AGN, Irache, Lib. 539, 35v.

DIEGO SÁENZ

B. C.

28-2-1613

Fr. José de Aguirre

Arlanzón (Burgos)

AGN, Irache, Lib. 539, 35v.

PEDRO DE LA VEGA MERODIO

B. T.

8-3-1663

Fr. Alonso de Mier

San Vicente de la Barquera (Burgos)

AGN, Irache, Lib. 539, 36r.

SEBASTIÁN DOMÍNGUEZ

B. A.

10-3-1663

Fr. Manuel Vela

Laguna (Calahorra)

AGN, Irache, Lib. 539, 36r.

\section{FRANCISCO LÓPEZ}

B. A. / B. T.

12-3-1663

Fr. Manuel Vela

Valgañón (Burgos)

AGN, Irache, Lib. 539, 36r.

JERÓNIMO GARCÍA DE LOS LLANOS

B. A. / B. T.

12-3-1663 / 11-12-1666

Fr. Manuel Vela / Fr. Diego de Arbeiza

Anguiano (Calahorra)

AGN, Irache, Lib. 539, 36r, 61v.

MATÍAS DE MARMANILLOS

B. A.

19-3-1663

Fr. Manuel Vela

Rana (Calahorra)

AGN, Irache, Lib. 539, 36r.

FRANCISCO MARTÍNEZ

B. A. / B. T.

2-4-1663

Fr. Manuel Vela

Valgañón (Burgos)

AGN, Irache, Lib. 539, 36r.

PEDRO DEL SAZ

B. C.

12-4-1663

Fr. Alonso de Mier

Ribafrecha (Calahorra)

AGN, Irache, Lib. 539, 36v.

ALONSO DE ANGULO

B. C.

16-4-1663

Fr. José de Aguirre

San Miguel de Palloso (Burgos)

AGN, Irache, Lib. 539, 36v.

JOSÉ JALÓN

B. C.

20-4-1613

Fr. Alonso de Mier

Palenzuela (Burgos)

AGN, Irache, Lib. 539, 36v. 
PLÁCIDO MARTÍNEZ

B. A. / B. T. / L. T. / D. T.

25-4-1663

Fr. Manuel Guerra, abad

O. S. B.

Abad de Oña

AGN, Irache, Lib. 539, 36v.

JUAN GONZÁLEZ DE PIÑERO

B. C.

1-5-1663

Fr. Alonso de Mier

San Vicente de la Barquera (Burgos)

AGN, Irache, Lib. 539, 36v.

FERMÍN DE URUÑUELA

B. C.

5-5-1663

Fr. Alonso de Mier

Pamplona

AGN, Irache, Lib. 539, 36v.

PEDRO DE BARCINA

B. C.

8-5-1613

Fr. José de Aguirre

Renedo (Burgos)

AGN, Irache, Lib. 539, 37r.

AGUSTÍN DE SARABIA

B. C.

12-5-1613

Fr. Regente

El Almiñé (Burgos)

AGN, Irache, Lib. 539, 37r.

ANTONIO FERNÁNDEZ DE LA PORTI-

LLA

B. C.

14-5-1663

Fr. Alonso de Mier

San Vicente de Arango (Burgos)

AGN, Irache, Lib. 539, 37r.

\section{FRANCISCO DELGADO}

B. A. / B. T.

23-5-1663

Fr. José de Aguirre
Cañizal de Amaya (Burgos)

AGN, Irache, Lib. 539, 37r.

DIEGO LÓPEZ DE VAILLO

B. C.

29-5-1663

Fr. Alonso de Mier

Medina de Pomar (Burgos)

AGN, Irache, Lib. 539, 37r.

JUAN GALLO DE ANDRADE

B. T.

20-6-1663

Fr. José de Aguirre

Tubilla del Agua (Burgos)

AGN, Irache, Lib. 539, 37r.

PEDRO DE CEBALLOS

B. A.

20-6-1663

Fr. José de Aguirre

San Andrés (Burgos)

AGN, Irache, Lib. 539, 37r.

ANTONIO SANTIAGO

B. A.

20-6-1663

Fr. José de Aguirre

Santander (Burgos)

AGN, Irache, Lib. 539, 37r.

JUAN DE MIEDES

B. A. / B. M.

30-6-1663

Fr. José de Aguirre

Tudela (Navarra)

AGN, Irache, Lib. 539, 37v.

LEONARDO DE LODOSA

B. $\mathrm{M}$.

3-7-1663

Fr. Regente / Dr. Juárez

Andosilla (Pamplona)

AGN, Irache, Lib. 539, 37v.

MATEO MAESTRE

B. A.

3-7-1663 
Fr. José de Aguirre

Alcanadre (Calahorra)

AGN, Irache, Lib. 539, 37v.

FRANCISCO DE PEREDA

B. C.

5-7-1663

Fr. Regente

Medina de Pomar (Burgos)

AGN, Irache, Lib. 539, 37v.

VENTURA VÉLEZ

B. M.

17-7-1663

Fr. Alonso de Mier

Cornago (Calahorra)

AGN, Irache, Lib. 539, 37v.

JUAN DÍAZ DEL CORRAL

L. A.

17-7-1663

Fr. Manuel Guerra, abad

Entrena (Calahorra)

AGN, Irache, Lib. 539, 37v.

FRANCISCO DE ZALDÍBAR

B. C.

24-7-1613

Fr. José de Aguirre

Briviesca (Burgos)

AGN, Irache, Lib. 539, 37v.

MARCOS DE URTASO

B. A.

26-7-1613

Fr. Regente

Caparroso (Pamplona)

AGN, Irache, Lib. 539, 37v.

SEBASTIÁN DE MONTAÑANA

B. A. / B. M.

26-7-1663 / 29-7-1663

Fr. Alonso de Mier / Fr. Manuel Guerra,

abad

Zaragoza

AGN, Irache, Lib. 539, 38r.

MATÍAS DE RADA

D. C.
31-7-1663

Fr. Manuel Guerra, abad

Pamplona

Caballero del Hábito de Calatrava

B. C. en Salamanca / L. C. en Valladolid

Maestrescuela de la Universidad de Salamanca

AGN, Irache, Lib. 539, 38r.

BERNARDO DE ARRÓNIZ

B. A. / B. M.

5-8-1663 / 7-9-1665

Fr. Manuel Guerra, abad / Fr. Primitivo

Ruiz

Estella (Pamplona)

AGN, Irache, Lib. 539, 38r, 52r, 56r, 71v.

PEDRO DÍEZ DE QUINTANILLA

B. C.

6-8-1663

Fr. Alonso de Mier

Melgar de Fernamental (Burgos)

AGN, Irache, Lib. 539, 38r.

TOMÁS DE OLLOQUI Y LARA

B. A. / B. M.

9-8-1663 / 13-7-1666

Fr. José de Aguirre / Fr. Juan de Valcázar

Villafranca (Pamplona)

AGN, Irache, Lib. 539, 38r, 58v.

JUAN CRISÓSTOMO DE PEÑA

B. A. / B. M.

11-8-1663

Fr. Regente

Sangüesa (Pamplona)

AGN, Irache, Lib. 539, 38v.

ANTONIO DE YLGUERO

B. C.

11-8-1663

Fr. Regente

... (Burgos)

AGN, Irache, Lib. 539, 38v.

JOSÉ RUIZ

B. A. / B. M.

12-8-1613 
Fr. Regente / Fr. Alonso de Mier Tarazona

AGN, Irache, Lib. 539, 38v.

FRANCISCO DÍAZ

B. C.

23-8-1613

Fr. José de Aguirre

Cilleruelo (Burgos)

AGN, Irache, Lib. 539, 38v.

JUAN DÍAZ DE ANDINO

B. C.

27-8-1663

Fr. Regente

Laredo (Burgos)

AGN, Irache, Lib. 539, 38v.

JUAN PABLO DE SAN PEDRO

B. C.

5-9-1663

Fr. Regente

Canales (Burgos)

AGN, Irache, Lib. 539, 38v.

MATÍAS DE AGUIRRE

B. A. / B. T.

5-9-1663

Fr. Regente

Calatayud (Tarazona)

AGN, Irache, Lib. 539, 39r.

BERNABÉ GONZÁLEZ

B. C.

6-9-1663

Fr. Regente

Villandiego (Burgos)

AGN, Irache, Lib. 539, 39r.

JUAN GÓMEZ BARONA

B. C.

12-9-1663

Fr. Alonso de Mier

Frías (Burgos)

AGN, Irache, Lib. 539, 39r.

ESTEBAN DE NOBA

B. C.
17-9-1663

Fr. Regente

Villarán (Burgos)

AGN, Irache, Lib. 539, 39r.

PEDRO DE ARNILLA

B. C.

17-9-1663

Fr. Regente

Villahizán (Burgos)

AGN, Irache, Lib. 539, 39r.

FRANCISCO SALDAÑA

B. C.

19-9-1663

Fr. Alonso de Mier

San Andrés de Arroyo (Palencia)

AGN, Irache, Lib. 539, 39r.

MIGUEL TAFADURA

B. C.

19-9-1663

Fr. Regente

Hornillos del Camino (Burgos)

AGN, Irache, Lib. 539, 39r.

FRANCISCO RODRÍGUEZ

B. C.

21-9-1663

Fr. Regente

Las Henestrosas (Burgos)

AGN, Irache, Lib. 539, 39r.

FRANCISCO DE JADO DEL MAZO

B. C.

7-10-1663

Fr. Alonso de Mier

Argoños (Burgos)

AGN, Irache, Lib. 539, 39v.

FAUSTO RUIZ DE URRA

B. A.

9-10-1663

Fr. Alonso de Mier

O. de M.

AGN, Irache, Lib. 539, 39v.

ANTONIO HERNÁNDEZ DE EMINILLAS

B. A. / B. T. 
12-10-1613

Fr. Alonso de Mier

El Almiñé (Burgos)

AGN, Irache, Lib. 539, 39v.

\section{JOSÉ DE SAGASTI Y GOITIA}

B. M. / L. M. / D. M.

14-10-1663

Fr. Manuel Guerra, abad / Juan Juárez, médico de Estella

Irache (Pamplona)

AGN, Irache, Lib. 539, 39v.

\section{JUAN JUÁREZ}

L. M. / D. M.

18-10-1663

Fr. Manuel Guerra, abad / Dr. Sagasti, médico de Estella

Tafalla

AGN, Irache, Lib. 539, 39v.

\section{BERNARDINO MARTÍNEZ}

B. M.

4-11-1663

Fr. José de Aguirre

Peralta (Pamplona)

AGN, Irache, Lib. 539, 39v.

\section{AMBROSIO GÓMEZ}

B. A. / B. T.

19-11-1663

Fr. José de Noboa / Fr. Regente

Villasandino (Burgos)

AGN, Irache, Lib. 539, 40r.

\section{DIEGO SÁINZ}

B. M.

3-12-1613

Calabazas (sic)

Dres. Sagasti y Juárez

Murillo (Calahorra)

AGN, Irache, Lib. 539, 40r.

\section{JUAN FERNÁNDEZ}

B. A. / B. T.

7-12-1613

Fr. José de Aguirre / Fr. Regente Quintanilla de Sobresierra (Burgos)

AGN, Irache, Lib. 539, 40r.

\section{PEDRO PÉREZ DE PARRA}

B. A. / B. T.

11-12-1663

Fr. José de Noboa, Maestro en Artes

Pampliega (Burgos)

AGN, Irache, Lib. 539, 40r.

\section{FRANCISCO CRUZADO}

B. C.

11-12-1663

Fr. Alonso de Mier

Villasandino (Burgos)

AGN, Irache, Lib. 539, 40r.

DIEGO BARRÓN

B. A. / B. T. / L. T. / D. T.

1-1-1664

Fr. Manuel Guerra, abad.

Logroño (Calahorra)

AGN, Irache, Lib. 539, 4or.

PRIMITIVO LASO

B. A. / L. A. / M. A. / B. T. / L. T. / D. T. 13-1-1664

Fr. Rosendo de Múgica, General de O. S. B. O. S. B.

Regente en Irache

AGN, Irache, Lib. 539, $40 v$.

\section{BENITO MONDRAGÓN}

B. A. / L. A. / M. A. / B. T. / L. T. / D. T. 13-1-1664

Fr. Rosendo de Múgica, General de O. S. B. O. S. B.

AGN, Irache, Lib. 539, $40 \mathrm{v}$.

JOSÉ DE NOBOA

B. A. / L. A. / M. A. / B. T. / L. T. / D. T. 13-1-1664

Fr. Rosendo de Múgica, General de O. S. B. O. S. B.

Lector de Artes en Irache

AGN, Irache, Lib. 539, $40 v$.

PEDRO DE CASTRO

B. A. / L. A. / M. A. / B. T. / L. T. / D. T.

13-1-1664

Fr. Rosendo de Múgica, General de O. S. B. 
O. S. B.

Maestro de Estudios de Irache

AGN, Irache, Lib. 539, 40v.

VENTURA RUPÉREZ O PÉREZ (sic)

B. A. / B. T.

14-1-1664

Fr. José de Noboa

¿Torre...? (Burgos)

AGN, Irache, Lib. 539, $40 v$.

FRANCISCO LARIBA

B. A. / B. T

5-2-1664

Fr. Alonso de Mier

Villanueva (Burgos)

AGN, Irache, Lib. 539, 40v.

MARTÍN RUIZ DE UBAGO

B. A. / L. A.

9-2-1664

Fr. Manuel Guerra, abad.

Ubago (Pamplona)

AGN, Irache, Lib. 539, 40v.

JUAN SÁNCHEZ

B. A. / B. T. / L. T. / M. T.

10-2-1664

Fr. Manuel Guerra, abad.

O. S. B.

AGN, Irache, Lib. 539, 40v.

GABRIEL DE CEBALLOS

B. A. / B. T. / L. T. / M. T.

11-2-1664

Fr. Manuel Guerra, abad.

O. S. B.

Predicador

AGN, Irache, Lib. 539, 41r.

MAURO DE SOSA

B. A. / B. T. / L. T. / M. T.

11-2-1664

Fr. Manuel Guerra, abad.

O. S. B.

AGN, Irache, Lib. 539, 41r.

MANUEL DE IGLESIAS

B. C.
26-2-1664

Fr. José de Aguirre

Burgos

AGN, Irache, Lib. 539, 41r.

GONZALO ROMERO SOTELO

B. C. / L. C.

26-2-1664

Fr. Manuel Guerra, abad.

Zamora

Deán de Coria

AGN, Irache, Lib. 539, 41r.

BLAS DE TEJADURA

B. $T$.

10-3-1664

Fr. Alonso de Mier

Quintanillas (Burgos)

AGN, Irache, Lib. 539, 41v.

FRANCISCO DE OREÑA

B. A. / B. T. / L. T.

17-3-1664

Fr. Manuel Guerra, abad.

Santander (Burgos)

AGN, Irache, Lib. 539, 41v.

JUAN DE QUINTANA

B. C.

18-3-1664

Fr. Alonso de Mier

Balmaseda (Burgos)

AGN, Irache, Lib. 539, 41v.

SIMÓN GONZÁLEZ

B. C.

18-3-1664

Fr. Alonso de Mier

El Valle de Acentales (Burgos)

AGN, Irache, Lib. 539, 41v.

JOSÉ MAULEÓN

B. M.

18-3-1664

Fr. Alonso de Mier / Dr. Juárez

Falces (Pamplona)

AGN, Irache, Lib. 539, 41v. 
JUAN VÉLEZ

B. A. / B. T.

21-3-1664

Fr. José de Noboa / Fr. José de Aguirre

Ontona (Burgos)

AGN, Irache, Lib. 539, 41v.

FRANCISCO FERNÁNDEZ DE UGARTE

B. $\mathrm{M}$.

31-3-1664

Fr. Alonso de Mier / Dr. Juárez

Milagro (Pamplona)

AGN, Irache, Lib. 539, 41v.

ANTONIO MARRÓN Y ALVARADO

B. A. / B. T.

7-4-1664

Fr. José de Aguirre

Madrid (Toledo)

AGN, Irache, Lib. 539, 42r.

JOSÉ FERNÁNDEZ PÉREZ

L. L.

22-4-1664

Fr. Manuel Guerra, abad

Calatayud (Tarazona)

AGN, Irache, Lib. 539, 42r.

JUAN MATEO MARÍN

B. A. / L. A.

25-4-1664

Fr. Manuel Guerra, abad

Huércanos (Calahorra)

AGN, Irache, Lib. 539, 42r.

DIEGO BRINGAS

B. A.

30-4-1664

Fr. José de Noboa

Bellorado (Burgos)

AGN, Irache, Lib. 539, 42r.

FRANCISCO RODRÍGUEZ

B. A.

30-4-1664

Fr. José de Noboa

Bellorado (Burgos)

AGN, Irache, Lib. 539, 42r.
ANDRÉS DE MARDONES

B. C.

2-5-1664

Fr. Alonso de Mier

Teza (Burgos)

AGN, Irache, Lib. 539, 42r.

BARTOLOMÉ MATEO DE SALAZAR

B. A. / L. A.

4-5-1664

Fr. José de Noboa

Haro (Calahorra)

AGN, Irache, Lib. 539, 42v.

TOMÁS PÉREZ

B. C.

16-5-1664

Reprobado

Fr. José de Aguirre

Penches (Burgos)

AGN, Irache, Lib. 539, 42v.

IGNACIO DE ESANDI

B. A.

27-5-1664

Fr. Pedro de Castro

Ochogavía (Pamplona)

Estudiante de Artes en los Teatinos de

Pamplona

AGN, Irache, Lib. 539, 42v.

DIEGO PÉREZ

B. C.

13-6-1664

Fr. Alonso de Mier

Zeballos (Burgos)

AGN, Irache, Lib. 539, 42v.

DOMINGO GONZÁLEZ

B. C.

22-6-1664

Fr. Alonso de Mier

Medina de Pomar (Burgos)

AGN, Irache, Lib. 539, 42v.

JOSÉ DE OLAETA

B. A. / L. A. / M. A. / B. T. / L. T. / D. T. 23-6-1664 
Fr. Manuel Guerra, abad.

O. S. B.

AGN, Irache, Lib. 539, 42v.

ANDRÉS PÁRAMO

B. A. / B. T.

15-7-1614

Fr. José de Noboa

Reprobado

Fr. Primitivo Ruiz

Pedrosa de Río Urbel (Burgos)

AGN, Irache, Lib. 539, 43r.

\section{JUAN BAUTISTA DE VILLORIA}

B. T.

28-7-1614

Fr. Primitivo Ruiz

Izcari (Burgos)

AGN, Irache, Lib. 539, 43r.

PLÁCIDO OROZ

B. A. / L. A. / M. A. / B. T. / L. T. / D. T.

8-8-1664

Fr. Manuel Guerra, abad.

O. S. B.

AGN, Irache, Lib. 539, 43r.

BERNARDO DE THERRY

B. A.

21-8-1664

Fr. José de Noboa

Andosilla (Pamplona)

AGN, Irache, Lib. 539, 43v.

MIGUEL DE LA CUESTA

B. A. / B. T.

24-8-1664

Fr. José de Noboa

Tosantos (Burgos)

AGN, Irache, Lib. 539, 43v.

JOSÉ DÍEZ DE IRLA

B. A. / B. M.

31-8-1664 / 6?-10-1667

Fr. José de Noboa / Fr. Diego de Arbeiza

Arnedo (Calahorra)

AGN, Irache, Lib. 539, 43v, 69v.
ALONSO NÚÑEZ

B. C.

18-9-1664

Fr. Primitivo Ruiz

Medina de Pomar (Burgos)

AGN, Irache, Lib. 539, 44r.

JUAN MATEO

B. C.

19-9-1664

Fr. Primitivo Ruiz

Arenillas (Burgos)

AGN, Irache, Lib. 539, 44r.

ANTONIO DE MEDINA

B. C.

19-9-1664

Fr. Primitivo Ruiz

Melgar de Fernamental (Burgos)

AGN, Irache, Lib. 539, 44r.

\section{DIEGO FERNÁNDEZ}

B. A.

20-9-1614

Fr. José de Noboa

Fuentebureba (Burgos)

AGN, Irache, Lib. 539, 44r.

JOSÉ OSTÉRIZ

B. A.

22-9-1664

Fr. José de Noboa

AGN, Irache, Lib. 539, 44r.

ESTEBAN OLOQUI

B. A.

22-9-1664

Fr. José de Noboa

AGN, Irache, Lib. 539, 44v.

MANUEL MÁRQUEZ

B. C.

23-9-1664

Fr. Primitivo Ruiz

Ezcaray (Burgos)

AGN, Irache, Lib. 539, 44v.

JUAN RODRÍGUEZ

B. C. 
26-9-1664

Fr. Primitivo Ruiz

Olea (Burgos)

AGN, Irache, Lib. 539, 44v.

PLÁCIDO DE LEZÁUN

B. A.

2-10-1664

Fr. José de Noboa

O. Cist.

AGN, Irache, Lib. 539, 44v.

JUAN LAÍN DE VINAQUE

B. T.

9-10-1664

Fr. Primitivo Ruiz

Boy...? (Jaca)

AGN, Irache, Lib. 539, 45r.

MANUEL DE OLIVAR

B. A. / L. A. / M. A. / B. T. / L. T. / D. T.

14-10-1664

Fr. Manuel Guerra, abad.

O. S. B.

AGN, Irache, Lib. 539, 45r.

ANTONIO DE FONTCUEVA

B. C.

16-10-1614

Fr. Primitivo Ruiz

Arnuero (Burgos)

AGN, Irache, Lib. 539, 45r.

BENITO FERNÁNDEZ

B. C.

28-10-1614

Fr. Juan de Balcarcel

Guir... (Burgos)

AGN, Irache, Lib. 539, 45r.

ANTONIO DE ARENILLAS

B. C.

31-10-1664

Fr. José de Aguirre

Frechilla (Burgos)

AGN, Irache, Lib. 539, 45r.

JUAN IBÁÑEZ DE ICARÁN DE BERRIATUA

B. A. / B. T.
7-11-1664

Fr. José de Noboa / Fr. José de Aguirre

Berriatua (Calahorra)

AGN, Irache, Lib. 539, 45v.

FRANCISCO ANTONIO DE ERILL

B. C. / L. C. / D. C.

19-11-1664

Fr. Manuel Guerra, abad

Barcelona

Caballero del Hábito de Santiago

Arcediano y canónigo de Barcelona

AGN, Irache, Lib. 539, 45v.

FRANCISCO DE PLASENCIA

B. A. / L. A.

29-11-1664 / 15-12-1665

Fr. José de Noboa / Fr. Pedro de Bergaño,

abad

Puente la Reina (Pamplona)

Estudiante de los Teatinos

AGN, Irache, Lib. 539, 45v, 54v.

JUAN MARTÍNEZ

B. A.

29-11-1664

Fr. José de Noboa

Mansilla (Burgos)

AGN, Irache, Lib. 539, 45v.

JOSÉ GUTIÉRREZ

B. A.

29-11-1664

Fr. José de Noboa

San Pedro Samuel (Burgos)

AGN, Irache, Lib. 539, 45v.

IGNACIO DE MUÑOZ Y ARCE

B. C.

2-12-1664

Fr. Juan de Balcárcel

Cueva (Burgos)

AGN, Irache, Lib. 539, 45v.

$-/-/ 1664$

AGN, Irache, Lib. 539, 46rv. 
JUAN CRISÓSTOMO DE IÑÍGUEZ Y PUYO

B. T. / L. T.

21-12-1664

Fr. Manuel Guerra, abad

Martés (Jaca)

Arcediano y canónigo de Daroca

AGN, Irache, Lib. 539, 47r.

JUAN DE LA PEÑA

B. C.

29-12-1664

Fr. José de Aguirre

Salinas de Rosío (Burgos)

AGN, Irache, Lib. 539, 47r.

\section{AMADOR DEL ARCO}

B. C.

31-12-1664

Fr. Juan de Valcázar

O... (Burgos)

AGN, Irache, Lib. 539, 47r.

JUAN DE VALCÁZAR

B. A. / L. A. / M. A. / B. T. / L. T. / D. T. 20-1-1664

Fr. Manuel Guerra, abad

O. S. B.

Regente de Irache

Profeso en San Pedro de Cardeña

AGN, Irache, Lib. 539, 47v.

\section{PRIMITIVO RUIZ}

B. A. / L. A. / M. A. / B. T. / L. T. / D. T.

20-1-1665

Fr. Manuel Guerra, abad

O. S. B.

Lector de Teología en Irache

Profeso en Sahagún

AGN, Irache, Lib. 539, 47v.

JOSÉ DE DOMÍNGUEZ

B. A. / B. M.

28-1-1665

Fr. José de Noboa

Le dieron calabazas (sic)

Tudela (Tarazona)

AGN, Irache, Lib. 539, 47v.
DIEGO DE OLABARRIETA

B. C.

4-2-1665

Fr. Juan de Valcázar

Domingo de la Calzada (Calahorra)

AGN, Irache, Lib. 539, 48r.

ANTONIO GONZÁLEZ

B. A. / B. T.

11-2- 1665

Fr. José de Noboa

Los Balbases (Burgos)

AGN, Irache, Lib. 539, 48r.

JUAN DE RIAÑO Y GAMBOA

B. A. $28-2-1665$

B. T. Calabazas (sic) 16-9-1665

Fr. José de Noboa / Fr. Primitivo Ruiz

Cerezo (Burgos)

AGN, Irache, Lib. 539, 48r, 52r.

JOSÉ SALINAS

B. C.

3-3-1665

Fr. Primitivo Ruiz

Cerezo (Burgos)

AGN, Irache, Lib. 539, 48r.

ANTONIO ÁLVAREZ

B. C.

11-3-1665

Fr. Juan de Valcázar

Belorado (Burgos)

AGN, Irache, Lib. 539, 48r.

JUAN SÁENZ DE TRIANA

B. A. / B. T.

13-3-1665

Fr. José de Noboa / Fr. José de Aguirre

Sasamón (Burgos)

AGN, Irache, Lib. 539, 48v.

\section{FRANCISCO BARONA VILLANUEVA}

RUIZ

B. C.

$-/ 3-1665$

Fr. José de Aguirre

Biloba (Burgos)

AGN, Irache, Lib. 539, 48v. 
FELIPE DE RIBAS

B. A. / B. T.

26-3-1665

Fr. José de Noboa / Fr. Regente Valcázar

Valmala (Burgos)

AGN, Irache, Lib. 539, 48v.

\section{BERNARDO DE BIENMA}

L. C.

31-3-1665

Fr. Juan de Valcázar, regente

Logroño (Calahorra)

AGN, Irache, Lib. 539, 48v.

GONZALO DE BEAR

B. C.

13-4-1665

Fr. Juan de Valcázar

Liaño (Burgos)

AGN, Irache, Lib. 539, 49r.

POLICARPO ANDRÉS

B. A. / B. M.

13-4-1665 / 14-4-1665

Fr. José de Noboa / Fr. Primitivo Ruiz / Dr.

Juárez

Sangüesa (Pamplona)

AGN, Irache, Lib. 539, 49r.

MIGUEL GUERRA DE LA VEGA

B. A. / L. A.

16-4-1665

Fr. Manuel Guerra, abad

Mués (Pamplona)

AGN, Irache, Lib. 539, 49r.

PRUDENCIO PORTUGUÉS

B. A.

17-4-1615

Fr. José de Noboa

O. de M.

AGN, Irache, Lib. 539, 49r.

JOSÉ GÁRATE

B. A.

17-4-1615

Fr. José de Noboa

O. de M.

AGN, Irache, Lib. 539, 49r.
JUAN DE EZQUÍROZ

B. A. / B. M.

21-4-1665

Fr. José de Noboa / Fr. Primitivo Ruiz / Dr.

Juárez

Zariquiegui (Pamplona)

AGN, Irache, Lib. 539, 49rv.

JOSÉ DE OCHOA Y ARTEAGA

B. C.

24-4-1665

Fr. Primitivo Ruiz

Briviesca (Burgos)

AGN, Irache, Lib. 539, 49v.

PEDRO GARCÍA DEL MORAL

B. C.

29-4-1665

Fr. Primitivo Ruiz

Medina de Pomar (Burgos)

AGN, Irache, Lib. 539, 49v.

PEDRO DE LA SIERRA

B. C.

1-5-1665

Fr. Primitivo Ruiz

Santuario (Burgos)

AGN, Irache, Lib. 539, 49v.

LESMES DE SALCEDO

B. C.

9-5-1665

Fr. Primitivo Ruiz

Vivar del Cid (Burgos)

AGN, Irache, Lib. 539, 49v.

FRANCISCO RODRÍGUEZ

B. A.

11-5-1665

Fr. José de Noboa

Cortiguera (Burgos)

AGN, Irache, Lib. 539, 49v.

MARTÍN DE EGUIARTE

B. A.

18-5-1665

Fr. José de Noboa

Uterga (Pamplona)

AGN, Irache, Lib. 539, 5or. 
JUAN PABLO GAZTELU

B. A.

18-5-1665

Fr. José de Noboa

Pamplona

AGN, Irache, Lib. 539, 5or.

MARTÍN ROS

B. A.

18-5-1665

Fr. José de Noboa

Los Arcos (Pamplona)

AGN, Irache, Lib. 539, 5or.

JOSÉ DE OLEO

B. A.

18-5-1665

Fr. José de Noboa

Estella (Pamplona)

AGN, Irache, Lib. 539, 5or.

MANUEL DE LABASTIDA

B. A.

18-5-1665

Fr. José de Noboa

Calahorra

AGN, Irache, Lib. 539, 5or.

MIGUEL DE JÁUREGUI

B. A.

18-5-1665

Fr. José de Noboa

Corera (Calahorra)

AGN, Irache, Lib. 539, 5or.

JUAN DE BELZUNEGUI

B. A.

18-5-1665

Fr. José de Noboa

Santisteban (Pamplona)

AGN, Irache, Lib. 539, 5 or.

MIGUEL DE JURIO

B. A.

18-5-1665

Fr. José de Noboa

Lerga (Pamplona)

AGN, Irache, Lib. 539, 5or.

\section{BERNARDO DE LA CUESTA}

B. A.

22-5-1665

Fr. José de Noboa

Briviesca (Burgos)

AGN, Irache, Lib. 539, 5or.

CRISTÓBAL BARBADILLO

B. A. / B. T.

12-6-1665

Fr. José de Noboa / Fr. Primitivo Ruiz

I... (Burgos)

AGN, Irache, Lib. 539, 5or.

JUAN MARTÍNEZ GARIJO

B. A.

13-6-1665

Fr. José de Noboa

Arnedo (Calahorra)

AGN, Irache, Lib. 539, 5or.

LUIS ANTONIO RAMIRO GÓMEZ

L. L.

6-7-1665

Fr. Pedro de Bergaño, abad y rector

Calatayud (Tarazona)

AGN, Irache, Lib. 539, $50 v$.

DOMINGO MARTÍNEZ DE LASTRAS

B. C.

17-7-1665

Fr. Primitivo Ruiz / Fr. José de Noboa / Fr.

Pedro de Castro

Le dieron calabazas dos veces (sic)

Cubillos (Burgos)

AGN, Irache, Lib. 539, $50 v$.

ANDRÉS FERNÁNDEZ MONTERO

B. C.

21-7-1615

Fr. Primitivo Ruiz

Laredo (Burgos)

AGN, Irache, Lib. 539, $50 v$.

GASPAR CRUZADO

B. T.

24-7-1665

Fr. Primitivo Ruiz 
Villasandino (Burgos)

B. A. en Ávila

AGN, Irache, Lib. 539, $50 v$.

FRANCISCO PRIETO

B. A. / B. T.

24-7-1665

Fr. Primitivo Ruiz

Villasandino (Burgos)

AGN, Irache, Lib. 539, $50 \mathrm{v}$.

TOMÁS DE ROSILLO

B. C.

24-7-1665

Fr. Primitivo Ruiz

Laredo (Burgos)

AGN, Irache, Lib. 539, 51r.

PEDRO GARCÍA DE SAN MARTÍN

B. C.

26-7-1665

Fr. Primitivo Ruiz

Villasandino (Burgos)

AGN, Irache, Lib. 539, 51r.

DIEGO PEREDA

B. T.

29-7-1665

Fr. Primitivo Ruiz

Montejo de Cebas (Burgos)

B. A. y L. A. en Alcalá

AGN, Irache, Lib. 539, 51r.

JUAN ALONSO DE PEREDA

B. A. / B. T.

31-7-1665

Fr. José de Noboa / Fr. Primitivo Ruiz

Heleches (Burgos)

AGN, Irache, Lib. 539, 51r.

FELIPE DE GÁNDARA

B. C.

1-8-1665

Fr. Primitivo Ruiz

Laredo (Burgos)

AGN, Irache, Lib. 539, 51r.

JUAN IÑÍGUEZ DE ARNEDO

L. C.
16-8-1665

Fr. Pedro de Bergaño, abad

Bergara (Calahorra)

AGN, Irache, Lib. 539, 51v.

ALONSO ESTÉBANEZ

B. C.

18-8-1665

Fr. Primitivo Ruiz

Quintanilla de las Torres (Burgos)

AGN, Irache, Lib. 539, 51v.

MARTÍN DE AOIZ

B. C.

21-8-1665

Fr. Pedro de Bergaño, abad

Pamplona

AGN, Irache, Lib. 539, 51v.

JUAN BAUTISTA DEL PEDREDO

B. C.

24-8-1665

Fr. Primitivo Ruiz

Laredo (Burgos)

AGN, Irache, Lib. 539, 51v.

JUAN ANTONIO DE SANTANDER

B. C.

24-8-1665

Fr. Primitivo Ruiz

Laredo (Burgos)

AGN, Irache, Lib. 539, 51v.

JUAN SOBREVILLA VADILLO

B. A. / B. T.

27-8-1665

Fr. Primitivo Ruiz

Bóveda (Burgos)

AGN, Irache, Lib. 539, 52r.

JUAN ORTIZ DE PINEDO

B. C.

27-8-1665

Fr. Primitivo Ruiz

Acebedo (Burgos)

AGN, Irache, Lib. 539, 52r.

PEDRO COLINA RUIZ

B. A. / B. T. 
11-9-1665

Fr. Primitivo Ruiz / Fr. José de Noboa Fresno de Rodilla (Burgos)

AGN, Irache, Lib. 539, 52r.

\section{ANDRÉS DE LA HERA}

B. A. / B. T.

14-9-1665

Fr. José de Noboa

Villoredo (Burgos)

AGN, Irache, Lib. 539, 52r.

\section{FRANCISCO DE LLANO}

B. C.

25-9-1665

Fr. Primitivo Ruiz

Concejo de Galdames (Burgos)

AGN, Irache, Lib. 539, 52v.

\section{JUAN DE OGAZÓN}

B. C.

25-9-1665

Fr. Primitivo Ruiz

Medina de Pomar (Burgos)

AGN, Irache, Lib. 539, 52v.

JULIÁN RAMOS DE HEREDIA

B. M.

2-10-1665

Fr. Primitivo Ruiz

Tudela (Tarazona)

AGN, Irache, Lib. 539, 52v.

BERNARDO IZQUIERDO DE RIVERA

B. $\mathrm{M}$.

5-10-1665

Fr. Primitivo Ruiz

Estella (Pamplona)

AGN, Irache, Lib. 539, 52v.

\section{FRANCISCO YOLDI}

B. A.

7-10-1665

Fr. José de Noboa

O. de M.

AGN, Irache, Lib. 539, 52v.

JUAN ANTONIO DE TORRES Y CASTEJÓN L. C.
8-10-1665

Fr. José de Noboa

Agreda (Tarazona)

AGN, Irache, Lib. 539, 52v.

MIGUEL GONZÁLEZ

B. C.

15-10-1665 / 29-10-1665

Reprobado

Fr. Juan de Valcázar / Fr. José de Olaeta

Valdebezana (Burgos)

AGN, Irache, Lib. 539, 53r, 54r.

TOMÁS DE RIVAS

B. C.

16-10-1665

Fr. José de Olaeta

San Pantaleón (Burgos)

AGN, Irache, Lib. 539, 53r.

AGUSTÍN DEL OYO

B. C.

17-10-1665

Fr. Primitivo Ruiz

Carasa (Burgos)

AGN, Irache, Lib. 539, 53r.

PEDRO PÉREZ

B. C.

20-10-1665

Fr. Juan de Valcázar

Salazar (Burgos)

AGN, Irache, Lib. 539, 53r.

JUAN DE CENCAN

B. A.

21-10-1665

Fr. José de Noboa

Balite (Calahorra)

AGN, Irache, Lib. 539, 53r.

FRANCISCO GONZÁLEZ

B. A. / B. T.

25-10-1665

Fr. José de Olaeta

Poza (Burgos)

AGN, Irache, Lib. 539, 53v. 
GREGORIO MACHUCA

B. A.

27-10-1665

Fr. José de Noboa

Alarcos (Valladolid)

AGN, Irache, Lib. 539, 53v.

GASPAR DE HERRÁN Y EZCARAY

L. C. / D. C.

29-10-1665

Fr. Pedro de Bergaño, abad

Madrid (Toledo)

Arcediano de Haza

AGN, Irache, Lib. 539, 53v.

JACINTO DE SEDANO

B. C.

29-10-1665

Fr. Primitivo Ruiz

Horna (Burgos)

AGN, Irache, Lib. 539, 54r.

JUAN ALONSO

B. C.

4-11-1665

Fr. ...

Arnedo (Calahorra)

AGN, Irache, Lib. 539, 54r.

PEDRO GONZÁLEZ

B. A.

8-11-1665

Fr. José de Noboa

Autol (Calahorra)

AGN, Irache, Lib. 539, 54r.

PEDRO SAINZ

B. C.

22-11-1665

Fr. Juan de Valcázar

Sangrices (Burgos)

AGN, Irache, Lib. 539, 54v.

VENTURA DE RIBAS

B. C.

19-12-1665

Fr. José de Olaeta

San Pantaleón (Burgos)

AGN, Irache, Lib. 539, 54v.
DIEGO DE LA PUERTA

B. C.

20-12-1665

Fr. Primitivo Ruiz

Lerma (Nullius Diocesis)

AGN, Irache, Lib. 539, 54v.

JUAN DE EGURROLA

B. C.

9-1-1666

Fr. Manuel Vela

Berriatúa (Calahorra)

AGN, Irache, Lib. 539, 54v.

DOMINGO DE LA PUENTE PADRONES

B. C.

13-1-1666

Fr. Juan de Valcázar

La Cueva (Burgos)

AGN, Irache, Lib. 539, 54v.

JUAN LÓPEZ DE BARRASA

B. C.

23-1-1666

Fr. José de Olaeta

Valderrama (Burgos)

AGN, Irache, Lib. 539, 55r.

JUAN DE ARCE

B. A.

9-2-1666

Fr. José de Noboa

Arce (Calahorra)

AGN, Irache, Lib. 539, 55r.

MARTÍN DE OÑATE

B. C.

27-2-1666

Fr. José de Noboa

Treviana (Burgos)

AGN, Irache, Lib. 539, 55r.

\section{MARTÍN RUIZ}

B. C.

6-3-1666

Fr. Manuel Vela

Medina de Pomar (Burgos)

AGN, Irache, Lib. 539, 55r. 
JUAN DE RANGADA

B. A.

9-3-1666

Fr. José de Noboa

Estella (Pamplona)

AGN, Irache, Lib. 539, 55r.

JUAN CALVO

B. A.

9-3-1666

Fr. José de Noboa

Lerin (Pamplona)

AGN, Irache, Lib. 539, 55r.

JUAN ANTONIO JUÁREZ

B. A.

9-3-1666

Fr. José de Noboa

Tafalla (Pamplona)

AGN, Irache, Lib. 539, 55r.

JERÓNIMO MEDRANO

B. A.

9-3-1666

Fr. José de Noboa

Iguzquiza (Pamplona)

AGN, Irache, Lib. 539, 55r.

FRANCISCO FERNÁNDEZ

B. A.

9-3-1666

Fr. José de Noboa

Leuza (Pamplona)

AGN, Irache, Lib. 539, 55r.

FRANCISCO ANTONIO BALTANÁS

B. A.

9-3-1666

Fr. José de Noboa

Nájera (Calahorra)

AGN, Irache, Lib. 539, 55r.

ANDRÉS DE URRUTIA

B. A.

9-3-1666

Fr. José de Noboa

Anguiano (Calahorra)

AGN, Irache, Lib. 539, 55r.

\section{PEDRO GADEA}

B. A. / B. T.

14-3-1666

Fr. José de Noboa / Fr. Juan de Valcázar

Briones (Calahorra)

AGN, Irache, Lib. 539, 55v.

FRANCISCO CORRAL

B. A. / B. T.

18-3-1666

Fr. José de Noboa / Fr. Primitivo Ruiz

Sasamón (Burgos)

AGN, Irache, Lib. 539, 55v.

JUAN DE PALACIO

B. C.

2-4-1666

Fr. Manuel Vella

Reprobado

Güemes (Burgos)

AGN, Irache, Lib. 539, 55v.

DOMINGO ALVARADO

B. A. / B. T.

4-4-1666

Fr. José de Noboa / Fr. Juan de Valcázar Burgos

AGN, Irache, Lib. 539, 55v.

JOSÉ CORREDOR

B. A. / B. T.

6-4-1666

Fr. José de Noboa / Fr. Juan de Valcázar

Sasamón (Burgos)

AGN, Irache, Lib. 539, 56r.

FRANCISCO VILLEGAS

B. A. / B. T.

6-4-1666

Fr. José de Noboa / Fr. Juan de Valcázar

Sasamón (Burgos)

AGN, Irache, Lib. 539, 56r.

TOMÁS DE SARASA

B. C.

8-4-1666

Fr. Juan de Valcázar

Ayerbe (Huesca)

AGN, Irache, Lib. 539, 56r. 


\section{JUAN GUILAZ}

L. A. / D. A.

11-4-1666 / 26-1-1668

Fr. Pedro Bergaño, abad

Arróniz (Pamplona)

AGN, Irache, Lib. 539, 56r, 71v.

IGNACIO DE LIZARGÁRATE

L. L. / D. L.

18-4-1666 / 26-4-1666

Fr. Pedro Bergaño, abad

Zaragoza

AGN, Irache, Lib. 539, 56v.

PABLO DE ROBLEDO

B. C.

21-4-1666

Fr. Primitivo Ruiz

Villota (Burgos)

AGN, Irache, Lib. 539, 56v.

SANTIAGO DE UBERICHAGA

B. C.

30-4-1666

Fr. Primitivo Ruiz

Medina de Pomar (Burgos)

AGN, Irache, Lib. 539, 56v.

MIGUEL ASTAR RUES

B. L.

2-5-1666

Fr. Primitivo Ruiz

Huesca

AGN, Irache, Lib. 539, 56r.

DOMINGO MARTÍNEZ

B. C.

4-5-1666

Fr. Manuel Vela

Arallares (Burgos)

AGN, Irache, Lib. 539, 56r.

MARCOS DE URTASO

B. M.

5-5-1666

Fr. Juan de Valcázar

Caparroso (Pamplona)

AGN, Irache, Lib. 539, 57r.
JOSÉ GENTO

B. C.

12-5-1666

Fr. Primitivo Ruiz

Santa María del Campo (Burgos)

AGN, Irache, Lib. 539, 57r.

JUAN DE BERASTEGUI

B. C.

19-5-1666

Fr. Manuel Vela

Balmaseda (Burgos)

AGN, Irache, Lib. 539, 57r.

DOMINGO DELGADO

B. C.

25-5-1666

Fr. Juan de Valcázar

Laredo (Burgos)

AGN, Irache, Lib. 539, 57r.

JUAN DE GOYENECHE

B. A.

25-5-1666

Fr. José de Noboa

Pamplona

AGN, Irache, Lib. 539, 57r.

JERÓNIMO DE RIEZU

B. A.

25-5-1666

Fr. José de Noboa

Riezu (Pamplona)

AGN, Irache, Lib. 539, 57r.

JOSÉ DE UBIRIA

B. A.

25-5-1666

Fr. José de Noboa

Leiza (Pamplona)

AGN, Irache, Lib. 539, 57r.

MARTÍN DE URQUIOLA

B. A.

25-5-1666

Fr. José de Noboa

Bergara (Calahorra)

AGN, Irache, Lib. 539, 57r. 
JOSÉ RUBÍN

B. C.

28-5-1666

Fr. Primitivo Ruiz

Melgar de Fernamental (Burgos)

AGN, Irache, Lib. 539, 57v.

AMBROSIO RODRÍGUEZ

B. $\mathrm{M}$.

19-5-1666

Fr. Manuel Vela

Raso (Pamplona)

AGN, Irache, Lib. 539, 57v.

\section{MIGUEL DE MAULEÓN}

L. C.

4-6-1666

Reprobado

Fr. Manuel Vela, Catedrático de vísperas Arróniz (Pamplona)

AGN, Irache, Lib. 539, 57v.

MARTÍN RUIZ

B. A. / B. T.

12-6-1666

Calabazas (sic)

Fr. Juan de Valcázar

Medina de Pomar (Burgos)

AGN, Irache, Lib. 539, 57v.

\section{DIEGO ALONSO DE NÁJERA}

B. C.

19-6-1666

Fr. Manuel Vela

Palenzuela (Burgos)

AGN, Irache, Lib. 539, 58r.

JUAN DE GUINEA

B. C.

24-6-1666

Fr. Manuel Vela

Haza (Burgos)

AGN, Irache, Lib. 539, 58r.

FRANCISCO GONZÁLEZ

B. C.

26-6-1666

Reprobado y le dio el grado a modo de agra- vio el P. Abad

Rebolledo de la Torre (Burgos)

AGN, Irache, Lib. 539, 58r.

ALONSO DE LA CÁMARA

B. L.

28-6-1666

Fr. Manuel Vela

Logroño (Calahorra)

AGN, Irache, Lib. 539, 58r.

DOMINGO DE LISÓN

B. $\mathrm{M}$.

28-6-1666

Fr. Manuel Vela

Lácar (Pamplona)

AGN, Irache, Lib. 539, 58r.

GABRIEL GARCÍA

B. C.

1-7-1666

Fr. Juan de Valcázar

Santurce (Burgos)

AGN, Irache, Lib. 539, 58v.

CRISTÓBAL DE ARTIGA

B. A.

13-7-1666

Fr. Manuel Vela

Borja (Tarazona)

AGN, Irache, Lib. 539, 58v.

DOMINGO DE HERREROS

B. A. / B. T.

13-7-1666

Fr. Manuel Vela

Canales (Burgos)

AGN, Irache, Lib. 539, 58v.

FELIPE BENITO

B. C.

16-7-1666

Fr. Manuel Vela

Sotresgudo (Burgos)

AGN, Irache, Lib. 539, 58v.

DOMINGO FERNÁNDEZ

B. C. 
16-7-1666

Reprobado dos veces

Fr. Juan de Valcázar

Pedrosa (Burgos)

AGN, Irache, Lib. 539, 58v.

JOSÉ MARTÍNEZ

B. C.

23-7-1666

Fr. Manuel Vela

Boadilla (Burgos)

AGN, Irache, Lib. 539, 59r.

DOMINGO ALVARADO

B. T.

23-7-1666

Fr. Manuel Vela

Burgos

AGN, Irache, Lib. 539, 59r.

AGUSTÍN GIRÓN

B. C.

27-7-1666

Fr. Pedro Bergaño, abad

Toro

AGN, Irache, Lib. 539, 59r.

JUAN DE AMECHEGURRA

B. C.

13-8-1666

Fr. Juan de Valcázar

Balmaseda (Burgos)

AGN, Irache, Lib. 539, 59r.

FRANCISCO ORTIZ

B. A.

23-8-1666

Fr. Manuel Vela

Laredo (Burgos)

AGN, Irache, Lib. 539, 59r.

PEDRO DE HUIDOBRO

B. A. / B. T.

27-8-1666

Fr. Manuel Vela

Burgos

AGN, Irache, Lib. 539, 59r.

\section{PEDRO CHINCHÓN}

B. A. / B. T.

31-8-1666

Fr. Juan de Valcázar

Burgos

AGN, Irache, Lib. 539, 59v.

LESMES GARCÍA

B. C.

4-9-1666

Reprobado dos veces

Fr. Juan de Valcázar / Fr. Manuel Vela

Burgos

AGN, Irache, Lib. 539, 59v.

\section{MARTÍN DE AZCONA}

B. A. / B. M.

26-9-1666 / 10-3-1670

Fr. Manuel Vela / Fr. Primitivo Ruiz

Estella (Pamplona)

AGN, Irache, Lib. 539, 59v, 94r.

ANTONIO FERNÁNDEZ SOGA

B. C.

27-9-1666

Reprobado dos veces

Fr. Manuel Vela / Fr. Juan de Valcázar

Melgar (Burgos)

AGN, Irache, Lib. 539, 59v.

TOMÁS DE ESCALANTE

B. C.

9-10-1666

Fr. Juan de Valcázar

Vejoris (Burgos)

AGN, Irache, Lib. 539, 6or.

BLAS RAMOS

B. A. / B. T. / L. T. / D. T.

9-10-1666 / 13-10-1668

Fr. Juan de Valcázar / Fr. Pedro de Berga-

ño, abad

Valencia

AGN, Irache, Lib. 539, 6or, 77r.

ANTONIO DE URSÚA Y ARRECHEA

B. A.

16-10-1666 
Fr. Juan de Valcázar

Azcona (Pamplona)

Estudió en Pamplona en la S. J.

AGN, Irache, Lib. 539, 6or.

BERNABÉ ORTUÑO

L. T. / D. T.

16-10-1666

Fr. Pedro Bergaño, abad

O. Cist.

AGN, Irache, Lib. 539, 6or.

AMBROSIO DE URBANEJA

B. C.

19-10-1666

Fr. Juan de Valcázar

Grijalbo (Burgos)

AGN, Irache, Lib. 539, 6ov.

\section{MATEO MERINO}

B. A.

23-10-1666

Fr. Francisco de Quesadas, Lector en Artes

Ausejo (Calahorra)

AGN, Irache, Lib. 539, 6ov.

\section{FRANCISCO RUBÍN}

B. C.

23-10-1666

Fr. Primitivo Ruiz

La Bureba (Burgos)

AGN, Irache, Lib. 539, 6ov.

\section{MARCOS PARDO}

B. A. / B. T.

28-10-1666

Fr. Francisco de Quesadas

Hormaza (Burgos)

AGN, Irache, Lib. 539, 6ov.

FRANCISCO DE LA PEÑA

B. C.

29-10-1666

Reprobado

Fr. Juan de Valcázar

AGN, Irache, Lib. 539, 6ov.
JOSÉ GALLO

B. A. / B. T.

7-11-1666

Fr. Francisco de Quesadas

Hontanas (Burgos)

AGN, Irache, Lib. 539, 61r.

MIGUEL MAULEÓN

L. C.

11-11-1666

Fr. Pedro Bergaño, abad

Arróniz (Pamplona)

AGN, Irache, Lib. 539, 61r.

FRANCISCO JIMÉNEZ DE ARELLANO

B. M.

3-12-1666

Fr. Juan de Valcázar

Fuenmayor (Calahorra)

AGN, Irache, Lib. 539, 61r.

FRANCISCO FERNÁNDEZ DE OÑATE

B. C.

$-/ 12 / 1666$

Fr. Juan de Valcázar

Arnedo (Calahorra)

AGN, Irache, Lib. 539, 61r.

GASPAR RODRÍGUEZ

B. C.

5-12-1666

Fr. Diego de Arbeiza

Los Carabeos (Burgos)

AGN, Irache, Lib. 539, 61v.

JOSÉ RODRIGO

B. A. / B. T.

7-12-1666

Fr. Francisco de Quesadas

... (Burgos)

AGN, Irache, Lib. 539, 61v.

JUAN MARTÍNEZ DE SOTO

B. A. / B. T.

15-12-1666

Fr. Francisco de Quesadas

Regules (Burgos)

AGN, Irache, Lib. 539, 61v. 
JOSÉ GARCÍA

B. A. / B. M.

15-12-1666

Fr. Francisco de Quesadas / Fr. Diego de Arbeiza

Noviercas (Osma)

AGN, Irache, Lib. 539, 61v.

JOSÉ DE ROCAS

B. C.

19-12-1666

Fr. Juan de Valcázar

Hontoria (Burgos)

AGN, Irache, Lib. 539, 62r.

JUAN DE MARQUINA

B. C.

31-12-1666

Reprobado

Fr. Pedro García

Hontoria (Burgos)

AGN, Irache, Lib. 539, 62r.

JULIÁN DE SOBA

B. C.

31-12-1666

Fr. Diego de Arbeiza

Sámano (Burgos)

AGN, Irache, Lib. 539, 62r.

DOMINGO JIMÉNEZ

B. C.

13-1-1667

Fr. Juan de Valcázar

Sil (Burgos)

AGN, Irache, Lib. 539, 62v.

DOMINGO DE VILLANUEVA

B. T.

8-2-1667

Fr. Pedro García

Ajo (Burgos)

AGN, Irache, Lib. 539, 62v.

FRANCISCO DEL VAL

B. C.

11-2-1667

Fr. Diego de Arbeiza
Santibáñez (Burgos)

AGN, Irache, Lib. 539, $62 \mathrm{v}$.

DIEGO DE ROSALES

B. C.

11-2-1667

Reprobado dos veces

Fr. Juan de Valcázar / Fr. Pedro de Castro /

Fr. Francisco de Quesadas

Río de Losa (Burgos)

AGN, Irache, Lib. 539, $62 \mathrm{v}$.

DIEGO DE SALCEDO

B. C.

1-3-1667

Fr. Pedro García

Concejo de Zalla (Burgos)

AGN, Irache, Lib. 539, 63r.

FRANCISCO DE AYERBE

L. L.

3-3-1667

Fr. Pedro Bergaño, abad

Tauste (Zaragoza)

AGN, Irache, Lib. 539, 63r.

BARTOLOMÉ MERINO

B. C.

7-3-1667

Fr. Diego de Arbeiza

Sotrasgudo (Burgos)

AGN, Irache, Lib. 539, 63r.

DOMINGO DÍAZ

B. C.

7-3-1667

Fr. Juan de Valcázar

Cabanzón (Burgos)

AGN, Irache, Lib. 539, 63v.

ANTONIO FUICA

B. A. / B. T.

9-3-1667

Fr. Pedro García

Landa (Burgos)

AGN, Irache, Lib. 539, 63v.

ANTONIO DE LEÓN

B. C. 
14-3-1667

Reprobado

Fr. Diego de Arbeiza

Castrillo del Río Pisuerga (Burgos)

AGN, Irache, Lib. 539, 63v.

JOSÉ GARCÍA

B. C.

7-4-1667

Fr. Juan de Valcázar

Palenzuela (Burgos)

AGN, Irache, Lib. 539, 63v.

\section{JUAN GONZÁLEZ}

B. A. / B. T.

11-4-1667

Fr. Pedro García

Quintanilla San García (Burgos)

AGN, Irache, Lib. 539, 63v.

\section{JUAN SERRANO}

B. A.

18-4-1667

Fr. Francisco de Quesadas

Cañaveras (Cuenca)

AGN, Irache, Lib. 539, 64r.

JOSÉ DE PERALTA

B. A.

18-4-1667

Fr. Francisco de Quesadas

Segovia

AGN, Irache, Lib. 539, 64r.

MANUEL DE MOREDA Y CARVAJAL

B. A. / L. A.

19-4-1667

Fr. Pedro de Bergaño, abad

Viana (Calahorra)

AGN, Irache, Lib. 539, 64r.

DIEGO DE ALVARADO

B. T.

19-4-1667

Fr. Diego de Arbeiza

Palenzuela (Burgos)

AGN, Irache, Lib. 539, 64r.
JERÓNIMO DE LA HOZ

B. A. / L. A. / M. A. / B. T. / L. T. / D. T.

22-4-1667

Fr. Pedro de Bergaño, abad

O. S. B.

AGN, Irache, Lib. 539, 64r.

FRANCISCO DE ANGULO

B. C.

29-4-1667

Fr. Pedro García

Angulo (Burgos)

AGN, Irache, Lib. 539, 64v.

PEDRO ANTOÑANO

B. C.

29-4-1667

Fr. Pedro García

La Campa (Burgos)

AGN, Irache, Lib. 539, 64v.

ALONSO GARRIDO GIL DE LA SERNA

B. T.

29-4-1667

Fr. Diego de Arbeiza

La Serna (Burgos)

AGN, Irache, Lib. 539, 64V.

LESMES DEL BARRIO

B. A. / B. T.

2-5-1667 / 10-6-1667

Fr. Francisco de Quesadas

Reprobado

Salcedo (Burgos)

AGN, Irache, Lib. 539, 64v, 66r.

JUAN DE CABRO DE SEVIL

L. A. / B. T.

2-5-1667 / 3-5-1667

Fr. Pedro de Bergaño, abad / Fr. Pedro García

Escalante (Burgos)

AGN, Irache, Lib. 539, 64v.

ATANASIO DE ANCHARTE

B. A. / B. M.

6-5-1667

Fr. Francisco de Quesadas / Fr. Diego de 
Arbeiza

Sangüesa (Pamplona)

AGN, Irache, Lib. 539, 65r.

JUAN FERMÍN DE BEASOAIN

B. A. / B. M.

15-5-1667 / 29-12-1674

Fr. Francisco de Quesadas / Fr. Benito de

Loyola

Pamplona

AGN, Irache, Lib. 539, 65r, 134 r.

\section{ANDRÉS DE GUILAZ}

B. A.

15-5-1667

Fr. Francisco de Quesadas

Arróniz (Pamplona)

AGN, Irache, Lib. 539, 65r.

JOSÉ PORTAL

B. A.

15-5-1667

Fr. Francisco de Quesadas

AGN, Irache, Lib. 539, 65r.

\section{MARTÍN DE ARDANAZ}

B. A.

15-5-1667

Fr. Francisco de Quesadas

Pamplona

AGN, Irache, Lib. 539, 65r.

\section{NICOLÁS MONZÓN}

B. A.

15-5-1667

Fr. Francisco de Quesadas

Pasaje (Pamplona)

AGN, Irache, Lib. 539, 65r.

FERMÍN DE VERTIZ

B. A.

15-5-1667

Fr. Francisco de Quesadas

Pamplona

AGN, Irache, Lib. 539, 65r.

JOSÉ DE ECHAURI

B. A.
15-5-1667

Fr. Francisco de Quesadas

Pamplona

AGN, Irache, Lib. 539, 65r.

JUAN GARCÍA IRIGOREN

B. A.

15-5-1667

Fr. Francisco de Quesadas

Pamplona

AGN, Irache, Lib. 539, 65r.

FRANCISCO DÍAZ IGLESIAS

B. C.

11-5-1667

Fr. Diego de Arbeiza

Casar (Burgos)

AGN, Irache, Lib. 539, 65v.

JUAN DÍAZ

B. C.

11-5-1667

Fr. Diego de Arbeiza

Oliña (Burgos)

AGN, Irache, Lib. 539, 65v.

ALONSO GARCÍA

B. A. / B. T.

13-5-1667

Fr. Francisco de Quesadas / Fr. Juan de

Valcázar

Quintanilla San García (Burgos)

AGN, Irache, Lib. 539, 65v.

FERNANDO MUÑOZ DE VILLEGAS

B. C.

17-5-1667

Fr. Pedro García

Castillo Pedroso (Burgos)

AGN, Irache, Lib. 539, 65v.

DIEGO DE OYAGA

B. A. / B. M.

20-5-1667

Fr. Diego de Arbeiza

Estella (Pamplona)

AGN, Irache, Lib. 539, 65v. 
BARTOLOMÉ DE INSESA

B. C.

28-5-1667

Fr. Diego de Arbeiza

Caraza (Burgos)

AGN, Irache, Lib. 539, 65v.

\section{DIEGO SÁENZ}

B. M.

28-5-1667

Fr. Juan de Valcázar

Murillo (Calahorra)

AGN, Irache, Lib. 539, 66r.

JOSÉ DE OLMOS

B. C.

4-6-1667

Fr. Pedro García

Quintana de Loma (Burgos)

AGN, Irache, Lib. 539, 66r.

BALTASAR DE MEDINA

B. C.

5-6-1667

Fr. Diego de Arbeiza

Burgos

AGN, Irache, Lib. 539, 66r.

MIGUEL LADRÓN DE CEGAMA

L. C.

7-6-1667

Fr. Pedro de Bergaño, abad

Estella (Pamplona)

AGN, Irache, Lib. 539, 66r.

BERNABÉ DE BARRIDO

B. C.

14-6-1667

Fr. Pedro García

San Martín de Don (Burgos)

AGN, Irache, Lib. 539, 66v.

TOMÁS DE CÁRCAMO

B. C.

15-6-1667

Reprobado

Fr. Pedro García

San Martín de Don (Burgos)

AGN, Irache, Lib. 539, 66v.

\section{SEBASTIÁN DE CARDIÑANOS}

B. C.

16-6-1667

Fr. Diego de Arbeiza

Barcina (Burgos)

AGN, Irache, Lib. 539, 66v.

LUIS DE LOBO Y PORRES

B. C.

1-7-1667

Reprobado

Fr. Juan de Valcázar

Medina de Pomar (Burgos)

AGN, Irache, Lib. 539, 66v.

JUAN ANTONIO DE AGUINO

B. A.

8-7-1667

Fr. Juan de Valcázar

Portugalete (Burgos)

AGN, Irache, Lib. 539, 66v.

JUAN ANTONIO DE BASUALDO

B. A.

8-7-1667

Fr. Juan de Valcázar

Portugalete (Burgos)

AGN, Irache, Lib. 539, 66v.

MARTÍN DE ZUGARRONDO

B. A. / B. M.

10-7-1667

Fr. Juan de Valcázar

Puente la Reina (Pamplona)

AGN, Irache, Lib. 539, 67r.

FRANCISCO RUIZ

B. C.

19-7-1667

Fr. Diego de Arbeiza

Revilla Vallejera (Burgos)

AGN, Irache, Lib. 539, 67r.

FELIPE MARTÍNEZ

B. C.

6-8-1667

Fr. Juan de Valcázar

Castro Urdiales (Burgos)

AGN, Irache, Lib. 539, 67r. 
JOSÉ BAZÁN

L. A.

29-8-1667

Fr. Francisco de Quesadas

Cenicero (Calahorra)

AGN, Irache, Lib. 539, 67r.

JUAN BAUTISTA [MARTÍNEZ] GARIJO

B. M.

29-8-1667

Fr. Pedro García

Arnedo (Calahorra)

AGN, Irache, Lib. 539, 67r.

FRANCISCO MANRIQUE

B. A. / B. T.

7-9-1667

Fr. Francisco de Quesadas / Fr. Diego de

Arbeiza

Sotragero (Burgos)

AGN, Irache, Lib. 539, 67v.

FRANCISCO DÍAZ DE ISLA

B. A.

13-9-1667

Fr. Francisco de Quesadas

Logroño (Calahorra)

AGN, Irache, Lib. 539, 67v.

JOSÉ ÁLVAREZ

B. A.

13-9-1667

Fr. Francisco de Quesadas

Logroño (Calahorra)

AGN, Irache, Lib. 539, 67v.

JUAN BAUTISTA DE SUA

B. C.

14-9-1667

Fr. Juan de Valcázar

Coza (Burgos)

AGN, Irache, Lib. 539, 67v.

PEDRO DE AYA

B. A. / L. A. / M. A. / B. T. / L. T. / D. T.

19-9-1667

Fr. Pedro de Bergeño, abad

O. C.

AGN, Irache, Lib. 539, 67v. $\cdots$

1667

...

AGN, Irache, Lib. 539, 68rv.

PEDRO GARCÍA DE GALDEANO

D. A. / B. T. / L. T. / D. T.

20-9-1667

Fr. Pedro de Bergaño, abad

Natural y Abad de Galdeano

AGN, Irache, Lib. 539, 69r.

FRANCISCO RODRÍGUEZ OLEO

B. A. / B. T.

21-9-1667

Fr. Francisco de Quesadas

Reinosa (Burgos)

AGN, Irache, Lib. 539, 69r.

FRANCISCO CORRAL Y CHÁVARRI

B. A. / B. T.

21-9-1667

Fr. Francisco de Quesadas

Bilbao (Calahorra)

AGN, Irache, Lib. 539, 69r.

ANDRÉS DE LA PEÑA

B. C.

26-9-1667

Reprobado

Fr. Juan de Valcázar

Acedo (Burgos)

AGN, Irache, Lib. 539, 69r.

FERNANDO CAMPO

B. C.

3-10-1667

Fr. Pedro García

Castercias (Burgos)

AGN, Irache, Lib. 539, 69r.

FRANCISCO DE RADO

B. C.

7-10-1667

Reprobado

Fr. Juan de Valcázar

Castro Urdiales (Burgos)

AGN, Irache, Lib. 539, 69v. 
JUAN LÓPEZ DE LA PRADA

B. C.

12-10-1667

Fr. Pedro García

Cubo (Burgos)

AGN, Irache, Lib. 539, 69v.

JUAN MARTÍNEZ

B. C.

14-10-1667

Fr. Juan de Valcázar

Vallarta (Burgos)

AGN, Irache, Lib. 539, 69v.

JUAN RUIZ DE LA CALZADA

B. C.

14-10-1667

Fr. Diego de Arbeiza

Cubo (Burgos)

AGN, Irache, Lib. 539, 69v.

VÍCTORES ORTIZ

B. C.

21-10-1667

Fr. Pedro García

Cerezo (Burgos)

AGN, Irache, Lib. 539, 69v.

ESTEBAN ARBIZU

B. A.

21-10-1667

Fr. Francisco de Quesadas

Estella (Pamplona)

AGN, Irache, Lib. 539, 69v.

PEDRO PÉREZ DE PALACIOS

B. C.

21-10-1667

Fr. Diego de Arbeiza

Beo (Burgos)

AGN, Irache, Lib. 539, 70r.

MIGUEL DE JUDEGO

B. A. / B. T.

26-10-1667

Fr. Francisco de Quesadas

Isar (Burgos)

AGN, Irache, Lib. 539, 70r.
PEDRO DE CABRO SEVIL

B. C.

26-10-1667

Fr. Pedro García

Escalante (Burgos)

AGN, Irache, Lib. 539, 70r.

MARTÍN DEL CORRAL

B. A. / B. T.

6-11-1667

Fr. Pedro García

Baños (Burgos)

AGN, Irache, Lib. 539, 70r.

MATEO DE BUSTAMANTE

B. T.

12-11-1667

Fr. Diego de Arbeiza

San Vicente (Burgos)

AGN, Irache, Lib. 539, 70r.

FRANCISCO ANTONIO DE CEBALLOS

B. $T$.

25-11-1667

Fr. Diego de Arbeiza

C... (Burgos)

AGN, Irache, Lib. 539, 70v.

JOSÉ ANTONIO MERINO

B. A. / B. T.

2-12-1667

Fr. Pedro García

Burgos

AGN, Irache, Lib. 539, 70v.

TORIBIO RUIZ DE BARREDA

B. C.

2-12-1667

Reprobado

Fr. Diego de Arbeiza

Puerto de Santoña (Burgos)

AGN, Irache, Lib. 539, 70v.

FRANCISCO BENERO CARRILLO

B. A. / B. T. / B. C.

7-12-1667

Fr. Francisco de Quesadas / Fr. Juan de

Valcázar / Fr. Pedro García 
Cierzo (Burgos)

AGN, Irache, Lib. 539, 70v.

FRANCISCO RUIZ

B. C.

9-12-1667

Fr. Pedro García

Rebolledo de la Torre (Burgos)

AGN, Irache, Lib. 539, $70 v$.

JUAN RUIZ

B. A. / B. T.

11-4-1667 / 9-12-1667

Fr. Juan de Valcázar

Reprobado

Fr. Pedro García / Fr. Diego de Arbeiza / Fr.

Pedro García

Huidobro (Burgos)

AGN, Irache, Lib. 539, 71r, 73r.

MATEO FERNÁNDEZ Y MARÍA

B. C.

13-12-1667

Fr. Diego de Arbeiza

Montejo de San Miguel (Burgos)

AGN, Irache, Lib. 539, 71r.

\section{ANTONIO DE PALACIO}

B. C.

19-12-1667

Fr. Juan de Valcázar

Ibáñez (Burgos)

AGN, Irache, Lib. 539, 71r.

FELIPE DE LA LLANA

B. C.

21-12-1667

Fr. Pedro García

Lusa (Burgos)

AGN, Irache, Lib. 539, 71r.

\section{ANTONIO GIL}

B. C.

28-12-1667

Fr. Diego de Arbeiza

Melgar de Fernamental (Burgos)

AGN, Irache, Lib. 539, 71r.

\section{MATEO GIL}

B. C.

29-12-1667

Fr. Diego de Arbeiza

Melgar de Fernamental (Burgos)

AGN, Irache, Lib. 539, 71r.

FRANCISCO DE LAGUNO

B. C.

1-1-1668

Fr. Pedro García

Agüera (Burgos)

AGN, Irache, Lib. 539, 71v.

JUAN DE URIBE

B. C.

11-1-1668

Fr. Diego de Arbeiza

Barriga (Burgos)

AGN, Irache, Lib. 539, 71v.

PEDRO DE SOLNADO

B. C.

22-1-1668

Fr. Juan de Valcázar

Cianca (Burgos)

AGN, Irache, Lib. 539, 71v.

JUAN DE SOLNADO

B. C.

22-1-1668

Fr. Pedro García

Cianca (Burgos)

AGN, Irache, Lib. 539, $71 \mathrm{v}$.

JOSÉ GONZÁLEZ

B. A. / B. T.

10-2-1668

Fr. Diego de Arbeiza

Burgos

AGN, Irache, Lib. 539, 72r.

NICOLÁS ROJO

B. A. / B. T.

13-2-1668

Fr. Francisco de Quesadas

Reprobado

Fr. Juan de Valcázar 
Las Rebolledas (Burgos)

AGN, Irache, Lib. 539, 72r.

\section{BALTASAR CAMPILLO}

B. C.

20-2-1668 Reprobado

5-8-1668 Aprobado

Fr. Pedro García

Rioseras (Burgos)

AGN, Irache, Lib. 539, 72r, 75r.

\section{JUAN DE BARDECI}

B. C.

25-2-1668 Reprobado

1-10-1668 Aprobado

Fr. Diego de Arbeiza / Fr. Pedro García

Villalba (Burgos)

AGN, Irache, Lib. 539, 72r, 76v.

CARLOS GAONA

L. T. / D. T.

17-3-1668

Fr. Pedro García

O. S. A.

AGN, Irache, Lib. 539, 72v.

\section{PEDRO GÓMEZ DE SALAZAR}

B. T.

17-3-1668 Reprobado

14-6-1668 Aprobado

Fr. Diego de Arbeiza / Fr. Pedro García

Nograro (Burgos)

AGN, Irache, Lib. 539, 72v, 74v.

MARTÍN PÉREZ RODRÍGUEZ SEGURA

L. C. / D. C.

30-3-1668

Fr. Pedro de Bergaño, abad

Cehegín (Cartagena)

Provisor y visitador General del Arzobispa-

do de Burgos

AGN, Irache, Lib. 539, 72v.

JULIÁN PARDO

B. A. / B. T.

31-3-1668 Reprobado B. T.

13-9-1669 Aprobado

Fr. Francisco de Quesadas / Fr. Pedro Gar- cía // Fr. Manuel Vela

Palacios de Benahiel (Burgos)

AGN, Irache, Lib. 539, 72v, 88r.

PEDRO FERNÁNDEZ DE IMAÑA

B. C.

8-4-1668

Fr. Diego de Arbeiza

Montejo de San Miguel (Burgos)

AGN, Irache, Lib. 539, 73r.

ANTONIO LÓPEZ TELLO

B. A. / B. T.

26-4-1668

Fr. Francisco de Quesadas

Fr. Juan de Valcázar

Sisamón (Burgos)

AGN, Irache, Lib. 539, 73r.

\section{PEDRO LABAIRU}

L. A.

29-4-1668

Fr. Pedro de Bergaño, abad

Isaba (Pamplona)

AGN, Irache, Lib. 539, 73r.

ANTONIO GARCÍA

B. A. / B. T.

30-4-1668

Fr. Francisco de Quesadas / Fr. Pedro Gar-

cía

Quintanasolmo (Burgos)

AGN, Irache, Lib. 539, 73v.

JUAN DE LAS HERAS

B. A. / B. T.

1-5-1668

Fr. Francisco de Quesadas / Fr. Diego de

Arbeiza

Santa Inés (Burgos)

AGN, Irache, Lib. 539, 73v.

ANTONIO GARCÍA

B. T.

2-5-1668

Fr. Juan de Valcázar

Grañón (Calahorra)

AGN, Irache, Lib. 539, 73v. 
JOSÉ BOZALBE

B. M.

5-5-1668

Fr. Pedro García / Dr. Diego de Morras

Tarazona

AGN, Irache, Lib. 539, 73v.

MIGUEL RAMÓN ZAPATER

B. A. / B. T. / L. T. / D. T.

7-5-1668

Fr. Pedro de Bergaño, abad

O. Cist.

AGN, Irache, Lib. 539, 74r.

ANTONIO DE VELASCO

B. A. / B. T.

14-5-1668

Fr. Francisco de Quesadas

Suesa (Burgos)

AGN, Irache, Lib. 539, 74r.

ISIDRO IBÁÑNZ

B. C.

20-5-1668

Fr. Pedro García

Arenillas del río Pisuerga (Burgos)

AGN, Irache, Lib. 539, 74r.

DIEGO DE QUINCOCES

B. A. / B. T.

5-6-1668

Fr. Diego de Arbeiza

Bobeda (Burgos)

AGN, Irache, Lib. 539, 74r.

ESTEBAN DE ARBIZU

B. $\mathrm{M}$.

7-6-1668

Fr. Pedro García

Estella (Pamplona)

AGN, Irache, Lib. 539, 74r.

JULIO DE DEHESO

B. C.

18-6-1668

Fr. Diego de Arbeiza

Ranedo (Burgos)

AGN, Irache, Lib. 539, 74v.
JUAN DEL GUEMBE

B. M.

6-7-1668

Fr. Pedro García

Muez (Burgos)

AGN, Irache, Lib. 539, 74v.

AGUSTÍN PÉREZ DE LA GORMA

B. A. / B. T.

10-7-1668 / 21-7-1668

Fr. Francisco de Quesadas / Fr. Pedro García

Guriezo (Burgos)

AGN, Irache, Lib. 539, 74v.

JUAN GIL DE QUINTANA

B. A. / B. T.

10-7-1668 / 21-7-1668

Fr. Francisco de Quesadas / Fr. Pedro Gar-

cía

Islares (Burgos)

AGN, Irache, Lib. 539, 74V.

FRANCISCO DE PADILLA

B. C.

11-7-1668

Fr. Pedro García

Padilla de Abajo (Burgos)

AGN, Irache, Lib. 539, 74v.

SIMÓN GONZÁLEZ

B. C.

15-7-1668

Fr. Pedro García

Padilla de Abajo (Burgos)

AGN, Irache, Lib. 539, 74v.

GASPAR GIL

B. A. / B. T.

1-8-1668

Fr. Francisco de Quesadas / Fr. Pedro García

Villasandino (Burgos)

AGN, Irache, Lib. 539, 75r.

DOMINGO PÉREZ DE ATOCHA

B. A. / L. A.

8-8-1668 
Fr. Pedro de Bergaño, abad Garde (Pamplona)

AGN, Irache, Lib. 539, 75v.

GABRIEL DE MATAPAJA

B. C.

13-8-1668

Fr. Pedro García

Matapaja (Burgos)

AGN, Irache, Lib. 539, 75v.

LUIS DE TOBA Y PORRES

B. C.

15-8-1668

Fr. Diego de Arbeiza

Medina de Pomar (Burgos)

AGN, Irache, Lib. 539, 75v.

PEDRO DE ALMAZÁN Y LIZARZA

B. A.

17-8-1668

Fr. Francisco de Quesadas

Casconza (Tarazona)

AGN, Irache, Lib. 539, 75v.

JOSÉ GIMÉNEZ

B. A. / L. A.

5-9-1668

Fr. Pedro de Bergaño, abad

Cervera (Calahorra)

AGN, Irache, Lib. 539, 75v.

DIEGO DE HUÉRCANOS Y ALBEAR

B. C.

5-9-1668

Fr. Pedro García

Navarrete (Calahorra)

AGN, Irache, Lib. 539, 76r.

MANUEL DE CARRIEDO

B. C.

11-9-1668

Fr. Pedro García

Quintanilla de San García (Burgos)

AGN, Irache, Lib. 539, 76r.

JUAN DURO DEL SAZ

B. C.
25-9-1668

Fr. Diego de Arbeiza

Nalda (Calahorra)

AGN, Irache, Lib. 539, 76r.

FELIPE AGUSTÍN DE BÁRCENA

B. C.

29-9-1668

Fr. Pedro García

Villadiego (Burgos)

AGN, Irache, Lib. 539, 76r.

BERNABÉ RODRÍGUEZ

B. A.

29-9-1668

Fr. Pedro García

Medrano (Calahorra)

AGN, Irache, Lib. 539, 76r.

JOSÉ DE LOSADA

B. A.

2-10-1668

Fr. Francisco de Quesadas

Calahorra

AGN, Irache, Lib. 539, 76v.

JUAN GÓMEZ

B. A. / B. T.

2-10-1668

Fr. Francisco de Quesadas / Fr. Diego de

Arbeiza

La Piedra (Burgos)

AGN, Irache, Lib. 539, 76v.

BERNARDO DE LA CUESTA

B. A. / B. T.

2-10-1668

Fr. Francisco de Quesadas

Tobar (Burgos)

AGN, Irache, Lib. 539, 76v.

JUAN DE BADILLO

B. C.

4-10-1668

Fr. Francisco de Quesadas

San Martín (Burgos)

AGN, Irache, Lib. 539, 76v. 


\section{ANTONIO RODRÍGUEZ}

B. A. / B. T.

7-10-1668 / 7-3-1670

Fr. Francisco de Quesadas

Belorado (Burgos)

AGN, Irache, Lib. 539, 76v, 93v.

\section{JUAN DE LA PEÑA}

B. A.

8-10-1668

Fr. Francisco de Quesadas

Padilla de Arriba (Burgos)

AGN, Irache, Lib. 539, 76v.

JOSÉ ABAD

B. A. / B. T.

10-10-1668

Fr. Francisco de Quesadas

Villadiego (Burgos)

AGN, Irache, Lib. 539, 77r.

JOSÉ DE RIAÑO

B. A. / B. T.

10-10-1668

Fr. Francisco de Quesadas

Villadiego (Burgos)

AGN, Irache, Lib. 539, 77r.

MARTÍN DE PINEDO

B. A.

10-10-1668

Fr. Francisco de Quesadas

Santa Gadea (Burgos)

AGN, Irache, Lib. 539, 77r.

JOSÉ FERNÁNDEZ

B. A. / B. T.

18-10-1668 / 25-4-1669

Fr. Francisco de Quesadas / Fr. Primitivo

Ruiz

Medina de Pomar (Burgos)

AGN, Irache, Lib. 539, 77r, 83r.

\section{ANTONIO MORTERUELO}

B. C.

25-10-1668

Fr. Pedro García

Islares (Burgos)

AGN, Irache, Lib. 539, 77r.

\section{ANTONIO GÓMEZ}

B. C.

25-10-1668

Reprobado dos veces

Fr. Diego de Arbeiza / Fr. Juan de Valcázar

/ Fr. Pedro García

Liendo (Burgos)

AGN, Irache, Lib. 539, 77v.

JUAN DE ARNUERO Y CASTILLO

B. A. / B. T.

29-10-1668

Fr. Francisco de Quesadas / Fr. Juan de

Valcázar

Castillo (Burgos)

AGN, Irache, Lib. 539, 77v.

DIEGO DE BRONDO Y ENRÍQUEZ

B. C.

10-11-1668

Fr. Pedro García

Logroño (Calahorra)

AGN, Irache, Lib. 539, 77v.

TOMÁS RUIZ DE QUINTANA

B. A. / B. T.

19-11-1668

Fr. Diego de Arbeiza

Cebolleros (Burgos)

AGN, Irache, Lib. 539, 77v.

PEDRO RUIZ DÍAZ

B. A. / L. A.

20-11-1668

Fr. Pedro de Bergaño, abad

Galilea (Calahorra)

AGN, Irache, Lib. 539, 77v.

BASILIO LOZANO

B. C.

26-11-1668

Fr. Juan de Valcázar

Tórtoles (Burgos)

AGN, Irache, Lib. 539, 78r.

ANTONIO CALDERÓN

B. C.

27-11-1668 
Fr. Pedro García

Poza (Burgos)

AGN, Irache, Lib. 539, 78r.

MARCOS ALONSO

B. A. / B. T.

3-12-1668

Fr. Diego de Arbeiza

Poza (Burgos)

AGN, Irache, Lib. 539, 78r.

LORENZO MIANA

B. A./ B. T.

3-12-1668

Fr. Diego de Arbeiza / Fr. Pedro García

Sasamón (Burgos)

AGN, Irache, Lib. 539, 78r.

\section{JERÓNIMO DE VILLEGAS}

B. A. / B. T.

3-12-1668

Fr. Diego de Arbeiza

Sasamón (Burgos)

AGN, Irache, Lib. 539, 78r.

\section{SANTIAGO ORTEGA}

B. C.

4-12-1668

Fr. Diego de Arbeiza

Villasandino (Burgos)

AGN, Irache, Lib. 539, 78v.

FERNANDO GONZÁLEZ HURTADO

B. A. / B. T.

4-12-1668

Reprobado de B. T.

Fr. Francisco de Quesadas / Fr. Juan de

Valcázar

Villasandino (Burgos)

AGN, Irache, Lib. 539, 78v.

JOSÉ GARCÍA

B. C.

4-12-1668

Fr. Pedro García

Villasandino (Burgos)

AGN, Irache, Lib. 539, 78v.

\section{ANDRÉS SAINZ DE VILLEGAS}

B. C.

6-12-1668

Fr. Diego de Arbeiza

Llano (Burgos)

AGN, Irache, Lib. 539, 78v.

GABRIEL DE BOCOS

B. C.

9-12-1668 / 2-1-1669

Reprobado

Fr. Juan de Valcázar / Fr. Pedro García

Villamediana (Burgos)

AGN, Irache, Lib. 539, 78v-79r.

JUAN GÓMEZ DE BUSTAMANTE

B. C.

9-12-1668

Fr. Pedro García

Villamediana (Burgos)

AGN, Irache, Lib. 539, 79r.

PEDRO DE URRUTIA

B. C.

12-12-1668

Fr. Diego de Arbeiza

Bozoó (Burgos)

AGN, Irache, Lib. 539, 79r.

MARTÍN FADRIQUE DE ERRAN

B. C.

12-12-1668

Fr. Diego de Arbeiza

Miranda de Ebro (Burgos)

AGN, Irache, Lib. 539, 79r.

JUAN DE SOLAS

B. C.

14-12-1668

Reprobado

Fr. Pedro García

Masa (Burgos)

AGN, Irache, Lib. 539, 79r.

MARCOS RODRÍGUEZ

B. A.

5-1-1669

Reprobado 
Fr. Francisco de Quesadas Ormajas (Burgos)

AGN, Irache, Lib. 539, 79r.

JOSÉ DE PEDROSA

B. C.

5-1-1669

Fr. Juan de Valcázar

Ormazos (Burgos)

AGN, Irache, Lib. 539, 79v.

DOMINGO MARTÍNEZ

B. C.

11-1-1669

Fr. Pedro García

Sigüenza (Burgos)

AGN, Irache, Lib. 539, 79v.

MIGUEL DE LABARI

B. A. / L. A.

9-1-1669

Fr. Pedro de Bergaño, abad

Navascués (Pamplona)

AGN, Irache, Lib. 539, 79v.

FRANCISCO VILLEGAS

B. C.

3-2-1669

Fr. Primitivo Ruiz, regente

Melgar de Fernamental (Burgos)

AGN, Irache, Lib. 539, 79v.

FRANCISCO DE BILBAO

B. C.

5-2-1669

Fr. Pedro García

San Llorente (Burgos)

AGN, Irache, Lib. 539, 79v.

JOSÉ DE LA VEGA

B. C.

5-2-1669

Fr. Primitivo Ruiz

Melgar de Fernamental (Burgos)

AGN, Irache, Lib. 539, 8or.

JUAN CALLEJAS

B. C.
9-2-1669

Fr. Pedro García

Melgar de Fernamental (Burgos)

AGN, Irache, Lib. 539, 8or.

JERÓNIMO ZURITA

B. C.

9-2-1669

Fr. Pedro García

Melgar de Fernamental (Burgos)

AGN, Irache, Lib. 539, 8or.

AGUSTÍN DE TELLERÍA

B. T.

11-2-1669

Fr. Pedro García

San Sebastián (Pamplona)

AGN, Irache, Lib. 539, 8or.

JOSÉ DE REDO

B. C.

5-3-1669

Fr. Primitivo Ruiz

Burcios (Burgos)

AGN, Irache, Lib. 539, $80 v$.

JERÓNIMO DE ESTRADA

B. C.

8-3-1669

Fr. Primitivo Ruiz

Salinas de Añana (Burgos)

AGN, Irache, Lib. 539, $80 v$.

LAMBERTO DE ALÓS

B. C. / L. C. / D. C.

15-3-1669 / 20-6-1675

Fr. Pedro García / Fr. Juan Sánchez, abad

Berbegal (Lérida)

AGN, Irache, Lib. 539, 80v, $137 \mathrm{r}$.

ANTONIO ZAMORANO

B. C.

18-3-1669

Fr. Manuel de Paredes

Balbases (Burgos)

AGN, Irache, Lib. 539, $80 v$.

ANTONIO DE LAS CASAS

... 
19-3-1669

Fr. Primitivo Ruiz

Concejo de Galdames (Burgos)

AGN, Irache, Lib. 539, 80v.

\section{ALFONSO GÓMEZ}

B. A. / B. M.

22-3-1669

Fr. Francisco de Quesadas / Fr. Manuel de

Paredes

Sestrica (Tarazona)

AGN, Irache, Lib. 539, 81r.

JUAN ARNÁIZ

B. A. / B. T.

26-3-1669

Fr. Francisco de Quesadas

Rioseras (Burgos)

AGN, Irache, Lib. 539, 81r.

LORENZO DE MATA

B. A. / B. T.

26-3-1669

Fr. Francisco de Quesadas

Olmos (Burgos)

AGN, Irache, Lib. 539, 81r.

PEDRO BERNET

B. T. / L. T. / D. T.

26-3-1669

Fr. Pedro de Bergaño, abad

O. S. B.

Prior del Convento de San Juan de la Peña

AGN, Irache, Lib. 539, 81r.

\section{MIGUEL BONET}

L. C. / D. C.

1-4-1669

Fr. Pedro de Bergaño, abad

Jaca

AGN, Irache, Lib. 539, 81r.

MARCOS JIMÉNEZ DE CENARBE

B. C. / L. L. / D. L.

2-4-1669

Fr. Pedro de Bergaño, abad

Cenarbe (Jaca)

AGN, Irache, Lib. 539, 81v.
FRANCISCO SAMITIER

L. M. / D. M.

2-4-1669

Fr. Pedro de Bergaño, abad

Bailo (Jaca)

AGN, Irache, Lib. 539, 81v.

JOSÉ DE ARBIZU

B. A.

3-4-1669

Fr. Francisco de Quesadas

Lodosa (Pamplona)

AGN, Irache, Lib. 539, 81v.

BENITO DE ARO

B. A.

3-4-1669

Fr. Francisco de Quesadas

Estella (Pamplona)

AGN, Irache, Lib. 539, 81v.

BONIFACIO DE LAÍN

L. C. / D. C.

3-4-1669

Fr. Pedro de Bergaño, abad

Jaca

AGN, Irache, Lib. 539, 81v.

JUAN DE FRÍAS

B. A. / B. T.

6-4-1669

Fr. Francisco de Quesadas / Fr. Manuel de

Paredes

Balbases (Burgos)

AGN, Irache, Lib. 539, 82r.

DIEGO DE ARCE

B. C.

6-4-1669

Fr. Manuel de Paredes

Reinosa (Burgos)

AGN, Irache, Lib. 539, 82r.

MIGUEL GALÁN

B. A.

8-4-1669

Fr. Francisco de Quesadas

Aranda (Zaragoza)

AGN, Irache, Lib. 539, 82r. 
JUAN DE ACINAS MARAÑÓN

B. A. / B. T.

8-4-1669

Fr. Francisco de Quesadas / Fr. Manuel de

Paredes

Sto. Domingo de Silos (Burgos)

AGN, Irache, Lib. 539, 82r.

JUAN MARTÍNEZ

B. A.

12-4-1669

Fr. Francisco de Quesadas

Redecilla del Camino (Calahorra)

AGN, Irache, Lib. 539, 82r.

PEDRO DE URÍZAR

B. A.

13-4-1669

Fr. Francisco de Quesadas

Torralba (Calahorra)

AGN, Irache, Lib. 539, 82r.

FERNANDO GONZÁLEZ

B. C.

20-4-1669

Fr. Pedro García

Villasandino (Burgos)

AGN, Irache, Lib. 539, 82v.

ROQUE SANTOS DE SAN PEDRO

L. C. / D. C.

20-4-1669

Fr. Pedro de Bergaño, Abad de Irache y

Maestro General de O. S. B.

Santervás (León)

Provisor y Vicario General de Pamplona

AGN, Irache, Lib. 539, 82v.

GREGORIO DE MENDIUNE

L. C. / D. C.

22-4-1669

Fr. Pedro de Bergaño, abad

Nalda (Calahorra)

AGN, Irache, Lib. 539, 82v.

ANDRÉS BOL PÉREZ

B. A. / B. T.

23-4-1669
Fr. Pedro García

Valles (Burgos)

AGN, Irache, Lib. 539, $82 \mathrm{v}$.

MANUEL DE ASITORES

B. C.

23-4-1669

Fr. Pedro García

Palenzuela (Burgos)

AGN, Irache, Lib. 539, 82v.

JUAN DE TOLEDO

B. C. / L. C.

26-4-1669

Fr. Pedro García / Fr. Pedro de Bergaño, abad

Nalda (Calahorra)

AGN, Irache, Lib. 539, 83r.

MARTÍN DE RIVERA

B. A. / B. T.

27-4-1669

Fr. Primitivo Ruiz

Espinosa del Monte (Burgos)

AGN, Irache, Lib. 539, 83r.

ANTONIO FRANCISCO DE OCHOGAVÍA

B. A. / B. T.

27-4-1669

Fr. Pedro García

Nalda (Calahorra)

AGN, Irache, Lib. 539, 83r.

BENITO SALGADO

B. A. / B. T.

28-8-1669

Fr. Francisco de Quesadas / Fr. Pedro García

Celanova (Orense)

AGN, Irache, Lib. 539, 83r.

ANDRÉS BENITO

B. A. / B. T.

3-5-1669

Fr. Benito Iglesias, prior

Sasamón (Burgos)

AGN, Irache, Lib. 539, 83r. 
JUAN DE SANTA MARÍA

B. C.

5-5-1669 Reprobado

21-11-1669 Aprobado

Fr. Benito Iglesias / Fr. Manuel Vela

Ameyugo (Burgos)

AGN, Irache, Lib. 539, 83v, 92r.

MIGUEL DE ILLARREGUI

B. A.

13-5-1669

Fr. Francisco de Quesadas

Pamplona

AGN, Irache, Lib. 539, 83v.

MARTÍN DE URRUTIA

B. A.

13-5-1669

Fr. Francisco de Quesadas

Aduain (Pamplona)

AGN, Irache, Lib. 539, 83v.

JUAN DE ISTÚRIZ

B. A.

13-5-1669

Fr. Francisco de Quesadas

Pamplona

AGN, Irache, Lib. 539, 83v.

JUAN DE LIANCE

B. A.

13-5-1669

Fr. Francisco de Quesadas

Pamplona

AGN, Irache, Lib. 539, 83v.

BLAS GUINDA

B. A.

13-5-1669

Fr. Francisco de Quesadas

Esparza (Pamplona)

AGN, Irache, Lib. 539, 83v.

JOSÉ DE VALDECILLOS

B. A.

13-5-1669

Fr. Francisco de Quesadas

Pamplona

AGN, Irache, Lib. 539, 83v.
JUAN MIGUEL DE AZPÍROZ

B. A.

13-5-1669

Fr. Francisco de Quesadas

Pamplona

AGN, Irache, Lib. 539, 83v.

ROMÁN DE BACÁICOA

B. A.

13-5-1669

Fr. Francisco de Quesadas

Arzoz (Pamplona)

AGN, Irache, Lib. 539, 83v.

GREGORIO QUÍLEZ

B. A.

13-5-1669

Fr. Francisco de Quesadas

Sero (Pamplona)

AGN, Irache, Lib. 539, 83v.

BLAS FERNÁNDEZ

B. A.

13-5-1669

Fr. Francisco de Quesadas

Ausejo (Calahorra)

AGN, Irache, Lib. 539, 83v.

FRANCISCO LORENZ

B. A.

13-5-1669

Fr. Francisco de Quesadas

Pamplona

AGN, Irache, Lib. 539, 83v.

CRISTÓBAL DE CASANUEVA

B. A.

13-5-1669

Fr. Francisco de Quesadas

Fuenterrabía (Pamplona)

AGN, Irache, Lib. 539, 83v.

JUAN DE HONDARZA

B. A.

13-5-1669

Fr. Francisco de Quesadas

San Sebastián (Pamplona)

AGN, Irache, Lib. 539, 83v. 
JUAN DOMÍNGUEZ DE VIDAURRETA

B. A.

13-5-1669

Fr. Francisco de Quesadas

Uterga (Pamplona)

AGN, Irache, Lib. 539, 83v.

JACINTO DE SAZONENA

B. A.

13-5-1669

Fr. Francisco de Quesadas

San Sebastián (Pamplona)

AGN, Irache, Lib. 539, 83v.

JOAQUÍN DE ILARREGUI

B. A.

13-5-1669

Fr. Francisco de Quesadas

Pamplona

AGN, Irache, Lib. 539, 83v.

PEDRO DE ESTARRIAGA

B. A.

13-5-1669

Fr. Francisco de Quesadas

Peralta (Pamplona)

AGN, Irache, Lib. 539, 83v.

\section{MANUEL MARTÍNEZ}

B. A.

13-5-1669

Fr. Francisco de Quesadas

Pamplona

AGN, Irache, Lib. 539, 83v.

MIGUEL DE GOÑI

B. A.

13-5-1669

Fr. Francisco de Quesadas

Peralta (Pamplona)

AGN, Irache, Lib. 539, 83v.

NICOLÁS DE JANIZ

B. A.

13-5-1669

Fr. Francisco de Quesadas

Los Arcos (Pamplona)

AGN, Irache, Lib. 539, 83v.

\section{JUAN DE VIDAJÚN}

L. A.

13-5-1669

Fr. Francisco de Quesadas

Pamplona

AGN, Irache, Lib. 539, 83v.

PEDRO GARCÍA DE GALDEANO

B. A.

13-5-1669

Fr. Francisco de Quesadas

Galdeano (Pamplona)

AGN, Irache, Lib. 539, 83v.

ANDRÉS MARTÍNEZ Y ORDÓNEZ

B. A. / B. T.

18-5-1669

Fr. Pedro García

Pampliega (Burgos)

AGN, Irache, Lib. 539, 83v.

FRANCISCO ANTONIO BALTANÁS

B. T. / L. T.

20-5-1669

Fr. Manuel de Paredes

Nájera (Calahorra)

AGN, Irache, Lib. 539, 84r.

PEDRO GONZÁLEZ

B. C.

23-5-1669

Fr. Manuel de Paredes

Quintana Ortuña (Burgos)

AGN, Irache, Lib. 539, 84r.

JUAN BARCEDO Y VELASCO

L. C. / D. C.

31-5-1669

Fr. Manuel de Paredes

Suesa (Burgos)

AGN, Irache, Lib. 539, 84r.

ANDRÉS DE OCHOA

B. C.

31-5-1669

Fr. Pedro García

Bergüenda (Burgos)

AGN, Irache, Lib. 539, 84r. 
DIEGO DE LA CÁMARA

B. T.

1-6-1669

Fr. Pedro García

Guriezo (Burgos)

AGN, Irache, Lib. 539, 84r.

ANDRÉS ORTIZ DEL VALLE

B. C.

4-6-1669

Fr. Pedro García

Guriezo (Burgos)

AGN, Irache, Lib. 539, 84v.

JUAN ANTONIO DEL HIGUERO

B. T.

5-6-1669

Fr. Pedro García

Portugalete (Burgos)

AGN, Irache, Lib. 539, 84v.

LESMES PÉREZ

B. A. / B. T. / D. T.

10-6-1669

Fr. Andrés de la Moneda, Abad de Irache y

Maestro General O. S. B.

O. S. B.

Predicador

AGN, Irache, Lib. 539, 84v.

\section{BENITO DE IGLESIAS}

B. A. / B. T. / L. T. / D. T.

10-6-1669

Fr. Andrés de la Moneda, Maestro General

O. S. B. y Abad de Irache

O.S. B.

Prior de Irache

AGN, Irache, Lib. 539, 84v.

PEDRO GARCÍA

B. A. / B. T. / L. T. / D. T.

10-6-1669

Fr. Andrés de la Moneda, Maestro General

O. S. B. y Abad de Irache

O. S. B.

Lector de Teología de Irache

AGN, Irache, Lib. 539, 84v.
MANUEL DE PAREDES

B. A. / B. T. / B. T. / D. T.

10-6-1669

Fr. Andrés de la Moneda, Maestro General

O. S. B. y Abad de Irache

O. S. B.

Lector de Teología de Irache

AGN, Irache, Lib. 539, 84v.

JUAN DE SANTACRUZ

B. T.

15-6-1669

Fr. Pedro García

Guriezo (Burgos)

AGN, Irache, Lib. 539, 84v.

MATÍAS DE MARIGIL

B. C.

18-6-1669 / 19-7-1669

Reprobado

Fr. Pedro García / Fr. Pedro García

Melgar de Fernamental (Burgos)

AGN, Irache, Lib. 539, 85r.

\section{PEDRO SANCHA}

B. C.

7-7-1669

Fr. Pedro García

Belorado (Burgos)

AGN, Irache, Lib. 539, 85r.

LUCAS DE ALBARO

B. C.

9-7-1669

Fr. Pedro García

Grisalba (Burgos)

AGN, Irache, Lib. 539, 85r.

DIEGO MIRANDA Y RIVERA

L. L. / D. L.

13-7-1669

Fr. Andrés de la Moneda, General O. S. B.,

Abad y Rector

Jaca

AGN, Irache, Lib. 539, 85r.

JUAN DEL POZO Y CASTILLO

B. T. 
25-7-1669

Fr. Pedro García

San... (Burgos)

AGN, Irache, Lib. 539, 85v.

JOSÉ LÓPEZ DE URBINA

B. A. / B. T.

25-7-1669

Fr. Pedro García

Altable (Burgos)

AGN, Irache, Lib. 539, 85v.

JERÓNIMO NEGRETE

B. C.

27-7-1669

Fr. Pedro García

Valle de Varranza (Burgos)

AGN, Irache, Lib. 539, 85v.

ANTONIO JUÁREZ

B. C.

3-8-1669

Fr. Pedro García

Grijalba (Burgos)

AGN, Irache, Lib. 539, 86r.

\section{MARCELO DOMÍNGUEZ}

B. A. / B. T.

3-8-1669 Reprobado B. T.

13-10-1669 Aprobado

Fr. Pedro García / Fr. Regente

Fresno de Rodilla (Burgos)

AGN, Irache, Lib. 539, 86r, $90 v$.

\section{LUIS DE HUIDOBRO}

B. C.

20-8-1669

Fr. Manuel Vela

Poza (Burgos)

AGN, Irache, Lib. 539, 86v.

JOSÉ CALDERÓN DEL CASTILLO

B. C.

20-8-1669

Fr. Manuel Vela

Poza (Burgos)

AGN, Irache, Lib. 539, 86v.

\section{MANUEL PRIETO}

B. C.

25-8-1669

Fr. Regente

Herrera de Valdecañas (Burgos)

AGN, Irache, Lib. 539, 86v.

JOSÉ GIL

B. A.

27-8-1669

Fr. Pedro García

O. de M.

Vera (Tarazona)

AGN, Irache, Lib. 539, 87r.

JOSÉ DE AVENDAÑO

B. A. / B. T.

2-9-1669

Fr. Pedro García

Villamayor de Treviño (Burgos)

AGN, Irache, Lib. 539, 87r.

TOMÁS MADRAZO ESCALERA

B. C.

5-9-1669 / 23-9-1669

Reprobado

Fr. Regente

Espinosa de los Monteros (Burgos)

AGN, Irache, Lib. 539, 87v.

PEDRO REVUELTA DE SOLÓRZANO

B. C.

6-9-1669

Fr. Manuel Vela

Praves (Burgos)

AGN, Irache, Lib. 539, 87v.

FRANCISCO DE LA FUENTE

B. A. / B. T.

6-9-1669 Reprobado

25-1-1670 Aprobado

Fr. Manuel Vela

Guriezo (Burgos)

AGN, Irache, Lib. 539, 87v, 92v.

BERNARDO GARCÍA DE ANGULO

B. C.

12-9-1669 
Fr. Manuel Vela

Nalda (Calahorra)

AGN, Irache, Lib. 539, 88r.

ANTONIO DE HEREDIA

B. A. / B. T. / L. T. / D. T.

15-9-1669

Fr. Andrés de la Moneda, Abad y Rector

O. S. B.

General de la Orden

AGN, Irache, Lib. 539, 88r.

JOSÉ DE ALARCOS

B. A. / B. T. / L. T. / D. T.

15-9-1669

Fr. Antonio de Heredia, General O. S. B. O. S. B.

Abad de San Millán de la Cogolla

AGN, Irache, Lib. 539, 88v.

\section{ANTONIO BERGADO}

B. C.

18-9-1669

Fr. Primitivo Ruiz

Arnedo (Calahorra)

Estudiante en Alcalá

AGN, Irache, Lib. 539, 88v.

JUAN DÍAZ

B. A. / B. T.

19-9-1669

Fr. Pedro García

Sasamón (Burgos)

AGN, Irache, Lib. 539, 89r.

\section{LUCAS DE IRUJO}

B. A.

25-9-1669

Fr. Regente

Estella (Pamplona)

AGN, Irache, Lib. 539, 89r.

JUAN TRIBALDOS

B. A. / B. T. / L. T. / D. T.

25-9-1669

Fr. Andrés de la Moneda, Abad y Rector

O. S. B.

AGN, Irache, Lib. 539, 89r.

\section{PABLO ARNÁEZ}

B. C.

29-9-1669

Fr. Pedro García

Villaveta. Abadía de Covarrubias

AGN, Irache, Lib. 539, 89v.

DOMINGO DE ZAMORA

B. A. / B. T.

2-10-1669

Fr. Manuel Vela

Sto. Domingo de la Calzada (Calahorra)

AGN, Irache, Lib. 539, 89v.

DOMINGO DE ZAMACONA

B. A. / B. T.

2-10-1669 / 24-11-1669

Fr. Manuel Vela / Fr. Benito de Loyola

Villa de Castro (Burgos)

AGN, Irache, Lib. 539, 89v, 92r.

PEDRO DE LAS HERAS

B. C.

3-10-1669

Fr. Manuel Vela

Barbadillo del Mercado (Burgos)

AGN, Irache, Lib. 539, 89v.

PEDRO DOSAL MATAZ

B. C.

6-10-1669

Fr. Regente

Sobrelapeña (Burgos)

AGN, Irache, Lib. 539, 9or.

\section{SANTIAGO ARROYO}

B. C.

8-10-1669

Fr. Pedro García

Talamillo (Burgos)

AGN, Irache, Lib. 539, 9or.

\section{BERNARDO RUIZ}

B. A. / B. T.

9-10-1669

Fr. Manuel Vela

Aguilar de Campo (Burgos)

AGN, Irache, Lib. 539, 90 . 


\section{JACINTO MARAÑÓN}

B. A. / B. T.

13-10-1669

Fr. Regente

Barbadillo del Mercado (Burgos)

AGN, Irache, Lib. 539, 90 .

FRANCISCO CURIEL

B. C.

13-10-1669

Fr. Regente

Villadiego (Burgos)

AGN, Irache, Lib. 539, $90 v$.

JUAN SANTAGADEA COVARRUBIAS

B. T.

14-10-1669

Fr. Pedro García

Salas de los Infantes (Burgos)

AGN, Irache, Lib. 539, 90v.

JUAN CARRILLO

B. A. / B. T.

16-10-1669

Fr. Manuel Vela

Pedrosa del río Urbel (Burgos)

AGN, Irache, Lib. 539, 90v.

MARCO GONZÁLEZ DE ARCE

B. A. / B. T.

17-10-1669

Fr. Manuel Vela

Santibáñez (Burgos)

AGN, Irache, Lib. 539, $90 v$.

PEDRO MARAÑÓN

B. A. / B. T.

19-10-1669

Fr. Alonso Verdesoto

Barbadillo del Mercado (Burgos)

AGN, Irache, Lib. 539, 91r.

SEBASTIÁN DE MANSILLA

B. C.

21-10-1669

Fr. Pedro García

Pedrosa del río Urbel (Burgos)

AGN, Irache, Lib. 539, 91r.

\section{DIEGO GONZÁLEZ}

B. C.

25-10-1669

Fr. Regente

Melgar de Fernamental (Burgos)

AGN, Irache, Lib. 539, 91r.

JUAN DE LARA

B. C.

26-10-1669

Fr. Regente

Bellari (Burgos)

AGN, Irache, Lib. 539, 91r.

SEBASTIÁN RUIZ DE QUEVEDO

B. C.

27-10-1669

Fr. Manuel Vela

Rosio (Burgos)

AGN, Irache, Lib. 539, 91r.

PEDRO DE MIER Y TERÁN

B. C.

30-10-1669 / 14-11-1669

Reprobado

Fr. Primitivo Ruiz

Reprobado

Fr. Vela / Fr. Novoa

Adrada (Burgos)

AGN, Irache, Lib. 539, 91v.

ANDRÉS GARCÍA MALTRANILLO

B. C.

3-11-1669

Fr. Manuel Vela

Pancorbo (Burgos)

AGN, Irache, Lib. 539, 91v.

PEDRO FERNÁNDEZ DEL OLMO

B. C.

7-11-1669

Fr. Regente

Canduela (Burgos)

AGN, Irache, Lib. 539, 91v.

JUAN ANTONIO BASUALDO

B. T.

11-11-1669 
Fr. Manuel Vela

Portugalete (Burgos)

AGN, Irache, Lib. 539, 91v.

FRANCISCO GARCÍA FRANCO

B. A. / B. T.

16-11-1669

Fr. Alonso Verdesoto

Villanueva de P... (Burgos)

AGN, Irache, Lib. 539, 91v.

MANUEL FERNÁNDEZ

B. A. / B. T.

21-11-1669

Fr. Alonso Verdesoto

Ubierna (Burgos)

AGN, Irache, Lib. 539, 92r.

JUAN DE BUSTAMANTE

B. C.

28-11-1669

Fr. Jacinto de Loyola

Rua... (Burgos)

AGN, Irache, Lib. 539, 92r.

PEDRO DE LA CALLE

B. C.

4-12-1669

Fr. Primitivo Ruiz

Nájera (Calahorra)

AGN, Irache, Lib. 539, 92r.

DIEGO DE BRIZUELA

B. A. / B. T

8-12-1669

Fr. Alonso Verdesoto

Izcari (Burgos)

AGN, Irache, Lib. 539, 92r.

DIEGO DE CARRANZA

B. C.

12-12-1669

Fr. Benito de Loyola

Castro Urdiales (Burgos)

AGN, Irache, Lib. 539, 92v.

GREGORIO RIAÑO GAMBOA

B. C.
22-12-1669

Fr. Primitivo Ruiz

Cerezo (Burgos)

AGN, Irache, Lib. 539, 92v.

BERNABÉ DE VALDIVIESO

B. C.

28-1-1670

Fr. Manuel Vela

Santa Gadea (Burgos)

AGN, Irache, Lib. 539, 92v.

PEDRO DE ISLA

B. A. / B. T.

12-2-1670

Fr. Alonso Verdesoto / Fr. Benito de Loyola Isla (Burgos)

AGN, Irache, Lib. 539, 93r.

\section{LARUEL FERNÁNDEZ DE CEA}

B. C.

12-2-1670

Fr. Benito de Loyola

Dobro (Burgos)

AGN, Irache, Lib. 539, 93r.

DIEGO PEDROSO

B. C.

28-2-1670

Fr. Manuel Vela

Briones (Calahorra)

AGN, Irache, Lib. 539, 93r.

LORENZO DE ORMAZA

B. A. / B. T.

5-3-1670 Reprobado dos veces de B. A.

20-8-1670 Aprobado de B. T.

Fr. Alonso Verdesoto / Fr. Vela / Fr. Loyola

// Fr. Benito de Loyola

Tapia (Burgos)

AGN, Irache, Lib. 539, 93r, 97v.

JOSÉ FERNÁNDEZ

B. A. / B. M.

7-3-1670

Fr. Alonso Verdesoto

Malón (Tarazona)

AGN, Irache, Lib. 539, 93v. 


\section{TOMÁS DE LONGÁS}

L. M. / D. M.

7-3-1670

Fr. Andrés de la Moneda, Abad y Rector Mallén (Zaragoza)

AGN, Irache, Lib. 539, 93v.

\section{DIEGO FRANCISCO NAVARRO}

B. M.

8-3-1670

Fr. Manuel Vela

Cascante (Tarazona)

AGN, Irache, Lib. 539, 94r.

\section{GASPAR GARCÍA Y MANSILLA}

L. C. / D. C.

13-3-1670

Fr. Andrés de la Moneda, Abad y Rector Aranda de Duero (Osma)

AGN, Irache, Lib. 539, 94r.

\section{MIGUEL CALVILLO}

B. M.

19-3-1670

Fr. Primitivo Ruiz

Cascante (Tarazona)

AGN, Irache, Lib. 539, 94r.

FRANCISCO PÉREZ DE NOBAL

B. C.

21-3-1670

Fr. Benito de Loyola

Valle de Liendo (Burgos)

AGN, Irache, Lib. 539, 94v.

ROQUE DE MATA

B. A.

27-3-1670

Fr. Alonso Verdesoto

Briviesca (Burgos)

AGN, Irache, Lib. 539, 94v.

BARTOLOMÉ DE CÁRCAMO

B. C.

31-3-1670

Fr. Benito de Loyola

Promediano (Burgos)

AGN, Irache, Lib. 539, 94V.
FELIPE DE UNGO Y VELASCO

B. C.

1-4-1670

Fr. Regente

Sotillo (Burgos)

AGN, Irache, Lib. 539, 94v.

\section{MIGUEL DE ARIZ}

B. A.

15-4-1670

Fr. Alonso Verdesoto

Mendivil (Pamplona)

AGN, Irache, Lib. 539, 94v.

FRANCISCO GIL

B. C.

26-4-1670

Fr. Manuel Vela

Villasana (Burgos)

AGN, Irache, Lib. 539, 95r.

TOMÁS GONZÁLEZ

B. A. / B. T.

27-4-1670

Fr. Alonso Verdesoto / Fr. Benito de Loyola

Covarrubias

AGN, Irache, Lib. 539, 95r.

MARTÍN GALAZ DE JARAUTA

B. A. / B. T.

4-5-1670

Fr. Alonso Verdesoto

Fresnedo (Burgos)

AGN, Irache, Lib. 539, 95r.

JUAN DE JARAUTA

B. C.

4-5-1670 / 4-7-1670

Reprobado

Fr. Regente / Fr. Primitivo Ruiz

Boros (Burgos)

AGN, Irache, Lib. 539, 95r, 97r.

JUAN SERRANO

B. A. / B. T.

9-5-1670

Fr. Alonso Verdesoto / Fr. Benito de Loyola Huerta de Suso (Burgos)

AGN, Irache, Lib. 539, 95v. 
JUAN RUBIO

B. C.

9-5-1670

Fr. Benito de Loyola

Huerta de Suso (Burgos)

AGN, Irache, Lib. 539, 95v.

PEDRO PÉREZ

B. C.

12-5-1670

Fr. Manuel Vela

Río Ubierna (Burgos)

AGN, Irache, Lib. 539, 95v.

TOMÁS DE TORREJÓN

B. A. / B. T.

14-5-1670

Fr. Alonso Verdesoto

Palacios de Benahiel (Burgos)

AGN, Irache, Lib. 539, 95v.

JUAN ZORRILLA DE VELASCO

L. T. / D. T.

20-5-1670

Fr. Andrés de la Moneda, Abad

Espinosa de los Monteros (Burgos)

AGN, Irache, Lib. 539, 96r.

MANUEL ARCINIEGA

B. A. / B. T.

22-5-1670

Fr. Alonso Verdesoto / Fr. Primitivo Ruiz

Frías (Burgos)

AGN, Irache, Lib. 539, 96r.

JUAN SAINZ

B. A. / B. T.

1-6-1670

Fr. Alonso Verdesoto

Quintanadueñas (Burgos)

AGN, Irache, Lib. 539, 96r.

SIMÓN SAINZ DE BARANDA

B. A. / B. T.

23-6-1670

Fr. Alonso Verdesoto

Baranda (Burgos)

AGN, Irache, Lib. 539, 96v.
JUAN RUIZ DE SALAZAR

B. A. / B. T.

23-6-1670

Fr. José de Noboa / Fr. Primitivo Ruiz

Colina (Burgos)

AGN, Irache, Lib. 539, 96v.

JOSÉ GUTIÉRREZ DE COSÍO

B. C.

27-6-1670

Reprobado

Fr. Manuel Vela

Novales (Burgos)

AGN, Irache, Lib. 539, 96v.

JOSÉ HIERRO

B. A. / B. T.

27-6-1670

Fr. Alonso Verdesoto

Villasandino (Burgos)

AGN, Irache, Lib. 539, 96v.

JOSÉ DE APARICIO

B. A. / B. T.

27-6-1670

Fr. Alonso Verdesoto

Villasandino (Burgos)

AGN, Irache, Lib. 539, 97r.

MIGUEL DE MANCEBO

B. A. / B. T.

27-6-1670

Fr. Alonso Verdesoto

Villasandino (Burgos)

AGN, Irache, Lib. 539, 97r.

JOSÉ FERMÍN DE ARZAGA

B. T.

10-7-1670

Fr. Benito de Loyola

O. Cist.

Pamplona

AGN, Irache, Lib. 539, 97r.

MARTÍN PÉREZ DE SALINAS

B. C.

14-7-1670 / 4-10-1670

Reprobado 
Fr. Primitivo Ruiz / Fr. Regente Salcedo (Calahorra)

AGN, Irache, Lib. 539, 97r, 99v.

PEDRO LÓPEZ DE LA CALLEJA

B. C.

17-7-1670

Fr. Benito de Loyola

San Martín de Losa (Burgos)

AGN, Irache, Lib. 539, 97v.

JOSÉ PRIETO

B. A.

9-8-1670

Fr. Alonso Verdesoto

Burgos

AGN, Irache, Lib. 539, 97v.

JOSÉ DE SOMAVILLA

B. A. / B. T.

9-8-1670

Fr. Alonso Verdesoto

Polientes (Burgos)

AGN, Irache, Lib. 539, 97v.

JUAN DE SOMAVILLA

B. C.

$13-8-1670$

Fr. Benito de Loyola

Polientes (Burgos)

AGN, Irache, Lib. 539, 97v.

FRANCISCO RIBAS

B. T. / L. T. / D. T.

26-8-1670

Fr. Andrés de la Moneda, Abad

O. S. B.

Predicador Mayor de Nájera

AGN, Irache, Lib. 539, 98r.

FRANCISCO BARRIUSO SANZ

B. A. / B. T.

27-8-1670

Fr. Alonso Verdesoto

Palacios de la Sierra (Osma)

AGN, Irache, Lib. 539, 98r.

JUAN GARCÍA DE VIZCAÍNOS

B. C.
3-9-1670

Fr. Regente

Barbadillo de Herreros (Burgos)

AGN, Irache, Lib. 539, 98r.

MANUEL AGUADO DE PEDROSA

B. C.

3-9-1670

Fr. Benito de Loyola

Pedrosa del Príncipe (Burgos)

AGN, Irache, Lib. 539, 98r.

FRANCISCO DE ROZAS

B. C.

6-9-1670

Fr. Benito de Loyola

Cisterna (Burgos)

AGN, Irache, Lib. 539, 98v.

PEDRO DE ACEDO

B. T.

7-9-1670

Fr. Regente

Falces (Pamplona)

AGN, Irache, Lib. 539, 98v.

JUAN FRANCÉS OROZCO

B. A.

9-9-1670

Fr. Alonso Verdesoto

Cenicero (Calahorra)

AGN, Irache, Lib. 539, 98v.

ANDRÉS DE CÁMARAS

B. $\mathrm{T}$.

12-9-1670

Fr. Manuel Vela

Ojacastro (Burgos)

AGN, Irache, Lib. 539, 98v.

JOSÉ CACHARRO

B. C.

15-9-1670

Fr. Benito de Loyola

Carrión de los Condes (Palencia)

AGN, Irache, Lib. 539, 98v.

ANDRÉS GARCÍA

B. A. / B. T. 
17-9-1670

Fr. Alonso Verdesoto

Tordo... (Burgos)

AGN, Irache, Lib. 539, 99r.

\section{JUAN BALBÍN}

L. T. / D. T.

18-9-1670

Fr. Andrés de la Moneda, Abad

Burgos

Fr. Predicador mayor de San Juan

AGN, Irache, Lib. 539, 99r.

JOSÉ DE CISNEROS

B. T.

18-9-1670

Fr. Manuel Vela

Borobia (Osma)

AGN, Irache, Lib. 539, 99r.

ANTONIO RUIZ DE VEREDO Y VALDIVIESO

B. A. / B. T.

20-9-1670

Fr. Benito de Loyola

Burgos

AGN, Irache, Lib. 539, 99r.

IGNACIO DE CALABAZANOS

B. A.

27-9-1670

Fr. Alonso Verdesoto

O. Cist.

Olite (Pamplona)

AGN, Irache, Lib. 539, 99v.

PEDRO MILLÁN MUÑOZ

B. C.

30-9-1670

Fr. Benito de Loyola

Barbadillo de Herreros (Burgos)

AGN, Irache, Lib. 539, 99v.

JOSÉ DE PRADO

B. C.

2-10-1670

Fr. Manuel Vela

Quintanilla de San García (Burgos)

AGN, Irache, Lib. 539, 99v.
ROQUE DE ORTEGA

B. A. / B. T.

8-10-1670

Fr. Alonso Verdesoto

Izcari (Burgos)

AGN, Irache, Lib. 539, 100 .

\section{ANTONIO CALDERÓN}

B. C.

13-10-1670

Fr. Primitivo Ruiz

Galizano (Burgos)

AGN, Irache, Lib. 539, 100 .

\section{MATEO FONCILLAS}

B. C.

31-10-1670

Fr. Benito de Loyola

Barbuñales (Lérida)

AGN, Irache, Lib. 539, 10or.

MARIO DE PAMPLIEGA

B. C.

2-11-1670

Reprobado

Fr. Benito de Loyola

Tardajos (Burgos)

AGN, Irache, Lib. 539, 100 .

\section{LUCAS SALAS}

B. A.

8-11-1670

Fr. Alonso Verdesoto

Calahorra

AGN, Irache, Lib. 539, 100 .

MARTÍN DE SACHAGA

B. C.

13-11-1670 / 15-12-1670

Reprobado

Fr. Benito de Loyola

Zalla (Burgos)

AGN, Irache, Lib. 539, 100v.

MATEO DE SAN CRISTÓBAL

B. C.

13-11-1670 / 27-12-1670

Reprobado dos veces 
Fr. Benito de Loyola

Zalla (Burgos)

AGN, Irache, Lib. 539, 100v, 101r.

FRANCISCO DE MELLA Y TERREROS

B. C.

14-11-1670

Fr. Benito de Loyola

Terreros (Burgos)

AGN, Irache, Lib. 539, $100 v$.

FRANCISCO DE SANTANDER MARROQUÍN

B. C.

28-11-1670

Reprobado dos veces

Fr. Regente / Fr. Manuel Vela

Laredo (Burgos)

AGN, Irache, Lib. 539, 100v.

JUAN BAUTISTA DE ANO

B. C.

28-11-1670

Fr. Manuel Vela

Laredo (Burgos)

AGN, Irache, Lib. 539, $100 v$.

TOMÁS MILLÁN DE BERZOSILLA

B. C.

13-12-1670

Fr. Benito de Loyola

Berzosilla (Burgos)

AGN, Irache, Lib. 539, 101r.

FRANCISCO MARTÍNEZ

B. A. / B. T.

13-12-1670

Fr. Alonso Verdesoto

Muñón (Burgos)

AGN, Irache, Lib. 539, 101r.

TOMÁS MARTÍNEZ

B. A. / B. T.

13-12-1670

Fr. Alonso Verdesoto

Muñón (Burgos)

AGN, Irache, Lib. 539, 101r.

\section{PEDRO LÓPEZ}

B. A. / B. T.

31-12-1670

Fr. Alonso Verdesoto / Fr. Benito de Loyola

Reprobado

Valle de Buriezo (Burgos)

AGN, Irache, Lib. 539, 101v.

MARTÍN DE ASADA

B. A. / B. T.

31-12-1670

Fr. Alonso Verdesoto / Fr. Benito de Loyola

Reprobado

Buriezo (Burgos)

AGN, Irache, Lib. 539, $101 \mathrm{v}$.

\section{JUAN MUÑOZ}

B. C.

5-1-1671

Fr. Manuel Vela

Santa María de Garona (Burgos)

AGN, Irache, Lib. 539, $101 \mathrm{v}$.

JUAN GONZÁLEZ DE MIERA

B. A. / B. T.

13-1-1671

Fr. Benito de Loyola

Navajeda (Burgos)

AGN, Irache, Lib. 539, 102r.

ANDRÉS DÍAZ

B. A. / B. T.

20-1-1671

Fr. Alonso Verdesoto / Fr. Primitivo Ruiz

Reprobado

Ribarredonda (Burgos)

AGN, Irache, Lib. 539, 102r.

FRANCISCO DEL HOYO

B. C.

29-1-1671

Fr. Primitivo Ruiz

Laredo y Santoña (Burgos)

AGN, Irache, Lib. 539, 102r.

JUAN RUBIO

B. A. / B. T.

18-2-1671 
Fr. Alonso Verdesoto Montenegro (Burgos)

AGN, Irache, Lib. 539, 102r.

MIGUEL DE ÁNIZ

B. M.

20-2-1671

Fr. Primitivo Ruiz

Mendívil (Pamplona)

AGN, Irache, Lib. 539, $102 \mathrm{v}$.

\section{JUAN DE ESPINOSA}

B. C.

5-3-1671

Fr. Manuel Vela

Pancorbo (Burgos)

AGN, Irache, Lib. 539, $102 \mathrm{v}$.

\section{FRANCISCO MARROQUÍN}

B. C.

9-3-1671

Fr. Benito de Loyola

Pancorbo (Burgos)

AGN, Irache, Lib. 539, $102 \mathrm{v}$.

DOMINGO RUIZ

B. A. / B. T.

15-3-1671 reprobado

18-3-1674 aprobado B. T.

Fr. Alonso Verdesoto

Guriezo (Burgos)

AGN, Irache, Lib. 539, 102v, $127 \mathrm{v}$.

ANTONIO GURREA

L. T.

1-4-1671

Fr. Andrés de la Moneda, Abad

Calahorra

AGN, Irache, Lib. 539, 103 r.

JUAN DE MAZANAL

B. C.

8-4-1671

Fr. Benito de Loyola

Somorrostro (Burgos)

AGN, Irache, Lib. 539, 103r.

FRANCISCO SIMÓN DE VILLANUEVA L. T. / D. T.
10-4-1671

Fr. Andrés de la Moneda, Abad

Ferreruela (Zaragoza)

B. A. / B.T.

AGN, Irache, Lib. 539, 103 r.

JOSÉ DE GUINEA

B. A. / B. T.

20-5-1671 / 13-9-1671

Fr. Primitivo Ruiz / Fr. Regente

Reprobado

Berberna (Burgos)

AGN, Irache, Lib. 539, 103r, $105 \mathrm{v}$.

VALENTÍN DE GUINEA

B. C.

26-5-1671

Fr. Benito de Loyola

Tesa (Burgos)

AGN, Irache, Lib. 539, $103 \mathrm{v}$.

JOSÉ DE ZAÑARTU

B. A. / L. A. / M. A. / B. T. / L. T. / D. T.

3-6-1671

Fr. Primitivo Ruiz

O. S. B.

Convento de Salamanca

Maestro de Estudiantes

AGN, Irache, Lib. 539, 103v.

FRANCISCO FERNÁNDEZ DE MANZA-

NOS

B. A.

3-6-1671

Fr. Alonso Verdesoto

Azama (Pamplona)

AGN, Irache, Lib. 539, $103 \mathrm{v}$.

FRANCISCO RUIZ DE CORQUERA

B. C.

1-7-1671

Fr. Benito de Loyola

Moriana (Burgos)

AGN, Irache, Lib. 539, 103v.

JUAN ANTONIO TABUENCA

B. M.

1-7-1671 
Fr. Regente

Talamantes (Zaragoza)

AGN, Irache, Lib. 539, 103v.

JOSÉ JAIMES

B. C.

8-7-1671

Fr. Benito de Loyola

Melgar de Fernamental (Burgos)

AGN, Irache, Lib. 539, 104r.

JUAN ITERO

B. C.

12-7-1671

Fr. Benito de Loyola

Castrojeriz (Burgos)

AGN, Irache, Lib. 539, 104r.

FRANCISCO DE TOCA

B. C.

12-7-1671

Fr. Benito de Loyola

Azas (Burgos)

AGN, Irache, Lib. 539, 104r.

FRANCISCO DEL RÍO

B. C.

2-8-1671

Fr. Benito de Loyola

Azas (Burgos)

AGN, Irache, Lib. 539, 104r.

BLAS MARTÍNEZ

B. C.

18-8-1671

Fr. Benito de Loyola

Medina de Pomar (Burgos)

AGN, Irache, Lib. 539, 104r.

JUAN DE HUIDOBRO

B. C.

26-8-1671

Fr. Regente

Burgos

AGN, Irache, Lib. 539, $104 \mathrm{~V}$.

JUAN PÉREZ

B. A. / B. T.
28-8-1671 Reprobado B. T.

8-4-1673 Aprobado

Fr. Benito de Loyola

Villazopeque (Burgos)

AGN, Irache, Lib. 539, 104v, 119r.

DOMINGO SOMAVILLA

B. A. / B. T.

31-8-1671

Fr. Benito de Loyola

Duj... (Burgos)

AGN, Irache, Lib. 539, 104v.

JOSÉ BERCEDO

B. C.

31-8-1671

Fr. Regente

Arenillas (Burgos)

AGN, Irache, Lib. 539, $104 \mathrm{~V}$.

ALONSO RIALES MANRIQUE

B. C.

31-8-1671

Fr. Benito de Loyola

Santibáñez (Burgos)

AGN, Irache, Lib. 539, 105r.

FRANCISCO PÉREZ

B. A. / B. T.

1-9-1671

Fr. Alonso Verdesoto

Santibáñez (Burgos)

AGN, Irache, Lib. 539, 105r.

TOMÁS VICENTE

B. A. / B. T.

8-9-1671 / 28-9-1671

Fr. Benito de Loyola

Reprobado

Santibáñez (Burgos)

AGN, Irache, Lib. 539, 105r.

PEDRO ÁLVAREZ

B. C.

8-9-1671

Fr. Benito de Loyola

Santibáñez (Burgos)

AGN, Irache, Lib. 539, 105r. 
LUCAS RODRÍGUEZ

B. A. / B. T.

10-9-1671

Fr. Benito de Loyola

Ros (Burgos)

AGN, Irache, Lib. 539, 105v.

JOSÉ DE ARZA

B. A.

13-9-1671

Fr. Alonso Verdesoto

Arm... (Pamplona)

AGN, Irache, Lib. 539, $105 \mathrm{v}$.

PRUDENCIO DE SICILIA

B. A.

14-9-1671

Fr. Alonso Verdesoto

Riba... (Calahorra)

AGN, Irache, Lib. 539, 105v.

JOSÉ DE ARCE

B. C.

17-9-1671

Reprobado

Fr. Benito de Loyola

San Martín de Ubierna (Burgos)

AGN, Irache, Lib. 539, 105v.

FRANCISCO DÍAZ DE TOLOSA

B. C.

28-9-1671

Fr. Benito de Loyola

Ballarta (Burgos)

AGN, Irache, Lib. 539, 106r.

JUAN DE CELADA

B. A. / B. T.

29-9-1671 / 14-10-1671

Fr. Regente

Reprobado

Santibáñez (Burgos)

AGN, Irache, Lib. 539, 106rv.

PEDRO SAINZ

B. A. / B. T.

3-10-1671

Fr. Alonso Verdesoto
Abadía de Lerma

AGN, Irache, Lib. 539, 106r.

ÍNIIGO BUITRÓN

B. A. / L. A. / M. A. / B. T. / L. T. / D. T.

8-10-1671

Fr. Andrés de la Moneda, Abad

Fraile. Predicador Mayor de Ávila

AGN, Irache, Lib. 539, 106v.

AGUSTÍN DÍAZ DE CANTABRANA

B. C.

10-10-1671

Fr. Benito de Loyola

Cerezo (Burgos)

AGN, Irache, Lib. 539, 106v.

FRANCISCO DE SANTANDER

B. T.

18-10-1671

Fr. Benito de Loyola

Laredo (Burgos)

AGN, Irache, Lib. 539, $106 \mathrm{v}$.

MANUEL RUIZ

B. A.

22-10-1671

Fr. Alonso Verdesoto

P... (Osma)

AGN, Irache, Lib. 539, 106v.

FRANCISCO GADEO

B. C.

4-11-1671

Fr. Regente

Santa María del Campo (Burgos)

AGN, Irache, Lib. 539, $106 \mathrm{v}$.

ANTONIO ZORRILLA

B. C.

11-11-1671

Fr. Manuel Vela

Medina de Pomar (Burgos)

AGN, Irache, Lib. 539, 107r.

DOMINGO FERNÁNDEZ

B. C.

27-11-1671 
Fr. Benito de Loyola Medina de Pomar (Burgos)

AGN, Irache, Lib. 539, 107r.

AGUSTÍN LÓPEZ VARONA

B. C.

2-12-1671

Fr. Benito de Loyola

Medina de Pomar (Burgos)

AGN, Irache, Lib. 539, 107r.

DIEGO BRAVO

B. A. / B. T.

5-12-1671

Fr. Benito de Loyola

Fresno de Rodilla (Burgos)

AGN, Irache, Lib. 539, 107 r.

MANUEL GONZÁLEZ

B. C.

5-12-1671

Fr. Benito de Loyola

Montorio (Burgos)

AGN, Irache, Lib. 539, 107r.

GREGORIO REDONDO

B. C.

6-12-1671

Fr. Primitivo Ruiz

Arcos (Burgos)

AGN, Irache, Lib. 539, 107r.

JOSÉ PÉREZ

B. A. / B. M.

6-12-1671

Fr. Alonso Verdesoto / Fr. Manuel Vela

Salvatierra (Pamplona)

AGN, Irache, Lib. 539, 107 r.

JUAN DE VILLANUEVA

B. T. / L. T. / D. T.

10-12-1671

Fr. Andrés de la Moneda, Abad

Cornejo (Calahorra)

AGN, Irache, Lib. 539, 107v.

JUAN ÁLVAREZ

B. A. / B. T.
11-12-1671

Fr. Regente

Modúbar de San Cibrián (Burgos)

AGN, Irache, Lib. 539, $107 \mathrm{v}$.

PEDRO GARCÍA

B. C.

23-12-1671 / 15-6-1671

Reprobado

Fr. Benito de Loyola

Medina de Pomar (Burgos)

AGN, Irache, Lib. 539, 107v, $110 v$.

FRANCISCO DE VILLOTA

B. C.

24-12-1671

Fr. Benito de Loyola

Laredo (Burgos)

AGN, Irache, Lib. 539, $107 \mathrm{v}$.

JUAN PÉREZ

B. $\mathrm{T}$.

9-1-1672

Fr. Benito de Loyola

Quintanilla (Burgos)

AGN, Irache, Lib. 539, 107v.

LORENZO DE LA TORRE

B. C.

12-1-1672

Fr. Manuel Vela

Novales (Burgos)

AGN, Irache, Lib. 539, 108r.

DIEGO TARANCO

B. A. / B. T.

16-1-1672

Fr. Benito de Loyola

Lezana (Burgos)

AGN, Irache, Lib. 539, 108r.

FRANCISCO JUÁREZ

B. C.

16-1-1672

Fr. Benito de Loyola

Villasandino (Burgos)

AGN, Irache, Lib. 539, 108r. 


\section{SIMÓN BENITO}

B. C.

31-1-1672

Fr. Benito de Loyola

Revilla del Campo (Burgos)

AGN, Irache, Lib. 539, 108r.

\section{ANDRÉS FERNÁNDEZ}

B. A.

4-2-1672

Fr. Alonso Verdesoto

Anguiano (Calahorra)

AGN, Irache, Lib. 539, 108v.

\section{PEDRO GREGORIO}

B. A.

5-2-1672

Fr. Alonso Verdesoto

Bargota (Calahorra)

AGN, Irache, Lib. 539, 108v.

\section{MATEO VALLEJO}

B. C.

8-2-1672

Fr. Regente

Vallejuelo (Burgos)

AGN, Irache, Lib. 539, 108v.

JUAN DE MEDIAVILLA

B. C.

24-2-1672

Reprobado

M. Vela / M. Loyola

Valcárceres (Burgos)

AGN, Irache, Lib. 539, 108v.

ANTONIO DE ANGULO ORIVE-SALAZAR

B. C.

9-3-1672

Fr. Manuel Vela

Retes (Calahorra)

AGN, Irache, Lib. 539, 108v.

FRANCISCO MARTÍNEZ ARAUJO

B. A.

30-3-1672

Fr. Manuel Vela

Burgos

AGN, Irache, Lib. 539, 109r.
JUAN ANTONIO LLAMOSA

B. A. / B. T.

30-3-1672

Fr. Manuel Vela

Bárcena (Burgos)

AGN, Irache, Lib. 539, 109r.

ANDRÉS RUIZ

B. C.

8-4-1672

Fr. Benito de Loyola

Oseja (Burgos)

AGN, Irache, Lib. 539, 109r.

BARTOLOMÉ BUSTAMANTE

B. A. / L. A. / M. A. / B. T. / L. T. / D. T.

29-4-1672

Fr. Andrés de la Moneda, General, Abad, Rector y Maestrescuela de Irache

O. S. B.

Abad de Sahagún

AGN, Irache, Lib. 539, 109 r.

ESTEBAN DE SOTO

B. C.

29-4-1672

Fr. Benito de Loyola

Rublacedo de Arriba (Burgos)

AGN, Irache, Lib. 539, $109 \mathrm{v}$.

PEDRO DE RAMOS LEZCANO ITURBAREN

B. A.

4-5-1672

Fr. Benito de Loyola

Cegama (Pamplona)

AGN, Irache, Lib. 539, $109 v$.

SIMÓN DE SAN JUANES

B. C.

4-5-1672 / 5-5-1672

Reprobado dos veces

Fr. Benito de Loyola / Fr. Antonio de Quevedo

Villa de ... (Burgos)

AGN, Irache, Lib. 539, $109 \mathrm{v}$.

JUAN DE PABLO Y BASAVE

B. A. / B. T. 
5-5-1672

Fr. Benito de Loyola

Torrecilla (Calahorra)

AGN, Irache, Lib. 539, 109v, 110r.

BERNARDO PORTILLA Y NAVARRO

B. A. / B. T.

20-5-1672

Fr. Benito de Loyola

San Asensio (Calahorra)

AGN, Irache, Lib. 539, 110r.

JUAN DE RIBA

B. C.

20-5-1672

Fr. Benito de Loyola

Valcázares (Burgos)

AGN, Irache, Lib. 539, 110 .

JOSÉ DE PEÑA

B. A. / B. M.

20-5-1672

Fr. Benito de Loyola

Tabuenca (Burgos)

AGN, Irache, Lib. 539, $110 v$.

\section{ANTONIO DE CASCAJARES}

D. C.

27-5-1672

Fr. Andrés de la Moneda, Abad

Tudela (Tarazona)

AGN, Irache, Lib. 539, $110 v$.

JUAN DE RENGADA

B. T. / L. T.

18-6-1672

Fr. Andrés de la Moneda, Abad

Estella (Pamplona)

AGN, Irache, Lib. 539, 111r.

MANUEL BERNARDO RUIZ DE LA BAS-

TIDA

B. C.

21-6-1672

Fr. Benito de Loyola

Peñacerrada (Calahorra)

AGN, Irache, Lib. 539, 111r.
PEDRO FERNÁNDEZ VALLEJO

B. C.

22-6-1672

Fr. Benito de Loyola

Anzó (Burgos)

AGN, Irache, Lib. 539, 111r.

GASPAR SEDANO

B. C.

24-6-1672

Fr. Benito de Loyola

Villarmero (Burgos)

AGN, Irache, Lib. 539, 111v.

JUAN MARTÍNEZ DE CANTABRANA

B. A. / B. T.

1-7-1672

Fr. Benito de Loyola

Loranquillo (Burgos)

AGN, Irache, Lib. 539, 111v.

FRANCISCO ARIZA

B. C.

3-7-1672

Fr. Benito de Loyola

Soto (Calahorra)

AGN, Irache, Lib. 539, 111v.

BALTASAR DE CASTRO

B. C.

5-7-1672

Fr. Benito de Loyola

Lerma (Nullius Diocesis)

AGN, Irache, Lib. 539, 111v.

PEDRO DE PINO

B. A. / B. T.

14-7-1672

Fr. Benito de Loyola

Reprobado

Sotragero (Burgos)

AGN, Irache, Lib. 539, 111v-112r.

JUAN BAUTISTA DEL RÍO

B. A. / B. T.

14-7-1672 / 16-7-1672

Reprobado

Fr. Andrés de la Moneda, Abad / Fr. Benito 
de Loyola

Salcedillo (Burgos)

AGN, Irache, Lib. 539, 112r.

\section{ALONSO DE PINO}

B. C.

14-7-1672 /14-10-1672

Reprobado

Fr. Andrés, abad / Fr. Benito de Loyola

Sotragero (Burgos)

AGN, Irache, Lib. 539, 112r, 114v.

\section{JUAN DE ARGAIZ}

B. C.

19-7-1672

Fr. Benito de Loyola

Arnedo (Calahorra)

AGN, Irache, Lib. 539, 112v.

\section{DIEGO MARTÍNEZ}

B. T.

21-7-1672

Fr. Benito de Loyola

Quintanaloranco (Burgos)

AGN, Irache, Lib. 539, 112v.

JUAN GÓMEZ DE VELASCO Y MANSILLA

B. A. / B. T.

$-/-/ 1672$

Fr. Benito de Loyola

AGN, Irache, Lib. 539, 112v.

DOMINGO LORENTE

B. A.

7-8-1672

Fr. Benito de Loyola, pero no se le dio el grado, por no presentar cursibus per actis Corella (Tarazona)

AGN, Irache, Lib. 539, 113r.

\section{FRANCISCO DE PAGOLA}

B. A. / B. T. / L. T. / D. T.

9-8-1672 /12-4-1673/ 17-2-1674 / 1675

Fr. Benito de Loyola / Fr. Pedro de Castro /

Fr. Juan Sánchez, abad

Andosilla (Pamplona)

AGN, Irache, Lib. 539, 113r, 119r, 126v, $135 \mathrm{v}$.
MARTÍN DE AZPILICUETA

B. A. / B. T. / L. T. / D. T.

3-9-1672

Fr. Andrés de la Moneda, Abad

Hijar (Zaragoza)

AGN, Irache, Lib. 539, 113r.

JUAN DE LA TORRE

B. C.

15-9-1672

Fr. Benito de Loyola

Antón (Burgos)

AGN, Irache, Lib. 539, 113v.

MIGUEL DE ELEJABEITIA

B. A.

20-9-1672

Fr. Benito de Loyola

Arteaga

AGN, Irache, Lib. 539, $113 \mathrm{v}$.

AGUSTÍN ANTONIO PÉREZ

B. T.

21-9-1672

Fr. Benito de Loyola

I... (Huesca)

AGN, Irache, Lib. 539, $113 \mathrm{v}$.

PEDRO PEÑA

B. M.

1-10-1672

Fr. Benito de Loyola

Arnedo (Calahorra)

AGN, Irache, Lib. 539, $113 \mathrm{v}$.

ALONSO IÑÍGUEZ

B. C.

9-10-1672

Fr. Benito de Loyola

Bisjueces (Burgos)

AGN, Irache, Lib. 539, 114r.

DIEGO RAMÓN DE BARRECHAL

B. A.

12-10-1672

Fr. Benito de Loyola

Borja (Tarazona)

AGN, Irache, Lib. 539, 114r. 
FRANCISCO DE ARTIGOSA

B. C.

14-10-1672

Fr. Benito de Loyola

Zaragoza

AGN, Irache, Lib. 539, 114r.

JUAN VICENTE

B. A. / B. M.

14-10-1672

Fr. Benito de Loyola

Cáseda (Pamplona)

AGN, Irache, Lib. 539, 114v.

\section{BARTOLOMÉ DE LA HELGUERA}

B. C.

16-10-1672 Reprobado

28-11-1675 Aprobado

Fr. Benito de Loyola / Fr. José de Sojo

Valle de Otáñez (Burgos)

AGN, Irache, Lib. 539, 114v, 141v.

PEDRO INÉS

B. M.

21-10-1672

Fr. Benito de Loyola

Bellpuig (Solsona)

AGN, Irache, Lib. 539, 114v.

BARTOLOMÉ DE MADRAZO

B. C.

21-10-1672

Fr. Benito de Loyola

Espinosa de los Monteros (Burgos)

AGN, Irache, Lib. 539, 114v.

\section{ALONSO DE CASTAÑEDA}

B. C.

22-10-1672

Fr. Primitivo Ruiz

Piedeconcha (Burgos)

AGN, Irache, Lib. 539, 115r.

\section{JACINTO ALONSO}

B. A. / B. T.

23-10-1672

Fr. Francisco de Ojea

Arenillas del río Pisuerga (Burgos)

AGN, Irache, Lib. 539, 115r.

\section{FRANCISCO DE ALCOZ}

B. A.

24-10-1672

No se le dio el grado por no haber pasado el examen en el Colegio de la Compañía

Barásoain (Pamplona)

AGN, Irache, Lib. 539, 115r.

ESTEBAN IÑÍGUEZ

B. C.

1-11-1672

Fr. Manuel Vela

Valdenoceda (Burgos)

AGN, Irache, Lib. 539, 115v.

FRANCISCO MUÑOZ

B. C.

1-11-1672

Fr. Manuel Vela

Céspedes (Burgos)

AGN, Irache, Lib. 539, 115v.

\section{MARCOS SÁNCHEZ}

B. A. / B. T.

3-12-1672

Fr. Benito de Loyola

Villan... (Burgos)

AGN, Irache, Lib. 539, 115v.

\section{LUCAS ALCALDE}

B. C.

19-12-1672

Fr. Manuel Vela

Villafranca de Montes de Oca (Burgos)

AGN, Irache, Lib. 539, 115v.

JUAN PÉREZ

B. A. / B. T.

22-12-1672

Fr. Francisco de Ojea / Fr. Benito de Loyola E... (Burgos)

AGN, Irache, Lib. 539, 116r.

JUAN DE VILLA VALLE

B. A. / B. T.

3-1-1673- 4-1-1673

Reprobado

Fr. Benito de Loyola / Fr. Francisco de Ojea 
Beranga (Burgos)

AGN, Irache, Lib. 539, 116r.

FRANCISCO DE ELCARTE

L. M. / D. M.

8-1-1673

Fr. Andrés de la Moneda, Abad

Pamplona

AGN, Irache, Lib. 539, 116v.

MARCOS DE LA FUENTE Y BUSTAMANTE

B. C.

12-1-1673

Fr. Benito de Loyola

Cortiguera (Burgos)

AGN, Irache, Lib. 539, 116v.

ANDRÉS GONZÁLEZ

B. C.

13-1-1673

Fr. Benito de Loyola

Villadiego (Burgos)

AGN, Irache, Lib. 539, 116v.

DIEGO DE MATIENZO

B. A. / B. T.

23-1-1673

Fr. Francisco de Ojea / Fr. Primitivo Ruiz

Ampuero (Burgos)

AGN, Irache, Lib. 539, 117 r.

LUCAS DE ARENAS

B. C.

23-1-1673

Fr. Primitivo Ruiz

Ampuero (Burgos)

AGN, Irache, Lib. 539, 117r.

JUAN FRANCISCO DE LETE

L. L.

23-1-1673

Fr. Andrés de la Moneda, Abad

Estella (Pamplona)

AGN, Irache, Lib. 539, 117r.

FRANCISCO GARCÍA DE LILLA

B. T.
21-2-1673

Fr. Benito de Loyola

Noja (Burgos)

AGN, Irache, Lib. 539, 117v.

BERNABÉ DE LA TORRE

B. C.

10-3-1673

Fr. Primitivo Ruiz

Comillas (Burgos)

AGN, Irache, Lib. 539, $117 \mathrm{v}$.

ESTEBAN DEL CAMPO

B. A. / B. T.

20-3-1673

Fr. Francisco de Ojea / Fr. Benito de Loyola Islares (Burgos)

AGN, Irache, Lib. 539, $117 \mathrm{v}$.

JUAN MERINO

B. A.

20-3-1673

Fr. Francisco de Ojea

Ausejo (Calahorra)

AGN, Irache, Lib. 539, 118r.

PEDRO BLANCO GONZÁLEZ

B. T.

21-3-1673

Fr. Benito de Loyola

Vega (Burgos)

AGN, Irache, Lib. 539, 118r.

MIGUEL DE UZQUIANO

B. C.

21-3-1673

Fr. Benito de Loyola

Espejo (Burgos)

AGN, Irache, Lib. 539, 118r.

MANUEL VELASCO

B. A. / B. T. / L. T.

28-3-1673

Fr. Andrés de la Moneda, Abad

Palencia

AGN, Irache, Lib. 539, 118r.

JOSÉ JOAQUÍN DE ECHAURI Y GARAY

L. C. 
2-4-1673

Fr. Andrés de la Moneda, Abad

Pamplona

AGN, Irache, Lib. 539, 118v.

AGUSTÍN DE ARCE

B. C.

5-4-1673

Fr. Benito de Loyola

San Martín de Ubierna (Burgos)

AGN, Irache, Lib. 539, 118v.

\section{JUAN DE RENGADRE}

D. T.

5-4-1673

Fr. Andrés de la Moneda, Abad

Estella (Pamplona)

AGN, Irache, Lib. 539, 119r.

FRANCISCO MARTÍNEZ DE VILLEGAS

B. C.

24-4-1673

Fr. Benito de Loyola

Villegas (Burgos)

AGN, Irache, Lib. 539, 119r.

JOSÉ VELASCO ESPARZA

B. A. / B. T.

29-4-1673

Fr. Francisco de Ojea / Fr. Benito de Loyola ...

AGN, Irache, Lib. 539, 119v.

FRANCISCO DE ANGULO

B. C.

29-4-1673

Fr. Benito de Loyola

Quincoces (Burgos)

AGN, Irache, Lib. 539, 119v.

JUAN DE OBREGÓN

B. C.

30-4-1673

Fr. Benito de Loyola

Santa María del Valle (Burgos)

AGN, Irache, Lib. 539, 119v.

\section{ANTONIO DE NANCLARES}

B. A.
1-5-1673

Fr. Francisco de Ojea

Santo Domingo de la Calzada (Calahorra)

AGN, Irache, Lib. 539, 119v.

TORIBIO DE BRINGAS

B. C.

5-5-1673

Fr. Benito de Loyola

Matienzo (Burgos)

AGN, Irache, Lib. 539, 120 .

FRANCISCO MANUEL DE SISNIEGA

B. C.

6-5-1673

Fr. Benito de Loyola

Matienzo (Burgos)

AGN, Irache, Lib. 539, 12 or.

JOSÉ DE BARRIGA Y MATA

L. C. / D. C.

6-5-1673

Fr. Benito de Loyola

Burgos

AGN, Irache, Lib. 539, 12 or.

MIGUEL HERMOSO

B. A. / B. T. / L. T.

9-5-1673

Fr. Benito de Loyola, catedrático de Víspe-

ras

Arróniz (Pamplona)

AGN, Irache, Lib. 539, $120 r$.

PEDRO DE CUESTA

B. C.

12-5-1673

Fr. Benito de Loyola

Villadiego (Burgos)

AGN, Irache, Lib. 539, $120 v$.

ANTONIO DE QUEVEDO

B. A. / B. T. / L. T. / D. T.

17-5-1673

Fr. Benito de Loyola

O. S. B.

Abad de Villanueva

AGN, Irache, Lib. 539, $120 v$. 
FRANCISCO DE OJEA

B. A. / B. T. / L. T. / D. T.

17-5-1673

Fr. Benito de Loyola

O. S. B.

Lector de Artes de Irache

AGN, Irache, Lib. 539, $120 v$.

FRANCISCO LÓPEZ DE DICASTILLO

B. C. / L. C.

23-5-1673 / 23-8-1677

Fr. Benito de Loyola / Fr. Gregorio de Tole-

do, Rector y Canciller

Dicastillo (Pamplona)

AGN, Irache, Lib. 539, 120v, 151r.

BERNARDO DE VIÑUELAS

B. A. / B. T. / L. T. / D. T

25-5-1673

Fr. Benito de Loyola

O. S. B.

Predicador Mayor de Nájera

AGN, Irache, Lib. 539, $120 v$.

\section{PEDRO MARURE}

B. C.

27-5-1673

Fr. Benito de Loyola

Villasana (Burgos)

AGN, Irache, Lib. 539, 121r.

\section{ANTONIO DE OQUERRURI}

B. C.

16-6-1673

Fr. Benito de Loyola

Salvatierra (Calahorra)

AGN, Irache, Lib. 539, 121r.

VEREMUNDO IBÁÑEZ

B. A. / B. T. / L. T. / D. T.

17-6-1673

Fr. Manuel Guerra, Abad, Rector de Irache y Calificador de la Suprema

O. S. B.

AGN, Irache, Lib. 539, 121r.

JOSÉ ZAPATA

B. T. / L. T. / D. T
5-7-1673

Fr. José Ruiz, Regente

Villafranca (Pamplona)

AGN, Irache, Lib. 539, 121v.

FRANCISCO LÓPEZ

B. A. / B. T. / L. T. / D. T

5-7-1673

Fr. José Noboa

Villafranca (Pamplona)

AGN, Irache, Lib. 539, 121v.

JUAN DE GADEÓN

B. C.

6-7-1673

Fr. José Noboa

Santa María de Villacampo (Burgos)

AGN, Irache, Lib. 539, $121 \mathrm{v}$.

DIEGO DE BASANTA

B. A. / L. A. / D. A. / B. T. / L. T. / D. T.

19-7-1673 / 29-7-1673

Fr. Manuel Guerra, abad

O. S. B.

AGN, Irache, Lib. 539, 122 r.

DOMINGO DE ARCELLA

L. M. / D. M.

25-7-1673

Fr. Manuel Guerra, abad

Cascante (Tarazona)

AGN, Irache, Lib. 539, 122 .

VENTURA DE CASANUEVA

B. C.

28-7-1673

Fr. José Noboa

Castillo (Burgos)

AGN, Irache, Lib. 539, 122 r.

MATEO DE OCEJO

B. C.

1-8-1673

Reprobado

Matienzo (Burgos)

AGN, Irache, Lib. 539, $122 \mathrm{v}$.

JUAN DE MATA

B. C. 
10-8-1673

Fr. José de Noboa

Iglesias (Burgos)

AGN, Irache, Lib. 539, 122v.

MANUEL DE PORRAS

B. A. / B. T. / L. T. / D. T

11-8-1673

Fr. Manuel Guerra, abad

O. S. B.

AGN, Irache, Lib. 539, 122v.

MARTÍN DE ARENAS

B. A. / B. T. / L. T. / D. T.

11-8-1673

Fr. Manuel Guerra, abad

O. S. B.

AGN, Irache, Lib. 539, 122v.

BERNARDO VARGAS

B. A. / L. A. / D. A. / B. T. / L. T. / D. T.

25-8-1673

Fr. Manuel Guerra, abad

O. S. B.

AGN, Irache, Lib. 539, 123 r.

FRANCISCO DE PINA

B. A. / B. T.

30-8-1673

Fr. Plácido Sanz / Fr. José de Noboa

Villanueva (Burgos)

AGN, Irache, Lib. 539, 123 r.

PEDRO RAFAEL ESPUÑA

B. M.

1-9-1673

Fr. José de Noboa

Berbegal (Lérida)

B. A.

AGN, Irache, Lib. 539, 123 r.

ANDRÉS VECINO

B. C.

6-9-1673

Fr. José Ruiz

Villasilos (Pamplona)

AGN, Irache, Lib. 539, 123v.
FRANCISCO RUIZ VÁZQUEZ

B. A.

20-9-1673

Fr. Plácido Sáenz

Nájera (Calahorra)

AGN, Irache, Lib. 539, $123 \mathrm{v}$.

JOSÉ JIMÉNEZ

B. $\mathrm{M}$.

20-9-1673

Fr. José Ruiz

Grávalos (Calahorra)

AGN, Irache, Lib. 539, $123 v$.

BERNARDO GÓMEZ

B. A. / B. T. / L. T. / D. T.

22-9-1673

Fr. Manuel Guerra, abad

O. S. B.

AGN, Irache, Lib. 539, 123v.

JOSÉ DE PORTILLO

B. A. / B. T. / L. T. / D. T.

22-9-1673

Fr. Manuel Guerra, abad

O. S. B.

AGN, Irache, Lib. 539, 123v.

JUAN ANTONIO JIMÉNEZ SALVADOR

B. C. / L. C. / D. C.

17-5-1673 / 23-9-1673

Fr. Pedro de Castro / Fr. Juan Sánchez,

abad

Villoslada (Calahorra)

AGN, Irache, Lib. 539, 124r, $129 \mathrm{v}$.

FRANCISCO DE OLCOZ

B. A.

30-9-1673

Fr. Plácido Sanz

Barasoain (Pamplona)

AGN, Irache, Lib. 539, 124r.

JOSÉ SALAS

B. C.

1-10-1673

Fr. Pedro de Castro

Burgos

AGN, Irache, Lib. 539, 124r. 
JUAN BERNAL

B. C.

8-10-1673

Fr. Pedro de Castro

Pancorbo (Burgos)

AGN, Irache, Lib. 539, 124 r.

\section{TOMÁS FRANCO}

B. C.

13-10-1673

Fr. José de Noboa

Bermallar (Burgos)

AGN, Irache, Lib. 539, 124v.

FRANCISCO SANZ DE LA IGLESIA

B. C.

16-10-1673

Fr. José de Noboa

Celadilla Sotobrín (Burgos)

AGN, Irache, Lib. 539, 124v.

MARTÍN DE AGUIRRE

B. A. / B. T. / L. T. / D. T.

15-10-1673

Fr. José Gómez, General O. S. B. de España e Inglaterra

O. S. B.

AGN, Irache, Lib. 539, 124v.

JUAN GUTIÉRREZ DE VILLEGAS

B. C.

22-10-1673

Fr. José Ruiz

La Serna (Burgos)

AGN, Irache, Lib. 539, 124v.

\section{MARCOS RONCAL}

B. $\mathrm{M}$.

23-10-1673

Fr. Pedro de Castro

Lerín (Pamplona)

AGN, Irache, Lib. 539, 125 r.

MIGUEL FERNÁNDEZ AGUAYO

B. T.

25-10-1673

Fr. José de Noboa

Silió (Burgos)

AGN, Irache, Lib. 539, 125r.
JOSÉ RUIZ

B. A. / B. T. / L. T. / D. T.

25-10-1673

Fr. José Gómez, General O. S. B. de España

e Inglaterra

O. S. B.

AGN, Irache, Lib. 539, 125r.

MAURO DE SORIA

B. A. / B. T. / L. T. / D. T.

25-10-1673

Fr. José Gómez, General O. S. B. de España e Inglaterra

O. S. B.

AGN, Irache, Lib. 539, 125r.

PLÁCIDO SANZ

B. A. / L. A. / D. A.

25-10-1673

Fr. José Gómez, General O. S. B. de España

e Inglaterra

O. S. B.

AGN, Irache, Lib. 539, 125 r.

DIEGO DE CERRO

B. C.

26-10-1673

Fr. José Ruiz

Castro Urdiales (Burgos)

AGN, Irache, Lib. 539, 125r.

\section{GREGORIO GUTIÉRREZ}

B. C.

8-11-1673 / 10-1-1674

Reprobado

Fr. Ruiz / Fr. Pedro de Castro

Fresnedo (Burgos)

AGN, Irache, Lib. 539, 125v.

MARTÍN DE LABRIT

B. A. / B. M.

16-11-1673

Fr. Plácido Sanz / Fr. José de Noboa

Izal (Pamplona)

AGN, Irache, Lib. 539, $125 \mathrm{v}$.

SEBASTIÁN ORTIZ

B. T. 
23-11-1673

Fr. José Ruiz

Labarces (Burgos)

AGN, Irache, Lib. 539, 125v.

PEDRO CUBILLAS

B. C.

26-11-1673

Fr. Pedro de Castro

Escalante (Burgos)

AGN, Irache, Lib. 539, 125v.

\section{ANTONIO DE GUIA}

B. C.

28-11-1673

Fr. José de Noboa

Castro Urdiales (Burgos)

AGN, Irache, Lib. 539, 125v.

PEDRO DE MONTELLANO

B. C.

28-11-1673

Fr. José Ruiz

Castro Urdiales (Burgos)

AGN, Irache, Lib. 539, 126r.

MIGUEL DE VILLANUEVA SALAZAR

B. C.

29-11-1673

Fr. Pedro de Castro

Concejo (Burgos)

AGN, Irache, Lib. 539, 126r.

ANTONIO DE PEDRAZA

B. A. / B. T.

16-12-1673

Fr. Plácido Sanz / Fr. José de Noboa

B... (Burgos)

AGN, Irache, Lib. 539, 126r.

BARTOLOMÉ DE ONZA

B. C.

23-12-1673

Fr. José Ruiz

Burgos

AGN, Irache, Lib. 539, 126r.

ANTONIO DE LA CUESTA

B. A. / B. T.
30-1-1674

Fr. Plácido Sanz / Fr. Pedro de Castro

Terrazos (Burgos)

AGN, Irache, Lib. 539, 126v.

MIGUEL DE LA MAGDALENA

B. C.

15-2-1674

Fr. José de Noboa

Guriezo (Burgos)

AGN, Irache, Lib. 539, 126v.

\section{ANDRÉS MARTÍNEZ}

B. A.

17-2-1674

Fr. Plácido Sanz

Castromocho (Palencia)

AGN, Irache, Lib. 539, 126v.

JUAN DE TERMIÑO

B. A. / B. T.

27-2-1674

Fr. Plácido Sanz / Fr. José Ruiz

Anturia de la Cantera (Burgos)

AGN, Irache, Lib. 539, 127 r.

JUAN DE OLAZANGUTÍA

L. M. / D. M.

7-3-1674

Fr. Juan Sánchez, abad

Pamplona

AGN, Irache, Lib. 539, 127r.

VENTURA JIMÉNEZ

B. A. / B. T.

10-3-1674

Fr. Plácido Sanz / Fr. Pedro de Castro

Burgos

AGN, Irache, Lib. 539, 127r.

JUAN DE ARTIGUES

B. A. / B. T.

10-3-1674

Fr. Plácido Sanz / Fr. José de Noboa

Ranedo (Burgos)

AGN, Irache, Lib. 539, 127r.

JUAN DE ARTIGUES

B. C. 
10-3-1674

Fr. José Ruiz

Quintana Martín Galíndez (Burgos)

AGN, Irache, Lib. 539, 127v.

\section{TORIBIO DE RADILLO DE ARCE}

B. T.

17-3-1674

Fr. Pedro de Castro

San Vicente de la Barquera (Burgos)

AGN, Irache, Lib. 539, 127v.

BERNARDO FERNÁNDEZ TAMAYO

B. C.

22-3-1674

Fr. José Ruiz

Poza (Burgos)

AGN, Irache, Lib. 539, 127v.

JUAN BAUTISTA IBÁÑNZZ

B. A. / B. M.

11-4-1674

Fr. Plácido Sanz / Fr. Pedro de Castro

Sangüesa (Pamplona)

AGN, Irache, Lib. 539, 127v.

PEDRO VERGARA

B. A. / B. T. / L. T.

16-4-1674

Fr. José Ruiz

O. S. B.

Abad de Oña

AGN, Irache, Lib. 539, 128r.

JOSÉ CENZANO

B. C.

17-4-1674

Fr. José de Noboa

Los Arcos (Pamplona)

AGN, Irache, Lib. 539, 128r.

ALEJANDRO DE TAGLE

B. C.

23-4-1674

Fr. José Ruiz

Ruilova (Burgos)

AGN, Irache, Lib. 539, 128r.
ANTONIO DE PRADO

B. A. / B. T.

24-4-1674

Fr. Plácido Sanz / Fr. Pedro de Castro

Villadiego (Burgos)

AGN, Irache, Lib. 539, 128r.

JUAN GALVES

B. A.

25-4-1674

Fr. Plácido Sanz

Pamplona

AGN, Irache, Lib. 539, 128r.

PEDRO VERGARA

B. A.

25-4-1674

Fr. Plácido Sanz

Pamplona

AGN, Irache, Lib. 539, 128r.

JUAN FRANCISCO SALVADOR

B. A.

25-4-1674

Fr. Plácido Sanz

Icar (Pamplona)

AGN, Irache, Lib. 539, 128r.

JUAN DE AÑESENA

B. A.

25-4-1674

Fr. Plácido Sanz

Vera (Pamplona)

AGN, Irache, Lib. 539, 128r.

JULIÁN DE ...ERICA

B. A.

25-4-1674

Fr. Plácido Sanz

Tafalla (Pamplona)

AGN, Irache, Lib. 539, 128v.

BALTASAR DE BELZUNCE

B. A.

25-4-1674

Fr. Plácido Sanz

Pamplona

AGN, Irache, Lib. 539, 128v. 
JUAN FAZOAGA

B. A.

25-4-1674

Fr. Plácido Sanz

Oyarzun (Pamplona)

AGN, Irache, Lib. 539, 128v.

JOSÉ DE VIDARTE

B. A.

25-4-1674

Fr. Plácido Sanz

Pamplona

AGN, Irache, Lib. 539, 128v.

DIEGO ARÍSTEGUI

B. A.

25-4-1674

Fr. Plácido Sanz

Pamplona

AGN, Irache, Lib. 539, 128v.

FERMÍN DE OLLO

B. A.

25-4-1674

Fr. Plácido Sanz

Pamplona

AGN, Irache, Lib. 539, 128v.

PEDRO ABADÍA

B. A.

25-4-1674

Fr. Plácido Sanz

Beasain (Pamplona)

AGN, Irache, Lib. 539, 128v.

ESTEBAN DE IBARROLA Y SAN VICEN-

TE

B. A.

25-4-1674

Fr. Plácido Sanz

Elorz (Pamplona)

AGN, Irache, Lib. 539, 128v.

JUAN DE ARIZA

B. A.

25-4-1674

Fr. Plácido Sanz

Pamplona

AGN, Irache, Lib. 539, 128v.

\section{JUAN DE AGUADO}

B. A.

25-4-1674

Fr. Plácido Sanz

Falces (Pamplona)

AGN, Irache, Lib. 539, 128v.

JUAN DE RIPALDA

B. A. / L. A.

25-4-1674

Fr. Juan Sánchez, abad

Olite (Pamplona)

AGN, Irache, Lib. 539, 128v.

DIONISIO DE COLMENARES

B. A. / L. A.

25-4-1674

Fr. Juan Sánchez, abad

Pamplona

AGN, Irache, Lib. 539, 128v.

JOAQUÍN DE ERRAZU

B. A. / L. A.

25-4-1674

Fr. Juan Sánchez, abad

Pamplona

AGN, Irache, Lib. 539, 128v.

JUAN DÍEZ IGLESIA BUSTAMANTE

B. C.

26-4-1674

Fr. José Ruiz

Casar de Periedo (Burgos)

AGN, Irache, Lib. 539, 128v.

SEBASTIÁN DE RUISEÑADA

B. T.

30-4-1674

Fr. José Ruiz

San Vicente de la Barquera (Burgos)

AGN, Irache, Lib. 539, 128v.

GABRIEL PÉREZ

B. C.

2-5-1674

Fr. Pedro de Castro

Presencio (Burgos)

AGN, Irache, Lib. 539, 129r. 
LUCAS DE GÁLLEGO

L. C. / D. C.

4-5-1674

Fr. Juan Sánchez, abad

Ayerbe (Huesca)

AGN, Irache, Lib. 539, 129 r.

MATEO RODRÍGUEZ

B. C.

10-5-1674

Fr. José de Noboa

La Trilla (Burgos)

AGN, Irache, Lib. 539, 129 r.

PEDRO LÓPEZ

B. T.

11-5-1674

Fr. José Ruiz

Guriezo (Burgos)

AGN, Irache, Lib. 539, 129 r.

JUAN DE LODOSA

B. M.

11-5-1674

Fr. Pedro de Castro

Calahorra

AGN, Irache, Lib. 539, $129 \mathrm{v}$.

JOSÉ FERNÁNDEZ BRAVO

B. C.

19-5-1674

Fr. José Ruiz

Renedo (Burgos)

AGN, Irache, Lib. 539, 129v.

JUAN FRANCISCO DEL PUEYO

B. M.

4-6-1674

Fr. José de Noboa

Caspe (Zaragoza)

AGN, Irache, Lib. 539, $129 \mathrm{v}$.

JERÓNIMO DE LA PLAZA

B. A. / B. T.

5-6-1674

Fr. Plácido Sanz

Albelda (Zaragoza)

AGN, Irache, Lib. 539, 129v.
DOMINGO DE MATANZA

B. C.

8-6-1674

Fr. Pedro de Castro

Villaverde (Burgos)

AGN, Irache, Lib. 539, 13 or.

JUAN DE ARCE

B. C.

19-6-1674

Fr. José Ruiz

La Pinilla (Burgos)

AGN, Irache, Lib. 539, 13 or.

DIEGO URIBE

B. C.

20-6-1674

Fr. Pedro de Castro

Tuesta (Burgos)

AGN, Irache, Lib. 539, 13 or.

PEDRO URIBE

B. C.

20-6-1674

Fr. Pedro de Castro

Tuesta (Burgos)

AGN, Irache, Lib. 539, 13 or.

PEDRO RODRIGO

B. A. / B. T.

23-6-1674

Fr. Plácido Sanz / Fr. José Ruiz

Osma

AGN, Irache, Lib. 539, $130 v$.

ANDRÉS REBOLLO MANRIQUE

B. C.

13-7-1674

Fr. Pedro de Castro

Solas (Burgos)

AGN, Irache, Lib. 539, $130 v$.

DOMINGO RUIZ DE ARREDONDO

B. C.

24-7-1674

Fr. Pedro de Castro

Cornejo (Burgos)

AGN, Irache, Lib. 539, $130 v$. 


\section{DIEGO PÉREZ REBOLLO}

B. C.

24-7-1674

Fr. Pedro de Castro

Lences (Burgos)

AGN, Irache, Lib. 539, $130 v$.

JOSÉ GUTIÉRREZ

B. A. / B. T.

27-7-1674

Fr. Plácido Sanz / Fr. José Ruiz

Burgos

AGN, Irache, Lib. 539, $130 v$.

PEDRO DÍAZ DE AGUSTÍN

B. C.

30-7-1674

Fr. Pedro de Castro

Ubierna (Burgos)

AGN, Irache, Lib. 539, 131r.

MANUEL DE IGAY

B. A. / B. T.

3-8-1674

Fr. Plácido Sanz / Fr. Pedro de Castro

Burgos

AGN, Irache, Lib. 539, 131r.

SIMÓN DE SAN JUAN

B. C.

3-8-1674

Fr. Pedro de Castro

Solas (Burgos)

AGN, Irache, Lib. 539, 131r.

JUAN MARTÍNEZ

B. A. / B. T.

19-8-1674

Fr. Plácido Sanz / Fr. José de Noboa

Burgos

AGN, Irache, Lib. 539, 131r.

JUAN DE MADRIGAL

B. C.

9-9-1674

Fr. José de Noboa

Presencio (Burgos)

AGN, Irache, Lib. 539, 131v.
JOSÉ IBÁÑEZ

B. C.

9-9-1674

Fr. José de Noboa

Presencio (Burgos)

AGN, Irache, Lib. 539, 131v.

JUAN DEL VAL

B. C.

10-9-1674

Fr. José de Noboa

Pangusión (Burgos)

AGN, Irache, Lib. 539, 131v.

MIGUEL JOSÉ ANTONIO DE NOVALLAS

L. M. / D. M.

12-9-1674

Fr. Juan Sánchez, abad

Tarazona

AGN, Irache, Lib. 539, 131v.

BERNARDO RUIZ DE CASTAÑEDA

B. C.

20-9-1674

Fr. José de Noboa

Llano (Burgos)

AGN, Irache, Lib. 539, 131v.

JOSÉ DE LA FUENTE

B. A. / B. T.

22-9-1674

Fr. Plácido Sanz / Fr. José Ruiz

Burgos

AGN, Irache, Lib. 539, 132r.

MANUEL DE ZÁRATE

B. C.

25-9-1674

Fr. José de Noboa

Salinas de Añana (Burgos)

AGN, Irache, Lib. 539, 132r.

JUAN DE SOLÍS

B. A. / B. T. / L. T. / D. T.

26-9-1674

Fr. Juan Sánchez, abad

O. S. B.

AGN, Irache, Lib. 539, 132r. 
JOSÉ cosío

B. C.

1-10-1674

Fr. José Ruiz

San Sebastián (Burgos)

AGN, Irache, Lib. 539, 132r.

DOMINGO BEAMONT Y ARIZCAIN

B. A.

3-10-1674

Fr. Juan Sánchez, abad

Pamplona

AGN, Irache, Lib. 539, 132v.

DIEGO DE IBRICU

B. A. / B. M.

7-10-1674

Fr. José de Noboa

Estella (Pamplona)

AGN, Irache, Lib. 539, 132v.

ANTONIO DE CASTEJÓN

L. A.

8-10-1674

Fr. Juan Sánchez, abad

Alfaro (Tarazona)

AGN, Irache, Lib. 539, 132v.

JOSÉ DE ICHASO EZTALAURRUTIA

B. A.

11-10-1674

Fr. Plácido Sanz

Santo Domingo de la Calzada (Calahorra)

AGN, Irache, Lib. 539, 132v.

DOMINGO FUENTES Y PERALTA

B. A.

11-10-1674

Fr. Plácido Sanz

Santo Domingo de la Calzada (Calahorra)

AGN, Irache, Lib. 539, 132v.

MATÍAS BARRÓN

B. C.

14-10-1674

Fr. José Ruiz

Villanueva (Burgos)

AGN, Irache, Lib. 539, 133r.

\section{JUAN AUGUSTO}

B. C.

14-10-1674

Fr. José de Noboa

... (Burgos)

AGN, Irache, Lib. 539, 133r.

JUAN MAGÍN

B. A.

14-10-1674

Fr. Plácido Sanz

O. de M.

AGN, Irache, Lib. 539, 133r.

JUAN DE REGULES

B. C.

19-10-1674

Fr. José Ruiz

Medina de Pomar (Burgos)

AGN, Irache, Lib. 539, 133 r.

SEBASTIÁN REBOLLO

B. A. / B. T.

6-11-1674

Fr. José de Noboa

Villarán (Burgos)

AGN, Irache, Lib. 539, 133v.

JUAN MATÍAS ENÉRIZ Y GUAVIL

B. M.

10-11-1674

Fr. José Ruiz

Puente La Reina (Pamplona)

AGN, Irache, Lib. 539, $133 \mathrm{v}$.

BALTASAR DÍAZ

B. C.

22-11-1674

Fr. José de Noboa

Presencio (Burgos)

AGN, Irache, Lib. 539, 133v.

PABLO DEL MORAL Y TEJADA

B. C.

28-11-1674

Fr. José de Noboa

Navarrete (Calahorra)

AGN, Irache, Lib. 539, 133 v. 
FRANCISCO DE CEBALLOS

B. A. / B. T. / L. T. / D. T.

4-12-1674

Fr. Juan Sánchez, abad

O. S. B.

AGN, Irache, Lib. 539, 133 v.

TOMÁS FERNÁNDEZ DEL CASTILLO

B. C.

5-12-1674

Fr. Benito de Loyola

Montenegro (Burgos)

AGN, Irache, Lib. 539, 134r.

PEDRO RUIZ DE VILLADIEGO

L. C. / D. C.

19-12-1674 / 19-11-1675

Fr. Juan Sánchez, abad

Alfaro (Tarazona)

AGN, Irache, Lib. 539, 134r, 141r.

\section{JUAN CALDERÓN}

B. C.

22-12-1674

Fr. José de Noboa

Pomar (Burgos)

AGN, Irache, Lib. 539, 134r.

PEDRO CANDUELA

B. C.

22-12-1674

Fr. José Ruiz

Pomar (Burgos)

AGN, Irache, Lib. 539, 134r.

PEDRO GÓMEZ DE OLEA

B. A. / B. T.

5-1-1675

Fr. Plácido Sanz / Fr. José de Noboa

Rebolleda (Burgos)

AGN, Irache, Lib. 539, 134v.

FRANCISCO GÓMEZ RAMÍREZ

B. C.

5-1-1675

Fr. José Ruiz

Aguilar de Campo (Burgos)

AGN, Irache, Lib. 539, 134v.
VALERIO DE LOS RÍOS Y SALCEDO

L. C.

15-2-1675

Fr. Juan Sánchez, abad

Alfaro (Tarazona)

AGN, Irache, Lib. 539, 134v.

DOMINGO DE LASARTE

B. C.

16-2-1675

Fr. Benito de Loyola

Concejo de Guines (Burgos)

AGN, Irache, Lib. 539, 134v.

MANUEL DE REBOLLEDO

B. C.

17-2-1675 Reprobado

31-7-1677 Aprobado

Fr. José Ruiz / Fr. Vicente Díez

Tosantos (Burgos)

AGN, Irache, Lib. 539, 134v, 151r.

FRANCISCO DE GÜEMES

B. C.

17-2-1675 / 16-3-1675

Reprobado

Fr. José Ruiz / Fr. Loyola

Villaverde (Burgos)

AGN, Irache, Lib. 539, 134v, 135v.

\section{DIEGO GARCÍA}

B. C.

19-2-1675 / 19-2-1675

Reprobado

Fr. José Ruiz / Fr. Mauro de Soria

Rebolledo de la Torre (Burgos)

AGN, Irache, Lib. 539, 135r.

DIEGO GIL

B. A.

20-2-1675

Fr. Plácido Sanz

Ausejo (Calahorra)

AGN, Irache, Lib. 539, 135r.

TOMÁS DE AUSEJO

B. A.

20-2-1675 
Fr. Plácido Sanz

Larraga (Pamplona)

AGN, Irache, Lib. 539, 135r.

JUAN IGNACIO DE RECONDO

B. A.

20-2-1675

Fr. Plácido Sanz

Astiaso (Pamplona)

AGN, Irache, Lib. 539, 135r.

ANDRÉS TOMÉ DE ÁBALOS

B. A.

3-3-1675

Fr. Plácido Sanz

Anguiano (Calahorra)

AGN, Irache, Lib. 539, 135r.

CUSTODIO DÍAZ

B. C.

3-3-1675

Fr. José de Noboa

Miravieve (Burgos)

AGN, Irache, Lib. 539, 135r.

JOSÉ DE LEZANA

L. C.

6-3-1675

Fr. José Ruiz

Robles (Calahorra)

AGN, Irache, Lib. 539, 135r.

JUAN ANTONIO DE LA BODEGA

B. A. / B. T.

13-3-1675

Fr. José Ruiz / Fr. Plácido Sanz

Cicero (Burgos)

AGN, Irache, Lib. 539, 135r.

LORENZO DE LA PEÑA

B. A. / B. T.

13-3-1675

Fr. José Ruiz / Fr. Plácido Sanz

Villadiego (Burgos)

AGN, Irache, Lib. 539, 135r.

JOSÉ SÁNCHEZ

B. A.
19-3-1675

Fr. Plácido Sanz

Anguiano (Calahorra)

AGN, Irache, Lib. 539, 135v.

PEDRO ÁLVAREZ CARRERA

B. C.

22-3-1675

Fr. José de Noboa

Villares (Burgos)

AGN, Irache, Lib. 539, 135v.

JERÓNIMO DE RUFIA

B. A. / B. M.

22-3-1675

Fr. Plácido Sanz

Lumbier (Pamplona)

AGN, Irache, Lib. 539, 135v.

JUAN DE DEIA Y AGOITIA

B. C.

24-3-1675

Fr. Benito de Loyola

Pancorbo (Burgos)

AGN, Irache, Lib. 539, 135v.

FRANCISCO DE LEIBA

B. C.

24-3-1675

Fr. Benito de Loyola

Pancorbo (Burgos)

AGN, Irache, Lib. 539, 135v.

TORIBIO RUBÍN DE CELIS

B. T.

25-3-1675

Fr. Benito de Loyola

Cades (Burgos)

AGN, Irache, Lib. 539, 135v.

DIEGO RUIZ DE OGARRIO

B. C.

30-3-1675

Fr. José Ruiz

Haedo de las Pueblas (Burgos)

AGN, Irache, Lib. 539, 135v.

JUAN DE FRÍAS

B. A. 
3-4-1675

Fr. Plácido Sanz

Sotés (Calahorra)

AGN, Irache, Lib. 539, 136r.

DOMINGO ALCALDE

B. A. / B. T.

20-4-1675

Fr. Plácido Sanz / Fr. Benito de Loyola

Burgos

AGN, Irache, Lib. 539, $136 r$.

BENITO SALA

B. A. / L. A. / D. A. / B. T. / L. T. / D. T.

12-5-1675 / 14-5-1675

Fr. Juan Sánchez, abad

O. S. B.

AGN, Irache, Lib. 539, 136r.

ANTONIO SAIZ

B. C.

17-5-1675

Fr. José Ruiz

Sasamón (Burgos)

AGN, Irache, Lib. 539, 136v.

FRANCISCO DE LEIZA

B. A.

21-5-1675

Fr. José Ruiz

Pamplona

AGN, Irache, Lib. 539, 136v.

JUAN ESTEBAN DE CENTENO

B. C.

27-5-1675

Fr. Benito de Loyola

Arenillas de Pisuerga (Burgos)

AGN, Irache, Lib. 539, 136v.

JUAN DE EZCURRA

B. $\mathrm{M}$.

14-6-1675

José de Noboa, Lector de Teología

Asiáin (Pamplona)

AGN, Irache, Lib. 539, 136v.

MANUEL DE ARÓZTEGUI

B. L. / L. L. / D. L.
16-6-1675

Fr. Juan Sánchez, abad

Benabarre (Lérida)

AGN, Irache, Lib. 539, 136v.

CRISTÓBAL DE LA TOBA

B. C.

16-6-1675

José de Noboa

Beci (Burgos)

AGN, Irache, Lib. 539, 137r.

JUAN GONZÁLEZ DE ANDRADE Y VE-

LÁZQUEZ

B. C. / L. C.

18-6-1675

Fr. Juan Sánchez, abad

Molina de Aragón (Sigüenza)

AGN, Irache, Lib. 539, 137r.

MARTÍN AMBROSIO BERNAL

B. C.

19-6-1675

Fr. Benito de Loyola

Oyón (Pamplona)

AGN, Irache, Lib. 539, 137r.

JERÓNIMO DE SAN CRISTÓBAL

B. A. / B. T.

23-6-1675

Fr. José de Noboa

M... (Burgos)

AGN, Irache, Lib. 539, 137v.

FELIPE DE DUREDO

B. C.

28-6-1675

Fr. Benito de Loyola

Sopuerta (Burgos)

AGN, Irache, Lib. 539, 137v.

FRANCISCO DE RIBAS

B. C.

30-6-1675

Fr. José de Noboa

Haedo (Burgos)

AGN, Irache, Lib. 539, 137v. 
JUAN DE LLARENA

B. C.

12-7-1675

Fr. José Ruiz

San Juan (Burgos)

AGN, Irache, Lib. 539, 137v.

JUAN DE LAS HERRERÍAS

B. C.

12-7-1675

Fr. José de Noboa

Sopuerta (Burgos)

AGN, Irache, Lib. 539, 138r.

FRANCISCO DE ALSÚA

B. T.

15-7-1675

Fr. José Ruiz

Marquina (Burgos)

AGN, Irache, Lib. 539, 138r.

PEDRO PÉREZ DE HOYOS

B. C.

21-7-1675

Fr. José Ruiz

Burgos

AGN, Irache, Lib. 539, 138r.

PEDRO PÉREZ DE ROBLES

B. C.

21-7-1675

Fr. José Ruiz

Burgos

AGN, Irache, Lib. 539, 138r.

GONZALO DE ZAMACONA

B. C.

23-7-1675

Fr. José Ruiz

Castro Urdiales (Burgos)

AGN, Irache, Lib. 539, 138v.

PEDRO CLEMENTE DE ORTIGOSA

B. T.

28-7-1675

Fr. José de Sojo, Regente

Ventrosa (Burgos)

AGN, Irache, Lib. 539, 138v.
PEDRO DE CAPETILLO

B. C.

30-7-1675

Fr. José Ruiz

Castro Urdiales (Burgos)

AGN, Irache, Lib. 539, 138v.

JOSÉ PLATERO

B. C.

30-7-1675

Fr. José Ruiz

Barbadillo del Mercado (Burgos)

AGN, Irache, Lib. 539, 138v.

TOMÁS PÉREZ

B. A. / B. T.

31-7-1675

Fr. José de Sojo

Reprobado

Olmos de la Picaza (Burgos)

AGN, Irache, Lib. 539, 138v.

FELIPE DE NAVEDA Y GARNICA

B. C.

7-8-1675

Fr. José Ruiz

Bárcena (Burgos)

AGN, Irache, Lib. 539, 139 r.

DOMINGO VILLANA

B. C.

13-8-1675

Fr. José de Sojo

Ayuelas (Burgos)

AGN, Irache, Lib. 539, 139 r.

GASPAR DE LA VIÑA

B. C.

13-8-1675

Fr. José Ruiz

Guinicio (Burgos)

AGN, Irache, Lib. 539, 139r.

ÍNIGO VÉLEZ DE FRÍAS

B. C.

8-9-1675

Fr. Mauro de Soria, Lector de Teología

Trespaderne (Burgos)

AGN, Irache, Lib. 539, 139r. 
ANDRÉS MONTERO DÍEZ

B. C.

9-9-1675 Reprobado

Fr. José de Sojo

8-4-1677 Aprobado

Fr. Mauro de Soria

Trespaderne (Burgos)

AGN, Irache, Lib. 539, 139v, $149 \mathrm{r}$.

MIGUEL DE LA PEÑA

B. C.

17-9-1675

Fr. José de Sojo

Villasilos (Burgos)

AGN, Irache, Lib. 539, 139v.

\section{ANDRÉS GONZÁLEZ}

B. C.

17-9-1675

Fr. José de Sojo

Villasilos (Burgos)

AGN, Irache, Lib. 539, 139v.

JUAN DE PALACIOS

B. A. / B. T.

18-9-1675

Fr. José de Sojo

Villacampo (Burgos)

AGN, Irache, Lib. 539, 139v.

FRANCISCO LÓPEZ FRÍAS

B. C.

21-9-1675

Fr. José de Sojo

Trespaderne (Burgos)

AGN, Irache, Lib. 539, 14 or.

LUCAS FERNÁNDEZ DE LA PEÑA

B. C. / B. T.

21-9-1675 / 22-9-1675

Reprobado dos veces

Fr. José de Sojo

Frías (Burgos)

AGN, Irache, Lib. 539, 14 or.

MANUEL MATÉ VÉLEZ

B. A. / B. T.

28-9-1675
Reprobado dos veces

Fr. José de Sojo

Alonsabilla (Palencia)

AGN, Irache, Lib. 539, 140 or.

PEDRO DE QUINTANA

B. C.

6-10-1675

Fr. Mauro de Soria

Quintanavides (Burgos)

AGN, Irache, Lib. 539, 140r.

BERNARDO DE BARONA

B. C.

6-10-1675

Fr. Mauro de Soria

Villanueva del Conde (Burgos)

AGN, Irache, Lib. 539, 14 or.

JOSÉ FRANCISCO FERNÁNDEZ MAR-

MANILLO

B. C.

13-10-1675

Fr. Mauro de Soria

Uruñuela (Calahorra)

AGN, Irache, Lib. 539, $140 v$.

DOMINGO DE LA PEÑA

B. A.

23-10-1675

Fr. Andrés del Busto

Valdeande (Osma)

AGN, Irache, Lib. 539, $140 v$.

DOMINGO DE VALPUESTA

B. A. / B. T.

24-10-1675 / 19-11-1675

Fr. Andrés del Busto

Reprobado dos veces

Fr. José de Sojo

Villanañe (Burgos)

AGN, Irache, Lib. 539, 140v-141v.

FRANCISCO DE ARROYO

B. A. / B. T.

28-10-1675 / 21-11-1675

Reprobado B. T.

Fr. Andrés del Busto / Fr. José de Sojo 
Hornillos del Camino (Burgos)

AGN, Irache, Lib. 539, $140 v$.

JOSÉ DE ALCEDO

B. C.

29-10-1675

Fr. José Ruiz

Somorrostro (Burgos)

AGN, Irache, Lib. 539, $140 v$.

JOSÉ DE CUÉLLAR RUESGA

B. C.

30-10-1675

Fr. José de Sojo

Santander (Burgos)

AGN, Irache, Lib. 539, $140 v$.

MIGUEL DE BONETA

B. M.

31-10-1675

Fr. José Ruiz

Peralta (Pamplona)

AGN, Irache, Lib. 539, $140 v$.

ANDRÉS ALCALDE

B. C.

1-11-1675

Fr. José de Sojo

Hornillos del Camino (Burgos)

AGN, Irache, Lib. 539, 141r.

\section{ANDRÉS MONTOJO}

B. C.

4-11-1675

Reprobado dos veces

Fr. José de Sojo

Traspaderne (Burgos)

AGN, Irache, Lib. 539, 141r.

JUAN DE URREZ

B. A. / B. T.

10-11-1675

Fr. Andrés del Busto / Fr. José de Sojo

Biedma de Juarros (Burgos)

AGN, Irache, Lib. 539, 141r.

BARTOLOMÉ DE PINEDO

B. A. / B. T.
13-11-1675

Fr. Andrés del Busto / Fr. José Ruiz

Guedes (Burgos)

AGN, Irache, Lib. 539, 141r.

MANUEL GARCÍA DE FRESNO

B. C.

20-11-1675

Fr. Mauro de Soria

Burgos

AGN, Irache, Lib. 539, 141r.

JOSÉ GONZÁLEZ

B. C.

22-11-1675 / 5-1-1676

Reprobado dos veces

Fr. José de Sojo

Presencio (Burgos)

AGN, Irache, Lib. 539, 141r, 142r.

DIEGO DE ÁLVAREZ

B. C.

22-11-1675

Fr. José Ruiz

Burgos

AGN, Irache, Lib. 539, 141v.

JUAN DE SOTO

B. A. / B. T.

23-11-1675

Fr. Andrés del Busto / Fr. Mauro de Soria

Solduengo (Burgos)

AGN, Irache, Lib. 539, 141v.

JUAN DE ARAGÓN

B. C.

4-12-1675

Fr. José Ruiz

Brieba de Juarros (Burgos)

AGN, Irache, Lib. 539, 141v.

TOMÁS PÉREZ

B. C.

8-12-1675

Reprobado

Fr. José de Sojo

Olmos de la Picaza (Burgos)

AGN, Irache, Lib. 539, 141v. 
DOMINGO PINTO

B. C.

12-12-1675

Fr. Mauro de Soria

Villahizán (Burgos)

AGN, Irache, Lib. 539, 141v.

JUAN RUIZ DE LA CANTERA

B. C.

21-12-1675

Fr. José de Sojo

Orbañanos (Burgos)

AGN, Irache, Lib. 539, 141v.

GASPAR DE SALINAS

B. A. / B. T.

29-12-1675

Fr. Andrés del Busto / Fr. Mauro de Soria

Reprobado

Cellorigo (Burgos)

AGN, Irache, Lib. 539, 141v.

JOSÉ SÁEZ

B. C.

14-1-1676

Fr. Mauro de Soria

Quintanilla de Loma (Burgos)

AGN, Irache, Lib. 539, 142r.

JOSÉ GONZÁLEZ

B. C.

27-1-1676 / 27-6-1676

Reprobado

Fr. José de Sojo / Fr. Mauro de Soria

Revenga (Burgos)

AGN, Irache, Lib. 539, 142r, $143 v$.

FRANCISCO DEL AGUA

B. C.

27-1-1676 / 7-3-1676

Reprobado

Fr. José Ruiz / Fr. José de Sojo

Mansilla (Burgos)

AGN, Irache, Lib. 539, 142 rv.

JUAN MANUEL DE LA PORTILLA

B. C.

30-1-1676
Fr. Mauro de Soria

Aguilar del Campo (Burgos)

AGN, Irache, Lib. 539, 142r.

DOMINGO GARCÍA

B. A. / B. T.

30-1-1676

Fr. José de Sojo

Terradillos

Burgos

AGN, Irache, Lib. 539, 142r.

JUAN BAUTISTA DE PUERTO ARCE

B. C.

7-2-1676

Fr. José Ruiz

Selaya (Burgos)

AGN, Irache, Lib. 539, 142r.

ANDRÉS GÓMEZ

B. C.

9-2-1676

Fr. Mauro de Soria

Villaquirán de los Infantes (Burgos)

AGN, Irache, Lib. 539, 142r.

BARTOLOMÉ DE OSÉS

B. M.

12-2-1676

Fr. José Ruiz

Mendogorria (Pamplona)

AGN, Irache, Lib. 539, 142r.

JUAN ANTONIO DE CHÁVARRI

B. C. / L. C. / D. C.

22-2-1676

Fr. Juan Sánchez, abad

Madrid (Toledo)

AGN, Irache, Lib. 539, $142 \mathrm{v}$.

ÁNGEL DE LEÓN

B. C.

3-3-1676

Fr. José de Sojo

Castrillo de Río Pisuerga (Burgos)

AGN, Irache, Lib. 539, 142V.

PEDRO GUTIÉRREZ

B. C. 
7-3-1676

Fr. Mauro de Soria

Selaya (Burgos)

AGN, Irache, Lib. 539, $142 \mathrm{v}$.

TADEO MERINO

B. C.

9-3-1676 / 10-3-1676

Reprobado

Fr. José de Sojo / Fr. Andrés del Busto

Padilla de Arriba (Burgos)

AGN, Irache, Lib. 539, 142v.

PEDRO DE BECERRIL

B. C.

9-3-1676 / 10-3-1676

Reprobado

Fr. José de Sojo / Fr. Andrés del Busto

Padilla de Arriba (Burgos)

AGN, Irache, Lib. 539, 142v.

JUAN DE VELASCO

B. A. / B. T.

26-3-1676

Fr. Andrés del Busto / Fr. Mauro de Soria

Pomaluengo (Burgos)

AGN, Irache, Lib. 539, 142v.

\section{LUCAS DE BERNALES}

B. C.

6-4-1676

Fr. José de Sojo

Amoz (Burgos)

AGN, Irache, Lib. 539, 143 r.

\section{MATEO PRIETO}

B. C.

13-4-1676

Fr. José Ruiz

Aguilar de Bureba (Burgos)

AGN, Irache, Lib. 539, 143r.

JUAN DE SOTO

B. C.

17-4-1676

Fr. Mauro de Soria

Las Bergas (Burgos)

AGN, Irache, Lib. 539, 143r.

\section{DIEGO DE SANABIA}

B. C.

20-4-1676

Fr. José de Sojo

Laredo (Burgos)

AGN, Irache, Lib. 539, 143r.

JUAN PASCUAL

B. C.

14-5-1676

Fr. José Ruiz

Santa María del Campo (Burgos)

AGN, Irache, Lib. 539, 143r.

\section{DOMINGO DE ODRIA}

B. A.

17-5-1676

Fr. Andrés del Busto

Egóibar (Calahorra)

AGN, Irache, Lib. 539, 143r.

TOMÁS DE LUCUZE

B. A

17-5-1676

Fr. Andrés del Busto

Pamplona

AGN, Irache, Lib. 539, 143r.

MARTÍN DE VERGARA

B. A.

17-5-1676

Fr. Andrés del Busto

Zizur Mayor (Pamplona)

AGN, Irache, Lib. 539, 143 r.

ESTEBAN ANTONIO

B. C.

18-5-1676

Fr. José Ruiz

Citores del Páramo (Burgos)

AGN, Irache, Lib. 539, 143r.

\section{SALVADOR CRUZAT}

B. M.

13-6-1676

Fr. Mauro de Soria

Tudela (Nullius Diocesis)

AGN, Irache, Lib. 539, $143 \mathrm{v}$. 
ISIDRO DE LA FUENTE

B. C.

21-6-1676

Reprobado

Fr. Mauro de Soria

Aguilar de la Bureba (Burgos)

AGN, Irache, Lib. 539, 143v.

\section{GREGORIO CASADO}

B. C.

29-6-1676

Fr. José Ruiz

Santa María del Campo (Burgos)

AGN, Irache, Lib. 539, 143v.

PEDRO MANSO

B. C.

4-7-1676

Fr. Mauro de Soria

Santa María del Campo (Burgos)

AGN, Irache, Lib. 539, 143v.

MANUEL SARMIENTO DE LA PEÑA

B. C.

17-7-1676

Fr. José Ruiz

Quintanaloma (Burgos)

AGN, Irache, Lib. 539, 143v.

PEDRO ORTIZ DE GUECHO

B. C.

23-7-1676

Fr. José Ruiz

Portilla (Burgos)

AGN, Irache, Lib. 539, 143v.

FRANCISCO DE LA CUESTA

B. C.

23-7-1676

Fr. Vicente Díez, vicecanciller

Villorejo (Burgos)

AGN, Irache, Lib. 539, 144r.

FRANCISCO ABAD HERRERO

B. C.

25-7-1676

Fr. Vicente Díez

Masa (Burgos)

AGN, Irache, Lib. 539, 144r.
MARCOS GONZÁLEZ HERRERO

B. C.

25-7-1676

Fr. José Ruiz

Masa (Burgos)

AGN, Irache, Lib. 539, 144r.

SEBASTIÁN BRAVO DE PEREDA

B. C.

30-7-1676

Fr. José Ruiz

Burgos

AGN, Irache, Lib. 539, 144r.

JUAN BAUTISTA CRIADO

B. C.

31-7-1676

Fr. Vicente Díez

Burgos

AGN, Irache, Lib. 539, 144r.

PEDRO DÍAZ DE MENA

B. A.

3-8-1676

Fr. Andrés del Busto

Briviesca (Burgos)

AGN, Irache, Lib. 539, 144r.

FRANCISCO HERNÁNDEZ

B. A. / B. M.

4-8-1676

Fr. Andrés del Busto

Pamplona

AGN, Irache, Lib. 539, 144r.

MIGUEL DE LACASA

B. A. / B. M.

5-8-1676

Fr. Andrés del Busto / Fr. Vicente Díez

Borja (Tarazona)

AGN, Irache, Lib. 539, 144v.

TOMÁS VICENTE DE BUESO

B. A. / B. M.

5-8-1676

Fr. Andrés del Busto / Fr. Vicente Díez

Aniñón (Tarazona)

AGN, Irache, Lib. 539, 144v. 
BARTOLOMÉ PÉREZ

B. C.

6-8-1676

Fr. José Ruiz

Tardajos (Burgos)

AGN, Irache, Lib. 539, 144V.

ANDRÉS DE VEGA

B. C.

6-8-1676

Fr. Vicente Díez

Briviesca (Burgos)

AGN, Irache, Lib. 539, 144v.

BLAS LÓPEZ

B. C.

8-8-1676

Fr. Vicente Díez

Palacios (Burgos)

AGN, Irache, Lib. 539, 144v.

FRANCISCO DE AEL

B. C.

11-8-1676

Fr. Vicente Díez

Burgos

AGN, Irache, Lib. 539, 144v.

PEDRO DE PALACIOS

B. C.

13-8-1676

Reprobado

Fr. Vicente Díez

Escalante (Burgos)

AGN, Irache, Lib. 539, 145r.

JUAN DE UMARÁN

B. C.

20-8-1676

Reprobado dos veces

Fr. Vicente Díez / Fr. Vicente de San Juan

Aray (Burgos)

AGN, Irache, Lib. 539, 145r.

PEDRO DEL CAÑO

B. C.

23-8-1676

Fr. Mauro de Soria
Cerezo (Burgos)

AGN, Irache, Lib. 539, 145r.

FRANCISCO MARTÍNEZ DE LOS RÍOS

B. A. / B. T.

25-8-1676

Fr. Juan Sánchez, abad

Medina del Pomar (Burgos)

AGN, Irache, Lib. 539, 145r.

JUAN DE PANCORBO

B. C.

27-8-1676

Fr. Vicente Díez

Octavilla de Poza

Burgos

AGN, Irache, Lib. 539, 145r.

ANDRÉS GÓMEZ DE QUINTANA

B. C.

27-8-1676

Fr. José Ruiz

Cutillo (Burgos)

AGN, Irache, Lib. 539, 145r.

FRANCISCO ANTONIO DE QUINTANO

B. C.

27-8-1676

Fr. Mauro de Soria

Briviesca (Burgos)

AGN, Irache, Lib. 539, 145v.

MIGUEL DE VIRUÉS ESPINOSA

B. C.

2-9-1676

Fr. Vicente Díez

Celada del Camino (Burgos)

AGN, Irache, Lib. 539, 145v.

JACINTO GUTIÉRREZ

B. C.

4-9-1676

Fr. José Ruiz

Poza (Burgos)

AGN, Irache, Lib. 539, 145v.

GREGORIO SAIZ

B. C. 
6-9-1676

Fr. Mauro de Soria

S... (Burgos)

AGN, Irache, Lib. 539, 145v.

JUAN MARTÍNEZ DE LEJARZA

B. C.

12-9-1676

Fr. Vicente Díez

Galdames (Burgos)

AGN, Irache, Lib. 539, 145v.

MANUEL NAVARRETE LADRÓN DE GUEVARA

B. T.

12-9-1676

Fr. José Ruiz

El Ciego (Calahorra)

AGN, Irache, Lib. 539, 145v.

FRANCISCO DE OLLOQUI

B. A.

28-9-1676

Fr. Andrés del Busto

Aldeanueva (Calahorra)

AGN, Irache, Lib. 539, 146r.

SEBASTIÁN GARCÍA

B. C.

8-10-1676

Fr. Mauro de Soria

Castillo Pedroso (Burgos)

AGN, Irache, Lib. 539, 146r.

MIGUEL SERRANO

B. C.

10-10-1676

Fr. Andrés del Busto

Barbadillo (Burgos)

AGN, Irache, Lib. 539, 146r.

DOMINGO SÁINZ TALÓN

B. A.

16-10-1676

Fr. Andrés del Busto

Nieva (Calahorra)

AGN, Irache, Lib. 539, 146r.
ANDRÉS DE MIRANDA

B. A.

16-10-1676

Fr. Andrés del Busto

Calahorra

AGN, Irache, Lib. 539, 146r.

DIEGO OBREGÓN Y CASTAÑEDA

B. C.

21-10-1676

Reprobado

Fr. José Ruiz

Santa María del Valle de Aguayo

AGN, Irache, Lib. 539, 146v.

JUAN DE CASTRO

B. A. / B. T. / L. T. / D. T.

22-10-1676

Fr. Juan Sánchez, abad

O.S. B.

AGN, Irache, Lib. 539, 146v.

JUAN DE ISLA

B. A. / B. T. / L. T. / D. T.

22-10-1676

Fr. Juan Sánchez, abad

O. S. B.

AGN, Irache, Lib. 539, 146v.

JUAN DE CALMEDA

B. A. / B. M.

19-11-1676

Fr. Andrés del Busto

Pamplona

AGN, Irache, Lib. 539, 146v.

JUAN DE ZAMORA MANSILLA

B. A. / B. T.

24-11-1676

Fr. Andrés del Busto / Fr. Vicente Díez

Santo Domingo de la Calzada (Calahorra)

AGN, Irache, Lib. 539, 146v.

JUAN SÁNCHEZ

B. M.

4-12-1676

Fr. Mauro de Soria

Borja (Tarazona)

AGN, Irache, Lib. 539, 147r. 
JUAN FERNÁNDEZ

B. A.

5-12-1676

Fr. Andrés del Busto

Arróniz (Pamplona)

AGN, Irache, Lib. 539, 147 r.

FRANCISCO DE ARENGUES Y COVARRUBIAS

B. T.

18-1-1677

Fr. José Ruiz

Santo Domingo de Silos (Burgos)

AGN, Irache, Lib. 539, 147 r.

JOSÉ DE LA CANTERA

B. C.

29-1-1677 / 2-6-1677

Reprobado dos veces

Fr. Vicente Díez, catedrático / Fr. Mauro de

Soria

San Martín de Losa (Burgos)

AGN, Irache, Lib. 539, 147r-15or.

JUAN ANTONIO DE LIENDO

B. C.

31-1-1677

Fr. José Ruiz

Laredo (Burgos)

AGN, Irache, Lib. 539, 147 r.

\section{JUAN DE MUGA ORTIZ}

B. C.

1-2-1677

Fr. Mauro de Soria

Castrobarto (Burgos)

AGN, Irache, Lib. 539, 147v.

MARTÍN DE SOLA MORRAS

B. A. / L. A.

3-2-1677/4-2-1677

Fr. Andrés de Busto, Lector de Artes / Fr.

Juan Sánchez, abad

Arróniz (Pamplona)

AGN, Irache, Lib. 539, $147 \mathrm{v}$.

PEDRO DE RIBAS

B. A. / B. T.
6-2-1677

Fr. Andrés de Busto / Fr. Vicente Díez

Altable (Burgos)

AGN, Irache, Lib. 539, $147 \mathrm{v}$.

MIGUEL DE AYALA

B. A. / B. T.

7-2-1677 / 5-8-1677 / 22-5-1677

Reprobado dos veces

Fr. José Ruiz / Fr. A. de Busto / Fr. Mauro

de Soria

Gabanes (Burgos)

AGN, Irache, Lib. 539, 147v, 151v, 174r.

FRANCISCO SANZ DE LECIÑANA

B. C.

8-2-1677 / 18-7-1677

Reprobado dos veces

Fr. Mauro de Soria / Fr. Vicente Díez

Colina (Burgos)

AGN, Irache, Lib. 539, 148r, 151r.

DIEGO FERNÁNDEZ DE BARREDA

B. C.

8-2-1677

Fr. Vicente Díez, Vicecanciller

Gabanes (Burgos)

AGN, Irache, Lib. 539, 148r.

JOSÉ ALONSO PÉREZ DE LOS RÍOS

B. A. / B. T.

10-2-1677

Fr. Andrés de Busto / Fr. José Ruiz

Poza (Burgos)

AGN, Irache, Lib. 539, 148r.

MATEO DE ESCALANTE

B. C.

13-2-1677

Fr. Mauro de Soria

Laredo (Burgos)

AGN, Irache, Lib. 539, 148r.

PEDRO DE ESPAÑA

B. A.

18-2-1677

Reprobado

Fr. Andrés de Busto 
Cubo (Burgos)

AGN, Irache, Lib. 539, 148r.

BALTASAR DE GUTIÉRREZ DE ROZAS

B. C.

\section{2-3-1677}

Fr. Vicente Díez

Arce Foncea (Burgos)

AGN, Irache, Lib. 539, 148r.

BLAS DE FORAYÓN VELASCO Y LASALA

B. C. / L. C. / D. C.

4-3-1677

Fr. Juan Sánchez, abad

Jaca

AGN, Irache, Lib. 539, 148r.

\section{MIGUEL HERMOSO}

L. A.

5-3-1677

Reprobado

Fr. Mauro de Llano

AGN, Irache, Lib. 539, 148v.

DIEGO RUIZ DE QUINTANA

B. C.

6-3-1677

Fr. Mauro de Soria

Cebolleros (Burgos)

AGN, Irache, Lib. 539, 148v.

GASPAR DE MAHAMUD

B. C.

3-4-1677

Fr. Mauro de Soria

Santa María del Campo (Burgos)

AGN, Irache, Lib. 539, 148v.

JUAN BAUTISTA DE ANGULO

B. C.

4-4-1677

Fr. Vicente Díez

Las Fuentes (Burgos)

AGN, Irache, Lib. 539, 148v.

TOMÁS ANDRÉS DE ESCARROZ

B. A. / L. A.
6-4-1677 / 7-4-1677

Fr. Juan Sánchez, abad

Cintruenigo (Tarazona)

AGN, Irache, Lib. 539, 149r.

ROQUE SANTOS

B. C.

8-4-1677

Fr. Mauro de Soria

Quintanillas (Burgos)

AGN, Irache, Lib. 539, 149r.

MATÍAS CRESPO

B. C.

27-4-1677

Fr. Vicente Díez

Santa María del Campo (Burgos)

AGN, Irache, Lib. 539, 149r.

SIMÓN HERMOSO

B. C.

27-4-1677

Fr. Vicente Díez

Santa María del Campo (Burgos)

AGN, Irache, Lib. 539, 149r.

JUAN ORTIZ DE EGUILUZ

B. C.

3-5-1677

Fr. Mauro de Soria

Villa de Maño (Burgos)

AGN, Irache, Lib. 539, $149 \mathrm{v}$.

FRANCISCO LUIS JIMÉNEZ

B. C.

14-5-1677

Fr. Vicente Díez

Burgos

AGN, Irache, Lib. 539, $149 \mathrm{v}$.

PABLO ZORRILLA DE SAN MARTÍN

B. C.

19-5-1677

Fr. Mauro de Soria

M... (Burgos)

AGN, Irache, Lib. 539, $149 \mathrm{v}$.

ANTONIO MARTÍNEZ DE VITORIA

B. C. 
26-5-1677

Fr. Vicente Díez

Burgos

AGN, Irache, Lib. 539, 149v.

MATÍAS RUIZ

B. A. / B. T.

26-5-1677

Fr. Andrés de Busto / Fr. Mauro de Soria

Gredilla la Polera (Burgos)

AGN, Irache, Lib. 539, 149v.

JUAN GONZÁLEZ DE LA MAZA

B. C.

27-5-1677

Reprobado

Fr. Mauro de Soria

Burgos

AGN, Irache, Lib. 539, 150r.

JOSÉ DE LOS ARCOS Y MEDRANO

B. A. / B. T.

29-5-1677

Fr. Andrés de Busto / Fr. Vicente Díez

Burgos

AGN, Irache, Lib. 539, 150r.

MANUEL GARCÍA DE SAGREDO

B. C.

29-5-1677

Fr. Mauro de Soria

Burgos

AGN, Irache, Lib. 539, 15 or.

PEDRO DE LAMO

B. A. / B. T.

8-6-1677 / 27-10-1677

Reprobado dos veces

Fr. Andrés del Busto / Fr. Mauro de Soria /

Fr. Vicente Díez

Burgos

AGN, Irache, Lib. 539, 150r, 154v.

JUAN DE GUILARTE

B. C.

14-6-1677 Reprobado

13-12-1677 Aprobado

Fr. Vicente Díez
Lences (Burgos)

AGN, Irache, Lib. 539, 150v, 155r.

JUAN LÓPEZ DE MENDOZA CASTILLO

B. A. / B. T.

16-6-1677

Fr. Andrés del Busto / Fr. Mauro de Soria

Bascuñuelos (Burgos)

AGN, Irache, Lib. 539, $150 v$.

BERNARDO CASADO DE ARREDONDO

B. C.

17-6-1677

Fr. José Ruiz

Rabé de las Calzadas (Burgos)

AGN, Irache, Lib. 539, $150 v$.

JOSÉ DE VIZANCO

B. C.

23-6-1677

Fr. Vicente Díez

Lezana (Burgos)

AGN, Irache, Lib. 539, $150 v$.

JUAN CARRILLO

B. C.

27-6-1677

Fr. José Ruiz

Lences (Burgos)

AGN, Irache, Lib. 539, $150 v$.

\section{ANTONIO CABEZÓN}

B. C.

3-7-1677

Fr. Vicente Díez

Castrillo de Matajudíos (Burgos)

AGN, Irache, Lib. 539, 150v.

DAMIÁN RUIZ DE VELASCO

B. C.

9-7-1677 / 3-1-1678

Reprobado dos veces

Fr. Vicente Díez

Burgos

AGN, Irache, Lib. 539, 151r, 155v.

MATEO DE ESCALANTE

B. C. 
14-7-1677 / 10-1-1678 / 21-3-1679

Reprobado dos veces

Fr. José Ruiz / Fr. Mauro de Soria

Castrillo de Murcia (Burgos)

AGN, Irache, Lib. 539, 151r, 155v, 172r.

JOSÉ PÉREZ

L. T. / D. T.

18-9-1677 / 19-9-1677

Fr. Gregorio de Toledo, abad

O. S. B.

AGN, Irache, Lib. 539, 151v.

VICENTE DÍEZ

B. A. / L. A. / B. T. / L. T. / D. T.

18-9-1677 / 19-9-1677

Fr. Gregorio de Toledo, abad

O. S. B.

AGN, Irache, Lib. 539, 152r.

JUAN DE ORÚE

B. C.

21-9-1677

Fr. Vicente Díez

Sojo (Burgos)

AGN, Irache, Lib. 539, 152r.

JUAN ANTONIO DE EZCURDIA

B. A.

23-1-1677

Fr. Andrés de Busto

San Sebastián (Pamplona)

AGN, Irache, Lib. 539, 152v.

FRANCISCO DE ORTEGA Y SOTO

B. C.

30-9-1677

Fr. Mauro de Soria

Santa María del Campo (Burgos)

AGN, Irache, Lib. 539, 152v.

JOSÉ ROMEO

B. M.

30-9-1677

Fr. Mauro de Soria

Zaragoza

AGN, Irache, Lib. 539, 152v.
MANUEL GÓMEZ

B. C.

2-10-1677

Fr. José Ruiz

La Vega (Burgos)

AGN, Irache, Lib. 539, 153r.

SIMÓN RUIZ

B. C.

2-10-1677

Fr. José Ruiz

Barresuso (Burgos)

AGN, Irache, Lib. 539, 153r.

\section{SANTOS SANZ}

B. C.

2-10-1677 / 8-2-1678

Reprobado dos veces

Fr. José Ruiz

Barresuso (Burgos)

AGN, Irache, Lib. 539, 153r, 157r.

JUAN BAUTISTA BELTRÁN

B. A. / L. A.

5-10-1677 / 6-10-1677

Fr. José Ruiz / Fr. Gregorio de Toledo, abad

Garde (Pamplona)

AGN, Irache, Lib. 539, 153r.

PEDRO DE SANTA MARÍA

B. C.

6-10-1677

Fr. Mauro de Soria

Marmellar de Abajo (Burgos)

AGN, Irache, Lib. 539, 153v.

FRANCISCO PASCUAL MUGA

B. C.

8-10-1677

Fr. José Ruiz

Colindres (Burgos)

AGN, Irache, Lib. 539, 153v.

DIEGO ZUAZO

B. A. / B. T.

8-10-1677

Fr. Mauro de Soria

Santurce (Burgos)

AGN, Irache, Lib. 539, 153v. 
ANTONIO GÓMEZ DE PALACIO

B. C.

10-10-1677

Fr. Vicente Díez

Valle de Liendo (Burgos)

AGN, Irache, Lib. 539, 154r.

DOMINGO DE LA SALA

B. C.

19-10-1677

Fr. José Ruiz

Laredo (Burgos)

AGN, Irache, Lib. 539, 154r.

PEDRO DE ARAS Y PORRAS

B. A. / B. T.

22-10-1677

Fr. Andrés del Busto / Fr. Mauro de Soria Espinosa de los Monteros (Burgos)

AGN, Irache, Lib. 539, 154r.

FRANCISCO DE FRESEDO

B. C.

22-10-1677

Reprobado

Fr. Vicente Díez

Nidáguila (Burgos)

AGN, Irache, Lib. 539, 154r.

BERNABÉ DE LA TORRE

B. C.

29-10-1677

Fr. José Ruiz

Islares (Burgos)

AGN, Irache, Lib. 539, 154v.

ANDRÉS PRIETO GALINDO

B. C.

30-10-1677

Fr. Vicente Díez

Herrera de Valdecañas (Burgos)

AGN, Irache, Lib. 539, 154v.

FRANCISCO DE OLEA GUTIÉRREZ

B. C.

6-11-1677

Reprobado

Fr. Vicente Díez
Cavia (Burgos)

AGN, Irache, Lib. 539, 154v.

JUAN GUTIÉRREZ

B. C.

7-11-1677

Fr. Vicente Díez

Valdecañas (Burgos)

AGN, Irache, Lib. 539, 154v.

GASPAR DE SALINAS

B. T.

10-11-1677

Reprobado

Fr. Vicente Díez

...

AGN, Irache, Lib. 539, 154v.

PEDRO GUTIÉRREZ

B. C.

14-11-1677

Reprobado

Fr. Mauro de Soria

Estépar (Burgos)

AGN, Irache, Lib. 539, 155r.

JUAN BENITO DE RIVERA

B. C.

1-12-1677

Fr. José Ruiz

Santa Olalla (Burgos)

AGN, Irache, Lib. 539, 155r.

FRANCISCO ÁLVAREZ DEL VALLE

B. C.

3-12-1677

Fr. José Ruiz

Santa Olalla (Burgos)

AGN, Irache, Lib. 539, 155r.

ANDRÉS DÍAZ

B. C.

8-12-1677

Fr. Vicente Díez

Marcilla (Palencia)

AGN, Irache, Lib. 539, 155r.

LORENZO DE ALBÉNIZ

B. L. 
4-1-1678

Fr. José Ruiz

Azcona (Burgos)

AGN, Irache, Lib. 539, 155v.

MIGUEL GARCÍA

B. C.

8-1-1678 / 19-2-1678

Reprobado

Fr. Mauro de Soria

Isar (Burgos)

AGN, Irache, Lib. 539, 155v.

JOSÉ GONZÁLEZ

B. C.

20-1-1678

Fr. Vicente Díez

Presencio (Burgos)

AGN, Irache, Lib. 539, 155v.

FRANCISCO OLEART GURIÉRREZ

B. C.

24-1-1678

Fr. José Ruiz

Cavia (Burgos)

AGN, Irache, Lib. 539, 156rv.

PASCUAL DE VILLACAMPA

B. C.

24-1-1678

Fr. José Ruiz

Madrid (Toledo)

Caballero. Orden de Montesa

AGN, Irache, Lib. 539, 156v.

ALONSO GONZÁLEZ ANDRADE Y VE-

LÁZQUEZ

B. C. / L. C.

8-2-1678 / 9-2-1678

Fr. Mauro de Soria

Molina (Sigüenza)

AGN, Irache, Lib. 539, 157r.

\section{ANDRÉS ROMERO}

B. C.

18-2-1678

Fr. Andrés de Busto

Alcanadre (Calahorra)

AGN, Irache, Lib. 539, 157r.
DIEGO RUIZ DE PORRAS

B. C.

18-2-1678

Fr. Vicente Díez

Cenicero (Burgos)

AGN, Irache, Lib. 539, 157v.

JOSÉ DE CHASCO

B. A.

20-2-1678

Fr. Andrés del Busto

Torralba (Calahorra)

AGN, Irache, Lib. 539, 157v.

ÁNGEL FRANCISCO MAROTO

B. C.

25-2-1678

Fr. José Ruiz

Presencio (Burgos)

AGN, Irache, Lib. 539, 157v.

JUAN DE ZORRILLA

B. C.

23-3-1678 / 6-5-1678

Reprobado dos veces

Fr. Mauro de Soria

Asa del Valle de Soba (Burgos)

AGN, Irache, Lib. 539, 157v, 16or.

\section{BERNARDO RODRÍGUEZ}

B. C.

26-3-1678 / 29-9-1678

Reprobado dos veces

Fr. Vicente Díez

Lerma (Nullius Diocesis)

AGN, Irache, Lib. 539, 158r, 167r.

JUAN DE LA FUENTE

B. A. / B. T.

9-4-1678

Fr. Andrés del Busto / Fr. José Ruiz

San Martín de Humada (Burgos)

AGN, Irache, Lib. 539, 158r.

FRANCISCO SEDANO

B. C.

13-4-1678

Fr. Mauro de Soria 
Villadiego (Burgos)

AGN, Irache, Lib. 539, 158r.

\section{JUAN MORENO}

B. C.

13-4-1678

Fr. Vicente Díez

Grisaleña (Burgos)

AGN, Irache, Lib. 539, 158v.

MANUEL DE YURRETAURIA

B. $\mathrm{T}$.

13-4-1678

Fr. José Ruiz

Elorrio (Calahorra)

AGN, Irache, Lib. 539, 158v.

JOSÉ ANTONIO DE LIZARAZU

B. A. / L. T. / D. T.

13-4-1678 / 14-4-1678

Vicecanciller / Fr. Vicente Díez

Alzola (Calahorra)

AGN, Irache, Lib. 539, 158v.

ANDRÉS DE TORRES

B. C.

16-4-1678

Fr. Vicente Díez

Quintanadueñas (Burgos)

AGN, Irache, Lib. 539, 159r.

\section{BARTOLOMÉ DE SANTOYO}

B. C.

17-4-1678

Fr. Vicente Díez

Villahoz (Burgos)

AGN, Irache, Lib. 539, 159r.

JUAN DE VELASCO

B. C.

19-4-1678

Fr. Vicente Díez

Villadiego (Burgos)

AGN, Irache, Lib. 539, 159r.

\section{LUIS DE LA PEÑA}

B. C.

19-4-1678
Fr. Vicente Díez

Villadiego (Burgos)

AGN, Irache, Lib. 539, 159v.

GABRIEL DE MONREAL

B. C.

25-4-1678

Fr. José Ruiz

Villadiego (Burgos)

AGN, Irache, Lib. 539, 159v.

LUCAS DE LA FUENTE

B. A. / B. T.

29-4-1678

Fr. Andrés de Busto / Fr. Mauro de Soria

Villadiego (Burgos)

AGN, Irache, Lib. 539, 16 or.

JUAN TERREROS

B. C.

10-5-1678

Fr. Vicente Díez

Islares (Burgos)

AGN, Irache, Lib. 539, $160 v$.

MATEO DE IZARRA HORRUMA

B. C.

12-5-1678

Fr. José Ruiz

Ayuelas (Burgos)

AGN, Irache, Lib. 539, 160v.

\section{SEBASTIÁN DE SAN MARTÍN}

B. C.

14-5-1678

Fr. Mauro de Soria

Guriezo (Burgos)

AGN, Irache, Lib. 539, $160 v$.

JUAN GARCÍA

B. A. / B. T.

25-5-1678

Fr. José Ruiz

Burgos

AGN, Irache, Lib. 539, 161r.

JOSÉ DE VIVAR CALLEJA

B. C. 
25-5-1678

Fr. Vicente Díez

Burgos

Pbro.

AGN, Irache, Lib. 539, 161r.

VICENTE DE ESCOBAR

B. T.

25-5-1678

Fr. José Ruiz

Ezcaray (Burgos)

AGN, Irache, Lib. 539, 161r.

ALONSO DE SALAZAR

B. A. / B. T.

28-5-1678

Fr. José Ruiz / Fr. Mauro de Soria

Quintanilla de Bon (Burgos)

AGN, Irache, Lib. 539, 161v.

ANDRÉS ORTIZ

B. C.

2-6-1678

Fr. Vicente Díez

Villa de Soto (Burgos)

AGN, Irache, Lib. 539, 161v.

ÍNIIGO DE ROJAS

B. C.

3-6-1678

Fr. Vicente Díez

Quintanilla de Bon (Burgos)

AGN, Irache, Lib. 539, 161v.

JOSÉ DE SANTA CLARA

B. A. / B. M.

4-6-1678

Fr. Vicente Díez

Tudela (Tarazona)

AGN, Irache, Lib. 539, 162r.

MIGUEL GONZÁLEZ

B. C.

5-6-1678

Fr. José Ruiz

Terrazos (Burgos)

AGN, Irache, Lib. 539, 162r.
MARCOS GÓMEZ

B. C.

11-6-1678

Fr. Mauro de Soria

Vesga (Burgos)

AGN, Irache, Lib. 539, 162r.

JUAN GARCÍA CLEMENTE

B. C.

11-6-1678

Fr. Vicente Díez

Pancorbo (Burgos)

AGN, Irache, Lib. 539, $162 \mathrm{v}$.

ANTONIO DE SANTO DOMINGO

B. C.

15-6-1678

Fr. José Ruiz

Los Arcos (Pamplona)

AGN, Irache, Lib. 539, $162 \mathrm{v}$.

JOSÉ ORTEGA

B. C.

17-7-1678 / 25-11-1678

Reprobado dos veces

Fr. Mauro de Soria

Presencio (Burgos)

AGN, Irache, Lib. 539, 162v, $170 \mathrm{v}$.

BLAS DE URGAÑO

B. C.

17-7-1678

Fr. Vicente Díez

Presencio (Burgos)

AGN, Irache, Lib. 539, 163r.

MARTÍN DE SAN MARTÍN

B. C.

22-7-1678

Fr. José Ruiz

Sopuerta (Burgos)

AGN, Irache, Lib. 539, 163r.

ISIDRO DE QUEVEDO Y BUSTAMANTE

B. A. / B. T.

6-8-1678

Fr. Mauro de Soria / Fr. Vicente Díez

Bárcena de Pie de Concha (Burgos)

AGN, Irache, Lib. 539, 163r. 


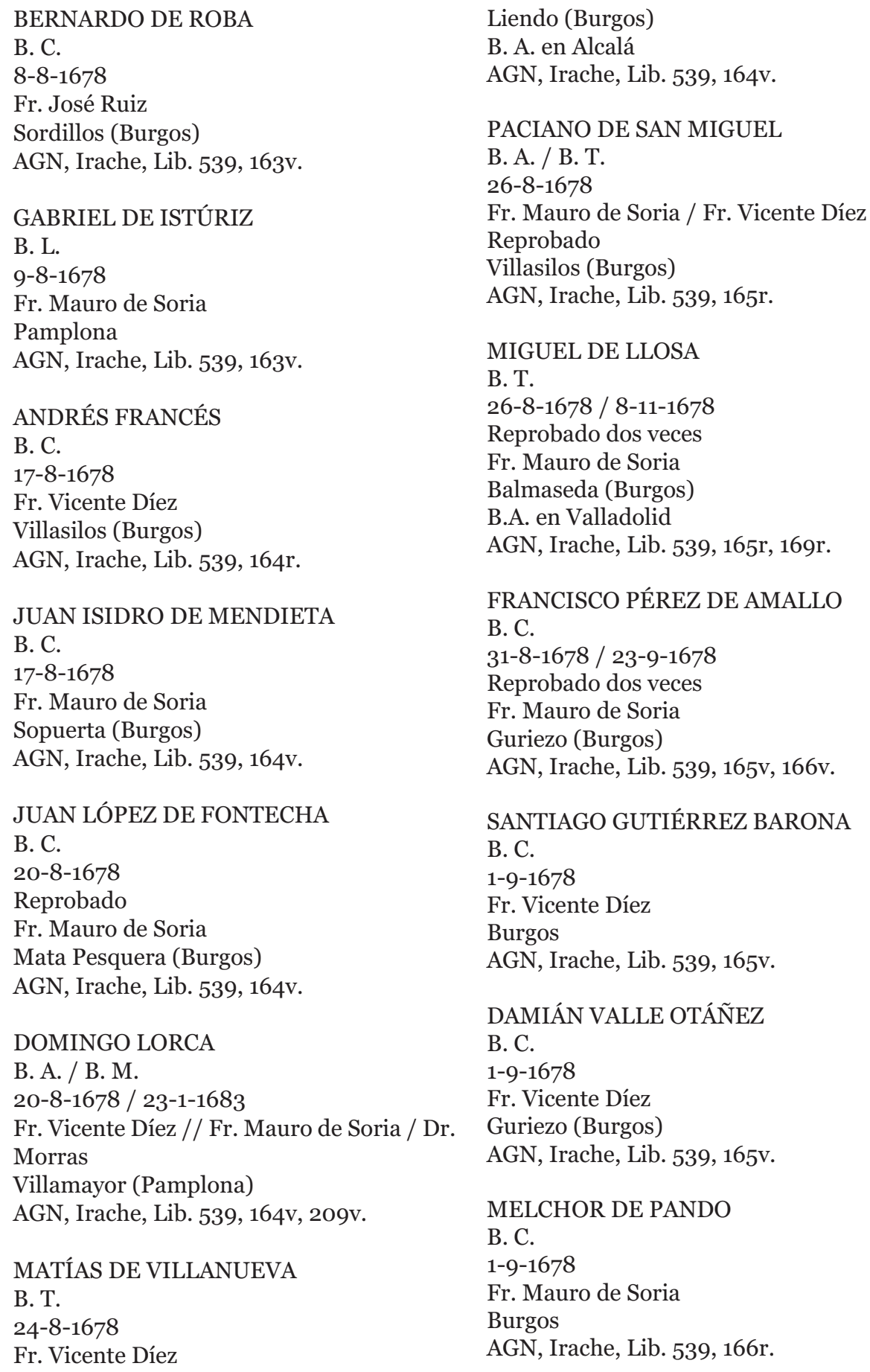


ANDRÉS DE RANERO

B. C.

3-9-1678

Fr. Vicente Díez

Guriezo (Burgos)

AGN, Irache, Lib. 539, 166r.

JUAN DE ZIARÁN

B. C.

4-9-1678

Fr. Mauro de Soria

Espinosa de los Monteros (Burgos)

AGN, Irache, Lib. 539, 166r.

\section{ANTONIO TERÁN}

B. C.

10-9-1678

Fr. Vicente Díez

Palacios de Río Pisuerga (Burgos)

AGN, Irache, Lib. 539, 166v.

TOMÁS GONZÁLEZ

B. C.

18-9-1678

Fr. Vicente Díez

Espinosa de los Monteros (Burgos)

AGN, Irache, Lib. 539, 166v.

DOMINGO FERNÁNDEZ DE QUINTANI-

LLA

B. C.

26-9-1678

Fr. Mauro de Soria

Río Quintanillas (Burgos)

AGN, Irache, Lib. 539, 167r.

FRANCISCO MARTÍNEZ

B. C.

30-9-1678 / 17-11-1678

Reprobado dos veces

Fr. Vicente Díez

Aguas Cándidas (Burgos)

AGN, Irache, Lib. 539, 167r, 170 .

\section{MELCHOR ESCUDERO}

B. C.

4-10-1678 / 15-11-1678

Reprobado dos veces
Fr. Vicente Díez

Grisaleña (Burgos)

AGN, Irache, Lib. 539, 167v, $170 r$.

GASPAR VARONA

B. C.

5-10-1678

Fr. Vicente Díez

La Nuez de Santibáñez (Burgos)

AGN, Irache, Lib. 539, 167v.

JOSÉ RODRÍGUEZ DE LA IGLESIA

B. C.

5-10-1678

Fr. Mauro de Soria

Villa Beta

Abadía de Covarrubias

AGN, Irache, Lib. 539, 167v.

JUAN DE LA CABADILLA

B. C.

13-10-1678

Fr. Vicente Díez

Parbayón (Burgos)

AGN, Irache, Lib. 539, 168r.

ALONSO FRANCÉS

B. C.

14-10-1678 / 14-11-1678

Reprobado dos veces

Fr. Mauro de Soria

Villa Beta

Abadía de Covarrubias

AGN, Irache, Lib. 539, 168r, $169 \mathrm{v}$.

JOSÉ DE SAN MIGUEL

B. T.

19-10-1678

Fr. Gregorio de Toledo, abad

Povar de Balmaseda (Burgos)

AGN, Irache, Lib. 539, 168r.

FRANCISCO ANTONIO DE CONTRERAS

B. A. / B. T.

20-10-1678

Fr. Mauro de Llano, vicecanciller / Fr. Vicente Díez

Burgos

AGN, Irache, Lib. 539, 168v. 
MARTÍN DE MARSÁIN Y ZABALETA

B. L.

21-10-1678

Fr. Vicente Díez

Burguete (Pamplona)

AGN, Irache, Lib. 539, 168v.

MIGUEL DE CASILLO

B. C.

30-10-1678

Fr. José Ruiz

Pancorbo (Burgos)

AGN, Irache, Lib. 539, 169r.

TOMÁS DE FRÍAS

B. C.

30-10-1678

Fr. José Ruiz

Pancorbo (Burgos)

AGN, Irache, Lib. 539, 169r.

JOSÉ DE SAMPER

L. L. / D. L.

8-11-1678

Fr. Gregorio de Toledo, abad

Tarazona

B. L. en Zaragoza el 20-4-1677

AGN, Irache, Lib. 539, 169 r.

\section{PASCUAL BLANCH}

B. M.

25-11-1678

Fr. Vicente Díez

Alcañiz (Zaragoza)

B. A. en Gandía

AGN, Irache, Lib. 539, 170 .

ALONSO VARONA

B. C.

25-11-1678 / 14-4-1679

Reprobado

Fr. José Ruiz

Villaverde-Mogina (Burgos)

AGN, Irache, Lib. 539, 170r, 173 r.

GREGORIO GARCÍA DE PEREDA

B. C.

27-11-1678
Fr. José Ruiz

Salinas de Rosío (Burgos)

AGN, Irache, Lib. 539, $170 v$.

\section{SANTIAGO GARCÍA}

B. C.

13-12-1678 Reprobado

9-6-1679 Aprobado

Fr. Vicente Díez

Villalmanzo

Abadía de Lerma

AGN, Irache, Lib. 539, 170v, 174v.

JUAN TOMÁS GONZÁLEZ

B. C.

16-12-1678

Fr. José Ruiz

Santibáñez Zarzaguda (Burgos)

AGN, Irache, Lib. 539, $170 v$.

DOMINGO MARTÍN

B. A. / B. T.

29-12-1678

Fr. Mauro de Soria

Quintanar (Calahorra)

AGN, Irache, Lib. 539, $170 v$.

DIEGO RUIZ

B. A. / L. A. / D. A. / B. T. / L. T. / D. T.

17-1-1679

Fr. Gregorio de Toledo, abad

O. S. B.

Abad de San Millán de la Cogolla

Dispensáronse los actos literarios por cons-

tar su suficiencia

AGN, Irache, Lib. 539, 171r.

JUAN DE SALINAS

B. A.

7-2-1679

Fr. Mauro de Llano, lector de Artes

San Vicente de la Sonsierra (Calahorra)

AGN, Irache, Lib. 539, 171r.

\section{LORENZO LÓPEZ}

B. C.

26-2-1679 
Quintana-Urria (Burgos)

AGN, Irache, Lib. 539, 171v.

JUAN FERNÁNDEZ DE TORRES

B. A. / B. T.

27-2-1679

Fr. Mauro de Llano / Fr. José Ruiz

Frías (Burgos)

AGN, Irache, Lib. 539, 171v.

JUAN PÉREZ SANCHO

L. C.

5-3-1679

Fr. Mauro de Soria

Leciñena (Zaragoza)

AGN, Irache, Lib. 539, 171v.

JOSÉ DE IBUSQUETA

B. L.

13-3-1679

Fr. Mauro de Soria

Pamplona

AGN, Irache, Lib. 539, 172r.

JOSÉ ESCALANTE

B. C.

16-3-1679

Reprobado

Fr. Mauro de Soria

Laredo (Burgos)

AGN, Irache, Lib. 539, 172r.

JUAN DE BÁRCENA

B. C.

20-3-1679

Fr. Mauro de Soria

Cantabrana (Burgos)

AGN, Irache, Lib. 539, 172 .

MATEO DE ESCALANTE Y RÍOS

B. C.

21-3-1679

Fr. Mauro de Soria

Laredo (Burgos)

AGN, Irache, Lib. 539, $172 \mathrm{v}$.

MIGUEL DE PORRAS

B. C.
27-3-1679 / 7-5-1679

Reprobado

Fr. Vicente Díez

Busto (Burgos)

AGN, Irache, Lib. 539, 172v, 173v.

JOSÉ PUELLES

B. C.

27-3-1679

Reprobado

Fr. Vicente Díez

Frías (Burgos)

AGN, Irache, Lib. 539, 172v.

FRANCISCO LABARI

B. A. / B. M.

28-3-1679

Fr. Mauro de Llano / Fr. Vicente Díez

San Martín de Unx (Pamplona)

AGN, Irache, Lib. 539, 172v.

ANTONIO DE SALAS Y AGÜERO

B. C.

13-4-1679

Fr. Vicente Díez

San Vicente (Calahorra)

AGN, Irache, Lib. 539, 173r.

JOSÉ PÉREZ

B. A. / B. T. / L. T. / D. T.

16-4-1679 / 6-4-1680

Fr. Mauro de Llano / Fr. Vicente Díez / Fr.

José Ruiz del Sotillo, abad

Olite (Pamplona)

AGN, Irache, Lib. 539, 173r, 190 r.

MIGUEL ORTIZ DE AEDO

B. C.

23-4-1679

Fr. Mauro de Soria

Zalla (Burgos)

AGN, Irache, Lib. 539, 173r.

DIEGO GÓMEZ DE REBOLLAR

B. C.

2-5-1679

Fr. Mauro de Soria

Riaño (Burgos)

AGN, Irache, Lib. 539, 173v. 
FRANCISCO NEGRO

B. C.

10-5-1679 / 18-6-1679

Reprobado

Fr. Vicente Díez

Castrojeriz (Burgos)

AGN, Irache, Lib. 539, 173v, 174v.

MANUEL DE SAMANIEGO

B. C.

12-5-1679

Fr. Mauro de Soria

Calahorra

Caicedo, residente en Santa Gadea

AGN, Irache, Lib. 539, 173v.

BERNARDO FRANCISCO QUIRÓS

B. M. / L. M. / D. M.

24-5-1679

Fr. Vicente Díez / Dres. Morras y Arilla

Tarazona

AGN, Irache, Lib. 539, 174r.

PEDRO DE OTERO

B. C.

3-6-1679

Fr. José Ruiz, abad

Castrojeriz (Burgos)

AGN, Irache, Lib. 539, 174r.

MIGUEL DE ATONDO

B. A. / B. M.

6-6-1679

Fr. Mauro de Llano / Fr. Mauro de Soria /

Dr. Morras

Estella (Pamplona)

AGN, Irache, Lib. 539, 174v.

PEDRO DE VILLAESCUSA

B. C.

9-6-1679

Fr. Vicente Díez

Castrillo de Matajudíos (Burgos)

AGN, Irache, Lib. 539, 174v.

PEDRO DÍEZ

B. A. / B. T.

21-6-1679 / 12-9-1679
Reprobado

Fr. Mauro de Llano / Fr. Mauro de Soria /

Fr. Vicente Díez

Mazoncillo de Juarros (Burgos)

AGN, Irache, Lib. 539, 175r, 178r.

CRISTÓBAL MAZÓN

B. C.

21-6-1679

Fr. Mauro de Soria

Castrojeriz (Burgos)

AGN, Irache, Lib. 539, 175r.

LÁZARO DE JARAMILLO

B. C.

21-6-1679 / 16-12-1679

Reprobado dos veces

Fr. Vicente Díez / Fr. Mauro de Soria

Galarde (Burgos)

AGN, Irache, Lib. 539, 175r, 18 or.

JUAN MIGUEL DE ARDANAZ

B. A. / L. A.

21-6-1679

Fr. Mauro de Llano

Pamplona

AGN, Irache, Lib. 539, 175v.

PEDRO PÉREZ DE HERRÁN

B. C.

24-6-1679

Fr. Vicente Díez

Oria (Burgos)

AGN, Irache, Lib. 539, 175v.

JUAN PÉREZ

B. C.

6-7-1679 Reprobado

12-8-1679 Aprobado

Fr. Vicente Díez

Pedrosa del Príncipe (Burgos)

AGN, Irache, Lib. 539, 176r, 177v.

FELIPE CASTRILLO

B. C.

6-7-1679 / 19-8-1679

Reprobado dos veces

Fr. José Ruiz, abad 
Castrojeriz (Burgos)

AGN, Irache, Lib. 539, 176r.

MIGUEL DE ARÓZTEGUI

L. L.

6-7-1679

Fr. José Ruiz, abad

Benabarre (Lérida)

B. C. y B. L.

AGN, Irache, Lib. 539, 176r.

\section{FRANCISCO ORIBE}

B. C.

19-7-1679

Fr. José Ruiz, abad

Quintanilla de Valdegovia (Burgos)

AGN, Irache, Lib. 539, 176v.

\section{ANTONIO ZATÓN}

B. C.

19-7-1679

Fr. José Ruiz, abad

San Llorente de Losa (Burgos)

AGN, Irache, Lib. 539, 176v.

JOSÉ DE VILLAMOR

B. C.

19-7-1679

Fr. José Ruiz, abad

San Llorente de Losa (Burgos)

AGN, Irache, Lib. 539, 176v.

TOMÁS DE SALAZAR

B. C.

19-7-1679

Fr. José Ruiz, abad

Murita (Burgos)

AGN, Irache, Lib. 539, 177 r.

JUAN HERNÁIZ

B. C.

1-8-1679 / 29-1-1680

Reprobado

Fr. José Ruiz, abad / Fr. Vicente Díez

Villambistia (Burgos)

AGN, Irache, Lib. 539, 177r, $180 v$.

JOSÉ DE CABAÑAS Y SANABIA

B. C.
3-8-1679

Fr. Vicente Díez

Solórzano (Burgos)

AGN, Irache, Lib. 539, 177r.

MANUEL DE HERNANDO

B. A. / B. T.

3-8-1679

Fr. Mauro de Llano / Fr. José Ruiz, abad

Valgañón (Burgos)

AGN, Irache, Lib. 539, 177rv.

FELIPE DE GORDOJUELA

B. C.

8-8-1679

Fr. Vicente Díez

Ezcaray (Burgos)

AGN, Irache, Lib. 539, 177v.

LORENZO LÓPEZ

B. C.

14-8-1679

Fr. Vicente Díez

Quintanaurria (Burgos)

AGN, Irache, Lib. 539, 177v.

ANTONIO RODRÍGUEZ

B. C.

20-8-1679

Fr. Vicente Díez

Tabanera (Burgos)

AGN, Irache, Lib. 539, 178r.

ANTONIO LA MAZA

B. $\mathrm{T}$.

2-9-1679

Fr. Vicente Díez

Ambrosero (Burgos)

B. A.

AGN, Irache, Lib. 539, 178r.

ANTONIO BASOCO

B. C.

5-9-1679 / 24-2-1680

Reprobado

Fr. Vicente Díez

Gordojuela (Calahorra)

AGN, Irache, Lib. 539, 178r, 181r. 
MIGUEL RUIZ

B. C.

18-9-1679 / 9-3-1679

Reprobado

Fr. Vicente Díez

Zalla (Burgos)

AGN, Irache, Lib. 539, 178v, $181 \mathrm{v}$.

\section{CARLOS DE HUERTA}

B. C.

20-9-1679

Fr. Vicente Díez

Castrojeriz (Burgos)

AGN, Irache, Lib. 539, 178v.

\section{ESTEBAN DE ATRIZTAN}

B. A.

20-9-1679

Fr. Mauro de Llano

Arana (Pamplona)

AGN, Irache, Lib. 539, 178v.

\section{ANTONIO LA CUESTA}

B. C.

1-10-1679

Fr. Vicente Díez

Castrojeriz (Burgos)

AGN, Irache, Lib. 539, 178v.

PEDRO DE MAULEÓN

B. A.

7-10-1679

Fr. Mauro de Llano

Agoncillo (Calahorra)

AGN, Irache, Lib. 539, 179r.

JOSÉ MARÍN

B. A.

9-10-1679

Fr. Mauro de Llano

Tudela (Tarazona)

AGN, Irache, Lib. 539, 179r.

FELIPE HERRERA VELARDE

B. C.

11-10-1679

Fr. Vicente Díez

Castrojeriz (Burgos)

AGN, Irache, Lib. 539, 179r.
SEBASTIÁN ALONSO MANSO

B. A. / B. T. / L. T.

27-10-1679

Fr. Mauro de Llano / Fr. José Ruiz, abad

Grañón (Calahorra)

AGN, Irache, Lib. 539, 179r.

JUAN ORTIZ DE OTEO

B. C.

9-11-1679

Fr. Mauro de Soria

Gabanes (Burgos)

AGN, Irache, Lib. 539, 179r.

DIEGO BERNÁRDEZ

B. A. / B. T. / L. T. / D. T.

10-11-1679 / 20-8-1687

Fr. Mauro de Llano / Fr. Vicente Díez // Fr.

Pedro Lozano / Fr. José Osorio / Fr. Grego-

rio Ruiz, abad

Anguiano (Calahorra)

AGN, Irache, Lib. 539, 179r, 277 r.

JUAN GARCÍA

B. C.

14-11-1679

Fr. José Ruiz, abad

Quintanillas (Burgos)

AGN, Irache, Lib. 539, 179r.

SIMÓN DE HIERRO

B. C.

24-11-1679

Fr. Mauro de Soria

Islares (Burgos)

AGN, Irache, Lib. 539, 18 or.

FRANCISCO LA IGLESIA GONZÁLEZ

B. A. / B. T.

12-12-1679

Fr. Mauro de Soria

Fresneda (Burgos)

AGN, Irache, Lib. 539, 18 or.

PEDRO GÓMEZ

B. C.

17-12-1679

Reprobado 
Fr. Mauro de Soria

Mansilla (Burgos)

AGN, Irache, Lib. 539, 18 or.

JOSÉ TORRENTE

B. A. / B. M.

9-1-1680

Fr. Mauro de Llano / Fr. Mauro de Soria /

Dr. Cercilla

Pilzán (Urgel)

AGN, Irache, Lib. 539, 18 or.

JUAN DE ARENZANA Y MONTENEGRO

B. A. / B. T.

9-1-1680

Fr. Mauro de Llano

Mansilla (Burgos)

AGN, Irache, Lib. 539, $180 v$.

JOSÉ HERMOSO

B. C.

20-1-1680 / 20-7-1680 Reprobado dos veces

13-5-1687

Fr. Vicente Díez / Fr. Mauro de Soria // Fr.

Pedro Lozano

Santa María del Campo (Burgos)

AGN, Irache, Lib. 539, 180v, 184r, 272r.

\section{JUAN CATIBIELA}

B. A. / B. T.

27-1-1680

Fr. Mauro de Llano / Fr. Mauro de Soria

Anso (Jaca)

Pbro.

AGN, Irache, Lib. 539, $180 v$.

LORENZO DE AYALA

B. C.

7-2-168o

Fr. Vicente Díez

Barbadillo del Mercado (Burgos)

AGN, Irache, Lib. 539, $180 v$.

GREGORIO DE IBARROLA

B. C.

8-2-1680

Fr. Vicente Díez
Martín de Don (Burgos)

AGN, Irache, Lib. 539, 181r.

JOSÉ DE IBARROLA

B. C.

8-2-1680

Fr. Mauro de Soria

Martín de Don (Burgos)

AGN, Irache, Lib. 539, 181r.

ANTONIO MARTÍNEZ

B. C.

14-2-1680

Fr. Alonso de Verdesoto

Prado La Mata (Burgos)

AGN, Irache, Lib. 539, 181r.

PEDRO ROSALES

L. C.

14-2-1680

Fr. José Ruiz, abad

Alfaro (Tarazona)

AGN, Irache, Lib. 539, 181r.

BARTOLOMÉ PANCORBO

B. L.

27-2-1680

Fr. Vicente Díez

Marcillo (Pamplona)

AGN, Irache, Lib. 539, 181r.

FRANCISCO RUIZ DE QUINTANA

B. C.

29-2-1680

Fr. Mauro de Soria

Poza (Burgos)

AGN, Irache, Lib. 539, $181 \mathrm{v}$.

JUAN SAIZ DE SETIÉN

B. A. / B. T.

17-3-1680

Fr. Mauro de Llano

Barbadillo (Burgos)

AGN, Irache, Lib. 539, 181v.

FELIPE GARCÍA

B. C.

19-3-1680 
Fr. Mauro de Soria

Villasandino (Burgos)

AGN, Irache, Lib. 539, $181 \mathrm{v}$.

\section{ALONSO SEDANO}

B. C.

23-3-1680

Reprobado

Fr. Mauro de Soria

Cubillo del Butrón (Burgos)

AGN, Irache, Lib. 539, 181v.

JOSÉ DE PIERNAS

B. A. / B. T.

27-3-1680

Fr. Mauro de Llano / Fr. Alonso de Verdesoto

Burgos

AGN, Irache, Lib. 539, 181v.

MANUEL REYES DE MANSILLA

B. C.

28-3-168o / 9-5-168o

Reprobado

Fr. Vicente Díez / Fr. Alonso de Verdesoto

Hay descripción física

Huerta de Arriba (Burgos)

AGN, Irache, Lib. 539, 182r, $182 \mathrm{v}$.

NICOLÁS DE BARRIGA TORRES Y MATA

B. C.

30-3-1680

Fr. Mauro de Soria

Burgos

AGN, Irache, Lib. 539, 182 r.

JUAN CARCEDO ESCOBAR

B. C.

31-3-1680

Fr. Alonso de Verdesoto

Burgos

AGN, Irache, Lib. 539, 182r.

MARTÍN DE GARDE

B. A. / B. T. / L. T. / D. T.

1-4-1680

Fr. Mauro de Llano, catedrático de Filosofía

/ Fr. Mauro de Soria / Fr. José Ruiz, abad
Estella (Pamplona)

AGN, Irache, Lib. 539, 182r.

JUAN DE BEARÍN

B. A. / B. T.

7-4-1680

Fr. Mauro de Llano / Fr. Mauro de Soria

Estella (Pamplona)

AGN, Irache, Lib. 539, 182r.

SEBASTIÁN DE RIAÑO Y GAMBOA

B. C.

13-4-1680

Fr. Mauro de Soria

Cerezo (Burgos)

AGN, Irache, Lib. 539, $182 \mathrm{v}$.

JUAN PÉREZ

B. C.

17-4-1680

Fr. Alonso Verdesoto

Salazar (Burgos)

AGN, Irache, Lib. 539, 182v.

ANTONIO GARCÍA RAMÍREZ

B. A. / B. T.

28-4-1680

Fr. Mauro de Llano / Fr. Mauro de Soria

Brieba (Burgos)

AGN, Irache, Lib. 539, $182 \mathrm{v}$.

MARTÍN DÍEZ

B. C.

3-5-1680

Fr. Mauro de Soria

Cerezo (Burgos)

AGN, Irache, Lib. 539, $182 \mathrm{v}$.

JOSÉ DE OLARIAGA

B. A.

4-5-1680

Fr. Mauro de Llano

Vergara (Calahorra)

AGN, Irache, Lib. 539, $182 \mathrm{v}$.

\section{MANUEL DE OBREGÓN}

B. C.

10-5-1680 
Fr. Alonso de Verdesoto

Santa Cruz del Valle de Iguña (Burgos)

AGN, Irache, Lib. 539, 182v.

CRISTÓBAL RUIZ

B. C.

10-5-1680 / 20-5-1680

Reprobado dos veces

Fr. Mauro de Soria

San Miguel de Aguayo (Burgos)

AGN, Irache, Lib. 539, 182v, $183 \mathrm{r}$.

PEDRO ÁLVAREZ

B. C.

13-5-1680 / 4-6-1680

Reprobado dos veces

Fr. Mauro de Soria

Susinos (Burgos)

AGN, Irache, Lib. 539, 183 rv.

FRANCISCO RUPÉREZ

B. C.

13-5-1680

Fr. Alonso de Verdesoto

Cartromorca (Burgos)

AGN, Irache, Lib. 539, 183 r.

PEDRO LLANILLO

B. C.

14-5-1680

Fr. Alonso de Verdesoto

San Martín de Humada (Burgos)

AGN, Irache, Lib. 539, 183 r.

MATEO DEL CORRAL

B. C.

17-5-1680

Reprobado

Fr. Mauro de Soria

Espinosa de los Monteros (Burgos)

AGN, Irache, Lib. 539, 183r.

MARTÍN PÉREZ DE POLANCO

B. C.

22-5-1680

Fr. Alonso de Verdesoto

Miraveche (Burgos)

AGN, Irache, Lib. 539, 183 r.
JUAN DE URBINA

B. C.

2-6-1680

Reprobado

Fr. Mauro de Soria

Valluércanes (Burgos)

AGN, Irache, Lib. 539, 183r.

\section{ATANASIO FERNÁNDEZ}

B. C.

2-6-1680

Fr. Mauro de Soria

Valluércanes (Burgos)

AGN, Irache, Lib. 539, $183 v$.

MELCHOR DE ESCUDERO

B. C.

5-6-168o

Fr. Alonso de Verdesoto

Grisaleña (Burgos)

AGN, Irache, Lib. 539, $183 \mathrm{v}$.

\section{BLAS GONZÁLEZ}

B. C.

12-6-1680

Fr. Alonso Verdesoto

Grisaleña (Burgos)

AGN, Irache, Lib. 539, $183 v$.

MATÍAS MÍNGUEZ

B. C.

$1-7-1680$

Fr. Alonso Verdesoto

Estépar (Burgos)

AGN, Irache, Lib. 539, 183v.

ANDRÉS ZURITA

B. C.

4-7-1680

Fr. Alonso Verdesoto

Villasandino (Burgos)

AGN, Irache, Lib. 539, $183 \mathrm{v}$.

\section{ALONSO DE ARCE}

B. C.

5-7-1680

Fr. Benito de Ortega

Ubierna (Burgos)

AGN, Irache, Lib. 539, $183 \mathrm{v}$. 
JOSÉ VILLALAR

B. C.

8-7-1680

Fr. Benito de Ortega

Frías (Burgos)

AGN, Irache, Lib. 539, 184r.

JOSÉ GONZÁLEZ

B. C.

13-7-1680

Fr. Alonso Verdesoto

Villagutiérrez (Burgos)

AGN, Irache, Lib. 539, 184 r.

MATEO DEL CORRAL

B. C.

1-8-1680

Fr. Alonso Verdesoto

Astrana (Burgos)

AGN, Irache, Lib. 539, 184 r.

JUAN DE VALLEJO

B. C.

5-8-1680

Fr. Alonso Verdesoto

Hornillos (Burgos)

AGN, Irache, Lib. 539, 184 r.

TOMÁS RODRÍGUEZ

B. C.

5-8-1680 / 29-8-1680

Reprobado

Fr. Mauro de Soria / Fr. Alonso Verdesoto Hornillos (Burgos)

AGN, Irache, Lib. 539, 184r, 184v.

LORENZO GARCÍA

B. A. / B. T.

11-8-1680

Fr. Mauro de Llano / Fr. Alonso Verdesoto Villalmanzo (Burgos)

AGN, Irache, Lib. 539, $184 \mathrm{~V}$.

DOMINGO LUIS DE GOÑI

B. A. / B. M.

12-8-1680

Fr. Alonso Verdesoto / Fr. Mauro de Soria / Dr. Morras
Pamplona

AGN, Irache, Lib. 539, $184 \mathrm{v}$.

GABRIEL ÁLVAREZ DE PALACIOS

B. C.

21-8-1680

Fr. Mauro de Soria

Villahoz (Burgos)

AGN, Irache, Lib. 539, 184v.

BARTOLOMÉ DE LODOSO

B. C.

21-8-1680 / 28-10-1680

Reprobado

Fr. Alonso Verdesoto

Isar (Burgos)

AGN, Irache, Lib. 539, 184v.

MIGUEL ÁLVAREZ Y CARRERA

B. C.

21-8-1680

Fr. Alonso de Verdesoto

Villahoz (Burgos)

AGN, Irache, Lib. 539, $184 \mathrm{v}$.

JUAN DE MONTEJO

B. C.

3-9-1680

Fr. Alonso Verdesoto

Villegas (Burgos)

AGN, Irache, Lib. 539, 185r.

\section{DOMINGO FERNÁNDEZ}

B. C.

10-9-1680

Fr. Alonso Verdesoto

Pedrosa de Arcellares (Burgos)

AGN, Irache, Lib. 539, 185r.

TOMÁS ESQUER

L. A.

16-9-168o

Fr. Mauro de Llano

Roncal (Pamplona)

AGN, Irache, Lib. 539, 185r.

MIGUEL FERNÁNDEZ DE LA PEÑA

B. C. 
8-10-1680

Fr. Mauro de Llano

Santa María de Ribarredonda (Burgos)

AGN, Irache, Lib. 539, 185r.

\section{DIEGO FERNÁNDEZ DE IMAÑA}

B. C.

27-10-1680

Fr. Benito de Ortega

Montejo de San Miguel (Burgos)

AGN, Irache, Lib. 539, 185r.

\section{LORENZO GONZÁLEZ}

B. C.

30-10-1680

Fr. Alonso de Verdesoto

Aguilar de Bureba (Burgos)

AGN, Irache, Lib. 539, 185v.

MANUEL ANTONIO DE SALAMANCA

B. C.

30-10-1680

Fr. Alonso de Verdesoto

Briviesca (Burgos)

AGN, Irache, Lib. 539, 185v.

SEBASTIÁN RUIZ DE EGUIDO

B. A.

8-11-1680

Fr. Mauro de Llano

Salvatierra (Calahorra)

AGN, Irache, Lib. 539, 185v.

SIMÓN DE AMPURO

B. A. / B. T.

15-11-1680

Fr. Mauro de Llano / Fr. Alonso Verdesoto

Castro Urdiales (Burgos)

AGN, Irache, Lib. 539, 185v.

JOSÉ RAMOS

B. C.

25-11-1680

Fr. Alonso Verdesoto

Cavia (Burgos)

AGN, Irache, Lib. 539, 186r.

FRANCISCO MERINO

B. C.
25-11-1680

Fr. Vicente Díez

Mazuela (Burgos)

AGN, Irache, Lib. 539, 186r.

ALONSO MIGUEL

B. C.

26-11-168o / 26-5-1681

Reprobado dos veces

Fr. Mauro de Soria

Mallos (Burgos)

AGN, Irache, Lib. 539, 186r, 192v.

TOMÁS RODRÍGUEZ

B. C.

26-11-1680

Fr. Alonso Verdesoto

Barrios (Burgos)

AGN, Irache, Lib. 539, 186r.

PEDRO FERNÁNDEZ

B. C.

26-11-1680

Fr. Vicente Díez

Villadiego (Burgos)

AGN, Irache, Lib. 539, 186r.

\section{FRANCISCO CUESTA}

B. C.

27-11-1680

Fr. Mauro de Soria

Castrecias (Burgos)

AGN, Irache, Lib. 539, 186v.

DOMINGO LA PEÑA

B. C.

11-12-1680

Fr. Alonso Verdesoto

Dobro (Burgos)

AGN, Irache, Lib. 539, 186v.

TORIBIO GONZÁLEZ

B. T.

11-12-1680

Fr. Vicente Díez

Los Tojos (Burgos)

AGN, Irache, Lib. 539, 186v. 
MELCHOR MONEDERO

B. C.

17-12-168o / 28-4-168o

Reprobado

Fr. Mauro de Soria / Fr. Alonso Verdesoto

Villasta (Nullius Diocesis)

AGN, Irache, Lib. 539, 186v, 191r.

DOMINGO RUIZ

B. C.

17-12-168o

Reprobado

Fr. Alonso Verdesoto

Sandoval de la Reina (Burgos)

AGN, Irache, Lib. 539, 186v.

MARTÍN PÉREZ

B. A. / B. T.

18-12-1680

Fr. Mauro de Llano / Fr. Vicente Díez

Avellanosa (Calahorra)

AGN, Irache, Lib. 539, 187 r.

JERÓNIMO VIDAURRE

B. A. / B. M.

18-12-1680

Fr. Mauro de Llano / Fr. Mauro de Soria /

Dr. Morras

Salinas (Pamplona)

AGN, Irache, Lib. 539, $187 \mathrm{r}$.

\section{PEDRO AGAZÓN}

B. T.

31-12-1680

Fr. Alonso de Verdesoto

Medina de Pomar (Burgos)

B.A.

AGN, Irache, Lib. 539, 187 r.

SIMÓN DE REVILLA

B. C.

3-1-1681

Fr. Vicente Díez

Pedreña (Burgos)

AGN, Irache, Lib. 539, 187v.

MARCOS DE BÁRCENA

B. C.
25-1-1681

Fr. Mauro de Soria

Bentretea (Burgos)

Estudiante en Valladolid

AGN, Irache, Lib. 539, $187 \mathrm{v}$.

BENITO SIMÓN

B. A. / B. T.

11-2-1681

Fr. Mauro de Llano / Fr. Alonso Verdesoto

Torre de Páramo (Burgos)

AGN, Irache, Lib. 539, 187v.

JUAN PÉREZ DE LAMA

B. C.

16-2-1681

Fr. Mauro de Soria

Mahallos (Burgos)

AGN, Irache, Lib. 539, 188r.

JUAN ALONSO

B. C.

16-2-1681

Reprobado

Fr. Mauro de Soria

Aboral...

AGN, Irache, Lib. 539, 188r.

JUAN BAUTISTA DE BERASTEGUI

B. C.

17-2-1681 / 4-4-1681

Reprobado

Fr. Alonso Verdesoto

Balmaseda (Burgos)

AGN, Irache, Lib. 539, 188r, $190 v$.

FRANCISCO SEDANO

B. C.

24-2-1681

Reprobado

Fr. Vicente Díez

Villarmero (Burgos)

AGN, Irache, Lib. 539, 188r.

FRANCISCO DÍEZ

B. A. / B. T.

4-3-1681

Fr. Mauro de Llano / Fr. Mauro de Soria 
Sasamón (Burgos)

AGN, Irache, Lib. 539, 188r.

FRANCISCO GONZÁLEZ

B. C.

4-3-1681

Fr. Alonso Verdesoto

Sasamón (Burgos)

AGN, Irache, Lib. 539, 188v.

FRANCISCO GAYANGOS BASTRIDA

B. A.

8-3-1681

Fr. Mauro de Llano

Haro (Calahorra)

AGN, Irache, Lib. 539, 188v.

SANTIAGO DE BERANGA

B. C.

10-3-1681

Fr. Vicente Díez

Valmaseda (Burgos)

AGN, Irache, Lib. 539, 188v.

JOSÉ CARPINTERO TELLO

B. C.

10-3-1681

Fr. Mauro de Soria

Sasamón (Burgos)

AGN, Irache, Lib. 539, 188v.

\section{ANTONIO MARTÍNEZ}

B. C.

10-3-1681

Fr. Alonso Verdesoto

Pedrosa del Páramo (Burgos)

AGN, Irache, Lib. 539, 188v.

JOSÉ DEL PUEYO

B. A.

17-3-1681

Fr. Mauro de Llano

Alfaro (Tarazona)

AGN, Irache, Lib. 539, 189 r.

JOSÉ SÁNCHEZ

B. A.

17-3-1681
Fr. Mauro de Llano

Lerín (Pamplona)

AGN, Irache, Lib. 539, 189r.

JOSÉ MARTÍNEZ VALLÉS

B. T. / L. T.

18-3-1681 / 4-4-1683

Fr. Mauro de Soria

Alfaro (Tarazona)

AGN, Irache, Lib. 539, 189r, 211v.

PEDRO PANCORBO

B. C.

18-3-1681

Fr. Vicente Díez

Briones (Burgos)

AGN, Irache, Lib. 539, 189 r.

DOMINGO ALFONSO DE OJEDA

B. C.

21-3-1681

Fr. Mauro de Soria

Río Quintanilla (Burgos)

AGN, Irache, Lib. 539, 189v.

JUAN DE HOYOS

B. C.

25-3-1681 Reprobado

5-9-1681 Aprobado

Fr. Alonso Verdesoto / Fr. Vicente Díez

AGN, Irache, Lib. 539, 189v, 194r.

PEDRO RUIZ CELEDÓN

B. A. / B. T. / L. A. / D. A. / D. T.

31-3-1681

Fr. Mauro de Soria / Fr. José Ruiz, abad

Estella (Pamplona)

AGN, Irache, Lib. 539, 189v, 190r.

AGUSTÍN DE ICEDO

B. C.

31-3-1681

Fr. Vicente Díez

Villadiego (Burgos)

AGN, Irache, Lib. 539, 189v.

JOSÉ DE VELASCO

B. C. 
12-4-1681

Fr. Mauro de Soria

Villadiego (Burgos)

AGN, Irache, Lib. 539, $190 v$.

FRANCISCO GARCÍA

B. A.

13-4-1681

Fr. Vicente Díez

Tudela (Tarazona)

AGN, Irache, Lib. 539, $190 v$.

ANTONIO DE LA VEGA

B. C.

17-4-1681

Fr. Alonso Verdesoto

Briviesca (Burgos)

AGN, Irache, Lib. 539, $190 v$.

ANTONIO DE ALTARACH

B. C.

16-4-1681

Reprobado

Fr. Alonso Verdesoto

Astudillo (Palencia)

AGN, Irache, Lib. 539, $190 v$.

ANDRÉS DE VILLATE

B. C.

19-4-1681

Fr. Alonso Verdesoto

Villar de Torre (Burgos)

AGN, Irache, Lib. 539, 191r.

JUAN DE TRISTÁN GONZÁLEZ

B. C.

21-4-1681

Fr. Vicente Díez

Burgos

AGN, Irache, Lib. 539, 191r.

ANTONIO FERNÁNDEZ HUIDOBRO

B. C.

24-4-1681

Fr. Alonso Verdesoto

Huidobro (Burgos)

AGN, Irache, Lib. 539, 191r.
MIGUEL AZNAR CORTÉS

B. A. / B. T.

3-5-1681

Fr. Alonso Verdesoto

Alfaro (Tarazona)

AGN, Irache, Lib. 539, $191 \mathrm{v}$.

PEDRO MATEO DE RÍO

B. T.

3-5-1681

Fr. Alonso Verdesoto

Alfaro (Tarazona)

AGN, Irache, Lib. 539, $191 \mathrm{v}$.

PEDRO INFANTE

B. A.

16-5-1681

Fr. Vicente Díez

Ocón

AGN, Irache, Lib. 539, 191v.

JUSTO DE OÑA Y SOTO

B. C.

18-5-1681

Fr. Vicente Díez

Bivriesca (Burgos)

AGN, Irache, Lib. 539, 192r.

PEDRO DE VARGA Y ESPAÑA

B. C.

18-5-1681

Fr. Alonso Verdesoto

Briviesca (Burgos)

AGN, Irache, Lib. 539, 192r.

FERNANDO GARCÍA

B. A.

23-5-1681

Fr. Vicente Díez

Tudela (Tarazona)

AGN, Irache, Lib. 539, 192 .

ALONSO DE VERDESOTO

B. A. / B. T. / L. T. / D. T.

29-5-1681

Fr. Antonio de Heredia, Abad y Rector

O. S. B.

Profesor en Irache

AGN, Irache, Lib. 539, 192r. 


\section{MARTÍN MIGUEL}

B. C.

11-6-1681

Fr. Benito de Ortega

Villahoz (Burgos)

AGN, Irache, Lib. 539, 192v.

FRANCISCO DE ESCAPADILLO

B. C.

2-6-1681

Fr. Vicente Díez

Hoz (Burgos)

AGN, Irache, Lib. 539, 192v.

\section{ANTONIO DE VELASCO}

B. A. / B. T.

18-6-1681

Fr. Benito de Ortega / Fr. Vicente Díez

Olmillos (Burgos)

AGN, Irache, Lib. 539, 192v, 193r.

AGUSTÍN DE REA

B. A. / B. T.

3-8-1681

Fr. Vicente Díez / Fr. Benito de Ortega

Corbes (Tarazona)

AGN, Irache, Lib. 539, 193r.

\section{MARCOS LÓPEZ DE HARO}

B. C.

17-8-1681

Fr. Benito de Ortega

Montañana (Burgos)

AGN, Irache, Lib. 539, 193v.

JOSÉ RUIZ DE UBAGO

B. C. / B. L.

22-8-1681

Fr. Vicente Díez

Elciego (Burgos)

AGN, Irache, Lib. 539, $193 \mathrm{v}$.

ANTONIO DE VILLASAÑANA BARRAL

B. C.

11-9-1681

Fr. Vicente Díez

Melgar de Fernamental (Burgos)

AGN, Irache, Lib. 539, 194r.

\section{GABRIEL ANTÓN}

B. A. / B. M.

25-9-1681

Fr. Benito de Ortega

Lodosa (Calahorra)

AGN, Irache, Lib. 539, 194r.

JERÓNIMO PÉREZ SERRANO

B. A.

26-9-1681

Fr. Mauro de Soria

Quart (Valencia)

AGN, Irache, Lib. 539, 194r.

FRANCISCO DE ROA

B. C.

6-10-1681

Fr. Vicente Díez

Pampliega (Burgos)

AGN, Irache, Lib. 539, 194V.

FRANCISCO DE AZAS

B. C.

7-10-1681

Fr. Vicente Díez

Azas (Burgos)

AGN, Irache, Lib. 539, 194v.

FÉLIX VELASCO

B. C.

10-10-1681

Fr. Benito de Ortega

Alaejos (Valladolid)

AGN, Irache, Lib. 539, 194V.

ÍNIIGO ROYO

D..

10-10-1681

Fr. Antonio de Heredia, Abad y Rector

AGN, Irache, Lib. 539, 194v.

LORENZO DE ISLA PALACIO

B. C.

17-10-1681

Reprobado

Fr. Vicente Díez

Bárcena (Burgos)

AGN, Irache, Lib. 539, 194v. 
JUAN FERNÁNDEZ TRUCHUELO

B. C.

21-10-1681

Fr. Benito de Ortega

Foncea (Burgos)

AGN, Irache, Lib. 539, 195r.

MATEO DE ISLA

B. C.

5-11-1681 / 15-11-1681

Reprobado dos veces

Fr. Mauro de Soria / Fr. Vicente Díez

Azas (Burgos)

AGN, Irache, Lib. 539, 195r.

PEDRO RUBIO PÉREZ

B. C.

8-11-1681

Fr. Vicente Díez

Vimegra (Burgos)

AGN, Irache, Lib. 539, 195r.

ANDRÉS DE LEBRETA

B. C.

10-11-1681 / 15-11-1681

Reprobado

Fr. Mauro de Soria

Revilla

AGN, Irache, Lib. 539, 195r.

JUAN ANTONIO DE SANTELICES

B. C.

15-11-1681

Fr, Vicente Díez

Escalantes (Burgos)

AGN, Irache, Lib. 539, 195v.

JUAN DE ARBIZU

B. A. / B. M.

24-11-1681

Fr. Andrés de Zeballos / Fr. Mauro de Soria

Irañeta (Pamplona)

AGN, Irache, Lib. 539, 195v.

PEDRO DE MONTALBÁN

B. C.

25-11-1681

Fr. Vicente Díez
Bárcena (Burgos)

AGN, Irache, Lib. 539, 195v.

MIGUEL DE ÁVILA

B. A. / B. T.

27-11-1681

Fr. Andrés de Zeballos / Fr. Mauro de Soria Bureba (Burgos)

AGN, Irache, Lib. 539, 195v.

ANTONIO PALACIOS

B. C.

1-12-1681

Fr. Vicente Díez

Noja (Burgos)

AGN, Irache, Lib. 539, 196r.

ANTONIO DE RUEDA

B. C.

18-12-1681

Fr. Mauro de Soria

Riba

AGN, Irache, Lib. 539, 196r.

JUAN JUEZ

B. C.

28-12-1681

Fr. Vicente Díez

Aceña de Lara (Burgos)

AGN, Irache, Lib. 539, 196r.

CLEMENTE GIL

B. C.

29-12-1681 Reprobado

16-6-1682 Reprobado en primera / Apto en segunda

Fr. Mauro de Soria / Fr. Vicente Díez

Bureba (Burgos)

AGN, Irache, Lib. 539, 196r, 199v.

ALONSO ANTONIO DE PALACIO

B. C.

1-1-1682

Fr. Vicente Díez

L... (Burgos)

AGN, Irache, Lib. 539, 196r.

MIGUEL CLAVER

L. C. / D. C. 
17-2-1682 / 24-4-1687

Fr. Antonio de Heredia, Abad y Rector / Fr. Gregorio Ruiz, abad

Sieso (Huesca)

AGN, Irache, Lib. 539, 196v, 271v.

ANTONÍN DEL AMACORIA

B. C.

17-2-1682

Fr. Mauro de Soria

Castro Urdiales (Burgos)

AGN, Irache, Lib. 539, 196v.

JUAN DE BURGOS

B. C.

18-2-1682

Fr. Vicente Díez

Campo de Lara

AGN, Irache, Lib. 539, 196v.

PEDRO MANSO

B. A.

18-2-1682

Fr. Mauro de Soria

Burgos

AGN, Irache, Lib. 539, 196v.

JUAN DE LAS HERAS

L. T.

22-2-1682

Fr. Antonio de Heredia, abad

Olvés (Tarazona)

AGN, Irache, Lib. 539, 196v.

GABRIEL PÉREZ

L. C.

5-3-1682

Reprobado

Fr. Vicente Díez

Las Medranas (Burgos)

AGN, Irache, Lib. 539, 196v.

JUAN DE CELIS DE LA MATA

B. A. / B. T.

18-3-1682 /10-5-1682 / 4-8-1682

Reprobado

Fr. Andrés de Ceballos, catedrático de Artes

/ Fr. Mauro de Soria / Fr. Vicente Díez
Uday (Burgos)

AGN, Irache, Lib. 539, 197r, $202 \mathrm{v}$.

\section{MATEO DE FONTECHA}

B. C.

30-3-1682 / 26-8-1682

Reprobado

Fr. Vicente Díez

Montañana (Burgos)

AGN, Irache, Lib. 539, 197r, 203r.

ANTONIO BARONA GAMARRA

B. C.

4-4-1682

Fr. Vicente Díez

Castrojeriz (Burgos)

AGN, Irache, Lib. 539, $197 \mathrm{v}$.

PEDRO DE HERRERA

B. C.

5-4-1682

Reprobado

Fr. Díez / Fr. Zeballos

Pamanes (Burgos)

AGN, Irache, Lib. 539, 197v.

FELIPE DE MIERA RUBALCABA

B. A. / B. T.

10-4-1682

Fr, Andrés Zeballos / Fr. Vicente Díez

Liérganes (Burgos)

AGN, Irache, Lib. 539, 197v.

JOSÉ ANTONIO DE LA VEGA

B. C.

13-4-1682

Fr. Vicente Díez

Pamanes (Burgos)

AGN, Irache, Lib. 539, 198r.

ANTONIO LÓPEZ DE RUEDA

B. C.

20-4-1682

Fr. Vicente Díez

Torres (Burgos)

AGN, Irache, Lib. 539, 198r.

CRISTÓBAL DE ARCE

B. C. 
24-4-1682

Fr. Vicente Díez

Lerma (Nullius Diocesis)

AGN, Irache, Lib. 539, 198v.

JUAN MARTÍNEZ DE RODRIGO

B. C.

6-5-1682

Fr. Vicente Díez

Hoz de Arreba (Burgos)

AGN, Irache, Lib. 539, 198v.

JOSÉ DE LATOR

B. M.

20-5-1682

Fr. Vicente Díez / Dr. Morras

Mendigorría (Pamplona)

AGN, Irache, Lib. 539, 198v.

GASPAR PASCUAL

B. A. / B. T.

1-6-1682

Fr. Andrés Zeballos / Fr. Juan Bta. Lardito

Santa María (Burgos)

AGN, Irache, Lib. 539, 199 r.

ESTEBAN DE YÁRNOZ Y SOLCHAGA

B. C.

9-6-1682

Fr. Antonio de Heredia, abad

Arazuri (Pamplona)

AGN, Irache, Lib. 539, 199v.

GABRIEL DE PAREDES

B. A. / B. T.

14-6-1682

Fr. Andrés Zeballos / Fr. Juan Bta. Lardito

Montijo

AGN, Irache, Lib. 539, 199v.

FRANCISCO GARCÉS DE FANECAS

B. A. / B. T. / L. T. / D. T.

29-6-1682

Fr, Andrés Zeballos / Fr. Vicente Díez / Fr.

Antonio de Heredia, abad

Borja (Tarazona)

AGN, Irache, Lib. 539, $200 r$.
MILLÁN DE LABREDO

B. C.

30-6-1682

Fr. Vicente Díez

Tribiana (Burgos)

AGN, Irache, Lib. 539, $200 v$.

GREGORIO GALLO

B. C.

1-7-1682 / 8-11-1682

Reprobado

Fr. Juan Bta. Lardito

Escalada (Burgos)

AGN, Irache, Lib. 539, 200v, 205r.

JOSÉ LÓPEZ

B. A. / B. T.

10-7-1682 / 12-2-1684

Fr. Andrés Zeballos / Fr. Vicente Díez

Altable (Nullius Diocesis) sujeto a San Mi-

llán de la Cogolla

AGN, Irache, Lib. 539, 201r, 223r.

MATÍAS VELASCO

B. A. / B. T. / L. T.

27-7-1682

Fr. Antonio de Heredia, abad

Sesma (Pamplona)

AGN, Irache, Lib. 539, 201rv.

JOSÉ DE ACU...

B. C.

2-8-1682

Reprobado

Fr. Vicente Díez

Alcampell (Lérida)

AGN, Irache, Lib. 539, 202 r.

JAIME DE ABIO

L. C. / D. C.

4-8-1682

Fr. Antonio de Heredia, abad

Sieso (Reino de Aragón)

AGN, Irache, Lib. 539, 202v.

FELIPE PÉREZ DEL RÍO

B. C.

9-8-1682 
Fr. Juan Bta. Lardito

Concejo de Udias (Burgos)

AGN, Irache, Lib. 539, 202v.

TORIBIO DE LA CUEVA

B. C.

9-8-1682

Fr. Juan Bta. Lardito

Concejo de Udias (Burgos)

AGN, Irache, Lib. 539, 203 r.

JUAN DE ALVARADO BRACAMONTE

B. C.

23-8-1682

Fr. Vicente Díez

Frías (Burgos)

AGN, Irache, Lib. 539, 203 r.

SANTIAGO MATEO

B. A. / B. T.

24-8-1682

Fr. Andrés Zeballos / Fr. Juan Bta. Lardito

Burgos

AGN, Irache, Lib. 539, 203v.

ANDRÉS MARTÍNEZ

B. A. / B. T.

4-9-1682

Fr. Juan Bta. Lardito / Fr. Vicente Díez

Pampliega (Burgos)

AGN, Irache, Lib. 539, 203v.

JOSÉ RUIZ

B. C.

4-9-1682

Fr. Juan Bta. Lardito

Pampliega (Burgos)

AGN, Irache, Lib. 539, $203 v$.

GABRIEL GULLÓN SOBREMONTE

B. C.

7-9-1682

Fr. Juan Bta. Lardito

Aguilar de Campos (Valladolid)

AGN, Irache, Lib. 539, 204 r.

FELIPE MATEO

B. T. / L. T. / D. T.
28-9-1682

Fr. Vicente Díez / Fr. Juan Bta. Lardito

Ojos Negros (Zaragoza)

AGN, Irache, Lib. 539, 204 r.

LEANDRO GONZÁLEZ VILLALOBOS

B. C.

2-10-1682

Fr. Juan Bta. Lardito

Villamoñico (Burgos)

AGN, Irache, Lib. 539, 204v.

JOSÉ HERNANDO

B. C.

3-10-1682

Fr. Vicente Díez

Villadiego (Burgos)

AGN, Irache, Lib. 539, 204v.

FRANCISCO RODRÍGUEZ MANSILLA

B. C.

16-10-1682

Reprobado

Fr. Juan Bta. Lardito

Susilla (Burgos)

AGN, Irache, Lib. 539, 205r.

CRISTÓBAL DE GARZARÁN

B. A. / L. A.

28-10-1682

Fr. Andrés Zeballos

Pamplona

AGN, Irache, Lib. 539, 205 r.

ANDRÉS BIELMA

B. C.

1-11-1682

Fr. Vicente Díez

Rábanos (Palencia)

AGN, Irache, Lib. 539, 205v.

FRANCISCO MARTÍNEZ DE VITORIA

B. C.

8-11-1682

Fr. Vicente Díez

Burgos

AGN, Irache, Lib. 539, 205v. 
ESTEBAN DEL HOYO

B. C.

8-11-1682

Fr. Vicente Díez

Villaespasa (Burgos)

AGN, Irache, Lib. 539, 205v.

DIEGO DE SANTANDER

B. C.

12-11-1682

Fr. Vicente Díez

Castrojeriz (Burgos)

AGN, Irache, Lib. 539, 206r.

JOSÉ DE ESPINOSA

B. C.

18-11-1682

Fr. Vicente Díez

Castrojeriz (Burgos)

AGN, Irache, Lib. 539, 206r.

PEDRO LÓPEZ DE BRIZUELA

B. C.

23-11-1682

Fr. Vicente Díez

B... (Burgos)

AGN, Irache, Lib. 539, $206 r$.

JOSÉ DE SOTO

B. A. / B. T. / L. T. / M. T.

24-11-1682

Fr. Antonio de Heredia, abad

O. S. B.

Definidor

AGN, Irache, Lib. 539, 206v.

SEBASTIÁN DE VALDEMORO

B. C.

6-12-1682

Fr. Mauro de Soria

Castrillo de Murcia (Burgos)

AGN, Irache, Lib. 539, 206v.

JUAN DE ROTA

B. A. / B. T. / L. T. / D. T.

15-12-1682

Fr. Andrés Zeballos / Fr. Vicente Díez / Fr. AGN, Irache, Lib. 539, 208r.

Antonio de Heredia, abad
Lerín (Pamplona)

AGN, Irache, Lib. 539, 206v, 207 r.

ANTONIO DE LA SIERRA

B. C.

17-12-1682

Fr. Juan Bta. Lardito

Cayón (Burgos)

AGN, Irache, Lib. 539, 207r.

IGNACIO FERNÁNDEZ DE MEDRANO

B. A. / B. M.

18-12-1682

Fr. Andrés Zeballos / Fr. Mauro Soria //

Dr. Arcilla

Viana (Pamplona)

AGN, Irache, Lib. 539, 207v.

PEDRO LUSARRETA

B. A. / B. M.

18-12-1682

Fr. Andrés Zeballos / Fr. Mauro Soria //

Dr. Arcilla

Urroz (Pamplona)

AGN, Irache, Lib. 539, 207v.

JUAN DE BUSTAMANTE

B. A. / B. T.

20-12-1682

Fr. Andrés Zeballos / Fr. Vicente Díez

Silió (Burgos)

AGN, Irache, Lib. 539, 208r.

TOMÁS DE TERREROS

B. C.

23-12-1682 / 28-1-1683

Reprobado

Fr. Mauro de Soria / Fr. Vicente Díez

Balmaseda (Burgos)

AGN, Irache, Lib. 539, 208r, 210 .

PEDRO ÁLVAREZ DE CASTRO

B. A. / B. T.

31-12-1682

Fr. Andrés Zeballos / Fr. Vicente Díez Burgos 


\section{LORENZO RODRÍGUEZ}

B. C.

10-1-1683 Reprobado

5-7-1683 Aprobado

Fr. Juan Bta. Lardito

Izán (Burgos)

AGN, Irache, Lib. 539, 208v, $215 \mathrm{v}$.

DOMINGO LA RIPA

B. A. / B. T. / L. T. / D. T.

20-1-1683

Fr. Antonio de Heredia, abad

O. S. B.

Villa de Hecho (Jaca)

Monasterio de San Juan de la Peña

AGN, Irache, Lib. 539, 208v.

\section{TOMÁS DE SARASA}

B. A. / B. T. / L. T. / D. T.

20-1-1683

Fr. Antonio de Heredia, abad

O. S. B.

Huesca

Monasterio de San Juan de la Peña

AGN, Irache, Lib. 539, 209r.

\section{MATÍAS VISÚS}

B. A. / B. T. / L. T. / D. T.

20-1-1683

Fr. Antonio de Heredia, abad

O. S. B.

Salinas

Monasterio de San Juan de la Peña

AGN, Irache, Lib. 539, 209 r.

\section{ANTONIO ENTRECANALES}

B. C.

25-1-1683

Fr. Vicente Díez

Pancorbo (Burgos)

AGN, Irache, Lib. 539, $209 \mathrm{v}$.

JUAN DE ARTIAGA

L. T.

26-1-1683

Fr. Vicente Díez

Arnaiz (Pamplona)

AGN, Irache, Lib. 539, 209v.

\section{SEBASTIÁN GUTIÉRREZ}

B. C.

3-2-1683

Fr. Juan Bta. Lardito

Santa María de Noba (Burgos)

AGN, Irache, Lib. 539, 210 .

\section{MATEO LARENA}

B. C.

7-2-1683

Fr. Mauro de Soria

Balmaseda (Burgos)

AGN, Irache, Lib. 539, $210 v$.

JUAN PASCUAL

B. C.

7-2-1683

Fr. Vicente Díez

Ballestera

AGN, Irache, Lib. 539, $210 v$.

JOSÉ RUIZ

B. A. / B. T.

27-2-1683

Fr. Andrés Zeballos / Fr. Mauro Soria

Burgos

AGN, Irache, Lib. 539, $210 v$.

JOSÉ TRIANA

B. C.

27-2-1683

Fr. Vicente Díez

Sasamón (Burgos)

AGN, Irache, Lib. 539, 211r.

DIEGO CALLEJA

B. C.

27-2-1683

Fr. Juan Bta. Lardito

Villasandino (Burgos)

AGN, Irache, Lib. 539, 211r.

\section{MIGUEL RODRÍGUEZ}

B. A. / B. T.

21-3-1683

Fr. Andrés Zeballos / Fr. Juan Bta. Lardito

Villavedón (Burgos)

AGN, Irache, Lib. 539, 211r. 
PEDRO DE BOLÍVAR

B. C.

5-4-1683/ 22-4-1683

Reprobado

Fr. Mauro Soria / Fr. Vicente Díez

Sodupe (Burgos)

AGN, Irache, Lib. 539, 211v, 212r.

DIEGO DE HERRERA

B. C.

8-4-1683

Fr. Vicente Díez

Medina de Pomar (Burgos)

AGN, Irache, Lib. 539, 211v.

JOSÉ DE AMATRIÁIN

B. A.

12-4-1683

Fr. Mauro Soria

Calahorra

AGN, Irache, Lib. 539, 212r.

JUAN VÍCTORES MARTÍNEZ DE MONTERRUBIO

B. A. / B. T.

22-4-1683

Fr. Andrés Zeballos / Fr. Juan Bta. Lardito

Cerezo (Burgos)

AGN, Irache, Lib. 539, 212v.

PEDRO DE CUÉLLAR Y CARRASCO

B. C.

12-5-1683 Reprobado

4-11-1683 Aprobado

Fr. Mauro Soria

Pancorbo (Burgos)

AGN, Irache, Lib. 539, 212v, $219 \mathrm{v}$.

FELIPE CALVO

B. C.

14-5-1683 / 14-11-1683

Reprobado dos veces

Fr. Vicente Díez

Burgos

AGN, Irache, Lib. 539, 212v, $220 v$.

DIEGO FERNÁNDEZ DE AMAÑA

L. T.
16-5-1683

Fr. Antonio de Heredia, abad

Herrán (Burgos)

AGN, Irache, Lib. 539, 213r.

FRANCISCO DÍEZ SAINZ

B. A. / B. T. / L. T.

17-5-1683

Fr. Andrés Zeballos / Fr. Juan Bta. Lardito

/ Fr. Mauro Soria

Quintana-Vides (Burgos)

AGN, Irache, Lib. 539, $213 v$.

\section{MARTÍN FERNÁNDEZ DE PELLÓN}

L. A.

22-5-1683

Fr. Vicente Díez / Fr. Mauro Soria

San Miguel de Meruelo (Burgos)

AGN, Irache, Lib. 539, 214r.

JOSÉ DE ALDALLUR

B. A.

25-5-1683

Fr. Andrés Zeballos

Oya (Pamplona)

AGN, Irache, Lib. 539, 214r.

MANUEL ANDRÉS

B. C.

28-5-1683

Fr. Mauro Soria

Isar (Burgos)

AGN, Irache, Lib. 539, $214 \mathrm{~V}$.

JOSÉ CALZADA

B. C.

4-6-1683/ 15-10-1683

Reprobado dos veces

Fr. Juan Bta. Lardito

Usuño (Burgos)

AGN, Irache, Lib. 539, 214v, 219r.

JACINTO ESCRIBANO

B. L.

6-6-1683

Fr. Juan Bta. Lardito

Tudela (Tarazona)

AGN, Irache, Lib. 539, $214 \mathrm{~V}$. 
FRANCISCO GARCÍA

B. C.

8-6-1683

Fr. Mauro Soria

Isar (Burgos)

AGN, Irache, Lib. 539, 215r.

MARTÍN DE RIAÑO

B. A. / B. T. / L. T. / D. T.

11-6-1683

Fr. Andrés Zeballos / Fr. Vicente Díez

San Asensio (Burgos)

AGN, Irache, Lib. 539, 215r.

PEDRO SIJERO

B. C.

11-6-1683

Fr. Juan Bta. Lardito

Santa María del Campo (Burgos)

AGN, Irache, Lib. 539, 215v.

JOSÉ GARCÍA

B. C.

15-7-1683

Fr. Juan Bta. Lardito

Quintanilla de las Carretas (Burgos)

AGN, Irache, Lib. 539, 215v.

PEDRO MERINO DE ROJAS

B. C.

8-8-1683

Fr. Juan Bta. Lardito

Madrid (Toledo)

AGN, Irache, Lib. 539, 216r.

FRANCISCO RUIZ

B. C.

10-8-1683

Fr. Juan Bta. Lardito

Santa María de Cayón (Burgos)

AGN, Irache, Lib. 539, 216r.

TOMÁS DE NAVASCUÉS

B. A. / B. M.

25-8-1683

Fr. Andrés Zeballos / Fr. Mauro de Soria /

Dr. Morras

Cintruénigo (Tarazona)

AGN, Irache, Lib. 539, 216v.
JOSÉ DE ANGULO

B. C.

30-8-1683

Fr. Vicente Díez

Limpias (Burgos)

AGN, Irache, Lib. 539, $216 \mathrm{v}$.

FRANCISCO VENTURA DE PALACIO

B. C.

2-9-1683

Fr. Vicente Díez

Limpias (Burgos)

AGN, Irache, Lib. 539, 216v.

MAMÉS ANTONIO MARTÍNEZ DE PAREDES

B. C. / L. C. / D. C.

2-9-1683 / 17-4-1699

Fr. Mauro de Soria / Fr. Gregorio de Prado, Abad, Rector y Canciller

Ampuero (Burgos)

AGN, Irache, Lib. 539, 217r; Lib. 549, 134r.

FRANCISCO OTÍN

L. M. / D. M.

22-9-1683

Fr. Mauro de Soria

Almudévar (Tarazona)

AGN, Irache, Lib. 539, 217r.

FRANCISCO DE PAMANES

B. C.

28-9-1683

Fr. Vicente Díez

Castro Urdiales (Burgos)

AGN, Irache, Lib. 539, $217 \mathrm{v}$.

JUAN LÓPEZ DEL CASTILLO

B. C.

28-9-1683

Fr. Juan Bta. Lardito

Santotis (Burgos)

AGN, Irache, Lib. 539, $217 \mathrm{v}$.

MIGUEL LÓPEZ DE LLANOS

B. C.

28-9-1683

Fr. Mauro de Soria 
Parainelo (Burgos)

AGN, Irache, Lib. 539, $217 \mathrm{v}$.

\section{JUSTO DE LA PEÑA BRIZUELAS}

B. T.

4-10-1683

Fr. Vicente Díez

Soncillo (Burgos)

AGN, Irache, Lib. 539, 218r.

JUAN MARTÍNEZ MATUTE DE VELASCO

L. C.

6-10-1683

Fr. Vicente Díez

Canales (Burgos)

AGN, Irache, Lib. 539, 218r.

\section{DAMIÁN DE PEÑARREDONDA}

B. A. / B. T.

10-10-1683

Fr. Andrés Zeballos / Fr. Vicente Díez

Castro Urdiales (Burgos)

AGN, Irache, Lib. 539, 218v.

FRANCISCO DE MOLINA

B. C.

15-10-1683

Fr. Mauro de Soria

Cerezo (Burgos)

AGN, Irache, Lib. 539, 218v.

\section{MIGUEL DE CANTABRANA}

B. A. / B. T.

22-10-1683

Fr. Andrés Zeballos / Fr. Vicente Díez

Santa Ollana (Burgos)

AGN, Irache, Lib. 539, 219 r.

\section{FRANCISCO GARCÍA}

B. C.

26-10-1683

Fr. Juan Bta. Lardito

Labadilla (Burgos)

AGN, Irache, Lib. 539, 219 r.

JOSÉ LLANO

B. C.

3-11-1683
Fr. Vicente Díez

Galdames (Burgos)

AGN, Irache, Lib. 539, $219 v$.

BARTOLOMÉ DE MURGA

B. C.

3-11-1683

Fr. Vicente Díez

Galdames (Burgos)

AGN, Irache, Lib. 539, $219 \mathrm{v}$.

ÁNGEL DE SALAZAR

B. A. / B. T.

4-11-1683

Fr. Andrés Zeballos / Fr. Juan Bta. Lardito

Villasandino (Burgos)

AGN, Irache, Lib. 539, $220 r$.

JUAN DEL CORRAL

B. C.

4-11-1683

Fr. Mauro de Soria

Villasandino (Burgos)

AGN, Irache, Lib. 539, 220 .

DIEGO DE SIGÜENZA

B. C.

9-11-1683

Fr. Vicente Díez

Redecilla del Campo (Burgos)

AGN, Irache, Lib. 539, $220 r$.

ANDRÉS ÁLVAREZ

B. C.

17-11-1683

Fr. Juan Bta. Lardito

Fresno de Río Tirón (Burgos)

AGN, Irache, Lib. 539, $220 v$.

DIEGO DE LA MONEDA

B. A. / B. T. / L. T. / D. T.

4-12-1683

Fr. José Zañartu, General

O. S. B.

San Juan de Burgos

AGN, Irache, Lib. 539, $220 v$.

MANUEL JOSÉ DE FABRO

B. A. 
10-12-1683

Fr. Andrés Zeballos

Viana (Calahorra)

AGN, Irache, Lib. 539, 221r.

FRANCISCO DE ZÁRRAGA

B. A. / B. T. / L. T. / D. T.

19-12-1683

Fr. Antonio de Heredia, abad

O. S. B.

De Nájera

AGN, Irache, Lib. 539, 221r.

\section{MANUEL DE VIANA}

B. A. / B. T.

30-12-1683 / 21-3-1685

Fr. Andrés Zeballos / Fr. Vicente Díez

Mecerreyes (Burgos)

AGN, Irache, Lib. 539, 221v, $240 v$.

BARTOLOMÉ GONZÁLEZ

B. A. / B. T.

30-12-1683

Fr. Andrés Zeballos / Fr. Mauro de Soria

Escóbados de Abajo (Burgos)

AGN, Irache, Lib. 539, 221v.

FRANCISCO AGUIRIANO LASANTA

B. A.

1-1-1684

Fr. Andrés Zeballos

San Asensio (Calahorra)

AGN, Irache, Lib. 539, 222 r.

FRANCISCO LASANTA ARGUIRIANO

B. A.

1-1-1684

Fr. Andrés Zeballos

San Asensio (Calahorra)

AGN, Irache, Lib. 539, 222 r.

DIEGO LASANTA

B. A.

1-1-1684

Fr. Andrés Zeballos

San Asensio (Calahorra)

AGN, Irache, Lib. 539, 222r.
ANTONIO LÓPEZ

B. C.

5-1-1684 / 10-6-1684

Reprobado

Fr. Juan Bta. Lardito

Burgos

AGN, Irache, Lib. 539, 222v, 226v.

FRANCISCO ANTONIO DE LA CASA PIE-

DRA Y ACEVEDO

B. A. / B. T. / L. T.

26-1-1684 / 9-3-1684 / 30-6-1685

Fr. Andrés Zeballos / Fr. Vicente Díez / Fr.

Pedro García, abad

Madrid (Toledo)

AGN, Irache, Lib. 539, 222v, 240v, $244 \mathrm{r}$.

JUAN BERNAL

B. C.

31-1-1684

Fr. Vicente Díez

Villanueva de Río de Ubierna (Burgos)

AGN, Irache, Lib. 539, 222v.

JUAN ANTONIO GARCÍA DE LA MATA

B. C.

11-2-1684

Fr. Mauro de Soria

Matamoros (Burgos)

AGN, Irache, Lib. 539, 223 r.

JOSÉ DE EGUÍLAZ

B. A.

11-2-1684

Fr. Andrés Zeballos

Arróniz (Pamplona)

AGN, Irache, Lib. 539, 223 r.

JUAN ANTONIO DE ESCOBEDO

B. C.

18-2-1684

Fr. Vicente Díez

Herrera del Río Pisuerga (Palencia)

AGN, Irache, Lib. 539, 223v.

FRANCISCO DE ARCE

B. C.

19-2-1684 
Fr. Mauro de Soria

Arcellares (Burgos)

AGN, Irache, Lib. 539, 224 r.

JUAN PÉREZ

B. C.

19-2-1684

Fr. Vicente Díez

Basconcillos (Burgos)

AGN, Irache, Lib. 539, 224r.

\section{DIEGO DE LA TORRE Y ROSALES}

B. A. / B. T.

24-2-1684 / 28-5-1684

Fr. Juan Bta. Lardito

Reprobado dos veces

Fr. Mauro Soria / Fr. Juan Bta. Lardito

Río de Lora (Burgos)

AGN, Irache, Lib. 539, 224r, 226v.

CARLOS MARTÍN

B. A. / B. M.

16-3-1684

Fr. Vicente Díez / Fr. Juan Bta. Lardito //

Dr. Arcilla

Torre de las Arcas (Teruel)

AGN, Irache, Lib. 539, 224v.

\section{JUAN DE ANGULO}

B. C.

11-4-1684

Fr. Vicente Díez

Quincoces de Yuso (Burgos)

AGN, Irache, Lib. 539, 224v.

JUAN BAUTISTA RODRÍGUEZ DE COS-

SÍO

B. C.

17-4-1684

Fr. Vicente Díez

Camesa (Burgos)

AGN, Irache, Lib. 539, 224v.

MIGUEL DE RIBAS RUBIO

B. C.

29-4-1684

Fr. Juan Bta. Lardito

Zael (Burgos)

AGN, Irache, Lib. 539, 225r.
DOMINGO ALBILLOS MADRIGAL

B. C.

29-4-1684

Fr. Juan Bta. Lardito

Presencio (Burgos)

AGN, Irache, Lib. 539, 225 r.

BARTOLOMÉ DE CUBILLAS

B. C.

10-5-1684

Reprobado

Fr. Vicente Díez

Escalante (Burgos)

AGN, Irache, Lib. 539, 225 r.

JUAN GARCÍA

B. M.

18-5-1684

Fr. Juan Bta. Lardito // Dr. Porras

Fresnedoso (Plasencia)

AGN, Irache, Lib. 539, $225 \mathrm{v}$.

JUAN DE MIER Y TERÁN

B. C.

19-5-1684

Fr. Vicente Díez

Hoz de Abiada, Reinosa (Burgos)

AGN, Irache, Lib. 539, 225v.

ATANASIO DE ESPINOSA

B. C.

20-5-1684

Fr. Vicente Díez

Pancorbo (Burgos)

AGN, Irache, Lib. 539, 225v.

MIGUEL DE RUBÍN DEL CORRO

B. A. / B. T.

22-5-1684

Fr. Juan Bta. Lardito / Fr. Mauro Soria

San Vicente de la Barquera (Burgos)

AGN, Irache, Lib. 539, 226r.

\section{RAFAEL GONZÁLEZ}

B. C.

25-5-1684

Fr. Vicente Díez

Santurce (Burgos)

AGN, Irache, Lib. 539, 226r. 
PEDRO DE PALACIO

B. C.

25-5-1684 / 23-9-1684

Reprobado dos veces

Fr. Juan Bta. Lardito

Villabasil (Burgos)

AGN, Irache, Lib. 539, 226r, 232r.

JUAN EZQUER

B. T. / L. T.

12-6-1684

Fr. Juan Bta. Lardito / Fr. José Osorio / Fr.

Antonio de Heredia, abad

Uztárroz, valle del Roncal (Pamplona)

AGN, Irache, Lib. 539, 226r.

\section{JUAN CATALÁN}

B. A. / B. T. / L. T. / D. T.

24-6-1684

Fr. Antonio de Heredia, abad

O. S. B.

Predicador

Monserrat de Cataluña

AGN, Irache, Lib. 539, 227 r.

JUAN ALONSO DE OBREGÓN

B. C.

4-7-1684

Reprobado

Fr. Juan Bta. Lardito

Encina, valle de Cayón (Burgos)

AGN, Irache, Lib. 539, $227 \mathrm{v}$.

PEDRO PÉREZ

B. C.

4-7-1684

Fr. Juan Bta. Lardito

Hontanas (Burgos)

AGN, Irache, Lib. 539, $227 \mathrm{v}$.

BLAS GARCÍA

B. C.

8-7-1684

Fr. Juan Bta. Lardito

Villadiego (Burgos)

AGN, Irache, Lib. 539, $227 \mathrm{v}$.

MANUEL RAMÍREZ DE MALAINA

B. C.
13-7-1684 / 7-10-1684

Reprobado

Fr. Juan Bta. Lardito

Grisaleña

AGN, Irache, Lib. 539, 228r, 233r.

ANTONIO ORTIZ CABALLERO

B. A. / B. T.

26-7-1684

Fr. Juan Bta. Lardito

Burgos

AGN, Irache, Lib. 539, 228r.

MARTÍN RODRIGO DE LA PEÑA

B. C.

30-7-1684 / 7-1-1685 / 23-3-1685

Reprobado dos veces

Fr. Juan Bta. Lardito

Lanzas, Valle de Carranza (Burgos)

AGN, Irache, Lib. 539, 228r, 238v, $240 v$.

JORGE DEL PRADO

B. A. / B. T.

1-8-1684

Fr. Juan Bta. Lardito

Medina de Pomar (Burgos)

AGN, Irache, Lib. 539, 228v.

JUAN CANAL

B. A. / B. T.

2-8-1684 / 2-10-1684

Reprobado dos veces

Fr. Juan Bta. Lardito

Renedo (Burgos)

AGN, Irache, Lib. 539, 228v, 232v.

GASPAR DE SANFELICES

B. C.

2-8-1684

Fr. Juan Bta. Lardito

Zalla (Burgos)

AGN, Irache, Lib. 539, 229 r.

ÍÑIGO DE REGÚLEZ

B. C.

7-8-1684

Fr. Juan Bta. Lardito

Medina de Pomar (Burgos)

AGN, Irache, Lib. 539, 229r. 
FRANCISCO ANTONIO DE SADO

B. C.

9-8-1684/10-8-1684

Reprobado

Fr. Juan Bta. Lardito / Fr. José Osorio

Puerto (Burgos)

AGN, Irache, Lib. 539, $229 r$.

PEDRO GIL

B. C.

14-8-1684

Fr. Juan Bta. Lardito

Villaveta (Nullius Diocesis)

Abadía de Covarrubias

AGN, Irache, Lib. 539, 229v.

\section{FRANCISCO PISÓN}

B. A. / B. T.

17-8-1684

Fr. Juan Bta. Lardito

Santo Domingo de la Calzada (Calahorra)

AGN, Irache, Lib. 539, 23 or.

MATEO DE BELTRANILLA

B. C.

19-8-1684

Fr. Juan Bta. Lardito

Santa María de Ribarredonda (Burgos)

AGN, Irache, Lib. 539, 23 or.

JUAN DE MOLINA

B. C.

19-8-1684

Fr. Juan Bta. Lardito

Cerezo (Burgos)

AGN, Irache, Lib. 539, 23 or.

MATÍAS DE LA SERNA

B. C.

20-8-1684

Reprobado

Fr. Juan Bta. Lardito

Montorio (Burgos)

AGN, Irache, Lib. 539, $230 v$.

JUAN FRANCISCO LÓPEZ DE LA MAZA

B. C.

20-8-1684
Fr. Juan Bta. Lardito

Laredo (Burgos)

AGN, Irache, Lib. 539, $230 v$.

JOSÉ SANTOYO DE ROJAS

B. C.

21-8-1684

Fr. Juan Bta. Lardito

Villahoz (Burgos)

AGN, Irache, Lib. 539, 231r.

JERÓNIMO IBÁÑEZ DE ZÁRATE

B. C.

22-8-1684

Fr. Juan Bta. Lardito

Logroño (Calahorra)

AGN, Irache, Lib. 539, 231r.

FRANCISCO PÉREZ DE VILLAESCUSA

B. C.

28-8-1684

Fr. Juan Bta. Lardito

Villanueva de Ubierna (Burgos)

AGN, Irache, Lib. 539, 231r.

FRANCISCO BALLESTEROS

B. C.

29-8-1684

Fr. Juan Bta. Lardito

Valle de Meruelo (Burgos)

AGN, Irache, Lib. 539, 231v.

MIGUEL DE ALBILLA

B. C.

4-9-1684

Fr. Juan Bta. Lardito

Burgos

AGN, Irache, Lib. 539, 231v.

DOMINGO MARTÍN

B. T.

4-9-1684

Fr. Juan Bta. Lardito

Quintanar (Burgos)

AGN, Irache, Lib. 539, 231v.

JUAN CANTERO VÉLEZ

B. A. / B. T. 
14-9-1684

Fr. Vicente Díez / Fr. Juan Bta. Lardito Medina de Pomar (Burgos)

AGN, Irache, Lib. 539, 232v.

ANDRÉS PÉREZ

B. C.

20-9-1684

Fr. Juan Bta. Lardito

Villafranca de Montes de Oca (Burgos)

AGN, Irache, Lib. 539, 232v.

\section{JUAN SERRANO}

B. C.

3-10-1684

Fr. Vicente Díez

Villaespasa (Burgos)

Hay descripción física

AGN, Irache, Lib. 539, 232v.

PEDRO DE ESCORZA

B. A. / B. T.

5-10-1684

Fr. Juan Bta. Lardito

Laredo (Burgos)

AGN, Irache, Lib. 539, 232v.

\section{ANTONIO DE MARDONES PINEDO}

B. C.

7-10-1684

Fr. Vicente Díez

Gr... (Burgos)

AGN, Irache, Lib. 539, 233 r.

JUAN FRANCISCO SALAZAR

B. A. / B. T.

11-10-1684

Fr. Juan Bta. Lardito

Villanueva de Valdegovía (Burgos)

AGN, Irache, Lib. 539, 233 r.

PEDRO DE BERGA

B. C.

13-10-1684

Reprobado

Fr. Vicente Díez

Quintanilla San García (Burgos)

AGN, Irache, Lib. 539, 233v.

\section{JUAN DOMINGO DE LATAS}

B. A. / B. M.

15-10-1684

Fr. Juan Bta. Lardito / Dr. Arcilla

Zaragoza

AGN, Irache, Lib. 539, 233v.

\section{SILVESTRE CORRAL}

B. A. / B. T.

16-10-1684

Fr. Vicente Díez / Fr. Juan Bta. Lardito

Olmillos de Sasamón (Burgos)

AGN, Irache, Lib. 539, 234r.

\section{MIGUEL DE CEREZO}

B. C.

17-10-1684

Fr. Juan Bta. Lardito

Santa María de Ribarredonda (Burgos)

AGN, Irache, Lib. 539, 234r.

JORGE DE UGALDE

B. A.

19-10-1684

Fr. Benito de Anguiano

Respaldiza, Álava (Calahorra)

AGN, Irache, Lib. 539, 234 r.

SEVERINO DE BEDIA

B. A. / B. T.

26-10-1684

Fr. Benito de Anguiano / Fr. Vicente Díez

Balmaseda (Burgos)

AGN, Irache, Lib. 539, 234v.

JOAQUÍN JOSÉ DE IBARROLA

B. C.

30-10-1684 Reprobado

4-1-1685 Aprobado

Fr. Juan Bta. Lardito

San Martín de Don (Burgos)

AGN, Irache, Lib. 539, 234v, 238v.

\section{JUAN ANTONIO DE LA MORA}

B. C.

4-11-1684

Fr. Juan Bta. Lardito

Cortaneda. Santander (Burgos)

AGN, Irache, Lib. 539, 234v. 
PEDRO DE MONTAÑO

B. C.

13-11-1684

Fr. Vicente Díez

San Jorge de Santurce (Burgos)

AGN, Irache, Lib. 539, 235r.

JUAN GONZÁLEZ

B. C.

16-11-1684

Fr. Juan Bta. Lardito

Villadiego (Burgos)

AGN, Irache, Lib. 539, 235r.

ANDRÉS DE GONZALO

B. A. / B. T.

18-11-1684

Fr. Benito de Anguiano / Fr. Juan Bta. Lar-

dito

Santurce (Burgos)

AGN, Irache, Lib. 539, 235r.

MATEO PRIETO

B. C.

21-11-1684

Fr. Vicente Díez

Herrera de Valdecañas (Burgos)

AGN, Irache, Lib. 539, $235 \mathrm{v}$.

\section{BARTOLOMÉ TORIBIO}

B. T. / L. T. / D. T.

21-11-1684 / 22-11-1684

Fr. Juan Bta. Lardito / Fr. Antonio de He-

redia, abad

Logroño (Calahorra)

AGN, Irache, Lib. 539, 235v.

JOSÉ DE VILLANUEVA

L. T.

25-11-1684

Fr. Antonio de Heredia, abad

Quel (Calahorra)

AGN, Irache, Lib. 539, 236r.

\section{PEDRO GONZÁLEZ}

B. C.

25-11-1684

Fr. Mauro de Soria
Melgar de Fernamental (Burgos)

AGN, Irache, Lib. 539, 236r.

\section{BERNARDINO JAIMES}

B. C.

25-11-1684

Fr. Mauro de Soria

Melgar de Fernamental (Burgos)

AGN, Irache, Lib. 539, 236r.

JUAN GONZÁLEZ DE PAREDES

B. C.

29-11-1684 / 29-11-1684

Reprobado

Fr. Juan Bta. Lardito / Fr. Vicente Díez

Melgar de Fernamental (Burgos)

AGN, Irache, Lib. 539, 236v.

BERNARDINO MULSA DE LA CASTA

B. A. / B. T. / L. T. / D. T.

2-12-1684

Fr. Benito de Anguiano / Fr. Mauro de So-

ria / Fr. Antonio de Heredia, abad

Ejea de los Caballeros (Zaragoza)

AGN, Irache, Lib. 539, 236v-237r.

\section{CARLOS SORACOIZ}

L. C.

4-12-1684

Fr. Antonio de Heredia, abad

Alfaro (Tarazona)

Fue Colegial Mayor de San Ildefonso y Oidor de Pamplona

AGN, Irache, Lib. 539, 237r.

TOMÁS PÉREZ DE AMALLO

B. C.

4-12-1684 / 29-4-1685

Reprobado

Fr. Mauro de Soria / Fr. Vicente Díez

Agustina, Valle de Guriezo (Burgos)

AGN, Irache, Lib. 539, 237r, 241v.

\section{JOSÉ DEL CAÑO}

B. C.

5-12-1684 / 22-12-1684 Reprobado dos veces

3-1-1685 Aprobado 
Fr. Vicente Díez

Valluércanes, Bureba (Burgos)

AGN, Irache, Lib. 539, 237v, 238r.

JUAN VÍCTORES DÍAZ DE LA QUINTANILLA

B. A. / B. T.

22-12-1684

Fr. Benito de Anguiano / Fr. Mauro de Soria

Cerezo (Burgos)

AGN, Irache, Lib. 539, $237 \mathrm{v}$.

MANUEL DE PALACIO

B. C.

30-12-1684

Fr. Vicente Díez

Consejero

Burgos

AGN, Irache, Lib. 539, 238 r.

JUAN ORTIZ

B. C.

30-12-1685

Fr. Juan Bta. Lardito

Guriezo (Burgos)

AGN, Irache, Lib. 539, 238r.

\section{ALONSO GARCÍA}

B. C.

4-1-1685 / 5-1-1685

Reprobado dos veces

Fr. Mauro de Soria / Fr. Vicente Díez

Burgos

AGN, Irache, Lib. 539, 238v.

JUAN DE SAN MARTÍN

B. A / B. T.

10-1-1685

Fr. Benito de Anguiano / Fr. Vicente Díez

Fresneda (Burgos)

AGN, Irache, Lib. 539, 239 r.

BARTOLOMÉ DE PANDO

B. C.

16-1-1685

Fr. Juan Bta. Lardito

Celaya (Burgos)
Pbro.

AGN, Irache, Lib. 539, 239 r.

PEDRO DE ROJAS

B. A. / B. T. / L. T. / M. T.

17-1-1685

Fr. Antonio de Heredia, abad

O.S. B.

San Benito el Real de Valladolid

AGN, Irache, Lib. 539, 239v.

ANTONIO GONZÁLEZ PARDO

B. C.

27-1-1685

Fr. Mauro de Soria

Celada del Camino (Burgos)

AGN, Irache, Lib. 539, 239v.

ESTEBAN DE LA CRUZ

B. T.

9-2-1685

Fr. Vicente Díez

Jor... (Burgos)

AGN, Irache, Lib. 539, 239v.

JOSÉ RUIZ

B. C.

12-2-1685

Fr. Juan Bta. Lardito

Villamorón (Burgos)

AGN, Irache, Lib. 539, 239v.

JOSÉ PÉREZ

B. C.

21-2-1685

Fr. Mauro de Soria

Quintanilla (Burgos)

AGN, Irache, Lib. 539, 240 .

MIGUEL DE ALBILLA

B. C.

27-2-1685

Fr. Juan Bta. Lardito

Villaizan (Burgos)

AGN, Irache, Lib. 539, 240 .

ANDRÉS DE GANDÍA

B. C. 
1-3-1685 / 8-6-1685

Reprobado

Fr. Mauro de Soria / Fr. Vicente Díez

Frías (Burgos)

AGN, Irache, Lib. 539, 240r, 243v.

\section{SEBASTIÁN HERRÁN}

B. C.

1-3-1685

Reprobado

Fr. Juan Bta. Lardito

Frías (Burgos)

AGN, Irache, Lib. 539, 240 or.

JOSÉ ARNÁIZ

B. C.

4-3-1685

Fr. Juan Bta. Lardito

Cogollos (Burgos)

AGN, Irache, Lib. 539, $240 v$.

\section{ALONSO GONZÁLEZ}

B. $\mathrm{M}$.

17-4-1685

Fr. Mauro de Soria / Dr. Ercilla

Villabar (Zamora)

AGN, Irache, Lib. 539, 241r.

\section{ANTONIO BLANCO}

B. M.

17-4-1685

Fr. Vicente Díez / Dr. Ercilla

Astorga

AGN, Irache, Lib. 539, 241r.

DOMINGO DE SIN

B. C.

18-4-1685

Fr. Juan Bta. Lardito

Olvena (Barbastro)

AGN, Irache, Lib. 539, 241r.

VICENTE ANGLÉS

B. L.

18-4-1685

Fr. Mauro de Soria / Ldo. Baltasar de Se-

rracín

San Martín (Tortosa)

AGN, Irache, Lib. 539, 241r.
JUAN DE VALLEJO

B. C.

18-4-1685

Fr. Vicente Díez

Castresana (Burgos)

AGN, Irache, Lib. 539, 241v.

JUAN DE PAZOS

B. A. / B. T. / L. A. / D. T.

23-4-1685

Fr. Antonio de Heredia, abad

O. S. B.

San Julián de Samos

AGN, Irache, Lib. 539, $241 \mathrm{v}$.

JACINTO DÍEZ

B. A. / B. T. / L. A. / D. T.

27-4-1685

Fr. Antonio de Heredia, abad

O. S. B.

San Zoilo de Carrión

AGN, Irache, Lib. 539, $241 \mathrm{v}$.

JUAN RUIZ DE AMAYA

B. C.

30-4-1685

Fr. José Osorio

Amaya (Burgos)

AGN, Irache, Lib. 539, 242 r.

BALTASAR FRANCISCO ÁLVAREZ DE MEDRANO

B. L. / L. L. / D. L.

2-5-1685/ 3-5-1685

Fr. Vicente Díez / Letrado Juan Fco. Le-

zaún

Cervera

AGN, Irache, Lib. 539, 242r.

PEDRO DE URÍZAR Y SAN PEDRO

B. T. / L. T. / D. T.

4-5-1685 / 5-5-1685

Fr. Vicente Díez

Torralba (Calahorra)

AGN, Irache, Lib. 539, $242 \mathrm{v}$.

DOMINGO DEL CAÑO

B. C. 
18-5-1685

Reprobado 2 veces

Fr. Juan Bta. Lardito

Valluércanes, Bureba (Burgos)

AGN, Irache, Lib. 539, 242v.

\section{JUAN DE OCEJO}

B. C.

25-5-1685

Fr. Vicente Díez

Escalante (Burgos)

AGN, Irache, Lib. 539, 243 r.

\section{SEBASTIÁN DE HERRÁN}

B. C.

26-5-1685

Fr. Juan Bta. Lardito

Frías (Burgos)

AGN, Irache, Lib. 539, 243 r.

JOSÉ DE LA SIERRA

B. C.

27-5-1685 / 6-8-1685

Reprobado

Fr. Juan Bta. Lardito / Fr. Pedro Lozano

Soscaño, Valle de Carranza (Burgos)

AGN, Irache, Lib. 539, 243r, 245r.

TORCADO DE SALAZAR

B. A. / B. T. / L. T. / M. T.

6- 6-1685

Fr. Pedro García, Abad y Rector

O. S. B.

Maestro General. Visitador

San Salvador de Celanova

AGN, Irache, Lib. 539, 243r.

JUAN MARTÍNEZ IZQUIERDO

B. A. / B. T.

6-6-1685

Fr. Benito de Anguiano / Fr. Vicente Díez

Canales (Burgos)

AGN, Irache, Lib. 539, 243 r.

FRANCISCO MARCOS BALLESTEROS

B. C.

11-6-1685 / 6-8-1685

Reprobado dos veces
Fr. Juan Bta. Lardito / Fr. Pedro Lozano

Villasandino (Burgos)

AGN, Irache, Lib. 539, 243r, 245r.

\section{JUAN BAUTISTA LARDITO}

B. A. / B. T. / L. T. / M. T.

13-6-1685 / 15-6-1685

Fr. Pedro García, abad

O. S. B.

Catedrático de Vísperas de Irache

San Martín de Madrid

AGN, Irache, Lib. 539, 244r.

FRANCISCO CEBALLOS ESTRADA

B. C.

8-7-1685

Fr. Pedro Lozano

Las Presillas (Burgos)

AGN, Irache, Lib. 539, 244v.

DIEGO GÓMEZ

B. A. / B. T. / L. T. / M. T.

11-7-1685

Fr. Pedro García, abad

O.S. B.

San Millán de la Cogolla

AGN, Irache, Lib. 539, 244V.

MANUEL DE QUINTANA BARREDA

B. C.

30-7-1685

Fr. Pedro Lozano

Isla (Burgos)

AGN, Irache, Lib. 539, 244v.

PEDRO SAIZ

B. C.

3-8-1685 / 26-1-1686

Reprobado

Fr. Pedro Lozano / Fr. José Osorio

Castrillo de Murcia (Burgos)

AGN, Irache, Lib. 539, 244v, 253r.

SIMÓN MARÍN

B. A.

6-8-1685

Fr. Benito de Anguiano

Calahorra

AGN, Irache, Lib. 539, 245r. 
JOSÉ PÉREZ

B. C.

6-8-1685

Fr. Pedro Lozano

Quintanilla (Burgos)

AGN, Irache, Lib. 539, 245r.

\section{JERÓNIMO LADRÓN}

B. C.

6-8-1685

Fr. Pedro Lozano

Castrojeriz (Burgos)

AGN, Irache, Lib. 539, 245v.

JOSÉ DE AMATRIÁIN

B. A. / B. M.

30-8-1685

Fr. Benito de Anguiano / Fr. Pedro Lozano

// Dr. Ambrosio Gómez

Beire (Pamplona)

AGN, Irache, Lib. 539, 245v.

FRANCISCO GALARÓN

B. A. / B. T.

9-9-1685

Fr. José Osorio

Yudego (Burgos)

AGN, Irache, Lib. 539, 245v.

JUAN DE ACHIAGA

B. A. / B. T.

15-9-1685

Fr. Benito de Anguiano / Fr. Pedro Lozano

Cameno (Burgos)

AGN, Irache, Lib. 539, 246r.

MANUEL DE ARROYO

B. C.

15-9-1685

Fr. José Osorio

Briviesca (Burgos)

AGN, Irache, Lib. 539, 246r.

JOSÉ DE ARRIETA

B. A.

15-9-1685

Fr. José Osorio

Calahorra

AGN, Irache, Lib. 539, 246r.
JOSÉ DE CASANAL TAMAYO

B. L.

16-9-1685

Fr. José Osorio / L. L. Baltasar de Lezáun

Burgos

AGN, Irache, Lib. 539, 246v.

ÍNIIGO DEL VAL

B. C.

17-9-1685

Fr. José Osorio

Cameno (Burgos)

AGN, Irache, Lib. 539, 246v.

JUAN CARRILLO TORDÓMAR

B. L.

17-9-1685

Fr. Pedro Lozano

Pamplona

AGN, Irache, Lib. 539, 246v.

ANTONIO DE LA PEÑA

B. C.

20-9-1685 / 26-1-1686

Reprobado

Fr. José Osorio

Yudego (Burgos)

AGN, Irache, Lib. 539, 246v, 253 r.

ANTONIO DÍAZ DE ARELLANO

B. A. / B. T. / L. T. / D. T.

20-9-1685 // 18-5-1686 / 19-5-1686 / / 6-91690

Fr. Benito de Anguiano // Fr. José Osorio / Fr. Gregorio Ruiz, abad // Fr. Martín de Arenas, Abad y Rector

Arróniz (Pamplona)

AGN, Irache, Lib. 539, 247r, 258v; Lib. 549, $28 \mathrm{v}$.

FRANCISCO LORENZ

B. A. / B. M.

25-9-1685

Fr. Benito de Anguiano / Fr. Pedro Lozano

// Dr. Ambrosio Gómez

Mendigorría (Pamplona)

AGN, Irache, Lib. 539, 247r. 
PEDRO DE SOTO

B. C.

27-9-1685

Fr. Pedro Lozano

Sotoluengo (Burgos)

AGN, Irache, Lib. 539, 247r.

JOSÉ DE VILLOTA Y LOYO

B. C.

9-10-1685

Fr. José Osorio

Laredo (Burgos)

AGN, Irache, Lib. 539, $247 \mathrm{v}$.

BERNARDO DE ISLA

L. T.

12-10-1685

Fr. Pedro García, abad

Isla (Burgos)

AGN, Irache, Lib. 539, 247v.

PEDRO RUIZ DEL RIVERO

B. C.

15-10-1685

Fr. José Fernández

Lanestosa (Burgos)

AGN, Irache, Lib. 539, 248r.

FRANCISCO NEGRETE

B. C.

15-10-1685 / 3-3-1686

Reprobado

Fr. Pedro Lozano

San Esteban (Burgos)

AGN, Irache, Lib. 539, 248r, 254r.

PEDRO DE BEITIA

B. A. / B. T.

17-10-1685

Fr. Benito de Anguiano / Fr. José Osorio

Quintana Martín Galíndez (Burgos)

AGN, Irache, Lib. 539, 248r.

DOMINGO GONZÁLEZ

B. C.

19-10-1685

Fr. José Fernández

Quintanilla Sotos Cueva (Burgos)

AGN, Irache, Lib. 539, 248v.

\section{ISIDRO DE SAN PEDRO}

B. L.

20-10-1685

Fr. Pedro Lozano / L. L. Baltasar de Lezáun

Canales (Burgos)

AGN, Irache, Lib. 539, 248v.

PEDRO DE LA HERRÁN Y MARDONES

B. C.

27-10-1685

Fr. José Osorio

Morés (Burgos)

AGN, Irache, Lib. 539, 249 r.

ANTONIO JUARBE

B. A. / B. M.

5-11-1685

Fr. Benito de Anguiano / Fr. José Fernández // Dr. Ezcurra

Estella (Pamplona)

AGN, Irache, Lib. 539, 249r.

ANTONIO RUIZ HIDALGO

B. C.

12-11-1685

Fr. Pedro Lozano

Los Tojos (Burgos)

AGN, Irache, Lib. 539, 249v.

\section{ALBERTO IBÁÑEZ DE IBERO}

B. L.

14-11-1685

Fr. José Osorio / L. L. Baltasar de Lezáun

Miranda (Pamplona)

AGN, Irache, Lib. 539, 249v.

\section{ANTONIO RODRÍGUEZ}

B. A. / B. T.

18-11-1685

Fr. Benito de Anguiano / Fr. José Fernández

Losa (Burgos)

AGN, Irache, Lib. 539, 250r.

JOSÉ DE EJEA

B. A. / B. M.

19-12-1685

Fr. Pedro Lozano / Dr. Ambrosio Gómez 
Pamplona

AGN, Irache, Lib. 539, 25 or.

JOSÉ DE RIPALDA

B. A. / B. M.

19-11-1685

Fr. Pedro Lozano / Dr. Ambrosio Gómez

Pamplona

AGN, Irache, Lib. 539, 250v.

ANDRÉS DE LOSA

B. A. / B. T.

21-11-1685

Fr. Benito de Anguiano / Fr. José Fernández

Medina de Pomar (Burgos)

AGN, Irache, Lib. 539, $250 v$.

\section{GREGORIO DE ALDABA}

B. M.

22-11-1685

Fr. Pedro Lozano / Dr. Ambrosio Gómez

Nájera (Calahorra)

B. A. Salamanca y estudios en Valladolid AGN, Irache, Lib. 539, 251r.

BERNARDO BENITO

B. C.

25-11-1685

Fr. José Osorio

Burgos

AGN, Irache, Lib. 539, 251r.

JOSÉ MARTÍNEZ DEL BARRIO

B. A. / B. T.

7-12-1685 / 9-2-1686

Reprobado

Fr. José Fernández / Fr. Benito de Anguiano

Burgos

AGN, Irache, Lib. 539, 251r, $253 v$.

BERNARDO MOREDA

B. A. / B. T. / L. T. / D. T.

15-12-1685

Fr. Pedro García, abad

Castañares (Calahorra)

AGN, Irache, Lib. 539, 251v.
FRANCISCO LA IGLESIA

B. C.

15-12-1685

Fr. Pedro Lozano

Villamayor de Treviño (Burgos)

AGN, Irache, Lib. 539, 252r.

JUAN DEL BARRIO

B. C.

16-12-1685

Fr. Pedro Lozano

Villalvilla (Burgos)

AGN, Irache, Lib. 539, 252 r.

\section{JUAN FERNÁNDEZ}

B. C.

16-12-1685

Fr. José Fernández

Zicancas (Burgos)

AGN, Irache, Lib. 539, 252r.

IGNACIO GONZÁLEZ DE LOS RÍOS

B. A. / B. T.

22-12-1685

Fr. Benito de Anguiano / Fr. Pedro Lozano

Los Tojos (Burgos)

AGN, Irache, Lib. 539, 252rv.

JUAN DE SALAZAR NEGRETE

B. A. / B. T.

23-12-1685

Fr. Benito de Anguiano / Fr. José Osorio

Villanueva Soportilla (Burgos)

AGN, Irache, Lib. 539, $252 \mathrm{v}$.

\section{SANTIAGO GÓMEZ}

B. A. / B. T.

2-1-1686

Fr. Benito de Anguiano / Fr. José Fernández

Cejancas (Burgos)

AGN, Irache, Lib. 539, 253 r.

\section{FABIÁN GARCÍA}

B. C.

4-2-1686

Fr. Pedro Lozano

Olmos de la Picaza (Burgos)

AGN, Irache, Lib. 539, 253 r. 
ANTONIO GARCÍA

B. C.

9-2-1686

Fr. José Osorio

Madrid (Toledo)

AGN, Irache, Lib. 539, 253v.

JOSÉ DE BURGOS

B. C.

9-2-1686

Fr. José Fernández

Ambario (Tarazona)

AGN, Irache, Lib. 539, $253 v$.

JOSÉ DE VALDIVIESO

B. C.

11-2-1686

Fr. Pedro Lozano

Burgos

AGN, Irache, Lib. 539, 253v.

FERMÍN DE SALCEDO

B. A. / B. M.

1-3-1686

Fr. Benito de Anguiano / Fr. José Osorio //

Dr. Ambrosio Gómez

Pamplona

AGN, Irache, Lib. 539, 254r.

JUAN DÍAZ DEL MOLINILLO

B. A. / B. T. / L. T.

3-3-1686

Fr. Benito de Anguiano / Fr. José Fernández

Espejo (Burgos)

AGN, Irache, Lib. 539, 254v.

SANTIAGO DE RUCOBA Y SENA

B. C.

11-3-1686

Fr. Pedro Lozano

Villa de Pomar (Burgos)

AGN, Irache, Lib. 539, 254v.

ANTONIO DE CARRIÓN

B. C.

18-3-1686

Fr. José Osorio
Villasandino (Burgos)

AGN, Irache, Lib. 539, 255r.

JUAN DE ORTEGA

B. C.

21-3-1686

Fr. José Osorio

Castrillo de Murcia (Burgos)

AGN, Irache, Lib. 539, 255r.

JOSÉ ÁLVAREZ

B. C.

21-3-1686

Fr. José Osorio

Villasandino (Burgos)

AGN, Irache, Lib. 539, 255r.

ANTONIO ESTEBAN Y GIL

B. C.

23-3-1686

Fr. José Osorio

Castrillo de Murcia

AGN, Irache, Lib. 539, 255v.

JUAN DE LAS VENERAS Y CEBALLOS

B. A. / B. T.

30-3-1686

Fr. Benito de Anguiano / Fr. Pedro Lozano

Broña (Burgos)

AGN, Irache, Lib. 539, 255v.

LORENZO POLANCO Y CEBALLOS

B. A. / B. T.

30-3-1686

Fr. Benito de Anguiano / Fr. Pedro Lozano

Broña (Burgos)

AGN, Irache, Lib. 539, 255v.

ANTONIO DE CASTROVIEJO

B. T.

31-3-1686

Fr. José Osorio

Escaray (Burgos)

AGN, Irache, Lib. 539, 256r.

BLAS DE SANTANDER

B. A. / B. T.

3-4-1686 
Fr. Benito de Anguiano / Fr. José Fernández

Castrojeriz (Burgos)

AGN, Irache, Lib. 539, 256r.

BENITO DE ULLOA

B. A. / B. T. / L. T. / D. T.

3-4-1686

Fr. José Fernández

O. S. B.

Valladolid

AGN, Irache, Lib. 539, 256r.

\section{FRANCISCO MORCAT}

B. L.

3-4-1686

Fr. José Osorio

Asa Huesca (Lérida)

AGN, Irache, Lib. 539, 256v.

NICOLÁS FRANCISCO CASTÁN

B. C. / L. C.

15-4-1686

Fr. José Fernández

Calatayud (Tarazona)

AGN, Irache, Lib. 539, 257r.

AGUSTÍN ANTONIO DE URIBE

L. L. / D. L.

19-4-1686

Fr. José Fernández

Calatayud (Tarazona)

AGN, Irache, Lib. 539, 257 r.

GREGORIO RUIZ

B. A. / B. T. / L. T. / D. T.

28-4-1686

Fr. José Fernández

O. S. B.

Abad de Irache

AGN, Irache, Lib. 539, $257 \mathrm{v}$.

DOMINGO DE QUINTANO

B. C.

3-5-1686

Fr. José Osorio

Los Ausines (Burgos)

AGN, Irache, Lib. 539, $257 \mathrm{v}$.
JOSÉ RUIZ QUINTANA

B. A.

5-5-1686

Fr. Benito de Anguiano

Poza (Burgos)

AGN, Irache, Lib. 539, $257 \mathrm{v}$.

JUAN DOMINGO ECHEVARRÍA Y ASIÁIN

B. L.

8-5-1686

Fr. Pedro Lozano / L. L. Baltasar de Lezáun

Pamplona

AGN, Irache, Lib. 539, 258r.

JUAN SECO FONTECHA

B. C.

16-5-1686

Fr. Pedro Lozano

Matamorosa (Burgos)

AGN, Irache, Lib. 539, 258r.

FRANCISCO PÉREZ

B. C.

16-5-1686

Fr. José Osorio

San Mamés (Burgos)

AGN, Irache, Lib. 539, 258v.

JUAN RODRÍGUEZ GARCÍA

B. C.

20-5-1686

Fr. José Osorio

Matamorosa (Burgos)

AGN, Irache, Lib. 539, 259r.

FRANCISCO MIGUEL GARCÍA

B. C.

20-5-1686

Fr. Pedro Lozano

Matamorosa (Burgos)

AGN, Irache, Lib. 539, 259 r.

FRANCISCO DE MEDINA

B. C.

22-5-1686

Fr. José Osorio

Hormaza (Burgos)

AGN, Irache, Lib. 539, $259 v$. 
JOSÉ RAMÍREZ

B. A. / B. T. / L. T. / D. T.

26-5-1686

O. S. B.

Abad de Valvanera

AGN, Irache, Lib. 539, 259v.

FRANCISCO DE LA TORRE

B. A. / B. T. / L. T. / D. T.

3-6-1686 / 4-6-1686

Fr. Benito de Anguiano / Fr. José Osorio /

Fr. Gregorio Ruiz, abad

O. Praem.

Casar, Concejo de Laredo (Burgos)

AGN, Irache, Lib. 539, 259v.

SIMÓN DE PALACIOS

B. C.

4-7-1686

Fr. Pedro Lozano

Villafranca de Montes de Oca (Burgos)

AGN, Irache, Lib. 539, 26or.

ANTONIO ESTÉBANEZ GIL

B. C.

7-7-1686

Reprobado por segunda vez

Fr. Pedro Lozano

Castrillo de Murcia (Burgos)

AGN, Irache, Lib. 539, 260v.

CUSTODIO DE CASTRESANA Y GUINEA

B. A. / B. T.

13-7-1686

Fr. Benito de Anguiano / Fr. Pedro Lozano

Mane (Burgos)

AGN, Irache, Lib. 539, 260v.

MANUEL DE SANTOJO

B. C.

16-7-1686

Fr. José Osorio

Villahoz (Burgos)

AGN, Irache, Lib. 539, 260v.

JUAN RODRÍGUEZ DE RÁBAGO

B. C.

23-7-1686
Fr. José Fernández

Mazandrero (Burgos)

AGN, Irache, Lib. 539, 261r.

BERNARDO BLANCO

B. T.

3-8-1686

Fr. José Osorio

O. Cist.

Zaragoza

AGN, Irache, Lib. 539, 261r.

JOAQUÍN DE OCARANZA

B. C.

12-8-1686 / 17-8-1686

Reprobado

Fr. José Fernández

Bilbao (Burgos)

AGN, Irache, Lib. 539, 261v, 262v.

FRANCISCO SÁENZ

B. C.

13-8-1686

Fr. José Fernández

Sasamón (Burgos)

AGN, Irache, Lib. 539, 261v.

FRANCISCO DE SANTIBÁÑEZ

B. C.

13-8-1686

Fr. José Fernández

Santibáñez (Burgos)

AGN, Irache, Lib. 539, 261v.

AGUSTÍN DE SANTA MARINA

B. C.

13-8-1686

Fr. José Fernández

Escárcega (Burgos)

AGN, Irache, Lib. 539, 261v.

AGUSTÍN DE SARACHO

B. C.

13-8-1686

Fr. José Fernández

Lasier (Burgos)

AGN, Irache, Lib. 539, 262r. 
DIEGO AGUSTÍN DE PORDEGUELA ZAMUDIO

B. C.

13-8-1686

Fr. José Fernández

Pancorbo (Burgos)

AGN, Irache, Lib. 539, 262r.

JUAN IGNACIO BARRENA

L. T.

19-8-1686

Fr. Gregorio Ruiz, abad

San Sebastián (Pamplona)

Colegial Mayor de San Bartolomé el Viejo,

Salamanca

AGN, Irache, Lib. 539, 262v.

\section{MANUEL DEL CAMPO}

B. C.

25-8-1686

Fr. José Fernández

Nuez.Valle de Santibáñez (Burgos)

AGN, Irache, Lib. 539, 262v.

JUAN PÉREZ ALONSO GARCÍA

B. C.

30-8-1686

Fr. José Fernández

Poza (Burgos)

AGN, Irache, Lib. 539, 263 r.

\section{JUAN DE BAIRI MIÑÓN}

B. A. / B. T.

4-9-1686

Fr. Benito de Anguiano / Fr. Pedro Lozano

Arlanzón (Burgos)

AGN, Irache, Lib. 539, 263r.

AGUSTÍN VICARIO RUIZ

B. C.

19-9-1686

Fr. José Osorio

Saelices (Burgos)

AGN, Irache, Lib. 539, 263 r.

\section{JUAN DÍEZ GUTIÉRREZ}

B. C.

27-9-1686
Fr. José Fernández

Lences (Burgos)

AGN, Irache, Lib. 539, 263 r.

MARCOS FONTURBEL DE ESPINOSA

B. A. / B. T.

1-10-1686

Fr. Benito de Anguiano / Fr. Pedro Lozano

San Pantaleón (Burgos)

AGN, Irache, Lib. 539, $263 \mathrm{v}$.

ANDRÉS DE RODRIGO

B. A. / B. T.

2-10-1686

Fr. Benito de Anguiano / Fr. José Osorio

Ojacastro (Burgos)

AGN, Irache, Lib. 539, 263v.

BERNARDO DE LA MATA

L. C. / D. C.

9-10-1686

Fr. Gregorio Ruiz, abad

Logroño

Provisor del Obispo de Calahorra

AGN, Irache, Lib. 539, 263v.

JOSÉ ROJO

B. C.

11-10-1686

Fr. José Fernández

Cañizar de los Ajos (Burgos)

AGN, Irache, Lib. 539, 264 r.

AGUSTÍN DE VIANA

B. C.

12-10-1686

Fr. Pedro Lozano

Ojacastro (Burgos)

AGN, Irache, Lib. 539, 264 r.

JUAN BERNAL RAMÍREZ

B. C.

23-10-1686

Fr. Pedro Lozano

Sotragero (Burgos)

AGN, Irache, Lib. 539, 264r.

PEDRO DE AEDO

B. C. 
25-10-1686 / 16-11-1686

Reprobado

Fr. Pedro Lozano

Zalla (Burgos)

AGN, Irache, Lib. 539, 264v, $265 \mathrm{r}$.

LUCAS LÓPEZ DE SOSCANO

B. C.

26-10-1686

Fr. Pedro Lozano

Sámano (Burgos)

AGN, Irache, Lib. 539, 264v.

FRANCISCO GUTIÉRREZ

B. C.

6-11-1686

Fr. Pedro Lozano

Villadiego (Burgos)

AGN, Irache, Lib. 539, 264v.

MARTÍN DE URUÑUELA

B. T.

12-11-1686

Fr. Pedro Lozano

Santo Domingo de La Calzada (Calahorra)

B. A. en Alcalá

AGN, Irache, Lib. 539, 265r.

JUAN DE TEJO

B. A. / B. T.

16-11-1686

Fr. Benito de Anguiano / Fr. Pedro Lozano

Ruiseñada (Burgos)

AGN, Irache, Lib. 539, 265r.

SIMEÓN DE GUINDA Y APÉSTEGUI

B. A. / B. T. / L. T. / D. T.

24-11-1686 / 25-11-1686

Fr. Benito de Anguiano / Fr. Pedro Lozano

Esparza. Valle de Salazar

AGN, Irache, Lib. 539, 265v.

\section{ANDRÉS RUIZ}

B. C.

1-12-1686

Fr. José Fernández

Quintana de Toranzo (Burgos)

AGN, Irache, Lib. 539, 265v.
JOSÉ GARCÍA

B. C.

2-12-1686

Fr. Pedro Lozano

Santurce (Burgos)

AGN, Irache, Lib. 539, 266r.

\section{FERMÍN DE MEARIN}

B. A. / B. M.

11-12-1686

Fr. Benito de Anguiano / Fr. Pedro Lozano

// Dr. Ambrosio Gómez

Pamplona

AGN, Irache, Lib. 539, 266r.

\section{MARTÍN GARCÍA BAQUERO}

B. A.

21-12-1686

Fr. Benito de Anguiano

Anguiain (Calahorra)

AGN, Irache, Lib. 539, 266v.

TOMÁS DE ALFARO

B. A.

21-12-1686

Fr. Benito de Anguiano

Ólvega (Tarazona)

AGN, Irache, Lib. 539, 266v.

ÁNGEL DÍEZ FONTANAL

B. $\mathrm{T}$.

24-12-1686

Fr. José Fernández

Poza (Burgos)

AGN, Irache, Lib. 539, 266v.

BARTOLOMÉ GONZÁLEZ

B. C.

9-1-1687

Fr. Pedro Lozano

Repudio (Burgos)

AGN, Irache, Lib. 539, 266v.

JUAN MILLAR

B. A. / B. T.

16-1-1687

Fr. Benito de Anguiano / Fr. Plácido Vea

Santa María (Burgos)

AGN, Irache, Lib. 539, 269 r. 
ANTONIO DE ARTIAGA

B. A. / B. T.

6-2-1687

Fr. Benito de Anguiano

Portugalete (Burgos)

AGN, Irache, Lib. 539, 269 r.

FRANCISCO DE PEREDA Y VILLAR

B. C.

8-2-1687

Fr. Regente

Bisjueces (Burgos)

AGN, Irache, Lib. 539, 269 r.

\section{ANTONIO PRIETO}

B. A. / B. T.

4-3-1687

Fr. Benito de Anguiano / Fr. Pedro Lozano

Herrera de Valdecañas (Burgos)

AGN, Irache, Lib. 539, 269v.

MANUEL GARCÍA

B. A. / B. T.

4-3-1687

Fr. Benito de Anguiano / Fr. Pedro Lozano

Burgos

AGN, Irache, Lib. 539, 269v.

MARCOS JIMÉNEZ

B. C.

4-3-1687

Fr. Pedro Lozano

Burgos

AGN, Irache, Lib. 539, $270 r$.

JOSÉ DEL PRADO

B. A.

22-3-1687

Fr. Benito de Anguiano

Rincón de Soto (Calahorra)

AGN, Irache, Lib. 539, $270 r$.

GASPAR LOZANO

B. C.

25-3-1687

Fr. Pedro Lozano

Celada del Camino (Burgos)

AGN, Irache, Lib. 539, $270 v$.
JUAN ANTONIO DE QUINTANILLA

B. C.

29-3-1687

Fr. Plácido Vea

Oña (Burgos)

AGN, Irache, Lib. 539, $270 v$.

JUSTO DE ARBIZU

B. M.

7-4-1687

Fr. Plácido Vea / Dr. Ambrosio Gómez

Navascués (Pamplona)

AGN, Irache, Lib. 539, $270 v$.

\section{MARTÍN CUEVAS}

B. C.

16-4-1687

Fr. Pedro Lozano

Mecerreyes (Burgos)

AGN, Irache, Lib. 539, 271r.

JOSÉ NEGRETE

B. C.

20-4-1687

Fr. Regente

Riopanero (Burgos)

AGN, Irache, Lib. 539, 271r.

PEDRO MAZÓN DE SOLARES

B. A. / B. T.

23-4-1687

Fr. Benito de Anguiano / Fr. Pedro Lozano

Santibáñez (Burgos)

AGN, Irache, Lib. 539, $271 \mathrm{v}$.

DIEGO ALONSO DE PRADO

B. C.

5-5-1687

Fr. Pedro Lozano

Oña (Burgos)

AGN, Irache, Lib. 539, 272r.

JUAN FERNÁNDEZ DE PORTILLO

B. C.

13-5-1687

Fr. Pedro Lozano

Santa María del Campo (Burgos)

AGN, Irache, Lib. 539, 272v. 
FRANCISCO RODRÍGUEZ DE LOS RÍOS

B. C.

12-5-[13-5-]-1687

Fr. Pedro Lozano

Campoo de Suso (Burgos)

AGN, Irache, Lib. 539, 272v.

JUAN LÓPEZ DE SUESA

L. T. / D. T.

13-5-1687

Fr. Gregorio Ruiz, abad

AGN, Irache, Lib. 539, 273r.

SANTIAGO DE LA FUENTE

B. C.

15-5-1687

Fr. José Fernández

Sobrón (Burgos)

AGN, Irache, Lib. 539, 273r.

ANTONIO ALONSO

B. C.

15-5-1687

Fr. Pedro Lozano

Pradoluengo (Burgos)

AGN, Irache, Lib. 539, 273v.

PEDRO DE AGUILAR

B. C.

15-5-1687

Fr. Pedro Lozano

Villaverde del Monte (Burgos)

AGN, Irache, Lib. 539, 273 v.

FRANCISCO PÉREZ DE LA VEGA

B. A. / B. T.

19-5-1687

Fr. Benito de Anguiano / Fr. Pedro Lozano

Bureba (Burgos)

AGN, Irache, Lib. 539, 274r.

\section{ANTONIO MOSQUECHO}

B. A. / B. T.

3-6-1687

Fr. Benito de Anguiano / Fr. José Fernán-

dez

Pancorbo (Burgos)

AGN, Irache, Lib. 539, 274r.
DIEGO SOLANA

B. A. / B. T.

14-6-1687

Fr. Pedro Lozano

Liaño (Burgos)

AGN, Irache, Lib. 539, 274v.

NICOLÁS RODRÍGUEZ

B. C.

19-6-1687

Fr. José Osorio

Matarrepudio (Burgos)

AGN, Irache, Lib. 539, 274v.

PEDRO GUTIÉRREZ

B. C.

25-6-1687

Fr. José Fernández

Poza (Burgos)

AGN, Irache, Lib. 539, 275r.

FRANCISCO PÉREZ

B. T.

10-7-1687

Fr. Pedro Lozano

Aedo (Burgos)

B. A. Salamanca

AGN, Irache, Lib. 539, 275r.

MATÍAS BURBANO

B. A. / B. T.

24-7-1687

Fr. José Osorio

Santa María de Rivarredonda (Burgos)

AGN, Irache, Lib. 539, 275v.

ANTONIO DE CÉSPEDES

B. C.

28-7-1687

Fr. José Osorio

Medina de Pomar (Burgos)

AGN, Irache, Lib. 539, $275 \mathrm{v}$.

\section{ALONSO CUEVAS}

B. C.

28-7-1687

Fr. José Osorio

Pedrosa (Burgos)

AGN, Irache, Lib. 539, 275v. 
FRANCISCO ANTONIO DE LA SOTA

B. C.

1-8-1687

Fr. Pedro Lozano

Obregón (Burgos)

AGN, Irache, Lib. 539, 276r.

AGUSTÍN LÓPEZ

B. M.

5-8-1687

Fr. Pedro Lozano / Dr. Ambrosio Gómez

Villar de Fallaves (León)

B. A. Valladolid

AGN, Irache, Lib. 539, 276r.

JUAN MANUEL DE LUCIO

B. C.

9-8-1687

Fr. José Osorio

Burgos

AGN, Irache, Lib. 539, 276v.

BERNARDO GONZÁLEZ

B. A. / B. T.

14-8-1687

Fr. Pedro Lozano

Medina de Pomar (Burgos)

AGN, Irache, Lib. 539, 276v.

ÁNGEL CUSTODIO DE MONTES

B. A. / B. T.

20-8-1687

Fr. José Osorio

Matute (Calahorra)

AGN, Irache, Lib. 539, 276v.

JOSÉ DE FABRE Y URTASO

B. A.

29-8-1687

Fr. Pedro Lozano

Caparroso (Pamplona)

AGN, Irache, Lib. 539, 277r.

JOSÉ FALCÓN

B. A.

7-9-1687

Fr. José Osorio

Vera (Tarazona)

AGN, Irache, Lib. 539, $277 \mathrm{v}$.
PEDRO MARTÍNEZ DE CORRES

B. C.

14-9-1687

Fr. Pedro Lozano

Cabredo (Calahorra)

AGN, Irache, Lib. 539, $277 v$.

JUAN DE ARBEIZA Y DICASTILLO

D. $\mathrm{T}$.

16-9-1687

Fr. Gregorio Ruiz, abad

Arbeiza (Pamplona)

L. T. Irache

AGN, Irache, Lib. 539, $277 \mathrm{v}$.

GASPAR DE BESGA

B. C.

21-9-1687

Fr. Pedro Lozano

Villanueva del Grillo (Burgos)

AGN, Irache, Lib. 539, 278r.

JUAN DE AYALA

B. C.

21-9-1687

Fr. Pedro Lozano

Gabanes (Burgos)

AGN, Irache, Lib. 539, 278r.

ROQUE GONZÁLEZ

B. C.

8-10-1687

Fr. Pedro Lozano

Burgos

AGN, Irache, Lib. 539, 278r.

JERÓNIMO DE ERCE Y PORTILLO

B. A.

8-10-1687

Fr. Pedro Lozano

Arnedo (Calahorra)

AGN, Irache, Lib. 539, 278v.

DIEGO DE IRIGUIEN

B. A. / B. T.

10-10-1687

Fr. Plácido Vea / Fr. José Osorio

Pamplona 
Colegial de S. J.

AGN, Irache, Lib. 539, 278v.

PABLO NEGRO

B. C.

24-10-1687

Fr. Pedro Lozano

Castrojeriz (Burgos)

AGN, Irache, Lib. 539, 278v.

JOSÉ CASASÚS Y MOLINOS

B. A.

27-10-1687

Fr. Esteban de Valcarce / Fr. Plácido Vea

Pamplona

Colegial de S. J.

AGN, Irache, Lib. 539, 279r.

PEDRO GAMARRA

B. C.

31-10-1687

Fr. Pedro Lozano

Castrojeriz (Burgos)

AGN, Irache, Lib. 539, 279r.

LUCAS GÓMEZ

B. A. / B. T.

7-11-1687

Fr. Esteban de Valcarce / Fr. José Fernán-

dez

Susinos (Burgos)

AGN, Irache, Lib. 549, 1r.

MANUEL ALONSO DE OVIEDO

B. C.

13-11-1687

Fr. Pedro Lozano

Poza (Burgos)

AGN, Irache, Lib. 549, 1r.

DOMINGO DE MIER

B. C.

13-11-1687

Fr. José Osorio

Mercadal (Burgos)

AGN, Irache, Lib. 549, 1r.

JUAN BLANCO

B. C.
13-11-1687

Fr. José Fernández

Valle (Burgos)

AGN, Irache, Lib. 549, 1 v.

JOSÉ FERNÁNDEZ VELARDE

B. C.

17-11-1687

Fr. Pedro Lozano

Sierradelsa (Burgos)

AGN, Irache, Lib. 549, $1 \mathrm{v}$.

JUAN DE LLORENTE

B. A. / B. T.

19-11-1687

Fr. Esteban de Valcarce / Fr. José Osorio

Salas de los Infantes (Burgos)

AGN, Irache, Lib. 549, 1 v.

ANTONIO DE LA ORDEN

B. C.

19-11-1687

Fr. José Fernández

Salas de los Infantes (Burgos)

AGN, Irache, Lib. 549, 2r.

LUCAS DE LOS CORRALES

B. C.

28-11-1687

Fr. José Osorio

So... (Burgos)

AGN, Irache, Lib. 549, 2r.

JOSÉ CALDERÓN

B. C.

2-12-1687

Fr. José Osorio

Poza (Burgos)

AGN, Irache, Lib. 549, 2r.

JOSÉ SÁNCHEZ DE ESPEJO Y CISNEROS

B. C.

3-12-1687

Fr. José Fernández

Alhama (Cartagena)

AGN, Irache, Lib. 549, 2v.

JERÓNIMO SANTIBÁÑEZ

B. C. 
5-12-1687

Fr. José Osorio

Villaverde (Burgos)

AGN, Irache, Lib. 549, 2v.

JOSÉ GONZÁLEZ DE TATE

B. C.

6-12-1687

Fr. José Osorio

Murillo de la Ribera (Calahorra)

AGN, Irache, Lib. 549, 2v.

ANDRÉS FERNÁNDEZ DEL OLMO

B. A. / B. T.

10-12-1687

Fr. Esteban de Valcarce / Fr. José Fernán-

dez

Tormantos (Burgos)

AGN, Irache, Lib. 549, 3r.

GREGORIO GARCÍA

B. T.

12-12-1687

Fr. Pedro Lozano

Poza (Burgos)

AGN, Irache, Lib. 549, 3r.

ADRIÁN TRECEÑO

B. C.

12-1-1688

Fr. Pedro Lozano

Grijalba (Burgos)

AGN, Irache, Lib. 549, 3v.

CLEMENTE JOSÉ DE MARQUINA

B. A. / B. M.

5-2-1688

Fr. Esteban de Valcarce / Fr. Pedro Lozano

// Dr. Ambrosio Gómez

Pamplona

Estudiante S. J.

Zaragoza

AGN, Irache, Lib. 549, 3v.

BERNARDINO GOT

B. A. / B. M.

10-2-1688

Fr. Esteban de Valcarce / Fr. Pedro Lozano
// Dr. Ambrosio Gómez

Gerona

AGN, Irache, Lib. 549, 4r.

FRANCISCO DE GAINZA

L. T. / D. T.

23-2-1688

Fr. Gregorio Ruiz, abad

Lezo (Pamplona)

B. A. y B. T. en Sevilla

AGN, Irache, Lib. 549, 4v.

BARTOLOMÉ GARCÍA

B. C.

27-2-1688

Fr. José Fernández

Villanueva del Rio Ubierna (Burgos)

AGN, Irache, Lib. 549, 4v.

LUIS RUIZ OBREGÓN

B. C.

27-2-1688

Fr. José Fernández

Lloreda (Burgos)

AGN, Irache, Lib. 549, 4v.

JUAN DE BUJANDA

B. A. / B. T.

27-2-1688

Fr. Esteban de Valcarce / Fr. Pedro Lozano

Torralba (Calahorra)

AGN, Irache, Lib. 549, 5r.

FRANCISCO SECO RODRÍGUEZ

B. C.

1-3-1688

Fr. José Osorio

Celada de Marlantes (Burgos)

AGN, Irache, Lib. 549, 5r.

BLAS DE SANTA CRUZ

B. A.

6-3-1688

Fr. Esteban de Valcarce

O. de M.

Caspe (Zaragoza)

AGN, Irache, Lib. 549, 5r. 
AGUSTÍN DE HERRÁN

B. A. / B. T.

7-3-1688

Fr. Esteban de Valcarce / Fr. José Fernández

Frías (Burgos)

Canónigo de Vadillo

AGN, Irache, Lib. 549, 5v.

FRANCISCO IBÁÑEZ

B. C.

23-3-1688

Fr. Pedro Lozano

Arenilla del Río Pisuerga (Burgos)

AGN, Irache, Lib. 549, 5v.

JUAN RUIZ

B. A. / B. M.

23-3-1688

Fr. Esteban de Valcarce / Fr. José Osorio //

Ambrosio Gómez

Aldeanueva (Calahorra)

AGN, Irache, Lib. 549, 5v.

AGUSTÍN DE LA PEDROSA Y CEBALLOS

B. C.

5-4-1688

Fr. José Fernández

Vadilla (Burgos)

AGN, Irache, Lib. 549, 6r.

MARTÍN DE LANDERA

B. C.

12-4-1688

Fr. Pedro Lozano

Guriezo (Burgos)

AGN, Irache, Lib. 549, 6r.

BARTOLOMÉ DEL MORAL

B. C.

12-4-1688

Fr. Pedro Lozano

Guriezo (Burgos)

AGN, Irache, Lib. 549, 6r.

FELIPE DE TRASLAVIÑA

B. T.

27-4-1688
Fr. Esteban de Valcarce

Arcentales (Burgos)

B. A. Valladolid

AGN, Irache, Lib. 549, 6v.

FRANCISCO MARTÍNEZ

B. C.

4-5-1688

Fr. Pedro Lozano

Medina de Pomar (Burgos)

AGN, Irache, Lib. 549, 6v.

DOMINGO MONZÓN

B. C.

9-5-1688

Fr. Pedro Lozano

San Andrés de Montorado (Burgos)

AGN, Irache, Lib. 549, 6v.

JOSÉ DEL PORTILLO

B. C.

10-5-1688

Fr. José Fernández

Lences (Burgos)

AGN, Irache, Lib. 549, 7r.

JOSÉ LUIS DE RADÍN

B. A. / B. M.

11-5-1688

Fr. Esteban de Valcarce / Fr. José Osorio //

Ambrosio Gómez

Tafalla (Pamplona)

Estudiante en S. J.

AGN, Irache, Lib. 549, 7r.

FRANCISCO ALONSO DEL PINO

B. C.

12-5-1688

Fr. José Osorio

Burgos

AGN, Irache, Lib. 549, 7r.

JUAN ARBELAIZ IBARRA

B. A.

14-5-1688

Fr. Esteban de Valcarce

Anteiglesia de Berriatúa (Calahora)

AGN, Irache, Lib. 549, 7v. 
JUAN DÍEZ DE TERÁN

B. C.

16-5-1688

Fr. José Fernández

Santa Olalla (Burgos)

AGN, Irache, Lib. 549, $7 \mathrm{v}$.

JUAN ANTONIO ORDOÑO ROSALES

B. C.

23-5-1688

Fr. Pedro Lozano

Medina de Pomar (Burgos)

AGN, Irache, Lib. 549, 7v.

BERNARDO DÍAZ

B. C.

23-5-1688

Fr. José Osorio

Oña (Burgos)

AGN, Irache, Lib. 549, 7v.

JUAN DE SOJO

B. A.

29-5-1688

Fr. Esteban de Valcarce

Sojo (Calahorra)

AGN, Irache, Lib. 549, 8r.

MANUEL DE TERÁN COSSÍO

B. C.

29-5-1688

Fr. José Fernández

Aguilar de Campo (Burgos)

AGN, Irache, Lib. 549, 8r.

JUAN PÉREZ DE HERRÁN

B. C.

4-6-1688

Fr. Pedro Lozano

Oña (Burgos)

AGN, Irache, Lib. 549, 8r.

MELCHOR DE PLAZA MÁRQUEZ

B. C.

16-6-1688

Fr. Pedro Lozano

Tardajos (Burgos)

AGN, Irache, Lib. 549, 8v.
FRANCISCO DE SILLARES CASADO

B. C.

19-6-1688

Fr. José Fernández

Tardajos (Burgos)

AGN, Irache, Lib. 549, 8v.

JUAN JOSÉ CALVO DÍEZ DE AUX

B. A. / B. M.

30-6-1688

Fr. Esteban de Valcarce / Fr. Pedro Lozano // Ambrosio Gómez

Ablitas (Tarazona)

Artes en S. J. / Medicina en Zaragoza

AGN, Irache, Lib. 549, 8v.

MANUEL JOSÉ RIBAS

B. A. / B. M.

30-6-1688

Fr. Esteban de Valcarce / Fr. Pedro Lozano

// Ambrosio Gómez

Tarazona

Artes en S. J. / Medicina en Zaragoza

AGN, Irache, Lib. 549, 9r.

FRANCISCO ANTONIO DE OTAÑES

B. C.

8-7-1688

Fr. José Fernández

Sopuerta (Burgos)

AGN, Irache, Lib. 549, 9r.

JUAN BAUTISTA DE LLANO

B. C.

8-7-1688

Fr. José Fernández

Sopuerta (Burgos)

AGN, Irache, Lib. 549, 9r.

SIMÓN DEL RÍO

B. A. / B. T.

10-7-1688

Fr. Esteban de Valcarce / Fr. José Fernández

Pedrosa el Río Urbel (Burgos)

AGN, Irache, Lib. 549, 9v.

FRANCISCO DEL BARRIO

B. C. 
10-7-1688

Fr. José Fernández

Pedrosa el Río Urbel (Burgos)

AGN, Irache, Lib. 549, 9v.

DOMINGO SÁINZ DE LA ERANUEVA

B. C.

16-7-1688

Fr. José Osorio

Urría (Burgos)

AGN, Irache, Lib. 549, 9v.

FRANCISCO DEL RÍO

B. C.

24-7-1688

Fr. José Osorio

Pedrosa el Río Urbel (Burgos)

AGN, Irache, Lib. 549, 9v.

JUAN BAUTISTA DE VINANCO

B. C.

2-8-1688

Fr. José Osorio

Villaventín (Burgos)

AGN, Irache, Lib. 549, 1 or.

JUAN DE PALACIO ARREDONDO

B. C.

2-8-1688

Fr. José Osorio

Limpias (Burgos)

AGN, Irache, Lib. 549, 1 or.

JOSÉ DE BURDASPAR

B. A. / B. M.

2-8-1688

Fr. Esteban de Valcarce / Fr. José Osorio //

Ambrosio Gómez

Peralta (Pamplona)

AGN, Irache, Lib. 549, 1 or.

SIMÓN SAINZ DE QUINTANILLA

B. C.

25-8-1688

Fr. José Osorio

Frías (Burgos)

AGN, Irache, Lib. 549, $10 \mathrm{v}$.
DOMINGO PÉREZ DE ATOCHA

B. C.

25-8-1688

Fr. José Osorio

Garde (Pamplona)

AGN, Irache, Lib. 549, $10 v$.

COSME DE LAS MUÑECAS

B. C.

27-8-1688

Fr. José Osorio

Sopuerta (Burgos)

AGN, Irache, Lib. 549, $10 v$.

FRANCISCO DE QUINTANA ANGULO

B. C.

3-9-1688

Fr. José Osorio

Teza (Burgos)

AGN, Irache, Lib. 549, 11r.

JUAN RUIZ DE RÍO FRANCOS

B. C.

8-9-1688

Fr. José Osorio

Santa María de Don (Burgos)

AGN, Irache, Lib. 549, 11r.

JUAN DE REBOLLEDO

B. C.

12-9-1688

Fr. Plácido Vea

Castrojeriz (Burgos)

AGN, Irache, Lib. 549, 11r.

JUAN DEL MONTE CORDERO

B. C.

20-9-1688

Fr. Plácido Vea, Regente

Retuerta (Burgos)

AGN, Irache, Lib. 549, 11v.

JUAN RUIZ DE LA ESCALERA

B. C.

20-9-1688

Fr. Plácido Vea

Hornedo (Burgos)

AGN, Irache, Lib. 549, 11v. 


\section{LORENZO VALERÓN}

B. C.

25-9-1688

Fr. José Fernández

Sasamón (Burgos)

AGN, Irache, Lib. 549, 11v.

JOSÉ HIDALGO

B. C. / L. C.

26-9-1688

Fr. Pedro Lozano

Diustes (Calahorra)

AGN, Irache, Lib. 549, 11v.

TOMÁS DE IRIARTE

B. $\mathrm{M}$.

27-9-1688

Fr. José Fernández / Ambrosio Gómez

Los Arcos (Pamplona)

B. A. en Huesca / Medicina en Zaragoza

AGN, Irache, Lib. 549, 12 r.

JOAQUÍN DE ORTIGOSA

B. A.

27-9-1688

Fr. Esteban de Valcarce

Los Arcos (Pamplona)

AGN, Irache, Lib. 549, 12r.

PEDRO GONZÁLEZ NIETO

B. C.

8-10-1688

Fr. José Fernández

Paúles del Agua (Burgos)

AGN, Irache, Lib. 549, 12 r.

MIGUEL DE ACHIGA

B. C.

10-10-1688

Fr. José Osorio

Somorrostro (Burgos)

AGN, Irache, Lib. 549, $12 \mathrm{v}$.

JUAN ANTONIO DE MONTAÑO

B. A. / B. T.

10-10-1688 / 16-10-1688

Fr. Esteban de Valcarce

Somorrostro (Burgos)

AGN, Irache, Lib. 549, 12v-13r.

\section{LESMES GARCÍA}

B. C.

12-10-1688

Fr. José Fernández

Burgos

AGN, Irache, Lib. 549, 12v.

MANUEL DE AGUAYO

B. C.

12-10-1688

Fr. José Osorio

Burgos

AGN, Irache, Lib. 549, 12v.

PEDRO DÍAZ DE ISLA

B. A. / B. T.

13-10-1688

Fr. Esteban de Valcarce / Fr. José Osorio

Villalaín (Burgos)

AGN, Irache, Lib. 549, 13 r.

FRANCISCO DE MALDA

B. C.

16-10-1688

Fr. Esteban de Valcarce

Cameno (Burgos)

AGN, Irache, Lib. 549, 13 r.

\section{PEDRO RODRÍGUEZ ALCALDE}

B. C.

16-10-1688

Fr. Esteban de Valcarce

Ojacastro (Burgos)

AGN, Irache, Lib. 549, $13 \mathrm{v}$.

ANTONIO THERRIS

B. A. / B. M. / L. M. / D. M.

19-10-1688 / 20-10-1688

Fr. Esteban de Valcarce / Fr. José Fernández // Ambrosio Gómez / Fr. Gregorio Ruiz, Abad y Rector

Perpiñán (Elna)

AGN, Irache, Lib. 549, 13v.

MIGUEL GARCÍA GALDIANO

B. C. / L. C.

21-10-1688 / 12-4-1690

Fr. José Fernández / Fr. José Osorio 
Galdiano (Pamplona)

AGN, Irache, Lib. 549, 14r, 26r.

\section{ALONSO GARCÍA}

B. C.

23-10-1688

Fr. José Osorio

Burgos

AGN, Irache, Lib. 549, 14r.

SIMÓN DÍAZ DE TUESTA

B. C.

12-11-1688

Fr. José Fernández

Burgos

AGN, Irache, Lib. 549, 14r.

JUAN SANZ

B. A. / B. M.

17-11-1688

Fr. Esteban de Valcarce / Fr. Pedro Lozano

// Bernardo Arróniz

Unzué (Pamplona)

AGN, Irache, Lib. 549, 14v.

JUAN DE TRIANA

B. A. / B. T.

12-12-1688

Fr. Esteban de Valcarce / Fr. José Osorio

Sasamón (Burgos)

AGN, Irache, Lib. 549, 14v.

FRANCISCO AMEZ

B. C.

19-12-1688

Fr. José Osorio

Sopuertas (Burgos)

AGN, Irache, Lib. 549, 15 r.

JOSÉ NAVARRO

B. C.

3-1-1689

Fr. Plácido Vea

Calahorra

AGN, Irache, Lib. 549, 15 r.

SIMÓN GÓMEZ DE RUFRANCOS

B. C.
6-1-1689

Fr. José Osorio

Quintana Martín Galíndez (Burgos)

AGN, Irache, Lib. 549, 15r.

DOMINGO DE ARAMONA

B. T.

14-2-1689

Fr. José Fernández

Valmaseda (Burgos)

AGN, Irache, Lib. 549, 15v.

FELIPE DEL CASTILLO

B. C.

22-2-1689

Fr. Pedro Lozano

Valmaseda (Burgos)

AGN, Irache, Lib. 549, 15v.

JUAN JIMÉNEZ DE LEORIN

B. A. / B. T. / L. T. / D. T.

15-3-1689 / 16-3-1689

Fr. Esteban de Valcarce / Fr. José Osorio /

Fr. Gregorio Ruiz, abad

Morentín (Pamplona)

AGN, Irache, Lib. 549, 15v, $16 \mathrm{r}$.

TOMÁS GUTIÉRREZ

B. C.

18-3-1689

Fr. José Osorio

Monegro (Burgos)

AGN, Irache, Lib. 549, 16r.

MANUEL NAVARRO

L. A. / D. A. / B. T. / L. T. / D. T.

23-3-1689

Fr. Gregorio Ruiz, abad

O. S. B.

AGN, Irache, Lib. 549, 16v.

FRANCISCO DE TORRES NAVARRETE

B. A. / B. T. / L. T.

28-3-1689

Fr. Esteban de Valcarce / Fr. José Fernández / Fr. Gregorio Ruiz, abad

Arocena (Calahorra)

AGN, Irache, Lib. 549, 16v. 


\section{HIPÓLITO DE MONTARANA}

B. C.

30-3-1689

Fr. José Fernández

Briviesca (Burgos)

AGN, Irache, Lib. 549, 17r.

\section{FRANCISCO DE SAN MARTÍN}

B. C.

30-3-1689

Fr. Pedro Lozano

Briviesca (Burgos)

AGN, Irache, Lib. 549, 17r.

\section{MARTÍN ORTIZ DE GUINEA}

B. C.

1-4-1689

Fr. José Fernández

Burgos

AGN, Irache, Lib. 549, 17 r.

\section{DIEGO DE URRUTIA}

B. C.

14-4-1689

Fr. Pedro Lozano

Briviesca (Burgos)

AGN, Irache, Lib. 549, 17v.

JOSÉ PÉREZ DE LA FUENTE

B. C.

14-4-1689

Fr. José Osorio

Laguardia (Calahorra)

AGN, Irache, Lib. 549, 17v.

\section{MANUEL MARTÍNEZ}

B. A. / B. M.

14-4-1689 / 30-11-1690

Fr. Esteban de Valcarce // Fr. José Fernández, Ambrosio Gómez

Nalda (Calahorra)

AGN, Irache, Lib. 549, 17v, 31r.

JOSÉ ANTÓN

B. C.

28-4-1689

Fr. José Osorio

Cañizal de los Asos (Burgos)

AGN, Irache, Lib. 549, 18r.

\section{JUAN ANTONIO PASCUAL}

B. A. / B. M.

16-5-1689

Fr. Esteban de Valcarce / Fr. Pedro Lozano

// Ambrosio Gómez

Torrellas (Zaragoza)

AGN, Irache, Lib. 549, 18r.

JOSÉ CASADO Y RUBIO

B. A. / B. T. / L. T. / D. T.

13-6-1689

Fr. Esteban de Valcarce / Fr. José Fernández / Fr. Martín de Arenas, Abad y Rector

Cintruénigo (Tarazona)

AGN, Irache, Lib. 549, 18r.

MANUEL DE QUIRÓS

B. A. / B. T. / L. T. / D. T.

23-6-1689

Fr. Martín de Arenas, Abad y Rector

O. S. B.

Abad de Espinareda

Obispo en Indias [Oaxaca]

AGN, Irache, Lib. 549, 18v.

GASPAR DE MAHAMUD

B. C.

26-6-1689

Fr. José Fernández

Santa María del Campo (Burgos)

AGN, Irache, Lib. 549, 19 r.

TOMÁS DE TORRES

B. C.

12-7-1689

Fr. José Fernández

Santa María del Campo (Burgos)

AGN, Irache, Lib. 549, 19 r.

PABLO DE LA ROCA

B. A.

22-7-1689

Fr. Esteban de Valcarce

Pamplona

AGN, Irache, Lib. 549, 19v.

JOSÉ DE IRAGUI

B. A. / B. M. 
6-8-1689

Fr. Esteban de Valcarce / Fr. Pedro Lozano // Ambrosio Gómez

Pamplona

AGN, Irache, Lib. 549, 19v.

ROQUE DEL BARRIO

B. C.

16-9-1689

Fr. Pedro Lozano

Espinosa de Bricia (Burgos)

AGN, Irache, Lib. 549, 20 .

JOSÉ ALONSO DE MATA

B. C.

28-9-1689

Fr. Pedro Lozano

Burgos

AGN, Irache, Lib. 549, 2 or.

TOMÁS FERNÁNDEZ

B. A. / B. M. / L. M. / D. M.

29-9-1689 / 1-10-1689

Fr. Esteban de Valcarce / Fr. José Fernández // Ambrosio Gómez / Fr. Martín de Arenas, Abad y Rector

Nájera (Calahorra)

AGN, Irache, Lib. 549, $20 v$.

JUAN ANTONIO GARCÍA DE SOTO Y COLMENARES

B. C.

2-10-1689

Fr. José Osorio

Soto (Burgos)

AGN, Irache, Lib. 549, 21r.

FRANCISCO DE OLEA

B. C.

7-10-1689

Fr. Pedro Lozano

Celada de los Calderones (Burgos)

AGN, Irache, Lib. 549, 21r.

\section{MANUEL GUTIÉRREZ}

B. C.

7-10-1689

Fr. José Fernández
Soto (Burgos)

AGN, Irache, Lib. 549, 21v.

ANTONIO DE POLANCO

B. C.

8-10-1689

Fr. José Osorio

Oruña (Burgos)

AGN, Irache, Lib. 549, $21 \mathrm{v}$.

DOMINGO DE LAS VENERAS

B. A. / B. T.

11-10-1689 / 12-10-1689

Fr. Esteban de Valcarce / Fr. Pedro Lozano

Oruña (Burgos)

AGN, Irache, Lib. 549, 21v, 22v.

MANUEL DE SANTA MARÍA

B. C.

29-10-1689

Fr. Pedro Lozano

Burgos

AGN, Irache, Lib. 549, 22r.

JOSÉ GOBEO

B. A. / B. T. / L. T. / D. T.

30-10-1689 / 31-10-1689

Fr. Martín de Arenas, Abad y Rector

O. S. B.

Abad de Valvanera

AGN, Irache, Lib. 549, 22 rv.

ANTONIO NAVARRO E IBÁÑEZ

B. A. / B. M. / L. M. / D. M.

8-11-1689 /10-11-1689

Fr. Esteban de Valcarce / Fr. José Osorio //

Ambrosio Gómez

Fr. Martín de Arenas, Abad y Rector

Tarazona

AGN, Irache, Lib. 549, 22v.

FELIPE DE PIEDRA

B. M.

8-12-1689

Fr. José Osorio

Tudela (Nullius Diocesis)

AGN, Irache, Lib. 549, 23 r. 
ANDRÉS PEÑA

B. A.

9-12-1689

Fr. Esteban de Valcarce

Anguiano (Calahorra)

AGN, Irache, Lib. 549, 23 r.

MANUEL DE MURO

B. A. / B. M.

14-12-1689 / 9-10-1693

Fr. Esteban de Valcarce // Fr. Plácido Vea /

Ambrosio Gómez

Calahorra

AGN, Irache, Lib. 549, 23v-24r, $60 v$.

\section{BUENAVENTURA DE PAREDES}

B. C.

16-12-1689

Fr. Pedro Lozano

Villabasil (Burgos)

AGN, Irache, Lib. 549, $23 \mathrm{v}$.

ANTONIO DE LLANO

B. C.

30-12-1689

Fr. José Osorio

Castillo (Burgos)

AGN, Irache, Lib. 549, $23 \mathrm{v}$.

FRANCISCO BENITO

B. A.

20-1-1690

Fr. Esteban de Valcarce

Anguiano (Calahorra)

AGN, Irache, Lib. 549, 24r.

JUAN JOSÉ DÍAZ DEL CORRAL

B. A.

21-1-1690

Fr. Esteban de Valcarce

Entrena (Calahorra)

AGN, Irache, Lib. 549, 24r.

FRANCISCO JIMÉNEZ

B. A.

23-1-1690

Fr. Esteban de Valcarce

Alfaro (Tarazona)

AGN, Irache, Lib. 549, $24 \mathrm{~V}$.

\section{PEDRO DE ARANGO}

B. A.

29-1-1690

Fr. Plácido del Castillo

Mendavia (Pamplona)

AGN, Irache, Lib. 549, 24v.

JUAN DE MAZA ROZAS

B. $\mathrm{M}$.

2-2-1690

Fr. José Osorio / Ambrosio Gómez

Gibaja (Burgos)

B. A. en Ávila

AGN, Irache, Lib. 549, 25r.

ANTONIO ESTÉVANEZ

B. C.

5-2-1690

Fr. Pedro Lozano

Arenillas de Pisuerga (Burgos)

AGN, Irache, Lib. 549, 25r.

MANUEL DE VILLASANTE

B. C.

18-2-1690

Fr. José Osorio

Espinosa de los Monteros (Burgos)

AGN, Irache, Lib. 549, 25r.

PEDRO FERNÁNDEZ Y ORTIZ

B. L.

25-2-1690

Fr. Pedro Lozano

Alfaro (Tarazona)

AGN, Irache, Lib. 549, 25r.

JUAN ANTONIO DE ABLITAS

B. L.

25-2-1690

Reprobado

Fr. Pedro Lozano // L. L. Baltasar de Lezáun, Letrado de Estella

Alfaro (Tarazona)

AGN, Irache, Lib. 549, 25v.

DIEGO DE VILLASANA Y PANIAGUA

B. C.

3-3-1690 
Fr. José Osorio

Melgar de Fernamental (Burgos)

AGN, Irache, Lib. 549, 25v.

JUAN MARTÍN DE CONTRERAS

B. A. / B. M.

22-3-1690 / 7-6-1691

Fr. José Fernández // Fr. José Fernández /

Fr. Plácido Vea / Ambrosio Gómez

Venganzones (Segovia)

AGN, Irache, Lib. 549, 25v, 35r.

JOSÉ ANTONIO GARCÍA

B. C.

24-3-1690

Fr. Pedro Lozano

Burgos

AGN, Irache, Lib. 549, 25v.

FELIPE DE AGUIRRE Y MARTÍNEZ

B. A. / B. M.

1-4-1690

Fr. José Osorio / Ambrosio Gómez

Ablitas (Tarazona)

Estudiante en Zaragoza

AGN, Irache, Lib. 549, 26r.

GREGORIO DÍAZ DE SALAZAR

B. C.

12-4-1690

Fr. José Osorio

Lir... (Burgos)

AGN, Irache, Lib. 549, 26r.

JUAN DE SOLA

B. C.

21-4-1690

Fr. José Osorio

Lácar (Pamplona)

AGN, Irache, Lib. 549, 26v.

FRANCISCO DE LA SIERRA PUENTE Y SOLÓRZANO

B. C.

28-4-1690

Fr. José Fernández

Solórzano (Burgos)

AGN, Irache, Lib. 549, 26v.
TOMÁS GARCÍA DE PALACIOS

B. C.

2-5-1690

Fr. José Osorio

Frías (Burgos)

AGN, Irache, Lib. 549, $26 \mathrm{v}$.

ANDRÉS DE AYALA

B. C.

10-5-1690

Fr. José Osorio

Villadiego (Burgos)

AGN, Irache, Lib. 549, 26v.

JUAN MARTÍNEZ FERNÁNDEZ DE CENZANO

B. A. / B. M.

16-5-1690

Fr. José Fernández / Fr. Pedro Lozano //

Ambrosio Gómez

Ribafrecha (Calahorra)

B. A. en Ávila

AGN, Irache, Lib. 549, 26v-27r.

PABLO CALZADA

B. C.

10-6-1690

Fr. José Osorio

Susinos (Burgos)

AGN, Irache, Lib. 549, 27r.

\section{ANTONIO DOMÍNGUEZ}

B. A.

6-7-1690

Fr. José Fernández

O. de M.

Los Fayos (Tarazona)

AGN, Irache, Lib. 549, 27r.

JOSÉ DE VALPUESTA

B. C.

11-7-1690

Fr. José Fernández

Villanañe (Burgos)

AGN, Irache, Lib. 549, 27r.

JUAN DE TAPIA Y CEBALLOS

B. C. 
22-7-1690

Fr. José Osorio

Castrojeriz (Burgos)

AGN, Irache, Lib. 549, 27v.

LUIS DE TAPIA Y CEBALLOS

B. C.

22-7-1690

Fr. Plácido Vea

Castrojeriz (Burgos)

AGN, Irache, Lib. 549, $27 \mathrm{v}$.

\section{FRANCISCO SÁNCHEZ}

B. A.

23-7-1690

Fr. Plácido Vea

O. de M.

Sinia (Urgell)

AGN, Irache, Lib. 549, 27v.

MIGUEL MARTÍNEZ

B. A. / B. M.

6-8-1690

Fr. José Osorio / Fr. Plácido Vea // Ambrosio Gómez

Falces (Pamplona)

Estudiante en Zaragoza

AGN, Irache, Lib. 549, $27 \mathrm{v}$.

FRANCISCO DEL PORTAL

B. A. / B. M.

6-8-169o

Fr. José Osorio / Fr. Plácido Vea // Ambrosio Gómez

Olite (Pamplona)

AGN, Irache, Lib. 549, 27v.

FRANCISCO LECUMBERRI

B. A. / B. M.

7-8-1690

Fr. Plácido Vea // Ambrosio Gómez

Ustárroz (Pamplona)

Estudiante en Zaragoza

AGN, Irache, Lib. 549, 28r.

ROQUE DE MIER Y TERÁN

B. C.

10-8-1690
Fr. Plácido Vea

Reinosa (Burgos)

AGN, Irache, Lib. 549, 28r.

VENTURA DE MIER Y TERÁN

B. C.

10-8-1690

Fr. Plácido Vea

Reinosa (Burgos)

AGN, Irache, Lib. 549, 28r.

ANTONIO GUTIÉRREZ DE LANZAS

B. C.

10-8-1690

Fr. Plácido Vea

Reinosa (Burgos)

AGN, Irache, Lib. 549, 28r.

JUAN MANTILLA

B. C.

10-8-1690

Fr. José Osorio

Ormas (Burgos)

AGN, Irache, Lib. 549, 28r.

JUAN GARCÍA DE LOS HOYOS

B. C.

22-8-1690

Fr. José Osorio

Brañosera (Burgos)

AGN, Irache, Lib. 549, 28r.

PEDRO DE SANTIAGO

B. C.

22-8-1690

Fr. José Osorio

Canduela (Burgos)

AGN, Irache, Lib. 549, 28r.

FRANCISCO SECO

B. C.

31-8-1690

Fr. Plácido Vea

Brañosera (Burgos)

AGN, Irache, Lib. 549, 28v.

ANTONIO RANERO

B. C. 
1-9-1690

Fr. Plácido Vea

[Quintanilla de la] Presa (Burgos)

AGN, Irache, Lib. 549, 28v.

MATÍAS BESGA

B. C.

3-9-1690

Fr. José Osorio

Herrán (Burgos)

AGN, Irache, Lib. 549, 28v.

FELIPE DE BUJEDO

B. C.

11-9-1690

Fr. Plácido Vea

Lomas de Villa Mediana (Burgos)

AGN, Irache, Lib. 549, 29r.

PEDRO DE TUDELA

B. A. / B. M.

22-9-1690 / 30-9-1691

Fr. José Osorio / Fr. Plácido Vea

Torrellas (Tarazona)

AGN, Irache, Lib. 549, 29r, 38v.

LUIS ANTONIO DE COVILLAS Y VENENO

B. A. / B. T.

22-9-1690

Fr. Plácido Vea

Colindres (Burgos)

AGN, Irache, Lib. 549, 29r.

FRANCISCO CAVERO

B. T.

25-9-1690

Fr. José Osorio

Berbegal (Lérida)

B. A. por Huesca

AGN, Irache, Lib. 549, $29 r$.

JUAN DE ISAR

B. C.

26-9-1690

Fr. Plácido Vea

Iglesias (Burgos)

AGN, Irache, Lib. 549, $29 \mathrm{v}$.
JUAN GONZÁLEZ DE LA PLAZA

B. C.

29-9-1690

Fr. José Osorio

Villajimeno (Burgos)

AGN, Irache, Lib. 549, $29 \mathrm{v}$.

GABRIEL GONZÁLEZ DE LA VID

B. C.

29-9-1690

Fr. José Osorio

Zeñeda (Burgos)

AGN, Irache, Lib. 549, 29v.

TOMÁS GARCÍA GÓMEZ

B. C.

29-9-1690

Fr. José Osorio

Fresno del Río Tirón (Burgos)

AGN, Irache, Lib. 549, $29 \mathrm{v}$.

PEDRO LÓPEZ DE SILANES

B. A. / B. T.

9-10-1690

Fr. José Fernández

Cellorigo (Burgos)

AGN, Irache, Lib. 549, $29 \mathrm{v}$.

PEDRO MARTÍNEZ DE LA CUESTA

B. C.

11-10-1690

Fr. José Osorio

Frandovínez (Burgos)

AGN, Irache, Lib. 549, 29v.

FRANCISCO AMATRIAIN

B. A. / B. M.

15-10-1690

Fr. José Fernández / Ambrosio Gómez

Beire (Pamplona)

AGN, Irache, Lib. 549, 3or.

TOMÁS GARCÍA

B. C.

21-10-1690

Fr. José Osorio

Burgos

AGN, Irache, Lib. 549, 3or. 
JUAN GALLEGO BLANCO

B. C.

30-10-1690

Fr. Plácido Vea

Paredes de Nava (Palencia)

AGN, Irache, Lib. 549, 30r.

JUAN ANTONIO ARRAIZA

B. C.

14-11-1690

Fr. José Fernández

Enériz (Pamplona)

Abad de Enériz

AGN, Irache, Lib. 549, 30v.

ANTONIO PÉREZ BORAITA

B. C.

15-11-1690

Fr. José Osorio

Cellorigo (Burgos)

AGN, Irache, Lib. 549, 30v.

JOSÉ SERRANO

B. A. / B. M.

15-11-1690

Fr. Plácido de Castillo / Fr. Plácido Vea //

Ambrosio Gómez

Ausol (Calahorra)

Estudiante en Zaragoza

AGN, Irache, Lib. 549, $30 \mathrm{v}$.

ROQUE DE LA PUENTE

B. A. / B. T.

2-12-1690

Fr. Plácido de Castillo / Fr. José Osorio

Valmaseda (Burgos)

AGN, Irache, Lib. 549, 31r.

DOMINGO DE LARA

B. A. / B. M.

22-12-1690

Fr. Plácido de Castillo / Fr. Plácido Vea //

Ambrosio Gómez

Ciria (Osma)

AGN, Irache, Lib. 549, 31r.

ANDRÉS DE LA PALIZA Y MOLINEDO

B. C. 23-12-169o

Reprobado

Fr. Plácido Vea

Valmaseda (Burgos)

AGN, Irache, Lib. 549, 31v.

ANTONIO DEL ANO

B. T.

10-1-1691

Fr. José Fernández

Madrid (Toledo)

B. A. en Alcalá

AGN, Irache, Lib. 549, 31v.

ALONSO DE ARAMERIA

B. C.

14-1-1691

Fr. Plácido Vea

Valmaseda (Burgos)

AGN, Irache, Lib. 549, 31v.

JOSÉ HERNÁNDEZ DE LA TORRE

B. C.

19-1-1691

Fr. José Fernández

Condado (Burgos)

AGN, Irache, Lib. 549, 32r.

PEDRO GARCÍA

B. A. / B.T.

23-1-1691

Fr. Plácido de Castillo / Fr. José Osorio

Pradoluengo (Burgos)

Pbro.

AGN, Irache, Lib. 549, 32r.

TOMÁS LÓPEZ

B. C.

3-2-1691

Fr. Plácido Vea

Briviesca (Burgos)

AGN, Irache, Lib. 549, 32r.

\section{MARTÍN GONZÁLEZ}

B. C.

6-2-1691

Fr. José Fernández

Grisaleña (Burgos)

AGN, Irache, Lib. 549, 32v. 
FRANCISCO ANTONIO DE ARREDONDO

B. C

13-2-1691

Fr. José Osorio

Medina de Pomar (Burgos)

AGN, Irache, Lib. 549, 32v.

BERNARDO DE TUDELA

B. A. / B. M.

20-2-1691

Fr. Plácido de Castillo / Fr. Plácido Vea //

Ambrosio Gómez

Pamplona

Estudiante en Pamplona y Zaragoza

AGN, Irache, Lib. 549, 32v.

BLAS MARTÍNEZ DE LOS RÍOS

B. C.

22-2-1691

Fr. José Fernández

Medina de Pomar (Burgos)

AGN, Irache, Lib. 549, 32v.

MARCOS CEBALLOS QUEVEDO

B. C.

1-3-1691

Fr. José Osorio

Somballe (Burgos)

AGN, Irache, Lib. 549, 33r.

\section{LORENZO MARÍN}

B. C.

2-3-1691

Fr. Plácido Vea

Fresneda (Burgos)

AGN, Irache, Lib. 549, 33r.

MATÍAS RODRÍGUEZ

B. C.

3-3-1691

Fr. José Fernández

Fresneda (Burgos)

AGN, Irache, Lib. 549, 33r.

MANUEL DE RUCOBA Y SAÑA

B. C.

17-3-1691

Fr. José Osorio
Medina de Pomar (Burgos)

AGN, Irache, Lib. 549, 33r.

JOSÉ DE SARRIÁ

B. A. / B. T.

30-3-1691

Fr. Plácido Vea

Portugalete (Burgos)

AGN, Irache, Lib. 549, 33v.

JUAN DE LA PEÑA

B. A. / B. T.

2-4-1691

Fr. Plácido de Castillo / Fr. José Fernández

Villadiego (Burgos)

AGN, Irache, Lib. 549, 33v.

ANTONIO GIMÉNEZ DE HOYOS

B. A. / B. T.

10-4-1691

Fr. Plácido de Castillo / Fr. José Osorio

Villadiego (Burgos)

AGN, Irache, Lib. 549, 33v.

JOSÉ DE HERRERA Y VELASCO

B. C.

10-4-1691

Fr. José Osorio

Villadiego (Burgos)

AGN, Irache, Lib. 549, 33v.

JUAN JOSÉ PRUDO Y ARTECHE

B. A.

24-4-1691

Fr. Plácido de Castillo

Logroño (Calahorra)

Pbro.

AGN, Irache, Lib. 549, 34r.

PEDRO MORENO

B. C.

28-4-1691

Fr. José Fernández

Zuñeda (Burgos)

AGN, Irache, Lib. 549, 34v.

LORENZO ALONSO

B. C. 
29-4-1691

Fr. José Osorio

Zuñeda (Burgos)

AGN, Irache, Lib. 549, 34v.

JOSÉ GARCÍA

B. C.

29-4-1691

Fr. José Osorio

San Vicente (Burgos)

AGN, Irache, Lib. 549, 34V.

MANUEL DE ORNEDO

B. C.

7-5-1691

Fr. José Fernández

Loranquillo (Burgos)

AGN, Irache, Lib. 549, 34v.

PEDRO DE ORNEDO

B. C.

7-5-1691

Fr. José Osorio

Loranquillo (Burgos)

AGN, Irache, Lib. 549, 34v.

JOSÉ DE AMEZ

B. C.

7-5-1691

Fr. José Osorio

L... (Burgos)

AGN, Irache, Lib. 549, 34v.

JERÓNIMO DE SORIA Y ARTIAGA

B. A. / B. M.

30-5-1691

Fr. Plácido de Castillo / Fr. José Fernández

// Ambrosio Gómez

Alfaro (Tarazona)

AGN, Irache, Lib. 549, 34v.

ANDRÉS LÓPEZ DE BAILLO

B. C.

3-6-1691

Fr. José Fernández

Medina de Pomar (Burgos)

AGN, Irache, Lib. 549, 34v.
PEDRO DE LA CANTOLLA

B. C.

6-6-1691

Fr. José Osorio

Retuerto (Burgos)

AGN, Irache, Lib. 549, 34v.

LORENZO DE GARAY

B. C.

13-6-1691

Fr. José Fernández

...genta

AGN, Irache, Lib. 549, 35r.

JOSÉ GÓMEZ DE GAYANGOS

B. C.

18-6-1691

Fr. Pedro de Granda

Cerezo (Burgos)

AGN, Irache, Lib. 549, 35r.

VÍCTORES DE GUINEA Y MÚJICA

B. C.

23-6-1691

Fr. Pedro de Granda

Cerezo (Burgos)

AGN, Irache, Lib. 549, 35r.

JUAN DE ROYO

B. C.

28-6-1691

Fr. Pedro de Granda

Los Ausines (Burgos)

AGN, Irache, Lib. 549, 35v.

PEDRO DE ARRONTE CASTILLO

B. C.

3-7-1691

Fr. Pedro de Granda

Retuerto (Burgos)

AGN, Irache, Lib. 549, 35v.

MANUEL SAINZ

B. C.

5-7-1691

Fr. Pedro de Granda

Andinillo (Burgos)

AGN, Irache, Lib. 549, 35v. 
FRANCISCO GARCÍA DE LA HIEDRA

B. C.

10-7-1691

Fr. Plácido Vea

Bisjueces (Burgos)

AGN, Irache, Lib. 549, 35v.

JOSÉ JUAN Y QUERALT

B. A. / B. M.

12-7-1691

Fr. Plácido de Castillo / Fr. Plácido Vea //

Ambrosio Gómez

Alcanar (Tortosa)

Estudiante en Valencia

AGN, Irache, Lib. 549, 36r.

MELCHOR DE BORRICÓN Y ARÉVALO

B. C.

19-7-1691

Fr. Plácido Vea

Briones (Calahorra)

AGN, Irache, Lib. 549, 36r.

JOSÉ DE SOJO

B. C.

1-8-1691

Fr. Plácido Vea

Ojón (Burgos)

AGN, Irache, Lib. 549, 36r.

FRANCISCO GÓMEZ DE QUINTANA

6-8-1691

Fr. Plácido Vea

Ogarrio (Burgos)

AGN, Irache, Lib. 549, 36v.

PEDRO DE CÁCERES Y LATORRE

B. A. / B. T.

7-8-1691

Fr. Plácido de Castillo / Fr. Pedro de Gran-

da

Burgos

AGN, Irache, Lib. 549, 36v.

\section{MANUEL DE MANSILLA VITORIA}

B. C.

13-8-1691

Fr. Plácido Vea
Ojacastro (Burgos)

AGN, Irache, Lib. 549, 36v.

JOSÉ DE IBARRA

B. A. / B. T.

14-8-1691

Fr. Plácido de Castillo / Fr. Plácido Vea

Burgos

AGN, Irache, Lib. 549, 37r.

JUAN DE SANTA GADEA

B. C.

16-8-1691

Fr. Plácido Vea

Miranda de Ebro (Burgos)

AGN, Irache, Lib. 549, 37r.

ANDRÉS GARCÍA MAZUECO

B. C.

16-8-1691

Fr. Plácido Vea

Burgos

AGN, Irache, Lib. 549, 37r.

SANTIAGO BARBERO

B. C.

16-8-1691

Fr. Plácido Vea

Sordillos (Burgos)

AGN, Irache, Lib. 549, 37r.

FRANCISCO SALGADO

B. A. / B. T.

22-8-1691

Fr. Plácido de Castillo / Fr. Plácido Vea

Azcaray (Burgos)

AGN, Irache, Lib. 549, 37v.

VICENTE PINILLOS

B. A.

27-8-1691

Fr. Plácido de Castillo

Logroño (Calahora)

AGN, Irache, Lib. 549, 37v.

ALONSO DE CELADA

B. C.

27-8-1691 
Fr. Pedro de Granda

Medina de Pomar (Burgos)

AGN, Irache, Lib. 549, 37v.

BARTOLOMÉ ÁLVAREZ

B. A. / B. T.

30-8-1691

Fr. Plácido de Castillo / Fr. Plácido Vea

Burgos

AGN, Irache, Lib. 549, 38r.

\section{FRANCISCO MARCO Y ENRÍQUEZ}

B. A. / B. M.

15-9-1691

Fr. Plácido de Castillo // Ambrosio Gómez

Cascante (Tarazona)

Estudiante en S. J.

AGN, Irache, Lib. 549, 38r.

\section{RODRIGO MONTERO}

B. C.

17-9-1691

Fr. José Fernández

Arana (Burgos)

AGN, Irache, Lib. 549, 38v.

FRANCISCO DE HUERTA

B. C.

30-9-1691

Fr. Plácido Vea

San Millán (Burgos)

AGN, Irache, Lib. 549, 38v.

TIBURCIO DE PRADA

B. C.

1-10-1691

Fr. José Fernández

Frías (Burgos)

AGN, Irache, Lib. 549, 38v.

JUAN DE IBARROLA

B. A.

4-10-1691

Fr. Plácido de Carrillo

Respaldiza (Calahorra)

AGN, Irache, Lib. 549, 39r.

PEDRO DE TORICES Y COSÍO

B. C.
7-10-1691

Fr. José Osorio

Revilla de San Millán (Burgos)

AGN, Irache, Lib. 549, 39r.

ROQUE GUTIÉRREZ

B. C.

7-10-1691

Fr. José Osorio

Los Carabeos (Burgos)

AGN, Irache, Lib. 549, 39r.

PEDRO MARTÍN SALINAS

B. M.

25-10-1691

Fr. José Osorio

Dueñas (Palencia)

AGN, Irache, Lib. 549, 39r.

PEDRO DÍAZ DE SELLAÑO

B. C.

1-11-1691

Fr. José Osorio

Zalla (Burgos)

AGN, Irache, Lib. 549, 39v.

JOSÉ ANSÓN DE LA TORRE

B. C.

10-11-1691

Fr. José Osorio

Burgos

AGN, Irache, Lib. 549, 39v.

JUAN DE CASARES

B. C.

24-11-1691

Fr. José Fernández

Cerrillo (Burgos)

AGN, Irache, Lib. 549, 39v.

PEDRO DE COSÍO CELY

L. C. / D. C.

24-11-1691

Fr. José Fernández

Carmona, Valle de Cabuérniga (Burgos)

AGN, Irache, Lib. 549, 39v.

JERÓNIMO ÁLVAREZ CARRERA

B. A. / B. T. 
26-11-1691

Fr. Plácido de Carrillo

Hoz (Burgos)

AGN, Irache, Lib. 549, 39v.

TOMÁS BARBADILLO

B. C.

27-11-1691

Fr. Plácido Vea

Covarrubias (Burgos)

AGN, Irache, Lib. 549, 39v.

CARLOS DE SENÉN

B. C.

3-12-1691

Fr. José Fernández

Puerto (Burgos)

AGN, Irache, Lib. 549, 39v.

ANTONIO ÁLVAREZ CARRERA

B. C.

8-12-1691

Fr. José Osorio

Hoz (Burgos)

AGN, Irache, Lib. 549, 40r.

JUAN FRANCISCO HERNÁNDEZ

B. C.

16-12-1691

Fr. Plácido Vea

Somorrostro (Burgos)

AGN, Irache, Lib. 549, 40r.

JOSÉ FERNÁNDEZ

B. A. / M. A. / B. T. / M. T.

8-12-1691

Fr. Antonio de Arroyo

O. S. B.

Lector y Regente de Irache

AGN, Irache, Lib. 549, $40 v$.

JOSÉ DE OSORIO

B. A. / M. A. / B. T. / M. T.

8-12-1691

Fr. Antonio de Arroyo

O. S. B.

Lector de Irache

AGN, Irache, Lib. 549, 40v.
DIEGO DE VARONA

B. C.

29-1-1692

Fr. José Osorio

Villaverde (Burgos)

AGN, Irache, Lib. 549, 40v.

JOSÉ DE VARONA

B. C.

29-1-1692

Fr. José Osorio

Villaverde (Burgos)

AGN, Irache, Lib. 549, 40v.

FRANCISCO ESPINOSA

B. C.

13-2-1692

Fr. Plácido Vea

Castrojeriz (Burgos)

AGN, Irache, Lib. 549, $40 v$.

LEÓN BERNARDO DE QUEVEDO

B. C.

16-2-1692

Fr. Plácido Vea

Reinosa (Burgos)

AGN, Irache, Lib. 549, 40v.

LEONARDO DE ORTEGA

B. C.

29-2-1692

Fr. José Osorio

Santibáñez (Burgos)

AGN, Irache, Lib. 549, 41r.

SEBASTIÁN DE ORTEGA

B. C.

6-3-1692

Fr. José Fernández

4 meses de penitencia (sic)

Barrios (Burgos)

AGN, Irache, Lib. 549, 41r.

ANDRÉS FERNÁNDEZ DE COSÍO

B. C.

6-3-1692

Fr. Plácido Vea

4 meses de penitencia (sic) 
Villadiego (Burgos)

AGN, Irache, Lib. 549, 41r.

FRANCISCO BERNARDO DE ARNEDO

B. C.

10-3-1692

Fr. José Osorio

Burgos

AGN, Irache, Lib. 549, 41r.

MANUEL DE HERRERA Y RÍO

B. A. / B. T.

10-3-1692

Fr. Plácido de Castillo / Fr. Plácido Vea Santibáñez (Burgos)

AGN, Irache, Lib. 549, 41v.

PEDRO BERNARDO DE QUEVEDO

B. C.

11-3-1692

Fr. José Fernández

4 meses de penitencia (sic)

San Millán (Burgos)

AGN, Irache, Lib. 549, 41v.

MANUEL FERNÁNDEZ

B. C.

10-3-1692

Fr. José Osorio

Burgos

AGN, Irache, Lib. 549, 41v.

CARLOS DE HOGUERAS

L. L. / D. L.

21-3-1692

Fr. Martín de Arenas, Abad y Rector

Zaragoza

AGN, Irache, Lib. 549, 41v.

JUAN PÉREZ DE EZQUERRA

B. C.

28-3-1692

Fr. Plácido Vea

... (Burgos)

AGN, Irache, Lib. 549, 42r.

ANTONIO DE MARRODÁN

B. T. / L. T.
31-3-1692

Fr. José Osorio / Fr. Plácido de Castillo /

Fr. José Fernández

Calahorra

AGN, Irache, Lib. 549, 42r.

JUAN MONEDERO

B. C.

19-4-1692

Fr. Plácido Vea / Fr. José Fernández

Bilbao (Nullius Diocesis)

AGN, Irache, Lib. 549, 42v.

FRANCISCO DE LA CUESTA

B. C.

19-4-1692

Fr. Plácido Vea / Fr. Pedro de Granda

Orbaneja del Castillo (Burgos)

AGN, Irache, Lib. 549, 42v.

JOSÉ DE LA FUENTE

B. C.

28-4-1692

Fr. Plácido Vea / Fr. Pedro de Granda

Burgos

AGN, Irache, Lib. 549, 42v.

CARLOS JOSÉ MARTÍNEZ DE ZALDUENDO

B. A. / B. M.

8-5-1692

Fr. Plácido de Castillo / Fr. José Fernández

// Ambrosio Gómez

Tafalla (Pamplona)

AGN, Irache, Lib. 549, 42v.

JUAN DE BASIO

B. C.

29-5-1692

Fr. José Osorio

Cubo (Burgos)

AGN, Irache, Lib. 549, 43r.

TOMÁS RUIZ CACHUPÍN

B. C.

30-5-1692

Fr. José Osorio

Medina de Pomar (Burgos)

AGN, Irache, Lib. 549, 43r. 
BERNABÉ ALONSO DE CELADA

B. C.

2-6-1692

Fr. Plácido de Castillo

Medina de Pomar (Burgos)

AGN, Irache, Lib. 549, 43r.

PEDRO SÁENZ

B. C.

9-6-1692

Fr. José Fernández

Castrillo de Murcia (Burgos)

AGN, Irache, Lib. 549, 43r.

TOMÁS GARCÍA DE LAS TORRES

B. C.

21-6-1692

Fr. José Fernández

Villanueva de la Barca (Burgos)

AGN, Irache, Lib. 549, 43v.

BERNARDO DÍEZ DE AGUSTÍN MEDINI-

LLA

B. C.

27-6-1692

Fr. Pedro de Granda

6 meses de penitencia, 2 horas al día (sic)

Ubierna (Burgos)

AGN, Irache, Lib. 549, 43v.

JUAN FERNÁNDEZ DE OGAZÓN

B. C.

15-7-1692

Fr. Pedro de Granda / Fr. Plácido de Castillo

Castrillo del Val (Burgos)

AGN, Irache, Lib. 549, 43v.

PRUDENCIO FERNÁNDEZ DEL PONSÓN

B. C.

17-7-1692

Fr. Pedro de Granda

Sabando (Calahorra)

AGN, Irache, Lib. 549, 43v.

\section{MATÍAS DE CHASCOS}

B. A. / B. M.

22-7-1692
Fr. Plácido de Castillo / Fr. Plácido Vea //

Ambrosio Gómez

Acedo (Pamplona)

AGN, Irache, Lib. 549, 44r.

FRANCISCO ORTEGA

B. C.

26-7-1692

Fr. Pedro de Granda

Fuencaliente de Puerta (Burgos)

AGN, Irache, Lib. 549, 44r.

ANTONIO MERINO

B. C.

26-7-1692

Fr. Pedro de Granda

Villasandino (Burgos)

AGN, Irache, Lib. 549, 44r.

\section{ANTONIO PELEGRÍN}

B. L.

31-7-1692

Fr. Pedro de Granda / Fr. Plácido de Casti-

llo // L. L. Baltasar de Lezaún

Tarazona

AGN, Irache, Lib. 549, 44v.

JUAN DE AGUIRRE

B. C.

1-8-1692

Fr. Pedro de Granda

Consejo (Burgos)

AGN, Irache, Lib. 549, 44v.

JUAN DE ROJAS

B. L. / L. L.

6-8-1692

Fr. Pedro de Granda / Fr. Plácido de Casti-

llo // L. L. Baltasar de Lezaún

Aranda de Duero (Burgos)

AGN, Irache, Lib. 549, 44v.

REMIGIO FERRER

B. A. / B. T. / L. T. / D. T.

9-8-1692

Fr. Martín de Arenas, Abad y Rector

Undués-Pintano (Pamplona)

AGN, Irache, Lib. 549, 45r. 
ANDRÉS GIL

B. A.

13-8-1692

Fr. Plácido de Castillo

Estella (Pamplona)

AGN, Irache, Lib. 549, 45r.

MANUEL DE ESPINOSA

B. C.

12-8-1692

Fr. Pedro de Granda

Castrojeriz (Burgos)

AGN, Irache, Lib. 549, 45r.

JUAN ANTONIO DE SESMA

B. A.

22-8-1692

Fr. Pedro de Granda

Villafranca (Pamplona)

AGN, Irache, Lib. 549, 45v.

JOSÉ DE LOSA

B. C.

7-9-1692

Fr. Plácido Vea

Puerto de Santoña (Burgos)

AGN, Irache, Lib. 549, 45v.

\section{PLÁCIDO MOSQUERA}

B. A. / L. A. / M. A. / B. T. / L. T. / D. T. 10-9-1692

Fr. Martín de Arenas, Abad y Rector

O. S. B.

San Martín de Santiago

AGN, Irache, Lib. 549, 45v.

\section{MELCHOR DE VAL}

B. C.

14-9-1692

Fr. Plácido Vea / Fr. Plácido de Castillo

Burgos

AGN, Irache, Lib. 549, 46r.

DIEGO ANTONIO GIMÉNEZ

B. A. / B. T. / L. T. / D. T.

14-9-1692

Fr. Plácido Vea / Fr. Plácido de Castillo /

Fr. Martín de Arenas, Abad y Rector
Jaca

AGN, Irache, Lib. 549, 46r.

JUAN FRANCISCO DE OCHOA

B. A. / B. T. / L. T.

14-9-1692

Fr. Plácido Vea / Fr. Plácido de Castillo /

Fr. Martín de Arenas

Nalda (Calahorra)

AGN, Irache, Lib. 549, 46r.

[Sin apellidar]

B. C.

16-9-1692

Fr. Plácido Vea / Fr. Pedro de Granda

Burgos

AGN, Irache, Lib. 549, 46v.

JUAN GIMÉNEZ DEL PALOMAR

B. A.

18-9-1692

Fr. Plácido de Castillo / Fr. Plácido Vea

Cornago (Calahorra)

AGN, Irache, Lib. 549, 46v.

JOSÉ DE MENDOZA Y GUARÓN

L. L. / D. L.

19-9-1692

Fr. Martín de Arenas, Abad y Rector

Calatayud (Tarazona)

AGN, Irache, Lib. 549, 46v.

JOSÉ NAVARRO Y BELLIDO

B. C. / L. C. / D. C.

19-9-1692

Fr. Plácido Vea / Fr. Plácido de Castillo /

Fr. Martín de Arenas, Abad y Rector

Calatayud (Tarazona)

AGN, Irache, Lib. 549, 47r.

ANTONIO ROSILLO

B. A. / B. T.

22-9-1692

Fr. Plácido Vea / Fr. Plácido de Castillo

Colindres (Burgos)

AGN, Irache, Lib. 549, 47r.

\section{ANTONIO DE RIBAS}

B. C. 
27-9-1692

Fr. Plácido Vea

Colindres (Burgos)

AGN, Irache, Lib. 549, 47v.

FRANCISCO ANTONIO HERRERO

B. C.

27-9-1692

Fr. Plácido Vea

Burgos

AGN, Irache, Lib. 549, 47v.

BENITO DE PAREDES

B. C.

3-10-1692

Fr. José Osorio

Ameyugo (Burgos)

AGN, Irache, Lib. 549, 47v.

FELIPE DE ZÚÑIGA

B. A. / B. T. / L. T.

3-10-1692 / 23-6-1697

Fr. José Osorio / Fr. Ángel Benito

Mendoza (Pamplona)

AGN, Irache, Lib. 549, 47v, 113 r.

FRANCISCO A. DE ISLA

B. A.

1-10-1692

Fr. Plácido del Castillo

Logroño (Calahorra)

AGN, Irache, Lib. 549, 47v.

FRANCISCO ANTONIO

B. C.

7-10-1692

Fr. José Fernández

Burgos

AGN, Irache, Lib. 549, 48r.

FRANCISCO DE SALAZAR

B. C.

9-10-1692

Fr. José Osorio

Burgos

AGN, Irache, Lib. 549, 48r.

DAMIÁN NAVAMUEL

B. C.
10-10-1692

Fr. José Osorio

Navamuel (Burgos)

AGN, Irache, Lib. 549, 48r.

JOSÉ PLASENCIA

B. A.

11-10-1692

Fr. Plácido del Castillo

O. de M.

Lapuente (Pamplona)

AGN, Irache, Lib. 549, 48r.

PEDRO DE SALANUEVA

B. A.

14-10-1692 Reprobado

23-10-1692 Aprobado

Fr. Plácido Castillo

Arróniz (Pamplona)

AGN, Irache, Lib. 549, 48v.

MIGUEL FERNÁNDEZ DE BARREDO

B. C.

19-10-1692

Fr. Isidoro Cardoso

Arroyo de Valdegovia (Burgos)

AGN, Irache, Lib. 549, 48v.

JUAN MARCOS RIPA

B. T. / L. T. / D. T.

22-10-1692

Fr. Martín de Arenas, Abad y Rector

Jaca

AGN, Irache, Lib. 549, 48v.

POLICARPO SÁNCHEZ

B. A. / B. M.

29-10-1692

Fr. Plácido de Castillo / Fr. José Fernández

// Ambrosio Gómez

Valle de Berdún (Jaca)

AGN, Irache, Lib. 549, 49r.

ANTONIO SOLACHE DE ÁVALOS

B. C.

4-11-1692

Fr. Plácido Vea

Tormantos (Burgos)

AGN, Irache, Lib. 549, 49r. 
JOSÉ ALONSO SÁIZ

B. C.

4-11-1692

Fr. Plácido Vea

Agés (Burgos)

AGN, Irache, Lib. 549, 49r.

MANUEL FERNÁNDEZ DE BERROCAL

B. C.

8-11-1692

Fr. Plácido Vea

Bárcena (Burgos)

AGN, Irache, Lib. 549, 49r.

PEDRO GONZÁLEZ

B. C.

8-11-1692

Fr. Plácido Vea

Quintanar de Valdelucio (Burgos)

AGN, Irache, Lib. 549, 49v.

JOSÉ DE BARRIOMIRÓN

B. C.

12-11-1692

Fr. Plácido Vea

Arlanza (Burgos)

AGN, Irache, Lib. 549, 49v.

JOSÉ DE BUSTOS

B. C.

12-11-1692

Fr. José Osorio

Valluércanes (Burgos)

AGN, Irache, Lib. 549, 49v.

JUAN DEL CORRAL

B. A.

15-11-1692

Fr. Plácido de Castillo

Duález (Burgos)

AGN, Irache, Lib. 549, 49v.

MATÍAS SAIZ

B. C.

21-11-1692

Fr. Isidoro Cardoso

Beas (Burgos)

AGN, Irache, Lib. 549, 5or.
PEDRO DE OÑATE

B. A. / B. C.

30-11-1692 / 27-8-1694

Fr. Plácido de Castillo // Fr. Antonio Larrea

/ Fr. Íñigo Ruiloba

Calahorra

AGN, Irache, Lib. 549, 5or, 77r.

JUAN DE BARREDA

B. A. / B. T.

4-12-1692 / 19-12-1692

Fr. Plácido de Castillo / Fr. Isidoro Cardoso

Duález (Burgos)

AGN, Irache, Lib. 549, 5or.

FRANCISCO VELASCO

B. C.

14-12-1692

Fr. José Fernández

Sevilla

AGN, Irache, Lib. 549, 5or.

VENTURA MAULEÓN

B. A. / B. T.

17-12-1692 / 16-3-1700

Fr. Plácido de Castillo // Fr. Plácido Vea /

Fr. Gregorio de Haro

Bastida (Calahorra)

AGN, Irache, Lib. 549, 50v, 152v.

PEDRO MAULEÓN

B. A.

17-12-1692

Fr. Plácido de Castillo

Bastida (Calahorra)

AGN, Irache, Lib. 549, $50 v$.

JUAN BAUTISTA RAMÍREZ

B. A.

17-12-1692

Fr. Plácido de Castillo

Bastida (Calahorra)

AGN, Irache, Lib. 549, $50 \mathrm{v}$.

JOSÉ MARQUINA

B. A.

17-12-1692

Fr. Plácido de Castillo 
Baradán (Calahorra)

AGN, Irache, Lib. 549, 5 Ov.

JUAN DE ZÚÑIGA

B. A.

17-12-1692

Fr. Plácido de Castillo

... [Calahorra]

AGN, Irache, Lib. 549, $50 v$.

JOSÉ PÉREZ

B. A. / B. M.

26-12-1692

Fr. Plácido de Castillo / Fr. Isidoro Cardoso

O... (Tarazona)

AGN, Irache, Lib. 549, $50 v$.

PEDRO SAIZ DE GAROÑA

B. C.

28-12-1692

Fr. Isidoro Cardoso

Ameyugo (Burgos)

AGN, Irache, Lib. 549, 51r.

JUAN FERMÍN TIBURCIO DE RIBAS

B. A.

18-1-1693

Fr. Plácido de Castillo

Fitero (Tarazona)

AGN, Irache, Lib. 549, 51r.

DIEGO FERNÁNDEZ

B. C.

27-1-1693

Fr. Isidoro Cardoso

Medina (Burgos)

AGN, Irache, Lib. 549, 51r.

BALTASAR DOMPER

B. T. / L. T. / D. T.

28-1-1693

Fr. Martín de Arenas, Abad y Rector

O. S. B.

San Juan de la Peña

AGN, Irache, Lib. 549, 51r.

JOSÉ PLÁCIDO CABRERO

L. A. / B. T. / L. T. / D. T.
28-1-1693

Fr. Martín de Arenas, Abad y Rector

O. S. B.

San Juan de la Peña

AGN, Irache, Lib. 549, 51v.

FRANCISCO LÓPEZ

B. A. / B. T. / L. T. / D. T.

30-1-1693

Fr. Martín de Arenas, Abad y Rector

O. S. B.

San Juan de la Peña

AGN, Irache, Lib. 549, 51v.

JACINTO TORNES

L. M. / D. M.

30-1-1693

Fr. Martín de Arenas, Abad y Rector

Jaca

AGN, Irache, Lib. 549, 51v.

JUAN ALONSO BERNAL

B. C.

6-2-1693

Fr. Plácido Vea

Reinosa (Burgos)

AGN, Irache, Lib. 549, 52r.

SEBASTIÁN GONZÁLEZ

B. C.

12-2-1693

Fr. José Osorio

Villacomparada de Medina (Burgos)

AGN, Irache, Lib. 549, 52r.

ANTONIO FERNÁNDEZ DE MARDONES

B. C.

12-2-1693

Fr. José Osorio / Fr. Plácido Vea

Villacomparada de Medina (Burgos)

AGN, Irache, Lib. 549, 52r.

ANTONIO GONZÁLEZ

B. C.

13-2-1693

Fr. Plácido Vea

Villacomparada de Medina (Burgos)

AGN, Irache, Lib. 549, 52r. 
JUAN FRANCISCO OLIVÁN

L. M. / D. M.

15-2-1693

Fr. Martín de Arenas, Abad y Rector

Biescas (Jaca)

AGN, Irache, Lib. 549, 52v.

FRANCISCO DÍAZ

B. C.

27-2-1693

Fr. Martín de Arenas, Abad y Rector

Burgos

AGN, Irache, Lib. 549, 52v.

DOMINGO DE SOLA

B. A.

3-3-1693

Fr. Plácido de Castillo

Arróniz (Pamplona)

AGN, Irache, Lib. 549, 52v.

MANUEL DE SEDANO

B. C.

5-3-1693

Fr. Isidoro Cardoso

Castrojeriz (Burgos)

AGN, Irache, Lib. 549, 52v.

JUAN RUIZ DE CELADA

B. C.

5-3-1693

Fr. Plácido Vea

Castrojeriz (Burgos)

AGN, Irache, Lib. 549, 53r.

ANTONIO DE FABIERAS

B. A. / B. M.

7-3-1693

Fr. Plácido de Castillo / Fr. Pedro de Granda

Tudela (Tarazona)

AGN, Irache, Lib. 549, 53r.

MANUEL DE CARRANZA

B. A. / B. T.

13-3-1693

Fr. Plácido de Castillo / Fr. Isidoro Cardoso 4 meses de penitencia (sic)
Baños de Campos (Calahorra)

AGN, Irache, Lib. 549, 53r.

FRANCISCO ALONSO GARCÍA

B. C.

15-3-1693

Fr. Plácido Vea

San Martín de Elines (Burgos)

AGN, Irache, Lib. 549, 53v.

ANTONIO DE BAROJA

L. T. / D. T.

27-3-1693

Fr. Martín de Arenas, Abad y Rector

Cornago (Calahorra)

AGN, Irache, Lib. 549, 53v.

\section{SEBASTIÁN VICENTE DEL HOYO}

L. T. / D. T.

29-3-1693

Fr. Isidoro Cardoso / Fr. Plácido Vea

Grañón (Calahorra)

AGN, Irache, Lib. 549, 53v.

JUAN GALINDO DE LUSA

B. A. / B. T.

2-4-1693

Fr. Plácido Vea

Canales (Burgos)

AGN, Irache, Lib. 549, 54r.

FRANCISCO DE LA RIBA

B. A. / B. T.

9-4-1693

Fr. Plácido Vea / Fr. Isidoro Cardoso

Mansilla de la Sierra (Burgos)

AGN, Irache, Lib. 549, 54r.

JUAN MARROQUÍN

B. C.

9-4-1693

Fr. Plácido Vea

Soscaño (Burgos)

AGN, Irache, Lib. 549, 54r.

MANUEL DE HORNILLOS

B. C.

12-4-1693 
Fr. Plácido Vea

2 meses de penitencia (sic)

Castrillo de Murcia (Burgos)

AGN, Irache, Lib. 549, 54v.

FRANCISCO DE ARCE CÁMARA

B. C.

20-4-1693

Fr. Plácido Vea

3 meses de penitencia (Arnuero)

Burgos

AGN, Irache, Lib. 549, 54V.

MANUEL DE SALINAS

B. C.

16-5-1693

Fr. Plácido Vea

Calahorra

AGN, Irache, Lib. 549, 54v.

MANUEL DE LA MORA QUEVEDO

B. T.

24-5-1693

Fr. Plácido Vea

Castañeda (Burgos)

AGN, Irache, Lib. 549, 55r.

FRANCISCO LÓPEZ DE LA PEÑA

B. C.

25-5-1693

Fr. Plácido Vea

Quintanilla (Burgos)

AGN, Irache, Lib. 549, 55r.

FRANCISCO DE QUINCOCES

B. A. / B. T.

26-5-1693

Fr. Plácido Vea

Villabasil (Burgos)

AGN, Irache, Lib. 549, 55r.

ANDRÉS IBEA

B. C.

5-6-1693

Fr. Plácido Vea

2 meses de penitencia (sic)

Cardeña Ximeno (Burgos)

AGN, Irache, Lib. 549, 55v.
AGUSTÍN SÁEZ DE LOS HERREROS

B. A. / B. T.

11-6-1693

Fr. Plácido Vea / Fr. José Osorio

Madrid (Toledo)

AGN, Irache, Lib. 549, 55v.

PEDRO EGUARAS FERNÁNDEZ DE ISAR

B. L.

16-6-1693

Fr. José Osorio

Zaragoza

AGN, Irache, Lib. 549, 55v.

AGUSTÍN DE QUIRÓS

B. T.

18-6-1693

Fr. José Osorio

Castañeda (Burgos)

AGN, Irache, Lib. 549, 56r.

DIEGO PÉREZ

B. C.

18-6-1693

Fr. José Osorio

2 meses de penitencia, 2 horas cada día (sic)

Torres de Abajo (Burgos)

AGN, Irache, Lib. 549, 56r.

PEDRO SALAZAR NEGRETE

B. A. / B. T.

26-6-1693

Fr. José Osorio

Villanueva de Soportilla (Burgos)

AGN, Irache, Lib. 549, 56r.

JUAN GREGORIO AGUESO

B. A. / B. M.

26-6-1693

Fr. Plácido Vea / Fr. José Osorio

Corella (Tarazona)

AGN, Irache, Lib. 549, 56v.

MANUEL ZORRILLA

B. C.

28-6-1693

Fr. José Osorio 
Ciguerza (Burgos)

AGN, Irache, Lib. 549, 56v.

GREGORIO RUIZ OTEO

B. C.

4-7-1693

Fr. Plácido Vea

Rufrancos (Burgos)

AGN, Irache, Lib. 549, 56v.

BARTOLOMÉ DEL OLMO

B. C.

4-7-1693

Fr. Plácido Vea

Burgos

AGN, Irache, Lib. 549, 57r.

JOSÉ PÉREZ DE MONTES

B. A. / B. M.

18-7-1693

Fr. José Osorio / Ambrosio Gómez

Soria (Osma)

AGN, Irache, Lib. 549, 57r.

JUAN RAMOS

B. C.

30-7-1693

Fr. José Osorio

Barruelo (Burgos)

AGN, Irache, Lib. 549, 57r.

JOSÉ ANTONIO LASTRE Y FRÍAS

B. C. / L. C. / D. C.

31-7-1693

Fr. José Osorio / Fr. Manuel Vela, Abad y

Rector

Huesca

Sobrino del Obispo de Jaca

AGN, Irache, Lib. 549, 57v.

BLAS LÓPEZ DE ANGUETA

B. A. / B. T. / L. T. / D. T.

31-7-1693

Fr. José Osorio / Fr. Manuel Vela, Abad y

Rector

Hecho (Jaca)

AGN, Irache, Lib. 549, 57v.
BLAS GONZÁLEZ SARABIA

B. C.

31-7-1693

Fr. José Osorio

Arroyo de Valdivieso (Burgos)

AGN, Irache, Lib. 549, 57v.

JUAN DE VILLATE

B. A. / B. T.

3-8-1693

Fr. Plácido Vea / Fr. José Osorio

Santa Eulalia, Valle de Valdivieso (Burgos)

AGN, Irache, Lib. 549, 58r.

FELIPE PEREDA

B. C.

5-8-1693

Fr. Plácido Vea

2 meses de penitencia (sic)

Céspedes, Medina de Pomar (Burgos)

AGN, Irache, Lib. 549, 58r.

JOSÉ DE LÍO

B. C.

17-8-1693

Fr. Plácido Vea

Pamplona

AGN, Irache, Lib. 549, 58v.

SEBASTIÁN FERRAZ

B. A.

19-8-1693

Fr. Plácido Vea

Castanesa (Urgel)

AGN, Irache, Lib. 549, 58v.

MATEO DE ZUBIAUR

B. A.

2-9-1693

Fr. Plácido Vea

Nalda (Calahorra)

AGN, Irache, Lib. 549, 58v.

FRANCISCO ANTONIO FERNÁNDEZ VI-

LLEGAS

B. A. / B. T.

11-9-1693

Fr. Plácido Vea / Fr. José Osorio 
Burgos

AGN, Irache, Lib. 549, 59r.

MIGUEL PÉREZ

B. M.

18-9-1693

Fr. Plácido Vea / Ambrosio Gómez

Letux (Zaragoza)

AGN, Irache, Lib. 549, 59r.

JOSÉ ALONSO REDONDO

B. C.

20-9-1693

Fr. Plácido Vea

Villagonzalo de Pedernales (Burgos)

AGN, Irache, Lib. 549, 59r.

\section{MIGUEL HERRERA}

B. A. / B. M.

21-9-1693

Fr. Plácido Vea / Miguel Atondo

Borja (Tarazona)

AGN, Irache, Lib. 549, 59v.

FRANCISCO ORTIZ DE SALAZAR

B. A. / B. T.

22-9-1693

Fr. Íñigo Ruiloba / Fr. Plácido Vea

Pancorbo (Burgos)

AGN, Irache, Lib. 549, 59v.

\section{DOMINGO GALÍNDEZ}

B. C.

26-9-1693

Fr. Plácido Vea

San Pedro (Burgos)

AGN, Irache, Lib. 549, 59v.

PEDRO DE QUEZBA

B. C.

4-10-1693

Fr. Plácido Vea

Molinilla (Calahorra)

AGN, Irache, Lib. 549, 6or.

NICOLÁS DE REBOLLEDO

B. A. / B. T.

4-10-1693
Fr. Íñigo Ruiloba / Fr. Plácido Vea

Nofuentes (Burgos)

AGN, Irache, Lib. 549, 6or.

SANTIAGO RUIZ GUTIÉRREZ

B. A. / B. T.

5-10-1693

Fr. Plácido Vea / Fr. M. Vela, Abad

... (Burgos)

AGN, Irache, Lib. 549, 6or.

DOMINGO DE ARROYUELO

B. A. / B. T.

5-10-1693

Fr. Plácido Vea / Fr. M. Vela, Abad

Rivarredonda (Burgos)

AGN, Irache, Lib. 549, 6ov.

\section{MIGUEL GUTIÉRREZ}

B. C.

7-10-1693

Fr. Íñigo Ruiloba / Fr. Plácido Vea

Cañizal de los Arcos (Burgos)

AGN, Irache, Lib. 549, $60 \mathrm{v}$.

JOSÉ NEGRETE

B. C.

13-10-1693

Fr. Benito Anguiano / Fr. Antonio de Larrea

4 meses de penitencia (sic)

Reportillo (Burgos)

AGN, Irache, Lib. 549, 61r.

JUAN ORTIZ DE ROALES

B. C.

14-10-1693

Fr. Plácido Vea

Pancorbo (Burgos)

AGN, Irache, Lib. 549, 61r.

FRANCISCO DE BUJANDA

B. C.

19-10-1693

Fr. Benito Anguiano / Fr. Plácido Vea

Valderías (Burgos)

AGN, Irache, Lib. 549, 61r. 
PEDRO DE ESCOBAR

B. C. / L. C.

19-10-1693

Fr. Plácido Vea / Fr. M. Vela, Abad

Teruel

AGN, Irache, Lib. 549, 61v.

FRANCISCO LA VARGA

B. C.

19-10-1693

Fr. Plácido Vea

San Miguel de Pedroso (Burgos)

AGN, Irache, Lib. 549, 61v.

FRANCISCO DE REBOLLEDA

B. C.

22-10-1693

Fr. Benito Anguiano

Nofuentes (Burgos)

AGN, Irache, Lib. 549, 62r.

JUAN GÓMEZ DE BUJANDA

B. C.

25-10-1693

Fr. Benito Anguiano / Fr. Plácido Vea

Valderías (Burgos)

AGN, Irache, Lib. 549, 62r.

DIEGO DE SALAZAR

B. C.

29-10-1693

Fr. Íñigo Ruiloba / Fr. Plácido Vea

Mirabeche (Burgos)

AGN, Irache, Lib. 549, 62r.

JUAN DE QUIJANO

B. C.

2-11-1693

Fr. Plácido Vea / Fr. Antonio de Larrea

Aguilar de Campoo (Burgos)

AGN, Irache, Lib. 549, 62v.

JOSÉ DE VALDECILLA

B. A. / B. T.

9-11-1693

Fr. Íñigo Ruiloba / Fr. Benito Anguiano

Valdecilla (Burgos)

AGN, Irache, Lib. 549, 62v.
FRANCISCO ORTEGA

B. C.

20-11-1693

Fr. Plácido Vea

Cameno (Burgos)

AGN, Irache, Lib. 549, 62v.

FRANCISCO MARTÍNEZ

B. C.

22-11-1693

Fr. Benito Anguiano / Fr. Fernando Salga-

do

San Martín de Helices (Burgos)

AGN, Irache, Lib. 549, 63r.

FRANCISCO DE OLEA TORRE

B. C.

26-11-1693

Fr. Benito Anguiano / Fr. Plácido Vea

Celada de los Calderones (Burgos)

AGN, Irache, Lib. 549, 63r.

JUAN RODRÍGUEZ

B. C.

26-11-1693

Fr. Benito Anguiano / Fr. Plácido Vea

La Hoz de Abiada (Burgos)

AGN, Irache, Lib. 549, 63r.

JOSÉ DE MIER Y TERÁN

B. C.

26-11-1693

Fr. Benito Anguiano / Fr. Plácido Vea

Reinosa (Burgos)

AGN, Irache, Lib. 549, 63v.

JOSÉ SÁIZ

B. C.

26-11-1693

Fr. Plácido Vea / Fr. Benito Anguiano

Briviesca (Burgos)

AGN, Irache, Lib. 549, 63v.

VENTURA CORTÉS DEL VALLE

B. C.

26-11-1693

Fr. Benito Anguiano / Fr. Plácido Vea

Oña (Burgos)

AGN, Irache, Lib. 549, 63v. 
FRANCISCO DE CASTRO

B. C.

28-11-1693

Fr. Íñigo Ruiloba / Fr. Plácido Vea

Briviesca (Burgos)

AGN, Irache, Lib. 549, 64r.

\section{BERNARDO DE MILLÁN}

B. C.

4-12-1693

Fr. Benito Anguiano / Fr. Antonio de Larrea

San Millán de Yécora (Burgos)

AGN, Irache, Lib. 549, 64r.

\section{JUAN TAULER}

B. A. / B. M. / L. M. / D. M.

11-12-1693 / 12-12-1693

Fr. Íñigo Ruiloba / Fr. Benito Anguiano //

Ambrosio Gómez / Fr. M. Vela, Abad

San Feliu de Guíxols (Gerona)

AGN, Irache, Lib. 549, 64rv.

JOSÉ BARRIO CANAL

B. C.

12-12-1693

Fr. Benito Anguiano / Fr. Plácido Vea

Quintanavides (Burgos)

AGN, Irache, Lib. 549, 64v.

\section{MIGUEL GUTIÉRREZ}

B. C.

13-12-1693

Fr. Benito Anguiano / Fr. Plácido Vea

Villanueva de la Torre (Burgos)

AGN, Irache, Lib. 549, 65r.

MIGUEL DE VESGA

B. C.

13-12-1693

Fr. Benito Anguiano / Fr. Plácido Vea

Quintanilla San García (Burgos)

AGN, Irache, Lib. 549, 65r.

\section{MATÍAS DEL CAÑO}

B. A. / B. T.

13-12-1693

Fr. Íñigo Ruiloba / Fr. Plácido Vea
Quintanilla San García (Burgos)

AGN, Irache, Lib. 549, 65r.

\section{SIMÓN DE TRISTÁN}

B. C.

13-12-1693

Fr. Benito Anguiano / Fr. Plácido Vea

Medina de Pomar (Burgos)

AGN, Irache, Lib. 549, 65v.

\section{BALTASAR DE SOLARES}

B. C.

13-12-1693

Fr. Benito Anguiano / Fr. Plácido Vea

Medina de Pomar (Burgos)

AGN, Irache, Lib. 549, 65v.

\section{JOSÉ MARTÍNEZ}

B. C.

15-12-1693

Fr. Benito Bea / Fr. Fernando Salgado

Ros (Burgos)

AGN, Irache, Lib. 549, 65v.

\section{MANUEL DEL CAMPO}

B. A. / B. T.

18-12-1693

Fr. Íñigo Ruiloba / Fr. Plácido Vea

Briviesca (Burgos)

AGN, Irache, Lib. 549, 66r.

\section{JUAN PÉREZ FERNÁNDEZ}

B. C.

18-12-1693

Fr. Íñigo Ruiloba / Fr. Plácido Vea

Quintanilla San García (Burgos)

AGN, Irache, Lib. 549, 66r.

JOSÉ DE VESGAS

B. A. / B. T.

18-12-1693

Fr. Íñigo Ruiloba / Fr. Fernando Salgado

Tricio (Calahorra)

AGN, Irache, Lib. 549, 66r.

\section{LUIS DE TERÁN}

B. A. / B. T.

18-12-1693 
Fr. Íñigo Ruiloba / Fr. Plácido Vea

Huidobro (Burgos)

AGN, Irache, Lib. 549, 66v.

JUAN ANTONIO DE PRADO

B. C.

22-12-1693

Fr. Íñigo Ruiloba / Fr. Plácido Vea

Quintanilla San García (Burgos)

AGN, Irache, Lib. 549, 66v.

\section{MANUEL DE SALAZAR CELADA}

B. C.

23-12-1693

Fr. Benito Anguiano / Fr. Fernando Salga-

do

Burgos

AGN, Irache, Lib. 549, 66v.

FRANCISCO DE LA RIVA AGÜERO

B. C.

24-12-1693

Fr. Plácido Vea / Fr. Fernando Salgado

Cianca (Burgos)

AGN, Irache, Lib. 549, 67r.

JUAN PÉREZ

B. C.

31-12-1693

Fr. Plácido Vea / Fr. Antonio de Larrea

Tubilla del Agua (Burgos)

AGN, Irache, Lib. 549, 67r.

FERNANDO DE ANGULO

B. C.

7-1-1694

Fr. Benito Anguiano / Fr. Plácido Vea

Burgos

AGN, Irache, Lib. 549, 67r.

MIGUEL GONZÁLEZ

B. C.

14-1-1694

Fr. Benito Anguiano / Fr. Antonio de Larrea

Fuentebureba (Burgos)

AGN, Irache, Lib. 549, 67v.

\section{GREGORIO GRANDA}

B. C.

18-1-1694

Fr. Benito Anguiano / Fr. Plácido Vea

Castresana (Burgos)

AGN, Irache, Lib. 549, 67v.

DIEGO DE LA REGATA SOSA

B. C.

27-1-1694

Fr. Plácido Vea / Fr. Íñigo Ruiloba

Cianca (Burgos)

AGN, Irache, Lib. 549, 67v.

PEDRO DE ROBA

B. A. / B. T.

7-2-1694

Fr. Íñigo Ruiloba / Fr. Plácido Vea

Villaizán (Burgos)

AGN, Irache, Lib. 549, 68r.

SILVESTRE DE ROBA

B. C.

7-2-1694

Fr. Plácido Vea / Fr. Íñigo Ruiloba

Villaizán (Burgos)

AGN, Irache, Lib. 549, 68r.

JOSÉ DE ANDRÉS

B. C.

20-2-1694

Fr. Plácido Vea / Fr. Fernando Salgado

Ojacastro (Burgos)

AGN, Irache, Lib. 549, 68v.

MANUEL RODRÍGUEZ

B. C.

21-2-1694

Fr. Plácido Vea / Fr. Íñigo Ruiloba

Burgos

AGN, Irache, Lib. 549, 68v.

PEDRO GARCÍA

B. C.

26-2-1694

Fr. Plácido Vea / Fr. Íñigo Ruiloba

Villaveta (Burgos)

AGN, Irache, Lib. 549, 68v. 
FELIPE LÓPEZ DE LA FUENTE

B. A. / L. A. / M. A.

28-2-1694 / 1-3-1694

Fr. M. Vela, Abad

Estella (Pamplona)

AGN, Irache, Lib. 549, 69r.

JOSÉ LÓPEZ

B. C.

7-3-1694

Fr. Plácido Vea / Fr. Benito Anguiano

Villazán (Burgos)

AGN, Irache, Lib. 549, 69v.

BERNARDO DE ASTORGA

B. C.

13-3-1694

Fr. Benito Anguiano / Fr. Plácido Vea Melgar de Fernamental (Burgos)

AGN, Irache, Lib. 549, 69v.

\section{SANTIAGO DE ALMURRIO}

B. C.

13-3-1694

Fr. Benito Anguiano / Fr. Plácido Vea

Melgar de Fernamental (Burgos)

AGN, Irache, Lib. 549, 69v.

NICOLÁS DE CEVALLOS

B. C.

23-3-1694

Fr. Plácido Vea / Fr. Benito Anguiano

Hinestrosa (Burgos)

AGN, Irache, Lib. 549, 70r.

JUAN ANTONIO DE LA VILLA

B. C.

30-3-1694

Fr. Benito Anguiano / Fr. Plácido Vea

Puerto de Santoña (Burgos)

AGN, Irache, Lib. 549, 70r.

\section{JUAN DE MENDOZA}

B. M.

30-3-1694

Fr. Íñigo Ruiloba / Fr. Benito Anguiano /

Ambrosio Gómez

[Medina de] Rioseco (Palencia)

AGN, Irache, Lib. 549, 70r.

\section{MARCOS PARDO}

B. C.

3-4-1694

Fr. Plácido Vea / Fr. Benito Anguiano

Hormaza (Burgos)

AGN, Irache, Lib. 549, $70 v$.

ANDRÉS GARCÍA

B. C.

3-4-1694

Fr. Plácido Vea / Fr. Benito Anguiano

Burgos

AGN, Irache, Lib. 549, $70 v$.

\section{MARTÍN HERMOSO}

B. A. / L. A.

3-4-1694 / 4-4-1694

Fr. Íñigo Ruiloba / Fr. Benito Anguiano /

Fr. M. Vela, Abad

Arróniz (Pamplona)

AGN, Irache, Lib. 549, 70v-71r.

GREGORIO GARCÍA

B. A. / L. A.

4-4-1694 / 18-2-1696

Fr. Íñigo Ruiloba / Fr. Fernando Salgado

Arróniz (Pamplona)

AGN, Irache, Lib. 549, 71r, 98v.

\section{JUAN DE CAÑAS}

B. A. / L. A. / M. A. / B. T. / L. T. / M. T.

15-4-1694 / 16-4-1694

Fr. M. Vela, Abad, Rector y Canciller

O.S. B.

Abad de Oña

AGN, Irache, Lib. 549, 71v.

JOSÉ TOMÁS Y FUENTES

B. T.

23-4-1694

Fr. Plácido Vea / Fr. Fernando Salgado

Zaragoza

B. A. en Huesca

AGN, Irache, Lib. 549, 72r.

DIEGO DE COSSÍO Y VELARDE

B. A. / B. T.

24-4-1694 
Fr. Íñigo Ruiloba / Fr. Plácido Vea

Salcedo (Burgos)

AGN, Irache, Lib. 549, 72r.

\section{FRANCISCO GÓMEZ}

B. C.

12-5-1694

Fr. Plácido Vea / Fr. Benito Anguiano

Madrigal del Monte (Burgos)

AGN, Irache, Lib. 549, 72r.

\section{FRANCISCO RUIZ VALLINES}

B. A. / B. T.

18-5-1694

Fr. Benito Anguiano / Fr. Íñigo Ruiloba

El Barcenal (Burgos)

AGN, Irache, Lib. 549, 72v.

\section{SANTIAGO IÑíGUEZ}

B. C.

20-5-1694

Fr. Plácido Vea / Fr. Benito Anguiano

Burgos

AGN, Irache, Lib. 549, 72v.

\section{ANTONIO PILARTE}

B. $\mathrm{M}$.

23-5-1694

Fr. Plácido Vea / Fr. Íñigo Ruiloba

Calahorra

B. A.

AGN, Irache, Lib. 549, $72 \mathrm{v}$.

PEDRO MADRID

B. C.

24-5-1694

Fr. Plácido Vea / Fr. Fernando Salgado

Presencio (Burgos)

AGN, Irache, Lib. 549, 73r.

\section{FRANCISCO VENCEY}

B. C.

25-5-1694

Fr. Plácido Vea / Fr. Íñigo Ruiloba

Villadiego (Burgos)

AGN, Irache, Lib. 549, 73r.

BALTASAR ALONSO DE CELADA

B. A. / B. T.
26-5-1694

Fr. Íñigo Ruiloba / Fr. Plácido Vea

Nofuentes (Burgos)

AGN, Irache, Lib. 549, 73r.

JOSÉ GARCÍA SEDANO

B. C.

26-5-1694

Fr. Plácido Vea / Fr. Íñigo Ruiloba

Ezcaray (Burgos)

AGN, Irache, Lib. 549, 73v.

BALTASAR DE MORALES

B. C.

28-5-1694

Fr. Plácido Vea / Fr. Fernando Salgado

Laiseca, Valle de Villaverde (Burgos)

AGN, Irache, Lib. 549, 73v.

BERNARDO LÓPEZ SAGREDO

B. C.

1-6-1694

Fr. Plácido Vea / Fr. Íñigo Ruiloba

Burgos

AGN, Irache, Lib. 549, 73v.

AGUSTÍN DE ALBILLA

B. A. / B. T.

8-6-1694

Fr. Íñigo Ruiloba / Fr. Benito Anguiano

Villaizán (Burgos)

AGN, Irache, Lib. 549, 74r.

JERÓNIMO DE MAR Y GIL

B. C.

8-6-1694

Fr. Benito Anguiano / Fr. Íñigo Ruiloba

Grijalba (Burgos)

AGN, Irache, Lib. 549, 74r.

JUAN JERÓNIMO IRIARTE

B. A. / B. T. / L. T. / D. T.

11-6-1694 / 12-6-1694

Fr. Íñigo Ruiloba / Fr. Benito Anguiano /

Fr. M. Vela, Abad

Estella (Pamplona)

AGN, Irache, Lib. 549, 74r. 


\section{SIMÓN BARRIO}

B. C.

12-6-1694

Fr. Plácido Vea / Fr. Benito Anguiano

Cascajares (Burgos)

AGN, Irache, Lib. 549, 74v.

LORENZO DE LA FUENTE

B. C.

16-6-1694

Fr. Benito Anguiano / Fr. Íñigo Ruiloba

Villadiego (Burgos)

AGN, Irache, Lib. 549, 75r.

ANTONIO SEDANO BUSTAMANTE

B. C.

20-6-1694

Fr. Benito Anguiano / Fr. Fernando Salga-

do

Barrio de Bricia (Burgos)

AGN, Irache, Lib. 549, 75r.

FRANCISCO GUTIÉRREZ

B. C.

20-6-1694

Fr. Benito Anguiano / Fr. Fernando Salga-

do

Vileña (Burgos)

AGN, Irache, Lib. 549, 75 r.

FRANCISCO DE SEDANO

B. C.

6-7-1694

Fr. Benito Anguiano / Fr. Fernando Salgado

Villadiego (Burgos)

AGN, Irache, Lib. 549, 75v.

ANDRÉS ROMERO

B. C.

6-7-1694

Fr. Benito Anguiano / Fr. Fernando Salga-

do

Vileña (Burgos)

AGN, Irache, Lib. 549, 75v.

JUAN FRANCISCO DE LA TORRE

B. C.
14-7-1694

Fr. Íñigo Ruiloba / Fr. Fernando Salgado

Herbosa (Burgos)

AGN, Irache, Lib. 549, 75v.

FRANCISCO DE OLMOS

B. C.

30-7-1694

Fr. Íñigo Ruiloba / Fr. Fernando Salgado

Presencio (Burgos)

AGN, Irache, Lib. 549, 76r.

DOMINGO DE VALDIVIESO

B. C.

30-7-1694

Fr. Plácido Vea / Fr. Fernando Salgado

Pesquera (Burgos)

AGN, Irache, Lib. 549, 76r.

JOSÉ FERNÁNDEZ GARCÍA

B. C.

2-8-1694

Fr. Plácido Vea / Fr. Fernando Salgado

Proaño (Burgos)

AGN, Irache, Lib. 549, 76r.

ÁNGEL DEL VAL

B. A. / B. T.

5-8-1694

Fr. Íñigo Ruiloba / Fr. Plácido Vea

Cameño (Burgos)

AGN, Irache, Lib. 549, 76v.

JUAN GUTIÉRREZ

B. C.

5-8-1694

Fr. Plácido Vea / Fr. Íñigo Ruiloba

Porquera de San Millán (Burgos)

AGN, Irache, Lib. 549, 76v.

MIGUEL MATEO

B. A. / B. M.

8-8-1694

Fr. Íñigo Ruiloba / Fr. Plácido Vea / Am-

brosio Gómez

Tudela (Tarazona)

AGN, Irache, Lib. 549, 76v. 
MANUEL PINILLOS

B. C.

9-8-1694

Fr. Plácido Vea / Fr. Fernando Salgado

Villafruela (Burgos)

AGN, Irache, Lib. 549, 77r.

\section{BARTOLOMÉ DE TERÁN}

B. T.

20-8-1694

Fr. Plácido Vea / Fr. Antonio Larrea

Hormas (Burgos)

B. A.

AGN, Irache, Lib. 549, 77r.

\section{TOMÁS GONZÁLEZ}

B. C.

30-8-1694

Fr. Plácido Vea / Fr. Íñigo Ruiloba

Sasamón (Burgos)

AGN, Irache, Lib. 549, 77v.

JUAN DE SAN MILLÁN

B. C.

31-8-1694

Fr. Plácido Vea / Fr. Antonio Larrea

Cillamayor (Burgos)

AGN, Irache, Lib. 549, 77v.

\section{SIMÓN CABALLERO}

B. C.

31-8-1694

Fr. Plácido Vea / Fr. Fernando Salgado

Mazuela (Burgos)

AGN, Irache, Lib. 549, 77v.

FRANCISCO DE AZCONA Y ECHARREN

B. L.

1-9-1694

Fr. M. Vela, Abad / Ldo. José de Briones

Lerate (Pamplona)

AGN, Irache, Lib. 549, 78r.

\section{MANUEL DE AZCONA Y ECHARREN}

B. L.

1-9-1694

Fr. M. Vela, Abad / Ldo. José de Briones

Lerate (Pamplona)

AGN, Irache, Lib. 549, 78r.

\section{JOSÉ DE SADA Y ANTILLÓN}

B. L.

1-9-1694

Fr. M. Vela, Abad / Ldo. José de Briones

Tudela (Tarazona)

AGN, Irache, Lib. 549, 78r.

VICENTE HERRERO

B. A.

11-9-1694

Fr. Fernando Salgado / Fr. Íñigo Riuloba

Zaragoza

AGN, Irache, Lib. 549, 78v.

CARLOS GARCÍA

B. C.

19-9-1694

Fr. Plácido Vea / Fr. Benito Anguiano

Villavega (Burgos)

AGN, Irache, Lib. 549, 78v.

FRANCISCO GARCÍA

B. C.

19-9-1694

Fr. Plácido Vea / Fr. Benito Anguiano

Renedo (Burgos)

AGN, Irache, Lib. 549, 78v.

BENITO DE ANGUIANO

B. A. / L. A. / M. A. / B. T. / L. T. / M. T. 29-9-1694

Fr. Manuel Vela, Abad, Rector y Canciller O. S. B.

Lector de Tercia. Definidor mayor

AGN, Irache, Lib. 549, 79r.

\section{PLÁCIDO VEA}

B. A. / L. A. / M. A. / B. T. / L. T. / M. T. 29-9-1694

Fr. Manuel Vela, Abad, Rector y Canciller

O. S. B.

Lector de Vísperas

AGN, Irache, Lib. 549, 79r.

ÍNIIGO DE RUILOBA

B. A. / L. A. / M. A. / B. T. / L. T. / M. T. 29-9-1694

Fr. Manuel Vela, Abad, Rector y Canciller 
O. S. B.

Maestro de Artes

AGN, Irache, Lib. 549, 79r.

\section{LORENZO CONGET}

B. M.

5-10-1694

Fr. Plácido Vea / Fr. Íñigo Ruiloba / Ambrosio Gómez

Funes (Pamplona)

B. A.

AGN, Irache, Lib. 549, 8or.

\section{ANTONIO LÓPEZ DE ECHAZARRETA}

B. A.

8-10-1694

Fr. Íñigo Riuloba / Fr. Fernando Salgado

Zalduendo (Calahorra)

AGN, Irache, Lib. 549, 8or.

\section{SEBASTIÁN DE MELGAR}

B. A. / L. A.

9-10-1694 / 5-6-1695

Fr. Íñigo Riuloba / Fr. Fernando Salgado /

Fr. M. Vela, abad

Sansol (Calahorra)

AGN, Irache, Lib. 549, 8or, 89r.

\section{VENTURA ZUGATONDO}

\section{B. A.}

11-10-1694

Fr. Fernando Salgado

Estella (Pamplona)

AGN, Irache, Lib. 549, 80v.

JOSÉ SÁNCHEZ

B. L.

12-10-1694

Fr. Íñigo Riuloba / Ldo. José de Briones

Corella (Tarazona)

AGN, Irache, Lib. 549, 80v.

PEDRO MATEO DE CASTELAR

L. C. / D. C.

12-10-1694 / 13-10-1694

Fr. Manuel Vela, Abad y Rector

Ojos Negros (Zaragoza)

AGN, Irache, Lib. 549, 80v-81r.
DIEGO IGNACIO MORRAS Y AZCONA

B. A.

5-11-1694

Fr. Íñigo Riuloba / Fr. Plácido de Castillo O. de M.

Metauren (Pamplona)

AGN, Irache, Lib. 549, 81r.

\section{JUAN LÓPEZ DE LINARES}

B. C.

21-11-1694

Fr. José Osorio / Fr. Plácido Vea

Espinosa de los Monteros (Burgos)

AGN, Irache, Lib. 549, 81v.

FRANCISCO DEL CORRAL Y VELASCO

B. C.

4-12-1694

Fr. José Osorio / Fr. Plácido Vea

Espinosa de los Monteros (Burgos)

AGN, Irache, Lib. 549, 81v.

FRANCISCO DE AVELLANOSA

B. A. / B. T.

18-12-1694

Fr. Íñigo Riuloba / Fr. Plácido Vea

Jarda (Burgos)

AGN, Irache, Lib. 549, 81v.

JUAN DE ARGÜESO

B. C.

24-12-1694

Fr. Plácido Vea / Fr. José Osorio

Llano (Burgos)

AGN, Irache, Lib. 549, 82r.

JOAQUÍN LÓPEZ DE ATOCHA

B. A. / B. T. / L. T. / D. T.

30-1-1695 / 31-1-1695

Fr. Manuel Vela, Abad

Roncal (Pamplona)

AGN, Irache, Lib. 549, 82rv.

\section{BARTOLOMÉ DE CONTRERAS}

B. A. / B. T.

14-2-1695

Fr. Íñigo Riuloba / Fr. Plácido de Castillo Villalbos (Burgos)

AGN, Irache, Lib. 549, 82v. 
MANUEL DE LA VARGA

B. C.

28-2-1695

Fr. Plácido de Castillo / Fr. Plácido Vea

Ocón de Villafranca de Montes (Burgos)

AGN, Irache, Lib. 549, 83r.

\section{ANTONIO GARCÍA DE LA TARGA}

B. C.

1695

[Al margen, sin más datos]

...

AGN, Irache, Lib. 549, 83r.

ANTONIO GUTIÉRREZ DE SOLANO

B. C.

4-3-1695

Fr. Plácido de Castillo / Fr. Íñigo Riuloba

Espinosa de los Monteros (Burgos)

AGN, Irache, Lib. 549, 83r.

FRANCISCO MARTÍNEZ DE ARCE

B. C.

5-3-1695

Fr. Plácido Vea / Fr. Plácido de Castillo

Valle de Liendo (Burgos)

AGN, Irache, Lib. 549, 83r.

ANDRÉS GARCÍA ESCRIBANO

L. T.

5-3-1695

Fr. Manuel Vela, Abad

...ronantos (Burgos)

B. T. en Irache

AGN, Irache, Lib. 549, 83v.

FRANCISCO DE ARROYO

B. C.

7-3-1695

Fr. Plácido de Castillo / Fr. Plácido Vea

Villagómez (Burgos)

AGN, Irache, Lib. 549, 83v.

MANUEL RODRIGO

B. M.

8-3-1695

Fr. Plácido Vea / Fr. Plácido de Castillo //

Dr. Miguel Atondo
Mendigorría (Pamplona)

AGN, Irache, Lib. 549, 84r.

BERNARDO ALONSO DE VILLALOBOS

B. C.

9-3-1695

Fr. Plácido Vea / Fr. Plácido de Castillo

Arcellares (Burgos)

AGN, Irache, Lib. 549, 84r.

ANTONIO MADRACO ESCALERA

B. C.

11-3-1695

Fr. José Osorio / Fr. Plácido de Castillo

Espinosa de los Monteros (Burgos)

AGN, Irache, Lib. 549, 84r.

ALONSO PELAYO

B. C.

11-3-1695

Fr. José Osorio / Fr. Plácido de Castillo

Espinosa de los Monteros (Burgos)

AGN, Irache, Lib. 549, 84v.

\section{PEDRO CRESPO}

B. C.

16-3-1695

Fr. Plácido Vea / Fr. Plácido de Castillo

Sobarzo (Burgos)

AGN, Irache, Lib. 549, 84v.

TOMÁS ANTÓN GONZÁLEZ

B. C.

16-3-1695

Fr. Plácido Vea / Fr. Plácido de Castillo

Citores (Burgos)

AGN, Irache, Lib. 549, 84v.

JUAN DE HAEDO Y SARABIA

B. C.

17-3-1695

Fr. Plácido Vea / Fr. Plácido de Castillo

Rasines (Burgos)

AGN, Irache, Lib. 549, 85r.

TOMÁS DE HAEDO Y SARABIA

B. C.

17-3-1695 
Fr. Plácido Vea / Fr. Plácido de Castillo Rasines (Burgos)

AGN, Irache, Lib. 549, 85r.

\section{DIEGO CONDE LASSO Y SAÑUDO}

B. A. / B. T.

23-3-1695

Fr. Înigo Riuloba / Fr. Plácido de Castillo Espinosa de los Monteros (Burgos)

AGN, Irache, Lib. 549, 85r.

\section{ANTONIO LUCIO DE VILLEGAS}

B. C.

23-3-1695

Fr. Plácido de Castillo / Fr. Plácido Vea Arija (Burgos)

AGN, Irache, Lib. 549, 85v.

\section{SANTOS HIERRO DEL SOLAR}

B. C.

23-3-1695

Fr. Plácido de Castillo / Fr. Plácido Vea

Cereceda (Burgos)

AGN, Irache, Lib. 549, 85v.

DIEGO MARROQUÍN Y MONTEHERMO-

SO

B. C.

23-3-1695

Fr. Plácido de Castillo / Fr. Plácido Vea

Cereceda (Burgos)

AGN, Irache, Lib. 549, 85v.

PEDRO GARCÍA DEL VALLE

B. C.

24-3-1695

Fr. Plácido Vea / Fr. Plácido de Castillo

Llanillo (Burgos)

AGN, Irache, Lib. 549, 86r.

FRANCISCO GÓMEZ DE COSÍO

B. C.

24-3-1695

Fr. Plácido Vea / Fr. Plácido de Castillo

Carmona (Burgos)

AGN, Irache, Lib. 549, 86r.

FRANCISCO LÓPEZ DE QUINTANA

B. C.
27-3-1695

Fr. Plácido Vea / Fr. Íñigo Ruiloba

Briviesca (Burgos)

AGN, Irache, Lib. 549, 86r.

FRANCISCO RUBÍN DE LA MADRID

B. C.

6-4-1695

Fr. Plácido de Castillo / Fr. José González, Catedrático de Artes

Carmona (Burgos)

AGN, Irache, Lib. 549, 86v.

JUAN DE FAJADURA

B. C.

6-4-1695

Fr. Plácido de Castillo / Fr. José González

Quintanillas (Burgos)

AGN, Irache, Lib. 549, 86v.

\section{ANTONIO DE LOMA OSORIO}

B. C.

7-4-1695

Fr. Plácido de Castillo / Fr. Plácido Vea

Sajazarra (Burgos)

AGN, Irache, Lib. 549, 86v.

JUAN PEREDA

B. A. / B. T.

15-4-1695

Fr. Íñigo Riuloba / Fr. Plácido de Castillo

Cornejo (Burgos)

AGN, Irache, Lib. 549, 87r.

FRANCISCO GARCÍA

B. $M$.

19-4-1695

Fr. Plácido de Castillo / Fr. José González // Dr. Antonio de Olano

Madrid (Toledo)

B. A.

AGN, Irache, Lib. 549, 87r.

JUAN BAUTISTA DE SEPÚLVEDA

B. $\mathrm{M}$.

19-4-1695

Fr. Plácido de Castillo / Fr. José González // Dr. Antonio de Olano 
Madrid (Toledo)

AGN, Irache, Lib. 549, 87r.

MANUEL DE REVILLA

B. C.

24-4-1695

Fr. Plácido de Castillo / Fr. Fernando Sal-

gado

Pedreña (Burgos)

AGN, Irache, Lib. 549, 87v.

JERÓNIMO DE MURGA

B. A. / B. T.

29-4-1695

Fr. José Osorio / Fr. Fernando Salgado

Sopuerta (Burgos)

AGN, Irache, Lib. 549, 87v.

\section{SEBASTIÁN DE LAS CASAS}

B. C.

5-5-1695

Fr. Plácido de Castillo / Fr. Íñigo Riuloba

Valle de Sopuerta (Burgos)

AGN, Irache, Lib. 549, 87v.

\section{JUAN MERINO}

B. C.

13-5-1695

Fr. Plácido de Castillo / Fr. José González Avellanosa del Páramo (Burgos)

AGN, Irache, Lib. 549, 88r.

\section{JUAN REBOLLO}

B. C.

13-5-1695

Fr. Plácido de Castillo / Fr. Fernando Salgado

Solas (Burgos)

AGN, Irache, Lib. 549, 88r.

JOSÉ DE GOÑI

B. A. / B. M.

16-5-1695

Fr. Íñigo Riuloba / Fr. Plácido de Castillo //

Miguel Atondo

Pamplona

AGN, Irache, Lib. 549, 88r.
JOSÉ LACAMBRA

B. A. / B. M.

4-6-1695

Fr. Íñigo Riuloba / Fr. Fernando Salgado //

Antonio de Olano

Fornillos (Barbastro)

AGN, Irache, Lib. 549, 88v.

DOMINGO MARTÍNEZ

B. C.

4-6-1695

Fr. Plácido de Castillo / Fr. José González

Fresnedo (Burgos)

AGN, Irache, Lib. 549, 88v.

\section{BERNARDO TORRANO}

B. A. / B. T. / L. T.

4-6-1695

Fr. José Osorio / Fr. Plácido de Castillo /

Fr. M. Vela, Abad

Corella (Pamplona)

AGN, Irache, Lib. 549, 88v.

FRANCISCO NAVARRETE

L. C. / D. C.

11-6-1695

Fr. Manuel Vela, Abad, Rector y Canciller

Nájera (Calahorra)

Vicario General del Obispado de Pamplona

AGN, Irache, Lib. 549, 89r.

\section{FRANCISCO DE APARICIO}

B. C.

18-6-1695

Fr. Plácido de Castillo / Fr. José González

Lanuez de Santibáñez (Burgos)

AGN, Irache, Lib. 549, 89r.

MIGUEL SIMÓN DE LARA

B. M.

19-6-1695

Fr. Plácido Vea / Fr. Plácido de Castillo

Pradoluengo (Burgos)

AGN, Irache, Lib. 549, 89v.

\section{FRANCISCO GÓMEZ}

B. C.

19-6-1695 
Fr. José Osorio / Fr. José González

Burgos

AGN, Irache, Lib. 549, 89v.

FRANCISCO CUÑADO

B. C.

19-6-1695

Fr. José Osorio / Fr. José González

Cogollos (Burgos)

AGN, Irache, Lib. 549, 89v.

DAMIÁN GARCÍA

B. C.

19-6-1695

Fr. José Osorio / Fr. José González

Quintanilla Pedro de Abarca (Burgos)

AGN, Irache, Lib. 549, 89v.

LORENZO ORTEGA

B. C.

24-6-1695

Fr. Plácido de Castillo / Fr. Fernando Salgado

Villagalijo (Burgos)

AGN, Irache, Lib. 549, 9or.

DOMINGO MARTÍNEZ

B. T.

26-6-1695

Fr. Plácido de Castillo / Fr. Plácido Vea

Fresneda (Burgos)

AGN, Irache, Lib. 549, 9 or.

JOSÉ DE CABAÑAS

B. M.

11-7-1695

Fr. José Osorio / Fr. José González / Miguel de Atondo

Salamanca

B. A.

AGN, Irache, Lib. 549, 90 .

JOSÉ RAMÍREZ DE BAQUEDANO

B. A. / B. M.

20-7-1695 / 21-4-1698

Fr. Íñigo Riuloba / Fr. Plácido de Castillo // Fr. Plácido Vea / Fr. Ángel Benito / Ambrosio Olano
Lerín (Pamplona)

AGN, Irache, Lib. 549, 90v, 122v.

JUAN DE BUSTO

B. C.

25-7-1695

Fr. Plácido Vea / Fr. José González

Valluércanes (Burgos)

AGN, Irache, Lib. 549, $90 v$.

PEDRO DE OLIVÁN

B. A.

6-8-1695

Fr. Íñigo Riuloba / Fr. Fernando Salgado

Calahorra

AGN, Irache, Lib. 549, 9ov.

\section{MARTÍN DE AYERRA}

B. M.

8-8-1695

Fr. Plácido Vea / Fr. Plácido de Castillo //

Antonio de Olano

Sansoain (Pamplona)

B. A.

AGN, Irache, Lib. 549, 91r.

FRANCISCO DE LORIA

B. C.

12-8-1695

Fr. Plácido Vea / Fr. Plácido de Castillo

Valluércanes (Burgos)

AGN, Irache, Lib. 549, 91r.

JUAN JOSÉ DE IMBERS

L. A.

1-9-1695

Fr. Manuel Vela, Abad

Sangüesa (Pamplona)

B. A. en Alcalá

AGN, Irache, Lib. 549, 91r.

ANTONIO DEL CASTILLO

B. A. / B. T.

3-9-1695

Fr. Íñigo Riuloba / Fr. Plácido de Castillo

Foncea (Burgos)

AGN, Irache, Lib. 549, 91v. 
JUAN SAINZ ANGULO

B. A. / B. T.

3-9-1695

Fr. Íñigo Riuloba / Fr. Plácido de Castillo

Foncea (Burgos)

AGN, Irache, Lib. 549, 91v.

\section{MANUEL MIGUEL GONZÁLEZ}

B. C.

9-9-1695

Fr. José Osorio / Fr. Plácido de Castillo

Cogollos (Burgos)

AGN, Irache, Lib. 549, 91v.

\section{ALONSO RAMÍREZ CALDERÓN}

B. C.

9-9-1695

Fr. José Osorio / Fr. Plácido de Castillo

Canduela (Burgos)

AGN, Irache, Lib. 549, 92r.

\section{FRANCISCO RODRÍGUEZ}

B. C.

9-9-1695

Fr. José Osorio / Fr. Plácido de Castillo

Formiguera (Burgos)

AGN, Irache, Lib. 549, 92r.

JUAN DE ESCALONA

B. A.

9-9-1695

Fr. Íñigo Riuloba /Fr. José González

Calahorra

AGN, Irache, Lib. 549, 92r.

JOSÉ DE BARAONA

B. A. / B. T.

10-9-1695

Fr. Plácido Vea / Fr. Íñigo Ruiloba

Villanueva del Conde (Burgos)

AGN, Irache, Lib. 549, 92v.

\section{FRANCISCO RUIZ}

B. C.

11-9-1695

Fr. Plácido Vea / Fr. José González

Coculina (Burgos)

AGN, Irache, Lib. 549, 92v.

\section{JUAN DE OVIEDO}

B. C.

16-9-1695

Fr. Plácido de Castillo / Fr. Fernando Salgado

Villanueva del Conde (Burgos)

AGN, Irache, Lib. 549, 92v.

\section{FRANCISCO VENTURA CASTELLANOS}

B. M.

22-9-1695

Fr. Plácido Vea / Fr. Fernando Salgado //

Antonio de Olano

Nalda (Calahorra)

AGN, Irache, Lib. 549, 93r.

BENITO CEBALLOS

B. C.

29-9-1695

Fr. Plácido Vea / Fr. Íñigo Ruiloba

Las Presillas (Burgos)

AGN, Irache, Lib. 549, 93r.

JUAN ANTONIO DE LA TORRE

B. C.

30-9-1695

Fr. Plácido de Castillo / Fr. Plácido Vea

Poza (Burgos)

AGN, Irache, Lib. 549, 93r.

GREGORIO RUIZ

B. A. / L. A. / M. A. / B. T. / L. T. / D. T.

7-10-1695

Fr. Manuel Vela, Abad, Rector y Canciller

O. S. B.

Definidor

San Benito de Valladolid

AGN, Irache, Lib. 549, 93v.

JUAN MONTIEL

B. A. / B. M.

17-10-1695

Fr. Íñigo Ruiloba / Fr. José Osorio // Miguel Atondo

El Redal (Calahorra)

AGN, Irache, Lib. 549, 94r.

CRISTÓBAL DE GONZALO

B. C. 
18-10-1695

Fr. Plácido Vea / Fr. Plácido de Castillo Padilla de Arriba (Burgos)

AGN, Irache, Lib. 549, 94r.

ANDRÉS PELÁEZ

B. C.

18-10-1695

Fr. Plácido Vea / Fr. Plácido de Castillo

Padilla de Arriba (Burgos)

AGN, Irache, Lib. 549, 94r.

\section{ANTONIO JAIMES}

B. C.

18-10-1695

Fr. Plácido Vea / Fr. Plácido de Castillo Melgar de Fernamental (Burgos)

AGN, Irache, Lib. 549, 94V.

PEDRO DE VILLASANA

B. C.

18-10-1695

Fr. Plácido Vea / Fr. Plácido de Castillo Melgar de Fernamental (Burgos)

AGN, Irache, Lib. 549, 94V.

\section{ESTEBAN GUTIÉRREZ}

B. C.

30-10-1695

Fr. Plácido de Castillo / Fr. Plácido Vea Burgos

Monasterio del Valle de San Millán

AGN, Irache, Lib. 549, 94v.

\section{ANTONIO DEL MONTE}

B. C.

1-11-1695

Fr. José Osorio / Fr. Plácido de Castillo Jermine (Burgos)

AGN, Irache, Lib. 549, 95r.

PEDRO DE ARZABE

B. C.

2-11-1695

Fr. Plácido Vea / Fr. Plácido de Castillo Zalla (Burgos)

AGN, Irache, Lib. 549, 95r.

\section{FRANCISCO DE ESPINOSA}

B. A.

6-11-1695

Fr. Íñigo Riuloba / Fr. José González

Enciso (Calahorra)

AGN, Irache, Lib. 549, 95r.

MARCOS DE CASTAÑOS

B. C.

7-11-1695

Fr. Plácido de Castillo / Fr. Fernando Salgado

Galdames (Burgos)

AGN, Irache, Lib. 549, 95r.

\section{ANTONIO SANTOS}

B. C.

16-11-1695

Fr. José Osorio / Fr. Plácido de Castillo

Melgar de Fernamental (Burgos)

AGN, Irache, Lib. 549, 95v.

FRANCISCO DE LA CUEVA

B. A. / B. T.

18-11-1695

Fr. Plácido Vea / Fr. Íñigo Ruiloba

Valle de Liendo (Burgos)

AGN, Irache, Lib. 549, 95v.

TOMÉ DE BUSTILLO

B. C.

21-11-1695

Fr. Plácido de Castillo / Fr. Fernando Salgado

Rasillo (Burgos)

AGN, Irache, Lib. 549, 95v.

FRANCISCO MEDEL

B. C.

23-11-1695

Fr. José Osorio / Fr. Plácido de Castillo

Burgos

AGN, Irache, Lib. 549, 95v.

FRANCISCO DE LOS RÍOS

B. C.

1-12-1695

Fr. Plácido Vea / Fr. Plácido de Castillo 
Argüeso (Burgos)

AGN, Irache, Lib. 549, 96r.

\section{AGUSTÍN DE ARANA Y POBES}

B. C.

1-12-1695

Fr. Plácido Vea / Fr. Plácido de Castillo Isla (Burgos)

AGN, Irache, Lib. 549, 96r.

\section{LUCAS DE FONTECHA}

B. C.

6-12-1695

Fr. José Osorio / Fr. Íñigo Riuloba

Ayuelas (Burgos)

AGN, Irache, Lib. 549, 96r.

\section{MANUEL GONZÁLEZ}

B. C.

7-12-1695

Fr. Plácido Vea / Fr. Íñigo Ruiloba

Villasandino (Burgos)

AGN, Irache, Lib. 549, 96r.

URBAN DEL RÍO

B. C.

12-12-1695

Fr. Plácido Vea / Fr. José González

Villasilos (Burgos)

AGN, Irache, Lib. 549, 96v.

\section{AGUSTÍN GONZÁLEZ}

B. C.

17-12-1695

Fr. Plácido Vea / Fr. Fernando Salgado

Pedrosa del Páramo (Burgos)

AGN, Irache, Lib. 549, 96v.

\section{LUCAS ANDRÉS}

B. C.

22-12-1695

Fr. Plácido Vea / Fr. Plácido de Castillo

Castromorca (Burgos)

AGN, Irache, Lib. 549, 96v.

JOSÉ MARTÍNEZ

B. C.

2-2-1696
Fr. José Osorio / Fr. Félix de la Rasilla

Burgos

AGN, Irache, Lib. 549, 96v.

FRANCISCO PÉREZ CAMINO

B. C.

5-2-1696

Fr. José Osorio / Fr. Plácido de Castillo

Burgos

AGN, Irache, Lib. 549, 97r.

\section{NICOLÁS SÁNCHEZ}

B. $\mathrm{M}$.

20-1-1696

Fr. Plácido de Castillo / Fr. Fernando Salgado // Antonio Olano

Córdoba

B. A.

AGN, Irache, Lib. 549, 97r.

TOMÁS GONZÁLEZ

B. C.

20-1-1696

Fr. Plácido de Castillo / Fr. Plácido Vea

Villadiego (Burgos)

AGN, Irache, Lib. 549, 97r.

ANTONIO RAMOS

B. A. / B. T.

22-1-1696

Fr. Plácido de Castillo / Fr. Íñigo Riuloba

Melgar de Fernamental (Burgos)

AGN, Irache, Lib. 549, 97r.

MARCOS CABALLERO

B. C.

25-1-1696

Fr. Plácido Vea / Fr. Fernando Salgado

Aldeacueva (Burgos)

AGN, Irache, Lib. 549, 97v.

JUAN ANTONIO RUBIANO

B. C.

25-1-1696

Fr. Plácido Vea / Fr. Fernando Salgado

Sangrices (Burgos)

AGN, Irache, Lib. 549, 97v. 


\section{DOMINGO MILLÁN DE LARA}

B. C.

25-1-1696

Fr. Plácido Vea / Fr. Fernando Salgado

Barbadillo de Herreros (Burgos)

AGN, Irache, Lib. 549, 97v.

\section{BALTASAR DE LA TORRE Y OCÓN}

B. A. / B. M.

28-1-1696

Fr. Plácido Vea / Fr. Íñigo Ruiloba // Miguel Atondo

Tudela (Tarazona)

AGN, Irache, Lib. 549, 97v.

\section{FERNANDO ALONSO}

B. A. / B. T.

1-2-1696

Fr. Plácido Vea / Fr. Íñigo Ruiloba

Lugar de Páramo (Burgos)

AGN, Irache, Lib. 549, 98r.

ANDRÉS DE SANTA MARÍA

B. C.

1-2-1696

Fr. Plácido Vea / Fr. Íñigo Ruiloba

Marmellar de Abajo (Burgos)

AGN, Irache, Lib. 549, 98r.

\section{MANUEL DE LA CUERTA}

B. C.

1-2-1696

Fr. Plácido Vea / Fr. Íñigo Ruiloba

Zumel (Burgos)

AGN, Irache, Lib. 549, 98r.

\section{JUAN ANTONIO CABALLERO}

B. C.

2-2-1696

Fr. Plácido Vea / Fr. Fernando Salgado

Aldeacueva (Burgos)

AGN, Irache, Lib. 549, 98r.

\section{MARCOS RUIZ DE AMAYA}

B. C.

19-2-1696

Fr. Plácido Vea / Fr. Fernando Salgado

Amaya (Burgos)

AGN, Irache, Lib. 549, 98v.
JOSÉ DE MEDIAVILLA Y GARCÍA

B. C.

19-2-1696

Fr. Plácido Vea / Fr. Fernando Salgado

Mundilla (Burgos)

AGN, Irache, Lib. 549, 98v.

DOMINGO APARICIO

B. C.

19-2-1696

Fr. Plácido Vea / Fr. Fernando Salgado

Revilla, junto a Pomar (Burgos)

AGN, Irache, Lib. 549, 99r.

JOSÉ ALONSO DE ANGULO

B. A. / B. T.

29-2-1696

Fr. Íñigo Ruiloba / Fr. Fernando Salgado

Burgos

AGN, Irache, Lib. 549, 99r.

JUAN ITURRALDE

B. C.

23-3-1696

Fr. Plácido Vea / Fr. Fernando Salgado

Covarrubias

Jurisdicción de la Abadía

AGN, Irache, Lib. 549, 99r.

JOSÉ MÍNGUEZ

B. C.

6-4-1696

Fr. Plácido de Castillo / Fr. Fernando Sal-

gado

Celada del Camino (Burgos)

AGN, Irache, Lib. 549, 99v.

IGNACIO DE URQUIETA

B. A. / B. T.

9-4-1696

Fr. Plácido de Castillo / Fr. Íñigo Riuloba

Bilbao (Calahorra)

AGN, Irache, Lib. 549, 99v.

LORENZO PAMPLIEGA

B. C.

11-4-1696

Fr. Plácido Vea / Fr. Plácido de Castillo 
Covarrubias

Jurisdicción de la Abadía

AGN, Irache, Lib. 549, 99v.

ANDRÉS ESPAÑOL

B. A. / B. M.

15-4-1696 / 21-4-1696

Fr. Plácido Vea / Fr. Fernando Salgado //

Antonio Olano

Reprobado

Fr. Íñigo Riuloba / Fr. José González / Mi-

guel Atondo / Fr. M. Vela, abad

Salardú (Lérida)

AGN, Irache, Lib. 549, 100 .

\section{PEDRO GARCÍA}

B. C.

19-4-1696

Fr. Plácido Vea / Fr. Fernando Salgado

Cuevas (Burgos)

AGN, Irache, Lib. 549, 100 .

MARTÍN DE ARÓSTEGUI

B. A. / B. M.

25-4-1696

Fr. Plácido Vea / Fr. Íñigo Ruiloba // Miguel Atondo

Rasuaña (Pamplona)

AGN, Irache, Lib. 549, $100 v$.

\section{PEDRO DE ZAMORA}

B. A. / B. T.

26-4-1696

Fr. Plácido Vea / Fr. Íñigo Ruiloba

Pradoluengo (Burgos)

AGN, Irache, Lib. 549, $100 v$.

\section{MANUEL MENAZA DE LA IGLESIA}

B. A. / B. T.

8-5-1696

Fr. Plácido de Castillo / Fr. José Osorio

Corbio (Burgos)

AGN, Irache, Lib. 549, 100v.

JUAN GARCÍA DE SANTA OLALLA

B. C.

12-5-1696

Fr. Plácido Vea / Fr. Fernando Salgado
Pradoluengo (Burgos)

AGN, Irache, Lib. 549, 101r.

\section{DIEGO RUIZ Y QUINTANO}

B. C.

28-5-1696

Fr. Plácido de Castillo / Fr. Fernando Salgado

Espinosa de los Monteros (Burgos)

AGN, Irache, Lib. 549, 101r.

JUAN DE BÁRCENA

B. C.

1-6-1696

Fr. Plácido de Castillo / Fr. Félix de la Rasilla

Bentestea (Burgos)

AGN, Irache, Lib. 549, 101r.

LUCAS LOZANO

B. C.

1-6-1696

Fr. Plácido de Castillo / Fr. Félix de la Rasilla

Pradoluengo (Burgos)

AGN, Irache, Lib. 549, 101v.

MATEO DE BOADA

B. C.

6-6-1696

Fr. Plácido Vea / Fr. Plácido de Castillo

Albacastro (Burgos)

AGN, Irache, Lib. 549, $101 \mathrm{v}$.

JUAN BAUTISTA DE VEGA

B. C.

6-6-1696

Fr. Plácido Vea / Fr. Plácido de Castillo

Cubillo (Palencia)

AGN, Irache, Lib. 549, $101 \mathrm{v}$.

NICOLÁS DE LA FUENTE

B. C.

6-6-1696

Fr. Plácido Vea / Fr. Plácido de Castillo

Mataporquera (Burgos)

AGN, Irache, Lib. 549, 102 r. 


GREGORIO FERNÁNDEZ
B. C.
9-6-1696
Fr. Plácido de Castillo / Fr. José González
Río Quintanilla (Burgos)
AGN, Irache, Lib. 549, 102r.
FRANCISCO CANTÓN
B. C.
13-6-1696
Fr. Plácido Vea / Fr. Plácido de Castillo
Cornudilla (Burgos)
AGN, Irache, Lib. 549, 102r.

\section{ESTEBAN GONZÁLEZ}

B. C.

14-6-1696

Fr. Plácido de Castillo / Fr. Fernando Salgado

Villa...

AGN, Irache, Lib. 549, 102r.

\section{FABIÁN NOGALES}

B. C.

20-6-1696

Fr. Plácido de Castillo / Fr. Fernando Salgado

Melgar de Fernamental (Burgos)

AGN, Irache, Lib. 549, $102 \mathrm{~V}$.

JUAN PÉREZ

B. A. / B. T.

20-6-1696

Fr. Plácido de Castillo / Fr. Fernando Salgado

Melgar de Fernamental (Burgos)

AGN, Irache, Lib. 549, 102v.

DIEGO DE VILLA

B. A. / B. T.

27-6-1696

Fr. Plácido de Castillo / Fr. Fernando Salgado

Valmaseda (Burgos)

AGN, Irache, Lib. 549, $102 \mathrm{v}$.

JUAN DÍEZ

B. A./ B. T.
30-6-1696

Fr. Fernando Salgado / Fr. José González Lándreves (Burgos)

AGN, Irache, Lib. 549, 102v.

MIGUEL MONJE

B. T.

4-7-1696

Fr. Fernando Salgado / Fr. José González

Hecho (Jaca)

B. A.

AGN, Irache, Lib. 549, 103r.

JUAN HIPÓLITO DE LA RIPA

B. A. / B. M.

4-7-1696

Fr. Fernando Salgado / Fr. José González

// Miguel Atondo

Hecho (Jaca)

AGN, Irache, Lib. 549, 103r.

MANUEL DE SAMANIEGO Y JACA

B. A.

9-7-1696

Fr. Fernando Salgado / Fr. José González

Logroño (Calahorra)

AGN, Irache, Lib. 549, 103r.

BLAS ANTONIO DE LIMPIAS Y SARABIA

B. C.

10-7-1696

Fr. Fernando Salgado / Fr. José González

Colindres (Burgos)

AGN, Irache, Lib. 549, 103 r.

FRANCISCO GUTIÉRREZ DEL OLMO

B. A. / B. T.

19-7-1696

Fr. Fernando Salgado / Fr. José González Izara (Burgos)

AGN, Irache, Lib. 549, 103v.

\section{ISIDORO GONZÁLEZ}

B. C.

21-7-1696

Fr. Fernando Salgado / Fr. José González

Colindres (Burgos)

AGN, Irache, Lib. 549, $103 \mathrm{v}$. 
FRANCISCO DE CASTANEDO Y CEBALLOS

B. C.

22-7-1696

Fr. Fernando Salgado / Fr. José González

Villanueva (Burgos)

AGN, Irache, Lib. 549, $103 \mathrm{v}$.

\section{FRANCISCO PALACIO}

B. A.

25-7-1696

Fr. Fernando Salgado / Fr. José González

Pedrola (Zaragoza)

AGN, Irache, Lib. 549, 103v.

JOSÉ RODRÍGUEZ

B. C.

25-7-1696

Fr. Fernando Salgado / Fr. José González

Coloma (Burgos)

AGN, Irache, Lib. 549, 104r.

\section{BALTASAR DE LEZAÚN}

L. L.

30-7-1696

Fr. Manuel Vela, abad // Abog. José Briones

Estella (Pamplona)

B. L.

AGN, Irache, Lib. 549, 104 r.

\section{MIGUEL LORENTE}

B. A. / B. M.

16-9-1696

Fr. Fernando Salgado / Fr. José González

// Miguel Atondo

Atea (Tarazona)

AGN, Irache, Lib. 549, 104r.

JOSÉ PÉREZ

B. C.

20-9-1696

Fr. Fernando Salgado / Fr. José González

Cañizal de los Ajos (Burgos)

AGN, Irache, Lib. 549, 104v.

JUAN DE MANZANAL

B. C.
22-9-1696

Fr. Fernando Salgado / Fr. José González Valtierra del Río Pisuerga (Burgos)

AGN, Irache, Lib. 549, 104v.

\section{FRANCISCO ALONSO}

B. C.

22-9-1696

Fr. Fernando Salgado / Fr. José González Olmos del Río Pisuerga (Burgos)

AGN, Irache, Lib. 549, 104v.

\section{LUCAS IBÁÑEZ}

B. C.

6-10-1696

Fr. Plácido Vea / Fr. Fernando Salgado

Arenillas del Río Pisuerga (Burgos)

AGN, Irache, Lib. 549, 105r.

ANDRÉS IBÁÑEZ

B. C.

6-10-1696

Fr. Plácido Vea / Fr. Fernando Salgado

Arenillas del Río Pisuerga (Burgos)

AGN, Irache, Lib. 549, 105 r.

TOMÁS POLO

B. C.

12-10-1696

Fr. Plácido Vea / Fr. José González

Arenillas del Río Pisuerga (Burgos)

AGN, Irache, Lib. 549, 105 r.

TOMÁS VALLEJO

B. C.

14-10-1696

Fr. Plácido Vea / Fr. Plácido de Castillo

2 meses de penitencia / 2 horas de estudio

al día

Pradilla (Burgos)

AGN, Irache, Lib. 549, $105 \mathrm{v}$.

JOSÉ BERAIZ Y ANTILLÓN

B. C.

17-10-1696

Fr. Plácido Vea / Fr. Plácido de Castillo

Tudela (Nullius Diocesis)

AGN, Irache, Lib. 549, 105v. 
MARCOS MARTÍNEZ

B. C.

25-10-1696 / 27-10-1696

Reprobado

Fr. Plácido Vea / Fr. Plácido de Castillo /

Fr. Manuel Vela, abad

Río Quintanilla (Burgos)

AGN, Irache, Lib. 549, 105v.

JUAN MARTÍNEZ

B. C.

7-11-1696

Fr. Plácido de Castillo / Fr. Plácido Vea

Urbel del Castillo (Burgos)

AGN, Irache, Lib. 549, 106r.

JOSÉ FRESEDO

B. C.

7-11-1696

Fr. Plácido de Castillo / Fr. Plácido Vea

Nidáguila (Burgos)

AGN, Irache, Lib. 549, 106r.

SEBASTIÁN DE BARRIO

B. C.

9-11-1696

Fr. Plácido de Castillo / Fr. Fernando Salgado

Fuentebureba (Burgos)

AGN, Irache, Lib. 549, 106v.

JUAN ABAD

B. C.

20-11-1696

Fr. Plácido Vea / Fr. Plácido de Castillo

Villallano (Burgos)

AGN, Irache, Lib. 549, 106v.

JUAN DE CASTRO

B. C.

22-11-1696

Fr. Plácido de Castillo / Fr. Ángel Benito,

Tercia de Teología

Burgos

AGN, Irache, Lib. 549, 106v.

DOMINGO GORBEA

B. C.
26-11-1696

Fr. Plácido de Castillo / Fr. Plácido Vea

Fuentebureba (Burgos)

AGN, Irache, Lib. 549, 106v.

JUAN BERNAD

B. A. / B. M.

9-12-1696

Fr. Plácido Vea / Fr. José González / Miguel

Atondo

Albalate (Zaragoza)

AGN, Irache, Lib. 549, 107r.

PEDRO DEL MAZO

B. A. / B. T.

28-12-1696

Fr. José González / Fr. Ángel Benito

San Román de Cayón (Burgos)

AGN, Irache, Lib. 549, 107r.

JUAN DE MORA

B. C.

5-1-1697

Fr. Plácido de Castillo / Fr. Ángel Benito

San Román (Burgos)

AGN, Irache, Lib. 549, 107r.

FRANCISCO FERNÁNDEZ

B. C.

11-1-1697

Fr. Plácido Vea / Fr. Ángel Benito

Cantabrana (Burgos)

AGN, Irache, Lib. 549, $107 \mathrm{v}$.

FRANCISCO BLANCO

B. C.

14-1-1697 / 21-6-1697

Reprobado

Fr. Plácido Vea / Fr. José González

Mudá (Palencia)

AGN, Irache, Lib. 549, 107v, 113r.

JOSÉ DE NOGUERADO

B. A.

14-1-1697

Fr. José González / Fr. Ángel Benito

Logroño (Calahorra)

AGN, Irache, Lib. 549, $107 \mathrm{v}$. 
PABLO DÍEZ

B. A. / B. T.

2-2-1697 / 5-2-1697

Fr. José González / Fr. Plácido de Castillo

Reprobado / Suficiente

Urbel del Castillo (Burgos)

AGN, Irache, Lib. 549, 108r.

\section{PEDRO TAPIS}

B. A. / B. T. / L. T. / D. T.

5-2-1697 / 6-2-1697

Fr. Plácido Vea / Fr. Manuel Vela, abad

Andosilla (Pamplona)

AGN, Irache, Lib. 549, 108r.

\section{ANDRÉS FERNÁNDEZ}

B. C.

6-2-1697

Fr. Plácido Vea / Fr. Ángel Benito

Valderrama (Burgos)

AGN, Irache, Lib. 549, 108v.

FRANCISCO DE BARCINA

B. C.

9-2-1697

Fr. Ángel Benito / Fr. Plácido de Castillo

Valderrama (Burgos)

AGN, Irache, Lib. 549, 108v.

DIEGO SAIZ DE ARQUINIGO

L. C.

23-2-1697

Fr. Ángel Benito / Fr. Plácido de Castillo /

Fr. José González

Alfaro (Tarazona)

B. C.

AGN, Irache, Lib. 549, 109r.

DOMINGO DE LA FUENTE

B. M.

24-2-1697

Fr. Plácido Vea / Fr. José González // Mi-

guel Atondo

Haro (Calahorra)

B. A. en Oñate

AGN, Irache, Lib. 549, 109 r.

PEDRO MARTÍNEZ DE CARRIEDO

B. C.

\section{5-3-1697}

Fr. Plácido Vea / Fr. Ángel Benito

Oña (Burgos)

AGN, Irache, Lib. 549, 109v.

JOSÉ DE ZALDÍVAR

B. C.

5-3-1697

Fr. Ángel Benito / Fr. Plácido de Castillo

Oña (Burgos)

AGN, Irache, Lib. 549, $109 \mathrm{v}$.

\section{ANDRÉS MANDURA}

B. A. / B. M.

15-3-1697

Fr. Plácido de Castillo / Fr. José González

// Antonio Olano

Sádaba (Pamplona)

AGN, Irache, Lib. 549, 109v.

PEDRO PARMO

B. C.

18-3-1697

Fr. Plácido Vea / Fr. José Barrionuevo

Pedrosa (Burgos)

AGN, Irache, Lib. 549, 110 .

PEDRO DEL BAÑO

B. C.

23-3-1697

Fr. Ángel Benito / Fr. Plácido de Castillo

Lerma (Abadía de Lerma)

AGN, Irache, Lib. 549, 11 or.

GABRIEL REBOLLEDO

B. C.

29-3-1697

Fr. Plácido de Castillo / Fr. Ángel Benito

Villán (Burgos)

AGN, Irache, Lib. 549, 110 .

PEDRO GONZÁLEZ

B. C.

31-3-1697

Fr. Plácido Vea / Fr. José Barrionuevo

Hormazas (Burgos)

AGN, Irache, Lib. 549, $110 v$. 
BENITO BUSTILLO

B. C.

1-4-1697

Fr. Ángel Benito / Fr. Plácido de Castillo

Hormazas (Burgos)

AGN, Irache, Lib. 549, $110 v$.

JOSÉ BARAÓN

B. C.

14-4-1697

Fr. Plácido de Castillo / Fr. Ángel Benito

Quintana de Somahoz (Burgos)

AGN, Irache, Lib. 549, $110 v$.

NICOLÁS DE LA CUADRA

B. C.

14-4-1697

Fr. Plácido de Castillo / Fr. Ángel Benito

Somorostro (Burgos)

AGN, Irache, Lib. 549, 111r.

MARTÍN DE BONILLA

B. C.

18-4-1697

Fr. Ángel Benito / Fr. Plácido de Castillo

Busto (Burgos)

AGN, Irache, Lib. 549, 111r.

JUAN BAUTISTA DE REZUSTA

B. M.

27-4-1697

Fr. Plácido de Castillo / Fr. Ángel Benito //

Miguel Atondo

Segura (Pamplona)

B. A. en Oñate

AGN, Irache, Lib. 549, 111r.

MATEO DE LA GUERRA PALACIOS

B. C.

10-5-1697

Fr. Ángel Benito / Fr. Fernando Salgado

Güemes (Burgos)

AGN, Irache, Lib. 549, 111v.

JOSÉ DE VAL

B. C. / B. L.

10-5-1697

Fr. Ángel Benito / Fr. José González // Ldo.
Baltasar de Lezaún

Agreda (Tarazona)

AGN, Irache, Lib. 549, 111v.

ANDRÉS FERNÁNDEZ DE LA PEÑA

B. C.

12-5-1697

Fr. Ángel Benito / Fr. José Barrionuevo

Busto (Burgos)

AGN, Irache, Lib. 549, 111v.

FRANCISCO ALFONSO DE VEGA

B. A. / B. T.

28-5-1697

Fr. Plácido Vea / Fr. José González

Castrojeriz (Burgos)

AGN, Irache, Lib. 549, 112r.

BLAS DE ARENAS

B. A. / B. T.

1-6-1697

Fr. José González / Fr. Plácido Vea

Castrojeriz (Burgos)

AGN, Irache, Lib. 549, 112r.

JOSÉ DE ARCOS

B. C.

1-6-1697

Fr. Plácido Vea / Fr. José González

Castrojeriz (Burgos)

AGN, Irache, Lib. 549, 112r.

JUAN DE SANTOYO

B. C.

1-6-1697

Fr. Plácido Vea / Fr. José González

Castrojeriz (Burgos)

AGN, Irache, Lib. 549, 112 r.

JOSÉ DE ARDIT

B. A. / B. M.

2-6-1697

Fr. José González / Fr. Plácido Vea

Pamplona

AGN, Irache, Lib. 549, 112v.

MANUEL HERNÁNDEZ

B. A. / B. T. 
7-6-1697

Fr. José González / Fr. Plácido Vea

Castrojeriz (Burgos)

AGN, Irache, Lib. 549, 112v.

\section{VALENTÍN PÉREZ DE NOVALES}

B. C.

7-6-1697

Fr. Plácido Vea / Fr. José González

Villasana (Burgos)

AGN, Irache, Lib. 549, 112v.

\section{PEDRO GIL ORTIZ DE TRASPEÑA}

B. C.

8-6-1697

Fr. Plácido Vea / Fr. José González

Reprobado

Villasana (Burgos)

AGN, Irache, Lib. 549, 112v.

\section{MANUEL ANGULO}

B. C.

17-6-1697

Fr. Plácido Vea / Fr. José González

Valmaseda (Burgos)

AGN, Irache, Lib. 549, 112v.

MANUEL DE ERASO

B. A. / B. T. / L. T. / M. T.

19-6-1697

Fr. Plácido Vea / Fr. José González

Zufía (Pamplona)

AGN, Irache, Lib. 549, 112v.

DIEGO MARTÍNEZ DE ONTALBARO

B. M.

27-6-1697

Fr. Plácido Vea / Fr. José González / Fr.

Gregorio de Haro, Catedrático de Vísperas

Oncala (Calahorra)

B. A.

AGN, Irache, Lib. 549, 113v.

MANUEL DE TOCORNAL

B. C.

28-6-1697

Fr. Plácido Vea / Fr. José González

Argoños (Burgos)

AGN, Irache, Lib. 549, 113v.
PEDRO DÍEZ DEL CORRAL COSÍO

B. C.

9-7-1697

Fr. Plácido Vea / Fr. José González

Carmona (Burgos)

AGN, Irache, Lib. 549, $113 \mathrm{v}$.

JOSÉ MAESTRO

B. C.

9-7-1697

Fr. Plácido Vea / Fr. José González Villamayor de Triviño (Burgos)

AGN, Irache, Lib. 549, 113v.

FRANCISCO GONZÁLEZ LABIA

B. C.

13-7-1697

Fr. Plácido Vea / Fr. José González

Presencio (Burgos)

AGN, Irache, Lib. 549, 114r.

MATÍAS GUTIÉRREZ

B. C.

15-7-1697

Fr. Plácido Vea / Fr. José González

Rebolledo de la Torre (Burgos)

AGN, Irache, Lib. 549, 114r.

DOMINGO DE SALAZAR

B. C.

16-7-1697

Fr. Plácido Vea / Fr. José González

Villaumbrosa (Burgos)

AGN, Irache, Lib. 549, 114r.

VICENTE ADÁN

B. C.

28-7-1697

Fr. Plácido Vea / Fr. José González

Villanueva de Odra (Burgos)

AGN, Irache, Lib. 549, 114r.

GASPAR ORTIZ

B. A. / B. T.

1-8-1697

Fr. Gregorio de Haro / Fr. José González

E... (Burgos)

AGN, Irache, Lib. 549, 114v. 
PEDRO LÓPEZ FRÍAS

B. C.

4-8-1697

Fr. Gregorio de Haro / Fr. Anselmo de la

Torre

Villapanillo (Burgos)

AGN, Irache, Lib. 549, 114V.

SIMÓN GARCÍA SARABIA

B. A. / B. T.

6-8-1697

Fr. Gregorio de Haro / Fr. José González

Trespaderne (Burgos)

AGN, Irache, Lib. 549, 114v.

FRANCISCO DE LAMA

B. A. / B. T. / L. T. / D. T.

7-8-1697 / 9-4-1699

Fr. Plácido Vea / Fr. José González / Fr.

Gregorio de Prado, Abad

Los Arcos (Pamplona)

Canónigo de Puebla de los Ángeles

AGN, Irache, Lib. 549, 115r, 133v.

\section{BASILIO DE ARRANEGUI}

B. A. / B. M.

25-8-1697

Fr. José González / Fr. Gregorio de Haro /

Miguel Atondo

Aoiz (Pamplona)

AGN, Irache, Lib. 549, 115r.

JUAN GUILLERMO PELAZA

B. $\mathrm{M}$.

31-8-1697

Fr. Gregorio de Haro / Miguel Atondo

Pareto (Milán)

B. A. en Salerno

AGN, Irache, Lib. 549, 115r.

JUAN LLOP Y LÓPEZ

B. A. / B. M.

13-9-1697

Fr. Gregorio de Haro / Fr. José González //

Antonio Olano

Retascón (Zaragoza)

AGN, Irache, Lib. 549, 115r.

\section{FRANCISCO DÍAZ}

B. C.

18-9-1697

Fr. Gregorio de Haro / Fr. José González

Quijas (Burgos)

AGN, Irache, Lib. 549, 115v.

\section{JUAN FRANCO}

B. A. / B. M.

29-9-1697

Fr. Ángel Benito // Miguel Atondo

Cascante (Tarazona)

AGN, Irache, Lib. 549, 115v.

\section{SIMÓN FERNÁNDEZ GARCÍA}

B. C.

30-9-1697

Fr. Gregorio de Haro / Fr. Plácido Vea

Bocos (Burgos)

AGN, Irache, Lib. 549, 115v.

\section{ANDRÉS SERRANO}

B. A. / B. T.

7-10-1697

Fr. Ángel Benito / Fr. José González

Salas de los Infantes (Burgos)

AGN, Irache, Lib. 549, 115v-116r.

JUAN DE VALMASEDA

B. C.

10-10-1697

Fr. Gregorio de Haro / Fr. Plácido Vea

Villarcayo (Burgos)

AGN, Irache, Lib. 549, 116r.

\section{FRANCISCO DE OCHANDIANO}

B. C.

13-10-1697

Fr. Plácido Vea / Fr. Ángel Benito

Salas de los Infantes (Burgos)

AGN, Irache, Lib. 549, 116r.

TOMÁS DE MATUTE

B. A. / B. M.

16-10-1697

Fr. José González / Fr. Ángel Benito // An-

tonio Olano

Estella (Pamplona)

AGN, Irache, Lib. 549, 116r. 
MIGUEL DE OTEIZA

B. M.

17-10-1697

Fr. Gregorio de Haro / Miguel Atondo

Estella (Pamplona)

B. A. en Oñate

AGN, Irache, Lib. 549, 116v.

JERÓNIMO BARDAJÍ Y GUZMÁN

B. A. / B. M.

18-10-1697

Fr. José González / Fr. Ángel Benito // Miguel Atondo

Tarazona

AGN, Irache, Lib. 549, 116v.

B. M.

$-/ 10-1697$

[Un médico, no dijo cómo se llamaba. Se llevó calabaza]

$\mathrm{Al}$ margen

AGN, Irache, Lib. 549, 116v.

GASPAR VÉLEZ DE ONTAÑÓN

B. A. / B .T.

31-10-1697

Fr. José González / Fr. Ángel Benito

Castillo (Burgos)

AGN, Irache, Lib. 549, 117 r.

JERÓNIMO MONCALIÁN

B. C.

4-11-697

Fr. Gregorio de Haro / Fr. Juan de San Martín

Moncalián (Burgos)

AGN, Irache, Lib. 549, 117r.

FELIPE ÁLVAREZ

B. C.

5-11-1697

Fr. Plácido Vea / Fr. Ángel Benito

Quintana de Ojanco (Burgos)

AGN, Irache, Lib. 549, 117r.

JERÓNIMO LÁZARO

B. A. / B. M.
6-11-1697

Fr. Josép González / Fr. Ángel Benito / Antonio Olano

Campillo (Tarazona)

AGN, Irache, Lib. 549, 117r.

FRANCISCO GONZÁLEZ

B. A. / B. T.

13-11-1697

Fr. José González / Fr. Plácido Vea

Villavieja (Burgos)

AGN, Irache, Lib. 549, $117 \mathrm{v}$.

JOSÉ GONZÁLEZ

B. C.

13-11-1697

Fr. Plácido Vea

Villavieja (Burgos)

AGN, Irache, Lib. 549, $117 \mathrm{v}$.

JUAN MARTÍNEZ DE LAISECA

B. C.

17-11-1697

Fr. Ángel Benito / Fr. Gregorio de Haro /

Fr. Juan de San Martín

Ampuero (Burgos)

AGN, Irache, Lib. 549, $117 \mathrm{v}$.

DOMINGO DE AGUIRRE

B. L.

22-11-1697

Fr. Gregorio de Haro / Ldo. Baltasar Lezáun

Tudela (Tarazona)

AGN, Irache, Lib. 549, $117 \mathrm{v}$.

MIGUEL GARCÍA

B. C.

24-11-1697

Fr. Gregorio de Haro / Fr. Juan de San

Martín

Palacios de Benaver (Burgos)

AGN, Irache, Lib. 549, 118r.

JUAN DE VILLADIEGO

B. C.

24-11-1697

Fr. Gregorio de Haro / Fr. Juan de San 
Martín

Hinestrosa (Burgos)

AGN, Irache, Lib. 549, 118r.

JUAN DE ROZAS

B. C.

26-11-1697

Fr. Gregorio de Haro / Fr. Plácido Vea

Cistierna (Burgos)

AGN, Irache, Lib. 549, 118r.

\section{FRANCISCO DE AYALA}

B. A. / B. T.

1-12-1697 / 2-1-1698

Fr. José González / Fr. Anselmo de la Torre

// Fr. Plácido Vea / Fr. Ángel Benito

Logroño (Calahorra)

AGN, Irache, Lib. 549, 118r, 119r.

FRANCISCO AZCONA

L. C.

4-12-1697

Fr. Regente

Lerate (Pamplona)

B. C.

AGN, Irache, Lib. 549, 118v.

\section{ANTONIO DE FRESNEDO}

B. C.

8-12-1697

Fr. Gregorio de Haro / Fr. Anselmo de la

Torre

Castillo (Burgos)

AGN, Irache, Lib. 549, 118v.

\section{CELEDONIO DE CEBALLOS}

B. C.

21-12-1697

Fr. Ángel Benito / Fr. Anselmo de la Torre

Santander (Burgos)

AGN, Irache, Lib. 549, 118v.

\section{SANTIAGO GUTIÉRREZ}

B. C.

21-12-1697

Fr. Ángel Benito / Fr. Anselmo de la Torre

Palacios de Benaver (Burgos)

AGN, Irache, Lib. 549, 119 r.

\section{LUIS DE VELASCO}

B. C.

6-1-1698

Fr. Ángel Benito / Fr. Gregorio de Haro

Noja (Burgos)

AGN, Irache, Lib. 549, 119 r.

\section{DIEGO DE MOREDA}

B. L.

8-1-1698

Fr. Gregorio de Haro / Fr. Plácido Vea //

Ldo. Baltasar Lezaún

Calahorra

AGN, Irache, Lib. 549, 119 r.

MIGUEL DE MORTERUELO

B. A. / B. T.

12-1-1698

Fr. José González / Fr. Plácido Vea

Islares (Burgos)

AGN, Irache, Lib. 549, 119v.

JOSÉ DE ALONAIZ [Asur]

B. C.

20-1-1698

Fr. Ángel Benito / Fr. Gregorio de Haro

Villasur de Herreros (Burgos)

AGN, Irache, Lib. 549, 119v.

ANTONIO URABAIN

B. A.

17-2-1698

Fr. José González / Fr. Anselmo de la Torre

Urbiola (Pamplona)

AGN, Irache, Lib. 549, 119v.

SEBASTIÁN ORTIZ DE LA LAGUNILLA

B. A. / B. T.

22-2-1698

Fr. Plácido Vea / Fr. Ángel Benito

Espinosa de los Monteros (Burgos)

AGN, Irache, Lib. 549, 12 or.

TOMÁS GUTIÉRREZ SOLANA

B. C.

22-2-1698

Fr. Ángel Benito / Fr. José González

Espinosa de los Monteros (Burgos)

AGN, Irache, Lib. 549, 12 or. 
BARTOLOMÉ DE LA CUESTA

B. C.

24-2-1698

Fr. Plácido Vea / Fr. Gregorio de Haro

Olmos de la Picaza (Burgos)

AGN, Irache, Lib. 549, 12 or.

JOSÉ IGNACIO BORRAU

B. T.

4-3-1698

Fr. Gregorio de Haro / Fr. Plácido Vea Anciles (Barbastro)

B. A.

AGN, Irache, Lib. 549, 120 .

JUAN ANTONIO DE AZA

B. C.

5-3-1698

Fr. Plácido Vea / Fr. Ángel Benito

Las Pilas (Burgos)

AGN, Irache, Lib. 549, $120 v$.

GERVASIO DE CASTILLA

B. C.

12-3-1698

Fr. Regente / Fr. Ángel Benito

Rubena (Burgos)

AGN, Irache, Lib. 549, $120 v$.

VENTURA DE BELORADO

B. C.

12-3-1698

Fr. Regente / Fr. Ángel Benito

Belorado (Burgos)

AGN, Irache, Lib. 549, $120 v$.

CARLOS PATRICIO DE PANDO

B. C.

12-3-1698

Fr. Plácido Vea / Fr. Ángel Benito

Burgos

AGN, Irache, Lib. 549, $120 v$.

JUAN GARCÍA URBINA

B. C.

12-3-1698

Fr. Plácido Vea / Fr. Ángel Benito

Vitoria (Burgos)

AGN, Irache, Lib. 549, 121r.

\section{JUAN DE IBEAS RUIZ}

B. C.

12-3-1698

Fr. Plácido Vea / Fr. Ángel Benito

Burgos

AGN, Irache, Lib. 549, 121r.

MANUEL DE SANCHA

B. C.

14-3-1698

Fr. Plácido Vea / Fr. Ángel Benito

Belorado (Burgos)

AGN, Irache, Lib. 549, 121r.

JOSÉ SAINZ

B. A. / B. T.

15-3-1698

Fr. José González / Fr. Plácido Vea

Orgaz de Rubiana (Burgos)

AGN, Irache, Lib. 549, 121 .

FRANCISCO ANTONIO DE LA SIERRA

B. A. / B. T.

15-3-1698

Fr. José González / Fr. Plácido Vea

Valle de Onésimo (Burgos)

AGN, Irache, Lib. 549, 121v.

JUAN RUIZ

B. C.

22-3-1698

Fr. Gregorio de Haro / Fr. Plácido Vea

Barrio Panizares (Burgos)

AGN, Irache, Lib. 549, 121v.

FERNANDO ANTONIO ORTIZ

B. C.

23-3-1698

Fr. Plácido Vea / Fr. Ángel Benito

Valle de Meruelo (Burgos)

AGN, Irache, Lib. 549, $121 \mathrm{v}$.

ANTONIO DE URABAIN

B. $\mathrm{M}$.

24-3-1698

Fr. Ángel Benito / Fr. Anselmo de la Torre

/ Miguel Atondo

Urbiola (Pamplona) 
B. A.

AGN, Irache, Lib. 549, 121v.

\section{ANTONIO IGLESIAS}

B. C.

7-4-1698

Fr. Gregorio de Haro / Fr. Plácido Vea

Sasamón (Burgos)

AGN, Irache, Lib. 549, 122 r.

BARTOLOMÉ DE ARCE

B. C.

8-4-1698

Fr. Plácido Vea / Fr. Ángel Benito

Arcellares (Burgos)

AGN, Irache, Lib. 549, 122 .

JUAN ANTONIO DE LA LASTRA

B. C.

10-4-1698

Fr. Ángel Benito / Fr. Gregorio de Haro

Meruelo (Burgos)

AGN, Irache, Lib. 549, 122 r.

MANUEL BRACERAS SALAZAR

B. C.

15-4-1698

Fr. Gregorio de Haro / Fr. Plácido Vea

Arceniaga (Burgos)

AGN, Irache, Lib. 549, 122 r.

ANDRÉS GONZÁLEZ DE LA TORRE Y AGUIRRE

B. C.

17-4-1698

Fr. Plácido Vea / Fr. Ángel Benito

Burgos

AGN, Irache, Lib. 549, 122v.

MARTÍN LÓPEZ GARCÍA

B. C.

17-4-1698

Fr. Plácido Vea / Fr. Ángel Benito

Santovenia (Burgos)

AGN, Irache, Lib. 549, $122 \mathrm{v}$.

LEONANDO DE LOS ROSALES

B. C.
20-4-1698

Fr. Gregorio de Haro / Fr. Plácido Vea

Medina de Pomar (Burgos)

AGN, Irache, Lib. 549, $122 \mathrm{v}$.

\section{PEDRO RUIZ DE QUINTANA}

B. C.

3-5-1698

Fr. Ángel Benito / Fr. Plácido Vea

Poza (Burgos)

AGN, Irache, Lib. 549, 123 r.

\section{ANTONIO PELEGRÍN}

B. C.

11-5-1698

Fr. Gregorio de Haro / Fr. Juan de San

Martín

Santoña (Burgos)

AGN, Irache, Lib. 549, 123 r.

JUAN DE CARRIGAL Y GUYMES

B. C.

21-5-1698

Fr. Ángel Benito / Fr. Gregorio de Haro

Valle de Hoz (Burgos)

AGN, Irache, Lib. 549, 123 r.

JUAN PÉREZ CARDADOR

B. A. / B. T.

4-6-1698

Fr. José González / Fr. Ángel Benito

Castrillo de Río Pisuerga (Burgos)

AGN, Irache, Lib. 549, 123v.

BALTASAR VICENTE IÑIIGUEZ

B. A. / B. M.

7-6-1698

Fr. José González / Fr. Ángel Benito // An-

tonio Olano

Santa Engracia (Calahorra)

Estudiante en Alcalá

AGN, Irache, Lib. 549, $123 \mathrm{v}$.

JUAN ANTONIO DEL MAZO

B. C.

10-6-1698

Fr. Plácido Vea / Fr. Ángel Benito

Castillo (Burgos)

AGN, Irache, Lib. 549, 123v. 
JOSÉ ROMEO

B. A. / B. M.

18-6-1698

Fr. José González / Fr. Ángel Benito // Antonio Olano

Sangüesa (Burgos)

AGN, Irache, Lib. 549, 123v.

JOSÉ DE VAL

L. T.

27-6-1698

Fr. P. Abad / Fr. Ángel Benito

Cameno (Burgos)

B. A. y B. T.

AGN, Irache, Lib. 549, 124r.

\section{BERNABÉ ARENAS}

B. C.

30-6-1698

Fr. Plácido Vea, regente / Fr. Juan de San Martín

Belitre (Burgos)

AGN, Irache, Lib. 549, 124r.

MIGUEL DE MEOZ

B. A. / B. M.

3-7-1698

Fr. Plácido Vea / Fr. José González // Antonio Olano

Aoiz (Pamplona)

Estudios en Zaragoza

AGN, Irache, Lib. 549, 124r.

\section{DIEGO EMELGO}

B. M.

13-7-1698

Fr. Ángel Benito / Fr. Juan de San Martín

// Miguel Atondo

Bercero (Valladolid)

Estudiante en Valladolid

AGN, Irache, Lib. 549, 124v.

\section{ANTONIO GARCÍA}

B. C.

6-8-1698

Fr. Gregorio de Haro / Fr. Ángel Benito

Presencio (Burgos)

AGN, Irache, Lib. 549, 124v.
FRANCISCO ANTONIO GONZÁLEZ CA$\mathrm{CHO}$

B. C.

16-8-1698

Fr. Ángel Benito / Fr. Gregorio de Haro

Polanco (Burgos)

AGN, Irache, Lib. 549, 124v.

JOSÉ MAYOR

B. C.

19-8-1698

Fr. Ángel Benito / Fr. Gregorio de Haro

Presencio (Burgos)

AGN, Irache, Lib. 549, 125r.

\section{GABRIEL RODRIGO}

B. C.

19-8-1698

Fr. Gregorio de Haro / Fr. Ángel Benito

Presencio (Burgos)

AGN, Irache, Lib. 549, 125r.

MARTÍN MERINO

B. C.

19-8-1698 / 29-8-1698

Fr. Gregorio de Haro / Fr. Ángel Benito

Reprobado / Suficiente

Sanfuentes (Burgos)

AGN, Irache, Lib. 549, 125rv.

\section{SIMÓN DE LUNA}

B. A.

27-8-1698

Fr. José González / Fr. Anselmo de la Torre Jubera (Calahorra)

AGN, Irache, Lib. 549, 125v.

JOSÉ MATÍAS BERBEGAL

B. A. / B. M.

7-9-1698

Fr. José González / Fr. Gregorio de Haro /

Miguel Atondo

Barbáguena (Zaragoza)

AGN, Irache, Lib. 549, $125 \mathrm{v}$.

TOMÁS DE VILLUENDAS

B. $\mathrm{M}$.

17-9-1698 
Fr. Gregorio de Haro / Fr. Ángel Benito / Miguel Atondo

Cortes de Daroca (Zaragoza)

B. A. en Zaragoza

AGN, Irache, Lib. 549, 126r.

\section{BALTASAR MARTÍNEZ PARDO}

B. A. / B. T.

29-9-1698 / 18-12-1698

Fr. José González / Fr. Plácido Vea

Reprobado Teología

Ezcaray (Burgos)

AGN, Irache, Lib. 549, 126r, 13 or.

\section{SANTIAGO SEGURA}

B. A. / B. T.

5-10-1698

Fr. Anselmo de la Torre / Fr. Gregorio de

Haro

Burgos

AGN, Irache, Lib. 549, 126r.

BALTASAR SAINZ DE LA FUENTE

B. C.

13-10-1698

Fr. Plácido Vea / Fr. Gregorio de Haro

Reprobado

Regules (Burgos)

AGN, Irache, Lib. 549, 126v.

FRANCISCO DEL RÍO MIERA

B. C.

17-10-1698

Fr. Plácido Vea / Fr. Ángel Benito

Solórzano (Burgos)

AGN, Irache, Lib. 549, 126v.

JOSÉ GRAN

B. A. / B. M.

21-10-1698

Fr. Ángel Benito / Fr. Gregorio de Haro /

Fr. José González // Miguel Atondo

Jarque (Zaragoza)

AGN, Irache, Lib. 549, 126v.

JUAN VENTURA ZUGARRONDO

B. M.

26-10-1698
Fr. Gregorio de Haro / Fr. Plácido Vea // Antonio Olano

Estella (Pamplona)

B. A. en Irache

Estudios de Medicina en Zaragoza

AGN, Irache, Lib. 549, 127r.

ANDRÉS ARNÁIZ

B. C.

6-11-1698

Fr. Plácido Vea / Fr. Ángel Benito

San Pedro de la Hoz (Burgos)

AGN, Irache, Lib. 549, 127r.

DIEGO PÉREZ

L. T. / D. T.

10-11-1698

Fr. Ángel Benito / Fr. Anselmo de la Torre / Fr. P. Abad

Autol (Calahorra)

B. A. y B. T. en Salamanca

AGN, Irache, Lib. 549, 127 rv.

FERNANDO ANTONIO DE CARIGA Y PALACIO

B. C.

15-11-1698

Fr. Ángel Benito / Fr. Gregorio de Haro

Carasa (Burgos)

AGN, Irache, Lib. 549, $127 \mathrm{v}$.

\section{MELCHOR ÁLVAREZ CARRERA}

B. $\mathrm{M}$.

17-11-1698

Fr. Plácido Vea / Fr. Gregorio de Haro //

Miguel Atondo

Villahoz (Burgos)

B. A.

AGN, Irache, Lib. 549, 127v-128r.

\section{PRUDENCIO RUBIO}

L. L. / D. L.

17-11-1698

Fr. Gregorio de Prado, Abad, Rector y Canciller

Tarazona

B. L. en Zaragoza

AGN, Irache, Lib. 549, 128r. 
FRANCISCO DE MEDIAVILLA

B. A. / B. T.

19-11-1698

Fr. Ángel Benito / Fr. José González

Frías (Burgos)

AGN, Irache, Lib. 549, 128v.

JUAN ANTONIO DE URBINA

B. A. / B. T.

19-11-1698

Fr. Ángel Benito / Fr. José González

Frías (Burgos)

AGN, Irache, Lib. 549, 128v.

\section{MARCELO BASCONES}

B. C.

24-11-1698 / 3-5-1699

Fr. Plácido Vea / Fr. Gregorio de Haro

Reprobado

Reprobado por incapaz

Modúbar de San Cibrián (Burgos)

AGN, Irache, Lib. 549, 128v, 136r.

PEDRO DE ARCE Y LEIVA

B. C.

25-11-1698

Fr. Plácido Vea / Fr. Gregorio de Haro

Carasa (Burgos)

AGN, Irache, Lib. 549, 129 r.

CARLOS DE LA PEÑA

B. C.

26-11-1698

Fr. Ángel Benito / Fr. Gregorio de Haro

Salinas de Rosío (Burgos)

AGN, Irache, Lib. 549, 129 r.

PEDRO DE RÁBAGO

B. C.

27-11-1698

Fr. Ángel Benito / Fr. Gregorio de Haro

Celada de Calderones (Burgos)

AGN, Irache, Lib. 549, 129 r.

\section{JUAN BLANCO}

B. C.

1-12-1698 / 3-12-1698

Fr. Plácido Vea / Fr. Ángel Benito
Reprobado

Fr. Gregorio de Haro / Fr. José González

Pozancos (Burgos)

AGN, Irache, Lib. 549, $129 v$.

\section{FRANCISCO GONZÁLEZ}

B. C.

5-12-1698

Fr. Ángel Benito / Fr. Gregorio de Haro

Melgar de Fernamental (Burgos)

AGN, Irache, Lib. 549, 129v.

JOSÉ DE SOTO

B. C.

5-12-1698

Fr. Ángel Benito / Fr. Gregorio de Haro

Castrojeriz (Burgos)

AGN, Irache, Lib. 549, 13 or.

FELIPE RUIZ DE SALAZAR

B. A. / B. T.

8-12-1698

Fr. Plácido Vea / Fr. José González

Salazar (Burgos)

AGN, Irache, Lib. 549, 13 or.

ANTONIO DE HERRERA VELARDE

B. C.

19-12-1698

Fr. Ángel Benito / Fr. Gregorio de Haro

Melgar de Fernamental (Burgos)

AGN, Irache, Lib. 549, $130 v$.

JUAN DÍAZ ALBIZ BORRICÓN

B. A. / B. T.

11-1-1699

Fr. Plácido Vea / Fr. José González

Ezcaray (Burgos)

AGN, Irache, Lib. 549, $130 v$.

GREGORIO MARCOS BALLESTERO

B. C.

11-2-1699

Fr. Plácido Vea / Fr. Ángel Benito

Villasandino (Burgos)

AGN, Irache, Lib. 549, $130 v$.

JUAN ANTONIO CORRAL MERINO

B. C. 
11-2-1699

Fr. Plácido Vea / Fr. Ángel Benito

Sasamón (Burgos)

AGN, Irache, Lib. 549, $130 v$.

ALONSO GARCÍA

B. A. / B. T.

21-2-1699

Fr. Ángel Benito / Fr. José González

Villaveta

Abadía de Covarrubias

AGN, Irache, Lib. 549, 131r.

JOSÉ GERMÁN

B. A. / B. T. / L. T. / D. T.

23-2-1699 / 24-2-1699

Fr. Gregorio de Prado, Abad, Rector y Can-

ciller

Malanquilla (Tarazona)

AGN, Irache, Lib. 549, 131r.

BERNARDINO ALMANSA

B. A. / B. T.

3-3-1699

Fr. Plácido Vea / Fr. José González

Burgos

AGN, Irache, Lib. 549, $131 v$.

EUSEBIO DE PALOMERA VALLEJO

B. C.

9-3-1699

Fr. Ángel Benito / Fr. Gregorio de Haro

Anza. Valle de Mena (Burgos)

AGN, Irache, Lib. 549, 131v.

JUAN YÁNGÜEZ

B. C.

10-3-1699

Fr. Gregorio de Haro / Fr. Plácido Vea

Santa María del Campo (Burgos)

AGN, Irache, Lib. 549, 132r.

FRANCISCO LÓPEZ RIVAS

B. C.

11-3-1699

Fr. Plácido Vea / Fr. Gregorio de Haro

Barbadillo de Herreros (Burgos)

AGN, Irache, Lib. 549, 132r.

\section{LÁZARO RUIZ DE SILLARIO}

B. C.

11-3-1699

Fr. Gregorio de Haro / Fr. Juan de San

Martín

Entrambasaguas,Valle de Mena (Burgos)

AGN, Irache, Lib. 549, 132r.

JOSÉ GARCÍA DE OYUELOS

B. C.

23-3-1699

Fr. Plácido Vea / Fr. Gregorio de Haro

Canales (Burgos)

AGN, Irache, Lib. 549, 132v.

CARLOS ALONSO DE ARCE

B. C.

25-3-1699

Fr. Plácido Vea / Fr. Gregorio de Haro

Burgos

AGN, Irache, Lib. 549, 132v.

TOMÁS DE ISLA

B. A. / B. T.

26-3-1699

Fr. Gregorio de Haro / Fr. José González

Gumiel del Mercado (Osma)

AGN, Irache, Lib. 549, 132v.

JUAN GARCÍA

B. C.

26-3-1699

Fr. Gregorio de Haro / Fr. José González

Villaneta

Abadía de Covarrubias

AGN, Irache, Lib. 549, 133r.

FERNANDO ORTÚÑEZ

B. A. / B. T.

3-4-1699

Fr. Gregorio de Haro / Fr. José González

Villaneta

Abadía de Covarrubias

AGN, Irache, Lib. 549, 133r.

FRANCISCO DE HERNANDO

B. C.

8-4-1699 
Fr. Plácido Vea / Fr. Gregorio de Haro Aguera (Burgos)

AGN, Irache, Lib. 549, 133v.

ANTONIO DE LA HELGUERA

B. C.

13-4-1699

Fr. Plácido Vea / Fr. Juan de San Martín

Otañes (Burgos)

AGN, Irache, Lib. 549, 133v.

MANUEL GONZÁLEZ

B. C.

13-4-1699

Fr. Plácido Vea / Fr. Juan de San Martín

Burgos

AGN, Irache, Lib. 549, 134r.

FRANCISCO GARCÍA DE EULATE

B. M.

14-4-1699

Fr. Plácido Vea / Fr. Juan de San Martín Larraona (Pamplona)

B. A.

Estudios de Medicina en Zaragoza

AGN, Irache, Lib. 549, 134r.

JOSÉ MIGUEL LORCA

B. A. / B. T.

18-4-1699

Fr. Plácido Vea / Fr. José González

O. Cist.

Pamplona

Monasterio de Iranzu

AGN, Irache, Lib. 549, 134v.

BENITO GUEMBE

B. A. / B. T.

18-4-1699

Fr. Plácido Vea / Fr. José González

O. Cist.

Pamplona

Monasterio de Iranzu

AGN, Irache, Lib. 549, 134v.

\section{ANTONIO ROS}

B. A. / B .T.

18-4-1699
Fr. Plácido Vea / Fr. José González

O. Cist.

Pamplona

Monasterio de Iranzu

AGN, Irache, Lib. 549, 134v.

MATÍAS DE ARANA Y ANDRACA

B. A. / B. T. / L. T. / D. T.

23-4-1699 / 24-4-1699

Fr. Plácido Vea / Fr. José González / Fr.

Gregorio de Prado, Abad y Rector

Luyando (Calahorra)

AGN, Irache, Lib. 549, 134v-135r.

\section{MANUEL DE CIGARÁN}

B. A.

24-4-1699

Fr. José González / Fr. Anselmo de La Torre

Marquina (Calahorra)

AGN, Irache, Lib. 549, 135r.

JUAN DE ZULAICA

B. A. / L. A.

24-4-1699

Fr. José González / Fr. Anselmo de la Torre

/ Fr. Gregorio del Prado, Abad y Rector

Aya (Pamplona)

AGN, Irache, Lib. 549, 135r.

MIGUEL DE SOS LUMBIER

B. A. / B. T. / L. T. / D. T.

2-5-1699

Fr. Ángel Benito / Fr. José González / Fr.

Gregorio del Prado, Abad y Rector

O. C.

Prior del Carmen de Jaca

AGN, Irache, Lib. 549, 135v.

IGNACIO MARTÍNEZ

B. A. / B. T.

9-5-1699

Fr. Ángel Benito / Fr. José González

Villegas (Burgos)

AGN, Irache, Lib. 549, 136r.

JUAN FRANCISCO PÉREZ DE AMALLO

B. C. 
12-5-1699

Fr. Plácido Vea / Fr. Gregorio de Haro

Guriezo (Burgos)

AGN, Irache, Lib. 549, 136r.

\section{GASPAR VALLEJO}

B. C.

15-5-1699

Fr. Ángel Benito / Fr. Gregorio de Haro

Anzo. Valle de Mena (Burgos)

AGN, Irache, Lib. 549, 136r.

BERNARDINO MACÍAS SANTALLA

B. C. / L. C.

16-5-1699

Fr. Gregorio de Haro / Fr. Gregorio del Prado, Abad y Rector

Ponferrada (Astorga)

AGN, Irache, Lib. 549, 136v.

FRANCISCO MACÍAS SANTALLA

B. A.

17-5-1699

Fr. José González / Fr. Anselmo de la Torre

Ponferrada (Astorga)

AGN, Irache, Lib. 549, 136v.

CARLOS DE LA PEÑA

B. C.

19-5-1699

Fr. Gregorio de Haro / Fr. Ángel Benito

Grijalba (Burgos)

AGN, Irache, Lib. 549, 137r.

\section{GREGORIO MARTÍNEZ}

B. A. / B. C.

22-5-1699

Fr. José González / Fr. Ángel Benito

Reprobado

Fr. Gregorio de Haro

Castrillo del Val (Burgos)

AGN, Irache, Lib. 549, 137r.

\section{ANTONIO LIZÓN}

B. C.

25-5-1699

Fr. Plácido Vea / Fr. Ángel Benito

Miranda de Arga (Pamplona)
Estudiante en Huesca y Valladolid

AGN, Irache, Lib. 549, 137r.

FRANCISCO DE URIOSTE

B. A. / B. T.

27-5-1699

Fr. Plácido Vea / Fr. Gregorio de Haro

Santurce (Burgos)

AGN, Irache, Lib. 549, 137v.

LUCAS PÉREZ

B. C.

1-6-1699

Fr. Ángel Benito / Fr. Gregorio de Haro

Puras (Burgos)

AGN, Irache, Lib. 549, $137 \mathrm{v}$.

JOSÉ SANZ

B. A.

4-6-1699

Fr. Gregorio de Haro / Fr. Plácido Vea

Alfaro (Tarazona)

AGN, Irache, Lib. 549, 137v.

\section{BERNARDO GONZÁLEZ}

B. A. / L. A.

4-6-1699

Fr. Plácido Vea / Fr. Gregorio de Prado, Abad y Rector

Pamplona

AGN, Irache, Lib. 549, 138r.

DOMINGO DE LA CANTERA

B. C.

7-6-1699

Fr. Ángel Benito / Fr. Gregorio de Haro

San Martín de Losa (Burgos)

AGN, Irache, Lib. 549, 138r.

BERNARDO LABORA

B. A. / B. M.

8-6-1699 /13-12-1699

Fr. Gregorio de Haro / Fr. Ángel Benito //

Miguel Atondo

Reprobado / Suficiente

Albalate (Zaragoza)

AGN, Irache, Lib. 549, 138r, 15orv. 
GABRIEL DE BAÑARES

B. A. / B. T.

12-6-1699

Fr. Plácido Vea / Fr. Ángel Benito

Cartañares de Rioja (Calahorra)

AGN, Irache, Lib. 549, 138v.

PLÁCIDO DE PINILLOS

B. A. / B. T. / L. T. / D. T.

15-6-1699 / 16-6-1699

Fr. Plácido Vea / Fr. Ángel Benito / Fr. Gre-

gorio de Prado, Abad y Rector

O.S. B.

Predicador Mayor en San Martín de Santiago

San Millán de la Cogolla

AGN, Irache, Lib. 549, 138v.

FELIPE DE LA PEÑA

B. C.

19-6-1699

Fr. Gregorio de Haro / Fr. Ángel Benito

Castellanos (Burgos)

AGN, Irache, Lib. 549, 138v.

MATEO JOSÉ DE CUÉLLAR CARRASCO

B. A. / B. T.

22-6-1699

Fr. Plácido Vea / Fr. Ángel Benito

Pancorbo (Burgos)

AGN, Irache, Lib. 549, 139r.

\section{SEBASTIÁN GÓMEZ DE FONCEA}

B. A. / B. T.

22-6-1699

Fr. Ángel Benito / Fr. Plácido Vea

Pancorbo (Burgos)

AGN, Irache, Lib. 549, 139 r.

JUAN BAUTISTA MORQUECHO

B. A. / B. T.

22-6-1699

Fr. Gregorio de Haro / Fr. Plácido Vea

Pancorbo (Burgos)

AGN, Irache, Lib. 549, 139r.

\section{JUAN ORBAÑANOS CANTERA}

B. C.
29-6-1699

Fr. Plácido Vea / Fr. Ángel Benito

Santa María de Garoña (Burgos)

Pbro.

AGN, Irache, Lib. 549, 139v.

\section{MANUEL DE PORRES}

B. M.

2-7-1699

Fr. Ángel Benito / Fr. Gregorio de Haro /

Antonio Olano

Valgañón (Burgos)

B. A. en Ávila

AGN, Irache, Lib. 549, 139v.

LUCAS MARTÍNEZ DE MONTERRUBIO

B. C.

5-7-1699

Fr. Gregorio de Haro / Fr. Plácido Vea

Pancorbo (Burgos)

AGN, Irache, Lib. 549, 139v.

JUAN ANTONIO DE LA CÁRCOBA

B. A. / B. T.

6-7-1699

Fr. Plácido Vea / Fr. Ángel Benito

Miera (Burgos)

AGN, Irache, Lib. 549, 139v.

JUAN CARRASCO

B. C.

14-7-1699

Fr. Gregorio de Haro / Fr. Ángel Benito

Villahizán (Burgos)

AGN, Irache, Lib. 549, 14 or.

LUCAS FERNÁNDEZ VEDÓN

B. C.

16-7-1699

Fr. Plácido Vea / Fr. Ángel Benito

Valladolid

AGN, Irache, Lib. 549, 140r.

FRANCISCO BERNAD

B. A. / B. M.

18-7-1699 / 1-8-1699 // 3-8-1699 / 30-9-

1700

Fr. Ángel Benito / Fr. Gregorio de Haro 
Reprobado / Suficiente

Fr. Gregorio de Haro / Fr. Plácido Vea // Antonio Olano

Fr. Gregorio de Haro / Fr. Anselmo de la Torre / Miguel Atondo

Valverde (Zaragoza)

Tarazona

AGN, Irache, Lib. 549, 140rv, 158v.

MANUEL LÓPEZ DE BRIZUELA

B. A. / B. T.

24-7-1699

Fr. Gregorio de Haro / Fr. Plácido Vea

Brizuela (Burgos)

AGN, Irache, Lib. 549, 14 or.

\section{MANUEL DE ABAJO Y MASSA}

B. A. / B. T.

24-7-1699

Fr. Ángel Benito / Fr. Gregorio de Haro

Burgos

AGN, Irache, Lib. 549, $140 v$.

TOMÁS DE LOS RÍOS VELASCO

B. C.

25-7-1699

Fr. Plácido Vea / Fr. Ángel Benito

Villamartín (Burgos)

AGN, Irache, Lib. 549, $140 v$.

FRANCISCO CORTÉS

B. C.

27-7-1699

Fr. Plácido Vea / Fr. Gregorio de Haro

Quintana (Burgos)

AGN, Irache, Lib. 549, $140 v$.

JUAN DE ROJAS

B. C.

8-8-1699

Fr. Plácido Vea / Fr. Ángel Benito

Salazar (Burgos)

AGN, Irache, Lib. 549, 141r.

\section{MANUEL VALLEJO}

B. A. / B. T.

8-8-1699

Fr. Plácido Vea / Fr. Gregorio de Haro
Salazar (Burgos)

AGN, Irache, Lib. 549, 141r.

TOMÁS GÓMEZ DE ARROYO

B. C.

20-8-1699

Fr. Plácido Vea / Fr. Gregorio de Haro

Hormazas (Burgos)

AGN, Irache, Lib. 549, 141r.

PEDRO SAINZ

B. A. / B. T.

28-8-1699

Fr. Ángel Benito / Fr. Gregorio de Haro

Villegas (Burgos)

AGN, Irache, Lib. 549, 141v.

BARTOLOMÉ DE LA ROBA

B. C.

28-8-1699

Fr. Ángel Benito / Fr. Gregorio de Haro

Villaizán (Burgos)

AGN, Irache, Lib. 549, 141v.

JUAN ALONSO DE CELADA

B. C.

3-9-1699

Fr. Ángel Benito / Fr. Gregorio de Haro

Moneo (Burgos)

AGN, Irache, Lib. 549, 141v.

\section{MANUEL VÉLEZ FRÍAS}

B. C.

3-9-1699

Fr. Ángel Benito / Fr. Gregorio de Haro

Villapanillo (Burgos)

AGN, Irache, Lib. 549, 142r.

BLAS MARTÍNEZ DE VALMAYOR

B. C.

4-9-1699

Fr. Ángel Benito / Fr. Gregorio de Haro

Moneo (Burgos)

AGN, Irache, Lib. 549, 142r.

PEDRO BAYUELO TOLILLO

B. A.

8-9-1699 
Fr. Ángel Benito / Fr. Gregorio de Haro Alfaro (Tarazona)

Estudiante en Zaragoza

AGN, Irache, Lib. 549, 142r.

\section{SEBASTIÁN DE SAN MARTÍN}

B. A. / B. T.

10-9-1699

Fr. Ángel Benito / Fr. Gregorio de Haro

Briviesca (Burgos)

AGN, Irache, Lib. 549, $142 \mathrm{v}$.

BARTOLOMÉ MARTÍNEZ DE LA HERA

B. C.

12-9-1699

Fr. Ángel Benito / Fr. Gregorio de Haro

Villegas (Burgos)

AGN, Irache, Lib. 549, 142v.

JOSÉ ORTIZ

B. A./ B. T.

14-9-1699

Fr. Gregorio de Haro / Fr. Ángel Benito

Trepiana (Burgos)

AGN, Irache, Lib. 549, 142v.

MARCOS GUTIÉRREZ DE LA MORA

B. C.

15-9-1699

Fr. Ángel Benito / Fr. Gregorio de Haro

Reinosa (Burgos)

AGN, Irache, Lib. 549, 143r.

JUAN LÓPEZ

B. A. / B. M.

15-9-1699

Fr. Gregorio de Haro / Fr. Ángel Benito //

Antonio Olano

Rocaforte (Pamplona)

AGN, Irache, Lib. 549, 143r.

MARCOS DE PEDROSO

B. C.

16-9-1699

Fr. Ángel Benito / Fr. Gregorio de Haro

Briones (Calahorra)

AGN, Irache, Lib. 549, 143r.
MIGUEL RUIZ VELASCO

B. C.

17-9-1699

Fr. Gregorio de Haro / Fr. Ángel Benito

Calahorra

AGN, Irache, Lib. 549, $143 v$.

\section{JUAN MIRANDA}

B. C.

17-9-1699

Fr. Gregorio de Haro / Fr. Ángel Benito

Calahorra

AGN, Irache, Lib. 549, $143 v$.

FRANCISCO GARCÍA

B. A. / B. T.

20-9-1699

Fr. Ángel Benito / Fr. Plácido Vea

Sigüenza (Burgos)

AGN, Irache, Lib. 549, $143 v$.

GREGORIO DE HARO

B. A. / B. T. / L. T. / D. T.

20-9-1699

Fr. Gregorio de Prado, Abad y Rector

O. S. B.

Lector de Teología en Irache

AGN, Irache, Lib. 549, $143 \mathrm{~V}$.

DIEGO GARCÍA DE LA MATA

B. C.

22-9-1699

Fr. Plácido Vea / Fr. Ángel Benito

Matamoros (Burgos)

AGN, Irache, Lib. 549, 144r.

FRANCISCO GARCÍA ARROYO

B. C.

24-9-1699

Fr. Ángel Benito / Fr. Gregorio de Haro

Céspedes (Burgos)

AGN, Irache, Lib. 549, 144r.

FRANCISCO ORTIZ VELA

B. C.

26-9-1699

Fr. Plácido Vea / Fr. Ángel Benito

Quintanilla de Bon (Burgos)

AGN, Irache, Lib. 549, 144r. 
AGUSTÍN LÓPEZ ANGULO

B. C.

26-9-1699

Fr. Plácido Vea / Fr. Ángel Benito

Cascajares (Burgos)

AGN, Irache, Lib. 549, 144v.

FRANCISCO PAGOLA

B. C. / L. C.

28-9-1699

Fr. Gregorio de Prado, Abad y Rector

Andosilla (Pamplona)

Canónigo y Tesorero de Calahorra

AGN, Irache, Lib. 549, 144v.

\section{PEDRO MEDIANO}

B. L.

30-9-1699

Fr. Plácido Vea / Fr. Gregorio de Haro / Dr.

José Briones

Tudela (Tarazona)

AGN, Irache, Lib. 549, 145r.

JUAN MUÑOZ

B. L.

30-9-1699

Fr. Plácido Vea / Fr. Gregorio de Haro / Dr.

José Briones

Tudela (Tarazona)

AGN, Irache, Lib. 549, 145r.

\section{MANUEL VELASCO}

B. C.

5-10-1699

Fr. Ángel Benito / Fr. Gregorio de Haro

Villanueva de Odra (Burgos)

AGN, Irache, Lib. 549, 145r.

DIEGO RUIZ

B. C.

5-10-1699

Fr. Ángel Benito / Fr. Gregorio de Haro

Villegas (Burgos)

AGN, Irache, Lib. 549, 145r.

JOSÉ ALONSO

B. C.

9-10-1699
Fr. Plácido Vea / Fr. Ángel Benito

Ros (Burgos)

AGN, Irache, Lib. 549, 145r.

JOSÉ GIL DE RAMALES

B. C.

12-10-1699

Fr. Ángel Benito / Fr. Gregorio de Haro

Presencio (Burgos)

AGN, Irache, Lib. 549, 145v.

\section{FRANCISCO BOCANEGRA}

B. C.

12-10-1699

Fr. Ángel Benito / Fr. Gregorio de Haro

Gradilla de Sedano (Burgos)

AGN, Irache, Lib. 549, 145v.

AGUSTÍN DE LA CONCHA CEBALLOS

B. C.

13-10-1699

Fr. Plácido Vea / Fr. Ángel Benito

Barrenilla (Burgos)

AGN, Irache, Lib. 549, 145v.

ÁNGEL RODRÍGUEZ VILLALOBOS

B. C.

16-10-1699

Fr. Ángel Benito / Fr. Gregorio de Haro

Sedano (Burgos)

AGN, Irache, Lib. 549, 145v.

FRANCISCO FERNÁNDEZ CALDERÓN

B. C.

19-10-1699

Fr. Gregorio de Haro / Fr. Plácido Vea

Moneo (Burgos)

AGN, Irache, Lib. 549, 146r.

MANUEL DE BURGOS

B. C.

20-10-1699

Fr. Plácido Vea / Fr. Ángel Benito

Mahamud (Burgos)

AGN, Irache, Lib. 549, 146r.

FRANCISCO MONEDERO

B. C. 
23-10-1699

Fr. Ángel Benito / Fr. Gregorio de Haro Valtierra del Río Pisuerga (Burgos)

AGN, Irache, Lib. 549, 146r.

BERNARDO DE LA PEÑA

B. C.

26-10-1699

Fr. Gregorio de Haro / Fr. Plácido Vea

Gradilla de Villamar (Burgos)

AGN, Irache, Lib. 549, 146v.

SILVESTRE VALLE

B. C.

29-10-1699

Fr. Plácido Vea / Fr. Ángel Benito

Escudero (Burgos)

AGN, Irache, Lib. 549, 146v.

FRANCISCO MARTÍNEZ FERNÁNDEZ

B. C.

31-10-1699

Fr. Ángel Benito / Fr. Gregorio de Haro

Castrojeriz (Burgos)

AGN, Irache, Lib. 549, 146v.

JOSÉ ALONSO

B. C.

31-10-1699 / 26-11-1699

Fr. Gregorio de Haro / Fr. Plácido Vea

Reprobado

Gama (Burgos)

AGN, Irache, Lib. 549, 146v, $149 \mathrm{v}$.

SANTIAGO GUTIÉRREZ

B. C.

1-11-1699

Fr. Plácido Vea / Fr. Ángel Benito

Rebolledo (Burgos)

AGN, Irache, Lib. 549, 147 r.

FRANCISCO DE BUSTO

B. C.

2-11-1699

Fr. Ángel Benito / Fr. Gregorio de Haro

Busto (Burgos)

AGN, Irache, Lib. 549, 147r.
ANDRÉS DE CALZADA

B. C.

2-11-1699

Fr. Ángel Benito / Fr. Gregorio de Haro

Cubo (Burgos)

AGN, Irache, Lib. 549, 147r.

ANDRÉS PÉREZ

B. C.

4-11-1699

Fr. Plácido Vea / Fr. Ángel Benito

Presencio (Burgos)

AGN, Irache, Lib. 549, 147r.

FRANCISCO ROLDÁN

B. A. / B. M.

7-11-1699

Fr. Ángel Benito / Fr. Anselmo de la Torre

// Miguel Atondo

Tudela (Tarazona)

AGN, Irache, Lib. 549, $147 \mathrm{v}$.

PEDRO GONZÁLEZ CABALLERO

B. C.

7-11-1699 / 20-4-1700

Fr. Gregorio de Haro / Fr. Ángel Benito

Reprobado

Fr. Ángel Benito / Fr. Plácido Vea

Padilla de Abajo (Burgos)

AGN, Irache, Lib. 549, 147v, 153v.

MANUEL SAINZ

B. C.

9-11-1699

Fr. Plácido Vea / Fr. Ángel Benito

Burgos

AGN, Irache, Lib. 549, 147v.

FRANCISCO GÓMEZ

B. C.

9-11-1699

Fr. Plácido Vea / Fr. Ángel Benito

Burgos

AGN, Irache, Lib. 549, $147 \mathrm{v}$.

DIEGO LEIVA

B. C.

9-11-1699 
Fr. Plácido Vea / Fr. Ángel Benito

Arlanzón (Burgos)

AGN, Irache, Lib. 549, 148r.

JOSÉ FACUNDO DELGADO

B. A. / B. T.

14-11-1699

Fr. Plácido Vea / Fr. Anselmo de la Torre

Burgos

AGN, Irache, Lib. 549, 148r.

MIGUEL DE CIADONCHA

B. A. / B. T.

14-11-1699

Fr. Gregorio de Haro / Fr. Anselmo de la

Torre

Mahamud (Burgos)

AGN, Irache, Lib. 549, 148r.

BERNARDO VILLAFRUELA

B. C.

14-11-1699

Fr. Gregorio de Haro / Fr. Anselmo de la

Torre

Mahamud (Burgos)

AGN, Irache, Lib. 549, 148r.

JUAN HERNÁIZ

B. C.

14-11-1699

Fr. Plácido Vea / Fr. Gregorio de Haro

Canales (Burgos)

AGN, Irache, Lib. 549, 148v.

JACINTO GUTIÉRREZ

B. C.

18-11-1699

Fr. Ángel Benito / Fr. Gregorio de Haro

Matamorisca (Burgos)

AGN, Irache, Lib. 549, 148v.

\section{MANUEL JIMÉNEZ}

B. C.

20-11-1699

Fr. Gregorio de Haro / Fr. Plácido Vea

Burgos

AGN, Irache, Lib. 549, 148v.

\section{SEBASTIÁN ÁLVAREZ}

B. A. / B. C.

21-11-1699 / 10-1-1700

Fr. Anselmo de la Torre / Fr. Plácido Vea // Fr. Ángel Benito / Fr. Gregorio de Haro Revillaruz (Burgos)

AGN, Irache, Lib. 549, 148v, 151r.

JUAN SANZ

B. C.

22-11-1699

Fr. Ángel Benito / Fr. Juan de San Martín

Polientes (Burgos)

AGN, Irache, Lib. 549, 149r.

\section{GASPAR DE SAN LLORENTE}

B. C.

23-11-1699

Fr. Ángel Benito / Fr. Gregorio de Haro

Los Tremellos (Burgos)

AGN, Irache, Lib. 549, 149r.

\section{LUCAS ANTONIO FERNÁNDEZ}

B. A. / B. T.

24-11-1699

Fr. Gregorio de Haro / Fr. Anselmo de la Torre

Nafuentes (Burgos)

AGN, Irache, Lib. 549, 149r.

FELIPE LÓPEZ

B. A. / B. T.

24-11-1699

Fr. Plácido Vea / Fr. Ángel Benito

Burgos

AGN, Irache, Lib. 549, 149r.

DIEGO DE ARIZA

B. C.

28-11-1699

Fr. Ángel Benito / Fr. Juan de San Martín

Sasamón (Burgos)

AGN, Irache, Lib. 549, $149 \mathrm{v}$.

FRANCISCO LORENZO

B. C.

1-12-1699

Fr. Gregorio de Haro / Fr. Ángel Benito 
Burgos

AGN, Irache, Lib. 549, 149v.

BERNARDO DÍEZ AGUSTÍN

B. C.

4-12-1699

Fr. Plácido Vea / Fr. Gregorio de Haro

Ubierna (Burgos)

AGN, Irache, Lib. 549, 149v.

TOMÁS DEL CAMPILLO

B. C.

6-12-1699

Fr. Ángel Benito / Fr. Plácido Vea

Quintana (Burgos)

AGN, Irache, Lib. 549, 150r.

FRANCISCO ORTEGA

B. C.

7-12-1699

Fr. Gregorio de Haro / Fr. Juan de San Martín

Burgos

AGN, Irache, Lib. 549, 15 or.

JOSÉ SAINZ

B. C.

9-12-1699 / 7-4-1700

Fr. Plácido Vea / Fr. Ángel Benito

Reprobado

Fr. Plácido Vea / Fr. Anselmo de la Torre

Sasamón (Burgos)

AGN, Irache, Lib. 549, 150r, 152v.

FERNANDO ANTONIO DE NATES MATIENZO

B. C.

13-12-1699

Fr. Gregorio de Haro / Fr. Plácido Vea

Matienzo (Burgos)

AGN, Irache, Lib. 549, $150 v$.

FRANCISCO MERINO

B. A. / B. T.

15-12-1699

Fr. Ángel Benito / Fr. Plácido Vea

Burgos

AGN, Irache, Lib. 549, $150 v$.
MELCHOR RODRÍGUEZ DE QUIJANO

B. C.

22-12-1699

Fr. Ángel Benito / Fr. Gregorio de Haro

Pesquera, Reinosa (Burgos)

AGN, Irache, Lib. 549, $150 v$.

JUAN DEL CASTILLO

B. A. / B. T.

7-1-1700

Fr. Gregorio de Haro / Fr. Anselmo de la

Torre

Foncea (Burgos)

AGN, Irache, Lib. 549, 151r.

JOSÉ DE LEÓN

B. A. / B. T.

7-1-1700 / 18-4-1700

Fr. Gregorio de Haro / Fr. Anselmo de la Torre

Reprobado

Fr. Plácido Vea / Fr. Anselmo de la Torre

Valles (Burgos)

AGN, Irache, Lib. 549, 151r, 153r.

JUAN MARTÍNEZ TEMIÑNO

B. C.

10-1-1700

Fr. Ángel Benito / Fr. Gregorio de Haro

Ontorio de la Cantera (Burgos)

AGN, Irache, Lib. 549, 151r.

\section{ANDRÉS CARRANZA}

B. C.

11-1-1700

Fr. Plácido Vea / Fr. Ángel Benito

Pancorbo (Burgos)

AGN, Irache, Lib. 549, 151v.

DIEGO ISLA DE HACES

B. A. / B. T.

18-1-1700

Fr. Ángel Benito / Fr. Anselmo de la Torre

Haces (Burgos)

AGN, Irache, Lib. 549, 151v.

FELIPE DE LA CAÑADA

B. A. / B. T. 
16-2-1700

Fr. Gregorio de Haro / Fr. Anselmo de la Torre

Sena (Burgos)

AGN, Irache, Lib. 549, 151v.

MANUEL DE GÜEMES Y ORCASITAS

B. C.

19-2-1700

Fr. Plácido Vea / Fr. Ángel Benito

Valmaseda (Burgos)

AGN, Irache, Lib. 549, 152r.

LEONARDO FERNÁNDEZ DE CASTAÑAGA

B. C.

3-3-1700

Fr. Gregorio de Haro / Fr. Plácido Vea

Tezarillos (Burgos)

AGN, Irache, Lib. 549, 152r.

MANUEL VALLE ZORRAQUÍN

B. C.

10-3-1700

Fr. Gregorio de Haro / Fr. Plácido Vea

Santo Domingo de la Calzada (Calahorra)

AGN, Irache, Lib. 549, 152r.

MATEO ROJAS

B. A. / B. T.

14-3-1700

Fr. Plácido Vea / Fr. Anselmo de la Torre Abajas (Burgos)

AGN, Irache, Lib. 549, 152r.

DIEGO ALONSO GUILARTE

B. C.

14-3-1700

Fr. Plácido Vea / Fr. Anselmo de la Torre

Abajas (Burgos)

AGN, Irache, Lib. 549, 152v.

PEDRO PÉREZ

B. A. / B. T.

21-3-1700

Fr. Plácido Vea / Fr. Anselmo de la Torre Agés (Burgos)

AGN, Irache, Lib. 549, 152v.

\section{AMBROSIO RUIZ}

B. C.

13-4-1700

Fr. Plácido Vea / Fr. Anselmo de la Torre

Lloreda (Burgos)

AGN, Irache, Lib. 549, 153r.

MARTÍN ANDRÉS DE PAREDES

B. C.

17-4-1700

Fr. Plácido Vea / Fr. Ángel Benito

Ameyugo (Burgos)

AGN, Irache, Lib. 549, 153r.

MANUEL MORANTE DE REBOLLEDO

B. C.

19-4-1700

Fr. Plácido Vea / Fr. Ángel Benito

Retornillo (Burgos)

AGN, Irache, Lib. 549, 153r.

MANUEL MARTÍNEZ DE QUEVEDO

B. C.

19-4-1700

Fr. Plácido Vea / Fr. Ángel Benito

Retornillo (Burgos)

AGN, Irache, Lib. 549, 153r.

ALFONSO GARCÍA

B. C.

19-4-1700

Fr. Plácido Vea / Fr. Ángel Benito

Retornillo (Burgos)

AGN, Irache, Lib. 549, 153r.

JOSÉ DE AMATRIÁIN

L. T. / D. T.

23-4-1700

Fr. Gregorio de Prado, Abad y Rector

Jaca

B. A. y B. T. en Huesca

AGN, Irache, Lib. 549, $153 \mathrm{v}$.

MIGUEL ANTONIO BERÁSTEGUI

B. A. / B. M.

30-4-1700

Fr. Anselmo de la Torre / Fr. Plácido Vea //

Miguel Atondo 
Pamplona

AGN, Irache, Lib. 549, 153v.

FRANCISCO MANSILLA

B. C.

4-5-1700

Fr. Ángel Benito / Fr. Gregorio de Haro

Reprobado

Pedrosa del Río Urbel (Burgos)

AGN, Irache, Lib. 549, 153v.

\section{JUAN INFANTE}

B. A. / B. T. / L. T.

4-5-1700

Fr. Gregorio de Prado, Abad y Rector

Ocón (Calahorra)

AGN, Irache, Lib. 549, 154r.

\section{FRANCISCO MIGUEL}

B. C.

23-5-1700

Fr. Ángel Benito / Fr. Plácido Vea

La Fuente (Burgos)

AGN, Irache, Lib. 549, 154r.

JUAN GARCÍA

B. C.

23-5-1700

Fr. Plácido Vea / Fr. Ángel Benito

Canduela (Burgos)

AGN, Irache, Lib. 549, 154v.

\section{BERNARDO MATIENZO}

B. C.

24-5-1700

Fr. Gregorio de Haro / Fr. Plácido Vea

Matienzo (Burgos)

AGN, Irache, Lib. 549, 154v.

ESTEBAN CALZADA

B. C.

1-6-1700

Fr. Plácido Vea / Fr. Ángel Benito

Cubo (Burgos)

AGN, Irache, Lib. 549, 154v.

BERNARDO DE UGARTE

B. C.
4-6-1700

Fr. Ángel Benito / Fr. Gregorio de Haro

Bugedo (Burgos)

AGN, Irache, Lib. 549, 154v.

VENTURA ALONSO

B. C.

5-6-1700

Fr. Gregorio de Haro / Fr. Ángel Benito

Santibáñez (Burgos)

AGN, Irache, Lib. 549, 155r.

\section{MARTÍN ALONSO DE SANTOCILDES}

B. C.

5-6-1700

Fr. Plácido Vea / Fr. Juan de San Martín

Cascajares (Burgos)

AGN, Irache, Lib. 549, 155r.

FRANCISCO ANTONIO CLAVERÍA

L. C. / D. C.

5-6-1700

Fr. Ángel Benito / Fr. Juan de San Martín

B. C. en Huesca

Jaca

AGN, Irache, Lib. 549, 155r.

JUAN FRANCISCO MARRACO

B. T. / L. T. / D. T.

5-6-1700

Fr. Gregorio de Prado, Abad y Rector

B. A. en Huesca

Jaca

AGN, Irache, Lib. 549, 155v.

JUAN GONZÁLEZ DELGADO

B. C.

7-6-1700

Fr. Ángel Benito / Fr. Gregorio de Haro

Santibáñez (Burgos)

AGN, Irache, Lib. 549, 156r.

FRANCISCO AYALA

B. C.

7-6-1700

Fr. Gregorio de Haro / Fr. Ángel Benito

Villavedón (Burgos)

AGN, Irache, Lib. 549, 156r. 
JUAN ANTONIO BUENO

B. C.

7-6-1700

Fr. Plácido Vea / Fr. Ángel Benito

Bilbao (Calahorra)

AGN, Irache, Lib. 549, 156r.

JUAN DE ORTEGA

B. C.

11-6-1700 / 14-6-1700

Fr. Ángel Benito / Fr. Gregorio de Haro

Reprobado

Fr. Plácido Vea / Fr. Juan de San Martín

Santibáñez (Burgos)

AGN, Irache, Lib. 549, 156r.

\section{PEDRO LÓPEZ}

B. C.

15-6-1700

Fr. Plácido Vea / Fr. Anselmo de la Torre Andosilla (Pamplona)

AGN, Irache, Lib. 549, 156v.

JOSÉ FERNÁNDEZ

B. A. / B. T.

17-6-1700

Fr. Plácido Vea / Fr. Anselmo de la Torre Olleros (Burgos)

AGN, Irache, Lib. 549, 156v.

\section{MELCHOR DE SANTELICES}

B. C.

17-6-1700

Fr. Plácido Vea / Fr. Anselmo de la Torre Zalla (Burgos)

AGN, Irache, Lib. 549, 156v.

MANUEL DE ARBEIZA

B. A.

19-6-1700

Fr. Anselmo de la Torre / Fr. M. Rueda

Estella (Pamplona)

AGN, Irache, Lib. 549, 156v.

FRANCISCO LAMBARÓN Y VILLEGAS

B. C.

4-7-1700

Fr. Gregorio de Haro / Fr. Anselmo de la
Torre

Arroyo (Burgos)

AGN, Irache, Lib. 549, 156v.

FRANCISCO DE HOYOS BRAVO

B. C.

7-7-1700

Fr. Gregorio de Haro / Fr. Anselmo de la Torre

Monegro (Burgos)

AGN, Irache, Lib. 549, 157r.

BERNARDO APARICIO

B. C.

11-7-1700

Fr. Anselmo de la Torre / Fr. Juan de San Martín

Revilla (Burgos)

AGN, Irache, Lib. 549, 157r.

ALEJANDRO DEL PRADO

B. A. / B. T.

16-7-1700

Fr. Anselmo de la Torre / Fr. Alonso Rueda Buezo (Burgos)

AGN, Irache, Lib. 549, 157r.

ANTONIO GONZÁLEZ DE LOS RÍOS

B. C.

23-7-1700

Fr. Anselmo de la Torre / Fr. Alonso Rueda Arzera (Burgos)

AGN, Irache, Lib. 549, 157v.

FRANCISCO DÍAZ ORTEGA

B. C.

23-7-1700

Fr. Anselmo de la Torre / Fr. Alonso Rueda La Costana (Burgos)

AGN, Irache, Lib. 549, 157v.

JOSÉ DE TÁRRAGA

B. A. / B. T.

25-7-1700

Fr. Gregorio de Haro / Fr. Anselmo de la Torre

Dueñas (Burgos)

AGN, Irache, Lib. 549, 157v. 
JUAN CRISÓSTOMO MARTÍNEZ

B. C.

29-7-1700

Fr. Gregorio de Haro / Fr. Anselmo de la

Torre

Villegas (Burgos)

AGN, Irache, Lib. 549, 157v.

FERNANDO DÍAZ CASTRO

B. A. / B. T.

1-9-1700

Fr. Gregorio de Haro / Fr. Anselmo de la

Torre

Hinojedo (Burgos)

AGN, Irache, Lib. 549, 158r.

JUAN SAIZ DE LA PEÑA

B. C.

10-9-1700

Fr. Gregorio de Haro / Fr. Anselmo de la

Torre

Robledo (Burgos)

AGN, Irache, Lib. 549, 158r.

JUAN FERNÁNDEZ DE CASTAÑEDA

B. C.

21-9-1700

Fr. Gregorio de Haro / Fr. Anselmo de la

Torre

Monegro (Burgos)

AGN, Irache, Lib. 549, 158r.

JOSÉ DE ARTIAGA

B. T. / L. T.

23-9-1700

Fr. Gregorio de Prado, Abad y Rector

Victoria (Calahorra)

AGN, Irache, Lib. 549, 158r.

JOSÉ FERNÁNDEZ

B. C.

1-10-1700

Fr. Anselmo de la Torre / Fr. Juan de San

Martín

Santa María del Campo (Burgos)

AGN, Irache, Lib. 549, 158v.

LORENZO DE MAHAMUD

B. C.
1-10-1700

Fr. Anselmo de la Torre / Fr. Juan de San Martín

Santa María del Campo (Burgos)

AGN, Irache, Lib. 549, 158v.

GONZALO GADEO

B. C.

5-10-1700

Fr. Gregorio de Haro / Fr. Anselmo de la Torre

Santa María del Campo (Burgos)

AGN, Irache, Lib. 549, 159r.

MARCOS ÁLVAREZ

B. C.

5-10-1700

Fr. Gregorio de Haro / Fr. Anselmo de la Torre

Santa María del Campo (Burgos)

AGN, Irache, Lib. 549, 159r.

BLAS DE ORTEGA

B. C.

19-10-1700

Fr. Ángel Benito / Fr. Gregorio de Haro

Ruyales del Agua

Abadía de Lerma

AGN, Irache, Lib. 549, 159r.

JUAN SANCHO

B. C.

23-10-1700

Fr. Gregorio de Haro / Fr. Ángel Benito

Sandoval (Burgos)

AGN, Irache, Lib. 549, 159r.

ALONSO BASCONCILLOS

B. C.

23-10-1700

Fr. Gregorio de Haro / Fr. Ángel Benito

Quintanas de Valdelucio (Burgos)

AGN, Irache, Lib. 549, 159v.

JAVIER CADIÑANOS

B. A.

27-10-1700

Fr. Anselmo de la Torre / Fr. Gregorio de Haro 
Grañón (Calahorra)

AGN, Irache, Lib. 549, 159v.

JUAN GÓMEZ DEL HIERRO

B. C.

29-10-1700

Fr. Ángel Benito / Fr. Gregorio de Haro

Revilla (Burgos)

AGN, Irache, Lib. 549, 159v.

\section{ANTONIO GARCÍA}

B. C.

2-11-1700

Fr. Gregorio de Haro / Fr. Ángel Benito

Lences (Burgos)

AGN, Irache, Lib. 549, 16 or.

PEDRO DE MOLINUEVO

B. A. / B. T.

3-11-1700

Fr. Anselmo de la Torre / Fr. Ángel Benito

San Martín de Losa (Burgos)

AGN, Irache, Lib. 549, 16or.

GREGORIO AZCÁRRAGA

B. T. / L. T.

18-11-1700

Fr. Ángel Benito
Vitoria (Calahorra)

B. A. en Alcalá

AGN, Irache, Lib. 549, 16 or.

JUAN MARTÍNEZ

B. C.

25-11-1700

Fr. Gregorio de Haro / Fr. Ángel Benito

Carrias (Burgos)

AGN, Irache, Lib. 549, $160 v$.

PEDRO MARTÍNEZ

B. L.

13-12-1700

Fr. Ángel Benito / Fr. Juan de San Martín /

Ldo. Manuel Lacayo

Tudela (Tarazona)

Estudiante en Zaragoza

AGN, Irache, Lib. 549, $160 v$.

JOSÉ DE VITAS

B. L.

13-12-1700

Fr. Ángel Benito / Fr. Juan de San Martín /

Ldo. Manuel Lacayo

Tudela (Tarazona)

Estudiante en Zaragoza

AGN, Irache, Lib. 549, $160 v$. 



\section{BiBLIOGRAFÍA}

Acta Curiarum Regni Sardiniae, 18. Il Parlamento del viceré Fabrizio Doria duca di Avellano (1641-1643), a cura di Giovanni Murgia, Cagliari, Consiglio regionale della Sardegna, 2006.

Ajo, C. M.,"Origen y desarrollo de la que fue célebre Universidad de Ávila (15041824)”, Estudios Abulenses, 1 (1954), pp. 5-55.

Ajo, C. M., Historia de las Universidades hispánicas, III, Ávila, CSIC, 1959.

Alcocer Martínez, M., Historia de la Universidad de Valladolid, Vol. 3, Valladolid, Imprenta castellana, 1918.

Alcocer Martínez, M. y Rivera, S., Historia de la Universidad de Valladolid: Bio-bibliografías de juristas notables, Valladolid, La Casa social católica, 1924.

Alonso y Lambán, M., "Apuntes sobre juristas aragoneses de los siglos XVI y XVII”, Anuario de Historia del Derecho Español, 33 (1963), pp. 625-637.

Álvarez y Baena, J. A., Hijos de Madrid ilustres en santidad, dignidades, armas, ciencias y artes, Tomo IV, Madrid, en la Oficina de Benito Cano, 1791.

Argaiz, G. de, La Perla de Cataluña. Historia de nuestra Señora de Monserrate, Madrid, imprenta de Andres Garcia de la Iglesia, 1677.

Ayerbe Iríbar, M. R., "Universidad de 'Sancti Spiritus' de Oñate: fuentes y líneas de investigación”, en L. E. Rodríguez San Pedro Bezares y J. L. Polo Rodríguez (eds.), Universidades Hispánicas. Modelos territoriales en la Edad Moderna (II), Salamanca, Universidad de Salamanca, 2007, pp. 97-161.

Barreiro Fernández, J. R., Historia de la Universidad de Santiago de Compostela, Vol. 1, Santiago, Universidad de Santiago de Compostela, 2000.

Barrientos García, J., La Facultad de Teología de la Universidad de Salamanca a través de los libros de visitas de cátedras (1560-1641), Madrid-Porto, Sindéresis, 2018.

Barrio Moya, J. L., "El abogado navarro Don Antonio de Feloaga y Ozcoidi, Fiscal del Real Consejo de Indias durante el reinado de Felipe IV", Boletín de la Real Sociedad Bascongada de Amigos del País, 65/2 (2009), pp. 667-688.

Bauer, E. J., Thomistische Metaphysik an der alten Benediktineruniversität Salzburg: Darstellung and Interpretation einer philosophischen Schule des 17./18. Jahrhunderts, Innsbruck, Tyrolia-Verlag, 1996.

Beltrán de Heredia, V., "Los benedictinos en la Universidad de Santiago", Boletín de la Real Academia Gallega, 179 (126), pp. 263-268; 181 (1926), pp. 12-19.

Beltrán de Heredia, V., "La Facultad de Teología de la Universidad de Oviedo", en Miscelánea Beltrán de Heredia, Vol. 4, Salamanca, San Esteban, 1973, pp. 387-439. 
Beltrán de Heredia, V., "La Facultad de Teología en la Universidad de Santiago", en Miscelánea Beltrán de Heredia, Vol. 4, pp. 191-309.

Cabeza, A., Clérigos y señores: política y religión en Palencia en el Siglo de Oro, Palencia, Diputación Provincial de Palencia, 1996.

Callado Estela, E., "El arzobispo de Valencia don Martín López de Hontiveros", en E. Callado Estela (ed.), La Catedral Barroca. Iglesia, sociedad y cultura en la Valencia del siglo XVII, Vol. I, Valencia, Institució Alfons el Magnànim, 2018, pp. 33-56.

Carabias Torres, A. M.; Benito Rodríguez, M. A.; Carrasco Mateos, M.; Pérez Paniagua, M. A., "Catálogo de colegiales del Colegio mayor de San Bartolomé en el siglo XVII", Studia Historica. Historia Moderna, 3 (1990), pp. 183-265.

Cerdà i Ballester, J., Los caballeros y religiosos de la Orden de Montesa en tiempo de los Austrias (1592-1700), Madrid, CSIC, 2014.

Colombás, G. M., "Historia de la fundación de tres cátedras de Teología de la Universidad de Salamanca (1692)”, Hispania Sacra, 13 (1960), pp. 305-394.

Colombás, G. M., "Los estudios en la Congregación de San Benito de Valladolid", en Los monjes y los estudios. Actas de la IV Semana de Estudios Monásticos, Poblet, Abadia de Poblet, 1963, pp. 339-362.

Colombás, G. M., La tradición benedictina. Ensayo histórico, Tomo VII, 2, Zamora, Ediciones Monte Cassino, 1998.

Couto de León, M. D., Pruebas para ingreso de religiosos en las Órdenes de Santiago, Calatrava y Alcántara, Madrid, Ministerio de Cultura, 1980.

Cristóbal Martín, Á., Confianza, fidelidad y obediencia: servidores inquisitoriales y dependencias personales en la ciudad de Logroño, siglo XVIII, Logroño, Instituto de Estudios Riojanos, 1994.

Cuenca Coloma, J. M., Sahagún: Monasterio y villa (1085-1985), Valladolid, Estudio Agustiniano, 1985.

Dávila Jalón, V., "Los burgaleses en las órdenes nobiliarias españolas”, Boletín de la Institución Fernán González, 120 (1952), pp. 236-242.

Domínguez Rodríguez, C., Los Oidores de las Salas de lo Civil de la Chancillería de Valladolid, Valladolid, Universidad de Valladolid, 1997.

España Sagrada, Vol. XLIX, Madrid, Imprenta de José Rodríguez, 1866.

España sagrada, Vol. L, Madrid, Imprenta de José Rodríguez, 1866.

Fatjó Gómez, P., "Aproximación a una élite institucional de la Catalunya moderna: los capitulares de la Seo de Barcelona en el siglo XVII”, Pedralbes, 13/2 (1993), pp. 149-161.

Faya Díaz, M. Á., "La fundación de la Universidad: las memorias y obras pías del arzobispo Fernando de Valdés y sus vicisitudes”, en J. Uría González, C. García García, A. Terrón Bañuelos (coord.), Historia de la Universidad de Oviedo, Oviedo, Universidad de Oviedo, Vol. 1, 2008, pp. 35-81. 
Ferrer Ezquerra, L. y Misol García, H., Catálogo de Colegiales del Colegio Mayor de Santiago el Cebedeo, del Arzobispo, de Salamanca, Salamanca, Universidad de Salamanca, 1956.

Fuente Fernández, F. J., "La universidad benedictina de Sahagún: 1534-1616", en J. Paniagua Pérez y M. I. Viforcos Marinas (eds.), Fray Bernardino de Sahagún y su tiempo, León, Universidad de León, 2000, pp. 51-68.

Gan Giménez, P., La Real Chancillería de Granada (1505-1834), Granada, Centro de Estudios Históricos de Granada y su Reino, 1988.

García de Quevedo, E., "De bibliografía burgense", Boletín de la Comisión Provincial de Monumentos Históricos y Artísticos de Burgos, 11/3 (1933), pp. 457-465.

García Pérez, F. J., “Los Predicadores reales de Carlos II”, Archivo Ibero-Americano, 75 (2015), pp. 673-711.

Gascón de Gotor, A., "Un Porter y Cassanate: Juan José, cronista de Aragón”, Boletín del Museo Provincial de Bellas Artes de Zaragoza y de la Real Academia de Nobles y Bellas Artes de San Luis, 1 (1950), pp. 31-35.

Gómez Zorrazquino, J. I., Patronazgo y clientelismo: Instituciones y ministros reales en el Aragón de los siglos XVI y XVII, Zaragoza, Universidad de Zaragoza, 2016.

González López, E., El águila caída: Galicia en los reinados de Felipe IV y Carlos II, Santiago, Editorial Galaxia, 1973.

Goñi Gaztambide, J., "Los premonstratenses en España”, Hispania sacra, 21 (1968), pp. 57-85.

Goñi Gaztambide, J., Historia de los Obispos de Pamplona. Siglo XVII, Vol. VI, Pamplona, Universidad de Navarra, 1979.

Goñi Gaztambide, J., "Orígenes de la universidad benedictina de Irache”, Príncipe de Viana, 245 (2008), pp. 841-868.

Guitarte Izquierdo, V., Episcopologio español (1500-1699): españoles obispos en España, América, Filipinas y otros países, Roma, Instituto Español de Historia Eclesiástica, 1994.

Gurpegui Resano, J. R., Pedro Tapiz y García (1673-1722), Andosilla, Ayuntamiento de Andosilla, 2004.

Gutiérrez Torrecilla, L. M., Catálogo biográfico de colegiales y capellanes del Colegio Mayor de San Ildefonso de la Universidad de Alcalá de Henares (15081786), Alcalá, Universidad de Alcalá de Henares, 1992.

Hermann, K. F., "Das Werk der Erzbischöfe Markus Sittikus und Paris Lodron" en VVAA, Universität Salzburg 1622-1962-1972, Salzburg, Universität Salzburg, 1972, pp. 3-34.

Herráez Hernández, J. M., Universidad y universitarios en Ávila durante el siglo XVII: análisis y cuantificación, Ávila, Institución “Gran Duque de Alba”, 1994. 
Ibarra Murillo, J., Historia del Monasterio benedictino y Universidad literaria de Irache, Pamplona, Impr. "La Acción Social”, 1939.

Jiménez Zubiría, M. C., "Aproximación biográfica a la figura de D. José de la Peña García, Obispo de las diócesis de Orense y de Calahorra-La Calzada, natural de la villa de Valtierra (Navarra)", Revista del Centro de Estudios Merindad de Tudela, 25 (2017), pp. 99-123.

Juan García, N., "San Juan de la Peña, la Monarquía y los conflictos bélicos en los siglos XVII y XVIII”, Studium, 12 (2006), pp. 209-230.

Juan García, N., "Contribución a las trazas arquitectónicas del siglo XVII: el diseño de la iglesia del Monasterio nuevo de San Juan de la Peña del arquitecto zaragozano Miguel Ximénez", Artigrama, 22 (2007), pp. 567-594.

Kerrebrouck, P. van, Les Capétiens: 987-1328, Vol. 2, Villeneuve d'Asq., 2000.

Lario, D. de, Escuelas de imperio. La formación de una élite en los Colegios Mayores (siglos XVI-XVII), Madrid, Dykinson, 2019.

Latassa, F. de, Biblioteca nueva de los escritores aragoneses: que florecieron desde el año de 1600 hasta 1640, Tomo II, Pamplona, en la Oficina de Joaquín de Domingo, 1799.

Linage Conde, A., "La Universidad de Irache en el Benedictinismo", Príncipe de Viana. Anejo, 15 (1993), pp. 211-217.

Marqués de Jaureguizar, "Relación de los canónigos de la santa Iglesia de Pamplona”, Hidalguía, 127 (1974), pp. 887-944.

Martínez Arce, M. D., Aproximación a la justicia en Navarra durante la Edad Moderna: jueces del Consejo Real en el siglo XVII, Pamplona, Ediciones Fecit, 2005.

Martínez Gomis, M., La Universidad de Orihuela, 1610-1807. Un centro de estudios superiores entre el Barroco y la Ilustración, 2 vols, Alicante, Instituto de Estudios Juan Gil Albert, 1987.

Minguella, T., Historia de la diócesis de Sigüenza y de sus Obispos, vol. III, [S.l.: s.n.], 1913.

Molas, P., "Colegiales mayores de Castilla en la Italia española", Studia historica. Historia moderna, 8 (1990), pp. 163-182.

Negredo del Cerro, F., Los Predicadores de Felipe IV, Madrid, Actas, 2006.

Ortiz de la Azuela, J., Monografía de la antigua Colegiata de Santillana del Mar, Santander, [s.e.], 1919.

Palacín Zueras, M. C., "El Real Monasterio de San Juan de la Peña y la desamortización”, Argensola, 111 (1997), pp. 153-186.

Pérez de Urbel, J., Varones insignes de la Congregación de Valladolid, Pontevedra, Museo Provincial, 1967.

Pérez Goyena, A., "La Teología dogmática entre los benedictinos españoles de la Observancia”, Razón y Fe, 44 (1916), pp. 61-72. 
Pérez Goyena, A., "La literatura teológica entre los benedictinos españoles", Razón y Fe, 48 (1917), pp. 174-179 y 49 (1917), pp. 167-179.

Pérez Goyena, A., "Controversias teológicas de los padres benedictinos de la Observancia”, Razón y Fe, 49 (1917), pp. 308-313.

Pérez Goyena, A., "La literatura teológica española. Los grandes teólogos benedictinos", Razón y Fe, 50 (1918), pp. 45-63.

Peset, M., "La organización de las universidades españolas en la edad moderna", en A. Romano (ed.), Studi e Diritto nell'area mediterranea in età moderna, Messina, Rubbettino, 1993, pp. 73-122.

Querol Coll, E., Estudis sobre cultura literària a Tortosa a l'edat moderna, Montserrat, Abadia de Montserrat, 2006.

Quijada Álamo, D., "El Cabildo de la Iglesia Catedral de Palencia: canónigos y Predicadores del sermón fúnebre regio durante el setecientos", Estudios $\mathrm{Hu}$ manísticos, 13 (2014), pp. 97-121.

Ramis Barceló, R., "La política universitaria de los Austrias en la Península Ibérica”, en G. P. Brizzi y A. Mattone (ed.), Le origini dello Studio Generale sassarese nel mondo universitario europeo dell'eta moderna, Bolonia, CLUEB, 2013, pp. 103-116.

Ramis Barceló, R., "Sobre los privilegios de la Universidad de Solsona y los grados en leyes, cánones y medicina durante el siglo XVII", Glossae. European Journal of Legal History, 12 (2015), pp. 661-678.

Ramis Barceló, R., "La peregrinatio academica y la movilidad estudiantil en la Corona de Aragón (ss. XIV-XVIII)”, en C. Fernández Cortizo y D. L. González Lopo (eds.), La movilidad estudiantil en Europa y América (siglos XIII al XXI). De la Peregrinatio Academica al Programa Erasmus, Santiago, Alvarellos Editora, 2020, pp. 69-104.

Ramis Barceló, R., y Ramis Serra, P., "Los primeros grados de la Universidad de Orihuela (1610-1643)”, Estudis. Revista de Historia Moderna, 43 (2017), pp. 235-260.

Ramis Barceló, R., y Ramis Serra, P., "Grados de la Universidad de Irache (16131620)”, Studia monastica, 6o/1 (2018), pp. 119-180.

Ramis Barceló, R. y Ramis Serra, P., "Grados de la Universidad de Irache (16211630)”, Studia monastica, 62/1 (2020), pp. 177-230.

Ramis Barceló, R. y Ramis Serra, P., Estudios sobre la Universidad de Tortosa (1600-1717), Madrid, Dykinson, 2020.

Ríos, R.,"The Benedictine University of Hirache, c. 1500-1835”, The Downside Review, 60 (1942), pp. 285-294.

Rodríguez Muñoz, J., "Estudios, profesorado y estudiantes", en J. Uría González, C. García García, A. Terrón Bañuelos (coord.), Historia de la Universidad de Oviedo, pp. 95-128. 
Rodríguez-San Pedro Bezares, L. E., La Universidad salmantina del Barroco, periodo 1598-1625, Salamanca, Universidad de Salamanca, 1986.

Rojas Contreras, J. de, Historia del Colegio Viejo de San Bartolomé Mayor de la Universidad de Salamanca, Madrid, por Andrés Ortega, 1768.

Rubio Merino, P., "Marín de Rodezno”, en Q. Aldea Vaquero, T. Marín Martínez y J. Vives Gatell (dirs.), Diccionario de Historia Eclesiástica de España, Vol. III, Madrid, CSIC, 1973, p. 1420.

Salvador y Conde, J., La Universidad en Pamplona, Madrid, Instituto Jerónimo Zurita-CSIC, 1949.

Salvador y Conde, J., La Universidad de Pamplona en el s. XVII, Pamplona, Diputación Foral de Navarra, 1977.

Sánchez de la Nieta, D., La Universidad de Almagro. Tres siglos de actividad (1574-1824), Ciudad Real, Museo de Ciudad Real, 1981.

Serra i Puig, E., Els Llibres de l'ànima de la Diputació del General de Catalunya (1493-1714), Barcelona, IEC, 2015.

Serrano Larráyoz, F., Graduados en Medicina por la Universidad de Irache (1613-1769), Pamplona, Editorial Universitas, 2019.

Serrano Larráyoz, F. y Martínez Hernández, G., "Los 'Estatutos de la Universidad Real de Hyrache en el Reyno de Navarra' (1618) y la concesión de grados en Medicina durante el siglo XVII", en D. Ruiz-Berdún (dir.), Ciencia y técnica en la universidad: trabajos de historia de las ciencias y de las técnicas, Vol. 1, Alcalá, Universidad de Alcalá, 2018, pp. 43-52.

Simón Pérez, A., El Monasterio y la Universidad de Irache: inventario del archivo (siglos XVI-XIX), Pamplona, Gobierno de Navarra, 2003.

Sobaler Seco, M. A., Catálogo de colegiales del Colegio Mayor de Santa Cruz de Valladolid (1484-1786), Valladolid, Universidad de Valladolid, 2000.

Tomás Laguía, C., La insigne Colegiata de Santa María de Mora de Rubielos, Teruel, CSIC, 1964.

Torremocha Hernández, M., "La población estudiantil de la Universidad de Oñate. Siglo XVII”, Investigaciones históricas, 15 (1995), pp. 209-240.

Torres y Villarroel, D. de, Sueños Morales, visiones y visitas de Torres con Don Francisco de Quevedo..., Madrid, Joseph Doblado, 1796.

Valladares, R., "Haro sin Mazarino. España y el fin del 'orden de los Pirineos' en 1661”, Pedralbes, 29 (2009), pp. 339-393.

Vallejo García-Hevia, J. M., "Domingo La Ripa”, en Diccionario Biográfico Español, vol. XXVIII, Madrid, Real Academia de la Historia, 2009, p. 524.

Velasco Bayón, B., Historia del carmelo español, Vol. 1, Roma, Institutum Carmelitanum, 1990.

Vizuete Mendoza, J. C., Los antiguos Colegios-Universidad de Toledo y Almagro (siglos XVI-XIX), Toledo, Publicaciones de la Universidad de Castilla-La Mancha, 2010. 
Wilkinson, A. S., y Ulla Lorenzo, A., Iberian Books Volumes II \& III, Leiden, Brill, 2015.

Yáñez Neira, M. D., "El Monasterio de la Espina y sus Abades", Archivos leoneses, 26 (1972), pp. 69-149.

Yepes, A. de, Coronica general de la Orden de San Benito, Patriarca de Religiosos, tomo III, centuria III, En la Vniversidad de $\mathrm{N}^{\mathrm{a}} \mathrm{S}^{\mathrm{a}}$ la Real de Yrache, de la Orden de San Benito, por Nicolas de Assiayn, Impresor del Reino de Navarra, 1610.

Zaragoza Pascual, E., Los Generales de la Congregación de San Benito de Valladolid, 6 vols., Silos, Abadía de Silos, 1973-1987.

Zaragoza Pascual, E., "Los monjes de Sopetrán (1601-1758)", Wad-al Hayara: Revista de estudios de Guadalajara, 5 (1978), pp. 123-141.

Zaragoza Pascual, E., "Abadologio del Monasterio de San Pedro de Eslonza (siglos X-XIX)”, Archivos Leoneses, 75 (1984), pp. 163-186.

Zaragoza Pascual, E., "Abadologio del Monasterio de San Claudio de León (14171835)”, Archivos Leoneses, 78 (1985), pp. 355-370.

Zaragoza Pascual, E., "Abadologio del Monasterio de San Salvador de Cornellana (siglos XII-XIX)", Boletín de Letras del Real Instituto de Estudios Asturianos, 119 (1986), pp. 879-904.

Zaragoza Pascual, E., "Abadologio del Monasterio de Montserrat de Madrid (1641-1835)”, Studia monastica, 29/1 (1987), pp. 125-153.

Zaragoza Pascual, E., "Monacologio emilianense (1500-1833)", Studia monastica, 29/2 (1987), pp. 291-331.

Zaragoza Pascual, E., "Abadologio del Monasterio de San Martín de Madrid (15941835)", Anales del Instituto de Estudios Madrileños, 25 (1988), pp. 151-182.

Zaragoza Pascual, E., "Los Estudios y Colegios monásticos españoles (siglos XVXIX)”, Memoria Ecclesiae, 13 (1998), pp. 377-424.

Zaragoza Pascual, E., "Abadologio (siglos X-XX) y Libro de Gradas del Monasterio de San Isidro de Dueñas”, Archivos Leoneses, 89-9o (1991), pp. 189-226.

Zaragoza Pascual, E., "Profesores del Colegio benedictino de San Vicente de Oviedo (1617-1835)", Boletín del Real Instituto de Estudios Asturianos, 137 (1991), pp. 323-356.

Zaragoza Pascual, E., "Libros de gradas de los monjes de San Martín Pinario de Santiago de Compostela (1502-1833)", Estudios Mindonenses, 7 (1991), pp. 471-557.

Zaragoza Pascual, E., "Monjes profesos de Montserrat (1493-1833)", Studia monastica, 33/2 (1991), pp. 329-377.

Zaragoza Pascual, E., "Profesores de los Colegios benedictinos asturianos de Obona y Celorio (siglos XVII-XIX)”, Boletín del Real Instituto de Estudios Asturianos, 139 (1992), pp. 277-304. 
Zaragoza Pascual, E., "Abadologio del Monasterio de Nuestra Señora de Sopetrán (1372-1835)”, Wad-al Hayara: Revista de estudios de Guadalajara, 20 (1993), pp. 223-240.

Zaragoza Pascual, E., "Abadologio del Monasterio de Santa María la Real de Irache”, Studia Monastica, 35/1 (1993), pp. 161-202.

Zaragoza Pascual, E., "Abadologio del Monasterio de Ntra. Sra. de El Espino", Boletín de la Institución Fernán González, 206 (1993), pp. 19-36.

Zaragoza Pascual, E., "Abadologio del Monasterio de San Pedro de Cardeña (Siglos IX-XX)”, Boletín de la Institución Fernán González, 207 (1993), pp. 367397.

Zaragoza Pascual, E., "Abadologio del Monasterio de San Zoilo de Carrión de los Condes (s. XI-XIX) y libro de gradas de los monjes que profesaron en él (15931833)", Publicaciones de la Institución Tello Téllez de Meneses, 64 (1993), pp. 273-322.

Zaragoza Pascual, E., "Abadologio del Monasterio de san Martín Pinario: 8981835”, Compostellanum, 39/1-2 (1994), pp. 209-240.

Zaragoza Pascual, E., "Abadologio del Monasterio de San Salvador de Oña (siglos XI-XIX)”, Burgense: Collectanea Scientifica, 35/2 (1994), pp. 557-594.

Zaragoza Pascual, E., "Abadologio del Monasterio de San Salvador de Lérez (Siglos XVI-XIX)”, El Museo de Pontevedra, 48 (1994), pp. 405-436.

Zaragoza Pascual, E., "Abadologio del Monasterio de San Salvador de Lorenzana (1015-1835)", Estudios mindonienses, 11 (1995), pp. 179-203.

Zaragoza Pascual, E., "Abadologio del Monasterio de San Pedro de Arlanza: siglos X-XIX”, Boletín de la Institución Fernán González, 210 (1995), pp. 85-110.

Zaragoza Pascual, E., "Abadologio del Monasterio de san Julián de Samos (siglos VIII-XX)”, Estudios mindonienses, 12 (1996), pp. 469-503.

Zaragoza Pascual, E., "Catálogo de monjes profesos del Monasterio de San Benito El Real de Valladolid (1436-1831)", Studia monastica, 38/1 (1996), pp. 83129.

Zaragoza Pascual, E., "Abadologio del Monasterio de San Juan Bautista de Burgos”, en S. López Santidrián (dir.), San Lesmes en su tiempo: Simposio organizado por la Facultad de Teología y la Parroquia de San Lesmes con el patrocinio del Ayuntamiento de Burgos, en el IX centenario de la muerte del Patrono de la Ciudad (1097-1997), Burgos, Publicaciones de la Facultad de Teología del Norte de España, 1997, pp. 345-384.

Zaragoza Pascual, E., Catàleg dels monestirs catalans, Montserrat, Abadia de Montserrat, 1997.

Zaragoza Pascual, E., "Abadologio (1503-1835) y Libro de Gradas (s. XVII-XIX) del Monasterio de San Benito de Sevilla”, Studia monastica, 39/2 (1997), pp. 377-402. 
Zaragoza Pascual, E., "Abadologio (siglos X-XIX) y Libro de gradas de los monjes (1715-1833) del Monasterio de Santa María La Real de Nájera”, Studia monastica, 40/1 (1998), pp. 121-158.

Zaragoza Pascual, E., Abaciologi del Monestir de Sant Feliu de Guíxols (segles $X$-XIX), Montserrat, Abadia de Montserrat, 1998.

Zaragoza Pascual, E., Abadologio de Santo Domingo de Silos, Burgos, Institución "Fernán González", 1998.

Zaragoza Pascual, E., "Abadologio del Monasterio de San Vicente de Oviedo", Studium Ovetense, 26 (1998), pp. 135-165.

Zaragoza Pascual, E., "Abadologio del Monasterio de San Millán de la Cogolla (siglos VI-XIX)”, Studia monastica, 42/1 (2000), pp. 185-223.

Zaragoza Pascual, E., "Abadologio del Monasterio de San Salvador de Celanova (Siglos X-XIX)”, Compostellanum, 45/1-2 (2000), pp. 81-100.

Zaragoza Pascual, E., "Profesores del Colegio Benedictino de San Juan de Poyo (1610-1835)", Compostellanum, 45/3-4 (2000), pp. 757-781.

Zaragoza Pascual, E., "Abadologio del Monasterio de Ntra Sra. de la Anunciación del Bueso: (1460-1789)”, Investigaciones históricas, 21 (2001), pp. 19-46.

Zaragoza Pascual, E., "Abadologio del Monasterio de Nuestra Señora de Valvanera (siglos X-XX)", Studia monastica, 43/2 (2001), pp. 333-372.

Zaragoza Pascual, E., "Profesores del Colegio benedictino de San Salvador de Lérez (1661-1835)”, El Museo de Pontevedra, 56 (2002), pp. 181-190.

Zaragoza Pascual, E., "Abadologio del Monasterio de san Esteban de Ribas de Sil (siglos X-XIX)”, Compostellanum, 47/3-4 (2002), pp. 359-400.

Zaragoza Pascual, E., "Abadologio del Monasterio de San Benito el Real de Valladolid (1390-1835)", Investigaciones históricas, 23 (2003), pp. 203-260.

Zaragoza Pascual, E., "Abadologio del Monasterio de San Juan Bautista de Poyo (ss. XII-XIX)”, Compostellanum, 48, 1-4 (2003), pp. 391-426.

Zaragoza Pascual, E., "Abadologio del Monasterio de San Pedro de Villanueva (siglos XII-XIX)”, Boletín de Letras del Real Instituto de Estudios Asturianos, 164 (2004), pp. 73-102.

Zaragoza Pascual, E., Història de la Congregació Benedictina Claustral Tarraconense i Cesaraugustana (1215-1835), Montserrat, Publicacions de l'Abadia de Montserrat, 2004.

Zaragoza Pascual, E., "Abadologio del Monasterio de San Salvador de Celorio (siglos XI-XIX)", Boletín de Letras del Real Instituto de Estudios Asturianos, 165 (2005), pp. 105-136.

Zaragoza Pascual, E., "Abadologio y Priorologio de Santo Toribio de Liébana (siglos LX-XIX)”, Altamira, 67 (2005), pp. 35-63.

Zaragoza Pascual, E., "Profesores de los Colegios benedictinos de San Julián de Samos y San Esteban de Ribas de Sil (s. XVI-XIX)", Estudios mindonienses, 21 (2005), pp. 771-804. 
Zaragoza Pascual, E., "Profesores del Colegio benedictino de San Vicente de Salamanca (1589-1835)”, Salmanticensis, 52/2 (2005), pp. 287-341.

Zaragoza Pascual, E., "Profesores del Colegio benedictino de San Andrés de Espinareda (1641-1835)", Compostellanum, 51/1-2 (2006), pp. 115-145.

Zaragoza Pascual, E., "Abadologio del Monasterio de San Juan Bautista de Corias (Siglos XI-XIX)", Boletín de Letras del Real Instituto de Estudios Asturianos, 167 (2006), pp. 135-172.

Zaragoza Pascual, E., "Profesores de los Colegios benedictinos de San Benito de Zamora, San Isidro de Dueñas y San Pedro de Eslonza (siglos XVII-XIX)", Compostellanum, 52/1-2 (2007), pp. 73-114.

Zaragoza Pascual, E., "Abadologio del Monasterio de San Vicente del Pino de Monforte de Lemos (siglos XV-XIX)”, Estudios mindonienses, 24 (2008), pp. 487-512.

Zaragoza Pascual, E., "Profesores benedictinos del Colegio y Universidad de Irache”, en L. E. Rodríguez-San Pedro Bezares y Juan Luis Polo Rodríguez (eds.), Universidades hispánicas: Colegios y conventos universitarios en la Edad Moderna, Vol. 1, 2009, Salamanca, Universidad de Salamanca, pp. 303-358.

Zaragoza Pascual, E., "Abadologio del Monasterio de San Benito de Sahagún (Siglos X-XIX)”, Compostellanum, 55/1-2 (2010), pp. 99-147.

Zaragoza Pascual, E., "Gradas del monasterio de Santa María de la Real de Nájera (1500-1833)”, Studia Monastica, 54/2 (2012), pp. 355-388.

Zaragoza Pascual, E., "Abadologio del Monasterio de San Vicente de Salamanca (Siglos XIII-XIX)”, Salmanticensis, 59/2 (2012), pp. 291-379.

Zaragoza Pascual, E., "Gradas del Monasterio de Sahagún (s. XVI-XIX)", Studia monastica, 55/2 (2013), pp. 311-373.

Zaragoza Pascual, E., "Abadologio del Monasterio de San Andrés de Espinareda (ss. XI-XIX)”, Compostellanum, 6o/1-2 (2015), pp. 207-237.

Zaragoza Pascual, E., "Abadologio (siglos X-XX) y libro de gradas (1614-1830) del Monasterio de San Isidro de Dueñas”, Studia monastica, 59/1 (2017), pp. 119-162.

Zaragoza Pascual, E., "Fernando el Católico y la reforma de los benedictinos y benedictinas españoles (1474-1516)", Anuario de Historia de la Iglesia, 26 (2017), pp. 157-184.

Zaragoza Pascual, E., "Abadologio del Monasterio de San Benito de Zamora (1400-1835)", Anuario del Instituto de Estudios Zamoranos Florián de Ocampo, 33 (2018), pp. 345-387.

Zoepfl, F., "Geschichte der ehemaligen Universität Ottobeuren", Archiv für die Geschichte des Hochstifts Augsburg, 5 (1916-1919), pp. 517-562. 


\section{INDICE ONOMÁSTICO}

[10 estudiantes sin nombre]

... DE AGÜERO

... DE MENDOZA

... DOMIN

... RUBIO

ADRIÁN GONZÁLEZ

ADRIÁN ISAURRAGA

ADRIÁN TRECEÑO

ADRIANO DE MONREAL Y SORIA

AGUSTÍN ANTONIO DE URIBE

AGUSTÍN ANTONIO PÉREZ

AGUSTÍN DE ABERASTURI Y GUEVARA

AGUSTÍN DE ALBILLA

AGUSTÍN DE ANCHETA

AGUSTÍN DE ARANA Y POBES

AGUSTÍN DE ARCE

AGUSTÍN DE ARELLANO

AGUSTÍN DE AZNÁREZ

AGUSTÍN DE BENAVENTE

AGUSTÍN DE ECHALAZ

AGUSTÍN DE ENRÍQUEZ

AGUSTÍN DE GORRIA

AGUSTÍN DE HERRÁN

AGUSTÍN DE ICEDO

AGUSTÍN DE IRICIO

AGUSTÍN DE LA CONCHA CEBALLOS

AGUSTÍN DE LA PEDROSA Y CEBALLOS

AGUSTÍN DE ONTANEDA

AGUSTÍN DE ORDUÑA

AGUSTÍN DE QUIRÓS

AGUSTÍN DE REA

AGUSTÍN DE RETA

AGUSTÍN DE RETOLA

AGUSTÍN DE SALAZAR

AGUSTÍN DE SANTA MARINA

AGUSTÍN DE SARABIA

AGUSTÍN DE SARACHO
AGUSTÍN DE TELLERÍA

AGUSTÍN DE VIANA

AGUSTÍN DEL ARCO

AGUSTÍN DEL OYO

AGUSTÍN DÍAZ DE CANTABRANA

AGUSTÍN GIRÓN

AGUSTÍN GÓMEZ

AGUSTÍN GONZÁLEZ

AGUSTÍN GONZÁLEZ

AGUSTÍN GONZÁLEZ

AGUSTÍN LÓPEZ

AGUSTÍN LÓPEZ ANGULO

AGUSTÍN LÓPEZ SASE

AGUSTÍN LÓPEZ VARONA

AGUSTÍN MARTÍNEZ DE PESQUERA

AGUSTÍN OSORIO

AGUSTÍN PÉREZ DE LA GORMA

AGUSTÍN PIÑANA

AGUSTÍN RUIZ

AGUSTÍN RUIZ DEL CASTILLO

AGUSTÍN SÁEZ DE LOS HERREROS

AGUSTÍN SUSINOS

AGUSTÍN SUSINOS

AGUSTÍN VICARIO RUIZ

ALBERTO DE EGUIERRETA

ALBERTO IBÁÑEZ DE IBERO

ALBERTO PÉREZ

ALEJANDRO DE ITURRALDE

ALEJANDRO DE TAGLE

ALEJANDRO DEL PRADO

ALEJANDRO ECHANAGUSIA

ALEJANDRO GONZÁLEZ JUNGUIRO

ALEJANDRO MARÍN

ALEJANDRO MARRACO

ALEJANDRO MARTÍNEZ

ALEJO GUTIÉRREZ

ALFONSO DE NOJA CASTILLO 
ALFONSO DE VILLASANDINO

ALFONSO GARCÍA

ALFONSO GÓMEZ

ALONSO CALVO

ALONSO ANTONIO DE PALACIO

ALONSO BARAHONA

ALONSO BASCONCILLOS

ALONSO CORTÉS

ALONSO CUEVAS

ALONSO DE ALARCÓN

ALONSO DE ANGULO

ALONSO DE ARAMERIA

ALONSO DE ARCE

ALONSO DE ARRIAGA

ALONSO DE BARRANTES

ALONSO DE CAÑAS

ALONSO DE CASTAÑEDA

ALONSO DE CASTELVÍ Y AIMERICH

ALONSO DE CELADA

ALONSO DE DUEÑAS

ALONSO DE IRISARRI

ALONSO DE ISLA

ALONSO DE LA CÁMARA

ALONSO DE LA PEÑA

ALONSO DE LISARRI

ALONSO DE LOS RÍOS

ALONSO DE MADRID

ALONSO DE MEDIAVILLA

ALONSO DE MIER

ALONSO DE MONTEALEGRE

ALONSO DE NEILA

ALONSO DE PINO

ALONSO DE RAMÍREZ DE SALAMANCA

ALONSO DE ROJAS

ALONSO DE SALAZAR

ALONSO DE SALINAS

ALONSO DE SALINAS

ALONSO DE TEJERINA

ALONSO DE URREA

ALONSO DE VERDESOTO

ALONSO DE VILLODAS

ALONSO DE VÍTORES

ALONSO DEL CASTILLO

ALONSO DÍEZ

ALONSO DÍEZ DE PIMENTEL

ALONSO DOMÍNGUEZ GALINDO

ALONSO ESTÉBANEZ

ALONSO ESTÉBANEZ
ALONSO FERNÁNDEZ

ALONSO FOLGOSO

ALONSO FRANCÉS

ALONSO FREILE

ALONSO GADEA

ALONSO GARCÍA

ALONSO GARCÍA

ALONSO GARCÍA

ALONSO GARCÍA

ALONSO GARCÍA

ALONSO GARCÍA

ALONSO GARCÍA

ALONSO GARCÍA

ALONSO GARCÍA PARACUELLOS

ALONSO GARCÍAS

ALONSO GARRIDO GIL DE LA SERNA

ALONSO GONZÁLEZ

ALONSO GONZÁLEZ

ALONSO GONZÁLEZ

ALONSO GONZÁLEZ

ALONSO GONZÁLEZ ALBAR

ALONSO GONZÁLEZ ANDRADE Y VE-

LÁZQUEZ

ALONSO GUTIÉRREZ DE LOS RÍOS

ALONSO GUTIÉRREZ DEL ÁGUILA

ALONSO IÑÍGUEZ

ALONSO LAÍNEZ

ALONSO LÓPEZ

ALONSO LÓPEZ

ALONSO MARQUÉS

ALONSO MARTÍNEZ

ALONSO MEDIANO

ALONSO MERINO DE PORRAS

ALONSO MIGUEL

ALONSO NAVAS

ALONSO NÚÑEZ

ALONSO PELAYO

ALONSO PEÑA

ALONSO PÉREZ

ALONSO PÉREZ

ALONSO PÉREZ

ALONSO PÉREZ GONZÁLEZ

ALONSO QUINTANO

ALONSO RAMÍREZ

ALONSO RAMÍREZ CALDERÓN

ALONSO RIALES MANRIQUE

ALONSO RODRÍGUEZ

ALONSO RODRÍGUEZ ARIAS 


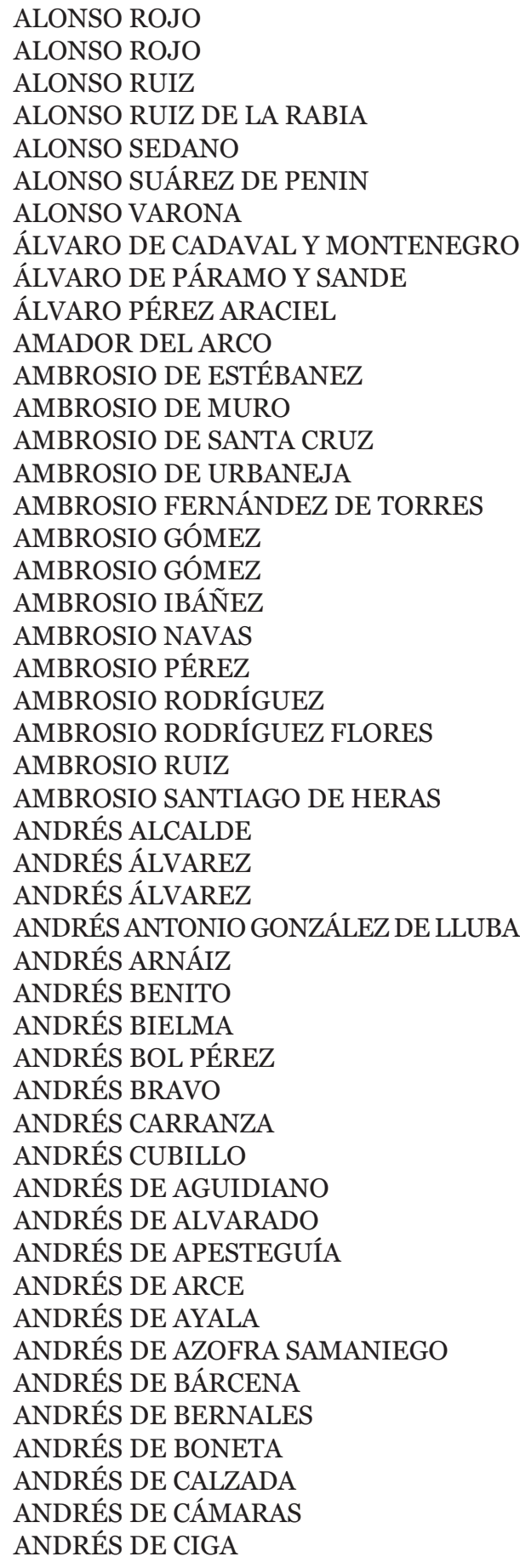

ANDRÉS DE ESPARZA

ANDRÉS DE GALVÁN

ANDRÉS DE GANDÍA

ANDRÉS DE GONZALO

ANDRÉS DE GUILAZ

ANDRÉS DE HERNANDO

ANDRÉS DE LA BOLLADA

ANDRÉS DE LA CRUZ

ANDRÉS DE LA FUENTE

ANDRÉS DE LA GÁNDARA

ANDRÉS DE LA HERA

ANDRÉS DE LA INCERA

ANDRÉS DE LA MONEDA

ANDRÉS DE LA PALIZA Y MOLINEDO

ANDRÉS DE LA PEÑA

ANDRÉS DE LA TORRE

ANDRÉS DE LA TORRE

ANDRÉS DE LA TORRE

ANDRÉS DE LEBRETA

ANDRÉS DE LEIVA

ANDRÉS DE LOSA

ANDRÉS DE MAGAZ

ANDRÉS DE MANSILLA

ANDRÉS DE MARAÑÓN

ANDRÉS DE MARDONES

ANDRÉS DE MIRANDA

ANDRÉS DE MONEO

ANDRÉS DE MONTEÓN

ANDRÉS DE OCHOA

ANDRÉS DE OLARAN

ANDRÉS DE ONTIVEROS

ANDRÉS DE ORTEGA

ANDRÉS DE PALENCIA

ANDRÉS DE PEDROSA

ANDRÉS DE PEREA

ANDRÉS DE QUINTANILLA

ANDRÉS DE RANERO

ANDRÉS DE RODRIGO

ANDRÉS DE SAN MARTÍN

ANDRÉS DE SANTA MARÍA

ANDRÉS DE SARABIA

ANDRÉS DE TORRES

ANDRÉS DE UGALDE ORMAECHEA

ANDRÉS DE URÍAS DE LA FUENTE

ANDRÉS DE URRUTIA

ANDRÉS DE VADILLO

ANDRÉS DE VEGA

ANDRÉS DE VILLATE 
ANDRÉS DE ZABALLOS

ANDRÉS DE ZAMORA

ANDRÉS DE ZULAIBAR

ANDRÉS DE ZÚÑIGA

ANDRÉS DEL CASTILLO

ANDRÉS DEL MORAL

ANDRÉS DEL POZO

ANDRÉS DELGADO

ANDRÉS DÍAZ

ANDRÉS DÍAZ

ANDRÉS DÍAZ

ANDRÉS ESPAÑOL

ANDRÉS FERNÁNDEZ

ANDRÉS FERNÁNDEZ

ANDRÉS FERNÁNDEZ

ANDRÉS FERNÁNDEZ

ANDRÉS FERNÁNDEZ DE COSÍO

ANDRÉS FERNÁNDEZ DE LA PEÑA

ANDRÉS FERNÁNDEZ DE OCHOA

ANDRÉS FERNÁNDEZ DEL OLMO

ANDRÉS FERNÁNDEZ MONTERO

ANDRÉS FRANCÉS

ANDRÉS GARCÍA

ANDRÉS GARCÍA

ANDRÉS GARCÍA

ANDRÉS GARCÍA

ANDRÉS GARCÍA

ANDRÉS GARCÍA DE SANTIAGO

ANDRÉS GARCÍA DEL MORAL

ANDRÉS GARCÍA ESCRIBANO

ANDRÉS GARCÍA MALTRANILLO

ANDRÉS GARCÍA MAZUECO

ANDRÉS GIL

ANDRÉS GÓMEZ

ANDRÉS GÓMEZ DE QUINTANA

ANDRÉS GÓMEZ DE SALAZAR

ANDRÉS GONZÁLEZ

ANDRÉS GONZÁLEZ

ANDRÉS GONZÁLEZ

ANDRÉS GONZÁLEZ

ANDRÉS GONZÁLEZ DE LA TORRE Y AGUIRRE

ANDRÉS GONZÁLEZ DE VILLA Y ARE-

$$
\text { LLANO }
$$

ANDRÉS GONZÁLEZ JUNGUIRO

ANDRÉS HERNANDO

ANDRÉS HERRERO

ANDRÉS IBÁÑEZ
ANDRÉS IBÁÑEZ

ANDRÉS IBEA

ANDRÉS LASTERRA

ANDRÉS LLORENTE

ANDRÉS LÓPEZ DE BAILLO

ANDRÉS LÓPEZ DE CADIÑANOS

ANDRÉS LÓPEZ FRÍAS

ANDRÉS LÓPEZ NIETO

ANDRÉS LÓPEZ TELLO

ANDRÉS MANDURA

ANDRÉS MARTÍNEZ

ANDRÉS MARTÍNEZ

ANDRÉS MARTÍNEZ

ANDRÉS MARTÍNEZ Y ORDÓNEZ

ANDRÉS MIGUEL

ANDRÉS MONASTERIO

ANDRÉS MONTERO DÍEZ

ANDRÉS MONTOJO

ANDRÉS ORTIZ

ANDRÉS ORTIZ DE ZÁRATE

ANDRÉS ORTIZ DEL VALLE

ANDRÉS PÁRAMO

ANDRÉS PELÁEZ

ANDRÉS PEÑA

ANDRÉS PÉREZ

ANDRÉS PÉREZ

ANDRÉS PÉREZ

ANDRÉS PÉREZ

ANDRÉS PRIETO GALINDO

ANDRÉS REAL

ANDRÉS REBOLLO MANRIQUE

ANDRÉS RODRÍGUEZ DE SOLÓRZANO

ANDRÉS ROMERO

ANDRÉS ROMERO

ANDRÉS RUBIO

ANDRÉS RUIZ

ANDRÉS RUIZ

ANDRÉS RUIZ

ANDRÉS RUIZ DE GAONA

ANDRÉS SAINZ DE VILLEGAS

ANDRÉS SÁNCHEZ DE LA CUESTA

ANDRÉS SANCHO

ANDRÉS SARABIA

ANDRÉS SERRANO

ANDRÉS TEJEDOR

ANDRÉS TEJERO

ANDRÉS TOMÉ DE ÁBALOS

ANDRÉS VECINO 
ANDRÉS ZURITA

ÁNGEL CUSTODIO DE MONTES

ÁNGEL DE LEÓN

ÁNGEL DE MONREAL Y SARRIÁ

ÁNGEL DE SALAZAR

ÁNGEL DEL ÁGUILA

ÁNGEL DEL VAL

ÁNGEL DÍEZ FONTANAL

ÁNGEL FRANCISCO MAROTO

ÁNGEL MORANTE DE LA MADRID

ÁNGEL RODRÍGUEZ VILLALOBOS

ANSELMO LÓPEZ

ANSELMO PÉREZ

ANTONÍN DEL AMACORIA

ANTONIO ALARCÓN

ANTONIO ALBERTO VIEJO

ANTONIO ALMAZÁN GRIJALVA

ANTONIO ALONSO

ANTONIO ALONSO

ANTONIO ÁLVAREZ

ANTONIO ÁLVAREZ

ANTONIO ÁLVAREZ

ANTONIO ÁLVAREZ CARRERA

ANTONIO AMIGO DE ARENILLAS

ANTONIO B...

ANTONIO BARONA GAMARRA

ANTONIO BASOCO

ANTONIO BENITO

ANTONIO BERGADO

ANTONIO BLANCO

ANTONIO BLANCO

ANTONIO BLANCO DE CETINA

ANTONIO BOLAÑOS

ANTONIO BUESO

ANTONIO CABEZÓN

ANTONIO CALDERÓN

ANTONIO CALDERÓN

ANTONIO CAMINO DE POLANCO

ANTONIO CARRERO

ANTONIO CASA DE UBANTE

ANTONIO COSCULLUELA

ANTONIO DE ALCOCER

ANTONIO DE ALTARACH

ANTONIO DE ANGULO

ANTONIO DE ANGULO ORIVE-SALAZAR

ANTONIO DE ARAMBURU

ANTONIO DE ARANGUREN

ANTONIO DE ARBIZU
ANTONIO DE ARENILLAS

ANTONIO DE ARISTEGUI

ANTONIO DE ARTIAGA

ANTONIO DE AYA

ANTONIO DE BAROJA

ANTONIO DE CANTABRANA

ANTONIO DE CARRIÓN

ANTONIO DE CASARES Y GARAY

ANTONIO DE CASCAJARES

ANTONIO DE CASCAJARES Y BLANCAS

ANTONIO DE CASTEJÓN

ANTONIO DE CASTRO

ANTONIO DE CASTRO

ANTONIO DE CASTROVIEJO

ANTONIO DE CAVALLERICES

ANTONIO DE CÉSPEDES

ANTONIO DE CUREDA Y HURTADO

ANTONIO DE ESCAULES

ANTONIO DE ESPINOSA

ANTONIO DE ESPINOSA Y SALCEDO

ANTONIO DE FABIERAS

ANTONIO DE FELOAGA

ANTONIO DE FELOAGA

ANTONIO DE FONTCUEVA

ANTONIO DE FRESNEDO

ANTONIO DE GUIA

ANTONIO DE HEREDIA

ANTONIO DE HERRERA

ANTONIO DE HERRERA VELARDE

ANTONIO DE ISLA

ANTONIO DE ISLA

ANTONIO DE JAURRIETA

ANTONIO DE LA CANAL

ANTONIO DE LA CUESTA

ANTONIO DE LA FUENTE

ANTONIO DE LA HELGUERA

ANTONIO DE LA IGLESIA

ANTONIO DE LA ORDEN

ANTONIO DE LA PEÑA

ANTONIO DE LA RIBA HERRERA

ANTONIO DE LA SIERRA

ANTONIO DE LA VEGA

ANTONIO DE LA VENERA

ANTONIO DE LA VILLANA

ANTONIO DE LAISECA

ANTONIO DE LANA

ANTONIO DE LAS CASAS

ANTONIO DE LEÓN 
ANTONIO DE LIZASOÁIN

ANTONIO DE LLANO

ANTONIO DE LLANO

ANTONIO DE LOMA OSORIO

ANTONIO DE LUNA Y PERALTA

ANTONIO DE MARDONES PINEDO

ANTONIO DE MARQUINA

ANTONIO DE MARRODÁN

ANTONIO DE MEDINA

ANTONIO DE MENDOZA E HIJAR

ANTONIO DE MOLLES

ANTONIO DE MUSANRIETA

ANTONIO DE NANCLARES

ANTONIO DE NOYA CASTILLO

ANTONIO DE OLIVER

ANTONIO DE OQUERRURI

ANTONIO DE ORDUÑA

ANTONIO DE OTERO

ANTONIO DE PALACIO

ANTONIO DE PALACIO

ANTONIO DE PALACIOS

ANTONIO DE PEDRAZA

ANTONIO DE PEDROSA

ANTONIO DE PEDROSO

ANTONIO DE PERALTA

ANTONIO DE PEREDA

ANTONIO DE POLANCO

ANTONIO DE PRADO

ANTONIO DE QUEVEDO

ANTONIO DE RIBAS

ANTONIO DE RUEDA

ANTONIO DE SABOYA

ANTONIO DE SALAS Y AGÜERO

ANTONIO DE SAN CRISTÓBAL

ANTONIO DE SANTO DOMINGO

ANTONIO DE SENDRA

ANTONIO DE TALLEDO

ANTONIO DE TORANZO

ANTONIO DE TORRES

ANTONIO DE URABAIN

ANTONIO DE URDAIZ

ANTONIO DE URSÚA Y ARRECHEA

ANTONIO DE VALDÉS

ANTONIO DE VEGA

ANTONIO DE VELASCO

ANTONIO DE VELASCO

ANTONIO DE VIGURIA

ANTONIO DE VILLASAÑANA BARRAL
ANTONIO DE VILLEGAS

ANTONIO DE VILLEGAS

ANTONIO DE YLGUERO

ANTONIO DE ZÁRRAGA

ANTONIO DEL ANO

ANTONIO DEL CAMPO

ANTONIO DEL CASTILLO

ANTONIO DEL CASTILLO

ANTONIO DEL MONTE

ANTONIO DEL RÍO

ANTONIO DELGADO

ANTONIO DÍAZ DE ARELLANO

ANTONIO DOMÍNGUEZ

ANTONIO EGUILUZ

ANTONIO ENTRECANALES

ANTONIO ESCUDERO

ANTONIO ESTEBAN DE PUIG

ANTONIO ESTEBAN Y GIL

ANTONIO ESTÉBANEZ GIL

ANTONIO ESTÉVANEZ

ANTONIO FERNÁNDEZ DE LA PORTILLA

ANTONIO FERNÁNDEZ DE MARDONES

ANTONIO FERNÁNDEZ HUIDOBRO

ANTONIO FERNÁNDEZ SOGA

ANTONIO FRANCISCO DE OCHOGAVÍA

ANTONIO FUICA

ANTONIO GARCÍA

ANTONIO GARCÍA

ANTONIO GARCÍA

ANTONIO GARCÍA

ANTONIO GARCÍA

ANTONIO GARCÍA

ANTONIO GARCÍA

ANTONIO GARCÍA DE LA TARGA

ANTONIO GARCÍA DE VELASCO

ANTONIO GARCÍA RAMÍREZ

ANTONIO GAYAN

ANTONIO GIL

ANTONIO GIL DEL CORRAL

ANTONIO GIMÉNEZ DE HOYOS

ANTONIO GÓMEZ

ANTONIO GÓMEZ

ANTONIO GÓMEZ

ANTONIO GÓMEZ

ANTONIO GÓMEZ DE CAPEÑA

ANTONIO GÓMEZ DE PALACIO

ANTONIO GÓMEZ MARAÑÓN

ANTONIO GONZÁLEZ 
ANTONIO GONZÁLEZ

ANTONIO GONZÁLEZ

ANTONIO GONZÁLEZ

ANTONIO GONZÁLEZ

ANTONIO GONZÁLEZ DE LOS RÍOS

ANTONIO GONZÁLEZ PARDO

ANTONIO GURREA

ANTONIO GUTIÉRREZ

ANTONIO GUTIÉRREZ DE LANZAS

ANTONIO GUTIÉRREZ DE SOLANO

ANTONIO GUTIÉRREZ Y DE NORIEGA

ANTONIO HERNÁNDEZ

ANTONIO HERNÁNDEZ

ANTONIO HERNÁNDEZ

ANTONIO HERNÁNDEZ DE EMINILLAS

ANTONIO HERRERA

ANTONIO HURTADO DE MENDOZA

ANTONIO IGLESIAS

ANTONIO JAIMES

ANTONIO JORDÁN GALBA

ANTONIO JOSÉ DE AOIZ

ANTONIO JUARBE

ANTONIO JUÁREZ

ANTONIO LA CUESTA

ANTONIO LA MAZA

ANTONIO LEZCANO

ANTONIO LIZÓN

ANTONIO LÓPEZ

ANTONIO LÓPEZ

ANTONIO LÓPEZ DE ECHAZARRETA

ANTONIO LÓPEZ DE PLASENCIA

ANTONIO LÓPEZ DE RUEDA

ANTONIO LÓPEZ DE VILLEGAS

ANTONIO LÓPEZ TELLO

ANTONIO LORENTE

ANTONIO LUCIO DE VILLEGAS

ANTONIO MADRACO ESCALERA

ANTONIO MARRÓN Y ALVARADO

ANTONIO MARTÍNEZ

ANTONIO MARTÍNEZ

ANTONIO MARTÍNEZ CUMPLIDO

ANTONIO MARTÍNEZ DE VITORIA

ANTONIO MASEDA

ANTONIO MATÍAS COSCOLÍN DE VALDÉS

ANTONIO MEDEROS

ANTONIO MÉNDEZ

ANTONIO MÉNDEZ DE SALAS
ANTONIO MERINO

ANTONIO MORTERUELO

ANTONIO MOSQUECHO

ANTONIO MUÑOZ DE CASTAÑEDA

ANTONIO NAVAMUEL SOBREMONTE

ANTONIO NAVARRO

ANTONIO NAVARRO E IBÁÑEZ

ANTONIO ORTIZ

ANTONIO ORTIZ CABALLERO

ANTONIO ORTIZ DE VÍCTORES

ANTONIO OSORIO DE LUGONES Y SAN-

DOVAL

ANTONIO PAINO

ANTONIO PALACIOS

ANTONIO PANIAGUA

ANTONIO PARCERO

ANTONIO PELÁEZ

ANTONIO PELEGRÍN

ANTONIO PELEGRÍN

ANTONIO PÉREZ

ANTONIO PÉREZ

ANTONIO PÉREZ BORAITA

ANTONIO PERLINES

ANTONIO PILARTE

ANTONIO PRIETO

ANTONIO RAMÍREZ DE ARELLANO

ANTONIO RAMOS

ANTONIO RAMOS

ANTONIO RANERO

ANTONIO RODRÍGUEZ

ANTONIO RODRÍGUEZ

ANTONIO RODRÍGUEZ

ANTONIO RODRÍGUEZ

ANTONIO RODRÍGUEZ

ANTONIO RODRÍGUEZ

ANTONIO RODRÍGUEZ

ANTONIO ROGEL

ANTONIO ROS

ANTONIO ROSILLO

ANTONIO RUIZ

ANTONIO RUIZ

ANTONIO RUIZ DE VEREDO Y VALDIVIESO

ANTONIO RUIZ HIDALGO

ANTONIO SÁENZ

ANTONIO SÁEZ

ANTONIO SAIZ

ANTONIO SALINAS 
ANTONIO SALINAS

ANTONIO SALVADOR

ANTONIO SÁNCHEZ

ANTONIO SÁNCHEZ DE LA GÁNDARA

ANTONIO SANTIAGO

ANTONIO SANTOS

ANTONIO SANTOS

ANTONIO SANZ

ANTONIO SEDANO BUSTAMANTE

ANTONIO SEIRA

ANTONIO SESE

ANTONIO SOLACHE DE ÁVALOS

ANTONIO SUÁREZ

ANTONIO TERÁN

ANTONIO THERRIS

ANTONIO URABAIN

ANTONIO VÁZQUEZ

ANTONIO VENEGAS

ANTONIO ZAMORANO

ANTONIO ZAPATA

ANTONIO ZATÓN

ANTONIO ZORRILLA

ANTONIO ZULOAGA

APARICIO DE LA ISECA

ATANASIO DE ANCHARTE

ATANASIO DE ESPINOSA

ATANASIO FERNÁNDEZ

ATANASIO FERNÁNDEZ

ATANASIO JIMÉNEZ

ATANASIO PASCASIO DE BOBADILLA

ATILANO GIL

ATILIANO DE COLLANTES

B. NIETO

BALTASAR ALONSO DE CELADA

BALTASAR ANTONIO DE LA PEÑA

BALTASAR CAMPILLO

BALTASAR DE ARIZÁBAL

BALTASAR DE BELZUNCE

BALTASAR DE CASTRO

BALTASAR DE GUTIÉRREZ DE ROZAS

BALTASAR DE LA MATA

BALTASAR DE LA TORRE Y OCÓN

BALTASAR DE LASAGA

BALTASAR DE LEZAÚN

BALTASAR DE MEDINA

BALTASAR DE MORALES

BALTASAR DE OZCÁRIZ

BALTASAR DE SAN JUAN
BALTASAR DE SOLARES

BALTASAR DÍAZ

BALTASAR DOMPER

BALTASAR FRANCISCO ÁLVAREZ DE MEDRANO

BALTASAR GÓMEZ

BALTASAR LÓPEZ DE VERGARA

BALTASAR MARTÍNEZ PARDO

BALTASAR SAINZ DE LA FUENTE

BALTASAR VICENTE IÑIGUEZ

BARTOLOMÉ CALDERÓN

BARTOLOMÉ ÁLVAREZ

BARTOLOMÉ ARGENTÉ

BARTOLOMÉ ASENJO

BARTOLOMÉ BUSTAMANTE

BARTOLOMÉ CALLEJA

BARTOLOMÉ DE ...

BARTOLOMÉ DE AGUIRRE

BARTOLOMÉ DE ÁLVARO

BARTOLOMÉ DE ARCE

BARTOLOMÉ DE ARLANAZ

BARTOLOMÉ DE ARRASTIA

BARTOLOMÉ DE AVELLANOSA

BARTOLOMÉ DE BURDASPAL Y BERBERANA

BARTOLOMÉ DE CÁRCAMO

BARTOLOMÉ DE CASUSO

BARTOLOMÉ DE CONTRERAS

BARTOLOMÉ DE CUBILLAS

BARTOLOMÉ DE DIEGO

BARTOLOMÉ DE FRANCIA

BARTOLOMÉ DE GARAY

BARTOLOMÉ DE GAYARRE

BARTOLOMÉ DE INSESA

BARTOLOMÉ DE LA CUESTA

BARTOLOMÉ DE LA GUARDIA

BARTOLOMÉ DE LA HELGUERA

BARTOLOMÉ DE LA ROBA

BARTOLOMÉ DE LA SERA

BARTOLOMÉ DE LODOSO

BARTOLOMÉ DE MADRAZO

BARTOLOMÉ DE MENDIETA

BARTOLOMÉ DE MONTAÑANA AGUIRRE

BARTOLOMÉ DE MURGA

BARTOLOMÉ DE ONZA

BARTOLOMÉ DE OSÉS

BARTOLOMÉ DE PALACIOS

BARTOLOMÉ DE PANDO 
BARTOLOMÉ DE PINEDO

BARTOLOMÉ DE SALAZAR

BARTOLOMÉ DE SALINAS

BARTOLOMÉ DE SAN CEBRIÁN

BARTOLOMÉ DE SANTOYO

BARTOLOMÉ DE TERÁN

BARTOLOMÉ DEL MORAL

BARTOLOMÉ DEL OLMO

BARTOLOMÉ DÍAZ

BARTOLOMÉ DÍAZ DE LA NAVILLA

BARTOLOMÉ FERNÁNDEZ

BARTOLOMÉ FERNÁNDEZ

BARTOLOMÉ FERNÁNDEZ

BARTOLOMÉ FERNÁNDEZ DE CARRIÓN

BARTOLOMÉ GARCÍA

BARTOLOMÉ GARCÍA DE MAYOR

BARTOLOMÉ GÓMEZ

BARTOLOMÉ GONZÁLEZ

BARTOLOMÉ GONZÁLEZ

BARTOLOMÉ GUTIÉRREZ DE LA RASILLA

BARTOLOMÉ LOZANO DE SARASA

BARTOLOMÉ MANTILLA

BARTOLOMÉ MAÑAS

BARTOLOMÉ MARTÍNEZ DE LA HERA

BARTOLOMÉ MATEO DE SALAZAR

BARTOLOMÉ MERINO

BARTOLOMÉ MOLINERO

BARTOLOMÉ ORTIZ

BARTOLOMÉ PANCORBO

BARTOLOMÉ PARAVICINI

BARTOLOMÉ PÉREZ

BARTOLOMÉ PÉREZ DE ESPEJO

BARTOLOMÉ RAMÍREZ

BARTOLOMÉ RODRÍGUEZ

BARTOLOMÉ RUIZ

BARTOLOMÉ SANZ

BARTOLOMÉ TORIBIO

BARTOLOMÉ VELA

BASILIO DE ARRANEGUI

BASILIO LOZANO

BAUTISTA DE OLAGARAY Y LIZONDO

BELTRÁN DE ABADÍA

BELTRÁN DE MORONDO

BELTRÁN GARRO

BENITO BUSTILLO

BENITO CEVALLOS

BENITO DE ANGUIANO
BENITO DE AÑAÑOS

BENITO DE ARAUJO

BENITO DE ARO

BENITO DE CASTRO

BENITO DE IGAR

BENITO DE IGLESIAS

BENITO DE LA CUESTA

BENITO DE OJEDA

BENITO DE PAREDES

BENITO DE SALA LLAUDES

BENITO DE ULLOA

BENITO DE VICUÑA

BENITO FER[NÁNDEZ] DEL CORRAL

BENITO FERNÁNDEZ

BENITO GÓMEZ RACIONERO

BENITO GONZÁLEZ

BENITO GONZÁLEZ

BENITO GUEMBE

BENITO MONDRAGÓN

BENITO NEVADO

BENITO PÉREZ DE ÁLAVA

BENITO RODRÍGUEZ

BENITO SALA

BENITO SALAZAR

BENITO SALGADO

BENITO SIMÓN

BENITO VILLAR RUIZ

BERNABÉ ALONSO DE CELADA

BERNABÉ ARENAS

BERNABÉ DE AMEZ

BERNABÉ DE BARRIDO

BERNABÉ DE HERRERA

BERNABÉ DE LA CONESA

BERNABÉ DE LA TORRE

BERNABÉ DE LA TORRE

BERNABÉ DE VALDIVIESO

BERNABÉ DE VILLAESCUSA

BERNABÉ DÍEZ

BERNABÉ GARCÍA

BERNABÉ GIL DE QUINTANA

BERNABÉ GONZÁLEZ

BERNABÉ GONZÁLEZ

BERNABÉ MARTEL

BERNABÉ MARTÍNEZ DE ALCÁNTARA

BERNABÉ ORTIZ

BERNABÉ ORTUÑO

BERNABÉ RODRÍGUEZ

BERNABÉ ROJO 
BERNABÉ ROMEU

BERNARDINO ALMANSA

BERNARDINO ÁLVAREZ

BERNARDINO DE ARIZALETA

BERNARDINO DE EZCARAY

BERNARDINO DE MENA

BERNARDINO DE VEGA

BERNARDINO GOT

BERNARDINO GUTIÉRREZ DE ROJAS ANGULO

BERNARDINO JAIMES

BERNARDINO MACÍAS SANTALLA

BERNARDINO MARTÍNEZ

BERNARDINO MULSA DE LA CASTA

BERNARDO ALONSO DE VILLALOBOS

BERNARDO ÁLVARO

BERNARDO APARICIO

BERNARDO BENITO

BERNARDO BLANCO

BERNARDO BLANCO

BERNARDO CALVO

BERNARDO CASADO DE ARREDONDO

BERNARDO DE ALZUETA

BERNARDO DE ALZUETA Y REPARAZ

BERNARDO DE ARANAZ

BERNARDO DE ARRÓNIZ

BERNARDO DE ASTORGA

BERNARDO DE BARONA

BERNARDO DE BIENMA

BERNARDO DE CALATAYUD

BERNARDO DE CASSO

BERNARDO DE ESCOBAR

BERNARDO DE ESTÚÑIIGA

BERNARDO DE GOÑI

BERNARDO DE GOÑI Y ASTRÁIN

BERNARDO DE IRISARRI

BERNARDO DE ISLA

BERNARDO DE LA CUESTA

BERNARDO DE LA CUESTA

BERNARDO DE LA MATA

BERNARDO DE LA PEÑA

BERNARDO DE MILLÁN

BERNARDO DE PERALTA

BERNARDO DE PORTAL

BERNARDO DE RETA

BERNARDO DE ROBA

BERNARDO DE SALAZAR

BERNARDO DE SAN ANDRÉS
BERNARDO DE SANCHA VALDERRAMA

BERNARDO DE SEIJA

BERNARDO DE SOTO

BERNARDO DE TAMAYO

BERNARDO DE THERRY

BERNARDO DE TUDELA

BERNARDO DE UGARTE

BERNARDO DE URIBARRI

BERNARDO DE VIÑUELAS

BERNARDO DEL FUEGO

BERNARDO DÍAZ

BERNARDO DÍEZ AGUSTÍN

BERNARDO DÍEZ DE AGUSTÍN MEDINI-

LLA

BERNARDO FERNÁNDEZ

BERNARDO FERNÁNDEZ TAMAYO

BERNARDO FRANCISCO QUIRÓS

BERNARDO GARCÍA

BERNARDO GARCÍA DE ANGULO

BERNARDO GÓMEZ

BERNARDO GONZÁLEZ

BERNARDO GONZÁLEZ

BERNARDO IZQUIERDO DE RIVERA

BERNARDO LABORA

BERNARDO LÓPEZ SAGREDO

BERNARDO MARTÍNEZ

BERNARDO MARTÍNEZ

BERNARDO MATIENZO

BERNARDO MOREDA

BERNARDO PÉREZ

BERNARDO PÉREZ DE CORELLA

BERNARDO POLO DE GÁMIZ

BERNARDO PORTILLA Y NAVARRO

BERNARDO RETA

BERNARDO RODRÍGUEZ

BERNARDO RUIZ

BERNARDO RUIZ DE CASTAÑEDA

BERNARDO SÁNCHEZ DE COS

BERNARDO SILA

BERNARDO TORRANO

BERNARDO VARGAS

BERNARDO VILLAFRUELA

BLAS ANTONIO DE LIMPIAS Y SARABIA

BLAS DE ARENAS

BLAS DE BARANGO

BLAS DE BUSTILLO

BLAS DE CASTAÑEDA

BLAS DE FORAYÓN VELASCO Y LASALA 
BLAS DE HERRERA

BLAS DE LA HERA

BLAS DE ORTEGA

BLAS DE SANTA CRUZ

BLAS DE SANTANDER

BLAS DE TEJADURA

BLAS DE URGAÑO

BLAS FERNÁNDEZ

BLAS GARCÍA

BLAS GONZÁLEZ

BLAS GONZÁLEZ DE RIVERO

BLAS GONZÁLEZ SARABIA

BLAS GUINDA

BLAS HERNÁIZ PÉREZ

BLAS JULIÁN DE LA PUENTE

BLAS LÓPEZ

BLAS LÓPEZ DE ANGUETA

BLAS MARTÍNEZ

BLAS MARTÍNEZ DE LOS RÍOS

BLAS MARTÍNEZ DE VALMAYOR

BLAS ORDÓÑEZ DE LARA

BLAS PÉREZ DE LA TORRE

BLAS RAMOS

BLAS RAMOS

BLAS SANZ

BLAS TASADURA

BONIFACIO DE LAÍN

BONIFACIO HURTADO LADRÓN DE CEGAMA

BRAULIO DE ASTORGA

BUENAVENTURA DE PAREDES

CARLOS ALONSO DE ARCE

CARLOS DE LA PEÑA

CARLOS DE HOGUERAS

CARLOS DE HUERTA

CARLOS DE LA PEÑA

CARLOS DE SENÉN

CARLOS DE VILLANUEVA

CARLOS DEL HOYO

CARLOS GAONA

CARLOS GARCÍA

CARLOS JOSÉ MARTÍNEZ DE ZALDUENDO

CARLOS MARTÍN

CARLOS PATRICIO DE PANDO

CARLOS RODRÍGUEZ

CARLOS ROMEO

CARLOS SORACOIZ
CECILIO DE HEREDIA

CEFERINO DE ULIBARRI

CELEDÓN ALCALDE

CELEDÓN DE ANDOSILLA Y ARRIETA

CELEDONIO DE CEBALLOS

CHACÓN MAZA

CLEMENTE CALLEJA

CLEMENTE DE AZCONA

CLEMENTE DE BÁRCENA

CLEMENTE DE LOYA

CLEMENTE GIL

CLEMENTE GORRAIZ

CLEMENTE JOSÉ DE MARQUINA

COSME CARDERÓN DEL CASTILLO

COSME DE LAS MUÑECAS

COSME MARTÍNEZ CALDERÓN

CRISTÓBAL BARBADILLO

CRISTÓBAL BARBO

CRISTÓBAL DE AGUILAR

CRISTÓBAL DE AMATRIAIN

CRISTÓBAL DE AÑORBE

CRISTÓBAL DE ARCE

CRISTÓBAL DE ARRIBILLAGA

CRISTÓBAL DE ARTIGA

CRISTÓBAL DE ATOCHA

CRISTÓBAL DE CASANUEVA

CRISTÓBAL DE GARZARÁN

CRISTÓBAL DE GONZALO

CRISTÓBAL DE LA TOBA

CRISTÓBAL DE LEDESMA

CRISTÓBAL DE LLANO PERAZA

CRISTÓBAL DE OLIVARES Y MÚJICA

CRISTÓBAL DE SALINAS AVELLANEDA

CRISTÓBAL DE SANTIBÁÑEZ

CRISTÓBAL DE TORRES

CRISTÓBAL DE URUÑUELA

CRISTÓBAL DÍAZ ANDINO

CRISTÓBAL FERNÁNDEZ DE VILLAROEL

CRISTÓBAL GAYARRE Y ATOCHA

CRISTÓBAL LABARRIETA

CRISTÓBAL MAZÓN

CRISTÓBAL RUIZ

CRISTÓBAL SANZ DE VALDIVIESO

CUSTODIO DE CASTRESANA Y GUINEA

CUSTODIO DÍAZ

DAMIÁN DE CERECEDA Y MENA

DAMIÁN DE FRÍAS 
DAMIÁN DE GAVILÁN

DAMIÁN DE PEÑARREDONDA

DAMIÁN GARCÍA

DAMIÁN MARQUÉS DE PRADO

DAMIÁN MÁRQUEZ

DAMIÁN NAVAMUEL

DAMIÁN RUIZ DE VELASCO

DAMIÁN VALLE OTÁÑEZ

DANIEL NÚÑEZ

DIEGO BRINGAS

DIEGO AGUADO

DIEGO AGUSTÍN DE PORDEGUELA ZAMUDIO

DIEGO ALONSO DE NÁJERA

DIEGO ALONSO DE OJEDA

DIEGO ALONSO DE PRADO

DIEGO ALONSO GUILARTE

DIEGO ANTONIO DE SANJUÁN

DIEGO ANTONIO GIMÉNEZ

DIEGO ARÍSTEGUI

DIEGO BARRÓN

DIEGO BENITO

DIEGO BERNÁRDEZ

DIEGO BERNÁRDEZ

DIEGO BRAVO

DIEGO CALIXTO RAMÍREZ

DIEGO CALLEJA

DIEGO CALLEJA

DIEGO CAMBERO

DIEGO COLAU

DIEGO CONDE LASSO Y SAÑUDO

DIEGO CORONADO

DIEGO DE ALCÁNTARA

DIEGO DE ALMEIDA

DIEGO DE ALVARADO

DIEGO DE ALVARADO

DIEGO DE ÁLVAREZ

DIEGO DE AMO

DIEGO DE ANDOSILLA Y ARRIETA

DIEGO DE ANGULO

DIEGO DE AQUERRETA

DIEGO DE ARANA

DIEGO DE ARCE

DIEGO DE ARCE

DIEGO DE ARCE REBOLLEDO

DIEGO DE ARENZANA

DIEGO DE ARIZA

DIEGO DE ARNALDO
DIEGO DE ARTEAGA

DIEGO DE AYARRA

DIEGO DE AYERRA

DIEGO DE BÁRCENA

DIEGO DE BARREDA

DIEGO DE BASANTA

DIEGO DE BRIZUELA

DIEGO DE BROAÑO Y MALDONADO

DIEGO DE BRONDO Y ENRÍQUEZ

DIEGO DE BULLÁN

DIEGO DE CABAÑAS

DIEGO DE CARRANZA

DIEGO DE CARRANZA

DIEGO DE CASTAÑEDA

DIEGO DE CASTEJÓN Y CONTRERAS

DIEGO DE CASTRO

DIEGO DE CASTRO RUIZ DE LA PEÑA

DIEGO DE CERRO

DIEGO DE CHARREN

DIEGO DE CHINCHÓN

DIEGO DE CHUECA

DIEGO DE CONCHA

DIEGO DE CORRAL

DIEGO DE COSSÍO Y VELARDE

DIEGO DE ECHARREN

DIEGO DE ECHARREN

DIEGO DE EGUÉS

DIEGO DE ENCÍO

DIEGO DE ESCALONA

DIEGO DE FRUTOS

DIEGO DE GAMBOA

DIEGO DE HERRERA

DIEGO DE HUÉRCANOS Y ALBEAR

DIEGO DE IBRICU

DIEGO DE IRIARTE

DIEGO DE IRIARTE

DIEGO DE IRIGUIEN

DIEGO DE JACA

DIEGO DE LA CÁMARA

DIEGO DE LA CUESTA

DIEGO DE LA HERA

DIEGO DE LA LANZA

DIEGO DE LA MANO

DIEGO DE LA MONEDA

DIEGO DE LA MONEDA

DIEGO DE LA PEÑA

DIEGO DE LA PEÑA BLANCA

DIEGO DE LA PORTILLA 
DIEGO DE LA PUENTE MONTECILLO

DIEGO DE LA PUERTA

DIEGO DE LA REGATA SOSA

DIEGO DE LA TORRE Y ROSALES

DIEGO DE LARRAURI

DIEGO DE LOS HEROS

DIEGO DE MATA

DIEGO DE MATIENZO

DIEGO DE MEDRANO

DIEGO DE MEÑACA

DIEGO DE MONROY

DIEGO DE MOREDA

DIEGO DE OCÓN Y CIRIZA

DIEGO DE OJEDA

DIEGO DE OLABARRIETA

DIEGO DE OLARTE

DIEGO DE OYAGA

DIEGO DE PARTE ARROYO

DIEGO DE QUINCOCES

DIEGO DE REDONDO

DIEGO DE ROSALES

DIEGO DE RUIZ

DIEGO DE SALAZAR

DIEGO DE SALCEDO

DIEGO DE SALINAS MEDINILLA

DIEGO DE SAN MARTÍN

DIEGO DE SANABIA

DIEGO DE SANDOVAL

DIEGO DE SANTANDER

DIEGO DE SARASA Y ARCE

DIEGO DE SIGÜENZA

DIEGO DE SILVA

DIEGO DE SOLÓRZANO

DIEGO DE SOTO

DIEGO DE TEJADA

DIEGO DE TEJADA

DIEGO DE TORANZO

DIEGO DE TORRES

DIEGO DE UNDA

DIEGO DE URQUIJO

DIEGO DE URRUTIA

DIEGO DE VARONA

DIEGO DE VIDORRETA

DIEGO DE VILLA

DIEGO DE VILLADIEGO

DIEGO DE VILLANUEVA

DIEGO DE VILLASANA Y PANIAGUA

DIEGO DE VÍCTORES
DIEGO DE YANGUAS

DIEGO DE ZUBIZARRETA

DIEGO DEL CASTILLO

DIEGO DEL HOYO

DIEGO DEL MORAL

DIEGO DEL POZO

DIEGO DEL POZO TELLO

DIEGO DELGADO

DIEGO DÍAZ

DIEGO DÍAZ DE ARBEIZA

DIEGO DÍAZ SALGADO

DIEGO EMELGO

DIEGO FELIZ GARCÍA

DIEGO FERNÁNDEZ

DIEGO FERNÁNDEZ

DIEGO FERNÁNDEZ

DIEGO FERNÁNDEZ

DIEGO FERNÁNDEZ DE AMAÑA

DIEGO FERNÁNDEZ DE BARREDA

DIEGO FERNÁNDEZ DE CÓRDOBA

DIEGO FERNÁNDEZ DE IMAÑA

DIEGO FERRER

DIEGO FRANCISCO NAVARRO

DIEGO GALLO DE ESCALADA

DIEGO GARCÍA

DIEGO GARCÍA

DIEGO GARCÍA

DIEGO GARCÍA

DIEGO GARCÍA DE LA MATA

DIEGO GARCÍA DE SOTO

DIEGO GIL

DIEGO GIL

DIEGO GÓMEZ

DIEGO GÓMEZ

DIEGO GÓMEZ DE REBOLLAR

DIEGO GÓMEZ DE SALAZAR

DIEGO GÓMEZ PIMENTEL

DIEGO GONZÁLEZ

DIEGO GONZÁLEZ

DIEGO GONZÁLEZ

DIEGO GONZÁLEZ

DIEGO GONZÁLEZ DE CASTRO

DIEGO GUTIÉRREZ DE TEJO

DIEGO HERNÁNDEZ DE LA TORRE

DIEGO IGNACIO MORRAS Y AZCONA

DIEGO ISLA DE HACES

DIEGO JALÓN

DIEGO JIMÉNEZ 
DIEGO JIMÉNEZ

DIEGO JIMÉNEZ DE ARELLANO LAGUNILLA

DIEGO LASANTA

DIEGO LEIVA

DIEGO LÓPEZ DE ANGULO

DIEGO LÓPEZ DE MIRAFUENTES

DIEGO LÓPEZ DE VAILLO

DIEGO LÓPEZ DEL VALLE

DIEGO LÓPEZ RUIZ

DIEGO MALO DE ANDUEZA

DIEGO MARCILLA

DIEGO MARROQUÍN Y MONTEHERMOSO

DIEGO MARTÍNEZ

DIEGO MARTÍNEZ

DIEGO MARTÍNEZ DE LA QUINTANA

DIEGO MARTÍNEZ DE LOSA

DIEGO MARTÍNEZ DE MORENTÍN

DIEGO MARTÍNEZ DE ONTALBARO

DIEGO MARTÍNEZ DE ZARZOSA

DIEGO MERINO

DIEGO MIRANDA Y RIVERA

DIEGO MORENO

DIEGO MORRAS

DIEGO OBREGÓN Y CASTAÑEDA

DIEGO OGAZÓN

DIEGO ORDÁS

DIEGO ORTIZ DE ZÁRATE

DIEGO PASCUAL

DIEGO PASCUAL

DIEGO PEDROSO

DIEGO PEREDA

DIEGO PÉREZ

DIEGO PÉREZ

DIEGO PÉREZ

DIEGO PÉREZ

DIEGO PÉREZ DE LARREA

DIEGO PÉREZ REBOLLO

DIEGO PLAZUELA DE MONTESERÍN

DIEGO PONCE DE LEÓN

DIEGO PRIETO

DIEGO RAM...

DIEGO RAMÓN DE BARRECHAL

DIEGO RUBÍN

DIEGO RUIZ

DIEGO RUIZ

DIEGO RUIZ

DIEGO RUIZ DE LA CALLEJA
DIEGO RUIZ DE OGARRIO

DIEGO RUIZ DE PORRAS

DIEGO RUIZ DE QUINTANA

DIEGO RUIZ DE SANTAYANA

DIEGO RUIZ MAROTO

DIEGO RUIZ MARTÍNEZ

DIEGO RUIZ Y QUINTANO

DIEGO SÁENZ

DIEGO SÁENZ

DIEGO SÁEZ DE BUSTAMANTE

DIEGO SÁINZ

DIEGO SÁINZ DE OCÓN

DIEGO SAIZ

DIEGO SAIZ DE ARQUINIGO

DIEGO SÁNCHEZ

DIEGO SÁNCHEZ DE GARAY

DIEGO SÁNCHEZ DE LA ROSA

DIEGO SÁNCHEZ DE LA VEGA

DIEGO SÁNCHEZ DE SAAVEDRA

DIEGO SANTOS

DIEGO SANZ

DIEGO SANZ DE LA MALETA

DIEGO SOLANA

DIEGO TARANCO

DIEGO TOMÁS

DIEGO URIBE

DIEGO ZUAZO

DIEGO ZURIA

DIONISIO DE ALQUIZA

DIONISIO DE ARZUN

DIONISIO DE COLMENARES

DIONISIO DE LERMA

DIONISIO DE MAZA

DIONISIO MARTÍNEZ

DIONISIO PENA

DIONISIO RODRÍGUEZ

DIONISIO TOMEI

DOMINGO ALBILLOS MADRIGAL

DOMINGO ALCALDE

DOMINGO ALFONSO DE OJEDA

DOMINGO ALVARADO

DOMINGO ALVARADO

DOMINGO ÁLVAREZ

DOMINGO APALATE

DOMINGO APARICIO

DOMINGO ARRUTARTE

DOMINGO BEAMONT Y ARIZCAIN

DOMINGO BRAIDINA 
DOMINGO BRINGAS

DOMINGO DANERO

DOMINGO DE AGUIRRE

DOMINGO DE ARAMONA

DOMINGO DE ARCELLA

DOMINGO DE ARENAS ALVARADO

DOMINGO DE ARROYUELO

DOMINGO DE AXAUS

DOMINGO DE BALLENT

DOMINGO DE BARRIO

DOMINGO DE BERINGAS

DOMINGO DE BONA

DOMINGO DE CASTRO

DOMINGO DE FORES

DOMINGO DE GARAY

DOMINGO DE GAZTAÑAGA

DOMINGO DE HERREROS

DOMINGO DE ITURGAIZ

DOMINGO DE LA AZUELA VELASCO

DOMINGO DE LA CANTERA

DOMINGO DE LA FUENTE

DOMINGO DE LA PEÑA

DOMINGO DE LA PEÑA

DOMINGO DE LA PLAZA

DOMINGO DE LA PUENTE PADRONES

DOMINGO DE LA SALA

DOMINGO DE LARA

DOMINGO DE LAS VENERAS

DOMINGO DE LASARTE

DOMINGO DE LISÓN

DOMINGO DE LLAÑO

DOMINGO DE MANSILLA

DOMINGO DE MATANZA

DOMINGO DE MIER

DOMINGO DE MIERES

DOMINGO DE MIJARES

DOMINGO DE MIÑÓN

DOMINGO DE ODRIA

DOMINGO DE ORNAT

DOMINGO DE OYARBIDE

DOMINGO DE PERAGALLO

DOMINGO DE QUINTANO

DOMINGO DE RASO

DOMINGO DE RUBAYO

DOMINGO DE SALAZAR

DOMINGO DE SALDAÑA

DOMINGO DE SIN

DOMINGO DE SOLA
DOMINGO DE TEJADA

DOMINGO DE TIEBAS

DOMINGO DE UBERRICHAGA

DOMINGO DE VALDIVIESO

DOMINGO DE VALPUESTA

DOMINGO DE VILLAMIEL

DOMINGO DE VILLANUEVA

DOMINGO DE ZAMACONA

DOMINGO DE ZAMORA

DOMINGO DEL CAÑO

DOMINGO DEL PORTILLO

DOMINGO DELGADO

DOMINGO DÍAZ

DOMINGO DÍAZ

DOMINGO FERNÁNDEZ

DOMINGO FERNÁNDEZ

DOMINGO FERNÁNDEZ

DOMINGO FERNÁNDEZ DE LA PEÑA

DOMINGO FERNÁNDEZ DE QUINTANI-

LLA

DOMINGO FERNÁNDEZ VIZARRA

DOMINGO FUENTES Y PERALTA

DOMINGO GALÍNDEZ

DOMINGO GÁRATE

DOMINGO GARCÍA

DOMINGO GARCÍA

DOMINGO GIL

DOMINGO GONZÁLEZ

DOMINGO GONZÁLEZ

DOMINGO GONZÁLEZ

DOMINGO GONZÁLEZ

DOMINGO GORBEA

DOMINGO GUTIÉRREZ

DOMINGO HURTADO

DOMINGO JIMÉNEZ

DOMINGO LA PEÑA

DOMINGO LA RIPA

DOMINGO LABORDA

DOMINGO LISÓN

DOMINGO LORCA

DOMINGO LORCA

DOMINGO LORENTE

DOMINGO LUIS DE GOÑI

DOMINGO MANSO

DOMINGO MARCO ENRÍQUEZ

DOMINGO MARTÍN

DOMINGO MARTÍN

DOMINGO MARTÍNEZ 
DOMINGO MARTÍNEZ

DOMINGO MARTÍNEZ

DOMINGO MARTÍNEZ

DOMINGO MARTÍNEZ

DOMINGO MARTÍNEZ DE LASTRAS

DOMINGO MARTÍNEZ DE MORENTÍN

DOMINGO MEZÓN

DOMINGO MILLÁN DE LARA

DOMINGO MONZÓN

DOMINGO NEGRETE

DOMINGO PABLO DE SAN PEDRO

DOMINGO PARDO

DOMINGO PEÑA

DOMINGO PÉREZ

DOMINGO PÉREZ DE ATOCHA

DOMINGO PÉREZ DE ATOCHA

DOMINGO PINTO

DOMINGO RUIZ

DOMINGO RUIZ

DOMINGO RUIZ

DOMINGO RUIZ

DOMINGO RUIZ

DOMINGO RUIZ

DOMINGO RUIZ DE ARREDONDO

DOMINGO SÁINZ DE LA ERANUEVA

DOMINGO SÁINZ TALÓN

DOMINGO SÁNCHEZ DE TRÁPAGA

DOMINGO SANTIAGO PÉREZ

DOMINGO SOMAVILLA

DOMINGO VILLANA

ENRIQUE DE LA GARMA

ENRIQUE DE QUESADA Y TOLEDO

ENRIQUE DE VIRIERZ

ENRIQUE URRIÉS Y CRUZAT

ESPINA DE VELASCO

ESTEBAN ANTONIO

ESTEBAN ARBIZU

ESTEBAN BAUTISTA

ESTEBAN CALZADA

ESTEBAN DE AMECHEZURRA

ESTEBAN DE ANGULO

ESTEBAN DE ARBELOA

ESTEBAN DE ARRAIDU

ESTEBAN DE ATRIZTAN

ESTEBAN DE AVACIOSA

ESTEBAN DE BARREDA

ESTEBAN DE CARVAJAL

ESTEBAN DE CASANUEVA
ESTEBAN DE CORRAL

ESTEBAN DE GAUNA

ESTEBAN DE HAZA

ESTEBAN DE IBARROLA Y SAN VICEN-

TE

ESTEBAN DE JÁUREGUI

ESTEBAN DE LA CRUZ

ESTEBAN DE LA GARZA

ESTEBAN DE LA TEJADA

ESTEBAN DE LANDETA

ESTEBAN DE NOBA

ESTEBAN DE OYEREGUI

ESTEBAN DE PERALTA

ESTEBAN DE QUINTANA

ESTEBAN DE SALINAS

ESTEBAN DE SARRO

ESTEBAN DE SOTO

ESTEBAN DE SUGADI

ESTEBAN DE YÁRNOZ Y SOLCHAGA

ESTEBAN DEL CAMPO

ESTEBAN DEL CORRAL

ESTEBAN DEL COTERO

ESTEBAN DEL HOYO

ESTEBAN FERNÁNDEZ

ESTEBAN FERNANDO DE ZUBIAUR

ESTEBAN GARCÍA

ESTEBAN GARCÍA DE ROQUE

ESTEBAN GONZÁLEZ

ESTEBAN GONZÁLEZ

ESTEBAN GRISALVO RAMOS

ESTEBAN GUTIÉRREZ

ESTEBAN GUTIÉRREZ DE MEDINA

ESTEBAN IÑIIIGUEZ

ESTEBAN OLOQUI

ESTEBAN VELASCO DE MORALES

ESTEBAN VERGEA GUEVARA

ESTEBAN VIU

EUGENIO DE ARTAZU

EUGENIO DE ARTAZU

EUGENIO DE SALAZAR

EUSEBIO DE PALOMERA VALLEJO

FABIÁN GARCÍA

FABIÁN NOGALES

FAUSTINO DE BÁRCENA

FAUSTO DE ARAMENDÍA

FAUSTO DE BURUTÁIN

FAUSTO DE ECHEVERRÍA

FAUSTO DE EUSA 
FAUSTO DE GÜESA

FAUSTO DE LA CRU...

FAUSTO RODRÍGUEZ DE SEGURA

FAUSTO RUIZ DE MUNIAIN

FAUSTO RUIZ DE URRA

FEDERICO RAMÍREZ

FELIPE AGUSTÍN DE BÁRCENA

FELIPE ÁLVAREZ

FELIPE BENITO

FELIPE BERJÓN

FELIPE BERNAL

FELIPE CALVO

FELIPE CASTRILLO

FELIPE DE AGUIRRE Y MARTÍNEZ

FELIPE DE ANTUÑANO

FELIPE DE ARCE

FELIPE DE ARIAS Y MEDINA

FELIPE DE BARCENA

FELIPE DE BUJEDO

FELIPE DE BURUAGA

FELIPE DE DUREDO

FELIPE DE FANDUAS

FELIPE DE GÁNDARA

FELIPE DE GAZTELU

FELIPE DE GORDOJUELA

FELIPE DE LA CAÑADA

FELIPE DE LA LLANA

FELIPE DE LA PEÑA

FELIPE DE LA POSTILLA

FELIPE DE LA REGATA

FELIPE DE LA SIERRA

FELIPE DE LOPE

FELIPE DE MIERA RUBALCABA

FELIPE DE NAVEDA Y GARNICA

FELIPE DE PIEDRA

FELIPE DE RIBAS

FELIPE DE TRASLAVIÑA

FELIPE DE UNGO Y VELASCO

FELIPE DE ZÚÑIGA

FELIPE DEL CASTILLO

FELIPE DÍAZ DE VALDIVIESO

FELIPE DÍAZ DE VALDIVIESO

FELIPE GARCÍA

FELIPE GONZÁLEZ

FELIPE GUTIÉRREZ

FELIPE GUTIÉRREZ

FELIPE HERRERA VELARDE

FELIPE ILASO
FELIPE LÓPEZ

FELIPE LÓPEZ

FELIPE LÓPEZ DE LA FUENTE

FELIPE MACHADO ESPÍNOLA

FELIPE MARTÍNEZ

FELIPE MARTÍNEZ

FELIPE MARTÍNEZ

FELIPE MATEO

FELIPE PEREDA

FELIPE PÉREZ

FELIPE PÉREZ DEL RÍO

FELIPE RIBERO BARREDA

FELIPE RUIZ

FELIPE RUIZ DE SALAZAR

FELIPE SANTIAGO

FELIPE VAMONDE

FELIPE VÉLEZ

FÉLIX DE RADA

FÉLIX DE SALTO

FÉLIX VELASCO

FERMÍN DE AZCÁRATE

FERMÍN DE ESPARZA

FERMÍN DE EZPELETA

FERMÍN DE IRIGOYEN

FERMÍN DE MARICHALAR

FERMÍN DE MARICHALAR

FERMÍN DE MEARIN

FERMÍN DE NOAIN

FERMÍN DE OLLO

FERMÍN DE ROA

FERMÍN DE SALCEDO

FERMÍN DE URUÑUELA

FERMÍN DE VERGARA

FERMÍN DE VERTIZ

FERMÍN DE VICUÑA

FERNANDO ALONSO

FERNANDO ANTONIO DE CARIGA Y PALACIO

FERNANDO ANTONIO DE NATES MATIENZO

FERNANDO ANTONIO ORTIZ

FERNANDO CAMPO

FERNANDO DE ANGULO

FERNANDO DE AOIZ

FERNANDO DE ARBARCA

FERNANDO DE CASTILLO Y NALDA

FERNANDO DE CORCUERA

FERNANDO DE ELCARTE 
FERNANDO DE ELCARTE

FERNANDO DE GAZÓLAZ

FERNANDO DE LA MOLINA

FERNANDO DE LAS CABEZAS

FERNANDO DE LORCA

FERNANDO DE MEDRANO

FERNANDO DE MENDOZA Y SOTOMAYOR

FERNANDO DE MIRANDA

FERNANDO DE SALAZAR Y VELASCO

FERNANDO DE SAN MARTÍN

FERNANDO DE SANTANDER

FERNANDO DEL HOYO

FERNANDO DEL MAZO CALDERÓN

FERNANDO DÍAZ

FERNANDO DÍAZ CASTRO

FERNANDO DÍAZ DE VILLEGAS

FERNANDO GARCÍA

FERNANDO GÓMEZ

FERNANDO GONZÁLEZ

FERNANDO GONZÁLEZ DE HOYOS

FERNANDO GONZÁLEZ HURTADO

FERNANDO GUTIÉRREZ DE TERÁN

FERNANDO IBÁÑEZ

FERNANDO MUÑOZ DE VILLEGAS

FERNANDO ORTÚÑEZ

FERNANDO SÁNCHEZ DE CASIGUERA

FLAMINIO BACCI ELPIDIANO

FRANCISCO A. DE ISLA

FRANCISCO ABAD HERRERO

FRANCISCO AGUIRIANO LASANTA

FRANCISCO AGUSTÍN

FRANCISCO ALFONSO DE VEGA

FRANCISCO ALONSO

FRANCISCO ALONSO

FRANCISCO ALONSO

FRANCISCO ALONSO

FRANCISCO ALONSO

FRANCISCO ALONSO

FRANCISCO ALONSO

FRANCISCO ALONSO DEL PINO

FRANCISCO ALONSO GARCÍA

FRANCISCO ALONSO VELÁZQUEZ

FRANCISCO ÁLVAREZ

FRANCISCO ÁLVAREZ

FRANCISCO ÁLVAREZ DEL VALLE

FRANCISCO AMATRIAIN

FRANCISCO AMETLLER
FRANCISCO AMEZ

FRANCISCO ANDRÉS

FRANCISCO ANGULO

FRANCISCO ANTONIO

FRANCISCO ANTONIO BALTANÁS

FRANCISCO ANTONIO BALTANÁS

FRANCISCO ANTONIO CLAVERÍA

FRANCISCO ANTONIO DE ARREDONDO

FRANCISCO ANTONIO DE CEBALLOS

FRANCISCO ANTONIO DE CONTRERAS

FRANCISCO ANTONIO DE ERILL

FRANCISCO ANTONIO DE LA CASA PIE-

DRA Y ACEVEDO

FRANCISCO ANTONIO DE LA SIERRA

FRANCISCO ANTONIO DE LA SOTA

FRANCISCO ANTONIO DE OTAÑES

FRANCISCO ANTONIO DE QUINTANO

FRANCISCO ANTONIO DE SADO

FRANCISCO ANTONIO FERNÁNDEZ VILLEGAS

FRANCISCO ANTONIO GONZÁLEZ CA$\mathrm{CHO}$

FRANCISCO ANTONIO HERRERO

FRANCISCO ANTONIO MATIENZO DE LA ÁGUILA

FRANCISCO ARANGUREN

FRANCISCO ARANGUREN

FRANCISCO ARIZA

FRANCISCO ARROYO

FRANCISCO ARTETA

FRANCISCO ASIÁIN Y MEDRANO

FRANCISCO AYALA

FRANCISCO AZCONA

FRANCISCO BAGUER SARASA

FRANCISCO BALLESTEROS

FRANCISCO BARAJO

FRANCISCO BARONA VILLANUEVA RUIZ

FRANCISCO BARRIUSO SANZ

FRANCISCO BAUTISTA GIRALDO

FRANCISCO BENERO CARRILLO

FRANCISCO BENITO

FRANCISCO BENITO

FRANCISCO BERNAD

FRANCISCO BERNARDINO

FRANCISCO BERNARDO DE ARNEDO

FRANCISCO BERNARDO PONCE

FRANCISCO BLANCO 
FRANCISCO BLANCO

FRANCISCO BOCANEGRA

FRANCISCO BRAVO

FRANCISCO BUENDÍA

FRANCISCO BURRIELA

FRANCISCO CABALLERO

FRANCISCO CACHO

FRANCISCO CALDERÓN DE LA BARCA

FRANCISCO CALVO

FRANCISCO CALVO

FRANCISCO CALVO

FRANCISCO CAMBERO

FRANCISCO CANTÓN

FRANCISCO CARLOS

FRANCISCO CARRERA

FRANCISCO CASCAJARES

FRANCISCO CASTILLO DE FILORGA

FRANCISCO CAVERO

FRANCISCO CEBALLOS ESTRADA

FRANCISCO CIDAD

FRANCISCO CLARET

FRANCISCO COLMENARES

FRANCISCO CORRAL

FRANCISCO CORRAL Y CHÁVARRI

FRANCISCO CORTÉS

FRANCISCO CRESPO

FRANCISCO CRUZADO

FRANCISCO CUESTA

FRANCISCO CUÑADO

FRANCISCO CURIEL

FRANCISCO DE ACEBEDO

FRANCISCO DE AEL

FRANCISCO DE AGÜERO

FRANCISCO DE AGUILAR

FRANCISCO DE AGUIRRE

FRANCISCO DE AIBAR

FRANCISCO DE AISANOA

FRANCISCO DE ALAIZA Y VICUÑA

FRANCISCO DE ALCOZ

FRANCISCO DE ALMARZA

FRANCISCO DE ALSÚA

FRANCISCO DE AMPUERO

FRANCISCO DE ANGULO

FRANCISCO DE ANGULO

FRANCISCO DE ANGULO

FRANCISCO DE APARICIO

FRANCISCO DE APARICIO

FRANCISCO DE ARAUJO
FRANCISCO DE ARCE

FRANCISCO DE ARCE

FRANCISCO DE ARCE

FRANCISCO DE ARCE CÁMARA

FRANCISCO DE ARCE GALA

FRANCISCO DE ARENGUES Y COVARRUBIAS

FRANCISCO DE ARGUIANO

FRANCISCO DE ARIA

FRANCISCO DE ARROYO

FRANCISCO DE ARROYO

FRANCISCO DE ARTACHO Y GAMBOA

FRANCISCO DE ARTETA

FRANCISCO DE ARTIGOSA

FRANCISCO DE ARZANE

FRANCISCO DE AVELLANOSA

FRANCISCO DE AYALA

FRANCISCO DE AYERBE

FRANCISCO DE AZAS

FRANCISCO DE AZCONA Y ECHARREN

FRANCISCO DE AZGOITIA

FRANCISCO DE AZPILICUETA

FRANCISCO DE BALANZA

FRANCISCO DE BARCINA

FRANCISCO DE BELTRÁN

FRANCISCO DE BERASTEGUI

FRANCISCO DE BILBAO

FRANCISCO DE BOLÍN

FRANCISCO DE BORJA

FRANCISCO DE BREBILLA

FRANCISCO DE BRIZUELA

FRANCISCO DE BUJANDA

FRANCISCO DE BUSTO

FRANCISCO DE CADENA

FRANCISCO DE CAMPOMANES

FRANCISCO DE CANZANO

FRANCISCO DE CASARES

FRANCISCO DE CASTANEDO Y CEBALLOS

FRANCISCO DE CASTRO

FRANCISCO DE CASTRO

FRANCISCO DE CASTRO BERMÚDEZ

FRANCISCO DE CEBALLOS

FRANCISCO DE CEBALLOS MADRID

FRANCISCO DE CEGAMA

FRANCISCO DE CÉSPEDES

FRANCISCO DE CESTONA

FRANCISCO DE CHAGUE SARASA 
FRANCISCO DE COLINA FRANCISCO DE COS Y DEL CORRO FRANCISCO DE COVARRUBIAS FRANCISCO DE DURANGO FRANCISCO DE EGEA FRANCISCO DE EGUILUZ FRANCISCO DE ELCARTE FRANCISCO DE ELCARTE FRANCISCO DE ELIZONDO FRANCISCO DE ELORZA FRANCISCO DE ESCALANTE FRANCISCO DE ESCAPADILLO FRANCISCO DE ESPINOSA FRANCISCO DE ESPINOSA FRANCISCO DE ESPINOSA FRANCISCO DE FRESEDO FRANCISCO DE FRÍAS FRANCISCO DE FRÍAS FRANCISCO DE GAINZA FRANCISCO DE GAMBOA LIAÑO FRANCISCO DE GANDARILLAS FRANCISCO DE GÜEMES FRANCISCO DE GUINEA SALAZAR FRANCISCO DE GUZMÁN FRANCISCO DE HARO FRANCISCO DE HERAS FRANCISCO DE HERNANDO FRANCISCO DE HERRADOR FRANCISCO DE HORCASITAS FRANCISCO DE HOYOS BRAVO FRANCISCO DE HUARTE FRANCISCO DE HUERTA FRANCISCO DE HUERTA FRANCISCO DE IGUAL FRANCISCO DE INOGEDA FRANCISCO DE IRABIEN FRANCISCO DE JADO DEL MAZO FRANCISCO DE LA ANDIÓN FRANCISCO DE LA CUESTA FRANCISCO DE LA CUESTA FRANCISCO DE LA CUESTA FRANCISCO DE LA CUEVA FRANCISCO DE LA FUENTE FRANCISCO DE LA GÁNDARA FRANCISCO DE LA LLANILLA FRANCISCO DE LA MAZA FRANCISCO DE LA MAZONA FRANCISCO DE LA PEÑA
FRANCISCO DE LA PEÑA FRANCISCO DE LA PEÑA FRANCISCO DE LA PORTILLA FRANCISCO DE LA PUENTE FRANCISCO DE LA QUINTANA FRANCISCO DE LA RIBA FRANCISCO DE LA RIVA AGÜERO FRANCISCO DE LA SARRA VENERO FRANCISCO DE LA SIERRA PUENTE Y SOLÓRZANO

FRANCISCO DE LA TORRE FRANCISCO DE LA VEGA FRANCISCO DE LAGUNO FRANCISCO DE LAMA FRANCISCO DE LAMO FRANCISCO DE LARREA FRANCISCO DE LARREGUI FRANCISCO DE LARRINAGA FRANCISCO DE LEIBA FRANCISCO DE LEIZA FRANCISCO DE LEMOS FRANCISCO DE LEÓN FRANCISCO DE LERMA FRANCISCO DE LIAÑO FRANCISCO DE LLANO FRANCISCO DE LOIZAGA FRANCISCO DE LORIA FRANCISCO DE LOS RÍOS FRANCISCO DE MAESTRESALA SAMANIEGO FRANCISCO DE MALDA FRANCISCO DE MATA FRANCISCO DE MATA FRANCISCO DE MAULEÓN FRANCISCO DE MEDIAVILLA FRANCISCO DE MEDINA FRANCISCO DE MELLA Y TERREROS FRANCISCO DE MENA FRANCISCO DE MENDIGUREN FRANCISCO DE MENDÍVIL FRANCISCO DE MOLINA FRANCISCO DE MONTEMAYOR FRANCISCO DE MONTENEGRO FRANCISCO DE MONTOYA FRANCISCO DE MORALES FRANCISCO DE MORCATE FRANCISCO DE MORENTÍN FRANCISCO DE MUGA 
FRANCISCO DE MURGA

FRANCISCO DE MURILLO

FRANCISCO DE MURO

FRANCISCO DE MURRIETA

FRANCISCO DE OBREGÓN

FRANCISCO DE OCHANDIANO

FRANCISCO DE OCÓN

FRANCISCO DE OJEA

FRANCISCO DE OLCOZ

FRANCISCO DE OLEA

FRANCISCO DE OLEA GUTIÉRREZ

FRANCISCO DE OLEA TORRE

FRANCISCO DE OLLOQUI

FRANCISCO DE OLMOS

FRANCISCO DE OLMOS

FRANCISCO DE OLÓNDRIZ

FRANCISCO DE OREÑA

FRANCISCO DE ORTEGA

FRANCISCO DE ORTEGA Y SOTO

FRANCISCO DE PADILLA

FRANCISCO DE PADILLA

FRANCISCO DE PAGOLA

FRANCISCO DE PALACIOS

FRANCISCO DE PALACIOS

FRANCISCO DE PAMANES

FRANCISCO DE PENIN

FRANCISCO DE PEÑARANDA

FRANCISCO DE PEREDA

FRANCISCO DE PEREDA

FRANCISCO DE PEREDA Y VILLAR

FRANCISCO DE PINA

FRANCISCO DE PLASENCIA

FRANCISCO DE PORRAS

FRANCISCO DE PUERTAS

FRANCISCO DE QUÍLEZ

FRANCISCO DE QUINCOCES

FRANCISCO DE QUINTANA ANGULO

FRANCISCO DE QUIRANO

FRANCISCO DE RADO

FRANCISCO DE REBOLLEDA

FRANCISCO DE RIBAS

FRANCISCO DE RIBERO

FRANCISCO DE ROA

FRANCISCO DE ROZAS

FRANCISCO DE SAGREDO

FRANCISCO DE SALAMANCA

FRANCISCO DE SALAZAR

FRANCISCO DE SALAZAR Y CEPEDA
FRANCISCO DE SALINAS

FRANCISCO DE SALINAS MEDINILLA

FRANCISCO DE SAN MARTÍN

FRANCISCO DE SAN MARTÍN

FRANCISCO DE SANTA MARÍA

FRANCISCO DE SANTACLARA

FRANCISCO DE SANTANDER

FRANCISCO DE SANTANDER

FRANCISCO DE SANTANDER MARROQUÍN

FRANCISCO DE SANTIBÁÑEZ

FRANCISCO DE SANTIBÁÑEZ

FRANCISCO DE SECADURA

FRANCISCO DE SEDANO

FRANCISCO DE SIERRA ALTA

FRANCISCO DE SILLARES CASADO

FRANCISCO DE SORIA

FRANCISCO DE SUNIEGA

FRANCISCO DE TOBAR

FRANCISCO DE TOCA

FRANCISCO DE TOLEDO

FRANCISCO DE TORRES

FRANCISCO DE TORRES

FRANCISCO DE TORRES NAVARRETE

FRANCISCO DE TREJANOS

FRANCISCO DE UGARTE

FRANCISCO DE UNDIANO

FRANCISCO DE URÍA Y MÚJICA

FRANCISCO DE URIBE

FRANCISCO DE URIERTA

FRANCISCO DE URIOSTE

FRANCISCO DE URREA

FRANCISCO DE URRETA

FRANCISCO DE URRUTIA

FRANCISCO DE URRUTIA

FRANCISCO DE URTIAGA

FRANCISCO DE VEGA Y VARGAS

FRANCISCO DE VELASCO

FRANCISCO DE VELESAR

FRANCISCO DE VILELLA

FRANCISCO DE VILLANUEVA

FRANCISCO DE VILLEGAS

FRANCISCO DE VILLOSLADA

FRANCISCO DE VILLOTA

FRANCISCO DE VITORIA

FRANCISCO DE VIVAR

FRANCISCO DE ZALDÍBAR

FRANCISCO DE ZÁRATE 
FRANCISCO DE ZÁRRAGA FRANCISCO DE ZITANO FRANCISCO DE ZUBIAGA FRANCISCO DEL AGUA FRANCISCO DEL BARRIO FRANCISCO DEL CASTILLO FRANCISCO DEL CASTILLO ALVARADO FRANCISCO DEL CORRAL Y VELASCO FRANCISCO DEL FOZ FRANCISCO DEL HOYO FRANCISCO DEL HOYO FRANCISCO DEL PONTÓN FRANCISCO DEL PORTAL FRANCISCO DEL RÍO FRANCISCO DEL RÍO FRANCISCO DEL RÍO FRANCISCO DEL RÍO MIERA FRANCISCO DEL VAL FRANCISCO DELGADO FRANCISCO DELGADO FRANCISCO DELGADO FRANCISCO DESCARAY FRANCISCO DÍAZ FRANCISCO DÍAZ FRANCISCO DÍAZ FRANCISCO DÍAZ FRANCISCO DÍAZ DE ISLA FRANCISCO DÍAZ DE MEDINA FRANCISCO DÍAZ DE TOLOSA FRANCISCO DÍAZ DE VALDIVIESO FRANCISCO DÍAZ IGLESIAS FRANCISCO DÍAZ ORTEGA FRANCISCO DÍAZ RODRÍGUEZ FRANCISCO DÍAZ RODRÍGUEZ FRANCISCO DÍEZ FRANCISCO DÍEZ FRANCISCO DÍEZ DE MIRANDA FRANCISCO DÍEZ SAINZ FRANCISCO DOMINGO GÓMEZ FRANCISCO DOMÍNGUEZ FRANCISCO DOREDEA FRANCISCO ENRÍQUEZ DE ABLITAS FRANCISCO ERASO FRANCISCO ESPINOSA FRANCISCO FERNÁNDEZ FRANCISCO FERNÁNDEZ FRANCISCO FERNÁNDEZ FRANCISCO FERNÁNDEZ
FRANCISCO FERNÁNDEZ FRANCISCO FERNÁNDEZ FRANCISCO FERNÁNDEZ CALDERÓN FRANCISCO FERNÁNDEZ DE MANZANOS FRANCISCO FERNÁNDEZ DE MARMANILLO

FRANCISCO FERNÁNDEZ DE MIÑANO FRANCISCO FERNÁNDEZ DE OÑATE FRANCISCO FERNÁNDEZ DE UGARTE FRANCISCO FERNÁNDEZ VELASCO FRANCISCO FRAILE FRANCISCO GADEO FRANCISCO GALARÓN FRANCISCO GALERÓN FRANCISCO GALLEGO FRANCISCO GALLEGO FRANCISCO GARCÉS DE FANECAS FRANCISCO GARCÍA FRANCISCO GARCÍA FRANCISCO GARCÍA FRANCISCO GARCÍA FRANCISCO GARCÍA FRANCISCO GARCÍA FRANCISCO GARCÍA FRANCISCO GARCÍA FRANCISCO GARCÍA ARROYO FRANCISCO GARCÍA BERMEJO FRANCISCO GARCÍA DE ARNEDO FRANCISCO GARCÍA DE COSSÍO FRANCISCO GARCÍA DE EULATE FRANCISCO GARCÍA DE LA HIEDRA FRANCISCO GARCÍA DE LILLA FRANCISCO GARCÍA DE OLALLA FRANCISCO GARCÍA DEL MORAL FRANCISCO GARCÍA FRANCO FRANCISCO GARRIDO FRANCISCO GAVILÁN FRANCISCO GAYANGOS BASTRIDA FRANCISCO GIL FRANCISCO GIL FRANCISCO GIL FRANCISCO GIL DE MENDOZA FRANCISCO GÓMEZ FRANCISCO GÓMEZ FRANCISCO GÓMEZ FRANCISCO GÓMEZ FRANCISCO GÓMEZ DE COSÍO FRANCISCO GÓMEZ DE QUINTANA 
FRANCISCO GÓMEZ RAMÍREZ

FRANCISCO GÓMEZ URBAN

FRANCISCO GONZÁLEZ

FRANCISCO GONZÁLEZ

FRANCISCO GONZÁLEZ

FRANCISCO GONZÁLEZ

FRANCISCO GONZÁLEZ

FRANCISCO GONZÁLEZ

FRANCISCO GONZÁLEZ

FRANCISCO GONZÁLEZ

FRANCISCO GONZÁLEZ

FRANCISCO GONZÁLEZ

FRANCISCO GONZÁLEZ

FRANCISCO GONZÁLEZ DE HEREDIA

FRANCISCO GONZÁLEZ DE MANSILLA

FRANCISCO GONZÁLEZ DE REBA

FRANCISCO GONZÁLEZ DE SALCEDO

FRANCISCO GONZÁLEZ DE SALCES

FRANCISCO GONZÁLEZ LABIA

FRANCISCO GUILAZ

FRANCISCO GURÉNDEZ

FRANCISCO GUTIÉRREZ

FRANCISCO GUTIÉRREZ

FRANCISCO GUTIÉRREZ

FRANCISCO GUTIÉRREZ AVINA

FRANCISCO GUTIÉRREZ DE AYALA

FRANCISCO GUTIÉRREZ DE LA PEÑA

FRANCISCO GUTIÉRREZ DE RIVA

FRANCISCO GUTIÉRREZ DEL OLMO

FRANCISCO HERNÁNDEZ

FRANCISCO HERNÁNDEZ BASURTO

FRANCISCO IBÁÑEZ

FRANCISCO IBÁÑEZ

FRANCISCO IDIAGUEZ

FRANCISCO JIMÉNEZ

FRANCISCO JIMÉNEZ DE ARELLANO

FRANCISCO JIMÉNEZ DE OCO

FRANCISCO JUÁREZ

FRANCISCO LA IGLESIA

FRANCISCO LA IGLESIA GONZÁLEZ

FRANCISCO LA VARGA

FRANCISCO LABARI

FRANCISCO LADRÓN

FRANCISCO LADRÓN DE CEGAMA

FRANCISCO LAMBARÓN Y VILLEGAS

FRANCISCO LARIBA

FRANCISCO LASANTA ARGUIRIANO

FRANCISCO LAZCANO
FRANCISCO LECUMBERRI

FRANCISCO LEQUIRIA CEBALLOS

FRANCISCO LÓPEZ

FRANCISCO LÓPEZ

FRANCISCO LÓPEZ

FRANCISCO LÓPEZ

FRANCISCO LÓPEZ

FRANCISCO LÓPEZ DE DICASTILLO

FRANCISCO LÓPEZ DE LA PEÑA

FRANCISCO LÓPEZ DE QUINTANA

FRANCISCO LÓPEZ DEL ÁGUILA

FRANCISCO LÓPEZ FRÍAS

FRANCISCO LÓPEZ MARTÍNEZ

FRANCISCO LÓPEZ RIVAS

FRANCISCO LORENZ

FRANCISCO LORENZ

FRANCISCO LORENZO

FRANCISCO LUIS JIMÉNEZ

FRANCISCO MACÍAS SANTALLA

FRANCISCO MALO DEL RÍO

FRANCISCO MALUENDA

FRANCISCO MANRIQUE

FRANCISCO MANSILLA

FRANCISCO MANSILLA

FRANCISCO MANUEL

FRANCISCO MANUEL DE SISNIEGA

FRANCISCO MARCO

FRANCISCO MARCO Y ENRÍQUEZ

FRANCISCO MARCOS

FRANCISCO MARCOS BALLESTEROS

FRANCISCO MARÍN DE RODEZNO

FRANCISCO MARRÓN Y MURGA

FRANCISCO MARROQUÍN

FRANCISCO MARTÍNEZ

FRANCISCO MARTÍNEZ

FRANCISCO MARTÍNEZ

FRANCISCO MARTÍNEZ

FRANCISCO MARTÍNEZ

FRANCISCO MARTÍNEZ

FRANCISCO MARTÍNEZ

FRANCISCO MARTÍNEZ

FRANCISCO MARTÍNEZ

FRANCISCO MARTÍNEZ DE UZQUIANO

FRANCISCO MARTÍNEZ ARAUJO

FRANCISCO MARTÍNEZ DE ARCE

FRANCISCO MARTÍNEZ DE LOS RÍOS

FRANCISCO MARTÍNEZ DE SOMAVILLA

FRANCISCO MARTÍNEZ DE SOTO 
FRANCISCO MARTÍNEZ DE VILLEGAS FRANCISCO MARTÍNEZ DE VITORIA FRANCISCO MARTÍNEZ FERNÁNDEZ FRANCISCO MATANZA FRANCISCO MAULEÓN FRANCISCO MEDEL FRANCISCO MÉNDEZ FRANCISCO MENDIGUREN FRANCISCO MERINO FRANCISCO MERINO FRANCISCO MERINO FRANCISCO MIGUEL FRANCISCO MIGUEL GARCÍA FRANCISCO MINER FRANCISCO MONEDERO FRANCISCO MORANTE DE LA MADRID FRANCISCO MORCAT FRANCISCO MUÑOZ FRANCISCO MUÑOZ FRANCISCO MUÑOZ FRANCISCO NAVARRETE FRANCISCO NEGRETE FRANCISCO NEGRETE FRANCISCO NEGRO FRANCISCO OCHOA FRANCISCO OCHOA DE CERQUERA FRANCISCO OLEART GURIÉRREZ FRANCISCO OLÓRIZ FRANCISCO ORIBE FRANCISCO ORTEGA FRANCISCO ORTEGA FRANCISCO ORTEGA FRANCISCO ORTIZ FRANCISCO ORTIZ FRANCISCO ORTIZ FRANCISCO ORTIZ DE SALAZAR FRANCISCO ORTIZ VELA FRANCISCO OTÍN FRANCISCO PABLOS FRANCISCO PAGOLA FRANCISCO PALACIO FRANCISCO PALACIO FRANCISCO PALOMINO FRANCISCO PARDO FRANCISCO PASCUAL MUGA FRANCISCO PEDRO FRANCISCO PÉREZ FRANCISCO PÉREZ
FRANCISCO PÉREZ FRANCISCO PÉREZ FRANCISCO PÉREZ FRANCISCO PÉREZ FRANCISCO PÉREZ FRANCISCO PÉREZ BARCENILLA FRANCISCO PÉREZ CAMINO FRANCISCO PÉREZ DE AMALLO FRANCISCO PÉREZ DE LA VEGA FRANCISCO PÉREZ DE NOBAL FRANCISCO PÉREZ DE VILLAESCUSA FRANCISCO PÉREZ MACHUCA FRANCISCO PISÓN FRANCISCO PRIETO FRANCISCO PUGA FRANCISCO QUINTANA FRANCISCO RADA RIBERO FRANCISCO RAMOS FRANCISCO REVALLOS BRAVO FRANCISCO RIBAS FRANCISCO RODRÍGUEZ FRANCISCO RODRÍGUEZ FRANCISCO RODRÍGUEZ FRANCISCO RODRÍGUEZ FRANCISCO RODRÍGUEZ DE AYALA FRANCISCO RODRÍGUEZ DE LA LASTRA FRANCISCO RODRÍGUEZ DE LOS RÍOS FRANCISCO RODRÍGUEZ MANSILLA FRANCISCO RODRÍGUEZ OLEO FRANCISCO ROLDÁN FRANCISCO ROMEO FRANCISCO RUBÍN FRANCISCO RUBÍN DE LA MADRID FRANCISCO RUIZ FRANCISCO RUIZ FRANCISCO RUIZ FRANCISCO RUIZ FRANCISCO RUIZ FRANCISCO RUIZ FRANCISCO RUIZ FRANCISCO RUIZ DE CORQUERA FRANCISCO RUIZ DE LA RABIA FRANCISCO RUIZ DE LEZA FRANCISCO RUIZ DE ORDOÑANA FRANCISCO RUIZ DE PEREDA FRANCISCO RUIZ DE PRADILLA FRANCISCO RUIZ DE QUINTANA FRANCISCO RUIZ DE SOBREMONTE 
FRANCISCO RUIZ TRECHUELO

FRANCISCO RUIZ VALLINES

FRANCISCO RUIZ VÁZQUEZ

FRANCISCO RUPÉREZ

FRANCISCO SÁENZ

FRANCISCO SÁENZ

FRANCISCO SÁENZ

FRANCISCO SÁENZ VALIENTE

FRANCISCO SÁEZ

FRANCISCO SAINZ DE ZALDÚA

FRANCISCO SAIZ

FRANCISCO SALDAÑA

FRANCISCO SALDAÑA BRAVO

FRANCISCO SALGADO

FRANCISCO SALVADOR

FRANCISCO SAMITIER

FRANCISCO SÁNCHEZ

FRANCISCO SÁNCHEZ

FRANCISCO SÁNCHEZ DE MOREDA

FRANCISCO SANTAMARÍA

FRANCISCO SANTOS

FRANCISCO SANZ DE ESPIGA

FRANCISCO SANZ DE LA IGLESIA

FRANCISCO SANZ DE LECIÑANA

FRANCISCO SANZ VALIENTE

FRANCISCO SECO

FRANCISCO SECO

FRANCISCO SECO RODRÍGUEZ

FRANCISCO SEDANO

FRANCISCO SEDANO

FRANCISCO SEGUROLA

FRANCISCO SERÍN Y LARRAZA

FRANCISCO SIMÓN

FRANCISCO SIMÓN DE VILLANUEVA

FRANCISCO TEJEDOR

FRANCISCO TOMÉ

FRANCISCO TORRIENTES

FRANCISCO TURRILLAS

FRANCISCO VALLES

FRANCISCO VELASCO

FRANCISCO VÉLEZ DE LOYOLA

FRANCISCO VENCEY

FRANCISCO VENTURA CASTELLANOS

FRANCISCO VENTURA DE PALACIO

FRANCISCO VERDEGUER

FRANCISCO VERGADO

FRANCISCO VILLEGAS

FRANCISCO VILLEGAS
FRANCISCO VISO

FRANCISCO YAGO

FRANCISCO YOLDI

FRANCISCO ZÁRATE

FRANCISCO ZORRILLA

GABRIEL ÁLVAREZ DE PALACIOS

GABRIEL ANTÓN

GABRIEL BERNARDO DE TORRES

GABRIEL DE ARANAZ

GABRIEL DE BAÑARES

GABRIEL DE BOCOS

GABRIEL DE BRIZUELA

GABRIEL DE CEBALLOS

GABRIEL DE CHERÁN

GABRIEL DE CONCHILLOS

GABRIEL DE ESLAVA

GABRIEL DE ESPARZA

GABRIEL DE FARO

GABRIEL DE HUARTE

GABRIEL DE IBARRA

GABRIEL DE IRIGARRI

GABRIEL DE ISTÚRIZ

GABRIEL DE LA RIBA DE HERRERA

GABRIEL DE LAVA

GABRIEL DE MATAPAJA

GABRIEL DE MAYA

GABRIEL DE MENCOA

GABRIEL DE MONREAL

GABRIEL DE PÁRAMO Y SANDE

GABRIEL DE PAREDES

GABRIEL DE PEREDA

GABRIEL DE SAN ROMÁN

GABRIEL DE TAMARIT

GABRIEL DE VELLISCA

GABRIEL DE VILLEGAS

GABRIEL DE YURRE

GABRIEL DE ZABALZA

GABRIEL DEL CORRAL

GABRIEL DEL SOLAR TORAYA

GABRIEL DÍAZ

GABRIEL ELIZONDO

GABRIEL GARCÍA

GABRIEL GONZÁLEZ

GABRIEL GONZÁLEZ DE LA VID

GABRIEL GULLÓN SOBREMONTE

GABRIEL MARTÍNEZ

GABRIEL MARTÍNEZ DE SUSO

GABRIEL PÉREZ 
GABRIEL PÉREZ

GABRIEL PÉREZ DE PALACIO

GABRIEL REBOLLEDO

GABRIEL RODRIGO

GABRIEL SÁINZ DE DUEÑAS

GARCÍA DE MIERA RUBALCABA

GARCÍA DE MORETA MALDONADO Y PAZ

GARCÍA DE TOLEDO MOCTEZUMA

GARCÍA HERMOSA

GARCÍA HURTADO DE MENDOZA

GARCÍA OSORIO

GASPAR BARAONA

GASPAR BARONA

GASPAR BERMÚDEZ

GASPAR CRUZADO

GASPAR DE ÁLAVA

GASPAR DE ANAYA

GASPAR DE BEDOYA

GASPAR DE BESGA

GASPAR DE CARIAGA

GASPAR DE CEBALLOS

GASPAR DE ECHEGUREN

GASPAR DE HERRÁN Y EZCARAY

GASPAR DE LA VIÑA

GASPAR DE MAHAMUD

GASPAR DE MAHAMUD

GASPAR DE PARADA

GASPAR DE SALAZAR

GASPAR DE SALINAS

GASPAR DE SALINAS

GASPAR DE SAN LLORENTE

GASPAR DE SANFELICES

GASPAR DE SANMARTÍN

GASPAR DE SANTA... ALBIEZ

GASPAR DE VILLELA

GASPAR DEL CAMPO

GASPAR DÍAZ

GASPAR FERNÁNDEZ

GASPAR GARCÍA

GASPAR GARCÍA DE OLEA

GASPAR GARCÍA Y MANSILLA

GASPAR GIL

GASPAR GÓMEZ

GASPAR GÓMEZ DE LA FUENTE

GASPAR GONZÁLEZ

GASPAR LÓPEZ

GASPAR LOZANO

GASPAR LUIS
GASPAR LUIS CAMACHO DE URREA

GASPAR MARCOS

GASPAR ORTIZ

GASPAR PASCUAL

GASPAR PÉREZ

GASPAR RODRÍGUEZ

GASPAR SEDANO

GASPAR TAPIA

GASPAR VALLEJO

GASPAR VARONA

GASPAR VÉLEZ DE ONTAÑÓN

GERARDO DE AZPILCUETA

GERMÁN DE BUGES

GERVASIO DE CASTILLA

GIL DE ALBORNOZ

GIL DE ALFARO

GIL DE URBINA

GIL RAMÍREZ DE ARELLANO

GINÉS DE PEÑALVER

GOFREDO DANIEL

GÓMEZ MARTÍN CORTÉS

GONZALO DE ANGULO

GONZALO DE ANSÓ

GONZALO DE ARGUIÑANO

GONZALO DE BEAR

GONZALO DE BERRIO

GONZALO DE EULATE

GONZALO DE VILLA

GONZALO DE ZAMACONA

GONZALO DEL BUSTO

GONZALO GADEO

GONZALO MORENO

GONZALO ROMERO SOTELO

GONZALO TOMÁS

GREGORIO ARROYO

GREGORIO ARROYO VÉLEZ DE VALDIVIESO

GREGORIO AZCÁRRAGA

GREGORIO CASADO

GREGORIO CORREA

GREGORIO DE ACEDO

GREGORIO DE ALDABA

GREGORIO DE ALEMPARTE Y MONTES

GREGORIO DE ARGAIZ

GREGORIO DE CANDUELA

GREGORIO DE CASTRO

GREGORIO DE HARO

GREGORIO DE IBARROLA 
GREGORIO DE LARA

GREGORIO DE LARRAGA

GREGORIO DE LUZÁRRAGA

GREGORIO DE MENDIUNE

GREGORIO DE NÁJERA CASTILLO

GREGORIO DE OLMOS

GREGORIO DE QUINTANILLA

GREGORIO DE SALAZAR SOLÓRZANO

GREGORIO DE SALAZAR SOLÓRZANO

GREGORIO DE SÁMANO

GREGORIO DE SILVA

GREGORIO DE TOLEDO

GREGORIO DE TORRECILLA

GREGORIO DE URBINA

GREGORIO DE VACA Y CASTRO

GREGORIO DEL BUSTO

GREGORIO DÍAZ DE SALAZAR

GREGORIO DÍEZ TRUCHUELO

GREGORIO ENRÍQUEZ

GREGORIO ESCUDERO

GREGORIO FERNÁNDEZ

GREGORIO FERNÁNDEZ

GREGORIO GALLO

GREGORIO GARCÍA

GREGORIO GARCÍA

GREGORIO GARCÍA

GREGORIO GARCÍA

GREGORIO GARCÍA

GREGORIO GARCÍA DE PEREDA

GREGORIO GARCÍA DEL CASTILLO

GREGORIO GÓMEZ

GREGORIO GRANDA

GREGORIO GURMENDI

GREGORIO GUTIÉRREZ

GREGORIO MACHUCA

GREGORIO MARCOS BALLESTERO

GREGORIO MARTÍNEZ

GREGORIO MARTÍNEZ

GREGORIO MARTÍNEZ

GREGORIO PARCERO

GREGORIO QUÍLEZ

GREGORIO REDONDO

GREGORIO RIAÑO GAMBOA

GREGORIO RODRIGO

GREGORIO RODRÍGUEZ

GREGORIO RUIZ

GREGORIO RUIZ

GREGORIO RUIZ
GREGORIO RUIZ DE SAGREDO Y PORRES

GREGORIO RUIZ OTEO

GREGORIO SAIZ

GREGORIO TAMARÓN

GUILLERMO BARÓN

GUILLERMO FERNÁNDEZ

GUILLERMO GIL

GUILLERMO OCÓN

HERMENEGILDO DE VIDAURRETA

HERNANDO DE HUIDOBRO

HERNANDO DE LA MATA LINARES

HERNANDO DE LA SOTA Y ACEVEDO

HERNANDO DE LA TORRE

HERNANDO DE MARÍN

HERNANDO DE RECALDE

HERNANDO DE SOBREMAZAS

HERNANDO DE VALDIZAN

HERNANDO ENRÍQUEZ

HERNANDO GONZÁLEZ DE HOYOS

HERNANDO RODRÍGUEZ

HERNANDO SANTOS

HERNANDO VIZQUEY Y AMBILA

HIPÓLITO DE MONTARANA

IGNACIO DE BELASCOÁIN

IGNACIO DE CALABAZANOS

IGNACIO DE CEBALLOS

IGNACIO DE ECHEVESTE

IGNACIO DE ESANDI

IGNACIO DE GOSEGUIN

IGNACIO DE LARREA Y VALDIVIESO

IGNACIO DE LATASA

IGNACIO DE LIZARGÁRATE

IGNACIO DE MUÑOZ Y ARCE

IGNACIO DE PEÑA

IGNACIO DE SOTO

IGNACIO DE URQUIETA

IGNACIO DE ZOZAYA

IGNACIO DEL RÍO

IGNACIO FERNÁNDEZ DE MEDRANO

IGNACIO GAZTELU Y LATASA

IGNACIO GONZÁLEZ

IGNACIO GONZÁLEZ

IGNACIO GONZÁLEZ DE LOS RÍOS

IGNACIO MARTÍNEZ

IGNACIO PÉREZ

ILDEFONSO DE ESCUDERO

ILDEFONSO OVEJAS 
ÍNIIGO BUITRÓN

ÍÑIGO DE CASTAÑIZA

ÍÑIGO DE FRÍAS

ÍÑIGO DE MAISTERRA

ÍÑIGO DE PÁRAMO

ÍÑIGO DE REGÚLEZ

ÍÑIGO DE ROJAS

ÍÑIGO DE RUILOBA

ÍÑIGO DE RUILOBA

ÍÑIGO DE VARONA

ÍNIIGO DEL VAL

ÍÑIGO GARVIDE

ÍÑIGO MARTÍNEZ DE SALAZAR

ÍÑIGO RECALDE

ÍÑIGO ROYO

ÍÑIGO ROYO

ÍÑIGO VÉLEZ DE FRÍAS

ISIDORO GONZÁLEZ

ISIDRO DE LA FUENTE

ISIDRO DE QUEVEDO Y BUSTAMANTE

ISIDRO DE SAN PEDRO

ISIDRO DEL CERRO

ISIDRO IBÁÑEZ

ISIDRO PÉREZ

IVO DE ILUNDÁIN

J. PARDO

JACINTO ALONSO

JACINTO DE GUEVARA

JACINTO DE ORTEGA

JACINTO DE SAZONENA

JACINTO DE SEDANO

JACINTO DE SOMOZA

JACINTO DE VALLES

JACINTO DE VELARDE

JACINTO DÍEZ

JACINTO ESCRIBANO

JACINTO FERNÁNDEZ DE SAN SALVADOR

JACINTO GARCÍA

JACINTO GARCÍA

JACINTO GUTIÉRREZ

JACINTO GUTIÉRREZ

JACINTO MANRIQUE

JACINTO MARAÑÓN

JACINTO MARTÍNEZ

JACINTO PÉREZ DE NUEROS

JACINTO RUIZ DE PAZUENGOS

JACINTO TORNES
JACINTO UROIZ

JACOBO DE RIOJA BADILLO

JAIME DE ABIO

JAIME GUDEL

JAIME LIARTE

JAIME PORTOLÉS

JAIME TEJERO

JAVIER CADIÑANOS

JERÓNIMO ... MODREGO

JERÓNIMO ALBOREZ

JERÓNIMO ÁLVAREZ CARRERA

JERÓNIMO ARCAYA

JERÓNIMO BALLESTER

JERÓNIMO BARDAJÍ Y GUZMÁN

JERÓNIMO BAROJA

JERÓNIMO CALVO

JERÓNIMO DE AZCONA

JERÓNIMO DE AZCONA

JERÓNIMO DE EGUÍA

JERÓNIMO DE ERCE Y PORTILLO

JERÓNIMO DE ESTRADA

JERÓNIMO DE FELOAGA

JERÓNIMO DE FORTUNIO

JERÓNIMO DE GAVADI

JERÓNIMO DE GÓMEZ

JERÓNIMO DE GOÑI

JERÓNIMO DE IPENGA

JERÓNIMO DE JÁUREGUI

JERÓNIMO DE LA HOZ

JERÓNIMO DE LA MUELA

JERÓNIMO DE LA PLAZA

JERÓNIMO DE LERMA

JERÓNIMO DE MAR Y GIL

JERÓNIMO DE MILLÁN

JERÓNIMO DE MIRANDA

JERÓNIMO DE MORENTÍN

JERÓNIMO DE MURGA

JERÓNIMO DE OROZ

JERÓNIMO DE RADA

JERÓNIMO DE RIEZU

JERÓNIMO DE RUFIA

JERÓNIMO DE SALANABA

JERÓNIMO DE SAN CRISTÓBAL

JERÓNIMO DE SANTOS

JERÓNIMO DE SILOS

JERÓNIMO DE SORIA Y ARTIAGA

JERÓNIMO DE SUVIA

JERÓNIMO DE TORQUEMADA 
JERÓNIMO DE UNZU

JERÓNIMO DE VELASCO

JERÓNIMO DE VILLEGAS

JERÓNIMO DE YANGUAS

JERÓNIMO DE YANGUAS

JERÓNIMO DÍAZ DE LA PEÑA

JERÓNIMO DÍEZ MAESTRO

JERÓNIMO DOMÍNGUEZ

JERÓNIMO ESCRIBANO

JERÓNIMO ESTEBAN LÓPEZ Y TORRELLAS

JERÓNIMO FERNÁNDEZ DE ALDEA

JERÓNIMO FRANCISCO MORALES

JERÓNIMO GARCÍA

JERÓNIMO GARCÍA DE LOS LLANOS

JERÓNIMO GARCÍA SALÓN

JERÓNIMO GÓMEZ

JERÓNIMO GONZÁLEZ

JERÓNIMO GUTIÉRREZ

JERÓNIMO IBÁÑEZ DE ZÁRATE

JERÓNIMO JULIÁN

JERÓNIMO JULIÁN FRANCÉS

JERÓNIMO LADRÓN

JERÓNIMO LÁZARO

JERÓNIMO LÓPEZ

JERÓNIMO MARCOS

JERÓNIMO MARTÍNEZ

JERÓNIMO MARTÍNEZ

JERÓNIMO MARTÍNEZ

JERÓNIMO MARTÍNEZ

JERÓNIMO MARTÍNEZ

JERÓNIMO MARTÍNEZ RUBIO

JERÓNIMO MEDRANO

JERÓNIMO MONCALIÁN

JERÓNIMO NEGRETE

JERÓNIMO PEREIRA

JERÓNIMO PÉREZ

JERÓNIMO PÉREZ

JERÓNIMO PÉREZ

JERÓNIMO PÉREZ DE LA VEGA

JERÓNIMO PÉREZ SERRANO

JERÓNIMO PUEBLA DE OREJA CAMARGO

JERÓNIMO PUIG

JERÓNIMO RAMÍREZ

JERÓNIMO ROMERO

JERÓNIMO SANTIBÁÑEZ

JERÓNIMO SEDANO
JERÓNIMO SEVILLA

JERÓNIMO TÉLLEZ LIZANA

JERÓNIMO VELARDE

JERÓNIMO VIDAURRE

JERÓNIMO VIRTO

JERÓNIMO ZURITA

JOAQUÍN DE ERRAZU

JOAQUÍN DE GUEVARA Y ZABALA

JOAQUÍN DE ILARREGUI

JOAQUÍN DE OCARANZA

JOAQUÍN DE ORTIGOSA

JOAQUÍN DE PLANTADA

JOAQUÍN DE VILLAFRANCA

JOAQUÍN JOSÉ DE IBARROLA

JOAQUÍN LÓPEZ DE ATOCHA

JORGE DE BURGOS

JORGE DE UGALDE

JORGE DEL PRADO

JORGE GRACIÁN

JORGE NUNES

JORGE NÚÑEZ

JOSÉ LÓPEZ

JOSÉ ABAD

JOSÉ ACEITORES

JOSÉ ALONSO

JOSÉ ALONSO

JOSÉ ALONSO

JOSÉ ALONSO DE ANGULO

JOSÉ ALONSO DE MATA

JOSÉ ALONSO PÉREZ DE LOS RÍOS

JOSÉ ALONSO REDONDO

JOSÉ ALONSO SÁIZ

JOSÉ ÁLVAREZ

JOSÉ ÁLVAREZ

JOSÉ AMO

JOSÉ AMUNÁRRIZ

JOSÉ ANSÓN DE LA TORRE

JOSÉ ANTÓN

JOSÉ ANTONIO DE LA VEGA

JOSÉ ANTONIO DE LIZARAZU

JOSÉ ANTONIO GARCÍA

JOSÉ ANTONIO LASTRE Y FRÍAS

JOSÉ ANTONIO MERINO

JOSÉ ARNÁIZ

JOSÉ ARRANZ

JOSÉ ARREDONDO

JOSÉ BARAÓN

JOSÉ BARREDA 
JOSÉ BARRIGA DE MATA

JOSÉ BARRIO CANAL

JOSÉ BAZÁN

JOSÉ BELTRÁN

JOSÉ BERAIZ Y ANTILLÓN

JOSÉ BERCEDO

JOSÉ BOZALBE

JOSÉ BRAVO

JOSÉ BURDEOS

JOSÉ BURUTÁIN

JOSÉ CACHARRO

JOSÉ CALDERÓN

JOSÉ CALDERÓN DEL CASTILLO

JOSÉ CALLEJA

JOSÉ CALZADA

JOSÉ CARPINTERO TELLO

JOSÉ CARRERA

JOSÉ CARRILLO

JOSÉ CASADO Y RUBIO

JOSÉ CASASÚS Y MOLINOS

JOSÉ CENZANO

JOSÉ CERÓN

JOSÉ CORREDOR

JOSÉ COSÍO

JOSÉ CUADRADO

JOSÉ DE ACEDO

JOSÉ DE ACU...

JOSÉ DE AGUIRRE

JOSÉ DE ALARCOS

JOSÉ DE ALBARES

JOSÉ DE ALCEDO

JOSÉ DE ALDALLUR

JOSÉ DE ALONAIZ

JOSÉ DE AMATRIÁIN

JOSÉ DE AMATRIÁIN

JOSÉ DE AMATRIÁIN

JOSÉ DE AMEZ

JOSÉ DE ANDRÉS

JOSÉ DE ANGULO

JOSÉ DE APARICIO

JOSÉ DE ARANGUREN

JOSÉ DE ARBIZU

JOSÉ DE ARCE

JOSÉ DE ARCOS

JOSÉ DE ARDIT

JOSÉ DE ARGAIZ

JOSÉ DE ARIA

JOSÉ DE ARLEGUI
JOSÉ DE ARRIETA

JOSÉ DE ARTIAGA

JOSÉ DE ARZA

JOSÉ DE AVENDAÑO

JOSÉ DE AYALDE

JOSÉ DE AZPE

JOSÉ DE AZPES

JOSÉ DE BADARÁN

JOSÉ DE BARAONA

JOSÉ DE BARRIGA Y MATA

JOSÉ DE BARRIOMIRÓN

JOSÉ DE BIDUARTE

JOSÉ DE BURDASPAR

JOSÉ DE BURGOS

JOSÉ DE BUSTOS

JOSÉ DE CABAÑAS

JOSÉ DE CABAÑAS Y SANABIA

JOSÉ DE CALDONIA

JOSÉ DE CÁRCAR

JOSÉ DE CARMONA

JOSÉ DE CASANAL TAMAYO

JOSÉ DE CASANOVA

JOSÉ DE CAVIA

JOSÉ DE CAZABAL

JOSÉ DE CHASCO

JOSÉ DE CISNEROS

JOSÉ DE CUÉLLAR RUESGA

JOSÉ DE DOMÍNGUEZ

JOSÉ DE DONA MARÍA

JOSÉ DE ECHAURI

JOSÉ DE EGUES

JOSÉ DE EGUÍLAZ

JOSÉ DE EGUIZÁBAL

JOSÉ DE EJEA

JOSÉ DE ENGUITA

JOSÉ DE ESPINOSA

JOSÉ DE ESPINOSA

JOSÉ DE FABRE Y URTASO

JOSÉ DE GOÑI

JOSÉ DE GUABARRI

JOSÉ DE GUINEA

JOSÉ DE GURPEGUI

JOSÉ DE HARO

JOSÉ DE HERRERA Y VELASCO

JOSÉ DE IBARRA

JOSÉ DE IBARROLA

JOSÉ DE IBUSQUETA

JOSÉ DE ICHASO EZTALAURRUTIA 
JOSÉ DE ILZARBE

JOSÉ DE IRAGUI

JOSÉ DE IRIGOYEN

JOSÉ DE IRÚN

JOSÉ DE JUBERA

JOSÉ DE LA CANTERA

JOSÉ DE LA CEPINA

JOSÉ DE LA CERDA

JOSÉ DE LA FUENTE

JOSÉ DE LA FUENTE

JOSÉ DE LA FUENTE

JOSÉ DE LA IGLESIA

JOSÉ DE LA PEÑA

JOSÉ DE LA SIERRA

JOSÉ DE LA TORRE

JOSÉ DE LA TORRE

JOSÉ DE LA VEGA

JOSÉ DE LARRAURI

JOSÉ DE LATOR

JOSÉ DE LEÓN

JOSÉ DE LEZANA

JOSÉ DE LÍO

JOSÉ DE LIZARRAGA

JOSÉ DE LODOSA

JOSÉ DE LOS ARCOS Y MEDRANO

JOSÉ DE LOSA

JOSÉ DE LOSADA

JOSÉ DE MAGAROLA

JOSÉ DE MAÑERAS

JOSÉ DE MAYA

JOSÉ DE MEDIAVILLA Y GARCÍA

JOSÉ DE MENDIETA

JOSÉ DE MENDOZA Y GUARÓN

JOSÉ DE MIER Y TERÁN

JOSÉ DE MONTERRUBIO

JOSÉ DE MUNÁRRIZ Y LIZÁRRAGA

JOSÉ DE NÁJERA SALVADOR

JOSÉ DE NEVADO

JOSÉ DE NOBOA

JOSÉ DE NOGUERADO

JOSÉ DE OCHOA Y ARTEAGA

JOSÉ DE OIPA

JOSÉ DE OLAETA

JOSÉ DE OLARIAGA

JOSÉ DE OLEO

JOSÉ DE OLMOS

JOSÉ DE OSORIO

JOSÉ DE OTEIZA
JOSÉ DE PALACIOS

JOSÉ DE PEDROSA

JOSÉ DE PEÑA

JOSÉ DE PEÑARANDA

JOSÉ DE PERALTA

JOSÉ DE PEREDA

JOSÉ DE PIERNAS

JOSÉ DE PORRASA

JOSÉ DE PORTILLO

JOSÉ DE PRADO

JOSÉ DE QUINTANA

JOSÉ DE REDO

JOSÉ DE RIAÑO

JOSÉ DE RIPALDA

JOSÉ DE ROCAS

JOSÉ DE RODRIGO

JOSÉ DE SADA

JOSÉ DE SADA Y ANTILLÓN

JOSÉ DE SAGASTI

JOSÉ DE SAGASTI Y GOITIA

JOSÉ DE SALAMANCA

JOSÉ DE SALAZAR

JOSÉ DE SALCEDO

JOSÉ DE SÁMANO

JOSÉ DE SAMPER

JOSÉ DE SAN MIGUEL

JOSÉ DE SANTA CLARA

JOSÉ DE SANTAFÉ

JOSÉ DE SARRIÁ

JOSÉ DE SOJO

JOSÉ DE SOLA

JOSÉ DE SOMAVILLA

JOSÉ DE SOTO

JOSÉ DE SOTO

JOSÉ DE SOTO

JOSÉ DE SOTO

JOSÉ DE TAFALLA

JOSÉ DE TÁRRAGA

JOSÉ DE TORRES CHASCO

JOSÉ DE TROCÓNIZ

JOSÉ DE UBIRIA

JOSÉ DE VAL

JOSÉ DE VAL

JOSÉ DE VALDECILLA

JOSÉ DE VALDECILLOS

JOSÉ DE VALDEVIESO

JOSÉ DE VALDIVIESO

JOSÉ DE VALPUESTA 
JOSÉ DE VAÑES

JOSÉ DE VARONA

JOSÉ DE VELASCO

JOSÉ DE VERGARA

JOSÉ DE VESGAS

JOSÉ DE VIBERRI

JOSÉ DE VIDARTE

JOSÉ DE VIDARTE

JOSÉ DE VILLAMAYOR

JOSÉ DE VILLAMOR

JOSÉ DE VILLANUEVA

JOSÉ DE VILLEGAS

JOSÉ DE VILLEGAS

JOSÉ DE VILLEGAS

JOSÉ DE VILLOTA Y LOYO

JOSÉ DE VITAS

JOSÉ DE VIVAR CALLEJA

JOSÉ DE VIVERO

JOSÉ DE VIVERO

JOSÉ DE VIZANCO

JOSÉ DE YOLDI

JOSÉ DE YOLDI

JOSÉ DE ZALDÍVAR

JOSÉ DE ZAÑARTU

JOSÉ DEL CAÑO

JOSÉ DEL PORTILLO

JOSÉ DEL PRADO

JOSÉ DEL PUEYO

JOSÉ DEL RINCÓN

JOSÉ DEL RÍO

JOSÉ DEL SANTÍSIMO

JOSÉ DÍAZ

JOSÉ DÍEZ

JOSÉ DÍEZ DE IRLA

JOSÉ DOMÍNGUEZ

JOSÉ ENRÍQUEZ

JOSÉ ESCALANTE

JOSÉ ESTRICH

JOSÉ FACUNDO DELGADO

JOSÉ FALCÓN

JOSÉ FERMÍN DE ARZAGA

JOSÉ FERNÁNDEZ

JOSÉ FERNÁNDEZ

JOSÉ FERNÁNDEZ

JOSÉ FERNÁNDEZ

JOSÉ FERNÁNDEZ

JOSÉ FERNÁNDEZ

JOSÉ FERNÁNDEZ BRAVO
JOSÉ FERNÁNDEZ DE ENCINILLAS

JOSÉ FERNÁNDEZ DE HEREDIA

JOSÉ FERNÁNDEZ GARCÍA

JOSÉ FERNÁNDEZ PÉREZ

JOSÉ FERNÁNDEZ VELARDE

JOSÉ FORCADA

JOSÉ FRANCISCO DE BAQUEDANO

JOSÉ FRANCISCO FERNÁNDEZ MAR-

MANILLO

JOSÉ FRESEDO

JOSÉ GALLO

JOSÉ GÁRATE

JOSÉ GARCÍA

JOSÉ GARCÍA

JOSÉ GARCÍA

JOSÉ GARCÍA

JOSÉ GARCÍA

JOSÉ GARCÍA

JOSÉ GARCÍA

JOSÉ GARCÍA

JOSÉ GARCÍA

JOSÉ GARCÍA

JOSÉ GARCÍA DE OYUELOS

JOSÉ GARCÍA SEDANO

JOSÉ GENTO

JOSÉ GERMÁN

JOSÉ GIL

JOSÉ GIL DE RAMALES

JOSÉ GIL DE VELASCO

JOSÉ GIMÉNEZ

JOSÉ GOBEO

JOSÉ GÓMEZ

JOSÉ GÓMEZ DE CORNEJO

JOSÉ GÓMEZ DE GAYANGOS

JOSÉ GONZÁLEZ

JOSÉ GONZÁLEZ

JOSÉ GONZÁLEZ

JOSÉ GONZÁLEZ

JOSÉ GONZÁLEZ

JOSÉ GONZÁLEZ

JOSÉ GONZÁLEZ

JOSÉ GONZÁLEZ DE TATE

JOSÉ GRAN

JOSÉ GUTIÉRREZ

JOSÉ GUTIÉRREZ

JOSÉ GUTIÉRREZ

JOSÉ GUTIÉRREZ

JOSÉ GUTIÉRREZ 
JOSÉ GUTIÉRREZ DE COSÍO

JOSÉ HERMOSO

JOSÉ HERNÁNDEZ DE LA TORRE

JOSÉ HERNÁNDEZ DE SOTO

JOSÉ HERNANDO

JOSÉ HIDALGO

JOSÉ HIERRO

JOSÉ HURTADO

JOSÉ IBÁÑEZ

JOSÉ IGNACIO BORRAU

JOSÉ JAIMES

JOSÉ JALÓN

JOSÉ JIMÉNEZ

JOSÉ JOAQUÍN DE ECHAURI Y GARAY

JOSÉ JUAN Y QUERALT

JOSÉ LACAMBRA

JOSÉ LARRUY

JOSÉ LLANO

JOSÉ LÓPEZ

JOSÉ LÓPEZ

JOSÉ LÓPEZ

JOSÉ LÓPEZ BARRIONUEVO

JOSÉ LÓPEZ BARRÓN

JOSÉ LÓPEZ DE ANGUIANO

JOSÉ LÓPEZ DE LLOVERA

JOSÉ LÓPEZ DE URBINA

JOSÉ LÓPEZ TELLO

JOSÉ LUIS DE RADÍN

JOSÉ MAESTRO

JOSÉ MARÍN

JOSÉ MARQUINA

JOSÉ MARTEL

JOSÉ MARTELL

JOSÉ MARTÍNEZ

JOSÉ MARTÍNEZ

JOSÉ MARTÍNEZ

JOSÉ MARTÍNEZ

JOSÉ MARTÍNEZ

JOSÉ MARTÍNEZ

JOSÉ MARTÍNEZ DE ARTAJONA

JOSÉ MARTÍNEZ DEL BARRIO

JOSÉ MARTÍNEZ JOVER

JOSÉ MARTÍNEZ VALLÉS

JOSÉ MATÍAS BERBEGAL

JOSÉ MAULEÓN

JOSÉ MAYOR

JOSÉ MIGUEL LORCA

JOSÉ MÍNGUEZ
JOSÉ MORQUEDO

JOSÉ NAVARRO

JOSÉ NAVARRO

JOSÉ NAVARRO Y BELLIDO

JOSÉ NEGRETE

JOSÉ NEGRETE

JOSÉ NIÑO ESPAÑOL DE MUR

JOSÉ ORTEGA

JOSÉ ORTIZ

JOSÉ OSTÉRIZ

JOSÉ PARICIO

JOSÉ PASCUAL JORDÁN

JOSÉ PEÑEÑORI

JOSÉ PÉREZ

JOSÉ PÉREZ

JOSÉ PÉREZ

JOSÉ PÉREZ

JOSÉ PÉREZ

JOSÉ PÉREZ

JOSÉ PÉREZ

JOSÉ PÉREZ BLANCO

JOSÉ PÉREZ DE LA FUENTE

JOSÉ PÉREZ DE MONTES

JOSÉ PÉREZ DE MOREDA

JOSÉ PLÁCIDO CABRERO

JOSÉ PLASENCIA

JOSÉ PLATERO

JOSÉ PORTAL

JOSÉ PORTER Y CASANATE

JOSÉ PRIETO

JOSÉ PUELLES

JOSÉ RAMÍREZ

JOSÉ RAMÍREZ DE BAQUEDANO

JOSÉ RAMÍREZ DE BAQUEDANO

JOSÉ RAMOS

JOSÉ RODRIGO

JOSÉ RODRÍGUEZ

JOSÉ RODRÍGUEZ

JOSÉ RODRÍGUEZ DE LA IGLESIA

JOSÉ ROJO

JOSÉ ROMEO

JOSÉ ROMEO

JOSÉ RUBÍN

JOSÉ RUIZ

JOSÉ RUIZ

JOSÉ RUIZ

JOSÉ RUIZ

JOSÉ RUIZ 
JOSÉ RUIZ

JOSÉ RUIZ DE UBAGO

JOSÉ RUIZ QUINTANA

JOSÉ SÁEZ

JOSÉ SAINZ

JOSÉ SAINZ

JOSÉ SÁIZ

JOSÉ SALAS

JOSÉ SALINAS

JOSÉ SÁNCHEZ

JOSÉ SÁNCHEZ

JOSÉ SÁNCHEZ

JOSÉ SÁNCHEZ

JOSÉ SÁNCHEZ DE ESPEJO Y CISNEROS

JOSÉ SANDINO

JOSÉ SANTOYO DE ROJAS

JOSÉ SANZ

JOSÉ SANZ

JOSÉ SANZ DE SAYE

JOSÉ SANZ MARERO

JOSÉ SERRANO

JOSÉ SERRANO

JOSÉ SINUÉS

JOSÉ SOMELINO

JOSÉ TOMÁS Y FUENTES

JOSÉ TORRENTE

JOSÉ TRIANA

JOSÉ TRIVIÑO

JOSÉ VELASCO ESPARZA

JOSÉ VILLALAR

JOSÉ VILLAVA

JOSÉ ZAPATA

JUAN ABAD

JUAN AGUAYO

JUAN AGÜERO

JUAN AGUSTÍN DE LAS FOYAS

JUAN AGUSTÍN DE USCARRÉS

JUAN ALONSO

JUAN ALONSO

JUAN ALONSO

JUAN ALONSO

JUAN ALONSO BERNAL

JUAN ALONSO DE CELADA

JUAN ALONSO DE OBREGÓN

JUAN ALONSO DE PEREDA

JUAN ALONSO FERNÁNDEZ

JUAN ALONSO GONZÁLEZ

JUAN ALONSO IZQUIERDO
JUAN ALONSO MARTÍNEZ

JUAN ÁLVAREZ

JUAN ÁLVAREZ

JUAN ÁLVAREZ DE VILLARROEL

JUAN AMBROSIO RODRÍGUEZ

JUAN ANDRÉS DE ESPINOSA

JUAN ANDRÉS MONTAÑA DE SALAZAR

JUAN ÁNGEL DEL RÍO

JUAN ANSÓN

JUAN ANTÓN

JUAN ANTONIO ARRAIZA

JUAN ANTONIO BASUALDO

JUAN ANTONIO BUENO

JUAN ANTONIO CABALLERO

JUAN ANTONIO CORRAL MERINO

JUAN ANTONIO CUELLO

JUAN ANTONIO DE ABLITAS

JUAN ANTONIO DE AGUINO

JUAN ANTONIO DE ARCE

JUAN ANTONIO DE ARIZALETA

JUAN ANTONIO DE AZA

JUAN ANTONIO DE BASUALDO

JUAN ANTONIO DE CHÁVARRI

JUAN ANTONIO DE EZCURDIA

JUAN ANTONIO DE LA BODEGA

JUAN ANTONIO DE LA CÁRCOBA

JUAN ANTONIO DE LA LASTRA

JUAN ANTONIO DE LA MORA

JUAN ANTONIO DE LA TORRE

JUAN ANTONIO DE LA VILLA

JUAN ANTONIO DE LEÓN

JUAN ANTONIO DE LIENDO

JUAN ANTONIO DE MONTAÑO

JUAN ANTONIO DE MORALES

JUAN ANTONIO DE ORTEGA

JUAN ANTONIO DE PRADO

JUAN ANTONIO DE QUINTANILLA

JUAN ANTONIO DE SAN CRISTÓBAL

JUAN ANTONIO DE SAN MARTÍN

JUAN ANTONIO DE SANTANDER

JUAN ANTONIO DE SANTELICES

JUAN ANTONIO DE SESMA

JUAN ANTONIO DE TORRES Y CASTEJÓN

JUAN ANTONIO DE URBINA

JUAN ANTONIO DEL HIGUERO

JUAN ANTONIO DEL MAZO

JUAN ANTONIO GARCÍA DE LA MATA 
JUAN ANTONIO GARCÍA DE SOTO Y COLMENARES

JUAN ANTONIO GIL

JUAN ANTONIO JIMÉNEZ SALVADOR

JUAN ANTONIO JUÁREZ

JUAN ANTONIO LLAMOSA

JUAN ANTONIO ORDOÑO ROSALES

JUAN ANTONIO PASCUAL

JUAN ANTONIO RUBIANO

JUAN ANTONIO SAN MARTÍN

JUAN ANTONIO TABUENCA

JUAN APERIUCHEA

JUAN ARBELAIZ IBARRA

JUAN ARIAS

JUAN ARNÁIZ

JUAN AUGUSTO

JUAN BALBÍN

JUAN BÁÑEZ

JUAN BARBA DE ESPINOSA

JUAN BARCEDO Y VELASCO

JUAN BARCOS

JUAN BARONA

JUAN BAUTISTA [MARTÍNEZ] GARIJO

JUAN BAUTISTA ARBIZU

JUAN BAUTISTA BELTRÁN

JUAN BAUTISTA CORTÉS

JUAN BAUTISTA CRIADO

JUAN BAUTISTA DE ANGULO

JUAN BAUTISTA DE ANO

JUAN BAUTISTA DE ARCE

JUAN BAUTISTA DE ARMIÑO

JUAN BAUTISTA DE BERASTEGUI

JUAN BAUTISTA DE CONTRERAS

JUAN BAUTISTA DE ESPINOSA

JUAN BAUTISTA DE GAMARRA

JUAN BAUTISTA DE HERRERA

JUAN BAUTISTA DE LAGUNILLA

JUAN BAUTISTA DE LLANO

JUAN BAUTISTA DE PUERTO ARCE

JUAN BAUTISTA DE REZUSTA

JUAN BAUTISTA DE SEPÚLVEDA

JUAN BAUTISTA DE SUA

JUAN BAUTISTA DE URO

JUAN BAUTISTA DE URO

JUAN BAUTISTA DE VEGA

JUAN BAUTISTA DE VILLAMOR

JUAN BAUTISTA DE VILLANUEVA

JUAN BAUTISTA DE VILLORIA
JUAN BAUTISTA DE VINANCO

JUAN BAUTISTA DE VITORINO

JUAN BAUTISTA DEL PEDREDO

JUAN BAUTISTA DEL PUERTO

JUAN BAUTISTA DEL REBOLLAR

JUAN BAUTISTA DEL RÍO

JUAN BAUTISTA DIEGO DE SEDANO

JUAN BAUTISTA EGUILUZ CORQUERA

JUAN BAUTISTA GANDINO

JUAN BAUTISTA GARCÍA

JUAN BAUTISTA GRACIA

JUAN BAUTISTA IBÁÑEZ

JUAN BAUTISTA LARDITO

JUAN BAUTISTA MÉNDEZ DE LOYOLA

JUAN BAUTISTA MORQUECHO

JUAN BAUTISTA NÚÑEZ DE LA PEÑA

JUAN BAUTISTA OCHOA

JUAN BAUTISTA PECIÑA RAMÍREZ

JUAN BAUTISTA RAMÍREZ

JUAN BAUTISTA RODRÍGUEZ

JUAN BAUTISTA RODRÍGUEZ DE COSSÍO

JUAN BENITO DE RIVERA

JUAN BERMEJO

JUAN BERNAD

JUAN BERNAL

JUAN BERNAL

JUAN BERNAL

JUAN BERNAL

JUAN BERNAL RAMÍREZ

JUAN BINUELO

JUAN BLANCO

JUAN BLANCO

JUAN BOCANGELINO BABA

JUAN BRAVO

JUAN CALDERÓN

JUAN CALLEJAS

JUAN CALVO

JUAN CALVO

JUAN CALVO SERRANO

JUAN CAMBERO

JUAN CAMPO

JUAN CANAL

JUAN CANTERO VÉLEZ

JUAN CANTÓN

JUAN CAPACHO

JUAN CARCEDO ESCOBAR

JUAN CARO 


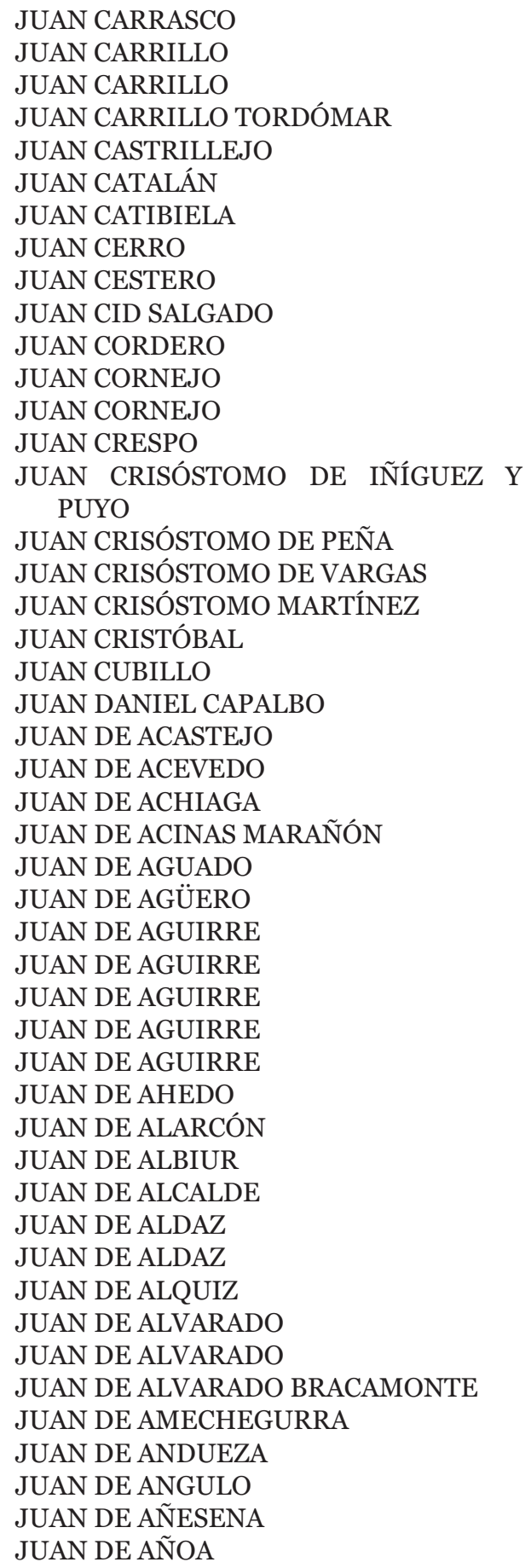

JUAN DE AÑOA

JUAN DE ARAGÓN

JUAN DE ARAGÓN

JUAN DE ARANCENA

JUAN DE ARANDA

JUAN DE ARANGUREN

JUAN DE ARBEIZA Y DICASTILLO

JUAN DE ARBIZU

JUAN DE ARBIZU

JUAN DE ARCE

JUAN DE ARCE

JUAN DE ARCE

JUAN DE ARCE

JUAN DE ARCINIEGA

JUAN DE ARÉCHAGA ARISPE

JUAN DE ARENAS

JUAN DE ARENZANA Y MONTENEGRO

JUAN DE ARGAIZ

JUAN DE ARGAÑO

JUAN DE ARGÜELLO

JUAN DE ARGÜESO

JUAN DE ARIZA

JUAN DE ARNUERO Y CASTILLO

JUAN DE AROCHE

JUAN DE ARRANEGUI

JUAN DE ARRESE

JUAN DE ARROYO

JUAN DE ARTASO

JUAN DE ARTETA

JUAN DE ARTIAGA

JUAN DE ARTIGUES

JUAN DE ARTIGUES

JUAN DE ARZABE

JUAN DE ASCARAY

JUAN DE ASIÁIN

JUAN DE AVENDAÑO

JUAN DE AXULAR

JUAN DE AYALA

JUAN DE AYALA

JUAN DE AYALA

JUAN DE AYENDI

JUAN DE AZCÁRATE

JUAN DE AZCONA

JUAN DE AZPILICUETA

JUAN DE BADILLO

JUAN DE BAIRI MIÑÓN

JUAN DE BALPUERTA

JUAN DE BAÑARES 
JUAN DE BARANDALLA

JUAN DE BÁRCENA

JUAN DE BÁRCENA

JUAN DE BÁRCENA

JUAN DE BARCINA

JUAN DE BARDECI

JUAN DE BARREDA

JUAN DE BARRENECHE

JUAN DE BARRENECHEA

JUAN DE BASCONES

JUAN DE BASIO

JUAN DE BEARÍN

JUAN DE BECARES

JUAN DE BELZUNEGUI

JUAN DE BERÁN

JUAN DE BERASTEGUI

JUAN DE BERASTEGUI

JUAN DE BERIÁIN

JUAN DE BERRENECHEA

JUAN DE BERZOSA

JUAN DE BERZOSA

JUAN DE BEZANA

JUAN DE BICURIA

JUAN DE BILBAO BASOZÁBAL

JUAN DE BONILLA

JUAN DE BORDA

JUAN DE BORDA

JUAN DE BRACAMONTE Y ALARCÓN

JUAN DE BRIZUELA

JUAN DE BUJANDA

JUAN DE BURGOS

JUAN DE BUSTAMANTE

JUAN DE BUSTAMANTE

JUAN DE BUSTAMANTE

JUAN DE BUSTINZA

JUAN DE BUSTO

JUAN DE CABERNI

JUAN DE CABEZÓN

JUAN DE CABILLO

JUAN DE CABRERA

JUAN DE CABRERA

JUAN DE CABRO DE SEVIL

JUAN DE CALMEDA

JUAN DE CANTABRANA

JUAN DE CAÑAS

JUAN DE CAPILLOS

JUAN DE CARRIGAL Y GUYMES

JUAN DE CARVAJAL Y MENDOZA
JUAN DE CASARES

JUAN DE CASARES

JUAN DE CASTILLA

JUAN DE CASTRESANA

JUAN DE CASTRO

JUAN DE CASTRO

JUAN DE CELADA

JUAN DE CELIS DE LA MATA

JUAN DE CENCAN

JUAN DE CÉSPEDES

JUAN DE CEVALLOS

JUAN DE CHÁVARRI

JUAN DE CHAVARRÍA

JUAN DE CIRIZA

JUAN DE CIRIZA

JUAN DE CIRIZA

JUAN DE CIRIZA

JUAN DE CLAVERÍA

JUAN DE COLINA

JUAN DE CORADA

JUAN DE COSSÍO

JUAN DE COVARRUBIAS

JUAN DE CUBILLA

JUAN DE CUETO

JUAN DE DEIA Y AGOITIA

JUAN DE DUEÑAS

JUAN DE EBALOS

JUAN DE ECHALAZ

JUAN DE ECHALAZ

JUAN DE ECHARRI

JUAN DE ECHEGARAY

JUAN DE ECHENIQUE

JUAN DE ECHEVERRÍA Y LANZ

JUAN DE EGUAS

JUAN DE EGUIARRETA

JUAN DE EGURROLA

JUAN DE ELENA

JUAN DE ELIZARI

JUAN DE ELZAMENDI Y MONREAL

JUAN DE ENCISO

JUAN DE ENÉRIZ

JUAN DE ERAUL Y ROMERO

JUAN DE ERAZU

JUAN DE ERMIAGA

JUAN DE ERVITI

JUAN DE ESCALONA

JUAN DE ESPINOSA

JUAN DE ESPOZ 
JUAN DE ESTEBAN JUAN DE ETCHEVERZ JUAN DE EZCAR Y OZCOZ JUAN DE EZCURRA JUAN DE EZPELETA JUAN DE EZPELETA JUAN DE EZQUERRA JUAN DE EZQUÍROZ JUAN DE FAJADURA JUAN DE FELGUERO SARABIA JUAN DE FLANDES JUAN DE FONCUEVA JUAN DE FONTECHA JUAN DE FREGO JUAN DE FRESNEDA JUAN DE FRÍAS JUAN DE FRÍAS JUAN DE FRÍAS JUAN DE FRÍAS JUAN DE GADEÓN JUAN DE GAMECHO Y ECHANDIA JUAN DE GANUZA JUAN DE GANUZA JUAN DE GARCERÓN JUAN DE GARRALDA JUAN DE GÁRRIZ JUAN DE GAYANGOS JUAN DE GILAR JUAN DE GOIRI JUAN DE GOMEZCORTA JUAN DE GORGUIARAN JUAN DE GORRITI JUAN DE GOYENECHE JUAN DE GUELBENZU Y VILLALVA JUAN DE GÜEMES JUAN DE GÜEMES CEBALLOS JUAN DE GUERRA JUAN DE GUILARTE JUAN DE GUINEA JUAN DE GUINEA JUAN DE HAEDO Y SARABIA JUAN DE HAZAS JUAN DE HEBALLEN JUAN DE HERAS MIERA JUAN DE HERRERA JUAN DE HINOJEDO REINOSO JUAN DE HONDARZA JUAN DE HOYA
JUAN DE HOYOS JUAN DE HUARTE JUAN DE HUARTE JUAN DE HUERTA JUAN DE HUESA JUAN DE HUIDOBRO JUAN DE HUIDOBRO JUAN DE IBARRA JUAN DE IBARROLA JUAN DE ICEDO JUAN DE IGOA JUAN DE ILUNDÁIN JUAN DE IRIARTE JUAN DE IRIARTE JUAN DE IRIBAS JUAN DE IRISARRI JUAN DE IRULEGUI JUAN DE ISAR JUAN DE ISITURRI JUAN DE ISLA JUAN DE ISTÚRIZ JUAN DE ITURIAL JUAN DE JARABA JUAN DE JARAUTA JUAN DE LA ARENA JUAN DE LA ARENA JUAN DE LA ARENA JUAN DE LA BASTIDA JUAN DE LA BRA... JUAN DE LA BUSTILLA JUAN DE LA CABADILLA JUAN DE LA CALLE JUAN DE LA CALLEJA JUAN DE LA CANTERA JUAN DE LA CUESTA JUAN DE LA FLOR JUAN DE LA FUENTE JUAN DE LA FUENTE JUAN DE LA FUENTE JUAN DE LA FUENTE JUAN DE LA GUARDIA JUAN DE LA HOYA JUAN DE LA IGLESIA JUAN DE LA PEÑA JUAN DE LA PEÑA JUAN DE LA PEÑA JUAN DE LA PEÑA JUAN DE LA PEÑA 
JUAN DE LA PEÑA JUAN DE LA PEÑA JUAN DE LA PEÑA JUAN DE LA REA ZÚÑIGA JUAN DE LA REGATA JUAN DE LA RIBA JUAN DE LA RIVA JUAN DE LA TORRE JUAN DE LA TORRE JUAN DE LA TORRE NEGRETE JUAN DE LA VIÑUELA JUAN DE LACUNZA JUAN DE LAEZAÚN Y ANDIA JUAN DE LANBARREN JUAN DE LANGARICA JUAN DE LARA JUAN DE LARA JUAN DE LAS HERAS JUAN DE LAS HERAS JUAN DE LAS HERAS JUAN DE LAS HERAS JUAN DE LAS HERAS JUAN DE LAS HERRERÍAS JUAN DE LAS VENERAS Y CEBALLOS JUAN DE LASAGA JUAN DE LASALA JUAN DE LEGAZPI JUAN DE LEIVA JUAN DE LEÓN JUAN DE LEZANA JUAN DE LEZÁUN JUAN DE LEZÁUN JUAN DE LIANCE JUAN DE LIENDO JUAN DE LIMPIAS JUAN DE LINAROZ JUAN DE LIZ JUAN DE LIZARAZU JUAN DE LIZERI JUAN DE LLANILLO JUAN DE LLARENA JUAN DE LLORENTE JUAN DE LODOSA JUAN DE LODOSA JUAN DE LOMA JUAN DE LORCA Y ARASO JUAN DE LORRAIN JUAN DE LORRIGUI
JUAN DE LOS COCTOS SOTO JUAN DE LOS POZOS JUAN DE LOYOLA TORRE JUAN DE LUCIO PARDO JUAN DE MADARIAGA JUAN DE MADRIGAL JUAN DE MAEDA SALAZAR JUAN DE MAEZTU JUAN DE MALUENDA JUAN DE MANZANAL JUAN DE MANZANARES JUAN DE MARCHUETA JUAN DE MARQUINA JUAN DE MATA JUAN DE MATA JUAN DE MAYA JUAN DE MAZA JUAN DE MAZA ROZAS JUAN DE MAZANAL JUAN DE MEDIAVILLA JUAN DE MEDRANO JUAN DE MENDAZA JUAN DE MENDI JUAN DE MENDIONDO JUAN DE MENDIZÁBAL JUAN DE MENDOZA JUAN DE MICHETO JUAN DE MIEDES JUAN DE MIER Y TERÁN JUAN DE MIRANDA JUAN DE MIRAVECHE JUAN DE MOLINA JUAN DE MOLLEDA CEBIS JUAN DE MONTALVO JUAN DE MONTEJO JUAN DE MONTENEGRO JUAN DE MONTOYA JUAN DE MORA JUAN DE MORALES BUENAÑO ANGUITA JUAN DE MUGA ORTIZ JUAN DE MUNÁRRIZ JUAN DE MURILLO JUAN DE NALDA JUAN DE NAVARRIETA JUAN DE NAVAS JUAN DE NEGRETE JUAN DE NOUNA JUAN DE NUIN 
JUAN DE OBREGÓN

JUAN DE OCEJO

JUAN DE OCHOA

JUAN DE OCHOA

JUAN DE OCHOA

JUAN DE OGAZÓN

JUAN DE OLAZANGUTÍA

JUAN DE OLEAMENDI Y MONREAL

JUAN DE OLIVÁN

JUAN DE OLLO

JUAN DE OLLOQUI

JUAN DE ORANEGUI

JUAN DE ORBEA

JUAN DE ORCOYEN

JUAN DE OREMIANA

JUAN DE ORTEGA

JUAN DE ORTEGA

JUAN DE ORTEGA

JUAN DE ORÚE

JUAN DE OTAMENDI Y MONREAL

JUAN DE OVIEDO

JUAN DE OVIEDO VERGARA

JUAN DE PABLO Y BASAVE

JUAN DE PALACILLO

JUAN DE PALACIO

JUAN DE PALACIO

JUAN DE PALACIO ARREDONDO

JUAN DE PALACIOS

JUAN DE PALACIOS

JUAN DE PAMPLIEGA

JUAN DE PANCORBO

JUAN DE PÁRAMO

JUAN DE PAREDES

JUAN DE PAREDES

JUAN DE PAZOS

JUAN DE PECHECHEA

JUAN DE PINEDO

JUAN DE PINEDO

JUAN DE PINEDO

JUAN DE PORRAS

JUAN DE PORRES

JUAN DE POZAL

JUAN DE PUERTA

JUAN DE QUEVEDO

JUAN DE QUIJANO

JUAN DE QUINTANA

JUAN DE QUINTANA

JUAN DE QUINTANA
JUAN DE QUINTANILLA

JUAN DE QUINTANO

JUAN DE RADA

JUAN DE RAMOS

JUAN DE RANGADA

JUAN DE REBOLLAR

JUAN DE REBOLLEDO

JUAN DE RECALDE

JUAN DE REDÍN

JUAN DE REGULES

JUAN DE REINARES

JUAN DE RENEDO

JUAN DE RENGADA

JUAN DE RENGADRE

JUAN DE REVUELTA

JUAN DE REZA

JUAN DE RIAÑO

JUAN DE RIAÑO Y GAMBOA

JUAN DE RIBA

JUAN DE RIBERO Y CASA

JUAN DE RIPALDA

JUAN DE ROBLES

JUAN DE RODRIGO

JUAN DE ROJAS

JUAN DE ROJAS

JUAN DE ROJAS

JUAN DE ROSALES

JUAN DE ROTA

JUAN DE ROTETA

JUAN DE ROYO

JUAN DE ROZAS

JUAN DE RÚA Y HERRERA

JUAN DE RUIZ

JUAN DE SALAZAR

JUAN DE SALAZAR NEGRETE

JUAN DE SALAZAR Y VELASCO

JUAN DE SALCEDO

JUAN DE SALDAÑA BRAVO

JUAN DE SALINAS

JUAN DE SALINAS

JUAN DE SALINAS

JUAN DE SALINAS MEDINILLA

JUAN DE SAMANIEGO

JUAN DE SAN MARTÍN

JUAN DE SAN MARTÍN

JUAN DE SAN MILLÁN

JUAN DE SAN MILLÁN

JUAN DE SANTA GADEA 
JUAN DE SANTA MARÍA

JUAN DE SANTA MARÍA

JUAN DE SANTACRUZ

JUAN DE SANTELIUS

JUAN DE SANTOYO

JUAN DE SARMIENTO

JUAN DE SEDANO

JUAN DE SERVITA

JUAN DE SICILIA

JUAN DE SILVA

JUAN DE SOJO

JUAN DE SOLA

JUAN DE SOLAS

JUAN DE SOLÍS

JUAN DE SOLNADO

JUAN DE SOMAVILLA

JUAN DE SOMAVILLA

JUAN DE SORO

JUAN DE SORRIBA

JUAN DE SOSA

JUAN DE SOTO

JUAN DE SOTO

JUAN DE SOTO

JUAN DE TAFALLA

JUAN DE TAPIA Y CEBALLOS

JUAN DE TASUGUERAS

JUAN DE TEJO

JUAN DE TERMIÑO

JUAN DE TOLEDO

JUAN DE TOMÁS

JUAN DE TORRES PEDROSA

JUAN DE TRIANA

JUAN DE TRISTÁN GONZÁLEZ

JUAN DE UDAVE

JUAN DE UDOBRO

JUAN DE ULAS

JUAN DE ULIBARRI

JUAN DE UMARÁN

JUAN DE UNGO

JUAN DE URBINA

JUAN DE URDÁNIZ

JUAN DE URDÁNIZ

JUAN DE URETA

JUAN DE URIBE

JUAN DE URNIZA

JUAN DE UROSTE SALAZAR

JUAN DE URRA Y ARIZALA

JUAN DE URREZ
JUAN DE URRIZOLA

JUAN DE URRUTIA

JUAN DE USTARROZ

JUAN DE UTERGA

JUAN DE VALCÁZAR

JUAN DE VALCÁZAR

JUAN DE VALDERRAMA

JUAN DE VALDIVIESO

JUAN DE VALENZUELA

JUAN DE VALLE

JUAN DE VALLEJERA

JUAN DE VALLEJO

JUAN DE VALLEJO

JUAN DE VALLEJO

JUAN DE VALLEJO

JUAN DE VALLEJO

JUAN DE VALLENILLA

JUAN DE VALMASEDA

JUAN DE VALTIERRA

JUAN DE VELASCO

JUAN DE VELASCO

JUAN DE VELILLA

JUAN DE VERA

JUAN DE VERDES CASTILLO

JUAN DE VERGARA

JUAN DE VESGA Y VALDERRAMA

JUAN DE VICTORIA

JUAN DE VICUNAA

JUAN DE VICUÑA

JUAN DE VICUÑA

JUAN DE VICURIA

JUAN DE VIDAJÚN

JUAN DE VIDONDO

JUAN DE VIGUEZAL

JUAN DE VILLA VALLE

JUAN DE VILLADIEGO

JUAN DE VILLADIEGO

JUAN DE VILLANUEVA

JUAN DE VILLANUEVA

JUAN DE VILLANUEVA

JUAN DE VILLARREAL

JUAN DE VILLASANDINO

JUAN DE VILLATE

JUAN DE VILLAVA

JUAN DE VILLEGAS

JUAN DE VILLORIA

JUAN DE VILLOSLADA

JUAN DE VIÑEGRA 
JUAN DE VIRUETE

JUAN DE VIZCAY

JUAN DE YBEAS RUIZ

JUAN DE YUBERO E ILZARBE

JUAN DE ZABALEGUI

JUAN DE ZADORNIL

JUAN DE ZAMORA

JUAN DE ZAMORA

JUAN DE ZAMORA MANSILLA

JUAN DE ZÁRATE

JUAN DE ZIARÁN

JUAN DE ZORRILLA

JUAN DE ZUALDE

JUAN DE ZUAZU

JUAN DE ZUGARRONDO

JUAN DE ZULAICA

JUAN DE ZÚÑIGA

JUAN DEL BARRIO

JUAN DEL BARRIO

JUAN DEL BARRIO

JUAN DEL CAMPO

JUAN DEL CASTILLO

JUAN DEL CASTILLO

JUAN DEL CASTILLO

JUAN DEL CORRAL

JUAN DEL CORRAL

JUAN DEL CORRO BUSTAMANTE

JUAN DEL GUEMBE

JUAN DEL HIERRO

JUAN DEL MAZO PEREDA

JUAN DEL MONTE CORDERO

JUAN DEL POZO Y CASTILLO

JUAN DEL PUERTO

JUAN DEL RÍO

JUAN DEL VAL

JUAN DÍAZ

JUAN DÍAZ

JUAN DÍAZ

JUAN DÍAZ

JUAN DÍAZ

JUAN DÍAZ

JUAN DÍAZ ALBIZ BORRICÓN

JUAN DÍAZ DE AGUSTÍN

JUAN DÍAZ DE ANDINO

JUAN DÍAZ DE BASURTO

JUAN DÍAZ DE LA COMA

JUAN DÍAZ DE LA FUENTE

JUAN DÍAZ DEL CORRAL
JUAN DÍAZ DEL MOLINILLO

JUAN DÍEZ

JUAN DÍEZ

JUAN DÍEZ

JUAN DÍEZ DE BON Y LUGA

JUAN DÍEZ DE LA PEÑA

JUAN DÍEZ DE TERÁN

JUAN DÍEZ DE VALDIVIESO

JUAN DÍEZ GUTIÉRREZ

JUAN DÍEZ IGLESIA BUSTAMANTE

JUAN DÍEZ MATA

JUAN DÍEZ UTEBO

JUAN DOMINGO DE ARTIOLA

JUAN DOMINGO DE LATAS

JUAN DOMINGO ECHEVARRÍA Y ASIAIN

JUAN DOMINGO RAMÍREZ CHÁVEZ

SANTUCHO Y RADA

JUAN DOMINGO SOLANO

JUAN DOMÍNGUEZ

JUAN DOMÍNGUEZ DE VIDAURRETA

JUAN DURO DEL SAZ

JUAN ELBIZ PADRÓN

JUAN ESCRIBANO

JUAN ESQUER

JUAN ESTEBAN

JUAN ESTEBAN DE CENTENO

JUAN ESTEBAN DE LA PORTILLA

JUAN ESTEBAN Y ELGUETA

JUAN EZQUER

JUAN FAZOAGA

JUAN FERMÍN DE BEASOAIN

JUAN FERMÍN DE MÚZQUIZ

JUAN FERMÍN TIBURCIO DE RIBAS

JUAN FERNÁNDEZ

JUAN FERNÁNDEZ

JUAN FERNÁNDEZ

JUAN FERNÁNDEZ

JUAN FERNÁNDEZ DE CASTAÑEDA

JUAN FERNÁNDEZ DE ESTOLA

JUAN FERNÁNDEZ DE FONTECHA

JUAN FERNÁNDEZ DE HERRERA

JUAN FERNÁNDEZ DE LA PEÑA

JUAN FERNÁNDEZ DE OGAZÓN

JUAN FERNÁNDEZ DE PORTILLO

JUAN FERNÁNDEZ DE TORRES

JUAN FERNÁNDEZ DE VALDERRAMA

JUAN FERNÁNDEZ DE VIRUÉS

JUAN FERNÁNDEZ MONTOTO 
JUAN FERNÁNDEZ ROJO JUAN FERNÁNDEZ TRUCHUELO JUAN FRANCÉS OROZCO JUAN FRANCISCO ANDRÉS JUAN FRANCISCO CEPERA JUAN FRANCISCO DE ABIELSA JUAN FRANCISCO DE BRIONES JUAN FRANCISCO DE EBRERA JUAN FRANCISCO DE ELORZA JUAN FRANCISCO DE LA TORRE JUAN FRANCISCO DE LETE JUAN FRANCISCO DE OCHOA JUAN FRANCISCO DEL PUEYO JUAN FRANCISCO FERRER JUAN FRANCISCO HERNÁNDEZ JUAN FRANCISCO JARABO JUAN FRANCISCO LARRIMPE Y MENDANIA

JUAN FRANCISCO LIZAUN Y OLLO JUAN FRANCISCO LÓPEZ DE LA MAZA JUAN FRANCISCO MARRACO JUAN FRANCISCO MORENO JUAN FRANCISCO OLIVÁN JUAN FRANCISCO PARDO JUAN FRANCISCO PÉREZ DE AMALLO JUAN FRANCISCO RIQUELME JUAN FRANCISCO RUIZ JUAN FRANCISCO SALAZAR JUAN FRANCISCO SALVADOR JUAN FRANCO JUAN FRANCO JUAN FUERTES JUAN GALARÓN JUAN GALINDO DE LUSA JUAN GALLEGO BLANCO JUAN GALLEGO GONZÁLEZ JUAN GALLO JUAN GALLO DE ANDRADE JUAN GALVES JUAN GARCÍA JUAN GARCÍA JUAN GARCÍA JUAN GARCÍA JUAN GARCÍA JUAN GARCÍA JUAN GARCÍA JUAN GARCÍA JUAN GARCÍA
JUAN GARCÍA JUAN GARCÍA JUAN GARCÍA JUAN GARCÍA JUAN GARCÍA JUAN GARCÍA JUAN GARCÍA CLEMENTE JUAN GARCÍA DE CAMPOS JUAN GARCÍA DE GALDEANO JUAN GARCÍA DE LOS HOYOS JUAN GARCÍA DE OROZ JUAN GARCÍA DE PRADO JUAN GARCÍA DE SANTA OLALLA JUAN GARCÍA DE VIZCAÍNOS JUAN GARCÍA ESCUDERO JUAN GARCÍA IRIGOREN JUAN GARCÍA MARRÓN JUAN GARCÍA RAMÍREZ JUAN GARCÍA TRUCHUELO JUAN GARCÍA URBINA JUAN GARCÍA Y CEBRIÁN JUAN GARRIDO JUAN GASCÓN DE VIANA JUAN GASPAR DE RILLO JUAN GIL DE ALFARO JUAN GIL DE QUINTANA JUAN GIL LÓPEZ JUAN GIMÉNEZ DEL PALOMAR JUAN GÓMEZ JUAN GÓMEZ JUAN GÓMEZ JUAN GÓMEZ JUAN GÓMEZ JUAN GÓMEZ JUAN GÓMEZ JUAN GÓMEZ JUAN GÓMEZ BARONA JUAN GÓMEZ DE BUJANDA JUAN GÓMEZ DE BUSTAMANTE JUAN GÓMEZ DE CADIÑANOS JUAN GÓMEZ DE LA SERNA JUAN GÓMEZ DE RUFRANCOS JUAN GÓMEZ DE SALINAS JUAN GÓMEZ DE VELASCO Y MANSILLA JUAN GÓMEZ DEL HIERRO JUAN GÓMEZ GARCÍA JUAN GÓMEZ HIERRO JUAN GONZÁLEZ 
JUAN GONZÁLEZ

JUAN GONZÁLEZ

JUAN GONZÁLEZ

JUAN GONZÁLEZ

JUAN GONZÁLEZ

JUAN GONZÁLEZ

JUAN GONZÁLEZ

JUAN GONZÁLEZ DE ANDRADE Y VELÁZQUEZ

JUAN GONZÁLEZ DE ARCE

JUAN GONZÁLEZ DE GINÉS

JUAN GONZÁLEZ DE LA CUESTA PEDROSA

JUAN GONZÁLEZ DE LA MAZA

JUAN GONZÁLEZ DE LA PLAZA

JUAN GONZÁLEZ DE MIERA

JUAN GONZÁLEZ DE PAREDES

JUAN GONZÁLEZ DE PAREDES

JUAN GONZÁLEZ DE PEDROSO

JUAN GONZÁLEZ DE PIÑERO

JUAN GONZÁLEZ DE QUEVEDO ALVARADO

JUAN GONZÁLEZ DELGADO

JUAN GONZÁLEZ ESCUDERO

JUAN GREGORIO AGUESO

JUAN GREGORIO DE MÚJICA Y BUITRÓN

JUAN GUILAZ

JUAN GUILLÉN DE ALLÉS

JUAN GUILLERMO PELAZA

JUAN GUTIÉRREZ

JUAN GUTIÉRREZ

JUAN GUTIÉRREZ

JUAN GUTIÉRREZ

JUAN GUTIÉRREZ

JUAN GUTIÉRREZ DE VILLEGAS

JUAN HERNÁIZ

JUAN HERNÁIZ

JUAN HERNÁNDEZ

JUAN HIPÓLITO DE LA RIPA

JUAN HURTADO DE MENDOZA

JUAN IBÁÑEZ

JUAN IBÁÑEZ

JUAN IBÁÑEZ DE BASTERRECHEA

JUAN IBÁÑEZ DE ICARÁN DE BERRIATUA

JUAN IGNACIO BARRENA

JUAN IGNACIO DE RECONDO
JUAN INFANTE

JUAN IÑÍGUEZ DE ARNEDO

JUAN IRIGOYEN

JUAN ISIDRO DE MENDIETA

JUAN ITERO

JUAN ITURRALDE

JUAN IZQUIERDO

JUAN JACINTO DE TORNÉS

JUAN JACINTO VELÁZQUEZ

JUAN JALÓN

JUAN JERÓNIMO IRIARTE

JUAN JERÓNIMO DE ESQUER Y MIRA-

VETE

JUAN JIMÉNEZ

JUAN JIMÉNEZ

JUAN JIMÉNEZ

JUAN JIMÉNEZ

JUAN JIMÉNEZ BAROJA

JUAN JIMÉNEZ DE LEORIN

JUAN JOSÉ CALVO DÍEZ DE AUX

JUAN JOSÉ DE IMBERS

JUAN JOSÉ DE TEJADA

JUAN JOSÉ DÍAZ DEL CORRAL

JUAN JOSÉ MAULEÓN

JUAN JOSÉ PRUDO Y ARTECHE

JUAN JUÁREZ

JUAN JUEZ

JUAN JUNCO DE ILLANES

JUAN LADRÓN

JUAN LAÍN DE VINAQUE

JUAN LERÍN

JUAN LLOP Y LÓPEZ

JUAN LLORENTE

JUAN LLORENTE

JUAN LÓPEZ

JUAN LÓPEZ

JUAN LÓPEZ

JUAN LÓPEZ

JUAN LÓPEZ

JUAN LÓPEZ BARAHONA

JUAN LÓPEZ BORRICÓN

JUAN LÓPEZ CUAZU

JUAN LÓPEZ DE ABÁIGAR

JUAN LÓPEZ DE ARCHAJA

JUAN LÓPEZ DE ARCINIEGA

JUAN LÓPEZ DE BARRASA

JUAN LÓPEZ DE CELADA

JUAN LÓPEZ DE ENRIQUE 
JUAN LÓPEZ DE FONTECHA JUAN LÓPEZ DE LA IGLESIA JUAN LÓPEZ DE LA PRADA JUAN LÓPEZ DE LANA JUAN LÓPEZ DE LEZCANO JUAN LÓPEZ DE LINARES JUAN LÓPEZ DE MENDOZA CASTILLO JUAN LÓPEZ DE REBOLLEDA JUAN LÓPEZ DE RIBAFORADA JUAN LÓPEZ DE SUESA JUAN LÓPEZ DE URRA JUAN LÓPEZ DE VARO JUAN LÓPEZ DE VERA JUAN LÓPEZ DE ZERRÓN OZALLA JUAN LÓPEZ DEL CASTILLO JUAN LORENZO JUAN LORENZO CASADO JUAN LOZANO JUAN LUCERO JUAN LUIS LADRÓN DE CEGAMA JUAN MACHÓN JUAN MAESTRO JUAN MAGÍN JUAN MANERO JUAN MANSO JUAN MANSO JUAN MANSO JUAN MANTILLA JUAN MANUEL DE ESPINOSA JUAN MANUEL DE LA PORTILLA JUAN MANUEL DE LUCIO JUAN MANZANO JUAN MARCOS JUAN MARCOS JUAN MARCOS DE LA TORRE JUAN MARCOS RIPA JUAN MARÍN JUAN MARÍN DE RODEZNO JUAN MARQUINA JUAN MARROQUÍN JUAN MARTÍN DE ARDAIZ JUAN MARTÍN DE CONTRERAS JUAN MARTÍN DE OLANO JUAN MARTÍN DE SAN PABLO JUAN MARTÍNEZ JUAN MARTÍNEZ JUAN MARTÍNEZ JUAN MARTÍNEZ
JUAN MARTÍNEZ JUAN MARTÍNEZ JUAN MARTÍNEZ JUAN MARTÍNEZ JUAN MARTÍNEZ JUAN MARTÍNEZ JUAN MARTÍNEZ JUAN MARTÍNEZ JUAN MARTÍNEZ JUAN MARTÍNEZ JUAN MARTÍNEZ JUAN MARTÍNEZ JUAN MARTÍNEZ JUAN MARTÍNEZ JUAN MARTÍNEZ DE ALCÁNTARA JUAN MARTÍNEZ DE ARAS JUAN MARTÍNEZ DE ARES JUAN MARTÍNEZ DE CANTABRANA JUAN MARTÍNEZ DE EGUIARRETA JUAN MARTÍNEZ DE ELIZALDE JUAN MARTÍNEZ DE LA HERRÁN JUAN MARTÍNEZ DE LAISECA JUAN MARTÍNEZ DE LEJARZA JUAN MARTÍNEZ DE LITURBIDE JUAN MARTÍNEZ DE MONTERRUBIO JUAN MARTÍNEZ DE OSMA JUAN MARTÍNEZ DE PORRES JUAN MARTÍNEZ DE RODRIGO JUAN MARTÍNEZ DE SAN MARTÍN JUAN MARTÍNEZ DE SANTAYANA JUAN MARTÍNEZ DE SANTIAGO JUAN MARTÍNEZ DE SILARAGA JUAN MARTÍNEZ DE SOTO JUAN MARTÍNEZ DE TODA JUAN MARTÍNEZ DE TORRES JUAN MARTÍNEZ DE VALLE JUAN MARTÍNEZ DE VILLAÑANA JUAN MARTÍNEZ DEL PINO JUAN MARTÍNEZ FERNÁNDEZ DE CENZANO

JUAN MARTÍNEZ GARIJO JUAN MARTÍNEZ IZQUIERDO JUAN MARTÍNEZ MATARRAL JUAN MARTÍNEZ MATUTE DE VELASCO JUAN MARTÍNEZ TEMIÑO JUAN MATEO JUAN MATEO MARÍN JUAN MATÍAS DE ENÉRIZ 


\begin{tabular}{ll} 
JUAN MATÍAS ENÉRIZY GUAVIL & JUAN PACHECO \\
JUAN MAZA & JUAN PADELLANO \\
JUAN MERINO & JUAN PALOMINO \\
JUAN MERINO & JUAN PANAO \\
JUAN MERINO & JUAN PARDO \\
JUAN MERLO & JUAN PARDO \\
JUAN MIGUEL DE ARDANAZ & JUAN PARDO \\
JUAN MIGUEL DE AZPÍROZ & JUAN PARDO DE LA TORRE \\
JUAN MIGUEL DE ECHARRI & JUAN PARDO DE VALENCIA \\
JUAN MIGUEL DE OCAMPO CIENFUE- & JUAN PARÍS \\
GOS & JUAN PASCUAL \\
JUAN MIGUEL NIÑO DE RIBERA & JUAN PASCUAL \\
JUAN MIGUEL SERAZ & JUAN PASCUAL \\
JUAN MILLAR & JUAN PASCUAL \\
JUAN MIRANDA & JUAN PEREDA \\
JUAN MONEDERO & JUAN PEREGRINO \\
JUAN MONTERO DE ESPINOSA & JUAN PÉREZ \\
JUAN MONTIEL & JUAN PÉREZ \\
JUAN MORATE & JUAN PÉREZ \\
JUAN MORENO & JUAN PÉREZ \\
JUAN MORENO & JUAN PÉREZ \\
JUAN MUÑOZ & JUAN PÉREZ \\
JUAN MUÑOZ & JUAN PÉREZ \\
JUAN MUÑOZ & JUAN PÉREZ \\
JUAN NADAL & JUAN PÉREZ \\
JUAN NAVARRO & JUAN PÉREZ \\
JUAN NAVARRO DE IRAZÁBAL & JUAN PÉREZ \\
JUAN NEGRETE & JUAN PÉREZ \\
JUAN NÚNEZ DE MURUA & JUAN PÉREZ \\
JUAN OCHOA DE ZUASTI & JUAN PÉREZ ALONSO GARCÍA \\
JUAN OJALVO & JUAN PÉREZ ARNAL \\
JUAN ORBAÑANOS CANTERA & JUAN PÉREZ CARDADOR \\
JUAN ORTIZ & JUAN PÉREZ DE EZQUERRA \\
JUAN ORTIZ & JUAN PÉREZ DE FRİAS \\
JUAN ORTIZ & JUAN PÉREZ DE GORRIT \\
JUAN ORTIZ DE ECHEANDIA DE GAME- & JUAN PÉREZ DE GRANADA \\
CHO & JUAN PÉREZ DE HERRÁN \\
JUAN ORTIZ DE EGUILUZ & JUAN PÉREZ DE LAMA \\
JUAN ORTIZ DE MUÑATONES & JUAN PÉREZ DE SAN ROMÁN \\
JUAN ORTIZ DE OTEO & JUAN PEEREZ FERNÁNDEZ \\
JUAN ORTIZ DE PINEDO & JUAN PÉREZ SANCHO \\
JUAN ORTIZ DE ROALES & JUAN PONS \\
JUAN ORTIZ DE VARDEBI & JUAN PORTAL \\
JUAN ORTOLANO & JUAN POZA \\
JUAN PABLO DE SAN PEDRO & JUAN RAMÍREZ DE ESPARZA \\
JUAN PABLO GAZTELU & JUAN RAMÍREZ DE NÁJERA \\
JUAN PABLO GÓMEZ & JUAN RAMIIREZ DE RIGA \\
JUAN PABLOS & JUAN RAMOS \\
\hline & \\
\hline
\end{tabular}


JUAN RAMOS DE IRAZAZÁBAL JUAN REBOLLO

JUAN RIQUELME

JUAN RODRÍGUEZ

JUAN RODRÍGUEZ

JUAN RODRÍGUEZ

JUAN RODRÍGUEZ

JUAN RODRÍGUEZ

JUAN RODRÍGUEZ

JUAN RODRÍGUEZ DE RÁBAGO

JUAN RODRÍGUEZ GARCÍA

JUAN RODRÍGUEZ OLEA

JUAN ROJO

JUAN ROMERO

JUAN ROMERO BOTELLA

JUAN RUBIO

JUAN RUBIO

JUAN RUBIO

JUAN RUIZ

JUAN RUIZ

JUAN RUIZ

JUAN RUIZ

JUAN RUIZ

JUAN RUIZ BARBADO

JUAN RUIZ DE AMAYA

JUAN RUIZ DE CELADA

JUAN RUIZ DE COLINA

JUAN RUIZ DE ESCALONA

JUAN RUIZ DE ESPINOSA

JUAN RUIZ DE HUERTAS

JUAN RUIZ DE LA CALZADA

JUAN RUIZ DE LA CANTERA

JUAN RUIZ DE LA ESCALERA

JUAN RUIZ DE LA PEÑA

JUAN RUIZ DE LARRAMENDI

JUAN RUIZ DE LUZURIAGA

JUAN RUIZ DE MATA

JUAN RUIZ DE RÍO FRANCOS

JUAN RUIZ DE SALAZAR

JUAN RUIZ DE SOTO

JUAN SÁENZ

JUAN SÁENZ DE TRIANA

JUAN SÁENZ PÉREZ

JUAN SÁEZ CUESTA DE VICUÑA

JUAN SÁEZ DE CORTÉS

JUAN SAINZ

JUAN SAINZ

JUAN SAINZ ANGULO
JUAN SAIZ DE LA PEÑA

JUAN SAIZ DE SETIÉN

JUAN SALCEDO

JUAN SALVADOR

JUAN SÁNCHEZ

JUAN SÁNCHEZ

JUAN SÁNCHEZ

JUAN SÁNCHEZ

JUAN SÁNCHEZ DE ÁVILA

JUAN SÁNCHEZ DE VICUÑA

JUAN SANCHO

JUAN SANTAGADEA COVARRUBIAS

JUAN SANTOS

JUAN SANZ

JUAN SANZ

JUAN SANZ

JUAN SANZ

JUAN SANZ

JUAN SANZ

JUAN SANZ DE ASÚA

JUAN SAZ

JUAN SEBASTIÁN BERNAD

JUAN SECO FONTECHA

JUAN SEDANO

JUAN SEGURA

JUAN SENAR DE SALINAS

JUAN SERRANO

JUAN SERRANO

JUAN SERRANO

JUAN SERRANO Y LUNA

JUAN SIMÓN DE ...

JUAN SOBREVILLA VADILLO

JUAN SOBRINO

JUAN SOMERO DE ARENAS

JUAN TAMBO

JUAN TASTEO

JUAN TAULER

JUAN TERREROS

JUAN TOMÁS GONZÁLEZ

JUAN TOMÉ

JUAN TRIBALDOS

JUAN URBAN BARONA

JUAN URROZ

JUAN VAL

JUAN VALENCIA DE LEÓN

JUAN VALLEJO

JUAN VELARDE

JUAN VELAZ 
JUAN VELÁZQUEZ

JUAN VÉLEZ

JUAN VELLAZ

JUAN VENTURA ZUGARRONDO

JUAN VICENTE

JUAN VICENTE

JUAN VICENTE PUJOL

JUAN VÍCTORES DÍAZ DE LA QUINTANILLA

JUAN VÍCTORES MARTÍNEZ DE MONTERRUBIO

JUAN YÁNGÜEZ

JUAN ZAPATIER CARPIO

JUAN ZORRILLA DE VELASCO

JUAN ZÚMEL

JULIÁN ANDRÉS USTÁRROZ

JULIÁN DE ...ERICA

JULIÁN DE LIZA

JULIÁN DE SOBA

JULIÁN DE VILLAR

JULIÁN LOZANO

JULIÁN MONEDERO

JULIÁN PARDO

JULIÁN RAMOS DE HEREDIA

JULIO DE DEHESO

JUSTO BUIL

JUSTO DE ARBIZU

JUSTO DE LA PEÑA BRIZUELAS

JUSTO DE OÑA Y SOTO

JUSTO DE OSTA Y OLAEGUI

JUSTO MARTÍNEZ DE ARROYO

JUSTO TOMÁS

LAMBERTO DE ALÓS

LAMBERTO LÓPEZ

LARUEL FERNÁNDEZ DE CEA

LAUREANO GIL

LÁZARO DE CASTRO

LÁZARO DE ISAR

LÁZARO DE JARAMILLO

LÁZARO DE PALACIOS

LÁZARO DE SANTANDER

LÁZARO LÓPEZ

LÁZARO MARCOS

LÁZARO MARTÍNEZ DE ROCAS

LÁZARO ROMEO

LÁZARO RUIZ DE SILLARIO

LEANDRO CONDE DE ÁVILA

LEANDRO GONZÁLEZ VILLALOBOS
LEANDRO NOGUEROL

LEÓN BERNARDO DE QUEVEDO

LEÓN DE ASIAIN

LEÓN DE GUILLÉN

LEÓN DE LARRUMBE

LEÓN FRANCÉS

LEONANDO DE LOS ROSALES

LEONARDO DE LODOSA

LEONARDO DE ORTEGA

LEONARDO FERNÁNDEZ DE CASTAÑAGA

LEONARDO GARCÍA

LEONARDO VENTURA Y LUNA

LESMES DE AMPIANO IBARRA

LESMES DE CASTRESANA

LESMES DE SALCEDO

LESMES DE SAN MARTÍN

LESMES DEL BARRIO

LESMES GARCÍA

LESMES GARCÍA

LESMES GARCÍA

LESMES PÉREZ

LOPE DE BORRICÓN

LOPE DE HUARTE

LOPE DE UGARTE

LOPE DE UNDIANO

LOPE DEL CAMPO

LOPE FRANCISCO DE LOS RÍOS

LOPE GARCÍA DE TÉBAR

LOPE MONTAÑO

LORENZO ALONSO

LORENZO ALONSO

LORENZO ANGULO

LORENZO BAUTISTA DE ROMERO

LORENZO BELTRÁN

LORENZO CHACÓN

LORENZO CONGET

LORENZO DE AGUERO

LORENZO DE ALBÉNIZ

LORENZO DE ARÓSTEGUI

LORENZO DE ARTETA

LORENZO DE AYALA

LORENZO DE ESPINOSA

LORENZO DE GARAY

LORENZO DE ISLA PALACIO

LORENZO DE ITURRIALDE

LORENZO DE LA FUENTE

LORENZO DE LA PEÑA 
LORENZO DE LA TORRE

LORENZO DE MAHAMUD

LORENZO DE MATA

LORENZO DE MENDOZA

LORENZO DE OLANO

LORENZO DE ORMAZA

LORENZO DE PEREDA

LORENZO DE QUIJANO

LORENZO DE SAN MARTÍN

LORENZO DE SOTO VARGAS

LORENZO DE TOUBES

LORENZO DE VICUÑA

LORENZO DE VIDANIA

LORENZO DEL DIESTRO

LORENZO DELGADO

LORENZO FRANCÉS DE URRIGOITI

LORENZO GARCÍA

LORENZO GIMÉNEZ

LORENZO GONZÁLEZ

LORENZO LÓPEZ

LORENZO LÓPEZ

LORENZO LUIS DE SANTAFE

LORENZO MARGÁIN

LORENZO MARÍN

LORENZO MARTÍNEZ

LORENZO MIANA

LORENZO MONTERO DE LA CONCHA

LORENZO MORENO

LORENZO ORTEGA

LORENZO PAMPLIEGA

LORENZO PÉREZ

LORENZO PERLINES

LORENZO POLANCO Y CEBALLOS

LORENZO REJÓN

LORENZO RODRÍGUEZ

LORENZO VALERÓN

LUCAS ALCALDE

LUCAS ANDRÉS

LUCAS ANTONIO FERNÁNDEZ

LUCAS BUSQUETA

LUCAS DE ALBARO

LUCAS DE ARENAS

LUCAS DE BERNALES

LUCAS DE FONTECHA

LUCAS DE GÁLLEGO

LUCAS DE ILARDUYA

LUCAS DE IRUJO

LUCAS DE LA FUENTE
LUCAS DE LA TEJERA

LUCAS DE LAPUENTE

LUCAS DE LARREA

LUCAS DE LLAEDA SALAZAR

LUCAS DE LOS CORRALES

LUCAS DE MACEDA

LUCAS DE MANZANEDA

LUCAS DE QUINTANA

LUCAS DE VILLADIEGO

LUCAS DEL ARCO

LUCAS FERNÁNDEZ

LUCAS FERNÁNDEZ DE LA PEÑA

LUCAS FERNÁNDEZ VEDÓN

LUCAS FIGUERAS

LUCAS GALLO

LUCAS GÓMEZ

LUCAS GONZÁLEZ

LUCAS HERNANDO

LUCAS IBÁÑEZ

LUCAS JACA

LUCAS LÓPEZ

LUCAS LÓPEZ DE SOSCANO

LUCAS LOZANO

LUCAS MARTÍNEZ DE BUSTOS

LUCAS MARTÍNEZ DE MONTERRUBIO

LUCAS MELÉNDEZ DE MIRANDA

LUCAS MERINO

LUCAS PANDO

LUCAS PASCUAL DE ZORRILLA

LUCAS PÉREZ

LUCAS PÉREZ

LUCAS PÉREZ ROJO

LUCAS RODRÍGUEZ

LUCAS RODRÍGUEZ

LUCAS RUIZ DE CENES

LUCAS SALAS

LUCAS SERENA

LUIS ÁLVAREZ DE QUIÑNONES

LUIS ANTONIO DE COVILLAS Y VENENO

LUIS ANTONIO RAMIRO GÓMEZ

LUIS BURGOS

LUIS CLAVIJO

LUIS DE ABADÍA

LUIS DE BUILLA

LUIS DE CASTRONOVO

LUIS DE ECHALAZ

LUIS DE EGUILIOR 
LUIS DE GUEVARA

LUIS DE HUIDOBRO

LUIS DE LA CARRERA

LUIS DE LA PEÑA

LUIS DE LA PIEDRA

LUIS DE LAMA

LUIS DE LOBO Y PORRES

LUIS DE MUR

LUIS DE OSCÁRIZ

LUIS DE QUIÑONES

LUIS DE SAGARRAGA

LUIS DE SALCEDO Y ARBIZU

LUIS DE SENOSIÁIN

LUIS DE TAPIA Y CEBALLOS

LUIS DE TERÁN

LUIS DE TOBA Y PORRES

LUIS DE TREBILLA

LUIS DE UZTÁRROZ

LUIS DE VALLE Y ALVARADO

LUIS DE VELASCO

LUIS DE VERGARA

LUIS FÉLIX DE RADA

LUIS FERNÁNDEZ DE MENDOZA

LUIS FLORES

LUIS FUSTER

LUIS GONZÁLEZ DEL VALLE

LUIS HERRERA

LUIS IBÁÑEZ

LUIS JIMÉNEZ DE MURILLO

LUIS JUÁNIZ DE ECHALAZ

LUIS LÓPEZ

LUIS MAURICIO INDURÁIN

LUIS PÉREZ DE SAGASETA

LUIS RUIZ OBREGÓN

LUIS ZAPATA

M. DE BASABE

MAMÉS ANTONIO MARTÍNEZ DE PAREDES

MANUEL AGUADO DE PEDROSA

MANUEL ALONSO DE AZAGRA

MANUEL ALONSO DE OVIEDO

MANUEL ANDRÉS

MANUEL ANGULO

MANUEL ANTONIO DE SALAMANCA

MANUEL ARCINIEGA

MANUEL BAQUERO Y ZALDÍVAR

MANUEL BERNARDO RUIZ DE LA BASTIDA
MANUEL BRACERAS SALAZAR

MANUEL CARVAZ

MANUEL CORERA

MANUEL DE ABAJO Y MASSA

MANUEL DE AGUAYO

MANUEL DE ALMEIDA

MANUEL DE ARBEIZA

MANUEL DE ARÓZTEGUI

MANUEL DE ARROYO

MANUEL DE ASITORES

MANUEL DE AZCONA Y ECHARREN

MANUEL DE BÁRCENA

MANUEL DE BURGOS

MANUEL DE CABAÑAS

MANUEL DE CARRANZA

MANUEL DE CARRIEDO

MANUEL DE CASTELLANOS

MANUEL DE CASTREJÓN

MANUEL DE CASTRO

MANUEL DE CELADA

MANUEL DE CERECEDA

MANUEL DE CIGARÁN

MANUEL DE CLARES

MANUEL DE ERASO

MANUEL DE ERZI

MANUEL DE ESPINOSA

MANUEL DE GARAY

MANUEL DE GÜEMES Y ORCASITAS

MANUEL DE HERNANDO

MANUEL DE HERRERA Y RÍO

MANUEL DE HORNILLOS

MANUEL DE IGAY

MANUEL DE IGLESIAS

MANUEL DE LA CUERTA

MANUEL DE LA MORA QUEVEDO

MANUEL DE LA VARGA

MANUEL DE LABASTIDA

MANUEL DE LEBRIJA

MANUEL DE LIZAUR

MANUEL DE LOSA

MANUEL DE MANSILLA VITORIA

MANUEL DE MOLLINEDO

MANUEL DE MORALEGRE

MANUEL DE MOREDA Y CARVAJAL

MANUEL DE MURO

MANUEL DE OBREGÓN

MANUEL DE OLIVAR

MANUEL DE ORNEDO 
MANUEL DE OTÁÑNZZ MANUEL DE OTAOLA MANUEL DE PALACIO MANUEL DE PALACIOS MANUEL DE PAREDES MANUEL DE PAZ Y NOVOA MANUEL DE PINEDO MANUEL DE PORRAS MANUEL DE PORRES MANUEL DE QUINTANA BARREDA MANUEL DE QUIRÓS MANUEL DE REBOLLEDO MANUEL DE REVILLA MANUEL DE RUCOBA Y SAÑA MANUEL DE SALAZAR CELADA MANUEL DE SALINAS MANUEL DE SAMANIEGO MANUEL DE SAMANIEGO Y JACA MANUEL DE SANCHA MANUEL DE SANTA MARÍA MANUEL DE SANTOJO MANUEL DE SEDANO MANUEL DE TERÁN COSSÍO MANUEL DE TOCORNAL MANUEL DE VALENCIA MANUEL DE VIANA MANUEL DE VILLASANTE MANUEL DE YURRETAURIA MANUEL DE ZÁRATE MANUEL DEL CAMPO MANUEL DEL CAMPO MANUEL DEL VALLE MANUEL DÍAZ MANUEL ELÍAS DON GUILLÉN MANUEL FERNÁNDEZ MANUEL FERNÁNDEZ MANUEL FERNÁNDEZ MANUEL FERNÁNDEZ DE BERROCAL MANUEL FUERTES MANUEL GARCÍA MANUEL GARCÍA MANUEL GARCÍA DE FRESNO MANUEL GARCÍA DE SAGREDO MANUEL GÓMEZ MANUEL GONZÁLEZ MANUEL GONZÁLEZ MANUEL GONZÁLEZ MANUEL GUTIÉRREZ

\author{
MANUEL HERNÁNDEZ \\ MANUEL IZQUIERDO \\ MANUEL JIMÉNEZ \\ MANUEL JOSÉ DE FABRO \\ MANUEL JOSÉ RIBAS \\ MANUEL LÓPEZ DE BRIZUELA \\ MANUEL MÁRQUEZ \\ MANUEL MARTÍNEZ \\ MANUEL MARTÍNEZ \\ MANUEL MARTÍNEZ DE QUEVEDO \\ MANUEL MARTÍNEZ DE ZUAZO \\ MANUEL MARTÍNEZ DEL ÁGUILA \\ MANUEL MARTÍNEZ GAMARRA \\ MANUEL MATÉ VÉLEZ \\ MANUEL MENAZA DE LA IGLESIA \\ MANUEL MIGUEL GONZÁLEZ \\ MANUEL MONTE DE VERGARA Y RESA \\ MANUEL MORANTE DE REBOLLEDO \\ MANUEL NAVARRETE LADRÓN DE \\ GUEVARA \\ MANUEL NAVARRO \\ MANUEL OREJÓN \\ MANUEL PANDO \\ MANUEL PINILLOS \\ MANUEL PRIETO \\ MANUEL RAMÍREZ DE MALAINA \\ MANUEL REYES DE MANSILLA \\ MANUEL RODRIGO \\ MANUEL RODRÍGUEZ \\ MANUEL RUIZ \\ MANUEL SAINZ \\ MANUEL SAINZ \\ MANUEL SAINZ \\ MANUEL SARMIENTO DE LA PEÑA \\ MANUEL VALLE ZORRAQUÍN \\ MANUEL VALLEJO \\ MANUEL VELA \\ MANUEL VELASCO \\ MANUEL VELASCO \\ MANUEL VÉLEZ FRÍAS \\ MANUEL ZAMARÓN \\ MANUEL ZORRILLA \\ MARCELINO MARTÍNEZ \\ MARCELO BASCONES \\ MARCELO DOMÍNGUEZ \\ MARCIAL DE EZPELETA \\ MARCO ANTONIO ALEGRE CASANATE \\ MARCO GONZÁLEZ DE ARCE
}


MARCOS ALONSO

MARCOS ÁLVAREZ

MARCOS ANTONIO BERGANZA

MARCOS CABALLERO

MARCOS CEBALLOS QUEVEDO

MARCOS DE ANDRADE

MARCOS DE ARGUETA

MARCOS DE ATIENZA

MARCOS DE ÁVILA MERCADILLO

MARCOS DE BÁRCENA

MARCOS DE BOBADILLA

MARCOS DE CASTAÑOS

MARCOS DE GIBARA

MARCOS DE GOITIA

MARCOS DE HERVÍAS

MARCOS DE LA FUENTE Y BUSTAMANTE

MARCOS DE LA SOTA

MARCOS DE LIAÑO

MARCOS DE LODOSA

MARCOS DE LUQUÍN

MARCOS DE PEDROSO

MARCOS DE URTASO

MARCOS DE URTASO

MARCOS DE VIANA BEAUMONT

MARCOS DEL CAMPO

MARCOS DEL RÍO

MARCOS FERNÁNDEZ

MARCOS FONTURBEL DE ESPINOSA

MARCOS GARCÍA

MARCOS GÓMEZ

MARCOS GONZÁLEZ

MARCOS GONZÁLEZ DE RUEDA

MARCOS GONZÁLEZ HERRERO

MARCOS GUTIÉRREZ DE LA MORA

MARCOS JIMÉNEZ

MARCOS JIMÉNEZ

MARCOS JIMÉNEZ DE CENARBE

MARCOS LÓPEZ

MARCOS LÓPEZ DE HARO

MARCOS MARTÍNEZ

MARCOS PARDO

MARCOS PARDO

MARCOS RODRÍGUEZ

MARCOS RONCAL

MARCOS RUIZ DE AMAYA

MARCOS SÁNCHEZ

MARCOS SERRANO

MARCOS TEZANOS
MARCOS ZÚMEL

MARIO DE EZA Y ROSALES

MARIO DE PAMPLIEGA

MARTÍN AGUADO

MARTÍN ALONSO DE SANTOCILDES

MARTÍN ÁLVARO

MARTÍN AMBROSIO BERNAL

MARTÍN ANDRÉS DE PAREDES

MARTÍN ANTONIO DE PUERTA

MARTÍN AZPILIAGA

MARTÍN BAPTISTA

MARTÍN BASURTO DE VALDÉS

MARTÍN BAZÁN DE LARRALDE

MARTÍN BECERRA

MARTÍN BELTRÁN DE ARNEDO

MARTÍN CALZAS

MARTÍN CONGET

MARTÍN CORNEJO

MARTÍN CORRAL Y GUZMÁN

MARTÍN COSCÓN

MARTÍN CUEVAS

MARTÍN DE ACEDO

MARTÍN DE AGUIRRE

MARTÍN DE ALBALA

MARTÍN DE ALBÉNIZ

MARTÍN DE ALDAMA

MARTÍN DE ALDUNATE

MARTÍN DE ALPIZUETA

MARTÍN DE AMATRIAIN

MARTÍN DE ANDÍA

MARTÍN DE ANDUEZA

MARTÍN DE ANTEZANA

MARTÍN DE AOIZ

MARTÍN DE AOIZ

MARTÍN DE ARANO

MARTÍN DE ARDAIZ

MARTÍN DE ARDANAZ

MARTÍN DE ARENAS

MARTÍN DE ARGOS

MARTÍN DE ARGUIÑANO EQUIZA

MARTÍN DE ARISTU

MARTÍN DE ARIZMENDI

MARTÍN DE ARLEGUI

MARTÍN DE ARMENDÁRIZ

MARTÍN DE ARÓSTEGUI

MARTÍN DE ARRUBIA

MARTÍN DE ASADA

MARTÍN DE ASTUDILLO 
MARTÍN DE AYA

MARTÍN DE AYERRA

MARTÍN DE AZAS

MARTÍN DE AZCONA

MARTÍN DE AZCONA

MARTÍN DE AZPILICUETA

MARTÍN DE AZPILICUETA

MARTÍN DE AZPILICUETA

MARTÍN DE BELZUNCE

MARTÍN DE BERASTEGUI

MARTÍN DE BERRIA

MARTÍN DE BEUNZA

MARTÍN DE BEUNZA

MARTÍN DE BONILLA

MARTÍN DE BUITRAGO

MARTÍN DE CALATAYUD

MARTÍN DE CAMINO

MARTÍN DE CASAL

MARTÍN DE CEBAUZ

MARTÍN DE CENARRO

MARTÍN DE CHINIGARRO

MARTÍN DE CIRIZA

MARTÍN DE ECHALECU

MARTÍN DE EGUIARRETA

MARTÍN DE EGUIARTE

MARTÍN DE EJEA

MARTÍN DE ERASO

MARTÍN DE ERICE

MARTÍN DE ESPINAL

MARTÍN DE ESQUIROZ

MARTÍN DE EUSA

MARTÍN DE EZCURRA

MARTÍN DE EZPELETA

MARTÍN DE GALAR

MARTÍN DE GARDE

MARTÍN DE GILABERT

MARTÍN DE GORRAIZ

MARTÍN DE GUELBENZU

MARTÍN DE HERRERA

MARTÍN DE HERRERA

MARTÍN DE ILZARBE

MARTÍN DE IRAOLA

MARTÍN DE IRIARTE

MARTÍN DE IRISARRI

MARTÍN DE ITURBURRU Y ERASO

MARTÍN DE JACUE

MARTÍN DE JURIO

MARTÍN DE LA PUENTE
MARTÍN DE LABRIT

MARTÍN DE LAHOZ

MARTÍN DE LANDERA

MARTÍN DE LAS HERAS

MARTÍN DE LENCES

MARTÍN DE LEOZ

MARTÍN DE LEOZ

MARTÍN DE LIZALDE

MARTÍN DE LIZASO

MARTÍN DE LIZASO

MARTÍN DE LUENGO

MARTÍN DE LUSARETA

MARTÍN DE MARQUINA

MARTÍN DE MARSÁIN Y ZABALETA

MARTÍN DE MARZANA

MARTÍN DE MAYA

MARTÍN DE MORALES

MARTÍN DE MURILLO

MARTÍN DE MURILLO

MARTÍN DE MUSQUES

MARTÍN DE NABEZ

MARTÍN DE OLÓNDRIZ

MARTÍN DE OÑATE

MARTÍN DE OQUERULI SANTA CRUZ

MARTÍN DE ORCASITAS

MARTÍN DE ORCONDONA

MARTÍN DE ORICAIN

MARTÍN DE ORTIZ DE OTEO

MARTÍN DE PARRAST

MARTÍN DE PINEDO

MARTÍN DE PIÑEÑORI

MARTÍN DE PORRAS

MARTÍN DE RADA

MARTÍN DE REA

MARTÍN DE REIZU

MARTÍN DE RIAÑO

MARTÍN DE RIAÑO

MARTÍN DE RIPALDA

MARTÍN DE RIVERA

MARTÍN DE ROCAFORTE

MARTÍN DE RUIZ GAMARRA

MARTÍN DE SACHAGA

MARTÍN DE SALINAS

MARTÍN DE SAN ESTEBAN

MARTÍN DE SAN MARTÍN

MARTÍN DE SANTISTEBAN

MARTÍN DE SANTOLARIA

MARTÍN DE SERRALTA 
MARTÍN DE SETA

MARTÍN DE SOLA MORRAS

MARTÍN DE SOTO Y GUZMÁN

MARTÍN DE SUBICA

MARTÍN DE SUESCUN

MARTÍN DE TURRILLAS

MARTÍN DE UGARTE

MARTÍN DE URQUIOLA

MARTÍN DE URRIZOLA

MARTÍN DE URRUTIA

MARTÍN DE URUÑUELA

MARTÍN DE VALENCIA

MARTÍN DE VALLEJO

MARTÍN DE VERGARA

MARTÍN DE VERIAIN

MARTÍN DE VILLALBILLA

MARTÍN DE VILLENA

MARTÍN DE ZUGARRONDO

MARTÍN DE ZUGARRONDO

MARTÍN DE ZULAIBA

MARTÍN DE ZULAIBAR

MARTÍN DE ZUNZARREN

MARTÍN DE ZUNZARREN

MARTÍN DEL BARRIO

MARTÍN DEL CAÑO

MARTÍN DEL CASTILLO

MARTÍN DEL CORRAL

MARTÍN DEL PRA

MARTÍN DEL PUCIO IRIGOYEN

MARTÍN DÍAZ

MARTÍN DÍAZ DE POZAS

MARTÍN DÍEZ

MARTÍN DOMÍNGUEZ DE VIDAURRETA

MARTÍN ESCUDERO

MARTÍN ESCUER

MARTÍN FADRIQUE DE ERRAN

MARTÍN FERNÁNDEZ

MARTÍN FERNÁNDEZ CORNEJO

MARTÍN FERNÁNDEZ DE BONILLA

MARTÍN FERNÁNDEZ DE MENDIBIDE

MARTÍN FERNÁNDEZ DE PELLÓN

MARTÍN FERNÁNDEZ DE ZÁRATE

MARTÍN FRANCÉS

MARTÍN GALAZ DE JARAUTA

MARTÍN GARCÍA

MARTÍN GARCÍA

MARTÍN GARCÍA

MARTÍN GARCÍA
MARTÍN GARCÍA BAQUERO

MARTÍN GÓMEZ MARAÑÓN

MARTÍN GONZÁLEZ

MARTÍN GONZÁLEZ

MARTÍN GONZÁLEZ

MARTÍN GONZÁLEZ DE LEZCANO Y TRONCÓNIZ

MARTÍN HERMOSO

MARTÍN IBÁÑEZ

MARTÍN IBARRA

MARTÍN IZQUIERDO

MARTÍN JIMÉNEZ DE ESPARZA

MARTÍN JUAN DE MUR

MARTÍN LADRÓN DE CEGAMA

MARTÍN LÓPEZ

MARTÍN LÓPEZ DE GAUNA

MARTÍN LÓPEZ DE GAUNA

MARTÍN LÓPEZ GARCÍA

MARTÍN LORENTE

MARTÍN MÁRQUEZ

MARTÍN MARTÍNEZ

MARTÍN MARTÍNEZ

MARTÍN MARTÍNEZ

MARTÍN MARTÍNEZ DE LOZOÑO

MARTÍN MARTÍNEZ DE OQUELLU LUZURIAGA

MARTÍN MERINO

MARTÍN MIGUEL

MARTÍN NEGRETE

MARTÍN ORTIZ

MARTÍN ORTIZ DE GUINEA

MARTÍN ORTIZ DE VITORIA

MARTÍN PARRAST

MARTÍN PEIRON Y QUERALT

MARTÍN PÉREZ

MARTÍN PÉREZ

MARTÍN PÉREZ DE ELIZALDE

MARTÍN PÉREZ DE HEREDIA

MARTÍN PÉREZ DE POLANCO

MARTÍN PÉREZ DE SALINAS

MARTÍN PÉREZ RODRÍGUEZ SEGURA

MARTÍN PÉREZ VENERO

MARTÍN RAMÍREZ

MARTÍN RODRIGO DE LA PEÑA

MARTÍN RODRÍGUEZ

MARTÍN ROS

MARTÍN RUIZ

MARTÍN RUIZ 
MARTÍN RUIZ

MARTÍN RUIZ DE UBAGO

MARTÍN SAINZ

MARTÍN SÁNCHEZ

MARTÍN SÁNCHEZ DE LA CUEVA

MARTÍN SÁNCHEZ DE LA TORRE

MARTÍN SÁNCHEZ DE MOREDA

MARTÍN SÁNCHEZ DE OLALLA

MARTÍN SIERRA SALAZAR

MARTÍN TOMÁS

MARTÍN UGALDE

MARTÍN VILLAVA

MARTÍN ZEMENO

MARTÍN ZORILLA

MATEO ALONSO

MATEO ANSÓN

MATEO ARNEDO

MATEO BLANCO

MATEO DE AGÜERO Y SARABIA

MATEO DE ARANDA

MATEO DE ARANDA

MATEO DE BELTRANILLA

MATEO DE BOADA

MATEO DE BUSTAMANTE

MATEO DE CAMARGO ARCE

MATEO DE CASTRO

MATEO DE ECHAURI Y ZÁRATE

MATEO DE ESCALANTE

MATEO DE ESCALANTE

MATEO DE ESCALANTE Y RÍOS

MATEO DE FONTECHA

MATEO DE GARRO

MATEO DE GUEVARA

MATEO DE IRACHETA

MATEO DE IRUCETA

MATEO DE ISLA

MATEO DE IZARRA HORRUMA

MATEO DE LA GUERRA PALACIOS

MATEO DE LESACA

MATEO DE OCEJO

MATEO DE PALOMERA

MATEO DE PUENTE

MATEO DE REZUSTA

MATEO DE SAN CRISTÓBAL

MATEO DE VIANA CALDERÓN

MATEO DE VILLA

MATEO DE ZUBIAUR

MATEO DEL CORRAL
MATEO DEL CORRAL

MATEO DEL RÍO

MATEO DEL RÍO

MATEO EZQUERRA

MATEO FERNÁNDEZ Y MARÍA

MATEO FONCILLAS

MATEO GARCÍA

MATEO GIL

MATEO GÓMEZ DE SOTO

MATEO GÓMEZ DE VELASCO

MATEO GONZÁLEZ

MATEO JOSÉ DE CUÉLLAR CARRASCO

MATEO JUÁREZ

MATEO LARENA

MATEO LLORENTE

MATEO LÓPEZ

MATEO LÓPEZ CHÁLEZ

MATEO MAESTRE

MATEO MARTÍNEZ

MATEO MERINO

MATEO MORENO DE CISNEROS

MATEO PÉREZ

MATEO PRIETO

MATEO PRIETO

MATEO RODRÍGUEZ

MATEO ROJAS

MATEO RUIZ DE HUIDOBRO

MATEO VALLEJO

MATÍAS BARRÓN

MATÍAS BENITO

MATÍAS BESGA

MATÍAS BURBANO

MATÍAS COLOMO

MATÍAS CRESPO

MATÍAS DE AGUIRRE

MATÍAS DE ARANA Y ANDRACA

MATÍAS DE ARCE

MATÍAS DE CHASCOS

MATÍAS DE CORELLA

MATÍAS DE ESCALANTE Y SARABIA

MATÍAS DE GARRALDA

MATÍAS DE HEVIA

MATÍAS DE LA IGLESIA

MATÍAS DE LA SERNA

MATÍAS DE LARRAÑAGA

MATÍAS DE LATORRE

MATÍAS DE LEÓN

MATÍAS DE MARIGIL 
MATÍAS DE MARMANILLOS

MATÍAS DE NIEVA

MATÍAS DE PESQUERA

MATÍAS DE RADA

MATÍAS DE SOBEJANO

MATÍAS DE VILLANUEVA

MATÍAS DEL CAÑO

MATÍAS DELGADO HERRERO

MATÍAS FRANCISCO FEMAT

MATÍAS GARCÍA

MATÍAS GONZÁLEZ

MATÍAS GONZÁLEZ DE CANEDA

MATÍAS GUTIÉRREZ

MATÍAS LÓPEZ

MATÍAS LÓPEZ

MATÍAS MÍNGUEZ

MATÍAS RODRÍGUEZ

MATÍAS RUIZ

MATÍAS SAIZ

MATÍAS SANZ

MATÍAS VELASCO

MATÍAS VISÚS

MAURO DE OLABARRIETA

MAURO DE PONTE

MAURO DE SOMOZA

MAURO DE SORIA

MAURO DE SOSA

MAURO DE TOBAR

MAURO DE VILLARROEL

MAURO GARCÍA DE MENDOZA

MEDA DE TAMAYO

MELCHOR ÁLVAREZ CARRERA

MELCHOR DE AHEDO

MELCHOR DE BORRICÓN Y ARÉVALO

MELCHOR DE ESCUDERO

MELCHOR DE MENDIVIL

MELCHOR DE MORALES

MELCHOR DE PANDO

MELCHOR DE PLAZA MÁRQUEZ

MELCHOR DE SANTELICES

MELCHOR DE SUSPIRÓN Y ORTIZ

MELCHOR DE VAL

MELCHOR DE VILLARÓN

MELCHOR ESCUDERO

MELCHOR ESCUDERO

MELCHOR LÓPEZ DE TORREJÓN

MELCHOR MONEDERO

MELCHOR RODRÍGUEZ DE QUIJANO
MELCHOR SÁNCHEZ

MENDO LÓPEZ

MIGUEL ...

MIGUEL ALONSO

MIGUEL ALONSO

MIGUEL ALONSO

MIGUEL ÁLVAREZ Y CARRERA

MIGUEL ANDUEZA

MIGUEL ANTONIO BERÁSTEGUI

MIGUEL ASTAR RUES

MIGUEL AZNAR CORTÉS

MIGUEL BARBO

MIGUEL BONET

MIGUEL BONETA

MIGUEL CABERNI

MIGUEL CALMEDO

MIGUEL CALVILLO

MIGUEL CALVO

MIGUEL CANTÓN

MIGUEL CLAVER

MIGUEL CORREDOR

MIGUEL DE ...

MIGUEL DE ACHIGA

MIGUEL DE ALBALA ÍÑIGO

MIGUEL DE ALBILLA

MIGUEL DE ALBILLA

MIGUEL DE ALDARRA OYANUME

MIGUEL DE ALDUNATE

MIGUEL DE ALTERAIN

MIGUEL DE ÁNIZ

MIGUEL DE ARBIZU

MIGUEL DE ARDANAZ

MIGUEL DE ARI...

MIGUEL DE ARIZ

MIGUEL DE ARIZAGA

MIGUEL DE ARLEGUI

MIGUEL DE ARNICA

MIGUEL DE ARÓZTEGUI

MIGUEL DE ARRIZAGA

MIGUEL DE ARZAMENDIA

MIGUEL DE ATONDO

MIGUEL DE ÁVILA

MIGUEL DE AYALA

MIGUEL DE AYALA

MIGUEL DE AZCONA DE LIZAIN

MIGUEL DE AZPARREN

MIGUEL DE AZPILICUETA

MIGUEL DE BALEZTENA 
MIGUEL DE BARREDA MIGUEL DE BASCONES MIGUEL DE BAYONA MIGUEL DE BERIAIN MIGUEL DE BO... MIGUEL DE BONETA MIGUEL DE BUSTO MIGUEL DE CABERNO MIGUEL DE CANTABRANA MIGUEL DE CASILLO MIGUEL DE CASTRO MIGUEL DE CASTRO MIGUEL DE CEREZO MIGUEL DE CEREZO MIGUEL DE CIADONCHA MIGUEL DE CIZUR MIGUEL DE COSSÍO MIGUEL DE COSTARENA MIGUEL DE ECHEVERRI MIGUEL DE EGUZQUIZA MIGUEL DE ELEJABEITIA MIGUEL DE ELIZALDE Y URSUA MIGUEL DE ELIZONDO MIGUEL DE ERASO MIGUEL DE ERRO MIGUEL DE ERVITI MIGUEL DE EZPELETA MIGUEL DE GANUZA MIGUEL DE GARIBAY MIGUEL DE GARRALDA MIGUEL DE GARRAZA MIGUEL DE GAZÓLAZ MIGUEL DE GOÑI MIGUEL DE GORRI MIGUEL DE GOYENECHEA MIGUEL DE GRESA MIGUEL DE GUEVARA MIGUEL DE IBARROLA MIGUEL DE IDOCÍN MIGUEL DE ILLARREGUI MIGUEL DE IRAIZOZ MIGUEL DE IRIBAS MIGUEL DE IRIONDO MIGUEL DE IRISARRI MIGUEL DE IRURZUM MIGUEL DE ITURBIDE MIGUEL DE ITURRIA MIGUEL DE JÁUREGUI
MIGUEL DE JUARBE MIGUEL DE JUDEGO MIGUEL DE JURIO MIGUEL DE LA CUESTA MIGUEL DE LA MAGDALENA MIGUEL DE LA PEÑA MIGUEL DE LA PEÑA MIGUEL DE LABARI MIGUEL DE LACASA MIGUEL DE LARRÁINZAR MIGUEL DE LARRAIZAR MIGUEL DE LARRASOAÑA MIGUEL DE LEBRIJA MIGUEL DE LEGASA MIGUEL DE LERMA MIGUEL DE LIÑÁN Y DE GALIANO MIGUEL DE LIZASOAIN MIGUEL DE LLOSA MIGUEL DE LOYA MIGUEL DE LUJÁN MIGUEL DE LUQUÍN MIGUEL DE MANCEBO MIGUEL DE MAULEÓN MIGUEL DE MECA BOBADILLA MIGUEL DE MEOZ MIGUEL DE MIAS MIGUEL DE MORTERUELO MIGUEL DE MUÉS MIGUEL DE OCAMPO Y CIENFUEGOS MIGUEL DE OLABERRI MIGUEL DE OLLO MIGUEL DE OLÓNDRIZ MIGUEL DE OSÉS MIGUEL DE OTEIZA MIGUEL DE PALACIO MIGUEL DE PANDO MIGUEL DE PATERNINA MIGUEL DE PORRAS MIGUEL DE QUINTANA MIGUEL DE RIBAS RUBIO MIGUEL DE RUBÍN DEL CORRO MIGUEL DE SADA MORILLO MIGUEL DE SALINAS MIGUEL DE SAN VICENTE MIGUEL DE SANZ MIGUEL DE SESMA MIGUEL DE SOS LUMBIER MIGUEL DE TORRES 
MIGUEL DE TORRES

MIGUEL DE UCAR Y AZCONA

MIGUEL DE URROZ

MIGUEL DE URRUTIA

MIGUEL DE URRUTIA

MIGUEL DE UZQUIANO

MIGUEL DE VESGA

MIGUEL DE VILLAESCUSA

MIGUEL DE VILLANUEVA SALAZAR

MIGUEL DE VIRUÉS ESPINOSA

MIGUEL DE ZABALZA

MIGUEL DEL CASTILLO

MIGUEL ESCUDERO DE PERALTA

MIGUEL FERNÁNDEZ AGUAYO

MIGUEL FERNÁNDEZ DE AHUMADA

MIGUEL FERNÁNDEZ DE BARREDO

MIGUEL FERNÁNDEZ DE LA PEÑA

MIGUEL FERNÁNDEZ Y VIZARRA

MIGUEL GALÁN

MIGUEL GALLO

MIGUEL GALLÓN

MIGUEL GARCÍA

MIGUEL GARCÍA

MIGUEL GARCÍA

MIGUEL GARCÍA

MIGUEL GARCÍA

MIGUEL GARCÍA GALDIANO

MIGUEL GIL

MIGUEL GIL

MIGUEL GIMÉNEZ

MIGUEL GONZÁLEZ

MIGUEL GONZÁLEZ

MIGUEL GONZÁLEZ

MIGUEL GONZÁLEZ

MIGUEL GONZÁLEZ

MIGUEL GUERRA DE LA VEGA

MIGUEL GUILLÉN

MIGUEL GUIZA DE CEGAMA

MIGUEL GUTIÉRREZ

MIGUEL GUTIÉRREZ

MIGUEL GUTIÉRREZ

MIGUEL HERMOSO

MIGUEL HERMOSO

MIGUEL HERRERA

MIGUEL IÑIIGUEZ

MIGUEL IRIBARREN

MIGUEL IZU

MIGUEL JIMÉNEZ
MIGUEL JOSÉ [PÉREZ] DE OLIVÁN Y VAQUER

MIGUEL JOSÉ ANTONIO DE NOVALLAS

MIGUEL LADRÓN DE CEGAMA

MIGUEL LÓPEZ

MIGUEL LÓPEZ DE BARRIONUEVO

MIGUEL LÓPEZ DE ESPINOSA

MIGUEL LÓPEZ DE LLANOS

MIGUEL LÓPEZ DE SAN JUAN

MIGUEL LORENTE

MIGUEL MALLÉN

MIGUEL MARCOS DE LUCÍA

MIGUEL MARÍN PARDINA

MIGUEL MARTÍNEZ

MIGUEL MARTÍNEZ

MIGUEL MARTÍNEZ

MIGUEL MARTÍNEZ DE GARAIZ

MIGUEL MARTÍNEZ TAZA

MIGUEL MATEO

MIGUEL MATÍAS

MIGUEL MAULEÓN

MIGUEL MERINO

MIGUEL MONJE

MIGUEL MONTERO

MIGUEL MORATE

MIGUEL MUÑOZ Y AGUSEJO

MIGUEL NIETO

MIGUEL OCHOA

MIGUEL ORTIZ DE AEDO

MIGUEL PARRAST

MIGUEL PÉREZ

MIGUEL PÉREZ

MIGUEL PÉREZ

MIGUEL POLO

MIGUEL RAM DE MONTORO

MIGUEL RAMÓN ZAPATER

MIGUEL RODRÍGUEZ

MIGUEL RUIZ

MIGUEL RUIZ

MIGUEL RUIZ VELASCO

MIGUEL SALANO Y ECHEVERZ

MIGUEL SÁNCHEZ

MIGUEL SANTOS

MIGUEL SANZ DE JUNGUITO

MIGUEL SERRANO

MIGUEL SIMÓN DE LARA

MIGUEL TAFADURA

MIGUEL TAMAMES 


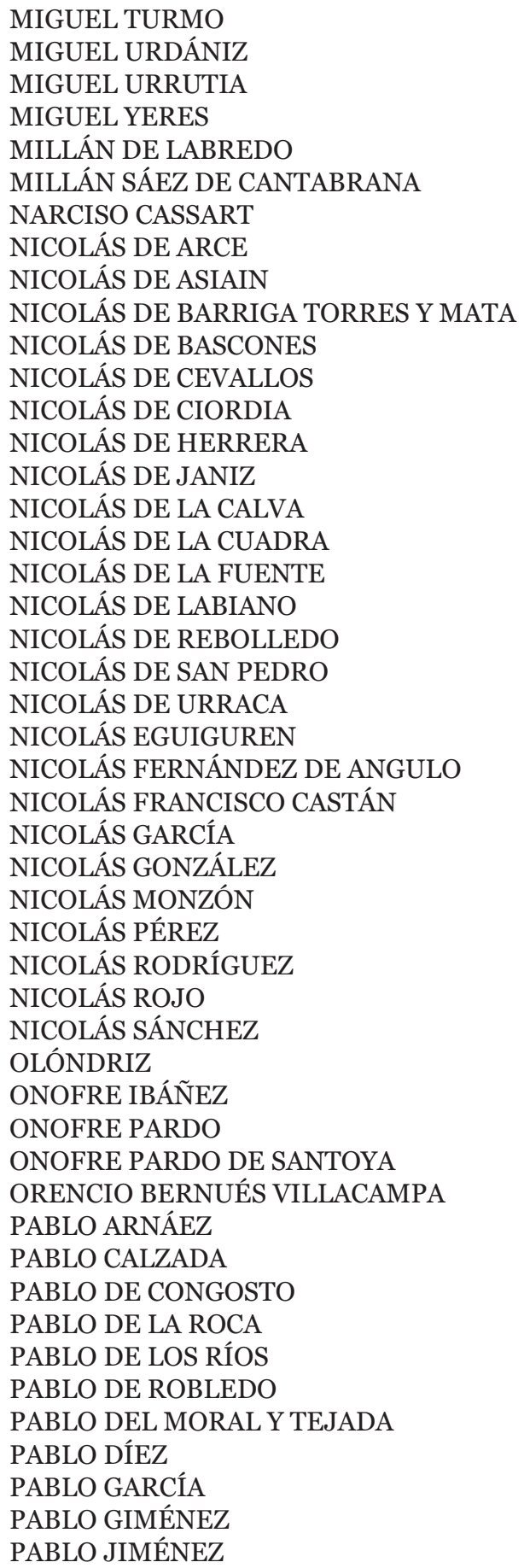

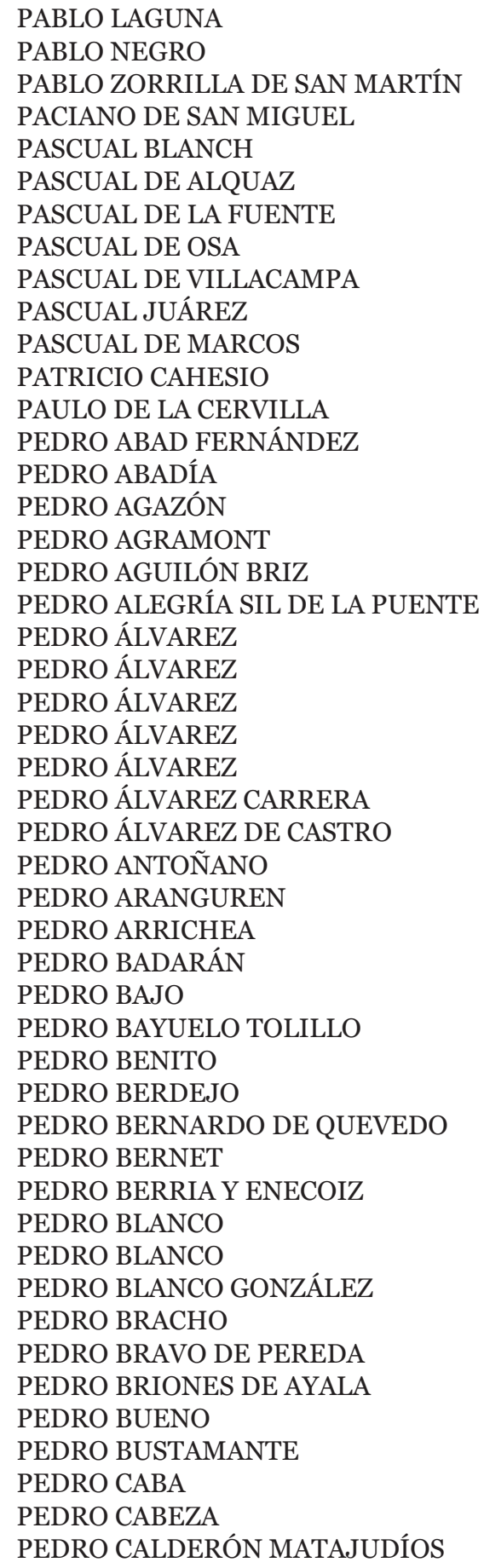


PEDRO CANDUELA

PEDRO CARRILLO

PEDRO CASTAÑOS

PEDRO CHINCHÓN

PEDRO CLEMENTE DE ORTIGOSA

PEDRO COLINA RUIZ

PEDRO CONDE

PEDRO CORADA

PEDRO CRESPO

PEDRO CUBILLAS

PEDRO DE ACEDO

PEDRO DE AEDO

PEDRO DE AGUERRE

PEDRO DE AGUILAR

PEDRO DE AIBAR

PEDRO DE ALGUERO

PEDRO DE ALMAR

PEDRO DE ALMAZÁN Y LIZARZA

PEDRO DE ALTUNA

PEDRO DE ÁLVAREZ

PEDRO DE AMÉZQUETA

PEDRO DE ANGULO

PEDRO DE ANGULO

PEDRO DE ANGULO

PEDRO DE ANGULO

PEDRO DE ANO

PEDRO DE ARAMENDIA

PEDRO DE ARANDIA DELGADO

PEDRO DE ARANGO

PEDRO DE ARAS Y PORRAS

PEDRO DE ARBIZU

PEDRO DE ARCE

PEDRO DE ARCE

PEDRO DE ARCE

PEDRO DE ARCE SOLÓRZANO

PEDRO DE ARCE Y LEIVA

PEDRO DE ARGANDA

PEDRO DE ARIAS

PEDRO DE ARINES Y TRONCOSO

PEDRO DE ARNILLA

PEDRO DE ARRIAGA Y ZUAZU

PEDRO DE ARRONTE CASTILLO

PEDRO DE ARROYO

PEDRO DE ARROYO

PEDRO DE ARTZAIN

PEDRO DE ARZABE

PEDRO DE ASAS

PEDRO DE AYA
PEDRO DE AYALA

PEDRO DE AYALA

PEDRO DE AZCÁRATE

PEDRO DE BALANZA

PEDRO DE BÁRCENA

PEDRO DE BARCINA

PEDRO DE BARREDA ESTRADA

PEDRO DE BARRIO

PEDRO DE BARRIOS

PEDRO DE BAYO

PEDRO DE BECERRIL

PEDRO DE BEITIA

PEDRO DE BEREZIARTUA

PEDRO DE BERGA

PEDRO DE BERNEDO

PEDRO DE BERRIA

PEDRO DE BIDAJÚN

PEDRO DE BOLÍVAR

PEDRO DE BUERAS

PEDRO DE BURGOS

PEDRO DE BUSTOS Y ESPINOSA

PEDRO DE CABRO SEVIL

PEDRO DE CÁCERES Y LATORRE

PEDRO DE CALVA

PEDRO DE CAMPO

PEDRO DE CAPETILLO

PEDRO DE CARRILLO

PEDRO DE CASILLAS

PEDRO DE CASTARRUBIO

PEDRO DE CASTRO

PEDRO DE CASUSO

PEDRO DE CEBALLOS

PEDRO DE CEBALLOS

PEDRO DE CELADA

PEDRO DE CERECEDA

PEDRO DE CESO

PEDRO DE CESURA HURTADO

PEDRO DE CHÁVARRI

PEDRO DE CHAVARRIA

PEDRO DE COLINA

PEDRO DE COSÍO CELY

PEDRO DE CUÉLLAR Y CARRASCO

PEDRO DE CUESTA

PEDRO DE CUEVAS

PEDRO DE DALLO

PEDRO DE DECA

PEDRO DE DICASTILLO

PEDRO DE DIEGO 
PEDRO DE DOMAICA

PEDRO DE DUEÑAS

PEDRO DE ECHART

PEDRO DE ECHASO

PEDRO DE ECHEGOYEN

PEDRO DE ECHEVERRÍA

PEDRO DE ELSO

PEDRO DE ENÉRIZ

PEDRO DE ESCARDI

PEDRO DE ESCOBAR

PEDRO DE ESCORZA

PEDRO DE ESPAÑA

PEDRO DE ESPARZA

PEDRO DE ESPINOSA

PEDRO DE ESQUÍROZ

PEDRO DE ESTARRIAGA

PEDRO DE EZQUERRA

PEDRO DE FRÍAS

PEDRO DE FUICA Y VERÁRTEGUI

PEDRO DE GALDAMES

PEDRO DE GÜESA

PEDRO DE HARO

PEDRO DE HERENCIA

PEDRO DE HERRERA

PEDRO DE HERRERA Y SOTO

PEDRO DE HOYO

PEDRO DE HUIDOBRO

PEDRO DE IBERO

PEDRO DE IRISARRI

PEDRO DE ISAR

PEDRO DE ISLA

PEDRO DE IZCO

PEDRO DE LA CABAÑA

PEDRO DE LA CALLE

PEDRO DE LA CALLEJA

PEDRO DE LA CALLEJA

PEDRO DE LA CANTOLLA

PEDRO DE LA CUESTA

PEDRO DE LA FUENTE

PEDRO DE LA HEDILLA

PEDRO DE LA HERRÁN

PEDRO DE LA HERRÁN Y MARDONES

PEDRO DE LA LLANDERA

PEDRO DE LA MAZA

PEDRO DE LA PUENTE

PEDRO DE LA PUENTE MONTECILLO

PEDRO DE LA RESECABA

PEDRO DE LA SERNA
PEDRO DE LA SIERRA

PEDRO DE LA TORRE

PEDRO DE LA VEGA

PEDRO DE LA VEGA MERODIO

PEDRO DE LABIANO

PEDRO DE LABID

PEDRO DE LAGUARDIA

PEDRO DE LAHERRÁN

PEDRO DE LAÍNEZ

PEDRO DE LAMO

PEDRO DE LAMO

PEDRO DE LANDA

PEDRO DE LANZ

PEDRO DE LARRAURI

PEDRO DE LAS HERAS

PEDRO DE LAS HERAS

PEDRO DE LAS RIBAS

PEDRO DE LASA

PEDRO DE LETE

PEDRO DE LIZARI

PEDRO DE LIZASO

PEDRO DE LLANO

PEDRO DE LLANO

PEDRO DE LOS ARCOS

PEDRO DE LOS HEROS

PEDRO DE LUMBRERAS

PEDRO DE MARUZA

PEDRO DE MAULEÓN

PEDRO DE MENA

PEDRO DE MERCADILLO

PEDRO DE MIER Y TERÁN

PEDRO DE MOLINUEVO

PEDRO DE MONTALBÁN

PEDRO DE MONTAÑO

PEDRO DE MONTELLANO

PEDRO DE MONTERRUBIO

PEDRO DE MORALES

PEDRO DE MOREDA

PEDRO DE MUNILLA

PEDRO DE MURGA

PEDRO DE NAVARRETE

PEDRO DE NAVASCUÉS

PEDRO DE NAVIA

PEDRO DE OCIO

PEDRO DE OLEA

PEDRO DE OLIVÁN

PEDRO DE OLOAIZ

PEDRO DE OLÓRIZ 
PEDRO DE OÑATE PEDRO DE ORNEDO PEDRO DE ORONIO PEDRO DE OSCÁRIZ PEDRO DE OSÉS PEDRO DE OSTÉRIZ PEDRO DE OTERO PEDRO DE OZCÁRIZ PEDRO DE PADILLA PEDRO DE PALACIO PEDRO DE PALACIOS PEDRO DE PARAYOS PEDRO DE PAREDES PEDRO DE PEÑARANDA PEDRO DE PERALTA PEDRO DE PEREGRÍN PEDRO DE PESADAS PEDRO DE PINO PEDRO DE PORRES PEDRO DE PRADO PEDRO DE QUEZBA PEDRO DE QUINTANA PEDRO DE QUINTANA PEDRO DE QUINTANILLA PEDRO DE RÁBAGO

PEDRO DE RAMOS LEZCANO ITURBAREN

PEDRO DE RIBAS PEDRO DE RIBAS PEDRO DE ROBA PEDRO DE ROJAS PEDRO DE ROSA PEDRO DE RUESGA PEDRO DE SAGASETA PEDRO DE SAGÜÉS PEDRO DE SALABERRI PEDRO DE SALANUEVA PEDRO DE SALAZAR PEDRO DE SALAZAR Y VELASCO PEDRO DE SALCEDO PEDRO DE SAMANIEGO PEDRO DE SAN BENITO PEDRO DE SAN JUAN DE BONILLA PEDRO DE SANMARTÍN PEDRO DE SANMARTÍN PEDRO DE SANTA FE PEDRO DE SANTA MARÍA PEDRO DE SANTA MARÍA
PEDRO DE SANTIAGO PEDRO DE SANZ DE LA CANTERA PEDRO DE SARACHEGA PEDRO DE SENA EDILLA PEDRO DE SETIÉN PEDRO DE SINOVAS PEDRO DE SOLNADO PEDRO DE SOLÓRZANO PEDRO DE SOSA PEDRO DE SOTILLO PEDRO DE SOTO PEDRO DE SOTO PEDRO DE TORICES Y COSÍO PEDRO DE TUDELA PEDRO DE UGARTE PEDRO DE UNZUÉ Y ASIAIN PEDRO DE URBINA PEDRO DE ÚRIZ PEDRO DE URÍZAR PEDRO DE URÍZAR Y SAN PEDRO PEDRO DE URRA PEDRO DE URRACA PEDRO DE URRUTIA PEDRO DE URTASUN PEDRO DE UTERGA PEDRO DE UZQUIANO PEDRO DE VALVERDE PEDRO DE VANDERAL PEDRO DE VARGA Y ESPAÑA PEDRO DE VELONDIA PEDRO DE VERA PEDRO DE VERGAÑO PEDRO DE VILLAESCUSA PEDRO DE VILLANUEVA PEDRO DE VILLARROEL PEDRO DE VILLASANA PEDRO DE VILLEGAS PEDRO DE VILLOTA PALACIO PEDRO DE VISEDA CEBALLOS PEDRO DE ZALDU PEDRO DE ZAMORA PEDRO DE ZÁRATE PEDRO DE ZUMETA PEDRO DE ZÚÑIGA PEDRO DEL ACEBAL PEDRO DEL BAÑO PEDRO DEL BARRIO PEDRO DEL BARRIO MIRÓN 
PEDRO DEL CAMPO

PEDRO DEL CAÑO

PEDRO DEL CASTILLO

PEDRO DEL CERRO SARAVIA

PEDRO DEL HIERRO

PEDRO DEL HOYO PELEGRÍN

PEDRO DEL MAZO

PEDRO DEL SAZ

PEDRO DEL VALLE

PEDRO DEL VALLE

PEDRO DÍAZ

PEDRO DÍAZ

PEDRO DÍAZ DE AGUSTÍN

PEDRO DÍAZ DE COSÍO

PEDRO DÍAZ DE INGUANZO

PEDRO DÍAZ DE ISLA

PEDRO DÍAZ DE MENA

PEDRO DÍAZ DE SELLAÑO

PEDRO DÍEZ

PEDRO DÍEZ

PEDRO DÍEZ BLANCO

PEDRO DÍEZ DE MATA

PEDRO DÍEZ DE QUINTANILLA

PEDRO DÍEZ DEL CORRAL COSÍO

PEDRO DOSAL MATAZ

PEDRO DURÁN

PEDRO EGUARAS FERNÁNDEZ DE ISAR

PEDRO ELSO

PEDRO ENRÍQUEZ

PEDRO FÉLIX

PEDRO FERNÁNDEZ

PEDRO FERNÁNDEZ

PEDRO FERNÁNDEZ

PEDRO FERNÁNDEZ

PEDRO FERNÁNDEZ DE CÉSPEDES

PEDRO FERNÁNDEZ DE IMAÑA

PEDRO FERNÁNDEZ DE MATA

PEDRO FERNÁNDEZ DE MIÑANO

PEDRO FERNÁNDEZ DE RETANA

PEDRO FERNÁNDEZ DE SIETES

PEDRO FERNÁNDEZ DE VILA

PEDRO FERNÁNDEZ DEL CAMPO

PEDRO FERNÁNDEZ DEL OLMO

PEDRO FERNÁNDEZ MOROSO

PEDRO FERNÁNDEZ VALLEJO

PEDRO FERNÁNDEZ Y ORTIZ

PEDRO FRANCÉS

PEDRO FRANCO
PEDRO GADEA

PEDRO GAMARRA

PEDRO GARCÍA

PEDRO GARCÍA

PEDRO GARCÍA

PEDRO GARCÍA

PEDRO GARCÍA

PEDRO GARCÍA

PEDRO GARCÍA

PEDRO GARCÍA

PEDRO GARCÍA

PEDRO GARCÍA

PEDRO GARCÍA

PEDRO GARCÍA DE GALDEANO

PEDRO GARCÍA DE GALDEANO

PEDRO GARCÍA DE GALDEANO

PEDRO GARCÍA DE OBALLE

PEDRO GARCÍA DE PEREDO

PEDRO GARCÍA DE SAN MARTÍN

PEDRO GARCÍA DE SOTO

PEDRO GARCÍA DEL CAMPO

PEDRO GARCÍA DEL MORAL

PEDRO GARCÍA DEL VALLE

PEDRO GIL

PEDRO GIL

PEDRO GIL

PEDRO GIL DE ALFARO

PEDRO GIL DE SEVILLA

PEDRO GIL ORTIZ DE TRASPEÑA

PEDRO GINEL

PEDRO GIRÓN PACHECO

PEDRO GÓMEZ

PEDRO GÓMEZ

PEDRO GÓMEZ

PEDRO GÓMEZ DE OLEA

PEDRO GÓMEZ DE SALAZAR

PEDRO GÓMEZ DE VELASCO

PEDRO GONZÁLEZ

PEDRO GONZÁLEZ

PEDRO GONZÁLEZ

PEDRO GONZÁLEZ

PEDRO GONZÁLEZ

PEDRO GONZÁLEZ

PEDRO GONZÁLEZ

PEDRO GONZÁLEZ

PEDRO GONZÁLEZ CABALLERO

PEDRO GONZÁLEZ DE CASTAÑEDA

PEDRO GONZÁLEZ DE COGOLLOS 
PEDRO GONZÁLEZ DE CURBANO PEDRO GONZÁLEZ DE MORA PEDRO GONZÁLEZ DE RIAÑO PEDRO GONZÁLEZ NIETO PEDRO GONZALO PEDRO GREGORIO PEDRO GREGORIO PEDRO GUEMBE PEDRO GUTIÉRREZ PEDRO GUTIÉRREZ PEDRO GUTIÉRREZ PEDRO GUTIÉRREZ PEDRO GUTIÉRREZ PEDRO GUTIÉRREZ PEDRO GUTIÉRREZ PEDRO GUTIÉRREZ DE LLANO PEDRO GUTIÉRREZ GAYÓN PEDRO HERRERO PEDRO HERRERO PEDRO HIPÓLITO PEDRO HORNILLOS PEDRO HURTADO DE SALCEDO PEDRO IBÁÑEZ PEDRO INÉS PEDRO INFANTE PEDRO IRIARTE PEDRO IZQUIERDO PEDRO JACOME PEDRO JAIME PEDRO JIMÉNEZ PEDRO JIMÉNEZ PEDRO JIMÉNEZ PEDRO JORDÁN PEDRO JORGE DE ARTETA PEDRO JOSÉ DEL ARCO PEDRO LABAIRU PEDRO LLANILLO PEDRO LLANO VELASCO PEDRO LÓPEZ PEDRO LÓPEZ PEDRO LÓPEZ PEDRO LÓPEZ PEDRO LÓPEZ DE BRIZUELA PEDRO LÓPEZ DE LA CALLEJA PEDRO LÓPEZ DE REBOLLEDA PEDRO LÓPEZ DE SILANES PEDRO LÓPEZ FRÍAS PEDRO LÓPEZ LOBO

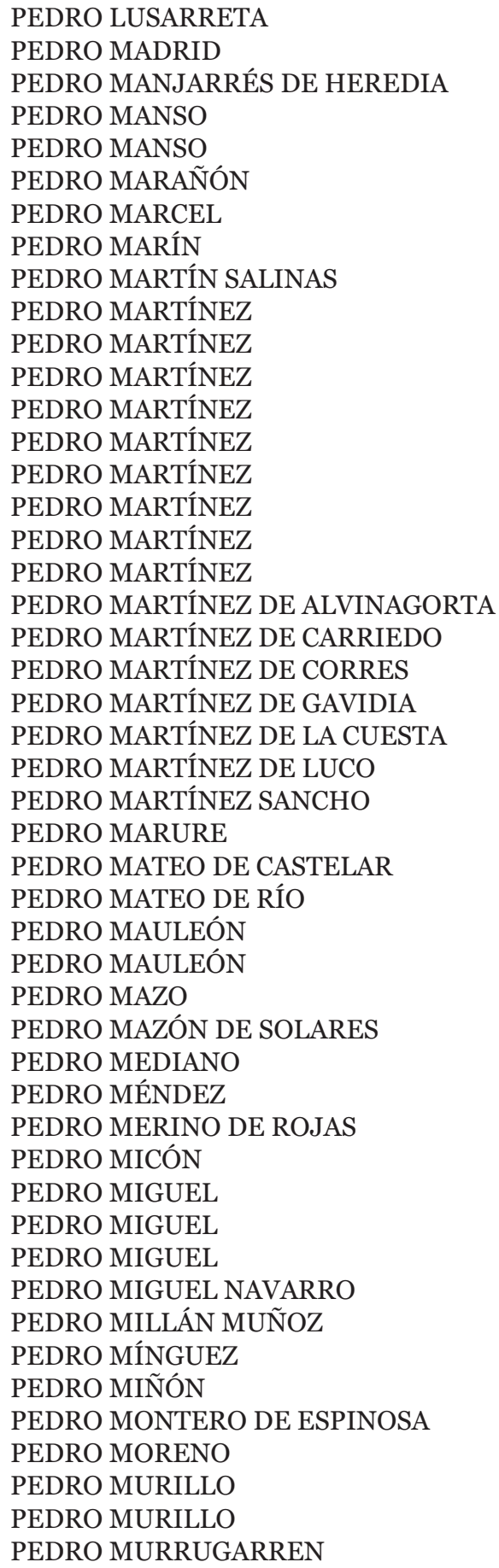


PEDRO NAVARRO

PEDRO NAVARRO

PEDRO NÚÑEZ GIL

PEDRO OGAZÓN

PEDRO ORTIZ

PEDRO ORTIZ

PEDRO ORTIZ

PEDRO ORTIZ DE GUECHO

PEDRO ORTIZ DE REJAS

PEDRO PANCORBO

PEDRO PANIAGUA

PEDRO PARMO

PEDRO PASCUAL

PEDRO PAULO JUÁREZ

PEDRO PAZOS

PEDRO PEDROSA

PEDRO PEÑA

PEDRO PEÑA

PEDRO PERALTA

PEDRO PÉREZ

PEDRO PÉREZ

PEDRO PÉREZ

PEDRO PÉREZ

PEDRO PÉREZ

PEDRO PÉREZ

PEDRO PÉREZ

PEDRO PÉREZ

PEDRO PÉREZ

PEDRO PÉREZ

PEDRO PÉREZ DE HERRÁN

PEDRO PÉREZ DE HOYOS

PEDRO PÉREZ DE PALACIOS

PEDRO PÉREZ DE PARRA

PEDRO PÉREZ DE REGULES

PEDRO PÉREZ DE ROBLES

PEDRO PORTER DE BELMONTE

PEDRO RAFAEL ESPUÑA

PEDRO REQUESENS

PEDRO REVUELTA DE SOLÓRZANO

PEDRO RICO

PEDRO RIPALDA

PEDRO RODRIGO

PEDRO RODRÍGUEZ

PEDRO RODRÍGUEZ ALCALDE

PEDRO ROSALES

PEDRO ROYO

PEDRO RUBIO PÉREZ

PEDRO RUIZ
PEDRO RUIZ

PEDRO RUIZ

PEDRO RUIZ

PEDRO RUIZ CELEDÓN

PEDRO RUIZ DE ...

PEDRO RUIZ DE ALLENDE

PEDRO RUIZ DE ANDREO

PEDRO RUIZ DE ARBOSO

PEDRO RUIZ DE ARRIOLA

PEDRO RUIZ DE DULANTO

PEDRO RUIZ DE QUINTANA

PEDRO RUIZ DE SOMOCURCIO

PEDRO RUIZ DE VILLADIEGO

PEDRO RUIZ DEL BURGO

PEDRO RUIZ DEL RIVERO

PEDRO RUIZ DÍAZ

PEDRO SÁENZ

PEDRO SÁENZ

PEDRO SAINZ

PEDRO SAINZ

PEDRO SAINZ

PEDRO SAINZ PRIETO

PEDRO SAIZ

PEDRO SAIZ DE GAROÑA

PEDRO SALAZAR NEGRETE

PEDRO SAN FUENTES

PEDRO SANCHA

PEDRO SÁNCHEZ

PEDRO SANCTORES DE URQUIETA

PEDRO SANZ

PEDRO SANZ DE LA CUEVA

PEDRO SANZ DE LA HERRÁN

PEDRO SARABIA VILLASANTE

PEDRO SERRANO

PEDRO SIJERO

PEDRO TAPIS

PEDRO TRIANA

PEDRO TURLAN

PEDRO URIBE

PEDRO USÚN

PEDRO VAL

PEDRO VALLEJO

PEDRO VÉLEZ

PEDRO VERGARA

PEDRO VERGARA

PEDRO ZAITEGUI

PEDRO ZAPATA

PEDRO ZORRILLA 
PLÁCIDO DE BÁRCENA PLÁCIDO DE ESLES PLÁCIDO DE HARO PLÁCIDO DE LEZÁUN PLÁCIDO DE PINILLOS PLÁCIDO DE PUGA PLÁCIDO DE REINOSO PLÁCIDO DE SALAZAR PLÁCIDO DE URBINA PLÁCIDO DEL RÍO PLÁCIDO MALDONADO PLÁCIDO MARTÍNEZ PLÁCIDO MOSQUERA PLÁCIDO NÚÑEZ PLÁCIDO OROZ PLÁCIDO RIQUER PLÁCIDO RODRÍGUEZ PLÁCIDO SANZ PLÁCIDO VEA POLICARPO ANDRÉS POLICARPO SÁNCHEZ PRIMITIVO LASO PRIMITIVO RUIZ PRUDENCIO DE MANZANARES PRUDENCIO DE MURGA PRUDENCIO DE SICILIA PRUDENCIO FERNÁNDEZ DEL PONSÓN PRUDENCIO GONZÁLEZ DE ANGULO PRUDENCIO PORTUGUÉS PRUDENCIO RUBIO RAFAEL ALONSO MARDONES RAFAEL DE ENDARA RAFAEL DE VALARZA RAFAEL DE ZAY RAFAEL GONZÁLEZ RAFAEL PÉREZ RAFAEL SIURANA RAIMUNDO DE ALEGUI RAIMUNDO DÍAZ DE GARIBAY RAMIRO DE GOÑI RAMIRO DE GORRI RAMIRO DE TORRES RAMIRO MARTÍNEZ REMIGIO FERRER RODRIGO CORRAL RODRIGO DE ESCOBAR RODRIGO DE FIGUEROA RODRIGO DE LA CUESTA
RODRIGO DE LA PEÑA RODRIGO DE PAREDES Y HERRERA RODRIGO DE SANMARTÍN RODRIGO MONTERO ROMÁN DE BACÁICOA ROQUE BENITO ROQUE DE ANO ROQUE DE ARROYO ROQUE DE LA PUENTE ROQUE DE MATA ROQUE DE MIER Y TERÁN ROQUE DE ORTEGA ROQUE DE RUEDA ROQUE DE SOTO ROQUE DE VIVAR ROQUE DEL BARRIO ROQUE GONZÁLEZ ROQUE GONZÁLEZ ROQUE GUTIÉRREZ ROQUE LÓPEZ ROQUE SANTOS ROQUE SANTOS DE SAN PEDRO ROQUE SERRANO ROSENDO ÁLVAREZ ROSENDO ÁLVAREZ ROSENDO DE MÚJICA ROSENDO DE SAN MARTÍN RUY SALAZAR SALVADOR CRUZAT SALVADOR DE ELIO SALVADOR DE OLÁIZ SALVADOR MARTÍN SANCHO DE ARRAIZA SANCHO DE GOÑI SANCHO DE ILUNDÁIN SANCHO DE ITUREN SANCHO DE URDIROZ SANCHO DE VILLEGAS SANCHO ORTIZ DE MONTELLANO SANCHO URSUA DE ARRECHEA SANJUÁN LÓPEZ SANTIAGO ALONSO SANTIAGO ARROYO SANTIAGO BARBERO SANTIAGO CRUZADO SANTIAGO DE ALMURRIO SANTIAGO DE BERANGA SANTIAGO DE CASTRO 
SANTIAGO DE CORTIGUERA

SANTIAGO DE IZCARI

SANTIAGO DE LA FUENTE

SANTIAGO DE LA TOBA

SANTIAGO DE MUGA

SANTIAGO DE REGE...

SANTIAGO DE RUCOBA Y SENA

SANTIAGO DE UBERICHAGA

SANTIAGO DÍAZ DE ROBLES

SANTIAGO GARCÍA

SANTIAGO GÓMEZ

SANTIAGO GONZÁLEZ

SANTIAGO GUTIÉRREZ

SANTIAGO GUTIÉRREZ

SANTIAGO GUTIÉRREZ

SANTIAGO GUTIÉRREZ BARONA

SANTIAGO IÑÍGUEZ

SANTIAGO MATEO

SANTIAGO ORTEGA

SANTIAGO ROJO

SANTIAGO RUIZ GUTIÉRREZ

SANTIAGO SARMIENTO

SANTIAGO SEGURA

SANTOS HIERRO DEL SOLAR

SANTOS SANZ

SEBASTIÁN ALONSO MANSO

SEBASTIÁN ALONSO PÉREZ

SEBASTIÁN ÁLVAREZ

SEBASTIÁN BENITO

SEBASTIÁN BLANCO

SEBASTIÁN BRAVO DE PEREDA

SEBASTIÁN BULLÓN

SEBASTIÁN CABALLERO QUINTANO

SEBASTIÁN CALDERÓN

SEBASTIÁN CALVO

SEBASTIÁN CANO

SEBASTIÁN DE ARCE

SEBASTIÁN DE BALMACEDA SALAR

SEBASTIÁN DE BARRIO

SEBASTIÁN DE BERICE

SEBASTIÁN DE CARDIÑANOS

SEBASTIÁN DE CARRANZA Y MONTAÑO

SEBASTIÁN DE CASTRO

SEBASTIÁN DE CENARRO

SEBASTIÁN DE ERICE

SEBASTIÁN DE GANUZA

SEBASTIÁN DE HERRÁN

SEBASTIÁN DE IBARROLA
SEBASTIÁN DE IDOCIN

SEBASTIÁN DE LAS CASAS

SEBASTIÁN DE LIZARRAGA

SEBASTIÁN DE LOS ARCOS SALAZAR

SEBASTIÁN DE LOS RÍOS

SEBASTIÁN DE MANSILLA

SEBASTIÁN DE MECA

SEBASTIÁN DE MELGAR

SEBASTIÁN DE MONTAÑANA

SEBASTIÁN DE ORTEGA

SEBASTIÁN DE ORTEGA

SEBASTIÁN DE RIAÑO Y GAMBOA

SEBASTIÁN DE RUISEÑADA

SEBASTIÁN DE SALANUEVA

SEBASTIÁN DE SALAZAR

SEBASTIÁN DE SAN MARTÍN

SEBASTIÁN DE SAN MARTÍN

SEBASTIÁN DE SANTOS

SEBASTIÁN DE SEDANO

SEBASTIÁN DE SEGURA

SEBASTIÁN DE SILDIAS

SEBASTIÁN DE TRECEDO

SEBASTIÁN DE VALDEMORO

SEBASTIÁN DE ZUAZU

SEBASTIÁN DÍAZ DE QUINTANILLA

SEBASTIÁN DOMÍNGUEZ

SEBASTIÁN FERRAZ

SEBASTIÁN GARCÍA

SEBASTIÁN GARCÍA CLEMENTE

SEBASTIÁN GOMBO

SEBASTIÁN GÓMEZ DE FONCEA

SEBASTIÁN GONZÁLEZ

SEBASTIÁN GUTIÉRREZ

SEBASTIÁN HERRÁN

SEBASTIÁN LÓPEZ DE TOJAL

SEBASTIÁN MARTÍNEZ

SEBASTIÁN MARTÍNEZ DE BUSTO

SEBASTIÁN MECA

SEBASTIÁN MIGUEL DE LOMAS

SEBASTIÁN ORTEGA

SEBASTIÁN ORTIZ

SEBASTIÁN ORTIZ

SEBASTIÁN ORTIZ DE LA LAGUNILLA

SEBASTIÁN PARDO

SEBASTIÁN RAMÍREZ

SEBASTIÁN REBOLLO

SEBASTIÁN RUIZ DE EGUIDO

SEBASTIÁN RUIZ DE QUEVEDO 
SEBASTIÁN SALDÍAS

SEBASTIÁN TREVIÑO

SEBASTIÁN VERINO

SEBASTIÁN VICENTE DEL HOYO

SEVERINO DE BEDIA

SILVESTRE CORRAL

SILVESTRE DE ROBA

SILVESTRE VALLE

SIMEÓN DE GUINDA Y APÉSTEGUI

SIMÓN BARRIO

SIMÓN BENITO

SIMÓN BENITO

SIMÓN CABALLERO

SIMÓN DE AMPURO

SIMÓN DE ANGULO

SIMÓN DE BUERAS

SIMÓN DE EGUILUZ CORQUERA

SIMÓN DE GAZTEA LÓPEZ

SIMÓN DE HIERRO

SIMÓN DE LINZOAIN

SIMÓN DE LUNA

SIMÓN DE MANSILLA

SIMÓN DE MURUGARREN

SIMÓN DE PALACIOS

SIMÓN DE REVILLA

SIMÓN DE RUIZ

SIMÓN DE SADA

SIMÓN DE SAN JUAN

SIMÓN DE SAN JUANES

SIMÓN DE TERÁN

SIMÓN DE TRISTÁN

SIMÓN DEL MORAL

SIMÓN DEL RÍO

SIMÓN DÍAZ DE TUESTA

SIMÓN DÍEZ

SIMÓN ELORZA

SIMÓN FERNÁNDEZ DE CELIS

SIMÓN FERNÁNDEZ GARCÍA

SIMÓN GARCÍA SARABIA

SIMÓN GÓMEZ DE RUFRANCOS

SIMÓN GONZÁLEZ

SIMÓN GONZÁLEZ

SIMÓN GONZÁLEZ

SIMÓN GONZÁLEZ DE MARSILLA

SIMÓN GONZÁLEZ DE PEDROSA

SIMÓN HERMOSO

SIMÓN LÓPEZ

SIMÓN MARÍN
SIMÓN PÉREZ

SIMÓN PRIETO

SIMÓN RUIZ

SIMÓN RUIZ DE LA REVILLA

SIMÓN SAINZ DE BARANDA

SIMÓN SAINZ DE QUINTANILLA

TADEO DE CEVALLOS

TADEO MERINO

TIBURCIO DE PRADA

TOMÁS ALFONSO

TOMÁS ANDRÉS DE ESCARROZ

TOMÁS ANGULO DE AEDO

TOMÁS ANTÓN GONZÁLEZ

TOMÁS BARBADILLO

TOMÁS CALLE

TOMÁS CORONEL

TOMÁS DE AGÜERO

TOMÁS DE ALFARO

TOMÁS DE ALLENDE

TOMÁS DE ANGLÁS

TOMÁS DE APARICIO

TOMÁS DE AUSEJO

TOMÁS DE AVELLANEDA

TOMÁS DE BERRAGIA

TOMÁS DE CÁRCAMO

TOMÁS DE CASAS

TOMÁS DE ESCALANTE

TOMÁS DE FRÍAS

TOMÁS DE HAEDO Y SARABIA

TOMÁS DE IBAIZÁBAL

TOMÁS DE IRIARTE

TOMÁS DE ISLA

TOMÁS DE LA IGLESIA

TOMÁS DE LONGÁS

TOMÁS DE LOS RÍOS VELASCO

TOMÁS DE LUCUZE

TOMÁS DE LUZÓN

TOMÁS DE MATUTE

TOMÁS DE MEDINA

TOMÁS DE MENA

TOMAS DE MUR

TOMÁS DE NAVASCUÉS

TOMÁS DE OLLOQUI Y LARA

TOMÁS DE RIVAS

TOMÁS DE ROBLES Y LERMA

TOMÁS DE ROSILLO

TOMÁS DE SALAZAR

TOMÁS DE SARASA 
TOMÁS DE SARASA

TOMÁS DE SESMA

TOMÁS DE TERREROS

TOMÁS DE TORREJÓN

TOMÁS DE TORRES

TOMÁS DE URIBARREN

TOMÁS DE VALLADOLID

TOMÁS DE VILLUENDAS

TOMÁS DEL CAMPILLO

TOMÁS DEL CAMPO

TOMÁS DEL CERRO

TOMAS DEL HOYO

TOMÁS DEL PIÑAL

TOMÁS DEL POZO

TOMÁS DÍEZ DE LA CUESTA

TOMÁS DÍEZ DE MEDINA

TOMÁS ESQUER

TOMÁS FERNÁNDEZ

TOMÁS FERNÁNDEZ DEL CASTILLO

TOMÁS FRANCO

TOMÁS GARCÍA

TOMÁS GARCÍA DE LAS TORRES

TOMÁS GARCÍA DE PALACIOS

TOMÁS GARCÍA GÓMEZ

TOMÁS GÓMEZ

TOMÁS GÓMEZ DE ARROYO

TOMÁS GONZÁLEZ

TOMÁS GONZÁLEZ

TOMÁS GONZÁLEZ

TOMÁS GONZÁLEZ

TOMÁS GONZÁLEZ

TOMÁS GUTIÉRREZ

TOMÁS GUTIÉRREZ SOLANA

TOMÁS HERRERO

TOMÁS IGNACIO DE BEINZA

TOMÁS LÓPEZ

TOMÁS MADRAZO ESCALERA

TOMÁS MARTÍNEZ

TOMÁS MIGUEL

TOMÁS MIGUEL DE SAMITIER

TOMÁS MILLÁN DE BERZOSILLA

TOMÁS PÉREZ

TOMÁS PÉREZ

TOMÁS PÉREZ

TOMÁS PÉREZ DE AMALLO

TOMÁS PÉREZ DE AMALLO

TOMÁS POLO

TOMÁS RODRÍGUEZ
TOMÁS RODRÍGUEZ

TOMÁS RUIZ CACHUPÍN

TOMÁS RUIZ DE LOZARES

TOMÁS RUIZ DE QUINTANA

TOMÁS SIMÓN

TOMÁS VALLEJO

TOMÁS VICENTE

TOMÁS VICENTE DE BUESO

TOMÉ DE BUSTILLO

TOMÉ DEL RÍO

TORCADO DE SALAZAR

TORIBIO CRESPO

TORIBIO DE BRINGAS

TORIBIO DE LA CUEVA

TORIBIO DE RADILLO DE ARCE

TORIBIO DÍAZ REAL

TORIBIO FERNÁNDEZ

TORIBIO FERNÁNDEZ

TORIBIO GARCÍA

TORIBIO GONZÁLEZ

TORIBIO RUBÍN DE CELIS

TORIBIO RUIZ DE BARREDA

TORIBIO RUIZ DE LA VEGA

TORIBIO SERNA

URBAN DEL RÍO

VALENTÍN DE GUINEA

VALENTÍN DE LA IGLESIA

VALENTÍN PÉREZ DE NOVALES

VALERIANO DOLZ DEL CASTELLAR

VALERIO DE LOS RÍOS Y SALCEDO

VALERIO GARCÍA

VASCO FERREIRA

VENTURA ALONSO

VENTURA CORTÉS DEL VALLE

VENTURA DE BELORADO

VENTURA DE CASANUEVA

VENTURA DE MIER Y TERÁN

VENTURA DE RIBAS

VENTURA DE URIZ

VENTURA GALVÁN

VENTURA JIMÉNEZ

VENTURA MAULEÓN

VENTURA PARCERO Y BAZÁN

VENTURA RODRÍGUEZ

VENTURA RUPÉREZ O PÉREZ (sic)

VENTURA VÉLEZ

VENTURA ZUGATONDO

VEREMUNDO IBÁÑEZ 
VICENTE ADÁN

VICENTE ANGLÉS

VICENTE DE ESCOBAR

VICENTE DE LA SERRADA

VICENTE DE TRAMBARRIA

VICENTE DE URVINO

VICENTE DEL CAMPO

VICENTE DÍEZ

VICENTE GARCÍA DE ISABA

VICENTE GONZÁLEZ

VICENTE HERRERO
VICENTE LÓPEZ

VICENTE MORROGÓN

VICENTE PINILLOS

VÍCTORES DE LOSANTOS

VÍCTORES DE RUILÓPEZ

VÍCTORES GARCÍA

VÍCTORES LÓPEZ DE TEJADA

VÍCTORES ORTIZ

VÍCTORES SÁENZ DE LA MALETA

VÍCTORES DE GUINEA Y MÚJICA VÍCTORES MARTÍNEZ 


\section{PROGRAMA HISTORIA DE LAS UNIVERSIDADES \\ PUBLICACIONES \\ ISSN: $1886-0710$}

1. Estado de la Universidad de Alcalá (1805), estudio preliminar de José Luis Peset, edición de Diego Navarro, Madrid 1999, 120 pp.

http://hdl.handle.net/10016/7875

2. La investigación en la universidad, edición de Carmen Merino, Madrid 1999, $217 \mathrm{pp}$.

http://hdl.handle.net/10016/7876

3. Aurora Rivière Gómez, Orientalismo y nacionalismo español. Estudios árabes y hebreos en la Universidad de Madrid (1843-1868), Madrid 2000, 143 pp.

http://hdl.handle.net/10016/7905

4. Manuel Martínez Neira, El estudio del derecho. Libros de texto y planes de estudio en la universidad contemporánea, Madrid 2001,318 pp.

http://hdl.handle.net/10016/7877

5. Daniel Comas Caraballo, Autonomía y reformas en la Universidad de Valencia (1900-1922), Madrid 2001, 334 pp.

http://hdl.handle.net/10016/7878

6. Carolina Rodríguez López, La Universidad de Madrid en el primer franquismo: ruptura y continuidad (1939-1951), Madrid 2002, 490 pp.

http://hdl.handle.net/10016/7879

7. Ramon Aznar i Garcia, Cánones y leyes en la universidad de Alcalá durante el reinado de Carlos III, Madrid 2002, 349 pp.

http://hdl.handle.net/10016/7880

8. Enrique Villalba Pérez, Consecuencias educativas de la expulsión de los jesuitas de América, Madrid 2003, 246 pp.

http://hdl.handle.net/10016/7881

9. Archivos universitarios e historia de las universidades, edición de José Ramón

Cruz Mundet, Madrid 2003, 345 pp.

http://hdl.handle.net/10016/7882

10. La enseñanza del derecho en el siglo XX. Homenaje a Mariano Peset, edición de Adela Mora Cañada, Madrid 2004, 578 pp.

http://hdl.handle.net/10016/7883 
11. Manuel Martínez Neira/José M. ${ }^{a}$ Puyol Montero/Carolina Rodríguez López, La universidad española 1889-1939. Repertorio de legislación, Madrid 2004, 389 pp. http://hdl.handle.net/10016/7884

12. Hacia un modelo universitario: la Universidad Carlos III de Madrid, edición de Adela Mora Cañada y Carolina Rodríguez López, Madrid 2004, 365 pp. http://hdl.handle.net/10016/7885

13. Manuales y textos de enseñanza en la universidad liberal, edición de Manuel Ángel Bermejo Castrillo, Madrid 2004, 750 pp.

http://hdl.handle.net/10016/7886

14. Susana Guijarro González, Maestros, escuelas y libros. El universo cultural de las catedrales en la Castilla medieval, Madrid 2004, CD + 349 pp.

http://hdl.handle.net/10016/7887

15. Filosofía para la universidad, filosofía contra la universidad, edición de Faustino Oncina Coves, Madrid 2008, 360 pp.

http://hdl.handle.net/10016/3506

16. Manuel Martínez Neira/José María Puyol Montero, El doctorado en derecho. 1930-1956, Madrid 2008, 340 pp.

http://hdl.handle.net/10016/3386

17. Germán Perales Birlanga, El estudiante liberal. Sociología y vida de la comunidad escolar universitaria de Valencia. 1875-1939, Madrid 2009, 326 pp.

http://hdl.handle.net/10016/4376

18. Alfons Aragoneses, Un jurista del Modernismo. Raymond Saleilles y los orígenes del derecho comparado, Madrid 2009, 259 pp.

http://hdl.handle.net/10016/5778

19. Antonio López Vega, Biobibliografía de Gregorio Marañón, Madrid 2009, 187 pp. http://hdl.handle.net/10016/6178

20. Pio Caroni, La soledad del historiador del derecho. Apuntes sobre la conveniencia de una disciplina diferente, Madrid 2010, 225 pp.

http://hdl.handle.net/10016/6560

21. Francisco Crosas López, De enanos y gigantes. Tradición clásica en la cultura medieval hispánica, Madrid 2010, 169 pp.

http://hdl.handle.net/10016/8346

22. Manuel Martínez Neira/Natividad Araque Hontangas, El marqués de Morante y la Universidad de Madrid, Madrid 2011, 277 pp.

http://hdl.handle.net/10016/10578 
23. Antonio Planas Rosselló/Rafael Ramis Barceló, La facultad de leyes y cánones de la Universidad Luliana y Literaria de Mallorca, Madrid 2011, 186 pp.

http://hdl.handle.net/10016/11325

24. Francisco Ayala/Eduardo L. Llorens/Nicolás Pérez Serrano, El derecho político de la Segunda República, estudio preliminar, edición y notas de Sebastián Martín, Madrid 2011, CLXXXIX + 396 pp.

http://hdl.handle.net/10016/11365

25. Pablo Campos Calvo-Sotelo, La evolución histórica del espacio físico de la universidad. Impulsos conceptuales, paradigmas arquitectónicos, estrategias institucionales y propuestas recientes de innovación, Madrid 2011, 236 pp.

http://hdl.handle.net/10016/12017

26. Andry Matilla Correa, Los primeros pasos de la ciencia del Derecho Administrativo en Cuba. José María Morilla y el Breve tratado de Derecho Administrativo (1847), Madrid 2011, 329 pp.

http://hdl.handle.net/10016/12033

27. José María Puyol Montero, La autonomía universitaria en Madrid (1919-1922), Madrid 2011, 545 pp.

http://hdl.handle.net/10016/12289

28. Manuel Cachón Cadenas, Historias de procesalistas, universidades y una guerra civil (1900-1950), Madrid 2012, 681 pp.

http://hdl.handle.net/10016/14588

29. María Paz Alonso Romero, Salamanca, escuela de juristas. Estudios sobre la enseñanza del derecho en el Antiguo Régimen, Madrid 2012, 722 pp.

http://hdl.handle.net/10016/15129

30. Carlos Nieto Sánchez, San Clemente de Bolonia (1788-1889): el fin del Antiguo Régimen en el último colegio mayor español, Madrid 2012, 480 pp.

http://hdl.handle.net/10016/15708

31. Natividad Araque Hontangas, Manuel José Quintana y la Instrucción pública, prólogo de Jean-Louis Guereña, Madrid 2013, 427 pp.

http://hdl.handle.net/10016/17196

32. La Universidad Central durante la Segunda República: Las Ciencias Humanas y Sociales y la vida universitaria, edición de Eduardo González Calleja y Álvaro Ribagorda, Madrid 2013, 376 pp.

http://hdl.handle.net/10016/17394

33. Manuel Martínez Neira, La creación del cuerpo de catedráticos de universidad (1812-1857). Estudio histórico-jurídico, Madrid 2013, 358 pp.

http://hdl.handle.net/10016/18077 
34. Luis Enrique Otero Carvajal (dir.), La Universidad nacionalcatólica. La reacción antimoderna, Madrid 2014, 1098 pp.

http://hdl.handle.net/10016/18911

35. Manuel Martínez Neira, La regulación de las oposiciones a cátedras universitarias: $1845-1931$, Madrid 2014, $146 \mathrm{pp}$.

http://hdl.handle.net/10016/19338

36. Leoncio López-Ocón (ed.), Aulas modernas. Nuevas perspectivas sobre las reformas de la enseñanza secundaria en la época de la JAE (1907-1939), Madrid 2014, 364 pp.

http://hdl.handle.net/10016/19883

37. María Ángeles Longás Lacasa, Historia de la Biblioteca de la Universidad de Mallorca (1767-1829), Madrid 2015, 437 pp.

http://hdl.handle.net/10016/21552

38. Fernando Liendo Tagle, Pablo de Olavide y la nueva planta de los estudios, Madrid 2016, 176 pp.

http://hdl.handle.net/10016/23895

39. Rafael Ramis Barceló, Doctores hispanos en leyes y cánones por la Universidad de La Sapienza de Roma (1549-1774), Madrid 2017, 274 pp.

http://hdl.handle.net/10016/24015

40. Julián Gómez de Maya, De Al-Ricotí al rector Sabater: estudios históricos sobre la Universidad de Murcia y sus antecedentes, Madrid 2017, 388 pp.

http://hdl.handle.net/10016/24848

41. Luigiaurelio Pomante, A Great Research Lab on University History and Higher Education in Spain: Instituto Antonio de Nebrija de Estudios sobre la Universidad (1997-2009), Madrid 2017, 253 pp.

http://hdl.handle.net/10016/25309

42. Pablo Campos Calvo-Sotelo/Laura Luceño Casals, Las formas de la educación. Vínculos entre dimensión docente y dimensión arquitectónica en disciplinas creativas, como expresión de innovación universitaria, Madrid 2018, 169 pp.

http://hdl.handle.net/10016/26594

43. Rafael Ramis Barceló/Pedro Ramis Serra, Los primeros grados de la Universidad de Baeza (1549-1580), Madrid 2018, 234 pp.

http://hdl.handle.net/10016/27079

44. Víctor Guijarro Mora, Artefactos y acción educativa. La cultura del objeto científico en la enseñanza secundaria en España (1845-1930), Madrid 2018, 273 pp.

http://hdl.handle.net/10016/27200 
45. Oposiciones a cátedras de derecho (1847-1943), edición de Javier Carlos Díaz Rico, Madrid 2018, 486 pp.

http://hdl.handle.net/10016/27454

46. Rafael Ramis Barceló, Estudios sobre la Universidad de Lérida (1561-1717), Madrid 2018, 190 pp.

http://hdl.handle.net/10016/27465

47. Leoncio López-Ocón/Víctor Guijarro/Mario Pedrazuela (eds.), Aulas Abiertas. Profesores viajeros y renovación de la enseñanza secundaria en los países ibéri$\cos$ (1900-1936), Madrid 2018, 561 pp. + ilustraciones.

http://hdl.handle.net/10016/27684

48. Dámaso de Lario, Escuelas de imperio. La formación de una elite en los Colegios Mayores (siglos XVI-XVII), Madrid 2019, 465 pp.

http://hdl.handle.net/10016/28127

49. Natividad Araque Hontangas, El Instituto Femenino Isabel la Católica: un centro modélico del CSIC, Madrid 2019, 455 pp.

http://hdl.handle.net/10016/29046

50. Rafael Ramis Barceló/Pedro Ramis Serra, Las Ordenaciones de la Universidad de Barcelona de 1638, Madrid 2019, 254 pp.

http://hdl.handle.net/10016/29070

51. Enrique Gudín de la Lama/Javier Voces Fernández, El Duque de Rivas y la Instrucción pública, Madrid 2019, 80 pp.

http://hdl.handle.net/10016/29150

52. Manuel Martínez Neira/Rafael Ramis Barceló, La libertad de enseñanza. Un debate del Ochocientos europeo, Madrid 2019, 476 pp.

http://hdl.handle.net/10016/29808

53. Francisco Javier Rubio Muñoz, La República de sabios. Profesores, cátedras y universidad en la Salamanca del siglo de Oro, Madrid 2020, 289 pp.

http://hdl.handle.net/10016/29856

54. Celia Alejandra Ramírez Santos/José Luis Egío, Conceptos, autores, instituciones. Revisión crítica de la investigación reciente sobre la Escuela de Salamanca (2008-19) y bibliografía multidisciplinar, Madrid 2020, 333 pp.

http://hdl.handle.net/10016/30100

55. Rafael Ramis Barceló/Pedro Ramis Serra, Estudios sobre la Universidad de Tortosa (1600-1717), Madrid 2020, 288 pp.

http://hdl.handle.net/10016/30367 
56. Rafael Ramis Barceló/Pedro Ramis Serra, Actos y grados de la Universidad de Alcalá (1523-1544), Madrid 2020, 563 pp. http://hdl.handle.net/10016/30817

57. Rafael Ramis Barceló/Pedro Ramis Serra, Los grados de la Universidad de Irache (1613-1700), Madrid 2020, 680 pp.

http://hdl.handle.net/10016/31395 